LUCAS LAUER VERDADE

Avaliação do uso de um polietileno de alta densidade e baixo peso molecular oxidado como agente de compatibilização em asfalto modificado com copolímero SBS

São Carlos

2015 

LUCAS LAUER VERDADE

\title{
Avaliação do uso de um polietileno de alta densidade e baixo peso molecular oxidado como agente de compatibilização em asfalto modificado com copolímero SBS
}

\begin{abstract}
Dissertação apresentada ao Departamento de Engenharia de Transportes da Escola de Engenharia de São Carlos, da Universidade de São Paulo, como parte dos requisitos para obtenção do título de mestre em Engenharia Civil.
\end{abstract}

Área de Concentração: Infraestrutura de Transportes

Orientador: Prof. Associado Adalberto Leandro Faxina

São Carlos

Setembro 
AUTORIZO A REPRODUÇÃO TOTAL OU PARCIAL DESTE TRABALHO, POR QUALQUER MEIO CONVENCIONAL OU ELETRÔNICO, PARA FINS DE ESTUDO E PESQUISA, DESDE QUE CITADA A FONTE.

Verdade, Lucas Lauer

Avaliação do uso de um polietileno de alta densidade e baixo peso molecular oxidado como agente de compatibilização em asfalto modificado com copolímero SBS / Lucas Lauer Verdade; orientador Adalberto Leandro Faxina. São Carlos, 2015.

Dissertação (Mestrado) - Programa de Pós-Graduação em Engenharia de Transportes e Área de Concentração em Infra-Estrutura de Transporte -- Escola de Engenharia de São Carlos da Universidade de São Paulo, 2015.

1. Iigante asfáltico modificado com SBS. 2. Polietileno de alta densidade e baixo peso molecular oxidado. 3. Estabilidade à estocagem. 4. Ensaios reologicos. 5. Curva-mestre. I. Título. 


\section{FOLHA DE JULGAMENTO}

Candidato: Engenheiro LUCAS LAUER VERDADE.

Título da dissertação: "Avaliação do uso de um polietileno de alta densidade e baixo peso molecular oxidado com agente de compatibilização em asfalto modificado com copolímero SBS".

Data da defesa: $26 / 08 / 2015$

\section{Comissão Julgadora:}

Prof. Associado Adalberto Leandro Faxina

(Orientador)

(Escola de Engenharia de São Carlos/EESC)

Prof. Dr. Glauco Tulio Pessa Fabbri

(Escola de Engenharia de São Carlos/EESC)

Profa. Dra. Verônica Teixeira Franco Castelo Branco

(Universidade Federal do Ceará/UFC)

\section{Resultado:}

APROVADO

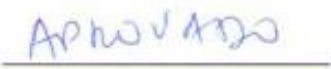

Coordenador do Programa de Pós-Graduação em Engenharia de Transportes: Prof. Associado Paulo Cesar Lima Segantine

Presidente da Comissão de Pós-Graduação:

Prof. Associado Paulo Cesar Lima Segantine 



\section{DEDICATÓRIA}

Ao meu avô Joaquim Henrique Lauer,

in memoriam. 



\section{AGRADECIMENTOS}

Aos meus pais Rogério Verdade e Leila Augusta Camargo Lauer Verdade, por todo o incentivo à minha formação e por acreditarem em mim.

À minha irmã Raquel Lauer Verdade pelo apoio constante, carinho e amizade.

Aos meus avós Myrna Lauer, Sônia Verdade e Roberto Verdade, por todo incentivo e apoio constante.

Ao Prof. Associado Adalberto Leandro Faxina, pela orientação, amizade, apoio, confiança e orientação durante esta dissertação.

À minha namorada Flávia Grzybowski Vriesman, pelo apoio e incentivo constantes durante a elaboração desta dissertação.

À coordenação de Aperfeiçoamento de Pessoal de Nível Superior (CAPES), pela concessão da bolsa de estudos.

Aos professores e funcionários do Departamento de Engenharia de Transportes da EESCUSP, pelas amizades, oportunidades e apoio constantes.

Aos professores Jesner e Yshiba da Universidade Estadual de Maringá, pela ajuda e incentivo a realização desta dissertação na EESC-USP.

Aos técnicos de laboratório Antonio Carlos Gigante, Paulo Toyama e João Pereira Filho, pela amizade, ajuda e paciência durante este período de convivência.

Aos colegas, colegas de sala e amigos da pós-graduação, pelas experiências compartilhadas nestes últimos anos.

Aos amigos, em especial o Eduardo, Estevo, Faysall, Felipe, Guilherme, Ismael, Mathias, Partala, Pedro, Petros, Poppi, Rodrigo, Tanaka, Walter, pela amizade. 

Verdade, L. L. Avaliação do uso de um polietileno de alta densidade e baixo peso molecular oxidado como agente de compatibilização em asfalto modificado com copolímero SBS. 2015. Dissertação (Mestrado) - Escola de Engenharia de São Carlos, Universidade de São Paulo, São Carlos, 2015.

O copolímero SBS é o aditivo mais empregado mundialmente na modificação de ligantes asfálticos, por melhorar diversas de suas características. Um dos principais problemas deste tipo de formulação é a separação de fases, que pode ser minimizada com a incorporação de aditivos. Um novo polietileno de alta densidade e baixo peso molecular oxidado (com denominação comercial TITAN 9686) foi utilizado nesta pesquisa, com o objetivo de testar a hipótese de que a adição de proporções adequadas deste aditivo possa melhorar as características reológicas do asfalto+SBS. O experimento laboratorial foi delineado com base na técnica de experimentos com misturas, englobando um total de nove formulações compostas com asfalto, SBS e TITAN. O teor de SBS variou entre 0 e $5 \%$ em peso e o de polietileno variou entre 0 e $2 \%$ em peso. Foi utilizado óleo aromático no teor de $4 \%$ em peso para todas as nove misturas. As misturas foram analisadas em três condições de envelhecimento: virgem, curto prazo (na estufa RTFO) e longo prazo (na estufa PAV). Foram realizados os seguintes ensaios reológicos: (i) de cisalhamento em regime oscilatório em diferentes condições de temperatura e frequência (para medida do módulo complexo e do ângulo de fase, usados na determinação do grau de desempenho, no cálculo dos parâmetros $\mathrm{G}^{*} / \operatorname{sen}(\delta)$ e $\mathrm{G}^{*} \cdot \operatorname{sen}(\delta)$ e na construção de curvas-mestre), (ii) de viscosidade Brookfield, (iii) de fluência e recuperação sob múltiplas tensões (para medida do percentual de recuperação e da compliância não-recuperável), (iv) de varredura de amplitude linear (para cálculo do parâmetro $a_{\mathrm{f}}$ e para ajuste do modelo de fadiga) e (v) de estabilidade à estocagem. Acerca das características escolhidas para mensurar a melhora ou piora das propriedades das misturas asfalto+SBS com a adição de TITAN, podem ser feitas as seguintes observações: (i) a estabilidade à estocagem é melhorada com a adição de TITAN, em particular no teores entre 1 e $2 \%$; (ii) a sensibilidade ao envelhecimento tanto a curto quanto a longo prazos diminui com a adição de TITAN; (iii) a adição de TITAN aumenta a resistência à deformação permanente, à luz dos parâmetros $\mathbf{J}_{\mathrm{nr}}$ e R e aumenta a sensibilidade dos ligantes asfálticos modificados com SBS a mudanças bruscas nos níveis de tensão aplicados; e (iv) a adição de TITAN contribui com o aumento da resistência à fadiga, à luz dos parâmetros $\mathrm{N}_{\mathrm{f}}$, a baixos níveis de deformação, e $\mathrm{a}_{\mathrm{f}}$, e a prejudica reduzindo o parâmetro $\mathrm{N}_{\mathrm{f}}$ a altos níveis de deformação e aumentando a temperatura crítica de fadiga ou o parâmetro $\mathrm{G}^{*} \cdot \operatorname{sen}(\delta)$. Tendo por base estas evidências, é possível concluir que a adição de TITAN, em linhas gerais, melhorou a estabilidade dos ligantes asfálticos modificados com até 5,0\% de SBS. Com base nas análises realizadas, é possível afirmar que teores da ordem de 1 a $2 \%$ de TITAN, para teores de SBS entre 3,0 e 5,0\%, são recomendáveis, à luz das propriedades, índices e parâmetros analisados neste trabalho. 
Palavras-chave: Ligante asfáltico modificado com SBS. Polietileno de alta densidade e baixo peso molecular oxidado. Estabilidade à estocagem. Ensaios reológicos. Curva-mestre. 
Verdade, L. L. Analysis of the use of an oxidized, high-density polyethylene with low molecular weight as a compatibilizing agent in asphalt binders modified with SBS copolymer. Thesis (Master of Transportation Engineering) - Sao Carlos School of Engineering, University of São Paulo, São Carlos, 2015.

The SBS copolymer is the most widely used additive in asphalt binder modification, since it enhances many of the properties of the original material. A critical problem that arises from this type of modification is phase separation, which can be minimized by adding other modifiers to the formulation. A new oxidized, high-density polyethylene with low molecular weight (commercial designation of "TITAN 9686") was used in the study with the purpose of verifying the hypothesis that the addition of suitable contents of this modifier can improve the rheological properties of the SBS-modified binder. The laboratory matrix of formulations was based on the experiments with mixtures, and nine types of materials were prepared with asphalt binder, SBS and TITAN. The SBS contents ranged from 0 to $5 \%$ by weight, whereas the polyethylene contents ranged from 0 to $2 \%$ by weight. These formulations also contained $4 \%$ of aromatic oil by weight. Three aging conditions were selected: unaged, short-term aged in the rolling thin-film oven (RTFO) and long-term aged in the pressurized aging vessel (PAV). The following tests were carried out: (i) dynamic oscillatory shear at different temperatures and frequencies of loading for the determination of the complex modulus, the phase angles and the master curves, as well as the performance grades and the numerical values of the parameters $G^{*} / \sin (\delta)$ and $G^{*} \cdot \operatorname{sen}(\delta)$; (ii) rotational viscosity; (iii) creep and recovery at multiple stress levels for the determination and the percent recovery and the nonrecoverable compliance; (iv) linear amplitude sweep, in order to calculate the parameter $\mathrm{a}_{\mathrm{f}}$ and fit the fatigue model to the data; and (v) storage stability. With respect to the characteristics used in the evaluation of the properties of the AC+SBS mixtures after the addition of TITAN, the following observations can be made: (i) storage stability is improved when TITAN is added to the formulation, especially at contents ranging from 1 to $2 \%$; (ii) the sensitivity to the short-term and long-term aging processes decreased with the incorporation of TITAN; (iii) the changes in the $\mathrm{R}$ and the $\mathrm{J}_{\mathrm{nr}}$ values indicate that the addition of TITAN makes the asphalt binder more resistant to rutting, and also increases the sensitivity of the SBS-modified binders to sudden increases in the stress level; and (iv) the presence of TITAN in the material leads to an increase in the fatigue resistance as based on the parameters $\mathrm{N}_{\mathrm{f}}$ and $\mathrm{a}_{\mathrm{f}}$ at low strain levels and the increases in the critical fatigue temperature and the parameter $\mathrm{G}^{*} . \operatorname{sen}(\delta)$. With reference to these evidences, it is possible to conclude that the addition of TITAN generally improves the storage stability of the SBS-modified binders with no more than $5 \%$ of copolymer by weight. Based on the results of the present study, it is possible to say that percentages between 1 and $2 \%$ of TITAN by weight are recommended for SBS contents between 3 and $5 \%$ by weight.

Keywords: SBS-modified asphalt binder, oxidized and high-density polyethylene with low molecular weight, storage stability, rheological tests, master curve. 



\section{LISTA DE TABELAS}

Tabela 2.1 - Propriedades convencionais de CAP + SBS (SENGOZ e ISIKYAKAR, 2008)

Tabela 2.2 - Viscosidade do ligante asfáltico puro e modificado antes e após o RTFOT (RODRIGUES, 2010)

Tabela 2.3 - Valores de temperatura de usinagem e compactação para as amostras de ligante asfáltico de base, LA + 4\% SBS e LA + 4\% SBS + 1\% LCC (RODRIGUES, 2010)

Tabela 2.4 - Efeito da adição de SBS e SBS + enxofre ao CAP de base (WEN et al., 2002)

Tabela 2.5 - Propriedades dos CAPs avaliados (FERNANDES e LOURENÇO, 2006) _66

Tabela 2.6 - Resultados de análise das amostras preparadas (FERNANDES e LOURENÇO, 2006)

Tabela 2.7 - Propriedades reológicas de CAP 20 e CAP 20 modificado (FERNANDES e LOURENÇO, 2006)

Tabela 2.8 - Formulações do ligante asfáltico e PG (DOMINGOS et al., 2012)

Tabela 2.9 - Temperaturas de usinagem, compactação e viscosidades Brookfield nas temperaturas de $135,143,150,163$ e $177^{\circ} \mathrm{C}$ para CAP 50/70, CAP+SBS e CAP+SBS+PPA (DOMINGOS et al., 2012)

Tabela 2.10 - Formulações dos ligantes asfálticos (DOMINGOS e FAXINA, 2013) _ 70

Tabela 2.11 - Resultados dos ensaios tradicionais dos ligantes asfálticos (DOMINGOS e FAXINA, 2013)

Tabela 2.12 - Níveis de tráfego adequados aos ligantes asfálticos (DOMINGOS e FAXINA, 2013)

Tabela 2.13 - Resultado de vida de fadiga (NUÑES 2013) 72

Tabela 2.14 - Viscosidade Brookfield a $135^{\circ} \mathrm{C}$ e ponto de amolecimento do topo e fundo de misturas de CAP + SBS + caulinita (OUYANG et al., 2005)

Tabela 2.15 - Propriedades físicas do CAP + SBS + argila (GALOOYAK et al., 2009) 74

Tabela 2.16 - Grau contínuo do CAP + SBS + argila (GALOOYAK et al., 2009) 75

Tabela 2.17 - Diferenças do ponto de amolecimento do topo e fundo do CAP + SBS + argila (GALOOYAK et al., 2009)

Tabela 2.18 - Penetração retida e aumento do ponto de amolecimento após envelhecimento a curto prazo para CAP + SBS + argila (GALOOYAK et al., 2009) _ 75

Tabela 3.1 - Proporção dos componentes e condições de processamento 79

Tabela 3.2 - Variabilidades máximas para $\mathrm{J}_{\mathrm{nr}}$ recomendadas pela ASTM D7405-10a 88 
Tabela 3.3 - Classificação dos ligantes asfálticos quanto ao valor de $\mathrm{J}_{\mathrm{nr}}$ de acordo com o critério proposto pelo FHWA (Tabela 3 da norma AASHTO M320)

Tabela 3.4 - Valores recomendados para o percentual de recuperação de acordo com o critério proposto pelo FHWA 90

Tabela 3.5 - Propriedades convencionais do CAP 50/70 Replan 96

Tabela 3.6 - Propriedades do ensaio MSCR para o CAP 50/70 Replan - amostras envelhecidas no RTFOT

Tabela 3.7 - Parâmetros do ensaio LAS para o CAP 50/70 Replan - amostras envelhecidas no PAV 96

Tabela 4.1 - Resultados de viscosidade na condição virgem em mPa.s 106

Tabela 4.2 - Resultados de viscosidade na condição envelhecida a curto prazo em mPa.s

Tabela 4.3 - Resultados de incremento de viscosidade 108

Tabela 4.4 - Resultados do grau contínuo, do parâmetro $a_{\mathrm{f}}$ e $\mathrm{N}_{\mathrm{f}}$ a $2 \%$ e $30 \%$ 109

Tabela 4.5 - Resultados de $\mathrm{J}_{\mathrm{nr}}$ a 100 e a $3.200 \mathrm{~Pa}, \mathrm{~J}_{\mathrm{nr}, \text { diff, }} \mathrm{R}$ a 100 e a $3.200 \mathrm{~Pa}$ após envelhecimento a curto prazo a $52^{\circ} \mathrm{C}$

Tabela 4.6 - Resultados de $\mathrm{J}_{\mathrm{nr}}$ a 100 e a $3.200 \mathrm{~Pa}, \mathrm{~J}_{\mathrm{nr}, \text { diff, }} \mathrm{R}$ a 100 e a $3.200 \mathrm{~Pa}$ após envelhecimento a curto prazo a $58^{\circ} \mathrm{C}$

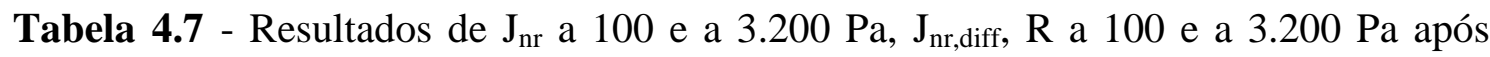
envelhecimento a curto prazo a $64^{\circ} \mathrm{C}$

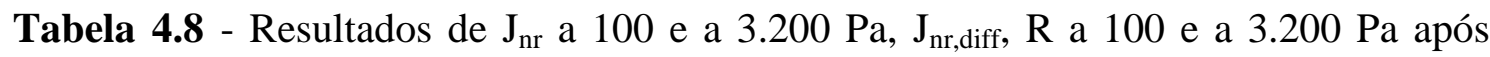
envelhecimento a curto prazo a $70^{\circ} \mathrm{C}$

Tabela 4.9 - Resultados das temperaturas de usinagem e compactação e $G^{*} \cdot \operatorname{sen}(\delta)$

Tabela 4.10 - Modelos de regressão e $\mathrm{R}^{2}$ para as propriedades descritas na subseção 4.3117

Tabela 4.11 - Variação média da viscosidade Brookfield na condição virgem para $1 \%$ de aumento nas proporções de SBS e TITAN, nas temperaturas de ensaio

Tabela 4.12 - Variação média da viscosidade Brookfield na condição envelhecida a curto prazo para $1 \%$ de aumento nas proporções de SBS e TITAN, nas temperaturas de ensaio

Tabela 4.13 - Variação média do incremento de viscosidade para $1 \%$ de aumento nas proporções de SBS e TITAN, nas temperaturas de ensaio

Tabela 4.14 - Variação média da compliância não-recuperável $\left(\mathrm{J}_{\mathrm{nr}}\right)$ a $3.200 \mathrm{~Pa}$ das misturas envelhecidas a curto prazo para $1 \%$ de aumento nas proporções de SBS e TITAN, nas temperaturas de ensaio 
Tabela 4.15 - Variação média do percentual de recuperação (R) a 3.200 Pa das misturas envelhecidas a curto prazo para $1 \%$ de aumento nas proporções de SBS e TITAN, nas temperaturas de ensaio

Tabela 4.16 - Variação média do $\mathrm{J}_{\text {nr,diff }}$ das misturas envelhecidas a curto prazo para $1 \%$ de aumento nas proporções de SBS e TITAN, nas temperaturas de ensaio

Tabela 4.17 - Variação média da vida de fadiga das misturas envelhecidas a longo prazo para $1 \%$ de aumento nas proporções de SBS e TITAN, nas deformações de 2 e $30 \%$ a $25^{\circ} \mathrm{C}$

Tabela 4.18 - Variação média da compliância não-recuperável $\left(\mathrm{J}_{\mathrm{nr}}\right)$ a $100 \mathrm{~Pa}$ das misturas envelhecidas a curto prazo para $1 \%$ de aumento nas proporções de SBS e TITAN, nas temperaturas de ensaio

Tabela 4.19 - Variação média do percentual de recuperação (R) a $100 \mathrm{~Pa}$ das misturas envelhecidas a curto prazo para $1 \%$ de aumento nas proporções de SBS e TITAN, nas temperaturas de ensaio

Tabela 4.20 - Variação média da temperatura em que $\mathrm{G}^{*} \cdot \operatorname{sen}(\delta)$ atinge 5 e $6 \mathrm{MPa}$, a 10 $\mathrm{rad} / \mathrm{s}$

Tabela 4.21 - Conclusões dos efeitos dos componentes

Tabela 5.1 - Valores de G*/sen $(\delta)$ usados no cálculo do PG das misturas 145

Tabela 5.2 - Viscosidades rotacionais em Pa.s dos ligantes asfálticos na condição virgem

Tabela 5.3 - Viscosidades rotacionais em Pa.s dos ligantes asfálticos na condição envelhecida a curto prazo

Tabela 5.4 - Incremento das viscosidades rotacionais dos ligantes asfálticos $\left(\mathrm{R}_{\mathrm{v}}\right)$ 152

Tabela 5.5 - Temperaturas de usinagem e compactação dos ligantes asfálticos 154

Tabela 5.6 - Perda de massa média das misturas 155

Tabela 5.7 - Percentuais de recuperação (R) das misturas 156

Tabela 5.8 - Compliâncias não-recuperáveis $\left(\mathrm{J}_{\mathrm{nr}}\right)$ das misturas 157

Tabela 5.9 - $\mathrm{J}_{\text {nr,diff }}$ das misturas 157

Tabela 5.10 - Classificação das misturas quanto aos níveis de tráfego de acordo com o critério proposto pelo FHWA (AASHTO M320) para diferentes temperaturas do pavimento

Tabela 5.11 - Comprimento da trinca na ruptura a $a_{\mathrm{f}}$ para as misturas após RTFOT+PAV a $25^{\circ} \mathrm{C}$

Tabela 5.12 - Parâmetros A e B do modelo de fadiga das misturas e vida de fadiga $\left(\mathrm{N}_{\mathrm{f}}\right)$ em diversos níveis de deformações $(\%)$ após RTFOT+PAV a $25^{\circ} \mathrm{C}$ 
Tabela 5.13 - $\mathrm{G}^{*} \cdot \operatorname{sen}(\delta)$ na condição envelhecida a longo prazo para várias temperaturas

Tabela 5.14 - Valores de módulo complexo do ligante asfáltico de base e da mistura 100-0-0 nas três condições de envelhecimento

Tabela 5.15 - Valores de ângulo de fase do ligante asfáltico de base e da mistura 100-00 nas três condições de envelhecimento

Tabela 5.16 - Relações do módulo complexo entre a mistura 100-0-0 e o ligante asfáltico de base

Tabela 5.17 - Relações do ângulo de fase entre a mistura 100-0-0 e o ligante asfáltico de base

Tabela 5.18 - Índices de envelhecimento com base em G* para o ligante asfáltico de base

Tabela 5.19 - Índices de envelhecimento com base em G* para a mistura 100-0-0 176

Tabela 5.20 - Índices de envelhecimento com base em G* para a mistura 99-0-1 177

Tabela 5.21 - Índices de envelhecimento com base em G* para a mistura 98-0-2 177

Tabela 5.22 - Índices de envelhecimento com base em G* para a mistura 97,5-2,5-0 _ 178

Tabela 5.23 - Índices de envelhecimento com base em $\mathrm{G}^{*}$ para a mistura 96,5-2,5-1 _ 178

Tabela 5.24 - Índices de envelhecimento com base em $\mathrm{G}^{*}$ para a mistura 95,5-2,5-2 _ 179

Tabela 5.25 - Índices de envelhecimento com base em $\mathrm{G}^{*}$ para a mistura 95-5-0 179

Tabela 5.26 - Índices de envelhecimento com base em G* para a mistura 94-5-1 180

Tabela 5.27 - Índices de envelhecimento com base em G* para a mistura 93-5-2 180

Tabela 5.28 - Índices de envelhecimento médios com base em $\mathrm{G}^{*}$ para as frequências entre 1E-5 a 1E+5 das misturas e do ligante asfáltico de base

Tabela 5.29 - Variações do ângulo de fase $(\delta)$ devidas ao envelhecimento para o ligante asfáltico de base

Tabela 5.30 - Variações do ângulo de fase $(\delta)$ devidas ao envelhecimento para a mistura 100-0-0

Tabela 5.31 - Variações do ângulo de fase $(\delta)$ devidas ao envelhecimento para a mistura 99-0-1

Tabela 5.32 - Variações do ângulo de fase $(\delta)$ devidas ao envelhecimento para a mistura 98-0-2

Tabela 5.33 - Variações do ângulo de fase $(\delta)$ devidas ao envelhecimento para a mistura 97,5-2,5-0 
Tabela 5.34 - Variações do ângulo de fase $(\delta)$ devidas ao envelhecimento para a mistura 96,5-2,5-1

Tabela 5.35 - Variações do ângulo de fase $(\delta)$ devidas ao envelhecimento para a mistura 95,5-2,5-2

Tabela 5.36 - Variações do ângulo de fase $(\delta)$ devidas ao envelhecimento para a mistura 95-5-0

Tabela 5.37 - Variações do ângulo de fase $(\delta)$ devidas ao envelhecimento para a mistura 94-5-1

Tabela 5.38 - Variações do ângulo de fase $(\delta)$ devidas ao envelhecimento para a mistura 93-5-2

Tabela 5.39 - Variações médias do ângulo de fase, nas frequências entre 1E-5 a 1E+5 em função dos níveis de envelhecimento

Tabela 5.40 - Relação dos valores de $G^{*}$ das misturas com a mistura 100-0-0, na condição virgem $\left(\mathrm{G}^{*}{ }_{\text {misturas }} / \mathrm{G}^{*}{ }_{100-0-0}\right)$

Tabela 5.41 - Relação dos valores de $G^{*}$ das misturas com a mistura 100-0-0, na condição envelhecida a curto prazo $\left(\mathrm{G}^{*}{ }_{\text {misturas }} / \mathrm{G}^{*}{ }_{100-0-0}\right)$

Tabela 5.42 - Relação dos valores de $G^{*}$ das misturas com a mistura 100-0-0, na condição envelhecida a longo prazo $\left(\mathrm{G}^{*}{ }_{\text {misturas }} / \mathrm{G}^{*}{ }_{100-0-0}\right)$ 202

Tabela 5.43 - Índices de envelhecimento dos valores de $\mathrm{G}^{*}$ das misturas com a mistura 100-0-0

Tabela 5.44 - Diferença dos valores de $\delta$ das misturas com a mistura 100-0-0, na condição virgem $\left(\delta_{\text {misturas }}-\delta_{100-0-0}\right)$

Tabela 5.45 - Diferença dos valores de $\delta$ das misturas com a mistura 100-0-0, na condição envelhecida a curto prazo $\left(\delta_{\text {misturas }} \delta_{100-0-0}\right)$

Tabela 5.46 - Diferença dos valores de $\delta$ das misturas com a mistura 100-0-0, na condição envelhecida a longo $\operatorname{prazo}\left(\delta_{\text {misturas }} \delta_{100-0-0}\right)$

Tabela 5.47 - Índices de envelhecimento de $\delta$ das misturas com a mistura 100-0-0 219

Tabela 5.48 - Relações entre valores de G* para a mistura 100-0-0 234

Tabela 5.49 - Relações entre valores de G* para a mistura 99-0-1 234

Tabela 5.50 - Relações entre valores de G* para a mistura 98-0-2 235

Tabela 5.51 - Relações entre valores de $\mathrm{G}^{*}$ para a mistura 97,5-2,5-0 235

Tabela 5.52 - Relações entre valores de $G^{*}$ para a mistura 96,5-2,5-1 236

Tabela 5.53 - Relações entre valores de $\mathrm{G}^{*}$ para a mistura 95,5-2,5-2 236

Tabela 5.54 - Relações entre valores de G* para a mistura 95-5-0 237 
Tabela 5.56 - Relações entre valores de G* para a mistura 93-5-2

Tabela 5.57 - Resumo das relações topo/fundo entre valores de $\mathrm{G}^{*}$ das misturas no ensaio de estabilidade à estocagem

Tabela 5.58 - Média das relações topo/fundo, fundo/original, topo/original entre valores de $G^{*}$ no ensaio de estabilidade à estocagem

Tabela 5.59 - Valores de $\mathrm{G}^{*}(\mathrm{~Pa}), \delta\left(^{\circ}\right), \mathrm{G}^{*} / \operatorname{sen}(\delta)(\mathrm{kPa})$ e $\mathrm{G}^{*} \operatorname{sen}(\delta)$ nas condições virgem, envelhecida a curto prazo e envelhecida a longo prazo, para o CAP Replan $50 / 70$

Tabela 5.60 - Valores de $\mathrm{G}^{*}(\mathrm{~Pa}), \delta\left({ }^{\circ}\right), \mathrm{G}^{*} / \operatorname{sen}(\delta)(\mathrm{kPa})$ e $\mathrm{G}^{*} \operatorname{sen}(\delta)$ nas condições virgem, envelhecida a curto prazo e envelhecida a longo prazo para a mistura $100-0-0 \_250$

Tabela 5.61 - Relações entre propriedades e parâmetros das misturas 100-0-0 e CAP Replan 50/70 nas condições virgem, envelhecida a curto prazo e envelhecida a longo prazo

Tabela 5.62 - Relações RTFOT/virgem e PAV/virgem para G*, $\delta, G^{*} / \operatorname{sen}(\delta)$ e $\mathrm{G}^{*} \operatorname{sen}(\delta)$ do ligante asfáltico de base (Replan 50/70)

Tabela 5.63 - Relações RTFOT/virgem e PAV/virgem para $G^{*}, \delta, G^{*} / \operatorname{sen}(\delta)$ e $\mathrm{G}^{*} \operatorname{sen}(\delta)$ da mistura $100-0-0$

Tabela 5.64 - Relações RTFOT/virgem e PAV/virgem para G*, $\delta, G^{*} / \operatorname{sen}(\delta)$ e $\mathrm{G}^{*} \operatorname{sen}(\delta)$ da mistura 99-0-1

Tabela 5.65 - Relações RTFOT/virgem e PAV/virgem para $\mathrm{G}^{*}, \delta, \mathrm{G}^{*} / \mathrm{sen}(\delta)$ e $\mathrm{G}^{*} \operatorname{sen}(\delta)$ da mistura $98-0-2$

Tabela 5.66 - Relações RTFOT/virgem e PAV/virgem para $\mathrm{G}^{*}, \delta, \mathrm{G}^{*} / \mathrm{sen}(\delta)$ e $\mathrm{G}^{*} \operatorname{sen}(\delta)$ da mistura $97,5-2,5-0$

Tabela 5.67 - Relações RTFOT/virgem e PAV/virgem para $G^{*}, \delta, G^{*} / \operatorname{sen}(\delta)$ e $\mathrm{G}^{*} \operatorname{sen}(\delta)$ da mistura $96,5-2,5-1$

Tabela 5.68 - Relações RTFOT/virgem e PAV/virgem para G*, $\delta$, G*/sen $(\delta)$ e $\mathrm{G}^{*} \operatorname{sen}(\delta)$ da mistura 95,5-2,5-2

Tabela 5.69 - Relações RTFOT/virgem e PAV/virgem para $\mathrm{G}^{*}, \delta, \mathrm{G}^{*} / \mathrm{sen}(\delta)$ e $\mathrm{G}^{*} \operatorname{sen}(\delta)$ da mistura 95-5-0

Tabela 5.70 - Relações RTFOT/virgem e PAV/virgem para $\mathrm{G}^{*}, \delta, \mathrm{G}^{*} / \mathrm{sen}(\delta)$ e $\mathrm{G}^{*} \operatorname{sen}(\delta)$ da mistura 94-5-1

Tabela 5.71 - Relações RTFOT/virgem e PAV/virgem para G*, $\delta, G^{*} / \operatorname{sen}(\delta)$ e $\mathrm{G}^{*} \operatorname{sen}(\delta)$ da mistura 93-5-2

Tabela 5.72 - Resumo das relações médias para $\mathrm{G}^{*}, \delta, \mathrm{G}^{*} / \operatorname{sen}(\delta)$ e $\mathrm{G}^{*} \operatorname{sen}(\delta)$ das misturas e do ligante asfáltico de base 
Tabela 5.73 - Relações de $\mathrm{G}^{*}$ das misturas com SBS e TITAN com a mistura 100-0-0 na condição virgem

Tabela 5.74 - Relações de $\mathrm{G}^{*}$ das misturas com SBS e TITAN com a mistura 100-0-0 na condição envelhecida a curto prazo

Tabela 5.75 - Relações de G* das misturas com SBS e TITAN com a mistura 100-0-0 na condição envelhecida a longo prazo

Tabela 5.76 - Diferenças entre valores de delta das misturas com SBS e TITAN com a mistura 100-0-0 na condição virgem

Tabela 5.77 - Diferenças entre valores de delta das misturas com SBS e TITAN com a mistura 100-0-0 na condição envelhecida a curto prazo

Tabela 5.78 - Diferenças entre valores de delta das misturas com SBS e TITAN com a mistura 100-0-0 na condição envelhecida a longo prazo

Tabela 5.79 - Relações de G*/sen $(\delta)$ das misturas com SBS e TITAN com a mistura 100-0-0 para na condição virgem

Tabela 5.80 - Relações de $G^{*} / \operatorname{sen}(\delta)$ das misturas com SBS e TITAN com a mistura 100-0-0 para na condição envelhecida a curto prazo

Tabela 5.81 - Relações de $\mathrm{G}^{*} / \operatorname{sen}(\delta)$ das misturas com SBS e TITAN com a mistura 100-0-0 para na condição envelhecida a longo prazo

Tabela 5.82 - Relações de $\mathrm{G}^{*} \cdot \operatorname{sen}(\delta)$ das misturas com SBS e TITAN com a mistura 100-0-0 na condição virgem

Tabela 5.83 - Relações de $G^{*}$.sen $(\delta)$ das misturas com SBS e TITAN com a mistura 100-0-0 na condição envelhecida a curto prazo

Tabela 5.84 - Relações de $G^{*}$.sen $(\delta)$ das misturas com SBS e TITAN com a mistura 100-0-0 na condição envelhecida a longo prazo 264

Tabela 5.85 - Ordenamento das misturas 268

Tabela 5.86 - Posições médias das misturas por requisitos de interesse 277

Tabela 5.87 - Resumo das misturas mais e menos adequadas segundo as categorias de interesse

Tabela 5.88 - Alteração da posição média em função da presença de modificadores 288

Tabela 6.1 - Resumo dos efeitos dos componentes 291

Tabela A.1 - Pontos referentes a cada mistura 315 


\section{LISTA DE FIGURAS}

Figura 2.1 - Aparência do SBS (fonte: próprio autor) ___ 48

Figura 2.2 - Copolímero SBS em bloco (RODRIGUES, 2010) 48

Figura 2.3 - Valores de $\mathrm{G} * / \operatorname{sen}(\delta)$ para ligantes asfálticos com teores variados de SBS (LU e ISACSSON, 1997) 51

Figura 2.4 - Imagens de amostras de CAP+SBS (SENGOZ e ISIKYAKAR, 2008) 53

Figura 2.5 - Viscosidade cinemática com diferentes tipos de ligante asfáltico de base com diferentes concentrações de SBS (LU e ISACSSON, 1997)

Figura 2.6 - Gráfico de viscosidade versus teor de SBS para as temperaturas de 135, 150 e $175^{\circ} \mathrm{C}$ (LUCENA et al., 2002)

Figura 2.7 - Ensaio BBR com resultados de módulo de rigidez ( $\mathrm{S}=300 \mathrm{Mpa}$ ) para três tipos de ligantes asfálticos com 4 teores de SBS (LU et al. 1998) 56

Figura 2.8 - Parte do topo (esquerda) e parte do fundo (direita) após o ensaio de estabilidade à estocagem de CAP + 4\% SBS (BECKER et al., 2003)

Figura 2.9 - $\mathrm{G}^{*}$ e $\delta$ em função da temperatura para as amostras de CAP, CAP + 4,5\%

SBS e CAP + 4,5\% SBS + 1,5\% óleo na condição virgem (BRINGEL et al., 2006) 60

Figura 2.10 - Curvas de $\mathrm{G}^{*} / \operatorname{sen}(\delta)$ em função da temperatura para as amostras de CAP, $\mathrm{CAP}+4,5 \% \mathrm{SBS}$ e CAP $+4,5 \% \mathrm{SBS}+1,5 \%$ óleo na condição virgem (BRINGEL et al., 2006)

Figura 2.11 - Constituintes do líquido da castanha do caju (MORAES, 2007) 62

Figura 2.12 - Efeito da adição de enxofre ao CAP+SBS sobre o ponto de amolecimento após o ensaio de estabilidade à estocagem. (a) sem enxofre, (b) com enxofre (WEN et al., 2002)

Figura 3.1 - Espaço amostral com restrições e misturas escolhidas 79

Figura 3.2 - Misturador de alto cisalhamento (esquerda); misturador de baixo cisalhamento (direita) (FAXINA, 2006)

Figura 3.3 - PAV (esquerda); RTFOT (direita) (FAXINA, 2006) 81

Figura 3.4 - Viscosímetro Brookfield DV II+Pro (esquerda); reômetro de cisalhamento dinâmico (DSR) (direita) (FAXINA, 2006)

Figura 3.5 - Determinação das temperaturas de usinagem e compactação. 86

Figura 3.6 - Deformações de interesse em um ciclo de fluência e recuperação do ensaio MSCR 88

Figura 3.7 - Relação entre as compliâncias não-recuperáveis e os percentuais de recuperação a 3.200 Pa (DOMINGOS, 2011) 
Figura 3.8 - Modelo de fadiga (JOHNSON 2010)

Figura 3.9 - (a) Incremento da deformação (em degraus) no ensaio LAS (JOHNSON, 2010) e (b) incremento linear de deformação no ensaio LAS modificado (HINTZ, 2012) 94

Figura 4.1 - Superfície de resposta 103

Figura 4.2 - Gráfico de efeitos dos componentes 104

Figura 5.1 - $\mathrm{G}^{*} / \operatorname{sen}(\delta)$ versus temperatura para as amostras virgens 145

Figura 5.2 - Viscosidades rotacionais dos ligantes asfálticos na condição virgem 148

Figura 5.3 - Viscosidades rotacionais dos ligantes asfálticos na condição envelhecida a curto prazo 151

Figura 5.4 - Modelos de vida de fadiga $\left(\mathrm{N}_{\mathrm{f}}\right)$ para as 9 amostras 165

Figura 5.5 - Vida de fadiga $\left(\mathrm{N}_{\mathrm{f}}\right)$ para as misturas 100-0-0, 99-0-1 e 98-0-2 166

Figura 5.6 - Vida de fadiga $\left(\mathrm{N}_{\mathrm{f}}\right)$ para as misturas 97,5-2,5-0, 96,5-2,5-1 e 95,5-2,5-2 _ 166

Figura 5.7 - Vida de fadiga $\left(\mathrm{N}_{\mathrm{f}}\right)$ para as misturas 95-5-0, 94-5-1 e 93-5-2 167

Figura 5.8 - Curvas-mestre para G* para a mistura 100-0-0 e o ligante asfáltico de base 171

Figura 5.9 - Curvas-mestre para $\mathrm{G}^{*}$ para a mistura 100-0-0 e o ligante asfáltico de base 172

Figura 5.10 - Curvas-mestre para $\mathrm{G}^{*}$ para a mistura 100-0-0 e o ligante asfáltico de base

Figura 5.11 - Curvas-mestre para $\delta$ para a mistura 100-0-0 e o ligante asfáltico de base_173

Figura 5.12 - Curvas-mestre para $\delta$ para a mistura 100-0-0 e o ligante asfáltico de base _173

Figura 5.13 - Curvas-mestre para $\delta$ para a mistura 100-0-0 e o ligante asfáltico de base_174

Figura 5.14 - Curvas-mestre de $G^{*}$ para o ligante asfáltico de base nas condições virgem, envelhecida a curto prazo e envelhecida a longo prazo 181

Figura 5.15 - Curvas-mestre de $\mathrm{G}^{*}$ para a mistura de 100-0-0 nas condições virgem, envelhecida a curto prazo e envelhecida a longo prazo 182

Figura 5.16 - Curvas-mestre de G* para a mistura de 99-0-1 nas condições virgem, envelhecida a curto prazo e envelhecida a longo prazo

Figura 5.17 - Curvas-mestre de $\mathrm{G}^{*}$ para a mistura de 98-0-2 nas condições virgem, envelhecida a curto prazo e envelhecida a longo prazo

Figura 5.18 - Curvas-mestre de $\mathrm{G}^{*}$ para a mistura de 97,5-2,5-0 nas condições virgem, envelhecida a curto prazo e envelhecida a longo prazo

Figura 5.19 - Curvas-mestre de $\mathrm{G}^{*}$ para a mistura de 96,5-2,5-1 nas condições virgem, envelhecida a curto prazo e envelhecida a longo prazo 
Figura 5.20 - Curvas-mestre de $G^{*}$ para a mistura de 95,5-2,5-2 nas condições virgem, envelhecida a curto prazo e envelhecida a longo prazo

Figura 5.21 - Curvas-mestre de $\mathrm{G}^{*}$ para a mistura de 95-5-0 nas condições virgem, envelhecida a curto prazo e envelhecida a longo prazo

Figura 5.22 - Curvas-mestre de $G^{*}$ para a mistura de 94-5-1 nas condições virgem, envelhecida a curto prazo e envelhecida a longo prazo

Figura 5.23 - Curvas-mestre de $\mathrm{G}^{*}$ para a mistura de 93-5-2 nas condições virgem, envelhecida a curto prazo e envelhecida a longo prazo

Figura 5.24 - Índices de envelhecimento médios com base em $\mathrm{G}^{*}$

Figura 5.25 - Curvas-mestre de $\delta$ para o ligante asfáltico de base para as condições virgem, envelhecida a curto prazo e envelhecida a longo prazo

Figura 5.26 - Curvas-mestre de $\delta$ para a mistura de 100-0-0 para as condições virgem, envelhecida a curto prazo e envelhecida a longo prazo

Figura 5.27 - Curvas-mestre de $\delta$ para a mistura de 99-0-1 para as condições virgem, envelhecida a curto prazo e envelhecida a longo prazo

Figura 5.28 - Curvas-mestre de $\delta$ para a mistura de 98-0-2 para as condições virgem, envelhecida a curto prazo e envelhecida a longo prazo

Figura 5.29 - Curvas-mestre de $\delta$ para a mistura de 97,5-2,5-0 para as condições virgem, envelhecida a curto prazo e envelhecida a longo prazo

Figura 5.30 - Curvas-mestre de $\delta$ para a mistura de 96,5-2,5-1 para as condições virgem, envelhecida a curto prazo e envelhecida a longo prazo

Figura 5.31 - Curvas-mestre de $\delta$ para a mistura de 95,5-2,5-2 para as condições virgem, envelhecida a curto prazo e envelhecida a longo prazo

Figura 5.32 - Curvas-mestre de $\delta$ para a mistura de 95-5-0 para as condições virgem, envelhecida a curto prazo e envelhecida a longo prazo

Figura 5.33 - Curvas-mestre de $\delta$ para a mistura de 94-5-1 para as condições virgem, envelhecida a curto prazo e envelhecida a longo prazo

Figura 5.34 - Curvas-mestre de $\delta$ para a mistura de 93-5-2 para as condições virgem, envelhecida a curto prazo e envelhecida a longo prazo

Figura 5.35 - Curvas-mestre para $\mathrm{G}^{*}$ na condição virgem para o ligante asfáltico de base e as misturas 100-0-0 e 99-0-1

Figura 5.36 - Curvas-mestre para $\mathrm{G}^{*}$ na condição virgem para o ligante asfáltico de base e as misturas 100-0-0 e 98-0-2

Figura 5.37 - Curvas-mestre para $G^{*}$ na condição virgem para o ligante asfáltico de base e as misturas 100-0-0 e 97,5-2,5-0 
Figura 5.38 - Curvas-mestre para $G^{*}$ na condição virgem para o ligante asfáltico de base e as misturas 100-0-0 e 96,5-2,5-1

Figura 5.39 - Curvas-mestre para $G^{*}$ na condição virgem para o ligante asfáltico de base e as misturas 100-0-0 e 95,5-2,5-2

Figura 5.40 - Curvas-mestre para $G^{*}$ na condição virgem para o ligante asfáltico de base e as misturas 100-0-0 e 95-5-0

Figura 5.41 - Curvas-mestre para $G^{*}$ na condição virgem para o ligante asfáltico de base e as misturas 100-0-0 e 94-5-1

Figura 5.42 - Curvas-mestre para $G^{*}$ na condição virgem para o ligante asfáltico de base e as misturas 100-0-0 e 93-5-2

Figura 5.43 - Curvas-mestre para $G^{*}$ na condição envelhecida a curto prazo para o ligante asfáltico de base e as misturas 100-0-0 e 99-0-1

Figura 5.44 - Curvas-mestre para $G^{*}$ na condição envelhecida a curto prazo para o ligante asfáltico de base e as misturas 100-0-0 e 98-0-2

Figura 5.45 - Curvas-mestre para $G^{*}$ na condição envelhecida a curto prazo para o ligante asfáltico de base e as misturas 100-0-0 e 97,5-2,5-0

Figura 5.46 - Curvas-mestre para $G^{*}$ na condição envelhecida a curto prazo para o ligante asfáltico de base e as misturas 100-0-0 e 96,5-2,5-1

Figura 5.47 - Curvas-mestre para $\mathrm{G}^{*}$ na condição envelhecida a curto prazo para o ligante asfáltico de base e as misturas 100-0-0 e 95,5-2,5-2 209

Figura 5.48 - Curvas-mestre para $G^{*}$ na condição envelhecida a curto prazo para o ligante asfáltico de base e as misturas 100-0-0 e 95-5-0

Figura 5.49 - Curvas-mestre para $G^{*}$ na condição envelhecida a curto prazo para o ligante asfáltico de base e as misturas 100-0-0 e 94-5-1

Figura 5.50 - Curvas-mestre para $G^{*}$ na condição envelhecida a curto prazo para o ligante asfáltico de base e as misturas 100-0-0 e 93-5-2

Figura 5.51 - Curvas-mestre para $G^{*}$ na condição envelhecida a longo prazo para o ligante asfáltico de base e as misturas 100-0-0 e 99-0-1

Figura 5.52 - Curvas-mestre para $G^{*}$ na condição envelhecida a longo prazo para o ligante asfáltico de base e as misturas 100-0-0 e 98-0-2

Figura 5.53 - Curvas-mestre para $\mathrm{G}^{*}$ na condição envelhecida a longo prazo para o ligante asfáltico de base e as misturas 100-0-0 e 97,5-2,5-0

Figura 5.54 - Curvas-mestre para $G^{*}$ na condição envelhecida a longo prazo para o ligante asfáltico de base e as misturas 100-0-0 e 96,5-2,5-1

Figura 5.55 - Curvas-mestre para $G^{*}$ na condição envelhecida a longo prazo para o ligante asfáltico de base e as misturas 100-0-0 e 95,5-2,5-2 
Figura 5.56 - Curvas-mestre para $G^{*}$ na condição envelhecida a longo prazo para o ligante asfáltico de base e as misturas 100-0-0 e 95-5-0

Figura 5.57 - Curvas-mestre para $\mathrm{G}^{*}$ na condição envelhecida a longo prazo para o ligante asfáltico de base e as misturas 100-0-0 e 94-5-1

Figura 5.58 - Curvas-mestre para $G^{*}$ na condição envelhecida a longo prazo para o ligante asfáltico de base e as misturas 100-0-0 e 93-5-2

Figura 5.59 - Curvas-mestre para $\delta$ na condição virgem para o ligante asfáltico de base e as misturas 100-0-0 e 99-0-1

Figura 5.60 - Curvas-mestre para $\delta$ na condição virgem para o ligante asfáltico de base e as misturas 100-0-0 e 98-0-2

Figura 5.61 - Curvas-mestre para $\delta$ na condição virgem para o ligante asfáltico de base e as misturas 100-0-0 e 97,5-2,5-0

Figura 5.62 - Curvas-mestre para $\delta$ na condição virgem para o ligante asfáltico de base e as misturas 100-0-0 e 96,5-2,5-1

Figura 5.63 - Curvas-mestre para $\delta$ na condição virgem para o ligante asfáltico de base e as misturas 100-0-0 e 95,5-2,5-2

Figura 5.64 - Curvas-mestre para $\delta$ na condição virgem para o ligante asfáltico de base e as misturas 100-0-0 e 95-5-0

Figura 5.65 - Curvas-mestre para $\delta$ na condição virgem para o ligante asfáltico de base e as misturas 100-0-0 e 94-5-1

Figura 5.66 - Curvas-mestre para $\delta$ na condição envelhecida a curto prazo para o ligante asfáltico de base e as misturas 100-0-0 e 99-0-1

Figura 5.67 - Curvas-mestre para $\delta$ na condição envelhecida a curto prazo para o ligante asfáltico de base e as misturas 100-0-0 e 98-0-2

Figura 5.68 - Curvas-mestre para $\delta$ na condição envelhecida a curto prazo para o ligante asfáltico de base e as misturas 100-0-0 e 97,5-2,5-0

Figura 5.69 - Curvas-mestre para $\delta$ na condição envelhecida a curto prazo para o ligante asfáltico de base e as misturas 100-0-0 e 96,5-2,5-1

Figura 5.70 - Curvas-mestre para $\delta$ na condição envelhecida a curto prazo para o ligante asfáltico de base e as misturas 100-0-0 e 95,5-2,5-2

Figura 5.71 - Curvas-mestre para $\delta$ na condição envelhecida a curto prazo para o ligante asfáltico de base e as misturas 100-0-0 e 95-5-0

Figura 5.72 - Curvas-mestre para $\delta$ na condição envelhecida a curto prazo para o ligante asfáltico de base e as misturas 100-0-0 e 94-5-1

Figura 5.73 - Curvas-mestre para $\delta$ na condição envelhecida a curto prazo para o ligante asfáltico de base e as misturas 100-0-0 e 93-5-2 
Figura 5.74 - Curvas-mestre para $\delta$ na condição envelhecida a longo prazo para o ligante asfáltico de base e as misturas 100-0-0 e 99-0-1

Figura 5.75 - Curvas-mestre para $\delta$ na condição envelhecida a longo prazo para o ligante asfáltico de base e as misturas 100-0-0 e 98-0-2

Figura 5.76 - Curvas-mestre para $\delta$ na condição envelhecida a longo prazo para o ligante asfáltico de base e as misturas 100-0-0 e 97,5-2,5-0

Figura 5.77 - Curvas-mestre para $\delta$ na condição envelhecida a longo prazo para o ligante asfáltico de base e as misturas 100-0-0 e 96,5-2,5-1

Figura 5.78 - Curvas-mestre para $\delta$ na condição envelhecida a longo prazo para o ligante asfáltico de base e as misturas 100-0-0 e 95,5-2,5-2

Figura 5.79 - Curvas-mestre para $\delta$ na condição envelhecida a longo prazo para o ligante asfáltico de base e as misturas 100-0-0 e 95-5-0

Figura 5.80 - Curvas-mestre para $\delta$ na condição envelhecida a longo prazo para o ligante asfáltico de base e as misturas 100-0-0 e 94-5-1

Figura 5.81 - Curvas-mestre para $\delta$ na condição envelhecida a longo prazo para o ligante asfáltico de base e as misturas 100-0-0 e 93-5-2

Figura 5.82 - Curvas-mestre de $\mathrm{G}^{*}$ da mistura 100-0-0 239

Figura 5.83 - Curvas-mestre de $\mathrm{G}^{*}$ da mistura 99-0-1 240

Figura 5.84 - Curvas-mestre de $\mathrm{G}^{*}$ da mistura 98-0-2 240

Figura 5.85 - Curvas-mestre de $G^{*}$ da mistura 97,5-2,5-0 241

Figura 5.86 - Curvas-mestre de $G^{*}$ da mistura 96,5-2,5-1 241

Figura 5.87 - Curvas-mestre de $\mathrm{G}^{*}$ da mistura 95,5-2,5-2 242

Figura 5.88 - Curvas-mestre de $\mathrm{G}^{*}$ da mistura 95-5-0 242

Figura 5.89 - Curvas-mestre de $G^{*}$ da mistura 94-5-1 243

Figura 5.90 - Curvas-mestre de $\mathrm{G}^{*}$ da mistura 93-5-2 243

Figura 5.91 - Curvas-mestre de $\delta$ da mistura 100-0-0 245

Figura 5.92 - Curvas-mestre de $\delta$ da mistura 99-0-1 245

Figura 5.93 - Curvas-mestre de $\delta$ da mistura 98-0-2 246

Figura 5.94 - Curvas-mestre de $\delta$ da mistura 97,5-2,5-0 246

Figura 5.95 - Curvas-mestre de $\delta$ da mistura 96,5-2,5-1 247

Figura 5.96 - Curvas-mestre de $\delta$ da mistura 95-5-0 247

Figura 5.97 - Curvas-mestre de $\delta$ da mistura 94-5-1 
Figura 5.98 - Posição média dos ordenamentos da sensibilidade ao envelhecimento a curto prazo

Figura 5.99 - Posição média dos ordenamentos da sensibilidade ao envelhecimento a longo prazo

Figura 5.100 - Posição média dos ordenamentos do grau de modificação 281

Figura 5.101 - Posição média dos ordenamentos das misturas com maior trabalhabilidade

Figura 5.102 - Posição média dos ordenamentos do grau contínuo 282

Figura 5.103 - Posição média dos ordenamentos da estabilidade à estocagem 283

Figura 5.104 - Posição média dos ordenamentos da contribuição à resistência a deformação permanente

Figura 5.105 - Posição média dos ordenamentos da contribuição à resistência a fadiga_284

Figura 6.1 - Restrições de norma no simplex para as propriedades e parâmetros avaliados na temperatura de $64^{\circ} \mathrm{C}$

Figura 6.2 - Restrições de norma no simplex para as propriedades e parâmetros avaliados na temperatura de $70^{\circ} \mathrm{C}$

Figura 6.3 - Ordenamento das colocações médias das misturas por requisites de interesse 300

Figura 6.4 - Posições médias das misturas por grupos com teores iguais de SBS 301

Figura 6.5 - Posições médias das misturas por grupos com teores iguais de TITAN _ 301

Figura A.1.1 - Análise de resíduos para o grau contínuo das misturas 316

Figura A.1.2 - Efeitos dos componentes para o grau contínuo das misturas 317

Figura A.1.3 - Superfície de resposta para o grau contínuo das misturas 317

Figura A.2.1 - Análise de resíduos para viscosidade na condição virgem a $135^{\circ} \mathrm{C}$ 318

Figura A.2.2 - Efeitos dos componentes para viscosidade na condição virgem a $135^{\circ} \mathrm{C} \_319$

Figura A.2.3 - Superfície de resposta para viscosidade na condição virgem a $135^{\circ} \mathrm{C}$ 319

Figura A.3.1 - Análise de resíduos para viscosidade na condição virgem a $143^{\circ} \mathrm{C}$ 320

Figura A.3.2 - Efeitos dos componentes para viscosidade na condição virgem a $143^{\circ} \mathrm{C} \_321$

Figura A.3.3 - Superfície de resposta para viscosidade na condição virgem a $143^{\circ} \mathrm{C}$ 321

Figura A.4.1 - Análise de resíduos para viscosidade na condição virgem a $150^{\circ} \mathrm{C}$ 322

Figura A.4.2 - Efeitos dos componentes para viscosidade na condição virgem a $150^{\circ} \mathrm{C} \_323$ 
Figura A.4.3 - Superfície de resposta para viscosidade na condição virgem a $150^{\circ} \mathrm{C} \_323$

Figura A.5.1 - Análise de resíduos para viscosidade na condição virgem a $163^{\circ} \mathrm{C}$ 324

Figura A.5.2 - Efeitos dos componentes para viscosidade na condição virgem a $163^{\circ} \mathrm{C} \_325$

Figura A.5.3 - Superfície de resposta para viscosidade na condição virgem a $163^{\circ} \mathrm{C} \_325$

Figura A.6.1 - Análise de resíduos para viscosidade na condição virgem a $177^{\circ} \mathrm{C}$ 326

Figura A.6.2 - Efeitos dos componentes para viscosidade na condição virgem a $177^{\circ} \mathrm{C} \_327$

Figura A.6.3 - Superfície de resposta para viscosidade na condição virgem a $177^{\circ} \mathrm{C}$ 327

Figura A.7.1 - Análise de resíduos para viscosidade na condição RTFOT a $135^{\circ} \mathrm{C}$ 328

Figura A.7.2 - Efeitos dos componentes para viscosidade na condição RTFOT a $135^{\circ} \mathrm{C} 329$

Figura A.7.3 - Superfície de resposta para viscosidade na condição RTFOT a $135^{\circ} \mathrm{C} \_329$

Figura A.8.1 - Análise de resíduos para viscosidade na condição RTFOT a $143^{\circ} \mathrm{C}$ 330

Figura A.8.2 - Efeitos dos componentes para viscosidade na condição RTFOT a $143^{\circ} \mathrm{C} 331$

Figura A.8.3 - Superfície de resposta para viscosidade na condição RTFOT a $143^{\circ} \mathrm{C} \_331$

Figura A.9.1 - Análise de resíduos para viscosidade na condição RTFOT a $150^{\circ} \mathrm{C}$ 332

Figura A.9.2 - Efeitos dos componentes para viscosidade na condição RTFOT a $150^{\circ} \mathrm{C} 333$ Figura A.9.3 - Superfície de resposta para viscosidade na condição RTFOT a $150^{\circ} \mathrm{C} \_333$

Figura A.10.1 - Análise de resíduos para viscosidade na condição RTFOT a $163^{\circ} \mathrm{C} \_334$

Figura A.10.2 - Efeitos dos componentes para viscosidade na condição RTFOT a $163^{\circ} \mathrm{C}$ 335

Figura A.10.3 - Superfície de resposta para viscosidade na condição RTFOT a $163^{\circ} \mathrm{C} \_335$

Figura A.11.1 - Análise de resíduos para viscosidade na condição RTFOT a $177^{\circ} \mathrm{C} \_336$

Figura A.11.2 - Efeitos dos componentes para viscosidade na condição RTFOT a $177^{\circ} \mathrm{C}$

Figura A.11.3 - Superfície de resposta para viscosidade na condição RTFOT a $177^{\circ} \mathrm{C} \_337$

Figura A.12.1 - Análise de resíduos para temperatura de compactação das misturas 338

Figura A.12.2 - Efeitos dos componentes para temperatura de compactação das misturas 339

Figura A.12.3 - Superfície de resposta para temperatura de compactação das misturas_339

Figura A.13.1 - Análise de resíduos para temperatura de usinagem das misturas 340

Figura A.13.2 - Efeitos dos componentes para temperatura de usinagem das misturas 341 
Figura A.13.3 - Superfície de resposta para temperatura de usinagem das misturas 341

Figura A.14.1 - Análise de resíduos para incremento de viscosidade a $135^{\circ} \mathrm{C}$ 342

Figura A.14.2 - Efeitos dos componentes para incremento de viscosidade a $135^{\circ} \mathrm{C}$ 343

Figura A.14.3 - Superfície de resposta para incremento de viscosidade a $135^{\circ} \mathrm{C}$ 343

Figura A.15.1 - Análise de resíduos para incremento de viscosidade a $143^{\circ} \mathrm{C}$ 344

Figura A.15.2 - Efeitos dos componentes para incremento de viscosidade a $143^{\circ} \mathrm{C}$ 345

Figura A.15.3 - Superfície de resposta para incremento de viscosidade a $143^{\circ} \mathrm{C}$ 345

Figura A.16.1 - Análise de resíduos para incremento de viscosidade a $150^{\circ} \mathrm{C}$ 346

Figura A.16.2 - Efeitos dos componentes para incremento de viscosidade a $150^{\circ} \mathrm{C}$ 347

Figura A.16.3 - Superfície de resposta para incremento de viscosidade a $150^{\circ} \mathrm{C}$ 347

Figura A.17.1 - Análise de resíduos para incremento de viscosidade a $163^{\circ} \mathrm{C}$ 348

Figura A.17.2 - Efeitos dos componentes para incremento de viscosidade a $163^{\circ} \mathrm{C}$ 349

Figura A.17.3 - Superfície de resposta para incremento de viscosidade a $163^{\circ} \mathrm{C}$ 349

Figura A.18.1 - Análise de resíduos para incremento de viscosidade a $177^{\circ} \mathrm{C}$ 350

Figura A.18.2 - Efeitos dos componentes para incremento de viscosidade a $177^{\circ} \mathrm{C}$ 351

Figura A.18.3 - Superfície de resposta para incremento de viscosidade a $177^{\circ} \mathrm{C}$ 351

Figura A.19.1 - Análise de resíduos para $\mathrm{J}_{\mathrm{nr}}$ a $3.200 \mathrm{~Pa}$ a $52^{\circ} \mathrm{C}$ após RTFOT 352

Figura A.19.2 - Efeitos dos componentes para $\mathrm{J}_{\mathrm{nr}}$ a $3.200 \mathrm{~Pa}$ a $52^{\circ} \mathrm{C}$ após RTFOT 353

Figura A.19.3 - Superfície de resposta para $\mathrm{J}_{\mathrm{nr}}$ a $3.200 \mathrm{~Pa}$ a $52^{\circ} \mathrm{C}$ após RTFOT 353

Figura A.20.1 - Análise de resíduos para $\mathrm{J}_{\mathrm{nr}}$ a $3.200 \mathrm{~Pa}$ a $58^{\circ} \mathrm{C}$ após RTFOT 354

Figura A.20.2 - Efeitos dos componentes para $\mathrm{J}_{\mathrm{nr}}$ a $3.200 \mathrm{~Pa}$ a $58^{\circ} \mathrm{C}$ após RTFOT 355

Figura A.20.3 - Superfície de resposta para $\mathrm{J}_{\mathrm{nr}}$ a $3.200 \mathrm{~Pa}$ a $58^{\circ} \mathrm{C}$ após RTFOT 355

Figura A.21.1 - Análise de resíduos para $\mathrm{J}_{\mathrm{nr}}$ a $3.200 \mathrm{~Pa}$ a $64^{\circ} \mathrm{C}$ após RTFOT 356

Figura A.21.2 - Efeitos dos componentes para $\mathrm{J}_{\mathrm{nr}}$ a $3.200 \mathrm{~Pa}$ a $62^{\circ} \mathrm{C}$ após RTFOT 357

Figura A.21.3 - Superfície de resposta para $\mathrm{J}_{\mathrm{nr}}$ a 3.200 Pa a $64^{\circ} \mathrm{C}$ após RTFOT 357

Figura A.22.1 - Análise de resíduos para $\mathrm{J}_{\mathrm{nr}}$ a $3.200 \mathrm{~Pa}$ a $70^{\circ} \mathrm{C}$ após RTFOT 358

Figura A.22.2 - Efeitos dos componentes para $\mathrm{J}_{\mathrm{nr}}$ a $3.200 \mathrm{~Pa}$ a $70^{\circ} \mathrm{C}$ após RTFOT 359

Figura A.22.3 - Superfície de resposta para $\mathrm{J}_{\mathrm{nr}}$ a 3.200 Pa a $70^{\circ} \mathrm{C}$ após RTFOT 359 
Figura A.23.1 - Análise de resíduos para R a 3.200 Pa a 52 ${ }^{\circ} \mathrm{C}$ após RTFOT 360

Figura A.23.2 - Efeitos dos componentes para $\mathrm{R}$ a 3.200 $\mathrm{Pa}$ a $52^{\circ} \mathrm{C}$ após RTFOT 361

Figura A.23.3 - Superfície de resposta para R a 3.200 Pa a $52^{\circ} \mathrm{C}$ após RTFOT 361

Figura A.24.1 - Análise de resíduos para R a 3.200 Pa a 58 ${ }^{\circ} \mathrm{C}$ após RTFOT 362

Figura A.24.2 - Efeitos dos componentes para R a 3.200 Pa a $58^{\circ} \mathrm{C}$ após RTFOT 363

Figura A.24.3 - Superfície de resposta para R a 3.200 Pa a $58^{\circ} \mathrm{C}$ após RTFOT 363

Figura A.25.1 - Análise de resíduos para R a 3.200 Pa a $64^{\circ} \mathrm{C}$ após RTFOT 364

Figura A.25.2 - Efeitos dos componentes para R a 3.200 Pa a $64^{\circ} \mathrm{C}$ após RTFOT 365

Figura A.25.3 - Superfície de resposta para R a 3.200 Pa a $64^{\circ} \mathrm{C}$ após RTFOT 365

Figura A.26.1 - Análise de resíduos para R a 3.200 Pa a 70 C após RTFOT 366

Figura A.26.2 - Efeitos dos componentes para $\mathrm{R}$ a $3.200 \mathrm{~Pa}$ a $70^{\circ} \mathrm{C}$ após RTFOT 367

Figura A.26.3 - Superfície de resposta para R a 3.200 Pa a $70^{\circ} \mathrm{C}$ após RTFOT 367

Figura A.27.1 - Análise de resíduos para $\mathrm{J}_{\mathrm{nr}, \mathrm{diff}}$ a $52^{\circ} \mathrm{C}$ após RTFOT 368

Figura A.27.2 - Efeitos dos componentes para $\mathrm{J}_{\mathrm{nr}, \text { diff }}$ a $52^{\circ} \mathrm{C}$ após RTFOT 369

Figura A.27.3 - Superfície de resposta para $\mathrm{J}_{\mathrm{nr}, \mathrm{diff}}$ a $52^{\circ} \mathrm{C}$ após RTFOT 369

Figura A.28.1 - Análise de resíduos para $\mathrm{J}_{\mathrm{nr}, \text { diff }}$ a $58^{\circ} \mathrm{C}$ após RTFOT 370

Figura A.28.2 - Efeitos dos componentes para $\mathrm{J}_{\mathrm{nr} \text {,diff }}$ a $58^{\circ} \mathrm{C}$ após RTFOT 371

Figura A.28.3 - Superfície de resposta para $\mathrm{J}_{\mathrm{nr}, \mathrm{diff}}$ a $58^{\circ} \mathrm{C}$ após RTFOT 371

Figura A.29.1 - Análise de resíduos para $\mathrm{J}_{\mathrm{nr} \text {,diff }}$ a $64^{\circ} \mathrm{C}$ após RTFOT 372

Figura A.29.2 - Efeitos dos componentes para $\mathrm{J}_{\mathrm{nr} \text {,diff }}$ a $64^{\circ} \mathrm{C}$ após RTFOT 373

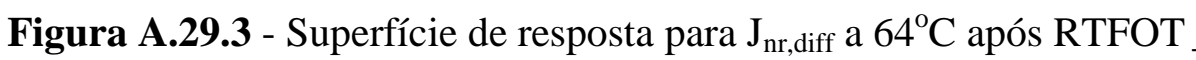
373

Figura A.30.1 - Análise de resíduos para $\mathrm{J}_{\mathrm{nr}, \text { diff }}$ a $70^{\circ} \mathrm{C}$ após RTFOT 374

Figura A.30.2 - Efeitos dos componentes para $\mathrm{J}_{\mathrm{nr} \text {,diff }}$ a $70^{\circ} \mathrm{C}$ após RTFOT 375

Figura A.30.3 - Superfície de resposta para $\mathrm{J}_{\mathrm{nr} \text {,diff }}$ a $70^{\circ} \mathrm{C}$ após RTFOT 375

Figura A.31.1 - Análise de resíduos para $\mathrm{a}_{\mathrm{f}}$ a $25^{\circ} \mathrm{C}$ após PAV 376

Figura A.31.2 - Efeitos dos componentes para $\mathrm{a}_{\mathrm{f}}$ a $25^{\circ} \mathrm{C}$ após PAV 377

Figura A.31.3 - Superfície de resposta para $\mathrm{a}_{\mathrm{f}}$ a $25^{\circ} \mathrm{C}$ após PAV 377

Figura A.32.1 - Análise de resíduos para $\mathrm{N}_{\mathrm{f}}$ a $2 \%$ a $25^{\circ} \mathrm{C}$ após PAV 378

Figura A.32.2 - Efeitos dos componentes para $\mathrm{N}_{\mathrm{f}}$ a $2 \%$ a $25^{\circ} \mathrm{C}$ após PAV 379 
Figura A.32.3 - Superfície de resposta para $\mathrm{N}_{\mathrm{f}}$ a $2 \%$ a $25^{\circ} \mathrm{C}$ após PAV 379

Figura A.33.1 - Análise de resíduos para $\mathrm{N}_{\mathrm{f}}$ a $30 \%$ a $25^{\circ} \mathrm{C}$ após PAV 380

Figura A.33.2 - Efeitos dos componentes para $\mathrm{N}_{\mathrm{f}}$ a $30 \%$ a $25^{\circ} \mathrm{C}$ após PAV 380

Figura A.33.3 - Superfície de resposta para $\mathrm{N}_{\mathrm{f}}$ a $30 \%$ a $25^{\circ} \mathrm{C}$ após PAV 381

Figura A.34.1 - Análise de resíduos para $\mathrm{J}_{\mathrm{nr}}$ a $100 \mathrm{~Pa}$ a $52^{\circ} \mathrm{C}$ após RTFOT 382

Figura A.34.2 - Efeitos dos componentes para $\mathrm{J}_{\mathrm{nr}}$ a $100 \mathrm{~Pa}$ a $52^{\circ} \mathrm{C}$ após RTFOT 383

Figura A.34.3 - Superfície de resposta para $\mathrm{J}_{\mathrm{nr}}$ a $100 \mathrm{~Pa}$ a $52^{\circ} \mathrm{C}$ após RTFOT 383

Figura A.35.1 - Análise de resíduos para $\mathrm{J}_{\mathrm{nr}}$ a $100 \mathrm{~Pa}$ a $58^{\circ} \mathrm{C}$ após RTFOT 384

Figura A.35.2 - Efeitos dos componentes $\mathrm{J}_{\mathrm{nr}}$ a $100 \mathrm{~Pa}$ a $58^{\circ} \mathrm{C}$ após RTFOT 385

Figura A.35.3 - Superfície de resposta para $\mathrm{J}_{\mathrm{nr}}$ a $100 \mathrm{~Pa}$ a $58^{\circ} \mathrm{C}$ após RTFOT 385

Figura A.36.1 - Análise de resíduos para $\mathrm{J}_{\mathrm{nr}}$ a $100 \mathrm{~Pa}$ a $64^{\circ} \mathrm{C}$ após RTFOT 386

Figura A.36.2 - Efeitos dos componentes para $\mathrm{J}_{\mathrm{nr}}$ a $100 \mathrm{~Pa}$ a $64^{\circ} \mathrm{C}$ após RTFOT 387

Figura A.36.3 - Superfície de resposta para $\mathrm{J}_{\mathrm{nr}}$ a $100 \mathrm{~Pa}$ a $64^{\circ} \mathrm{C}$ após RTFOT 387

Figura A.37.1 - Análise de resíduos para $\mathrm{J}_{\mathrm{nr}}$ a $100 \mathrm{~Pa}$ a $70^{\circ} \mathrm{C}$ após RTFOT 388

Figura A.37.2 - Efeitos dos componentes para $\mathrm{J}_{\mathrm{nr}}$ a $100 \mathrm{~Pa}$ a $70^{\circ} \mathrm{C}$ após RTFOT 389

Figura A.37.3 - Superfície de resposta para $\mathrm{J}_{\mathrm{nr}}$ a $100 \mathrm{~Pa}$ a $70^{\circ} \mathrm{C}$ após RTFOT 389

Figura A.38.1 - Análise de resíduos para R a 100 Pa após RTFOT a 52 C 390

Figura A.38.2 - Efeitos dos componentes para R a 100 Pa após RTFOT a $52^{\circ} \mathrm{C}$ 391

Figura A.38.3 - Superfície de resposta para R a $100 \mathrm{~Pa}$ após RTFOT a $52^{\circ} \mathrm{C}$ 391

Figura A.39.1 - Análise de resíduos para R a $100 \mathrm{~Pa}$ a $58^{\circ} \mathrm{C}$ após RTFOT 392

Figura A.39.2 - Efeitos dos componentes para R a $100 \mathrm{~Pa}$ a $58^{\circ} \mathrm{C}$ após RTFOT 393

Figura A.39.3 - Superfície de resposta para R a $100 \mathrm{~Pa}$ a $58^{\circ} \mathrm{C}$ após RTFOT 393

Figura A.40.1 - Análise de resíduos para R a $100 \mathrm{~Pa}$ a $64^{\circ} \mathrm{C}$ após RTFOT 394

Figura A.40.2 - Efeitos dos componentes para R a 100 Pa a $64^{\circ} \mathrm{C}$ após RTFOT 395

Figura A.40.3 - Superfície de resposta para R a $100 \mathrm{~Pa}$ a $64^{\circ} \mathrm{C}$ após RTFOT 395

Figura A.41.1 - Análise de resíduos para R a $100 \mathrm{~Pa}$ a $70^{\circ} \mathrm{C}$ após RTFOT 396

Figura A.41.2 - Efeitos dos componentes para R a $100 \mathrm{~Pa} \mathrm{a} 70^{\circ} \mathrm{C}$ após RTFOT 397

Figura A.41.3 - Superfície de resposta para R a $100 \mathrm{~Pa}$ a $70^{\circ} \mathrm{C}$ após RTFOT 397 
Figura A.42.1 - Análise de resíduos para $\mathrm{G}^{*} \cdot \operatorname{sen}(\delta)=5 \mathrm{MPa}$ após PAV 398

Figura A.42.2 - Efeitos dos componentes para $\mathrm{G}^{*} \cdot \operatorname{sen}(\delta)=5 \mathrm{MPa}$ após PAV 399

Figura A.42.3 - Superfície de resposta para $\mathrm{G}^{*} \cdot \operatorname{sen}(\delta)=5 \mathrm{MPa}$ após PAV 399

Figura A.43.1 - Análise de resíduos para $\mathrm{G}^{*} \cdot \operatorname{sen}(\delta)=6 \mathrm{MPa}$ após PAV 400

Figura A.43.2 - Efeitos dos componentes para $\mathrm{G}^{*} \cdot \operatorname{sen}(\delta)=6 \mathrm{MPa}$ após PAV 401

Figura A.43.3 - Superfície de resposta para $\mathrm{G}^{*} \cdot \operatorname{sen}(\delta)=6 \mathrm{MPa}$ após PAV 401 



\section{LISTA DE SÍMBOLOS}

\begin{tabular}{|c|c|}
\hline$\alpha$ & Nível de significância \\
\hline$\beta$ & Estimativa do coeficiente do modelo de regressão \\
\hline$\delta$ & Ângulo de fase \\
\hline$\varepsilon_{\mathrm{c}}$ & $\begin{array}{l}\text { Deformação medida no final do ciclo de fluência e início do ciclo de } \\
\text { recuperação }\end{array}$ \\
\hline$\varepsilon_{\mathrm{o}}$ & Deformação medida no início de um ciclo de fluência e recuperação \\
\hline$\varepsilon_{\mathrm{r}}$ & Deformação medida no final de um ciclo de fluência e recuperação \\
\hline$\sigma$ & Tensão aplicada em um ciclo de fluência e recuperação \\
\hline $\mathrm{A}, \mathrm{B}$ & Parâmetros da vida de fadiga \\
\hline$a_{f}$ & parâmetro da análise de tolerância ao dano no ensaio LAS \\
\hline $\mathrm{E}$ & Tráfego extremamente pesado \\
\hline $\mathrm{G}^{*}$ & Módulo complexo de cisalhamento em regime oscilatório \\
\hline $\mathrm{G}^{*} \cdot \operatorname{sen}(\delta)$ & parâmetro de fadiga \\
\hline $\mathrm{G}^{*} / \operatorname{sen}(\delta)$ & parâmetro de deformação permanente \\
\hline $\mathrm{H}$ & Tráfego pesado \\
\hline $\mathrm{H}_{\mathrm{o}}, \mathrm{H}_{1}$ & Hipóteses nula e alternativa, respsctivamente \\
\hline Iv & Incremento de viscosidade \\
\hline $\mathrm{J}_{\mathrm{nr}}$ & Compliância não-recuperável do ligante asfáltico \\
\hline $\mathrm{J}_{\mathrm{nr}, \mathrm{diff}}$ & $\begin{array}{l}\text { Diferença percentual entre as compliâncias não-recuperáveis nas tensões de } 100 \\
\text { e } 3.200 \mathrm{~Pa}\end{array}$ \\
\hline $\mathrm{m}$ & Taxa de relaxação no BBR \\
\hline $\mathrm{N}_{\mathrm{f}}$ & Número de ciclos na falha por fadiga \\
\hline $\mathrm{R}$ & Percentual de recuperação do ligante asfáltico \\
\hline $\mathrm{R}^{2}$ & Coeficiente de determinação \\
\hline $\mathrm{R}_{\text {AJUSTADO }}^{2}$ & Coeficiente de determinação ajsutado \\
\hline $\mathrm{R}_{\text {PREVISÃO }}^{2}$ & Coeficiente de determinação para previsão \\
\hline s & Desvio padrão amostral \\
\hline S & Módulo de rigidez no BBR \\
\hline $\mathrm{S}$ & tráfego padrão \\
\hline $\mathrm{TC}$ & Temperatura de compactação \\
\hline TU & Temperatura de usinagem \\
\hline $\mathrm{V}$ & Tráfego muito pesado \\
\hline $\mathrm{Vr}$ & Viscosidade envelhecida a curto prazo \\
\hline Vv & Viscosidade virgem \\
\hline $\mathrm{x}_{1}, \mathrm{x}_{2}, \mathrm{x}_{3}$ & teores de CAP+óleo, SBS e TITAN, respectivamente \\
\hline
\end{tabular}




\title{
LISTA DE SIGLAS E ABREVIAÇÕES
}

\author{
AASHTO American Association of State Highway and Transportation \\ Officials \\ ANP Agência Nacional do Petróleo, Gás Natural e Biocombustíveis \\ ASTM American Society for Testing and Materials \\ BBR Bending Beam Rheometer \\ CAP Cimento Asfáltico de Petróleo \\ DNER Departamento Nacional de Estradas de Rodagem \\ DSR Reômetro de Cisalhamento Dinâmico \\ FHWA Administração Rodoviária Federal dos Estados Unidos \\ FIV Fator de Inflação da Variância \\ IST Índice de susceptibilidade térmica \\ LA Ligante asfáltico \\ LAS Varredura com amplitude linear \\ LCC Líquido da castanha de caju \\ MSCR Fluência e recuperação sob tensão múltipla \\ PAV Pressure Aging Vessel, material envelhecido a longo prazo \\ PG Grau de desempenho \\ PPA Ácido polifosfórico \\ PRESS Soma de quadrados dos resíduos da previsão \\ RTFOT Rolling Thin Film Oven Test, material envelhecido a curto prazo \\ SBS Copolímero de estireno-butadieno-estireno \\ SSE Soma de quadrados dos resíduos \\ SSR Soma de quadrados da regressão \\ SST Soma dos quadrados totais \\ TITAN Polietileno de alta densidade e baixo peso molecular oxidado \\ VECD Dano Contínuo Viscoelástico \\ VIF Variance Inflation Factor
}




\section{SUMÁRIO}

1. INTRODUÇÃO — 41

1.1. Apresentação do tema e sua relevância ___ 41

1.2. Objetivos da dissertação ___ 42

1.3. Programa laboratorial___ 43

1.4. Estrutura da dissertação___ 45

2. REVISÃO BIBLIOGRÁFICA _

2.1. Copolímero SBS 47

2.2. Ligantes asfálticos modificados com o copolímero SBS _ 49

2.3. Estabilidade à estocagem dos ligantes asfálticos modificados com o copolímero SBS _ 57

2.4. Agentes compatibilizantes usados para ligantes asfálticos com SBS _ 59

2.4.1. Óleo extensor ou óleo aromático__ 59

2.4.2. Líquido da castanha de caju ___ 61

2.4.3. Enxofre _ 64

2.4.4. Ácido Polifosfórico (PPA) _ 68

2.4.5. Argila__ 73

3. MATERIAIS E MÉTODOS

3.1. Delineamento do experimento __ 77

3.2. Equipamentos__ 80

3.3. Ensaios realizados e métodos de ensaio ___ 81

3.3.1. Envelhecimento dos ligantes asfálticos a curto prazo em estufa de filme rotativo (RTFOT)

3.3.2. Envelhecimento dos ligantes asfálticos a longo prazo em estufa de vaso pressurizado (PAV)

3.3.3. Estabilidade à estocagem___ 84

3.3.4. Ensaio de viscosidade rotacional (Viscosidade Brookfield) ___

3.3.5. Grau de desempenho $(\mathrm{PG}) \_\mathbf{8 6}$

3.3.6. Balanço de massa __

3.3.7. Ensaio de fluência e recuperação sob tensão múltipla (MSCR) ___ 87

3.3.8. Ensaio de varredura de amplitude linear (LAS) ___ 91 
3.3.9. Varredura de frequência para construção das curvas-mestre 95

3.4. Materiais utilizados 95

4. ANÁLISE ESTATÍSTICA DOS RESULTADOS 98

4.1. Hipóteses e procedimentos empregados na análise dos resultados 98

4.1.1. Hipóteses adotadas na análise___ 98

4.1.2. Procedimento de análise ___ 99

4.2. Resultados obtidos 105

4.3. Análise estatística dos resultados 115

4.4. Comentários sobre as propriedades, parâmetros e índices modelados 118

4.5. Conclusões obtidas da análise de efeitos dos componentes 138

4.6. Conclusões obtidas da análise de superfícies de resposta 142

5. ANÁLISES ADICIONAIS E DISCUSSÕES 144

5.1. Grau de desempenho (PG) e grau contínuo 144

5.2. Viscosidade rotacional 146

5.2.1. Ligantes asfálticos virgens e envelhecidos a curto prazo 146

5.2.2. Incrementos de viscosidade rotacional 151

5.2.3. Temperaturas de usinagem e compactação dos ligantes asfálticos__ 153

5.3. Balanço de massa 154

5.4. Ensaio de fluência e recuperação sob múltiplas tensões (MSCR) 156

5.5. Ensaio de varredura linear de amplitude (LAS) 162

5.5.1. Comprimento da trinca na ruptura por fadiga $\left(a_{\mathrm{f}}\right)$ 162

5.5.2. Vida de fadiga $\left(\mathrm{N}_{\mathrm{f}}\right)$ 163

5.5.3. $\mathrm{G}^{*} \cdot \operatorname{sen}(\delta)$ 167

5.6. Curvas-mestre 168

5.6.1. Comparação entre a mistura 100-0-0 e o ligante asfáltico de base (Replan 50/70)

5.6.2. Efeito dos envelhecimentos a curto e alongo prazo à luz dos resultados de $\mathrm{G}^{*}$

5.6.3. Efeito dos envelhecimentos a curto e a longo prazos à luz dos valores de delta $(\delta)$

5.6.4. Efeito das aditivações à luz dos resultados de $G^{*}$ nos diferentes níveis de envelhecimento 
5.6.5. Efeito das aditivações à luz dos resultados de delta nos diferentes níveis de envelhecimento

5.6.6. Comparação das curvas-mestre para uma mesma mistura quanto ao ensaio de estabilidade à estocagem (relação topo/fundo) para o módulo complexo $\left(\mathrm{G}^{*}\right)$

5.6.7. Estabilidade à estocagem com base nos valores do ângulo de fase $(\delta)$

5.7. Valores de $G *, \delta, G * / \operatorname{sen}(\delta)$ e $G * \operatorname{sen}(\delta)$ obtidos através da varredura de frequências

5.7.1. Comparação entre a mistura 100-0-0 e o ligante asfáltico de base (Replan 50/70)

5.7.2. Efeito do envelhecimento 251

5.7.3. Comparação das formulações com SBS e TITAN com a mistura 100-0-0 nas diferentes condições de envelhecimento 258

5.8. Análises simultâneas dos resultados 265

6. CONCLUSÕES 289

6.1. Introdução 289

6.2. Conclusões principais 290

6.2.1. Efeitos dos componentes 290

6.2.2. Superfícies de resposta 296

6.2.3. Ordenamento das misturas 299

6.2.4. Considerações finais 303

6.3. Sugestões para pesquisas futuras 306 REFERÊNCIAS BIBLIOGRÁFICAS 307 ANEXO A - Modelos de regressão, gráficos de efeitos dos componentes, superfícies de resposta e gráficos da análise de resíduos 315 



\section{INTRODUÇÃO}

\subsection{Apresentação do tema e sua relevância}

O estudo de materiais usados na pavimentação se torna essencial, para obtenção de melhorias significativas no campo. Dentre os materiais utilizados, no que diz respeito ao ligante asfáltico, este pode ser melhorado com a adição de modificadores de diferentes classes (AIREY, 2002). Suas características finais dependem do ligante asfáltico utilizado, do teor e o tipo de modificador empregado, bem como, do processo de fabricação da mistura (BRINGEL et al., 2006). Polímeros, fíleres mineirais, óleos aromáticos, ácidos e materiais reciclados e outros produtos à base de polímeros são os exemplos mais comuns de modificadores (PAMPLONA, 2013).

Os asfaltos modificados por polímeros são os ligantes obtidos pela incorporação de polímeros ao asfalto. Dentre os polímeros destaca-se o copolímero SBS, que é provavelmente o modificador mais utilizado para fins rodoviários (AIREY, 2003; POLACCO et al., 2006a).

O SBS é um bom modificador de asfalto porque sua estrutura química e a polaridade o tornam adequado para a mistura com um grande número de tipos de asfaltos (POLLACO et al., 2006b). O SBS tem como característica principal sua alta resposta elástica. Além disso, possui características de elastômeros termoplásticos. Também demonstra apresentar boa resistência mecânica (BRINGEL et al., 2006). A melhoria das propriedades também inclui maior resistência ao envelhecimento e à oxidação (AIREY, 2003; POLACCO et al., 2006b). No entanto pode ocorrer a mistura de CAP + SBS a separação de fases. Esta separação é uma indicação da incompatibilidade do asfalto com o polímero e que, neste caso, pode ser melhorada com a adição de óleos aromáticos (AIREY, 2003). A adição de altos teores de óleos aromáticos na mistura pode dissolver os blocos de poliestireno do copolímero SBS. Portanto, a quantidade adicionada de óleo aromático é um fator importante para que não se perca as características benéficas da incorporação do SBS ao ligante asfáltico de base (AIREY, 2003; FERNANDES et al., 2008).

Estudos como os de Airey (2003), Silva et al. (2004) e Fernandes et al. (2008) avaliaram os efeitos da adição do SBS nas propriedades do ligante asfáltico. Para as 
propriedades tradicionais, percebe-se que ocorre uma redução da penetração e um aumento do ponto de amolecimento do CAP após a incorporação do SBS, indicando um aumento da rigidez do material. Efeitos inversos foram observados após a adição de óleos ao ligante asfáltico modificado (Fernandes et al., 2008). Para as propriedades reológicas, os estudos apontaram uma redução do ângulo de fase $(\delta)$ e um aumento do módulo complexo $\left(\mathrm{G}^{*}\right)$ com a adição do SBS, sendo que a adição de óleos proporcionou efeitos contrários em ambas as propriedades (Fernandes et al., 2008). O aumento no valor de $\mathrm{G}^{*}$ indica uma maior resistência total do CAP à deformação, ao passo que a redução no valors de $\delta$ sinaliza uma melhoria na resposta elástica do material.

O polietileno de alta densidade e baixo peso molecular oxidado usado nesta pesquisa tenta melhorar a incorporação do SBS ao ligante asfáltico de base, para que não ocorra a separação de fases. Portanto nesta pesquisa, foi adicionado uma quantidade em peso de óleo aromático e deste polietileno. A principal contribuição deste trabalho é analisar se a adição do polietileno de alta densidade e baixo peso molecular oxidado no ligante asfáltico modificado com SBS é benéfica ou não. Foram obtidos modelos e ordenamentos das misturas em relação aos diversos parâmetros obtidos pelos ensaios para a realização desta análise.

Neste trabalho, emprega-se o termo misturas em referência à mistura entre ligante asfáltico, óleo aromático, SBS e polietileno (TITAN), sem qualquer correspondência com o termo mistura asfáltica comumente à mistura entre o ligante asfáltico e agregados minerais.

\subsection{Objetivos da dissertação}

O objetivo principal da pesquisa é:

- testar a hipótese de que a adição de proporções adequadas da cera de polietileno (TITAN) possa melhorar as características reológicas do CAP+SBS; 
Os objetivos secundários da pesquisa são:

- verificar a viabilidade técnica do emprego do TITAN em asfaltos modificados com SBS;

- testar a hipótese de que a adição de proporções adequadas da cera de polietileno (TITAN) possa melhorar a estabilidade do CAP+SBS;

- avaliar os efeitos das proporções de TITAN e SBS sobre algumas propriedades reológicas de ligantes asfálticos modificados com esses componentes;

- definir teores de TITAN indicados para a formulação de asfaltos modificados com copolímero SBS.

\subsection{Programa laboratorial}

O experimento foi delineado com base na técnica de experimentos com misturas, utilizando restrições nas proporções dos componentes, pois uma quantidade razoável de emprego de SBS é de 5\% e testou-se a adição da cera (TITAN) em concentrações de até $2 \%$. As variáveis de processo (temperatura, tempo, velocidade de agitação), que foram fixadas, sem variações. O programa experimental englobou um total de 9 misturas com estes 3 componentes. O ligante asfáltico utilizado foi um CAP de classificação 50/70 obtido da Refinaria Replan da Petrobras. Utilizou-se uma porcentagem fixa de óleo aromático de $4 \%$ em peso, de maneira que o componente chamado de "asfalto" é, na verdade, a mistura entre o ligante asfáltico e $4 \%$ de óleo aromático.

Os ligantes asfálticos foram submetidos a ensaios de laboratório para medida de propriedades reológicas fundamentais. Os ligantes foram ensaiados nas condições virgem, envelhecida a curto prazo (RTFOT) e a longo prazo (PAV), seguindo as normas indicadas pela especificação Superpave. Os ensaios empregados foram: (i) viscosidade Brookfield; (ii) perda de massa; (iii) estabilidade à estocagem; (iv) grau contínuo da mistura; (v) ensaio MSCR; (vi) ensaio LAS; (vii) ensaio de varredura de frequência;

O ensaio de viscosidade Brookfield foi realizado nas temperaturas de 135, 143, 150, 163 e $177^{\circ} \mathrm{C}$ para amostras virgens e envelhecidas a curto prazo, de acordo com a norma ASTM 
D4402:2006. O ensaio de perda de massa foi realizado juntamente ao envelhecimento a curto prazo da mistura. $\mathrm{O}$ ensaio de estabilidade à estocagem foi realizado de acordo com o prescrito na norma ASTM D2872:2004 e após o ensaio obteve-se a diferença entre topo e fundo pela comparação de curvas-mestre geradas a partir das amostras.

O grau contínuo da mistura foi obtido a partir do ensaio de grau de desempenho pela norma Superpave nas temperaturas prescritas na norma ASTM D7175:2005. Os parâmetros analisados neste ensaio são o módulo complexo $\left(\mathrm{G}^{*}\right)$ e o ângulo de fase $(\delta)$. O grau contínuo da mistura é obtido na temperatura em que $\mathrm{G}^{*} / \mathrm{sen}(\delta)$ for igual a $1,00 \mathrm{kPa}$.

O ensaio de fluência e recuperação sob tensão múltipla (MSCR) foi realizado para amostras envelhecidas a curto prazo, nas temperaturas de $\mathrm{PG}$ de 52 a $70^{\circ} \mathrm{C}$ para as amostras com baixos teores de modificadores e de 52 a $76^{\circ} \mathrm{C}$ nas misturas com altos teores de modificadores, exceto a mistura de ligante asfáltico de base + óleo aromático em que a temperatura foi de 52 a $64^{\circ} \mathrm{C}$, pela norma ASTM D7405:2010a. Neste ensaio foram analisados a compliância não recuperável $\left(\mathrm{J}_{\mathrm{nr}}\right)$, o percentual de recuperação $(\mathrm{R})$ e a diferença de compliâncias entre níveis de tensões ( $\left.\mathrm{J}_{\text {nr,diff }}\right)$.

O ensaio de varredura de amplitude linear (LAS) foi realizado para amostras que passaram no processo de envelhecimento a longo prazo e, foi ensaiado na temperatura de $25^{\circ} \mathrm{C}$, de acordo com a norma AASHTO TP-101-12-UL. Neste ensaio foram analisados o comprimento da trinca na fissura por fadiga $\left(\mathrm{a}_{\mathrm{f}}\right)$ e o modelo de vida de fadiga $\left(\mathrm{N}_{\mathrm{f}}\right)$ obtido para as misturas.

O ensaio de varredura de frequência para obter as curvas-mestre das misturas foi realizado de acordo com o prescrito na norma ASTM D7075:2005. Foram obtidas curvasmestre para as seguintes condições: (a) amostra virgem, (b) envelhecida a curto prazo, (c) envelhecida a longo prazo, (d) parte superior (topo) do ensaio de estabilidade à estocagem e, (e) parte inferior (fundo) do ensaio de estabilidade à estocagem. 


\subsection{Estrutura da dissertação}

O capítulo 1 apresenta o problema e a relevância do tema da pesquisa, os objetivos da pesquisa, o programa laboratorial utilizado e a estrutura do trabalho.

O capítulo 2 traz uma revisão bibliográfica sobre a adição do copolímero SBS em ligantes asfálticos, suas vantagens, desvantagens e seu problema de estabilidade à estocagem.

O capítulo 3 apresenta os materiais e métodos utilizados para a realização do trabalho, iniciando com o delineamento do experimento utilizado ("experimento com misturas" Cornell, 2002), os equipamentos utilizados na pesquisa, os ensaios realizados já discutidos no item 1.3 (programa laboratorial) e os materiais utilizados: (a) CAP Replan 50/70, (b) óleo aromático, (c) SBS, (d) TITAN.

O capítulo 4 apresenta os resultados e as análises modeladas pelo programa Minitab 16.1. Inicia-se apresentando as hipóteses e procedimentos empregados, apresentação dos dados brutos obtidos nos ensaios empregados, as análises estatísticas realizadas com o auxílio do programa Minitab 16.1: (a) "continuos grade", (b) viscosidade virgem em 5 temperaturas $\left(135,143,150,163\right.$ e $\left.177^{\circ} \mathrm{C}\right)$, (c) viscosidade envelhecida a curto prazo em 5 temperaturas $\left(135,143,150,163\right.$ e $\left.177^{\circ} \mathrm{C}\right)$, (d) incremento de viscosidade, (e) temperaturas de compactação e usinagem, (f) compliância não-recuperável $\left(\mathrm{J}_{\mathrm{nr}}\right)$ para amostras envelhecidas a curto prazo em 4 temperaturas $\left(52,58,64\right.$ e $\left.70^{\circ} \mathrm{C}\right)$, (g) percentual de recuperação $(\mathrm{R})$ para amostras envelhecidas a curto prazo em 4 temperaturas $\left(52,58,64\right.$ e $\left.70^{\circ} \mathrm{C}\right)$, (h) $\mathrm{J}_{\mathrm{nr} \text {,diff }}$ para amostras envelhecidas a curto prazo em 4 temperaturas $\left(52,58,64\right.$ e $\left.70^{\circ} \mathrm{C}\right)$, (i) comprimento da trinca na ruptura por fadiga $\left(a_{\mathrm{f}}\right)$ para amostras envelhecidas a longo prazo a $25^{\circ} \mathrm{C} \mathrm{e},(\mathrm{j})$ vida de fadiga $\left(\mathrm{N}_{\mathrm{f}}\right)$ para amostras envelhecidas a longo prazo a $25^{\circ} \mathrm{C}$ em duas amplitudes de deformação ( $2 \%$ e $30 \%$ ). Ainda neste capítulo tem-se uma breve conclusão sobre os efeitos dos componentes e da superfície de resposta das análises realizadas.

O capítulo 5 apresenta os resultados e análises não-modeladas. Neste capítulo se faz uma comparação de todas as misturas com o ligante asfáltico de base (Replan 50/70). As análises realizadas são: (a) temperatura alta do grau de desempenho, (b) viscosidade Brookfield para a condição virgem e envelhecida a curto prazo, incrementos de viscosidade e temperaturas de usinagem e compactação. A seguir segue-se com (c) balanço de massa, (d) ensaio MSCR com análise de deformação permanente, (e) ensaio LAS com análise de fadiga, 
(f) varredura de frequências para comparação entre curvas-mestre, $(\mathrm{g})$ propriedades $\mathrm{G}^{*}$ e $\delta$ nas temperaturas de ensaio e por fim, (h) um ordenamento das misturas para análise global das propriedades.

O capítulo 6 apresenta as conclusões relevantes sobre os ensaios realizados, as validações dos objetivos da dissertação e sugestões para novas pesquisas acerca do tema em questão. Ao final é apresentado as referências bibliográficas utilizadas nessa dissertação.

O Anexo A apresenta as análises modeladas pelo programa Minitab 16.1 nas formas gráficas da superfície de resposta, dos efeitos dos componentes, as análises de resíduos e os modelos obtidos. 


\section{REVISÃO BIBLIOGRÁFICA}

Neste capítulo, é apresentada uma revisão bibliográfica sobre a adição de SBS em ligantes asfálticos do ponto de vista reológico, destacando em que aspectos sua adição melhora ou piora as propriedades reológicas do ligante asfáltico. O capítulo divide-se em uma breve descrição da estrutura química o copolímero SBS, a adição do SBS em ligantes asfálticos, problemas de estabilidade à estocagem de ligantes asfálticos com SBS e alguns aditivos que podem ser adicionados para tentar amenizar problemas relacionados à estabilidade à estocagem.

\subsection{Copolímero SBS}

O SBS pode ser descrito como um copolímero em bloco, formado por um bloco de estireno, um bloco de butadieno e outro bloco de estireno. Possui uma aparência como isopor picado assim como ilustrado na Figura 2.1. O copolímero é um polímero formado por dois ou mais tipos de monômeros. Nos copolímeros aleatórios, os monômeros estão distribuídos aleatoriamente na cadeia polimérica. Nos copolímeros em bloco, um polímero constituído por um determinado tipo de monômero está unido quimicamente a um bloco de outro tipo de monômero (KING et al., 1999). As ligações do SBS (estireno e butadieno) estão unidas quimicamente, conforme ilustrado na Figura 2.2.

O SBS é um exemplo de elastômero termoplástico, composto de domínios rígidos de poliestireno dispersos em uma matriz flexível de polibutadieno. Como ilustrado na Figura 2.2, as cadeias de poliestireno funcionam como pontos de ligação das extremidades das cadeias de polibutadieno (KING et al., 1999). Segundo Ceratti et al. (1996), quando o polímero é disperso no asfalto a quente, os domínios de poliestireno dissolvem-se, assumindo características termoplásticas, que facilitam as operações de mistura e compactação. Ao resfriar, os blocos de poliestireno reassociam-se, conferindo à mistura um aumento de sua consistência, o que acarreta no aumento do ponto de amolecimento, enquanto os blocos de polibutadieno são responsáveis pelo aumento da elasticidade da mistura. 

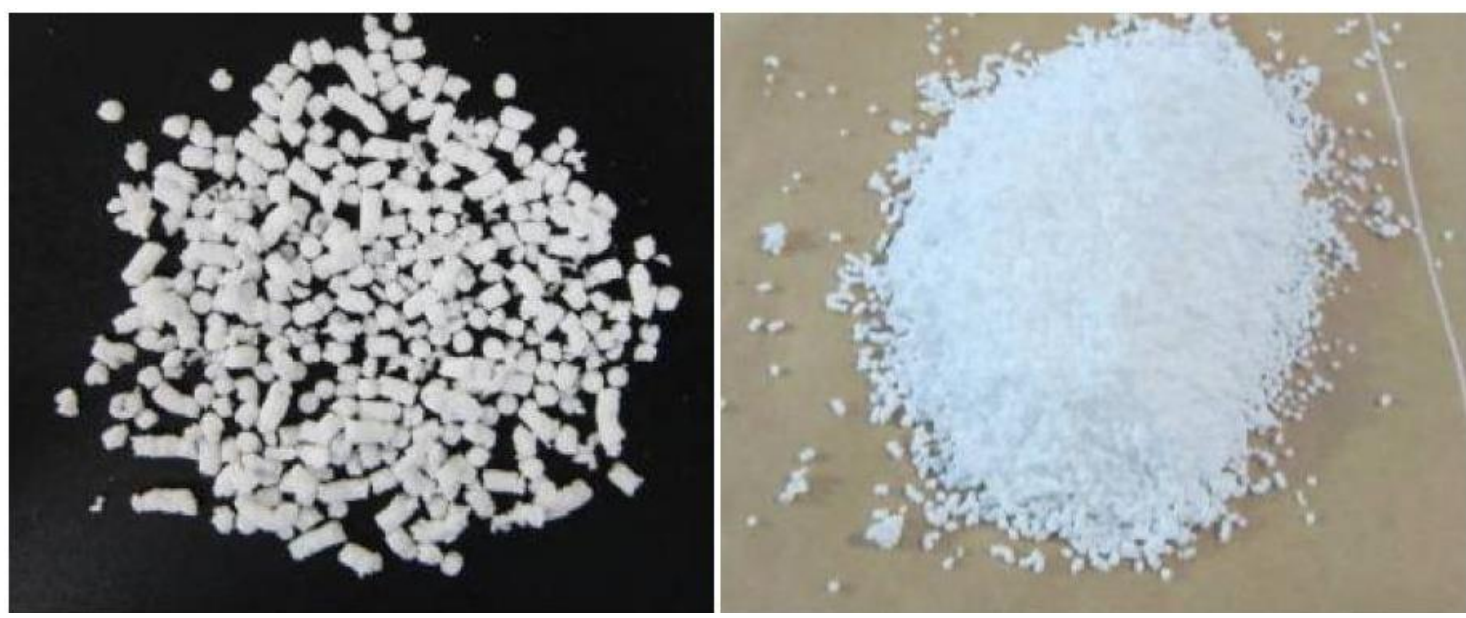

Figura 2.1 - Aparência do SBS (Fonte: próprio autor)

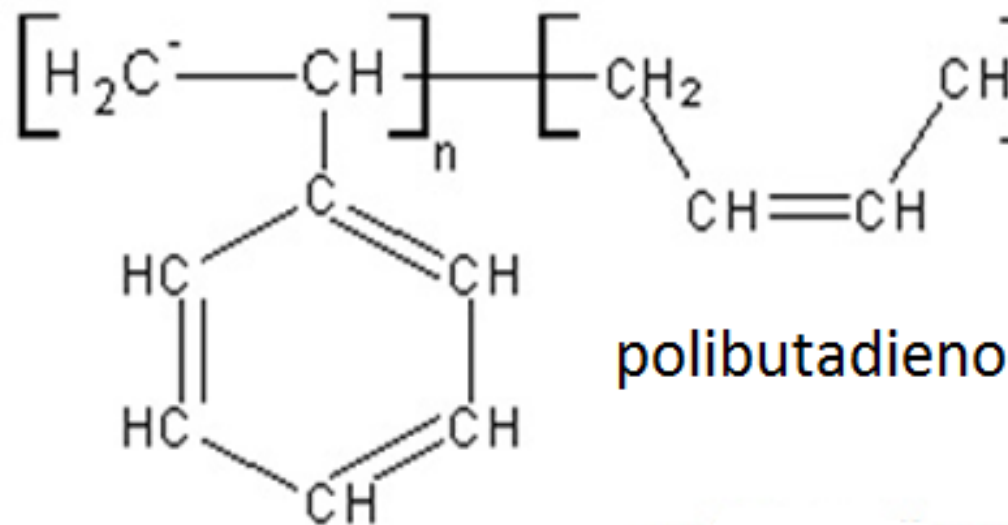

poliestireno

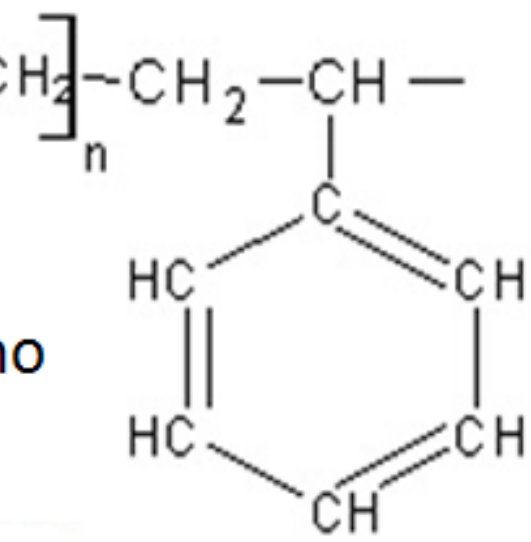

poliestireno

Figura 2.2 - Copolímero SBS em bloco (RODRIGUES, 2010)

Segundo Petzhold (1989), a característica física mais importante dos elastômeros (que é o caso do SBS) é a sua capacidade de sofrer grandes deformações elásticas quando ocorre a aplicação de forças relativamente baixas. Os elastômeros podem alcançar elongações cinco a dez vezes maiores que seu comprimento inicial, retornando espontaneamente à suas dimensões iniciais após remoção de força. Devido à composição e à estrutura do SBS, este também pode ser empregado em misturas poliméricas como agente compatibilizante entre polímeros imiscíveis (VERONESE, 2003). Ao misturar o copolímero SBS ao ligante asfáltico, a fase elastômera do polímero absorve os maltenos presentes no ligante asfáltico de base e seu volume inicial pode ser aumentado em até 9 vezes (LU e ISACSSON, 1997). 
Segundo IBP (1996), os copolímeros em bloco de SBS são macromoléculas que combinam as propriedades termoplásticas e elastoméricas, sem necessidade de vulcanização e sua utilização, em larga escala nas últimas duas décadas, tem sido obtidos excelentes resultados, pois este sistema polimérico apresenta recuperação elástica e resistência mecânica à tração, propriedades essenciais para que o revestimento asfáltico permaneça resistente e flexível em todos os níveis de tensões e de temperaturas a que ele está sujeito.

\subsection{Ligantes asfálticos modificados com o copolímero SBS}

Segundo o DNER (1998), os domínios poliestirênicos se fundem acima dos $90^{\circ} \mathrm{C}$ e o domínio polibutadiênico só se torna rígido próximo a $-90^{\circ} \mathrm{C}$ e, por esta razão, o SBS é usado como modificador de CAP tanto nos locais onde as temperaturas são muito altas quanto nos locais onde as temperaturas são muito baixas.

Nos locais onde as temperaturas são muito altas, que ultrapassam em muito o ponto de amolecimento do ligante asfáltico de base, o SBS forma uma malha que envolve o ligante, mantendo alta consistência no sistema em virtude do estado ainda sólido dos domínios estirênicos. Só a partir da fusão completa dos domínios estirênicos é que a mistura CAP-SBS passa a ter fluxo viscoso. Nos locais onde as temperaturas são muito baixas, o CAP teria comportamento vítreo com trincamento correspondente. O SBS diminui bastante o ponto de ruptura Fraass da mistura, conferindo a ela elasticidade a temperaturas bem abaixo daquela correspondente ao trincamento do ligante asfáltico de base (DNER, 1998; AMARAL, 2000).

Os asfaltos modificados por SBS são obtidos pela incorporação deste polímero ao asfalto por mistura mecânica ou por reação química e as características finais dependem do tipo e do teor de SBS e do tipo de asfalto utilizado, bem como do processo de fabricação da mistura. O processo de fabricação da mistura possui algumas variáveis chamadas "variáveis de processo". As variáveis de processo para o caso de misturas entre ligantes asfálticos e aditivos são três: tempo, temperatura e velocidade. O tempo de mistura entre o CAP e os aditivos, a temperatura em que esta mistura será realizada e a velocidade de agitação da mistura (rpm). Vários estudos têm demonstrado que a adição do copolímero SBS melhora as propriedades mecânicas dos asfaltos convencionais (LU e ISACSSON, 1997; LU et al., 1998; 
LEITE, 1999; COSTA, 2002; WEN et al., 2002; AIREY, 2003; LUCENA et al., 2002, 2003, 2004; SILVA et al., 2004; LUCENA, 2005; BRINGEL et al., 2006; MORAES, 2007; FERNANDES et al., 2008; SENGOZ e ISIKYAKAR, 2008; KHODAII E MEHRARA, 2009; RODRIGUES, 2010; DOMINGOS, 2011; DOMINGOS et al. 2012; DOMINGOS e FAXINA, 2013, NUÑES, 2013).

Como o SBS pode sofrer com variações de massa moleculares e comprimentos das cadeias dos blocos de estireno e de butadieno, existe uma variedade deste copolímero que pode ser utilizada na fabricação de ligantes asfálticos. O desempenho no campo será diferente em decorrência destas variações. Estas variações influenciam na compatibilidade e nas propriedades que serão alcançadas com a adição do SBS no ligante asfáltico de base (KING et al., 1999). O estudo de Airey (2003) mostrou a diferença de comportamento do SBS dependendo do tipo de ligante asfáltico de base empregado, no qual o SBS também é responsável pela capacidade de compatibilidade e características reológicas obtidas com a incorporação do SBS ao CAP empregado.

O SBS ao apresentar concentrações entre 5 e $7 \%$ em peso no ligante asfáltico, faz com que ocorra uma formação de uma rede polimérica contínua de todo o CAP + SBS, alterando significativamente as propriedades do material. As cadeias poliméricas ao apresentar massas moleculares superiores ou iguais que as dos asfaltenos, ocorre o início de uma disputa pelo poder de solvente da fase maltênica do ligante asfáltico e quando a quantidade de maltenos presente no ligante asfáltico for insuficiente, pode ocorrer uma separação de fases (AIREY, 2003). Segundo Airey (2003), observou-se que a formação das redes poliméricas ocorreu pelo entrelaçamento físico dos blocos de poliestireno. Segundo Airey (2003) e Silva et al. (2004), estudos da estabilidade à estocagem de ligantes asfálticos modificados com o copolímero SBS mostraram que os materiais com maior estabilidade são os que possuem uma dispersão mais homogênea de todo o material.

Com relação às propriedades reológicas, pesquisas realizadas por Airey (2003), Silva et al. (2004) e Fernandes et al. (2008) mostraram que a adição do copolímero SBS no ligante asfáltico de base proporcionou aumento do módulo complexo $\left(\mathrm{G}^{*}\right)$ e redução do ângulo de fase $(\delta)$. Foram observadas menores variações tanto nos valores de módulo complexo quanto ângulo de fase com o aumento da temperatura no ligante asfáltico com o copolímero SBS em relação ao CAP puro, o que indica uma menor susceptibilidade térmica do material. 
O estudo de Lu e Isacsson (1997) também mostrou um aumento do módulo complexo e redução do ângulo de fase, como ilustrado na Figura 2.3. Este estudo ainda mostrou que o CAP modificado com SBS com cadeias ramificadas apresenta resultados expressivos se comparado com o CAP modificado com SBS com cadeias lineares. A única exceção foi para o ligante asfáltico A que apresentou o maior ganho de $\mathrm{G}^{*} / \operatorname{sen}(\delta)$ para o CAP modificado com $6 \%$ de SBS com cadeia linear. Observou-se ainda que ao se utilizar cadeias mistas (50\% ramificado e $50 \%$ linear), obteve-se para os CAPs B e C valores de $\mathrm{G}^{*} / \operatorname{sen}(\delta)$ mais expressivos do que utilizar apenas cadeias lineares de SBS.

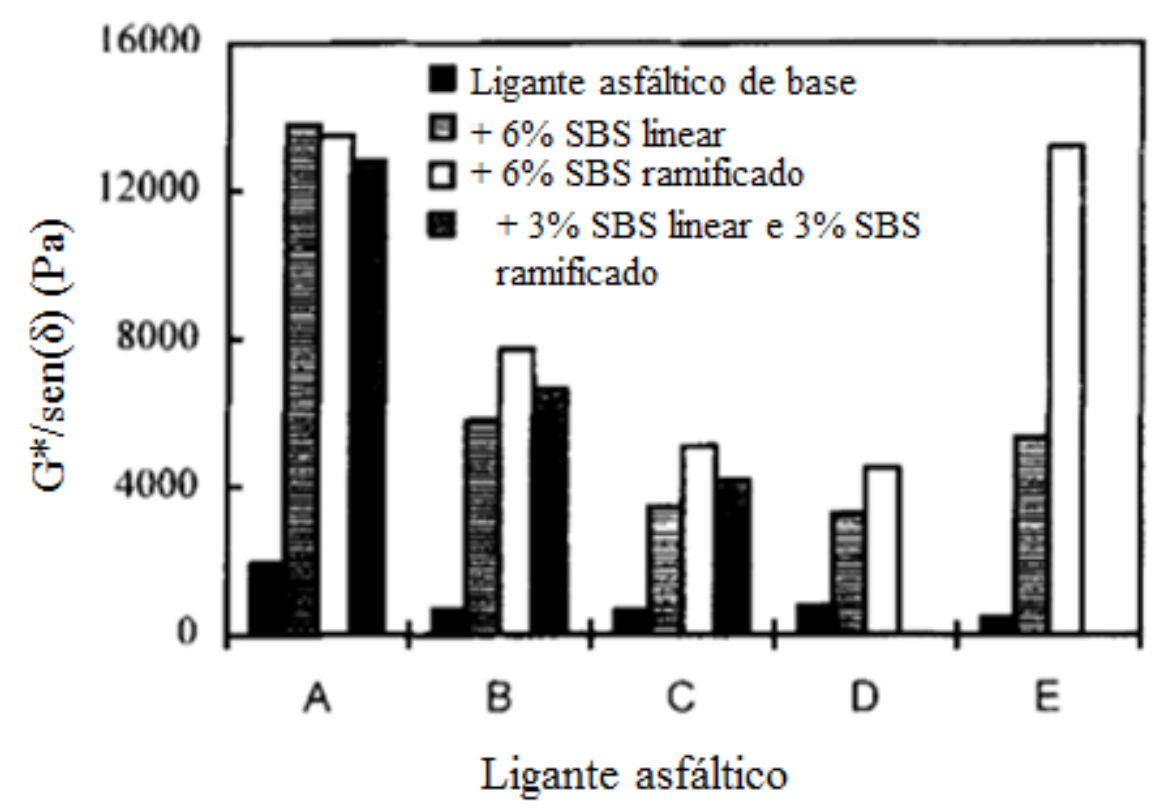

\section{Figura 2.3 - Valores de $G^{*} / \operatorname{sen}(\delta)$ para ligantes asfálticos com teores variados de SBS (LU e ISACSSON, 1997)}

Kang et al. (2015) observou sobre algumas características convencionas que a adição do SBS ao CAP de base causou as seguintes alterações: diminuição da penetração de 68 para 52 decímetros de milímetros, aumento do ponto de amolecimento de 48,5 para $83^{\circ} \mathrm{C}$ e aumento da viscosidade a $60^{\circ} \mathrm{C}$ de 218,2 para 49.566 Pa.s. Sengoz e Isikyakar (2008) observou as características convencionais do $\mathrm{CAP}+\mathrm{SBS}$ e a aparência microscopia do CAP+SBS nos teores entre 2 a $6 \%$ de SBS. A Tabela 2.1 e a Figura 2.4 apresentam as características convencionais do CAP+SBS estudado e a morfologia da mistura de CAP+SBS, respectivamente. Percebe-se que com o aumento da proporção de SBS, ocorreu um ganho no valor do ponto de amolecimento e na viscosidade Brookfield a $135^{\circ} \mathrm{C}$. A diferença do ponto 
de amolecimento não segue uma regra, assim como a perda de massa se mantem praticamente constante (varia apenas $0,01 \%$ entre todas as proporções de SBS observadas). Observa-se que com o aumento da concentração de SBS, o ligante asfáltico apresentou claras transformações, como observado na Figura 2.4. Nas imagens percebe-se que com o aumento da concentração de SBS adicionada ao CAP de base, ocorreu o aumento de pontos brancos na imagem, que é o SBS. Para a concentração de $2 \%$ de SBS observa-se uma homogeneização de toda a mistura de CAP + SBS. Para a concentração de $3 \%$ inicia-se o processo de aglomeração de SBS e a formação de diferentes tamanhos de circunferências. Para o teor de $4 \%$ percebe-se o início de uma rede polimérica do SBS. Para os teores de 5 e $6 \%$, pode-se observar uma rede polimérica que visualmente se mostra muito mais resistente que as outras imagens com menores proporções de SBS. (SENGOZ e ISIKYAKAR, 2008).

Tabela 2.1 - Propriedades convencionais de CAP + SBS (SENGOZ e ISIKYAKAR, 2008)

\begin{tabular}{ccccccc}
\hline Propriedade & \multicolumn{5}{c}{ Proporção de SBS } \\
\cline { 2 - 7 } & $\mathbf{0}$ & $\mathbf{2}$ & $\mathbf{3}$ & $\mathbf{4}$ & $\mathbf{5}$ & $\mathbf{6}$ \\
\hline Penetração $(\mathrm{dmm})$ & 63 & 61 & 51 & 49 & 48 & 48 \\
Ponto de amolecimento $\left({ }^{\circ} \mathrm{C}\right)$ & 49 & 50 & 54 & 57 & 67 & 69 \\
Perda de massa $(\%)$ & 0,07 & 0,06 & 0,06 & 0,07 & 0,07 & 0,07 \\
Diferença de ponto de amolecimento após RTFOT $\left({ }^{\circ} \mathrm{C}\right)$ & 2 & 4 & 4 & 2 & 3 & 2 \\
Viscosidade Brookfield a 135 ${ }^{\circ} \mathrm{C}(\mathrm{Pa} . \mathrm{s})$ & 0,51 & 0,55 & 0,62 & 0,76 & 1,20 & 1,50 \\
\hline
\end{tabular}

A viscosidade de CAP + SBS aumentou se comparada ao CAP puro. Percebeu-se que esta propriedade não é diretamente proporcional à quantidade de modificador colocado (LU e ISACSSON, 1997; WEN et al., 2002; LUCENA et al., 2002). A Figura 2.5 ilustra a viscosidade cinemática do trabalho de Lu e Isacsson (1997). Ainda pelo estudo de Lu e Isacsson (1997), observa-se que existem diferenças significativas ao utilizar um SBS com cadeias ramificadas ou cadeias lineares, o que também é ilustrado na Figura 2.5. 


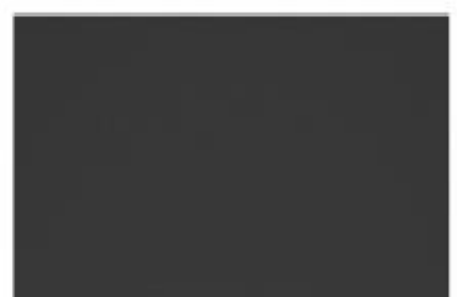

(a) Base bitumen

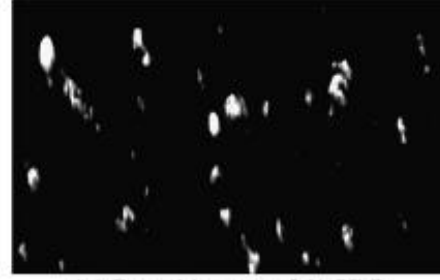

(c) Base bitumen $+3 \%$ SBS

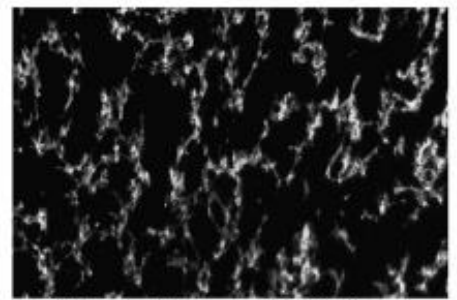

(e) Base bitumen $+5 \%$ SBS

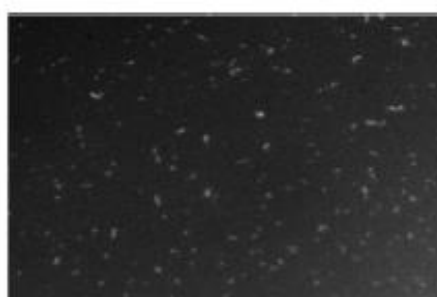

(b) Base bitumen $+2 \%$ SBS

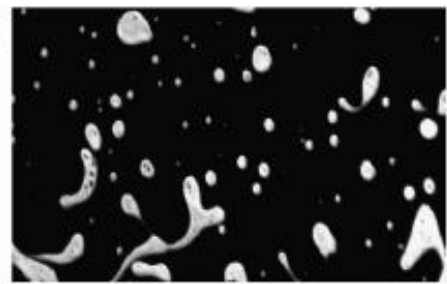

(d) Base bitumen+4\% SBS

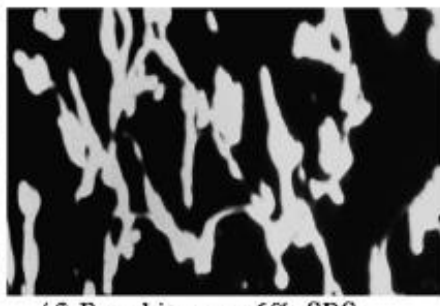

(f) Base bitumen+6\% SBS

Figura 2.4 - Imagens de amostras de CAP+SBS (SENGOZ e ISIKYAKAR, 2008)

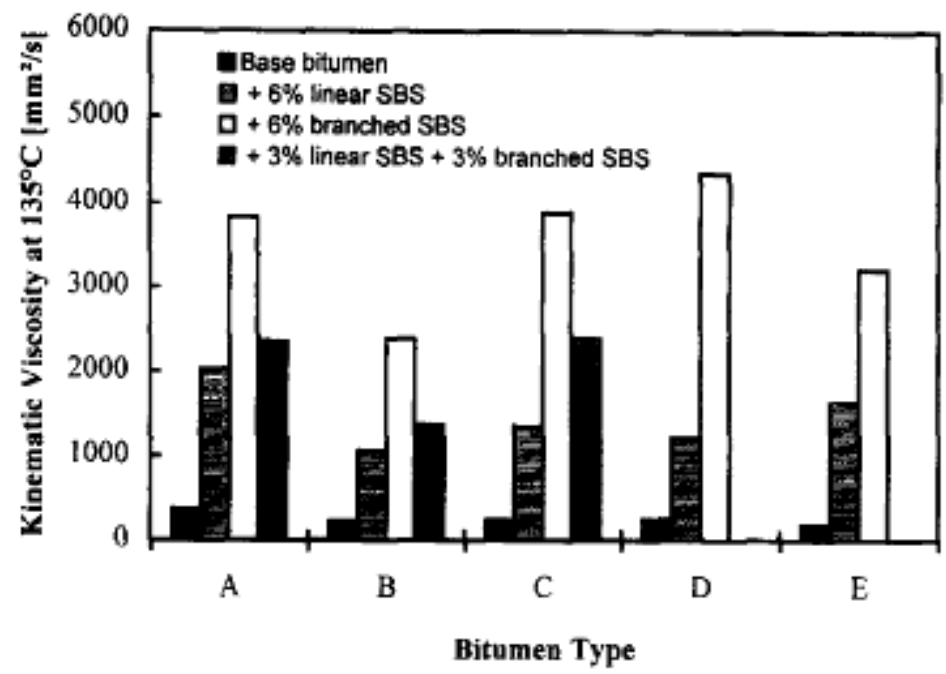

Figura 2.5 - Viscosidade cinemática com diferentes tipos de ligante asfáltico de base com diferentes concentrações de SBS (LU e ISACSSON, 1997)

Lucena et al.(2002) realizou um estudo com ligantes asfálticos modificados com SBS com três teores de SBS: 3,0\%, 4,5\% e 6,5\%. O estudou mostrou que o SBS não é um aditivo 
completamente inerte, isto é, alguma interação deve existir entre as moléculas de SBS e do CAP (LUCENA et al., 2002). Observa-se que o aumento da viscosidade do asfalto modificado não ocorre de uma forma proporcional ao teor de SBS incorporado ao asfalto (LU e ISSACSSON, 1997; WEN et al., 2002; LUCENA et al., 2002). A Figura 2.6 apresenta a viscosidade obtida pelo estudo de Lucena et al. (2002) com o teor de SBS adicionado ao CAP de base. Lucena et al. (2002) constatou que ao se adicionar teores de SBS acima de 3\% em peso no ligante asfáltico, o PG (grau de desempenho) do ligante asfáltico aumenta.

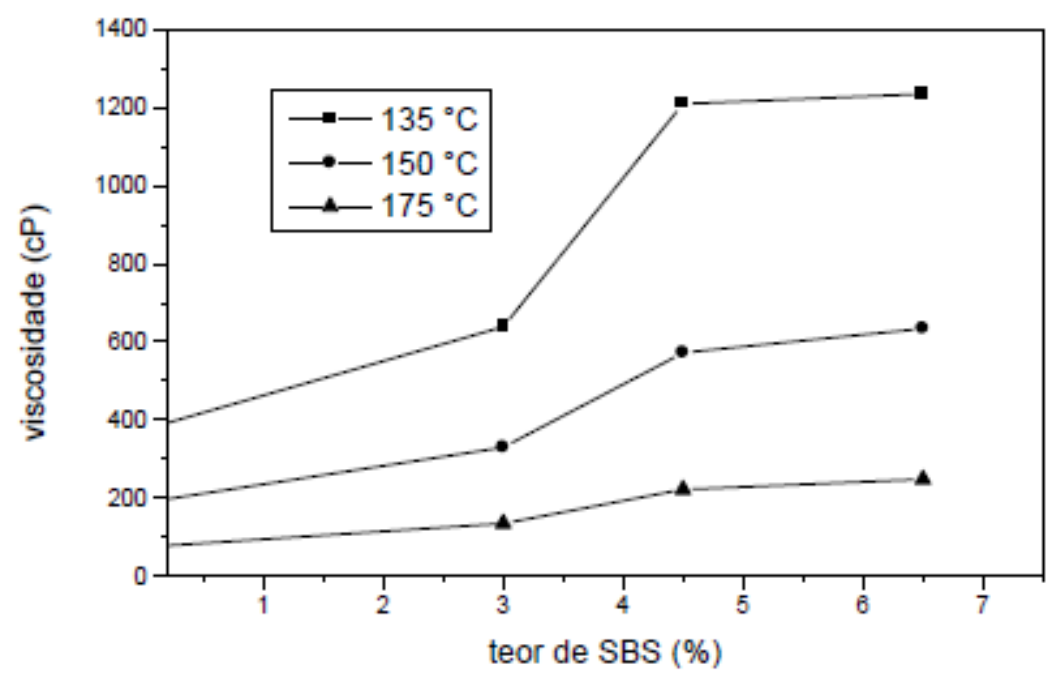

Figura 2.6 - Gráfico de viscosidade versus teor de SBS para as temperaturas de 135, 150 e $175^{\circ} \mathrm{C}$ (LUCENA et al., 2002)

Quanto ao envelhecimento a curto prazo, mais especificamente a análise de deformação permanente da adição de SBS ao ligante asfáltico, tem-se alguns trabalhos realizados. O SBS garante uma melhora no componente elástico ao adicioná-lo no ligante asfáltico de base. $\mathrm{O}$ CAP + SBS possui uma recuperação elástica mais expressiva se comparado com o ligante asfáltico de base. Consequentemente, o problema de deformação permanente sofrida por parte do ligante asfáltico foi reduzido (DOMINGOS, 2011; SOBREIRO, 2014).

O estudo realizado por Domingos (2011) mostrou que o ligante asfáltico modificado com SBS possui resultados superiores do que o CAP puro, na ordem de 5 vezes menor o valor da compliância não-recuperável e possui percentual de recuperação pelo menos 4 vezes maior. O menor valor de compliância não-recuperável e maior valor do percentual de recuperação mostra que o ligante asfáltico com SBS possui uma diferença entre a deformação inicial e final de um ciclo de fluência menor. Logo, ao final de todos os ciclos de fluência, a 
soma das deformações será menor, indicando uma maior tolerância à deformação permanente. Este estudo foi realizado com base entre um CAP 50/70 de classificação e este mesmo CAP com adição de $4,5 \%$ de SBS.

Sobre o efeito do envelhecimento a curto prazo sobre as propriedades convencionais, pode-se destacar que a adição do copolímero SBS no ligante asfáltico de base, em qualquer concentração, reduziu a sua sensibilidade ao envelhecimento, quanto à penetração retida e ao incremento do ponto de amolecimento (DOMINGOS e FAXINA, 2013). Sobre o efeito do envelhecimento a longo prazo, o ponto de amolecimento dos ligantes asfálticos modificados com SBS são resultados superiores aos apresentados pelo ligante asfáltico de base sem modificação (WU et al, 2008). No estudo de Wu et al. (2008), as amostras de CAP + SBS foram envelhecidas pelo período de 500 horas no PAV. Observou-se que o ponto de amolecimento do ligante asfáltico de base aumentou, ao passo que o ponto de amolecimento do CAP + SBS diminuiu após o período de 500 horas. Outro envelhecimento acima de 500 horas mostrou que ambos os materiais tiveram o valor do ponto de amolecimento aumentado. Acredita-se que no ligante asfáltico de base ocorra a formação de mais asfaltenos com alto peso molecular, por causa do processo de envelhecimento. Já no caso do ligante asfáltico modificado com SBS, ocorre a degradação do polímero ao mesmo que tempo em que ocorre a oxidação do ligante asfáltico. A degradação tende a diminuir o valor do ponto de amolecimento e a oxidação tende a aumentá-la. Este comportamento depende do tipo de ligante asfáltico de base empregado e da estrutura do copolímero SBS.

Para baixos níveis de deformação na condição envelhecida a longo prazo, Bahia et al. (1999) constataram um aumento da vida de fadiga ao se adicionar o SBS ao ligante asfáltico de base e no caso de altos níveis de deformação foi constatado uma diminuição da vida de fadiga. Esta conclusão foi obtida por outros pesquisadores como Soenen e Eckmann (2004) e Nuñes (2013). Estas pesquisas mostraram que amostras envelhecidas a longo prazo apresentam maior resistência ao dano por fadiga em baixos níveis de deformação para o ligante asfáltico modificado com SBS se comparado ao CAP de base. Todavia, para altos níveis de deformação, obteve-se o resultado inverso, ou seja, as amostras de ligante asfáltico com o copolímero SBS possuem menor resistência à fadiga do que amostras de ligantes asfálticos puros. Esta característica do SBS em altos e baixos níveis de deformação pode ser explicado através que: a adição de SBS no CAP de base torna o ligante asfáltico mais rígido. Materiais rígidos podem ter excelente comportamento à fadiga, mas no momento que é 
solicitado a altas deformações, ele pode se degradar mecanicamente mais rápido. Segundo Farhri et al. (2013), a vida de fadiga para o caso das misturas asfálticas (CAP modificado com SBS + agregado) ao utilizar um ligante asfáltico modificado com 5\% de SBS se mostrou ser 3 vezes maior do que a vida de fadiga apresentada pelo CAP puro.

Para o caso de baixas temperaturas, em testes realizados por Lu et al. (1998), a adição do copolímero SBS no ligante asfáltico de base apresenta um ganho de temperatura (neste caso, um ganho negativo, ou seja, a temperatura negativa diminui) para o mesmo valor das propriedades de coeficiente angular e módulo de rigidez, obtidas através do ensaio de fluência, realizado no BBR, da especificação Superpave. Os resultados obtidos através da utilização do reômetro de viga (BBR) mostrou que, os valores obtidos com a adição de pelo menos 3\% de SBS resultaram em parâmetros obtidos no ensaio de fluência (coeficiente angular e módulo de rigidez) superiores do que o CAP puro. Lu et al. (1998) estudaram 3 tipos de ligantes asfálticos. Observa-se pela Figura 2.7 que os ligantes asfálticos possuem respostas diferentes. Percebe-se que para um mesmo asfalto, ao se adicionar SBS, a tendência é que a temperatura em que se chega ao valor do módulo de rigidez ( $\mathrm{S}=300 \mathrm{Mpa}$ ) diminua, isso faz com que a adição de SBS ao CAP aumente sua capacidade de suportar as trincas de origem térmicas para temperaturas mais negativas. Apenas o CAP B não apresentou melhora com a adição de SBS.

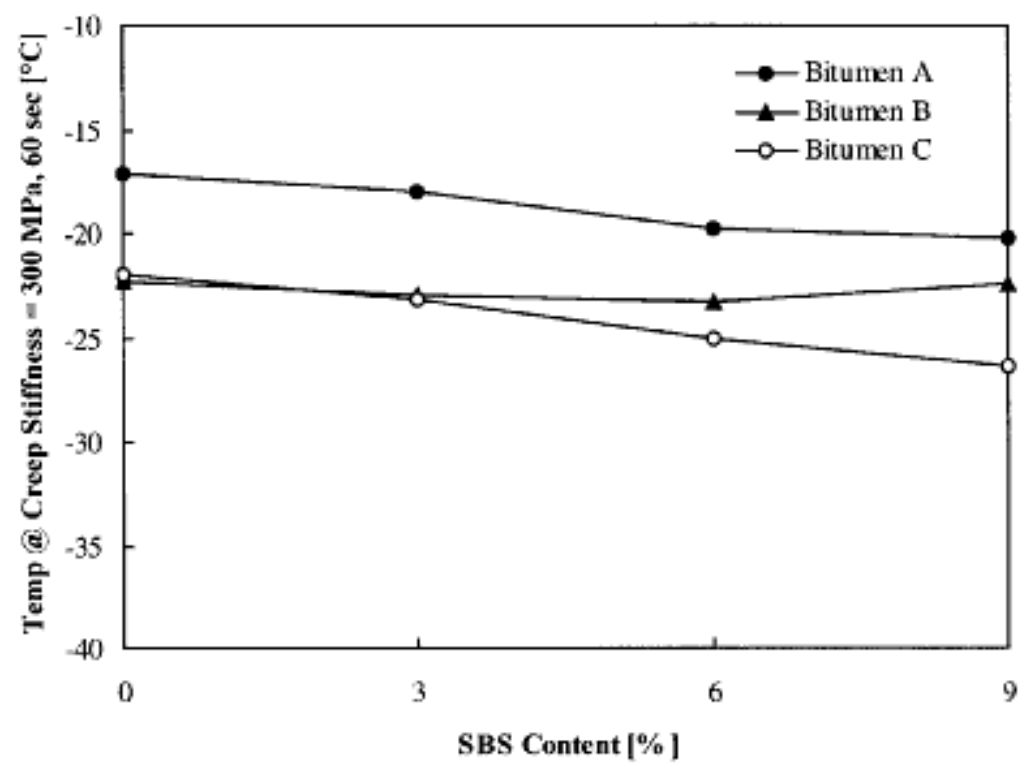

Figura 2.7 - Ensaio BBR com resultados de módulo de rigidez ( $\mathrm{S}=300 \mathrm{MPa})$ para três tipos de ligantes asfálticos com 4 teores de SBS (LU et al. 1998) 
Aflaki e Hajikarimi (2012) realizaram o ensaio de BBR com a adição de três teores de SBS (1, 2 e $3 \%$ em peso) e obteve que apenas a formulação com $2 \%$ de SBS alcançou um limite inferior de $1,1^{\circ} \mathrm{C}$ em comparação com o CAP de base utilizado. A temperatura foi de $26,1^{\circ} \mathrm{C}$ para o $\mathrm{CAP}+2 \%$ de SBS em peso.

\subsection{Estabilidade à estocagem dos ligantes asfálticos modificados com o copolímero SBS}

O SBS tem como principal característica sua alta resposta elástica, ou seja, o SBS aumenta a resistência à deformação permanente. Além disso, como já dito anteriormente, possui características de elastômeros termoplásticos. Também demonstra apresentar uma melhor resistência mecânica e de resiliência se comparado ao ligante asfáltico de base (BRINGEL et al., 2007).

Dependendo da origem do asfalto e do SBS, a morfologia da mistura varia: pode haver uma fase contínua de asfalto com partículas de SBS dispersas, uma fase contínua de polímero com glóbulos de asfalto dispersos, ou duas fases contínuas entrelaçadas (YILDIRIM, 2007). É esta formação de uma rede crítica entre o ligante asfáltico e o polímero que propicia um aumento do módulo complexo $\left(\mathrm{G}^{*}\right)$. No entanto, algumas vezes pode ocorrer uma separação entre o polímero e o ligante asfáltico, em virtude da dificuldade de compatibilizar as espécies. Assim, surge a necessidade do uso de um agente compatibilizante, como é o caso de diluentes aromáticos (BRINGEL et al., 2006; YILDIRIM, 2007). O estudo de Carcer et al. (2014) mostrou que a estabilidade à estocagem depende tanto da origem do asfalto quanto a do SBS.

O copolímero SBS é uma macromolécula não polar com baixa densidade e grande peso molecular. $\mathrm{O}$ asfalto é um composto complexo que contém diversos compostos polares e possui densidade alta e peso molecular pequeno. A separação de fases ocorre no armazenamento por causa da diferença de estrutura e propriedade entre o polímero e o CAP. Se adiciona outro modificador ao CAP + SBS de tal modo a melhorar a compatibilidade entre o polímero e o ligante asfáltico, a fim de formar uma estrutura firme e estável (CONG et al., 2005). Cong et al. (2005) propõe que para uma boa compatibilidade do CAP com o SBS (no 
máximo $2^{\circ} \mathrm{C}$ de diferença de topo e fundo do ponto de amolecimento) é que a quantidade de asfalteno presente na mistura final seja no máximo de 10\%. Liang et al. (2015) adicionou SBS e borracha moída e percebeu uma grande separação de fases, ou seja, a adição de SBS e borracha moída não melhorou a estabilidade à estocagem do CAP modificado por estes polímeros.

O ensaio de ponto de amolecimento realizado após a estabilidade à estocagem do asfalto modificado mostra a diferença obtida entre a parte superior da amostra (topo) e a parte inferior da amostra (fundo). Esta diferença geralmente é observada pela diferença de temperaturas do ponto de amolecimento do topo e do fundo. O estudo de Becker et al. (2003) mostra que ao se adicionar SBS em um CAP e ao realizar o ensaio de estabilidade à estocagem, o SBS flutua no ligante asfáltico e a parte do topo possui uma concentração de SBS muito maior que a parte do fundo, ocorrendo a separação de fase. Com a adição de $4 \%$ de SBS, uma diferença no ponto de amolecimento foi registrada de $26,7^{\circ} \mathrm{C}$, com a parte superior com resultado de $84,1^{\circ} \mathrm{C}$ e a parte inferior de $57,7^{\circ} \mathrm{C}$. A Figura 2.8 mostra a diferença entre a parte do topo e do fundo após o ensaio de estabilidade à estocagem de um CAP com 4\% de SBS (BECKER et al., 2003). Percebe-se a parte do topo muito mais clara que a parte do fundo, decorrente da enorme concentração de SBS na parte superior da amostra.
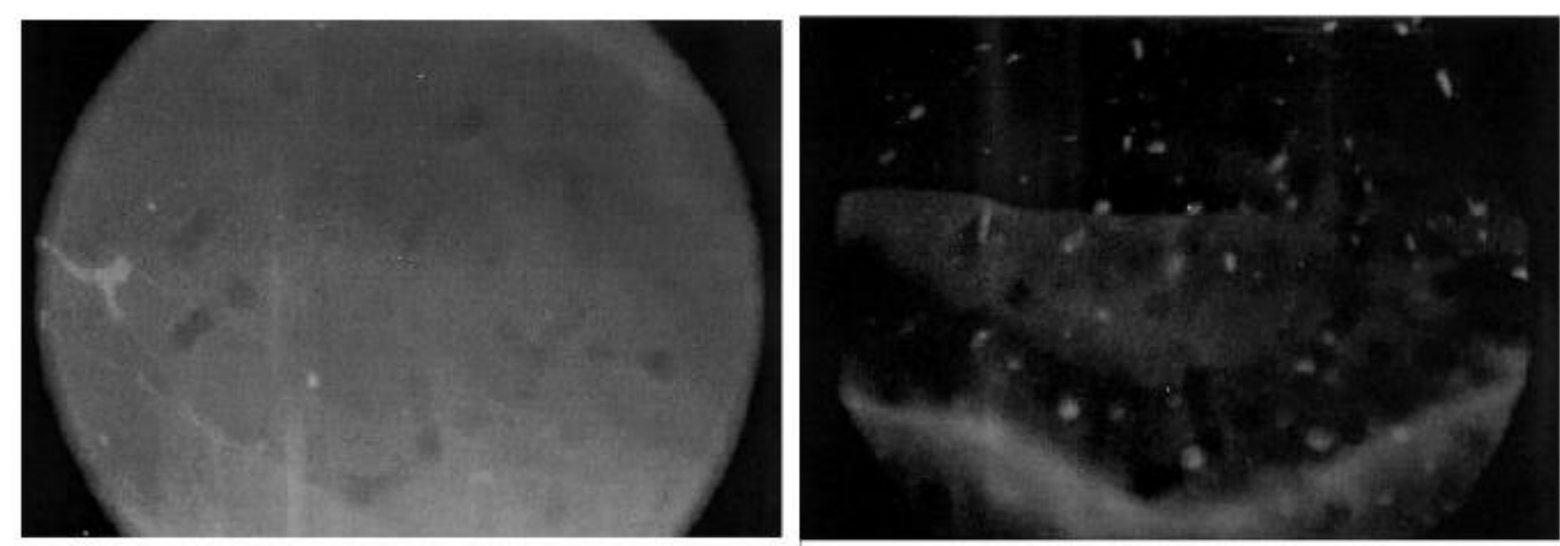

Figura 2.8 - Parte do topo (esquerda) e parte do fundo (direita) após o ensaio de estabilidade à estocagem de CAP + 4\% SBS (BECKER et al., 2003) 


\subsection{Agentes compatibilizantes usados para ligantes asfálticos com SBS}

\subsection{1 Óleo extensor ou óleo aromático}

A compatibilidade entre o ligante asfáltico e o SBS pode ser alcançada por meio da adição de óleo extensor. O óleo extensor é normalmente adicionado ao ligante asfáltico anteriormente à adição do SBS, para amolecer o CAP (MORILHA, 2004). Segundo Faxina (2002), a adição do óleo extensor (ou óleo aromático) pode corrigir a composição química do asfalto, assim favorecendo a reação entre o CAP e o polímero, melhorando a compatibilidade entre eles e levando a viscosidade destes ligantes aos níveis aceitáveis para o uso em serviços de pavimentação. Todavia, uma grande quantidade de óleo aromático acarretará na dissolução dos blocos de poliestireno, acarretando na perda dos benefícios do SBS quando misturado com o ligante asfáltico (AIREY, 2003).

O estudo realizado por Bringel et al. (2006) apresenta resultados da adição de SBS e óleo aromático NP C698/00 ao ligante asfáltico, na frequência de 1,6 Hz. Neste estudo, três amostras foram ensaiadas. A primeira sendo apenas ligante asfáltico de base, a segunda com a adição de 4,5\% de SBS e a terceira com a adição de 4,5\% de SBS e 1,5\% de óleo aromático. A avaliação feita por Bringel et al. (2006) mostra o módulo complexo, ângulo de fase e o parâmetro $\mathrm{G}^{*} / \mathrm{sen}(\delta)$. Observa-se pelas Figuras 2.9 e 2.10 que com a adição de SBS e com a adição de óleo aromático obteve-se um ganho do módulo complexo e do ângulo de fase da mistura de CAP + SBS + óleo, o que causa um aumento do parâmetro G*/sen $(\delta)$. Pela Figura 2.9, nota-se que o óleo aromático causa um aumento do módulo complexo em relação à amostra com apenas SBS na maioria das temperaturas. Acima de $85^{\circ} \mathrm{C}$, percebe-se que a adição de óleo aromático produz um efeito positivo menor do que a amostra com SBS apenas. Para o ângulo de fase, pode-se observar que a amostra de SBS+óleo apresenta valores maiores que a amostra com SBS para todas as temperaturas ensaiadas. Para as temperaturas acima de $70^{\circ} \mathrm{C}$, nota-se que existe uma tendência de elevação do $\delta$ para o SBS+óleo com o aumento da temperatura.

A Figura 2.10 evidencia que para temperaturas até $80^{\circ} \mathrm{C}$, a adição de óleo na mistura de $\mathrm{CAP}+\mathrm{SBS}$ é benéfica em relação a amostra com apenas SBS para o parâmetro $\mathrm{G}^{*} / \operatorname{sen}(\delta)$. 
Acima desta temperatura, as curvas se invertem e a amostra sem a adição de óleo apresenta a melhor resposta. Na comparação com o CAP de base, o parâmetro $G^{*} / \operatorname{sen}(\delta)$ se mostra muito superior para a mistura de CAP + SBS + óleo, no qual se observa um ganho de grau do PG. Ao se associar o parâmetro $\mathrm{G}^{*} / \operatorname{sen}(\delta)$ à deformação permanente, percebe-se que ocorre um aumento da resistência à deformação permanente ao se incorporar o SBS e o óleo aromático ao ligante asfáltico de base (BRINGEL et al., 2006).

Fernandes et al. (2008) apresentou resultados diferentes com a adição do óleo aromático ao CAP + SBS. O óleo causou uma piora das propriedades de ponto de amolecimento e penetração ao se comparar com o CAP + SBS. Diferente de Bringel et al. (2006), esta pesquisa mostra que a adição de óleo aromático (em uma concentração de $4 \%$ em peso) se mostra maléfica para todas as misturas com o CAP e o SBS.
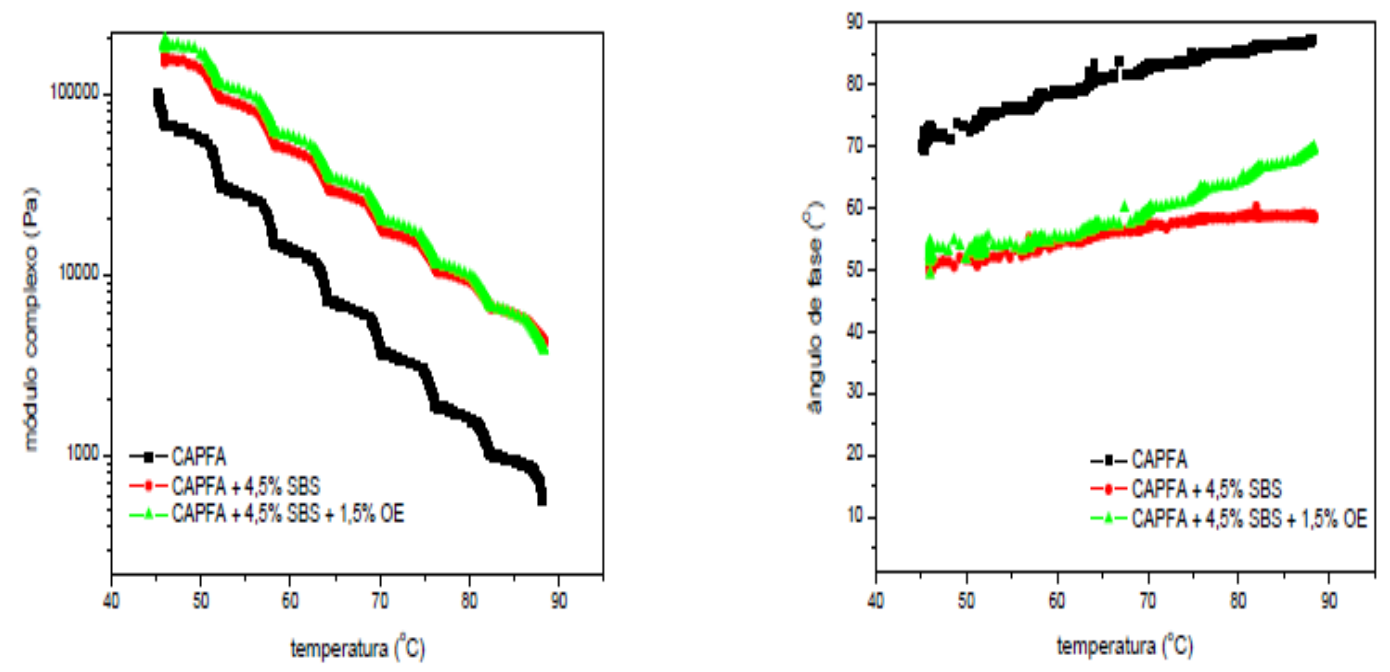

Figura 2.9 - G* e $\delta$ em função da temperatura para as amostras de CAP, CAP + 4,5\% SBS e CAP + 4,5\% SBS + 1,5\% óleo na condição virgem (BRINGEL et al., 2006) 


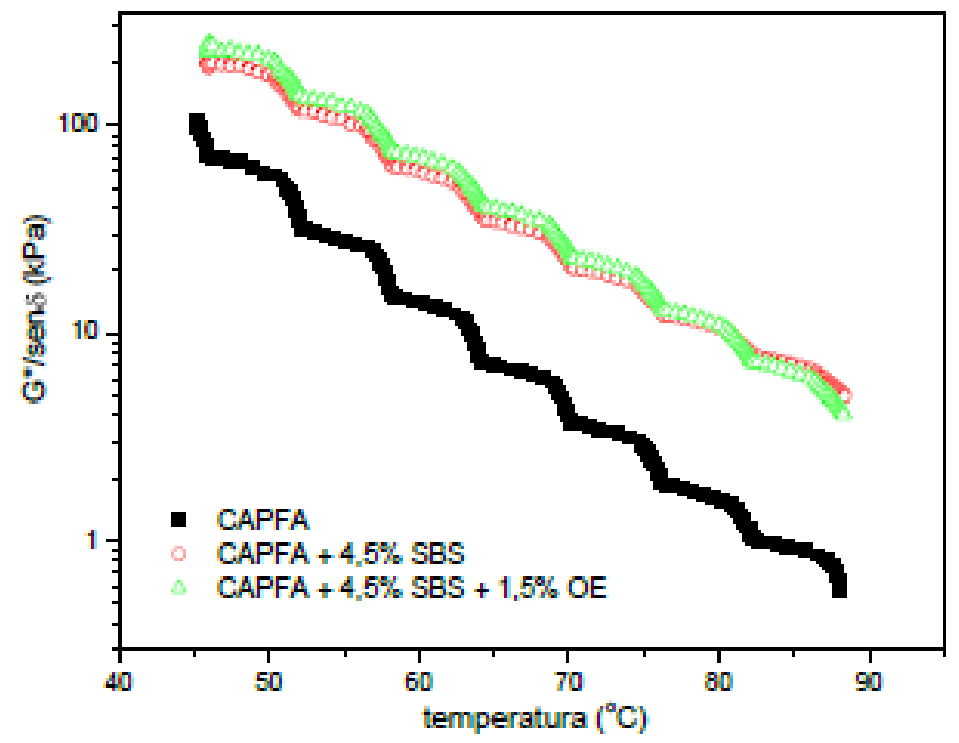

Figura 2.10 - Curvas de $G * / \operatorname{sen}(\delta)$ em função da temperatura para as amostras de CAP, CAP + 4,5\% SBS e CAP + 4,5\% SBS + $1,5 \%$ óleo na condição virgem (BRINGEL et al., 2006)

\subsubsection{Líquido da castanha de caju}

O Líquido da Castanha do Caju (LCC) é constituído de uma mistura de compostos fenólicos extraídos da casca da castanha de caju. O principal componente do LCC é o ácido anacárdico (ácido 3-n-pentadecilsalicílico), um composto aromático com uma cadeia alquilica longa e insaturada, presente em 80-90\%. O cardol (3-n-pentadecilresorcinol), o cardanol (3-npentadecilfenol) e o metilcardol (2-metil-5-n-pentadecilresorcinol) estão presentes em menores quantidades, como se vê na Figura 2.11 (MORAES, 2007). 
<smiles>[R]c1cccc(O)c1C(=O)O</smiles>

ácido anacárdio

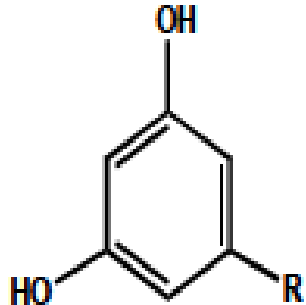

carbol

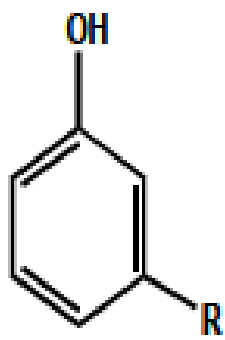

cardanol<smiles>[R]c1cc(O)c(C)c(O)c1</smiles>

2-metilcarbol

Figura 2.11 - Constituintes do líquido da castanha do caju (MORAES, 2007)

Moraes (2007) constatou que o líquido extraído da castanha pode ser utilizado como antioxidante e ser adicionado a combustíveis e lubrificantes. Os antioxidantes são adicionados aos lubrificantes para aumentar sua durabilidade, manter suas propriedades e garantir o bom funcionamento do motor. O LCC tem mostrado aumentar a estabilização da gasolina (DANTAS, 2000; DANTAS et al., 2003).

Em se tratando da pavimentação, os ensaios de caracterização do líquido da castanha de caju demonstraram a viabilidade da sua utilização como diluente asfáltico, devido às suas qualidades antioxidantes, baixo teor residual no aquecimento, alto ponto de ebulição, alto ponto de fulgor $\left(140{ }^{\circ} \mathrm{C}\right)$, além da formação de uma mistura homogênea e sem sedimentação com o cimento asfáltico de petróleo (CAP) (RABÊLO, 2006; MORAES, 2007).

Rodrigues (2010) apresenta resultados obtidos para misturas com 3, 4 e 4,5\% de SBS e a adição de $1 \%$ do liquido da castanha de caju (LCC) nesses 3 teores de SBS. A Tabela 2.2 apresenta os valores para a viscosidade (cP) a $20 \mathrm{rpm}$ na condição virgem e envelhecida a curto prazo. De acordo com Rodrigues (2010) a adição de 1\% do líquido da castanha de caju causa uma diminuição da viscosidade se comparada com o ligante asfáltico modificado com SBS. Isso mostra que o líquido da castanha de caju é um recurso útil para reduzir a viscosidade. A diminuição da viscosidade faz com que a temperatura de usinagem e compactação também diminua, e isto implica em temperaturas menores e menor quantidade de energia utilizada para atingir as temperaturas necessárias. 
Tabela 2.2 - Viscosidade do ligante asfáltico puro e modificado antes e após o RTFOT (RODRIGUES, 2010)

\begin{tabular}{cccc}
\hline \multicolumn{4}{c}{$\begin{array}{c}\text { Viscosidade (cP) } \\
\text { 20 rpm antes/após RTFOT }\end{array}$} \\
\hline Amostra & $\mathbf{1 3 5}^{\circ} \mathbf{C}$ & $\mathbf{1 5 0}^{\circ} \mathbf{C}$ & $\mathbf{1 7 5}^{\circ} \mathbf{C}$ \\
\hline LA 50/70 puro & $523 / 910$ & $253 / 405$ & $095 / 138$ \\
LA + 3\% SBS & $1.100 / 2.088$ & $519 / 850$ & $200 / 288$ \\
LA + 3\% SBS + 1\% LCC & $925 / 1.838$ & $450 / 825$ & $175 / 263$ \\
LA + 4\% SBS & $1.900 / 2.338$ & $863 / 1.075$ & $325 / 363$ \\
LA + 4\% SBS + 1\% LCC & $1.275 / 2.263$ & $625 / 1.038$ & $250 / 350$ \\
LA + 4,5\% SBS & $2.780 / 4.413$ & $1.206 / 1.788$ & $413 / 575$ \\
LA + 4,5\% SBS + 1\% LCC & $1.825 / 2.800$ & $875 / 1.013$ & $344 / 463$ \\
\hline
\end{tabular}

A Tabela 2.3 mostra os valores definidos para as temperaturas de usinagem e compactação para o ligante asfáltico de base (LA), LA + 4\% SBS e LA + 4\% SBS $+1 \%$ LCC. Rodrigues (2010) conclui que ao se adicionar 1\% do líquido da castanha de caju na mistura com $4 \%$ de SBS ocorre uma diminuição da temperatura de usinagem e compactação em torno de 5 e $7^{\circ} \mathrm{C}$, respectivamente.

Tabela 2.3 - Valores de temperatura de usinagem e compactação para as amostras de ligante asfáltico de base, LA + 4\% SBS e LA + 4\% SBS + 1\% LCC (RODRIGUES, 2010)

\begin{tabular}{ccc}
\hline Amostra & $\mathrm{TU}\left({ }^{\circ} \mathrm{C}\right)$ & $\mathrm{TC}\left({ }^{\circ} \mathrm{C}\right)$ \\
\hline LA 50/70 puro & $160-166$ & $147-150$ \\
LA $+4 \%$ SBS & $186-193$ & $175-181$ \\
LA $+4 \%$ SBS $+1 \%$ LCC & $181-186$ & $168-174$ \\
\hline
\end{tabular}

Rodrigues (2010) constata ainda que os ligantes modificados por adição de SBS e SBS + LCC apresentam melhor desempenho que o ligante não modificado em relação aos parâmetros reológicos representativos do grau de desempenho, rigidez (deformação permanente) e elasticidade, como já mostrado por outros autores citados anteriormente.

O LCC atua como aditivo compatibilizante de ligantes modificados por SBS, quando teores maiores do que $4 \%$ de SBS são utilizados. A presença de $1 \%$ de LCC favoreceu a estabilidade à estocagem, medido através da diminuição da diferença do ponto de amolecimento entre o topo e fundo, da mistura com teores de 4 e 4,5\% de SBS. O líquido da castanha de caju supre a fração aromática do ligante, que foi absorvida pelo polímero SBS e, 
deste modo, restabelece a estabilidade coloidal da mistura CAP $+4 \%$ SBS e CAP $+4,5 \%$ SBS, mostrando resultados promissores em relação à estabilidade à estocagem de CAPs modificados por SBS (RODRIGUES, 2010).

Rodrigues (2010) ainda conclui que ocorre aumento no ponto de amolecimento do LA + SBS 4\%, o que indica que o asfalto modificado tende a ser mais resistente à deformação permanente e ainda foi observado que a adição do líquido da castanha de caju diminui essa resistência à deformação permanente.

\subsubsection{Enxofre}

O enxofre como agente de compatibilização entre o CAP e o SBS são estudados há um certo tempo, em especial nos Estados Unidos (WELBORN e BABASHAK, 1958; MALDONADO et al., 1979; PLANCHE, 1990; BELLOMY e MCGINNIS, 1994; WEN et al., 2002; FERNANDES e LOURENÇO, 2006; ZHANG et a., 2010).

A separação de fase pode ocorrer em virtude da diferença de solubilidade e de densidade entre o ligante asfáltico de base e o copolímero SBS. Durante a estocagem da mistura em altas temperaturas, observa-se que algumas partículas do copolímero SBS dispersas no ligante asfáltico flutuam, por terem menor densidade que o ligante asfáltico, fazendo com que ao se avaliar a estabilidade à estocagem do material, pelo ensaio de ponto de amolecimento, os valores apresentados pela parte superior (topo) do material são superiores aos apresentados pela parte inferior (fundo) do material. Isto se deve ao fato da concentração do copolímero SBS ser maior no topo do que no fundo. Quando adicionado enxofre, observase que ocorre uma maior homogeneização do ligante asfáltico modificado com SBS no ensaio de estabilidade à estocagem (WEN et al., 2002).

O estudo de Wen et al. (2002) mostra os benefícios da adição de enxofre ao CAP + SBS. A quantidade de enxofre utilizada foi na proporção de SBS/enxofre igual a 100/5 em peso de enxofre em diferentes teores de SBS (2, 3,5, 5 e 6\%). Para 2\% de SBS adicionou-se $0,1 \%$ de enxofre, para 3,5\% de SBS adicionou-se $0,175 \%$ de enxofre, para $5 \%$ de SBS adicionou-se $0,25 \%$ de enxofre e para $6 \%$ de SBS adicionou-se 0,30\% de enxofre. A Tabela 2.4 apresenta o valor do grau contínuo obtido no estudo de acordo com a concentração de 
SBS em peso adicionada ao CAP de base e a Figura 2.12 apresenta a relação do ponto de amolecimento do topo e fundo, após o ensaio de estabilidade à estocagem. O CAP de base utilizado neste estudo possui as seguintes características: CAP 90 de penetração, ponto de amolecimento de $45^{\circ} \mathrm{C}$ e viscosidade a $135^{\circ} \mathrm{C}$ de $332 \mathrm{~Pa} . s$.

Tabela 2.4 - Efeito da adição de SBS e SBS + enxofre ao CAP de base (WEN et al., 2002)

\begin{tabular}{|c|c|c|}
\hline \multirow{2}{*}{$\%$ de SBS } & \multicolumn{2}{|c|}{ Temperatura de $G * / \operatorname{sen}(\delta)=1 \mathrm{kPa}$} \\
\hline & Sem adição de enxofre & Com adição de enxofre \\
\hline 0,0 & \multicolumn{2}{|c|}{68,3} \\
\hline 2,0 & 74,3 & 76,4 \\
\hline 3,5 & 76,4 & 79,8 \\
\hline 5,0 & 84,1 & 87,8 \\
\hline 6,0 & 87,0 & 90,4 \\
\hline
\end{tabular}

(a)

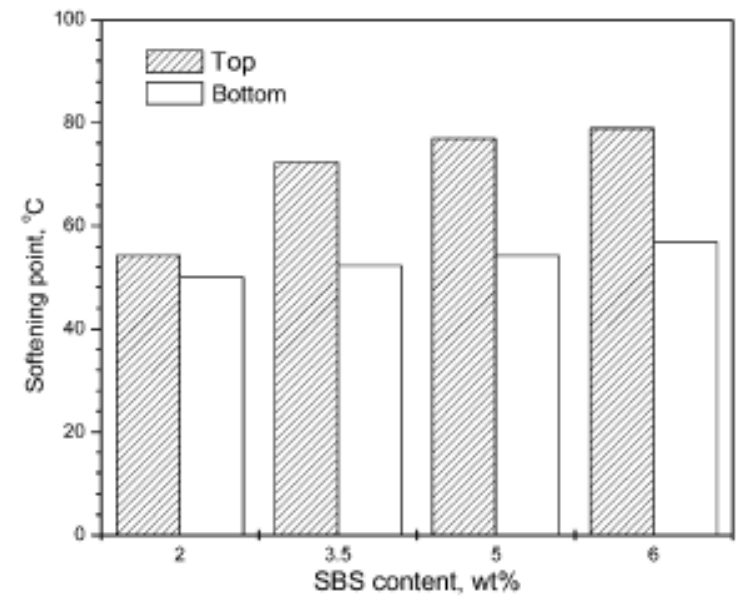

(b)

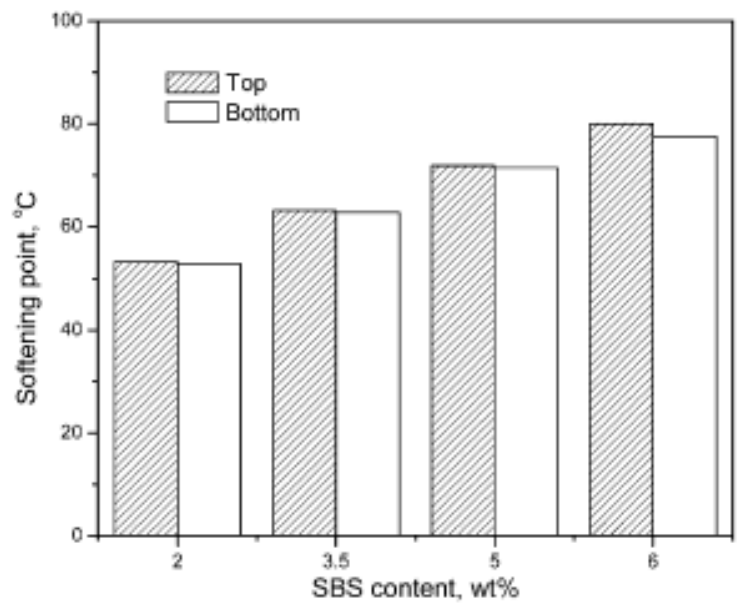

Figura 2.12 - Efeito da adição de enxofre ao CAP+SBS sobre o ponto de amolecimento após o ensaio de estabilidade à estocagem. (a) sem enxofre, (b) com enxofre (WEN et al., 2002)

Para as concentrações de 3,5, 5 e 6\% de SBS sem a adição de enxofre, observa-se que ocorre uma variação do ponto de amolecimento entre topo e fundo de pelo menos $15^{\circ} \mathrm{C}$. Isto mostra que a parte do topo possui uma maior concentração de SBS se comparada com a parte do fundo. A separação de fases neste caso está muito bem evidenciada. Com a adição de enxofre na proporção SBS/enxofre 100/5, percebe-se que o topo e o fundo das misturas apresentam resultados semelhantes pelo resultado obtido através do ensaio de ponto de 
amolecimento (Figura 2.12). A mistura que possui a maior diferença após a adição de enxofre é a mistura contendo $6 \%$ de SBS. Os valores de topo e fundo apresentados ainda diferem um pouco (em torno de $4^{\circ} \mathrm{C}$ ), porém se comparado com a mistura de $6 \%$ de SBS sem a adição de enxofre, (em torno de $22^{\circ} \mathrm{C}$ ) apresenta uma melhora muito significativa (WEN et al. 2002). Com a adição de $\mathrm{SBS}$, ocorre o aumento do grau contínuo do $\mathrm{PG}\left(\mathrm{G}^{*} / \operatorname{sen}(\delta)=1 \mathrm{kPa}\right)$ e com a adição de enxofre ocorre um aumento ainda maior do grau contínuo para a mesma concentração de SBS (aumento em torno de $3^{\circ} \mathrm{C}$ ).

O enxofre é largamente utilizado como agente compatibilizante nos Estados Unidos (FERNANDES e LOURENÇO, 2006). O estudo de Fernandes e Lourenço (2006) mostra a utilização de enxofre como agente compatibilizante entre o CAP+SBS. As Tabelas 2.5 e 2.6 mostram resultados obtidos para os 3 CAPs utilizados (Tabela 2.5) e os efeitos das adições de SBS e enxofre aos CAPs de base (Tabela 2.6). Percebe-se que ocorre a redução da penetração e o aumento da viscosidade do ligante asfáltico em função da adição de SBS e do enxofre. Ao se comparar entre as misturas $\mathrm{A} 1$ com $\mathrm{A} 2 \mathrm{~S}, \mathrm{~B} 1 \mathrm{com} \mathrm{B} 2 \mathrm{~S}$ e $\mathrm{C} 1$ com $\mathrm{C} 2 \mathrm{~S}$, percebe-se que a adição de enxofre ao CAP+SBS aumenta a penetração, exceto para C1 e C2S, aumenta o ponto de amolecimento e aumenta a viscosidade em todas as temperaturas analisadas (FERNANDES e LOURENÇO, 2006).

A Tabela 2.7 mostra a utilização de uma quantidade de 3\% de SBS e 0,09\% de enxofre com um CAP 20. A amostra 3 que possui CAP + SBS + enxofre apresenta o maior intervalo de temperatura possível, ao passo que melhora a temperatura alta do PG em um grau. Portanto, no que diz a algumas características reológicas, a adição de enxofre melhora as características do asfalto modificado com SBS e aumenta a consistência da mistura (FERNANDES e LOURENÇO, 2006).

O estudo realizado por Zhang et al. (2010) conclui que mesmo com a adição do enxofre, outro modificador deve ser utilizado junto ao CAP + SBS para melhorar ainda mais a estabilidade à estocagem.

Tabela 2.5 - Propriedades dos CAPs avaliados (FERNANDES e LOURENÇO, 2006)

\begin{tabular}{cccc}
\hline CAP 50/70 & A & B & C \\
\hline penetração, $\mathbf{d m m}$ & 51 & 50 & 65 \\
ponto de amolecimento, ${ }^{\mathbf{0}} \mathbf{C}^{\mathbf{0}}$ & 50 & 51 & 45 \\
viscosidade Brookfield, cp a $\mathbf{1 3 5}^{\mathbf{C}} \mathbf{C}$ & 450 & 438 & 412 \\
\hline
\end{tabular}


Tabela 2.6 - Resultados de análise das amostras preparadas (FERNANDES e LOURENÇO, 2006)

\begin{tabular}{ccccccc}
\hline Amostra & A1 & B1 & C1 & A2S & B2S & C2S \\
\hline CAP & A & B & C & A & B & C \\
\hline \% de SBS & 3,5 & 3,5 & 3,5 & 3,5 & 3,5 & 3,5 \\
\hline \% de enxofre & 0 & 0 & 0 & 0,05 & 0,05 & 0,05 \\
\hline Propriedade & & & & & & \\
\hline Penetração & 39 & 41 & 51 & 45 & 48 & 49 \\
Ponto de amolecimento ${ }^{\mathbf{O}} \mathbf{C}$ & 53 & 55 & 53 & 64 & 62 & 56 \\
Viscosidade Brookfield, cp a $\mathbf{~ 1 3 5}^{\circ} \mathbf{C}$ & 987 & 888 & 788 & 1.275 & 1.237 & 1.100 \\
Viscosidade Brookfield, cp a $\mathbf{~ 1 4 5}^{\circ} \mathbf{C}$ & 675 & 550 & 562 & 800 & 800 & 700 \\
Viscosidade Brookfield, cp a $\mathbf{1 5 5}^{\circ} \mathbf{C}$ & 487 & 350 & 437 & 538 & 588 & 462 \\
Viscosidade Brookfield, cp a $\mathbf{~ 1 7 5}^{\circ} \mathbf{C}$ & 278 & 215 & 275 & 300 & 313 & 262 \\
\hline
\end{tabular}

Tabela 2.7 - Propriedades reológicas de CAP 20 e CAP 20 modificado (FERNANDES e LOURENÇO, 2006)

\begin{tabular}{|c|c|c|c|}
\hline Amostras & 1 & 2 & 3 \\
\hline$\%$ de SBS & 0 & 3,0 & 3,0 \\
\hline \% de enxofre em relação ao SBS & 0 & 0 & 3,0 \\
\hline PG & $64-16$ & $64-16$ & $70-16$ \\
\hline SHRP High grade & 64 & 64 & 70 \\
\hline SHRP Low grade & -16 & -16 & -16 \\
\hline Temp. virgem de $G^{*} / \operatorname{sen}(\delta)=1,0 \mathrm{kPa}, 10 \mathrm{rad} / \mathrm{s},{ }^{\circ} \mathrm{C}$ & 66,2 & 71,9 & 76,1 \\
\hline Temp. RTFOT de $G * / \mathrm{sen}(\delta)=2,2 \mathrm{kPa}, 10 \mathrm{rad} / \mathrm{s},{ }^{\circ} \mathrm{C}$ & 64,8 & 69,0 & 70,3 \\
\hline Temp. PAV BBR S=300 Mpa a $60 \mathrm{~s},{ }^{\circ} \mathrm{C}$ & $-9,2$ & $-10,3$ & $-11,8$ \\
\hline Temp. PAV BBR m>0,30 a $60 \mathrm{~s},{ }^{\circ} \mathrm{C}$ & $-11,8$ & $-10,8$ & $-15,0$ \\
\hline Temperatura limite superior, ${ }^{\circ} \mathrm{C}$ & 64,8 & 69,0 & 70,3 \\
\hline Temperatura limite inferior, ${ }^{\circ} \mathrm{C}$ & $-19,2$ & $-20,3$ & $-21,8$ \\
\hline Intervalo de temperatura, ${ }^{\circ} \mathrm{C}$ & 84,0 & 89,3 & 92,1 \\
\hline
\end{tabular}

Zhang e Hu (2013) adicionaram tanto enxofre quanto PPA (ácido polifosfórico) as formulações de CAP+SBS. O SBS tipo 1301 foi adicionado 3,5\% em peso ao CAP de base. Outra formulação foi feita com CAP $+3,5 \%$ de SBS em peso $+0,5 \%$ de PPA em peso. Uma terceira formulação com CAP $+3,5 \%$ de SBS em peso $+0,1 \%$ de PPA em peso $+0,5 \%$ de enxofre em peso. Quanto a estabilidade à estocagem, o CAP+SBS teve uma diferença no ensaio de ponto de amolecimento entre o topo e fundo de $60,5^{\circ} \mathrm{C}$. A adição de PPA reduziu esta diferença para $50,1^{\circ} \mathrm{C}$. A adição de PPA e enxofre fez com que a diferença de ponto de amolecimento fosse de $1,6^{\circ} \mathrm{C}$. 
Para as amostras na condição virgem os resultados para o CAP + SBS para o ponto de amolecimento, penetração, viscosidade a $135^{\circ} \mathrm{C}$ e ductilidade a $5^{\circ} \mathrm{C}$ foram $53,2^{\circ} \mathrm{C}, 63 \mathrm{dmm}$, $1.270 \mathrm{cp}$ e $39,1 \mathrm{~cm}$, respectivamente. Para as amostras na condição virgem os resultados para o CAP + SBS + PPA para o ponto de amolecimento, penetração, viscosidade a $135^{\circ} \mathrm{C}$ e ductilidade a $5^{\circ} \mathrm{C}$ foram $59,2^{\circ} \mathrm{C}, 55,7 \mathrm{dmm}, 1.560 \mathrm{cp}$ e $28,4 \mathrm{~cm}$, respectivamente. Para as amostras na condição virgem os resultados para o CAP + SBS + PPA + enxofre para o ponto de amolecimento, penetração, viscosidade a $135^{\circ} \mathrm{C}$ e ductilidade a $5^{\circ} \mathrm{C}$ foram $64,8^{\circ} \mathrm{C}, 64,6$ dmm, $1.845 \mathrm{cp}$ e $28,4 \mathrm{~cm}$, respectivamente. Para os ensaios após envelhecimento a curto prazo, esta tendência se manteve tanto para as formulações que aumentavam ou diminuíam as propriedades analisadas (ZHANG e LU, 2013).

\subsection{4 Ácido Polifosfórico (PPA)}

O estudo de Masson (2008) mostra que o ácido polisfosfórico é um oligômero do ácido fosfórico, sendo que a produção de PPA com alto grau de pureza pode ser realizada tanto pela desidratação do ácido fosfórico quanto pelo aquecimento de pentóxido de fósforo disperso em ácido fosfórico. Masson (2008) apresenta que a adição do PPA a um CAP de base ou um CAP modificado com polímeros não acarreta qualquer tipo de problema de estocagem do ligante asfáltico. A adição de PPA aos ligantes asfálticos apresenta benefícios diferenciados, dependendo da natureza do CAP utilizado. A interação do PPA com a CAP, assim como a maioria dos modificadores, é dependente da composição química do CAP de base (BUNCHER, 2005; DOMINGOS, 2011).

O mecanismo de interação entre o PPA e o ligante asfáltico ainda não é conhecido pelos pesquisadores (BAUMGARDNER et al., 2005; MASSON, 2008; FEE et al., 2010). Fee et al. (2010) sugere que o PPA consegue reagir com vários grupos funcionais do ligante asfáltico, rompendo os aglomerados de asfaltenos e permitindo que as unidades individuais destas moléculas formem uma maior dispersão na fase rica em maltenos. Após esta dispersão, as unidades de asfaltenos apresentam maior capacidade de formar longas redes dentro do ligante asfáltico e, com isso, alteram as características físicas e reológicas do material (DOMINGOS, 2011). 
O SBS é um dos polímeros em que o PPA pode ser utilizado. Para esta modificação, os teores de SBS variam entre 2,5 e 5,0\% em peso e os de PPA, entre $0,2 \%$ e 1,2\% em peso. Nas usinas de ligante asfáltico, as temperaturas de estocagem deste material modificado geralmente estão entre $155^{\circ} \mathrm{C}$ e $177^{\circ} \mathrm{C}$, para o caso da utilização imediata. Nos casos de estocagem por longo prazo, o procedimento é suspender o aquecimento do ligante asfáltico e depois reaquecê-lo vagarosamente até uma temperatura máxima de $177^{\circ} \mathrm{C}$ (ICL PERFORMANCE PRODUCTS LP, 2008; DOMINGOS, 2011).

O estudo de Domingos et al. (2012) traz o efeito da adição do PPA ao CAP com SBS. As Tabelas 2.8 e 2.9 mostram as formulações feitas e os resultados obtidos por meio do ensaio de viscosidade Brookfield, respectivamente. Observa-se que a adição de 0,5\% de PPA faz com que a quantidade de SBS para atingir um PG 76-XX seja diminuída de 4,5\% para $3,0 \%$. Sobre as viscosidades nas temperaturas ensaiadas, percebe-se que apenas na temperatura de $135^{\circ} \mathrm{C}$ ocorre uma diferença considerável de viscosidade (1,34 e 1,20 Pa.s), e que nas outras temperaturas a variação é muito pequena. Isso mostra que para a viscosidade e o PG, um CAP modificado com 4,5\% de SBS possui características semelhantes ao um CAP modificado com 3,0\% de SBS + 0,5\% de PPA (DOMINGOS et al., 2012).

Tabela 2.8 - Formulações do ligante asfáltico e PG (DOMINGOS et al., 2012)

\begin{tabular}{ccccc}
\hline Ligante & & \multicolumn{3}{c}{ Formulações (\% em massa) } \\
asfáltico & PG & CAP & Modificador & PPA \\
\hline $50 / 70$ & $64-X X$ & 100,0 & 0,0 & 0,0 \\
SBS & $76-X X$ & 95,5 & 4,5 & 0,0 \\
SBS+PPA & $76-X X$ & 96,5 & 3,0 & 0,5 \\
\hline
\end{tabular}

Tabela 2.9 - Temperaturas de usinagem, compactação e viscosidades Brookfield nas temperaturas de $135,143,150,163$ e $177^{\circ} \mathrm{C}$ para CAP 50/70, CAP+SBS e CAP+SBS+PPA (DOMINGOS et al., 2012)

\begin{tabular}{|c|c|c|c|}
\hline Propriedade & $50 / 70$ & SBS & SBS+PPA \\
\hline Compactação $\left({ }^{\circ} \mathrm{C}\right)$ & $138-142$ & $167-173$ & $166-172$ \\
\hline Usinagem $\left({ }^{\circ} \mathrm{C}\right)$ & $149-155$ & $180-186$ & $179-185$ \\
\hline Viscosidade Brookfield a $135^{\circ} \mathrm{C}$ (Pa.s) & 0,36 & 1,34 & 1,20 \\
\hline Viscosidade Brookfield a $143^{\circ} \mathrm{C}$ (Pa.s) & 0,24 & 0,76 & 0,78 \\
\hline Viscosidade Brookfield a $150^{\circ} \mathrm{C}$ (Pa.s) & 0,18 & 0,57 & 0,58 \\
\hline Viscosidade Brookfield a $163^{\circ} \mathrm{C}$ (Pa.s) & 0,11 & 0,36 & 0,35 \\
\hline Viscosidade Brookfield a $177^{\circ} \mathrm{C}$ (Pa.s) & 0,07 & 0,21 & 0,21 \\
\hline
\end{tabular}


O estudo de Domingos e Faxina (2013) mostra a adição de PPA ao CAP+SBS no que diz respeito aos ensaios MSCR (referentes à deformação permanente). As Tabelas de $2.10 \mathrm{a}$ 2.12 apresentam alguns dos resultados obtidos do estudo de Domingos e Faxina (2013).

Tabela 2.10 - Formulações dos ligantes asfálticos (DOMINGOS e FAXINA, 2013)

\begin{tabular}{ccccc}
\hline Ligante & & \multicolumn{3}{c}{ Formulações (\% em massa) } \\
asfáltico & PG & CAP & SBS & PPA \\
\hline 50/70 & $64-\mathrm{XX}$ & 100,0 & 0,0 & 0,0 \\
PPA & $76-\mathrm{XX}$ & 98,8 & 0,0 & 1,2 \\
SBS & $76-\mathrm{XX}$ & 95,5 & 4,5 & 0,0 \\
SBS+PPA & $76-\mathrm{XX}$ & 96,5 & 3,0 & 0,5 \\
\hline
\end{tabular}

Tabela 2.11 - Resultados dos ensaios tradicionais dos ligantes asfálticos (DOMINGOS e FAXINA, 2013)

\begin{tabular}{ccccc}
\hline \multirow{2}{*}{ Propriedade ou parâmetro } & \multicolumn{4}{c}{ Ligantes asfálticos } \\
\cline { 2 - 5 } & $\mathbf{5 0 / 7 0}$ & PPA & SBS & SBS+PPA \\
\hline Penetração a $25^{\circ} \mathrm{C}$ virgem $(\mathrm{dmm})$ & 58,0 & 36,5 & 44,5 & 36,3 \\
Penetração a $25^{\circ} \mathrm{C}$ RTFFOT $(\mathrm{dmm})$ & 30,8 & 23,8 & 26,0 & 26,0 \\
Ponto de amolecimento virgem $\left({ }^{\circ} \mathrm{C}\right)$ & 49,4 & 56,8 & 60,8 & 58,9 \\
Ponto de amolecimento RTFOT $\left({ }^{\circ} \mathrm{C}\right)$ & 56,1 & 67,2 & 64,8 & 65,7 \\
Penetração retida $(\%)$ & 53,1 & 65,2 & 58,4 & 71,6 \\
Incremento do ponto de amolecimento $\left({ }^{\circ} \mathrm{C}\right)$ & 6,7 & 10,4 & 4,0 & 6,8 \\
\hline
\end{tabular}

Tabela 2.12 - Níveis de tráfego adequados aos ligantes asfálticos (DOMINGOS e FAXINA, 2013)

\begin{tabular}{cccccc}
\hline Ligante & \multicolumn{5}{c}{ Níveis de tráfego por temperatura $\left({ }^{\circ} \mathbf{C}\right)$} \\
\cline { 2 - 6 } asfáltico & $\mathbf{5 2}^{\circ} \mathbf{C}$ & $\mathbf{5 8}^{\circ} \mathbf{C}$ & $\mathbf{6 4}^{\circ} \mathbf{C}$ & $\mathbf{7 0}^{\circ} \mathbf{C}$ & $\mathbf{7 6}^{\circ} \mathbf{C}$ \\
\hline $50 / 70$ & E & H & S & - & - \\
PPA & E & E & E & V & S \\
SBS & E & E & V & H & S \\
SBS+PPA & E & E & E & H & S \\
\hline
\end{tabular}

A adição de SBS e PPA proporciona uma diminuição da penetração (tanto virgem quanto envelhecido a curto prazo) e um aumento do ponto de amolecimento (tanto virgem quanto envelhecido a curto prazo), como pode ser observado na Tabela 2.11. A Tabela 2.12 apresenta o nível de tráfego adequado para cada temperatura. Percebe-se que com a utilização dos modificadores, o nível de tráfego para as temperaturas de 64 e $70^{\circ} \mathrm{C}$ aumentam se 
comparados com o CAP de base. Para a temperatura de $64^{\circ} \mathrm{C}$, o nível de tráfego antes padrão (CAP de base) passa a suportar um tráfego extremamente pesado ou muito pesado, dependendo do modificador utilizado. Para a temperatura de $70^{\circ} \mathrm{C}$, o nível de tráfego antes inexistente (CAP de base) passa a suportar um tráfego muito pesado ou pesado, dependendo do modificador utilizado (DOMINGOS e FAXINA, 2013).

Ainda segundo Domingos e Faxina (2013), a adição de SBS e PPA faz com que ocorra um aumento dos percentuais de recuperação e uma redução dos valores de compliâncias nãorecuperáveis do CAP de base. O limite de $75 \%$ para o $\mathrm{J}_{\text {nr,diff, }}$, recomendado pela Tabela 3 da norma AASHTO M320 (2009), não foi superado nas temperaturas do PG dos ligantes asfálticos. Isto é um indicativo que estes materiais não possuem uma alta sensibilidade a variações nos níveis de tensões aplicados (100 Pa e $3.200 \mathrm{~Pa})$. Ao se comparar o CAP modificado com SBS e o CAP modificado com SBS e PPA percebe-se que o CAP+SBS+PPA apresenta resultados de $\mathrm{J}_{\mathrm{nr}}, \mathrm{R}$ e $\mathrm{J}_{\mathrm{nr} \text {,diff }}$ melhores que o $\mathrm{CAP}+\mathrm{SBS}$. Isto faz com que o CAP modificado com SBS e PPA possua melhor desempenho à deformação permanente que o CAP+SBS, mesmo que a mistura com PPA apresente apenas $3 \%$ de SBS, ou seja, $1,5 \%$ de teor a menos que a mistura $\mathrm{CAP}+\mathrm{SBS}$.

O estudo de Nuñes (2013) mostra a modificação do CAP com SBS e PPA nas concentrações usadas por Domingos e Faxina (2013). Tem-se o ligante asfáltico de base 50/70, o CAP $+4,5 \%$ SBS e o CAP $+3 \%$ SBS + 0,5\% PPA. Nuñes (2013) analisa resultados obtidos por parâmetros obtidos após o ensaio LAS, nas condições de envelhecimento a curto e a longo prazo, nas temperaturas de 25 e de $35^{\circ} \mathrm{C}$.

Os resultados obtidos da caracterização reológica na região de viscoelasticidade linear e da varredura de amplitude de deformação são utilizados para ajustar um modelo de fadiga do ligante asfáltico, utilizando o princípio de dano contínuo viscoelástico. Para a caracterização da fadiga em ligantes asfálticos, o modelo é derivado da relação entre a carga aplicada e a vida de fadiga do material. Misturas asfálticas e ligantes asfálticos demonstram apresentar uma boa relação entre a carga aplicada e a vida de fadiga $\left(\mathrm{N}_{\mathrm{f}}\right)$ de acordo com a Equação 2.1 (PAMPLONA et al., 2014):

$$
N_{f}=A\left(\gamma_{M A ́ X}\right)^{B}
$$


onde os parâmetros A e B são característicos do material e $\gamma_{M A ́ X}$ é a deformação máxima esperada para uma dada estrutura do pavimento.

A Tabela 2.13 apresenta um pedaço do estudo de Nuñes (2013). De uma maneira geral, percebe-se que sob baixas deformações $\left(\mathrm{N}_{\mathrm{f}} 3 \%\right)$, a adição do PPA ao SBS é benéfica, o que indica que este modificador incorporado ao SBS apresenta maiores ganhos para a vida de fadiga. Se for considerar uma alta deformação $\left(\mathrm{N}_{\mathrm{f}} 30 \%\right)$, percebe-se que o CAP puro apresenta a maior vida de fadiga. Ao comparar o SBS e SBS + PPA, nota-se que o SBS, neste caso, apresenta resultados superiores de vida de fadiga.

$\mathrm{Na}$ temperatura de $25^{\circ} \mathrm{C}$, percebe-se que em baixas deformações, os melhores resultados obtidos para a mesma mistura de ligante asfáltico é observada sob as condições envelhecidas a longo prazo. $\mathrm{Na}$ temperatura de $35^{\circ} \mathrm{C}$, percebe-se que em baixas deformações, os melhores resultados obtidos para a mesma mistura de ligante asfáltico é observada sob as condições envelhecidas a longo prazo, exceto para o CAP $+\mathrm{SBS}$. Na temperatura de $25^{\circ} \mathrm{C}$, percebe-se que em altas deformações, os melhores resultados obtidos para a mesma mistura de ligante asfáltico é observada sob as condições envelhecidas a curto prazo. $\mathrm{Na}$ temperatura de $35^{\circ} \mathrm{C}$, percebe-se que em altas deformações, os melhores resultados obtidos para a mesma mistura de ligante asfáltico é observada sob as condições envelhecidas a curto prazo (NUÑES, 2013).

$\mathrm{Na}$ condição envelhecida a curto prazo, percebe-se que tanto para baixas e altas deformações, os melhores resultados obtidos para a mesma mistura de ligante asfáltico é observada para a temperatura de $35^{\circ} \mathrm{C}$. Na condição envelhecida a longo prazo, percebe-se que tanto para baixas e altas deformações, os melhores resultados obtidos para a mesma mistura de ligante asfáltico é observada para a temperatura de $35^{\circ} \mathrm{C}$ (NUÑES, 2013).

Tabela 2.13 - Resultado de vida de fadiga (NUÑES 2013)

\begin{tabular}{|c|c|c|c|c|c|c|c|c|}
\hline \multirow[b]{2}{*}{$\begin{array}{c}\text { Ligante } \\
\text { asfáltico }\end{array}$} & \multicolumn{2}{|c|}{ RTFOT $-25^{\circ} \mathrm{C}$} & \multicolumn{2}{|c|}{ RTFOT $-\mathbf{3 5}^{\circ} \mathrm{C}$} & \multicolumn{2}{|c|}{ PAV $-25^{\circ} \mathrm{C}$} & \multicolumn{2}{|c|}{ PAV $-35^{\circ} \mathrm{C}$} \\
\hline & $\begin{array}{c}\mathbf{N f} \\
(3 \%)\end{array}$ & $\begin{array}{c}\mathbf{N f} \\
(30 \%)\end{array}$ & $\begin{array}{c}\mathbf{N f} \\
(3 \%)\end{array}$ & $\begin{array}{c}\mathbf{N f} \\
(30 \%)\end{array}$ & $\begin{array}{c}\mathbf{N f} \\
(3 \%)\end{array}$ & $\begin{array}{c}\mathbf{N f} \\
(30 \%)\end{array}$ & $\begin{array}{c}\mathbf{N f} \\
(3 \%)\end{array}$ & $\begin{array}{c}\mathbf{N f} \\
(30 \%)\end{array}$ \\
\hline $50 / 70$ & 4.624 & 7 & 12.221 & 56 & 5.852 & 3 & 13.329 & 27 \\
\hline SBS & 7.672 & 5 & 21.694 & 35 & 9.788 & 2 & 21.013 & 18 \\
\hline SBS+PPA & 8.127 & 4 & 25.231 & 29 & 12.742 & 1 & 26.718 & 8 \\
\hline
\end{tabular}

Xiao et al. (2014), utilizou dois CAPs de bases com PGs 64-22 e adicionou 3\% de SBS e posteriormente adicionou PPA. Para o CAP+SBS+PPA, a concentração de SBS diminuiu para $2 \%$ em peso e a concentração de PPA foi de $0,5 \%$ em peso. Para o ensaio de viscosidade 
Brookfield foi constatado que a viscosidade do CAP+SBS foi relativamente menor do que o CAP+SBS+PPA (1.700 cp para $2.000 \mathrm{cp})$. O grau de desempenho do ligante asfáltico mostrou que a relação $\mathrm{G}^{*} / \operatorname{sen}(\delta)=1 \mathrm{kPa}$ para a formulação de $\mathrm{CAP}+\mathrm{SBS}\left(79^{\circ} \mathrm{C}\right.$ para o primeiro tipo de CAP de base e $77^{\circ} \mathrm{C}$ para o segundo tipo de CAP de base) foi menor que a formulação de $\mathrm{CAP}+\mathrm{SBS}+\mathrm{PPA}\left(81^{\circ} \mathrm{C}\right.$ para o primeiro tipo de $\mathrm{CAP}$ de base e $79^{\circ} \mathrm{C}$ para o segundo tipo de CAP de base). A adição de PPA porém não conseguiu elevar o PG que já se encontrava em $76^{\circ} \mathrm{C}$. Ainda neste estudo, observou-se que a formulação de CAP+SBS obteve uma maior redução do ângulo de fase do que a formulação que apresentava PPA. Para os dois tipos de CAP de base, a adição de PPA resultou em um aumento em torno de $8^{\circ} \mathrm{C}$ do ângulo de fase.

\subsubsection{Argila}

Alguns estudos com a adição de argilas e seus derivados mostram que ela pode reduzir a incompatibilidade do CAP com o SBS. As argilas podem melhorar a estabilidade à estocagem dos ligantes asfálticos modificados com o copolímero SBS (OUYANG et al., 2005; GALOOYAK et al., 2009; EL-SHAFIE et al., 2012; MERUSI et al., 2012).

O estudo realizado por Ouyang et al. (2005) apresenta a adição de caulinita ao CAP + SBS na tentativa de melhorar a estabilidade à estocagem. Percebe-se pela Tabela 2.14 que os resultados de diferenças de viscosidade Brookfield a $135^{\circ} \mathrm{C}$ e ponto de amolecimento do topo e do fundo mostram que a adição de uma quantidade de 1,2\% de caulinita em peso consegue melhorar a estabilidade à estocagem do CAP 90 de penetração com 4\% de SBS. As concentrações de 0,4 e $2 \%$ de caulinita mostram que o efeito para a estabilidade à estocagem piora nestes teores. O teor de $0,4 \%$ aparentemente se mostra uma modificação muito pequena de caulinita para produzir algum efeito positivo e o teor de $2 \%$ se mostra uma modificação muito alta, e produz resultados insatisfatórios, mas interessantes. Com $2 \%$ de proporção de caulinita a maior viscosidade e ponto de amolecimento se encontram no fundo da amostra, não observado antes para nenhum outro tipo de modificador. 
Tabela 2.14 - Viscosidade Brookfield a $135^{\circ} \mathrm{C}$ e ponto de amolecimento do topo e fundo de misturas de CAP + SBS + caulinita (OUYANG et al., 2005)

\begin{tabular}{ccccc}
\hline Material / propriedades & \multicolumn{4}{c}{ Formulações / valores } \\
\hline CAP & 96,0 & 95,6 & 94,8 & 94,0 \\
SBS/caulinita & $4 / 0$ & $4 / 0,4$ & $4 / 1,2$ & $4 / 2$ \\
Viscosidade do topo a $135^{\circ} \mathrm{C}$ (Pa.s) & 0,88 & 0,93 & 0,87 & 0,58 \\
Viscosidade do fundo a $135^{\circ} \mathrm{C}(\mathrm{Pa} . \mathrm{s})$ & 0,70 & 0,76 & 0,85 & 1,05 \\
Proporção de viscosidade & 1,25 & 1,22 & 1,03 & 0,56 \\
Ponto de amolecimento topo $\left({ }^{\circ} \mathrm{C}\right)$ & 59,5 & 64,0 & 58,2 & 52,5 \\
Ponto de amolecimento fundo $\left({ }^{\circ} \mathrm{C}\right)$ & 51,0 & 53,0 & 58,0 & 84,5 \\
Diferença Topo - fundo $\left({ }^{\circ} \mathrm{C}\right)$ & 8,5 & 11,0 & 0,2 & $-32,0$ \\
\hline
\end{tabular}

A adição de nano argila é estudada por Galooyak et al. (2009). Neste estudo utilizou-se um CAP 85/100 de penetração com 5\% de SBS. O teor de adição da nano argila foi da relação SBS/argila $=100 / 35,100 / 50$ e 100/65 em peso. As Tabelas 2.15 a 2.18 apresentam resultados reológicos empíricos e fundamentais do estudo de Galooyak et al. (2009).

Tabela 2.15 - Propriedades físicas do CAP + SBS + argila (GALOOYAK et al., 2009)

\begin{tabular}{cccccc}
\hline Propriedades & CAP base & \multicolumn{4}{c}{ SBS/nano argila } \\
\cline { 2 - 6 } & & $\mathbf{1 0 0 / 0}$ & $\mathbf{1 0 0 / 3 5}$ & $\mathbf{1 0 0 / 5 0}$ & $\mathbf{1 0 0 / 6 5}$ \\
\hline Ponto de amolecimento $\left({ }^{\circ} \mathrm{C}\right)$ & 47,2 & 62,5 & 66 & 67,5 & 70,2 \\
Penetração a $25^{\circ} \mathrm{C}(\mathrm{dmm})$ & 85 & 62 & 58,5 & 57,5 & 56,6 \\
Ductilidade a $15^{\circ} \mathrm{C}(\mathrm{cm})$ & 150 & 114 & 111 & 109,5 & 105,5 \\
Ductilidade a $4{ }^{\circ} \mathrm{C}(\mathrm{cm})$ & 4,1 & 28 & 30 & 32 & 29 \\
Recuperação elástica a $25^{\circ} \mathrm{C}(\%)$ & - & 82 & 86 & 87 & 86,5 \\
\hline
\end{tabular}

De uma maneira geral, a adição da argila ao CAP+SBS se mostra positiva. A penetração diminui. Ocorre o aumento do ponto de amolecimento e da recuperação elástica. O grau contínuo da mistura aumenta, mas não a ponto de aumentar de 76 para $82^{\circ} \mathrm{C}$ com a adição de argila na proporção 100/50 de SBS/argila. Quanto ao ensaio de estabilidade à estocagem, a adição de argila faz com que a diferença obtida entre o topo e fundo no ensaio de ponto de amolecimento seja menor do que $1^{\circ} \mathrm{C}$, em todas as misturas que apresentam teores de argila. A mistura que apresenta 100/65 de SBS/argila foi a que obteve o melhor resultado para a estabilidade. Quanto ao envelhecimento a curto prazo, a penetração retida aumentou com a adição de argila. A diferença do ponto de amolecimento depois e antes do envelhecimento com a adição de argila, mostrou se manter mais próximos (diferenças de no máximo de $0,8^{\circ} \mathrm{C}$ ) 
do que a diferença do ponto de amolecimento apresentada pelo CAP puro $\left(4,8^{\circ} \mathrm{C}\right)$ ou $\mathrm{CAP}+$ SBS $\left(2,3^{\circ} \mathrm{C}\right)$ (GALOOYAK et al., 2009).

Tabela 2.16 - Grau contínuo do CAP + SBS + argila (GALOOYAK et al., 2009)

\begin{tabular}{cc}
\hline SBS/nano argila proporção & $\mathbf{T}(\mathbf{G} * / \mathbf{s e n}(\boldsymbol{\delta})=\mathbf{1} \mathbf{~ k P a}$ \\
\hline $100 / 0$ & 76 \\
$100 / 35$ & 79,3 \\
$100 / 50$ & 81,8 \\
$100 / 65$ & 81,7 \\
\hline
\end{tabular}

Tabela 2.17 - Diferenças do ponto de amolecimento do topo e fundo do CAP + SBS + argila (GALOOYAK et al., 2009)

\begin{tabular}{ccccc}
\hline $\begin{array}{c}\text { \% } \\
\text { SBS }\end{array}$ & $\begin{array}{c}\text { SBS/nano argila } \\
\text { proporção }\end{array}$ & $\begin{array}{c}\text { ponto de } \\
\text { amolecimento } \\
\text { (topo) }\end{array}$ & $\begin{array}{c}\text { ponto de } \\
\text { amolecimento } \\
\text { (fundo) }\end{array}$ & $\begin{array}{c}\text { diferenças de } \\
\text { temperatura }\left({ }^{\circ} \mathbf{C}\right)\end{array}$ \\
\hline 5 & $100 / 0$ & 67,7 & 62,5 & 5,2 \\
5 & $100 / 35$ & 66,8 & 66 & 0,8 \\
5 & $100 / 50$ & 69 & 68,6 & 0,4 \\
5 & $100 / 65$ & 70,9 & 71 & $-0,1$ \\
\hline
\end{tabular}

Tabela 2.18 - Penetração retida e aumento do ponto de amolecimento após envelhecimento a curto prazo para CAP + SBS + argila (GALOOYAK et al., 2009)

\begin{tabular}{cccc}
\hline $\begin{array}{c}\text { SBS/nano argila } \\
\text { proporção }\end{array}$ & $\begin{array}{c}\text { penetração retida } \\
\mathbf{a ~ 2 5}^{\mathbf{2}} \mathbf{C}(\boldsymbol{\%})\end{array}$ & $\begin{array}{c}\text { Ponto de } \\
\text { amolecimento } \\
\left({ }^{\mathbf{0}} \mathbf{C}\right)\end{array}$ & $\begin{array}{c}\text { Aumento do ponto de } \\
\text { amolecimento (RTFOT-virgem) }\end{array}$ \\
\hline $0 / 0$ & 65,9 & 52 & 4,8 \\
$100 / 0$ & 68,5 & 64,8 & 2,3 \\
$100 / 35$ & 71,7 & 66,8 & 0,8 \\
$100 / 50$ & 72,2 & 67,9 & 0,4 \\
$100 / 65$ & 73,3 & 69,8 & $-0,4$ \\
\hline
\end{tabular}

O estudo de El-Shafie et al. (2012) comparou a adição da argila e da nano argila nas porcentagens de 2, 4, 6 e $8 \%$ de adição do material em peso. A adição tanto da argila quanto da nano aumentou o ponto de amolecimento do CAP de base de $52^{\circ} \mathrm{C}$ para até $65^{\circ} \mathrm{C}$, na condição de $8 \%$ de nano argila em peso. Em comparação para a mesma quantidade de modificador (exemplo: CAP $+2 \%$ em peso de argila e CAP $+2 \%$ em peso de nano argila), a adição de nano argila aumenta em torno de $3^{\circ} \mathrm{C}$ a mais do que a adição de $2 \%$ de argila. A 
penetração do CAP de base que era de $64 \mathrm{dm}$ de milímetros diminuiu para até $46 \mathrm{dm}$ de milímetros com a adição de $8 \%$ em peso da nano argila. Em comparação para a mesma quantidade de modificador (exemplo: CAP $+2 \%$ em peso de argila e CAP $+2 \%$ em peso de nano argila), a adição de nano argila diminui em torno de $4 \mathrm{dm}$ de milímetros a mais do que a adição de $2 \%$ de argila.

Jahromi e Khoadii (2009) adicionaram dois tipos de argila no CAP de base em concentrações em peso de 2, 4 e $7 \%$. A penetração do primeiro modificador aumentou a penetração, com aumento máximo para a concentração de $4 \%$ em peso. O segundo tipo de argila diminui a penetração de $62 \mathrm{dmm}$ para até $42 \mathrm{dmm}$. Ambos os modificadores aumentaram o ponto de amolecimento, visto que o segundo modificador apresentou um aumento maior. A ductilidade de ambos diminuíram com o aumento da concentração de modificadores adicionada. O CAP de base apresentou uma ductilidade de $126 \mathrm{~cm}$ e para o segundo tipo de argila com $7 \%$ em peso observou-se uma ductilidade de $94 \mathrm{~cm}$.

Merusi et al. (2012) comparou a adição de 6\% de SBS com $4 \%$ de argila e as formulações de CAP + SBS e CAP + argila. Sobre o módulo complexo e ângulo de fase, as melhores respostas foram as formulações com adição de ambos os modificadores (SBS e argila). A adição de argila fez com que o ligante asfáltico modificado apresentou a melhor homogeneidade dentre todas. Jasso et al. (2013) adicionou SBS e argila para ensaios convencionais e ensaios reológicos no ligante asfáltico. Para a penetração, tanto a adição de SBS quanto a adição de argila diminuiu esta propriedade que era de $247 \mathrm{dmm}$ para o CAP de base para até $110 \mathrm{dmm}$ com os modificadores. Em contra partida, para a viscosidade a $135^{\circ} \mathrm{C}$, a adição dos modificadores aumentou a viscosidade em torno de 5 vezes mais. O grau contínuo aumentou de $54^{\circ} \mathrm{C}$ (CAP de base) para até $80,1^{\circ} \mathrm{C}$ em uma mistura com $5 \%$ em peso de SBS. A temperatura intermediária após o envelhecimento a longo prazo diminuiu de $13^{\circ} \mathrm{C}$ (CAP de base) para até $7,1^{\circ} \mathrm{C}$, que era de uma mistura de $2,64 \%$ em peso de SBS e $1,33 \%$ de argila em peso. A adição de ambos os modificadores fizeram com que a temperatura intermediária diminuísse. Para a temperatura baixa de serviço não houve grandes variações com o CAP de base $\left(-26^{\circ} \mathrm{C}\right)$. A variação ficou entre -23 a $-29^{\circ} \mathrm{C}$ com a adição dos modificadores. 


\section{MATERIAIS E MÉTODOS}

Este capítulo é dedicado à descrição dos ensaios de laboratório e dos materiais empregados nesta pesquisa, além da apresentação do planejamento estatístico utilizado. São apresentados também os procedimentos de laboratório para realização do envelhecimento a curto e a longo prazos das amostras, assim como os procedimentos dos ensaios para composição das curvas-mestre. Dentre os ensaios de laboratório realizados estão: ensaios de viscosidade Brookfield bem como os ensaios realizados no reômetro de cisalhamento dinâmico (grau de desempenho, fluência e recuperação sob múltiplas tensões e varredura de amplitude linear). Conforme já destacado na introdução do trabalho, emprega-se o termo misturas em referência à mistura entre ligante asfáltico, óleo aromático, SBS e TITAN, sem qualquer correspondência com o termo mistura asfáltica comumente empregado na área de pavimentação e referente à mistura entre ligante asfáltico e agregados minerais.

\subsection{Delineamento do experimento}

O experimento foi delineado com base na técnica estatística de "experimentos com misturas" (CORNELL, 2002). As amostras são chamadas de "misturas" e os fatores considerados na análise global do experimento são denominados "componentes". Fatores associados ao processamento da mistura, como temperatura, tempo ou velocidade de agitação, são denominados "fatores de processo" ou "variáveis de processo". Embora tais fatores, individualmente ou em associação, possam afetar o comportamento reológico das misturas, optou-se pela condução do experimento com níveis fixos para estes fatores, no intuito de viabilizar a pesquisa com um número de amostras maior que o mínimo (sete para ajustar um modelo cúbico especial com três componentes, segundo Cornell (2002)) e compatível com o período disponível para realização do experimento. O delineamento do experimento pautado apenas pela variação dos componentes e sem a presença de variáveis de processamento está em plena consonância com os objetivos do trabalho.

Os três componentes avaliados são o ligante asfáltico obtido da Refinaria ReplanPetrobras com uma concentração previamente definida de óleo aromático de 4\%, o 
copolímero SBS e o polietileno de alta densidade e baixo peso molecular (com denominação comercial TITAN 9686). Estes materiais serão referenciados como asfalto, SBS e TITAN, respectivamente. As misturas originadas destes materiais podem conter um, dois ou três destes componentes. Misturas primárias são as compostas com apenas um componente, binárias são as misturas compostas com dois componentes e ternárias, as compostas com três componentes. Para este estudo, as misturas possíveis são: (i) primárias: asfalto; (ii) binárias: asfalto+SBS e asfalto+TITAN; (iii) ternárias: asfalto+SBS+TITAN.

Os componentes empregados devem ter uma porcentagem na mistura entre zero e um dado valor de tal forma que o somatório dos três componentes seja igual a um ou $100 \%$. Por esta razão, algumas limitações nas proporções foram impostas para cada um dos componentes. Estas limitações são denominadas "restrições". As proporções arbitradas foram: $0,93 \leq \mathrm{x}_{1} \leq 1,00$ (asfalto); $0,00 \leq \mathrm{x}_{2} \leq 0,05$ (SBS) e $0,00 \leq \mathrm{x}_{3} \leq 0,02$ (TITAN).

A seleção das misturas para composição do espaço amostral também é orientada pela teoria de planejamento com misturas. Para sistemas com três componentes, as restrições devem, preferencialmente, formar uma poligonal com misturas localizadas nos vértices, nos pontos médios dos lados e no centro geométrico da região experimental.

O número de misturas deve ser suficiente para detalhar o espaço amostral e dar suporte ao modelo estatístico escolhido. Os modelos mais usados em planejamento com misturas são os polinomiais de grau um, dois ou três. Para este estudo, foram escolhidas nove misturas e um modelo polinomial de terceiro grau (cúbico especial). A Figura 3.1 mostra o espaço amostral com restrições e as nove misturas escolhidas.

$\mathrm{Na}$ Tabela 3.1 estão indicadas as misturas correspondentes a cada um dos pontos mostrados na Figura 3.1, a identificação da mistura $\left(\mathrm{x}_{1}-\mathrm{x}_{2}-\mathrm{x}_{3}\right)$, a porcentagem de cada componente, as condições de processamento: (i) temperatura $\left({ }^{\circ} \mathrm{C}\right.$ ); (ii) tempo (min); (iii) velocidade de rotação (rpm). Para as misturas que apresentaram os três componentes, o SBS foi o último a ser colocado na mistura, após vinte minutos de agitação entre o asfalto, o óleo e o TITAN. 
Tabela 3.1 - Proporção dos componentes e condições de processamento

\begin{tabular}{|c|c|c|c|c|c|c|c|c|}
\hline \multirow{2}{*}{ mistura } & \multirow[b]{2}{*}{$\begin{array}{c}\text { identificação } \\
\text { da mistura }\end{array}$} & \multicolumn{3}{|c|}{$\begin{array}{l}\text { porcentagem dos } \\
\text { componentes }\end{array}$} & \multicolumn{4}{|c|}{ Condições de processamento } \\
\hline & & asfalto & SBS & TITAN & $\begin{array}{c}\text { temperatura } \\
\left({ }^{\circ} \mathrm{C}\right)\end{array}$ & $\begin{array}{l}\text { tempo } \\
(\text { min) }\end{array}$ & $\begin{array}{l}\text { velocidade } \\
(\mathbf{r p m})\end{array}$ & observação \\
\hline 1 & $100-0-0$ & 100,0 & 0,0 & 0,0 & 135 & 30 & 300 & \\
\hline 2 & $98-0-2$ & 98,0 & 0,0 & 2,0 & 150 & 120 & 440 & \\
\hline 3 & $95-5-0$ & 95,0 & 5,0 & 0,0 & 180 & 120 & 4000 & \\
\hline 4 & $93-5-2$ & 93,0 & 5,0 & 2,0 & 180 & 120 & 4000 & SBS aos 20' \\
\hline 5 & 99-0-1 & 99,0 & 0,0 & 1,0 & 150 & 120 & 440 & \\
\hline 6 & $97,5-2,5-0$ & 97,5 & 2,5 & 0,0 & 180 & 120 & 4000 & \\
\hline 7 & $94-5-1$ & 94,0 & 5,0 & 1,0 & 180 & 120 & 4000 & SBS aos $20^{\prime}$ \\
\hline 8 & $95,5-2,5-2$ & 95,5 & 2,5 & 2,0 & 180 & 120 & 4000 & SBS aos 20 \\
\hline 9 & $95,5-2,5-1$ & 96,5 & 2,5 & 1,0 & 180 & 120 & 4000 & SBS aos $20^{\prime}$ \\
\hline
\end{tabular}

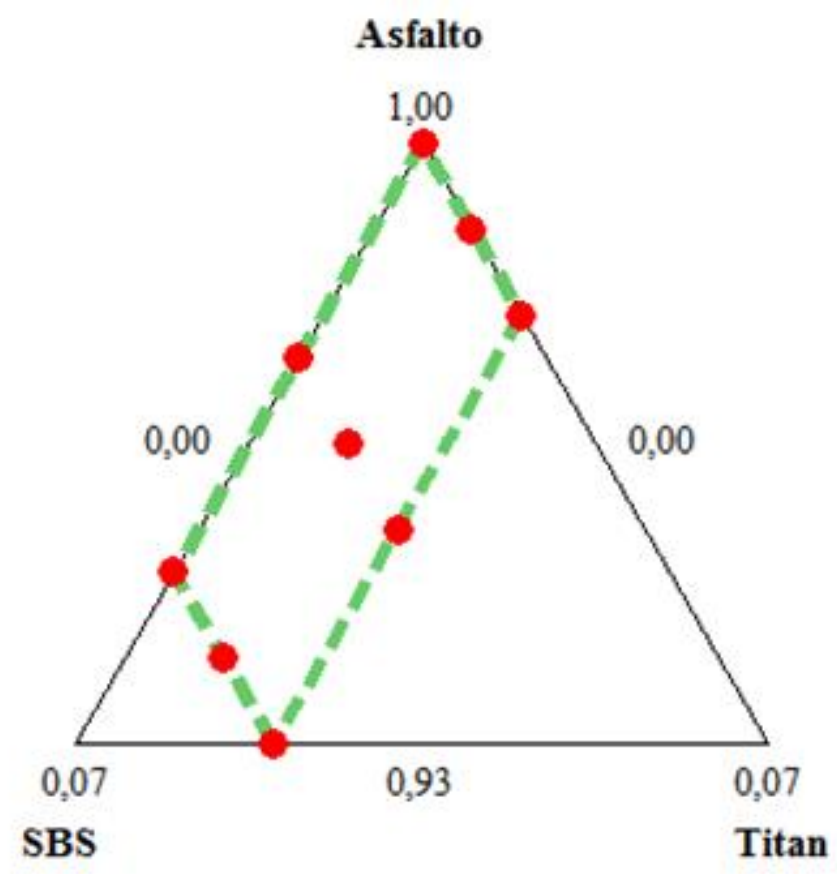

Figura 3.1 - Espaço amostral com restrições e misturas escolhidas 


\subsection{Equipamentos}

Na produção das misturas, foram utilizados dois tipos de misturadores, dependendo da necessidade de agressividade exigida para promover a adequada incorporação dos modificadores. Na produção das misturas asfalto+SBS, foi utilizado o misturador de alto cisalhamento da marca Silverson modelo L4R. Para as misturas que contêm apenas asfalto ou asfalto+TITAN, foi utilizado um misturador de baixo cisalhamento da marca Fisatom, modelo $722 \mathrm{D}$.

O envelhecimento das misturas a curto prazo foi feito na estufa de filme fino rotativo (RTFO), da marca Matest, segundo a norma ASTM D2872-97. O envelhecimento das misturas a longo prazo foi feito na estufa de vaso pressurizado (PAV) da marca Prentex, modelo 9300, segundo a norma ASTM D6521-03a. Na Figura 3.2 e 3.3 são mostradas imagens dos equipamentos utilizados nesta pesquisa. Os ensaios de viscosidade rotacional foram realizados no viscosímetro Brookfield, modelo DV II+Pro, dotado de Thermosel, utilizando o "spindle" 21. O reômetro de cisalhamento dinâmico (DSR) utilizado foi o da marca TA Instruments modelo AR-2000ex. A Figura 3.4 mostra o viscosímetro Brookfield e o reômetro de cisalhamento dinâmico.
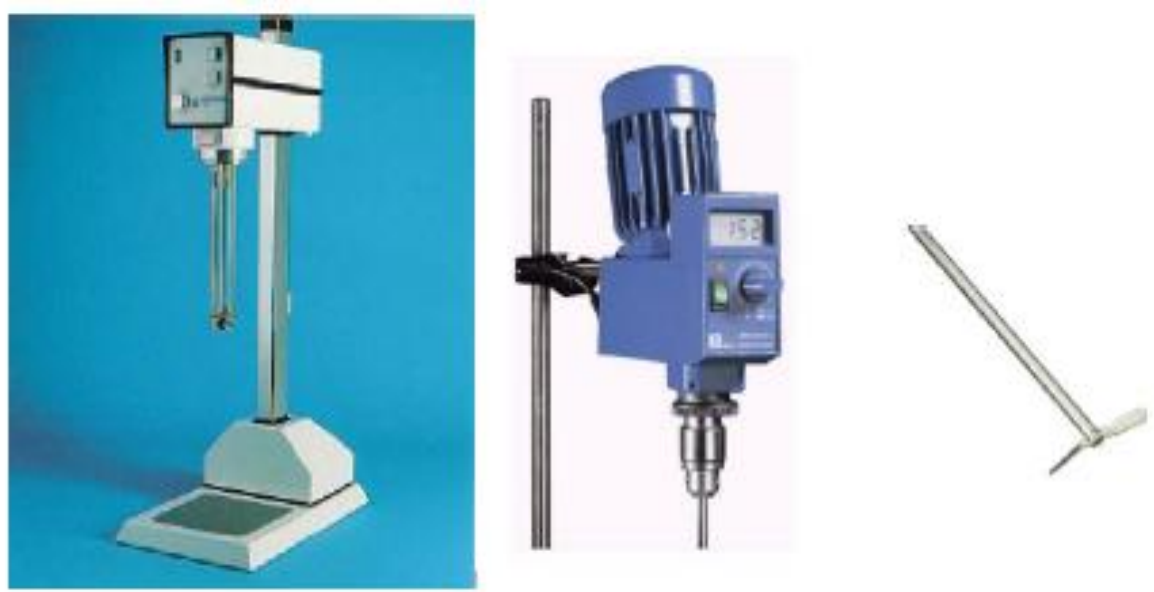

Figura 3.2 - Misturador de alto cisalhamento (esquerda); misturador de baixo cisalhamento (direita) (FAXINA, 2006) 

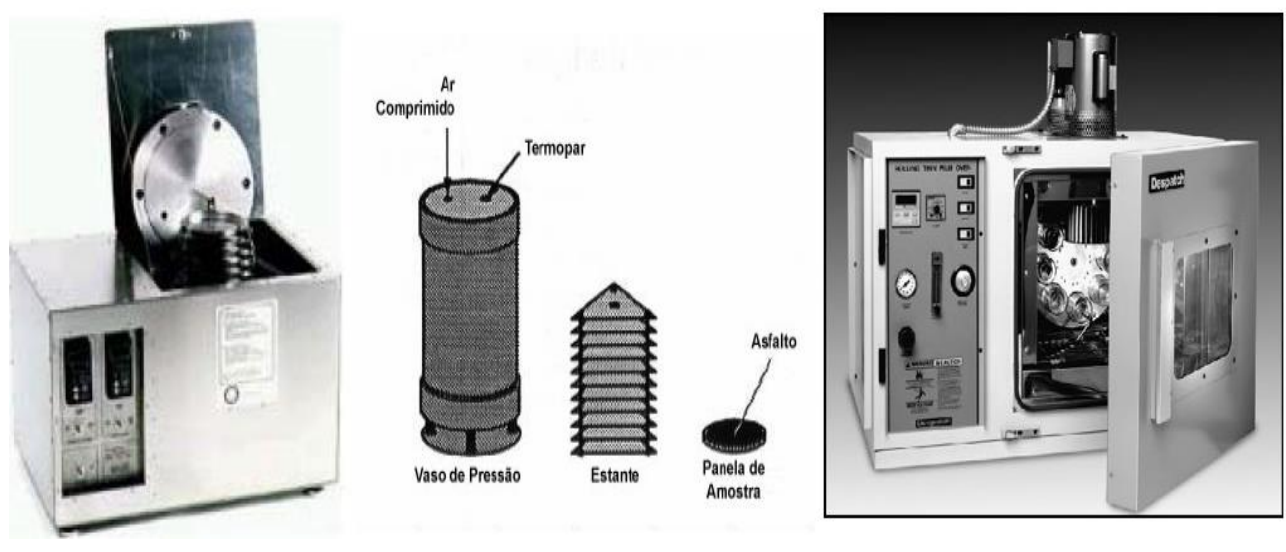

Figura 3.3 - PAV (esquerda); RTFOT (direita) (FAXINA, 2006)
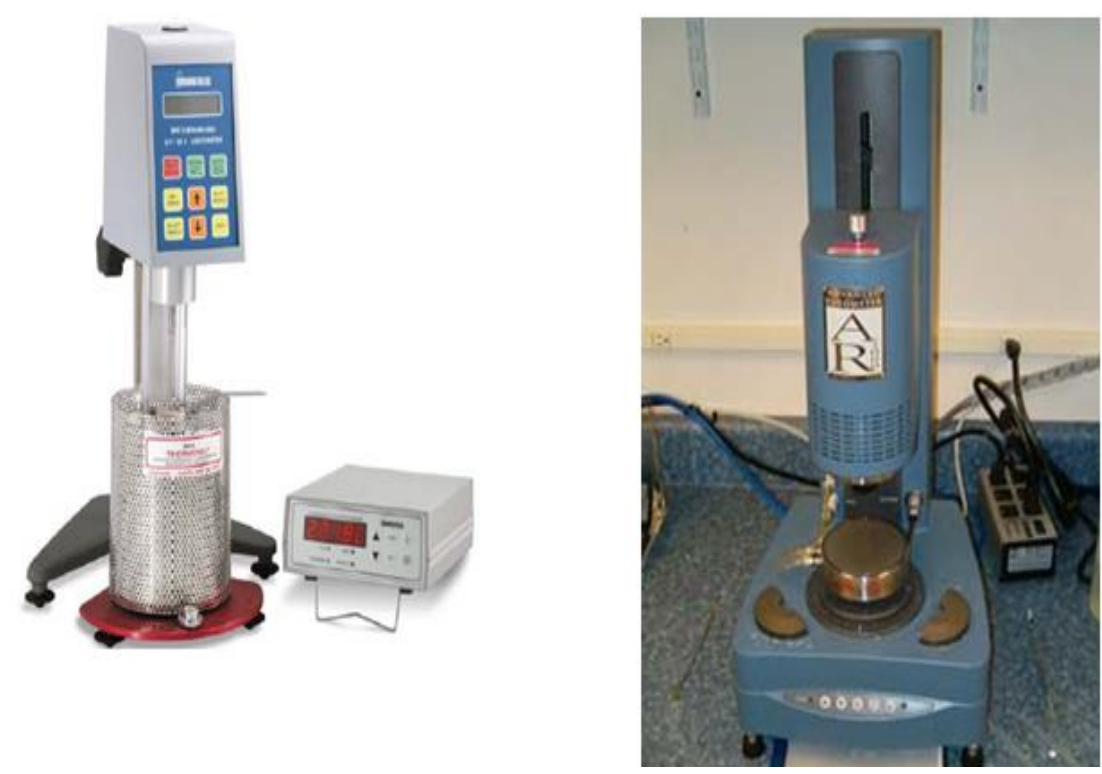

Figura 3.4 - Viscosímetro Brookfield DV II+Pro (esquerda); reômetro de cisalhamento dinâmico (DSR) (direita) (FAXINA, 2006)

\subsection{Ensaios realizados e métodos de ensaio}

Essa seção tem por objetivo o detalhamento dos ensaios realizados e dos procedimentos empregados para a caracterização dos ligantes asfálticos utilizados nesta pesquisa. Para cada ensaio, foram realizados 4 medições por mistura, totalizando 36 medições ou resultados por ensaio. Diferentemente dos demais ensaios, na obtenção das curvas-mestre, foi feita apenas uma réplica. 
3.3.1 Envelhecimento dos ligantes asfálticos a curto prazo em estufa de filme fino rotativo $($ RTFOT)

O envelhecimento a curto prazo em estufa RTFO (Roling Thin-Film Oven) de ligantes asfálticos foi realizado com base na norma ASTM D2872-04 ("Standard test method for effect of heat and air on a moving film of asphalt"). Neste procedimento, um filme móvel de ligante asfáltico é aquecido em estufa por 85 minutos a $163^{\circ} \mathrm{C}$. Os efeitos do calor e do ar são avaliados com base nas alterações observadas em valores de ensaios de caracterização física medidos antes e depois do tratamento e por meio de um procedimento opcional que é indicado para determinação da variação de massa. Esta variação é uma medida do quanto o material volatiliza durante o envelhecimento a curto prazo.

O efeito do envelhecimento deve ser medido por meio de ensaios de caracterização física realizados com material virgem e com o resíduo envelhecido. A variação de massa deve ser reportada com o percentual de massa original. A perda de massa deve ser indicada com sinal negativo e o ganho com sinal positivo. Durante o condicionamento, componentes leves do ligante asfáltico volatilizam, provocando uma diminuição da massa, ao mesmo tempo em que o oxigênio reage com a amostra, causando aumento da massa. O efeito combinado determina se a amostra apresenta perda ou ganho global de massa. Amostras com percentual muito baixo de componentes leves normalmente apresentam ganho, ao passo que amostras com alto teor de voláteis normalmente sofrem perda (FAXINA, 2006).

O resíduo obtido deste condicionamento é empregado em ensaios de viscosidade e outros ensaios reológicos a fim de avaliar as mudanças ocorridas nas propriedades do ligante asfáltico quando submetido a atividades convencionais de usinagem, a temperaturas da ordem de $150^{\circ} \mathrm{C}$. Este procedimento de condicionamento fornece um resíduo que tenta simular as características do ligante asfáltico quando da construção da camada asfáltica. Se a temperatura de usinagem diferir muito de $150^{\circ} \mathrm{C}$, um efeito maior ou menor será observado sobre as características avaliadas.

Em linhas gerais, o método prescreve: (a) aquecer a amostra e verter $35 \pm 0,5$ gramas em cada frasco; (b) permitir o resfriamento da amostra por pelo menos 60 minutos; (c) préaquecer o forno por um período de 16 horas; (d) posicionar os frascos no carrossel e aguardar a estabilização da temperatura e, em seguida, iniciar a contagem do tempo de ensaio (85 
minutos); (e) terminado o condicionamento, retirar os frascos da estufa e armazenar o material destes frascos em um recipiente apropriado; (f) o resíduo deve ser ensaiado até 72 horas após o término do envelhecimento e ser homogeneizado antes da moldagem dos corpos de prova.

3.3.2 Envelhecimento dos ligantes asfálticos a longo prazo em estufa de vaso pressurizado $(P A V)$

O envelhecimento a longo prazo no PAV (Pressure Aging Vassel) foi realizado com base na norma ASTM D6521-03a ("Standard practice for acelerated aging of asphalt binder using a pressurized aging vassel"). Neste ensaio, uma quantidade de $50 \pm 0,5$ gramas oriunda do RTFOT de ligante asfáltico é colocada em pratos de inox e envelhecida a $100^{\circ} \mathrm{C} \pm 0,5^{\circ} \mathrm{C}$ por 20horas \pm 10 minutos em um vaso pressurizado a 2,10 \pm 0,1 $\mathrm{MPa}$ de pressão. Em seguida, removem-se as amostras, que são colocadas em estufa a $163^{\circ} \mathrm{C}$ durante 15 minutos. Em seguida, as amostras são colocadas em estufa a vácuo para a extração de bolhas a $170 \pm 5^{\circ} \mathrm{C}$ por 30 minutos. Após a retirada das bolhas, as amostras podem ser utilizadas para ensaios de caracterização ou podem ser armazenadas para usos futuros.

Este procedimento tem a finalidade de simular o envelhecimento por oxidação que os ligantes asfálticos sofrem durante a vida útil do pavimento. $\mathrm{O}$ resíduo deste condicionamento pode ser usado na estimativa de propriedades físicas ou químicas de ligantes asfálticos após vários anos de envelhecimento em campo, embora não existam correlações entre o tempo de condicionamento no PAV e o tempo equivalente de exposição do material na pista (FAXINA, 2006).

Para ligantes asfálticos de diferentes tipos ou obtidos de petróleos diferentes, não há uma correlação única entre o tempo e a temperatura de envelhecimento nesse procedimento e a idade e a temperatura do pavimento. Portanto, para um dado conjunto de condições climáticas, não é possível selecionar o tempo de condicionamento e de valores de temperatura e nem de pressões comuns que irão simular as propriedades de todos os ligantes asfálticos após um conjunto específico de condições de exposição em campo (FAXINA, 2006).

O grau de endurecimento dos diferentes ligantes asfálticos varia com a temperatura e a pressão no PAV. Dois ligantes asfálticos podem apresentar uma mesma taxa de 
envelhecimento sob uma determinada condição de temperatura e de pressão, mas podem envelhecer diferentemente sob outra condição. Assim, as taxas relativas de envelhecimento para um conjunto de ligantes asfálticos sob as condições simuladas no PAV podem ser significativamente diferentes das taxas relativas reais destes mesmos materiais em serviço se estiverem sujeitos a condições diferentes de temperatura e de pressão (FAXINA, 2006).

Ligantes asfálticos modificados podem apresentar separação de fase ou formação de película durante o condicionamento a curto prazo. Os resultados dos ensaios subsequentes podem não ser representativos do envelhecimento sofrido por estes materiais nas condições de campo. Separação de fase ou formação de película, ou ambas, também podem ocorrer durante o envelhecimento no PAV.

\subsubsection{Estabilidade à estocagem}

O ensaio de estabilidade à estocagem foi realizado conforme especificado pela norma ASTM D5892-00 ("Standard test method for type IV polymer modified asphalt cement for use in pavement construction") com algumas modificações. Este ensaio visa avaliar a compatibilidade entre o polímero empregado e o ligante asfáltico durante estocagem sem agitação sob altas temperaturas. O emprego deste ensaio visa observar a separação de fases no ligante asfáltico modificado com ambos os polímeros envolvidos (SBS e TITAN).

Em linhas gerais, o ensaio compreende em preencher tubos com 50 gramas de amostra, posicionados verticalmente em um raque. Coloca-se o raque com os tubos em estufa a $163 \pm$ $5^{\circ} \mathrm{C}$ durante $48 \pm 1$ hora. Após esse período, o raque com os tubos é colocado em um freezer ou banho a $-6,7^{\circ} \mathrm{C} \pm 5^{\circ} \mathrm{C}$ durante um período mínimo de 4 horas, deixando os tubos sempre na vertical. Em seguida, o raque é removido do resfriamento e os tubos são cortados em 3 partes iguais. A parte superior (topo) e a parte inferior (fundo) são analisadas para observar se houve separação de fase.

A única diferença do ensaio empregado para o descrito em norma foi a realização posterior do tipo de análise. Não foi realizado o ensaio de ponto de amolecimento para comparação entre a parte superior (topo) e a parte inferior (fundo) do tubo de ensaio, mas, sim, uma varredura de frequência em diferentes temperaturas, obtendo-se uma curva mestre 
do material da parte superior e outra da parte inferior, fazendo, assim, a comparação entre os materiais do topo e do fundo.

\subsubsection{Ensaio de viscosidade rotacional (viscosidade Brookfield)}

O ensaio de viscosidade rotacional foi realizado de acordo com a norma ASTM D440206 ("Standard test method for viscosity determination of asphalt at elevated temperatures using a rotacional viscometer"). É empregado um viscosímetro rotacional para a medida da viscosidade rotacional do ligante asfáltico sobre temperaturas elevadas.

As viscosidades foram determinadas utilizando o viscosímetro Brookfield com um controlador de temperatura Thermosel, utilizando o spindle 21. A medida da viscosidade acontece por meio do torque necessário para rodar o spindle imerso na amostra do ligante asfáltico a uma velocidade constante pré-estabelecida. O ensaio foi realizado em 5 temperaturas: (i) $135^{\circ} \mathrm{C}$; (ii) $143^{\circ} \mathrm{C}$; (iii) $150^{\circ} \mathrm{C}$; (iv) $163^{\circ} \mathrm{C}$; (v) $177^{\circ} \mathrm{C}$. A escolha das velocidades em cada temperatura foi feita para respeitar os limites de torque aplicado pelo equipamento e apresentados na norma (entre 10\% e 98\%). As velocidades escolhidas foram de $20 \mathrm{rpm}, 40 \mathrm{rpm}, 60 \mathrm{rpm}, 80 \mathrm{rpm}, 100 \mathrm{rpm}$ para as 5 temperaturas, respectivamente. A variabilidade recomendada pela norma para experimentos sob condições de repetibilidade é de $3,5 \%$ entre os resultados de duas determinações.

A viscosidade é um fator importante nas obras rodoviárias, pois serve para determinar as temperaturas de usinagem e de compactação das misturas asfálticas. Segundo a especificação Superpave, a temperatura de usinagem é aquela em que o ligante asfáltico apresenta uma viscosidade de 0,17 \pm 0,02 Pa.s e a temperatura de compactação é aquela em que o ligante asfáltico apresenta uma viscosidade entre 0,28 \pm 0,03 Pa.s. A Figura 3.5 ilustra o formato de um gráfico de viscosidade versus temperatura e como é feita a determinação das temperaturas de usinagem e de compactação. 


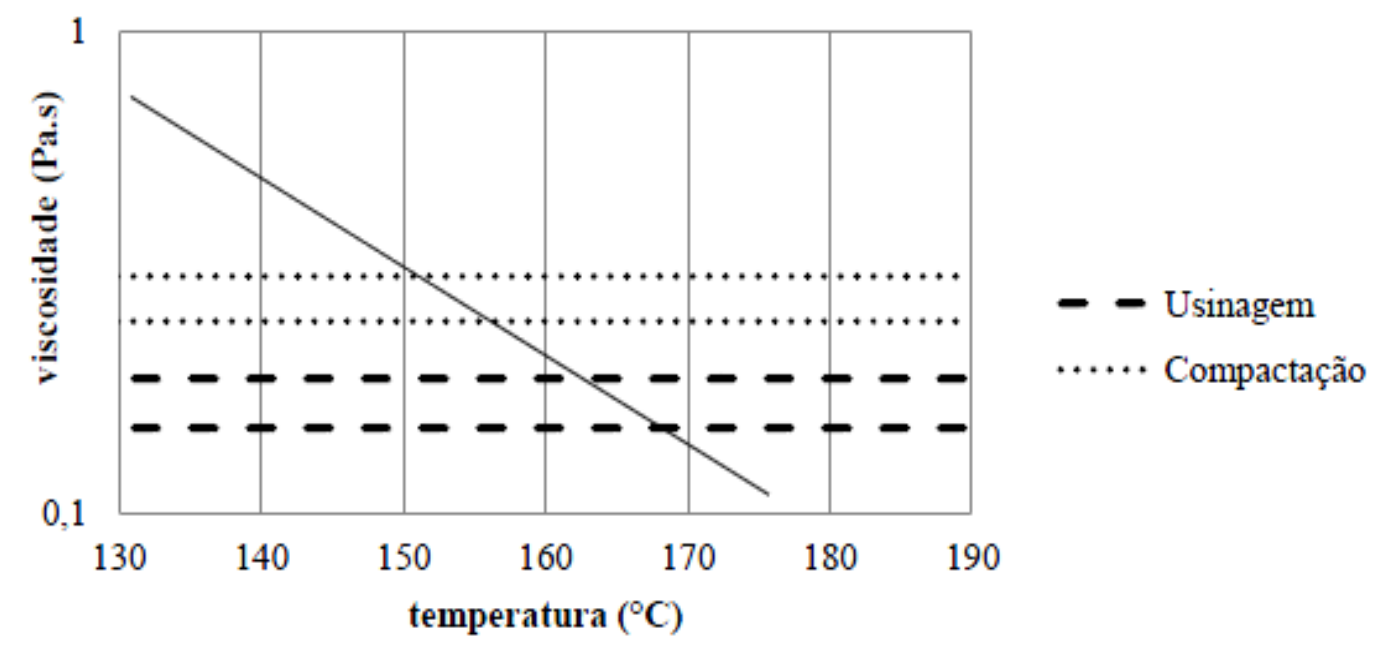

Figura 3.5 - Determinação das temperaturas de usinagem e compactação.

Foram ensaiadas as amostras virgens e também as amostras envelhecidas a curto prazo (RTFOT). O incremento de viscosidade pode ser obtido por meio de uma simples divisão entre a viscosidade a curto prazo e a viscosidade virgem, como mostrado na Equação 3.1. Quanto maior for o valor desta relação, maior será a sensibilidade da mistura ao envelhecimento a curto prazo.

$$
I v=\frac{\text { VRTFOT }}{\text { Vvirgem }}
$$

\subsubsection{Grau de desempenho $(P G)$}

O grau de desempenho das misturas foi obtido utilizando o reômetro de cisalhamento dinâmico, onde foi realizada uma varredura do parâmetro $G^{*} / \operatorname{sen}(\delta)$ para as temperaturas especificadas na norma Superpave $\left(52,58,64,70,76,82,88^{\circ} \mathrm{C}\right)$. As amostras foram classificadas pela Tabela 3 da AASHTO que considera apenas as amostras virgens para determinação do PG.

O método utilizado neste ensaio foi o demonstrado na norma ASTM D7175-05 ("Standard test method for determining the rheological properties of asphalt binder using a dynamic shear rheometer"). Esta norma contém o procedimento para a determinação do 
módulo complexo $\left(\mathrm{G}^{*}\right)$ e do ângulo de fase $(\delta)$, usando o reômetro DSR. Para o caso específico do PG, utiliza-se a geometria de $25 \mathrm{~mm}$ e o espaçamento de $1 \mathrm{~mm}$ entre placas. A frequência de carregamento especificada pela norma é de $10 \mathrm{rad} / \mathrm{s}$.

\subsubsection{Balanço de massa}

O balanço de massa é realizado durante o ensaio de envelhecimento do ligante asfáltico a curto prazo (RTFOT) pela norma ASTM D2872-04 ("Standard test method for effect of heat and air on a moving film of asphalt"). A variação de massa, assim como citada no item 3.3.1, é um indicativo de quanto o material é volátil. Após colocar 35 gramas da mistura no frasco, espera-se o resfriamento do mesmo por pelo menos 60 minutos e anota-se o peso. Após a retirada do frasco da estufa RTFOT, espera-se 60 minutos para a realização da pesagem do material. A perda de massa do material é feita através do peso do material em massa préestufa e do peso do material em massa pós-estufa.

\subsubsection{Ensaio de fluência e recuperação sob tensão múltipla (MSCR)}

O ensaio de fluência e recuperação sob tensão múltipla foi realizado segundo a norma ASTM D7405-10a ("Standard test method for mutiple stress creep and recovery (MSCR) of asphalt binder using a dynamic shear rheometer"). O ensaio foi feito apenas com as amostras envelhecidas a curto prazo (RTFOT).

O ensaio é realizado em dois níveis de tensão para cada temperatura: $100 \mathrm{~Pa}$ e $3200 \mathrm{~Pa}$. As amostras foram ensaiadas até a temperatura dos seus respectivos PGs. Os tempos de carregamento e repouso foram os prescritos em norma, ou seja, 1 segundo e 9 segundos, respectivamente. O número de ciclos foi igual a 10 ciclos para cada nível de tensão. Foi utilizada a geometria de $25 \mathrm{~mm}$ de diâmetro e o espaçamento de $1 \mathrm{~mm}$ entre placas. A variabilidade máxima permitida na norma para os valores de percentual de recuperação $(\mathrm{R})$ nas tensões de 100 e 3.200 Pa são de 6,7\% e 8,5\%, respectivamente. Para a compliância não- 
recuperável, os valores de variabilidade máxima são função dos diferentes níveis de $\mathrm{J}_{\mathrm{nr}}$ e estão descritos na Tabela 3.2 .

Tabela 3.2 - Variabilidades máximas para $\mathbf{J}_{\mathrm{nr}}$ recomendadas pela ASTM D7405-10a

\begin{tabular}{ccc}
\hline Tensão $(\mathrm{Pa})$ & Valores de $\mathrm{J}_{\mathrm{nr}}\left(\mathrm{kPa}^{-1}\right)$ & Variabilidade máxima (\%) \\
\hline 100 & acima de 1,00 & 12,8 \\
100 & entre 0,26 e 1,00 & 15,2 \\
100 & entre 0,10 e 0,25 & 38,3 \\
100 & abaixo de 0,10 & - \\
3.200 & acima de 1,00 & 16,0 \\
3.200 & entre 0,26 e 1,00 & 15,3 \\
3.200 & entre 0,10 e 0,25 & 26,6 \\
3.200 & abaixo de 0,10 & - \\
\hline
\end{tabular}

Duas propriedades são obtidas no MSCR: o percentual de recuperação $(\mathrm{R})$ e a compliância não-recuperável $\left(\mathrm{J}_{\mathrm{nr}}\right)$. Ambas são determinadas por meio de três leituras de deformação na amostra do ligante asfáltico em cada um dos 10 ciclos de fluência e recuperação, sendo elas: (a) uma no início do ciclo de fluência $\left(\varepsilon_{0}\right)$, medida no tempo de 0 segundos; (b) outra no final do ciclo de fluência $\left(\varepsilon_{\mathrm{c}}\right)$, medida no tempo de 1 segundo; e (c) outra no final do ciclo de recuperação $\left(\varepsilon_{\mathrm{r}}\right)$, medida no tempo de 10 segundos. A Figura 3.6 ilustra a localização destas deformações em um ciclo de fluência e recuperação.

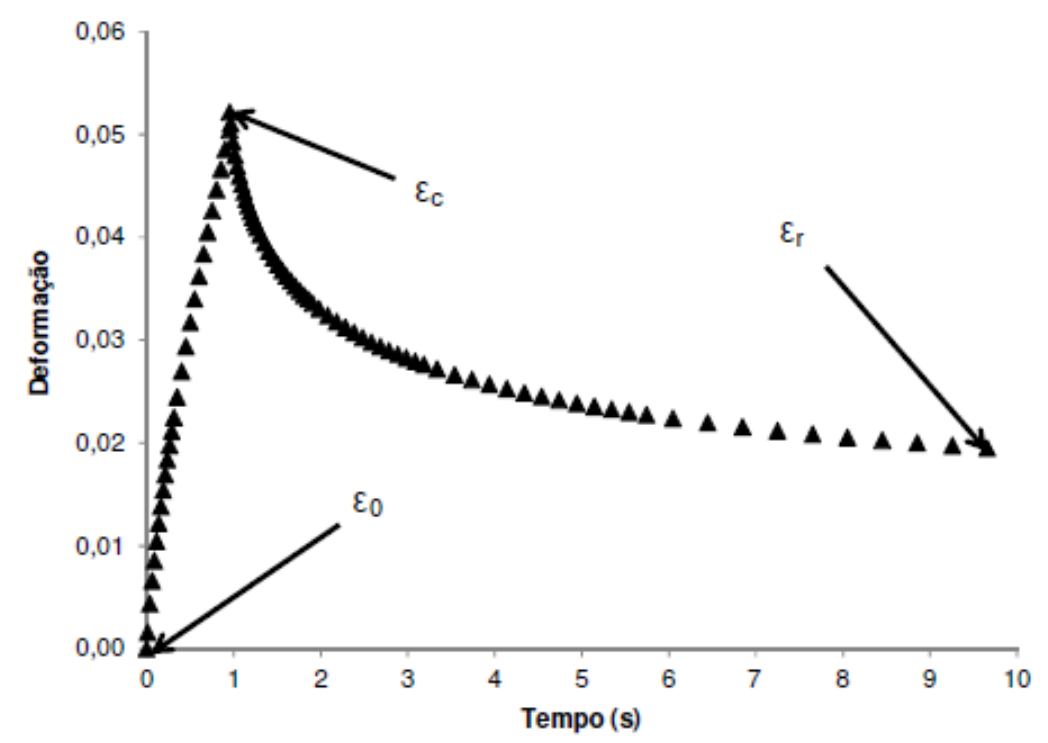

Figura 3.6 - Deformações de interesse em um ciclo de fluência e recuperação do ensaio MSCR 
Os cálculos do percentual de recuperação e da compliância não-recuperável são realizados por meio de equações prescritas na norma ASTM D7405-10a. No caso do percentual de recuperação, este cálculo é efetuado por meio da Equação 4.2:

$$
R(\sigma, N)=\frac{[(\varepsilon c-\varepsilon o)-(\varepsilon r-\varepsilon o)] \cdot 100}{\varepsilon c-\varepsilon O}
$$

onde $R(\sigma, N)$ é o percentual de recuperação na tensão $\sigma$ (para $\sigma=100 \mathrm{~Pa}$ ou 3.200 Pa) para o ciclo de fluência e recuperação número $\mathrm{N}$ (onde $1 \leq \mathrm{N} \leq 10$ ). Para o caso da compliância nãorecuperável, este cálculo é efetuado por meio da Equação 4.3:

$$
\operatorname{Jnr}(\sigma, N)=\frac{\varepsilon r-\varepsilon O}{\sigma}
$$

onde $\mathrm{J}_{\mathrm{nr}}(\sigma, N)$ é a compliância não-recuperável na tensão $\sigma$, em $\mathrm{Pa}$, e no ciclo de fluência e recuperação número $\mathrm{N}$, para $\sigma$ e $\mathrm{N}$ apresentando os mesmos valores mencionados anteriormente (para $\sigma=100 \mathrm{~Pa}$ ou $3.200 \mathrm{~Pa}$ e $1 \leq \mathrm{N} \leq 10$ ). De posse de todos os valores individuais de $R(\sigma, N)$ e $\mathrm{J}_{\mathrm{nr}}(\sigma, N)$ nos 10 ciclos de fluência e recuperação, seus resultados são calculados por meio da média aritmética simples dos valores obtidos nestes 10 ciclos (ANDERSON et al., 2010; DOMINGOS, 2011), em cada uma das temperaturas de ensaio.

A Tabela 3 da norma AASHTO M320 ("Standard Specification for PerformanceGraded Asphalt Binder") traz a classificação dos ligantes asfálticos quanto ao valor de $\mathrm{J}_{\mathrm{nr}}$ de acordo com o critério proposto pelo FHWA. A Tabela 3.3 reproduz estes valores. A compliância não-recuperável é a propriedade que quantifica a suscetibilidade do ligante asfáltico à deformação permanente. Valores mínimos do percentual de recuperação são recomendados para os ligantes asfálticos de acordo com o valor desta compliância (Tabela 3.4). Os materiais que apresentam $J_{n r}>2,0 \mathrm{kPa}^{-1}$ não são considerados nestas recomendações, ou seja, não há um valor mínimo de $\mathrm{R}$ recomendado para tais ligantes asfálticos. De acordo com Anderson et al. (2010) e Domingos (2011), o percentual de recuperação fornece uma indicação da resposta elástica retardada do ligante asfáltico, de modo que valores elevados para esta propriedade sinalizam uma componente elástica significativa no material na temperatura de realização do ensaio MSCR. 
Tabela 3.3 - Classificação dos ligantes asfálticos quanto ao valor de $\mathbf{J}_{\mathrm{nr}}$ de acordo com o critério proposto pelo FHWA (Tabela 3 da norma AASHTO M320)

\begin{tabular}{cccc}
\hline Propriedade & $\begin{array}{c}\text { Valor máximo } \\
\left(\mathbf{k P a}^{-\mathbf{1}}\right)\end{array}$ & Tipo de tráfego & $\begin{array}{c}\text { Número de } \\
\text { passadas de um eixo } \\
\text { padrão simples } \\
\text { (ESAL) }\end{array}$ \\
\hline $\mathrm{J}_{\mathrm{nr}}$ a 3.200 Pa e & 2,0 & Padrão $(\mathrm{S})$ & $<10$ milhões \\
na temperatura & 1,0 & Pesado $(\mathrm{H})$ & $>10$ milhões \\
máxima do PG & 0,5 & $\begin{array}{c}\text { Muito Pesado }(\mathrm{V}) \\
\text { Extremamente Pesado }\end{array}$ & $>30$ milhões \\
& $(\mathrm{E})$ & $>100$ milhões \\
\hline
\end{tabular}

Tabela 3.4 - Valores recomendados para o percentual de recuperação de acordo com o critério proposto pelo FHWA

\begin{tabular}{cc}
\hline $\begin{array}{c}\text { Compliância não-recuperável a } \\
\text { 3.200 Pa }\left(\mathbf{k P a}^{-1}\right)\end{array}$ & $\begin{array}{c}\text { Percentual de recuperação } \\
\text { mínimo }(\%)\end{array}$ \\
\hline 1,01 a 2,00 & 30 \\
0,51 a 1,00 & 35 \\
0,251 a 0,50 & 45 \\
0,125 a 0,25 & 50 \\
\hline
\end{tabular}

Os valores mínimos do percentual de recuperação também podem ser apresentados na forma gráfica, como mostrado na Figura 3.7. Os ligantes asfálticos com pares ordenados $\left(\mathrm{J}_{\mathrm{nr}}\right.$, R) acima da curva são considerados de alta elasticidade e aqueles com pares ordenados $\left(\mathrm{J}_{\mathrm{nr}}\right.$, R) abaixo da curva são considerados de baixa elasticidade. Em uma comparação com os resultados da Tabela 3.4, a zona de alta elasticidade seria aquela na qual o valor de $\mathrm{R}$ é superior ao mínimo recomendado para um determinado valor de $\mathrm{J}_{\mathrm{nr}} \mathrm{e}$, da mesma maneira, a zona de baixa elasticidade é aquela na qual o valor de $\mathrm{R}$ é inferior ao mínimo recomendado para um determinado valor de $\mathrm{J}_{\mathrm{nr}}$. A interrupção da curva em $\mathrm{J}_{\mathrm{nr}}=2,0 \mathrm{kPa}^{-1}$ significa que não há qualquer recomendação de percentual mínimo de recuperação para os ligantes asfálticos com valores de $\mathrm{J}_{\mathrm{nr}}$ superiores a 2,0 $\mathrm{kPa}^{-1}$ (DOMINGOS, 2011).

Apesar de o novo critério de resistência dos ligantes asfálticos à deformação permanente levar em consideração a compliância não-recuperável a 3.200Pa, o valor desta mesma propriedade a $100 \mathrm{~Pa}$ também é importante. A fim de assegurar que o material não seja demasiadamente sensível a mudanças no nível de tensão, a relação entre as compliâncias nãorecuperáveis a 100Pa $\left(\mathrm{J}_{\mathrm{nr}} 100\right)$ e a 3.200Pa $\left(\mathrm{J}_{\mathrm{nr}} 3200\right)$, calculada de acordo com a Equação 4.4 e designada por $\mathrm{J}_{\mathrm{nr}}$,diff, não deve superar os $75 \%$ (ANDERSON et al., 2010; ASPHALT 
INSTITUTE, 2010a, 2010b; DOMINGOS, 2011). De acordo com Asphalt Institute (2010a), estas mudanças contemplam os carregamentos elevados não previstos e a ocorrência de temperaturas maiores que as esperadas para o pavimento.

$$
J n r, \operatorname{diff}=\left(\frac{\operatorname{Jnr} 3200-J n r 100}{J n r 100}\right) \cdot 100
$$

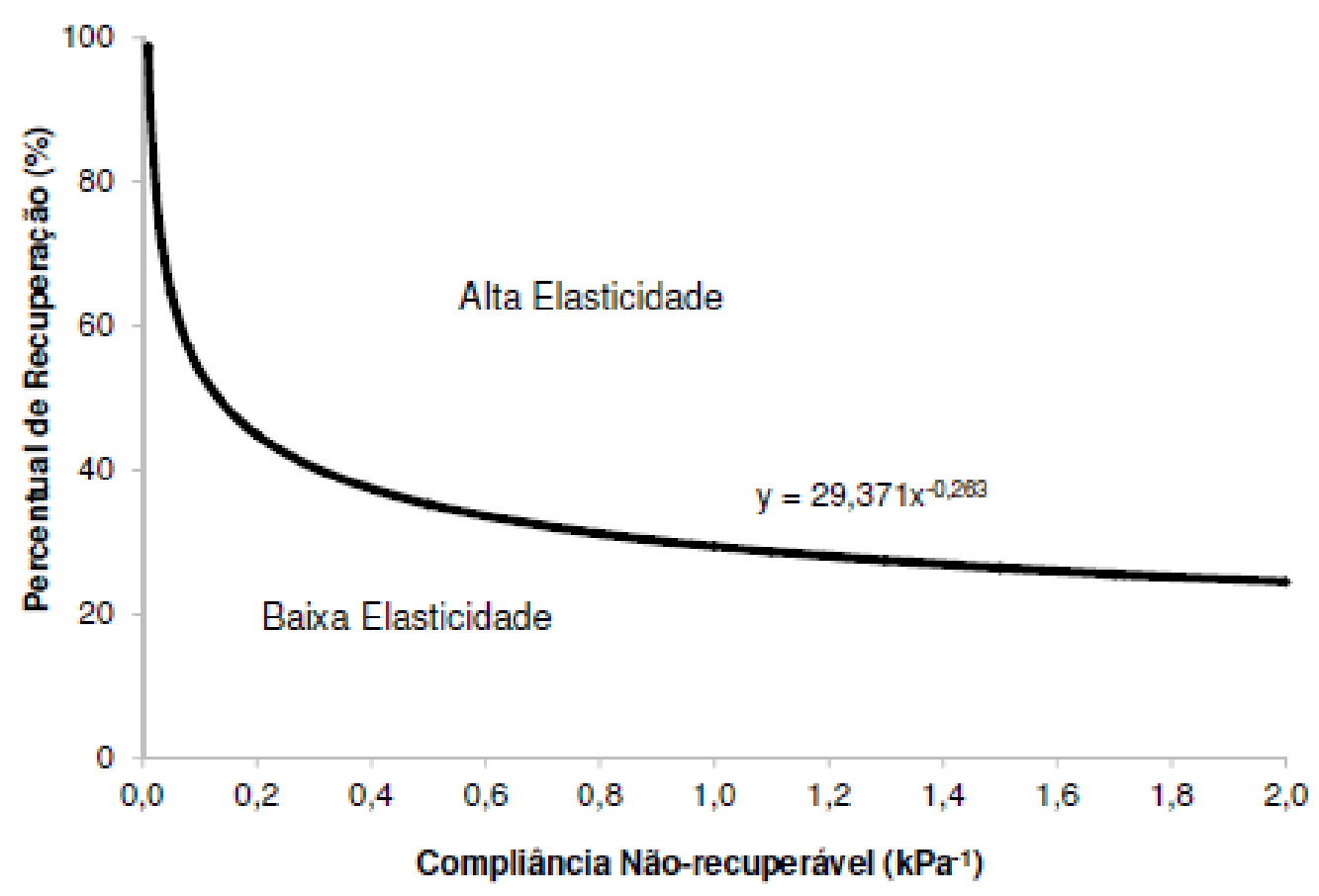

Figura 3.7 - Relação entre as compliâncias não-recuperáveis e os percentuais de recuperação a 3.200 Pa (DOMINGOS, 2011)

3.3.8 Ensaio de varredura de amplitude linear (LAS)

O ensaio LAS foi realizado de acordo com a norma da AASHTO TP 101-12-UL. Este ensaio pode ser realizado após a amostra ser envelhecida a curto prazo e a longo prazo. Neste trabalho realizou-se apenas para as amostras após o envelhecimento a longo prazo. É utilizado o reômetro de cisalhamento dinâmico (DSR), com geometria de $8 \mathrm{~mm}$ de diâmetro e espaçamento de $2 \mathrm{~mm}$ entre placas. 
O ensaio possui duas etapas: (i) varredura de frequência de 0,2 a $30 \mathrm{~Hz}$, com $0,1 \%$ de deformação; e (ii) varredura de amplitude, com incremento linear na amplitude de deformação, variando de 0 a 30\%, no intervalo de tempo de 300 segundos e a uma frequência de $10 \mathrm{~Hz}$.

Embora se saiba da importância da temperatura sobre os resultados, o ensaio foi realizado apenas para a temperatura de $25^{\circ} \mathrm{C}$. A temperatura de $25^{\circ} \mathrm{C}$ foi adotada, tendo em vista que diversos pesquisadores têm adotado esta temperatura para ensaios de fadiga (BAHIA et al., 2001; SHENOY, 2002; MARTONO et al., 2007). Neste ensaio, são obtidos o comprimento da trinca na ruptura por fadiga $\left(a_{f}\right)$ e um modelo de fadiga que relaciona o número de solicitação necessário para levar o material à fadiga $\left(\mathrm{N}_{\mathrm{f}}\right)$ e o nível de deformação sofrida pelo ligante asfáltico no pavimento. Detalhes dos procedimentos de ensaio e de cálculo são apresentados em Pamplona et al. (2014).

Os resultados obtidos da caracterização reológica na região de viscoelasticidade linear e da varredura de amplitude de deformação são utilizados para ajustar um modelo de fadiga do ligante asfáltico, utilizando o princípio de dano contínuo viscoelástico. Para a caracterização da fadiga em ligantes asfálticos, o modelo é derivado da relação entre a carga aplicada e a vida de fadiga do material (Figura 3.8).

Misturas asfálticas e ligantes asfálticos demonstram apresentar uma boa relação entre a carga aplicada e a vida de fadiga $\left(\mathrm{N}_{\mathrm{f}}\right)$ de acordo com a Equação 4.5:

$$
N_{f}=A\left(\gamma_{M A ́ X}\right)^{B}
$$

onde os parâmetros A e B são característicos do material e $\gamma_{M A ́ X}$ é a deformação máxima esperada para uma dada estrutura do pavimento. O parâmetro B é calculado de acordo com a Equação 4.6:

$$
B=2 \propto
$$

sendo $\propto=\frac{1}{m}$, onde $m$ é a inclinação da reta do gráfico log-log do módulo de armazenamento $\left(\mathrm{G}^{*} \cos \delta\right)$ versus frequência. O parâmetro A é calculado de acordo com a Equação 4.7: 


$$
A=\frac{f\left(D_{f}\right)^{k}}{k\left(\pi I_{D} C_{1} C_{2}\right)^{\alpha}}
$$

onde f é a frequência $(10 \mathrm{~Hz}), \mathrm{D}_{\mathrm{f}}$ é o valor $\mathrm{D}_{(\mathrm{t})}$ na falha, $I_{D}$ é o valor inicial de $\mathrm{G}^{*} \mathrm{sen} \delta$, em $\mathrm{MPa}$, do intervalo de amplitude de deformação de $1 \%$ e k é definido pela Equação 4.8:

$$
K=1+\left(1-C_{2}\right) \propto
$$

Os coeficientes $\mathrm{C}_{0}, \mathrm{C}_{1}$ e $\mathrm{C}_{2}$ podem ser determinados linearizando o modelo ajustado para a relação $\mathrm{G}^{*} \operatorname{sen} \delta$ versus $\mathrm{D}_{(\mathrm{t})}$ (Equação 4.9$)$, onde $\mathrm{D}_{(\mathrm{t})}$ é o dano acumulado na amostra, calculado de acordo com a Equação 4.10.

$$
\begin{gathered}
G^{*} \operatorname{sen} \delta=C_{0}-C_{1}(D)^{C_{2}} \\
D(t)=\sum_{i=1}^{N}\left[\pi I_{D} \gamma_{0}^{2}\left(G^{*} \operatorname{sen} \delta_{i-1}-G^{*} \operatorname{sen} \delta_{i-1 i}\right)\right]^{\frac{\alpha}{1+\alpha}}\left(t_{i}-t_{i-1}\right)^{\frac{1}{1+\alpha}}
\end{gathered}
$$

A seleção de um bom critério de falha por trincas por fadiga para misturas asfálticas e ligantes asfálticos vêm sendo assunto de discussão. O critério tradicional mais aceito é o de redução de 50\% do módulo inicial. Segundo Johnson (2010), a redução de 35\% no valor de $\mathrm{G}^{*} \operatorname{sen} \delta$ proporciona uma correlação razoável entre os resultados do ensaio de varredura de tempo e do LAS. Por esta razão, o valor de $\mathrm{D}_{(\mathrm{t})}$ pode ser calculado pela Equação 4.11:

$$
D(t)=0,35\left(\frac{C_{0}}{C_{1}}\right)^{\frac{1}{C_{2}}}
$$

Com as modificações propostas por Hintz (2012), o ensaio passou a ser denominado por LAS modificado. A diferença entre os dois procedimentos de ensaio é o formato da sequência de amplitudes de deformação conforme indicados na Figura 3.9. 


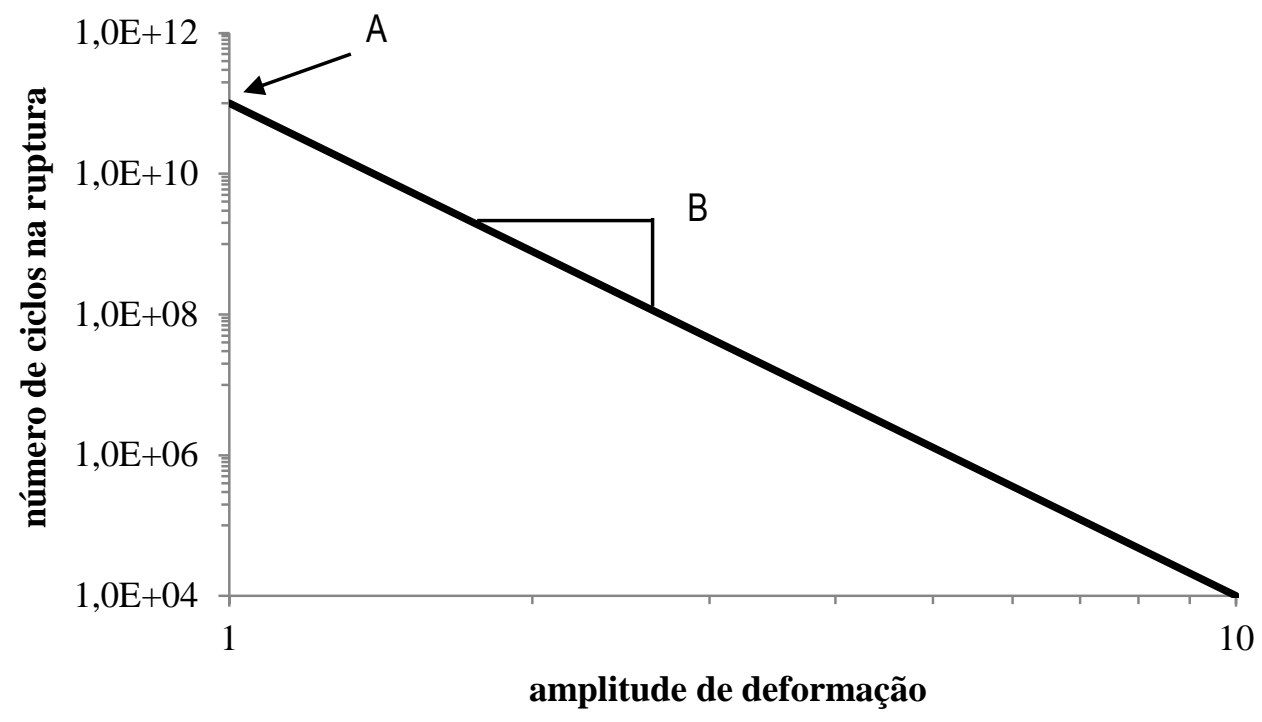

Figura 3.8 - Modelo de fadiga (JOHNSON, 2010)

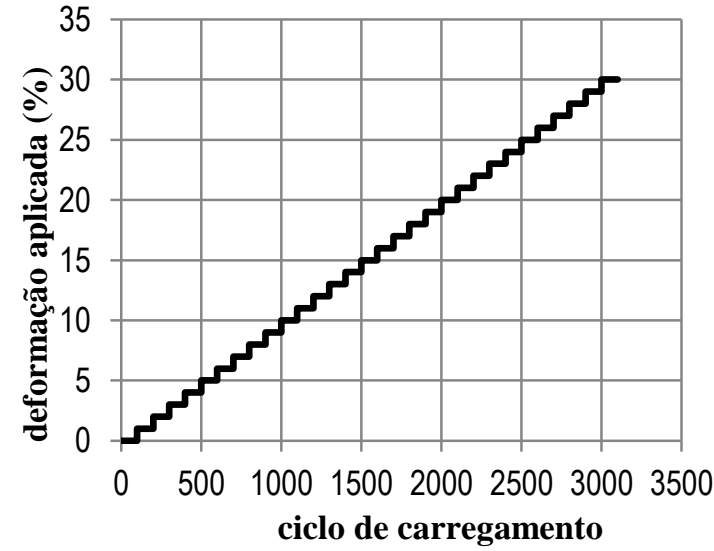

(a)

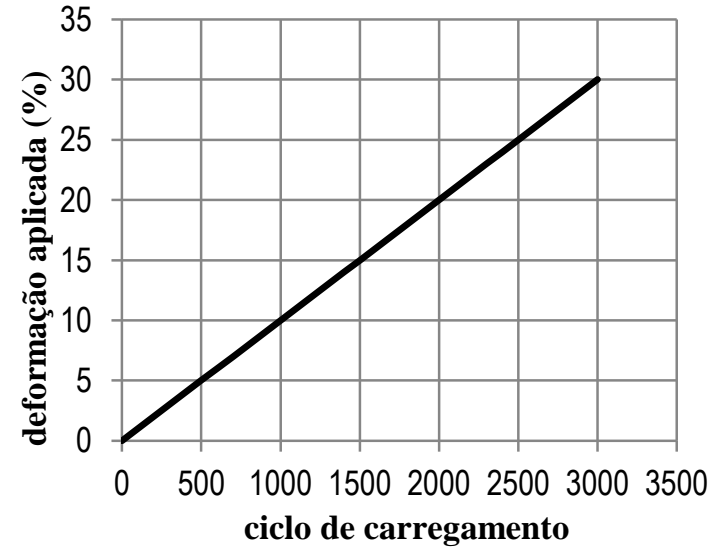

(b)

Figura 3.9 - (a) Incremento da deformação (em degraus) no ensaio LAS (JOHNSON, 2010) e (b) incremento linear de deformação no ensaio LAS modificado (HINTZ, 2012)

Hintz (2012), mostrou que os valores de $a_{\mathrm{f}}$ obtidos no ensaio LAS e de $\mathrm{N}_{\mathrm{f}}$ obtidos do ensaio de varredura de tempo apresentam uma boa correlação. O critério de ruptura adotado no LAS modificado $\left(\mathrm{a}_{\mathrm{f}}\right)$ apresenta boa correlação com o critério de ruptura adotado no ensaio de varredura de tempo (time sweep), tanto para ligantes asfálticos puros como para ligantes asfálticos modificados com diferentes tipos de polímero (PAMPLONA et al., 2014). 


\subsubsection{Varreduras de frequência para construção das curvas-mestre}

O método utilizado para a realização das varreduras de frequência para construção das curvas-mestre segue as recomendações da norma ASTM D D7175-05 ("Standard test method for determining the rheological properties of asphalt binder using a dynamic shear rheometer") para obtenção das propriedades viscoelástico-lineares de materiais asfálticos.

As amostras foram submetidas à varredura de frequência de 0,1 a $100 \mathrm{rad} / \mathrm{s}$, no DSR. Este ensaio é dividido em duas etapas: (i) varredura de frequência a baixas temperaturas (4, 16,28 e $40^{\circ} \mathrm{C}$ ) com geometria de $8 \mathrm{~mm}$ de diâmetro com espaçamento de $2 \mathrm{~mm}$ entre placas; e (ii) varredura de frequência a altas temperaturas $\left(52,64,76,88^{\circ} \mathrm{C}\right)$ com geometria de $25 \mathrm{~mm}$ de diâmetro com espaçamento de $1 \mathrm{~mm}$ entre placas. As curvas obtidas nas diferentes temperaturas são sobrepostas utilizando o princípio de superposição tempo-temperatura de maneira a obter a curva-mestre a $25^{\circ} \mathrm{C}$, que é a representação da variação das propriedades reológicas do material ao longo de uma extensão de faixa de frequências de carregamento.

\subsection{Materiais utilizados}

O ligante asfáltico de base é o fornecido pela REPLAN-Petrobras, apresentando classificação PG 64-XX e 50/70 na classificação por penetração. Com as porcentagens de SBS e TITAN adicionadas, este CAP teve sua classificação PG alterada para cima ou para baixo, conforme será discutido posteriormente. Os valores de algumas propriedades convencionais do CAP Replan estão apresentadas na Tabela 3.5. Na Tabela 3.6, estão apresentados os resultados dos ensaios MSCR e na Tabela 3.7 os resultados dos ensaios LAS do ligante de base. 
Tabela 3.5 - Propriedades convencionais do CAP 50/70 Replan

\begin{tabular}{lccc}
\hline \multicolumn{1}{c}{ Características } & \multirow{2}{*}{ Método } & \multicolumn{2}{c}{ Resultados } \\
\cline { 3 - 4 } & & virgem & RTFOT \\
\hline Penetração, $25^{\circ} \mathrm{C}, 1 / 10 \mathrm{~mm}$ & ASTM D5 & 58,0 & 30,7 \\
Ponto de amolecimento $\left({ }^{\circ} \mathrm{C}\right)$ & ASTM D36 & 49,3 & 56,1 \\
Viscosidade aparente (mPa.s) & & & \\
$135^{\circ} \mathrm{C}$ & & 344,3 & 573,8 \\
$143^{\circ} \mathrm{C}$ & & 234,6 & 374,9 \\
$150^{\circ} \mathrm{C}$ & ASTM D4402 & 172,6 & 267,2 \\
$163^{\circ} \mathrm{C}$ & & 103,6 & 153,5 \\
$177^{\circ} \mathrm{C}$ & & 64,0 & 92,1 \\
Balanço de massa $(\%)$ & ASTM D & 0,103 & 0,103 \\
Índice de susceptibilidade térmica & 2872 & $-1,0$ & $-0,8$ \\
(IST) & - & & \\
\hline
\end{tabular}

Tabela 3.6 - Propriedades do ensaio MSCR para o CAP 50/70 Replan - amostras envelhecidas no RTFOT

\begin{tabular}{|c|c|c|c|c|c|}
\hline \multirow{2}{*}{ Parâmetro } & \multicolumn{5}{|c|}{ Temperaturas - RTFOT } \\
\hline & $52^{\circ} \mathrm{C}$ & $58^{\circ} \mathrm{C}$ & $64^{\circ} \mathrm{C}$ & $7^{\circ} \mathrm{C}$ & $76^{\circ} \mathrm{C}$ \\
\hline $\mathrm{J}_{\mathrm{nr}} 100 \mathrm{~Pa}$ & 0,33 & 0,92 & 2,44 & 5,96 & 13,53 \\
\hline $\mathrm{J}_{\mathrm{nr}} 3.200 \mathrm{~Pa}$ & 0,35 & 1,02 & 2,78 & 6,79 & 15,23 \\
\hline $\mathrm{R} 100 \mathrm{~Pa}$ & 12,40 & 5,80 & 1,00 & 0,00 & 0,00 \\
\hline $\mathrm{R} 3.200 \mathrm{~Pa}$ & 8,90 & 0,50 & 0,00 & 0,00 & 0,00 \\
\hline $\mathrm{J}_{\mathrm{nr}, \mathrm{diff}}$ & 6,06 & 10,87 & 13,93 & 13,93 & 12,56 \\
\hline $\begin{array}{c}\text { classes de } \\
\text { tráfego }\end{array}$ & $\mathrm{E}$ & $\mathrm{H}$ & $S$ & - & - \\
\hline
\end{tabular}

Tabela 3.7 - Parâmetros do ensaio LAS para o CAP 50/70 Replan - amostras envelhecidas no PAV

\begin{tabular}{cc}
\hline Parâmetro & $\begin{array}{c}\text { Valor obtido para PAV a } \\
\mathbf{2 5}^{\circ} \mathbf{C}\end{array}$ \\
\hline $\mathrm{a}_{\mathrm{f}}$ & 1,08 \\
$\mathrm{~A}$ & 213.831 \\
$\mathrm{~B}$ & $-3,28$ \\
$\mathrm{~N}_{\mathrm{f}}(2 \%)$ & 22.014 \\
$\mathrm{~N}_{\mathrm{f}}(30 \%)$ & 3,06 \\
\hline
\end{tabular}

O copolímero SBS utilizado é o do tipo TR-1101 e foi adquirido da Kraton Polymers do Brasil, tendo sido fornecido pela empresa Betunel. Apresenta as seguintes características 
técnicas: teor de poliestireno de $31 \%$, densidade igual a 0,94 , resistência à tração de $33 \mathrm{MPa}$ e alongamento na ruptura igual a $880 \%$.

O polietileno utilizado foi fornecido pela empresa Honeywell. Sua designação comercial é TITAN 7686. Ele é um polímero de alta densidade linear e baixo peso molecular oxidado. O grau de oxidação do polímero é adequado para facilitar a dispersão do SBS no asfalto. O produto apresenta a forma física de pó branco com granulometria ao redor de 250 micra. O produto é obtido por meio da polimerização do gás etileno em condições controladas de pressão e temperatura para alcançar as características especificadas: peso molecular entre 5.000 e 15.000 , penetração $(1 / 10 \mathrm{~mm})$ entre 0,5 e 1 , viscosidade aparente $(\mathrm{cP})$ entre 450 e 4.500 e elasticidade alta.

O óleo aromático foi fornecido pela empresa Stratura Asfaltos e tem denominação comercial NPA. A mistura 100-0-0, que consiste em 96\% do ligante asfáltico de base e 4\% de óleo aromático, apresentou penetração a $25^{\circ} \mathrm{C}$, de 62,3 décimos de milímetro na condição virgem. 


\section{ANÁLISE ESTATÍSTICA DOS RESULTADOS}

Neste capítulo, serão apresentados os resultados dos ensaios realizados e suas respectivas análises. Será dividido por sessões, sendo mostrados, primeiramente, os resultados brutos dos ensaios e, depois, as análises estatísticas destes dados.

\subsection{Hipóteses e procedimentos empregados na análise dos resultados}

Esta subseção tem por objetivo a apresentação das hipóteses e do procedimento adotados na análise estatística dos resultados dos ensaios. Essa análise está fundamentada no estudo de modelos estatísticos lineares polinomiais do tipo cúbico especial, efetuado por meio do pacote estatístico Minitab versão 16.1. Os modelos empregados na modelagem das propriedades monitoradas no experimento apresentam interações até de terceira ordem para os componentes. Com base nos modelos obtidos, gráficos de efeitos dos componentes e superfícies de resposta tipo "contour plot" foram gerados pelo pacote estatístico e são discutidos.

\subsubsection{Hipóteses adotadas na análise}

O fenômeno em estudo nesse experimento é, fundamentalmente, um problema de interação entre componentes físicos. O asfalto, o SBS e o TITAN interagem de forma complexa, resultando ligantes asfálticos modificados cujo comportamento físico é avaliado por meio de ensaios de laboratório. Os resultados coletados são empregados no ajuste de modelos polinomiais próprios para a modelagem de problemas com misturas. Esses modelos descrevem a variabilidade de uma dada propriedade em função das variações nas proporções dos componentes e nas variáveis de processo. Representam, portanto, modelos que descrevem os efeitos dos componentes. 
Efeitos de multicolinearidade, típicos de regiões experimentais altamente restritas como a empregada neste estudo, e de heterocedasticidade presentes em alguns dos modelos são provocados por características inerentes aos materiais, dificultando a proposição dos modelos obtidos como modelos genéricos de interação asfalto-SBS-TITAN. Gráficos de efeitos de componentes e superfícies de resposta são os recursos básicos empregados nessa avaliação. Parâmetros de especificações de ligantes asfálticos não-modificados e de especificações para ligantes asfalto-SBS são empregados para delimitar áreas do espaço amostral em que figuram misturas asfalto-SBS-TITAN que atendem aos requisitos de tais especificações.

Optou-se pelo estudo exclusivo por modelos lineares do tipo polinomial, visto que o fenômeno em estudo é típico de experimentos com misturas, os quais tradicionalmente são modelados por polinômios (CORNELL, 2002).

\subsubsection{Procedimento de análise}

Os dados coletados nos ensaios são inseridos no pacote estatístico Minitab, versão 16.1, na seção "delineamento de experimentos" para ajuste dos modelos polinomiais. A análise de regressão fornece a estimativa dos coeficientes dos termos dos modelos com os seus respectivos testes de significância, bem como valores de coeficiente de determinação $\left(\mathrm{R}^{2}\right)$, coeficiente de determinação ajustado ( $\mathrm{R}^{2}$ AJUSTADO), coeficiente de determinação para previsão

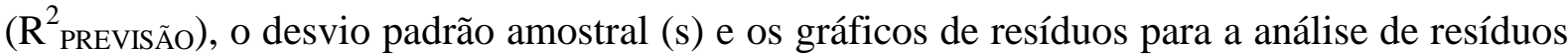
dos modelos. O teste de hipóteses para a avaliação da significância dos termos do modelo é dado por:

$$
\mathrm{H}_{0}: \beta=0 \text { (o coeficiente do termo é igual a zero) }
$$

$\mathrm{H}_{1}: \beta \neq 0$ (o coeficiente do termo é diferente a zero)

Esse teste indica se o coeficiente é zero (não é significativo no nível de significância $\alpha$ adotado, então deve ser excluído) ou é diferente de zero (é significativo, no nível de significância adotado e deve ser mantido no modelo). Se $p>\alpha$, o valor de t calculado pertence à região de não rejeição de $\mathrm{H}_{0}$, podendo-se concluir que o coeficiente do termo é zero; do 
contrário, é diferente de zero. O teste indica se, estatisticamente, o termo é zero ou não, dependendo da relação entre o valor do coeficiente e seu erro padrão.

O pacote estatístico empregado disponibiliza quatro métodos diferentes de ajuste dos modelos, baseados na técnica de regressão de mínimos quadrados: "mixture regression", "stepwise", "forward selection" e "backward elimination". O método "mixture regression" não foi empregado, pois não elimina automaticamente os termos não-significativos no nível de confiança adotado. Os modelos foram gerados pelo método "stepwise", com nível de significância de 5\%.

Regiões experimentais resultantes de restrições das porcentagens dos componentes, como a originada no delineamento deste experimento, normalmente influenciam a qualidade dos modelos resultantes, produzindo coeficientes altamente correlacionados. É possível reduzir esse efeito ao transformar os componentes em pseudocomponentes (CORNELL, 2002; MYERS e MONTGOMERY, 1995). Os pseudocomponentes têm a função de ampliar a região experimental restrita de forma que a porcentagem mínima de cada componente seja zero. Esse procedimento torna a região restrita em pseudocomponentes igual à região sem restrições em proporções reais.

Embora o efeito de multicolinearidade esteja presente, o que é indicado pelos valores altos do Fator de Inflação da Variância (FIV) ou VIF ("variance inflation factor") nos relatórios do Minitab, não se recorreu à modelagem em pseudocomponentes. Segundo a literatura, FIVs acima de 10 indicam efeito expressivo de multicolinearidade. A modelagem em pseudocomponentes é um dos artifícios para contornar o problema da multicolinearidade. No entanto, não permite a interpretação dos coeficientes do modelo (FAXINA, 2006).

Por causa do efeito da multicolinearidade (MONTGOMERY e PECK, 1992), o significado físico das interações do modelo pode ser prejudicado. Mesmo assim, os modelos podem ser empregados para estimativas de novas ocorrências. No caso deste experimento, a análise estatística se baseia fundamentalmente na avaliação dos efeitos dos componentes, por meio de gráficos de efeitos de componentes e na variação das propriedades modeladas, sobre a região experimental, por meio de superfícies de resposta. Independentemente da existência de correspondência física (CORNELL, 2002), os modelos podem ser empregados para previsão sem quaisquer restrições, desde que a previsão seja realizada dentro dos limites da região experimental.

O modelo cúbico especial, sem as variáveis de processo, é descrito por: 


$$
\eta=\sum_{i=1}^{q} \beta_{i}^{0} x_{i}+\sum \sum_{i<j}^{q} \beta_{i j}^{0} x_{i} x_{j}+\beta_{i j k}^{0} x_{i} x_{j} x_{k}
$$

com $\mathrm{i}, \mathrm{j}, \mathrm{k}=1,2, \ldots \mathrm{q}$, sendo q o número de componentes da mistura, $\beta_{\mathrm{i}}, \beta_{\mathrm{ij}}$ e $\beta_{\mathrm{ijk}}$ as estimativas dos coeficientes dos termos $x_{i}, x_{i j}$ e $x_{i j k}$, respectivamente, $x_{i}, x_{j}$ e $x_{k}$ correspondentes aos teores de asfalto, de SBS e de TITAN, respectivamente.

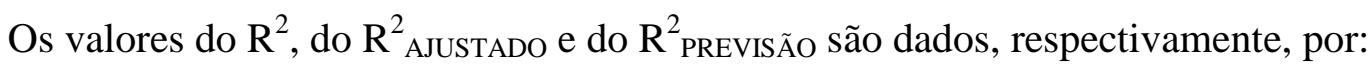

$$
\begin{gathered}
R^{2}=\frac{S S R}{S S T} \\
R_{A J U S T A D O}^{2}=1-\frac{\frac{S S E}{n-p}}{\frac{S S T}{n-1}}=1-\left(\frac{n-1}{n-p}\right)\left(1-R^{2}\right) \\
R_{P R E V I S \tilde{O} O}^{2}=1-\frac{P R E S S}{S S T}
\end{gathered}
$$

onde:

$\mathrm{n}$ = número total de observações, inclui as réplicas de todas as misturas;

$\mathrm{p}$ = número de misturas ou, neste caso, número de termos do modelo;

SSR $=\sum_{u=1}^{N}\left(\widehat{y_{u}}-\bar{y}\right)^{2}$ (4.5), sendo $\widehat{y_{u}} \mathrm{o}$ valor fornecido pelo modelo no ponto e $\bar{y}$ a média de n;

$\mathrm{SSE}=\sum_{u=1}^{N}\left(y_{u}-\widehat{y_{u}}\right)^{2}(4.6)$, sendo $\mathrm{y}_{\mathrm{u}} \mathrm{o}$ valor medido;

$\operatorname{SST}=\sum_{u=1}^{N}\left(y_{u}-\bar{y}\right)^{2}(4.7)$;

PRESS $=\sum_{i=1}^{n}\left(\frac{e_{i}}{1-h_{j}}\right)^{2}$ (4.8), sendo $e_{i}$ o resíduo i e $h_{j}$ o "leverage value" da observação i.

Para ajustar os modelos, foram levados em consideração os critérios tradicionais recomendados pela estatística para verificar a adequabilidade das regressões. Os gráficos de resíduos padronizados versus valores ajustados e o de distribuição normal de resíduos foram empregados na avaliação visual da qualidade da distribuição dos resíduos. Os primeiros foram 
empregados para verificar a existência de tendências na distribuição dos resíduos, indicando a necessidade de termos adicionais no modelo, e a existência de heterocedasticidade (tendência de afunilamento dos resíduos, indicando a presença de variância heterogênea). A verificação da homogeneidade da variância ficou restrita à análise visual. Os gráficos de distribuição normal são empregados para avaliar se a distribuição dos resíduos é normal. A análise foi feita apenas visualmente (FAXINA, 2006).

Nos casos em que a análise visual dos gráficos de resíduos indicava que os modelos não estariam bem ajustados, estudou-se a possibilidade de extrair os pontos indicados como “outliers" pelo Minitab. O critério empregado pelo Minitab é o que aponta como "outlier" a medida cujo resíduo padronizado não está contido no intervalo entre -2 e +2 . Nos casos em que era possível justificar, alguns "outliers" foram excluídos.

Obtidos os modelos de regressão, foram gerados gráficos de efeitos dos componentes e superfícies de resposta. Um gráfico de efeitos dos componentes mostra o efeito que cada componente, isoladamente, tem sobre a resposta, com base no modelo ajustado. Este tipo de gráfico indica o efeito da variação da proporção de um dado componente, mantendo constante a relação entre proporções dos demais. Isto quer dizer que ao avaliar o efeito da variação da proporção de SBS, por exemplo, as proporções de asfalto e de TITAN na mistura também variam, mas a relação entre estes últimos dois componentes se mantém constante. As alterações nas proporções dos componentes cujos efeitos estão sendo avaliados em paralelo com as variações nos demais componentes podem ser entendidas como uma direção ao longo da região experimental. Cada linha no gráfico indica o efeito de mudar o componente correspondente em uma linha imaginária (direção) conectando a mistura de referência (normalmente o centroide da região experimental) ao vértice da região experimental e a mistura de referência ao lado oposto ao vértice.

Ao interpretar um gráfico de efeitos de componentes é necessário observar que: (a) todos os componentes são interpretados em relação à mistura de referência; (b) os componentes que apresentam maior efeito na resposta apresentarão curvas com maior inclinação; (c) componentes que apresentam faixas mais amplas de ocorrência (limite superior - limite inferior) apresentarão curvas mais extensas e componentes com faixas mais restritas apresentarão curvas mais curtas; (d) o efeito total de um componente depende da sua faixa de ocorrência e da inclinação da curva correspondente. O efeito total de um componente é definido pela diferença na resposta entre o ponto na curva correspondente ao seu limite 
superior e o ponto na curva correspondente ao seu limite inferior; (e) componentes com curvas aproximadamente horizontais em relação à mistura de referência não apresentam virtualmente nenhum efeito sobre a resposta; (f) componentes com curvas semelhantes apresentarão efeitos semelhantes sobre a resposta; ( $\mathrm{g}$ ) os componentes não têm efeitos totalmente isolados, uma vez que, alterar a proporção de um implica em alterar também a proporção de pelo menos um dos complementares (FAXINA, 2006).

As superfícies de resposta permitem mostrar como uma resposta se relaciona com os componentes da mistura com base no modelo ajustado. Nesses gráficos, a superfície de resposta é vista como um plano bidimensional, no qual todos os pontos que apresentam a mesma resposta estão conectados para produzir curvas de nível. As superfícies de resposta são úteis para estabelecer valores ideais de uma dada propriedade e as misturas ideais correspondentes. As superfícies de respostas representam uma ferramenta efetiva na determinação de regiões em que o TITAN pode ser empregado em conjunto com o copolímero SBS.

Cabe ressaltar que os modelos apresentados são limitados ao tipo de ligante asfáltico, do copolímero SBS e do TITAN empregados, bem como, às condições experimentais adotadas para este estudo, não podendo ser generalizados para qualquer tipo de ligante asfáltico, de SBS ou TITAN 9686 com características similares fora das faixas adotadas nesse estudo.

As Figuras 4.1 e 4.2 apresentam um gráfico de superfície de resposta e de efeitos dos componentes com o intuito de esclarecer como são realizadas suas análises.

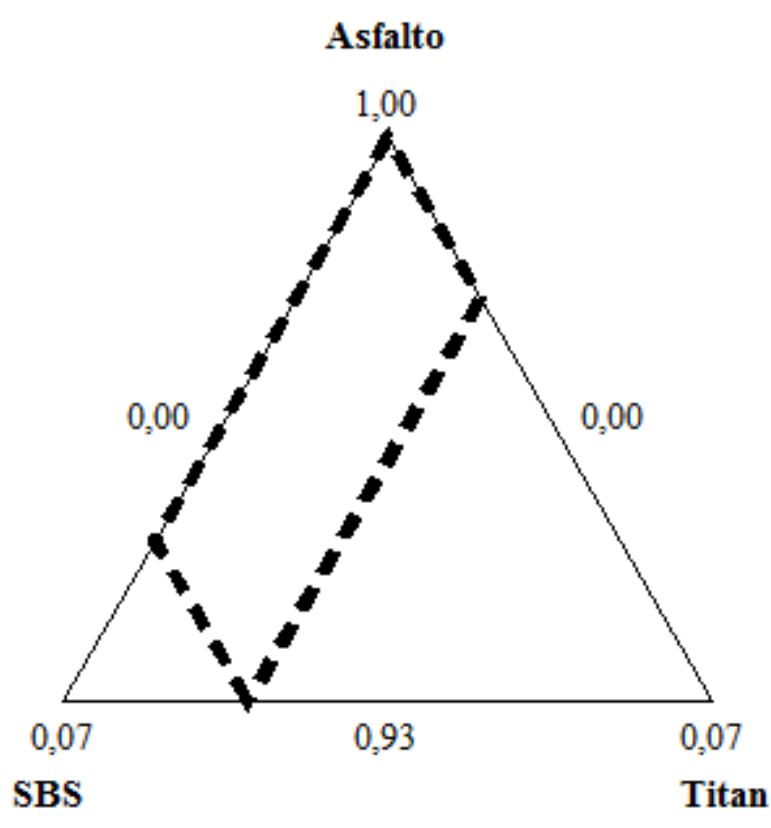

Figura 4.1 - Superfície de resposta 
Na Figura 4.1, a região delimitada é a região experimental de interesse. Na linha entre Asfalto e TITAN, têm-se somente as misturas com adição de TITAN, sendo que ao andar nessa linha no sentido do asfalto-TITAN ocorre o aumento da concentração do polímero, de 0 a 2\%. Na linha entre Asfalto e SBS, têm-se somente as misturas com adição de SBS, sendo que ao andar nessa linha no sentido do asfalto-SBS ocorre o aumento da concentração do SBS, de 0 a 5\%. As outras duas linhas pontilhadas, têm-se a adição de ambos os modificadores. No entanto, ao andar na linha que liga os lados Asfalto-SBS e SBS-TITAN, encontram-se misturas com 5\% de SBS e concentrações crescentes de TITAN. Ao andar na linha que liga Asfalto-TITAN e SBS-TITAN, encontram-se as misturas com 2\% de TITAN e concentrações crescentes de SBS. No interior da região experimental, encontram-se misturas com combinações de diversas concentrações destes dois modificadores. As superfícies de resposta serão construídas dentro da região experimental, fazendo uso de curvas de níveis para uma dada propriedade.

\section{Efeitos dos componentes}

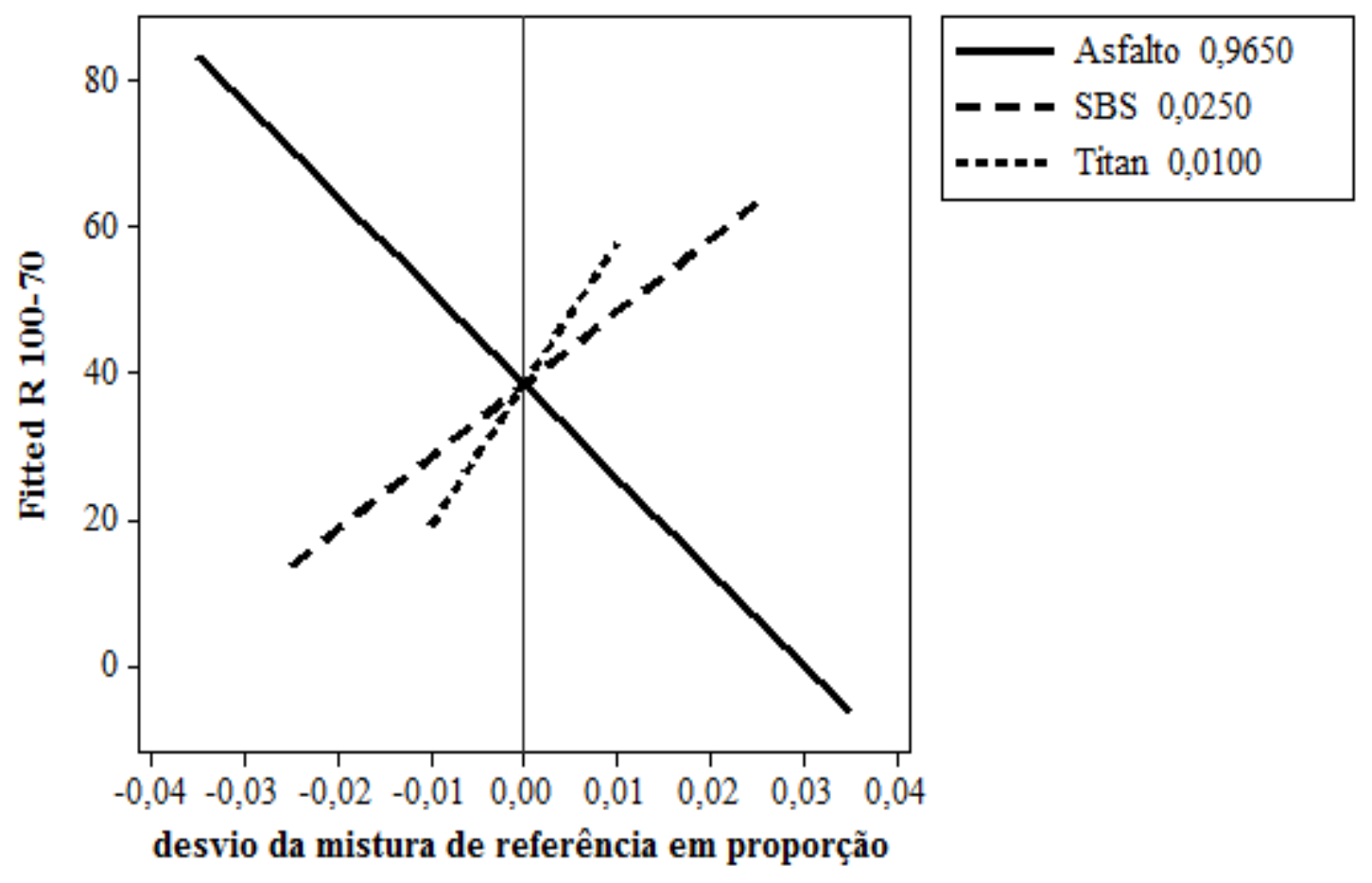

Figura 4.2 - Gráfico de efeitos dos componentes

Na Figura 4.2 é apresentado um exemplo de gráfico de efeitos dos componentes. Este gráfico mostra o efeito que cada componente tem isoladamente sobre a propriedade analisada. Cabe salientar que a análise realizada por este tipo de gráfico é apenas uma dentre muitas 
possibilidades de análise (várias direções). Neste caso, a direção analisada corresponde à reta ligando o vértice ao lado oposto da região experimental passando pela mistura do centroide da figura. Este efeito é indicado pela variação da proporção de um componente, mantendo constante a relação entre as proporções dos demais. O eixo horizontal indica a faixa de variação da proporção dos componentes partindo da mistura de referência $(0,0)$ para $+50 \%$ da faixa da variação e $-50 \%$ da faixa. O eixo vertical indica a intensidade do efeito da variação da proporção do componente sobre a propriedade avaliada. De maneira geral, os componentes que apresentam maior efeito sobre a propriedade avaliada são os que possuem curvas mais inclinadas. $\mathrm{O}$ efeito do componente é calculado mediante a diferença entre o ponto da curva no limite superior e o ponto da curva no seu limite inferior dividida pela concentração máxima desse componente considerado no simplex. Cabe ressaltar que os componentes não têm efeitos isolados, pois à medida que se altera um componente, tem-se a alteração de pelo menos mais um. No entanto, este tipo de gráfico auxilia na tentativa de entender a maneira como cada elemento atua nas propriedades monitoradas (SOBREIRO, 2014). A linha contínua representa o asfalto+óleo, a linha tracejada com menor espaçamento representa o TITAN, e a última representa o SBS.

\subsection{Resultados obtidos}

A Tabela 4.1 mostra os resultados de viscosidade na condição virgem para as 5 temperaturas em que o ensaio foi realizado $\left(135^{\circ} \mathrm{C}, 143^{\circ} \mathrm{C}, 150^{\circ} \mathrm{C}, 163^{\circ} \mathrm{C}\right.$ e $\left.177^{\circ} \mathrm{C}\right)$ em $\mathrm{mPa} . \mathrm{s}$. A Tabela 4.2 mostra os resultados de viscosidade envelhecida a curto prazo para as 5 temperaturas em que o ensaio foi realizado $\left(135^{\circ} \mathrm{C}, 143^{\circ} \mathrm{C}, 150^{\circ} \mathrm{C}, 163^{\circ} \mathrm{C}\right.$ e $\left.177^{\circ} \mathrm{C}\right) \mathrm{em} \mathrm{mPa.s}$. A Tabela 4.3 mostra os resultados de incremento de viscosidade para as 5 temperaturas em que o ensaio foi realizado $\left(135^{\circ} \mathrm{C}, 143^{\circ} \mathrm{C}, 150^{\circ} \mathrm{C}, 163^{\circ} \mathrm{C}\right.$ e $\left.177^{\circ} \mathrm{C}\right)$. A Tabela 4.4 mostra os resultados de grau contínuo (continuous grade) das misturas, de vida de fadiga com 2 e $30 \%$ de deformação ( $\mathrm{N}_{\mathrm{f}} 2 \%$ e $\mathrm{N}_{\mathrm{f}} 30 \%$ ) e do parâmetro $\mathrm{a}_{\mathrm{f}} \mathrm{em} \mathrm{mm}$. As Tabelas de 4.5 a 4.8 mostram os resultados de compliância não-recuperável a 100 e a $3.200 \mathrm{~Pa}$, de percentual de recuperação a 100 e a $3.200 \mathrm{~Pa}$ e $\mathrm{J}_{\text {nr,diff }}$ nas temperaturas de $52,58,64$ e $70^{\circ} \mathrm{C}$. A Tabela 4.9 mostra os resultados de temperatura de usinagem e compactação das misturas como descritas 
no item 3.3.4 e de temperatura crítica de fadiga (temperaturas em que o parâmetro $G^{*}$.sen $(\delta)$ é igual a $5 \mathrm{MPa}$ para tráfego S e igual a $6 \mathrm{MPa}$ para tráfegos $\mathrm{H} \mathrm{e} \mathrm{V.)}$

Tabela 4.1 - Resultados de viscosidade na condição virgem em mPa.s

\begin{tabular}{|c|c|c|c|c|c|c|c|c|}
\hline Medição & Asfalto & SBS & Titan & Vv-135 & Vv-143 & Vv-150 & Vv-163 & Vv-177 \\
\hline 1 & 1,000 & 0,000 & 0,00 & 333,9 & 217,8 & 157,3 & 97,1 & 61,9 \\
\hline 2 & 0,980 & 0,000 & 0,02 & 339,3 & 228,6 & 171,3 & 107,4 & 69,6 \\
\hline 3 & 0,950 & 0,050 & 0,00 & 982,3 & 735,1 & 543,3 & 329,5 & 220,5 \\
\hline 4 & 0,930 & 0,050 & 0,02 & 1128,5 & 710,0 & 527,8 & 369,0 & 242,0 \\
\hline 5 & 0,990 & 0,000 & 0,01 & 323,0 & 219,2 & 162,0 & 99,1 & 62,5 \\
\hline 6 & 0,975 & 0,025 & 0,00 & 528,0 & 379,9 & 292,2 & 176,4 & 110,4 \\
\hline 7 & 0,940 & 0,050 & 0,01 & 1087,8 & 699,5 & 549,2 & 365,2 & 227,2 \\
\hline 8 & 0,955 & 0,025 & 0,02 & 507,5 & 359,1 & 278,7 & 183,8 & 118,6 \\
\hline 9 & 0,965 & 0,025 & 0,01 & 547,8 & 391,9 & 304,2 & 193,1 & 121,1 \\
\hline 10 & 1,000 & 0,000 & 0,00 & 299,5 & 201,9 & 150,0 & 91,6 & 57,5 \\
\hline 11 & 0,980 & 0,000 & 0,02 & 334,5 & 230,9 & 171,7 & 104,9 & 66,0 \\
\hline 12 & 0,950 & 0,050 & 0,00 & 1112,1 & 813,6 & 627,1 & 355,8 & 228,7 \\
\hline 13 & 0,930 & 0,050 & 0,02 & 1012,0 & 633,9 & 470,0 & 321,7 & 213,1 \\
\hline 14 & 0,990 & 0,000 & 0,01 & 324,8 & 223,8 & 166,3 & 101,1 & 63,4 \\
\hline 15 & 0,975 & 0,025 & 0,00 & 531,5 & 386,8 & 297,4 & 180,9 & 113,5 \\
\hline 16 & 0,940 & 0,050 & 0,01 & 1041,0 & 707,6 & 541,8 & 356,4 & 213,1 \\
\hline 17 & 0,955 & 0,025 & 0,02 & 557,8 & 384,9 & 291,7 & 187,5 & 120,5 \\
\hline 18 & 0,965 & 0,025 & 0,01 & 571,0 & 397,4 & 306,3 & 192,3 & 120,8 \\
\hline 19 & 1,000 & 0,000 & 0,00 & 293,8 & 197,3 & 146,2 & 89,3 & 56,3 \\
\hline 20 & 0,980 & 0,000 & 0,02 & 333,8 & 231,6 & 172,5 & 105,6 & 66,3 \\
\hline 21 & 0,950 & 0,050 & 0,00 & 1097,3 & 796,8 & 615,9 & 350,4 & 219,3 \\
\hline 22 & 0,930 & 0,050 & 0,02 & 1168,0 & 718,0 & 518,2 & 364,1 & 223,1 \\
\hline 23 & 0,990 & 0,000 & 0,01 & 325,0 & 225,0 & 167,1 & 101,5 & 63,5 \\
\hline 24 & 0,975 & 0,025 & 0,00 & 563,0 & 396,8 & 300,5 & 179,9 & 112,1 \\
\hline 25 & 0,940 & 0,050 & 0,01 & 1078,0 & 717,4 & 548,8 & 360,8 & 222,5 \\
\hline 26 & 0,955 & 0,025 & 0,02 & 589,8 & 408,0 & 303,3 & 192,8 & 124,5 \\
\hline 27 & 0,965 & 0,025 & 0,01 & 567,3 & 398,8 & 306,3 & 193,0 & 120,3 \\
\hline 28 & 1,000 & 0,000 & 0,00 & 295,8 & 199,9 & 148,3 & 90,6 & 56,9 \\
\hline 29 & 0,980 & 0,000 & 0,02 & 328,8 & 229,8 & 170,9 & 104,6 & 65,8 \\
\hline 30 & 0,950 & 0,050 & 0,00 & 947,3 & 680,5 & 531,7 & 316,8 & 200,6 \\
\hline 31 & 0,930 & 0,050 & 0,02 & 1082,8 & 686,1 & 499,8 & 333,3 & 223,6 \\
\hline 32 & 0,990 & 0,000 & 0,01 & 327,8 & 226,0 & 167,5 & 101,4 & 63,4 \\
\hline 33 & 0,975 & 0,025 & 0,00 & 552,3 & 393,1 & 299,8 & 181,1 & 112,9 \\
\hline 34 & 0,940 & 0,050 & 0,01 & 1074,5 & 737,5 & 570,0 & 376,3 & 230,4 \\
\hline 35 & 0,955 & 0,025 & 0,02 & 568,5 & 393,8 & 294,1 & 186,3 & 119,5 \\
\hline 36 & 0,965 & 0,025 & 0,01 & 571,5 & 406,8 & 308,9 & 194,1 & 121,3 \\
\hline
\end{tabular}


Tabela 4.2 - Resultados de viscosidade na condição envelhecida a curto prazo em mPa.s

\begin{tabular}{|c|c|c|c|c|c|c|c|c|}
\hline Medição & Asfalto & SBS & Titan & Vr-135 & Vr-143 & Vr-150 & Vr-163 & Vr-177 \\
\hline 1 & 1,000 & 0,000 & 0,00 & 422,8 & 279,0 & 203,8 & 120,6 & 73,5 \\
\hline 2 & 0,980 & 0,000 & 0,02 & 484,8 & 329,1 & 240,3 & 143,0 & 87,4 \\
\hline 3 & 0,950 & 0,050 & 0,00 & 1653,8 & 1131,0 & 820,3 & 450,1 & 272,2 \\
\hline 4 & 0,930 & 0,050 & 0,02 & 1427,3 & 955,6 & 713,1 & 449,7 & 284,2 \\
\hline 5 & 0,990 & 0,000 & 0,01 & 461,0 & 310,0 & 226,1 & 133,8 & 81,5 \\
\hline 6 & 0,975 & 0,025 & 0,00 & 751,3 & 512,6 & 377,8 & 220,8 & 132,5 \\
\hline 7 & 0,940 & 0,050 & 0,01 & 1426,0 & 981,6 & 738,3 & 449,3 & 270,3 \\
\hline 8 & 0,955 & 0,025 & 0,02 & 776,5 & 534,5 & 397,7 & 244,3 & 151,5 \\
\hline 9 & 0,965 & 0,025 & 0,01 & 861,0 & 584,3 & 428,8 & 258,2 & 157,1 \\
\hline 10 & 1,000 & 0,000 & 0,00 & 428,5 & 287,5 & 209,3 & 123,8 & 75,1 \\
\hline 11 & 0,980 & 0,000 & 0,02 & 481,3 & 326,9 & 239,2 & 141,4 & 86,4 \\
\hline 12 & 0,950 & 0,050 & 0,00 & 1614,8 & 1085,1 & 785,3 & 432,7 & 260,7 \\
\hline 13 & 0,930 & 0,050 & 0,02 & 1385,3 & 945,5 & 712,7 & 455,1 & 289,1 \\
\hline 14 & 0,990 & 0,000 & 0,01 & 465,3 & 315,1 & 230,0 & 136,0 & 82,6 \\
\hline 15 & 0,975 & 0,025 & 0,00 & 737,5 & 503,8 & 370,1 & 214,9 & 129,5 \\
\hline 16 & 0,940 & 0,050 & 0,01 & 1358,5 & 945,5 & 711,1 & 435,0 & 259,5 \\
\hline 17 & 0,955 & 0,025 & 0,02 & 786,0 & 540,4 & 401,3 & 247,7 & 153,5 \\
\hline 18 & 0,965 & 0,025 & 0,01 & 814,8 & 550,9 & 408,2 & 244,8 & 148,3 \\
\hline 19 & 1,000 & 0,000 & 0,00 & 446,0 & 297,4 & 216,1 & 126,9 & 77,0 \\
\hline 20 & 0,980 & 0,000 & 0,02 & 484,0 & 328,3 & 240,3 & 142,4 & 86,9 \\
\hline 21 & 0,950 & 0,050 & 0,00 & 1625,3 & 1100,9 & 796,9 & 438,2 & 263,2 \\
\hline 22 & 0,930 & 0,050 & 0,02 & 1417,3 & 953,0 & 710,8 & 447,9 & 282,4 \\
\hline 23 & 0,990 & 0,000 & 0,01 & 452,8 & 306,3 & 223,5 & 132,5 & 81,0 \\
\hline 24 & 0,975 & 0,025 & 0,00 & 741,0 & 505,8 & 371,9 & 216,8 & 130,5 \\
\hline 25 & 0,940 & 0,050 & 0,01 & 1418,0 & 983,8 & 741,6 & 450,3 & 268,9 \\
\hline 26 & 0,955 & 0,025 & 0,02 & 1068,5 & 560,0 & 415,2 & 254,9 & 157,8 \\
\hline 27 & 0,965 & 0,025 & 0,01 & 813,5 & 553,8 & 409,0 & 245,3 & 148,0 \\
\hline 28 & 1,000 & 0,000 & 0,00 & 445,0 & 297,4 & 215,8 & 126,9 & 76,9 \\
\hline 29 & 0,980 & 0,000 & 0,02 & 473,0 & 319,5 & 234,3 & 139,6 & 85,3 \\
\hline 30 & 0,950 & 0,050 & 0,00 & 1613,0 & 1090,5 & 786,9 & 436,4 & 264,9 \\
\hline 31 & 0,930 & 0,050 & 0,02 & 1411,0 & 970,5 & 737,9 & 497,6 & 296,7 \\
\hline 32 & 0,990 & 0,000 & 0,01 & 476,5 & 322,6 & 234,4 & 138,2 & 84,0 \\
\hline 33 & 0,975 & 0,025 & 0,00 & 774,5 & 522,8 & 383,9 & 223,8 & 135,0 \\
\hline 34 & 0,940 & 0,050 & 0,01 & 1391,8 & 968,3 & 730,3 & 442,4 & 266,0 \\
\hline 35 & 0,955 & 0,025 & 0,02 & 777,3 & 535,3 & 398,2 & 246,8 & 153,0 \\
\hline 36 & 0,965 & 0,025 & 0,01 & 829,8 & 562,6 & 414,8 & 248,8 & 149,8 \\
\hline
\end{tabular}


Tabela 4.3 - Resultados de incremento de viscosidade

\begin{tabular}{|c|c|c|c|c|c|c|c|c|}
\hline Medição & Asfalto & SBS & Titan & Iv-135 & Iv-143 & Iv-150 & Iv-163 & Iv-177 \\
\hline 1 & 1,000 & 0,000 & 0,00 & 1,27 & 1,28 & 1,30 & 1,24 & 1,19 \\
\hline 2 & 0,980 & 0,000 & 0,02 & 1,43 & 1,44 & 1,40 & 1,33 & 1,26 \\
\hline 3 & 0,950 & 0,050 & 0,00 & 1,68 & 1,54 & 1,51 & 1,37 & 1,23 \\
\hline 4 & 0,930 & 0,050 & 0,02 & 1,26 & 1,35 & 1,35 & 1,22 & 1,17 \\
\hline 5 & 0,990 & 0,000 & 0,01 & 1,43 & 1,41 & 1,40 & 1,35 & 1,30 \\
\hline 6 & 0,975 & 0,025 & 0,00 & 1,42 & 1,35 & 1,29 & 1,25 & 1,20 \\
\hline 7 & 0,940 & 0,050 & 0,01 & 1,31 & 1,40 & 1,34 & 1,23 & 1,19 \\
\hline 8 & 0,955 & 0,025 & 0,02 & 1,53 & 1,49 & 1,43 & 1,33 & 1,28 \\
\hline 9 & 0,965 & 0,025 & 0,01 & 1,57 & 1,49 & 1,41 & 1,34 & 1,30 \\
\hline 10 & 1,000 & 0,000 & 0,00 & 1,43 & 1,42 & 1,40 & 1,35 & 1,31 \\
\hline 11 & 0,980 & 0,000 & 0,02 & 1,44 & 1,42 & 1,39 & 1,35 & 1,31 \\
\hline 12 & 0,950 & 0,050 & 0,00 & 1,45 & 1,33 & 1,25 & 1,22 & 1,14 \\
\hline 13 & 0,930 & 0,050 & 0,02 & 1,37 & 1,49 & 1,52 & 1,41 & 1,36 \\
\hline 14 & 0,990 & 0,000 & 0,01 & 1,43 & 1,41 & 1,38 & 1,35 & 1,30 \\
\hline 15 & 0,975 & 0,025 & 0,00 & 1,39 & 1,30 & 1,24 & 1,19 & 1,14 \\
\hline 16 & 0,940 & 0,050 & 0,01 & 1,30 & 1,34 & 1,31 & 1,22 & 1,22 \\
\hline 17 & 0,955 & 0,025 & 0,02 & 1,41 & 1,40 & 1,38 & 1,32 & 1,27 \\
\hline 18 & 0,965 & 0,025 & 0,01 & 1,43 & 1,39 & 1,33 & 1,27 & 1,23 \\
\hline 19 & 1,000 & 0,000 & 0,00 & 1,52 & 1,51 & 1,48 & 1,42 & 1,37 \\
\hline 20 & 0,980 & 0,000 & 0,02 & 1,45 & 1,42 & 1,39 & 1,35 & 1,31 \\
\hline 21 & 0,950 & 0,050 & 0,00 & 1,48 & 1,38 & 1,29 & 1,25 & 1,20 \\
\hline 22 & 0,930 & 0,050 & 0,02 & 1,21 & 1,33 & 1,37 & 1,23 & 1,27 \\
\hline 23 & 0,990 & 0,000 & 0,01 & 1,39 & 1,36 & 1,34 & 1,31 & 1,28 \\
\hline 24 & 0,975 & 0,025 & 0,00 & 1,32 & 1,27 & 1,24 & 1,20 & 1,16 \\
\hline 25 & 0,940 & 0,050 & 0,01 & 1,32 & 1,37 & 1,35 & 1,25 & 1,21 \\
\hline 26 & 0,955 & 0,025 & 0,02 & 1,81 & 1,37 & 1,37 & 1,32 & 1,27 \\
\hline 27 & 0,965 & 0,025 & 0,01 & 1,43 & 1,39 & 1,34 & 1,27 & 1,23 \\
\hline 28 & 1,000 & 0,000 & 0,00 & 1,50 & 1,49 & 1,46 & 1,40 & 1,35 \\
\hline 29 & 0,980 & 0,000 & 0,02 & 1,44 & 1,39 & 1,37 & 1,33 & 1,30 \\
\hline 30 & 0,950 & 0,050 & 0,00 & 1,70 & 1,60 & 1,48 & 1,38 & 1,32 \\
\hline 31 & 0,930 & 0,050 & 0,02 & 1,30 & 1,41 & 1,48 & 1,49 & 1,33 \\
\hline 32 & 0,990 & 0,000 & 0,01 & 1,45 & 1,43 & 1,40 & 1,36 & 1,33 \\
\hline 33 & 0,975 & 0,025 & 0,00 & 1,40 & 1,33 & 1,28 & 1,24 & 1,20 \\
\hline 34 & 0,940 & 0,050 & 0,01 & 1,30 & 1,31 & 1,28 & 1,18 & 1,15 \\
\hline 35 & 0,955 & 0,025 & 0,02 & 1,37 & 1,36 & 1,35 & 1,33 & 1,28 \\
\hline 36 & 0,965 & 0,025 & 0,01 & 1,45 & 1,38 & 1,34 & 1,28 & 1,23 \\
\hline
\end{tabular}


Tabela 4.4 - Resultados do grau contínuo, do parâmetro $a_{f}$ e $N_{f}$ a $2 \%$ e $30 \%$

\begin{tabular}{|c|c|c|c|c|c|c|c|}
\hline Medição & Asfalto & SBS & Titan & grau contínuo & $a_{f}(\mathbf{m m})$ & Nf2\% & Nf30\% \\
\hline 1 & 1,000 & 0,000 & 0,00 & 63,3 & 0,75 & 21170,32 & 6,16 \\
\hline 2 & 0,980 & 0,000 & 0,02 & 76,2 & 1,05 & 23630,51 & 2,92 \\
\hline 3 & 0,950 & 0,050 & 0,00 & 80,7 & 1,22 & 38201,77 & 3,19 \\
\hline 4 & 0,930 & 0,050 & 0,02 & 110,5 & 1,38 & 53027,29 & 1,51 \\
\hline 5 & 0,990 & 0,000 & 0,01 & 68,6 & 0,97 & 24507,69 & 5,64 \\
\hline 6 & 0,975 & 0,025 & 0,00 & 69,6 & 0,97 & 25187,91 & 3,66 \\
\hline 7 & 0,940 & 0,050 & 0,01 & 92,3 & 1,32 & 28549,80 & 1,78 \\
\hline 8 & 0,955 & 0,025 & 0,02 & 82,5 & 1,21 & 34757,60 & 2,38 \\
\hline 9 & 0,965 & 0,025 & 0,01 & 72,2 & 1,16 & 29471,77 & 3,02 \\
\hline 10 & 1,000 & 0,000 & 0,00 & 63,5 & 0,82 & 19548,85 & 5,78 \\
\hline 11 & 0,980 & 0,000 & 0,02 & 74,1 & 1,03 & 27311,64 & 3,26 \\
\hline 12 & 0,950 & 0,050 & 0,00 & 79,5 & 1,13 & 42701,09 & 3,58 \\
\hline 13 & 0,930 & 0,050 & 0,02 & 110,6 & 1,40 & 47560,56 & 1,36 \\
\hline 14 & 0,990 & 0,000 & 0,01 & 67,2 & 0,98 & 22119,88 & 5,05 \\
\hline 15 & 0,975 & 0,025 & 0,00 & 69,1 & 1,00 & 26491,13 & 3,91 \\
\hline 16 & 0,940 & 0,050 & 0,01 & 93,1 & 1,20 & 35205,70 & 2,00 \\
\hline 17 & 0,955 & 0,025 & 0,02 & 86,0 & 1,08 & 35534,99 & 2,26 \\
\hline 18 & 0,965 & 0,025 & 0,01 & 72,3 & 1,14 & 29334,02 & 3,54 \\
\hline 19 & 1,000 & 0,000 & 0,00 & 63,5 & 0,82 & 17047,25 & 5,09 \\
\hline 20 & 0,980 & 0,000 & 0,02 & 74,5 & 1,13 & 25304,53 & 3,02 \\
\hline 21 & 0,950 & 0,050 & 0,00 & 78,9 & 1,16 & 37811,96 & 3,07 \\
\hline 22 & 0,930 & 0,050 & 0,02 & 109,9 & 1,38 & 41917,44 & 1,24 \\
\hline 23 & 0,990 & 0,000 & 0,01 & 67,7 & 0,98 & 21895,30 & 4,92 \\
\hline 24 & 0,975 & 0,025 & 0,00 & 68,9 & 1,01 & 25464,48 & 3,70 \\
\hline 25 & 0,940 & 0,050 & 0,01 & 91,9 & 1,28 & 39560,83 & 2,17 \\
\hline 26 & 0,955 & 0,025 & 0,02 & 86,3 & 1,22 & 37670,54 & 2,36 \\
\hline 27 & 0,965 & 0,025 & 0,01 & 71,8 & 1,03 & 26027,65 & 3,02 \\
\hline 28 & 1,000 & 0,000 & 0,00 & 63,6 & 0,91 & 19403,22 & 5,95 \\
\hline 29 & 0,980 & 0,000 & 0,02 & 75,8 & 1,12 & 22540,24 & 2,92 \\
\hline 30 & 0,950 & 0,050 & 0,00 & 79,6 & 1,19 & 38688,33 & 3,28 \\
\hline 31 & 0,930 & 0,050 & 0,02 & 110,7 & 1,40 & 49199,61 & 1,21 \\
\hline 32 & 0,990 & 0,000 & 0,01 & 68,2 & 0,98 & 22060,61 & 5,24 \\
\hline 33 & 0,975 & 0,025 & 0,00 & 69,4 & 0,99 & 29960,28 & 4,48 \\
\hline 34 & 0,940 & 0,050 & 0,01 & 91,1 & 1,35 & 38716,07 & 2,18 \\
\hline 35 & 0,955 & 0,025 & 0,02 & 86,5 & 1,18 & 37105,22 & 2,36 \\
\hline 36 & 0,965 & 0,025 & 0,01 & 72,5 & 1,17 & 25236,77 & 2,78 \\
\hline
\end{tabular}


Tabela 4.5 - Resultados de $J_{n r}$ a 100 e a $3.200 \mathrm{~Pa}, \mathrm{~J}_{\mathrm{nr}, \text { diff, }} \mathrm{R}$ a 100 e a 3.200 Pa após envelhecimento a curto prazo a $52^{\circ} \mathrm{C}$

\begin{tabular}{|c|c|c|c|c|c|c|c|c|}
\hline Medição & Asfalto & SBS & Titan & $\begin{array}{c}\text { Jnr 100- } \\
52\end{array}$ & $\begin{array}{c}\text { Jnr 3200- } \\
52\end{array}$ & $\begin{array}{c}\text { Jnr diff- } \\
52\end{array}$ & R 100-52 & $\begin{array}{c}\text { R 3200- } \\
52\end{array}$ \\
\hline 1 & 1,000 & 0,000 & 0,00 & 0,73 & 0,79 & 7,79 & 5,83 & 1,63 \\
\hline 2 & 0,980 & 0,000 & 0,02 & 0,09 & 0,22 & 146,96 & 62,78 & 26,78 \\
\hline 3 & 0,950 & 0,050 & 0,00 & 0,08 & 0,10 & 18,43 & 58,29 & 51,58 \\
\hline 4 & 0,930 & 0,050 & 0,02 & 0,01 & 0,02 & 59,04 & 82,72 & 75,27 \\
\hline 5 & 0,990 & 0,000 & 0,01 & 0,30 & 0,41 & 40,09 & 27,75 & 12,68 \\
\hline 6 & 0,975 & 0,025 & 0,00 & 0,30 & 0,32 & 9,15 & 23,32 & 18,02 \\
\hline 7 & 0,940 & 0,050 & 0,01 & 0,04 & 0,05 & 29,08 & 70,91 & 64,48 \\
\hline 8 & 0,955 & 0,025 & 0,02 & 0,03 & 0,07 & 105,03 & 76,01 & 58,37 \\
\hline 9 & 0,965 & 0,025 & 0,01 & 0,10 & 0,13 & 34,74 & 55,01 & 43,53 \\
\hline 10 & 1,000 & 0,000 & 0,00 & 0,72 & 0,78 & 8,04 & 6,15 & 1,78 \\
\hline 11 & 0,980 & 0,000 & 0,02 & 0,06 & 0,21 & 247,41 & 71,40 & 29,14 \\
\hline 12 & 0,950 & 0,050 & 0,00 & 0,09 & 0,10 & 14,77 & 56,40 & 50,84 \\
\hline 13 & 0,930 & 0,050 & 0,02 & 0,01 & 0,02 & 46,35 & 81,39 & 74,92 \\
\hline 14 & 0,990 & 0,000 & 0,01 & 0,32 & 0,43 & 34,96 & 26,82 & 11,62 \\
\hline 15 & 0,975 & 0,025 & 0,00 & 0,29 & 0,32 & 9,75 & 23,99 & 18,37 \\
\hline 16 & 0,940 & 0,050 & 0,01 & 0,04 & 0,05 & 27,71 & 70,19 & 63,76 \\
\hline 17 & 0,955 & 0,025 & 0,02 & 0,03 & 0,06 & 93,98 & 76,59 & 60,79 \\
\hline 18 & 0,965 & 0,025 & 0,01 & 0,10 & 0,13 & 33,46 & 54,28 & 43,40 \\
\hline 19 & 1,000 & 0,000 & 0,00 & 0,70 & 0,76 & 9,01 & 7,07 & 2,12 \\
\hline 20 & 0,980 & 0,000 & 0,02 & 0,09 & 0,23 & 155,27 & 63,15 & 26,65 \\
\hline 21 & 0,950 & 0,050 & 0,00 & 0,09 & 0,10 & 11,94 & 54,69 & 50,17 \\
\hline 22 & 0,930 & 0,050 & 0,02 & 0,01 & 0,02 & 51,42 & 81,32 & 74,30 \\
\hline 23 & 0,990 & 0,000 & 0,01 & 0,31 & 0,41 & 32,11 & 26,79 & 12,20 \\
\hline 24 & 0,975 & 0,025 & 0,00 & 0,28 & 0,31 & 9,26 & 24,25 & 19,13 \\
\hline 25 & 0,940 & 0,050 & 0,01 & 0,04 & 0,05 & 27,02 & 68,95 & 62,39 \\
\hline 26 & 0,955 & 0,025 & 0,02 & 0,03 & 0,07 & 111,52 & 76,76 & 59,02 \\
\hline 27 & 0,965 & 0,025 & 0,01 & 0,10 & 0,13 & 34,55 & 54,21 & 42,77 \\
\hline 28 & 1,000 & 0,000 & 0,00 & 0,71 & 0,76 & 8,04 & 6,40 & 1,94 \\
\hline 29 & 0,980 & 0,000 & 0,02 & 0,08 & 0,21 & 174,53 & 66,14 & 28,54 \\
\hline 30 & 0,950 & 0,050 & 0,00 & 0,09 & 0,10 & 15,01 & 56,01 & 50,40 \\
\hline 31 & 0,930 & 0,050 & 0,02 & 0,01 & 0,02 & 47,08 & 81,68 & 75,37 \\
\hline 32 & 0,990 & 0,000 & 0,01 & 0,29 & 0,40 & 40,09 & 29,25 & 13,07 \\
\hline 33 & 0,975 & 0,025 & 0,00 & 0,28 & 0,31 & 9,23 & 23,46 & 19,56 \\
\hline 34 & 0,940 & 0,050 & 0,01 & 0,04 & 0,05 & 31,00 & 70,58 & 63,31 \\
\hline 35 & 0,955 & 0,025 & 0,02 & 0,04 & 0,08 & 108,22 & 74,28 & 55,22 \\
\hline 36 & 0,965 & 0,025 & 0,01 & 0,09 & 0,12 & 30,37 & 55,66 & 45,85 \\
\hline
\end{tabular}


Tabela 4.6 - Resultados de $J_{n r}$ a 100 e a $3.200 ~ P a, J_{n r, d i f f, ~} R$ a 100 e a 3.200 Pa após envelhecimento a curto prazo a $58^{\circ} \mathrm{C}$

\begin{tabular}{|c|c|c|c|c|c|c|c|c|}
\hline Medição & Asfalto & SBS & Titan & $\begin{array}{c}\text { Jnr 100- } \\
58\end{array}$ & $\begin{array}{c}\text { Jnr 3200- } \\
58\end{array}$ & $\begin{array}{c}\text { Jnr diff- } \\
58\end{array}$ & $\begin{array}{c}\text { R 100- } \\
58\end{array}$ & R 3200-58 \\
\hline 1 & 1,000 & 0,000 & 0,00 & 1,90 & 2,12 & 11,60 & 0,88 & 0,00 \\
\hline 2 & 0,980 & 0,000 & 0,02 & 0,21 & 0,78 & 263,65 & 61,12 & 10,44 \\
\hline 3 & 0,950 & 0,050 & 0,00 & 0,16 & 0,25 & 56,09 & 60,56 & 41,68 \\
\hline 4 & 0,930 & 0,050 & 0,02 & 0,02 & 0,06 & 148,60 & 83,78 & 65,49 \\
\hline 5 & 0,990 & 0,000 & 0,01 & 0,80 & 1,23 & 57,58 & 22,45 & 2,85 \\
\hline 6 & 0,975 & 0,025 & 0,00 & 0,76 & 0,89 & 17,65 & 15,64 & 6,75 \\
\hline 7 & 0,940 & 0,050 & 0,01 & 0,07 & 0,13 & 77,82 & 70,70 & 52,60 \\
\hline 8 & 0,955 & 0,025 & 0,02 & 0,07 & 0,22 & 227,68 & 77,85 & 42,68 \\
\hline 9 & 0,965 & 0,025 & 0,01 & 0,22 & 0,40 & 78,01 & 53,36 & 28,13 \\
\hline 10 & 1,000 & 0,000 & 0,00 & 1,86 & 2,08 & 11,99 & 1,07 & 0,00 \\
\hline 11 & 0,980 & 0,000 & 0,02 & 0,15 & 0,80 & 444,77 & 70,49 & 11,28 \\
\hline 12 & 0,950 & 0,050 & 0,00 & 0,17 & 0,26 & 54,59 & 60,29 & 41,70 \\
\hline 13 & 0,930 & 0,050 & 0,02 & 0,03 & 0,06 & 127,38 & 82,34 & 65,03 \\
\hline 14 & 0,990 & 0,000 & 0,01 & 0,86 & 1,26 & 47,28 & 20,36 & 2,24 \\
\hline 15 & 0,975 & 0,025 & 0,00 & 0,75 & 0,89 & 18,72 & 16,74 & 7,04 \\
\hline 16 & 0,940 & 0,050 & 0,01 & 0,08 & 0,13 & 73,83 & 69,59 & 51,69 \\
\hline 17 & 0,955 & 0,025 & 0,02 & 0,06 & 0,20 & 209,63 & 78,28 & 45,65 \\
\hline 18 & 0,965 & 0,025 & 0,01 & 0,22 & 0,41 & 82,89 & 53,47 & 27,74 \\
\hline 19 & 1,000 & 0,000 & 0,00 & 1,81 & 2,05 & 13,60 & 2,55 & 0,00 \\
\hline 20 & 0,980 & 0,000 & 0,02 & 0,22 & 0,83 & 264,28 & 60,80 & 10,29 \\
\hline 21 & 0,950 & 0,050 & 0,00 & 0,17 & 0,26 & 52,68 & 59,19 & 40,87 \\
\hline 22 & 0,930 & 0,050 & 0,02 & 0,03 & 0,06 & 124,88 & 81,75 & 64,07 \\
\hline 23 & 0,990 & 0,000 & 0,01 & 0,83 & 1,21 & 45,16 & 20,29 & 2,58 \\
\hline 24 & 0,975 & 0,025 & 0,00 & 0,73 & 0,86 & 18,66 & 17,04 & 7,71 \\
\hline 25 & 0,940 & 0,050 & 0,01 & 0,08 & 0,14 & 74,44 & 68,84 & 50,50 \\
\hline 26 & 0,955 & 0,025 & 0,02 & 0,07 & 0,22 & 231,41 & 78,32 & 43,47 \\
\hline 27 & 0,965 & 0,025 & 0,01 & 0,22 & 0,41 & 82,39 & 52,50 & 27,16 \\
\hline 28 & 1,000 & 0,000 & 0,00 & 1,82 & 2,05 & 12,54 & 1,54 & 0,00 \\
\hline 29 & 0,980 & 0,000 & 0,02 & 0,20 & 0,78 & 296,09 & 63,18 & 10,94 \\
\hline 30 & 0,950 & 0,050 & 0,00 & 0,17 & 0,26 & 54,20 & 59,84 & 41,32 \\
\hline 31 & 0,930 & 0,050 & 0,02 & 0,02 & 0,05 & 124,35 & 82,59 & 65,65 \\
\hline 32 & 0,990 & 0,000 & 0,01 & 0,77 & 1,21 & 57,58 & 24,31 & 3,08 \\
\hline 33 & 0,975 & 0,025 & 0,00 & 0,72 & 0,87 & 20,95 & 17,63 & 8,05 \\
\hline 34 & 0,940 & 0,050 & 0,01 & 0,07 & 0,13 & 79,00 & 70,41 & 51,61 \\
\hline 35 & 0,955 & 0,025 & 0,02 & 0,08 & 0,26 & 222,85 & 75,79 & 39,07 \\
\hline 36 & 0,965 & 0,025 & 0,01 & 0,20 & 0,36 & 73,88 & 54,35 & 30,66 \\
\hline
\end{tabular}


Tabela 4.7 - Resultados de $J_{n r}$ a 100 e a $3.200 \mathrm{~Pa}, \mathrm{~J}_{\mathrm{nr}, \text { diff, }} \mathrm{R}$ a 100 e a 3.200 Pa após envelhecimento a curto prazo a $64^{\circ} \mathrm{C}$

\begin{tabular}{|c|c|c|c|c|c|c|c|c|}
\hline Medição & Asfalto & SBS & Titan & $\begin{array}{c}\text { Jnr 100- } \\
64\end{array}$ & $\begin{array}{c}\text { Jnr } \\
\text { 3200-64 }\end{array}$ & $\begin{array}{c}\text { Jnr diff- } \\
64\end{array}$ & R 100-64 & $\begin{array}{c}\text { R 3200- } \\
64\end{array}$ \\
\hline 1 & 1,000 & 0,000 & 0,00 & 4,59 & 5,23 & 14,08 & 0,00 & 0,00 \\
\hline 2 & 0,980 & 0,000 & 0,02 & 0,76 & 2,32 & 205,21 & 47,87 & 1,35 \\
\hline 3 & 0,950 & 0,050 & 0,00 & 0,36 & 0,64 & 78,72 & 58,32 & 33,07 \\
\hline 4 & 0,930 & 0,050 & 0,02 & 0,05 & 0,19 & 311,87 & 83,02 & 47,64 \\
\hline 5 & 0,990 & 0,000 & 0,01 & 2,05 & 3,40 & 69,76 & 16,79 & 0,00 \\
\hline 6 & 0,975 & 0,025 & 0,00 & 1,82 & 2,25 & 23,82 & 9,75 & 0,11 \\
\hline 7 & 0,940 & 0,050 & 0,01 & 0,17 & 0,38 & 129,85 & 67,10 & 37,27 \\
\hline 8 & 0,955 & 0,025 & 0,02 & 0,14 & 0,76 & 439,15 & 76,88 & 21,28 \\
\hline 9 & 0,965 & 0,025 & 0,01 & 0,58 & 1,19 & 105,87 & 46,19 & 12,08 \\
\hline 10 & 1,000 & 0,000 & 0,00 & 4,42 & 5,12 & 15,71 & 0,00 & 0,00 \\
\hline 11 & 0,980 & 0,000 & 0,02 & 0,55 & 2,42 & 342,48 & 58,83 & 1,56 \\
\hline 12 & 0,950 & 0,050 & 0,00 & 0,35 & 0,65 & 84,24 & 60,38 & 34,01 \\
\hline 13 & 0,930 & 0,050 & 0,02 & 0,05 & 0,20 & 263,45 & 81,18 & 47,31 \\
\hline 14 & 0,990 & 0,000 & 0,01 & 2,23 & 3,45 & 54,85 & 13,43 & 0,00 \\
\hline 15 & 0,975 & 0,025 & 0,00 & 1,84 & 2,29 & 24,71 & 10,16 & 0,19 \\
\hline 16 & 0,940 & 0,050 & 0,01 & 0,18 & 0,39 & 121,11 & 65,53 & 36,22 \\
\hline 17 & 0,955 & 0,025 & 0,02 & 0,13 & 0,69 & 420,69 & 77,19 & 23,55 \\
\hline 18 & 0,965 & 0,025 & 0,01 & 0,57 & 1,21 & 112,33 & 46,23 & 11,80 \\
\hline 19 & 1,000 & 0,000 & 0,00 & 4,37 & 5,09 & 16,51 & 0,00 & 0,00 \\
\hline 20 & 0,980 & 0,000 & 0,02 & 0,76 & 2,36 & 209,39 & 48,78 & 1,30 \\
\hline 21 & 0,950 & 0,050 & 0,00 & 0,36 & 0,65 & 80,79 & 59,16 & 33,26 \\
\hline 22 & 0,930 & 0,050 & 0,02 & 0,06 & 0,19 & 239,50 & 79,81 & 46,07 \\
\hline 23 & 0,990 & 0,000 & 0,01 & 2,14 & 3,33 & 55,07 & 13,91 & 0,00 \\
\hline 24 & 0,975 & 0,025 & 0,00 & 1,79 & 2,24 & 24,82 & 10,54 & 0,66 \\
\hline 25 & 0,940 & 0,050 & 0,01 & 0,18 & 0,40 & 120,67 & 65,01 & 35,79 \\
\hline 26 & 0,955 & 0,025 & 0,02 & 0,14 & 0,76 & 444,96 & 77,27 & 21,84 \\
\hline 27 & 0,965 & 0,025 & 0,01 & 0,57 & 1,23 & 114,88 & 45,76 & 11,42 \\
\hline 28 & 1,000 & 0,000 & 0,00 & 4,49 & 5,08 & 13,36 & 0,00 & 0,00 \\
\hline 29 & 0,980 & 0,000 & 0,02 & 0,72 & 2,32 & 221,00 & 49,97 & 1,57 \\
\hline 30 & 0,950 & 0,050 & 0,00 & 0,37 & 0,65 & 75,27 & 58,25 & 33,89 \\
\hline 31 & 0,930 & 0,050 & 0,02 & 0,05 & 0,18 & 241,65 & 80,84 & 48,30 \\
\hline 32 & 0,990 & 0,000 & 0,01 & 1,99 & 3,38 & 69,76 & 17,81 & 0,00 \\
\hline 33 & 0,975 & 0,025 & 0,00 & 1,77 & 2,26 & 28,16 & 11,82 & 0,95 \\
\hline 34 & 0,940 & 0,050 & 0,01 & 0,17 & 0,39 & 125,62 & 66,50 & 36,71 \\
\hline 35 & 0,955 & 0,025 & 0,02 & 0,17 & 0,86 & 407,78 & 74,32 & 18,60 \\
\hline 36 & 0,965 & 0,025 & 0,01 & 0,52 & 1,08 & 108,61 & 48,03 & 14,03 \\
\hline
\end{tabular}


Tabela 4.8 - Resultados de $J_{n r}$ a 100 e a $3.200 ~ P a, ~ J_{n r, d i f f, ~} R$ a 100 e a 3.200 Pa após envelhecimento a curto prazo a $70^{\circ} \mathrm{C}$

\begin{tabular}{|c|c|c|c|c|c|c|c|c|}
\hline Medição & Asfalto & SBS & Titan & $\begin{array}{c}\text { Jnr 100- } \\
70\end{array}$ & $\begin{array}{c}\text { Jnr } \\
\text { 3200-70 }\end{array}$ & $\begin{array}{c}\text { Jnr diff- } \\
70\end{array}$ & R 100-70 & $\begin{array}{c}\text { R 3200- } \\
70\end{array}$ \\
\hline 1 & 1,000 & 0,000 & 0,00 & - & - & - & 0,00 & 0,00 \\
\hline 2 & 0,980 & 0,000 & 0,02 & 2,39 & 6,11 & 155,14 & 31,18 & 0,00 \\
\hline 3 & 0,950 & 0,050 & 0,00 & 0,80 & 1,52 & 89,14 & 54,09 & 26,55 \\
\hline 4 & 0,930 & 0,050 & 0,02 & 0,11 & 0,62 & 453,61 & 79,39 & 28,29 \\
\hline 5 & 0,990 & 0,000 & 0,01 & 5,54 & 8,62 & 55,63 & 6,72 & 0,00 \\
\hline 6 & 0,975 & 0,025 & 0,00 & 4,27 & 5,39 & 26,07 & 4,83 & 0,00 \\
\hline 7 & 0,940 & 0,050 & 0,01 & 0,40 & 1,05 & 162,21 & 60,45 & 22,97 \\
\hline 8 & 0,955 & 0,025 & 0,02 & 0,41 & 2,27 & 452,11 & 69,46 & 5,79 \\
\hline 9 & 0,965 & 0,025 & 0,01 & 1,52 & 3,23 & 112,67 & 36,18 & 1,69 \\
\hline 10 & 1,000 & 0,000 & 0,00 & - & - & - & 0,00 & 0,00 \\
\hline 11 & 0,980 & 0,000 & 0,02 & 2,01 & 6,42 & 219,81 & 39,55 & 0,00 \\
\hline 12 & 0,950 & 0,050 & 0,00 & 0,74 & 1,52 & 104,19 & 58,99 & 28,49 \\
\hline 13 & 0,930 & 0,050 & 0,02 & 0,13 & 0,64 & 377,00 & 76,83 & 28,05 \\
\hline 14 & 0,990 & 0,000 & 0,01 & 5,85 & 8,60 & 46,93 & 5,15 & 0,00 \\
\hline 15 & 0,975 & 0,025 & 0,00 & 4,23 & 5,48 & 29,47 & 6,62 & 0,00 \\
\hline 16 & 0,940 & 0,050 & 0,01 & 0,42 & 1,05 & 148,61 & 58,44 & 22,28 \\
\hline 17 & 0,955 & 0,025 & 0,02 & 0,38 & 2,10 & 447,43 & 70,08 & 6,93 \\
\hline 18 & 0,965 & 0,025 & 0,01 & 1,46 & 3,29 & 125,37 & 37,46 & 1,55 \\
\hline 19 & 1,000 & 0,000 & 0,00 & - & - & - & 0,00 & 0,00 \\
\hline 20 & 0,980 & 0,000 & 0,02 & 2,37 & 6,16 & 159,70 & 32,79 & 0,00 \\
\hline 21 & 0,950 & 0,050 & 0,00 & 0,77 & 1,51 & 97,09 & 57,44 & 28,15 \\
\hline 22 & 0,930 & 0,050 & 0,02 & 0,14 & 0,62 & 334,01 & 74,63 & 26,12 \\
\hline 23 & 0,990 & 0,000 & 0,01 & 5,62 & 8,34 & 48,46 & 5,32 & 0,00 \\
\hline 24 & 0,975 & 0,025 & 0,00 & 4,27 & 5,41 & 26,73 & 5,16 & 0,00 \\
\hline 25 & 0,940 & 0,050 & 0,01 & 0,43 & 1,06 & 145,03 & 58,42 & 23,12 \\
\hline 26 & 0,955 & 0,025 & 0,02 & 0,40 & 2,28 & 465,94 & 70,03 & 6,04 \\
\hline 27 & 0,965 & 0,025 & 0,01 & 1,43 & 3,28 & 128,92 & 37,71 & 1,57 \\
\hline 28 & 1,000 & 0,000 & 0,00 & - & - & - & 0,00 & 0,00 \\
\hline 29 & 0,980 & 0,000 & 0,02 & 2,23 & 6,09 & 172,63 & 34,69 & 0,00 \\
\hline 30 & 0,950 & 0,050 & 0,00 & 0,79 & 1,50 & 91,22 & 56,59 & 28,82 \\
\hline 31 & 0,930 & 0,050 & 0,02 & 0,13 & 0,59 & 357,25 & 76,39 & 27,69 \\
\hline 32 & 0,990 & 0,000 & 0,01 & 5,38 & 8,69 & 61,54 & 8,37 & 0,00 \\
\hline 33 & 0,975 & 0,025 & 0,00 & 4,20 & 5,48 & 30,61 & 6,84 & 0,00 \\
\hline 34 & 0,940 & 0,050 & 0,01 & 0,42 & 1,06 & 149,62 & 59,04 & 23,06 \\
\hline 35 & 0,955 & 0,025 & 0,02 & 0,49 & 2,47 & 400,46 & 65,95 & 4,67 \\
\hline 36 & 0,965 & 0,025 & 0,01 & 1,33 & 2,99 & 124,86 & 39,17 & 2,68 \\
\hline
\end{tabular}


Tabela 4.9 - Resultados das temperaturas de usinagem e compactação e $G^{*} \cdot \operatorname{sen}(\delta)$

\begin{tabular}{|c|c|c|c|c|c|c|c|}
\hline Medição & Asfalto & SBS & Titan & $\begin{array}{c}\mathbf{T}_{\text {Usinagem }} \\
\left({ }^{\circ} \mathbf{C}\right)\end{array}$ & $\begin{array}{c}\mathbf{T}_{\text {Compactação }} \\
\left({ }^{\circ} \mathrm{C}\right)\end{array}$ & $\begin{array}{c}\mathbf{T}_{\text {Fadiga }}\left({ }^{\circ} \mathrm{C}\right) \\
\left(\mathrm{G}^{*} \cdot \operatorname{sen}(\delta)=5\right. \\
\mathrm{MPa})\end{array}$ & $\begin{array}{c}\mathbf{T}_{\text {Fadiga }}\left({ }^{\circ} \mathrm{C}\right) \\
\left(\mathrm{G}^{*} \cdot \operatorname{sen}(\delta)=6\right. \\
\mathrm{MPa})\end{array}$ \\
\hline 1 & 1,000 & 0,000 & 0,00 & 148,5 & 138,7 & 19,8 & 18,4 \\
\hline 2 & 0,980 & 0,000 & 0,02 & 150,3 & 139,3 & 21,0 & 20,0 \\
\hline 3 & 0,950 & 0,050 & 0,00 & 186,1 & 169,4 & 20,0 & 18,4 \\
\hline 4 & 0,930 & 0,050 & 0,02 & 185,5 & 172,8 & 22,1 & 20,5 \\
\hline 5 & 0,990 & 0,000 & 0,01 & 149,0 & 138,3 & 20,6 & 19,1 \\
\hline 6 & 0,975 & 0,025 & 0,00 & 164,4 & 151,4 & 20,0 & 18,8 \\
\hline 7 & 0,940 & 0,050 & 0,01 & 185,4 & 171,6 & 20,7 & 19,3 \\
\hline 8 & 0,955 & 0,025 & 0,02 & 166,0 & 149,9 & 21,2 & 20,0 \\
\hline 9 & 0,965 & 0,025 & 0,01 & 167,5 & 152,8 & 21,2 & 19,8 \\
\hline 10 & 1,000 & 0,000 & 0,00 & 147,3 & 136,6 & 19,0 & 18,0 \\
\hline 11 & 0,980 & 0,000 & 0,02 & 150,3 & 139,2 & 21,6 & 20,0 \\
\hline 12 & 0,950 & 0,050 & 0,00 & 186,5 & 171,4 & 20,0 & 18,8 \\
\hline 13 & 0,930 & 0,050 & 0,02 & 183,2 & 168,4 & 21,9 & 20,5 \\
\hline 14 & 0,990 & 0,000 & 0,01 & 149,5 & 138,5 & 20,4 & 19,5 \\
\hline 15 & 0,975 & 0,025 & 0,00 & 165,3 & 151,9 & 20,2 & 18,8 \\
\hline 16 & 0,940 & 0,050 & 0,01 & 183,9 & 170,5 & 20,5 & 19,1 \\
\hline 17 & 0,955 & 0,025 & 0,02 & 166,7 & 151,5 & 21,2 & 19,6 \\
\hline 18 & 0,965 & 0,025 & 0,01 & 167,4 & 153,0 & 21,4 & 20,0 \\
\hline 19 & 1,000 & 0,000 & 0,00 & 146,7 & 136,1 & - & - \\
\hline 20 & 0,980 & 0,000 & 0,02 & 150,5 & 139,2 & - & - \\
\hline 21 & 0,950 & 0,050 & 0,00 & 182,9 & 170,5 & - & - \\
\hline 22 & 0,930 & 0,050 & 0,02 & 184,5 & 171,4 & - & - \\
\hline 23 & 0,990 & 0,000 & 0,01 & 149,6 & 138,6 & - & - \\
\hline 24 & 0,975 & 0,025 & 0,00 & 165,0 & 152,2 & - & - \\
\hline 25 & 0,940 & 0,050 & 0,01 & 183,5 & 171,2 & - & - \\
\hline 26 & 0,955 & 0,025 & 0,02 & 167,7 & 152,7 & - & - \\
\hline 27 & 0,965 & 0,025 & 0,01 & 167,4 & 153,0 & - & - \\
\hline 28 & 1,000 & 0,000 & 0,00 & 147,1 & 136,3 & - & - \\
\hline 29 & 0,980 & 0,000 & 0,02 & 150,2 & 138,9 & - & - \\
\hline 30 & 0,950 & 0,050 & 0,00 & 180,5 & 167,4 & - & - \\
\hline 31 & 0,930 & 0,050 & 0,02 & 184,0 & 169,8 & - & - \\
\hline 32 & 0,990 & 0,000 & 0,01 & 149,7 & 138,8 & - & - \\
\hline 33 & 0,975 & 0,025 & 0,00 & 165,3 & 152,2 & - & - \\
\hline 34 & 0,940 & 0,050 & 0,01 & 184,2 & 172,2 & - & - \\
\hline 35 & 0,955 & 0,025 & 0,02 & 166,4 & 151,7 & - & - \\
\hline 36 & 0,965 & 0,025 & 0,01 & 167,6 & 153,3 & - & - \\
\hline
\end{tabular}


O ensaio MSCR para a mistura 100-0-0 não foi realizado na temperatura de $70^{\circ} \mathrm{C}$, pois o PG relativo a esta mistura foi de $58^{\circ} \mathrm{C}$. Esta mistura jamais poderia ser empregada nesta temperatura, consequentemente, o MSCR foi realizado até a temperatura de $64^{\circ} \mathrm{C}$ para este caso específico. Para o parâmetro $\mathrm{G}^{*} \cdot \operatorname{sen}(\delta)$ apenas uma réplica foi realizada.

\subsection{Análise estatística dos resultados}

Esta subseção tem por finalidade a apresentação dos resultados da análise estatística dos dados obtidos no experimento. Em função do grande número de modelos e da grande quantidade de gráficos gerados, optou-se por alocá-los no Anexo A. O Anexo A mostra os modelos obtidos, os gráficos da análise de resíduos, os gráficos de efeitos dos componentes e os gráficos de superfície de resposta. No corpo do trabalho, serão mostradas as expressões para os modelos obtidos, os coeficientes de determinação $\left(R^{2}\right)$ e será feita uma análise sobre cada uma das propriedades modeladas.

Os modelos de regressão foram ajustados no pacote estatístico Minitab 16.1. No Anexo A, estão apresentados os modelos de regressão e as suas respectivas estatísticas. Foram modeladas as seguintes propriedades:

- grau de desempenho contínuo das misturas (continuous grade) com base no valor $\mathrm{G}^{*} / \operatorname{sen} \delta$ igual a 1

- viscosidade na condição virgem (Vv) nas temperaturas de 135, 143, 150, 163 e $177^{\circ} \mathrm{C}$

- viscosidade envelhecida a curto prazo (Vr) nas temperaturas de 135, 143, 150, 163 e $177^{\circ} \mathrm{C}$;

- incremento de viscosidade (Iv) nas temperaturas de 135, 143, 150, 163 e $177^{\circ} \mathrm{C}$;

- compliância não-recuperável $\left(\mathrm{J}_{\mathrm{nr}}\right)$ a 100 Pa após envelhecimento a curto prazo nas temperaturas de $52,58,64$ e $70^{\circ} \mathrm{C}$;

- compliância não-recuperável $\left(\mathrm{J}_{\mathrm{nr}}\right.$ ) a $3.200 \mathrm{~Pa}$ após envelhecimento a curto prazo nas temperaturas de $52,58,64$ e $70^{\circ} \mathrm{C}$;

- percentual de recuperação (R) a 100 Pa após envelhecimento a curto prazo nas temperaturas de $52,58,64$ e $70^{\circ} \mathrm{C}$; 
- percentual de recuperação (R) a 3.200 Pa após envelhecimento a curto prazo nas temperaturas de $52,58,64$ e $70^{\circ} \mathrm{C}$;

- $\mathrm{J}_{\mathrm{nr}, \text { diff }}$ após envelhecimento a curto prazo nas temperaturas de 52, 58, 64 e $70^{\circ} \mathrm{C}$;

- comprimento da trinca na ruptura por fadiga $\left(\mathrm{a}_{\mathrm{f}}\right)$ após envelhecimento a longo prazo na temperatura de $25^{\circ} \mathrm{C}$;

- vida de fadiga $\left(\mathrm{N}_{\mathrm{f}}\right)$ com amplitude de deformação de 2 e 30\%, após envelhecimento a longo prazo na temperatura de $25^{\circ} \mathrm{C}$;

- temperaturas de usinagem ( $\left.\mathrm{T}_{\text {usinagem }}\right)$ e compactação $\left(\mathrm{T}_{\text {compactação }}\right)$;

- temperaturas críticas de fadiga (temperatura em que $\mathrm{G}^{*} \cdot \operatorname{sen}(\delta)$ é igual a $5 \mathrm{MPa}$ para tráfego $\mathrm{S}$ e igual a $6 \mathrm{MPa}$ para tráfegos $\mathrm{H}$ e $\mathrm{V}$ após envelhecimento a longo prazo a $10 \mathrm{rad} / \mathrm{s}-\mathrm{T}_{\text {Fadiga }}$ ).

Os modelos obtidos estão apresentados no Anexo A, de acordo com o Modelo A.1 até o Modelo A.43. Os gráficos da análise dos resíduos para estes modelos estão apresentados no Anexo A, de acordo com a Figura A.1.1 até a Figura A.43.1. Os gráficos de efeitos de componentes estão apresentados no Anexo A, de acordo com a Figura A.1.2 até a Figura A.43.2. Os gráficos de superfície de resposta estão apresentados no Anexo A, de acordo com a Figura A.1.3 até a Figura A.43.3. Os modelos de regressão obtidos e seus respectivos R $^{2}$ estão representados na Tabela 4.10 para as propriedades analisadas. Vale lembrar que $\mathrm{x}_{1}, \mathrm{x}_{2} \mathrm{e}$ $\mathrm{x}_{3}$ são asfalto, SBS e TITAN, respectivamente. 
Tabela 4.10 - Modelos de regressão e $R^{2}$ para as propriedades descritas na subseção 4.3

\begin{tabular}{|c|c|c|}
\hline Propriedade & Modelos de Regressão & $\begin{array}{c}\mathbf{R}^{2} \\
(\%)\end{array}$ \\
\hline Grau contínuo & $\begin{aligned} 65 \times 1+8.515 \times 2 & +33.486 \times 3-8.564 \times 1 \times 2-33.571 \times 1 \times 3 \\
& -24.850 \times 1 \times 2 \times 3\end{aligned}$ & 99,24 \\
\hline Vv $135^{\circ} \mathrm{C}$ & $297 x 1+234.370 x 2+2.454 \times 3-229.631 \times 1 \times 2-283.734 \times 2 \times 3$ & 99,86 \\
\hline Vv $143^{\circ} \mathrm{C}$ & $206 \times 1+119.895 \times 2+1.553 \times 3-115.110 \times 1 \times 2-166.661 \times 1 \times 2 \times 3$ & 99,84 \\
\hline Vv $150^{\circ} \mathrm{C}$ & $127 x 1+8.743 x 2-92.795 x 3+96.253 \times 1 \times 3$ & 96,20 \\
\hline Vv $163^{\circ} \mathrm{C}$ & $91 \times 1+70.936 \times 2-67.038 \times 3-69.071 \times 1 \times 2+69.075 \times 1 \times 3$ & 99,90 \\
\hline Vv $177^{\circ} \mathrm{C}$ & $56 \times 1+41.250 \times 2-43.246 \times 3-39.913 \times 1 \times 2+44.654 \times 1 \times 3$ & 99,96 \\
\hline VR $135^{\circ} \mathrm{C}$ & $419 x 1+31.9141 \times 2+4.507 \times 3-310.867 \times 1 \times 2-572.554 \times 2 \times 3$ & 99,22 \\
\hline VR $143^{\circ} \mathrm{C}$ & $279 \times 1+198.854 \times 2+3.351 \times 3-192.596 \times 1 \times 2-356.096 \times 2 \times 3$ & 99,32 \\
\hline VR $150^{\circ} \mathrm{C}$ & $205 \times 1+146.778 x 2+2.352 \times 3-142.308 \times 1 \times 2-236.630 \times 2 \times 3$ & 99,55 \\
\hline VR $163^{\circ} \mathrm{C}$ & $122 x 1+80.676 x 2-74.729 x 3-78.259 x 1 \times 2+77.313 \times 1 \times 3$ & 99,91 \\
\hline VR $177^{\circ} \mathrm{C}$ & $75 x 1+53.533 x 2+705 x 3-52.366 \times 1 \times 2-40.369 \times 2 \times 3$ & 99,87 \\
\hline $\mathbf{T}_{\text {Usinagem }}$ & $147 x 1+865 \times 2-10.526 \times 3+11.051 \times 1 \times 3+8.695 \times 2 \times 3$ & 99,88 \\
\hline $\mathbf{T}_{\text {Compactação }}$ & $136 x 1+3.743 \times 2-7.548 \times 3-3.063 \times 1 \times 2+7.982 \times 1 \times 3$ & 99,90 \\
\hline Iv $135^{\circ} \mathrm{C}$ & $1,472 \times 1-1,098 \times 2-0,143 \times 3$ & 75,28 \\
\hline Iv $143^{\circ} \mathrm{C}$ & $1,3873 \times 1+0,3978 \times 2+2,7202 \times 3$ & 39,97 \\
\hline Iv $150^{\circ} \mathrm{C}$ & $1,3032 \times 1+0,5312 \times 2+6,3177 \times 3$ & 75,04 \\
\hline Iv $163^{\circ} \mathrm{C}$ & $1,3234 \times 1-0,8017 \times 2+2,7899 \times 3$ & 83,29 \\
\hline Iv $177^{\circ} \mathrm{C}$ & $1,33 \times 1+41,59 \times 2-0,44 \times 3-47,13 \times 1 \times 2+182,44 \times 2 \times 3$ & 86,10 \\
\hline $\mathrm{J}_{\mathrm{nr}} 10052^{\circ} \mathrm{C}$ & $0,7 x 1-11,3 \times 2+516,1 \times 3-556,6 \times 1 \times 3$ & 96,25 \\
\hline $\mathrm{J}_{\mathrm{nr}} 10058^{\circ} \mathrm{C}$ & $2 \times 1-31 \times 2+1.394 \times 3-1.501 \times 1 \times 3$ & 96,50 \\
\hline $\mathrm{J}_{\mathrm{nr}} 10064^{\circ} \mathrm{C}$ & $4 \times 1-75 \times 2+3.189 \times 3-3.435 \times 1 \times 3$ & 96,41 \\
\hline $\mathrm{J}_{\mathrm{nr}} 100 \mathbf{7 0}^{\circ} \mathrm{C}$ & $8 \times 1-136 x 2-268 \times 3+94.732 \times 2 \times 3-96.428 \times 1 \times 2 \times 3$ & 97,03 \\
\hline $\mathrm{J}_{\mathrm{nr}} 320052^{\circ} \mathrm{C}$ & $0,7 x 1-12,3 \times 2+443,2 \times 3-478,7 \times 1 \times 3$ & 95,52 \\
\hline $\mathrm{J}_{\mathrm{nr}} 320058^{\circ} \mathrm{C}$ & $2 \times 1+360 \times 2+1.214 \times 3-414 \times 1 \times 2-1.300 \times 1 \times 3-636 \times 2 \times 3$ & 99,50 \\
\hline $\mathrm{J}_{\mathrm{nr}} 320064^{\circ} \mathrm{C}$ & $5 \times 1+853 x 2+2.212 \times 3-985 \times 1 \times 2-2.392 \times 1 \times 3-1.059 \times 2 \times 3$ & 99,70 \\
\hline $\mathrm{J}_{\mathrm{nr}} 320070^{\circ} \mathrm{C}$ & $10 x 1-157 x 2-163 \times 3+108.878 \times 2 \times 3-114.117 \times 1 \times 2 \times 3$ & 98,54 \\
\hline $\mathrm{R} 10052^{\circ} \mathrm{C}$ & $2 \times 1+1.043 \times 2+2.943 \times 3-428.742 \times 2 \times 3+427.131 \times 1 \times 2 \times 3$ & 98,64 \\
\hline R $10058^{\circ} \mathrm{C}$ & $-5 x 1+1.211 \times 2+3.318 \times 3-489.638 \times 2 \times 3+483.759 \times 1 \times 2 \times 3$ & 96,98 \\
\hline R $10064^{\circ} \mathrm{C}$ & $-9 \times 1+1.191 \times 2+2.906 \times 3-645.004 \times 2 \times 3+662.179 \times 1 \times 2 \times 3$ & 95,31 \\
\hline R $10070^{\circ} \mathrm{C}$ & $-6,45 \times 1+1.005,1 \times 2+1.953,6 x 3$ & 90,77 \\
\hline R $320052^{\circ} \mathrm{C}$ & $-0,34 \times 1+980,73 \times 2+1.494 \times 3$ & 97,85 \\
\hline R $320058^{\circ} \mathrm{C}$ & $831 \times 2+22.895 \times 3-22.809 \times 1 \times 3-9.483 \times 2 \times 3$ & 99,96 \\
\hline R $320064^{\circ} \mathrm{C}$ & $-2 \times 1+13.831 \times 2+223 \times 3-13.893 \times 1 \times 2$ & 97,56 \\
\hline R $320070^{\circ} \mathrm{C}$ & $-1 \times 1+16.470 \times 2+100 \times 3-16.783 \times 1 \times 2-17.248 \times 2 \times 3$ & 97,53 \\
\hline $\mathbf{J}_{\mathrm{nr}, \mathrm{diff}} \mathbf{5 2}^{\circ} \mathrm{C}$ & $-5 \times 1+354 \times 2+6.820 \times 3-96.935 \times 2 \times 3$ & 87,99 \\
\hline $\mathbf{J}_{\text {nr,diff }} 58^{\circ} \mathrm{C}$ & $3 \times 1+763 \times 2+13.772 \times 3-200.504 \times 1 \times 2 \times 3$ & 96,12 \\
\hline $\mathrm{J}_{\text {nr,diff }} 64^{\circ} \mathrm{C}$ & $1,72 \times 1+1.122,03 \times 2+8.988,41 \times 3$ & 92,38 \\
\hline $\mathrm{J}_{\mathrm{nr}, \mathrm{diff}} \mathbf{7 0 ^ { \circ } \mathrm { C }}$ & $-91,8 \times 1+3.168,5 \times 2+16.023,2 \times 3$ & 79,72 \\
\hline $\mathbf{a}_{\mathrm{f}} 25^{\circ} \mathrm{C}$ & $0,8551 \times 1+7,2750 \times 2+11,9483 \times 3$ & 95,88 \\
\hline $\mathrm{N}_{\mathrm{f}} 2 \% 25^{\circ} \mathrm{C}$ & $18.212 x 1+401.102 x 2+398.018 \times 3$ & 94,62 \\
\hline $\mathrm{N}_{\mathrm{f}} 30 \% 25^{\circ} \mathrm{C}$ & $5,9 \times 1+530,5 \times 2-117,1 \times 3-609,9 \times 1 \times 2$ & 94,45 \\
\hline $\begin{array}{c}\mathbf{T}_{\text {Fadiga }} \\
\left(G^{*} \cdot \operatorname{sen}(\delta)=5 \mathrm{MPa}\right)\end{array}$ & $19,64 x 1+28,98 \times 2+102,98 \times 3$ & 80,98 \\
\hline $\begin{array}{c}\mathbf{T}_{\text {Fadiga }} \\
\left(G^{*} \cdot \operatorname{sen}(\delta)=6 \mathrm{MPa}\right)\end{array}$ & $18,45 x 1+23,78 x 2+96,78 x 3$ & 81,65 \\
\hline
\end{tabular}




\subsection{Comentários sobre as propriedades, parâmetros e índices modelados}

Grau contínuo. Como indicado pela Figura A.1.2, os efeitos da proporção de SBS e TITAN tendem a aumentar o valor do grau de desempenho contínuo do ligante asfáltico. Ambos aumentam o grau de maneira aproximadamente linear, sendo que para baixos teores o aumento é menor do que para altos teores. O TITAN causa um maior aumento do grau contínuo que o SBS, visto que a inclinação da curva é maior para o TITAN. Para uma variação de $1 \%$ de SBS, obtém-se um ganho médio de $5^{\circ} \mathrm{C}$ no grau contínuo, enquanto para uma variação de $1 \%$ de TITAN, obtém-se um ganho médio de $12^{\circ} \mathrm{C}$ no grau contínuo. Valores de PG mais altos são desejáveis para os casos em que se exigem materiais mais resistentes às altas temperaturas do pavimento a aos altos níveis de tráfego pesado.

A Figura A.1.3 mostra a superfície de resposta para o grau de desempenho contínuo do ligante asfáltico. As curvas de nível presentes no simplex indicam que a quantidade de TITAN é o fator que mais influencia o aumento deste parâmetro. Para se alcançar um PG 64XX, é necessária a adição de $1 \%$ de SBS ou de $0,5 \%$ de TITAN ou uma mistura destes componentes cujo somatório das proporções seja menor que 1,5\%. Para se obter um PG 70XX, é necessária a adição de 2,5\% de SBS ou 1,5\% de TITAN ou uma mistura destes componentes cujo somatório das proporções seja menor que 4,0\%. Para se obter um PG 76XX, é necessária a adição de $4 \%$ de SBS ou de $2 \%$ de TITAN ou uma mistura destes componentes cujo somatório das proporções seja menor que 6,0\%. O menor PG possível é da mistura 100-0-0 (PG 58-XX), enquanto o maior PG possível é da mistura 93-5-2 (PG 106$\mathrm{XX)}$.

Viscosidade Brookfield na condição virgem. As Figuras A.2.2 a A.6.2 apresentam os efeitos dos componentes sobre a viscosidade Brookfield nas temperaturas de 135, 143, 150, 163 e $177^{\circ} \mathrm{C}$ das amostras virgens. Em linhas gerais, os efeitos do SBS e do TITAN diferem. O SBS atua no sentido de aumentar a viscosidade e seu efeito é aproximadamente linear para as temperaturas $135,143,163$ e $177^{\circ} \mathrm{C}$, sendo pouco efetivo em baixas concentrações e possui efeito linear para a temperatura de $150^{\circ} \mathrm{C}$. Já o TITAN não provoca variações substanciais da viscosidade na condição virgem. Nas temperaturas de 135 e $143^{\circ} \mathrm{C}$ o efeito do TITAN é nulo. Para a temperatura de $150^{\circ} \mathrm{C}$, o TITAN possui um ponto de máximo com $0,5 \%$ em peso. Para 
as temperaturas de 163 e $177^{\circ} \mathrm{C}$, o ponto de máximo ocorre com a concentração de $1 \%$ em peso. A Tabela 4.11 apresenta a variação média da viscosidade Brookfield na condição virgem, em mPa.s, provocada pelo aumento de $1 \%$ na proporção de SBS e TITAN. Nesta tabela, o sinal positivo indica um aumento da viscosidade e o negativo indica uma redução da viscosidade.

Tabela 4.11 - Variação média da viscosidade Brookfield na condição virgem para 1\% de aumento nas proporções de SBS e TITAN, nas temperaturas de ensaio

\begin{tabular}{ccc}
\hline temperatura de ensaio $\left({ }^{\mathbf{o}} \mathbf{C}\right)$ & $\begin{array}{c}\text { efeito da proporção } \\
\text { de SBS (mPa.s) }\end{array}$ & $\begin{array}{c}\text { efeito da proporção de } \\
\text { TITAN (mPa.s) }\end{array}$ \\
\hline 135 & +150 & 0 \\
143 & +100 & 0 \\
150 & +50 & -10 \\
163 & +50 & -5 \\
177 & +25 & -5 \\
\hline
\end{tabular}

Observa-se que à medida que aumenta a temperatura do ensaio, a intensidade dos efeitos desses componentes varia, como pode ser observado na Tabela 4.11. Com o aumento da temperatura de ensaio, a intensidade do efeito do SBS em aumentar a viscosidade diminui e a intensidade do efeito do TITAN tem seu pico na temperatura de $150^{\circ} \mathrm{C}$. Para temperaturas baixas $\left(135\right.$ e $\left.143^{\circ} \mathrm{C}\right)$, ocorre um aumento da propriedade com a adição de TITAN e, para as demais temperaturas $\left(150,163\right.$ e $\left.177^{\circ} \mathrm{C}\right)$, ocorre uma diminuição da propriedade com a adição de TITAN. Embora haja algum efeito do TITAN nas temperaturas mais altas, o efeito global é praticamente nulo. Isto indica que o TITAN, que é uma cera, não causa acréscimos excessivos na viscosidade, fazendo com que a trabalhabilidade do asfalto modificado com TITAN seja equivalente à do ligante asfáltico de base.

As Figuras A.2.3 a A.6.3 mostram as superfícies de resposta para a viscosidade Brookfield na condição virgem nas temperaturas de $135,143,150,163$ e $177^{\circ} \mathrm{C}$. Para um teor fixo de SBS, para as temperaturas de 135 e $143^{\circ} \mathrm{C}$, não ocorre variação do valor da viscosidade com o aumento do teor de TITAN e nas temperaturas de 150,163 e $177^{\circ} \mathrm{C}$, ocorre apenas uma ligeira variação da viscosidade. Na especificação Superpave, recomenda-se que a viscosidade a $135^{\circ} \mathrm{C}$ na condição virgem seja inferior a 3 Pa.s ou $3.000 \mathrm{mPa}$.s, para efeito de bombeamento, porém, os valores aqui obtidos atendem plenamente este limite. 
Viscosidade Brookfield na condição envelhecida a curto prazo. As Figuras A.7.2 a A.11.2 apresentam os efeitos dos componentes sobre a viscosidade Brookfield nas temperaturas de $135,143,150,163$ e $177^{\circ} \mathrm{C}$ das amostras envelhecidas a curto prazo. Em linhas gerais, os efeitos do SBS e do TITAN diferem. O SBS atua no sentido de aumentar a viscosidade e seu efeito é aproximadamente linear em todas as temperaturas, sendo pouco efetivo em baixas concentrações. Já o TITAN não produz variações substanciais na viscosidade envelhecida a curto prazo. Para as temperaturas de 135,143 e $150^{\circ} \mathrm{C}$, ocorre uma redução muito pequena, com efeito aproximadamente linear. A maior redução ocorre para a temperatura de $135^{\circ} \mathrm{C}$. Para a temperatura de $163^{\circ} \mathrm{C}$, o TITAN possui um ponto de máximo com $1,5 \%$ em peso. Para a temperatura de $177^{\circ} \mathrm{C}$, o ponto de máximo ocorre com a concentração de $2 \%$ em peso. A Tabela 4.12 apresenta a variação média da viscosidade Brookfield na condição envelhecida a curto prazo, em mPa.s, provocada pelo aumento de $1 \%$ na proporção de SBS e TITAN. Nesta tabela, o sinal positivo indica um aumento da viscosidade e o negativo indica uma redução da viscosidade.

Tabela 4.12 - Variação média da viscosidade Brookfield na condição envelhecida a curto prazo para $1 \%$ de aumento nas proporções de SBS e TITAN, nas temperaturas de ensaio

\begin{tabular}{ccc}
\hline temperatura de ensaio $\left({ }^{\circ} \mathbf{C}\right)$ & $\begin{array}{c}\text { efeito da proporção } \\
\text { de SBS (mPa.s) }\end{array}$ & $\begin{array}{c}\text { efeito da proporção de } \\
\text { TITAN (mPa.s) }\end{array}$ \\
\hline 135 & +225 & -20 \\
143 & +100 & -10 \\
150 & +90 & -5 \\
163 & +50 & +5 \\
177 & +35 & +10 \\
\hline
\end{tabular}

Observa-se que à medida que aumenta a temperatura do ensaio, a intensidade dos efeitos desses componentes varia como pode ser observado na Tabela 4.12. Com o aumento da temperatura de ensaio, a intensidade do efeito do SBS em aumentar a viscosidade diminui. Para o TITAN, nas primeiras três temperaturas, ele diminui levemente a viscosidade e para as temperaturas de 163 e $177^{\circ} \mathrm{C}$ ocorre um leve aumento da propriedade. Observa-se que com o envelhecimento a curto prazo, o efeito do TITAN mostra-se diferente ao do apresentado na condição virgem.

As Figuras A.7.3 a A.11.3 mostram as superfícies de resposta para viscosidade Brookfield nas temperaturas de $135,143,150,163$ e $177^{\circ} \mathrm{C}$ na condição envelhecida a curto 
prazo. Para as temperaturas de 135,143 e $150^{\circ} \mathrm{C}$, para um teor fixo de SBS, ocorre uma pequena diminuição da viscosidade ao se adicionar TITAN. Para um teor fixo de SBS, para as temperaturas de 163 e $177^{\circ} \mathrm{C}$, ocorre um pequeno aumento da viscosidade ao se adicionar TITAN. Esta diminuição e aumento é praticamente desprezível em relação à magnitude dos valores que são apresentados de viscosidade Brookfield na condição envelhecida a curto prazo.

Temperaturas de usinagem e compactação. As Figuras A.12.2 e A.13.2 apresentam os efeitos da temperatura de usinagem e compactação para os valores de 0,17 Pa.s e 0,28 Pa.s, respectivamente. Em linhas gerais, os efeitos do SBS e do TITAN diferem. O SBS atua no sentido de aumentar as temperaturas de usinagem e compactação e seu efeito é aproximadamente linear para a compactação e linear para a usinagem. Já o TITAN não provoca variações substanciais na temperatura de compactação e usinagem. Para a compactação têm-se um ponto de máximo com a concentração de $1 \%$, enquanto para a usinagem este ponto de máximo é observado com concentração de 1,5\%. Para uma variação de $1 \%$ de SBS, obtém-se um ganho médio na temperatura de compactação de $7^{\circ} \mathrm{C}$ e de $6^{\circ} \mathrm{C}$ para usinagem, enquanto para uma variação de $1 \%$ de TITAN, não se observa uma variação significativa, para ambos os casos (compactação e usinagem) ocorre uma variação de $1^{\circ} \mathrm{C}$ positiva para baixos teores e $1^{\circ} \mathrm{C}$ negativa para altos teores.

As Figuras A.12.3 e A.13.3 mostram as superfícies de resposta para as temperaturas de compactação e usinagem das misturas. Observa-se que para uma mesma mistura, a temperatura média em que a usinagem é maior que a compactação é em torno de $15^{\circ} \mathrm{C}$, ou seja, para uma mesma mistura, a usinagem será $15^{\circ} \mathrm{C}$ superior a temperatura de compactação. Com o aumento da concentração de SBS é que o ocorre o maior aumento das temperaturas de compactação e usinagem. Ao se observar as temperaturas de usinagem, se não se quiser aquecer a mistura mais de $150^{\circ} \mathrm{C}$, recomenda-se a utilização de no máximo $0,5 \%$ de SBS nas misturas. Para uma temperatura de aquecimento máxima de $160^{\circ} \mathrm{C}$, recomenda-se o uso máximo de $1,8 \%$ de SBS. Para uma temperatura de aquecimento máxima de $170^{\circ} \mathrm{C}$, recomenda-se não mais do que 3,5\% de SBS na mistura. Para uma temperatura de aquecimento máxima de $180^{\circ} \mathrm{C}$, recomenda-se o uso máximo de $4,5 \%$ de SBS. 
Incremento de viscosidade. As Figuras A.14.2 a A.18.2 apresentam os efeitos dos componentes sobre o incremento de viscosidade nas temperaturas de 135, 143, 150, 163 e $177^{\circ} \mathrm{C}$. Em linhas gerais, os efeitos do SBS e do TITAN diferem. O efeito do SBS se expressa na forma de diminuição linear do incremento de viscosidade para as temperaturas de 135 , 143,150 e $163^{\circ} \mathrm{C}$. Para a temperatura de $177^{\circ} \mathrm{C}$, ocorre uma redução aproximadamente linear do incremento de viscosidade, sendo o efeito do SBS pouco efetivo em altos teores. Já o TITAN tende a diminuir linearmente o incremento de viscosidade para a temperatura de $135^{\circ} \mathrm{C}$. Para as temperaturas de $143,150,163$ e $177^{\circ} \mathrm{C}$, a adição do TITAN concorre para um aumento linear do incremento de viscosidade. A Tabela 4.13 apresenta a variação média do incremento de viscosidade, provocada pelo aumento de $1 \%$ na proporção de SBS e TITAN. Nesta tabela, o sinal positivo indica um aumento do incremento e o negativo indica uma redução do incremento.

Tabela 4.13 - Variação média do incremento de viscosidade para $1 \%$ de aumento nas proporções de SBS e TITAN, nas temperaturas de ensaio

\begin{tabular}{ccc}
\hline temperatura de ensaio $\left({ }^{\circ} \mathbf{C}\right)$ & $\begin{array}{c}\text { efeito da proporção } \\
\text { de SBS }\end{array}$ & $\begin{array}{c}\text { efeito da proporção de } \\
\text { TITAN }\end{array}$ \\
\hline 135 & $-0,02$ & $-0,01$ \\
143 & $-0,01$ & $+0,015$ \\
150 & $-0,005$ & $+0,05$ \\
163 & $-0,05$ & $+0,02$ \\
177 & $-0,025$ & $+0,04$ \\
\hline
\end{tabular}

Observa-se que, à medida que aumenta a temperatura do ensaio, a intensidade dos efeitos desses componentes varia, como pode ser observado na Tabela 4.13. A maior redução da intensidade do efeito do SBS em reduzir o incremento de viscosidade se dá para a temperatura de $163^{\circ} \mathrm{C}$ e a menor se dá para a temperatura de $150^{\circ} \mathrm{C}$. Para o TITAN, a maior intensidade do efeito de aumentar o incremento de viscosidade se dá para a temperatura de $150^{\circ} \mathrm{C}$ e a menor se dá para a temperatura de $135^{\circ} \mathrm{C}$. A única temperatura em que o TITAN atua no sentido de reduzir o incremento de viscosidade é a $135^{\circ} \mathrm{C}$, mostrando que com o envelhecimento o efeito do TITAN na mistura é positivo, ou seja, ele contribui para reduzir o efeito do envelhecimento a curto prazo sobre o aumento da viscosidade da mistura. Já o do SBS causa uma diminuição do incremento de viscosidade, ou seja, ele contribui para 
minimizar o efeito do envelhecimento a curto prazo sobre o aumento da viscosidade rotacional.

As Figuras A.14.3 a A.18.3 mostram as superfícies de resposta para o incremento de viscosidade nas temperaturas de $135,143,150,163$ e $177^{\circ} \mathrm{C}$. Para a temperatura de $135^{\circ} \mathrm{C}$, para um teor fixo de SBS ocorre uma diminuição do incremento de viscosidade ao se adicionar TITAN. Para um teor fixo de SBS, para as temperaturas de $143,150,163$ e $177^{\circ} \mathrm{C}$, ocorre um aumento do incremento de viscosidade ao se adicionar TITAN. Vale ressaltar que, para a temperatura de $177^{\circ} \mathrm{C}$, as curvas de nível obtidas mostram que $2 \%$ de TITAN causam um aumento maior no incremento de viscosidade, ao se manter constante a concentração de SBS.

No caso específico do incremento de viscosidade medido a $135^{\circ} \mathrm{C}$, os efeitos de multicolinearidade podem ser desconsiderados, em virtude dos baixos valores do fator de inflação de variância, e os coeficientes do modelo podem ser interpretados como indicadores do peso que cada componente do modelo tem sobre a variabilidade dos resultados de incremento de viscosidade nesta temperatura. Como se vê no modelo indicado abaixo, tanto o SBS quanto o TITAN contribuem com a diminuição do incremento de viscosidade, sendo a contribuição do SBS 7,68 vezes maior que a do TITAN $(1,098 / 0,143=7,68)$.

$\begin{array}{lrllll}\text { Term } & \text { Coef } & \text { SE Coef } & \text { T } & \text { P } & \text { VIF } \\ \text { Asfalto } & 1,472 & 0,01310 & * & * & 3,628 \\ \text { SBS } & -1,098 & 0,32428 & \text { * } & * & 2,055 \\ \text { Titan } & -0,143 & 0,88831 & \text { * } & * & 3,221\end{array}$

No caso específico do incremento de viscosidade medido a $143^{\circ} \mathrm{C}$, os efeitos de multicolinearidade podem ser desconsiderados, em virtude dos baixos valores do fator de inflação de variância, e os coeficientes do modelo podem ser interpretados como indicadores do peso que cada componente do modelo tem sobre a variabilidade dos resultados de incremento de viscosidade nesta temperatura. Como se vê no modelo indicado abaixo, tanto o SBS quanto o TITAN contribuem com o aumento do incremento de viscosidade, sendo a contribuição do TITAN 6,84 vezes maior que a do SBS $(2,7202 / 0,3978=6,84)$.

$\begin{array}{lrrrrr}\text { Term } & \text { Coef } & \text { SE Coef } & \text { T } & \text { P } & \text { VIF } \\ \text { Asfalto } & 1,3873 & 0,01363 & \star & \star & 4,941 \\ \text { SBS } & 0,3978 & 0,28346 & \star & \star & 2,396 \\ \text { Titan } & 2,7202 & 0,77818 & \star & \star & 3,275\end{array}$


No caso específico do incremento de viscosidade medido a $150^{\circ} \mathrm{C}$, os efeitos de multicolinearidade podem ser desconsiderados, em virtude dos baixos valores do fator de inflação de variância, e os coeficientes do modelo podem ser interpretados como indicadores do peso que cada componente do modelo tem sobre a variabilidade dos resultados de incremento de viscosidade nesta temperatura. Como se vê no modelo indicado abaixo, tanto o SBS quanto o TITAN contribuem com o aumento do incremento de viscosidade, sendo a contribuição do TITAN 11,89 vezes maior que a do SBS $(6,3177 / 0,5312=11,89)$.

$\begin{array}{lrrrrr}\text { Term } & \text { Coef } & \text { SE Coef } & \text { T } & \text { P } & \text { VIF } \\ \text { Asfalto } & 1,3032 & 0,01168 & \star & \star & 4,965 \\ \text { SBS } & 0,5312 & 0,25639 & \star & \star & 2,466 \\ \text { Titan } & 6,3177 & 0,65688 & \star & \star & 3,072\end{array}$

No caso específico do incremento de viscosidade medido a $163^{\circ} \mathrm{C}$, os efeitos de multicolinearidade podem ser desconsiderados, em virtude dos baixos valores do fator de inflação de variância, e os coeficientes do modelo podem ser interpretados como indicadores do peso que cada componente do modelo tem sobre a variabilidade dos resultados de incremento de viscosidade nesta temperatura. Como se vê no modelo indicado abaixo, o SBS diminui e o TITAN aumenta o incremento de viscosidade, sendo a contribuição do TITAN 3,48 vezes maior que a do SBS $(2,7899 / 0,8017=3,48)$.

$\begin{array}{lrrrrr}\text { Term } & \text { Coef } & \text { SE Coef } & \text { T } & \text { P } & \text { VIF } \\ \text { Asfalto } & 1,3234 & 0,01037 & \star & \star & 5,308 \\ \text { SBS } & -0,8017 & 0,21557 & \star & \star & 2,277 \\ \text { Titan } & 2,7899 & 0,58174 & \star & \star & 3,585\end{array}$

\section{Compliância não-recuperável a 3.200 Pa $\left(\mathrm{J}_{\mathrm{nr}}\right.$ 3.200 Pa) na condição envelhecida a} curto prazo. As Figuras A.19.2 a A.22.2 apresentam os efeitos dos componentes sobre a compliância não-recuperável a $3.200 \mathrm{~Pa}$ nas temperaturas de $52,58,64$ e $70^{\circ} \mathrm{C}$ das misturas envelhecidas a curto prazo. Em linhas gerais, os efeitos do SBS e do TITAN são parecidos. O SBS reduz a compliância de forma aproximadamente linear em todas as temperaturas, exceto à $52^{\circ} \mathrm{C}$, em que a redução é linear. Já o TITAN provoca redução aproximadamente linear da compliância para todas as temperaturas. A Tabela 4.14 apresenta a variação média da compliância não-recuperável $\left(\mathrm{J}_{\mathrm{nr}}\right)$ das misturas envelhecidas a curto prazo, em $\mathrm{kPa}^{-1}$, provocada pelo aumento de $1 \%$ na proporção de SBS e TITAN. Nesta tabela, o sinal positivo 
indica um aumento da compliância não-recuperável e o negativo indica uma redução da compliância não-recuperável.

Observa-se que, à medida que aumenta a temperatura do ensaio, a intensidade dos efeitos desses componentes varia, como pode ser visto na Tabela 4.14. Com o aumento da temperatura de ensaio, a intensidade do efeito do SBS em diminuir a compliância nãorecuperável aumenta. O mesmo se observa para o TITAN: com o aumento da temperatura de ensaio, a intensidade do efeito do TITAN em diminuir a compliância não-recuperável aumenta. Observa-se que o TITAN é ligeiramente mais efetivo que o SBS em reduzir a compliância não-recuperável das misturas em todas as temperaturas de ensaio.

Tabela 4.14 - Variação média da compliância não-recuperável $\left(J_{n r}\right)$ a 3.200 Pa das misturas envelhecidas a curto prazo para $1 \%$ de aumento nas proporções de SBS e TITAN, nas temperaturas de ensaio

\begin{tabular}{ccc}
\hline temperatura de ensaio $\left({ }^{\mathbf{}} \mathbf{C}\right)$ & $\begin{array}{c}\text { efeito da proporção } \\
\text { de SBS }\left(\mathbf{k P a}^{-1}\right)\end{array}$ & $\begin{array}{c}\text { efeito da proporção de } \\
\text { TITAN }\left(\mathbf{k P a}^{-1}\right)\end{array}$ \\
\hline 52 & $-0,1$ & $-0,15$ \\
58 & $-0,3$ & $-0,4$ \\
64 & $-0,75$ & $-1,0$ \\
70 & $-1,5$ & $-1,75$ \\
\hline
\end{tabular}

As Figuras A.19.3 a A.22.3 mostram as superfícies de resposta para a compliância nãorecuperável nas temperaturas de $52,58,64$ e $70^{\circ} \mathrm{C}$ das misturas envelhecidas a curto prazo. Observa-se o mesmo padrão da variação da propriedade em função da proporção dos componentes para todas as temperaturas de ensaio. Para um teor fixo de SBS ocorre uma diminuição da compliância não-recuperável $\left(\mathrm{J}_{\mathrm{nr}}\right)$ com a adição de TITAN. Portanto, tanto o SBS quanto o TITAN melhoram a resistência à deformação permanente, diminuindo o valor da compliância não-recuperável.

Para a temperatura de $64^{\circ} \mathrm{C}$, misturas com altos teores de modificadores (proporção total em torno de 5,5\%) seriam indicadas para a utilização em pavimentos para atender um nível de tráfego extremamente pesado (E). Misturas com 4\% de SBS ou misturas com 2,5\% de SBS e $2 \%$ de TITAN seriam indicadas para atender tráfego muito pesado (V). Misturas com 2,5\% de SBS ou misturas com $0,5 \%$ de SBS e $2 \%$ de TITAN seriam indicadas para atender tráfego pesado $(\mathrm{H})$. Misturas com $0,5 \%$ de SBS ou $0,5 \%$ de TITAN seriam indicadas para atender um nível de tráfego padrão (S). Misturas compostas com proporções dos modificadores inferiores 
aos valores mencionados não se enquadram na classificação de tráfego e por esta razão não seriam indicadas para uso em pavimentos cuja temperatura máxima atingisse $64^{\circ} \mathrm{C}$.

Para a temperatura de $70^{\circ} \mathrm{C}$, misturas com altos teores de modificadores (proporção total em torno de 6,5\%) seriam indicadas para a utilização em pavimentos para atender um nível de tráfego muito pesado (V). Misturas com 4,8\% de SBS ou misturas com 3\% de SBS e 2\% de TITAN seriam indicadas para atender tráfego pesado $(\mathrm{H})$. Misturas com 3\% de SBS ou misturas com 1,5\% de SBS e 2\% de TITAN seriam indicadas para atender um nível de tráfego padrão (S). Misturas compostas com proporções dos modificadores inferiores aos valores mencionados não se enquadram na classificação de tráfego e por esta razão não seriam indicadas para uso em pavimentos cuja temperatura máxima atingisse $70^{\circ} \mathrm{C}$.

\section{Percentual de recuperação $(R)$ a 3.200 Pa das misturas na condição envelhecida a} curto prazo. As Figuras A.23.2 a A.26.2 apresentam os efeitos dos componentes sobre o percentual de recuperação a $3.200 \mathrm{~Pa}$ nas temperaturas de $52,58,64$ e $70^{\circ} \mathrm{C}$ das misturas envelhecidas a curto prazo. Em linhas gerais, os efeitos do SBS e do TITAN são parecidos. O SBS aumenta o percentual de recuperação de forma linear para as temperaturas de 52 e $58^{\circ} \mathrm{C}$. Para as temperaturas de 64 e $70^{\circ} \mathrm{C}$, ocorre um aumento aproximadamente linear do percentual de recuperação com o aumento da proporção de SBS, se mostrando pouco expressivo em baixos teores de SBS. Já o TITAN aumenta o percentual de recuperação linearmente para todas as temperaturas, exceto à $70^{\circ} \mathrm{C}$, na qual apresenta um aumento pouco expressivo. A Tabela 4.15 apresenta a variação média do percentual de recuperação $(\mathrm{R})$ das misturas envelhecidas a curto prazo, em porcentagem, provocada pelo aumento de $1 \%$ na proporção de SBS e TITAN. Nesta tabela, o sinal positivo indica um aumento do percentual de recuperação e o negativo indica uma redução do percentual de recuperação.

Tabela 4.15 - Variação média do percentual de recuperação $(R)$ a 3.200 Pa das misturas envelhecidas a curto prazo para $1 \%$ de aumento nas proporções de SBS e TITAN, nas temperaturas de ensaio

\begin{tabular}{ccc}
\hline temperatura de ensaio $\left({ }^{\mathbf{}} \mathbf{C}\right)$ & $\begin{array}{c}\text { efeito da proporção } \\
\text { de SBS }(\%)\end{array}$ & $\begin{array}{c}\text { efeito da proporção de } \\
\text { TITAN }(\%)\end{array}$ \\
\hline 52 & +10 & +15 \\
58 & +10 & +10 \\
64 & +9 & +5 \\
70 & $+7,5$ & +1 \\
\hline
\end{tabular}


Observa-se que, à medida que aumenta a temperatura do ensaio, a intensidade dos efeitos desses componentes varia como pode ser visto na Tabela 4.15. Com o aumento da temperatura de ensaio, a intensidade do efeito do SBS em aumentar o percentual de recuperação diminui. $\mathrm{O}$ mesmo se observa para o TITAN: com o aumento da temperatura de ensaio a intensidade do efeito do TITAN em aumentar o percentual de recuperação diminui. O SBS se mostra mais efetivo que o TITAN em aumentar o percentual de recuperação nas temperaturas mais altas do pavimento (superiores a $64^{\circ} \mathrm{C}$ ), ao passo que o TITAN é mais efetivo que o SBS nas temperaturas mais baixas do pavimento (inferiores a $58^{\circ} \mathrm{C}$ ).

As Figuras A.23.3 a A.26.3 mostram as superfícies de resposta para a compliância nãorecuperável nas temperaturas de $52,58,64$ e $70^{\circ} \mathrm{C}$ das misturas envelhecidas a curto prazo. Para um teor fixo de SBS, para as temperaturas de 52,58 e $64^{\circ} \mathrm{C}$ ocorre um aumento do percentual de recuperação com a adição de TITAN na mistura. Para a temperatura de $70^{\circ} \mathrm{C}$, ao se manter constante uma mesma concentração de SBS, o percentual de recuperação se mantém praticamente estável, pois neste caso a adição de TITAN não melhora esta propriedade. Portanto, tanto o SBS quanto o TITAN têm potencial de contribuir com a resistência à deformação permanente, aumentando o valor do percentual de recuperação, que se reflete em uma maior capacidade de recuperação do ligante asfáltico. A adição de TITAN se mostrou positiva para as temperaturas de 52,58 e $64^{\circ} \mathrm{C}$, não surtindo efeitos positivos nem negativos para a temperatura de $70^{\circ} \mathrm{C}$. Vale ressaltar que os percentuais de recuperação obtidos mesmo com as adições podem ser considerados ainda baixos para as temperaturas de 64 e $70^{\circ} \mathrm{C}$. Para a temperatura de $64^{\circ} \mathrm{C}$, apenas misturas com altos teores de modificadores atingem uma recuperação elástica de $30 \%$ a $45 \%$. Para a temperatura de $70^{\circ} \mathrm{C}$, nenhuma mistura apresenta uma recuperação elástica acima de $28 \%$.

No caso específico da recuperação elástica medida a $52^{\circ} \mathrm{C}$, os efeitos de multicolinearidade podem ser desconsiderados, em virtude dos baixos valores do fator de inflação de variância, e os coeficientes do modelo podem ser interpretados como indicadores do peso que cada componente do modelo tem sobre a variabilidade dos resultados de recuperação elástica nesta temperatura. Como se vê no modelo indicado abaixo, tanto o SBS quanto o TITAN contribuem com o aumento da recuperação elástica, sendo a contribuição do TITAN 1,52 vezes maior que a do SBS $(1.984,79 / 980,73=1,52)$. 


$\begin{array}{lrrrrr}\text { Term } & \text { Coef } & \text { SE Coef } & \text { T } & \text { P } & \text { VIF } \\ \text { Asfalto } & -0,34 & 1,211 & \star & * & 3,727 \\ \text { SBS } & 980,73 & 28,934 & \star & \star & 2,379 \\ \text { Titan } & 1494,79 & 73,413 & \star & * & 2,451\end{array}$

$\mathbf{J}_{n \mathbf{n r d i f f}}$ das misturas na condição envelhecida a curto prazo. As Figuras A.27.2 a A.30.2 apresentam os efeitos dos componentes sobre o $\mathrm{J}_{\mathrm{nr} \text {,diff }}$ nas temperaturas de 52, 58, $64 \mathrm{e}$ $70^{\circ} \mathrm{C}$ das misturas envelhecidas a curto prazo. O SBS atua no sentido de diminuir os valores de $\mathrm{J}_{\mathrm{nr} \text {,diff }}$ de forma linear para as temperaturas de 52 e $58^{\circ} \mathrm{C}$. Para as temperaturas de 64 e $70^{\circ} \mathrm{C}$, ocorre um aumento linear dos valores de $\mathrm{J}_{\mathrm{nr} \text {,diff }}$ com a adição de SBS. Já o TITAN aumenta os valores de $\mathrm{J}_{\mathrm{nr} \text {,diff }}$ linearmente para todas as temperaturas. A Tabela 4.16 apresenta a variação média do $\mathrm{J}_{\mathrm{nr}, \text { diff }}$ das misturas envelhecidas a curto prazo em porcentagem provocada pelo aumento de $1 \%$ na proporção de SBS e TITAN. Nesta tabela, o sinal positivo indica um aumento do $\mathrm{J}_{\mathrm{nr} \text {,diff }}$ e o negativo indica uma redução do $\mathrm{J}_{\mathrm{nr} \text {,diff. }}$.

Tabela 4.16 - Variação média do $\mathrm{J}_{\mathrm{nr} \text {,diff }}$ das misturas envelhecidas a curto prazo para $1 \%$ de aumento nas proporções de SBS e TITAN, nas temperaturas de ensaio

\begin{tabular}{ccc}
\hline temperatura de ensaio $\left({ }^{\circ} \mathbf{C}\right)$ & $\begin{array}{c}\text { efeito da proporção } \\
\text { de SBS }(\%)\end{array}$ & $\begin{array}{c}\text { efeito da proporção de } \\
\text { TITAN }(\%)\end{array}$ \\
\hline 52 & -10 & +40 \\
58 & -20 & +80 \\
64 & +10 & +75 \\
70 & +40 & +150 \\
\hline
\end{tabular}

Observa-se que, à medida que aumenta a temperatura do ensaio a intensidade dos efeitos desses componentes varia, como pode ser visto na Tabela 4.16. O SBS atua de maneira diferente, a depender da temperatura de ensaio. Para as temperaturas de 52 e $58^{\circ} \mathrm{C}$, o SBS provoca diminuição do $\mathrm{J}_{\mathrm{nr} \text {,diff }}$ e a intensidade deste efeito aumenta de 52 para $58^{\circ} \mathrm{C}$. Para as temperaturas de 64 e $70^{\circ} \mathrm{C}$, o SBS passa a aumentar o $\mathrm{J}_{\mathrm{nr} \text {,diff }}$ e a intensidade deste efeito aumenta de 64 para $70^{\circ} \mathrm{C}$. Já o TITAN aumenta os valores de Jnr,diff em todas as temperaturas, com intensidade que aumenta proporcionalmente com a temperatura de ensaio.

As Figuras A.27.3 a A.30.3 mostram as superfícies de resposta para o $\mathrm{J}_{\mathrm{nr} \text {,diff }}$ nas temperaturas de $52,58,64$ e $70^{\circ} \mathrm{C}$ das misturas envelhecidas a curto prazo. Para um teor fixo de SBS, para todas as temperaturas, ocorre um aumento do $\mathrm{J}_{\mathrm{nr} \text {,diff }}$ com a adição de TITAN na mistura. Vale ressaltar que o valor de $\mathrm{J}_{\text {nr,diff }}$ máximo recomendado é de $75 \%$. Para a 
temperatura de $52^{\circ} \mathrm{C}$, mantendo-se constante o teor de $\mathrm{SBS}$, a porcentagem máxima recomendada de TITAN gira em torno de 1 a 1,5\%. Para as demais temperaturas o teor de TITAN deve ser menor (da ordem de 0,5\%). Para concentrações altas de SBS (5\%), a quantidade recomendada de TITAN seria no máximo de $0,2 \%$ para que o valor de $\mathrm{J}_{\mathrm{nr} \text {,diff }}$ seja inferior a $75 \%$, na temperatura de $64^{\circ} \mathrm{C}$. Para concentrações intermediárias de SBS (1 a 3\%), a quantidade recomendada de TITAN varia entre 0 a $1 \%$. Para concentrações altas de SBS $(5 \%)$, é recomendado a não utilização do TITAN para que o valor de $\mathrm{J}_{\mathrm{nr} \text {,diff }}$ seja inferior a $75 \%$, na temperatura de $70^{\circ} \mathrm{C}$. Para concentrações intermediárias de SBS (1 a 3\%), a quantidade recomendada de TITAN varia entre 0 a $0,5 \%$. Abaixo se pode observar o peso dos coeficientes de cada termo. Individualmente o TITAN contribui de forma expressiva para o

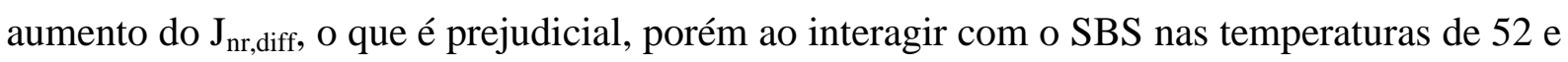
$58^{\circ} \mathrm{C}$, o TITAN em conjunto com os outros componentes, influencia de maneira

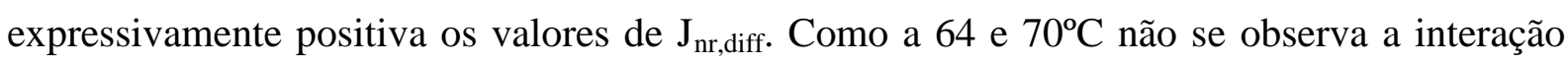
destes componentes, tanto o SBS quanto o TITAN contribuem para o aumento do $\mathrm{J}_{\mathrm{nr} \text {,diff, }}$, sendo o efeito do TITAN maior que o do SBS. Percebe-se que para estes casos os modelos apresentaram um $\mathrm{R}^{2}$ que pode ser considerados baixos $\left(\mathrm{J}_{\mathrm{nr} \text {,diff }}\right.$ a $70^{\circ} \mathrm{C}$ apresentou $\mathrm{R}^{2}$ de $79,72 \%$ ) e também os resíduos obtidos apresentaram um comportamento ruim. Pode ser que nestas temperaturas, estes modelos podem não ser tão confiáveis quanto os demais.

No caso específico da diferença de compliância não-recuperável medida a $52^{\circ} \mathrm{C}$, os efeitos de multicolinearidade podem ser desconsiderados, em virtude dos baixos valores do fator de inflação de variância, e os coeficientes do modelo podem ser interpretados como indicadores do peso que cada componente do modelo tem sobre a variabilidade dos resultados da diferença de compliância não-recuperável nesta temperatura. Como se vê no modelo indicado abaixo, tanto o SBS quanto o TITAN contribuem com o aumento da diferença de compliância não-recuperável, sendo a contribuição do TITAN 19,27 vezes maior que a do SBS $(6.820 / 354=19,27)$.

$\begin{array}{lrrrrr}\text { Term } & \text { Coef } & \text { SE Coef } & \text { T } & \text { P } & \text { VIF } \\ \text { Asfalto } & -5 & 6,1 & \star & * & 5,607 \\ \text { SBS } & 354 & 184,7 & \star & * & 6,017 \\ \text { Titan } & 6820 & 535,9 & \star & \star & 7,026 \\ \text { SBS*Titan } & -96935 & 15912,7 & -6,09 & 0,000 & 7,447\end{array}$

No caso específico da diferença de compliância não-recuperável medida a $58^{\circ} \mathrm{C}$, os efeitos de multicolinearidade podem ser desconsiderados, em virtude dos baixos valores do 
fator de inflação de variância, e os coeficientes do modelo podem ser interpretados como indicadores do peso que cada componente do modelo tem sobre a variabilidade dos resultados da diferença de compliância não-recuperável nesta temperatura. Como se vê no modelo indicado abaixo, tanto o SBS quanto o TITAN contribuem com o aumento da diferença de compliância não-recuperável, sendo a contribuição do TITAN 18,05 vezes maior que a do SBS $(13.772 / 763=18,05)$.

$\begin{array}{lrrrrr}\text { Term } & \text { Coef } & \text { SE Coef } & \text { T } & \text { P } & \text { VIF } \\ \text { Asfalto } & 3 & 8,1 & * & * & 5,731 \\ \text { SBS } & 763 & 237,2 & * & * & 6,486 \\ \text { Titan } & 13772 & 617,7 & * & * & 6,098 \\ \text { Asfalto*SBS*Titan } & -200504 & 20166,7 & -9,94 & 0,000 & 6,859\end{array}$

No caso específico da diferença de compliância não-recuperável medida a $64^{\circ} \mathrm{C}$, os efeitos de multicolinearidade podem ser desconsiderados, em virtude dos baixos valores do fator de inflação de variância, e os coeficientes do modelo podem ser interpretados como indicadores do peso que cada componente do modelo tem sobre a variabilidade dos resultados da diferença de compliância não-recuperável nesta temperatura. Como se vê no modelo indicado abaixo, tanto o SBS quanto o TITAN contribuem com o aumento da diferença de compliância não-recuperável, sendo a contribuição do TITAN 8,01 vezes maior que a do SBS $(8.988,41 / 1.122,03=8,01)$.

$\begin{array}{lrrrrr}\text { Term } & \text { Coef } & \text { SE Coef } & \text { T } & \text { P } & \text { VIF } \\ \text { Asfalto } & 1,72 & 7,392 & \star & \star & 3,281 \\ \text { SBS } & 1122,03 & 179,870 & \star & \star & 2,249 \\ \text { Titan } & 8988,41 & 523,320 & \star & \star & 2,109\end{array}$

No caso específico da diferença de compliância não-recuperável medida a $70^{\circ} \mathrm{C}$, os efeitos de multicolinearidade podem ser desconsiderados, em virtude dos baixos valores do fator de inflação de variância, e os coeficientes do modelo podem ser interpretados como indicadores do peso que cada componente do modelo tem sobre a variabilidade dos resultados da diferença de compliância não-recuperável nesta temperatura. Como se vê no modelo indicado abaixo, tanto o SBS quanto o TITAN contribuem com o aumento da diferença de compliância não-recuperável, sendo a contribuição do TITAN 5,06 vezes maior que a do SBS $(16.023,2 / 3.168,5=5,06)$. 


$\begin{array}{lrrccr}\text { Term } & \text { Coef } & \text { SE Coef } & \text { T } & \text { VIF } \\ \text { Asfalto } & -91,8 & 30,13 & * & * & 5,908 \\ \text { SBS } & 3168,5 & 605,94 & * & * & 3,033 \\ \text { Titan } & 16023,2 & 1546,67 & * & * & 3,161\end{array}$

\section{Comprimento da trinca na ruptura por fadiga $\left(a_{f}\right)$ na condição envelhecida a longo} prazo. Como indicado pela Figura A.31.2, o SBS e o TITAN tendem a aumentar linearmente o valor do parâmetro $a_{\mathrm{f}}$ a $25^{\circ} \mathrm{C}$ para as misturas envelhecidas a longo prazo. O TITAN causa um maior aumento do parâmetro $a_{\mathrm{f}}$ que o SBS, visto que sua inclinação da reta é maior. Para uma variação de $1 \%$ de SBS obtêm-se um ganho médio de $0,075 \mathrm{~mm}$ no comprimento da trinca na fissura por fadiga, enquanto que para uma variação de $1 \%$ de TITAN, obtém-se um ganho médio de $0,125 \mathrm{~mm}$ no comprimento da trinca na ruptura por fadiga.

A Figura A.31.3, mostra a superfície de resposta para o comprimento da trinca na ruptura por fadiga a $25^{\circ} \mathrm{C}$ para as misturas envelhecidas a longo prazo. Para um teor fixo de SBS, ocorre um aumento do comprimento da trinca antes de ocorrer a fissura com o aumento da proporção de TITAN. Se se mantiver fixo o teor de TITAN, ao se adicionar proporções crescentes de SBS também ocorre um aumento do comprimento da trinca antes de ocorrer a fissura. Observa-se um crescimento maior do comprimento da trinca com a adição de TITAN do que com a adição de SBS.

No caso específico do comprimento da trinca na ruptura por fadiga medido a $25^{\circ} \mathrm{C}$, os efeitos de multicolinearidade podem ser desconsiderados, em virtude dos baixos valores do fator de inflação de variância, e os coeficientes do modelo podem ser interpretados como indicadores do peso que cada componente do modelo tem sobre a variabilidade dos resultados do comprimento da trinca na ruptura por fadiga nesta temperatura. Como se vê no modelo indicado abaixo, tanto o SBS quanto o TITAN contribuem com o aumento do comprimento da trinca na ruptura por fadiga, sendo a contribuição do TITAN 1,64 vezes maior que a do SBS $(11,9483 / 7,2750=1,64)$.

$\begin{array}{lrrrrr}\text { Term } & \text { Coef } & \text { SE Coef } & \text { T } & \text { P } & \text { VIF } \\ \text { Asfalto } & 0,8551 & 0,01227 & * & \star & 3,771 \\ \text { SBS } & 7,2750 & 0,28690 & * & \star & 2,335 \\ \text { Titan } & 11,9483 & 0,72847 & * & * & 2,409\end{array}$


Vida de fadiga $\left(\mathrm{N}_{\mathrm{f}}\right)$ a $25^{\circ} \mathrm{C}$ das misturas na condição envelhecida a longo prazo. As Figuras A.32.2 e A.33.2 apresentam os efeitos dos componentes sobre a vida de fadiga $\left(\mathrm{N}_{\mathrm{f}}\right)$ na temperatura de $25^{\circ} \mathrm{C}$ com deformação de 2 e $30 \%$ das misturas envelhecidas a longo prazo. Tanto o SBS quanto o TITAN aumentam linearmente a vida de fadiga dos ligantes asfálticos para a deformação de $2 \%$. Já para a deformação de $30 \%$, o TITAN provoca diminuição de forma linear da vida de fadiga e o SBS diminui a vida de fadiga de forma aproximadamente linear, tendo efeito pouco expressivo para altos teores. A Tabela 4.17 apresenta a variação média da vida de fadiga $\left(\mathrm{N}_{\mathrm{f}}\right)$ das misturas envelhecidas a longo prazo em número de solicitações do eixo-padrão, provocada pelo aumento de $1 \%$ na proporção de SBS e TITAN. $\mathrm{Na}$ tabela abaixo, o sinal positivo indica um aumento da vida de fadiga e o negativo indica uma redução da vida de fadiga.

Observa-se que, à medida que aumenta o nível de deformação, a intensidade dos efeitos dos componentes muda bruscamente. O SBS e o TITAN apresentam efeitos diferentes a depender do nível de deformação aplicado. Para a deformação de $2 \%$, SBS e TITAN aumentam a vida de fadiga com intensidade similar (4.000 solicitações a cada $1 \%$ de modificador adicionado). Já para a deformação de 30\%, SBS e TITAN provocam diminuição da vida de fadiga, da ordem de $-0,5$ e -1 , respectivamente, para cada $1 \%$ de modificador adicionado. Para altos níveis de deformação, o TITAN é mais prejudicial do que o SBS sobre a vida de fadiga. Sob baixas deformações, quanto maior a proporção dos modificadores, melhor será a resposta para a vida de fadiga da mistura. No entanto, para altas deformações, quanto maior a proporção dos modificadores, menor será a vida de fadiga da mistura. Neste último caso, a mistura com maior vida de fadiga é a 100-0-0.

Tabela 4.17 - Variação média da vida de fadiga das misturas envelhecidas a longo prazo para $1 \%$ de aumento nas proporções de SBS e TITAN, nas deformações de 2 e $30 \%$ a $25^{\circ} \mathrm{C}$

\begin{tabular}{ccc}
\hline nível de deformação $(\%)$ & $\begin{array}{c}\text { efeito da proporção } \\
\text { de SBS (número de } \\
\text { solicitações) }\end{array}$ & $\begin{array}{c}\text { efeito da proporção de } \\
\text { TITAN (número de } \\
\text { solicitaçõs) }\end{array}$ \\
\hline 2 & +4.000 & +4.000 \\
30 & $-0,5$ & -1 \\
\hline
\end{tabular}

De acordo com a análise realizada, não é possível indicar o efeito global da adição dos modificadores, uma vez que a adição deles contribui para o aumento da vida de fadiga do 
ligante asfáltico em uma determinada faixa de deformações (baixas) e prejudica o comportamento à fadiga do ligante asfáltico em outra faixa de deformações (altas). Tal efeito paradoxal da aditivação sobre a vida de fadiga dos ligantes asfálticos se dá por conta da maior sensibilidade dos ligantes asfálticos modificados à variação do nível de deformação imposto.

Embora se saiba que rigidez é um elemento importante sobre a resistência de qualquer material a qualquer tipo de solicitação, o entendimento que se tem do fenômeno de fadiga em um pavimento indica que o desempenho à fadiga de um dado material não depende apenas do valor absoluto da sua rigidez. No caso do pavimento, o comportamento deflectométrico (ou a interação entre as camadas e entre as camadas e a fundação) afeta drasticamente o comportamento à fadiga do material asfáltico. Regra geral, pavimentos com comportamento deflectométrico similar ao de um pavimento flexível têm o fenômeno de fadiga por deformação controlada, ou seja, a camada asfáltica acompanha a deformação das camadas inferiores. Neste caso, há evidências de que quanto menos consistente o asfalto, maior a vida de fadiga. Já em pavimentos com comportamento deflectométrico similar ao rígido, a própria camada asfáltica ou o conjunto camada asfáltica e base cimentada aderidas absorve a maior parte das tensões oriundas do tráfego, gerando fadiga por tensão controlada. Há indícios de que, neste caso, asfaltos mais consistentes sejam mais indicados.

A lógica que se apreende das Figuras de 5.4 a 5.7 vai ao encontro do raciocínio exposto anteriormente: os ligantes asfálticos modificados são mais rígidos que o puro nas temperaturas ao redor de $25^{\circ} \mathrm{C}$ (ver Tabela 5.75 - a $16^{\circ} \mathrm{C}$, os asfaltos modificados são em média 1,2 vezes mais rígidos que o CAP puro e a $28^{\circ} \mathrm{C}$ são 1,4 vezes mais rígidos) e, como consequência, apresentam maiores vidas de fadiga sob baixas deformações (neste caso o mecanismo de fadiga se dá por tensão controlada e asfaltos mais consistentes são mais indicados) e menores vidas de fadiga sob altas deformações (neste caso o mecanismo de fadiga se dá por deformação controlada e asfaltos menos consistentes são mais indicados). A conclusão é que asfaltos modificados que, na temperatura de fadiga, sejam mais rígidos que o CAP puro somente apresentariam vantagem quando o pavimento sofre baixas deformações.

Quando se observam os resultados do ensaio LAS (Tabela 5.11), a tendência é de aumento do parâmetro $a_{\mathrm{f}}$ por conta das aditivações. Tais resultados estão relacionados com os resultados de $\mathrm{N}_{\mathrm{f}}$ a baixas deformações, dando a entender que o atual protocolo do ensaio LAS impõe baixos níveis de deformação à amostra. 
As Figuras A.32.3 e A.33.3 mostram as superfícies de resposta para a vida de fadiga na temperatura de $25^{\circ} \mathrm{C}$ das misturas envelhecidas a longo prazo para uma deformação de 2 e de $30 \%$, respectivamente. Para um teor fixo de SBS, para a deformação de $2 \%$, ocorre aumento da vida de fadiga com a adição de TITAN na mistura. Para um teor fixo de SBS, para a deformação de 30\%, nota-se diminuição da vida de fadiga com a adição de TITAN na mistura.

No caso específico da vida de fadiga medida com $2 \%$ de deformação a $25^{\circ} \mathrm{C}$, os efeitos de multicolinearidade podem ser desconsiderados, em virtude dos baixos valores do fator de inflação de variância, e os coeficientes do modelo podem ser interpretados como indicadores do peso que cada componente do modelo tem sobre a variabilidade dos resultados da vida de fadiga com $2 \%$ de deformação nesta temperatura. Como se vê no modelo indicado abaixo, tanto o SBS quanto o TITAN contribuem com o aumento da vida de fadiga com $2 \%$ de deformação, sendo a contribuição do SBS 1,01 vezes maior que a do TITAN $(401 \cdot 102 / 398.018=1,01)$.

$\begin{array}{lrrrrr}\text { Term } & \text { Coef } & \text { SE Coef } & \text { T } & \text { P } & \text { VIF } \\ \text { Asfalto } & 18212 & 720,5 & * & * & 3,303 \\ \text { SBS } & 401102 & 18662,6 & * & \star & 2,067 \\ \text { Titan } & 398018 & 44392,9 & * & * & 2,317\end{array}$

\section{Compliância não-recuperável ( $J_{\mathrm{nr}} 100$ Pa) na condição envelhecida a curto prazo.} As Figuras A.34.2 a A.37.2 apresentam os efeitos dos componentes sobre a compliância nãorecuperável a $100 \mathrm{~Pa}$ nas temperaturas de $52,58,64$ e $70^{\circ} \mathrm{C}$ das misturas envelhecidas a curto prazo. Em linhas gerais, os efeitos do SBS e do TITAN são parecidos. O SBS reduz os valores de compliância não-recuperável de forma linear em todas as temperaturas, exceto a $70^{\circ} \mathrm{C}$, na qual se nota uma redução aproximadamente linear. Já o TITAN atua no sentido de reduzir a compliância de maneira aproximadamente linear para concentrações entre 0 e $1 \%$ e reduz a compliância linearmente para concentrações entre 1 e $2 \%$ para as temperaturas de 52 , 58 e $64^{\circ} \mathrm{C}$. Para a temperatura de $70^{\circ} \mathrm{C}$, o TITAN reduz a compliância de forma linear. A Tabela 4.18 apresenta a variação média da compliância não-recuperável $\left(\mathrm{J}_{\mathrm{nr}}\right)$ a $100 \mathrm{~Pa}$ das misturas envelhecidas a curto prazo, em $\mathrm{kPa}^{-1}$, provocada pelo aumento de $1 \%$ na proporção de SBS e TITAN. Nesta tabela, o sinal positivo indica um aumento da compliância nãorecuperável e o negativo indica uma redução da compliância não-recuperável. 
Tabela 4.18 - Variação média da compliância não-recuperável $\left(J_{n r}\right)$ a 100 Pa das misturas envelhecidas a curto prazo para $1 \%$ de aumento nas proporções de SBS e TITAN, nas temperaturas de ensaio

\begin{tabular}{ccc}
\hline temperatura de ensaio $\left({ }^{\mathbf{}} \mathbf{C}\right)$ & $\begin{array}{c}\text { efeito da proporção } \\
\text { de SBS }\left(\mathbf{k P a}^{-\mathbf{1}}\right)\end{array}$ & $\begin{array}{c}\text { efeito da proporção de } \\
\text { TITAN }\left(\mathbf{k P a}^{-1}\right)\end{array}$ \\
\hline 52 & $-0,1$ & $-0,2$ \\
58 & $-0,3$ & $-0,6$ \\
64 & $-0,5$ & $-1,5$ \\
70 & $-0,5$ & $-1,5$ \\
\hline
\end{tabular}

Observa-se que, à medida que aumenta a temperatura do ensaio a intensidade dos efeitos desses componentes varia, como pode ser visto na Tabela 4.18. Com o aumento da temperatura de ensaio a intensidade do efeito do SBS em diminuir a compliância nãorecuperável aumenta. O mesmo se observa para o TITAN: com o aumento da temperatura de ensaio a intensidade do efeito do TITAN em diminuir a compliância não-recuperável aumenta. O TITAN se mostra mais efetivo que o SBS na redução da compliância nãorecuperável em todas as temperaturas de ensaio.

As Figuras A.34.3 a A.37.3 mostram as superfícies de resposta para a compliância não recuperável nas temperaturas de $52,58,64$ e $70^{\circ} \mathrm{C}$ das misturas envelhecidas a curto prazo. Misturas com maiores teores de modificadores apresentam menores valores para a compliância não-recuperável, de tal modo que misturas com baixos teores de modificadores apresentam maiores valores de compliância não-recuperável.

\section{Percentual de recuperação $(R)$ a 100 Pa das misturas na condição envelhecida a} curto prazo. As Figuras A.38.2 a A.41.2 apresentam os efeitos dos componentes sobre o percentual de recuperação a $100 \mathrm{~Pa}$ nas temperaturas de $52,58,64$ e $70^{\circ} \mathrm{C}$ das misturas envelhecidas a curto prazo. Em linhas gerais, os efeitos do SBS e do TITAN são parecidos. O SBS aumenta o percentual de recuperação de forma aproximadamente linear para as temperaturas de 52,58 e $64^{\circ} \mathrm{C}$. Para a temperatura de $70^{\circ} \mathrm{C}$ ocorre um aumento linear do percentual de recuperação com o aumento do teor de SBS. Já o TITAN aumenta o percentual de recuperação de maneira linear para todas as temperaturas. A Tabela 4.19 apresenta a variação média do percentual de recuperação $(\mathrm{R})$ a $100 \mathrm{~Pa}$ das misturas envelhecidas a curto prazo em porcentagem provocada pelo aumento de $1 \%$ na proporção de SBS e TITAN. Nesta 
tabela, o sinal positivo indica um aumento do percentual de recuperação e o negativo indica uma redução do percentual de recuperação.

Observa-se que, à medida que aumenta a temperatura do ensaio, a intensidade dos efeitos desses componentes varia, como pode ser visto na Tabela 4.19. A intensidade do efeito do SBS é maior a $100 \mathrm{~Pa}$ nas temperaturas de 58 e $64^{\circ} \mathrm{C}$ e menor na temperatura de $52^{\circ} \mathrm{C}$. O TITAN possui maior intensidade na temperatura de $58^{\circ} \mathrm{C}$ e menor intensidade na temperatura de $70^{\circ} \mathrm{C}$. O TITAN se mostra mais efetivo que o SBS no aumento do percentual de recuperação em todas as temperaturas de ensaio.

Tabela 4.19 - Variação média do percentual de recuperação (R) a 100 Pa das misturas envelhecidas a curto prazo para $1 \%$ de aumento nas proporções de SBS e TITAN, nas temperaturas de ensaio

\begin{tabular}{ccc}
\hline temperatura de ensaio $\left({ }^{\mathbf{}} \mathbf{C}\right)$ & $\begin{array}{c}\text { efeito da proporção } \\
\text { de SBS }(\%)\end{array}$ & $\begin{array}{c}\text { efeito da proporção de } \\
\text { TITAN }(\%)\end{array}$ \\
\hline 52 & +5 & +25 \\
58 & +10 & +30 \\
64 & +10 & +20 \\
70 & $+7,5$ & +10 \\
\hline
\end{tabular}

As Figuras A.38.3 a A.41.3 mostram as superfícies de resposta para o percentual de recuperação nas temperaturas de $52,58,64$ e $70^{\circ} \mathrm{C}$ das misturas envelhecidas a curto prazo. Misturas com maiores teores de modificadores apresentam maiores valores para o percentual de recuperação, de tal modo que misturas com baixos teores de modificadores apresentam menores valores do percentual de recuperação.

No caso específico da recuperação elástica a $100 \mathrm{~Pa}$ medida a $70^{\circ} \mathrm{C}$, os efeitos de multicolinearidade podem ser desconsiderados, em virtude dos baixos valores do fator de inflação de variância, e os coeficientes do modelo podem ser interpretados como indicadores do peso que cada componente do modelo tem sobre a variabilidade dos resultados de recuperação elástica nesta temperatura. Como se vê no modelo indicado abaixo, tanto o SBS quanto o TITAN contribuem com o aumento da recuperação elástica, sendo a contribuição do TITAN 1,94 vezes maior que a do SBS $(1.953,60 / 1.005,10=1,94)$.

$\begin{array}{lrrccr}\text { Term } & \text { Coef } & \text { SE Coef } & \text { T } & \text { P } & \text { VIF } \\ \text { Asfalto } & -6,45 & 2,900 & \star & * & 3,727 \\ \text { SBS } & 1005,10 & 69,286 & \star & \star & 2,379 \\ \text { Titan } & 1953,60 & 175,799 & \star & * & 2,451\end{array}$


Temperatura crítica de fadiga (temperatura em que $\mathrm{G}^{*} \cdot \operatorname{sen}(\delta)$ é igual a $5 \mathrm{MPa}$ para tráfego S e 6 MPa para tráfegos $\mathrm{H}$ e V, a $10 \mathrm{rad} / \mathrm{s}$ na condição envelhecida a longo prazo. As Figuras A.42.2 e A.43.2 apresentam os efeitos dos componentes sobre a temperatura crítica de fadiga das misturas envelhecidas a longo prazo para tráfego $\mathrm{S}$ $\left(\mathrm{G}^{*} \cdot \operatorname{sen}(\delta)=5,0 \mathrm{MPa}\right)$, e para tráfego $\mathrm{H} \mathrm{e} \mathrm{V}\left(\mathrm{G}^{*} \cdot \operatorname{sen}(\delta)=5,0 \mathrm{MPa}\right)$. Em linhas gerais, os efeitos do SBS e do TITAN são parecidos. Tanto o SBS quanto o TITAN aumentam a temperatura crítica de fadiga de forma linear. A Tabela 4.20 apresenta a variação média da temperatura crítica de fadiga das misturas envelhecidas a longo prazo em porcentagem provocada pelo aumento de $1 \%$ nas proporções de SBS e de TITAN. Nesta tabela, o sinal positivo indica aumento da temperatura e o negativo indica redução.

Tabela 4.20 - Variação média da temperatura crítica de fadiga

\begin{tabular}{ccc}
\hline propriedade & $\begin{array}{c}\text { efeito da proporção } \\
\text { de SBS }(\%)\end{array}$ & $\begin{array}{c}\text { efeito da proporção de } \\
\text { TITAN }(\%)\end{array}$ \\
\hline $\mathrm{T}_{\text {Fadiga }}\left(\mathrm{G}^{*} \cdot \operatorname{sen}(\delta)=5 \mathrm{MPa}\right)$ & $+0,25$ & $+1,5$ \\
$\mathrm{~T}_{\text {Fadiga }}\left(\mathrm{G}^{*} \cdot \operatorname{sen}(\delta)=6 \mathrm{MPa}\right)$ & $+0,15$ & $+1,5$ \\
\hline
\end{tabular}

Observa-se que o efeito da proporção do SBS em aumentar a temperatura crítica de fadiga é maior quando a temperatura de fadiga é obtida para um nível mais baixo de rigidez, ou seja, $0,25^{\circ} \mathrm{C} / 1 \% \mathrm{SBS}$ para tráfego $\mathrm{S}(5 \mathrm{MPa})$ e $0,15^{\circ} \mathrm{C} / 1 \% \mathrm{SBS}$ para tráfegos $\mathrm{H}$ e $\mathrm{V}$ (6 $\mathrm{MPa}$ ). No caso do TITAN, a intensidade com que o material aumenta a temperatura crítica de fadiga é a mesma para os dois níveis de rigidez. O TITAN se mostra mais efetivo que o SBS no aumento da temperatura crítica de fadiga das misturas envelhecidas a longo prazo.

As Figuras A.42.3 e A.43.3 mostram as superfícies de resposta da temperatura crítica de fadiga das misturas envelhecidas a longo prazo para tráfego $S\left(\mathrm{G}^{*} \cdot \operatorname{sen}(\delta)=5,0 \mathrm{MPa}\right)$, e para tráfego $\mathrm{H}$ e $\mathrm{V}\left(\mathrm{G}^{*} \cdot \operatorname{sen}(\delta)=5,0 \mathrm{MPa}\right)$. Misturas com maiores teores de modificadores apresentam valores mais da temperatura crítica de fadiga e as misturas com baixos teores de modificadores apresentam valores mais baixos.

No caso da temperatura crítica de fadiga para $\mathrm{G}^{*} \cdot \operatorname{sen}(\delta)=5 \mathrm{MPa}$ (tráfego $\mathrm{S}$ ), os efeitos de multicolinearidade podem ser desconsiderados, em virtude dos baixos valores do fator de inflação de variância, e os coeficientes do modelo podem ser interpretados como indicadores do peso que cada componente do modelo tem sobre a variabilidade dos resultados da temperatura crítica de fadiga. Como se vê no modelo indicado abaixo, tanto o SBS quanto o 
TITAN contribuem com o aumento da temperatura crítica de fadiga, sendo a contribuição do TITAN 3,6 vezes maior que a do SBS $(102,98 / 28,98=3,55)$.

$\begin{array}{lrrrrr}\text { Term } & \text { Coef } & \text { SE Coef } & \text { T } & \text { P } & \text { VIF } \\ \text { Asfalto } & 19,64 & 0,1768 & \star & \star & 3,727 \\ \text { SBS } & 28,98 & 4,2259 & \star & \star & 2,379 \\ \text { Titan } & 102,98 & 10,7224 & \star & \star & 2,451\end{array}$

Os efeitos de multicolinearidade podem ser desconsiderados também no caso da temperatura critica de fadiga para $\mathrm{G}^{*} \cdot \operatorname{sen}(\delta)=6 \mathrm{MPa}$. Como se vê no modelo indicado abaixo, tanto o SBS quanto o TITAN contribuem com o aumento da temperatura crítica de fadiga, sendo a contribuição do TITAN 4,1 vezes maior que a do SBS $(96,78 / 23,78=4,07)$.

$\begin{array}{lrrrrr}\text { Term } & \text { Coef } & \text { SE Coef } & \text { T } & \text { P } & \text { VIF } \\ \text { Asfalto } & 18,45 & 0,1589 & \star & \star & 3,727 \\ \text { SBS } & 23,78 & 3,7959 & \star & \star & 2,379 \\ \text { Titan } & 96,78 & 9,6313 & \star & \star & 2,451\end{array}$

\subsection{Conclusões obtidas da análise de efeitos dos componentes}

A Tabela 4.21 apresenta um resumo com as principais conclusões obtidas na análise dos efeitos dos componentes, os quais podem ser observados nas Figuras de A.1.2 até A.43.2.

Tabela 4.21 - Conclusões dos efeitos dos componentes (continua)

\begin{tabular}{|c|c|c|c|}
\hline Propriedade & Asfalto+óleo & SBS & TITAN \\
\hline Grau contínuo & $\begin{array}{c}\text { reduz, efeito } \\
\text { aproximadamente linear, } \\
\text { pouco efetiva nos teores altos }\end{array}$ & $\begin{array}{c}\text { aumenta, efeito } \\
\text { aproximadamente linear, } \\
\text { pouco efetiva nos teores } \\
\text { baixos }\end{array}$ & $\begin{array}{l}\text { aumenta, efeito } \\
\text { aproximadamente linear, } \\
\text { pouco efetiva nos teores } \\
\text { baixos, com efeito mais } \\
\text { intenso que o do SBS }\end{array}$ \\
\hline $\mathrm{Vv} 135^{\circ} \mathrm{C}$ & $\begin{array}{l}\text { reduz, efeito } \\
\text { aproximadamente linear }\end{array}$ & $\begin{array}{c}\text { aumenta, efeito } \\
\text { aproximadamente linear, } \\
\text { pouco efetiva nos teores } \\
\text { baixos }\end{array}$ & efeito praticamente nulo \\
\hline Vv $143^{\circ} \mathrm{C}$ & $\begin{array}{c}\text { reduz, efeito } \\
\text { aproximadamente linear }\end{array}$ & $\begin{array}{c}\text { aumenta, efeito } \\
\text { aproximadamente linear, } \\
\text { pouco efetiva nos teores } \\
\text { baixos }\end{array}$ & efeito praticamente nulo \\
\hline
\end{tabular}


Tabela 4.21 - Conclusões dos efeitos dos componentes (continuação)

\begin{tabular}{|c|c|c|c|}
\hline Propriedade & Asfalto+óleo & SBS & TITAN \\
\hline $\mathrm{Vv} 150^{\circ} \mathrm{C}$ & $\begin{array}{l}\text { reduz, efeito } \\
\text { aproximadamente linear }\end{array}$ & aumenta, efeito linear & $\begin{array}{c}\text { efeito praticamente nulo, } \\
\text { ponto de máximo em torno de } \\
0,5 \%\end{array}$ \\
\hline $\mathrm{Vv} 163^{\circ} \mathrm{C}$ & $\begin{array}{l}\text { reduz, efeito } \\
\text { aproximadamente linear }\end{array}$ & $\begin{array}{c}\text { aumenta, efeito } \\
\text { aproximadamente linear, } \\
\text { pouco efetiva nos teores } \\
\text { baixos }\end{array}$ & $\begin{array}{l}\text { efeito praticamente nulo, } \\
\text { ponto de máximo em torno de } \\
1 \%\end{array}$ \\
\hline $\mathrm{Vv} 177^{\circ} \mathrm{C}$ & $\begin{array}{c}\text { reduz, efeito } \\
\text { aproximadamente linear }\end{array}$ & $\begin{array}{c}\text { aumenta, efeito } \\
\text { aproximadamente linear, } \\
\text { pouco efetiva nos teores } \\
\text { baixos }\end{array}$ & $\begin{array}{l}\text { efeito praticamente nulo, } \\
\text { ponto de máximo em torno de } \\
1 \%\end{array}$ \\
\hline VR $135^{\circ} \mathrm{C}$ & $\begin{array}{l}\text { reduz, efeito } \\
\text { aproximadamente linear }\end{array}$ & $\begin{array}{l}\text { aumenta, efeito } \\
\text { aproximadamente linear, } \\
\text { pouco efetiva nos teores } \\
\text { baixos }\end{array}$ & efeito praticamente nulo \\
\hline VR $143^{\circ} \mathrm{C}$ & $\begin{array}{l}\text { reduz, efeito } \\
\text { aproximadamente linear }\end{array}$ & $\begin{array}{c}\text { aumenta, efeito } \\
\text { aproximadamente linear, } \\
\text { pouco efetiva nos teores } \\
\text { baixos }\end{array}$ & efeito praticamente nulo \\
\hline VR $150^{\circ} \mathrm{C}$ & $\begin{array}{c}\text { reduz, efeito } \\
\text { aproximadamente linear }\end{array}$ & $\begin{array}{c}\text { aumenta, efeito } \\
\text { aproximadamente linear, } \\
\text { pouco efetiva nos teores } \\
\text { baixos }\end{array}$ & efeito praticamente nulo \\
\hline VR $163^{\circ} \mathrm{C}$ & $\begin{array}{l}\text { reduz, efeito } \\
\text { aproximadamente linear }\end{array}$ & $\begin{array}{c}\text { aumenta, efeito } \\
\text { aproximadamente linear, } \\
\text { pouco efetiva nos teores } \\
\text { baixos }\end{array}$ & $\begin{array}{l}\text { efeito praticamente nulo, } \\
\text { ponto de máximo em torno de } \\
1,5 \%\end{array}$ \\
\hline VR $177^{\circ} \mathrm{C}$ & $\begin{array}{l}\text { reduz, efeito } \\
\text { aproximadamente linear }\end{array}$ & $\begin{array}{c}\text { aumenta, efeito } \\
\text { aproximadamente linear, } \\
\text { pouco efetiva nos teores } \\
\text { baixos }\end{array}$ & $\begin{array}{l}\text { efeito praticamente nulo, } \\
\text { ponto de máximo em torno de } \\
2 \%\end{array}$ \\
\hline Tusinagem & reduz, efeito linear & aumenta, efeito linear & $\begin{array}{l}\text { efeito praticamente nulo, } \\
\text { ponto de máximo em torno de } \\
1 \%\end{array}$ \\
\hline Tcompactação & reduz, efeito linear & aumenta, efeito linear & $\begin{array}{l}\text { efeito praticamente nulo, } \\
\text { ponto de máximo em torno de } \\
1 \%\end{array}$ \\
\hline Iv $135^{\circ} \mathrm{C}$ & aumenta, efeito linear & reduz, efeito linear & $\begin{array}{c}\text { reduz, efeito linear, com } \\
\text { intensidade mais suave que o } \\
\text { do SBS }\end{array}$ \\
\hline Iv $143^{\circ} \mathrm{C}$ & aumenta, efeito linear & reduz, efeito linear & $\begin{array}{l}\text { aumenta, efeito linear, com } \\
\text { efeito mais intenso que o } \\
\text { asfalto+óleo }\end{array}$ \\
\hline Iv $150^{\circ} \mathrm{C}$ & reduz, efeito linear & $\begin{array}{l}\text { reduz, efeito linear, efeito } \\
\text { similar ao do asfalto+óleo }\end{array}$ & aumenta, efeito linear \\
\hline Iv $163^{\circ} \mathrm{C}$ & aumenta, efeito linear & reduz, efeito linear & $\begin{array}{l}\text { aumenta, efeito linear, com } \\
\text { efeito similar ao do } \\
\text { asfalto+óleo }\end{array}$ \\
\hline Iv $177^{\circ} \mathrm{C}$ & $\begin{array}{l}\text { ponto de mínimo em torno de } \\
96 \%\end{array}$ & $\begin{array}{c}\text { reduz, efeito } \\
\text { aproximadamente linear, } \\
\text { pouco efetiva nos teores altos }\end{array}$ & aumenta, efeito linear \\
\hline
\end{tabular}


Tabela 4.21 - Conclusões dos efeitos dos componentes (continuação)

\begin{tabular}{|c|c|c|c|}
\hline Propriedade & Asfalto+óleo & SBS & TITAN \\
\hline $\mathrm{J}_{\mathrm{nr}} 52^{\circ} \mathrm{C}$ RTFOT & $\begin{array}{c}\text { aumenta, efeito } \\
\text { aproximadamente linear, } \\
\text { pouco efetiva nos teores } \\
\text { baixos }\end{array}$ & reduz, efeito linear & $\begin{array}{c}\text { reduz, efeito } \\
\text { aproximadamente linear, } \\
\text { com efeito mais intenso que } \\
\text { o SBS }\end{array}$ \\
\hline $\mathrm{J}_{\mathrm{nr}} 58^{\circ} \mathrm{C}$ RTFOT & $\begin{array}{c}\text { aumenta, efeito } \\
\text { aproximadamente linear, } \\
\text { pouco efetiva nos teores } \\
\text { baixos }\end{array}$ & $\begin{array}{c}\text { reduz, efeito } \\
\text { aproximadamente linear }\end{array}$ & $\begin{array}{c}\text { reduz, efeito } \\
\text { aproximadamente linear, } \\
\text { com efeito mais intenso que } \\
\text { o SBS }\end{array}$ \\
\hline $\mathrm{J}_{\mathrm{nr}} 64^{\circ} \mathrm{C}$ RTFOT & $\begin{array}{c}\text { aumenta, efeito } \\
\text { aproximadamente linear, } \\
\text { pouco efetiva nos teores } \\
\text { baixos }\end{array}$ & $\begin{array}{c}\text { reduz, efeito } \\
\text { aproximadamente linear }\end{array}$ & $\begin{array}{c}\text { reduz, efeito } \\
\text { aproximadamente linear, } \\
\text { com efeito similar ao do SBS }\end{array}$ \\
\hline $\mathrm{J}_{\mathrm{nr}} 70^{\circ} \mathrm{C}$ RTFOT & $\begin{array}{l}\text { aumenta, efeito } \\
\text { aproximadamente linear, } \\
\text { pouco efetiva nos teores } \\
\text { baixos }\end{array}$ & $\begin{array}{c}\text { reduz, efeito } \\
\text { aproximadamente linear }\end{array}$ & $\begin{array}{c}\text { reduz, efeito } \\
\text { aproximadamente linear, } \\
\text { com efeito similar ao do SBS }\end{array}$ \\
\hline $\mathrm{R} 52^{\circ} \mathrm{C}$ RTFOT & reduz, efeito linear & aumenta, efeito linear & $\begin{array}{l}\text { aumenta, efeito linear, com } \\
\text { efeito mais intenso que o } \\
\text { SBS }\end{array}$ \\
\hline $\mathrm{R} 58^{\circ} \mathrm{C}$ RTFOT & reduz, efeito linear & aumenta, efeito linear & $\begin{array}{l}\text { aumenta, efeito linear, com } \\
\text { efeito similar ao do SBS }\end{array}$ \\
\hline $\mathrm{R} 64^{\circ} \mathrm{C}$ RTFOT & $\begin{array}{l}\text { reduz, efeito } \\
\text { aproximadamente linear }\end{array}$ & $\begin{array}{l}\text { aumenta, efeito } \\
\text { aproximadamente linear, } \\
\text { pouco efetiva nos teores } \\
\text { baixos }\end{array}$ & $\begin{array}{l}\text { aumenta, efeito linear, com } \\
\text { efeito mais suave que o do } \\
\text { SBS }\end{array}$ \\
\hline $\mathrm{R} 70^{\circ} \mathrm{C}$ RTFOT & $\begin{array}{c}\text { reduz, efeito } \\
\text { aproximadamente linear com } \\
\text { ponto de mínimo em torno de } \\
99 \%\end{array}$ & $\begin{array}{l}\text { aumenta, efeito } \\
\text { aproximadamente linear, } \\
\text { pouco efetiva nos teores } \\
\text { baixos, com ponto de } \\
\text { mínimo em torno de } 1 \%\end{array}$ & efeito praticamente nulo \\
\hline $\mathrm{J}_{\text {nr,diff }} 52^{\circ} \mathrm{C}$ RTFOT & $\begin{array}{l}\text { reduz, com ponto de máximo } \\
\text { em torno de } 94,5 \%\end{array}$ & $\begin{array}{l}\text { reduz, efeito linear, efeito } \\
\text { mais suave que o do } \\
\text { asfalto+óleo } \\
\text { reduz, efeito }\end{array}$ & aumenta, efeito linear \\
\hline $\mathrm{J}_{\text {nr,diff }} 58^{\circ} \mathrm{C}$ RTFOT & $\begin{array}{l}\text { reduz, com ponto de máximo } \\
\text { em torno de } 95 \%\end{array}$ & $\begin{array}{l}\text { aproximadamente linear, } \\
\text { efeito mais suave que o do } \\
\text { asfalto+óleo }\end{array}$ & aumenta, efeito linear \\
\hline $\mathrm{J}_{\text {nr,diff }} 64^{\circ} \mathrm{C}$ RTFOT & reduz, efeito linear & aumenta, efeito linear & $\begin{array}{l}\text { aumenta, efeito linear, com } \\
\text { efeito mais intenso que o } \\
\text { SBS }\end{array}$ \\
\hline $\mathrm{J}_{\mathrm{nr}, \text { diff }} 70^{\circ} \mathrm{C}$ RTFOT & reduz, efeito linear & aumenta, efeito linear & $\begin{array}{c}\text { aumenta, efeito linear, com } \\
\text { efeito mais intenso que o } \\
\text { SBS }\end{array}$ \\
\hline$a_{\mathrm{f}} 25^{\circ} \mathrm{C} \mathrm{PAV}$ & reduz, efeito linear & aumenta, efeito linear & $\begin{array}{l}\text { aumenta, efeito linear, com } \\
\text { efeito mais intenso que o } \\
\text { SBS }\end{array}$ \\
\hline $\mathrm{N}_{\mathrm{f}} 2 \% 25^{\circ} \mathrm{CPAV}$ & reduz, efeito linear & aumenta, efeito linear & $\begin{array}{l}\text { aumenta, efeito linear, com } \\
\text { efeito similiar ao do SBS }\end{array}$ \\
\hline $\mathrm{N}_{\mathrm{f}} 30 \% 25^{\circ} \mathrm{C} \mathrm{PAV}$ & $\begin{array}{l}\text { aumenta, efeito } \\
\text { aproximadamente linear }\end{array}$ & $\begin{array}{c}\text { reduz, efeito } \\
\text { aproximadamente linear, } \\
\text { pouco efetiva nos teores altos }\end{array}$ & $\begin{array}{l}\text { reduz, efeito linear, com } \\
\text { efeito mais intenso que o } \\
\text { SBS }\end{array}$ \\
\hline
\end{tabular}


Tabela 4.21 - Conclusões dos efeitos dos componentes (continuação)

\begin{tabular}{|c|c|c|c|}
\hline Propriedade & Asfalto+óleo & SBS & TITAN \\
\hline $\mathrm{J}_{\mathrm{nr}} 10052^{\circ} \mathrm{C}$ RTFOT & $\begin{array}{c}\text { aumenta, efeito } \\
\text { aproximadamente linear, } \\
\text { pouco efetiva nos teores } \\
\text { baixos }\end{array}$ & $\begin{array}{c}\text { reduz, efeito linear, com } \\
\text { efeito mais suave que o } \\
\text { TITAN }\end{array}$ & $\begin{array}{c}\text { reduz, efeito } \\
\text { aproximadamente linear, } \\
\text { pouco efetiva nos teores } \\
\text { altos }\end{array}$ \\
\hline $\mathrm{J}_{\mathrm{nr}} 10058^{\circ} \mathrm{C}$ RTFOT & $\begin{array}{c}\text { aumenta, efeito } \\
\text { aproximadamente linear, } \\
\text { pouco efetiva nos teores } \\
\text { baixos }\end{array}$ & $\begin{array}{l}\text { reduz, efeito linear, com } \\
\text { efeito mais suave que o } \\
\text { TITAN }\end{array}$ & $\begin{array}{c}\text { reduz, efeito } \\
\text { aproximadamente linear, } \\
\text { pouco efetiva nos teores } \\
\text { altos }\end{array}$ \\
\hline $\mathrm{J}_{\mathrm{nr}} 10064^{\circ} \mathrm{C}$ RTFOT & $\begin{array}{c}\text { aumenta, efeito } \\
\text { aproximadamente linear, } \\
\text { pouco efetiva nos teores } \\
\text { baixos }\end{array}$ & $\begin{array}{c}\text { reduz, efeito linear, com } \\
\text { efeito mais suave que o } \\
\text { TITAN }\end{array}$ & $\begin{array}{c}\text { reduz, efeito } \\
\text { aproximadamente linear, } \\
\text { pouco efetiva nos teores } \\
\text { altos }\end{array}$ \\
\hline $\mathrm{J}_{\mathrm{nr}} 10070^{\circ} \mathrm{C}$ RTFOT & $\begin{array}{c}\text { aumenta, efeito } \\
\text { aproximadamente linear, } \\
\text { pouco efetiva nos teores } \\
\text { baixos }\end{array}$ & $\begin{array}{l}\text { reduz, efeito } \\
\text { aproximadamente linear, }\end{array}$ & $\begin{array}{l}\text { reduz, efeito linear, com } \\
\text { efeito mais intenso que o } \\
\text { SBS }\end{array}$ \\
\hline R $10052^{\circ} \mathrm{C}$ RTFOT & $\begin{array}{c}\text { reduz, efeito } \\
\text { aproximadamente linear, } \\
\text { pouco efetiva nos teores } \\
\text { baixos }\end{array}$ & $\begin{array}{l}\text { aumenta, efeito } \\
\text { aproximadamente linear }\end{array}$ & $\begin{array}{c}\text { aumenta, efeito linear, com } \\
\text { efeito mais intenso que o } \\
\text { SBS }\end{array}$ \\
\hline R $10058^{\circ} \mathrm{C}$ RTFOT & $\begin{array}{c}\text { reduz, efeito } \\
\text { aproximadamente linear, } \\
\text { pouco efetiva nos teores } \\
\text { baixos }\end{array}$ & $\begin{array}{l}\text { aumenta, efeito } \\
\text { aproximadamente linear }\end{array}$ & $\begin{array}{l}\text { aumenta, efeito linear, com } \\
\text { efeito mais intenso que o } \\
\text { SBS }\end{array}$ \\
\hline R $10064^{\circ} \mathrm{C}$ RTFOT & $\begin{array}{c}\text { reduz, efeito } \\
\text { aproximadamente linear, } \\
\text { pouco efetiva nos teores } \\
\text { baixos }\end{array}$ & $\begin{array}{c}\text { aumenta, efeito } \\
\text { aproximadamente linear }\end{array}$ & $\begin{array}{c}\text { aumenta, efeito linear, com } \\
\text { efeito mais intenso que o } \\
\text { SBS }\end{array}$ \\
\hline R $10070^{\circ} \mathrm{C}$ RTFOT & reduz, efeito linear & aumenta, efeito linear & $\begin{array}{l}\text { aumenta, efeito linear, com } \\
\text { efeito mais intenso que o } \\
\text { SBS }\end{array}$ \\
\hline $\begin{array}{c}\mathrm{T}_{\text {Fadiga }} \\
\left(\mathrm{G}^{*} \cdot \operatorname{sen}(\delta)=5 \mathrm{MPa}\right)\end{array}$ & reduz, efeito linear & aumenta, efeito linear & $\begin{array}{l}\text { aumenta, efeito linear, com } \\
\text { efeito mais intenso que o } \\
\text { SBS }\end{array}$ \\
\hline $\begin{array}{c}\mathrm{T}_{\text {Fadiga }} \\
\left(\mathrm{G}^{*} \cdot \operatorname{sen}(\delta)=6 \mathrm{MPa}\right)\end{array}$ & reduz, efeito linear & aumenta, efeito linear & $\begin{array}{l}\text { aumenta, efeito linear, com } \\
\text { efeito mais intenso que o } \\
\text { SBS }\end{array}$ \\
\hline
\end{tabular}




\subsection{Conclusões obtidas da análise de superfícies de resposta}

As principais conclusões obtidas na análise de superfícies de resposta em relação às proporções de SBS e TITAN são:

- ocorre aumento do grau contínuo tanto com o aumento da concentração de SBS quanto de TITAN; para obter ligantes asfálticos que atendam os graus de desempenho recomendado para as rodovias brasileiras (PG 64-10 e PG 70-10), são necessárias concentrações médias de SBS e TITAN de 2,5\% e 1,0\%, respectivamente; concentrações muito altas dos componentes elevam o PG da mistura para acima de $82^{\circ} \mathrm{C}$; o TITAN aumenta o grau contínuo com intensidade maior que o SBS;

- a viscosidade virgem aumenta com o aumento do teor de SBS e o TITAN possui efeito praticamente nulo sobre a viscosidade virgem;

- a viscosidade envelhecida a curto prazo aumenta com o aumento da proporção de SBS; o TITAN possui efeito praticamente nulo sobre a viscosidade envelhecida a curto prazo;

- quando se comparam os resultados de viscosidade virgem e envelhecida nas temperaturas mais baixas $\left(135,143\right.$ e $\left.150^{\circ} \mathrm{C}\right)$, observa-se um pequeno aumento da viscosidade envelhecida a curto prazo com a adição de TITAN para uma mesma quantidade de SBS;

- as temperaturas de usinagem e compactação aumentam com a proporção de SBS; o TITAN tem efeito praticamente nulo sobre as temperaturas de usinagem e compactação;

- o aumento da concentração de SBS reduz o incremento de viscosidade e o aumento da concentração de TITAN aumenta o incremento de viscosidade, indicando que o SBS torna o ligante asfáltico menos sensível ao envelhecimento a curto prazo e o TITAN torna o ligante asfáltico mais sensível ao envelhecimento a curto prazo;

- sobre as propriedades do MSCR a $64^{\circ} \mathrm{C}$ tem-se: a compliância não-recuperável ultrapassa o limite de 4,0 $\mathrm{kPa}^{-1}$ para misturas com baixos teores de modificadores, não sendo recomendada sequer para uma rodovia com tráfego padrão; para uma mistura com teores intermediários (2,5\% de SBS e $1 \%$ de TITAN), o valor de $\mathrm{J}_{\mathrm{nr}}$ é $1,5 \mathrm{kPa}^{-1}$, o que a faz ser recomendada para uma rodovia com tráfego pesado; para uma mistura com altos teores dos modificadores, o valor de $\mathrm{J}_{\mathrm{nr}}$ é menor que $0,5 \mathrm{kPa}^{-1}$, o que a faz ser recomendada para uma rodovia com tráfego extremamente pesado; altos teores de modificadores (em torno de 5,5\% de combinação de 
SBS e TITAN) são capazes de proporcionar uma recuperação elástica de $30 \%$ e, para teores intermediários (2,5\% SBS e $1 \%$ TITAN), a recuperação elástica cai para em torno de 10\%; para não ultrapassar o valor de $\mathrm{J}_{\mathrm{nr} \text {,diff }}$ de $75 \%$, o teor máximo de TITAN que pode ser adicionado na mistura é em torno de $0,5 \%$; acima deste teor, o limite de $75 \%$ para o parâmetro $\mathrm{J}_{\mathrm{nr}, \text { diff }}$ não é atendido;

- sobre as propriedades do MSCR a $70^{\circ} \mathrm{C}$ tem-se: a compliância não-recuperável atinge o limite de 4,0 $\mathrm{kPa}^{-1}$ para misturas com teores intermediários (3\% de SBS e $1 \%$ de TITAN ou uma combinação de ambas totalizando 4\%); para uma mistura com altos teores dos modificadores, o valor de $\mathrm{J}_{\mathrm{nr}}$ é menor que $1,5 \mathrm{kPa}^{-1}$, o que a faz ser recomendada para uma rodovia com tráfego muito pesado; nenhuma mistura é recomendada para tráfego extremamente pesado nesta temperatura; altos teores de modificadores (em torno de 5,5\% de combinação de ambos) é capaz de proporcionar uma recuperação elástica de $20 \%$ e, para valores intermediários de teores $(2,5 \%$ SBS e $1 \%$ TITAN), a recuperação elástica cai para em torno de $4 \%$; valores abaixo de 2,0\% de SBS não apresentam nenhuma recuperação; para não ultrapassar o limite de $\mathrm{J}_{\mathrm{nr} \text {,diff }}$ de $75 \%$, o teor máximo de TITAN que pode ser adicionado na mistura é em torno de $1 \%$ para baixas concentrações de SBS e em torno de $0,2 \%$ de TITAN para altas concentrações (acima de 4,5\%) de SBS; acima deste teor, o limite de $75 \%$ para o parâmetro $\mathrm{J}_{\text {nr,diff }}$ não é atendido;

- o índice de tolerância ao dano por fadiga $\left(\mathrm{a}_{\mathrm{f}}\right)$ aumenta com a adição dos modificadores, sendo o TITAN mais efetivo que o SBS;

- ambos os modificadores aumentam igualmente a vida de fadiga a $2 \%$ de deformação; a $30 \%$ de deformação, ambos os modificadores diminuem a vida de fadiga, sendo o TITAN responsável por uma perda maior que a provocada pelo SBS;

- ambos os modificadores aumentam a temperatura crítica de fadiga (temperatura em que o parâmetro $\mathrm{G}^{*} \cdot \operatorname{sen}(\delta)$ é igual a $5 \mathrm{MPa}($ tráfego $\mathrm{S}$ ) e igual a $6 \mathrm{MPa}$ (tráfegos $\mathrm{H} \mathrm{e} \mathrm{V}$ ), sendo o TITAN responsável por um aumento maior do que o provocado pelo SBS. 


\section{ANÁLISES ADICIONAIS E DISCUSSÕES}

O objetivo deste capítulo complementar de análise dos resultados é apresentar os resultados dos ensaios e comparar o desempenho das misturas em relação às propriedades, parâmetros e índices monitorados. Serão apresentados e discutidos os resultados referentes ao grau de desempenho, à viscosidade, ao balanço de massa, ao ensaio de fluência e recuperação sob tensões múltiplas (MSCR), ao ensaio de varredura de amplitude linear (LAS) e às curvasmestre.

\subsection{Grau de desempenho (PG) e grau contínuo}

Os valores do grau contínuo (temperatura correspondente ao ponto em que o parâmetro $\mathrm{G}^{*} / \mathrm{sen} \delta$ é igual a $1,0 \mathrm{kPa}$ ) são apresentados na Tabela 5.1, em conjunto com os valores do parâmetro $\mathrm{G}^{*} / \operatorname{sen} \delta$ nas diferentes temperaturas de ensaio. Os valores apresentados correspondem à média aritmética simples de 4 determinações. A representação gráfica destes dados é feita na Figura 5.1. O CAP puro (asfalto + 4\% de óleo aromático) apresenta PG 58, mas ao se adicionar 5\% de SBS, o PG sobe para 76 (3 graus), ao se adicionar $1 \%$ de TITAN, o PG sobe para 64 (1 grau) e ao se adicionar 2\% de TITAN, o PG sobe para 70 (2 graus), indicando que ambos os modificadores são efetivos no aumento do PG do ligante asfáltico de base.

Adições sucessivas de TITAN ao CAP + 2,5\% de SBS são capazes de elevar o PG de 64 (0\% de TITAN) para 70 com $1 \%$ de TITAN e para 82 com $2 \%$ de TITAN. Adições sucessivas de TITAN ao CAP + 5,0\% de SBS são capazes de elevar o PG de $76(0 \%$ de TITAN) para 88 com $1 \%$ de TITAN e para 88 (embora hipoteticamente fosse 106) com $2 \%$ de TITAN. Teores de TITAN próximos a $2 \%$ provocam um enrijecimento excessivo do CAPSBS, restringindo o seu uso a proporções máximas de aproximadamente 1,5\%. A adição de $4 \%$ de óleo só se justifica se sua função for a de óleo extensor, uma vez que a simples modificação com óleo seria absolutamente desvantajosa, já que provoca redução de um grau no PG do ligante asfáltico de base (de 64 para 58). Para corrigir tal defasagem, seria 
necessário acrescentar ou $1,0 \%$ de TITAN ou 2,5\% de SBS ao CAP com $4 \%$ de óleo aromático.

Tabela 5.1 - Valores de G*/sen( $(\delta)$ usados no cálculo do PG das misturas

\begin{tabular}{|c|c|c|c|c|c|c|c|c|c|c|c|c|}
\hline misturas & $52^{\circ}$ & $58^{\circ}$ & $64^{\circ}$ & $7^{\circ}$ & $76^{\circ}$ & $82^{\circ}$ & $\mathbf{8 8}^{\circ}$ & $94^{\circ}$ & $100^{\circ}$ & $106^{\circ}$ & $112^{\circ}$ & $\begin{array}{c}\text { Grau } \\
\text { contínuo }\end{array}$ \\
\hline $100-0-0$ & 4,95 & 2,05 & 0,90 & & & & & & & & & 63,5 \\
\hline $99-0-1$ & 7,71 & 3,36 & 1,53 & 0,73 & & & & & & & & 68,0 \\
\hline 98-0-2 & 15,77 & 7,76 & 3,79 & 1,83 & 0,89 & & & & & & & 75,3 \\
\hline $97,5-2,5-0$ & 9,20 & 4,04 & 1,84 & 0,88 & & & & & & & & 69,3 \\
\hline $96,5-2,5-1$ & 11,79 & 5,23 & 2,46 & 1,22 & 0,63 & & & & & & & 72,2 \\
\hline $95,5-2,5-2$ & 28,29 & 14,77 & 7,68 & 3,98 & 2,06 & 1,30 & 0,79 & & & & & 85,5 \\
\hline $95-5-0$ & 17,28 & 8,65 & 4,41 & 2,34 & 1,32 & 0,80 & & & & & & 79,7 \\
\hline $94-5-1$ & 28,97 & 16,13 & 9,05 & 5,15 & 2,98 & 1,94 & 1,28 & 0,87 & & & & 92,1 \\
\hline $93-5-2$ & 47,55 & 27,90 & 16,51 & 9,50 & 5,42 & 3,68 & 2,45 & 1,78 & 1,46 & 1,75 & 0,73 & 110,4 \\
\hline $\begin{array}{c}\text { CAP de } \\
\text { base }\end{array}$ & 8,58 & 3,50 & 1,49 & 0,68 & & & & & & & & 67,0 \\
\hline
\end{tabular}

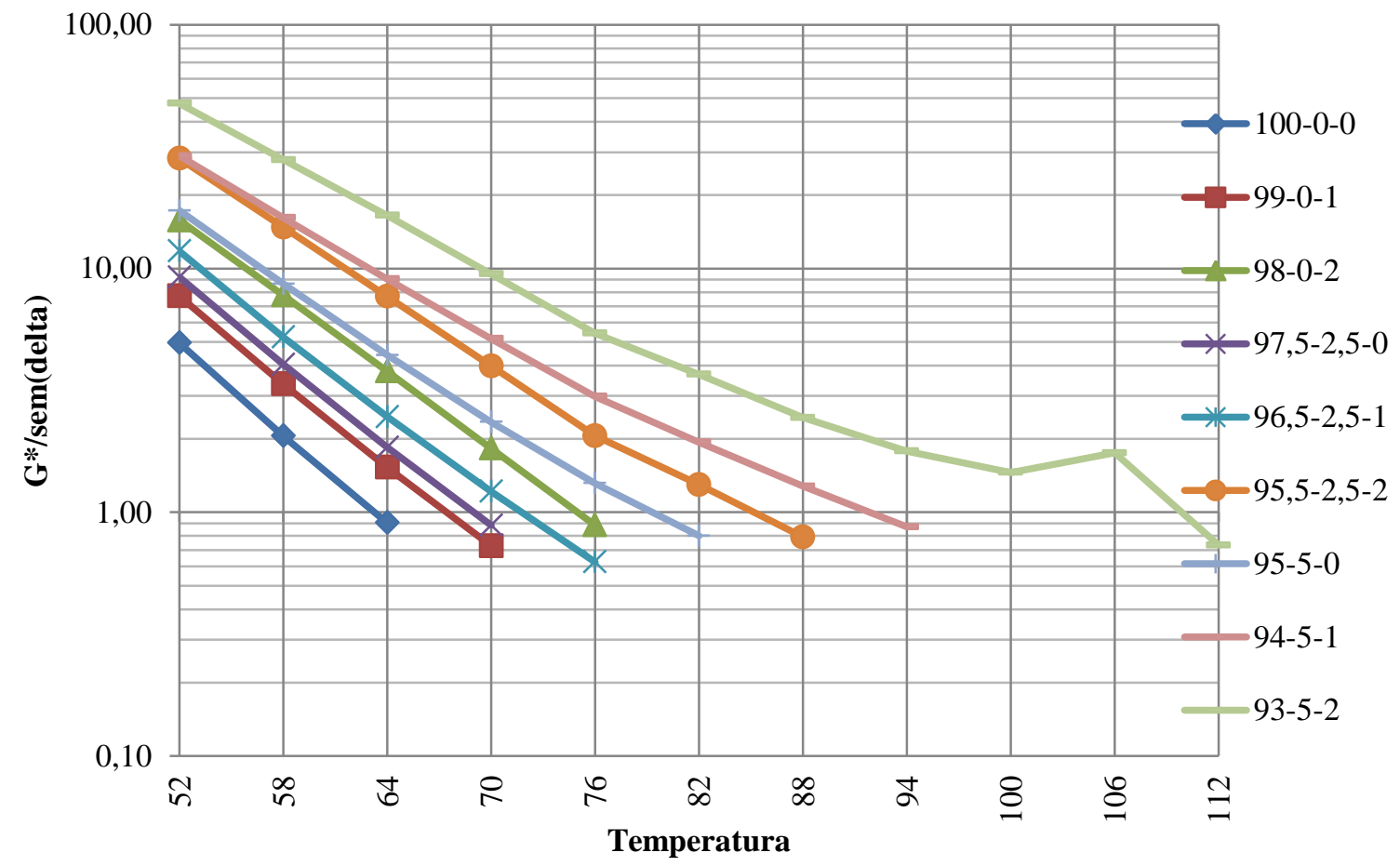

Figura 5.1 - $G^{*} / \operatorname{sen}(\delta)$ versus temperatura para as amostras virgens 


\subsection{Viscosidade rotacional}

\subsubsection{Ligantes asfálticos virgens e envelhecidos a curto prazo}

A Tabela 5.2 mostra as viscosidades rotacionais dos ligantes asfálticos na condição virgem, nas temperaturas de $135,143,150,163,177^{\circ} \mathrm{C}$. Para a temperatura inicial de $135^{\circ} \mathrm{C}$, a mistura 93-5-2 apresenta a maior viscosidade (1,07 Pa.s) seguida pela mistura de 94-5-1 (1,07 Pa.s). A menor viscosidade foi apresentada pela mistura 100-0-0 (0,31 Pa.s) seguida das misturas 99-0-1 e 98-0-2 (ambas com 0,33 Pa.s). Observa-se ainda que, para a temperatura de $135^{\circ} \mathrm{C}$, as misturas com a mesma concentração de SBS, ou seja, 0,0, 2,5 e 5,0\%, apresentam valores de viscosidade rotacional equivalentes, mostrando que o TITAN afeta marginalmente a viscosidade rotacional nesta temperatura. Apesar dos altos índices de modificação de algumas misturas, nenhuma delas apresenta viscosidade rotacional superior a 3 Pa.s, indicando que não haverá problemas de bombeamento com estes materiais.

Tabela 5.2 - Viscosidades rotacionais em Pa.s dos ligantes asfálticos na condição virgem

\begin{tabular}{cccccc}
\hline misturas & $\mathbf{1 3 5}^{\mathbf{C}} \mathbf{C}$ & $\mathbf{1 4 3}^{\mathbf{}} \mathbf{C}$ & $\mathbf{1 5 0}^{\mathbf{}} \mathbf{C}$ & $\mathbf{1 6 3}^{\mathbf{}} \mathbf{C}$ & $\mathbf{1 7 7}^{\mathbf{}} \mathbf{C}$ \\
\hline $100-0-0$ & 0,31 & 0,20 & 0,15 & 0,09 & 0,06 \\
$99-0-1$ & 0,33 & 0,22 & 0,17 & 0,10 & 0,06 \\
$98-0-2$ & 0,33 & 0,23 & 0,17 & 0,11 & 0,07 \\
$97,5-2,5-0$ & 0,54 & 0,39 & 0,30 & 0,18 & 0,11 \\
$96,5-2,5-1$ & 0,56 & 0,40 & 0,31 & 0,19 & 0,12 \\
$95,5-2,5-2$ & 0,56 & 0,39 & 0,29 & 0,19 & 0,12 \\
$95-5-0$ & 1,03 & 0,76 & 0,58 & 0,34 & 0,22 \\
$94-5-1$ & 1,07 & 0,72 & 0,55 & 0,36 & 0,22 \\
$93-5-2$ & 1,10 & 0,69 & 0,50 & 0,35 & 0,23 \\
CAP de base & 0,34 & 0,23 & 0,17 & 0,10 & 0,06 \\
\hline
\end{tabular}

Para a temperatura de $143^{\circ} \mathrm{C}$, na condição virgem, a mistura 95-5-0 apresenta a maior viscosidade (0,76 Pa.s) seguida pela mistura de 94-5-1 (0,72 Pa.s). A menor viscosidade foi apresentada pela mistura 100-0-0 (0,20 Pa.s) seguida da mistura 99-0-1 (0,22 Pa.s). Observase ainda que, para a temperatura de $143^{\circ} \mathrm{C}$, as misturas com a mesma concentração de SBS 
apresentam valores de viscosidade rotacional equivalentes, mostrando que o TITAN afeta marginalmente a viscosidade rotacional também nesta temperatura.

Para a temperatura de $150^{\circ} \mathrm{C}$, na condição virgem, a mistura com 95-5-0 apresenta a maior viscosidade (0,58 Pa.s) seguida pela mistura de 94-5-1 (0,55 Pa.s). A menor viscosidade foi apresentada pela mistura 100-0-0 (0,15 Pa.s) seguida pela mistura 99-0-1 e 980-2 (ambas com 0,17 Pa.s). Observa-se ainda que, para a temperatura de $150^{\circ} \mathrm{C}$, as misturas com a mesma concentração de SBS apresentam valores de viscosidade rotacional equivalentes, mostrando que o TITAN afeta marginalmente a viscosidade rotacional também nesta temperatura.

Para a temperatura de $163^{\circ} \mathrm{C}$, na condição virgem, a mistura 94-5-1 apresenta a maior viscosidade (0,36 Pa.s) seguida pela mistura de 93-5-2 (0,35 Pa.s). A menor viscosidade foi apresentada pela mistura 100-0-0 (0,09 Pa.s) seguida da mistura 99-0-1 (0,10 Pa.s). Observase ainda que, para a temperatura de $163^{\circ} \mathrm{C}$, as misturas com a mesma concentração de SBS apresentam com valores de viscosidade rotacional equivalentes, mostrando que o TITAN afeta marginalmente o valor da viscosidade rotacional.

Para a temperatura de $177^{\circ} \mathrm{C}$, na condição virgem, a mistura 93-5-2 apresenta a maior viscosidade (0,23 Pa.s) seguida pelas misturas de 94-5-1 e 95-5-0 (ambas com 0,22 Pa.s). A menor viscosidade foi apresentada pelas misturas 100-0-0 e 99-0-1(ambas com 0,06 Pa.s) seguidas pela mistura 98-0-2 (0,07 Pa.s). Observa-se ainda que para a temperatura de $177^{\circ} \mathrm{C}$ misturas com a mesma concentração de SBS apresentam valores de viscosidade rotacional equivalentes, mostrando que o TITAN afeta marginalmente o valor da viscosidade rotacional.

A Figura 5.2 mostra o gráfico de viscosidade rotacional (Pa.s) versus temperatura $\left({ }^{\circ} \mathrm{C}\right)$ das misturas na condição virgem. Observa-se claramente que ocorre uma divisão entre as misturas estudadas em três grupos. Isto ocorre por conta da pequena influência que o TITAN produz no resultado de viscosidade rotacional. Tem-se um grupo composto pelas misturas 100-0-0, 99-0-1 e 99-0-2, caracterizadas pela ausência de SBS, outro composto pelas misturas 97,5-2,5-0, 96,5-2,5-1 e 95,5-2,5-2, caracterizado pela presença de 2,5\% de SBS, e outro composto pelas misturas 95-5-0, 94-5-1 e 93-5-2, caracterizado pela presença de 5\% de SBS. 


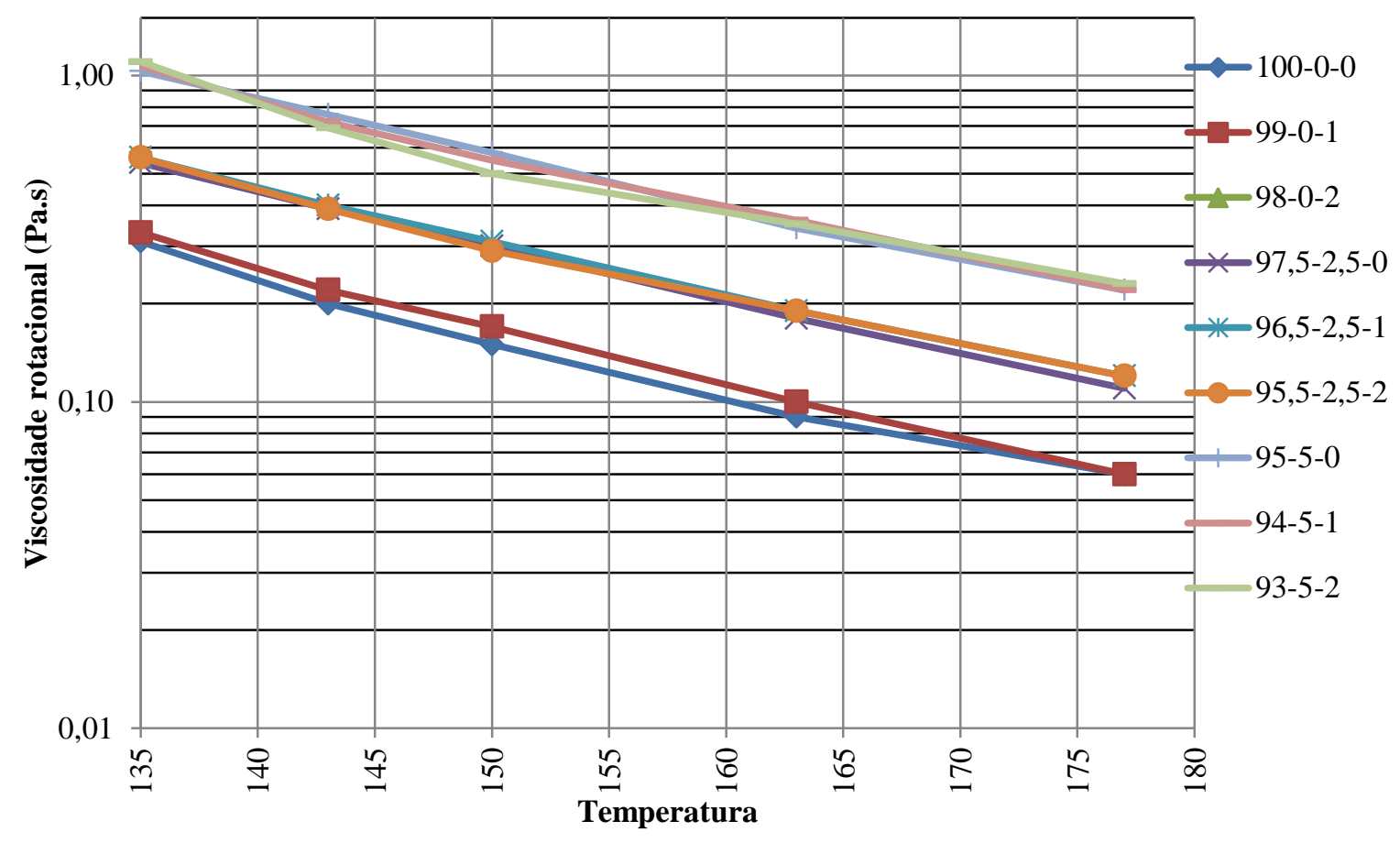

Figura 5.2 - Viscosidades rotacionais dos ligantes asfálticos na condição virgem

Em relação ao ligante asfáltico de base, pode-se observar, comparando as Tabelas $3.5 \mathrm{e}$ 5.2 a adição de $4 \%$ de óleo aromático causa redução da viscosidade em todas as temperaturas de ensaio. À exceção das misturas 100-0-0, 99-0-1 os valores apresentados na Tabela 5.2 se mostram maiores do que os apresentados para o ligante asfáltico de base (Tabela 3.5). Isto se deve à adição de SBS ou à adição da quantidade máxima de TITAN para compensar a diferença que os $4 \%$ de óleo aromático em peso causa na viscosidade da mistura.

A Tabela 5.3 mostra as viscosidades rotacionais dos ligantes asfálticos na condição envelhecida a curto prazo (RTFOT) nas temperaturas de ensaio $\left(135,143,150,163,177^{\circ} \mathrm{C}\right)$. Para a temperatura de $135^{\circ} \mathrm{C}$, na condição envelhecida a curto prazo, a mistura 95-5-0 apresenta a maior viscosidade (1,63 Pa.s), seguida pela mistura de 93-5-2 (1,41 Pa.s). A menor viscosidade foi apresentada pela mistura 100-0-0 (0,44 Pa.s), seguida pela mistura 990-1 (0,46 Pa.s). Observa-se ainda que, para a temperatura de $135^{\circ} \mathrm{C}$, misturas com a mesma concentração de SBS e diferentes teores de TITAN apresentaram resultados de viscosidade expressivamente diferentes, por conta do efeito mais pronunciado do TITAN na condição envelhecida a curto prazo. No caso de misturas com 5\% de SBS (95-5-0, 94-5-1, 93-5-2) ocorre uma diminuição de 0,23 Pa.s e 0,22 Pa.s com o aumento de TITAN em comparação 
com a mistura 95-5-0. No caso de misturas com 2,5\% de SBS (97,5-2,5-0, 96,5-2,5-1, 95,52,5-2) ocorre um aumento de 0,12 Pa.s e 0,10 Pa.s com o aumento de TITAN em comparação com a mistura 97,5-2,5-0. Para o caso sem SBS, os valores de viscosidade rotacional se mostraram equivalentes.

\section{Tabela 5.3 - Viscosidades rotacionais em Pa.s dos ligantes asfálticos na condição envelhecida a curto prazo}

\begin{tabular}{cccccc}
\hline misturas & $\mathbf{1 3 5}^{\mathbf{}} \mathbf{C}$ & $\mathbf{1 4 3}^{\mathbf{}} \mathbf{C}$ & $\mathbf{1 5 0}^{\mathbf{}} \mathbf{C}$ & $\mathbf{1 6 3}^{\mathbf{}} \mathbf{C}$ & $\mathbf{1 7 7}^{\mathbf{}} \mathbf{C}$ \\
\hline $100-0-0$ & 0,44 & 0,29 & 0,21 & 0,12 & 0,08 \\
$99-0-1$ & 0,46 & 0,31 & 0,23 & 0,14 & 0,08 \\
$98-0-2$ & 0,48 & 0,33 & 0,24 & 0,14 & 0,09 \\
$97,5-2,5-0$ & 0,75 & 0,51 & 0,38 & 0,22 & 0,13 \\
$96,5-2,5-1$ & 0,83 & 0,56 & 0,42 & 0,25 & 0,15 \\
$95,5-2,5-2$ & 0,85 & 0,54 & 0,40 & 0,25 & 0,15 \\
$95-5-0$ & 1,63 & 1,10 & 0,80 & 0,44 & 0,27 \\
$94-5-1$ & 1,40 & 0,97 & 0,73 & 0,44 & 0,27 \\
$93-5-2$ & 1,41 & 0,96 & 0,72 & 0,46 & 0,29 \\
CAP de base & 0,57 & 0,37 & 0,28 & 0,15 & 0,09 \\
\hline
\end{tabular}

Para a temperatura de $143^{\circ} \mathrm{C}$, na condição envelhecida a curto prazo, a mistura 95-5-0 apresenta a maior viscosidade (1,10 Pa.s), seguida pela mistura de 94-5-1 (0,97 Pa.s). A menor viscosidade foi apresentada pela mistura 100-0-0 (0,29 Pa.s), seguida pela mistura com $1 \%$ de TITAN, 99-0-1 (0,31 Pa.s). Como já observado na temperatura de $135^{\circ} \mathrm{C}$, o envelhecimento intensificou o efeito do TITAN quando se observam os grupos com 0,25 , e 5,0\% de SBS. No caso de misturas com 5\% de SBS (95-5-0, 94-5-1, 93-5-2), ocorre uma diminuição de 0,13 Pa.s e 0,14 Pa.s com o aumento de TITAN em comparação com a mistura 95-5-0. Para os demais casos com 2,5\% e 0\% de SBS, as variações que ocorrem foram pequenas, mostrando que o aumento da quantidade de TITAN na mistura não alterou significativamente o valor de viscosidade rotacional.

Para a temperatura de $150^{\circ} \mathrm{C}$, na condição envelhecida a curto prazo, a mistura 95-5-0 apresenta a maior viscosidade (0,80 Pa.s), seguida pela mistura de 94-5-1 (0,73 Pa.s). A menor viscosidade foi apresentada pela mistura 100-0-0 (0,21 Pa.s), seguida pela mistura 990-1 (0,23 Pa.s). Observa-se ainda que nesta temperatura e na condição de envelhecida a curto prazo, o TITAN não afetou significativamente os valores de viscosidade pra um mesmo teor de SBS. 
Para a temperatura de $163^{\circ} \mathrm{C}$, na condição envelhecida a curto prazo, a mistura 93-5-2 apresenta a maior viscosidade (0,46 Pa.s) seguida pelas misturas de 94-5-1 e 95-5-0 (ambas com 0,44 Pa.s). A menor viscosidade foi apresentada pela mistura 100-0-0 (0,12 Pa.s), seguida pelas misturas 99-0-1 e 98-0-2 (ambas com 0,14 Pa.s). Observa-se ainda que nesta temperatura e na condição de envelhecida a curto prazo, o TITAN não afetou significativamente os valores de viscosidade pra um mesmo teor de SBS.

Para a temperatura de $177^{\circ} \mathrm{C}$, na condição envelhecida a curto prazo, a mistura 93-5-2 apresenta a maior viscosidade (0,29 Pa.s), seguida pelas misturas de 94-5-1 e 95-5-0 (ambas com 0,27 Pa.s). A menor viscosidade foi apresentada pelas misturas 100-0-0 e 99-0-1 (ambas com 0,08 Pa.s), seguida pela mistura 98-0-2 (0,09 Pa.s). Observa-se ainda que nesta temperatura e na condição de envelhecida a curto prazo, o TITAN não afetou significativamente os valores de viscosidade pra um mesmo teor de SBS.

A Figura 5.3 mostra o gráfico de viscosidade rotacional (Pa.s) versus temperatura $\left({ }^{\circ} \mathrm{C}\right)$ das misturas na condição envelhecida a curto prazo. Observa-se claramente que ocorre uma divisão entre as misturas estudadas em três grupos. Isto ocorre pela pequena influência que o TITAN tem sobra a viscosidade rotacional. Observam-se três grupos distintos: um composto pelas misturas 100-0-0, 99-0-1 e 99-0-2, caracterizadas pela ausência de SBS, outro composto pelas misturas 97,5-2,5-0, 96,5-2,5-1 e 95,5-2,52, caracterizadas pela presença de $2,5 \%$ de SBS, e outro composto pelas misturas 95-5-0, 94-5-1 e 93-5-2, caracterizadas pela presença de $5,0 \%$ de SBS.

Em comparação da mistura 100-0-0 com o ligante asfáltico de base, pode-se observar, ao comparar as Tabelas 5.3 e 3.5, que, no caso da viscosidade envelhecida a curto prazo, a adição de $4 \%$ de óleo aromático provoca redução da viscosidade em todas as temperaturas de ensaio. Ao se comparar as misturas 100-0-0, 99-0-1 e 98-0-2 com o ligante asfáltico de base, observa-se uma diferença de viscosidade envelhecida a curto prazo maior do que a viscosidade virgem, mostrando que ou o óleo aromático ou o TITAN são responsáveis por esta mudança no envelhecimento a curto prazo, visto que estas misturas não apresentam SBS. 


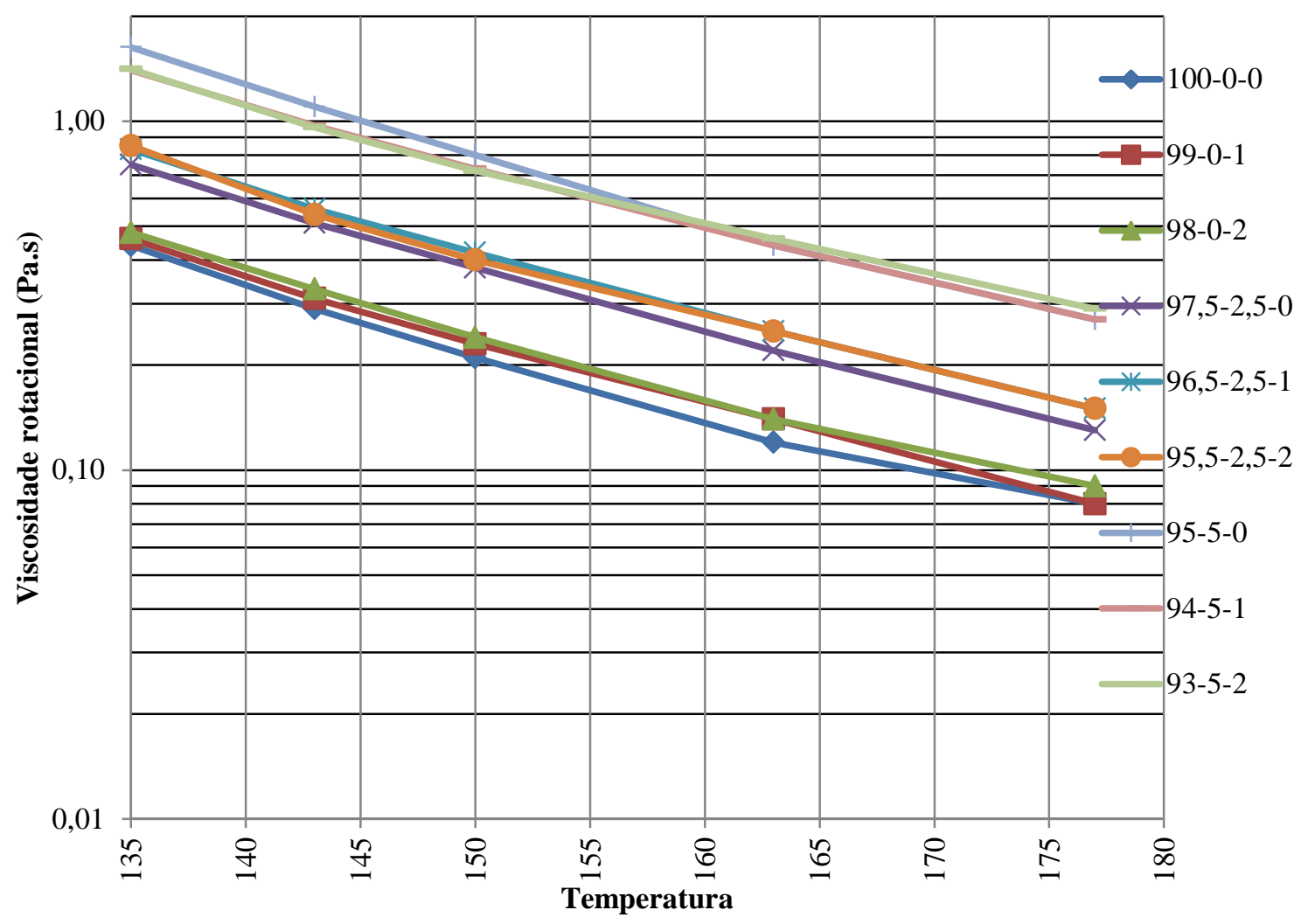

Figura 5.3 - Viscosidades rotacionais dos ligantes asfálticos na condição envelhecida a curto prazo

\subsubsection{Incrementos de viscosidade rotacional}

A Tabela 5.4 mostra o incremento das viscosidades rotacionais dos ligantes asfálticos (parâmetro $I_{v}$ ) nas temperaturas de ensaios $\left(135,143,150,163,177^{\circ} \mathrm{C}\right.$ ), decorrente do envelhecimento a curto prazo. Na Tabela 5.4, figuram em negrito os valores máximos e mínimos de incrementos para todas as temperaturas. Para a temperatura de $135^{\circ} \mathrm{C}$, a mistura 95-5-0 apresenta o maior incremento de viscosidade (1,58 vezes), seguida pelas misturas 95,5-2,5-2 (1,52 vezes), 96,5-2,5-1 (1,48 vezes) e 98-0-2 (1,45 vezes). O menor incremento de viscosidade foi apresentado pela mistura 93-5-2 (1,28 vezes), seguida pelas misturas 94-51 (1,31 vezes) e 99-0-1 e 97,5-2,5-0 (ambas aumentaram 1,39 vezes). A mistura que apresentou incremento de viscosidade intermediário foi a 100-0-0 (1,42 vezes). 
Tabela 5.4 - Incremento das viscosidades rotacionais dos ligantes asfálticos $\left(I_{v}\right)$

\begin{tabular}{cccccc}
\hline $\begin{array}{c}\text { Lig/Temp } \\
\text { (RTFOT/original) }\end{array}$ & $\mathbf{1 3 5}^{\mathbf{}} \mathbf{C}$ & $\mathbf{1 4 3}^{\mathbf{C}} \mathbf{C}$ & $\mathbf{1 5 0}^{\mathbf{}} \mathbf{C}$ & $\mathbf{1 6 3}^{\mathbf{}} \mathbf{C}$ & $\mathbf{1 7 7}^{\mathbf{C}} \mathbf{C}$ \\
\hline $100-0-0$ & 1,42 & $\mathbf{1 , 4 5}$ & 1,40 & 1,33 & $\mathbf{1 , 3 3}$ \\
$99-0-1$ & 1,39 & 1,41 & 1,35 & $\mathbf{1 , 4 0}$ & $\mathbf{1 , 3 3}$ \\
$98-0-2$ & 1,45 & 1,43 & 1,41 & 1,27 & 1,29 \\
$97,5-2,5-0$ & 1,39 & $\mathbf{1 , 3 1}$ & $\mathbf{1 , 2 7}$ & $\mathbf{1 , 2 2}$ & $\mathbf{1 , 1 8}$ \\
$96,5-2,5-1$ & 1,48 & 1,40 & 1,35 & 1,32 & 1,25 \\
$95,5-2,5-2$ & 1,52 & 1,38 & 1,38 & 1,32 & 1,25 \\
$95-5-0$ & $\mathbf{1 , 5 8}$ & $\mathbf{1 , 4 5}$ & 1,38 & 1,29 & 1,23 \\
$94-5-1$ & 1,31 & 1,35 & 1,33 & $\mathbf{1 , 2 2}$ & 1,23 \\
$93-5-2$ & $\mathbf{1 , 2 8}$ & 1,39 & $\mathbf{1 , 4 4}$ & 1,31 & 1,26 \\
Replan 50/70 & 1,67 & 1,60 & 1,55 & 1,48 & 1,44 \\
\hline
\end{tabular}

Para a temperatura de $143^{\circ} \mathrm{C}$, as misturas $100-0-0$ e 95-5-0 apresentam os maiores incrementos de viscosidade (ambas 1,45 vezes), seguidas pela 98-0-2 (1,43 vezes) e pela 990-1 (1,41 vezes). O menor incremento de viscosidade foi apresentado pela mistura 97,5-2,5-0 (1,31 vezes), seguida pelas misturas 94-5-1 (1,35 vezes), 95,5-2,5-2 (1,38 vezes) e 93-5-2 (1,39 vezes). A mistura que apresentou incremento de viscosidade intermediário foi a 96,52,5-1 (1,40 vezes).

Para a temperatura de $150^{\circ} \mathrm{C}$, a mistura $93-5-2$ foi a que apresentou o maior incremento de viscosidade (1,44 vezes), seguida pelas misturas 98-0-2 (1,41 vezes), 100-0-0 (1,40 vezes) e 95-5-0 e 95,5-2,5-2 (ambas com 1,38 vezes). O menor incremento de viscosidade foi apresentado pela mistura 93-5-2 (1,28 vezes), seguida pelas misturas 97,5-2,5-0 (1,27 vezes), 94-5-1 (1,33 vezes) e 96,5-2,5-1 e 99-0-1 (ambas aumentaram 1,35 vezes).

Para a temperatura de $163^{\circ} \mathrm{C}$, a mistura $99-0-1$ foi a que apresentou o maior incremento de viscosidade (1,40 vezes), seguida pelas misturas 100-0-0 (1,33 vezes) e 96,5-2,5-1 e 95,52,5-2 (1,32 vezes). Os menores incrementos de viscosidade foram apresentados pelas misturas 94-5-1 e 97,5-2,5-0 (1,22 vezes), seguidas pelas misturas 98-0-2 (1,27 vezes) e 95-5-0 (1,29 vezes). A mistura que apresentou incremento de viscosidade intermediário foi a 93-5-2 (1,31 vezes).

Para a temperatura de $177^{\circ} \mathrm{C}$, as misturas $100-0-0$ e $99-0-1$ foram as que apresentaram os maiores incrementos de viscosidade (1,33 vezes), seguidas pelas misturas $98-0-2$ (1,29 vezes) e 93-5-2 (1,26 vezes). O menor incremento de viscosidade foi apresentado pela mistura 
97,5-2,5-0 (1,18 vezes), seguidas pelas misturas 95-5-0 e 94-5-1 (ambas aumentaram 1,23 vezes) e 96,5-2,5-1 e 95,5-2,5-2 (ambas aumentaram 1,25 vezes).

A mistura 95-5-0 teve o maior incremento de viscosidade em duas temperaturas (135 e $143^{\circ} \mathrm{C}$ ). A mistura 99-0-1 teve o maior incremento de viscosidade em duas temperaturas (163 e $177^{\circ} \mathrm{C}$ ). A mistura $100-0-0$ teve o maior incremento de viscosidade em duas temperaturas $\left(143\right.$ e $\left.177^{\circ} \mathrm{C}\right)$. A mistura 93-5-2 teve o maior incremento de viscosidade em uma temperatura $\left(150^{\circ} \mathrm{C}\right)$. Observa-se que, em temperaturas mais elevadas, as misturas com pequenas proporções dos modificadores sofrem um maior incremento de viscosidade do que as misturas com quantidades altas dos modificadores. A variação do valor máximo de incremento de viscosidade foi de 0,25 vezes entre as temperaturas de 135 e $177^{\circ} \mathrm{C}(1,58$ da mistura $95-5-0$ e 1,33 das misturas 100-0-0 e 99-0-1). A mistura 93-5-2 teve o menor incremento de viscosidade em uma temperatura $\left(135^{\circ} \mathrm{C}\right)$. A mistura 97,5-2,5-0 teve o menor incremento de viscosidade em quatro temperaturas $\left(143,150,163,177^{\circ} \mathrm{C}\right)$. Observa-se que a mistura que obteve o menor incremento de viscosidade foi a 97,5-2,5-0, para a maioria das temperaturas, visto que na temperatura em que ela não ficou com o menor valor de incremento $\left(135^{\circ} \mathrm{C}\right)$, ela também apresentou o terceiro mais baixo incremento. A variação do valor mínimo de incremento foi de 0,13 vezes entre as temperaturas de 143 e $177^{\circ} \mathrm{C}(1,31$ da mistura 97,5-2,50 na temperatura de $143^{\circ} \mathrm{C}$ e 1,18 da mistura $97,5-2,5-0$ na temperatura de $177^{\circ} \mathrm{C}$ ).

Quando se compara o ligante asfáltico de base com os demais, observa-se que os incrementos de viscosidade para o CAP puro são maiores que o das misturas. Isto se deve à adição dos modificadores, que atuam no sentido de tornar o ligante asfáltico menos sensível ao efeito do envelhecimento a curto prazo. Importante ressaltar que o máximo incremento de viscosidade obtido foi de 1,6, quando incrementos superiores a 2,0 podem ser considerados excessivos. Ao se comparar a mistura 100-0-0 com o CAP de base, percebe-se que o óleo apresenta resultados satisfatórios para o incremento de viscosidade. Realizou-se um ensaio de viscosidade apenas com o óleo extensor NPA envelhecido a curto prazo e chegou-se à conclusão que o NPA funciona como uma espécie de agente antioxidante, reduzindo a sensibilidade ao envelhecimento, pois o incremento máximo de viscosidade observado apenas para o óleo extensor foi de $11 \%(1,11)$ na temperatura de $150^{\circ} \mathrm{C}$. Para as outras temperaturas, este incremento ficou entre 1,00 e 1,11 . 


\subsubsection{Temperaturas de usinagem e compactação dos ligantes asfálticos}

As temperaturas de usinagem e compactação dos ligantes asfálticos foram obtidas graficamente com base nas Figuras 5.2 e 5.3. A temperatura de usinagem compreende aquela em que o ligante asfáltico original apresenta uma viscosidade de 0,17 $\pm 0,02 \mathrm{~Pa}$.s e a temperatura de compactação é aquela em que o ligante asfáltico apresenta uma viscosidade entre 0,28 \pm 0,03 Pa.s. A Tabela 5.5 mostra o intervalo e o valor médio das temperaturas de usinagem e compactação para as nove misturas.

Tabela 5.5 - Temperaturas de usinagem e compactação dos ligantes asfálticos

\begin{tabular}{ccccc}
\hline \multirow{2}{*}{ mistura } & \multicolumn{2}{c}{ compactação $\left({ }^{\mathbf{0}} \mathbf{C}\right)$} & \multicolumn{2}{c}{ usinagem $\left({ }^{\circ} \mathbf{C}\right)$} \\
\cline { 2 - 5 } & \multicolumn{2}{c}{ valor } & \multicolumn{2}{c}{ valor } \\
intervalo & médio & intervalo & médio \\
\hline $100-0-0$ & $135-139$ & 137 & $144-150$ & 147 \\
$99-0-1$ & $136-140$ & 138 & $148-154$ & 151 \\
$98-0-2$ & $136-140$ & 138 & $148-154$ & 151 \\
$97,5-2,5-0$ & $149-155$ & 152 & $162-170$ & 166 \\
$96,5-2,5-1$ & $150-156$ & 153 & $163-171$ & 167 \\
$95,5-2,5-2$ & $149-155$ & 152 & $163-171$ & 167 \\
$95-5-0$ & $166-174$ & 170 & $180-186$ & 183 \\
$94-5-1$ & $167-175$ & 171 & $181-187$ & 184 \\
$93-5-2$ & $166-174$ & 170 & $181-187$ & 184 \\
Replan 50/70 & $137-141$ & 139 & $148-152$ & 150 \\
\hline
\end{tabular}

A mistura 100-0-0 possui o menor valor médio tanto para a temperatura de compactação como para a de usinagem, ou seja, $137^{\circ} \mathrm{C}$ e $147^{\circ} \mathrm{C}$, respectivamente. Este resultado já era esperado, visto que com a adição de modificadores aumenta os valores de viscosidade rotacional. As misturas 99-0-1 e 98-0-2 apresentaram temperaturas de compactação equivalentes $\left(138^{\circ} \mathrm{C}\right)$, com valor médio muito parecido ao da mistura 100-0-0, mas, no caso da temperatura de usinagem, ocorreu um aumento em $4^{\circ} \mathrm{C}$. Ao aumentar a quantidade de SBS, aumentam-se as temperaturas de usinagem e compactação ideais. No caso das misturas com 2,5\% de SBS, ocorreu uma pequena inversão. As misturas 97,5-2,5-0 e 97,5-2,5-2 apresentaram valores iguais para compactação $\left(152^{\circ} \mathrm{C}\right)$, enquanto que para usinagem ocorreu uma diferença de $1^{\circ} \mathrm{C}$ entre as mesmas. As 3 misturas com 2,5\% de SBS forneceram 
temperaturas de usinagem e compactação equivalentes. As misturas 95-5-0 e 95-5-2 apresentaram valores iguais para compactação $\left(170^{\circ} \mathrm{C}\right)$, enquanto que para usinagem ocorreu uma diferença de $1^{\circ} \mathrm{C}$ entre elas. As 3 misturas com 5\% de SBS forneceram temperaturas de usinagem e compactação equivalentes.

Em comparação à mistura 100-0-0, as misturas contendo 2,5\% de SBS tiveram suas temperaturas de usinagem aumentadas em $16^{\circ} \mathrm{C}$ e as misturas contendo $5,0 \%$ de SBS tiveram suas temperaturas de usinagem aumentadas em $34^{\circ} \mathrm{C}$. No que se refere à temperatura de compactação estes aumentos foram de 14 e $37^{\circ} \mathrm{C}$, para as misturas contendo 2,5 e $5,0 \%$ de SBS, respectivamente.

A adição de 4\% de óleo aromático ao CAP puro diminuiu as temperaturas de usinagem e de compactação. As misturas 99-0-1 e 98-0-2 apresentaram temperaturas iguais de usinagem e compactação à do CAP puro. No que se refere às misturas que contêm SBS, as temperaturas de usinagem e de compactação se mostraram superiores às observadas para ao CAP puro.

\subsection{Balanço de massa}

A determinação da perda de massa é feita em paralelo com o envelhecimento a curto prazo. Para este cálculo, foram utilizados quatro frascos com 35 gramas de ligante asfáltico de cada mistura, sendo o valores médios apresentado na Tabela 5.6.

Tabela 5.6 - Perda de massa média das misturas

\begin{tabular}{cc}
\hline misturas & perda de Massa $(\%)$ \\
\hline $100-0-0$ & $-0,12$ \\
$99-0-1$ & $-0,28$ \\
$99-0-2$ & $-0,27$ \\
$97,5-2,5-0$ & $-0,12$ \\
$96,5-2,5-1$ & $-0,19$ \\
$95,5-2,5-2$ & $-0,21$ \\
$95-5-0$ & $-0,06$ \\
$94-5-1$ & $-0,12$ \\
$94-5-2$ & $-0,14$ \\
CAP de base & $-0,10$ \\
\hline
\end{tabular}


A menor perda de massa observada foi a da mistura $95-5-0(-0,06 \%)$ e a maior foi a da mistura 99-0-1 (-0,28\%). A mistura 100-0-0 teve uma perda de massa de 0,12\%, próxima à observada para o CAP puro. Importante relembrar que as misturas contêm $4 \%$ de óleo aromático na sua composição, o que justifica o ligeiro aumento da perda de massa em relação ao CAP puro (-0,10\%), à exceção da mistura 95-5-0. A perda de massa do óleo puro foi de 0,5\%. Segundo o Regulamento Técnico n.3/2005 da Associação Nacional do Petróleo, Gás e Biocombustíveis (ANP), perdas de massa superiores a 0,5\% seriam críticas, o que não se verificou para as amostras analisadas.

\subsection{Ensaio de fluência e recuperação sob múltiplas tensões (MSCR)}

Os valores de percentual de recuperação, compliância não-recuperável e $\mathrm{J}_{\text {nr,diff, em }}$ função da temperatura, são apresentadas nas Tabelas 5.7, 5.8 e 5.9, respectivamente, apenas para as amostras envelhecidas a curto prazo. Os resultados serão apresentados nas temperaturas de $52^{\circ} \mathrm{C}, 58^{\circ} \mathrm{C}, 64^{\circ} \mathrm{C}, 70^{\circ} \mathrm{C}$ e $76^{\circ} \mathrm{C}$, lembrando o ensaio é interrompido na temperatura correspondente ao PG do ligante asfáltico.

Tabela 5.7 - Percentuais de recuperação (R) das misturas

\begin{tabular}{|c|c|c|c|c|c|c|c|c|c|c|}
\hline \multirow{2}{*}{ misturas } & \multicolumn{5}{|c|}{$100 \mathrm{~Pa}\left(\mathrm{R}_{100}\right)$, em \% } & \multicolumn{5}{|c|}{ 3.200 Pa $\left(\mathbf{R}_{3.200}\right)$, em \% } \\
\hline & $52^{\circ} \mathrm{C}$ & $58^{\circ} \mathrm{C}$ & $64^{\circ} \mathrm{C}$ & $7^{\circ} \mathrm{C}$ & $76^{\circ} \mathrm{C}$ & $52^{\circ} \mathrm{C}$ & $5^{\circ} \mathrm{C}$ & $64^{\circ} \mathrm{C}$ & $7^{\circ} \mathrm{C}$ & $76^{\circ} \mathrm{C}$ \\
\hline $100-0-0$ & 6,4 & 1,5 & - & - & - & 1,9 & - & - & - & - \\
\hline $99-0-1$ & 27,7 & 21,9 & 15,5 & 6,4 & - & 12,4 & 2,7 & - & - & - \\
\hline $98-0-2$ & 65,9 & 63,9 & 51,4 & 34,6 & 14,3 & 27,8 & 10,7 & 1,4 & - & - \\
\hline $97,5-2,5-0$ & 23,8 & 16,8 & 10,6 & 5,9 & - & 18,8 & 7,4 & 0,5 & - & - \\
\hline $96,5-2,5-1$ & 54,8 & 53,4 & 46,6 & 37,6 & - & 43,9 & 28,4 & 12,3 & 1,9 & - \\
\hline $95,5-2,5-2$ & 75,9 & 77,6 & 76,4 & 68,9 & 50,9 & 58,4 & 42,7 & 21,3 & 5,9 & - \\
\hline $95-5-0$ & 56,3 & 60,0 & 59,0 & 56,8 & 49,5 & 50,8 & 41,4 & 33,6 & 28,0 & 18,1 \\
\hline $94-5-1$ & 70,2 & 69,9 & 66,0 & 59,1 & 46,9 & 63,5 & 51,6 & 36,5 & 22,9 & 12,1 \\
\hline $93-5-2$ & 81,8 & 82,6 & 81,2 & 76,8 & 67,0 & 75,0 & 65,1 & 47,3 & 27,5 & 12,5 \\
\hline CAP de base & 12,4 & 5,8 & 1,0 & - & - & 8,9 & 0,5 & - & - & - \\
\hline
\end{tabular}

A temperatura de análise do MSCR é a do PG do pavimento e não a do PG do ligante asfáltico. O Instituto do Asfalto dos Estados Unidos analisa o os resultados do MSCR apenas 
nas temperaturas de 64 e $70^{\circ} \mathrm{C}$, que são os PGs típicos dos pavimentos americanos. Pode-se aplicar estas temperaturas também para os pavimentos brasileiros.

Tabela 5.8 - Compliâncias não-recuperáveis $\left(\mathbf{J}_{n r}\right)$ das misturas

\begin{tabular}{|c|c|c|c|c|c|c|c|c|c|c|}
\hline \multirow{2}{*}{ misturas } & \multicolumn{5}{|c|}{100 Pa $\left(J_{\text {nr100 }}\right), \mathrm{em} \mathrm{kPa}^{-1}$} & \multicolumn{5}{|c|}{ 3.200 Pa $\left(J_{n r 3.200}\right), \mathrm{em} \mathrm{kPa}^{-1}$} \\
\hline & $52^{\circ} \mathrm{C}$ & $58^{\circ} \mathrm{C}$ & $64^{\circ} \mathrm{C}$ & $7^{\circ} \mathrm{C}$ & $76^{\circ} \mathrm{C}$ & $52^{\circ} \mathrm{C}$ & $58^{\circ} \mathrm{C}$ & $64^{\circ} \mathrm{C}$ & $7^{\circ} \mathrm{C}$ & $76^{\circ} \mathrm{C}$ \\
\hline $100-0-0$ & 0,7 & 1,9 & 4,5 & - & - & 0,8 & 2,1 & 5,1 & - & - \\
\hline $99-0-1$ & 0,3 & 0,8 & 2,1 & 5,6 & - & 0,4 & 1,2 & 3,4 & 8,6 & - \\
\hline $98-0-2$ & 0,1 & 0,2 & 0,7 & 2,3 & 7,4 & 0,2 & 0,8 & 2,4 & 6,2 & 14,7 \\
\hline $97,5-2,5-0$ & 0,3 & 0,8 & 1,8 & 4,2 & - & 0,3 & 0,9 & 2,3 & 5,4 & - \\
\hline $96,5-2,5-1$ & 0,1 & 0,2 & 0,6 & 1,4 & - & 0,1 & 0,4 & 1,2 & 3,2 & - \\
\hline $95,5-2,5-2$ & 0,03 & 0,1 & 0,2 & 0,4 & 1,6 & 0,1 & 0,2 & 0,8 & 2,3 & 6,0 \\
\hline $95-5-0$ & 0,1 & 0,2 & 0,4 & 0,8 & 1,8 & 0,1 & 0,3 & 0,7 & 1,5 & 3,6 \\
\hline $94-5-1$ & 0,04 & 0,1 & 0,2 & 0,4 & 1,1 & 0,1 & 0,1 & 0,4 & 1,1 & 2,7 \\
\hline $93-5-2$ & 0,01 & 0,02 & 0,1 & 0,1 & 0,4 & 0,02 & 0,1 & 0,2 & 0,6 & 1,8 \\
\hline CAP de base & 0,3 & 0,9 & 2,4 & 6,0 & 13,5 & 0,4 & 1,0 & 2,8 & 6,8 & 15,2 \\
\hline
\end{tabular}

Tabela 5.9 - $\mathbf{J}_{\mathrm{nr}, \text { diff }}$ das misturas

\begin{tabular}{cccccc}
\hline \multirow{2}{*}{ misturas } & \multicolumn{5}{c}{ Jnr,diff, em $^{\mathbf{~ \%}}$} \\
\cline { 2 - 6 } & $\mathbf{5 2}^{\mathbf{0}} \mathbf{C}$ & $\mathbf{5 8}^{\mathbf{O}} \mathbf{C}$ & $\mathbf{6 4}^{\mathbf{}} \mathbf{C}$ & $\mathbf{7 0}^{\mathbf{}} \mathbf{C}$ & $\mathbf{7 6}^{\mathbf{}} \mathbf{C}$ \\
\hline $100-0-0$ & 8,2 & 12,4 & 12,9 & - & - \\
$99-0-1$ & 35,8 & 50,8 & 61,4 & 53,1 & - \\
$98-0-2$ & $\mathbf{1 8 1 , 0}$ & $\mathbf{3 1 7 , 2}$ & $\mathbf{2 4 4 , 5}$ & $\mathbf{1 7 6 , 8}$ & $\mathbf{9 8 , 8}$ \\
$97,5-2,5-0$ & 9,4 & 19,0 & 25,4 & 28,2 & - \\
$96,5-2,5-1$ & 33,3 & $\mathbf{7 9 , 3}$ & $\mathbf{1 1 0 , 4}$ & $\mathbf{1 2 3 , 0}$ & - \\
$95,5-2,5-2$ & $\mathbf{1 0 4 , 6}$ & $\mathbf{2 2 2 , 9}$ & $\mathbf{4 2 8 , 2}$ & $\mathbf{4 4 1 , 5}$ & $\mathbf{2 7 9 , 6}$ \\
$95-5-0$ & 15,0 & 54,4 & $\mathbf{7 9 , 8}$ & $\mathbf{9 5 , 4}$ & $\mathbf{1 0 0 , 1}$ \\
$94-5-1$ & 28,7 & $\mathbf{7 6 , 3}$ & $\mathbf{1 2 4 , 3}$ & $\mathbf{1 5 1 , 4}$ & $\mathbf{1 4 1 , 7}$ \\
$93-5-2$ & 51,0 & $\mathbf{1 3 1 , 3}$ & $\mathbf{2 6 4 , 1}$ & $\mathbf{3 8 0 , 5}$ & $\mathbf{3 5 6 , 3}$ \\
CAP de base & 6,0 & 10,9 & 13,9 & 13,9 & 12,6 \\
\hline
\end{tabular}

Para a mistura 100-0-0, que possui grau de desempenho PG 58-XX, observa-se que nesta temperatura são atendidos os valores apresentados no subitem 3.3.7. Pela Tabela 5.8, tem-se o valor de $\mathrm{J}_{\mathrm{nr}}$ igual a $2,1 \mathrm{kPa}^{-1}$, a $3.200 \mathrm{~Pa}$, o qual classifica a rodovia como um tipo de tráfego padrão (S) pela Tabela 3 da norma AASHTO M320. Em relação ao percentual de recuperação a $3.200 \mathrm{~Pa}$ para esta faixa de $\mathrm{J}_{\mathrm{nr}}$, não existe um percentual mínimo de recuperação. $\mathrm{O}$ valor de $\mathrm{J}_{\mathrm{nr} \text {,diff }}$ obtido a $58^{\circ} \mathrm{C}$ é de $12,4 \%$, abaixo dos $75 \%$ especificados. Para qualquer temperatura acima $\left(64\right.$ e $\left.70^{\circ} \mathrm{C}\right)$, o valor de compliância não-recuperável é 
considerado muito alto pela norma, não sendo recomendável a utilização desta mistura para as temperaturas de 64 e $70^{\circ} \mathrm{C}$.

Para a mistura 99-0-1, que possui grau de desempenho PG 64-XX, observa-se que nesta temperatura são atendidos os valores recomendados apresentados no subitem 3.3.7. Pela Tabela 5.18, tem-se o valor de $J_{\mathrm{nr}}$ igual a $3,4 \mathrm{kPa}^{-1}$, a $3.200 \mathrm{~Pa}$, o qual classifica a rodovia como um tipo de tráfego padrão (S) pela Tabela 3 da norma AASHTO M320. Em relação ao percentual de recuperação a 3.200 Pa para esta faixa de $\mathrm{J}_{\mathrm{nr}}$, não existe um percentual mínimo de recuperação. $\mathrm{O}$ valor de $\mathrm{J}_{\mathrm{nr} \text {,diff }}$ obtido a $64^{\circ} \mathrm{C}$ é de $61,4 \%$, abaixo dos $75 \%$ especificados. A $70^{\circ} \mathrm{C}$ o limite de $75 \%$ é excedido para o $\mathrm{J}_{\text {nr,diff. }}$.

Para a mistura 98-0-2, que possui grau de desempenho PG 70-XX, observa-se que nesta temperatura não são atendidos alguns valores recomendados apresentados no subitem 3.3.7. Pela Tabela 5.8, tem-se o valor de $\mathrm{J}_{\mathrm{nr}}$ igual a $6,2 \mathrm{kPa}^{-1}$, o qual está acima do valor máximo de 4,00 $\mathrm{kPa}^{-1}$ apresentado pela Tabela 3 da norma AASHTO M320. Esta mistura apresenta valores de $\mathrm{J}_{\mathrm{nr} \text {,diff }}$ muito altos para todas as temperaturas analisadas, o que a torna muito sensível a mudanças bruscas nos níveis de tensão. Para a temperatura de $64^{\circ} \mathrm{C}$, esta mistura apresenta $\mathrm{J}_{\mathrm{nr}}$ de 2,4 $\mathrm{kPa}^{-1}$ e $\mathrm{J}_{\mathrm{nr} \text {,diff }}$ de $244,5 \%$.

Para a mistura 97,5-2,5-0, que possui grau de desempenho PG 64-XX, observa-se que nesta temperatura são atendidos os valores apresentados no subitem 3.3.7. Pela Tabela 5.10, tem-se o valor de $\mathrm{J}_{\mathrm{nr}}$ igual a 2,3 $\mathrm{kPa}^{-1}$, a $3.200 \mathrm{~Pa}$, o qual classifica a rodovia com um tipo de tráfego padrão (S) pela Tabela 3 da norma AASHTO M320. Em relação ao percentual de recuperação a $3.200 \mathrm{~Pa}$, não existe um percentual mínimo de recuperação para esta faixa de $\mathrm{J}_{\mathrm{nr}}$. O $\mathrm{J}_{\mathrm{nr} \text {,diff }}$ obtido a $64^{\circ} \mathrm{C}$ é de $25,4 \%$, abaixo dos $75 \%$ especificados.

Para a mistura 96,5-2,5-1, que possui grau de desempenho PG 70-XX, observa-se que nesta temperatura não são atendidos alguns valores apresentados no subitem 3.3.7. Pela Tabela 5.8, tem-se o valor de $\mathrm{J}_{\mathrm{nr}}$ igual a $3,2 \mathrm{kPa}^{-1}$, a $3.200 \mathrm{~Pa}$, o qual classifica a rodovia como um tipo de tráfego padrão (S) pela Tabela 3 da norma AASHTO M320. Em relação ao percentual de recuperação a 3.200 Pa, não existe um percentual mínimo de recuperação para esta faixa de $\mathrm{J}_{\mathrm{nr}}$. $\mathrm{O} \mathrm{J}_{\mathrm{nr}, \text { diff }}$ obtido a $70^{\circ} \mathrm{C}$ é de $123,0 \%$, acima dos $75 \%$ especificados. Nesta temperatura, a mistura 96,5-2,5-1 é muito sensível a mudanças bruscas nos níveis de tensão nesta temperatura. Para a temperatura de $64^{\circ} \mathrm{C}$, esta mistura apresenta $J_{\mathrm{nr}}$ de $1,2 \mathrm{kPa}^{-1}$ e $J_{\mathrm{nr} \text {,diff }}$ de $110,4 \%$. Para esta atender o limite do parâmetro $J_{\text {nr,diff }}$ temperatura do pavimento não poderia passar de $52^{\circ} \mathrm{C}$ de $52^{\circ} \mathrm{C}\left(\mathrm{J}_{\mathrm{nr} \text {,diff }}\right.$ de $\left.33,3 \%\right)$. Nesta temperatura, esta mistura seria 
indicada para tráfego extremamente pesado (E), com valores de $\mathrm{J}_{\mathrm{nr}}$ igual a $0,1 \mathrm{kPa}^{-1} \mathrm{e}$ percentual de recuperação de 43,9\% (ligeiramente abaixo, do recomendado 50\%).

Para a mistura 95,5-2,5-2, que possui grau de desempenho PG 82-XX, o ensaio foi conduzido apenas até $76^{\circ} \mathrm{C}$. Observa-se, nas Tabelas 5.7, 5.8 e 5.9, que, nesta temperatura, não são atendidos alguns valores apresentados no subitem 3.3.7. Esta mistura sofre o mesmo problema da mistura 98-0-2, que apresenta valores de $\mathbf{J}_{\mathrm{nr} \text {,diff }}$ muito altos (acima de $75 \%$ ) para todas as temperaturas analisadas, indicando que ela é muito sensível a mudanças bruscas nos níveis de tensão. $\mathrm{O} \mathrm{J}_{\mathrm{nr}}$ é de 0,8 e $2,3 \mathrm{kPa}^{-1}$ para as temperaturas de 64 e $70^{\circ} \mathrm{C}$, respectivamente.

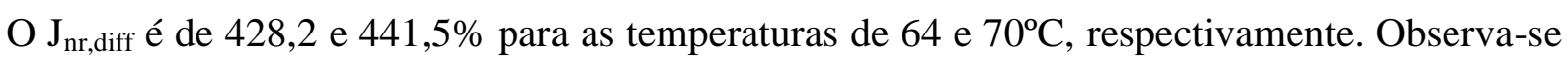
que para temperaturas mais baixas o $\mathrm{J}_{\mathrm{nr} \text {,diff }}$ continua muito acima de $75 \%$, portanto esta mistura é sensível a variações bruscas nos níveis de tensão.

Para a mistura 95-5-0, que possui grau de desempenho PG 76-XX, observa-se que, nesta temperatura, não são atendidos alguns valores apresentados no subitem 3.3.7. Pela Tabela 5.8, tem-se o valor de $\mathrm{J}_{\mathrm{nr}}$ igual a $3,6 \mathrm{kPa}^{-1}$, a $3.200 \mathrm{~Pa}$, o qual classifica a rodovia como um tipo de tráfego padrão (S) pela Tabela 3 da norma AASHTO M320. Em relação ao percentual de recuperação a 3.200 Pa, não existe um percentual mínimo de recuperação para esta faixa de $\mathrm{J}_{\mathrm{nr}}$. $\mathrm{O} \mathrm{J}_{\mathrm{nr} \text {,diff }}$ obtido a $76^{\circ} \mathrm{C}$ teve valor de $100,1 \%$, acima dos $75 \%$ especificados, indicando que nesta temperatura, a mistura 95-5-0 é muito sensível a mudanças bruscas nos

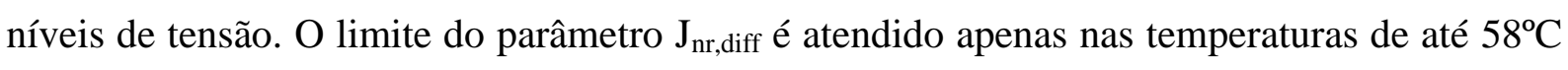
$(54,4 \%)$. Nesta temperatura, esta mistura seria adequada para suportar um tráfego extremamente pesado (E), com $J_{n r}$ de $0,3 \mathrm{kPa}^{-1}$ e percentual de recuperação de $41,4 \%$ (ligeiramente abaixo do recomendado pela norma $45 \%$ ). O $\mathrm{J}_{\mathrm{nr}}$ é de 0,7 e $1,5 \mathrm{kPa}^{-1}$ para as temperaturas de 64 e $70^{\circ} \mathrm{C}$, respectivamente. $\mathrm{O} \mathrm{J}_{\mathrm{nr} \text {,diff }}$ é de 79,8 e 95,4\%\% para as temperaturas de 64 e $70^{\circ} \mathrm{C}$, respectivamente. A temperatura de $64^{\circ} \mathrm{C}$ possui o Jnr,diff ligeiramente acima, portanto pode ser uma alternativa, pois possui uma classe de tráfego muito pesado (V).

Para a mistura 94-5-1, que possui grau de desempenho PG 88-XX, o ensaio foi conduzido apenas até a temperatura de $76^{\circ} \mathrm{C}$. Observa-se que, nesta temperatura, não são atendidos alguns valores apresentados no subitem 3.3.7. Esta mistura sofre o mesmo problema da mistura 95-5-0, que apresenta valores de $\mathrm{J}_{\text {nr,diff }}$ muito altos $76^{\circ} \mathrm{C}(141,7 \%)$, denotando que a mistura 94-5-1 é muito sensível a mudanças bruscas nos níveis de tensão. $\mathrm{O}$ $\mathrm{J}_{\mathrm{nr}}$ é de 0,4 e $1,1 \mathrm{kPa}^{-1}$ para as temperaturas de 64 e $70^{\circ} \mathrm{C}$, respectivamente. $\mathrm{O} \mathrm{J}_{\mathrm{nr} \text {,diff }}$ é de 124,3 e $151,4 \%$ para as temperaturas de 64 e $70^{\circ} \mathrm{C}$, respectivamente. Observa-se que para 
temperaturas mais baixas o $\mathrm{J}_{\mathrm{nr} \text {,diff }}$ continua muito acima de $75 \%$, portanto esta mistura é sensível a variações bruscas nos níveis de tensão.

Para a mistura 93-5-2, que possui grau de desempenho PG 106-XX, o ensaio foi conduzindo apenas até a temperatura de $76^{\circ} \mathrm{C}$. Observa-se que, nesta temperatura, não são atendidos alguns valores apresentados no subitem 3.3.7. Esta mistura sofre o mesmo problema das misturas 95-5-0 e 95-5-1, que apresentam valores de $\mathrm{J}_{\mathrm{nr}, \text { diff }}$ muito altos a $76^{\circ} \mathrm{C}$ (356,3\%), denotando alta sensibilidade a mudanças bruscas nos níveis de tensão. O parâmetro $\mathrm{J}_{\mathrm{nr} \text {,diff }}$ é atendido apenas na temperatura de $52^{\circ} \mathrm{C}(51,0 \%)$ e, nesta temperatura, esta mistura suportaria um tráfego extremamente pesado (E), com valores de $J_{\mathrm{nr}}$ de $0,02 \mathrm{kPa}^{-1}$ e de percentual de recuperação de 75,0\%. $\mathrm{O} \mathrm{J}_{\mathrm{nr}}$ é de 0,2 e $0,6 \mathrm{kPa}^{-1}$ para as temperaturas de $64 \mathrm{e}$ $70^{\circ} \mathrm{C}$, respectivamente. $\mathrm{O} \mathrm{J}_{\mathrm{nr}, \text { diff }}$ é de 264,1 e $380,5 \%$ para as temperaturas de 64 e $70^{\circ} \mathrm{C}$, respectivamente. Observa-se que para temperaturas mais baixas o $\mathrm{J}_{\mathrm{nr} \text {,diff }}$ continua muito acima de $75 \%$, portanto esta mistura é sensível a variações bruscas nos níveis de tensão.

Observa-se que todas as misturas contendo $2 \%$ de TITAN apresentaram um valor de $\mathrm{J}_{\mathrm{nr}, \text { diff }}$ superior a $75 \%$ indicando a alta sensibilidade destas composições a mudanças bruscas no nível de tensão aplicado ao pavimento. Ao se adicionar 5\% de SBS, também se observa o mesmo problema decorrente da adição de $2 \%$ de TITAN, apenas nas temperaturas acima de $58^{\circ} \mathrm{C}$. Em relação à mistura $100-0-0$, ao se acrescentar até $1 \%$ de TITAN e até $2,5 \%$ de SBS, foram obtidos ganhos para os parâmetros analisados.

A Tabela 5.10 mostra classificação das misturas quanto ao nível de tráfego nas diferentes temperaturas de ensaio, representativas de diferentes temperaturas do pavimento. Tomando por base os PGs recomendados para o Brasil (64 e 70), observa-se que a $64^{\circ} \mathrm{C}$ a mistura 100-0-0 (contendo 4\% de óleo) não poderia ser aplicada, uma vez que não atende sequer o menor nível de tráfego, porém, com a adição de $1 \%$ de TITAN ou 2\% de TITAN ou $2,5 \%$ de SBS, as formulações passam a atender um tráfego padrão (S) nesta temperatura. Adicionando-se $1 \%$ de TITAN ao CAP com 2,5\% de SBS, o nível de tráfego sobe para V. A adição de 5\% de SBS é suficiente para elevar o nível de tráfego para muito pesado (V) e, com a adição de 1 ou $2 \%$ de TITAN, o nível de tráfego sobe para extremamente pesado (E). Observa-se que o TITAN é capaz de elevar os níveis de tráfego nos três tipos de mistura (CAP puro, CAP com 2,5\% de SBS e CAP com 5,0\% de SBS), sendo o efeito do TITAN mais pronunciado quando na presença do copolímero SBS. Os resultados indicam que, a $64^{\circ} \mathrm{C}$, misturas do tipo CAP+óleo+TITAN necessitam de percentuais de TITAN superiores a 
$2 \%$ para atender classes mais altas de tráfego. Já na presença de 5,0\% de SBS, $1 \%$ de TITAN seria suficiente para obter misturas asfálticas que suportariam tráfego extremamente pesado.

$\mathrm{Na}$ temperatura de $70^{\circ} \mathrm{C}$, formulações com $2,5 \%$ de SBS e 1 ou $2 \%$ de TITAN são necessárias para atender um tráfego do tipo padrão (S). As formulações 95-5-0 e 94-5-1 são suficientes para atender um tráfego pesado $(\mathrm{H})$ e a formulação 93-5-2 atende tráfego muito pesado (V). Observa-se que tanto para 64 quanto a $70^{\circ} \mathrm{C}$, a presença do TITAN é vantajosa, pois atua no sentido de aumentar a classe de tráfego a ser atendido pela rodovia composta com tais materiais. Ao aumentar a temperatura do pavimento de 64 para $70^{\circ} \mathrm{C}$, o nível de tráfego cai uma ou duas classes, a depender da formulação. Para uma rodovia vicinal, de baixo volume de tráfego, em Estados onde se exige CAPs com PG 70, a formulação 96,5-2,51 seria suficiente para atender tal tráfego. Já no caso de rodovias para altos volumes de tráfego (classe E), não há nenhuma formulação, dentre as estudadas, que seria indicada para tal situação. Rodovias com alto volume de tráfego poderiam empregar a mistura 94-5-1, porém o PG do pavimento não poderia ser superior a $64^{\circ} \mathrm{C}$.

A classe de tráfego do CAP de base é $\mathrm{S}$ a $64^{\circ} \mathrm{C}$, sendo equivalente às misturas 99-0-1, 98-0-2, 97,5-2,5-0. A adição de 4\% de óleo ao CAP, na ausência dos demais modificadores, tornou a mistura 100-0-0 contra indicada na temperatura de $64^{\circ} \mathrm{C}$. A mistura $100-0-0$ apresenta uma piora de todas as características obtidas no ensaio MSCR ao ser comparada com o CAP de base.

Tabela 5.10 - Classificação das misturas quanto aos níveis de tráfego de acordo com o critério proposto pelo FHWA (AASHTO M320) para diferentes temperaturas do pavimento

\begin{tabular}{cccccc}
\hline \multirow{2}{*}{ mistura } & \multicolumn{5}{c}{ temperaturas } \\
\cline { 2 - 6 } & $\mathbf{5 2}^{\mathbf{o}} \mathbf{C}$ & $\mathbf{5 8}^{\mathbf{C}} \mathbf{C}$ & $\mathbf{6 4}^{\mathbf{}} \mathbf{C}$ & $\mathbf{7 0}^{\circ} \mathbf{C}$ & $\mathbf{7 6}^{\mathbf{}} \mathbf{C}$ \\
\hline $100-0-0$ & $\mathrm{~V}$ & $\mathrm{~S}$ & - & - & - \\
$99-0-1$ & $\mathrm{E}$ & $\mathrm{H}$ & $\mathrm{S}$ & - & - \\
$98-0-2$ & $\mathrm{E}$ & $\mathrm{V}$ & $\mathrm{S}$ & - & - \\
$97,5-2,5-0$ & $\mathrm{E}$ & $\mathrm{V}$ & $\mathrm{S}$ & - & - \\
$96,5-2,5-1$ & $\mathrm{E}$ & $\mathrm{E}$ & $\mathrm{H}$ & $\mathrm{S}$ & - \\
$95,5-2,5-2$ & $\mathrm{E}$ & $\mathrm{E}$ & $\mathrm{V}$ & $\mathrm{S}$ & - \\
$95-5-0$ & $\mathrm{E}$ & $\mathrm{E}$ & $\mathrm{V}$ & $\mathrm{H}$ & $\mathrm{S}$ \\
$94-5-1$ & $\mathrm{E}$ & $\mathrm{E}$ & $\mathrm{E}$ & $\mathrm{H}$ & $\mathrm{S}$ \\
$93-5-2$ & $\mathrm{E}$ & $\mathrm{E}$ & $\mathrm{E}$ & $\mathrm{V}$ & $\mathrm{S}$ \\
CAP de base & $\mathrm{E}$ & $\mathrm{H}$ & $\mathrm{S}$ & - & - \\
\hline
\end{tabular}




\subsection{Ensaio de varredura linear de amplitude (LAS)}

\subsubsection{Comprimento da trinca na ruptura por fadiga $\left(a_{f}\right)$}

Os valores do comprimento da trinca na ruptura por fadiga $\left(\mathrm{a}_{\mathrm{f}}\right)$, a $25^{\circ} \mathrm{C}$, das misturas envelhecidas a longo prazo estão apresentados na Tabela 5.11. Observa-se que o menor valor de comprimento da trinca foi da mistura $100-0-0(0,83 \mathrm{~mm})$ enquanto que o maior valor foi da mistura 93-5-2 (1,39 mm). Ocorre aumento do comprimento da trinca ao se adicionar os dois modificadores. Para uma mesma concentração de SBS, a variação média dos $\mathrm{a}_{\mathrm{f}}$ das misturas é de: (a) 0,25 mm entre 0 e $2 \%$ de TITAN para as misturas com $0 \%$ de SBS, (b) 0,18 mm entre 0 e $2 \%$ de TITAN para as misturas com $2,5 \%$ de SBS e, (c) $0,21 \mathrm{~mm}$ entre 0 e $2 \%$ de TITAN para as misturas com 5\% de SBS. Para uma mesma concentração de TITAN, a variação média dos $a_{\mathrm{f}}$ das misturas é de: (a) $0,35 \mathrm{~mm}$ entre 0 e $5 \%$ de SBS para as misturas com $0 \%$ de TITAN, (b) 0,31 mm entre 0 e 5\% de SBS para as misturas com $1 \%$ de TITAN e, (c) 0,31 mm entre 0 e 5\% de SBS para as misturas com 2\% de TITAN. As formulações 100-0-0, 99-0-1 e 97,5-2,5-0 são menos tolerantes à fadiga que o CAP puro, porém, com a adição de teores maiores dos dois modificadores, observa-se aumento da tolerância à fadiga.

Tabela 5.11 - Comprimento da trinca na ruptura a para as misturas após RTFOT+PAV a $25^{\circ} \mathrm{C}$

\begin{tabular}{cc}
\hline misturas & $\mathbf{a}_{\mathbf{f}}(\mathbf{m m})$ \\
\hline $100-0-0$ & 0,83 \\
$99-0-1$ & 0,98 \\
$98-0-2$ & 1,08 \\
$97,5-2,5-0$ & 0,99 \\
$96,5-2,5-1$ & 1,13 \\
$95,5-2,5-2$ & 1,17 \\
$95-5-0$ & 1,18 \\
$94-5-1$ & 1,29 \\
$93-5-2$ & 1,39 \\
CAP puro & 1,08 \\
\hline
\end{tabular}




\subsubsection{Vida de fadiga $\left(N_{f}\right)$}

Os valores dos parâmetros A e B do modelo de fadiga obtidos por meio da análise do dano contínuo viscoelástico (VECD) dos resultados do ensaio LAS modificado estão apresentados na Tabela 5.12, juntamente com valores de vida de fadiga $\left(\mathrm{N}_{\mathrm{f}}\right)$ das misturas, obtidos dos modelos de fadiga ajustados. O modelo $N_{f}=A\left(\gamma_{M A ́ X}\right)^{B}$ utiliza os parâmetros A e B e depende da deformação aplicada. Os valores de vida de fadiga foram estimados para as seguintes deformações: $1 \%, 2 \%, 3 \%, 20 \%, 30 \%$ e $55 \%$.

Pode-se observar que o parâmetro A aumenta com a adição de ambos os modificadores. O menor valor é da mistura 100-0-0 com 1,54E+05 (154.000) e o maior valor é da mistura 935-2 com 7,04E+05 (704.000). O aumento deste parâmetro implica no deslocamento vertical para cima das curvas de fadiga e está associado ao ganho de integridade do material por conta da adição dos modificadores. Já o parâmetro B diminui com a adição de ambos os modificadores, indicando aumento da declividade da curva de fadiga, o que se traduz em materiais mais sensíveis a variações nos níveis de deformação do pavimento. O menor valor é da mistura 93-5-2 com -3,875, que é a mais sensível a variações no nível de deformação do pavimento, e o maior valor é da mistura 100-0-0 com -2,998. O CAP puro apresenta valores de A e B intermediários em comparação com as formulações estudadas.

Tabela 5.12 - Parâmetros A e B do modelo de fadiga das misturas e vida de fadiga $\left(\mathbf{N}_{\mathrm{f}}\right)$ em diversos níveis de deformações (\%) após RTFOT+PAV a $25^{\circ} \mathrm{C}$

\begin{tabular}{|c|c|c|c|c|c|c|c|c|}
\hline \multirow{2}{*}{ misturas } & \multicolumn{2}{|c|}{$25^{\circ} \mathrm{C}$} & \multicolumn{6}{|c|}{ Amplitude de deformação (\%) } \\
\hline & $\mathbf{A}$ & B & 1 & 2 & 3 & 20 & 30 & 55 \\
\hline $100-0-0$ & $1,54 \mathrm{E}+05$ &, 998 & 154.152 & 19.295 & 5.721 & 19,38 & 5,75 & 0,93 \\
\hline $99-0-1$ & $1,93 \mathrm{E}+05$ & $-3,093$ & 193.287 & 22.645 & 6.460 & 18,26 & 5,21 & 0,80 \\
\hline $98-0-2$ & $2,48 \mathrm{E}+05$ & -3 , & 247.644 & 24.711 & 6.417 & 11,69 & 3,04 & 0,40 \\
\hline $97,5-2$, & $2,56 \mathrm{E}+05$ & $-3,259$ & 256.285 & 26.770 & 7.141 & 4 & 3,93 & 0,55 \\
\hline $96,5-2,5-1$ & $2,82 \mathrm{E}+05$ & $-3,359$ & 282.353 & 27.524 & 7.051 & 12,05 & 3,09 & 0,40 \\
\hline $95,5-2,5-2$ & $4,29 \mathrm{E}+05$ & $-3,563$ & 428.671 & 36.277 & 8.556 & 9,93 & 2,34 & 0,27 \\
\hline & $4,36 \mathrm{E}+05$ & $-3,468$ & 435.536 & 39.348 & 9.641 & 13,38 & 3,28 & 0,40 \\
\hline $94-5-1$ & $4,33 \mathrm{E}+05$ & $-3,605$ & 432.794 & 35.563 & 8.244 & 8,83 & 2,05 & 0,23 \\
\hline $93-5-2$ & $7,04 \mathrm{E}+05$ & $-3,875$ & 703.515 & 47.962 & 9.968 & 6,40 & 1,33 & 0,13 \\
\hline CAP puro & $2,14 \mathrm{E}+05$ & $-3,280$ & 214.000 & 22.014 & 5.827 & 11,56 & 3,06 & 0,42 \\
\hline
\end{tabular}


A Tabela 5.12 deixa claro que em baixas deformações $(1 \%, 2 \%$ e $3 \%$ ), a adição de modificadores é benéfica para a vida de fadiga, aumentando em até 3,29 vezes o número de solicitações necessárias para levar a mistura a atingir sua vida de fadiga na amplitude de $1 \%$ se comparadas com o CAP puro. A comparação foi feita entre a mistura mais modificada (935-2) e a mistura menos modificada (100-0-0). Para a amplitude de $2 \%$, tem-se uma diferença de 2,18 vezes entre a mistura mais modificada e o CAP puro. Para a amplitude de $3 \%$ tem-se uma diferença de 1,71 vezes entre a mistura mais modificada para o CAP puro.

Ainda sobre a Tabela 5.12, pode-se observar que, em altas deformações (20\%, 30\% e $55 \%$ ), a adição de modificadores se mostra ineficaz sobre a vida de fadiga, visto que para estas três deformações a mistura que apresenta um maior valor da vida de fadiga é a 100-0-0, $(19,38$ para $20 \%, 5,75$ para $30 \%$ e 0,93 para $55 \%)$. A mistura que apresenta a menor vida de fadiga é a 93-5-2 (6,40 para 20\%, 1,33 para 30\% e 0,13 para 55\%). Isto pode ser explicado pelo parâmetro B que, ao ter seu valor diminuído, causa um aumento na declividade da curva, fazendo com que em uma certa deformação (em torno de 4 a 5\%) ocorra o cruzamento das curvas. Tal cruzamento faz, com que o asfalto com menos modificação resista a altas deformações mais que os asfaltos altamente modificados.

Pode-se observar que o aumento de $2,5 \%$ de SBS se mostra mais benéfico para as misturas do que o aumento de $2 \%$ de TITAN a baixas deformações e, para as altas deformações, esta relação se inverte a favor do TITAN. A título de ilustração, as Figuras 5.4, 5.5, 5.6 e 5.7 mostram os valores da Tabela 5.13 em forma gráfica, apresentando as 9 misturas (Figura 5.4) e três grupos: (a) 100-0-0, 99-0-1 e 99-0-2 (Figura 5.5), (b) 97,5-2,5-0, 96,5-2,5-1 e 95,5-2,5-2 (Figura 5.6) e (c) 95-5-0, 94-5-1 e 93-5-2 (Figura 5.7).

De acordo com a análise realizada, não é possível indicar o efeito global da adição dos modificadores, uma vez que a adição deles contribui para o aumento da vida de fadiga do ligante asfáltico em uma determinada faixa de deformações (baixas) e prejudica o comportamento à fadiga do ligante asfáltico em outra faixa de deformações (altas). Tal efeito paradoxal da aditivação sobre a vida de fadiga dos ligantes asfálticos se dá por conta da maior sensibilidade dos ligantes asfálticos modificados à variação do nível de deformação imposto.

Embora se saiba que rigidez é um elemento importante sobre a resistência de qualquer material a qualquer tipo de solicitação, o entendimento que se tem do fenômeno de fadiga em um pavimento indica que o desempenho à fadiga de um dado material não depende apenas do valor absoluto da sua rigidez. No caso do pavimento, o comportamento deflectométrico (ou a 
interação entre as camadas e entre as camadas e a fundação) afeta drasticamente o comportamento à fadiga do material asfáltico. Regra geral, pavimentos com comportamento deflectométrico similar ao de um pavimento flexível têm o fenômeno de fadiga por deformação controlada, ou seja, a camada asfáltica acompanha a deformação das camadas inferiores. Neste caso, há evidências de que quanto menos consistente o asfalto, maior a vida de fadiga. Já em pavimentos com comportamento deflectométrico similar ao rígido, a própria camada asfáltica ou o conjunto camada asfáltica e base cimentada aderidas absorve a maior parte das tensões oriundas do tráfego, gerando fadiga por tensão controlada. Há indícios de que, neste caso, asfaltos mais consistentes sejam mais indicados.

A lógica que se apreende das Figuras de 5.4 a 5.7 vai ao encontro do raciocínio exposto anteriormente: os ligantes asfálticos modificados são mais rígidos que o puro nas temperaturas ao redor de $25^{\circ} \mathrm{C}$ (ver Tabela 5.75 - a $16^{\circ} \mathrm{C}$, os asfaltos modificados são em média 1,2 vezes mais rígidos que o CAP puro e a $28^{\circ} \mathrm{C}$ são 1,4 vezes mais rígidos) e, como consequência, apresentam maiores vidas de fadiga sob baixas deformações (neste caso o mecanismo de fadiga se dá por tensão controlada e asfaltos mais consistentes são mais indicados) e menores vidas de fadiga sob altas deformações (neste caso o mecanismo de fadiga se dá por deformação controlada e asfaltos menos consistentes são mais indicados). A conclusão é que asfaltos modificados que, na temperatura de fadiga, sejam mais rígidos que o CAP puro somente apresentariam vantagem quando o pavimento sofre baixas deformações.

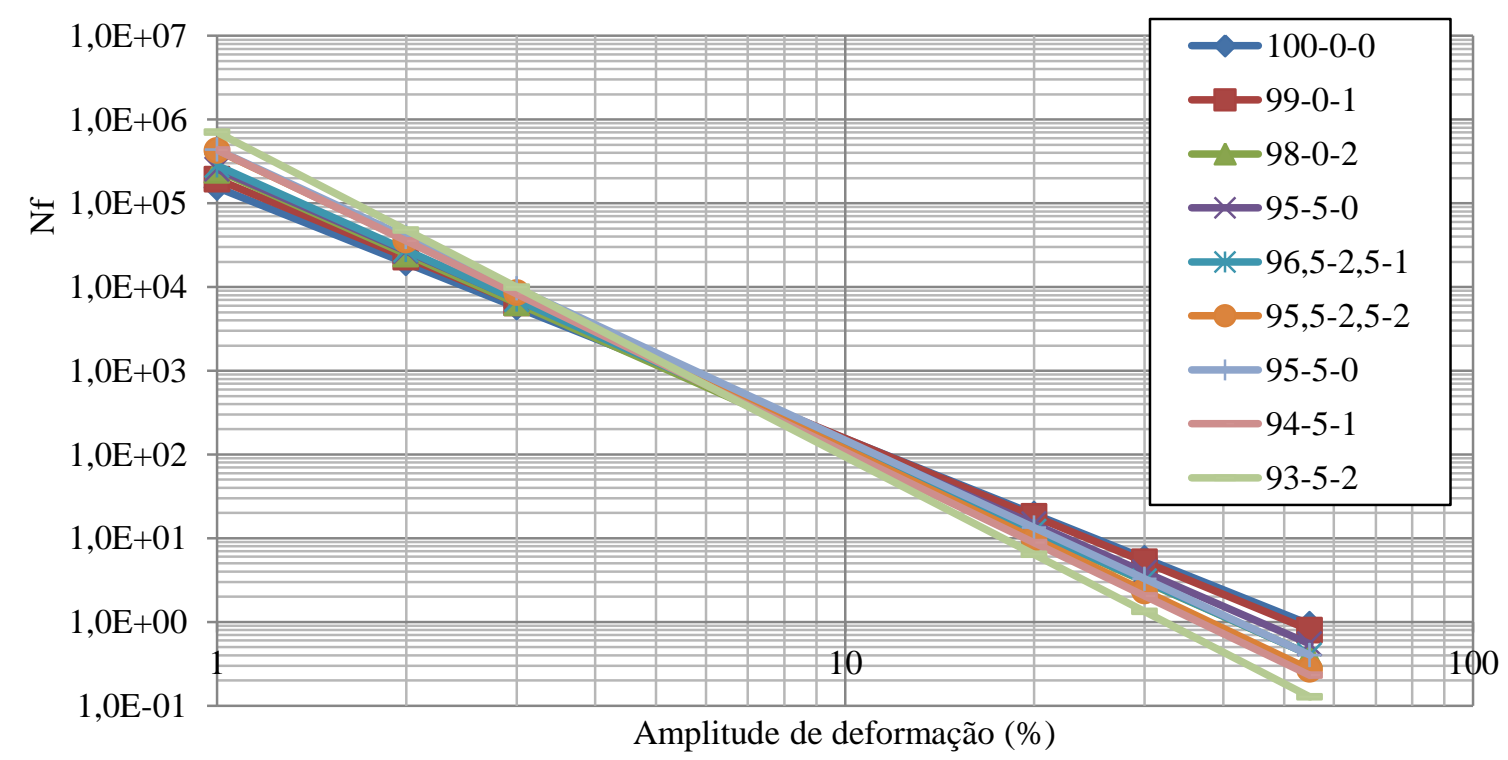

Figura 5.4 - Modelos de vida de fadiga $\left(\mathrm{N}_{\mathrm{f}}\right)$ para as nove amostras 


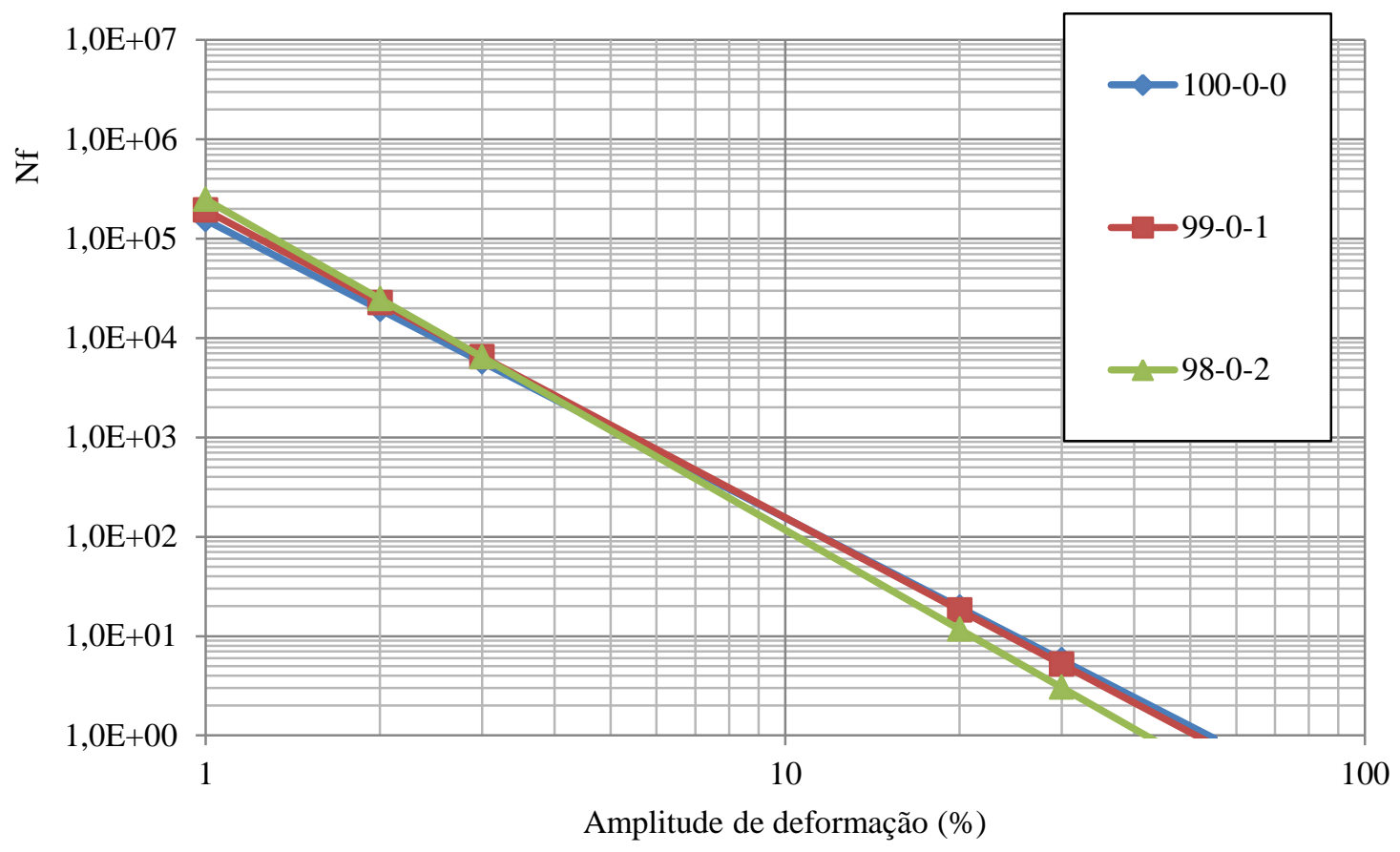

Figura 5.5 - Vida de fadiga $\left(\mathrm{N}_{\mathrm{f}}\right)$ para as misturas 100-0-0, 99-0-1 e 98-0-2

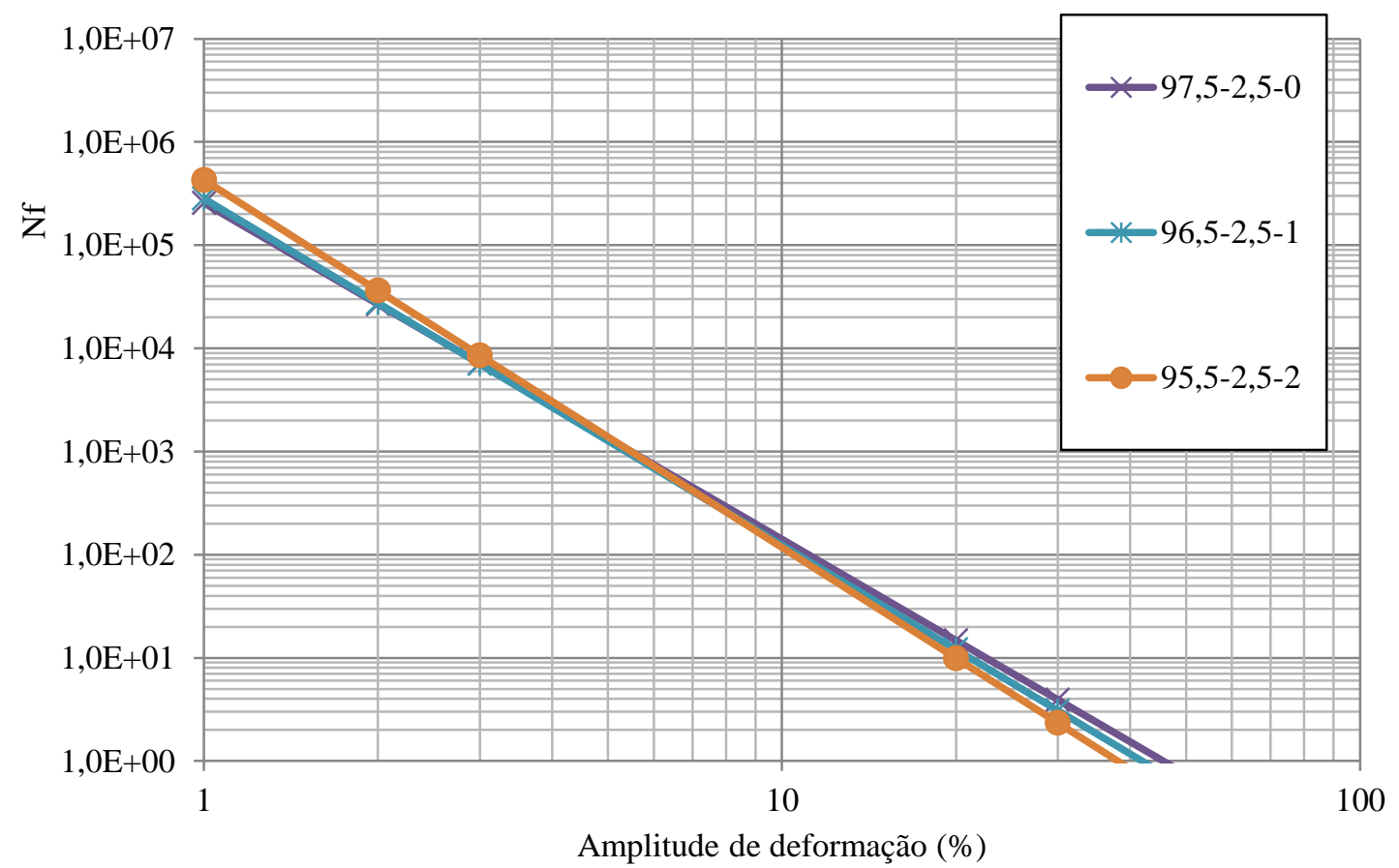

Figura 5.6 - Vida de fadiga $\left(\mathrm{N}_{\mathrm{f}}\right)$ para as misturas 97,5-2,5-0, 96,5-2,5-1 e 95,5-2,5-2 


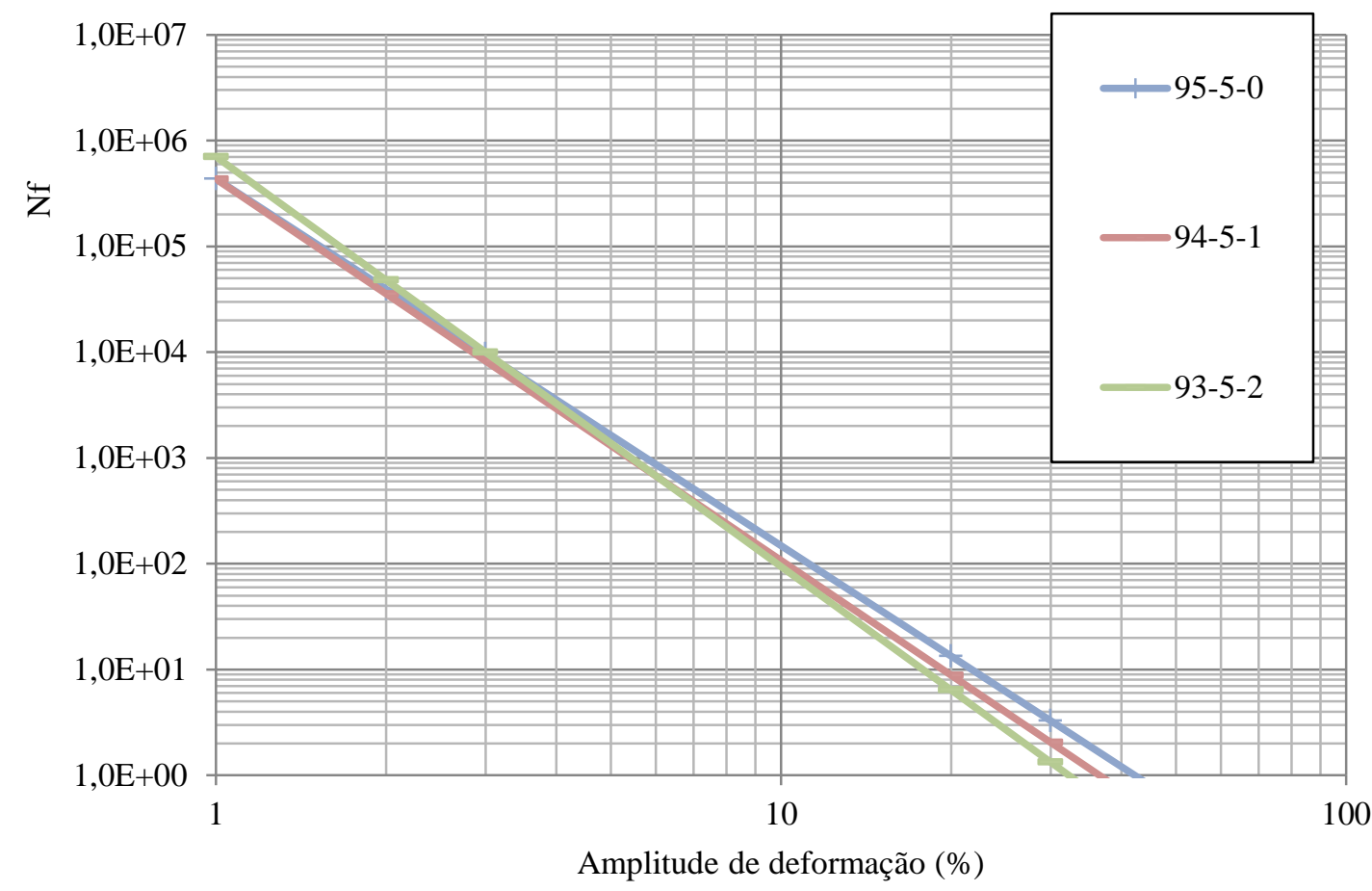

Figura 5.7 - Vida de fadiga $\left(\mathrm{N}_{\mathrm{f}}\right)$ para as misturas 95-5-0, 94-5-1 e 93-5-2

\subsubsection{Parâmetro $G^{*} . \operatorname{sen}(\delta)$ para fadiga e temperatura crítica de fadiga}

A Tabela 5.13 apresenta o parâmetro de fadiga $\mathrm{G}^{*} \cdot \operatorname{sen}(\delta)$ das amostras envelhecidas a longo prazo, nas temperaturas de $5,10,15,20,25,30$ e $35^{\circ} \mathrm{C}$ e a temperatura crítica de fadiga (temperatura em que o parâmetro $\mathrm{G}^{*} \cdot \operatorname{sen}(\delta)$ é igual a $5 \mathrm{MPa}$ para tráfego $\mathrm{S}$ e igual a $6 \mathrm{MPa}$ para tráfego $\mathrm{H}$ e V. Pela Tabela 5.13 fica evidente que tanto a adição de SBS quanto a de TITAN aumentam a temperatura crítica de fadiga. $\mathrm{O}$ menor valor de temperatura crítica de fadiga é obtido para a mistura 100-0-0 tanto para o limite de $\mathrm{G}^{*} \cdot \operatorname{sen}(\delta)$ de 5 como de $6 \mathrm{MPa}$. O maior valor de temperatura é da mistura 93-5-2, para ambos os limites. Percebe-se, que ao aumentar o teor de SBS para uma mesma proporção fixa de TITAN, a temperatura aumenta. Ao aumentar o teor de TITAN, para uma mesma proporção fixa de SBS, a temperatura crítica de fadiga sofre um aumento mais significativo que o proporcionado pelo aumento da proporção de SBS. 
Tabela 5.13 - Valores de $G^{*} \cdot \operatorname{sen}(\delta)$ e temperaturas críticas de fadiga na condição envelhecida a longo prazo

\begin{tabular}{|c|c|c|c|c|c|c|c|c|c|}
\hline $\begin{array}{l}\text { temperatura e } \\
\text { parâmetros }\end{array}$ & $\begin{array}{c}100-0- \\
0\end{array}$ & 99-0-1 & $98-0-2$ & $\begin{array}{c}97,5-2,5- \\
0\end{array}$ & $\begin{array}{c}96,5-2,5- \\
1\end{array}$ & $\begin{array}{c}95,5-2,5- \\
2\end{array}$ & $95-5-0$ & $94-5-1$ & $93-5-2$ \\
\hline $5^{\circ} \mathrm{C}$ & 43.451 & 47.392 & 46.525 & 42.067 & 42.203 & 40.869 & 36.046 & 36.455 & 37.798 \\
\hline $10^{\circ} \mathrm{C}$ & 20.525 & 22.953 & 23.453 & 20.786 & 21.922 & 21.336 & 18.630 & 19.319 & 20.848 \\
\hline $15^{\circ} \mathrm{C}$ & 9.695 & 11.117 & 11.822 & 10.270 & 11.387 & 11.138 & 9.629 & 10.238 & 11.499 \\
\hline $20^{\circ} \mathrm{C}$ & 4.580 & 5.384 & 5.960 & 5.075 & 5.915 & 5.815 & 4.977 & 5.425 & 6.342 \\
\hline $25^{\circ} \mathrm{C}$ & 2.163 & 2.608 & 3.004 & 2.507 & 3.072 & 3.036 & 2.572 & 2.875 & 3.498 \\
\hline $30^{\circ} \mathrm{C}$ & 1.022 & 1.263 & 1.514 & 1.239 & 1.596 & 1.585 & 1.329 & 1.524 & 1.929 \\
\hline $35^{\circ} \mathrm{C}$ & 483 & 612 & 763 & 612 & 829 & 827 & 687 & 807 & 1.064 \\
\hline $\begin{array}{c}\mathrm{T}_{\text {Fadiga }} \\
\left(\mathrm{G}^{*} \cdot \operatorname{sen}(\delta)=5 \mathrm{MP}\right. \\
\mathrm{a})\end{array}$ & $19,4^{\circ} \mathrm{C}$ & $20,5^{\circ} \mathrm{C}$ & $21,3^{\circ} \mathrm{C}$ & $20,1^{\circ} \mathrm{C}$ & $21,3^{\circ} \mathrm{C}$ & $21,2^{\circ} \mathrm{C}$ & $\begin{array}{l}20,0 \\
{ }^{\circ} \mathrm{C}\end{array}$ & $\begin{array}{l}20,6 \\
{ }^{\circ} \mathrm{C}\end{array}$ & $\begin{array}{l}22,0 \\
{ }^{\circ} \mathrm{C}\end{array}$ \\
\hline $\begin{array}{c}\mathrm{T}_{\text {Fadiga }} \\
\left(\mathrm{G}^{*} \cdot \operatorname{sen}(\delta)=6 \mathrm{MP}\right. \\
\mathrm{a})\end{array}$ & $\begin{array}{l}18,2 \\
{ }^{\circ} \mathrm{C}\end{array}$ & $\begin{array}{l}19,3 \\
{ }^{\circ} \mathrm{C}\end{array}$ & $\begin{array}{l}20,0 \\
{ }^{\circ} \mathrm{C}\end{array}$ & $18,8^{\circ} \mathrm{C}$ & $19,9^{\circ} \mathrm{C}$ & $19,8^{\circ} \mathrm{C}$ & $\begin{array}{l}18,6 \\
{ }^{\circ} \mathrm{C}\end{array}$ & $\begin{array}{l}19,2 \\
{ }^{\circ} \mathrm{C}\end{array}$ & $\begin{array}{l}20,5 \\
{ }^{\circ} \mathrm{C}\end{array}$ \\
\hline
\end{tabular}

\subsection{Curvas-mestre}

As curvas-mestre foram obtidas para avaliar os efeitos do envelhecimento (curto e longo prazos) e a estabilidade dos materiais à estocagem sob temperaturas altas e sem agitação. Este item será dividido entre duas partes, uma dedicada ao efeito do envelhecimento, e outra dedicada à análise da estabilidade à estocagem. Ao longo deste item, $\mathrm{G}^{*}$ será expresso em Pa e o ângulo de fase será expresso em graus. 
5.6.1 Comparação entre a mistura 100-0-0 e o ligante asfáltico de base (Replan 50/70)

As Figuras 5.8 a 5.10 apresentam as curvas-mestre a $25^{\circ} \mathrm{C}$ de $\mathrm{G}^{*}$ da mistura $100-0-0$ e do CAP de base nas condições virgem, envelhecida a curto prazo e envelhecida a longo prazo, respectivamente. As Figuras 5.11 a 5.13 apresentam as curvas-mestre a $25^{\circ} \mathrm{C}$ do ângulo de fase da mistura 100-0-0 e do CAP de base nas condições nas condições virgem, envelhecida a curto prazo e envelhecida a longo prazo, respectivamente. As Tabelas 5.14 e 5.15 apresentam os valores de $\mathrm{G}^{*}$ e delta, respectivamente, para as frequências entre $1 \mathrm{E}-5 \mathrm{e} 1 \mathrm{E}+5$, em rad/s, do ligante asfáltico de base (Replan 50/70) e da mistura 100-0-0, nas três condições de envelhecimento (virgem, curto prazo e longo prazo).

A Tabela 5.16 apresenta as relações: (i) 100-0-0/50/70 virgem, (ii) 100-0-0/50/70 RTFOT e (iii) 100-0-0/50/70 PAV para G* a $25^{\circ} \mathrm{C}$. A Tabela 5.19 apresenta as relações: (i) 100-0-0/50/70 virgem, (ii) 100-0-0/50/70 RTFOT e (iii) 100-0-0/50/70 PAV para o ângulo de fase a $25^{\circ} \mathrm{C}$.

Tabela 5.14 - Valores de módulo complexo do ligante asfáltico de base e da mistura 1000-0 nas três condições de envelhecimento

\begin{tabular}{ccccccc}
\hline \multirow{2}{*}{ Freq. Angular } & \multicolumn{3}{c}{ Replan 50/70 } & & & $100-0-0$ \\
\cline { 2 - 7 } & $\mathrm{G}^{*}$ virgem & $\mathrm{G}^{*}$ RFTOT & $\mathrm{G}^{*} \mathrm{PAV}$ & $\mathrm{G}^{*}$ virgem & $\mathrm{G}^{*}$ RFTOT & G* PAV \\
\hline $1,00 \mathrm{E}-05$ & $4,91 \mathrm{E}+00$ & $1,54 \mathrm{E}+01$ & $6,46 \mathrm{E}+01$ & $1,50 \mathrm{E}+00$ & $4,32 \mathrm{E}+00$ & $2,39 \mathrm{E}+01$ \\
$1,00 \mathrm{E}-04$ & $4,92 \mathrm{E}+01$ & $1,53 \mathrm{E}+02$ & $6,39 \mathrm{E}+02$ & $1,50 \mathrm{E}+01$ & $4,33 \mathrm{E}+01$ & $2,36 \mathrm{E}+02$ \\
$1,00 \mathrm{E}-03$ & $4,87 \mathrm{E}+02$ & $1,46 \mathrm{E}+03$ & $5,47 \mathrm{E}+03$ & $1,50 \mathrm{E}+02$ & $4,29 \mathrm{E}+02$ & $2,22 \mathrm{E}+03$ \\
$1,00 \mathrm{E}-02$ & $4,67 \mathrm{E}+03$ & $1,22 \mathrm{E}+04$ & $4,00 \mathrm{E}+04$ & $1,43 \mathrm{E}+03$ & $3,77 \mathrm{E}+03$ & $1,73 \mathrm{E}+04$ \\
$1,00 \mathrm{E}-01$ & $3,89 \mathrm{E}+04$ & $9,06 \mathrm{E}+04$ & $2,73 \mathrm{E}+05$ & $1,27 \mathrm{E}+04$ & $3,24 \mathrm{E}+04$ & $1,13 \mathrm{E}+05$ \\
$1,00 \mathrm{E}+00$ & $2,79 \mathrm{E}+05$ & $5,74 \mathrm{E}+05$ & $1,35 \mathrm{E}+06$ & $1,02 \mathrm{E}+05$ & $2,24 \mathrm{E}+05$ & $6,52 \mathrm{E}+05$ \\
$1,00 \mathrm{E}+01$ & $1,73 \mathrm{E}+06$ & $2,98 \mathrm{E}+06$ & $5,71 \mathrm{E}+06$ & $7,05 \mathrm{E}+05$ & $1,36 \mathrm{E}+06$ & $3,16 \mathrm{E}+06$ \\
$1,00 \mathrm{E}+02$ & $8,02 \mathrm{E}+06$ & $1,21 \mathrm{E}+07$ & $1,80 \mathrm{E}+07$ & $3,79 \mathrm{E}+06$ & $5,99 \mathrm{E}+06$ & $1,10 \mathrm{E}+07$ \\
$1,00 \mathrm{E}+03$ & $2,78 \mathrm{E}+07$ & $3,85 \mathrm{E}+07$ & $4,84 \mathrm{E}+07$ & $1,54 \mathrm{E}+07$ & $2,05 \mathrm{E}+07$ & $3,15 \mathrm{E}+07$ \\
$1,00 \mathrm{E}+04$ & $7,50 \mathrm{E}+07$ & $9,59 \mathrm{E}+07$ & $1,07 \mathrm{E}+08$ & $4,65 \mathrm{E}+07$ & $5,51 \mathrm{E}+07$ & $7,42 \mathrm{E}+07$ \\
$1,00 \mathrm{E}+05$ & $1,64 \mathrm{E}+08$ & $1,99 \mathrm{E}+08$ & $2,05 \mathrm{E}+08$ & $1,14 \mathrm{E}+08$ & $1,25 \mathrm{E}+08$ & $1,51 \mathrm{E}+08$ \\
\hline
\end{tabular}


Tabela 5.15 - Valores de ângulo de fase do ligante asfáltico de base e da mistura 100-0-0 nas três condições de envelhecimento

\begin{tabular}{ccccccc}
\hline \multirow{2}{*}{$\begin{array}{c}\text { Freq. } \\
\text { Angular }\end{array}$} & \multicolumn{3}{c}{ Replan 50/70 } & \multicolumn{3}{c}{$100-0-0$} \\
\cline { 2 - 6 } & virgem & $\begin{array}{c}\text { Delta } \\
\text { RFTOT }\end{array}$ & $\begin{array}{c}\text { Delta } \\
\text { PAV }\end{array}$ & $\begin{array}{c}\text { Delta } \\
\text { virgem }\end{array}$ & $\begin{array}{c}\text { Delta } \\
\text { RFTOT }\end{array}$ & $\begin{array}{c}\text { Delta } \\
\text { PAV }\end{array}$ \\
\hline $1,00 \mathrm{E}-05$ & 89,92 & 89,58 & 87,32 & 89,98 & 89,60 & 88,76 \\
$1,00 \mathrm{E}-04$ & 89,28 & 87,77 & 83,15 & 89,73 & 88,55 & 85,20 \\
$1,00 \mathrm{E}-03$ & 86,77 & 83,80 & 78,14 & 92,43 & 85,44 & 80,07 \\
$1,00 \mathrm{E}-02$ & 83,69 & 79,13 & 71,38 & 85,81 & 81,70 & 73,75 \\
$1,00 \mathrm{E}-01$ & 79,36 & 74,03 & 65,85 & 82,21 & 77,41 & 68,37 \\
$1,00 \mathrm{E}+00$ & 73,80 & 68,50 & 59,88 & 77,87 & 71,96 & 62,55 \\
$1,00 \mathrm{E}+01$ & 67,21 & 61,72 & 53,39 & 72,27 & 66,20 & 56,66 \\
$1,00 \mathrm{E}+02$ & 58,01 & 53,06 & 45,52 & 63,47 & 58,30 & 49,20 \\
$1,00 \mathrm{E}+03$ & 48,30 & 44,38 & 38,55 & 53,60 & 49,16 & 41,52 \\
$1,00 \mathrm{E}+04$ & 39,14 & 36,28 & 32,01 & 44,10 & 41,16 & 34,89 \\
$1,00 \mathrm{E}+05$ & 30,86 & 28,99 & 26,46 & 35,45 & 33,69 & 29,01 \\
\hline
\end{tabular}

Tabela 5.16 - Relações do módulo complexo entre a mistura 100-0-0 e o ligante asfáltico de base

\begin{tabular}{cccc}
\hline & \multicolumn{3}{c}{ Relações } \\
\cline { 2 - 4 } Freq. Angular & $100-0-0 / 50 / 70$ - virgem & $100-0-0 / 50 / 70-$ RTFOT & $100-0-0 / 50 / 70$ - PAV \\
\hline $1,00 \mathrm{E}-05$ & 0,31 & 0,28 & 0,37 \\
$1,00 \mathrm{E}-04$ & 0,30 & 0,28 & 0,37 \\
$1,00 \mathrm{E}-03$ & 0,31 & 0,29 & 0,41 \\
$1,00 \mathrm{E}-02$ & 0,31 & 0,31 & 0,43 \\
$1,00 \mathrm{E}-01$ & 0,33 & 0,36 & 0,42 \\
$1,00 \mathrm{E}+00$ & 0,37 & 0,39 & 0,48 \\
$1,00 \mathrm{E}+01$ & 0,41 & 0,46 & 0,55 \\
$1,00 \mathrm{E}+02$ & 0,47 & 0,49 & 0,61 \\
$1,00 \mathrm{E}+03$ & 0,55 & 0,53 & 0,65 \\
$1,00 \mathrm{E}+04$ & 0,62 & 0,57 & 0,69 \\
$1,00 \mathrm{E}+05$ & 0,69 & 0,63 & 0,74 \\
\hline média & 0,42 & 0,42 & 0,52 \\
\hline
\end{tabular}


Tabela 5.17 - Relações do ângulo de fase entre a mistura 100-0-0 e o ligante asfáltico de base

\begin{tabular}{cccc}
\hline & \multicolumn{3}{c}{ Diferença } \\
\cline { 2 - 4 } Freq. Angular & 100-0-0/50/70 - virgem & 100-0-0/50/70 - RTFOT & 100-0-0/50/70 - PAV \\
\hline $1,00 \mathrm{E}-05$ & 1,00 & 1,00 & 1,00 \\
$1,00 \mathrm{E}-04$ & 1,01 & 1,01 & 1,02 \\
$1,00 \mathrm{E}-03$ & 1,07 & 1,02 & 1,02 \\
$1,00 \mathrm{E}-02$ & 1,03 & 1,03 & 1,02 \\
$1,00 \mathrm{E}-01$ & 1,04 & 1,05 & 1,03 \\
$1,00 \mathrm{E}+00$ & 1,06 & 1,05 & 1,04 \\
$1,00 \mathrm{E}+01$ & 1,08 & 1,07 & 1,04 \\
$1,00 \mathrm{E}+02$ & 1,09 & 1,10 & 1,06 \\
$1,00 \mathrm{E}+03$ & 1,11 & 1,11 & 1,08 \\
$1,00 \mathrm{E}+04$ & 1,13 & 1,13 & 1,08 \\
$1,00 \mathrm{E}+05$ & 1,15 & 1,16 & 1,09 \\
\hline média & 1,07 & 1,07 & 1,04 \\
\hline
\end{tabular}

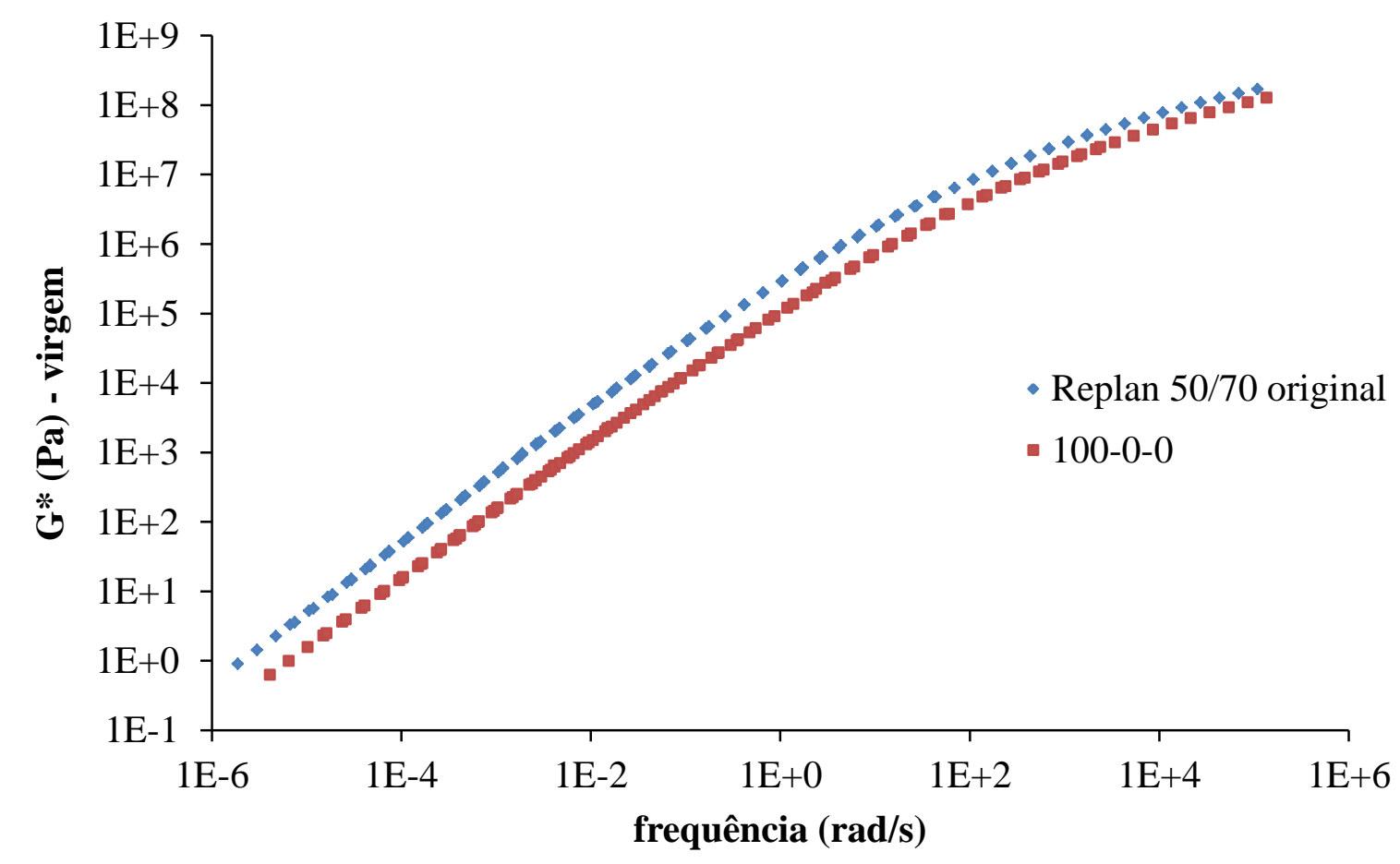

Figura 5.8 - Curvas-mestre para G* para a mistura 100-0-0 e o ligante asfáltico de base 


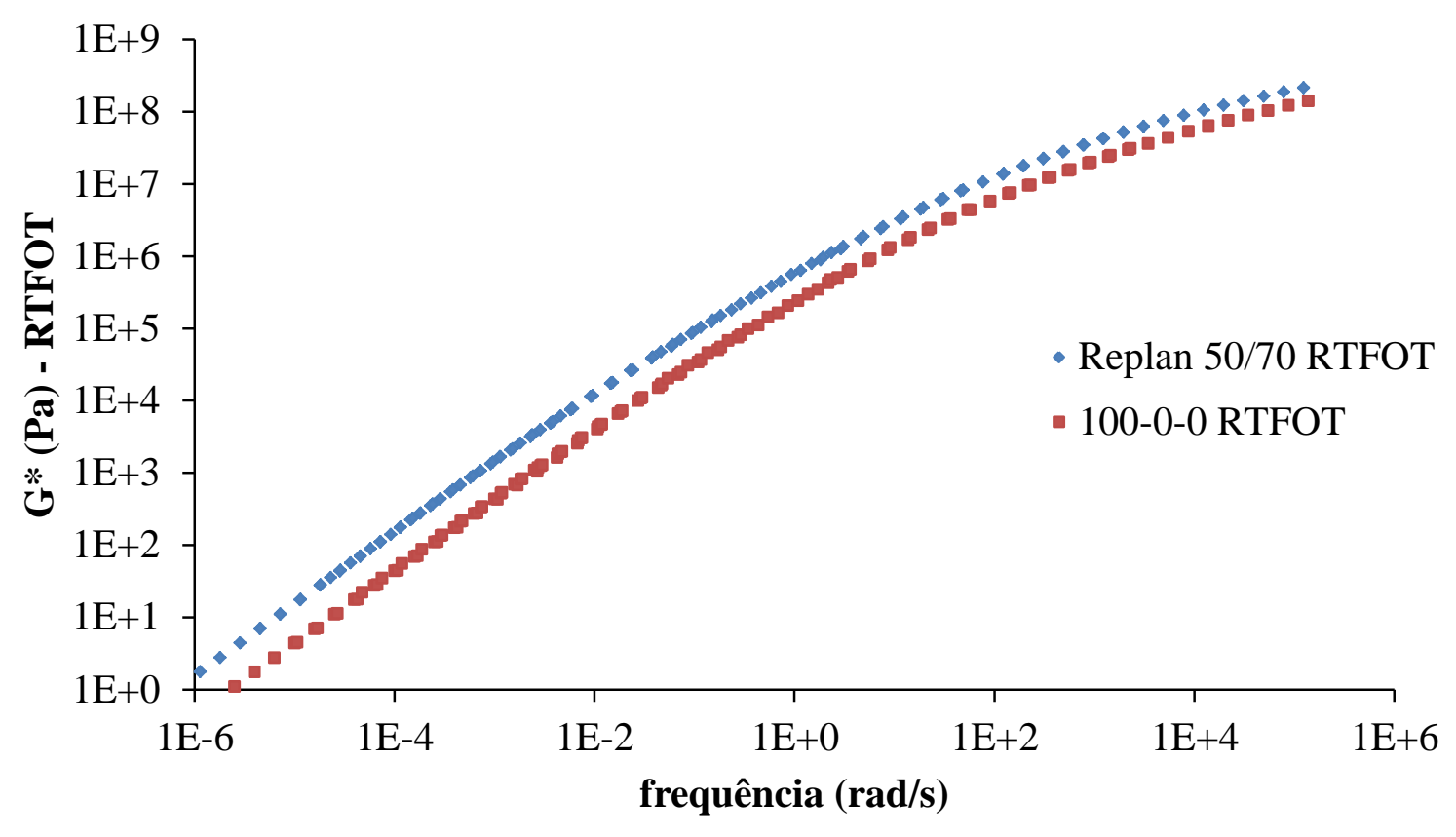

Figura 5.9 - Curvas-mestre para G* para a mistura 100-0-0 e o ligante asfáltico de base

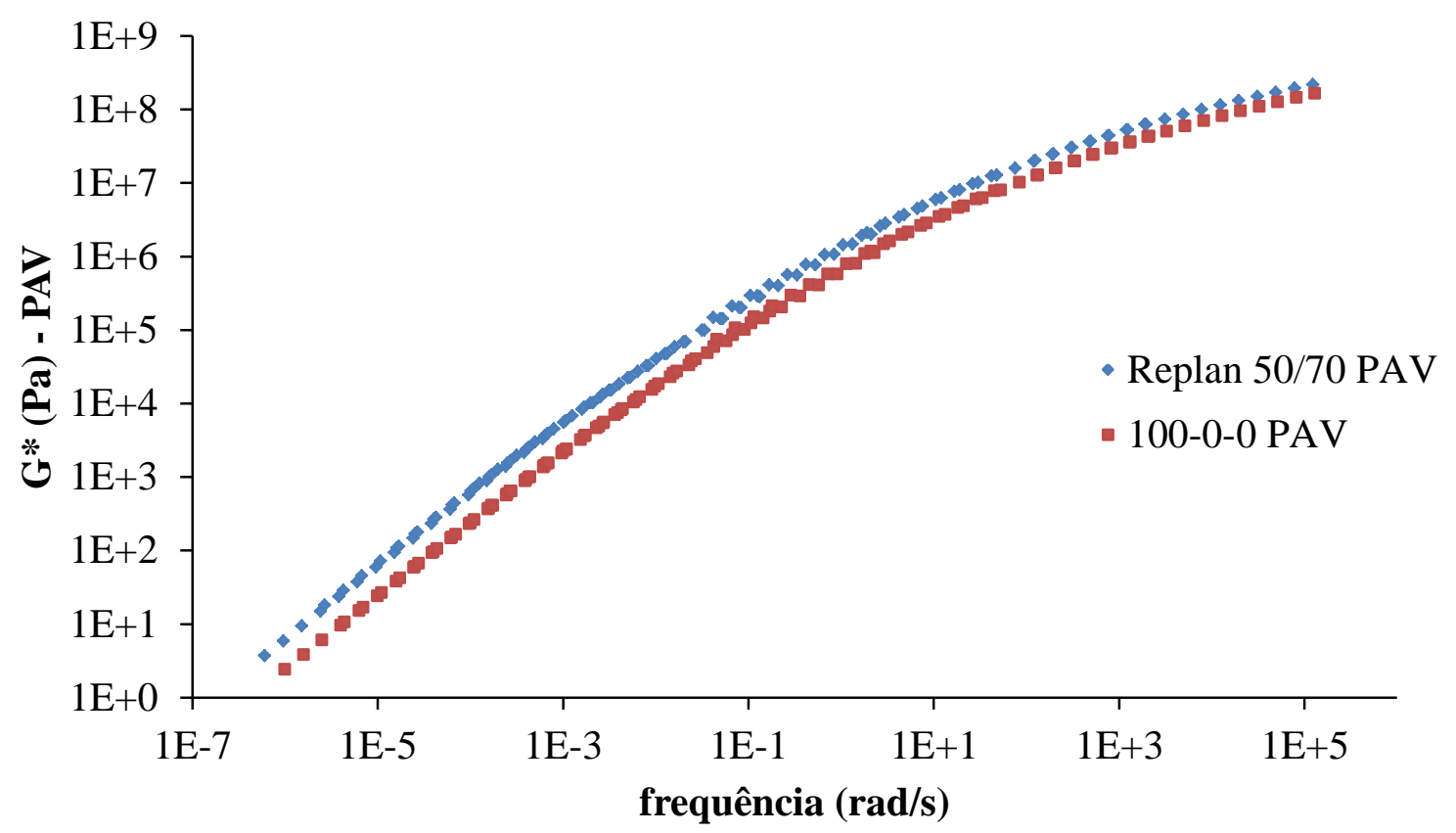

Figura 5.10 - Curvas-mestre para G* para a mistura 100-0-0 e o ligante asfáltico de base 


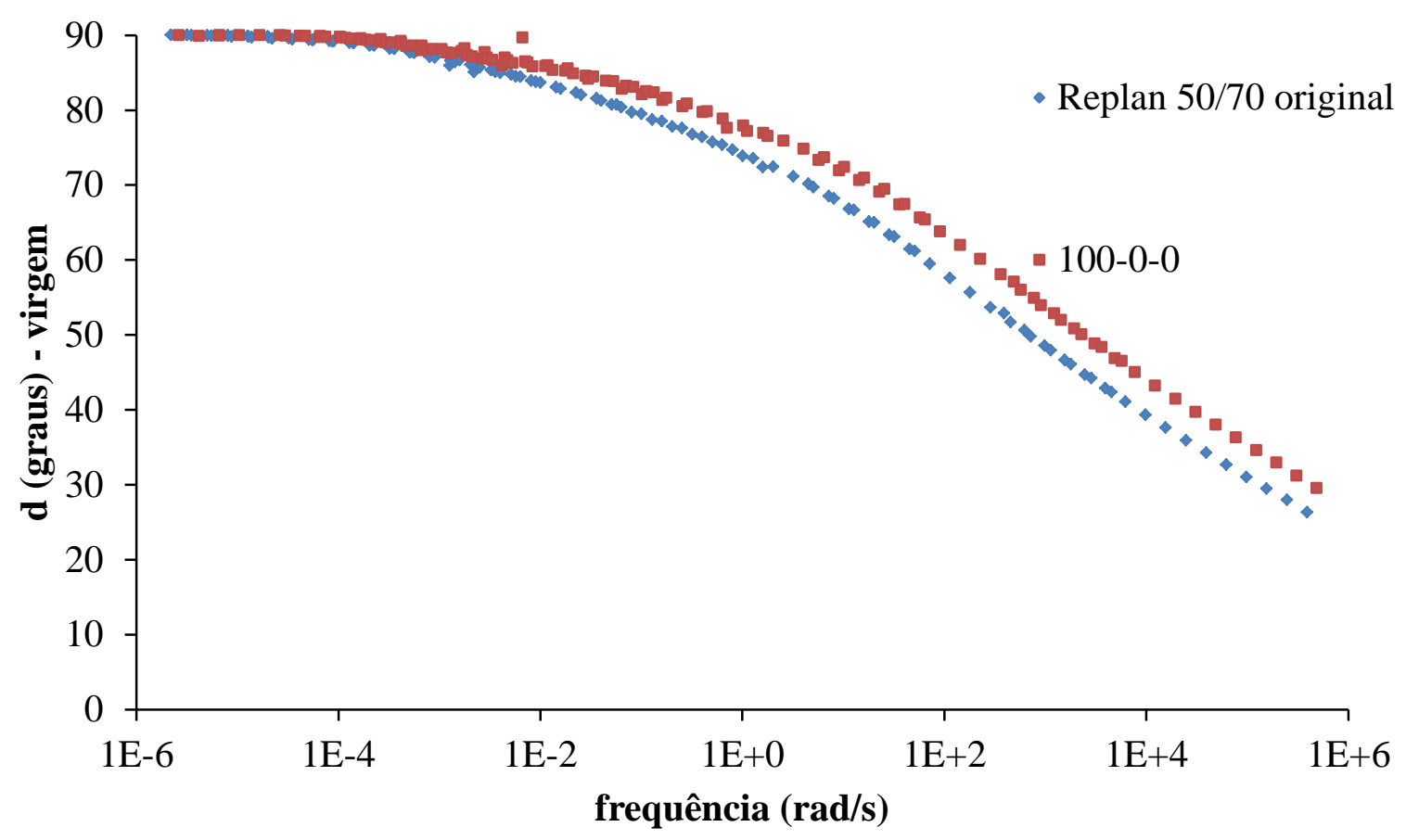

Figura 5.11 - Curvas-mestre para $\delta$ para a mistura 100-0-0 e o ligante asfáltico de base

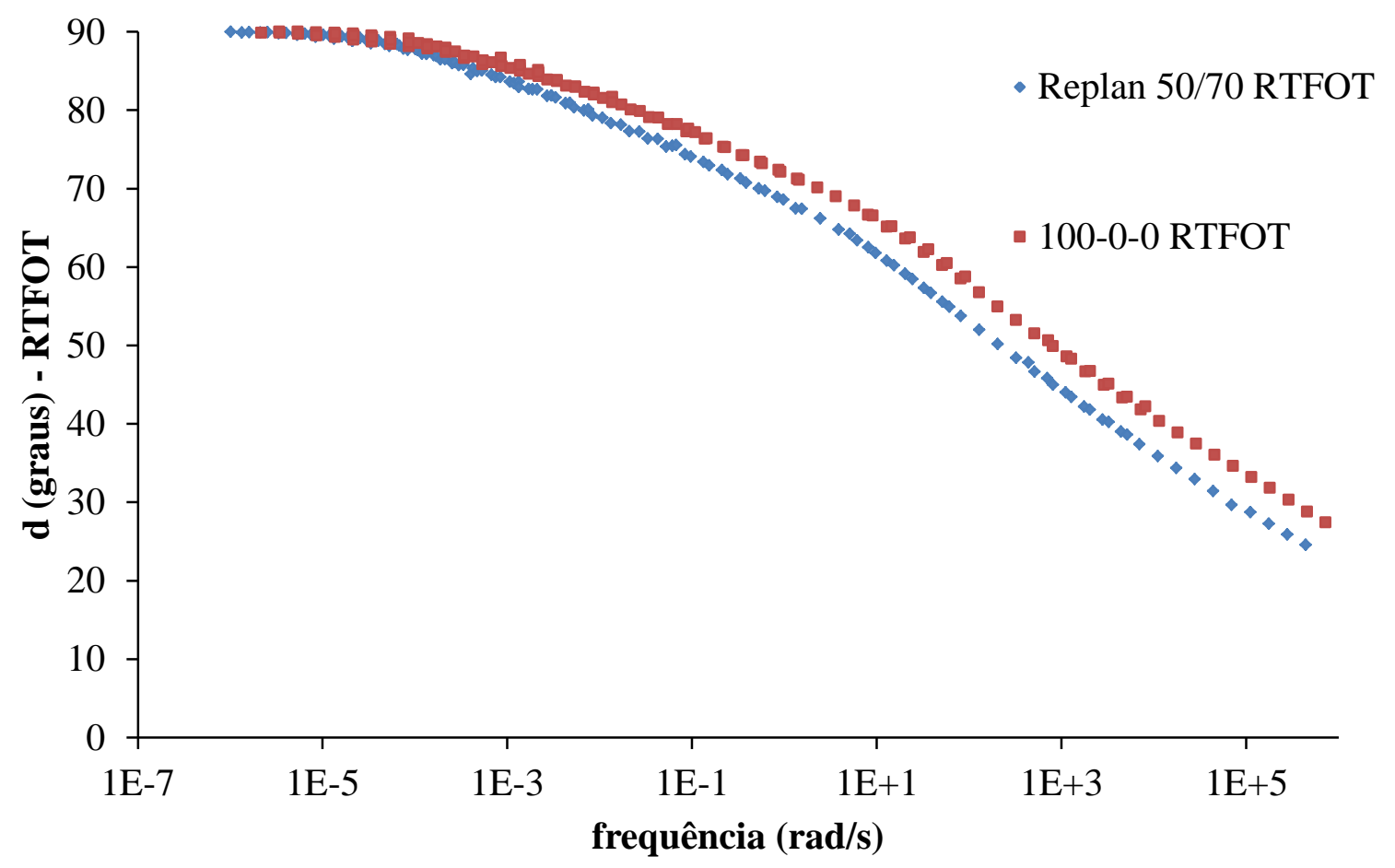

Figura 5.12 - Curvas-mestre para $\delta$ para a mistura 100-0-0 e o ligante asfáltico de base 


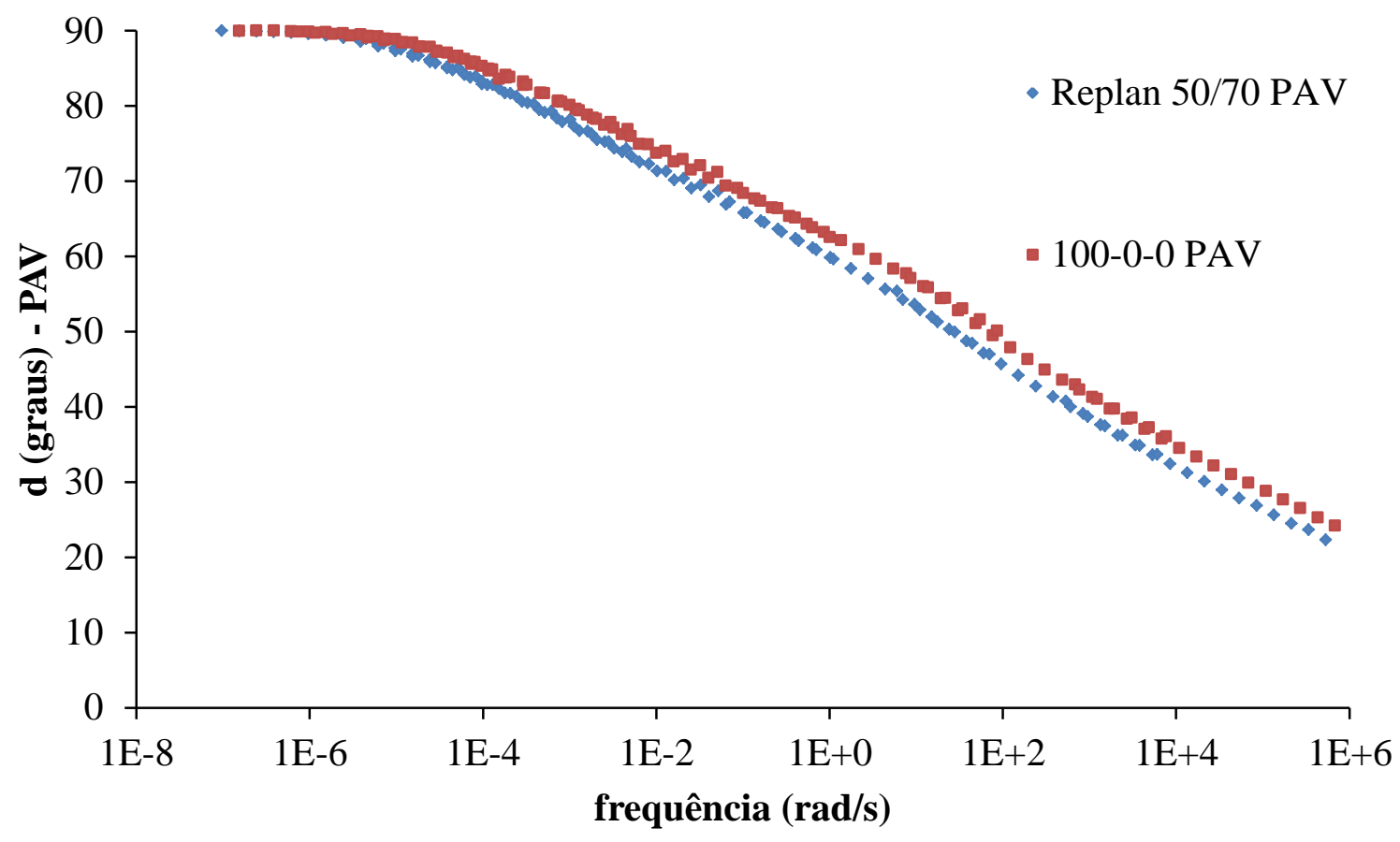

Figura 5.13 - Curvas-mestre para $\delta$ para a mistura 100-0-0 e o ligante asfáltico de base

As Tabelas 5.14 e 5.16 e as Figuras 5.8 a 5.10 mostram que o módulo complexo da mistura 100-0-0 é inferior ao módulo complexo do ligante asfáltico de base, o que se dá ao longo de praticamente todo o espectro de frequências de carregamento. Como se esperava, a adição de $4 \%$ de óleo aromático faz com que a mistura se torne menos rígida do que o ligante asfáltico de base. A Tabela 5.16 mostra que os valores de $G^{*}$ da amostra 100-0-0 correspondem, em média a 0,42 dos valores de $\mathrm{G}^{*}$ do CAP puro. A mesma média de 0,42 foi observada na relação entre os valores de $\mathrm{G}^{*}$ das duas amostras envelhecidas a curto prazo. Após o envelhecimento a longo prazo, os valores de $\mathrm{G}^{*}$ da amostra 100-0-0 correspondem em média a 0,52 dos valores de $\mathrm{G}^{*}$ do CAP puro. O enrijecimento equivalente das duas amostras na condição de envelhecimento a curto prazo indica que os dois materiais são equivalentes em termos de sensibilidade ao envelhecimento a curto prazo, no entanto, a longo prazo, a mistura 100-0-0 sofreu um enrijecimento ligeiramente maior que o CAP puro, provocado pela tendência do óleo em favorecer o processo de oxidação do ligante asfáltico.

Através das Tabelas 5.15 e 5.17 e das Figuras 5.11 a 5.13 observa-se que o ângulo de fase obtido pela mistura 100-0-0 é superior ao ângulo de fase do ligante asfáltico de base. Como se esperava, a adição de $4 \%$ de óleo aromático faz com que a mistura se torne menos rígida do que o ligante asfáltico de base. Portanto, ocorre um aumento no valor do parâmetro 
$\delta$. A Tabela 5.20 mostra um aumento médio de 1,07 nas faixas de frequência entre 1E-5 a 1E+5 para a relação entre amostras virgens e envelhecidas a curto prazo. Para o caso da comparação na condição envelhecida a longo prazo entre a mistura 100-0-0 e o ligante asfáltico de base obteve-se um aumento médio de 1,04, ou seja, assim como explicado no parágrafo anterior, o ângulo de fase da mistura 100-0-0 apresenta um valor mais próximo do ligante asfáltico de base passando pelos processos de envelhecimentos, muito provavelmente decorrente de que o óleo aromático sofre uma volatilização no processo de envelhecimento, fazendo com que na mistura final exista menores concentrações de óleo aromático do que na mistura virgem.

\subsubsection{Efeito dos envelhecimentos a curto e a longo prazos à luz dos resultados de $G^{*}$}

As Tabelas de 5.18 a 5.27 apresentam as relações RTFOT/virgem, PAV/virgem e PAV/RTFOT das misturas e do ligante asfáltico de base para as frequências entre 1E-5 e $1 \mathrm{E}+5 \mathrm{em} \mathrm{rad} / \mathrm{s}$ para os valores de módulo complexo $\left(\mathrm{G}^{*}\right)$. As Figuras de 5.14 a 5.23 apresentam as curvas-mestre obtidas para o módulo complexo, para as condições original, envelhecida a curto prazo e envelhecida a longo prazo. A Tabela 5.28 apresenta os valores médios das relações ao longo da faixa de frequências de carregamento, com base nos valores de $\mathrm{G}^{*}$. A Figura 5.24 representa a Tabela 5.28 em forma gráfica para melhor visualização. 
Tabela 5.18 - Índices de envelhecimento com base em G* para o ligante asfáltico de base

\begin{tabular}{cccc}
\hline \multirow{2}{*}{$\begin{array}{c}\text { Frequência } \\
\text { (rad/s) }\end{array}$} & $\begin{array}{c}\text { RTFOT/virgem } \\
\text { Replan 50/70 }\end{array}$ & $\begin{array}{c}\text { PAV/virões } \\
\text { Replan 50/70 }\end{array}$ & $\begin{array}{c}\text { PAV/RTFOT } \\
\text { Replan 50/70 }\end{array}$ \\
\hline $1,00 \mathrm{E}-05$ & 3,13 & 13,16 & 4,20 \\
$1,00 \mathrm{E}-04$ & 3,12 & 12,97 & 4,16 \\
$1,00 \mathrm{E}-03$ & 3,01 & 11,23 & 3,73 \\
$1,00 \mathrm{E}-02$ & 2,61 & 8,57 & 3,28 \\
$1,00 \mathrm{E}-01$ & 2,33 & 7,01 & 3,01 \\
$1,00 \mathrm{E}+00$ & 2,06 & 4,83 & 2,35 \\
$1,00 \mathrm{E}+01$ & 1,72 & 3,29 & 1,91 \\
$1,00 \mathrm{E}+02$ & 1,51 & 2,25 & 1,49 \\
$1,00 \mathrm{E}+03$ & 1,38 & 1,74 & 1,26 \\
$1,00 \mathrm{E}+04$ & 1,28 & 1,42 & 1,11 \\
$1,00 \mathrm{E}+05$ & 1,22 & 1,25 & 1,03 \\
\hline média & 2,12 & 6,16 & 2,50 \\
\hline
\end{tabular}

Tabela 5.19 - Índices de envelhecimento com base em G* para a mistura 100-0-0

\begin{tabular}{cccc}
\hline \multirow{2}{*}{$\begin{array}{c}\text { Frequência } \\
\text { (rad/s) }\end{array}$} & \begin{tabular}{c} 
Relações \\
\cline { 2 - 4 }
\end{tabular} & $\begin{array}{c}\text { RTOT/virgem } \\
\text { PAV/virgem }\end{array}$ & $\begin{array}{c}\text { PAV/RTFOT } \\
100-0-0\end{array}$ \\
\hline $1,00 \mathrm{E}-05$ & 2,88 & 15,90 & 5,53 \\
$1,00 \mathrm{E}-04$ & 2,89 & 15,75 & 5,46 \\
$1,00 \mathrm{E}-03$ & 2,87 & 14,82 & 5,17 \\
$1,00 \mathrm{E}-02$ & 2,63 & 12,07 & 4,59 \\
$1,00 \mathrm{E}-01$ & 2,55 & 8,94 & 3,50 \\
$1,00 \mathrm{E}+00$ & 2,20 & 6,40 & 2,91 \\
$1,00 \mathrm{E}+01$ & 1,93 & 4,48 & 2,32 \\
$1,00 \mathrm{E}+02$ & 1,58 & 2,90 & 1,83 \\
$1,00 \mathrm{E}+03$ & 1,33 & 2,04 & 1,54 \\
$1,00 \mathrm{E}+04$ & 1,19 & 1,60 & 1,35 \\
$1,00 \mathrm{E}+05$ & 1,10 & 1,33 & 1,21 \\
\hline média & 2,10 & 7,84 & 3,22 \\
\hline
\end{tabular}


Tabela 5.20 - Índices de envelhecimento com base em $G^{*}$ para a mistura 99-0-1

\begin{tabular}{cccc}
\hline \multirow{2}{*}{$\begin{array}{c}\text { Frequência } \\
(\mathbf{r a d} / \mathbf{s})\end{array}$} & $\begin{array}{c}\text { RTFOT/virgem } \\
\text { 99-0-1 }\end{array}$ & $\begin{array}{c}\text { PAV/virges } \\
99-0-1\end{array}$ & $\begin{array}{c}\text { PAV/RTFOT } \\
99-0-1\end{array}$ \\
\cline { 2 - 4 } $1,00 \mathrm{E}-05$ & 3,09 & 13,93 & 4,51 \\
$1,00 \mathrm{E}-04$ & 3,14 & 13,54 & 4,31 \\
$1,00 \mathrm{E}-03$ & 3,07 & 12,66 & 4,13 \\
$1,00 \mathrm{E}-02$ & 2,79 & 10,27 & 3,68 \\
$1,00 \mathrm{E}-01$ & 2,48 & 7,93 & 3,19 \\
$1,00 \mathrm{E}+00$ & 2,13 & 5,35 & 2,52 \\
$1,00 \mathrm{E}+01$ & 1,78 & 3,69 & 2,08 \\
$1,00 \mathrm{E}+02$ & 1,50 & 2,50 & 1,66 \\
$1,00 \mathrm{E}+03$ & 1,30 & 1,83 & 1,40 \\
$1,00 \mathrm{E}+04$ & 1,17 & 1,45 & 1,24 \\
$1,00 \mathrm{E}+05$ & 1,09 & 1,25 & 1,14 \\
\hline média & 2,14 & 6,76 & 2,71 \\
\hline
\end{tabular}

Tabela 5.21 - Índices de envelhecimento com base em G* para a mistura 98-0-2

\begin{tabular}{|c|c|c|c|}
\hline \multirow{2}{*}{$\begin{array}{l}\text { Frequência } \\
(\mathrm{rad} / \mathrm{s})\end{array}$} & \multicolumn{3}{|c|}{ Relações } \\
\hline & $\begin{array}{c}\text { RTFOT/virgem } \\
98-0-2\end{array}$ & $\begin{array}{c}\text { PAV/virgem } \\
98-0-2\end{array}$ & $\begin{array}{c}\text { PAV/RTFOT } \\
98-0-2\end{array}$ \\
\hline $1,00 \mathrm{E}-05$ & 1,20 & 4,02 & 3,36 \\
\hline $1,00 \mathrm{E}-04$ & 1,95 & 7,52 & 3,85 \\
\hline $1,00 \mathrm{E}-03$ & 1,97 & 6,28 & 3,19 \\
\hline $1,00 \mathrm{E}-02$ & 1,92 & 5,43 & 2,83 \\
\hline $1,00 \mathrm{E}-01$ & 1,80 & 4,58 & 2,54 \\
\hline $1,00 \mathrm{E}+00$ & 1,59 & 3,29 & 2,06 \\
\hline $1,00 \mathrm{E}+01$ & 1,41 & 2,47 & 1,75 \\
\hline $1,00 \mathrm{E}+02$ & 1,24 & 1,91 & 1,53 \\
\hline $1,00 \mathrm{E}+03$ & 1,17 & 1,61 & 1,38 \\
\hline $1,00 \mathrm{E}+04$ & 1,09 & 1,37 & 1,25 \\
\hline $1,00 \mathrm{E}+05$ & 1,04 & 1,21 & 1,16 \\
\hline média & 1,49 & 3,61 & 2,26 \\
\hline
\end{tabular}


Tabela 5.22 - Índices de envelhecimento com base em G* para a mistura 97,5-2,5-0

\begin{tabular}{cccc}
\hline & \multicolumn{3}{c}{ Relações } \\
\cline { 2 - 4 } $\begin{array}{c}\text { Frequência } \\
\text { (rad/s) }\end{array}$ & $\begin{array}{c}\text { RTFOT/virgem } \\
97,5-2,5-0\end{array}$ & $\begin{array}{c}\text { PAV/virgem } \\
97,5-2,5-0\end{array}$ & $\begin{array}{c}\text { PAV/RTFOT } \\
97,5-2,5-0\end{array}$ \\
\hline $1,00 \mathrm{E}-05$ & 3,05 & 18,02 & 5,91 \\
$1,00 \mathrm{E}-04$ & 3,16 & 17,46 & 5,52 \\
$1,00 \mathrm{E}-03$ & 3,13 & 15,09 & 4,83 \\
$1,00 \mathrm{E}-02$ & 2,68 & 10,15 & 3,79 \\
$1,00 \mathrm{E}-01$ & 2,25 & 8,27 & 3,67 \\
$1,00 \mathrm{E}+00$ & 2,11 & 6,44 & 3,05 \\
$1,00 \mathrm{E}+01$ & 1,94 & 4,53 & 2,34 \\
$1,00 \mathrm{E}+02$ & 1,58 & 2,92 & 1,85 \\
$1,00 \mathrm{E}+03$ & 1,41 & 2,12 & 1,51 \\
$1,00 \mathrm{E}+04$ & 1,27 & 1,65 & 1,31 \\
$1,00 \mathrm{E}+05$ & 1,17 & 1,39 & 1,18 \\
\hline média & 2,16 & 8,00 & 3,18 \\
\hline
\end{tabular}

Tabela 5.23 - Índices de envelhecimento com base em G* para a mistura 96,5-2,5-1

\begin{tabular}{cccc}
\hline & \multicolumn{3}{c}{ Relações } \\
\cline { 2 - 4 } $\begin{array}{c}\text { Frequência } \\
\text { (rad/s) }\end{array}$ & $\begin{array}{c}\text { RTFOT/virgem } \\
96,5-2,5-1\end{array}$ & $\begin{array}{c}\text { PAV/virgem } \\
96,5-2,5-1\end{array}$ & $\begin{array}{c}\text { PAV/RTFOT } \\
96,5-2,5-1\end{array}$ \\
\hline $1,00 \mathrm{E}-05$ & 2,57 & 15,72 & 6,12 \\
$1,00 \mathrm{E}-04$ & 2,99 & 16,48 & 5,51 \\
$1,00 \mathrm{E}-03$ & 2,94 & 13,44 & 4,57 \\
$1,00 \mathrm{E}-02$ & 2,57 & 9,20 & 3,58 \\
$1,00 \mathrm{E}-01$ & 2,29 & 7,26 & 3,17 \\
$1,00 \mathrm{E}+00$ & 2,11 & 5,54 & 2,62 \\
$1,00 \mathrm{E}+01$ & 1,76 & 3,78 & 2,15 \\
$1,00 \mathrm{E}+02$ & 1,49 & 2,63 & 1,76 \\
$1,00 \mathrm{E}+03$ & 1,33 & 1,95 & 1,46 \\
$1,00 \mathrm{E}+04$ & 1,23 & 1,59 & 1,30 \\
$1,00 \mathrm{E}+05$ & 1,16 & 1,37 & 1,18 \\
\hline média & 2,04 & 7,18 & 3,04 \\
\hline
\end{tabular}


Tabela 5.24 - Índices de envelhecimento com base em G* para a mistura 95,5-2,5-2

\begin{tabular}{cccc}
\hline & \multicolumn{3}{c}{ Relações } \\
\cline { 2 - 4 } $\begin{array}{c}\text { Frequência } \\
\text { (rad/s) }\end{array}$ & $\begin{array}{c}\text { RTFOT/virgem } \\
95,5-2,5-2\end{array}$ & $\begin{array}{c}\text { PAV/virgem } \\
95,5-2,5-2\end{array}$ & $\begin{array}{c}\text { PAV/RTFOT } \\
95,5-2,5-2\end{array}$ \\
\hline 1,00E-05 & 1,56 & 5,52 & 3,55 \\
$1,00 \mathrm{E}-04$ & 2,13 & 7,29 & 3,43 \\
$1,00 \mathrm{E}-03$ & 2,00 & 5,34 & 2,67 \\
$1,00 \mathrm{E}-02$ & 1,74 & 4,13 & 2,38 \\
$1,00 \mathrm{E}-01$ & 1,84 & 3,84 & 2,09 \\
$1,00 \mathrm{E}+00$ & 1,63 & 2,91 & 1,78 \\
$1,00 \mathrm{E}+01$ & 1,50 & 2,29 & 1,53 \\
$1,00 \mathrm{E}+02$ & 1,39 & 1,82 & 1,31 \\
$1,00 \mathrm{E}+03$ & 1,29 & 1,53 & 1,19 \\
$1,00 \mathrm{E}+04$ & 1,23 & 1,34 & 1,09 \\
$1,00 \mathrm{E}+05$ & 1,19 & 1,21 & 1,02 \\
\hline média & 1,59 & 3,38 & 2,00 \\
\hline
\end{tabular}

Tabela 5.25 - Índices de envelhecimento com base em G* para a mistura 95-5-0

\begin{tabular}{|c|c|c|c|}
\hline \multirow{2}{*}{$\begin{array}{c}\text { Frequência } \\
(\mathrm{rad} / \mathrm{s})\end{array}$} & \multicolumn{3}{|c|}{ Relações } \\
\hline & $\begin{array}{c}\text { RTFOT/virgem } \\
95-5-0\end{array}$ & $\begin{array}{c}\text { PAV/virgem } \\
95-5-0\end{array}$ & $\begin{array}{c}\text { PAV/RTFOT } \\
95-5-0\end{array}$ \\
\hline $1,00 \mathrm{E}-05$ & 2,28 & 11,48 & 5,04 \\
\hline $1,00 \mathrm{E}-04$ & 2,44 & 11,58 & 4,76 \\
\hline $1,00 \mathrm{E}-03$ & 2,25 & 8,60 & 3,83 \\
\hline $1,00 \mathrm{E}-02$ & 1,94 & 6,52 & 3,37 \\
\hline $1,00 \mathrm{E}-01$ & 1,90 & 6,82 & 3,58 \\
\hline $1,00 \mathrm{E}+00$ & 1,82 & 5,34 & 2,93 \\
\hline $1,00 \mathrm{E}+01$ & 1,72 & 3,88 & 2,26 \\
\hline $1,00 \mathrm{E}+02$ & 1,47 & 2,58 & 1,76 \\
\hline $1,00 \mathrm{E}+03$ & 1,32 & 1,90 & 1,44 \\
\hline $1,00 \mathrm{E}+04$ & 1,19 & 1,49 & 1,25 \\
\hline $1,00 \mathrm{E}+05$ & 1,13 & 1,27 & 1,13 \\
\hline média & 1,77 & 5,59 & 2,85 \\
\hline
\end{tabular}


Tabela 5.26 - Índices de envelhecimento com base em G* para a mistura 94-5-1

\begin{tabular}{cccc}
\hline \multirow{2}{*}{$\begin{array}{c}\text { Frequência } \\
\text { (rad/s) }\end{array}$} & $\begin{array}{c}\text { RTFOT/virgem } \\
\text { 94-5-1 }\end{array}$ & $\begin{array}{c}\text { PAV/vĩes } \\
94-5-1\end{array}$ & $\begin{array}{c}\text { PAV/RTFOT } \\
94-5-1\end{array}$ \\
\hline $1,00 \mathrm{E}-05$ & 2,09 & 7,67 & 3,68 \\
$1,00 \mathrm{E}-04$ & 2,07 & 7,27 & 3,51 \\
$1,00 \mathrm{E}-03$ & 1,96 & 5,36 & 2,73 \\
$1,00 \mathrm{E}-02$ & 1,81 & 4,63 & 2,57 \\
$1,00 \mathrm{E}-01$ & 1,77 & 4,54 & 2,57 \\
$1,00 \mathrm{E}+00$ & 1,68 & 3,84 & 2,28 \\
$1,00 \mathrm{E}+01$ & 1,55 & 2,93 & 1,89 \\
$1,00 \mathrm{E}+02$ & 1,37 & 2,13 & 1,56 \\
$1,00 \mathrm{E}+03$ & 1,26 & 1,67 & 1,32 \\
$1,00 \mathrm{E}+04$ & 1,17 & 1,37 & 1,17 \\
$1,00 \mathrm{E}+05$ & 1,12 & 1,20 & 1,07 \\
\hline média & 1,62 & 3,87 & 2,21 \\
\hline
\end{tabular}

Tabela 5.27 - Índices de envelhecimento com base em G* para a mistura 93-5-2

\begin{tabular}{cccc}
\hline \multirow{2}{*}{$\begin{array}{c}\text { Frequência } \\
\text { (rad/s) }\end{array}$} & \begin{tabular}{c} 
Relações \\
\cline { 2 - 4 }
\end{tabular} & $\begin{array}{c}\text { RTFT/virgem } \\
\text { PAV/virgem } \\
93-5-2\end{array}$ & $\begin{array}{c}\text { PAV/RTFOT } \\
93-5-2\end{array}$ \\
\hline $1,00 \mathrm{E}-05$ & 1,47 & 4,43 & 3,01 \\
$1,00 \mathrm{E}-04$ & 1,48 & 4,27 & 2,89 \\
$1,00 \mathrm{E}-03$ & 1,44 & 3,77 & 2,63 \\
$1,00 \mathrm{E}-02$ & 1,35 & 3,22 & 2,38 \\
$1,00 \mathrm{E}-01$ & 1,31 & 3,02 & 2,32 \\
$1,00 \mathrm{E}+00$ & 1,23 & 2,49 & 2,03 \\
$1,00 \mathrm{E}+01$ & 1,12 & 1,92 & 1,72 \\
$1,00 \mathrm{E}+02$ & 1,01 & 1,51 & 1,49 \\
$1,00 \mathrm{E}+03$ & 0,95 & 1,28 & 1,34 \\
$1,00 \mathrm{E}+04$ & 0,91 & 1,10 & 1,22 \\
$1,00 \mathrm{E}+05$ & 0,88 & 1,00 & 1,14 \\
\hline média & 1,19 & 2,55 & 2,01 \\
\hline
\end{tabular}


Tabela 5.28 - Índices de envelhecimento médios com base em G* para as frequências entre 1E-5 a 1E+5 das misturas e do ligante asfáltico de base

\begin{tabular}{cccc}
\hline Misturas & RTFOT/virgem & PAV/virgem & PAV/RTFOT \\
\hline Replan 50/70 & 2,12 & 6,16 & 2,90 \\
$100-0-0$ & 2,10 & 7,84 & 3,73 \\
$99-0-1$ & 2,14 & 6,76 & 3,16 \\
$98-0-2$ & 1,49 & 3,61 & 2,42 \\
$97,5-2,5-0$ & 2,16 & 8,00 & 3,71 \\
$96,5-2,5-1$ & 2,04 & 7,18 & 3,52 \\
$95,5-2,5-2$ & 1,59 & 3,38 & 2,13 \\
$95-5-0$ & 1,77 & 5,59 & 3,16 \\
$94-5-1$ & 1,62 & 3,87 & 2,39 \\
$93-5-2$ & 1,19 & 2,55 & 2,13 \\
\hline
\end{tabular}

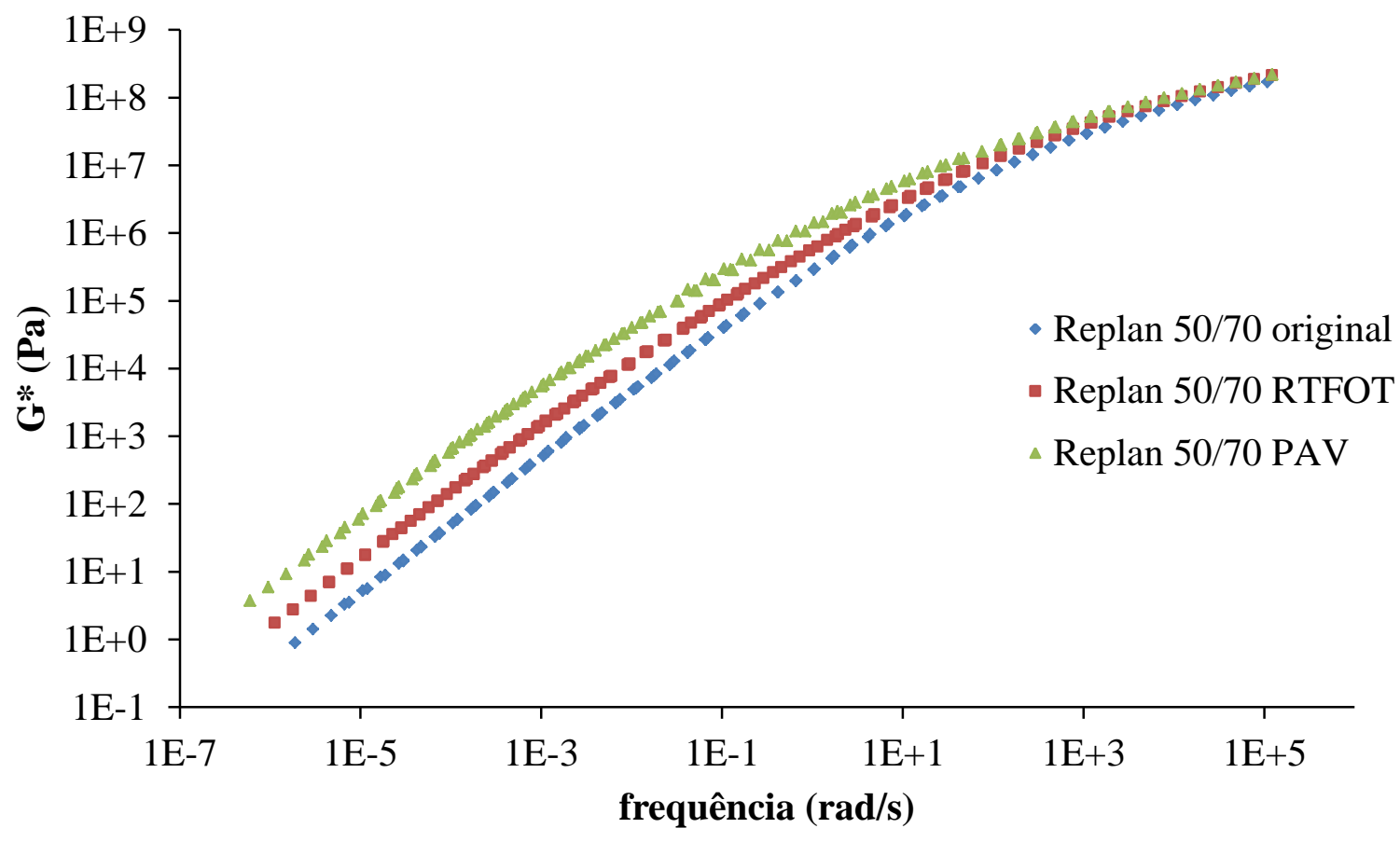

Figura 5.14 - Curvas-mestre de G* para o ligante asfáltico de base nas condições virgem, envelhecida a curto prazo e envelhecida a longo prazo 


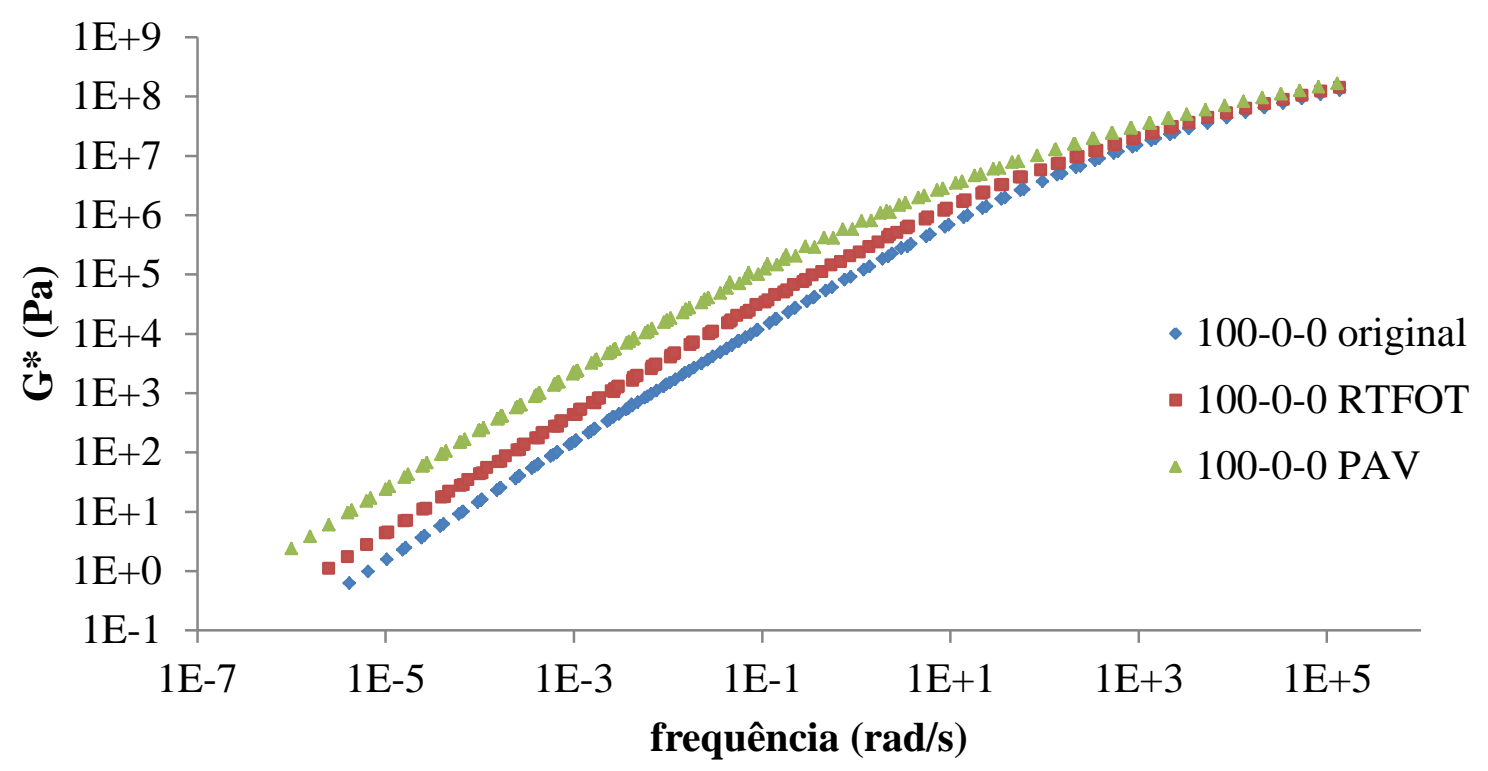

Figura 5.15 - Curvas-mestre de $G^{*}$ para a mistura de 100-0-0 nas condições virgem, envelhecida a curto prazo e envelhecida a longo prazo

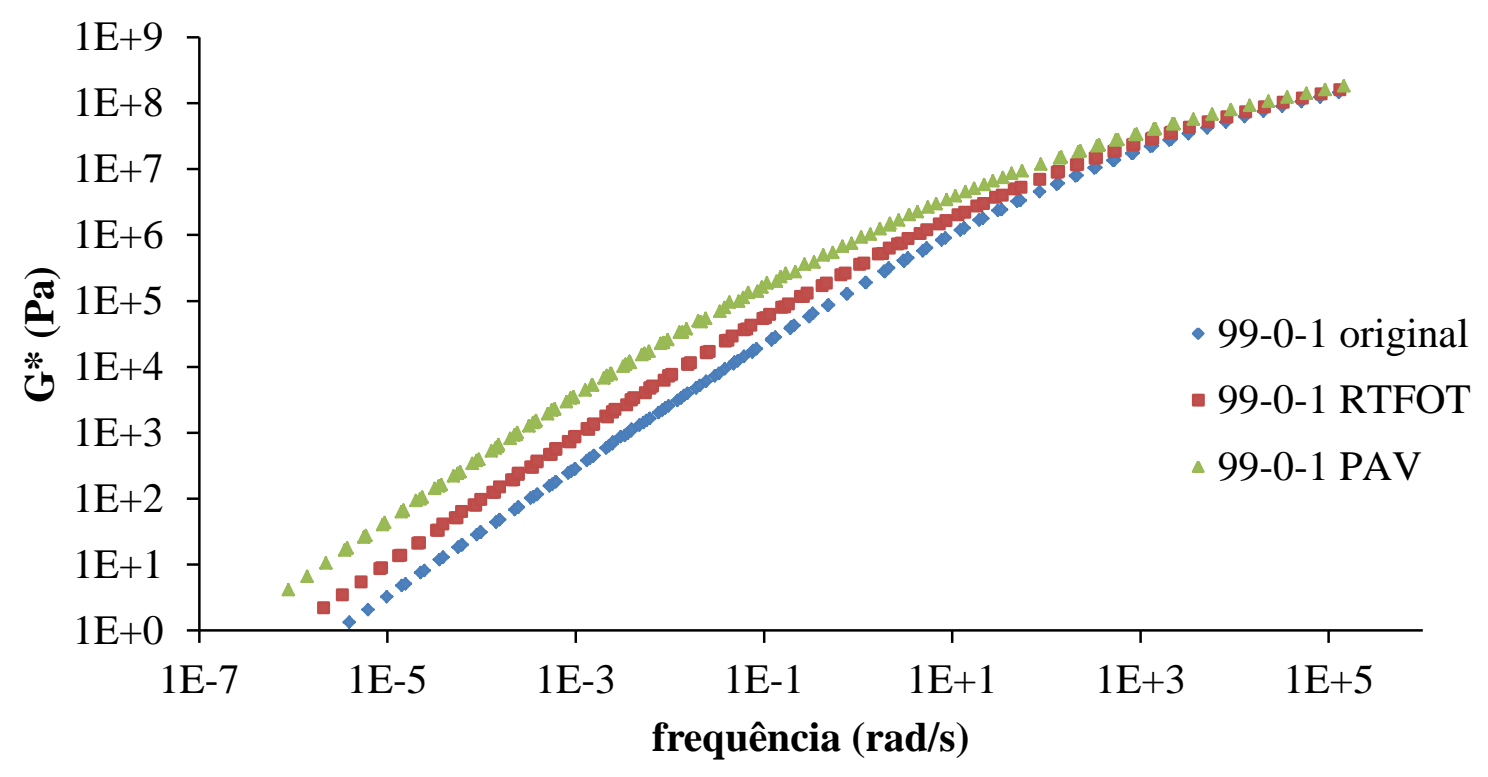

Figura 5.16 - Curvas-mestre de G* para a mistura de 99-0-1 nas condições virgem, envelhecida a curto prazo e envelhecida a longo prazo 


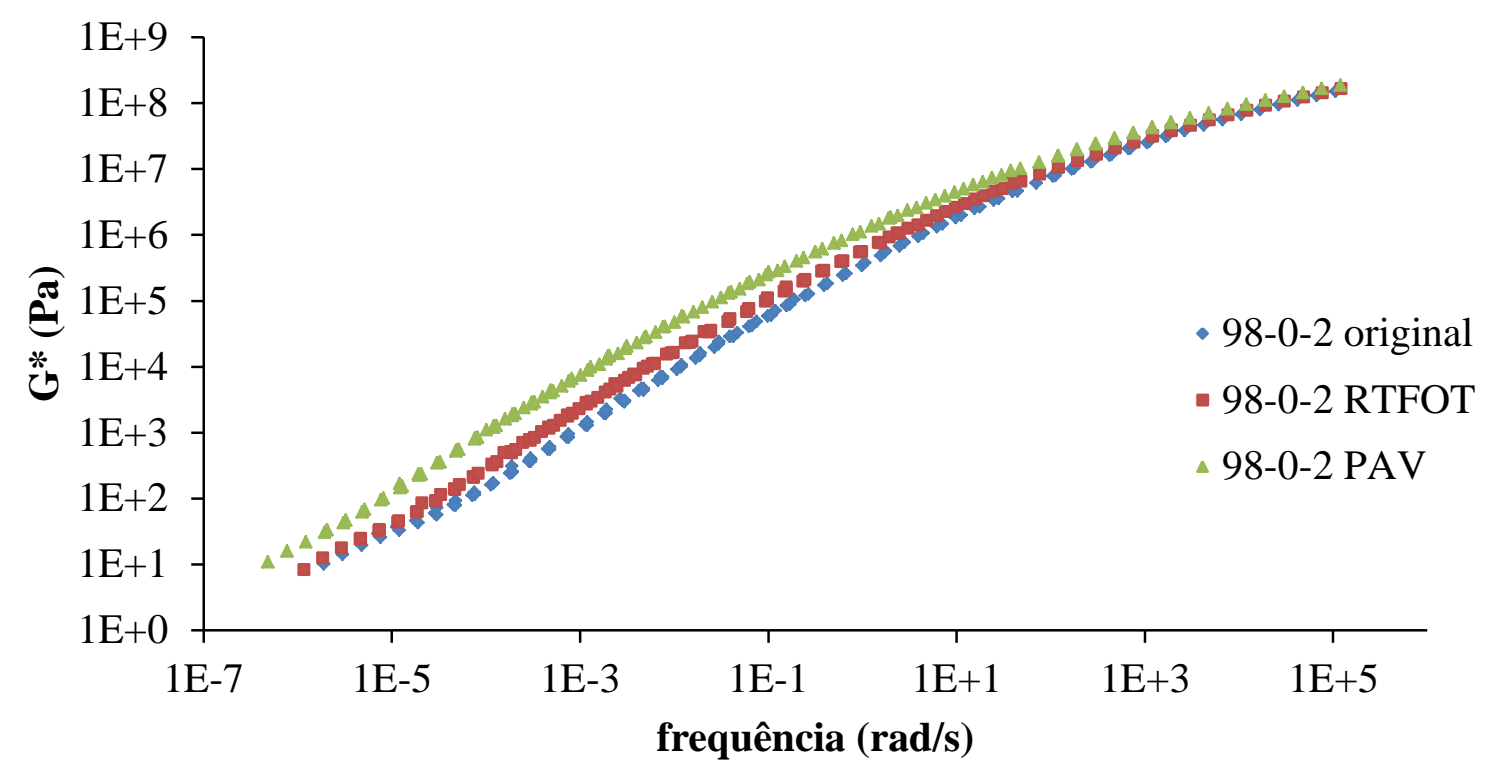

Figura 5.17 - Curvas-mestre de $G^{*}$ para a mistura de 98-0-2 nas condições virgem, envelhecida a curto prazo e envelhecida a longo prazo

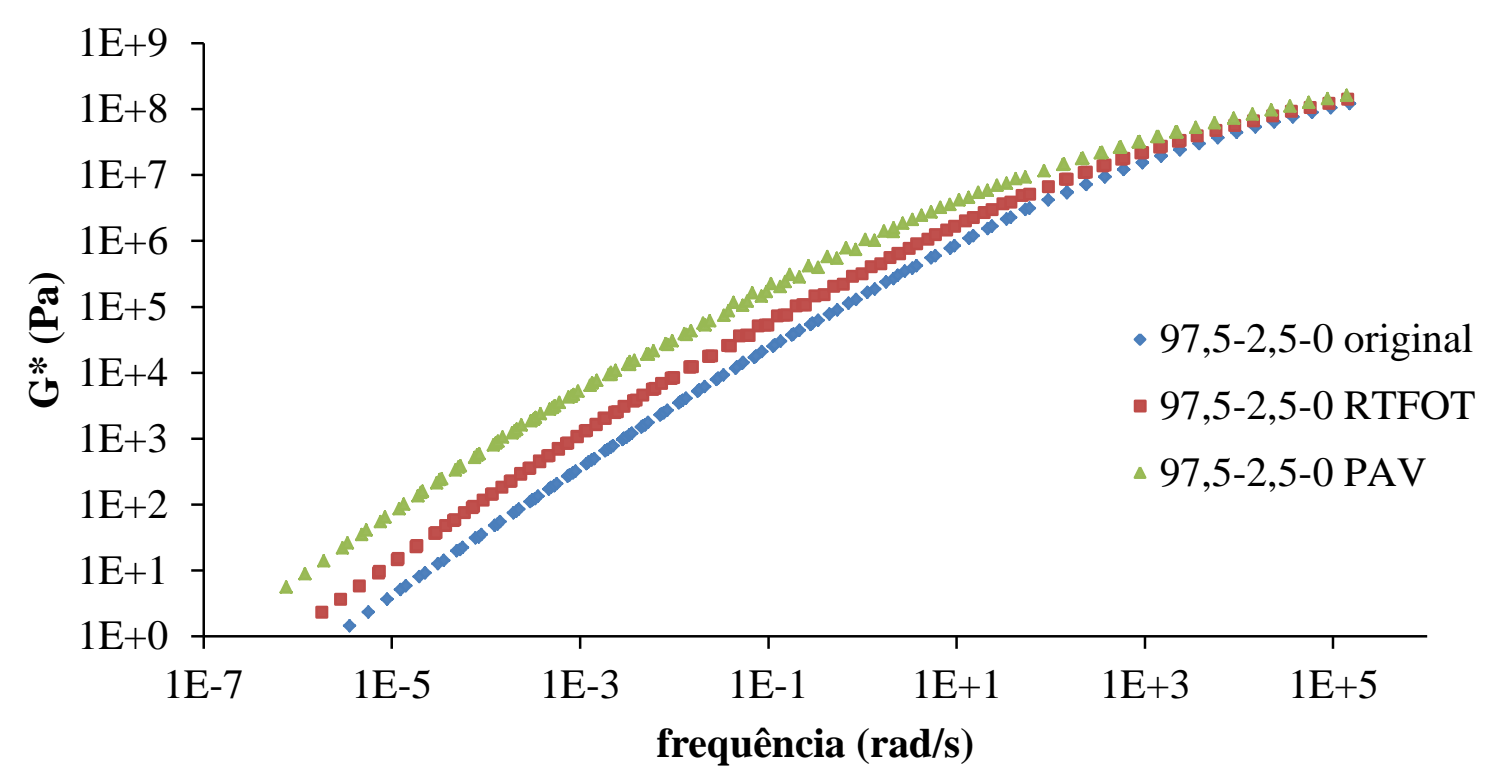

Figura 5.18 - Curvas-mestre de G* para a mistura de 97,5-2,5-0 nas condições virgem, envelhecida a curto prazo e envelhecida a longo prazo 


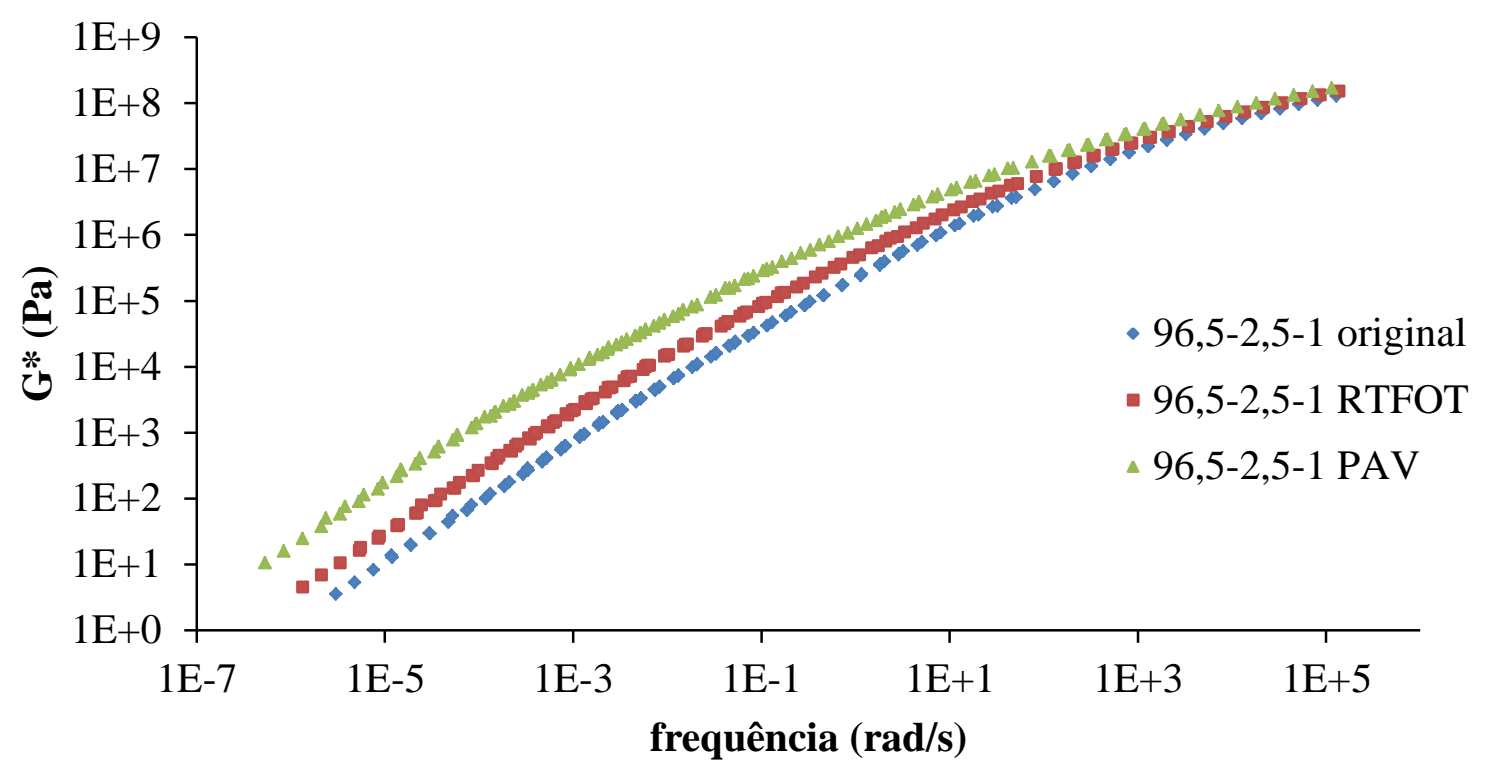

Figura 5.19 - Curvas-mestre de G* para a mistura de 96,5-2,5-1 nas condições virgem, envelhecida a curto prazo e envelhecida a longo prazo

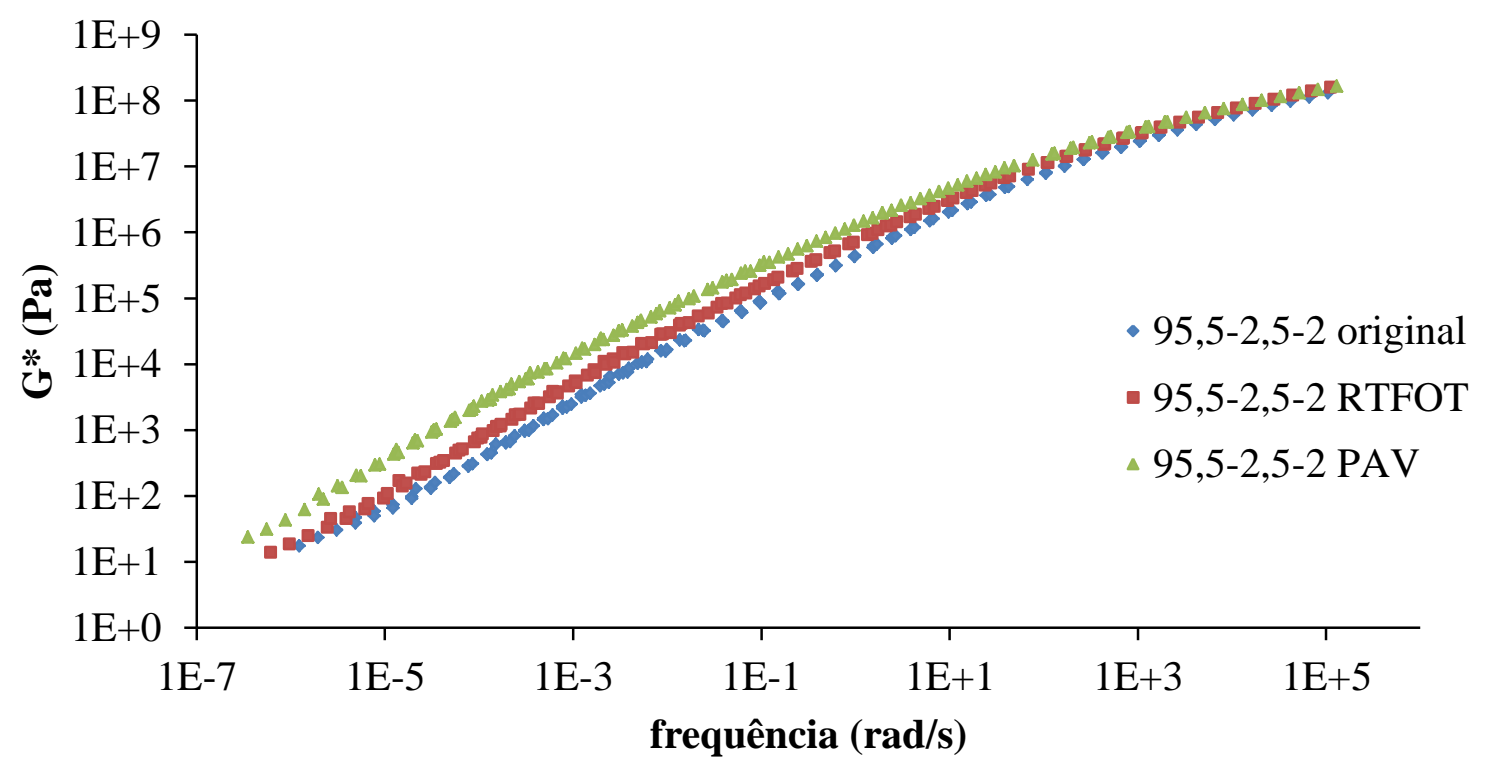

Figura 5.20 - Curvas-mestre de G* para a mistura de 95,5-2,5-2 nas condições virgem, envelhecida a curto prazo e envelhecida a longo prazo 


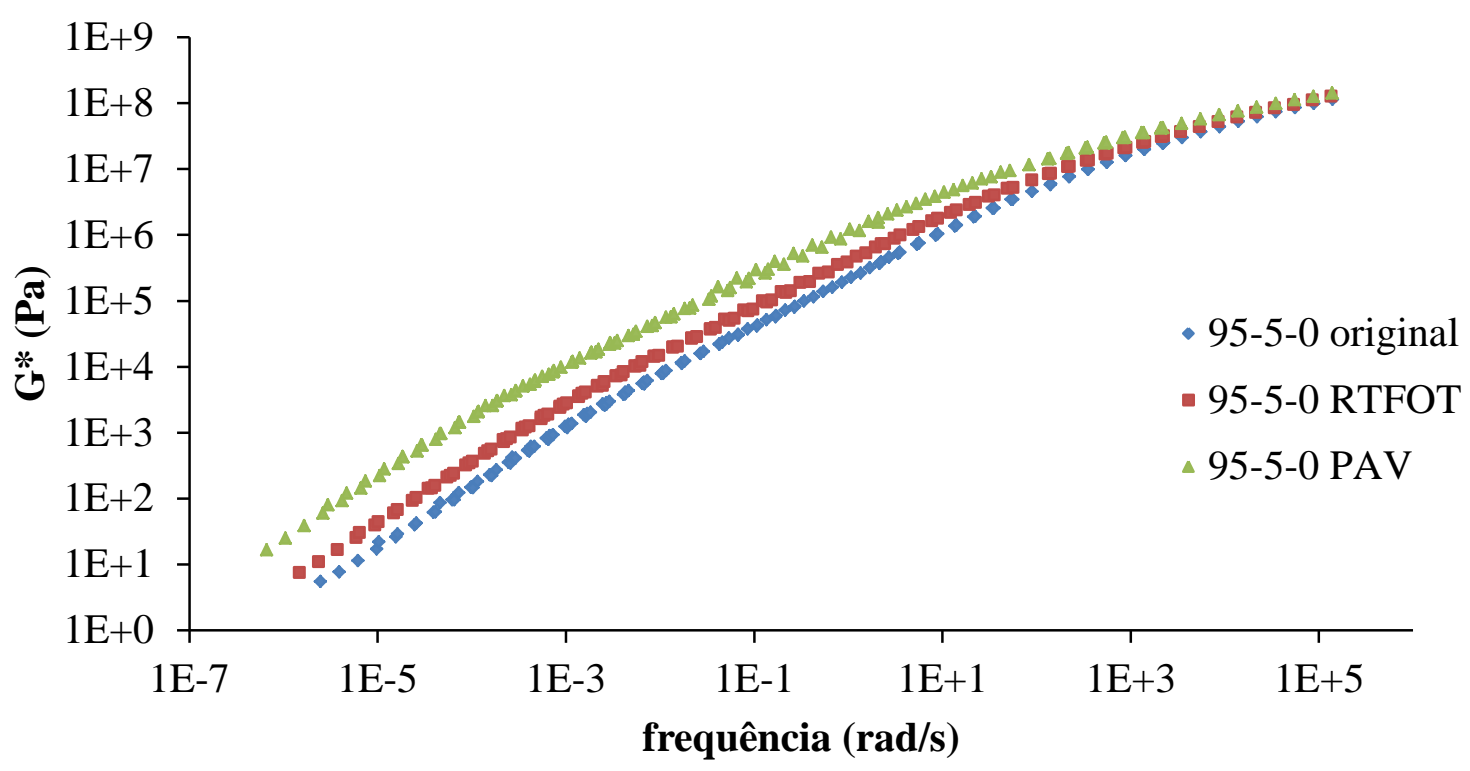

Figura 5.21 - Curvas-mestre de $G^{*}$ para a mistura de 95-5-0 nas condições virgem, envelhecida a curto prazo e envelhecida a longo prazo

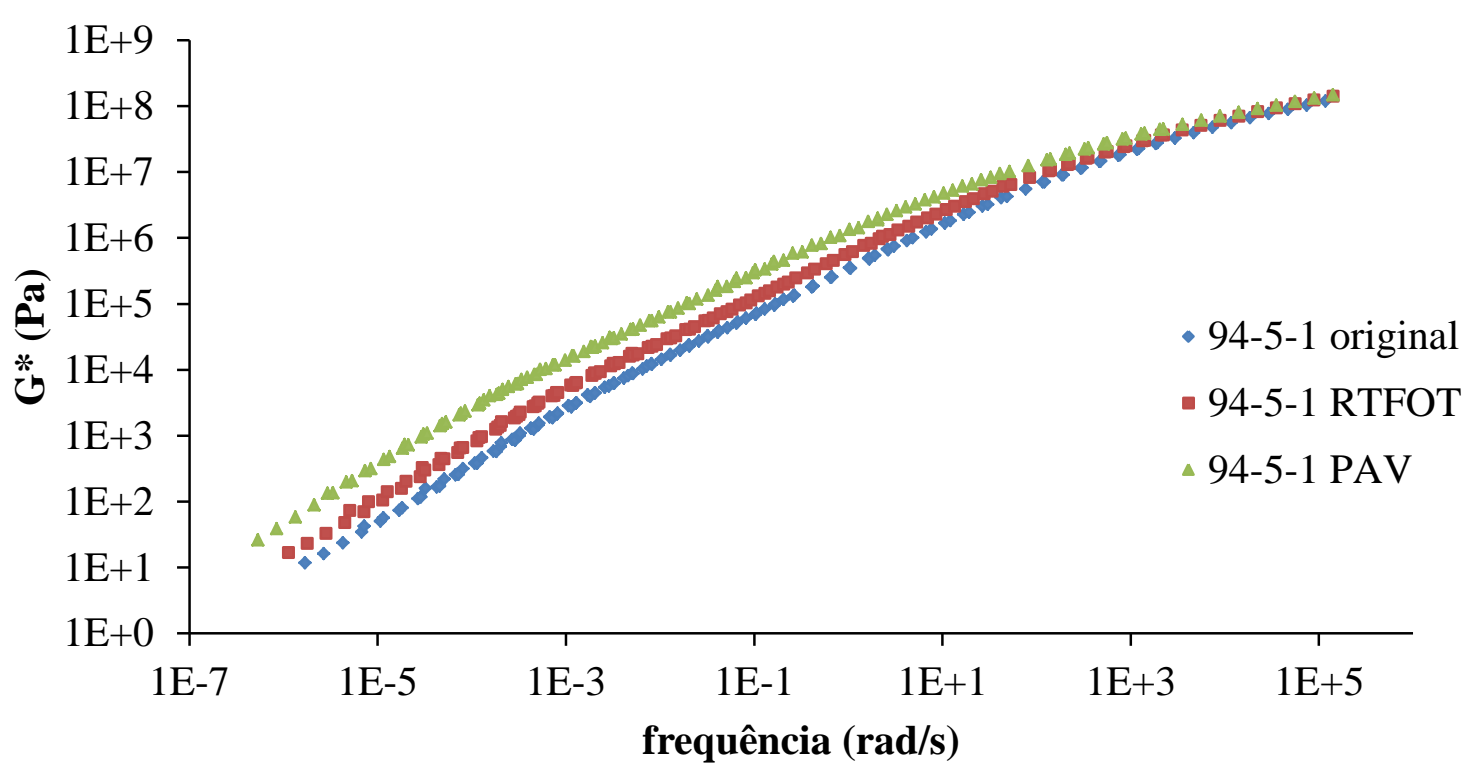

Figura 5.22 - Curvas-mestre de $G^{*}$ para a mistura de 94-5-1 nas condições virgem, envelhecida a curto prazo e envelhecida a longo prazo 


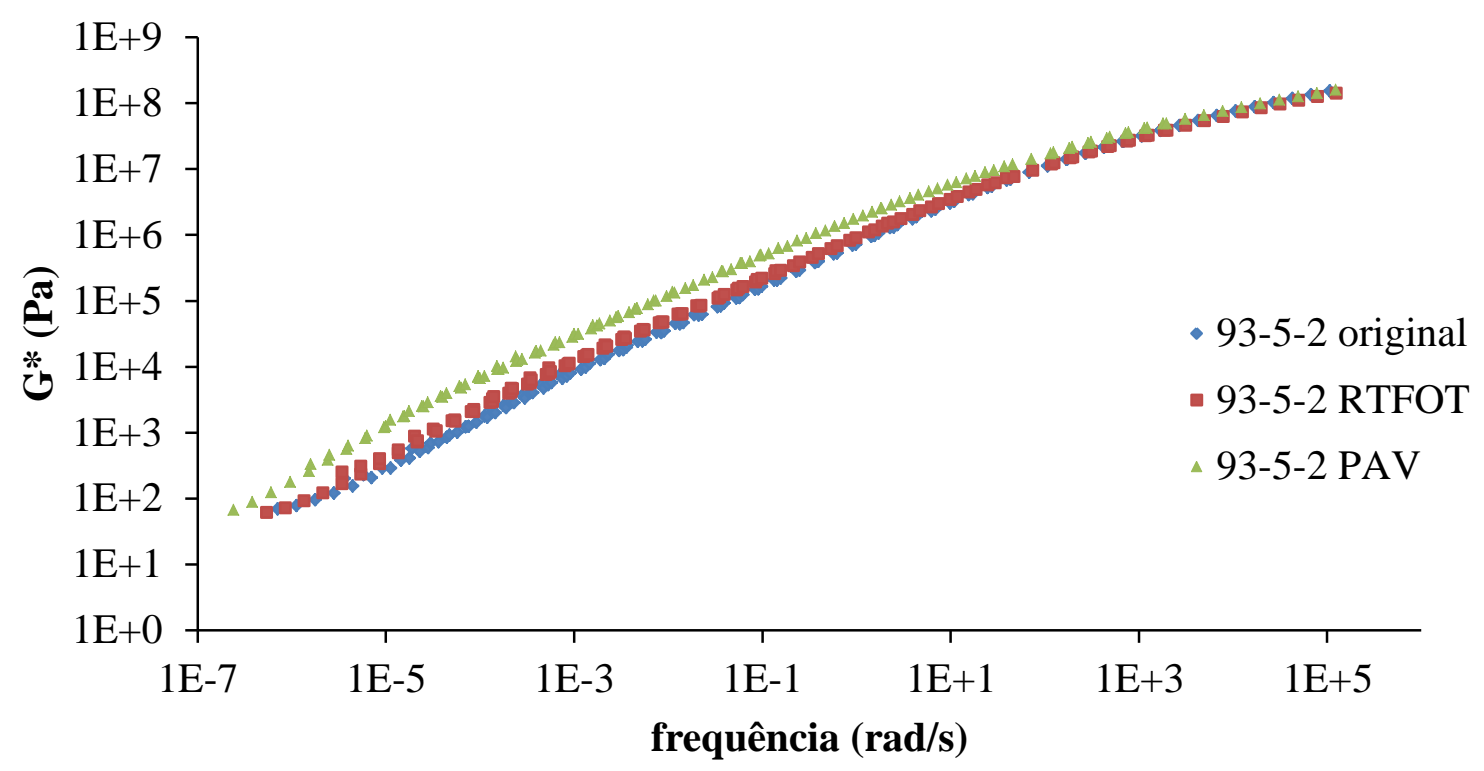

Figura 5.23 - Curvas-mestre de $G^{*}$ para a mistura de 93-5-2 nas condições virgem, envelhecida a curto prazo e envelhecida a longo prazo

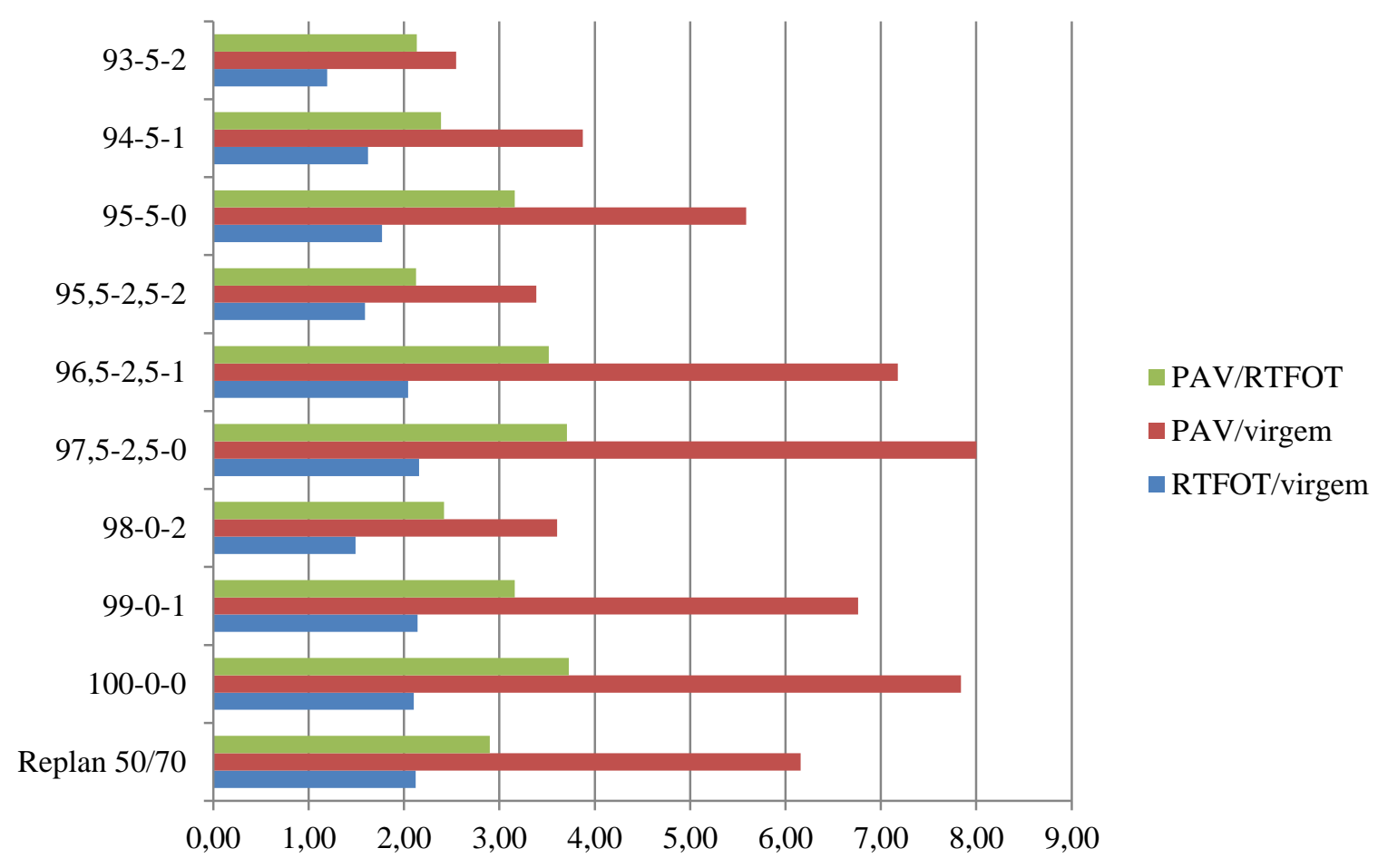

Figura 5.24 - Índices de envelhecimento médios com base em G* 
As seguintes observações podem ser feitas acerca do efeito do envelhecimento a curto e a longo prazos sobre os valores de $\mathrm{G}^{*}$ das misturas:

- para o índice RTFOT/virgem, o menor valor foi obtido para a mistura 93-5-2 (1,19), seguida da mistura 98-0-2 (1,49). O maior índice obtido foi o da mistura 97,5-2,5-0 (2,16), seguida da mistura 99-0-1 (2,14). De maneira geral, as misturas com 2\% de TITAN apresentaram os melhores índices de envelhecimento. Os maiores valores deste índice estão associados a misturas com $0 \%$ de TITAN e valores intermediários estão associados com a proporção de $1 \%$ de TITAN;

- para o índice RTFOT/virgem, tem-se que, ao se fixar o teor de SBS e variar o teor de TITAN, a adição de TITAN diminui o valor médio do índice. Ao se fixar o teor de TITAN e variar o teor de SBS, observa-se que a adição de SBS pode tanto aumentar como diminuir esse valor médio. Ocorre aumento e diminuição do índice (dependendo da quantidade de TITAN presente) entre 0 e 2,5\% de SBS e diminuição entre 2,5 e 5\% de SBS;

- para o índice PAV/virgem, o menor valor foi obtido para a mistura 93-5-2 (2,55), seguida da mistura 95,5-2,5-2 (3,38). O maior índice obtido foi o da mistura 97,5-2,5-0 (8,00), seguida da mistura 100-0-0 (7,84). De maneira geral, as misturas com $2 \%$ de TITAN apresentaram os menores índices de envelhecimento. Os maiores valores deste índice estão associados com a proporção de $1 \%$ de TITAN;

- para o índice PAV/virgem, tem-se que, ao se fixar o teor de SBS e variar o teor de TITAN, a adição de TITAN diminui o valor médio do índice. Ao se fixar o teor de TITAN e variar o teor de SBS, observa-se que a adição de SBS pode aumentar como diminuir esse valor médio. Ocorre aumento e diminuição do índice (dependendo da quantidade de TITAN presente) entre 0 e $2,5 \%$ de SBS e diminuição entre 2,5 e $5 \%$ de SBS;

- para o índice PAV/RTFOT, o menor valor foi obtido para as misturas 93-5-2 e 97,5-2,5-2 (ambas com 2,13), seguidas da mistura 94-5-1 (2,39). O maior índice obtido foi da mistura 100-0-0 (3,73), seguida da mistura 97,5-2,5-0 (3,71). De maneira geral, as misturas com $2 \%$ de TITAN apresentaram os menores índices de envelhecimento. Os maiores valores deste índice estão associados a misturas com $0 \%$ de TITAN e valores intermediários estão associados com a proporção de $1 \%$ de TITAN;

- para o índice PAV/RTFOT, tem-se que, ao se fixar o teor de SBS e variar o teor de TITAN, a adição de TITAN diminui o valor médio do índice. Ao se fixar o teor de TITAN e variar o teor de SBS, a adição de SBS pode aumentar como diminuir esse valor médio. Ocorre 
aumento e diminuição do índice (dependendo da quantidade de TITAN presente) entre 0 e $2,5 \%$ de SBS e diminuição entre 2,5 e $5 \%$ de SBS;

- com o aumento da frequência ocorre a diminuição dos índices, ou seja, nas frequências baixas (da ordem de 1E-5) os índices de envelhecimento são maiores que os índices obtidos nas frequências mais altas (ordem de $1 \mathrm{E}+5$ ). Isto indica que velocidades mais altas do tráfego atuam no sentido de diminuir o efeito negativo do envelhecimento;

Em linhas gerais, a mistura 93-5-2 apresenta os menores índices de envelhecimento, o que justifica em parte pela presença do SBS e em parte, e especialmente, pela presença do TITAN. Seja na presença de $0 \%$ de SBS, de $2,5 \%$ ou de $5,0 \%$, a adição de TITAN contribui significativamente para a redução da sensibilidade ao envelhecimento, seja a curto seja a longo prazo. Dentre as misturas com maiores índices de envelhecimento, destacam-se a 97,52,5-0 e a 100-0-0, caracterizadas pelo baixo índice de modificação. No caso desta duas misturas e de outras com baixos níveis de modificação, o óleo aromático é fator determinante sobre o prejuízo causado a tais misturas, por ser mais um produto suscetível a volatilização e a oxidação. Vale ainda a pena salientar que os baixos teores de modificadores adicionados não foram suficientes para amenizar o efeito negativo do envelhecimento sobre o óleo aromático.

\subsubsection{Efeito dos envelhecimentos a curto e a longo prazos à luz dos valores de delta $(\delta)$}

As Tabelas de 5.29 a 5.38 apresentam as relações, RTFOT-virgem, PAV-virgem e PAV-RTFOT das misturas e do ligante asfáltico de base para as frequências entre 1E-5 e $1 \mathrm{E}+5 \mathrm{em} \mathrm{rad} / \mathrm{s}$ com base nos valores do ângulo de fase ( $\delta$ ). As Figuras de 5.25 a 5.34 apresentam as curvas-mestre de ângulo de fase, para as condições original, envelhecida a curto prazo e envelhecida a longo prazo. A Tabela 5.39 apresenta as variações médias nos valores de delta provocadas pelo envelhecimento ao longo da faixa de frequências de carregamento. A Tabela 5.38 não apresentou um bom ajuste devido a mistura 93-5-2 não apresentar bons resultados para a condição virgem. 
Tabela 5.29 - Variações do ângulo de fase (ס) devidas ao envelhecimento para o ligante asfáltico de base

\begin{tabular}{cccc}
\hline & \multicolumn{3}{c}{ Diferenças } \\
\cline { 2 - 4 } $\begin{array}{c}\text { Frequência } \\
\text { (rad/s) }\end{array}$ & RTFOT-virgem & PAV-virgem & PAV-RTFOT \\
\hline $1,00 \mathrm{E}-05$ & $-0,34$ & $-2,60$ & $-2,26$ \\
$1,00 \mathrm{E}-04$ & $-1,51$ & $-6,13$ & $-4,62$ \\
$1,00 \mathrm{E}-03$ & $-2,97$ & $-8,63$ & $-5,66$ \\
$1,00 \mathrm{E}-02$ & $-4,56$ & $-12,31$ & $-7,75$ \\
$1,00 \mathrm{E}-01$ & $-5,33$ & $-13,51$ & $-8,18$ \\
$1,00 \mathrm{E}+00$ & $-5,30$ & $-13,92$ & $-8,62$ \\
$1,00 \mathrm{E}+01$ & $-5,48$ & $-13,81$ & $-8,33$ \\
$1,00 \mathrm{E}+02$ & $-4,95$ & $-12,49$ & $-7,54$ \\
$1,00 \mathrm{E}+03$ & $-3,93$ & $-9,75$ & $-5,82$ \\
$1,00 \mathrm{E}+04$ & $-2,87$ & $-7,13$ & $-4,27$ \\
$1,00 \mathrm{E}+05$ & $-1,86$ & $-4,39$ & $-2,53$ \\
\hline média & $-3,55$ & $-9,52$ & $-5,96$ \\
\hline
\end{tabular}

Tabela 5.30 - Variações do ângulo de fase ( $\delta$ ) devidas ao envelhecimento para a mistura 100-0-0

\begin{tabular}{cccc}
\hline & \multicolumn{3}{c}{ Diferenças } \\
\cline { 2 - 4 } $\begin{array}{c}\text { Frequência } \\
\text { (rad/s) }\end{array}$ & $\begin{array}{c}\text { RTFOT-virgem } \\
100-0-0\end{array}$ & $\begin{array}{c}\text { PAV-virgem } \\
100-0-0\end{array}$ & $\begin{array}{c}\text { PAV-RTFOT } \\
100-0-0\end{array}$ \\
\hline $1,00 \mathrm{E}-05$ & $-0,38$ & $-1,22$ & $-0,84$ \\
$1,00 \mathrm{E}-04$ & $-1,18$ & $-4,54$ & $-3,35$ \\
$1,00 \mathrm{E}-03$ & $-6,99$ & $-12,36$ & $-5,37$ \\
$1,00 \mathrm{E}-02$ & $-4,11$ & $-12,06$ & $-7,95$ \\
$1,00 \mathrm{E}-01$ & $-4,81$ & $-13,84$ & $-9,04$ \\
$1,00 \mathrm{E}+00$ & $-5,91$ & $-15,33$ & $-9,41$ \\
$1,00 \mathrm{E}+01$ & $-6,07$ & $-15,61$ & $-9,54$ \\
$1,00 \mathrm{E}+02$ & $-5,17$ & $-14,27$ & $-9,10$ \\
$1,00 \mathrm{E}+03$ & $-4,45$ & $-12,09$ & $-7,64$ \\
$1,00 \mathrm{E}+04$ & $-2,93$ & $-9,21$ & $-6,27$ \\
$1,00 \mathrm{E}+05$ & $-1,76$ & $-6,44$ & $-4,68$ \\
\hline média & $-3,98$ & $-10,63$ & $-6,65$ \\
\hline
\end{tabular}


Tabela 5.31 - Variações do ângulo de fase ( $\delta$ ) devidas ao envelhecimento para a mistura 99-0-1

\begin{tabular}{cccc}
\hline & \multicolumn{3}{c}{ Diferenças } \\
\cline { 2 - 4 } $\begin{array}{c}\text { Frequência } \\
\text { (rad/s) }\end{array}$ & $\begin{array}{c}\text { RTFOT-virgem } \\
99-0-1\end{array}$ & $\begin{array}{c}\text { PAV-virgem } \\
99-0-1\end{array}$ & $\begin{array}{c}\text { PAV-RTFOT } \\
99-0-1\end{array}$ \\
\hline $1,00 \mathrm{E}-05$ & $-1,12$ & $-3,69$ & $-2,57$ \\
$1,00 \mathrm{E}-04$ & $-1,82$ & $-6,64$ & $-4,82$ \\
$1,00 \mathrm{E}-03$ & $-3,90$ & $-9,83$ & $-5,93$ \\
$1,00 \mathrm{E}-02$ & $-5,27$ & $-12,23$ & $-6,95$ \\
$1,00 \mathrm{E}-01$ & $-6,32$ & $-14,44$ & $-8,12$ \\
$1,00 \mathrm{E}+00$ & $-3,17$ & $-13,26$ & $-10,09$ \\
$1,00 \mathrm{E}+01$ & $-4,52$ & $-13,99$ & $-9,48$ \\
$1,00 \mathrm{E}+02$ & $-4,10$ & $-13,15$ & $-9,06$ \\
$1,00 \mathrm{E}+03$ & $-3,07$ & $-10,32$ & $-7,25$ \\
$1,00 \mathrm{E}+04$ & $-1,50$ & $-7,44$ & $-5,94$ \\
$1,00 \mathrm{E}+05$ & $-0,63$ & $-4,86$ & $-4,23$ \\
\hline média & $-3,22$ & $-9,99$ & $-6,77$ \\
\hline
\end{tabular}

Tabela 5.32 - Variações do ângulo de fase ( $\delta$ ) devidas ao envelhecimento para a mistura 98-0-2

\begin{tabular}{cccc}
\hline & \multicolumn{3}{c}{ Diferenças } \\
\cline { 2 - 4 } $\begin{array}{c}\text { Frequência } \\
\text { (rad/s) }\end{array}$ & $\begin{array}{c}\text { RTFOT-virgem } \\
98-0-2\end{array}$ & $\begin{array}{c}\text { PAV-virgem } \\
98-0-2\end{array}$ & $\begin{array}{c}\text { PAV-RTFOT } \\
98-0-2\end{array}$ \\
\hline $1,00 \mathrm{E}-05$ & $-2,45$ & $-6,12$ & $-3,66$ \\
$1,00 \mathrm{E}-04$ & $-4,06$ & $-8,40$ & $-4,34$ \\
$1,00 \mathrm{E}-03$ & $-3,24$ & $-8,06$ & $-4,82$ \\
$1,00 \mathrm{E}-02$ & $-4,84$ & $-10,16$ & $-5,32$ \\
$1,00 \mathrm{E}-01$ & $-4,54$ & $-10,00$ & $-5,46$ \\
$1,00 \mathrm{E}+00$ & $-5,12$ & $-10,89$ & $-5,78$ \\
$1,00 \mathrm{E}+01$ & $-5,60$ & $-10,94$ & $-5,34$ \\
$1,00 \mathrm{E}+02$ & $-5,47$ & $-10,48$ & $-5,01$ \\
$1,00 \mathrm{E}+03$ & $-4,43$ & $-8,63$ & $-4,21$ \\
$1,00 \mathrm{E}+04$ & $-3,56$ & $-7,15$ & $-3,58$ \\
$1,00 \mathrm{E}+05$ & $-3,15$ & $-5,93$ & $-2,78$ \\
\hline média & $-4,22$ & $-8,80$ & $-4,57$ \\
\hline
\end{tabular}


Tabela 5.33 - Variações do ângulo de fase ( $\delta$ ) devidas ao envelhecimento para a mistura 97,5-2,5-0

\begin{tabular}{cccc}
\hline \multirow{2}{*}{$\begin{array}{c}\text { Frequência } \\
\text { (rad/s) }\end{array}$} & $\begin{array}{c}\text { RTFOT-virgem } \\
\text { 97,5-2,5-0 }\end{array}$ & $\begin{array}{c}\text { PAV-virgem } \\
97,5-2,5-0\end{array}$ & $\begin{array}{c}\text { PAV-RTFOT } \\
97,5-2,5-0\end{array}$ \\
\hline $1,00 \mathrm{E}-05$ & 0,00 & 0,00 & 0,00 \\
$1,00 \mathrm{E}-04$ & $-2,14$ & $-11,10$ & $-8,96$ \\
$1,00 \mathrm{E}-03$ & $-6,48$ & $-15,79$ & $-9,31$ \\
$1,00 \mathrm{E}-02$ & $-8,85$ & $-14,45$ & $-5,60$ \\
$1,00 \mathrm{E}-01$ & $-4,10$ & $-10,87$ & $-6,78$ \\
$1,00 \mathrm{E}+00$ & $-4,48$ & $-13,54$ & $-9,06$ \\
$1,00 \mathrm{E}+01$ & $-5,96$ & $-16,86$ & $-10,90$ \\
$1,00 \mathrm{E}+02$ & $-8,02$ & $-19,84$ & $-11,82$ \\
$1,00 \mathrm{E}+03$ & $-8,17$ & $-19,64$ & $-11,47$ \\
$1,00 \mathrm{E}+04$ & $-7,54$ & $-16,30$ & $-8,76$ \\
$1,00 \mathrm{E}+05$ & $-5,71$ & $-12,24$ & $-6,53$ \\
\hline média & $-6,15$ & $-15,06$ & $-8,92$ \\
\hline
\end{tabular}

Tabela 5.34 - Variações do ângulo de fase ( $\delta$ ) devidas ao envelhecimento para a mistura 96,5-2,5-1

\begin{tabular}{cccc}
\hline \multirow{2}{*}{$\begin{array}{c}\text { Frequência } \\
\text { (rad/s) }\end{array}$} & $\begin{array}{c}\text { DTFOT-virgem } \\
\text { 96,5-2,5-1 }\end{array}$ & $\begin{array}{c}\text { PAV-virgem } \\
96,5-2,5-1\end{array}$ & $\begin{array}{c}\text { PAV-RTFOT } \\
96,5-2,5-1\end{array}$ \\
\hline $1,00 \mathrm{E}-05$ & $-2,77$ & $-11,51$ & $-8,74$ \\
$1,00 \mathrm{E}-04$ & $-5,19$ & $-13,40$ & $-8,22$ \\
$1,00 \mathrm{E}-03$ & $-5,19$ & $-11,55$ & $-6,36$ \\
$1,00 \mathrm{E}-02$ & $-4,01$ & $-9,06$ & $-5,05$ \\
$1,00 \mathrm{E}-01$ & $-3,73$ & $-10,52$ & $-6,80$ \\
$1,00 \mathrm{E}+00$ & $-5,04$ & $-13,20$ & $-8,16$ \\
$1,00 \mathrm{E}+01$ & $-9,02$ & $-17,85$ & $-8,83$ \\
$1,00 \mathrm{E}+02$ & $-10,20$ & $-18,91$ & $-8,71$ \\
$1,00 \mathrm{E}+03$ & $-10,85$ & $-17,89$ & $-7,04$ \\
$1,00 \mathrm{E}+04$ & $-9,48$ & $-14,97$ & $-5,48$ \\
$1,00 \mathrm{E}+05$ & $-7,91$ & $-11,81$ & $-3,89$ \\
\hline média & $-7,06$ & $-13,92$ & $-6,85$ \\
\hline
\end{tabular}


Tabela 5.35 - Variações do ângulo de fase ( $\delta$ ) devidas ao envelhecimento para a mistura 95,5-2,5-2

\begin{tabular}{cccc}
\hline \multirow{2}{*}{$\begin{array}{c}\text { Frequência } \\
\text { (rad/s) }\end{array}$} & $\begin{array}{c}\text { DTFOT-virgem } \\
\text { 95,5-2,5-2 }\end{array}$ & $\begin{array}{c}\text { PAV-virgem } \\
95,5-2,5-2\end{array}$ & $\begin{array}{c}\text { PAV-RTFOT } \\
95,5-2,5-2\end{array}$ \\
\cline { 2 - 4 } & & $-9,13$ & $-7,01$ \\
$1,00 \mathrm{E}-05$ & $-2,12$ & $-7,74$ & $-2,65$ \\
$1,00 \mathrm{E}-04$ & $-5,09$ & $-6,47$ & $-6,13$ \\
$1,00 \mathrm{E}-03$ & $-0,34$ & $-6,09$ & $-3,68$ \\
$1,00 \mathrm{E}-02$ & $-2,41$ & $-8,40$ & $-4,88$ \\
$1,00 \mathrm{E}-01$ & $-3,52$ & $-10,51$ & $-6,58$ \\
$1,00 \mathrm{E}+00$ & $-3,94$ & $-12,70$ & $-7,56$ \\
$1,00 \mathrm{E}+01$ & $-5,14$ & $-12,12$ & $-7,17$ \\
$1,00 \mathrm{E}+02$ & $-4,96$ & $-10,69$ & $-6,79$ \\
$1,00 \mathrm{E}+03$ & $-3,90$ & $-8,97$ & $-5,90$ \\
$1,00 \mathrm{E}+04$ & $-3,07$ & $-7,68$ & $-5,11$ \\
$1,00 \mathrm{E}+05$ & $-2,57$ & $-9,14$ & $-5,64$ \\
\hline média & $-3,49$ & &
\end{tabular}

Tabela 5.36 - Variações do ângulo de fase (ס) devidas ao envelhecimento para a mistura 95-5-0

\begin{tabular}{cccc}
\hline & \multicolumn{3}{c}{ Diferenças } \\
\cline { 2 - 4 } $\begin{array}{c}\text { Frequência } \\
\text { (rad/s) }\end{array}$ & $\begin{array}{c}\text { RTFOT-virgem } \\
95-5-0\end{array}$ & $\begin{array}{c}\text { PAV-virgem } \\
95-5-0\end{array}$ & $\begin{array}{c}\text { PAV-RTFOT } \\
95-5-0\end{array}$ \\
\hline $1,00 \mathrm{E}-05$ & 0,90 & $-18,56$ & $-19,46$ \\
$1,00 \mathrm{E}-04$ & 0,29 & $-17,59$ & $-17,89$ \\
$1,00 \mathrm{E}-03$ & $-1,53$ & $-12,31$ & $-10,78$ \\
$1,00 \mathrm{E}-02$ & $-1,17$ & $-6,01$ & $-4,84$ \\
$1,00 \mathrm{E}-01$ & $-1,30$ & $-7,40$ & $-6,10$ \\
$1,00 \mathrm{E}+00$ & $-2,21$ & $-11,19$ & $-8,98$ \\
$1,00 \mathrm{E}+01$ & $-2,96$ & $-11,91$ & $-8,95$ \\
$1,00 \mathrm{E}+02$ & $-2,81$ & $-11,73$ & $-8,92$ \\
$1,00 \mathrm{E}+03$ & $-2,14$ & $-9,76$ & $-7,62$ \\
$1,00 \mathrm{E}+04$ & $-1,51$ & $-7,48$ & $-5,97$ \\
$1,00 \mathrm{E}+05$ & $-0,95$ & $-5,03$ & $-4,08$ \\
\hline média & $-1,40$ & $-10,82$ & $-9,42$ \\
\hline
\end{tabular}


Tabela 5.37 - Variações do ângulo de fase ( $\delta$ ) devidas ao envelhecimento para a mistura 94-5-1

\begin{tabular}{cccc}
\hline & \multicolumn{3}{c}{ Diferenças } \\
\cline { 2 - 4 } $\begin{array}{c}\text { Frequência } \\
\text { (rad/s) }\end{array}$ & $\begin{array}{c}\text { RTFOT-virgem } \\
94-5-1\end{array}$ & $\begin{array}{c}\text { PAV-virgem } \\
94-5-1\end{array}$ & $\begin{array}{c}\text { PAV-RTFOT } \\
94-5-1\end{array}$ \\
\hline $1,00 \mathrm{E}-05$ & 0,81 & $-2,26$ & $-3,07$ \\
$1,00 \mathrm{E}-04$ & $-0,25$ & $-3,58$ & $-3,33$ \\
$1,00 \mathrm{E}-03$ & $-1,11$ & $-4,32$ & $-3,21$ \\
$1,00 \mathrm{E}-02$ & $-0,03$ & $-2,68$ & $-2,65$ \\
$1,00 \mathrm{E}-01$ & 0,14 & $-5,03$ & $-5,17$ \\
$1,00 \mathrm{E}+00$ & $-1,19$ & $-7,91$ & $-6,72$ \\
$1,00 \mathrm{E}+01$ & 1,63 & $-7,60$ & $-9,24$ \\
$1,00 \mathrm{E}+02$ & 1,71 & $-7,65$ & $-9,36$ \\
$1,00 \mathrm{E}+03$ & 3,54 & $-5,53$ & $-9,07$ \\
$1,00 \mathrm{E}+04$ & 3,87 & $-2,92$ & $-6,79$ \\
$1,00 \mathrm{E}+05$ & 4,37 & $-1,44$ & $-5,81$ \\
\hline média & 1,23 & $-4,63$ & $-5,86$ \\
\hline
\end{tabular}

Tabela 5.38 - Variações do ângulo de fase ( $\delta$ ) devidas ao envelhecimento para a mistura 93-5-2

\begin{tabular}{cccc}
\hline & \multicolumn{3}{c}{ Diferenças } \\
\cline { 2 - 4 } $\begin{array}{c}\text { Frequência } \\
\text { (rad/s) }\end{array}$ & $\begin{array}{c}\text { RTFOT-virgem } \\
93-5-2\end{array}$ & $\begin{array}{c}\text { PAV-virgem } \\
93-5-2\end{array}$ & $\begin{array}{c}\text { PAV-RTFOT } \\
93-5-2\end{array}$ \\
\hline $1,00 \mathrm{E}-05$ & - & - & - \\
$1,00 \mathrm{E}-04$ & - & - & - \\
$1,00 \mathrm{E}-03$ & - & - & - \\
$1,00 \mathrm{E}-02$ & - & - & - \\
$1,00 \mathrm{E}-01$ & $-7,77$ & $-11,10$ & $-3,33$ \\
$1,00 \mathrm{E}+00$ & $-3,89$ & $-8,69$ & $-4,80$ \\
$1,00 \mathrm{E}+01$ & $-8,98$ & $-13,43$ & $-4,46$ \\
$1,00 \mathrm{E}+02$ & $-9,95$ & $-13,37$ & $-3,42$ \\
$1,00 \mathrm{E}+03$ & $-9,84$ & $-12,61$ & $-2,77$ \\
$1,00 \mathrm{E}+04$ & $-9,02$ & $-11,22$ & $-2,20$ \\
$1,00 \mathrm{E}+05$ & $-8,13$ & $-9,46$ & $-1,33$ \\
\hline média & $-5,23$ & $-7,26$ & $-2,03$ \\
\hline
\end{tabular}


Tabela 5.39 - Variações médias do ângulo de fase, nas frequências entre 1E-5 a 1E+5 em função dos níveis de envelhecimento

\begin{tabular}{cccc}
\hline Misturas & RTFOT-virgem & PAV-virgem & PAV-RTFOT \\
\hline Replan 50/70 & $-3,55$ & $-9,52$ & $-5,96$ \\
$\mathbf{1 0 0 - 0 - 0}$ & $-3,98$ & $-10,63$ & $-6,65$ \\
$\mathbf{9 9 - 0 - 1}$ & $-3,22$ & $-9,99$ & $-6,77$ \\
$\mathbf{9 8 - 0 - 2}$ & $-4,22$ & $-8,80$ & $-4,57$ \\
$\mathbf{9 7 , 5 - 2 , 5 - 0}$ & $-6,15$ & $-15,06$ & $-8,92$ \\
$\mathbf{9 6 , 5 - 2 , 5 - 1}$ & $-7,06$ & $-13,92$ & $-6,85$ \\
$\mathbf{9 5 , 5 - 2 , 5 - 2}$ & $-3,49$ & $-9,14$ & $-5,64$ \\
$\mathbf{9 5 - 5 - 0}$ & $-1,40$ & $-10,82$ & $-9,42$ \\
$\mathbf{9 4 - 5 - 1}$ & 1,23 & $-4,63$ & $-5,86$ \\
$\mathbf{9 3 - 5 - 2}$ & $-5,23$ & $-7,26$ & $-2,03$ \\
\hline
\end{tabular}

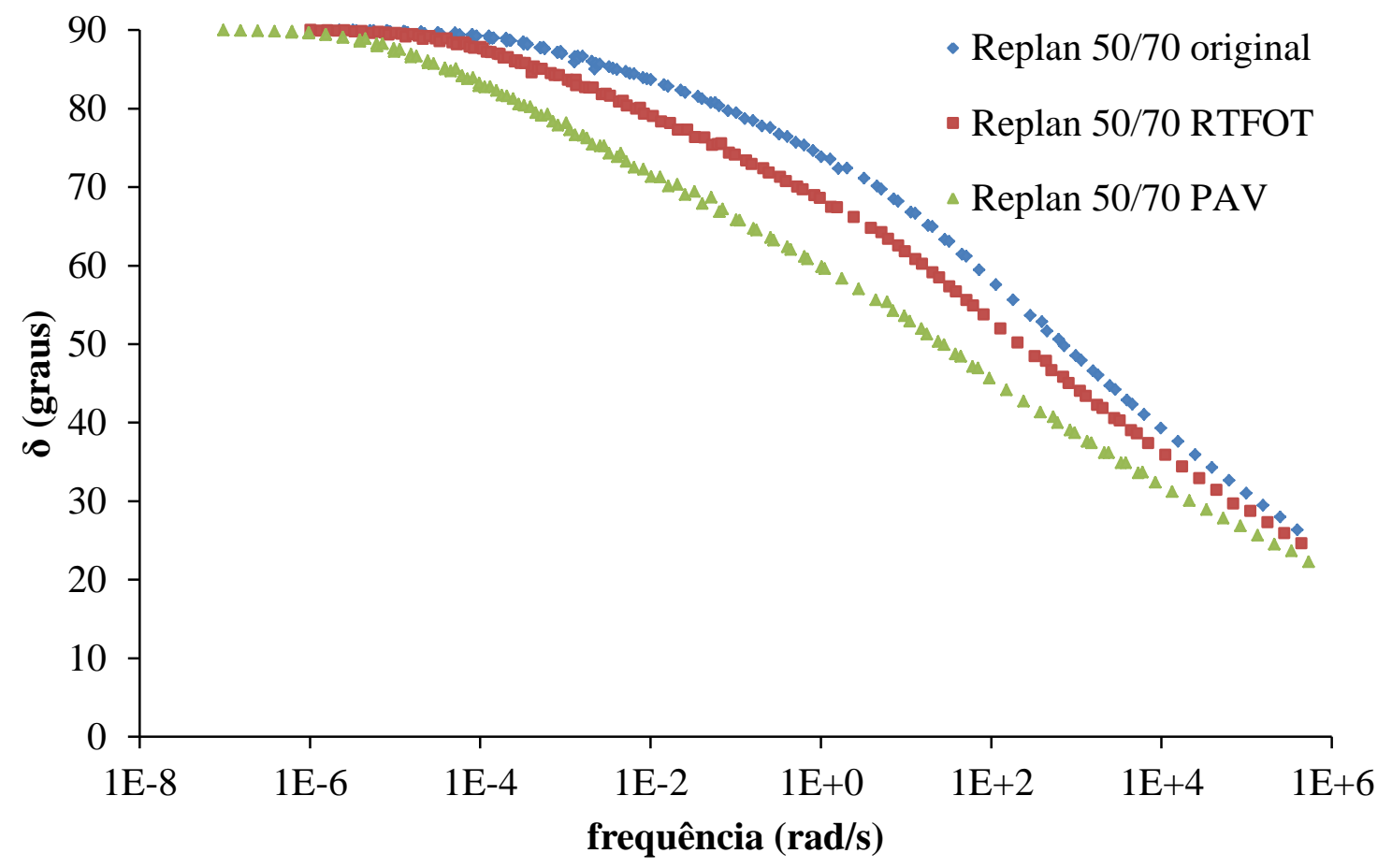

Figura 5.25 - Curvas-mestre de $\delta$ para o ligante asfáltico de base para as condições virgem, envelhecida a curto prazo e envelhecida a longo prazo 


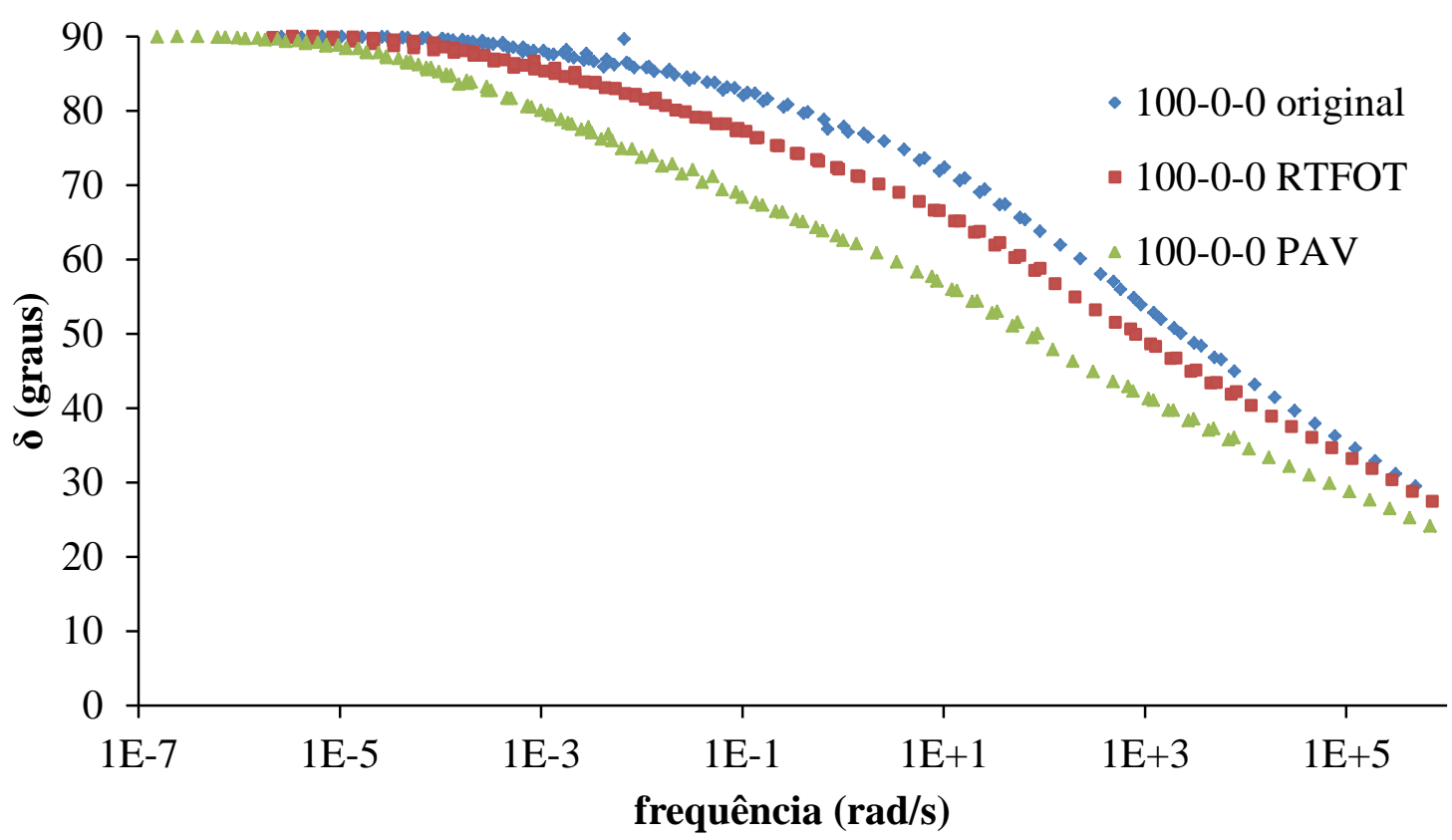

Figura 5.26 - Curvas-mestre de $\delta$ para a mistura de 100-0-0 para as condições virgem, envelhecida a curto prazo e envelhecida a longo prazo

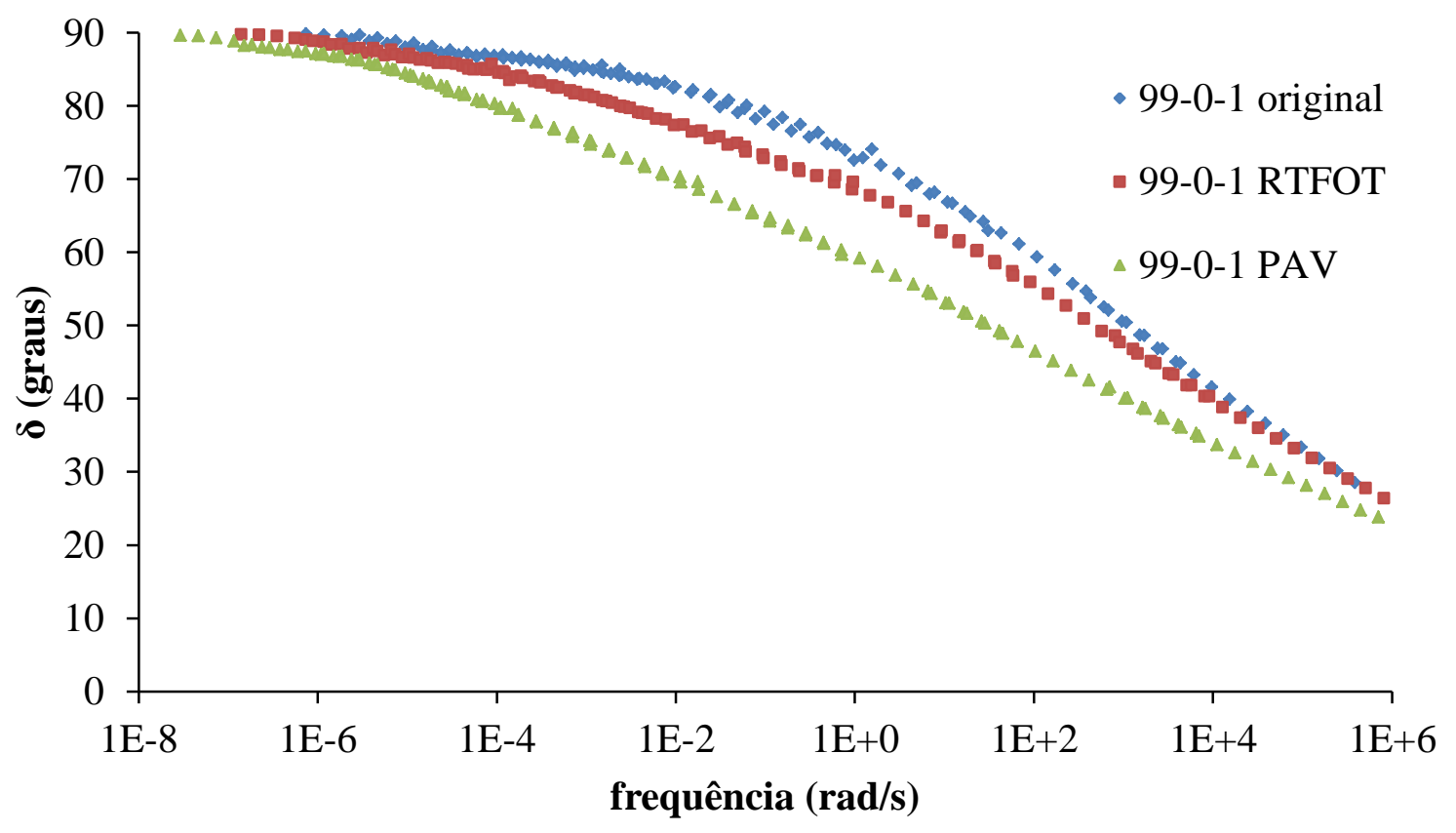

Figura 5.27 - Curvas-mestre de $\delta$ para a mistura de 99-0-1 para as condições virgem, envelhecida a curto prazo e envelhecida a longo prazo 


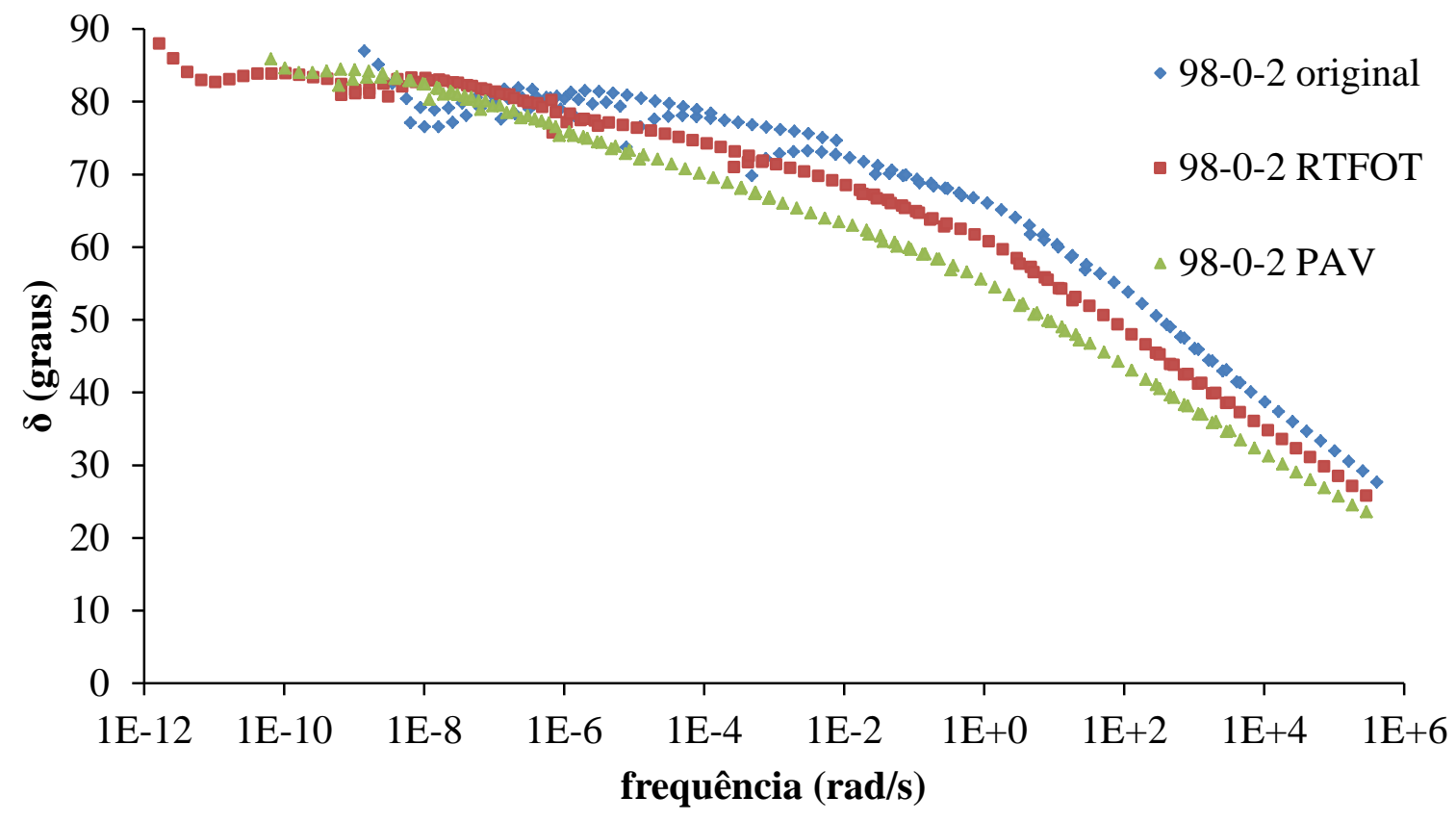

Figura 5.28 - Curvas-mestre de $\delta$ para a mistura de 98-0-2 para as condições virgem, envelhecida a curto prazo e envelhecida a longo prazo

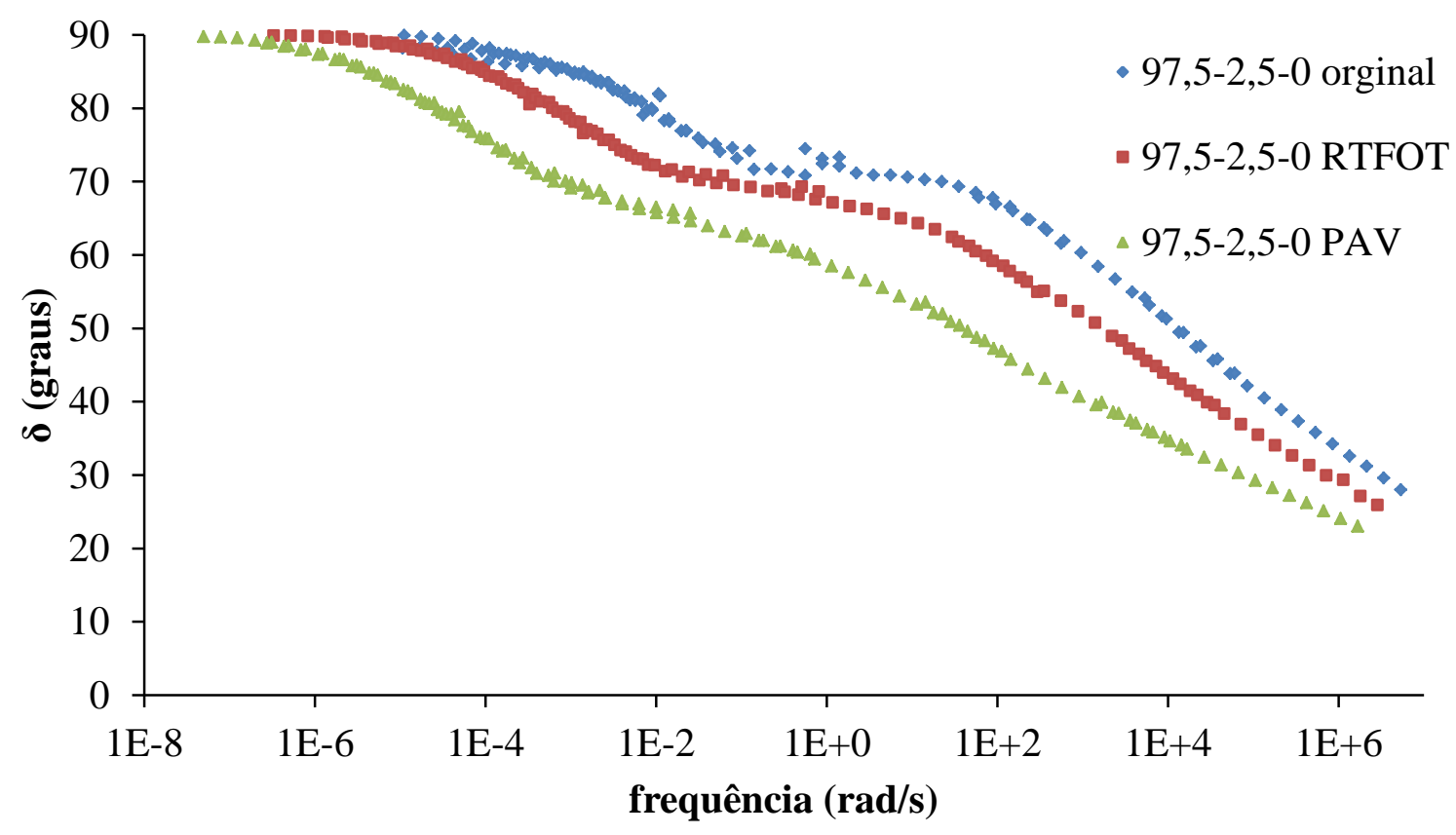

Figura 5.29 - Curvas-mestre de $\delta$ para a mistura de 97,5-2,5-0 para as condições virgem, envelhecida a curto prazo e envelhecida a longo prazo 


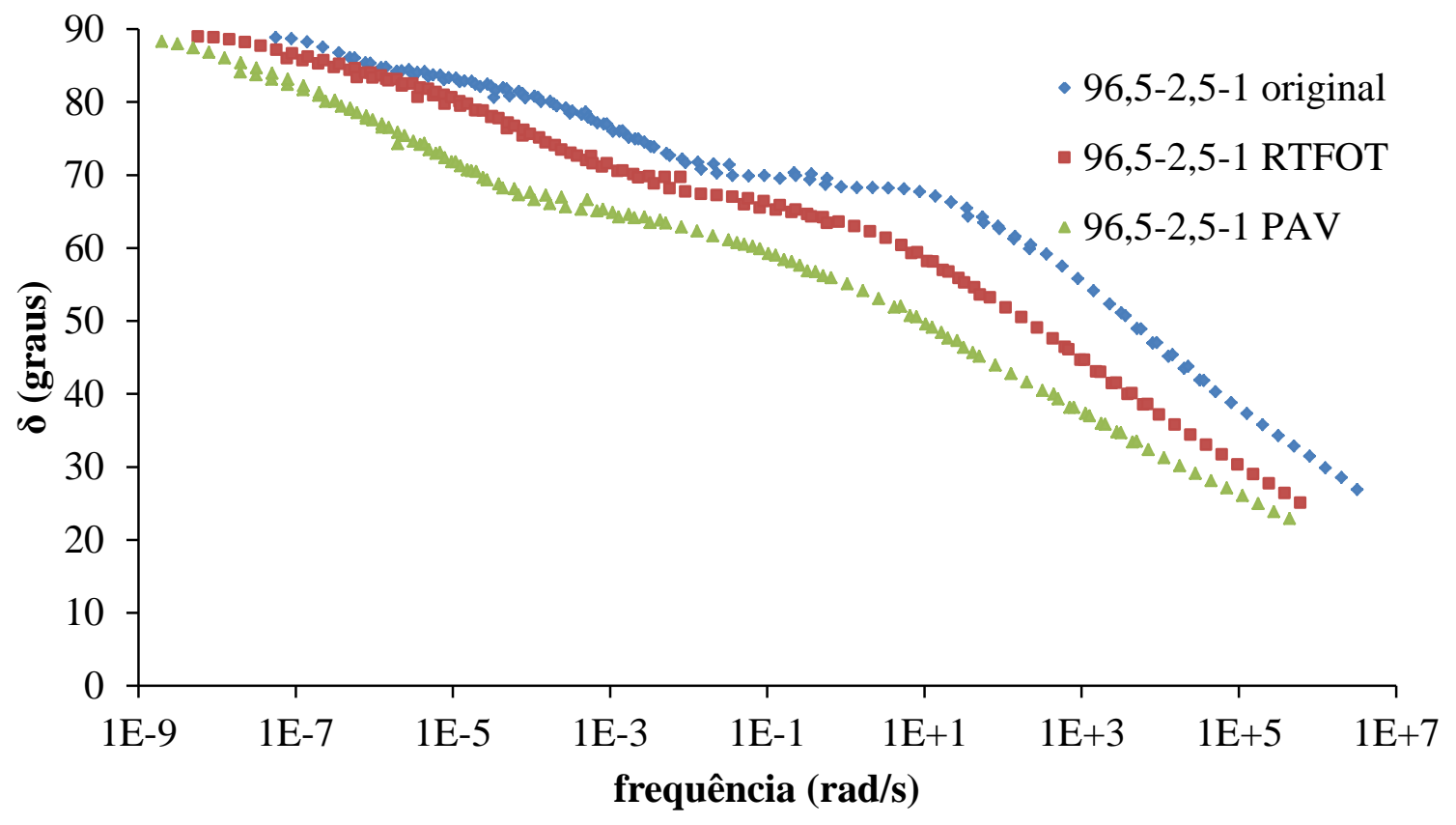

Figura 5.30 - Curvas-mestre de $\delta$ para a mistura de 96,5-2,5-1 para as condições virgem, envelhecida a curto prazo e envelhecida a longo prazo

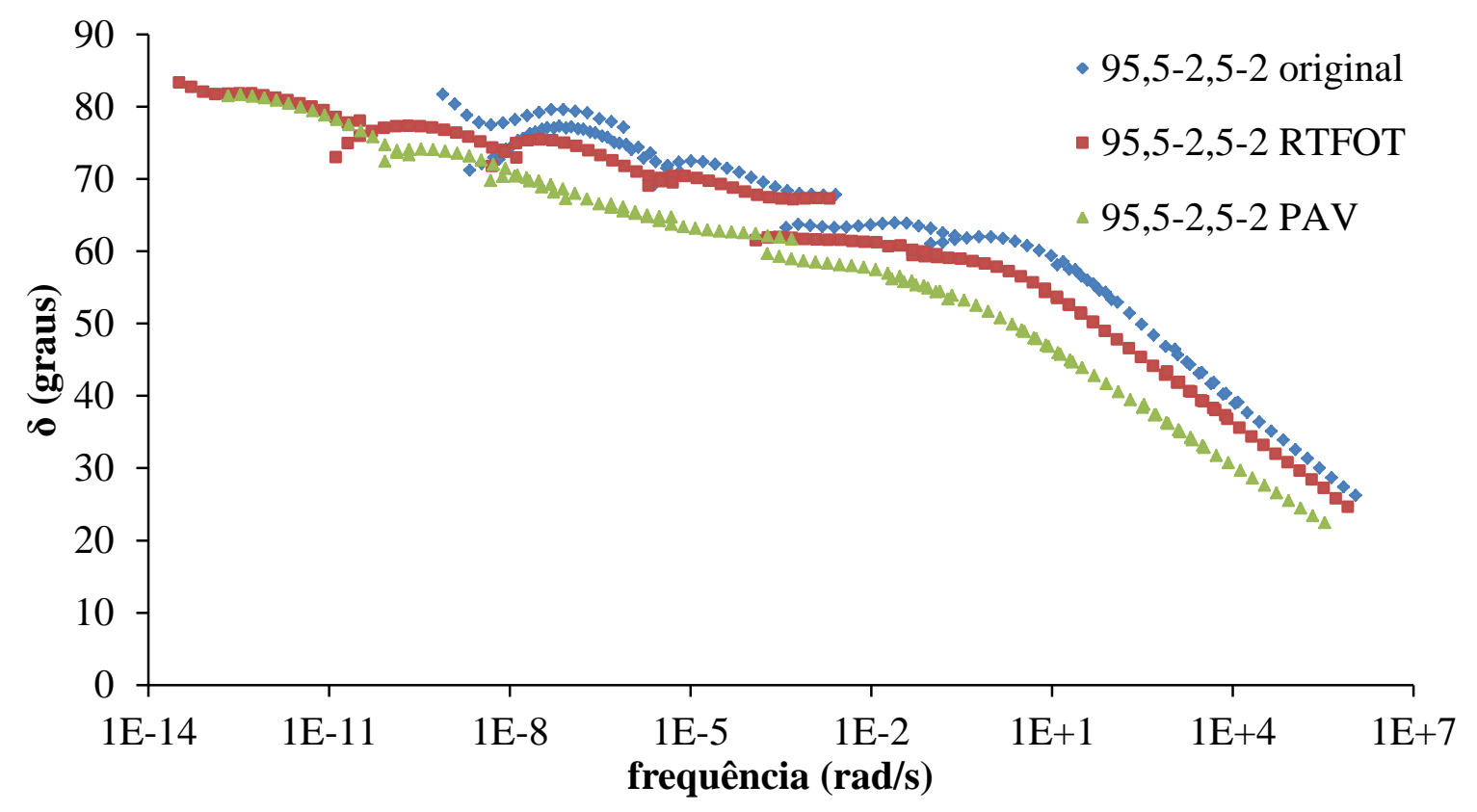

Figura 5.31 - Curvas-mestre de $\delta$ para a mistura de 95,5-2,5-2 para as condições virgem, envelhecida a curto prazo e envelhecida a longo prazo 


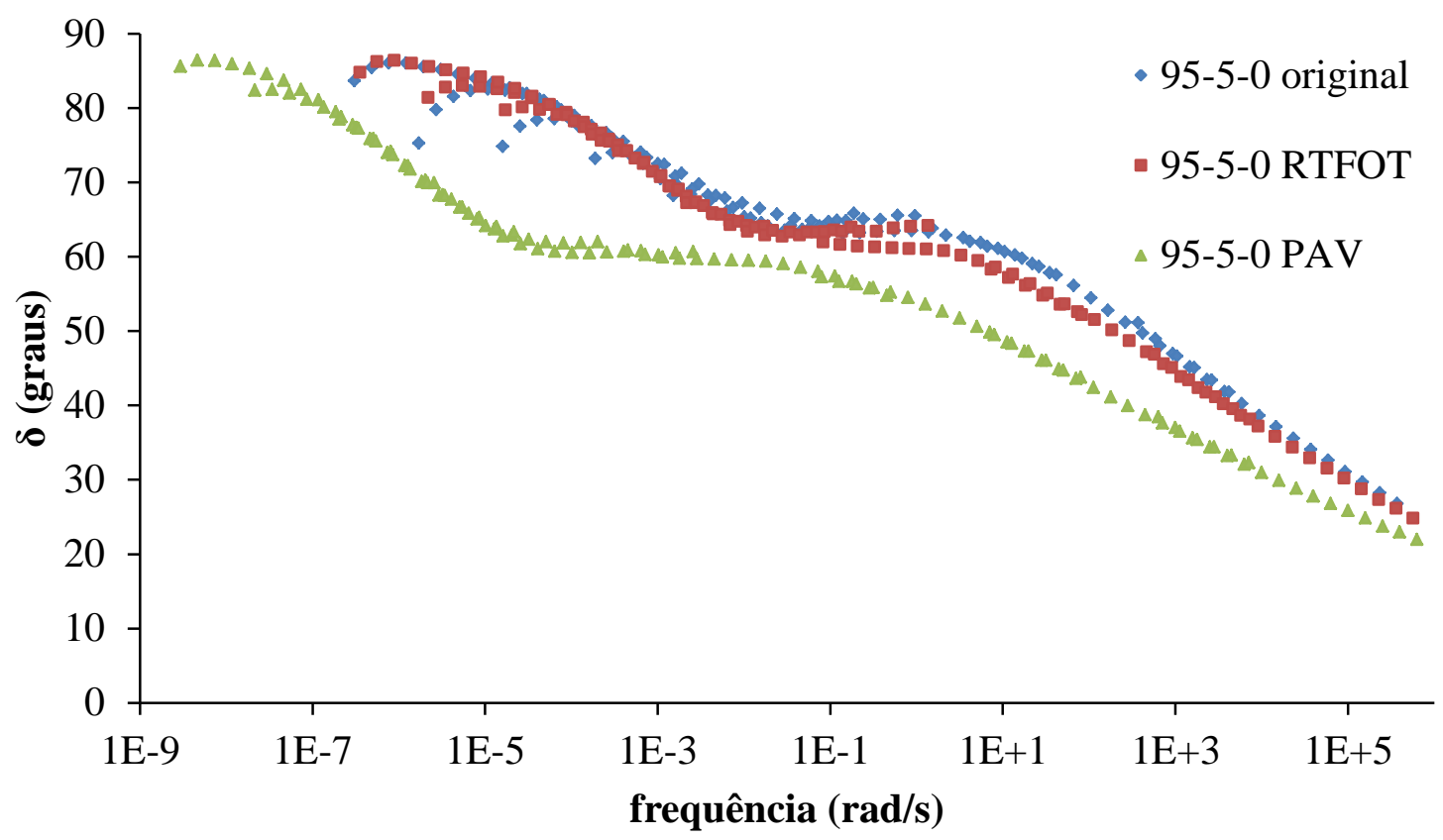

Figura 5.32 - Curvas-mestre de $\delta$ para a mistura de 95-5-0 para as condições virgem, envelhecida a curto prazo e envelhecida a longo prazo

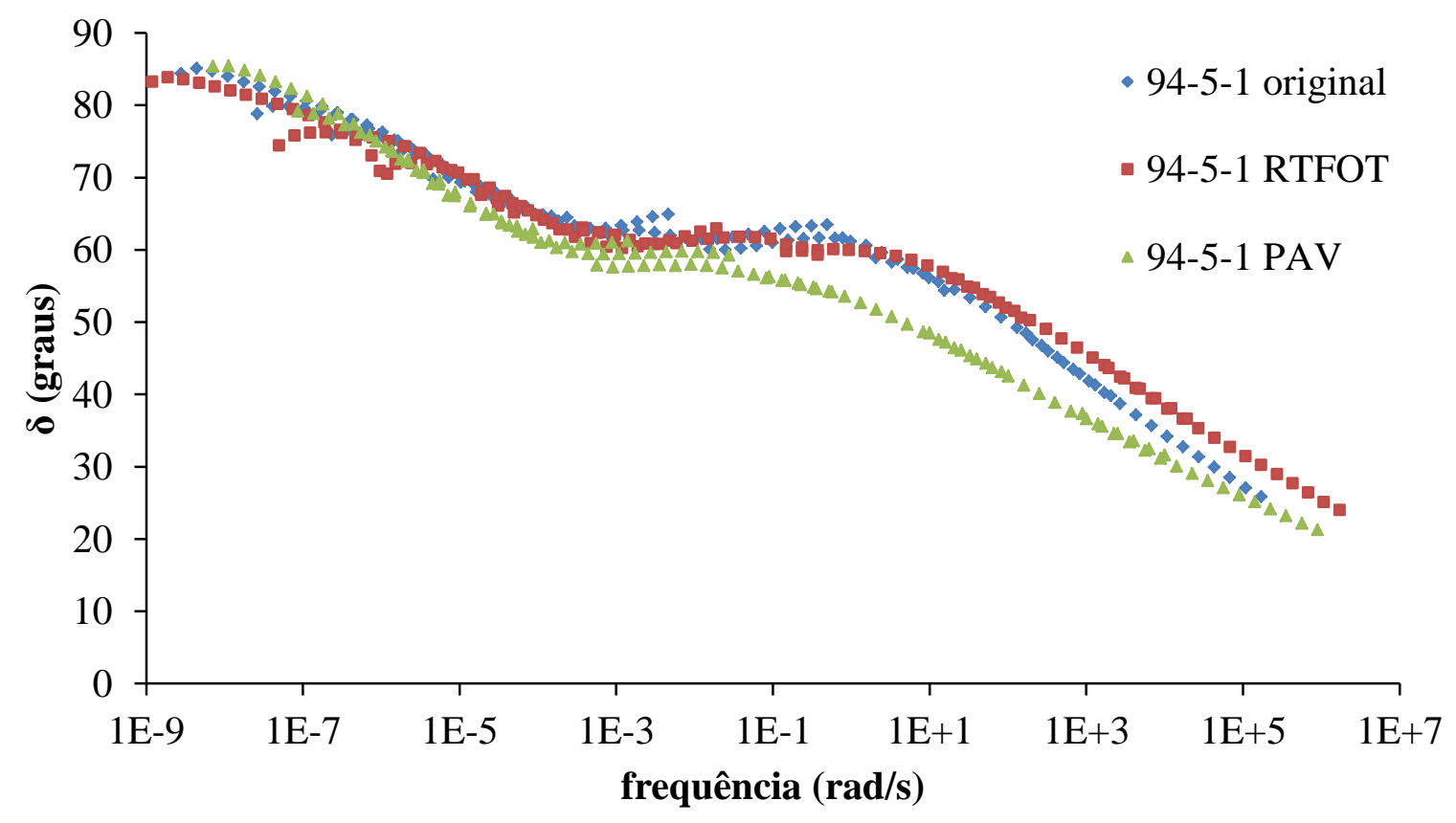

Figura 5.33 - Curvas-mestre de $\delta$ para a mistura de 94-5-1 para as condições virgem, envelhecida a curto prazo e envelhecida a longo prazo 


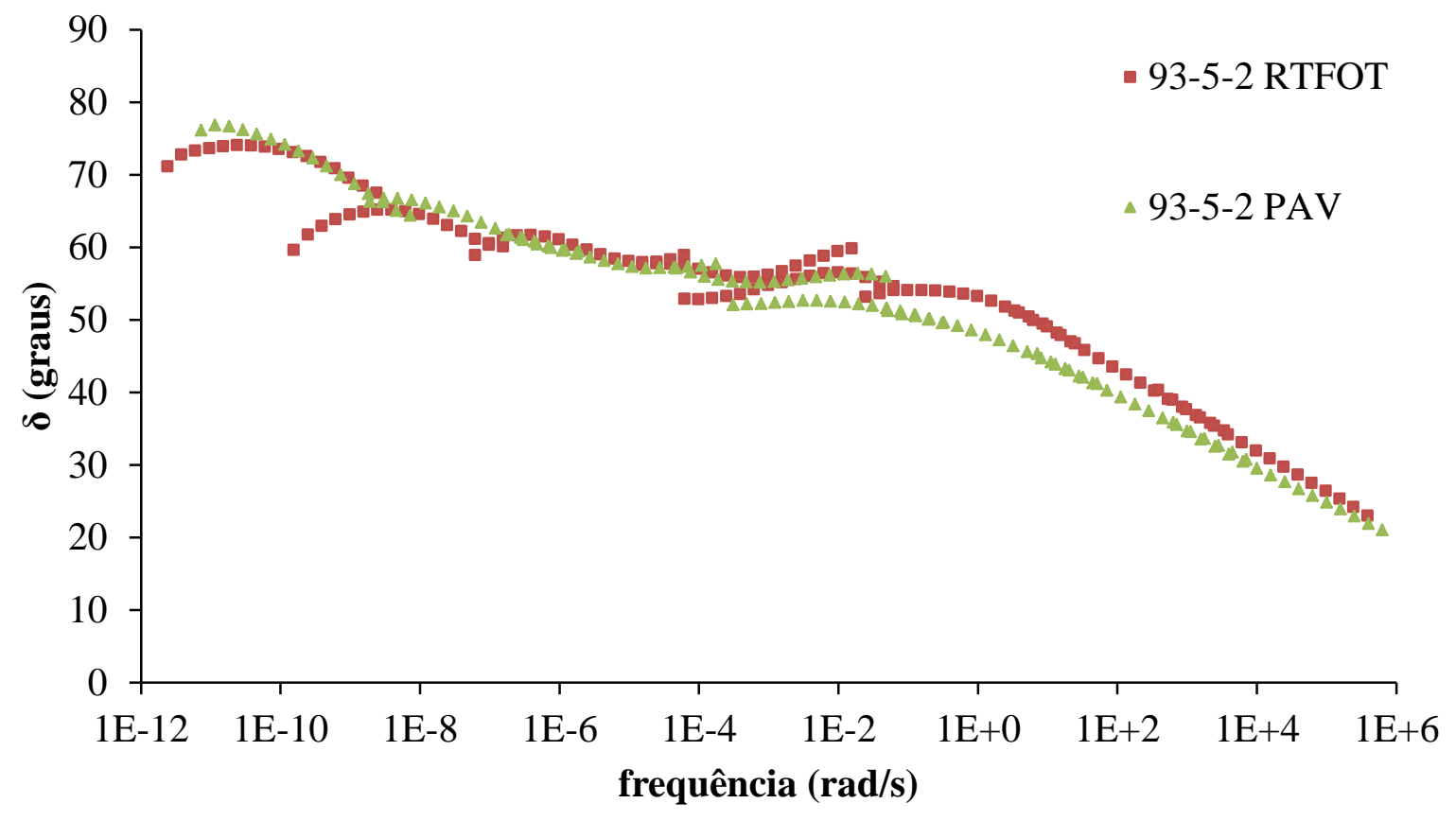

Figura 5.34 - Curvas-mestre de $\delta$ para a mistura de 93-5-2 para as condições virgem, envelhecida a curto prazo e envelhecida a longo prazo

As seguintes observações podem ser feitas acerca do efeito dos envelhecimentos a curto e a longo prazos sobre os valores de delta das misturas:

- para a relação RTFOT-virgem, tem-se que a menor diferença obtida foi para a mistura 94-5-1 $(1,23)$ seguida da mistura 95-5-0 (-1,40); a maior diferença obtida foi para a mistura 93-5-2 ($8,22)$ seguida da mistura 97,5-2,5-1 (-6,67); tais variações pequenas nos valores de delta indica que as misturas com alto teor de SBS sofrem pequeno efeito do envelhecimento a curto prazo, no entanto, ao aumentar a proporção de TITAN para $2 \%$, em combinação com $5 \%$ de SBS, a sensibilidade ao envelhecimento a curto prazo aumenta substancialmente;

- para a relação PAV-virgem, tem-se que a menor diferença obtida foi para a mistura 94-5-1 (4,63) seguida da mistura 98-0-2 (-8,80); a maior diferença obtida foi para a mistura 97,5-2,5-0 $(-15,06)$ seguida da mistura 96,5-2,5-1 (-13,70); novamente a mistura 94-5-1 se mostrou pouco sensível ao envelhecimento, agora a longo prazo e, por outro lado e curiosamente, as misturas mais sensíveis são duas que apresentam baixas proporções de SBS e TITAN;

- para a relação PAV-RTFOT, tem-se que a menor diferença obtida foi para a mistura 93-5-2 ($2,03)$ seguida da mistura $98-0-2(-4,57)$; a maior diferença obtida foi para a mistura $95-5-0$ ($9,42)$ seguida da mistura 97,5-2,5-0 (-8,92); neste caso as misturas com $2 \%$ de TITAN se 
mostraram pouco sensíveis ao envelhecimento e as misturas mais sensíveis ao envelhecimento são as que não apresentam TITAN;

- a mistura 94-5-1 apresenta na relação RTFOT/virgem algumas frequências em que houve ganho do ângulo de fase, ou seja, o ângulo de fase da mistura envelhecida a curto prazo é maior do que na condição virgem. É um resultado incomum, visto que apenas ocorreu esse ganho uma vez para esta mistura em uma condição de envelhecimento.

5.6.4 Efeito das aditivações à luz dos resultados de $G^{*}$ nos diferentes níveis de envelhecimento

As Tabelas de 5.40 a 5.43 apresentam as relações entre os valore de $\mathrm{G}^{*}$ da mistura 1000-0 com as demais $\left(\mathrm{G}^{*}{ }_{\text {misturas }} / \mathrm{G}^{*}{ }_{100-0-0}\right)$, nas condições virgem (Tabela 5.40), envelhecida a curto prazo (tabela 5.41), envelhecida a longo prazo (Tabela 5.42) e índice de envelhecimento médio. As Figuras de 5.35 a 5.42 mostram os comparativos entre as curvas-mestre, na condição virgem. As Figuras de 5.43 a 5.50 mostram os comparativos entre as curvas-mestre na condição envelhecida a curto prazo. As Figuras de 5.51 a 5.58 mostram os comparativos entre as curvas-mestre na condição envelhecida a longo prazo. A título de comparação, as curvas-mestre do CAP puro virgem, envelhecido a curto prazo e envelhecido a longo prazo acompanharão as curvas-mestre dos demais materiais. 
Tabela 5.40 - Relação dos valores de $G^{*}$ das misturas com a mistura 100-0-0, na condição virgem $\left(\mathrm{G}^{*}{ }_{\text {misturas }} / \mathrm{G}^{*}{ }_{100-0-0}\right)$

\begin{tabular}{cccccccccc}
\hline $\begin{array}{c}\text { Frequências } \\
\text { (rad/s) }\end{array}$ & \multicolumn{10}{c}{ Misturas } \\
\cline { 2 - 9 } & $\mathbf{1 0 0 - 0 - 0}$ & $\mathbf{9 9 - 0 - 1}$ & $\mathbf{9 8 - 0 - 2}$ & $\mathbf{9 7 , 5 - 2 , 5 - 0}$ & $\mathbf{9 6 , 5 - 2 , 5 - 1}$ & $\mathbf{9 5 , 5 - 2 , 5 - 2}$ & $\mathbf{9 5 - 5 - 0}$ & $\mathbf{9 4 - 5 - 1}$ & $\mathbf{9 3 - 5 - 2}$ \\
\hline $1,00 \mathrm{E}-05$ & 1,00 & 2,17 & 21,86 & 2,72 & 7,59 & 41,81 & 12,40 & 32,15 & 191,24 \\
$1,00 \mathrm{E}-04$ & 1,00 & 2,07 & 9,62 & 2,58 & 5,96 & 23,70 & 9,76 & 24,09 & 104,65 \\
$1,00 \mathrm{E}-03$ & 1,00 & 1,91 & 7,82 & 2,37 & 4,88 & 17,35 & 8,14 & 17,59 & 55,58 \\
$1,00 \mathrm{E}-02$ & 1,00 & 1,81 & 6,02 & 2,17 & 4,07 & 11,81 & 5,35 & 9,66 & 26,54 \\
$1,00 \mathrm{E}-01$ & 1,00 & 1,70 & 4,63 & 1,81 & 2,99 & 6,80 & 3,13 & 5,29 & 13,05 \\
$1,00 \mathrm{E}+00$ & 1,00 & 1,57 & 3,41 & 1,44 & 2,15 & 4,39 & 2,08 & 3,32 & 7,10 \\
$1,00 \mathrm{E}+01$ & 1,00 & 1,44 & 2,59 & 1,24 & 1,77 & 2,94 & 1,56 & 2,27 & 4,35 \\
$1,00 \mathrm{E}+02$ & 1,00 & 1,32 & 1,98 & 1,12 & 1,46 & 2,05 & 1,27 & 1,68 & 2,82 \\
$1,00 \mathrm{E}+03$ & 1,00 & 1,24 & 1,58 & 1,02 & 1,26 & 1,54 & 1,08 & 1,32 & 1,99 \\
$1,00 \mathrm{E}+04$ & 1,00 & 1,21 & 1,40 & 0,97 & 1,13 & 1,29 & 0,98 & 1,12 & 1,58 \\
$1,00 \mathrm{E}+05$ & 1,00 & 1,16 & 1,28 & 0,93 & 1,03 & 1,13 & 0,90 & 0,98 & 1,31 \\
\hline média & 1,00 & 1,60 & 5,65 & 1,67 & 3,12 & 10,44 & 4,24 & 9,04 & 37,29 \\
\hline
\end{tabular}

Tabela 5.41 - Relação dos valores de $G^{*}$ das misturas com a mistura 100-0-0, na condição envelhecida a curto prazo $\left(G^{*}{ }_{\text {misturas }} / G^{*}{ }_{100-0-0}\right)$

\begin{tabular}{|c|c|c|c|c|c|c|c|c|c|}
\hline \multirow{2}{*}{$\begin{array}{l}\text { Frequências } \\
(\mathrm{rad} / \mathrm{s})\end{array}$} & \multicolumn{9}{|c|}{ Misturas } \\
\hline & 100-0-0 & 99-0-1 & 98-0-2 & $97,5-2,5-0$ & $96,5-2,5-1$ & $95,5-2,5-2$ & 95-5-0 & 94-5-1 & $93-5-2$ \\
\hline $1,00 \mathrm{E}-05$ & 1,00 & 2,33 & 9,08 & 2,89 & 6,78 & 22,61 & 9,82 & 23,30 & 97,71 \\
\hline $1,00 \mathrm{E}-04$ & 1,00 & 2,26 & 6,51 & 2,82 & 6,18 & 17,48 & 8,24 & 17,26 & 53,57 \\
\hline $1,00 \mathrm{E}-03$ & 1,00 & 2,05 & 5,36 & 2,58 & 5,01 & 12,13 & 6,38 & 12,04 & 27,83 \\
\hline $1,00 \mathrm{E}-02$ & 1,00 & 1,92 & 4,39 & 2,21 & 3,97 & 7,80 & 3,93 & 6,63 & 13,61 \\
\hline $1,00 \mathrm{E}-01$ & 1,00 & 1,66 & 3,27 & 1,60 & 2,69 & 4,90 & 2,34 & 3,66 & 6,67 \\
\hline $1,00 \mathrm{E}+00$ & 1,00 & 1,52 & 2,47 & 1,38 & 2,07 & 3,27 & 1,73 & 2,55 & 3,97 \\
\hline $1,00 \mathrm{E}+01$ & 1,00 & 1,32 & 1,89 & 1,24 & 1,61 & 2,28 & 1,38 & 1,82 & 2,51 \\
\hline $1,00 \mathrm{E}+02$ & 1,00 & 1,26 & 1,56 & 1,12 & 1,38 & 1,80 & 1,18 & 1,45 & 1,80 \\
\hline $1,00 \mathrm{E}+03$ & 1,00 & 1,22 & 1,39 & 1,08 & 1,26 & 1,51 & 1,07 & 1,25 & 1,43 \\
\hline $1,00 \mathrm{E}+04$ & 1,00 & 1,19 & 1,29 & 1,04 & 1,17 & 1,34 & 0,99 & 1,11 & 1,20 \\
\hline $1,00 \mathrm{E}+05$ & 1,00 & 1,15 & 1,22 & 0,99 & 1,09 & 1,22 & 0,92 & 1,00 & 1,05 \\
\hline média & 1,00 & 1,62 & 3,49 & 1,72 & 3,02 & 6,94 & 3,45 & 6,55 & 19,21 \\
\hline
\end{tabular}


Tabela 5.42 - Relação dos valores de $G^{*}$ das misturas com a mistura 100-0-0, na condição envelhecida a longo prazo $\left(G^{*}{ }_{\text {misturas }} / G^{*}{ }_{100-0-0}\right)$

\begin{tabular}{cccccccccc}
\hline $\begin{array}{c}\text { Frequências } \\
\text { (rad/s) }\end{array}$ & \multicolumn{10}{c}{ Misturas } \\
\cline { 2 - 10 } & $\mathbf{1 0 0 - 0 - 0}$ & $\mathbf{9 9 - 0 - 1}$ & $\mathbf{9 8 - 0 - 2}$ & $\mathbf{9 7 , 5 - 2 , 5 - 0}$ & $\mathbf{9 6 , 5 - 2 , 5 - 1}$ & $\mathbf{9 5 , 5 - 2 , 5 - 2}$ & $\mathbf{9 5 - 5 - 0}$ & $\mathbf{9 4 - 5 - 1}$ & $\mathbf{9 3 - 5 - 2}$ \\
\hline $1,00 \mathrm{E}-05$ & 1,00 & 1,90 & 5,52 & 3,09 & 7,51 & 14,51 & 8,95 & 15,51 & 53,22 \\
$1,00 \mathrm{E}-04$ & 1,00 & 1,78 & 4,59 & 2,86 & 6,24 & 10,98 & 7,18 & 11,11 & 28,35 \\
$1,00 \mathrm{E}-03$ & 1,00 & 1,63 & 3,31 & 2,41 & 4,42 & 6,25 & 4,73 & 6,37 & 14,14 \\
$1,00 \mathrm{E}-02$ & 1,00 & 1,54 & 2,71 & 1,83 & 3,10 & 4,04 & 2,89 & 3,71 & 7,07 \\
$1,00 \mathrm{E}-01$ & 1,00 & 1,51 & 2,37 & 1,68 & 2,43 & 2,92 & 2,39 & 2,69 & 4,41 \\
$1,00 \mathrm{E}+00$ & 1,00 & 1,31 & 1,75 & 1,45 & 1,86 & 2,00 & 1,74 & 1,99 & 2,77 \\
$1,00 \mathrm{E}+01$ & 1,00 & 1,18 & 1,43 & 1,25 & 1,49 & 1,50 & 1,35 & 1,48 & 1,86 \\
$1,00 \mathrm{E}+02$ & 1,00 & 1,14 & 1,30 & 1,13 & 1,32 & 1,28 & 1,13 & 1,23 & 1,47 \\
$1,00 \mathrm{E}+03$ & 1,00 & 1,11 & 1,25 & 1,06 & 1,20 & 1,16 & 1,00 & 1,08 & 1,24 \\
$1,00 \mathrm{E}+04$ & 1,00 & 1,10 & 1,19 & 1,00 & 1,13 & 1,08 & 0,92 & 0,97 & 1,09 \\
$1,00 \mathrm{E}+05$ & 1,00 & 1,09 & 1,17 & 0,97 & 1,07 & 1,03 & 0,86 & 0,89 & 0,99 \\
\hline média & 1,00 & 1,39 & 2,42 & 1,70 & 2,89 & 4,25 & 3,01 & 4,28 & 10,60 \\
\hline
\end{tabular}

Tabela 5.43 - Índices de envelhecimento dos valores de $\mathrm{G}^{*}$ das misturas com a mistura 100-0-0

\begin{tabular}{cccc}
\hline Misturas & virgem & RTFOT & PAV \\
\hline $\mathbf{1 0 0 - 0 - 0}$ & 1,00 & 1,00 & 1,00 \\
$\mathbf{9 9 - 0 - 1}$ & 1,60 & 1,62 & 1,39 \\
$\mathbf{9 8 - 0 - 2}$ & 5,65 & 3,49 & 2,42 \\
$\mathbf{9 7 , 5 - 2 , 5 - 0}$ & 1,67 & 1,72 & 1,70 \\
$\mathbf{9 6 , 5 - 2 , 5 - 1}$ & 3,12 & 3,02 & 2,89 \\
$\mathbf{9 5 , 5 - 2 , 5 - 2}$ & 10,44 & 6,94 & 4,25 \\
$\mathbf{9 5 - 5 - 0}$ & 4,24 & 3,45 & 3,01 \\
$\mathbf{9 4 - 5 - 1}$ & 9,04 & 6,55 & 4,28 \\
$\mathbf{9 3 - 5 - 2}$ & 37,29 & 19,21 & 10,60 \\
\hline
\end{tabular}




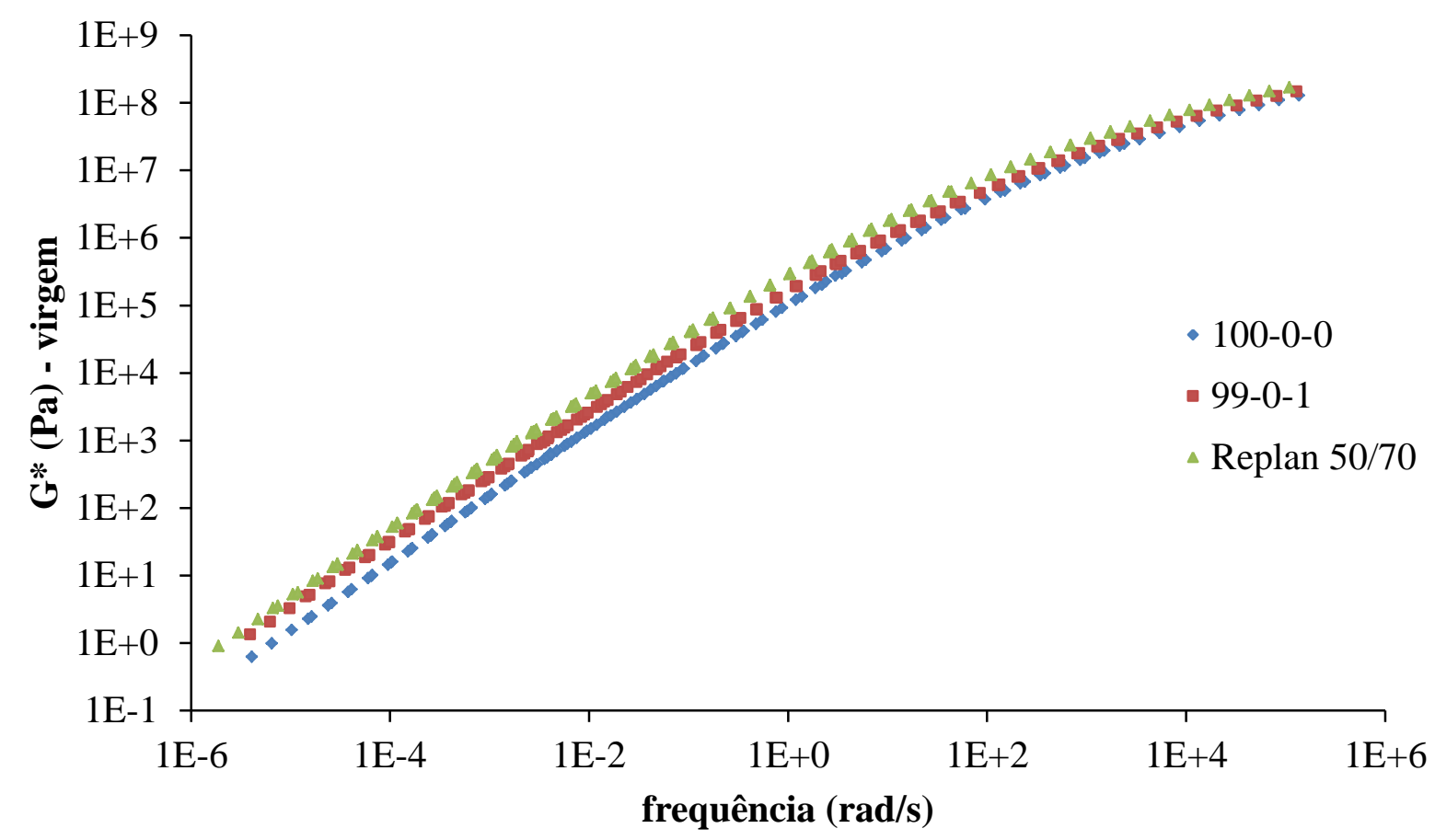

Figura 5.35 - Curvas-mestre para $G^{*}$ na condição virgem para o ligante asfáltico de base e as misturas 100-0-0 e 99-0-1

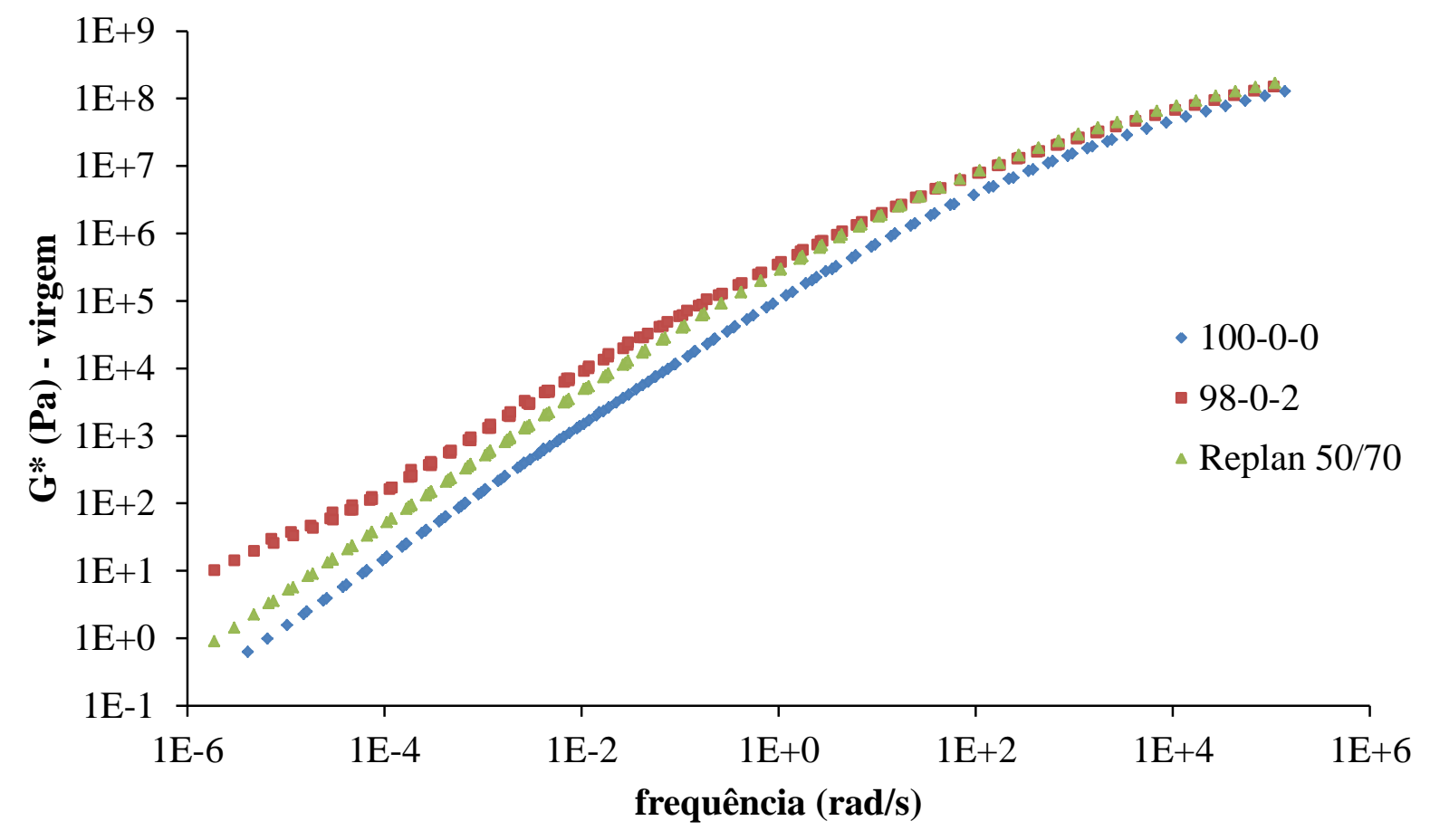

Figura 5.36 - Curvas-mestre para $G *$ na condição virgem para o ligante asfáltico de base e as misturas 100-0-0 e 98-0-2 


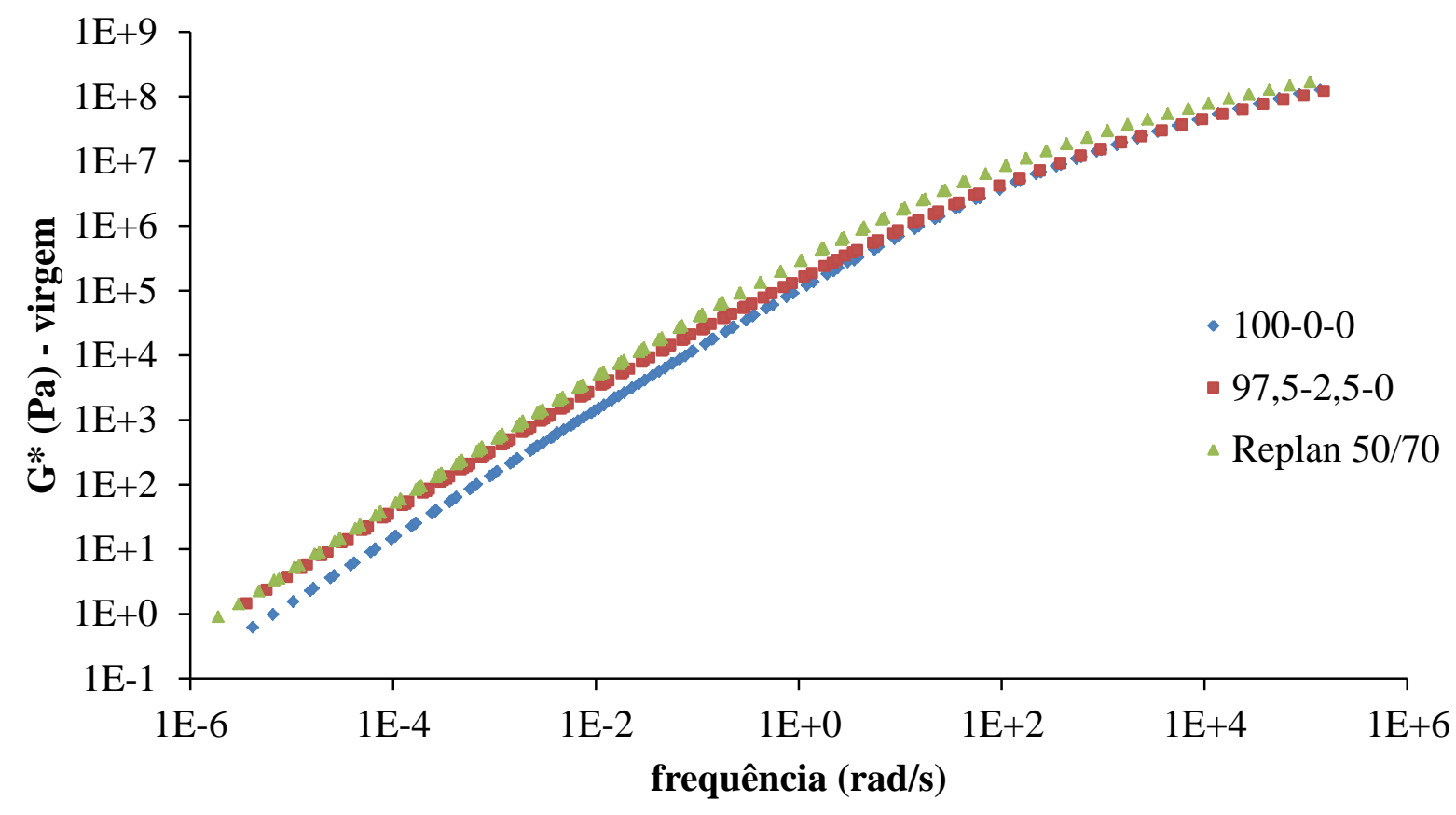

Figura 5.37 - Curvas-mestre para $G *$ na condição virgem para o ligante asfáltico de base e as misturas 100-0-0 e 97,5-2,5-0

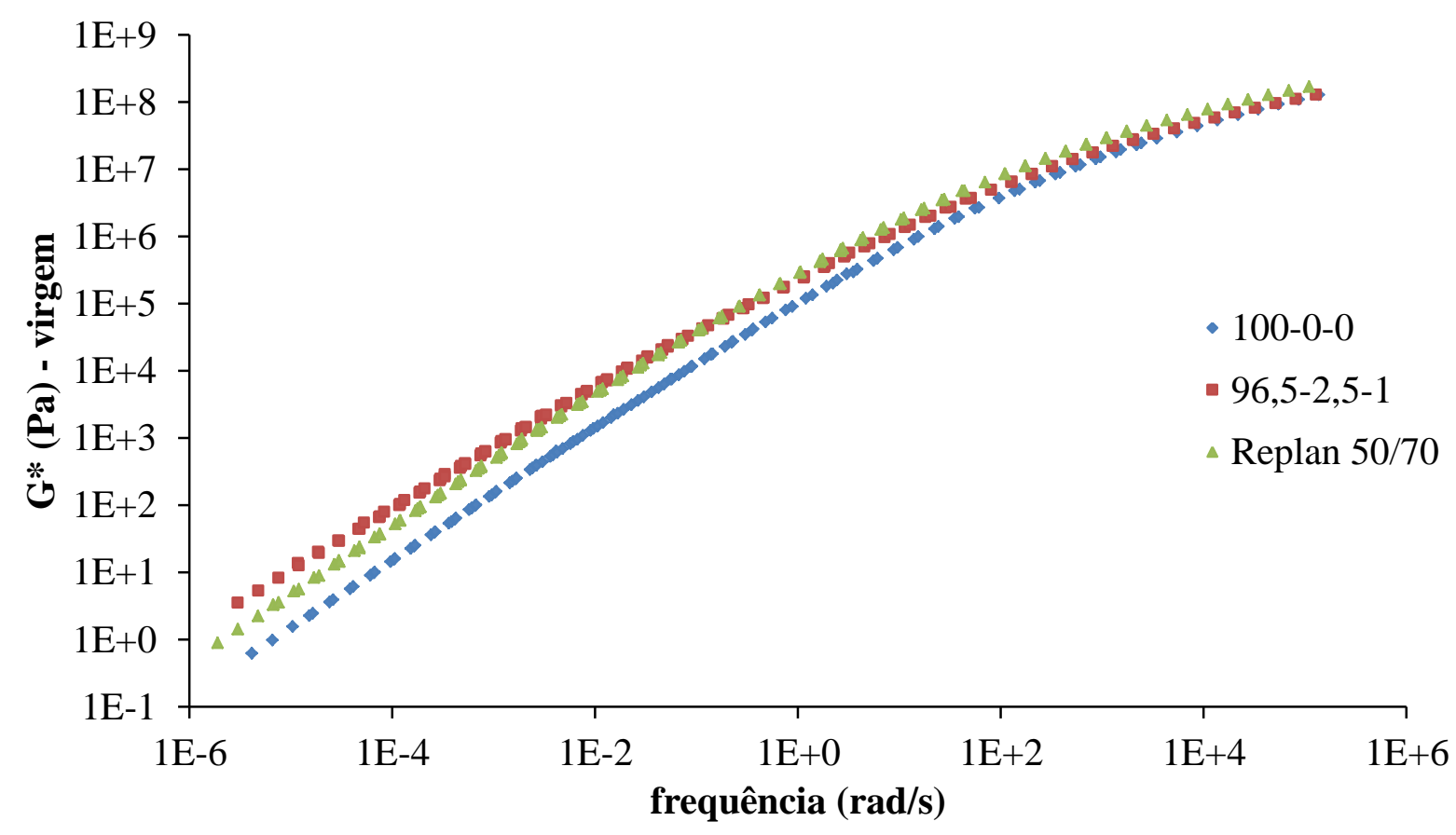

Figura 5.38 - Curvas-mestre para $G^{*}$ na condição virgem para o ligante asfáltico de base e as misturas 100-0-0 e 96,5-2,5-1 


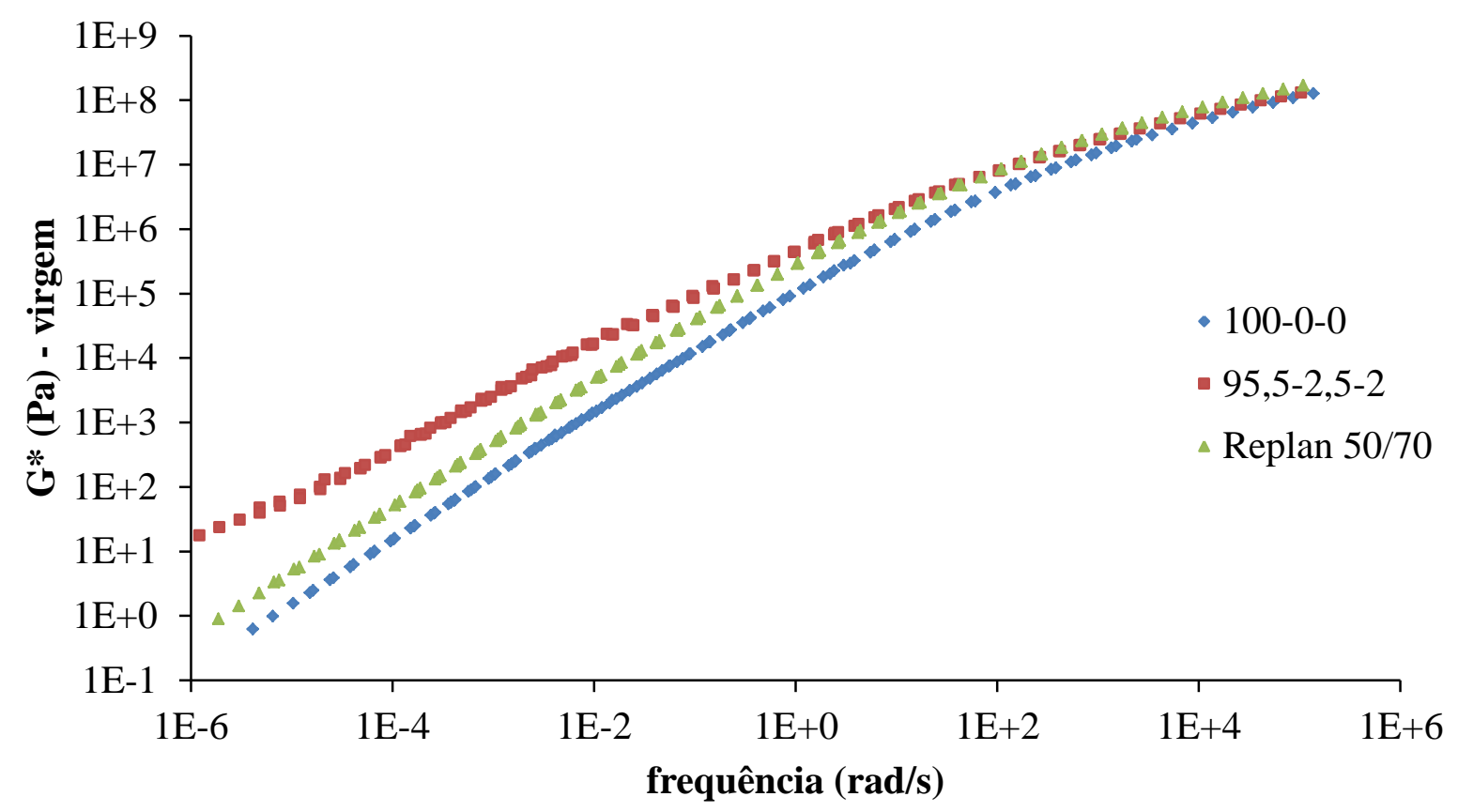

Figura 5.39 - Curvas-mestre para $G *$ na condição virgem para o ligante asfáltico de base e as misturas 100-0-0 e 95,5-2,5-2

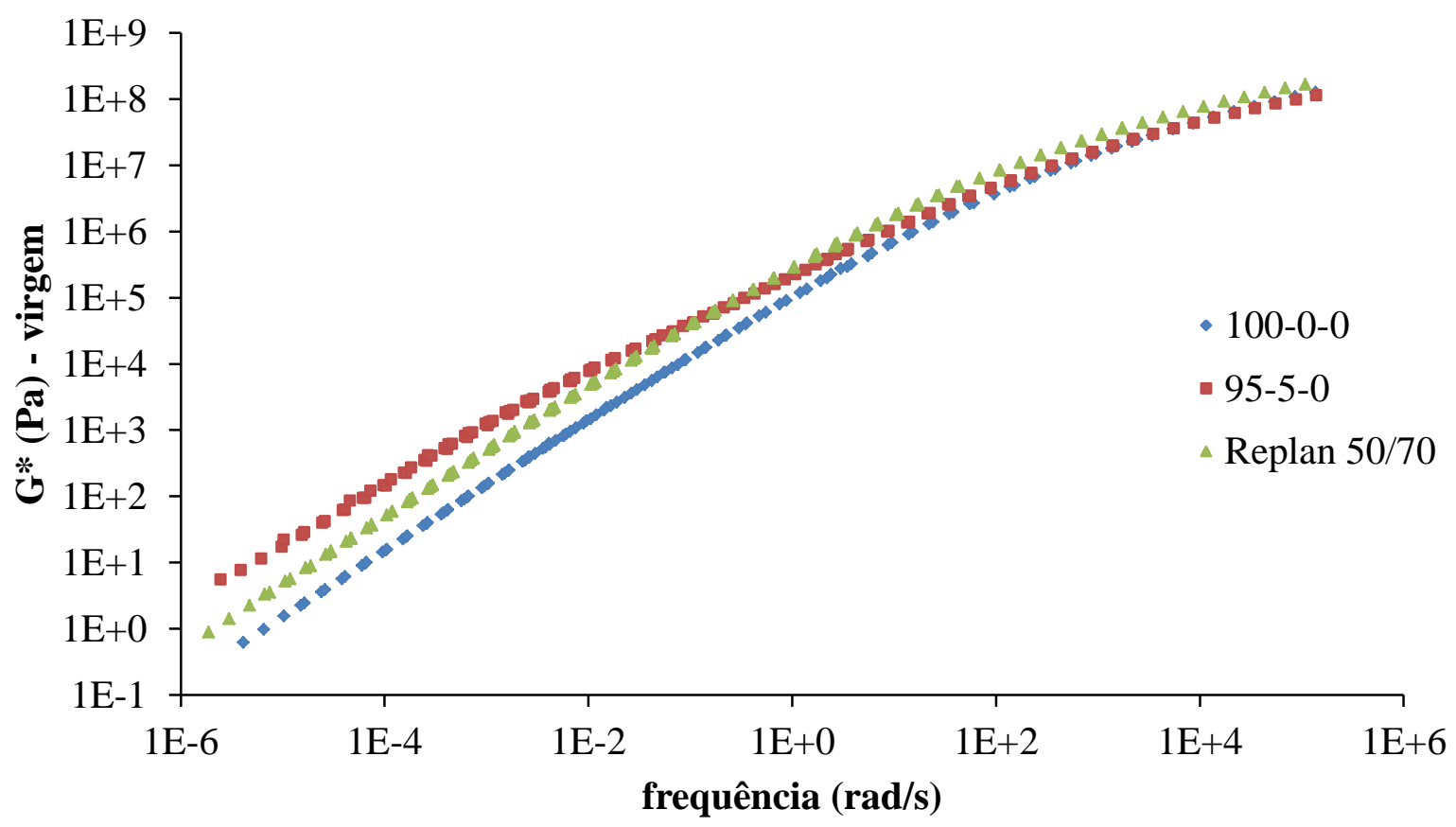

Figura 5.40 - Curvas-mestre para $G^{*}$ na condição virgem para o ligante asfáltico de base e as misturas 100-0-0 e 95-5-0 


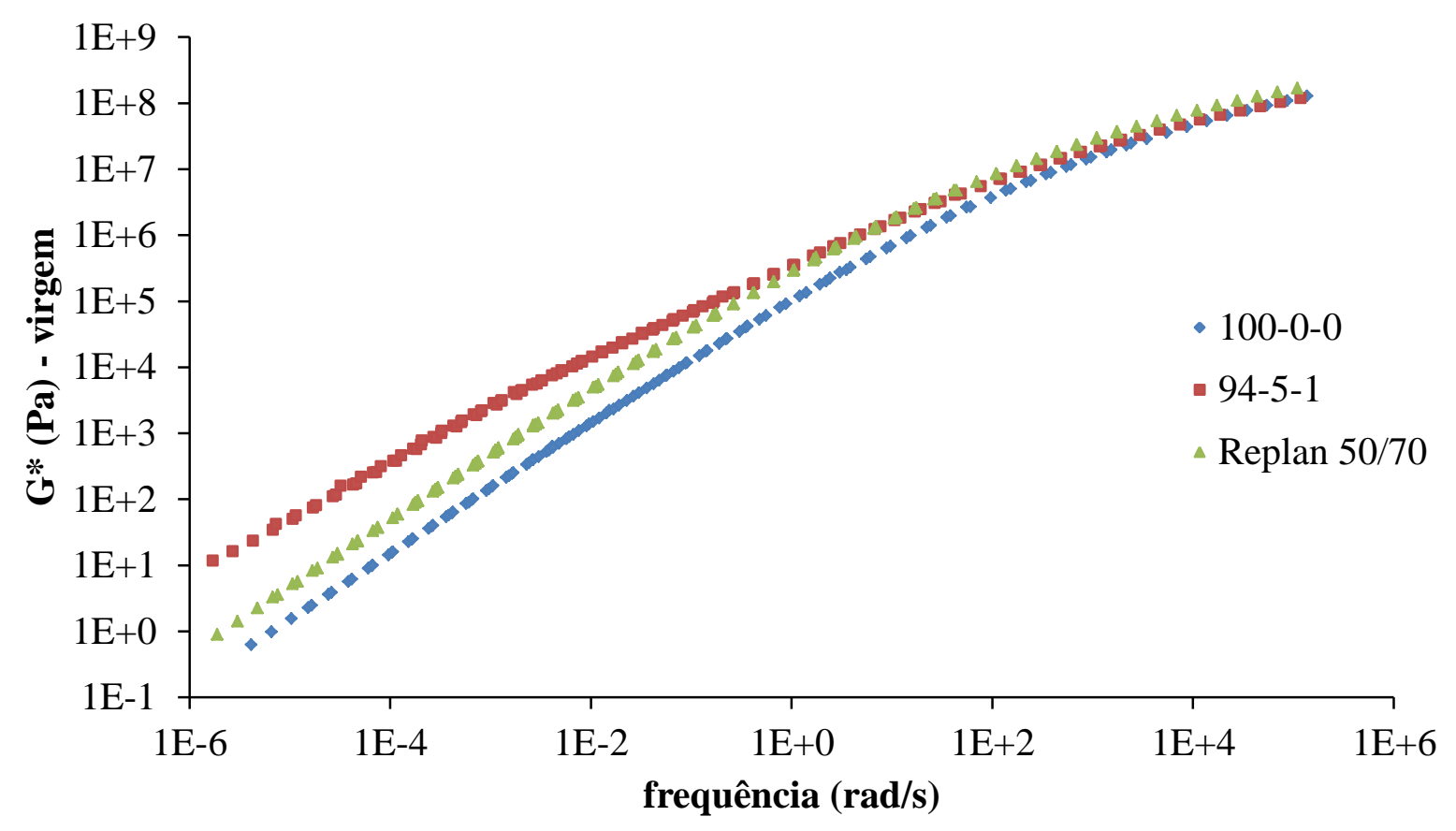

Figura 5.41 - Curvas-mestre para $G^{*}$ na condição virgem para o ligante asfáltico de base e as misturas 100-0-0 e 94-5-1

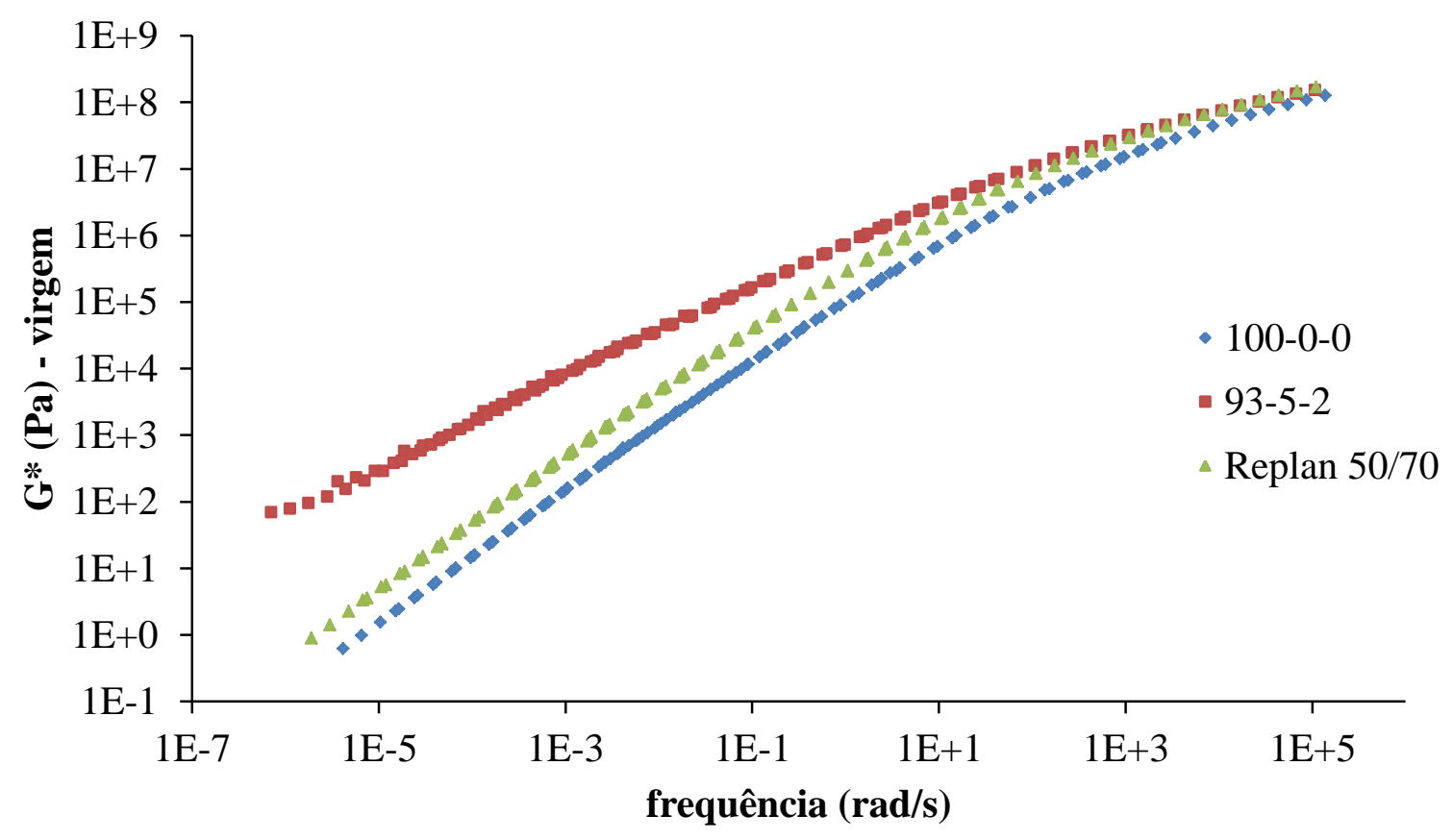

Figura 5.42 - Curvas-mestre para $G^{*}$ na condição virgem para o ligante asfáltico de base e as misturas 100-0-0 e 93-5-2 


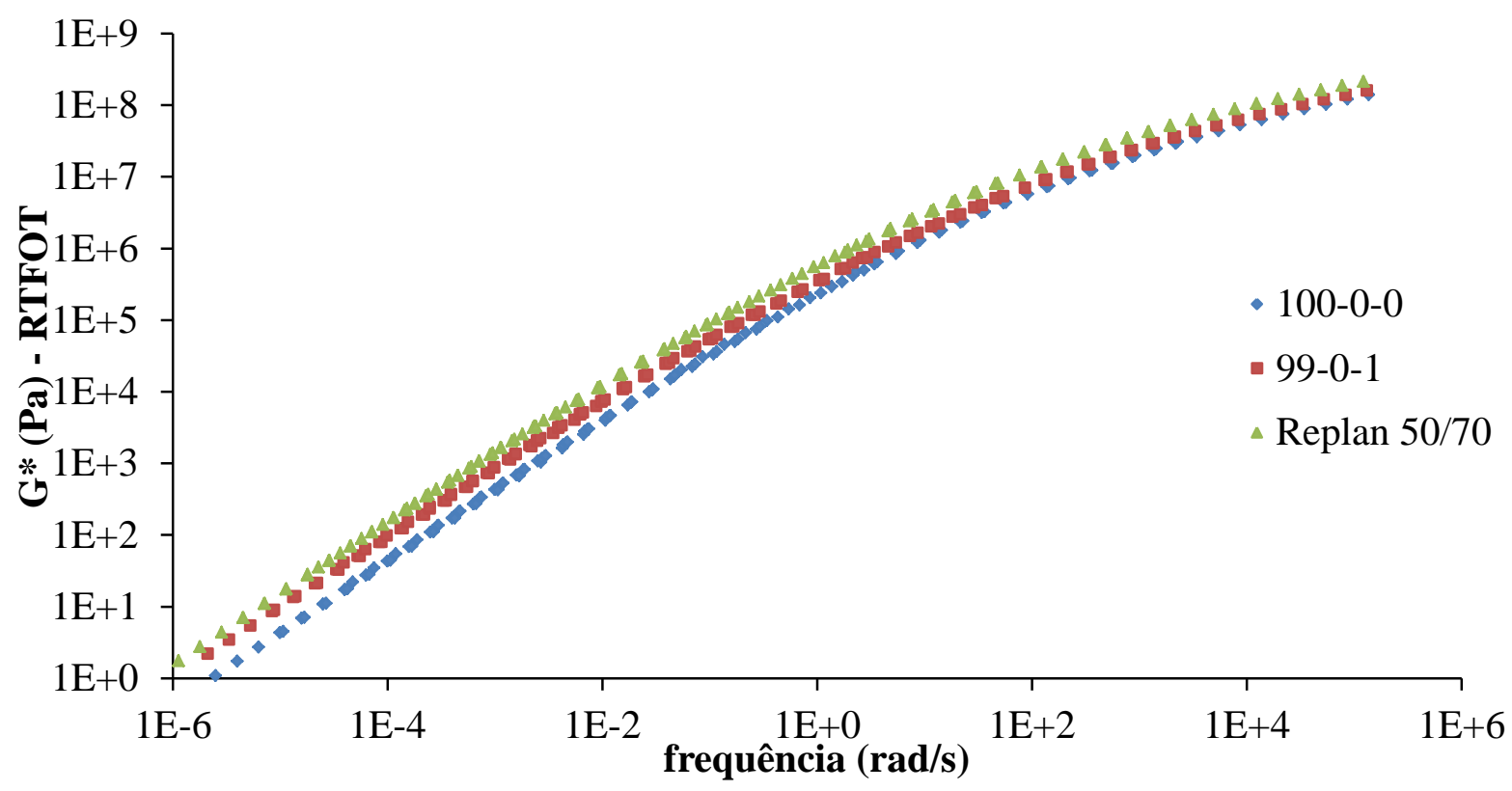

Figura 5.43 - Curvas-mestre para $G^{*}$ na condição envelhecida a curto prazo para o ligante asfáltico de base e as misturas 100-0-0 e 99-0-1

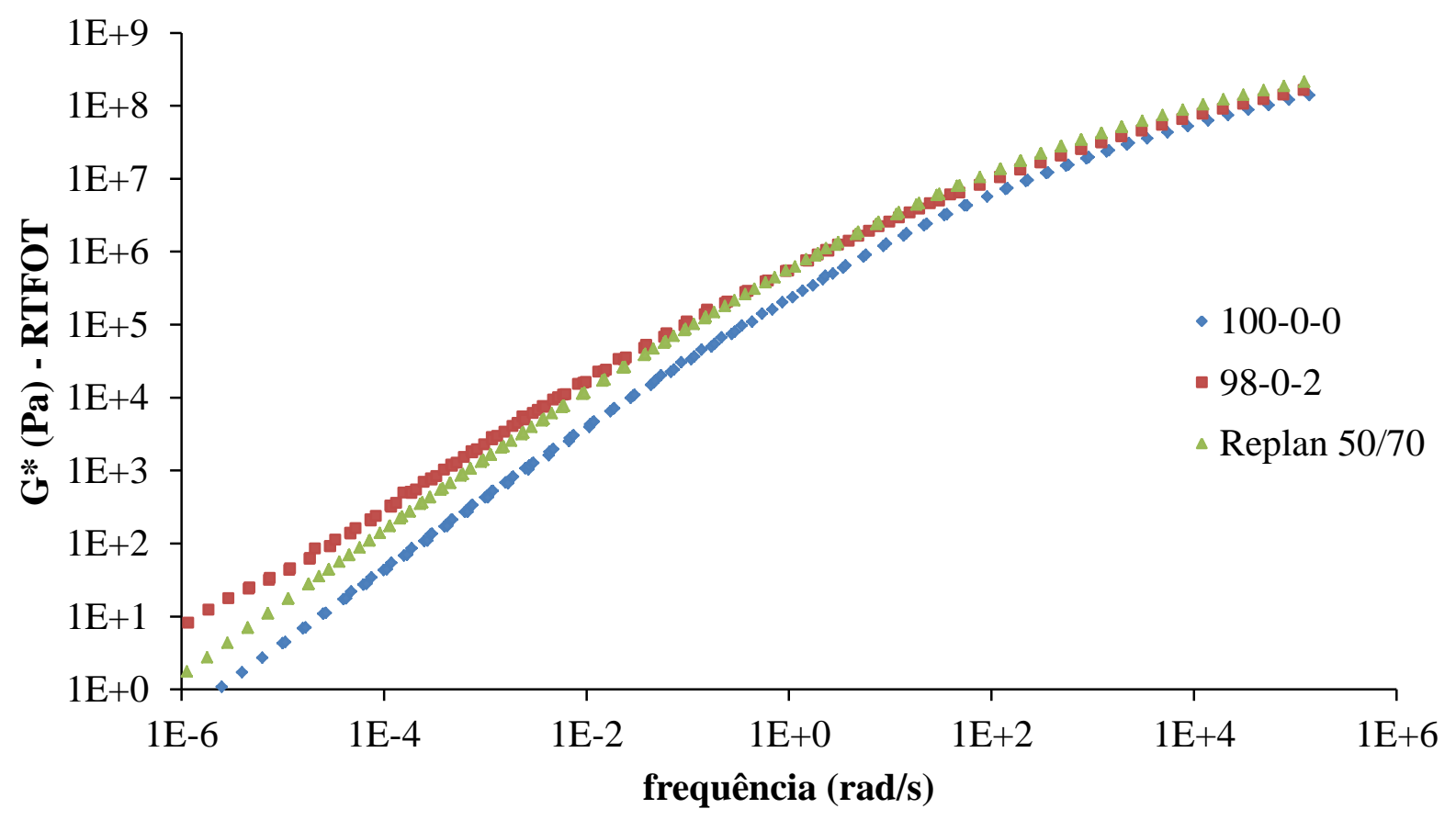

Figura 5.44 - Curvas-mestre para $G^{*}$ na condição envelhecida a curto prazo para o ligante asfáltico de base e as misturas 100-0-0 e 98-0-2 


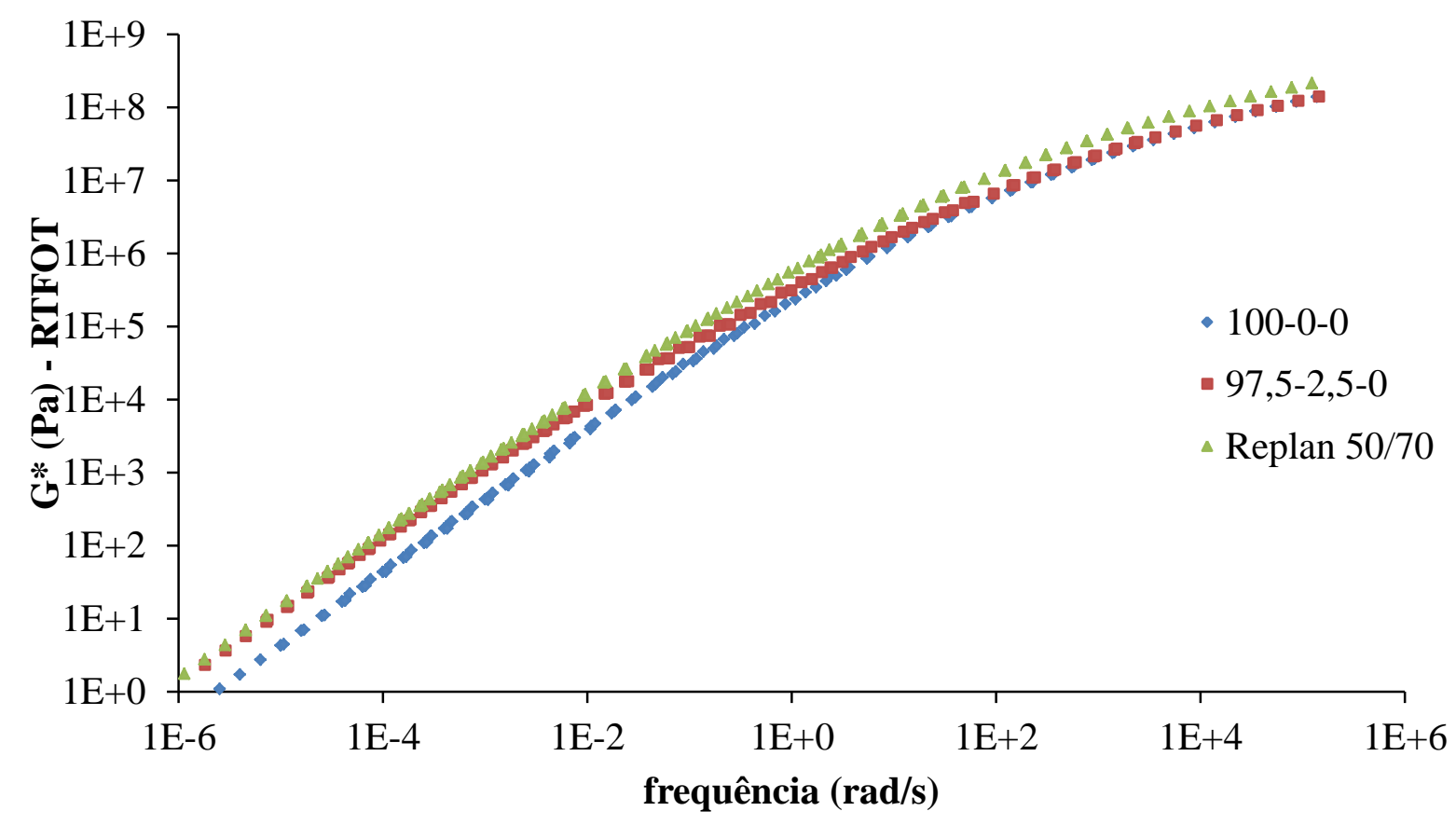

Figura 5.45 - Curvas-mestre para $G^{*}$ na condição envelhecida a curto prazo para o ligante asfáltico de base e as misturas 100-0-0 e 97,5-2,5-0

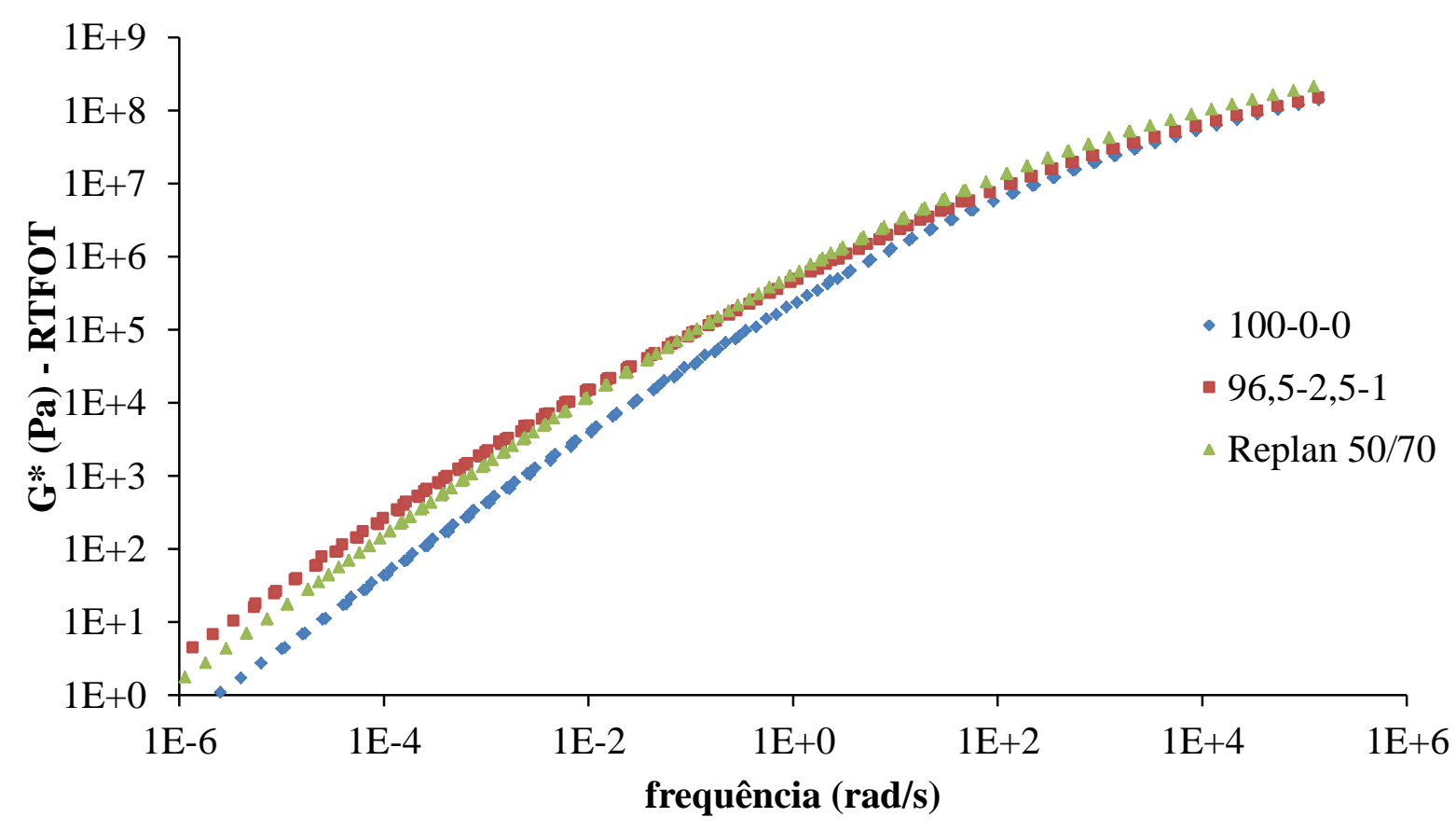

Figura 5.46 - Curvas-mestre para $G^{*}$ na condição envelhecida a curto prazo para o ligante asfáltico de base e as misturas 100-0-0 e 96,5-2,5-1 


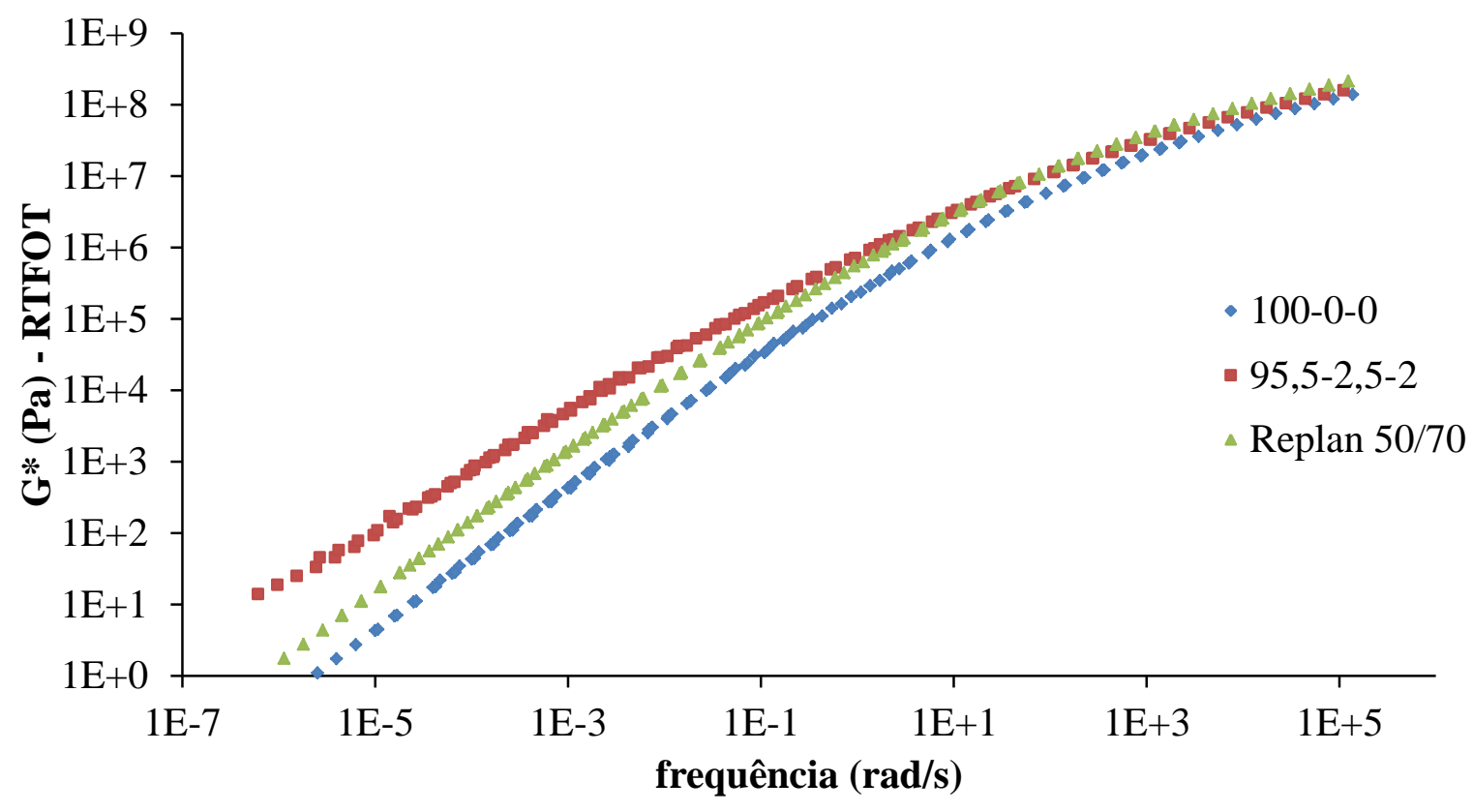

Figura 5.47 - Curvas-mestre para $G^{*}$ na condição envelhecida a curto prazo para o ligante asfáltico de base e as misturas 100-0-0 e 95,5-2,5-2

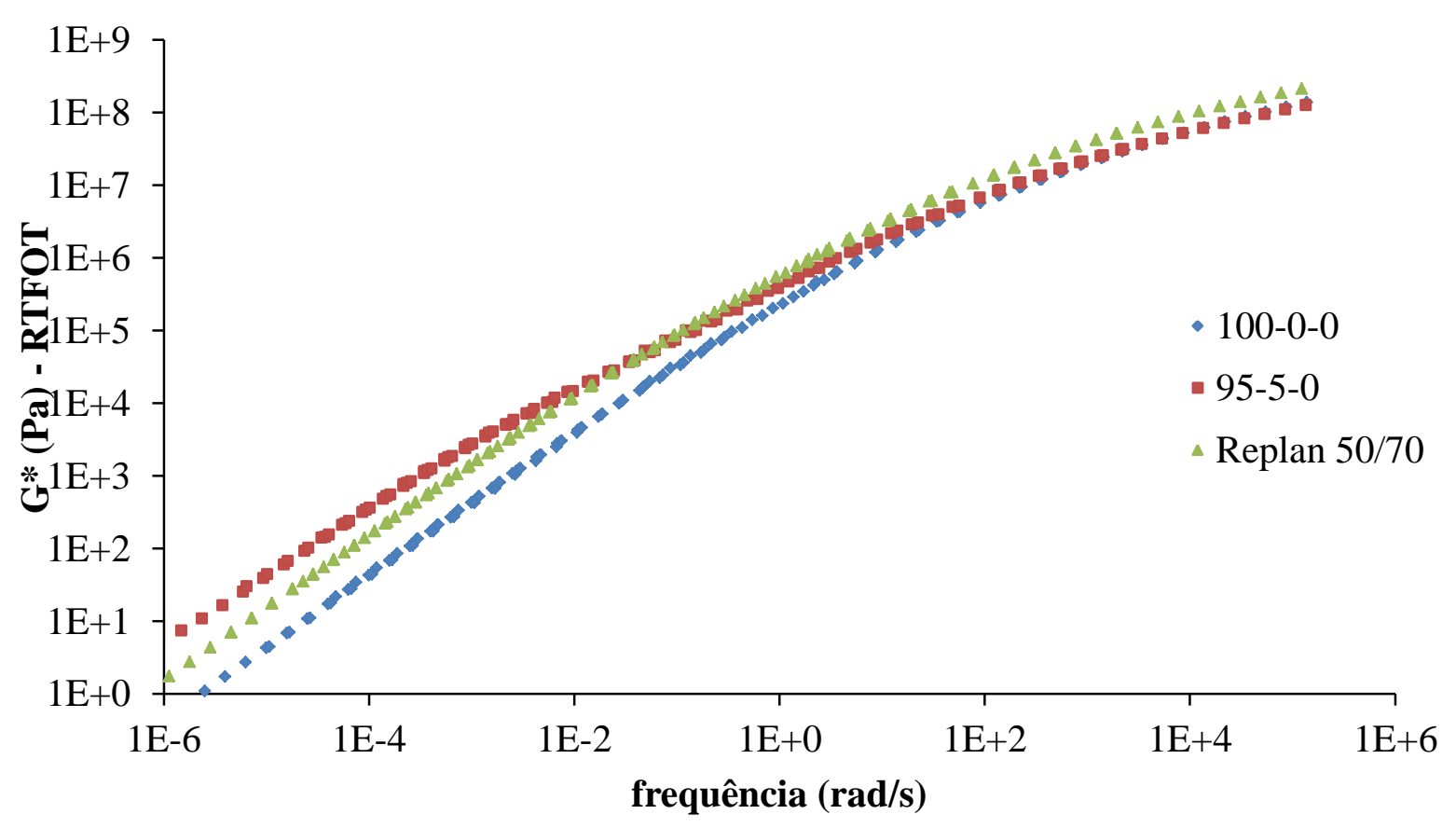

Figura 5.48 - Curvas-mestre para $G^{*}$ na condição envelhecida a curto prazo para o ligante asfáltico de base e as misturas 100-0-0 e 95-5-0 


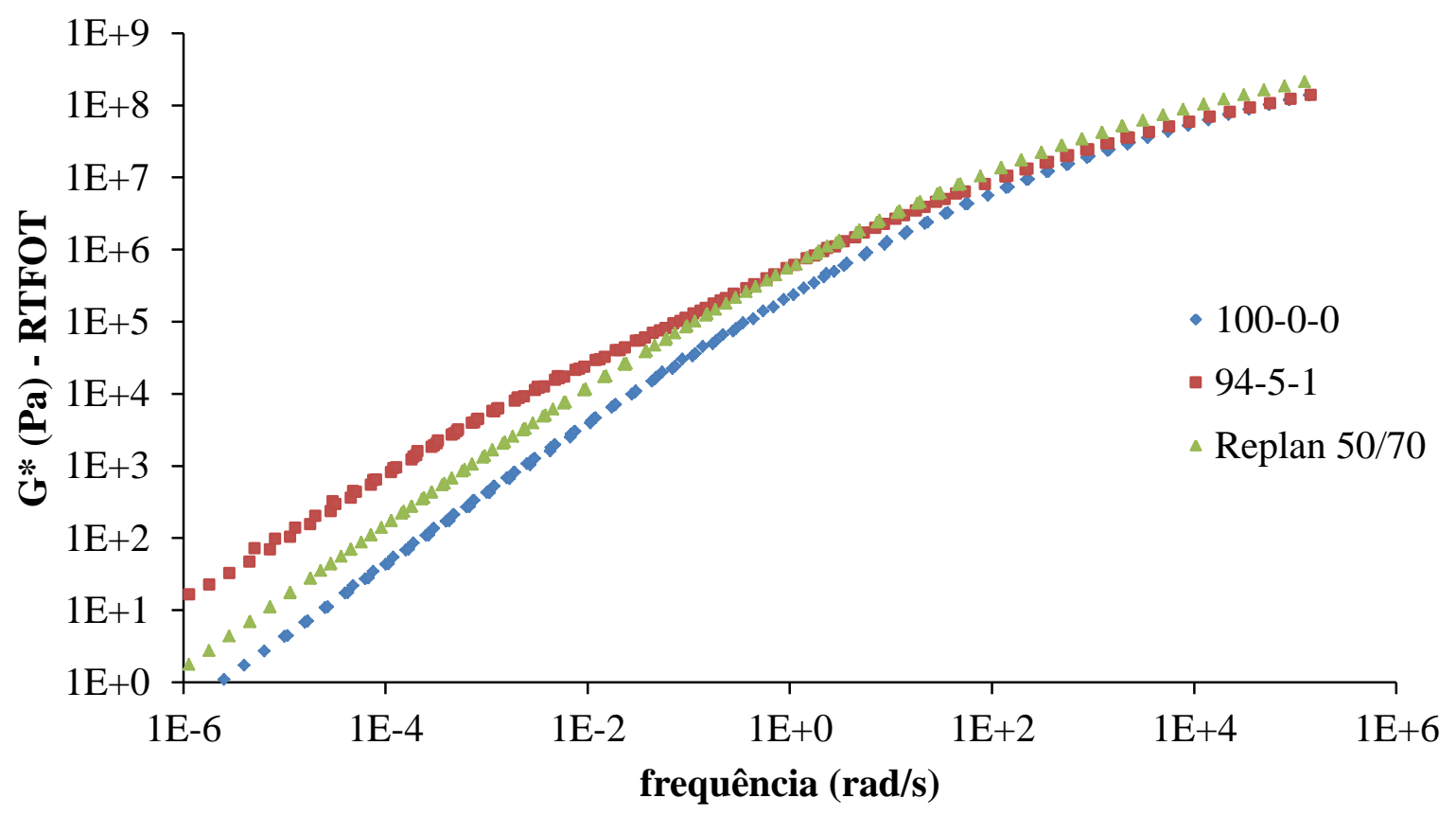

Figura 5.49 - Curvas-mestre para $G^{*}$ na condição envelhecida a curto prazo para o ligante asfáltico de base e as misturas 100-0-0 e 94-5-1

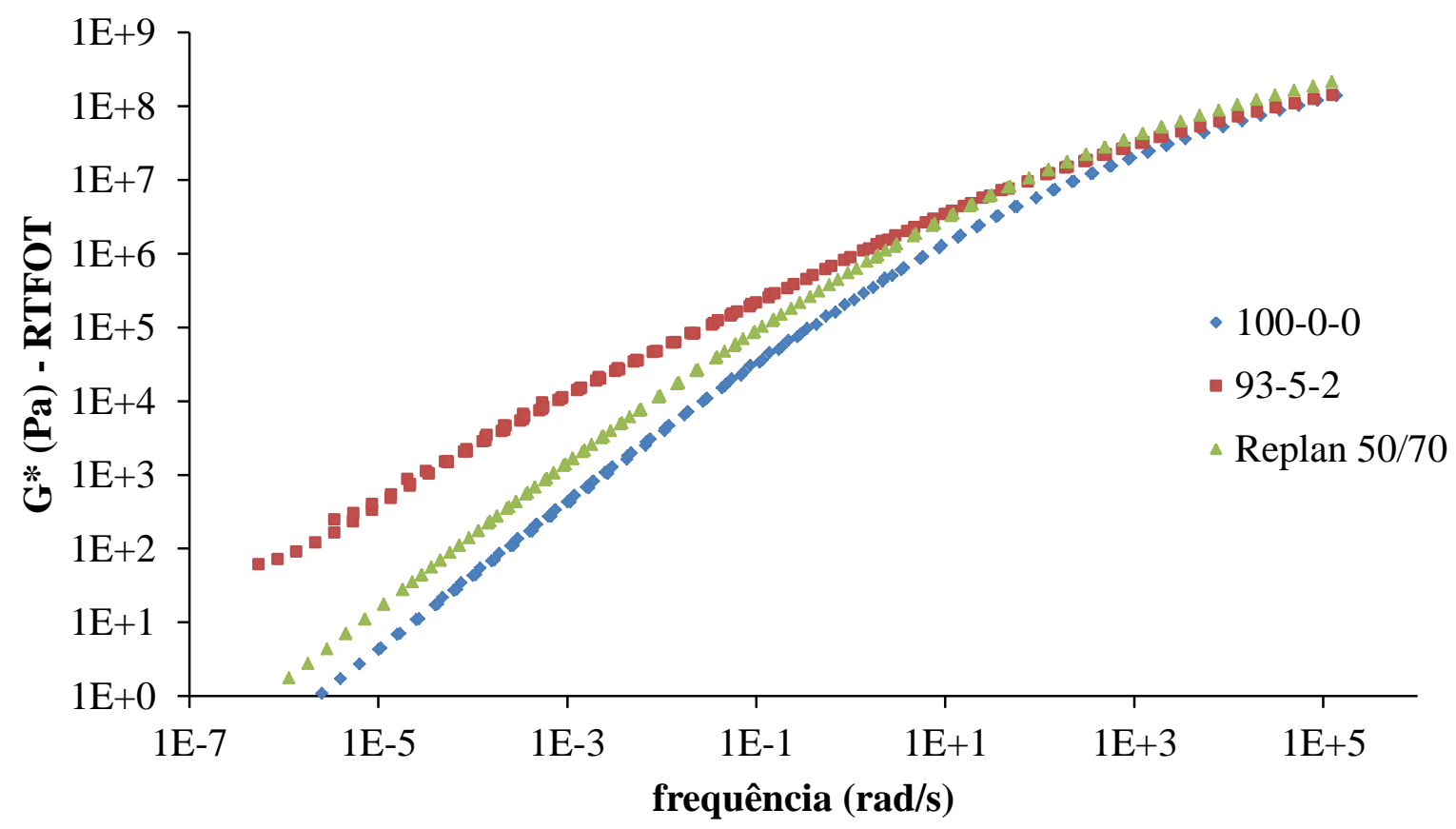

Figura 5.50 - Curvas-mestre para $G^{*}$ na condição envelhecida a curto prazo para o ligante asfáltico de base e as misturas 100-0-0 e 93-5-2 


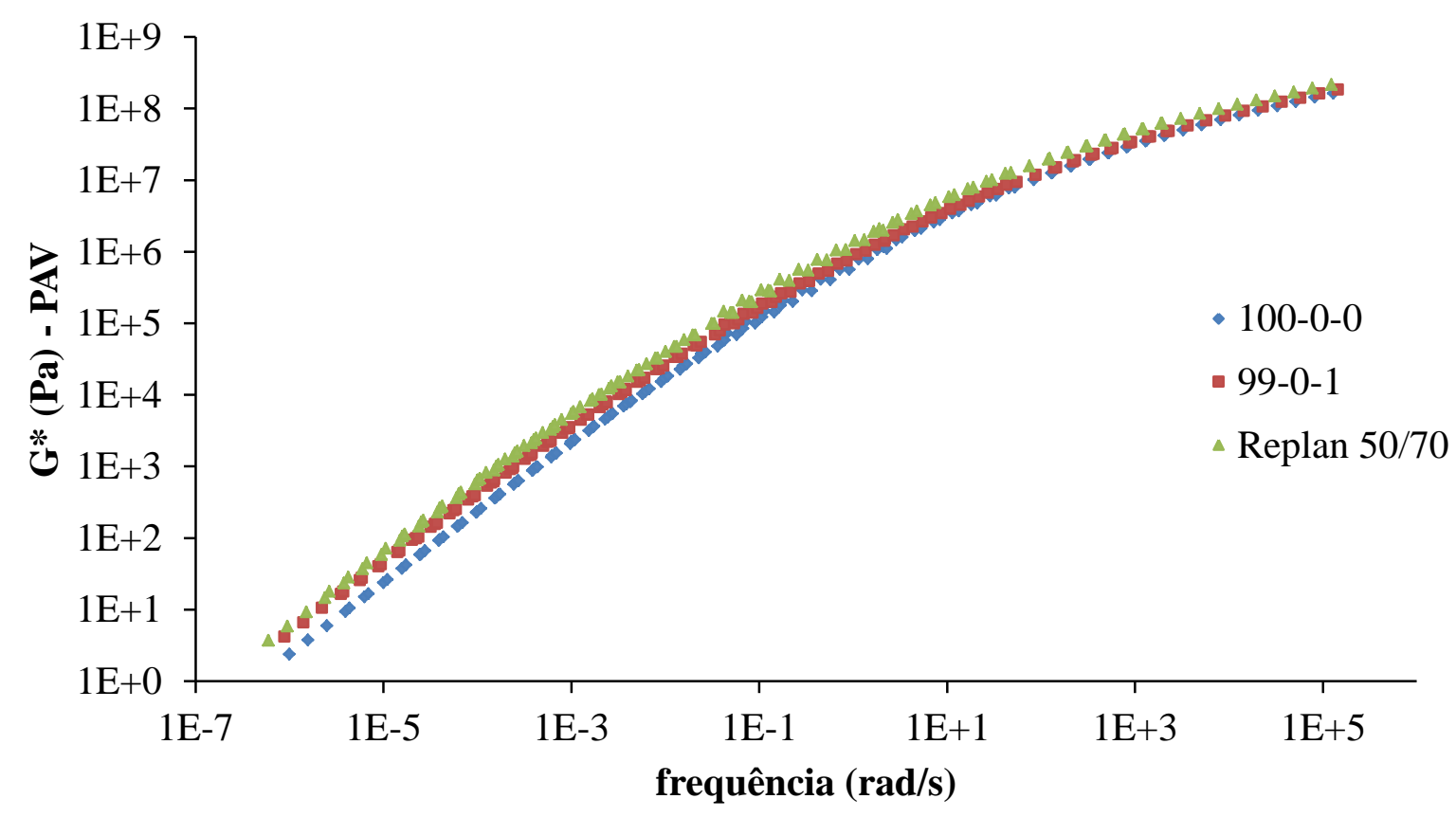

Figura 5.51 - Curvas-mestre para $G^{*}$ na condição envelhecida a longo prazo para o ligante asfáltico de base e as misturas 100-0-0 e 99-0-1

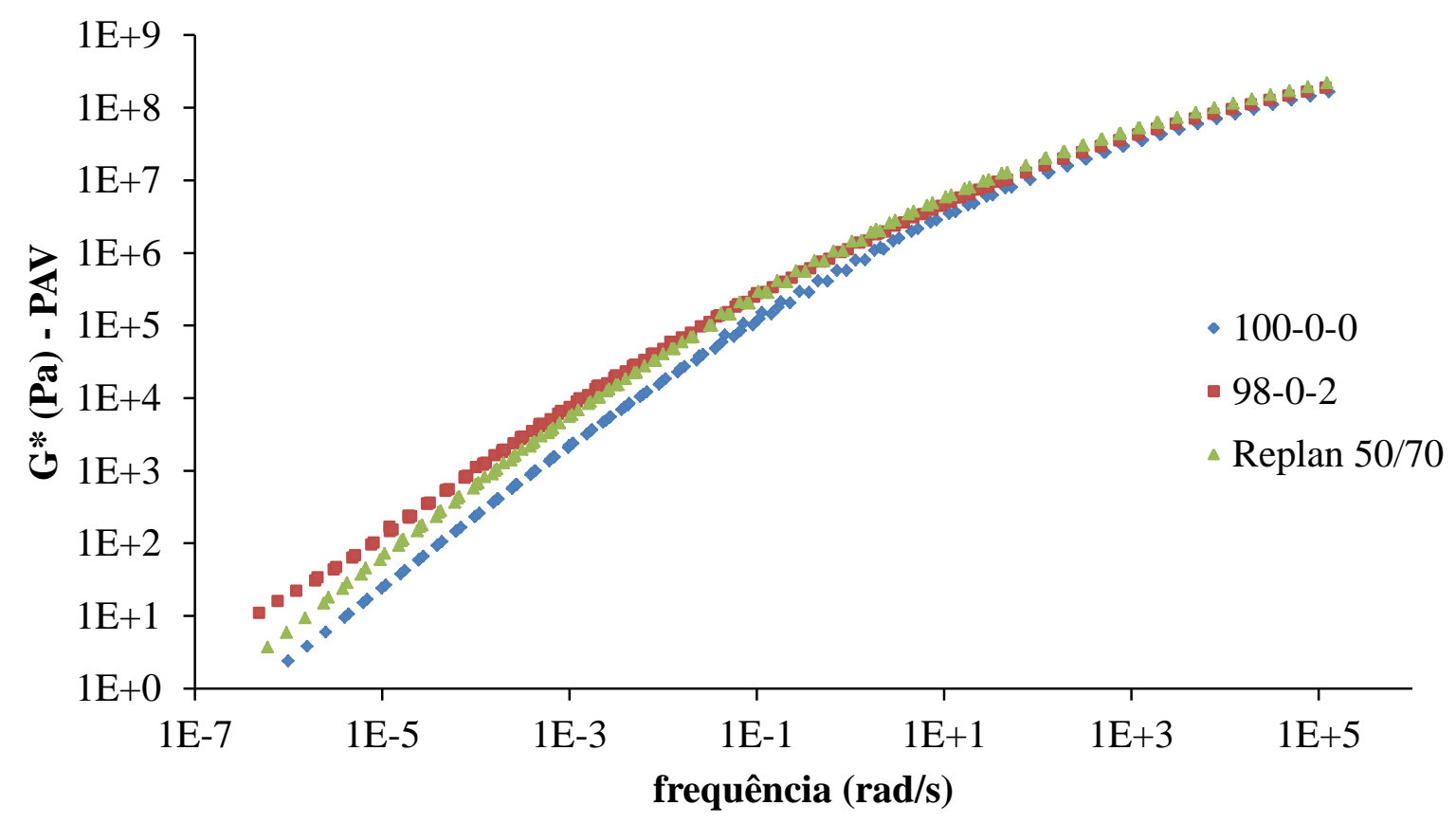

Figura 5.52 - Curvas-mestre para $G^{*}$ na condição envelhecida a longo prazo para o ligante asfáltico de base e as misturas 100-0-0 e 98-0-2 


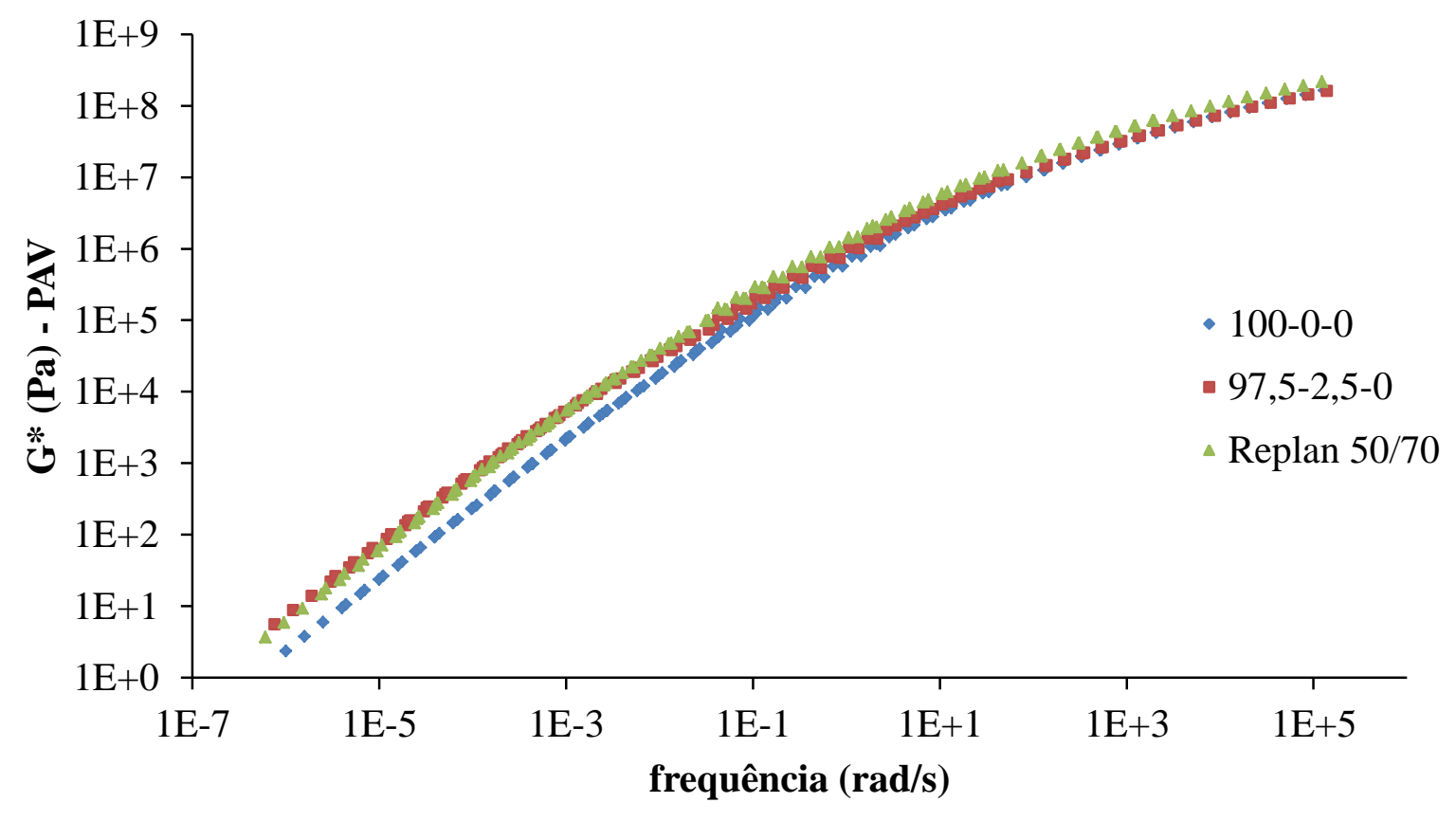

Figura 5.53 - Curvas-mestre para $G^{*}$ na condição envelhecida a longo prazo para o ligante asfáltico de base e as misturas 100-0-0 e 97,5-2,5-0

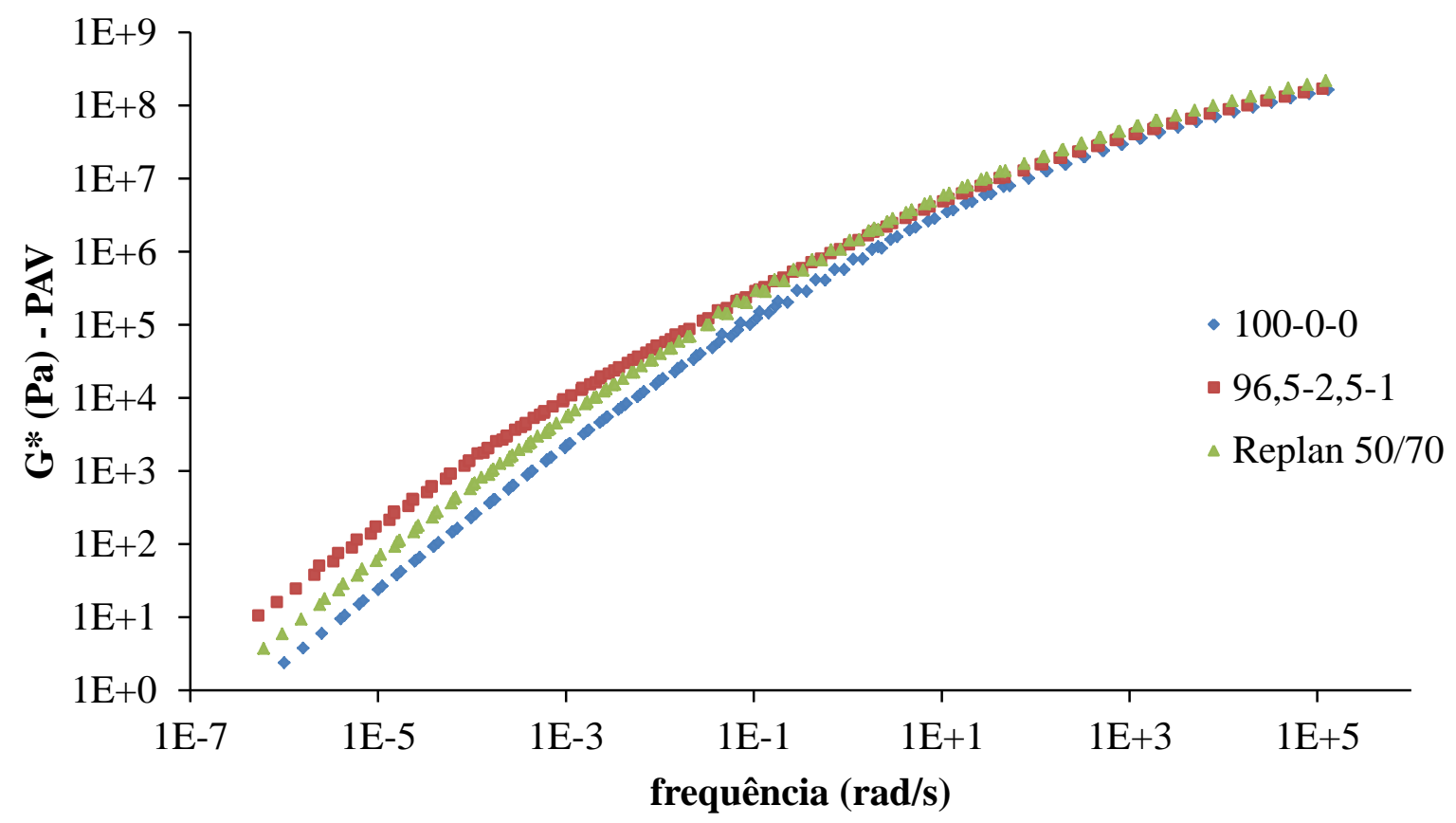

Figura 5.54 - Curvas-mestre para $G^{*}$ na condição envelhecida a longo prazo para o ligante asfáltico de base e as misturas 100-0-0 e 96,5-2,5-1 


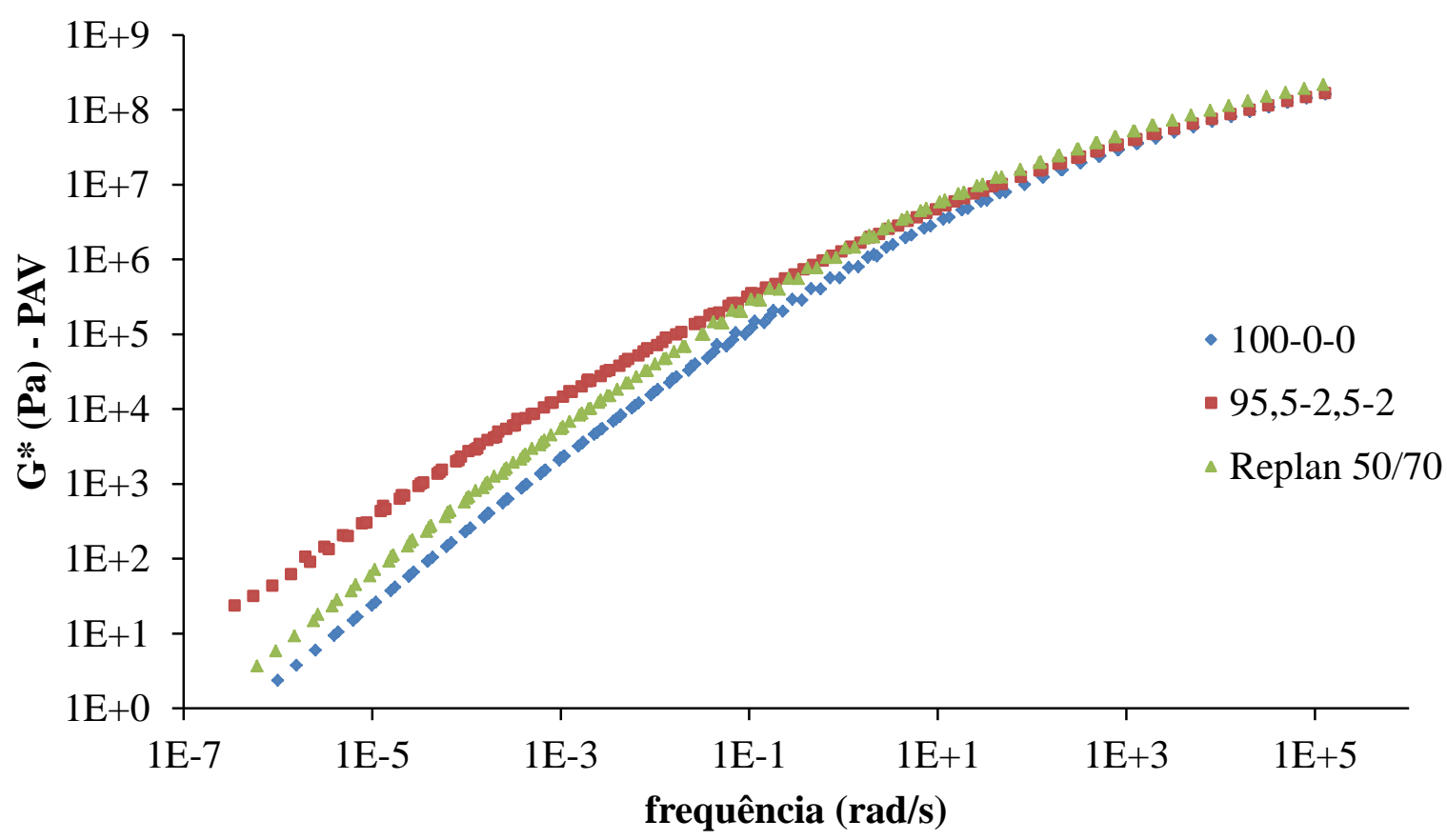

Figura 5.55 - Curvas-mestre para $G^{*}$ na condição envelhecida a longo prazo para o ligante asfáltico de base e as misturas 100-0-0 e 95,5-2,5-2

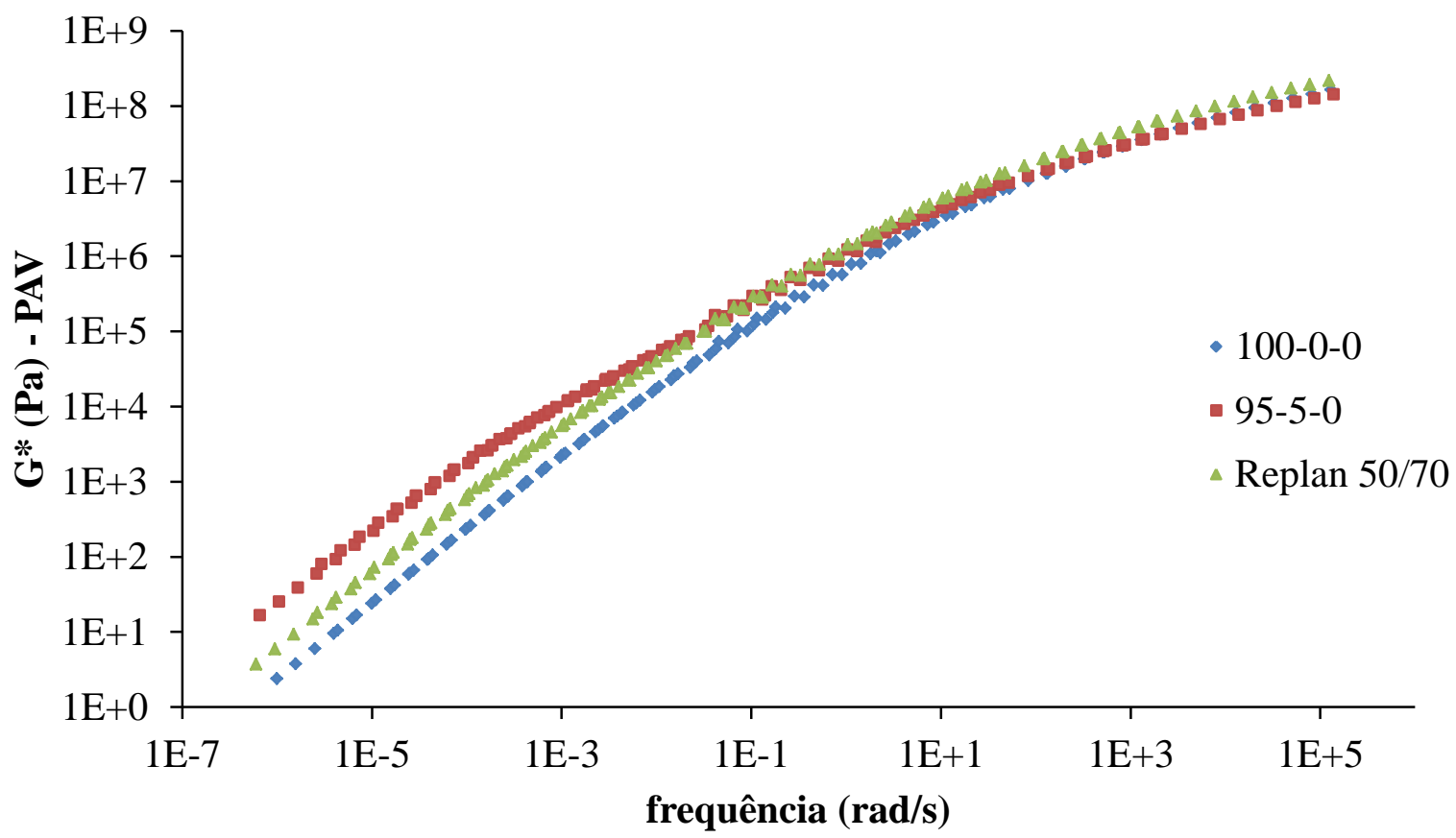

Figura 5.56 - Curvas-mestre para $G^{*}$ na condição envelhecida a longo prazo para o ligante asfáltico de base e as misturas 100-0-0 e 95-5-0 


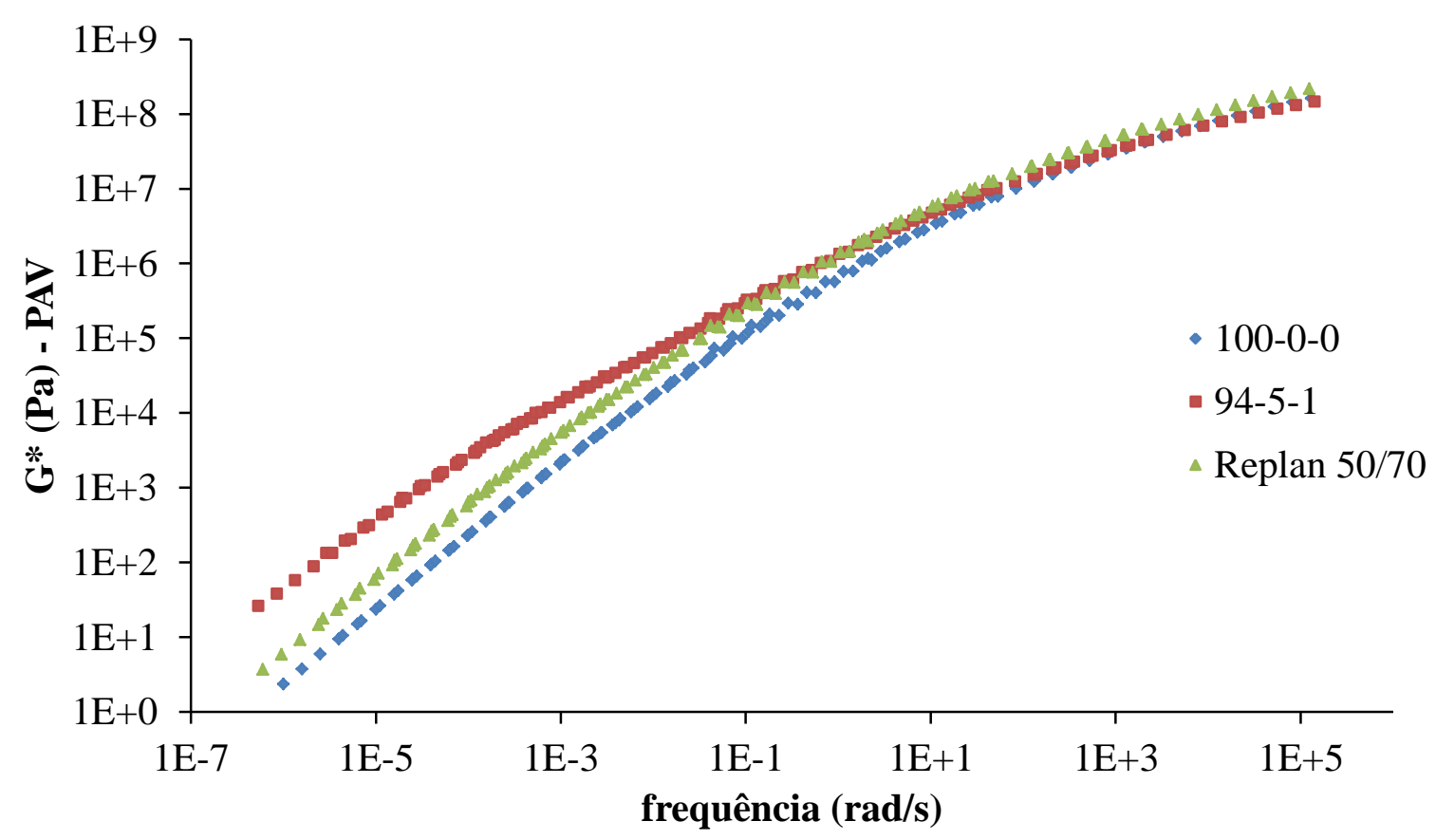

Figura 5.57 - Curvas-mestre para $G^{*}$ na condição envelhecida a longo prazo para o ligante asfáltico de base e as misturas 100-0-0 e 94-5-1

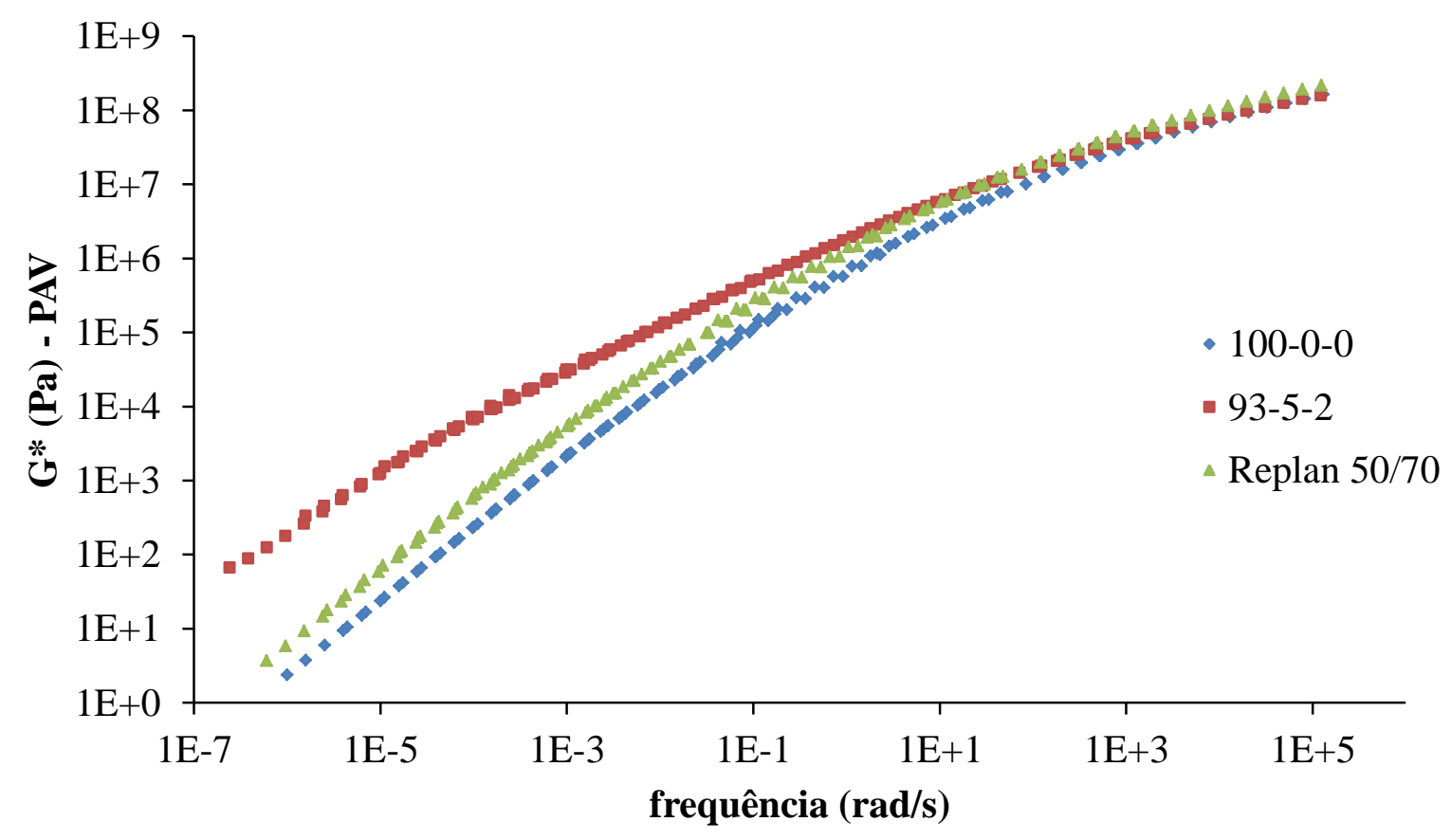

Figura 5.58 - Curvas-mestre para $G^{*}$ na condição envelhecida a longo prazo para o ligante asfáltico de base e as misturas 100-0-0 e 93-5-2 
Tendo em vista a Tabela 5.40 e as Figuras 5.35 a 5.42, que apresentam os dados de G* na condição virgem, tem-se que:

- a mistura 100-0-0 apresenta menores valores de $\mathrm{G}^{*}$, especialmente ao longo das frequências baixas e intermediárias, indicando ser a mistura menos consistente do conjunto;

- a mistura que apresenta maior aumento médio de $\mathrm{G}^{*}$ é a 93-5-2 (37,29) seguida pela 95,5-2,5$2(10,44)$; a mistura que apresenta menor aumento médio de $\mathrm{G}^{*}$ é a 99-0-1 (1,60) seguida pela 97,5-2,5-0 (1,67);

- as misturas 97,5-2,5-0, 95-5-0 e 94-5-1 apresentam valores de aumento de G* abaixo de 1,00 para altas frequências, ou seja, sob baixas temperaturas, estas misturas são menos consistentes que a 100-0-0, o que pode representar um ganho discreto nas propriedades sob baixas temperaturas;

- ao se manter o teor de SBS constante e variar a quantidade de TITAN, ocorre aumento do valor de módulo complexo, indicando que o TITAN tem capacidade de enrijecer o CAP a $25^{\circ} \mathrm{C}$;

- ao manter o teor de TITAN constante e variar a quantidade de SBS, nota-se aumento dos valores de $\mathrm{G}^{*}$, indicando que o SBS também é capaz de enrijecer o ligante asfáltico a $25^{\circ} \mathrm{C}$;

- as misturas 100-0-0, 99-0-1 e 97,5-2,5-0 apresentam valores de módulo complexo inferiores aos obtidos para o ligante asfáltico de base (Replan 50/70);

- sob baixas temperaturas (altas frequências), o ligante asfáltico de base apresenta (visualmente) valores de $\mathrm{G}^{*}$ maiores ou similares à maioria das misturas, apresentando valores ligeiramente menores apenas no caso das misturas 98-0-2 e 93-5-2, isto indica que a adição destes polímeros nestas proporções contribui para a melhoria das propriedades sob baixas temperaturas da maioria dos ligantes asfálticos modificados.

Tendo em vista a Tabela 5.41 e as Figuras 5.43 a 5.50, que apresentam os dados de G* na condição envelhecida a curto prazo, tem-se que:

- assim como observado para as amostras virgens, a mistura 100-0-0 apresenta menores valores de $G^{*}$, especialmente ao longo das frequências intermediárias e baixas, indicando ser a mistura menos consistente do conjunto mesmo após o envelhecimento a curto prazo;

- assim como observado para as amostras virgens, a mistura que apresenta maior aumento médio de $\mathrm{G}^{*}$ é a 93-5-2 (19,21) seguida pela 95,5-2,5-2 (6,94); assim como observado para as 
amostras virgens, a mistura que apresenta menor aumento médio de $\mathrm{G}^{*}$ é a $99-0-1(1,62)$ seguida pela $97,5-2,5-0(1,72)$;

- como observado para as amostras virgens, as misturas 97,5-2,5-0 e 95-5-0 apresentam valores de aumento médio de $\mathrm{G}^{*}$ abaixo de 1,00 nas frequências altas, ou seja, sob baixas temperaturas, estas misturas são menos consistentes que a 100-0-0, o que pode representar um ganho discreto nas propriedades sob baixas temperaturas;

- conforme já notado para as amostras virgens, ao se manter o teor de SBS constante e variar a quantidade de TITAN, ocorre o aumento do valor de módulo complexo, indicando que o TITAN tem a capacidade de enrijecer o CAP a $25^{\circ} \mathrm{C}$;

- conforme já observado para as amostras virgens, ao manter o teor de TITAN cosntatne e variar a quantidade de SBS, nota-se o aumento dos valores de $\mathrm{G}^{*}$, indicando que o SBS também é capaz de enrijecer o ligante asfáltico a $25^{\circ} \mathrm{C}$;

- as misturas 100-0-0, 99-0-1 e 97,5-2,5-0 apresentam valores de módulo complexo inferiores aos obtidos para o ligante asfáltico de base (Replan 50/70);

- sob baixas temperaturas (altas frequências) o ligante asfáltico de base apresenta (visualmente) valores de $\mathrm{G}^{*}$ maiores ou similares à maioria das misturas, apresentando valores ligeiramente menores apenas no caso da mistura 95,5-2,5-2, isto indica que a adição destes polímeros nestas proporções contribui para a melhoria das propriedades sob baixas temperaturas da maioria dos ligantes asfálticos modificados.

Tendo em vista a Tabela 5.42 e as Figuras 5.51 a 5.58, que apresentam os dados de $\mathrm{G}^{*}$ na condição envelhecida a longo prazo, tem-se que:

- assim como observado para as amostras virgens e envelhecidas a curto prazo, a mistura 1000-0 apresenta menores valores de $\mathrm{G}^{*}$, especialmente ao longo das frequências intermediárias e baixas, indicando ser a mistura menos consistente do conjunto mesmo após o envelhecimento a longo prazo;

- a mistura que apresenta maior aumento médio de $\mathrm{G}^{*}$ é a 93-5-2 $(10,60)$ seguida pela 94-5-1 $(4,28)$, assim como observado para as amostras virgens e envelhecidas a curto prazo; a mistura que apresenta menor aumento médio de $\mathrm{G}^{*}$ é a 99-0-1 (1,39) seguida pela 97,5-2,5-0 $(1,70)$;

- as misturas 97,5-2,5-0, 95-5-0, 94-5-1 e 93-5-2 apresentam valores de aumento médio de G* abaixo de 1,00 nas frequências altas, ou seja, sob baixas temperaturas, estas misturas são 
menos consistentes que a 100-0-0, o que pode representar um ganho discreto nas propriedades sob baixas temperaturas;

- conforme já notado para as amostras virgens e envelhecidas a curto prazo, ao se manter o teor de SBS constante e variar a quantidade de TITAN, ocorre o aumento do valor de módulo complexo, indicando que o TITAN tem capacidade de enrijecer o CAP a $25^{\circ}$;

- conforme já observado para as amostras virgens e envelhecidas a curto prazo, ao manter o teor de TITAN constante e variar a quantidade de SBS, nota-se aumento dos valores de $\mathrm{G}^{*}$, indicando que o SBS também é capaz de enrijecer o ligante asfáltico a $25^{\circ} \mathrm{C}$;

- as misturas 100-0-0 e 99-0-1 apresentam valores de módulo complexo inferiores aos obtidos para o ligante asfáltico de base (Replan 50/70);

- sob baixas temperaturas (altas frequências) o ligante asfáltico de base apresenta (visualmente) valores de $\mathrm{G}^{*}$ maiores ou similares à maioria das misturas, apresentando valores ligeiramente menores apenas no caso da mistura 98-0-2, isto indica que a adição destes polímeros nestas proporções contribui para a melhoria das propriedades sob baixas temperaturas da maioria dos ligantes asfálticos modificados.

Observa-se que ao aumentar o nível de envelhecimento, a diferença do módulo complexo entre elas diminui. Como exemplo, a mistura 93-5-2 possui um valor médio de aumento de $\mathrm{G}^{*}$ em relação à mistura 100-0-0 na condição virgem de 37,29. No caso da comparação para a condição envelhecida a curto prazo, o aumento médio de $\mathrm{G}^{*}$ diminui para 19,21 e para a condição envelhecida a longo prazo, o aumento médio de $\mathrm{G}^{*}$ diminui para 10,60. Isto mostra que, com o envelhecimento o ligante asfáltico e o óleo aromático são mais suscetíveis ao nível de envelhecimento do que o SBS e o TITAN. Neste sentido, quanto maior o nível de modificação do ligante asfáltico com polímeros, menor será a variação do módulo complexo em relação à condição virgem, indicando menor sensibilidade ao efeito do envelhecimento. 
5.6.5 Efeito das aditivações à luz dos resultados de delta nos diferentes níveis de envelhecimento

As Tabelas de 5.44 a 5.47 apresentam as diferenças entre os valores de delta da mistura 100-0-0 com as demais $\left(\delta_{\text {misturas }}-\delta_{100-0-0}\right)$, nas condições virgem (Tabela 5.44), envelhecida a curto prazo (Tabela 5.45), envelhecida a longo prazo (Tabela 5.46) e os índices de envelhecimento médios (Tabela 5.47). As Figuras de 5.59 a 5.65 mostram os comparativos entre as curvas-mestre na condição virgem. As Figuras de 5.66 a 5.73 mostram os comparativos entre as curvas-mestre na condição envelhecida a curto prazo. As Figuras de 5.74 a 5.81 mostram os comparativos entre as curvas-mestre na condição envelhecida a longo prazo. A título de comparação, as curvas-mestre do CAP puro virgem, envelhecido a curto prazo e envelhecido a longo prazo acompanharão as curvas-mestre dos demais materiais.

Tabela 5.44 - Diferença dos valores de $\delta$ das misturas com a mistura 100-0-0, na condição virgem $\left(\delta_{\text {misturas }}-\delta_{100-0-0}\right)$

\begin{tabular}{cccccccccc}
\hline $\begin{array}{c}\text { Frequências } \\
(\mathbf{r a d} / \mathbf{s})\end{array}$ & $\mathbf{1 0 0 - 0 - 0}$ & $\mathbf{9 9 - 0 - 1}$ & $\mathbf{9 8 - 0 - 2}$ & $\mathbf{9 7 , 5 - 2 , 5 - 0}$ & $\mathbf{9 6 , 5 - 2 , 5 - 1}$ & $\mathbf{9 5 , 5 - 2 , 5 - 2}$ & $\mathbf{9 5 - 5 - 0}$ & $\mathbf{9 4 - 5 - 1}$ & $\mathbf{9 3 - 5 - 2}$ \\
\hline $1,00 \mathrm{E}-05$ & 1,00 & $-1,93$ & $-11,06$ & 0,00 & $-6,70$ & $-17,61$ & $-7,12$ & $-20,23$ & 0,00 \\
$1,00 \mathrm{E}-04$ & 1,00 & $-3,03$ & $-11,36$ & $-2,76$ & $-9,05$ & $-19,50$ & $-11,48$ & $-24,82$ & 0,00 \\
$1,00 \mathrm{E}-03$ & 1,00 & $-7,06$ & $-17,77$ & $-7,47$ & $-15,91$ & $-27,41$ & $-19,94$ & $-29,52$ & 0,00 \\
$1,00 \mathrm{E}-02$ & 1,00 & $-3,19$ & $-12,36$ & $-4,84$ & $-14,16$ & $-22,17$ & $-20,29$ & $-24,23$ & 0,00 \\
$1,00 \mathrm{E}-01$ & 1,00 & $-3,07$ & $-12,70$ & $-8,73$ & $-12,38$ & $-19,12$ & $-17,48$ & $-21,05$ & $-20,36$ \\
$1,00 \mathrm{E}+00$ & 1,00 & $-5,25$ & $-11,62$ & $-5,53$ & $-9,54$ & $-15,89$ & $-12,60$ & $-16,72$ & $-20,85$ \\
$1,00 \mathrm{E}+01$ & 1,00 & $-5,03$ & $-11,79$ & $-1,73$ & $-4,72$ & $-13,00$ & $-11,51$ & $-16,17$ & $-14,45$ \\
$1,00 \mathrm{E}+02$ & 1,00 & $-3,70$ & $-9,18$ & 3,45 & $-1,14$ & $-10,15$ & $-8,86$ & $-13,30$ & $-10,46$ \\
$1,00 \mathrm{E}+03$ & 1,00 & $-3,04$ & $-7,41$ & 6,56 & 1,88 & $-7,06$ & $-6,87$ & $-11,44$ & $-6,30$ \\
$1,00 \mathrm{E}+04$ & 1,00 & $-2,60$ & $-5,30$ & 7,04 & 2,42 & $-4,71$ & $-5,67$ & $-9,60$ & $-3,32$ \\
$1,00 \mathrm{E}+05$ & 1,00 & $-2,13$ & $-3,37$ & 6,22 & 2,70 & $-2,54$ & $-4,59$ & $-8,10$ & $-1,12$ \\
\hline média & 1,00 & $-3,64$ & $-10,36$ & $-0,78$ & $-6,05$ & $-14,47$ & $-11,49$ & $-17,74$ & $-10,98$ \\
\hline
\end{tabular}


Tabela 5.45 - Diferença dos valores de $\delta$ das misturas com a mistura 100-0-0, na condição envelhecida a curto prazo $\left(\delta_{\text {misturas }}-\delta_{100-0-0}\right)$

\begin{tabular}{|c|c|c|c|c|c|c|c|c|c|}
\hline \multirow{2}{*}{$\begin{array}{c}\text { Frequências } \\
(\mathrm{rad} / \mathrm{s})\end{array}$} & \multicolumn{9}{|c|}{ Misturas } \\
\hline & 100-0-0 & 99-0-1 & $98-0-2$ & $97,5-2,5-0$ & $96,5-2,5-1$ & $95,5-2,5-2$ & 95-5-0 & 94-5-1 & 93-5-2 \\
\hline $1,00 \mathrm{E}-05$ & 1,00 & $-2,67$ & $-13,14$ & $-1,19$ & $-9,10$ & $-19,35$ & $-5,85$ & $-19,05$ & $-31,62$ \\
\hline $1,00 \mathrm{E}-04$ & 1,00 & $-3,67$ & $-14,24$ & $-3,72$ & $-13,05$ & $-23,41$ & $-10,01$ & $-23,90$ & $-35,14$ \\
\hline $1,00 \mathrm{E}-03$ & 1,00 & $-3,98$ & $-14,02$ & $-6,96$ & $-14,12$ & $-20,75$ & $-14,48$ & $-23,65$ & $-30,39$ \\
\hline $1,00 \mathrm{E}-02$ & 1,00 & $-4,35$ & $-13,08$ & $-9,58$ & $-14,06$ & $-20,47$ & $-17,35$ & $-20,15$ & $-24,67$ \\
\hline $1,00 \mathrm{E}-01$ & 1,00 & $-4,58$ & $-12,43$ & $-8,02$ & $-11,30$ & $-17,84$ & $-13,97$ & $-16,10$ & $-23,32$ \\
\hline $1,00 \mathrm{E}+00$ & 1,00 & $-2,50$ & $-10,83$ & $-4,09$ & $-8,66$ & $-13,91$ & $-8,89$ & $-12,00$ & $-18,82$ \\
\hline $1,00 \mathrm{E}+01$ & 1,00 & $-3,48$ & $-11,32$ & $-1,62$ & $-7,67$ & $-12,07$ & $-8,40$ & $-8,47$ & $-17,35$ \\
\hline $1,00 \mathrm{E}+02$ & 1,00 & $-2,62$ & $-9,48$ & 0,60 & $-6,17$ & $-9,94$ & $-6,50$ & $-6,42$ & $-15,24$ \\
\hline $1,00 \mathrm{E}+03$ & 1,00 & $-1,66$ & $-7,39$ & 2,83 & $-4,53$ & $-6,51$ & $-4,57$ & $-3,45$ & $-11,70$ \\
\hline $1,00 \mathrm{E}+04$ & 1,00 & $-1,16$ & $-5,93$ & 2,43 & $-4,13$ & $-4,84$ & $-4,25$ & $-2,79$ & $-9,40$ \\
\hline $1,00 \mathrm{E}+05$ & 1,00 & $-1,00$ & $-4,76$ & 2,27 & $-3,45$ & $-3,35$ & $-3,78$ & $-1,97$ & $-7,49$ \\
\hline média & 1,00 & $-2,88$ & $-10,60$ & $-2,46$ & $-8,75$ & $-13,86$ & $-8,91$ & $-12,54$ & $-20,47$ \\
\hline
\end{tabular}

Tabela 5.46 - Diferença dos valores de $\delta$ das misturas com a mistura 100-0-0, na condição envelhecida a longo $\operatorname{prazo}\left(\delta_{\text {misturas }}-\boldsymbol{\delta}_{100-0-0}\right)$

\begin{tabular}{cccccccccc}
\hline $\begin{array}{c}\text { Frequências } \\
(\mathbf{r a d} / \mathbf{s})\end{array}$ & \multicolumn{10}{c}{ Misturas } \\
\cline { 2 - 9 } & $\mathbf{1 0 0 - 0 - 0}$ & $\mathbf{9 9 - 0 - 1}$ & $\mathbf{9 8 - 0 - 2}$ & $\mathbf{9 7 , 5 - 2 , 5 - 0}$ & $\mathbf{9 6 , 5 - 2 , 5 - 1}$ & $\mathbf{9 5 , 5 - 2 , 5 - 2}$ & $\mathbf{9 5 - 5 - 0}$ & $\mathbf{9 4 - 5 - 1}$ & $\mathbf{9 3 - 5 - 2}$ \\
\hline $1,00 \mathrm{E}-05$ & 1,00 & $-4,40$ & $-15,96$ & $-5,92$ & $-16,99$ & $-25,53$ & $-24,47$ & $-21,27$ & $-31,33$ \\
$1,00 \mathrm{E}-04$ & 1,00 & $-5,14$ & $-15,22$ & $-9,33$ & $-17,92$ & $-22,71$ & $-24,54$ & $-23,87$ & $-27,99$ \\
$1,00 \mathrm{E}-03$ & 1,00 & $-4,54$ & $-13,47$ & $-10,90$ & $-15,11$ & $-21,52$ & $-19,89$ & $-21,49$ & $-26,27$ \\
$1,00 \mathrm{E}-02$ & 1,00 & $-3,36$ & $-10,46$ & $-7,22$ & $-11,16$ & $-16,20$ & $-14,24$ & $-14,85$ & $-19,23$ \\
$1,00 \mathrm{E}-01$ & 1,00 & $-3,67$ & $-8,86$ & $-5,76$ & $-9,06$ & $-13,68$ & $-11,03$ & $-12,24$ & $-17,62$ \\
$1,00 \mathrm{E}+00$ & 1,00 & $-3,18$ & $-7,19$ & $-3,74$ & $-7,41$ & $-11,08$ & $-8,46$ & $-9,31$ & $-14,21$ \\
$1,00 \mathrm{E}+01$ & 1,00 & $-3,41$ & $-7,12$ & $-2,98$ & $-6,96$ & $-10,08$ & $-7,81$ & $-8,16$ & $-12,27$ \\
$1,00 \mathrm{E}+02$ & 1,00 & $-2,58$ & $-5,39$ & $-2,12$ & $-5,78$ & $-8,01$ & $-6,33$ & $-6,69$ & $-9,56$ \\
$1,00 \mathrm{E}+03$ & 1,00 & $-1,27$ & $-3,96$ & $-0,99$ & $-3,92$ & $-5,66$ & $-4,54$ & $-4,88$ & $-6,83$ \\
$1,00 \mathrm{E}+04$ & 1,00 & $-0,83$ & $-3,24$ & $-0,05$ & $-3,34$ & $-4,47$ & $-3,94$ & $-3,31$ & $-5,33$ \\
$1,00 \mathrm{E}+05$ & 1,00 & $-0,55$ & $-2,86$ & 0,42 & $-2,66$ & $-3,78$ & $-3,18$ & $-3,10$ & $-4,14$ \\
\hline média & 1,00 & $-2,99$ & $-8,52$ & $-4,42$ & $-9,12$ & $-12,97$ & $-11,68$ & $-11,74$ & $-15,89$ \\
\hline
\end{tabular}


Tabela 5.47 - Índices de envelhecimento de $\delta$ das misturas com a mistura 100-0-0

\begin{tabular}{cccc}
\hline Misturas & virgem & RTFOT & PAV \\
\hline $\mathbf{1 0 0 - 0 - 0}$ & 1,00 & 1,00 & 1,00 \\
$\mathbf{9 9 - 0 - 1}$ & $-3,64$ & $-2,88$ & $-2,99$ \\
$\mathbf{9 8 - 0 - 2}$ & $-10,36$ & $-10,60$ & $-8,52$ \\
$\mathbf{9 7 , 5 - 2 , 5 - 0}$ & $-0,78$ & $-2,46$ & $-4,42$ \\
$\mathbf{9 6 , 5 - 2 , 5 - 1}$ & $-6,05$ & $-8,75$ & $-9,12$ \\
$\mathbf{9 5 , 5 - 2 5 , - 2}$ & $-14,47$ & $-13,86$ & $-12,97$ \\
$\mathbf{9 5 - 5 - 0}$ & $-11,49$ & $-8,91$ & $-11,68$ \\
$\mathbf{9 4 - 5 - 1}$ & $-17,74$ & $-12,54$ & $-11,74$ \\
$\mathbf{9 3 - 5 - 2}$ & $-10,98$ & $-20,47$ & $-15,89$ \\
\hline
\end{tabular}

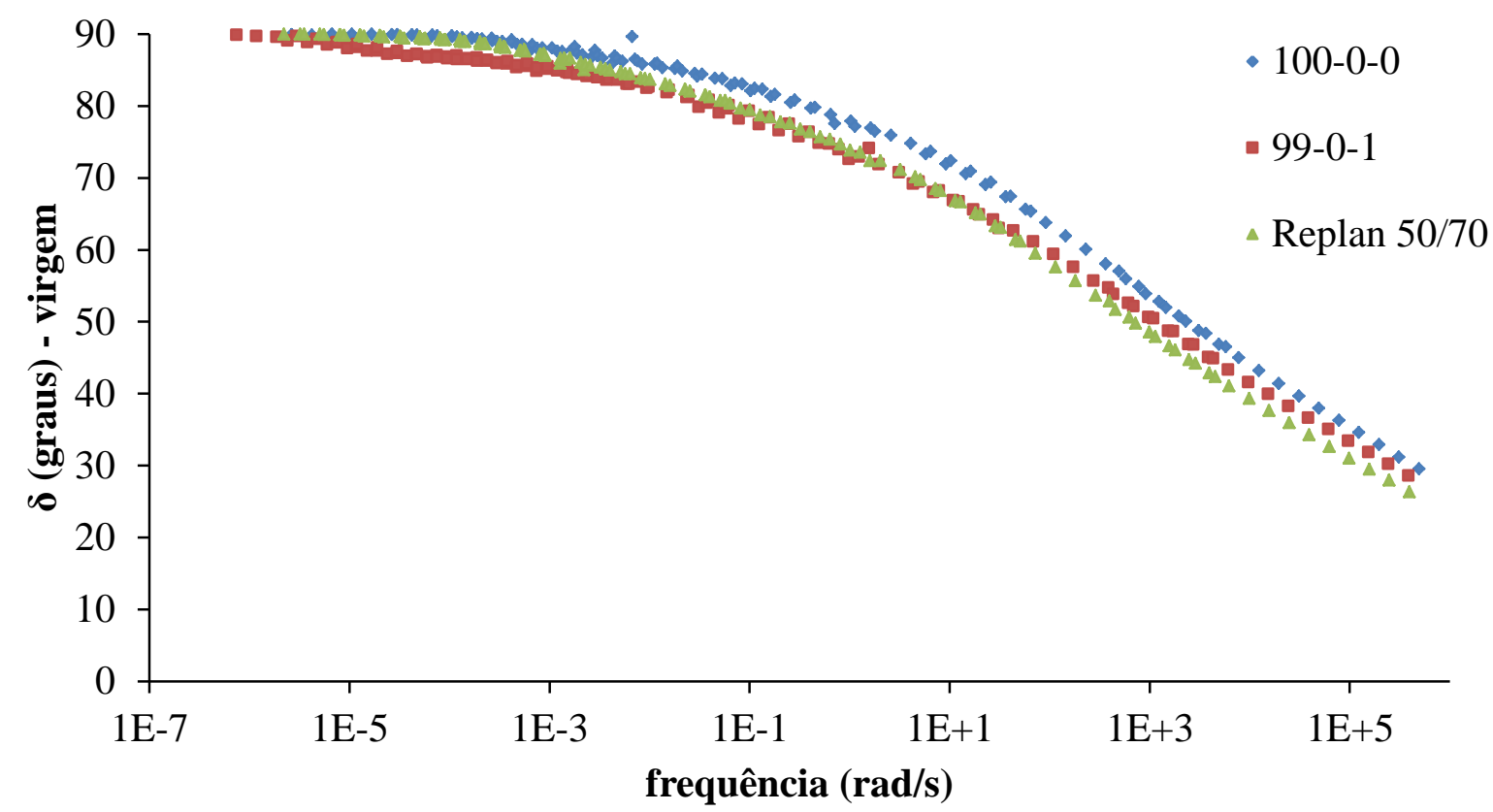

Figura 5.59 - Curvas-mestre para $\delta$ na condição virgem para o ligante asfáltico de base e as misturas 100-0-0 e 99-0-1 


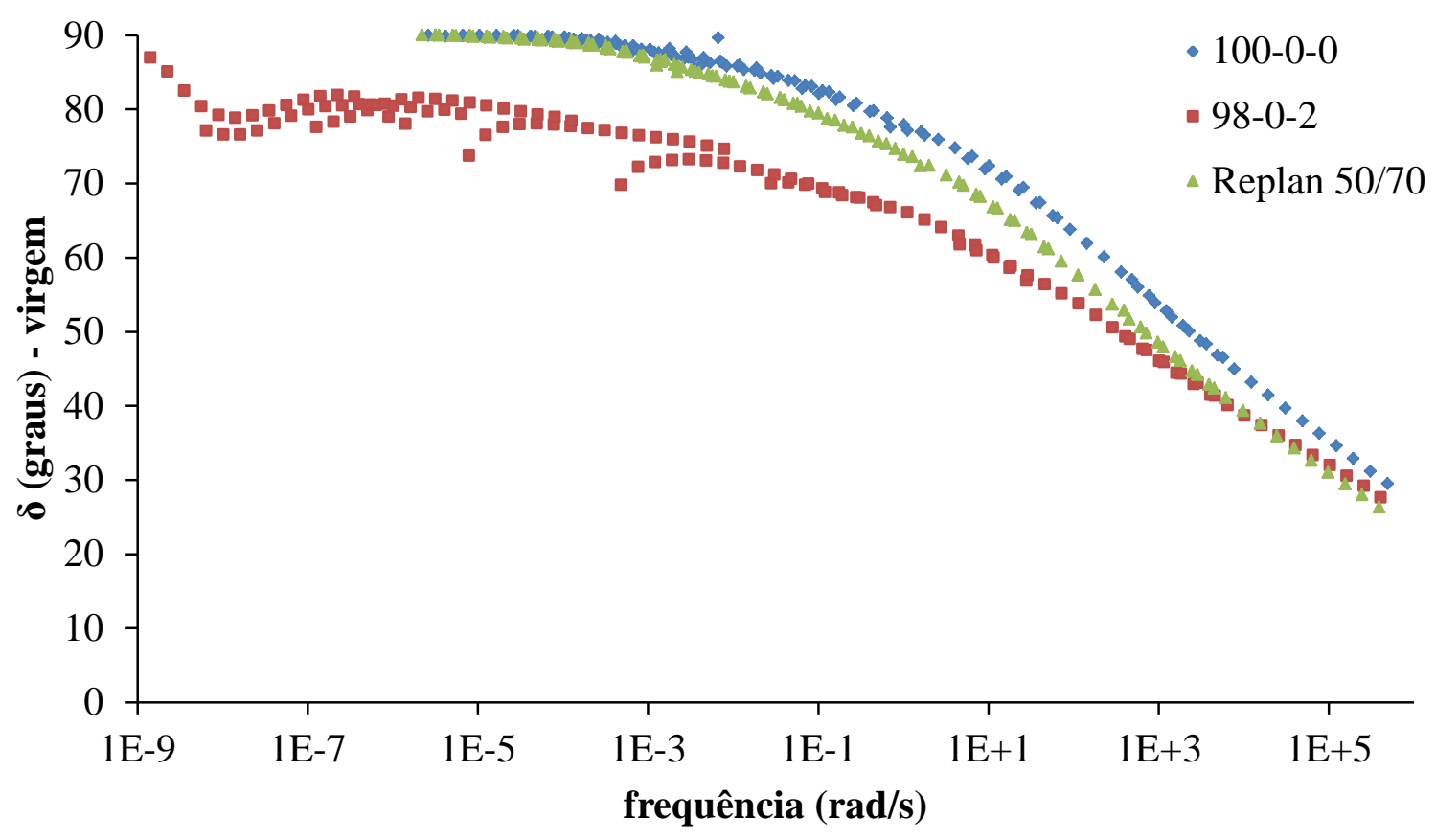

Figura 5.60 - Curvas-mestre para $\delta$ na condição virgem para o ligante asfáltico de base e as misturas 100-0-0 e 98-0-2

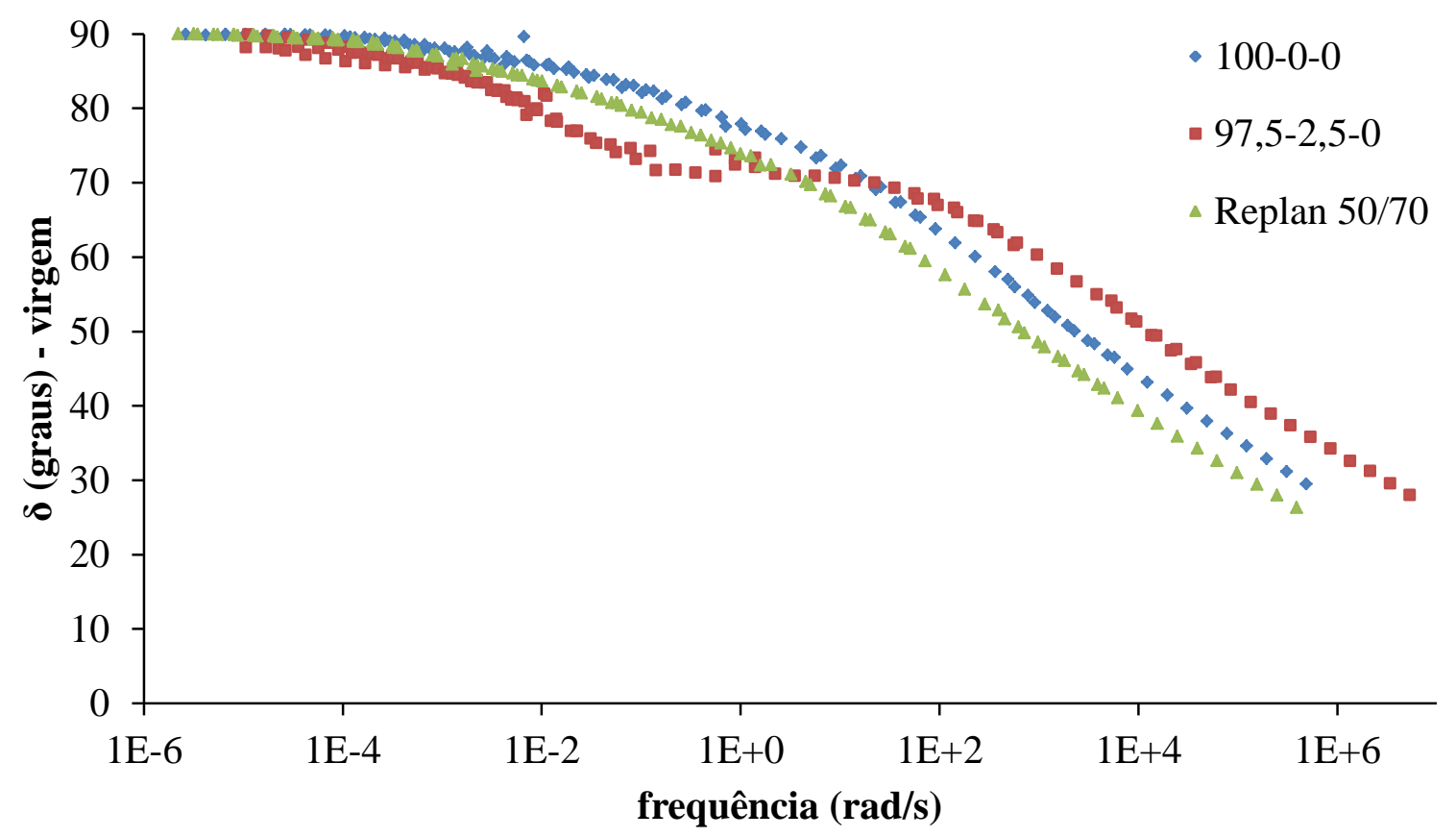

Figura 5.61 - Curvas-mestre para $\delta$ na condição virgem para o ligante asfáltico de base e as misturas 100-0-0 e 97,5-2,5-0 


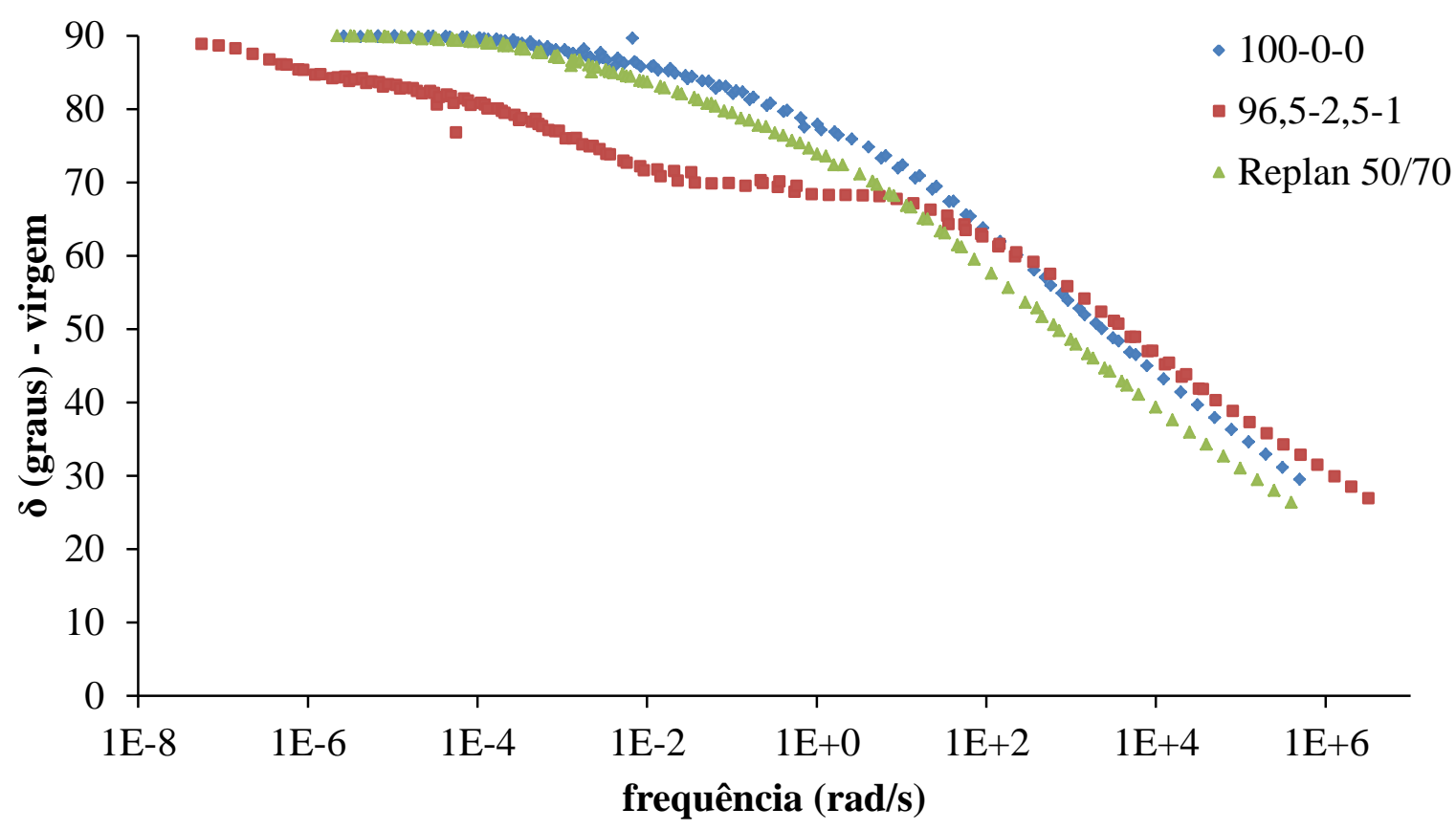

Figura 5.62 - Curvas-mestre para $\delta$ na condição virgem para o ligante asfáltico de base e as misturas 100-0-0 e 96,5-2,5-1

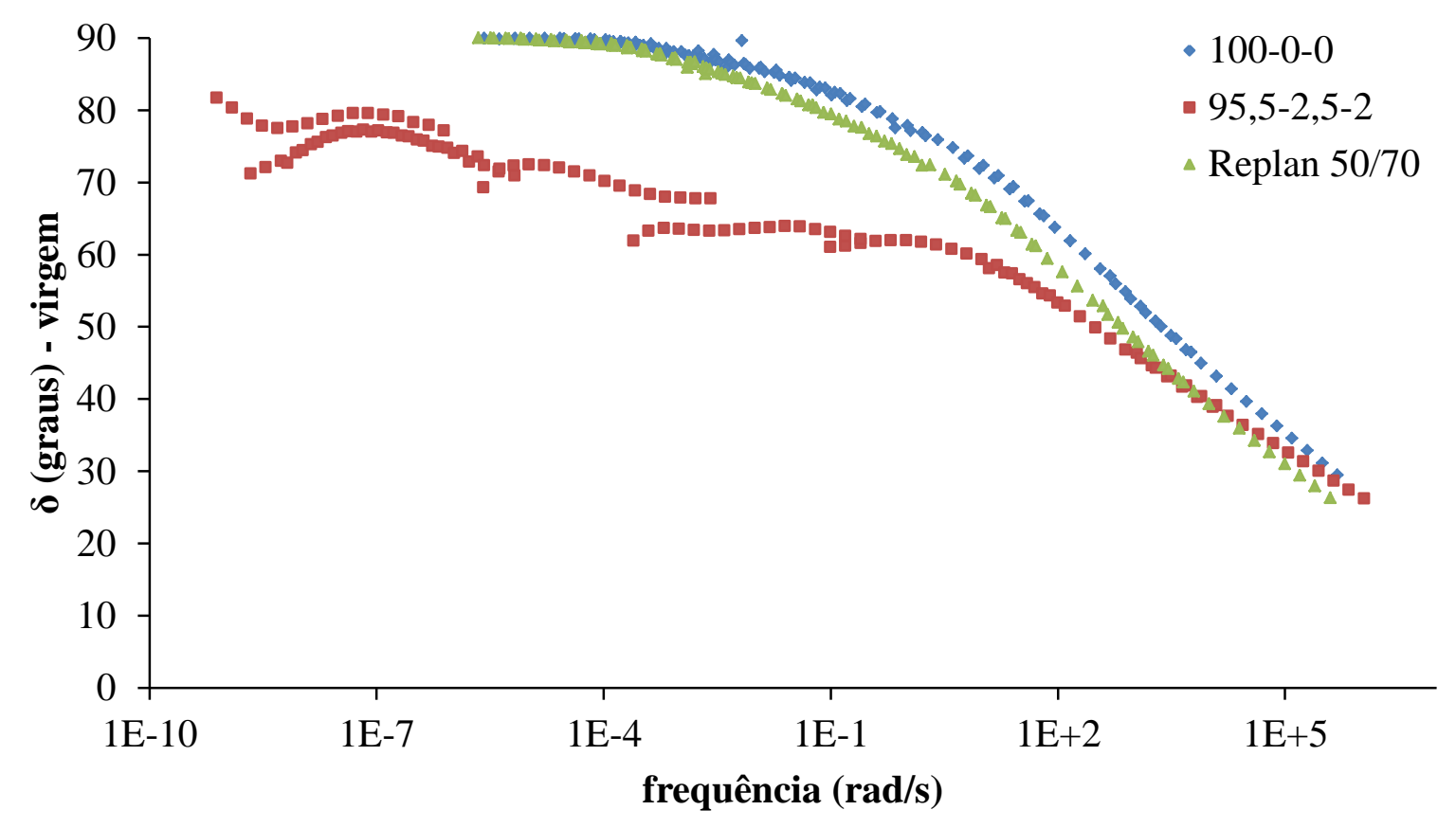

Figura 5.63 - Curvas-mestre para $\delta$ na condição virgem para o ligante asfáltico de base e as misturas 100-0-0 e 95,5-2,5-2 


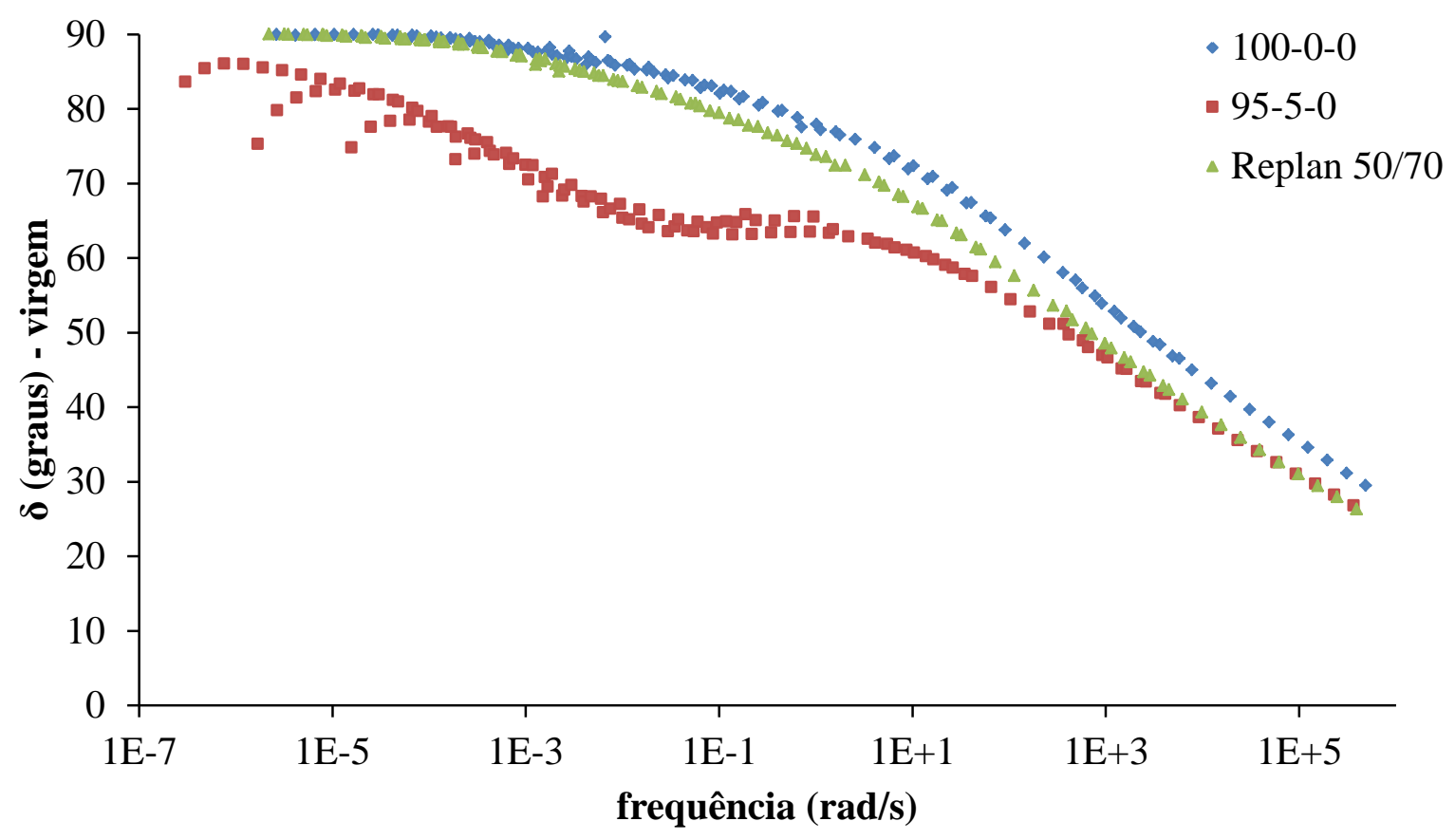

Figura 5.64 - Curvas-mestre para $\delta$ na condição virgem para o ligante asfáltico de base e as misturas 100-0-0 e 95-5-0

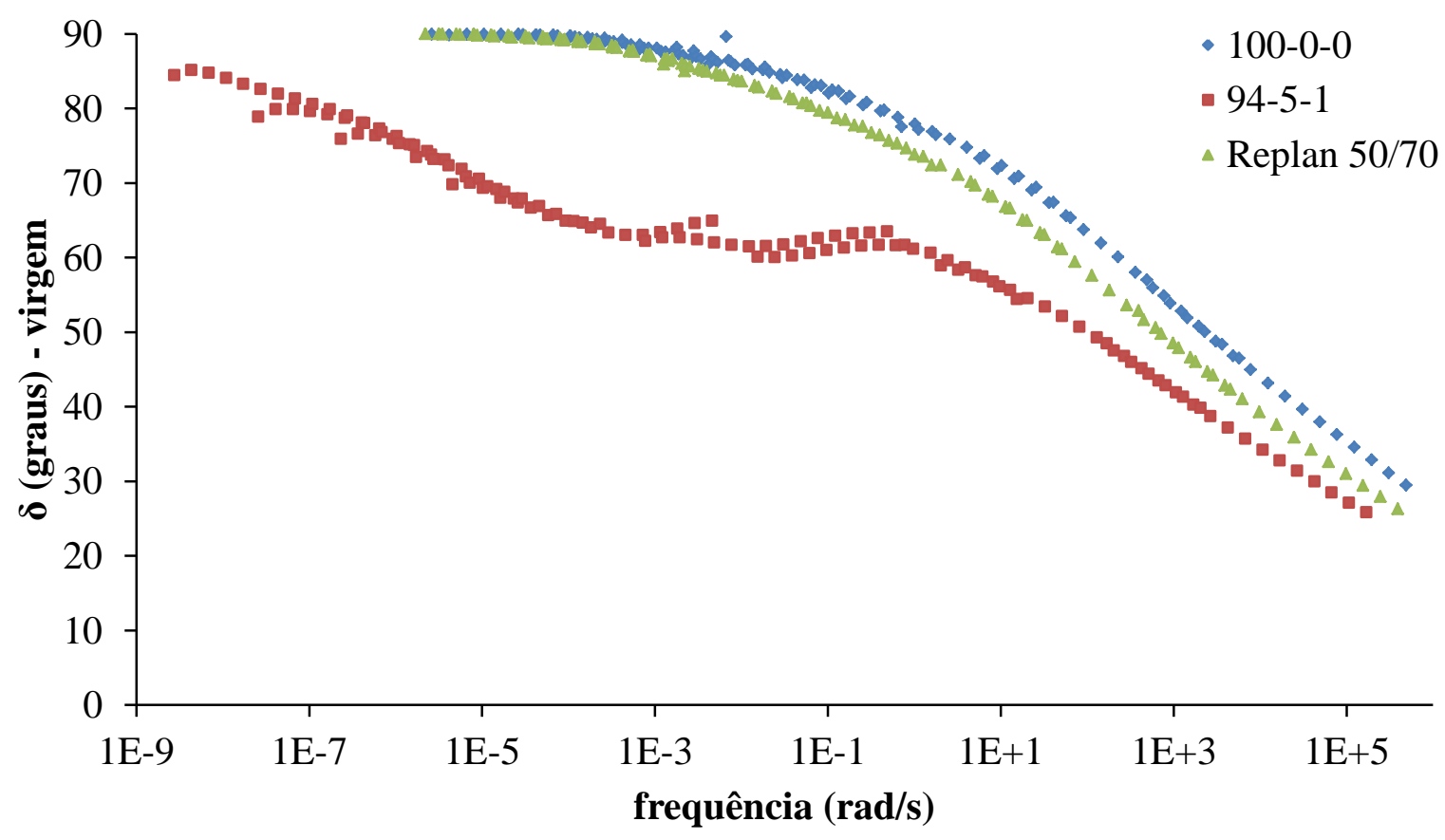

Figura 5.65 - Curvas-mestre para $\delta$ na condição virgem para o ligante asfáltico de base e as misturas 100-0-0 e 94-5-1 


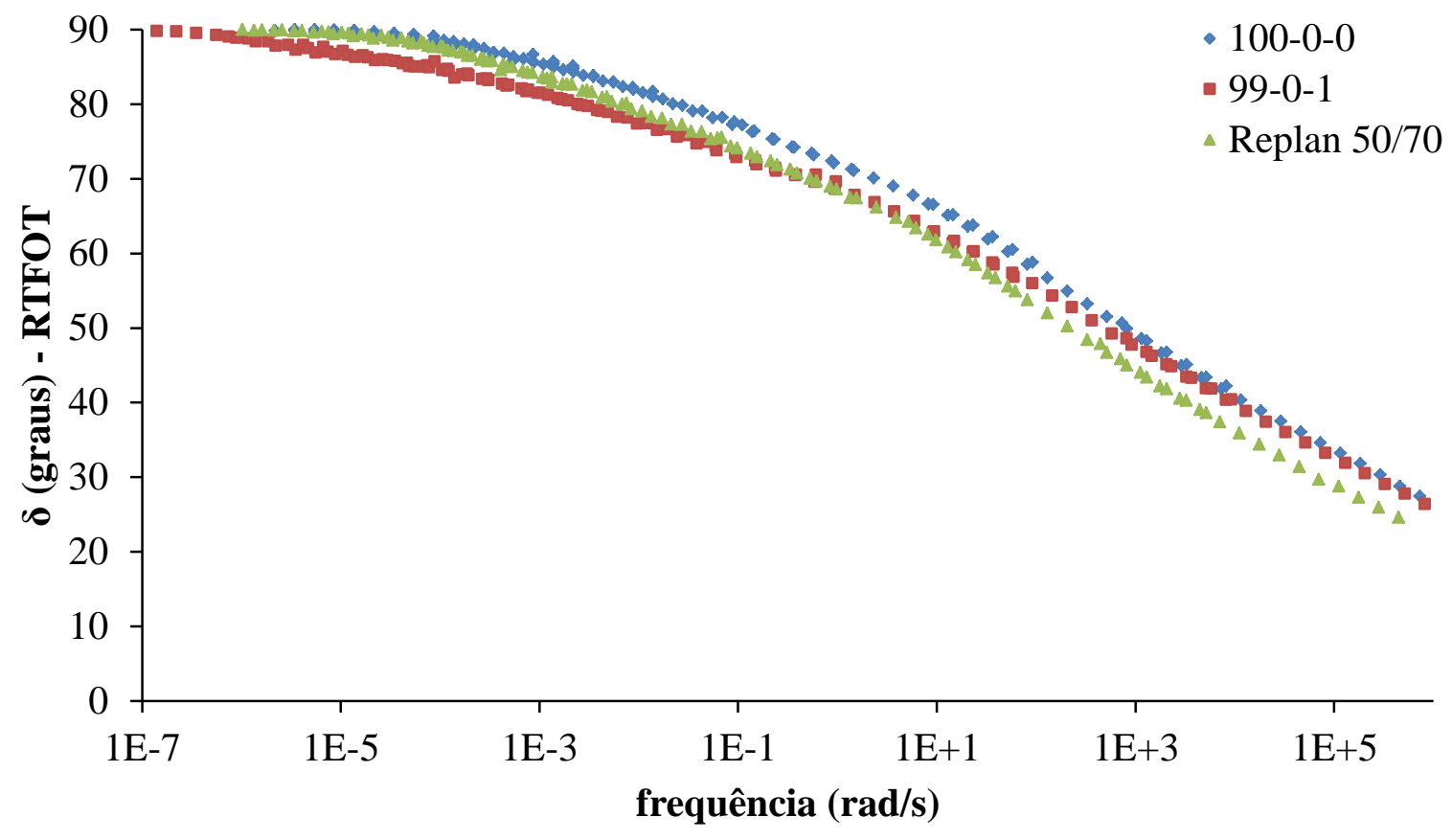

Figura 5.66 - Curvas-mestre para $\delta$ na condição envelhecida a curto prazo para o ligante asfáltico de base e as misturas 100-0-0 e 99-0-1

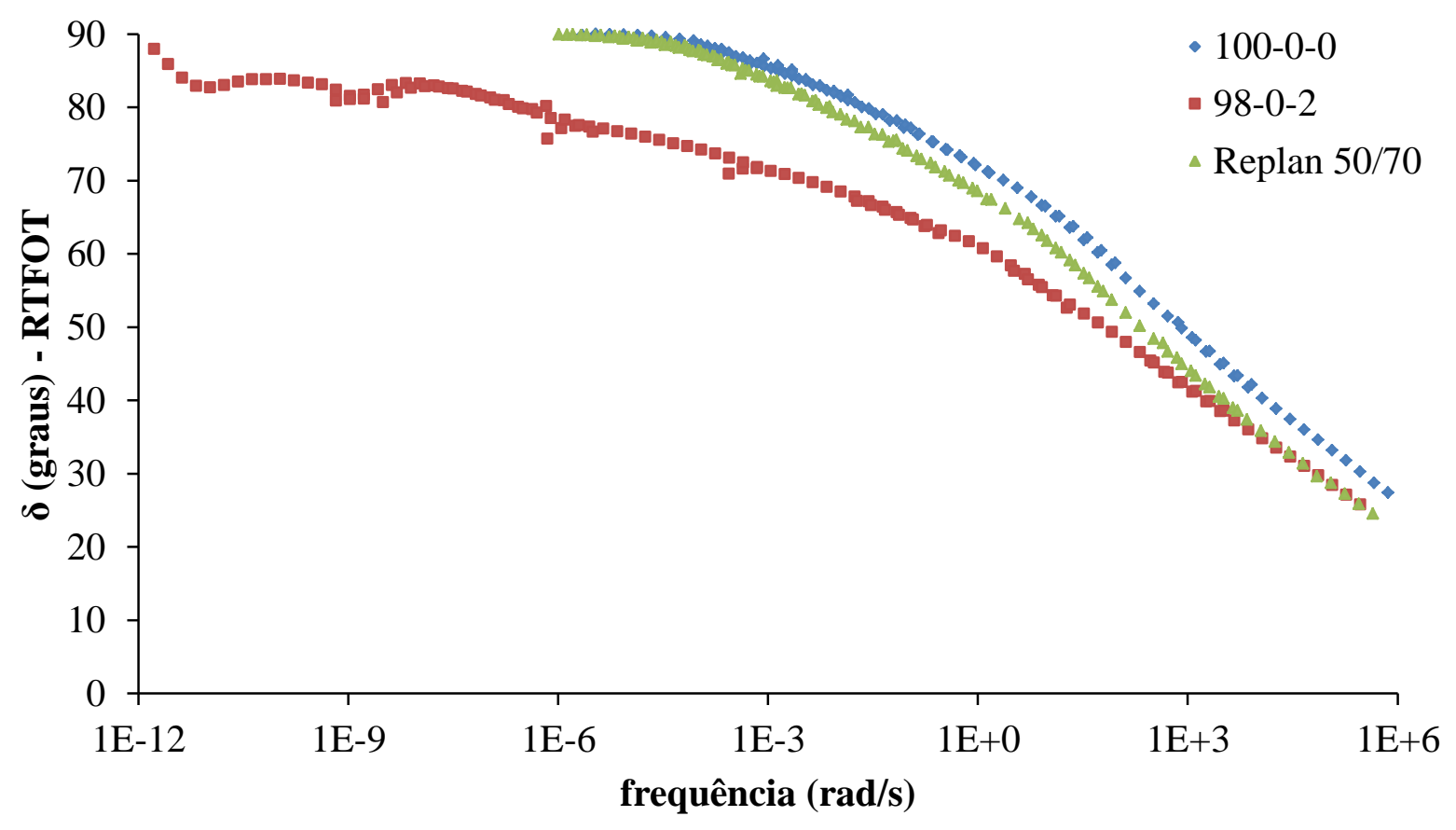

Figura 5.67 - Curvas-mestre para $\delta$ na condição envelhecida a curto prazo para o ligante asfáltico de base e as misturas 100-0-0 e 98-0-2 


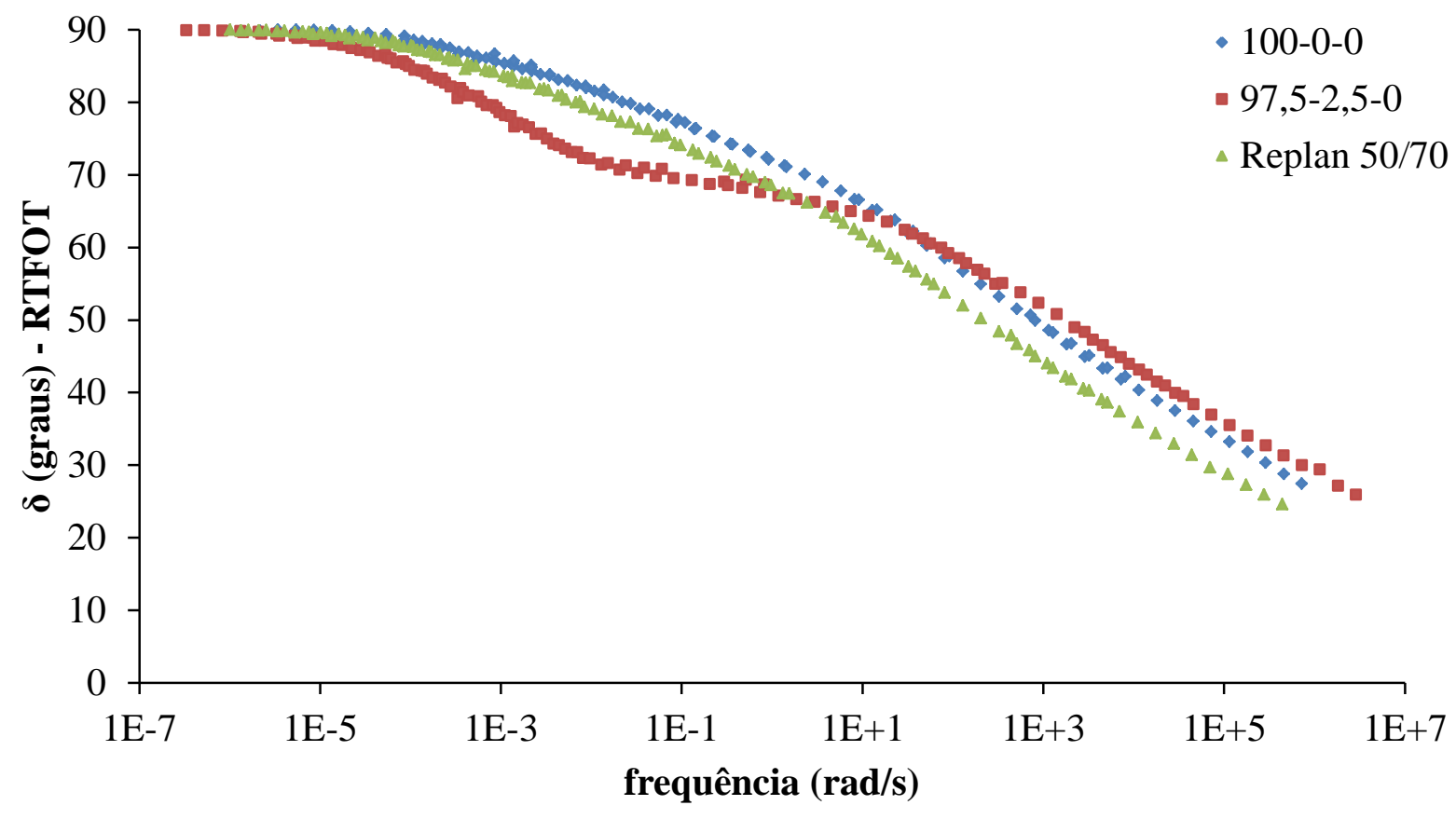

Figura 5.68 - Curvas-mestre para $\delta$ na condição envelhecida a curto prazo para o ligante asfáltico de base e as misturas 100-0-0 e 97,5-2,5-0

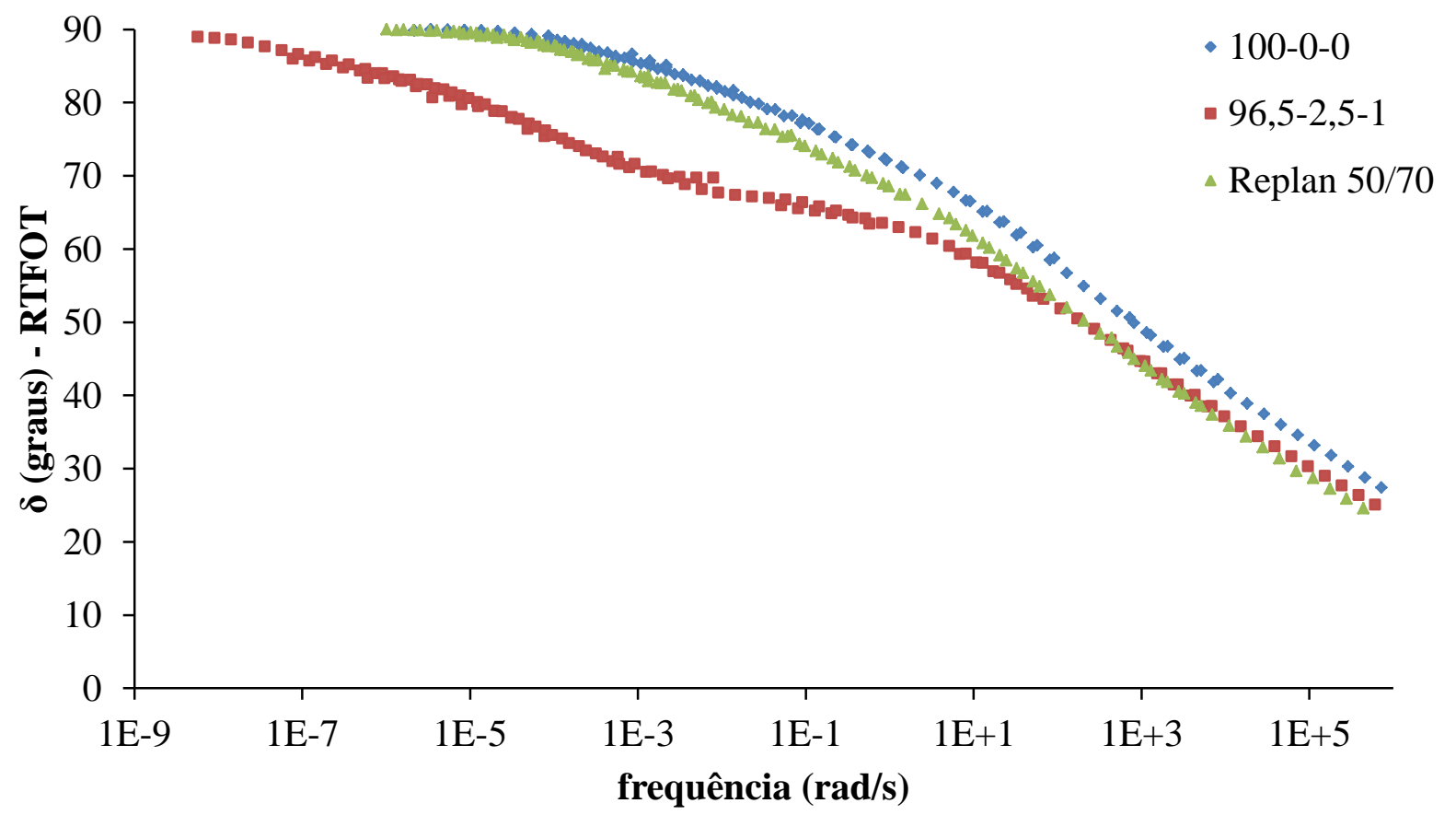

Figura 5.69 - Curvas-mestre para $\delta$ na condição envelhecida a curto prazo para o ligante asfáltico de base e as misturas 100-0-0 e 96,5-2,5-1 


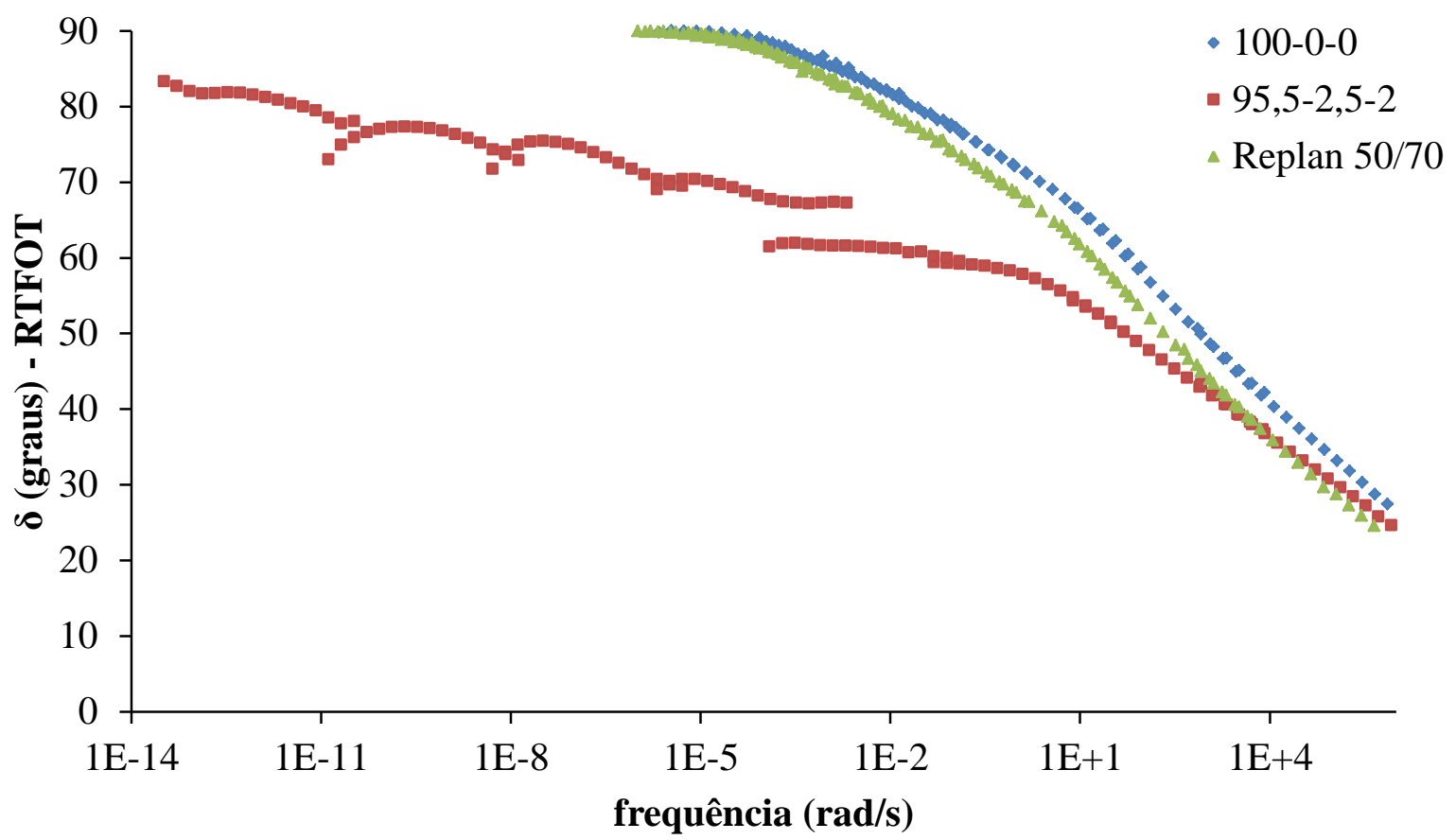

Figura 5.70 - Curvas-mestre para $\delta$ na condição envelhecida a curto prazo para o ligante asfáltico de base e as misturas 100-0-0 e 95,5-2,5-2

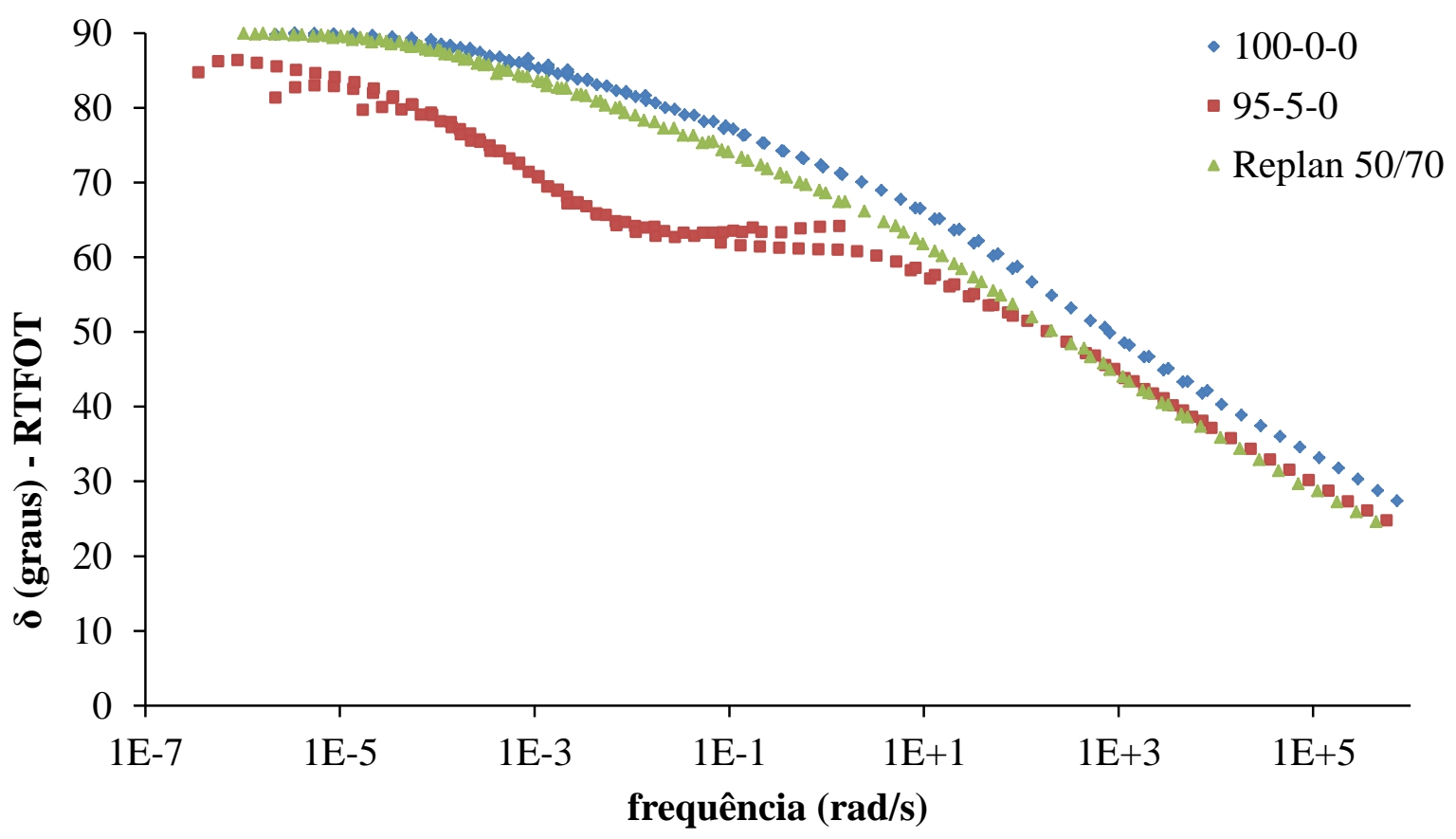

Figura 5.71 - Curvas-mestre para $\delta$ na condição envelhecida a curto prazo para o ligante asfáltico de base e as misturas 100-0-0 e 95-5-0 


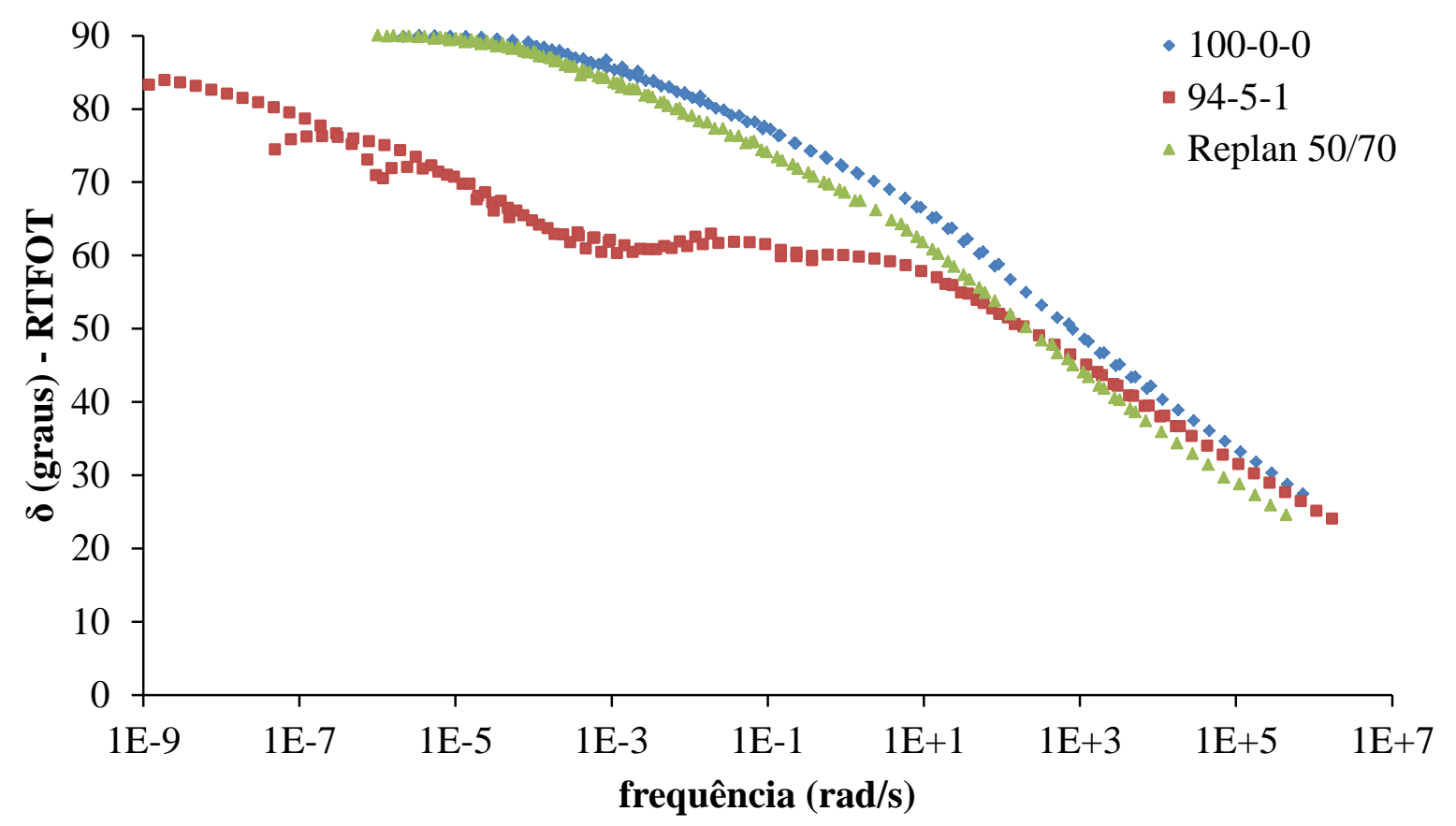

Figura 5.72 - Curvas-mestre para $\delta$ na condição envelhecida a curto prazo para o ligante asfáltico de base e as misturas 100-0-0 e 94-5-1

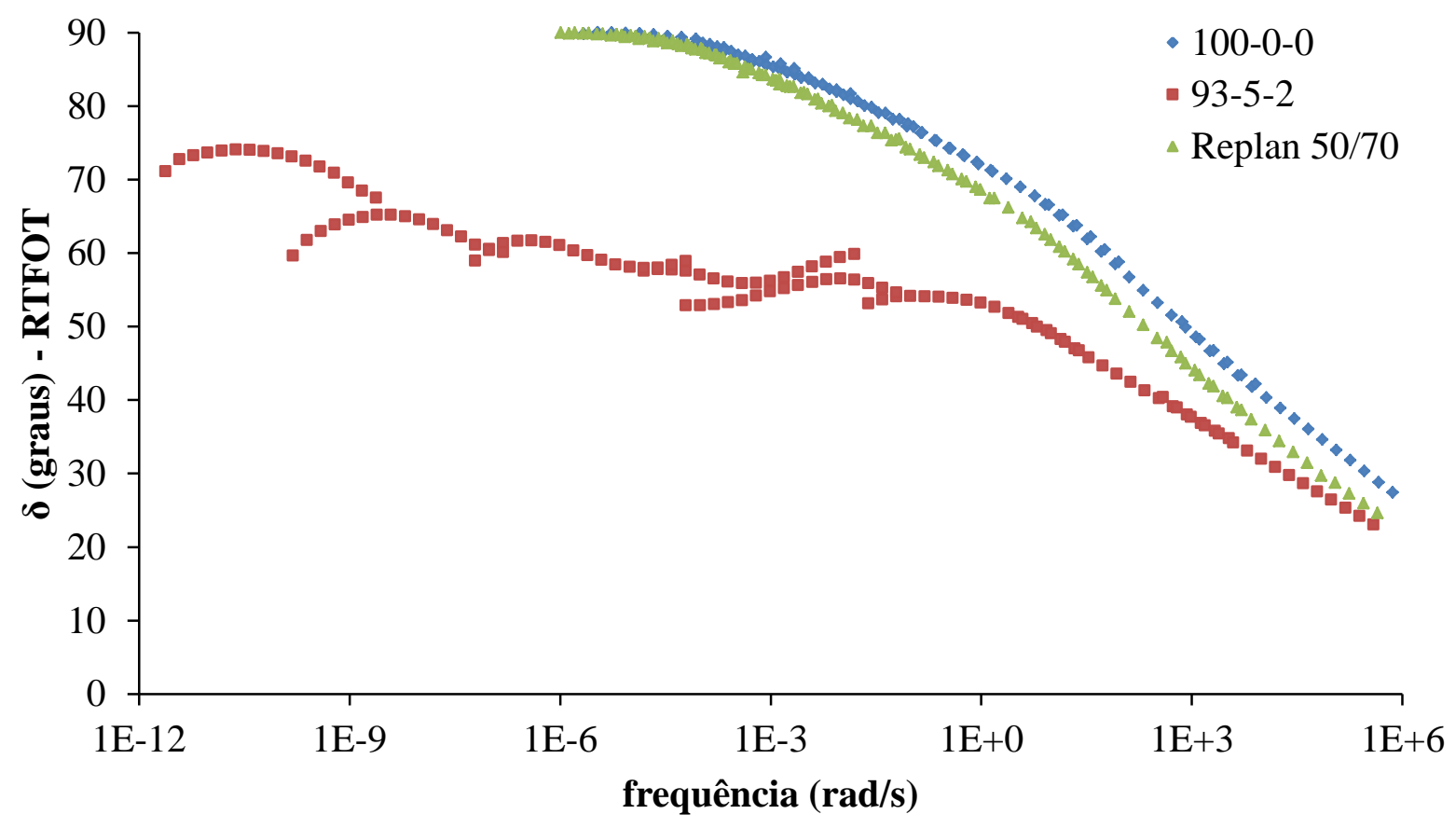

Figura 5.73 - Curvas-mestre para $\delta$ na condição envelhecida a curto prazo para o ligante asfáltico de base e as misturas 100-0-0 e 93-5-2 


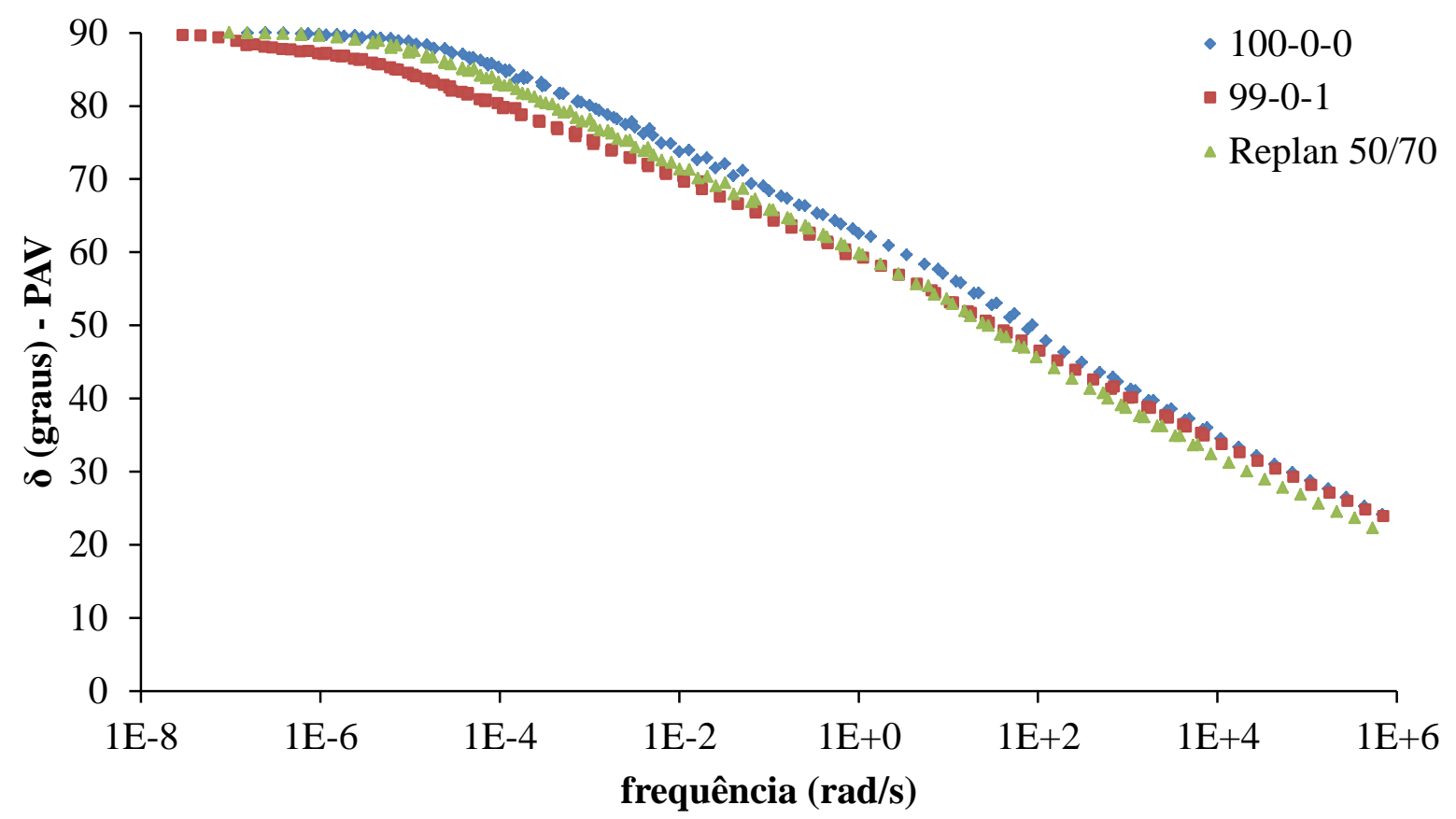

Figura 5.74 - Curvas-mestre para $\delta$ na condição envelhecida a longo prazo para o ligante asfáltico de base e as misturas 100-0-0 e 99-0-1

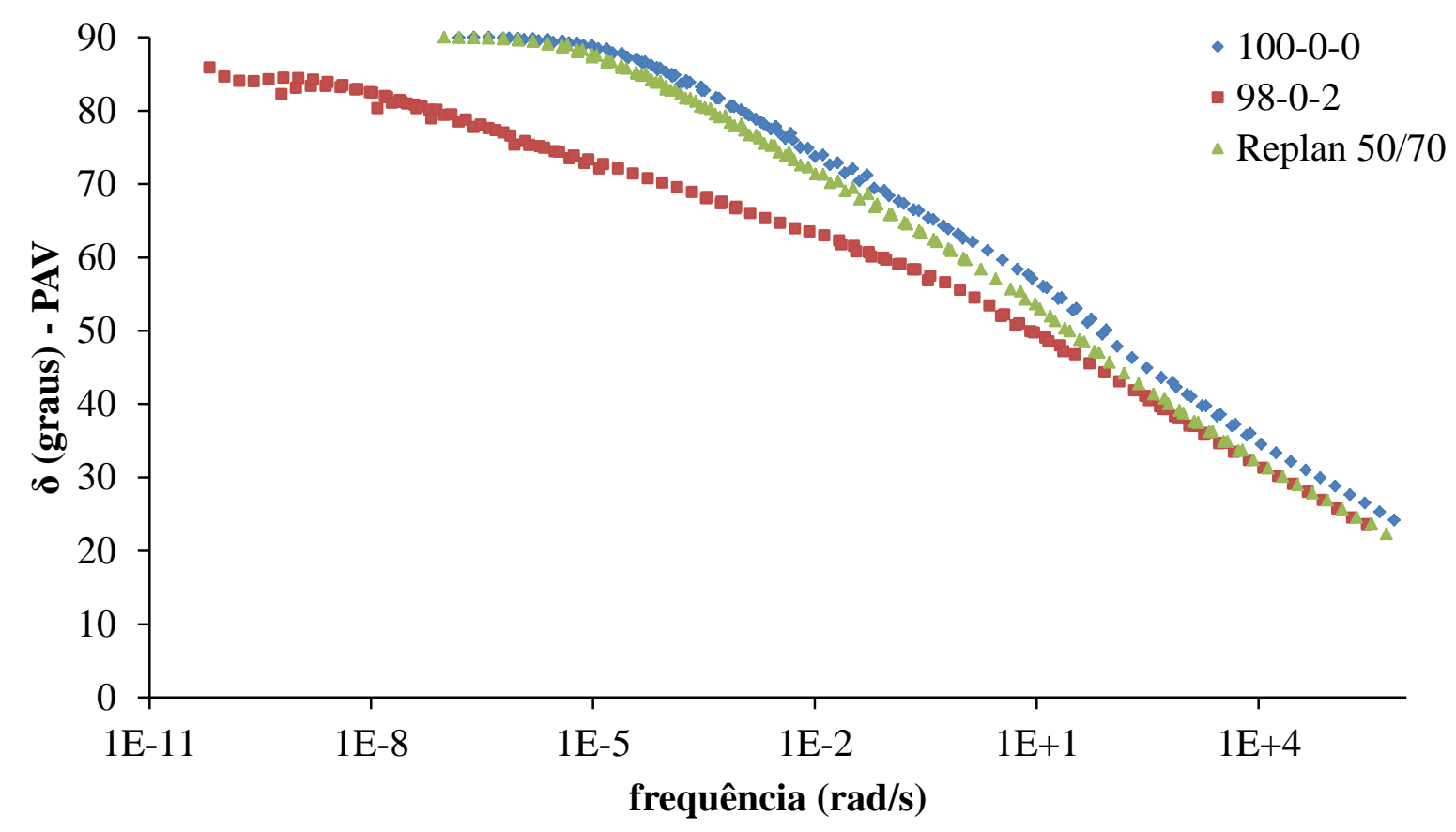

Figura 5.75 - Curvas-mestre para $\delta$ na condição envelhecida a longo prazo para o ligante asfáltico de base e as misturas 100-0-0 e 98-0-2 


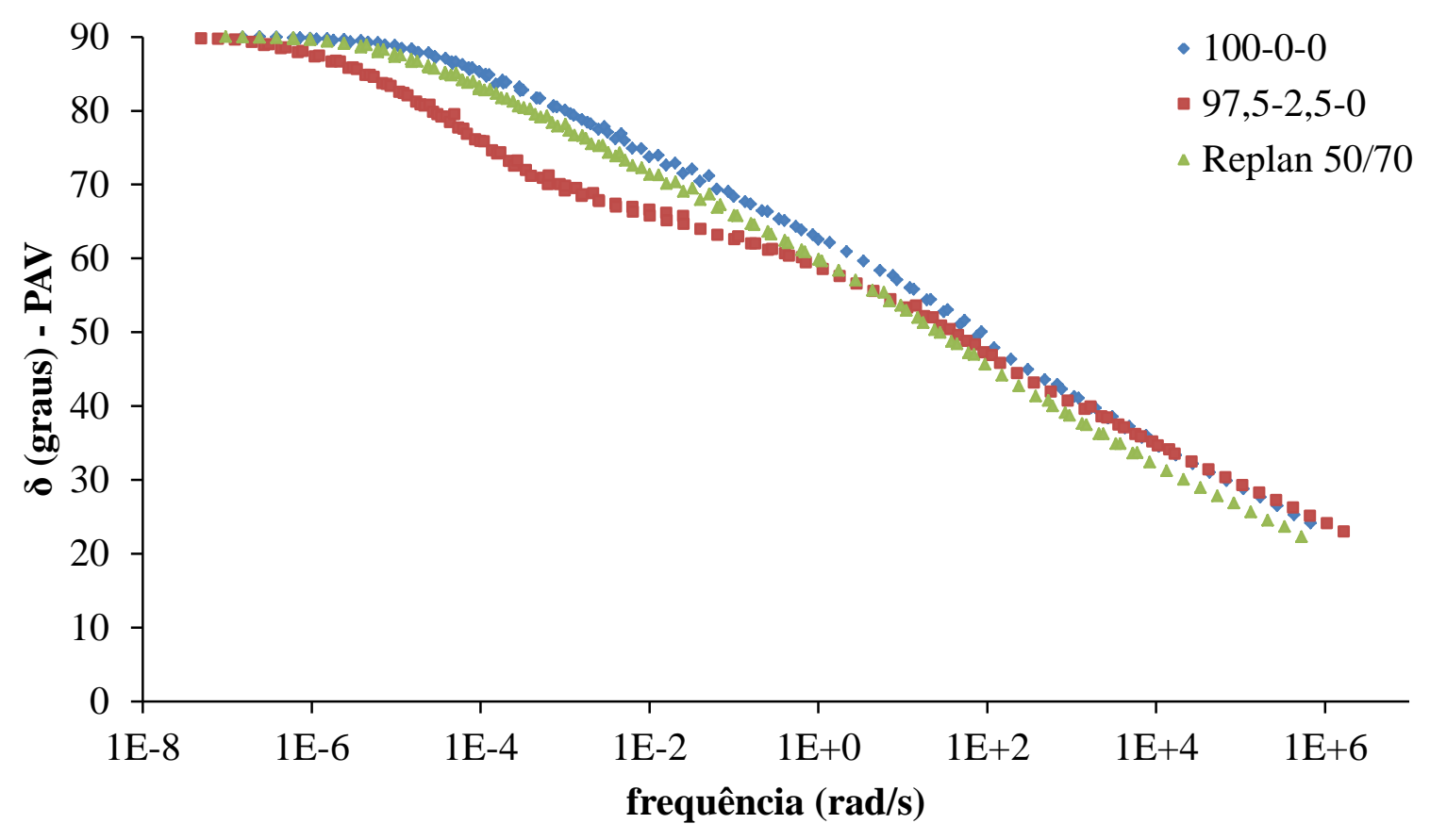

Figura 5.76 - Curvas-mestre para $\delta$ na condição envelhecida a longo prazo para o ligante asfáltico de base e as misturas 100-0-0 e 97,5-2,5-0

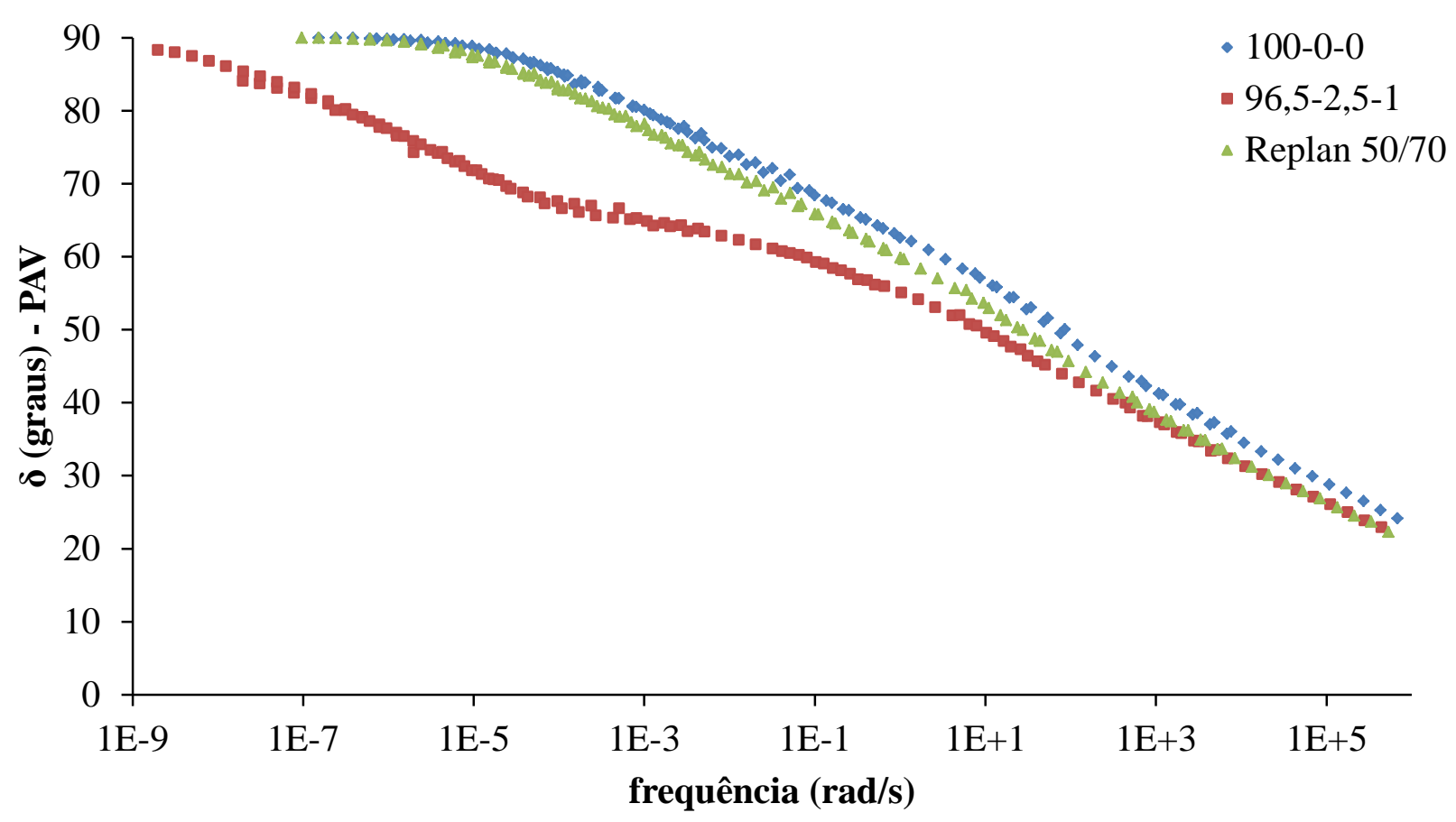

Figura 5.77 - Curvas-mestre para $\delta$ na condição envelhecida a longo prazo para o ligante asfáltico de base e as misturas 100-0-0 e 96,5-2,5-1 


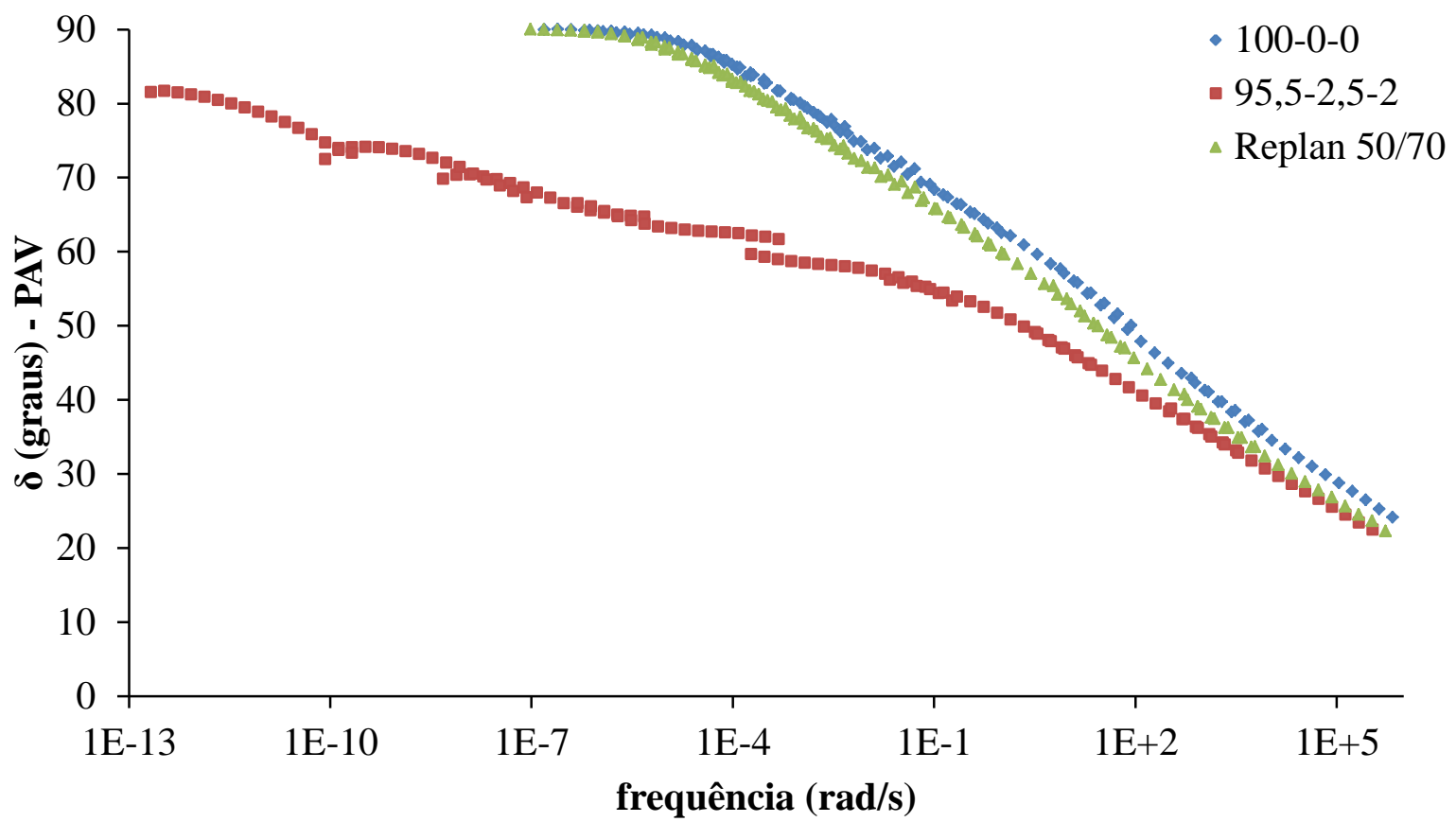

Figura 5.78 - Curvas-mestre para $\delta$ na condição envelhecida a longo prazo para o ligante asfáltico de base e as misturas 100-0-0 e 95,5-2,5-2

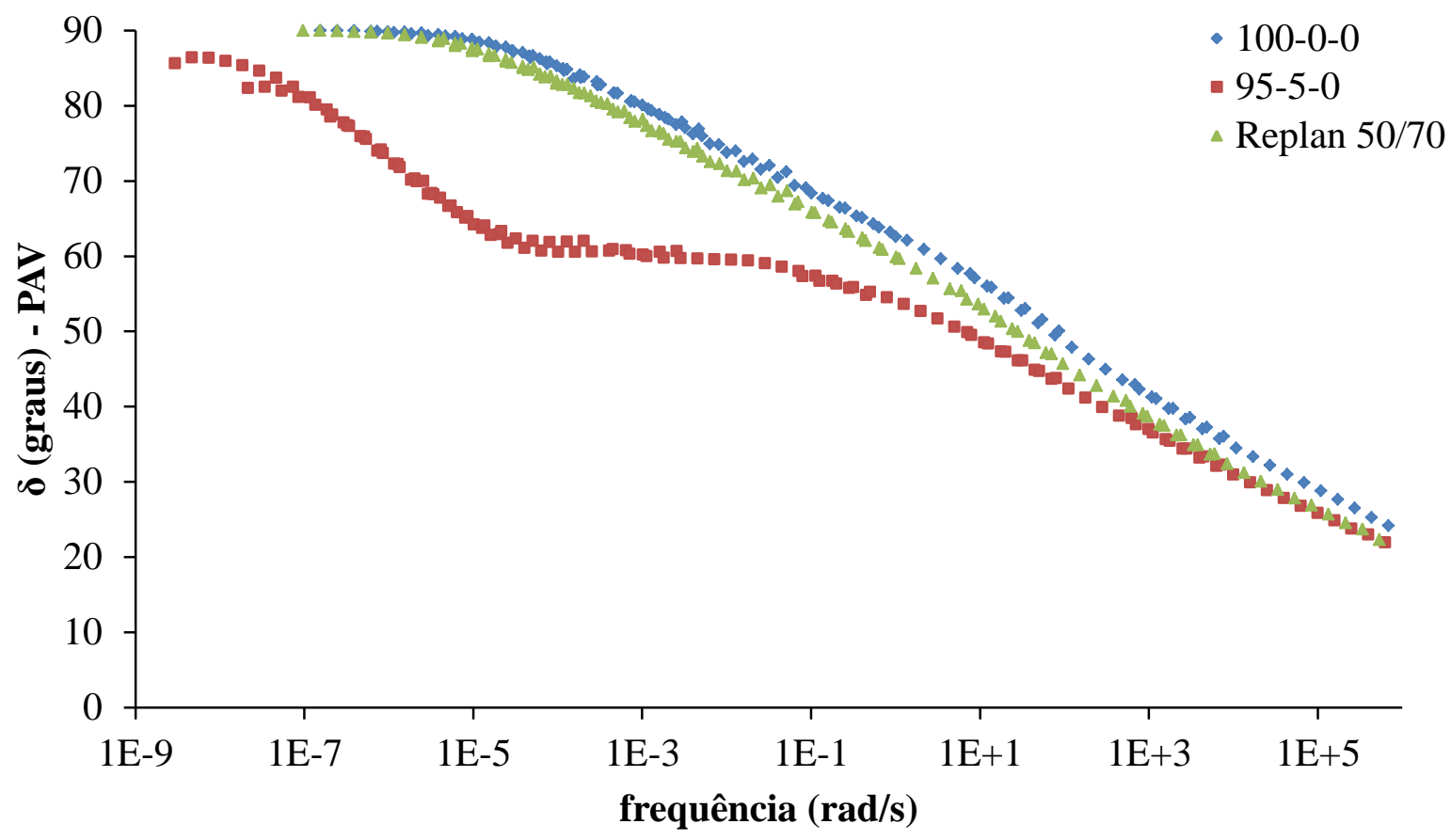

Figura 5.79 - Curvas-mestre para $\delta$ na condição envelhecida a longo prazo para o ligante asfáltico de base e as misturas 100-0-0 e 95-5-0 


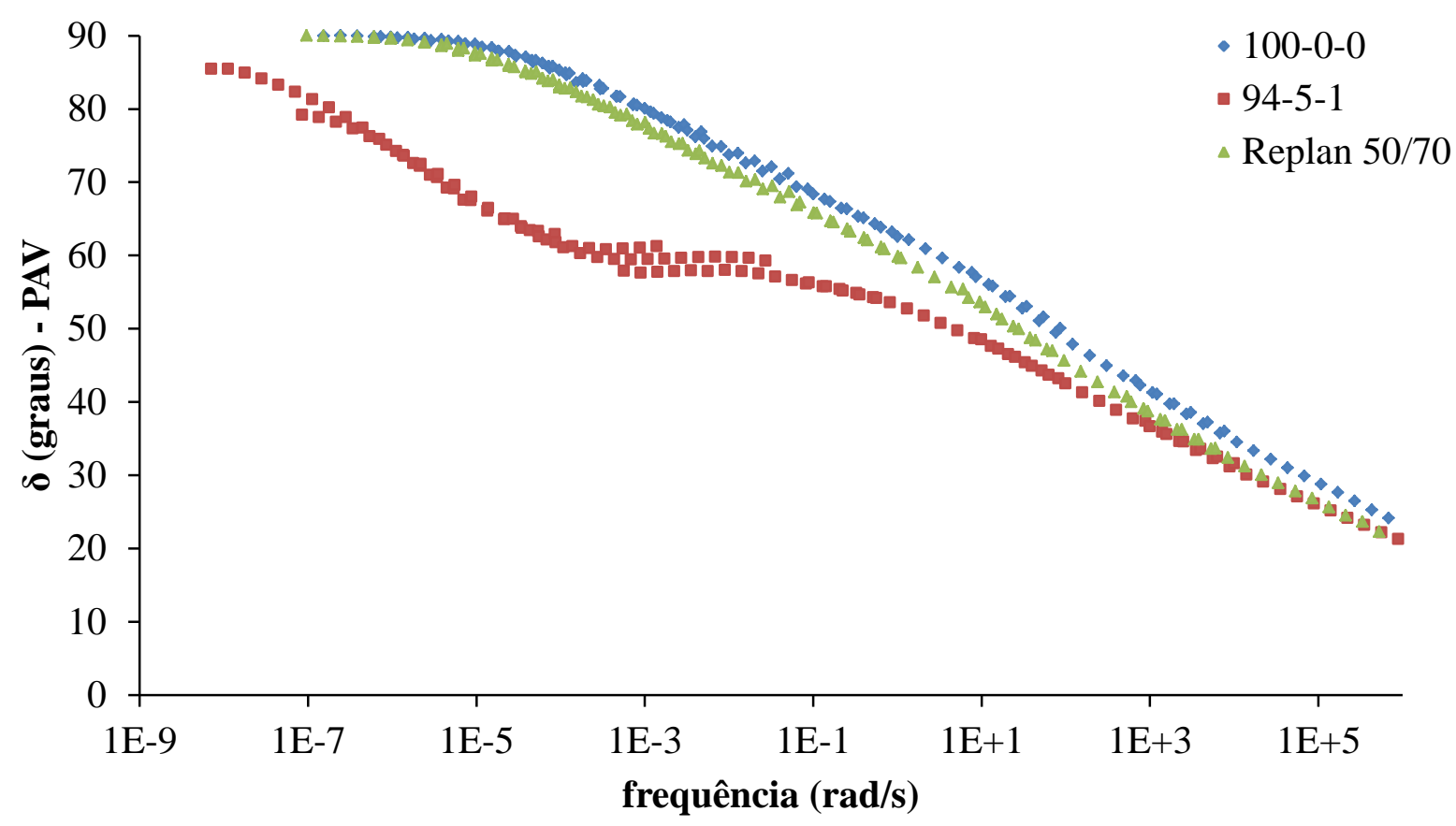

Figura 5.80 - Curvas-mestre para $\delta$ na condição envelhecida a longo prazo para o ligante asfáltico de base e as misturas 100-0-0 e 94-5-1

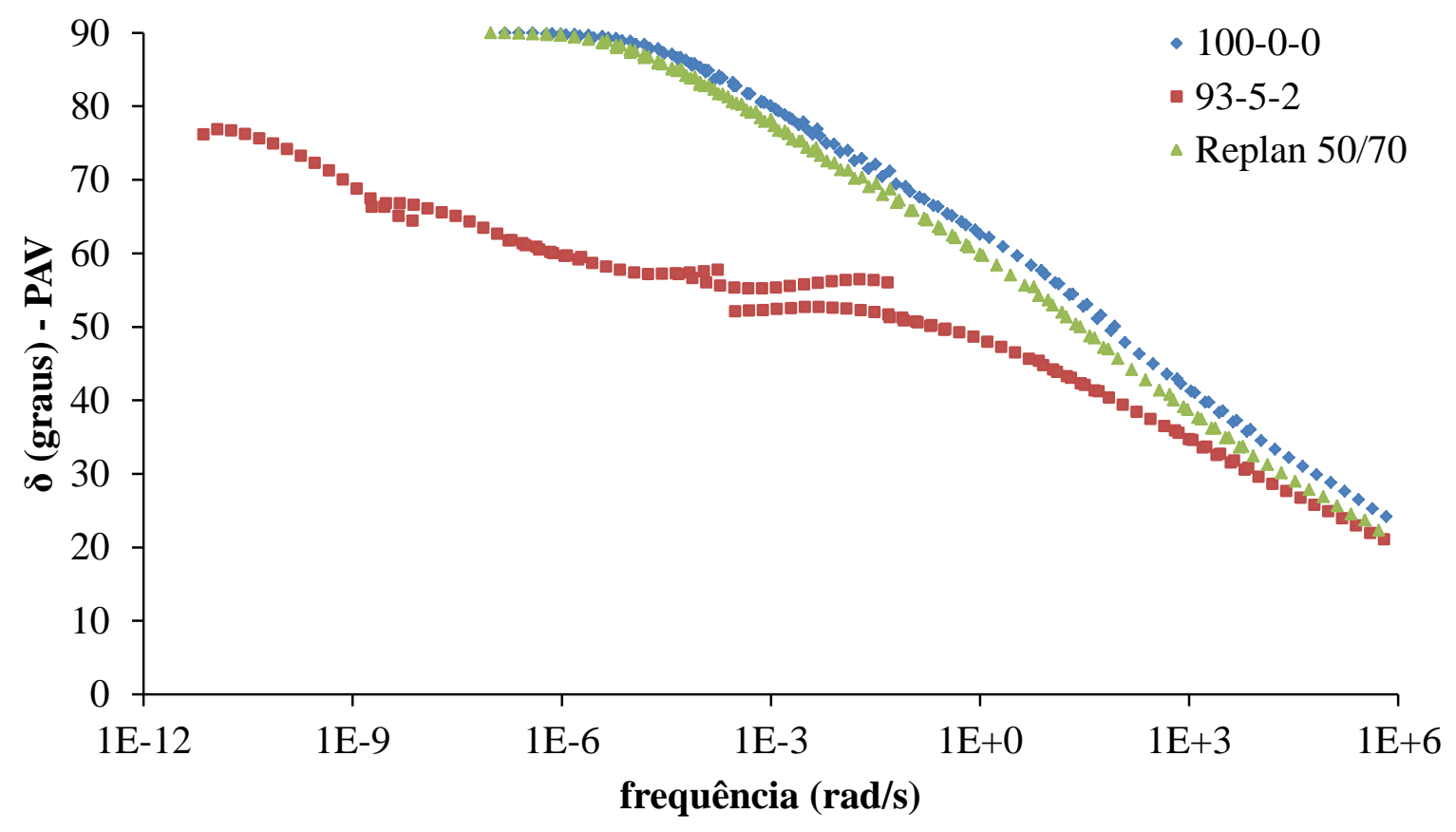

Figura 5.81 - Curvas-mestre para $\delta$ na condição envelhecida a longo prazo para o ligante asfáltico de base e as misturas 100-0-0 e 93-5-2 
Tendo em vista a Tabela 5.44 e as Figuras 5.59 a 5.65, que apresentam os dados de delta na condição virgem, tem-se que:

- a mistura que apresenta maior diferença média entre os valores de delta é a 94-5-1 $(-17,74)$ seguida pela 95,5-2,5-2 (-14,47); a mistura que apresenta menor diferença média entre os valore de delta é a 97,5-2,5-0 (-0,78) seguida pela 99-0-1 (-3,64);

- ao se manter o teor de SBS constante e variar a quantidade de TITAN, ocorre um aumento da diferença entre os valores de ângulo de fase, indicando que o TITAN tem a capacidade de aumentar a elasticidade do ligante asfáltico;

- ao se manter o teor de TITAN constante e variar a quantidade de SBS, ocorre um aumento da diferença entre valores de ângulo de fase, indicando que o SBS também aumenta a elasticidade do ligante asfáltico.

Tendo em vista a Tabela 5.45 e as Figuras 5.66 a 5.73, que apresentam os dados de delta na condição envelhecida a curto prazo, tem-se que:

- a mistura que apresenta maior diferença entre valores de delta média é a 93-5-2 (-20,47) seguida pela 95,5-2,5-2 (-13,86); a mistura que apresenta menor diferença média entre valores de delta é a 97,5-2,5-0 (-2,46) seguida pela 99-0-1 (-2,88);

- ao se manter o teor de SBS constante e variar a quantidade de TITAN, ocorre um aumento da diferença entre os valores de ângulo de fase, indicando que o TITAN tem a capacidade de aumentar a elasticidade do ligante asfáltico, conforme observado também para as amostras virgens;

- ao se manter o teor de TITAN constante e variar a quantidade de SBS, ocorre um aumento da diferença entre valores de ângulo de fase, indicando que o SBS também aumenta a elasticidade do ligante asfáltico, o que também se observa para as amostras virgens.

Tendo em vista a Tabela 5.46 e as Figuras 5.74 a 5.81, que apresentam os dados de delta na condição envelhecida a longo prazo, tem-se que:

- a mistura que apresenta maior diferença média entre valores de delta é a 93-5-2 $(-15,89)$ seguida pela 95,5-2,5-2 (-12,97); a mistura que apresenta menor diferença média entre valores de delta é a 99-0-1 (-2,99) seguida pela 97,5-2,5-0 (-4,42);

- ao se manter o teor de SBS constante e variar a quantidade de TITAN, ocorre um aumento da diferença entre os valores de ângulo de fase, indicando que o TITAN tem a capacidade de 
aumentar a elasticidade do ligante asfáltico, como já observado nas condições virgem e envelhecida a curto prazo;

- ao se manter o teor de TITAN constante e variar a quantidade de SBS, ocorre um aumento da diferença entre valores de ângulo de fase, indicando que o SBS também aumenta a elasticidade do ligante asfáltico, o que também se observou com as amostras virgens e as envelhecidas a curto prazo.

Observa-se que as misturas com maiores modificadores apresentam uma diminuição média de delta maiores que as misturas com baixos teores de modificadores. Como exemplo, a mistura 93-5-2 possui um valor médio de diminuição de delta em relação à mistura 100-0-0 na condição virgem de 10,98 . No caso da comparação para a condição envelhecida a curto prazo, a diminuição média de delta aumenta para 20,47 e para a condição envelhecida a longo prazo, a diminuição média de delta aumenta para 15,89. Isto mostra que, quanto maior o nível de modificação do ligante asfáltico com polímeros, maior será a variação do delta, indicando que o envelhecimento torna as misturas mais elásticas.

5.6.6 Comparação das curvas-mestre para uma mesma mistura quanto ao ensaio de estabilidade à estocagem (relação topo/fundo) para módulo complexo $\left(G^{*}\right)$

As Tabelas de 5.48 a 5.56 apresentam as relações topo/fundo, fundo/original e topo/original, entre valores de módulo complexo $\left(\mathrm{G}^{*}\right)$ das misturas obtidas das respectivas curvas-mestre. A Tabela 5.57 apresenta as relações topo/fundo para os valores de $\mathrm{G}^{*}$ das nove misturas. A Tabela 5.58 apresenta a média das três relações mostradas nas Tabelas 5.48 a 5.56. As Figuras 5.82 a 5.90 apresentam na forma gráfica, a título de ilustração, as curvasmestre obtidas para o módulo complexo, para as condições original, topo e fundo. Na curvamestre, as baixas frequências estão relacionadas às altas temperaturas e, as altas frequências estão relacionadas às baixas temperaturas. 
Tabela 5.48 - Relações entre valores de G* para a mistura 100-0-0

\begin{tabular}{cccc}
\hline & \multicolumn{3}{c}{ Relações } \\
\cline { 2 - 4 } Frequência (rad/s) & topo/fundo & fundo/original & topo/original \\
\hline $1,00 \mathrm{E}-05$ & 1,31 & 0,86 & 1,13 \\
$1,00 \mathrm{E}-04$ & 1,31 & 0,87 & 1,14 \\
$1,00 \mathrm{E}-03$ & 1,31 & 0,87 & 1,13 \\
$1,00 \mathrm{E}-02$ & 1,29 & 0,88 & 1,13 \\
$1,00 \mathrm{E}-01$ & 1,28 & 0,89 & 1,14 \\
$1,00 \mathrm{E}+00$ & 1,24 & 0,89 & 1,10 \\
$1,00 \mathrm{E}+01$ & 1,19 & 0,90 & 1,08 \\
$1,00 \mathrm{E}+02$ & 1,12 & 0,94 & 1,05 \\
$1,00 \mathrm{E}+03$ & 1,10 & 0,94 & 1,04 \\
$1,00 \mathrm{E}+04$ & 1,07 & 0,96 & 1,03 \\
$1,00 \mathrm{E}+05$ & 1,05 & 0,97 & 1,02 \\
\hline média & 1,21 & 0,91 & 1,09 \\
\hline
\end{tabular}

Tabela 5.49 - Relações entre valores de G* para a mistura 99-0-1

\begin{tabular}{cccc}
\hline & \multicolumn{3}{c}{ Relações } \\
\cline { 2 - 4 } Frequência (rad/s) & topo/fundo & fundo/original & topo/original \\
\hline $1,00 \mathrm{E}-05$ & 0,99 & 1,14 & 1,13 \\
$1,00 \mathrm{E}-04$ & 1,01 & 1,09 & 1,10 \\
$1,00 \mathrm{E}-03$ & 0,94 & 1,07 & 1,01 \\
$1,00 \mathrm{E}-02$ & 0,95 & 1,03 & 0,97 \\
$1,00 \mathrm{E}-01$ & 0,94 & 1,03 & 0,97 \\
$1,00 \mathrm{E}+00$ & 0,94 & 1,02 & 0,96 \\
$1,00 \mathrm{E}+01$ & 0,95 & 1,01 & 0,96 \\
$1,00 \mathrm{E}+02$ & 0,96 & 1,00 & 0,96 \\
$1,00 \mathrm{E}+03$ & 0,96 & 0,97 & 0,94 \\
$1,00 \mathrm{E}+04$ & 0,95 & 0,96 & 0,91 \\
$1,00 \mathrm{E}+05$ & 0,95 & 0,96 & 0,91 \\
\hline média & 0,96 & 1,03 & 0,98 \\
\hline
\end{tabular}


Tabela 5.50 - Relações entre valores de G* para a mistura 98-0-2

\begin{tabular}{cccc}
\hline & \multicolumn{3}{c}{ Relações } \\
\cline { 2 - 4 } Frequência (rad/s) & fundo/original & topo/original \\
\hline $1,00 \mathrm{E}-05$ & 1,10 & 0,99 & 1,10 \\
$1,00 \mathrm{E}-04$ & 1,24 & 1,05 & 1,30 \\
$1,00 \mathrm{E}-03$ & 1,38 & 0,95 & 1,32 \\
$1,00 \mathrm{E}-02$ & 1,20 & 0,98 & 1,18 \\
$1,00 \mathrm{E}-01$ & 1,18 & 0,99 & 1,17 \\
$1,00 \mathrm{E}+00$ & 1,15 & 1,00 & 1,14 \\
$1,00 \mathrm{E}+01$ & 1,12 & 0,98 & 1,09 \\
$1,00 \mathrm{E}+02$ & 1,11 & 0,95 & 1,05 \\
$1,00 \mathrm{E}+03$ & 1,10 & 0,93 & 1,03 \\
$1,00 \mathrm{E}+04$ & 1,09 & 0,92 & 1,00 \\
$1,00 \mathrm{E}+05$ & 1,07 & 0,93 & 0,99 \\
\hline média & 1,16 & 0,97 & 1,12 \\
\hline
\end{tabular}

Tabela 5.51 - Relações entre valores de G* para a mistura 97,5-2,5-0

\begin{tabular}{cccc}
\hline & \multicolumn{3}{c}{ Relações } \\
\cline { 2 - 4 } Frequência (rad/s) & topo/fundo & fundo/original & topo/original \\
\hline $1,00 \mathrm{E}-05$ & 16,13 & 0,89 & 14,30 \\
$1,00 \mathrm{E}-04$ & 9,79 & 0,92 & 8,96 \\
$1,00 \mathrm{E}-03$ & 4,03 & 0,95 & 3,81 \\
$1,00 \mathrm{E}-02$ & 1,57 & 0,95 & 1,49 \\
$1,00 \mathrm{E}-01$ & 0,75 & 0,99 & 0,75 \\
$1,00 \mathrm{E}+00$ & 0,63 & 1,05 & 0,66 \\
$1,00 \mathrm{E}+01$ & 0,55 & 1,09 & 0,59 \\
$1,00 \mathrm{E}+02$ & 0,53 & 1,07 & 0,56 \\
$1,00 \mathrm{E}+03$ & 0,56 & 1,06 & 0,60 \\
$1,00 \mathrm{E}+04$ & 0,57 & 1,06 & 0,61 \\
$1,00 \mathrm{E}+05$ & 0,60 & 1,05 & 0,63 \\
\hline média & 3,25 & 1,01 & 3,00 \\
\hline
\end{tabular}


Tabela 5.52 - Relações entre valores de G* para a mistura 96,5-2,5-1

\begin{tabular}{cccc}
\hline & \multicolumn{3}{c}{ Relações } \\
\cline { 2 - 4 } Frequência (rad/s) & topo/fundo & fundo/original & topo/original \\
\hline $1,00 \mathrm{E}-05$ & 4,10 & 1,10 & 4,52 \\
$1,00 \mathrm{E}-04$ & 3,50 & 1,08 & 3,77 \\
$1,00 \mathrm{E}-03$ & 2,17 & 1,02 & 2,23 \\
$1,00 \mathrm{E}-02$ & 1,41 & 0,97 & 1,37 \\
$1,00 \mathrm{E}-01$ & 0,93 & 1,02 & 0,95 \\
$1,00 \mathrm{E}+00$ & 0,71 & 1,13 & 0,80 \\
$1,00 \mathrm{E}+01$ & 0,62 & 1,12 & 0,69 \\
$1,00 \mathrm{E}+02$ & 0,60 & 1,10 & 0,66 \\
$1,00 \mathrm{E}+03$ & 0,60 & 1,08 & 0,65 \\
$1,00 \mathrm{E}+04$ & 0,61 & 1,09 & 0,66 \\
$1,00 \mathrm{E}+05$ & 0,62 & 1,09 & 0,68 \\
\hline média & 1,44 & 1,07 & 1,54 \\
\hline
\end{tabular}

Tabela 5.53 - Relações entre valores de G* para a mistura 95,5-2,5-2

\begin{tabular}{cccc}
\hline & \multicolumn{3}{c}{ Relações } \\
\cline { 2 - 4 } Frequência (rad/s) & topo/fundo & fundo/original & topo/original \\
\hline $1,00 \mathrm{E}-05$ & 5,22 & 1,24 & 6,46 \\
$1,00 \mathrm{E}-04$ & 3,93 & 1,00 & 3,92 \\
$1,00 \mathrm{E}-03$ & 2,24 & 0,91 & 2,03 \\
$1,00 \mathrm{E}-02$ & 1,59 & 0,80 & 1,27 \\
$1,00 \mathrm{E}-01$ & 1,28 & 0,92 & 1,18 \\
$1,00 \mathrm{E}+00$ & 1,03 & 0,93 & 0,96 \\
$1,00 \mathrm{E}+01$ & 0,92 & 0,96 & 0,88 \\
$1,00 \mathrm{E}+02$ & 0,89 & 0,99 & 0,88 \\
$1,00 \mathrm{E}+03$ & 0,86 & 1,00 & 0,86 \\
$1,00 \mathrm{E}+04$ & 0,84 & 1,02 & 0,86 \\
$1,00 \mathrm{E}+05$ & 0,83 & 1,04 & 0,87 \\
\hline média & 1,78 & 0,98 & 1,83 \\
\hline
\end{tabular}


Tabela 5.54 - Relações entre valores de G* para a mistura 95-5-0

\begin{tabular}{cccc}
\hline & \multicolumn{3}{c}{ Relações } \\
\cline { 2 - 4 } Frequência (rad/s) & topo/fundo & fundo/original & topo/original \\
\hline $1,00 \mathrm{E}-05$ & 590,54 & 0,39 & 228,81 \\
$1,00 \mathrm{E}-04$ & 100,94 & 0,48 & 48,92 \\
$1,00 \mathrm{E}-03$ & 15,39 & 0,55 & 8,50 \\
$1,00 \mathrm{E}-02$ & 2,71 & 0,73 & 1,98 \\
$1,00 \mathrm{E}-01$ & 0,61 & 1,08 & 0,66 \\
$1,00 \mathrm{E}+00$ & 0,27 & 1,30 & 0,35 \\
$1,00 \mathrm{E}+01$ & 0,14 & 1,42 & 0,20 \\
$1,00 \mathrm{E}+02$ & 0,11 & 1,42 & 0,16 \\
$1,00 \mathrm{E}+03$ & 0,11 & 1,41 & 0,16 \\
$1,00 \mathrm{E}+04$ & 0,12 & 1,39 & 0,17 \\
$1,00 \mathrm{E}+05$ & 0,00 & 1,36 & 0,00 \\
\hline média & 71,10 & 1,05 & 28,99 \\
\hline
\end{tabular}

Tabela 5.55 - Relações entre valores de G* para a mistura 94-5-1

\begin{tabular}{cccc}
\hline & \multicolumn{3}{c}{ Relações } \\
\cline { 2 - 4 } Frequência (rad/s) & topo/fundo & fundo/original & topo/original \\
\hline $1,00 \mathrm{E}-05$ & 128,05 & 0,42 & 53,50 \\
$1,00 \mathrm{E}-04$ & 43,47 & 0,44 & 19,28 \\
$1,00 \mathrm{E}-03$ & 9,22 & 0,50 & 4,57 \\
$1,00 \mathrm{E}-02$ & 1,88 & 0,74 & 1,40 \\
$1,00 \mathrm{E}-01$ & 0,47 & 1,02 & 0,48 \\
$1,00 \mathrm{E}+00$ & 0,22 & 1,18 & 0,26 \\
$1,00 \mathrm{E}+01$ & 0,14 & 1,29 & 0,17 \\
$1,00 \mathrm{E}+02$ & 0,14 & 1,31 & 0,18 \\
$1,00 \mathrm{E}+03$ & 0,14 & 1,32 & 0,18 \\
$1,00 \mathrm{E}+04$ & 0,14 & 1,33 & 0,19 \\
$1,00 \mathrm{E}+05$ & 0,00 & 1,32 & 0,00 \\
\hline média & 18,39 & 0,99 & 8,02 \\
\hline
\end{tabular}


Tabela 5.56 - Relações entre valores de G* para a mistura 93-5-2

\begin{tabular}{cccc}
\hline & \multicolumn{3}{c}{ Relações } \\
\cline { 2 - 4 } Frequência (rad/s) & topo/fundo & fundo/original & topo/original \\
\hline $1,00 \mathrm{E}-05$ & 102,84 & 0,37 & 38,12 \\
$1,00 \mathrm{E}-04$ & 30,21 & 0,39 & 11,75 \\
$1,00 \mathrm{E}-03$ & 6,84 & 0,46 & 3,16 \\
$1,00 \mathrm{E}-02$ & 1,68 & 0,63 & 1,06 \\
$1,00 \mathrm{E}-01$ & 0,59 & 0,78 & 0,46 \\
$1,00 \mathrm{E}+00$ & 0,33 & 0,90 & 0,30 \\
$1,00 \mathrm{E}+01$ & 0,20 & 0,96 & 0,19 \\
$1,00 \mathrm{E}+02$ & 0,16 & 0,99 & 0,16 \\
$1,00 \mathrm{E}+03$ & 0,14 & 1,01 & 0,15 \\
$1,00 \mathrm{E}+04$ & 0,14 & 1,03 & 0,15 \\
$1,00 \mathrm{E}+05$ & 0,00 & 1,05 & 0,00 \\
\hline média & 14,32 & 0,78 & 5,55 \\
\hline
\end{tabular}

Tabela 5.57 - Resumo das relações topo/fundo entre valores de $G^{*}$ das misturas no ensaio de estabilidade à estocagem

\begin{tabular}{cccccccccc}
\hline $\begin{array}{c}\text { Frequências } \\
\text { (rad/s) }\end{array}$ & \multicolumn{10}{c}{ Misturas relação topo/fundo } \\
\cline { 2 - 10 } & $\mathbf{1 0 0 - 0 - 0}$ & $\mathbf{9 9 - 0 - 1}$ & $\mathbf{9 8 - 0 - 2}$ & $\mathbf{9 7 , 5 - 2 , 5 - 0}$ & $\mathbf{9 6 , 5 - 2 , 5 - 1}$ & $\mathbf{9 5 , 5 - 2 , 5 - 2}$ & $\mathbf{9 5 - 5 - 0}$ & $\mathbf{9 4 - 5 - 1}$ & $\mathbf{9 3 - 5 - 2}$ \\
\hline $1,00 \mathrm{E}-05$ & 1,31 & 0,99 & 1,10 & 16,13 & 4,10 & 5,22 & 590,54 & 128,05 & 102,84 \\
$1,00 \mathrm{E}-04$ & 1,31 & 1,01 & 1,24 & 9,79 & 3,50 & 3,93 & 100,94 & 43,47 & 30,21 \\
$1,00 \mathrm{E}-03$ & 1,31 & 0,94 & 1,38 & 4,03 & 2,17 & 2,24 & 15,39 & 9,22 & 6,84 \\
$1,00 \mathrm{E}-02$ & 1,29 & 0,95 & 1,20 & 1,57 & 1,41 & 1,59 & 2,71 & 1,88 & 1,68 \\
$1,00 \mathrm{E}-01$ & 1,28 & 0,94 & 1,18 & 0,75 & 0,93 & 1,28 & 0,61 & 0,47 & 0,59 \\
$1,00 \mathrm{E}+00$ & 1,24 & 0,94 & 1,15 & 0,63 & 0,71 & 1,03 & 0,27 & 0,22 & 0,33 \\
$1,00 \mathrm{E}+01$ & 1,19 & 0,95 & 1,12 & 0,55 & 0,62 & 0,92 & 0,14 & 0,14 & 0,20 \\
$1,00 \mathrm{E}+02$ & 1,12 & 0,96 & 1,11 & 0,53 & 0,60 & 0,89 & 0,11 & 0,14 & 0,16 \\
$1,00 \mathrm{E}+03$ & 1,10 & 0,96 & 1,10 & 0,56 & 0,60 & 0,86 & 0,11 & 0,14 & 0,14 \\
$1,00 \mathrm{E}+04$ & 1,07 & 0,95 & 1,09 & 0,57 & 0,61 & 0,84 & 0,12 & 0,14 & 0,14 \\
$1,00 \mathrm{E}+05$ & 1,05 & 0,95 & 1,07 & 0,60 & 0,62 & 0,83 & 0,00 & 0,00 & 0,00 \\
\hline média & 1,21 & 0,96 & 1,16 & 3,25 & 1,44 & 1,78 & 71,10 & 18,39 & 14,32 \\
\hline
\end{tabular}


Tabela 5.58 - Média das relações topo/fundo, fundo/original, topo/original entre valores de $G^{*}$ no ensaio de estabilidade à estocagem

\begin{tabular}{cccc}
\hline Misturas & média topo/fundo & média fundo/original & média topo/original \\
\hline $\mathbf{1 0 0 - 0 - 0}$ & 1,21 & 0,91 & 1,09 \\
$\mathbf{9 9 - 0 - 1}$ & 0,96 & 1,03 & 0,98 \\
$\mathbf{9 8 - 0 - 2}$ & 1,16 & 0,97 & 1,12 \\
$\mathbf{9 7 , 5 - 2 , 5 - 0}$ & 3,25 & 1,01 & 3,00 \\
$\mathbf{9 6 , 5 - 2 , 5 - 1}$ & 1,44 & 1,07 & 1,54 \\
$\mathbf{9 5 , 5 - 2 , 5 - 2}$ & 1,78 & 0,98 & 1,83 \\
$\mathbf{9 5 - 5 - 0}$ & 71,10 & 1,05 & 28,99 \\
$\mathbf{9 4 - 5 - 1}$ & 18,39 & 0,99 & 8,02 \\
$\mathbf{9 3 - 5 - 2}$ & 14,32 & 0,78 & 5,55 \\
\hline
\end{tabular}

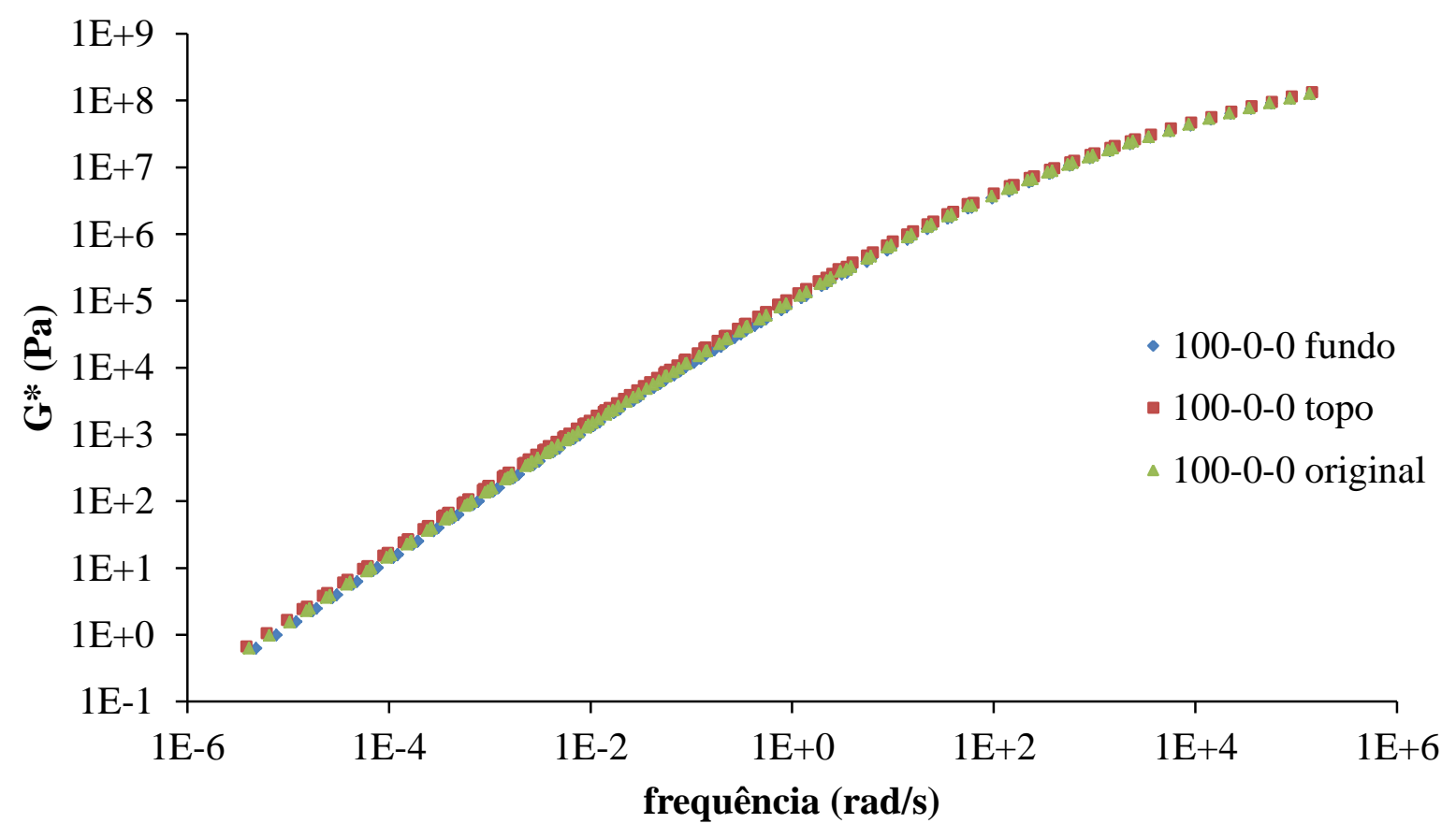

Figura 5.82 - Curvas-mestre de $G^{*}$ da mistura 100-0-0 


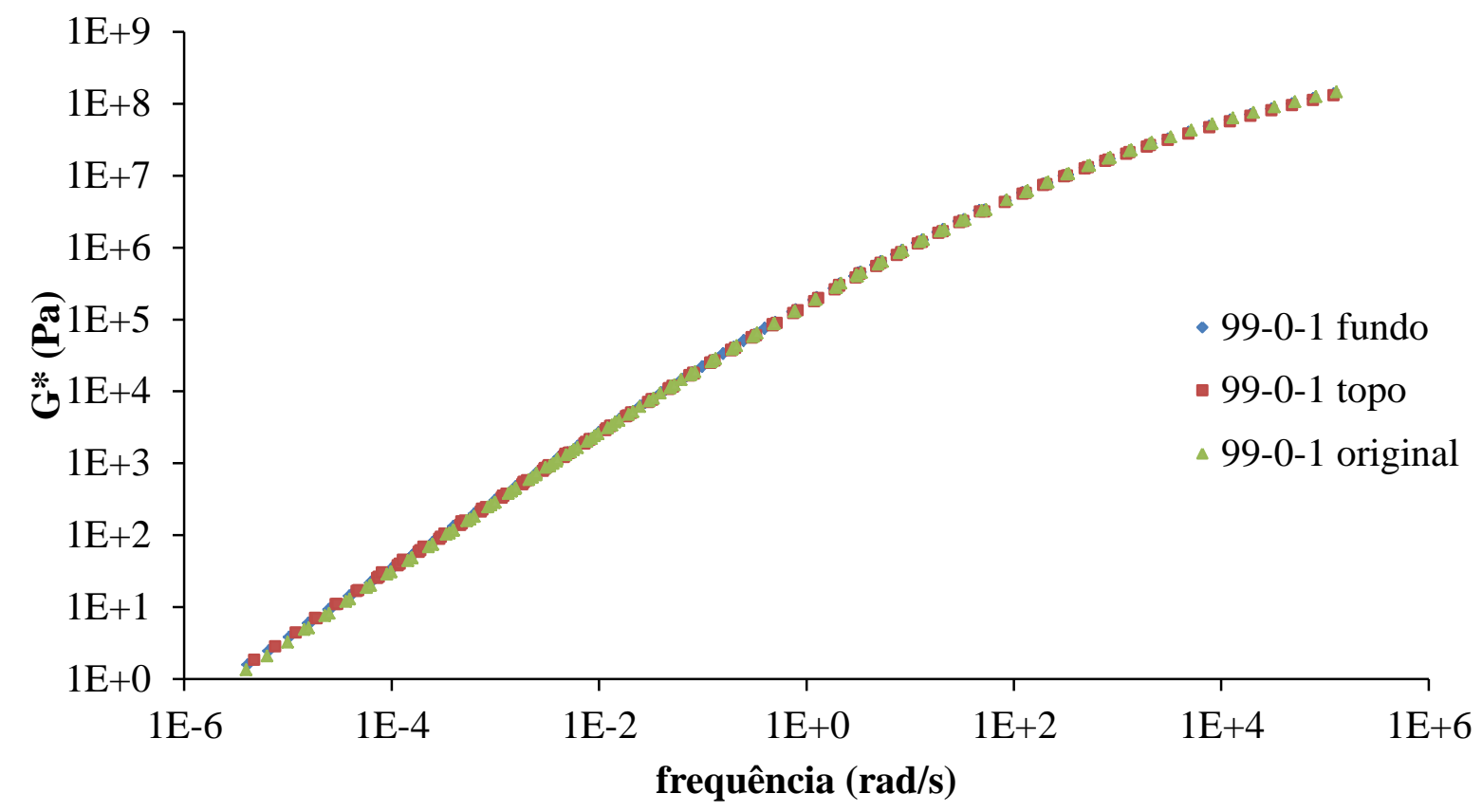

Figura 5.83 - Curvas-mestre de $G^{*}$ da mistura 99-0-1

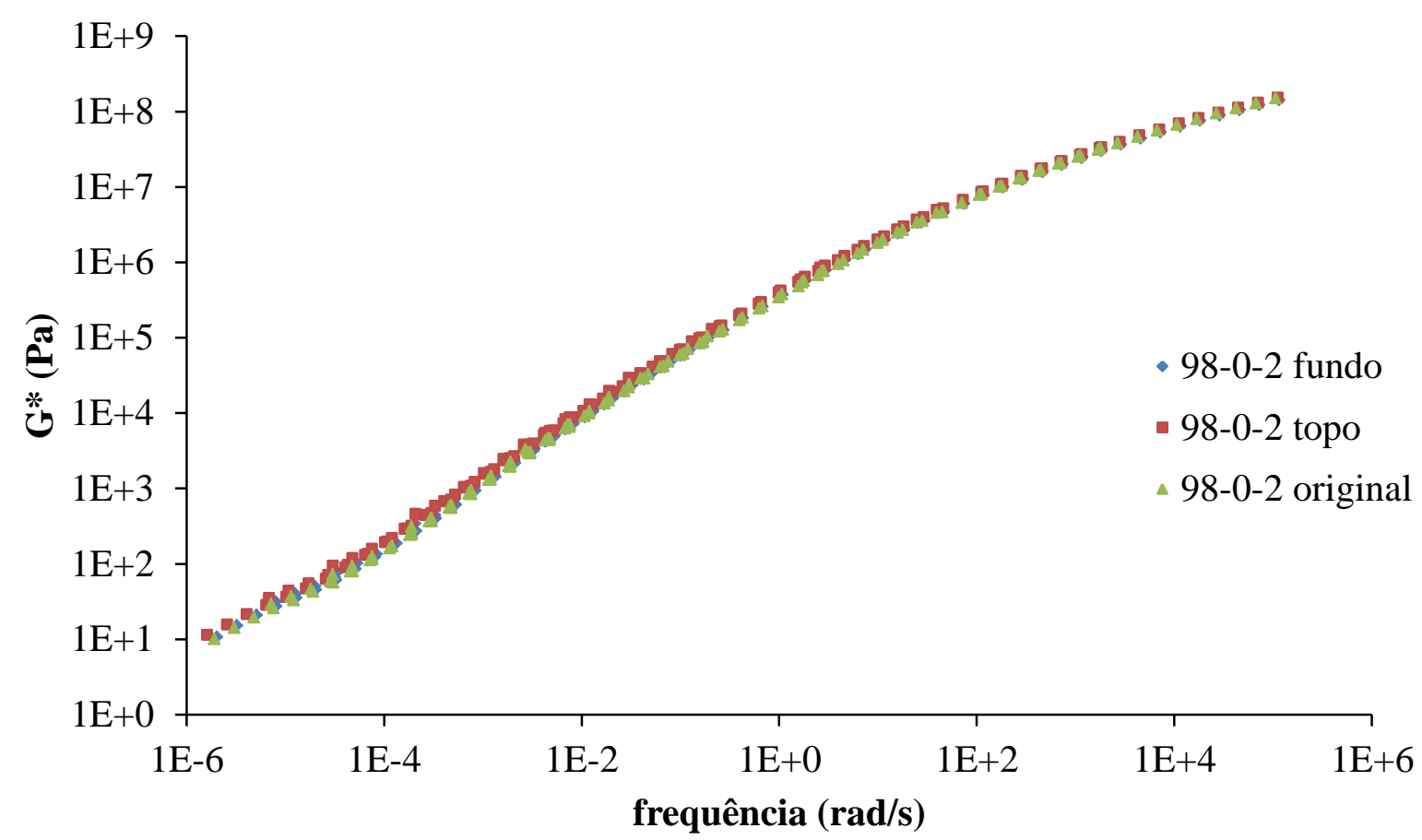

Figura 5.84 - Curvas-mestre de $G^{*}$ da mistura 98-0-2 


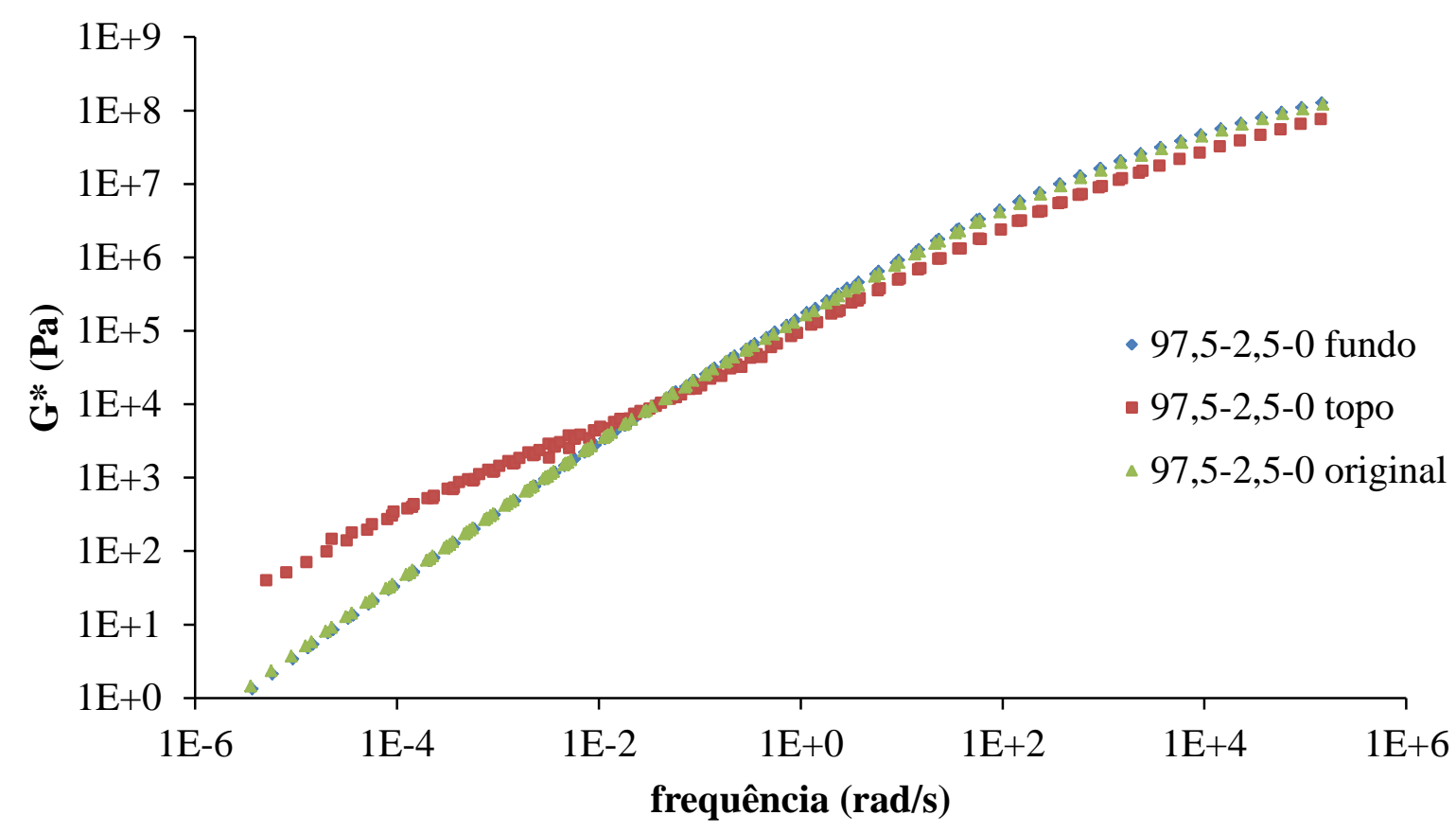

Figura 5.85 - Curvas-mestre de $G^{*}$ da mistura 97,5-2,5-0

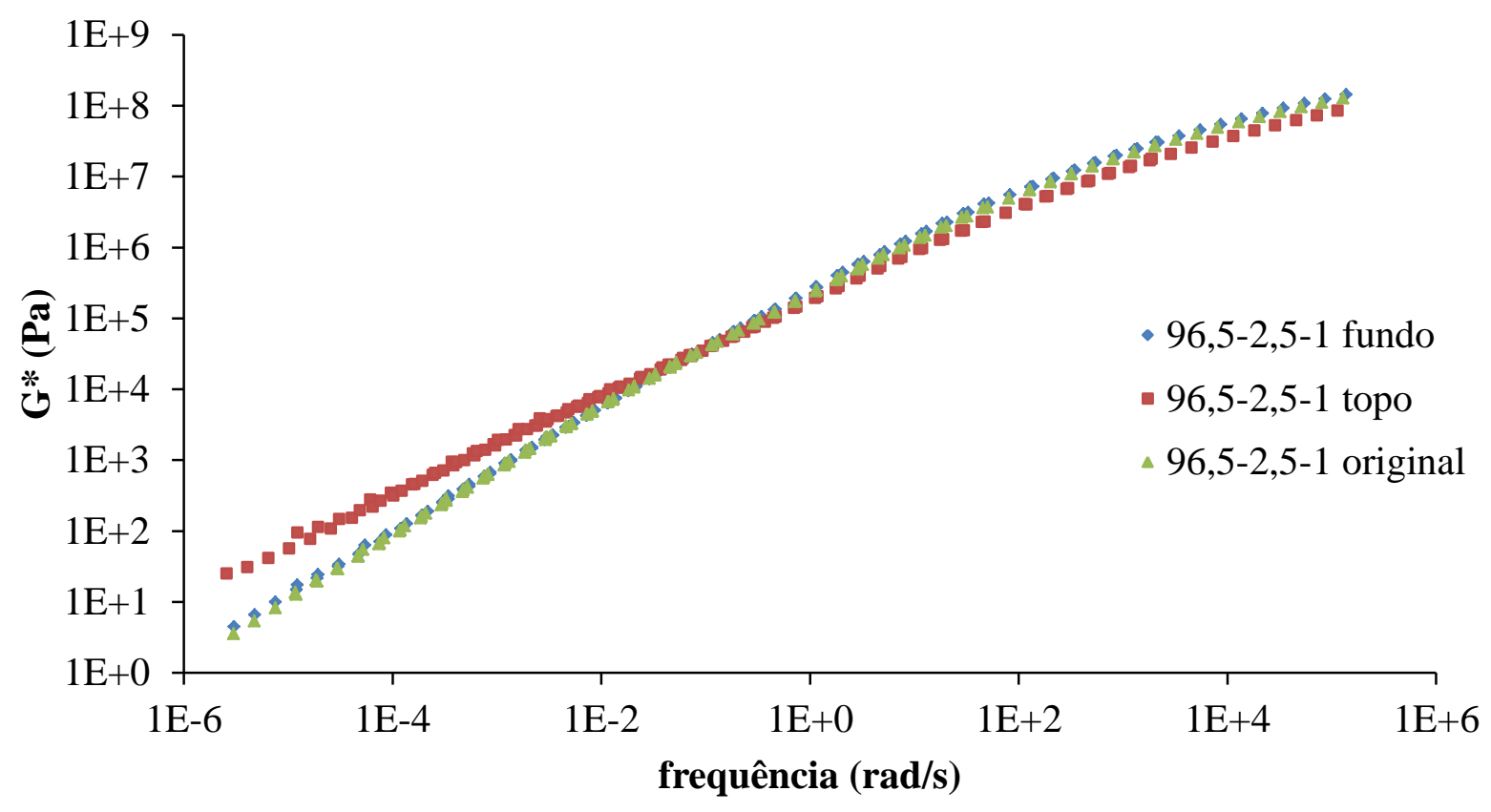

Figura 5.86 - Curvas-mestre de $G^{*}$ da mistura 96,5-2,5-1 


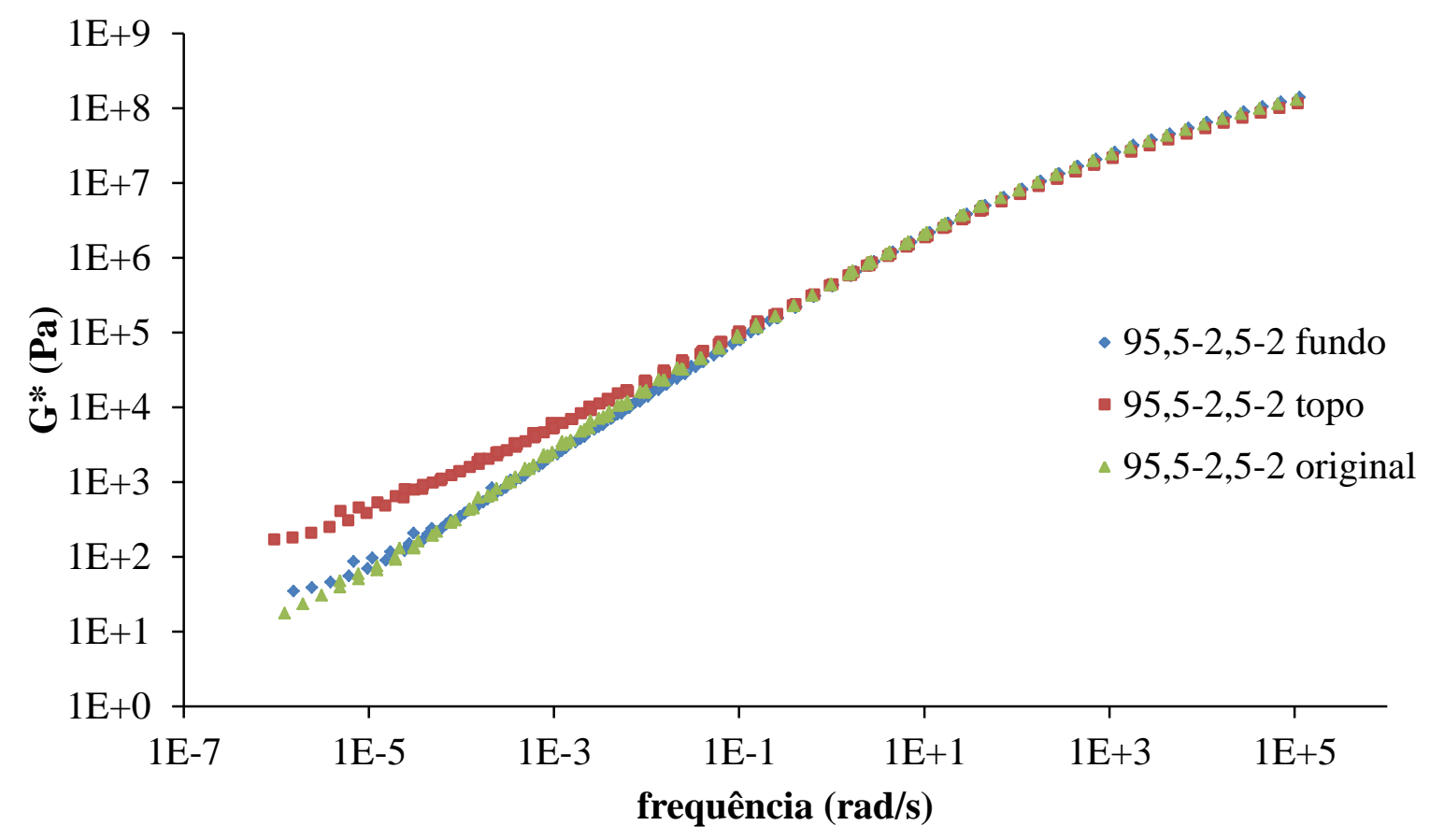

Figura 5.87 - Curvas-mestre de G* da mistura 95,5-2,5-2

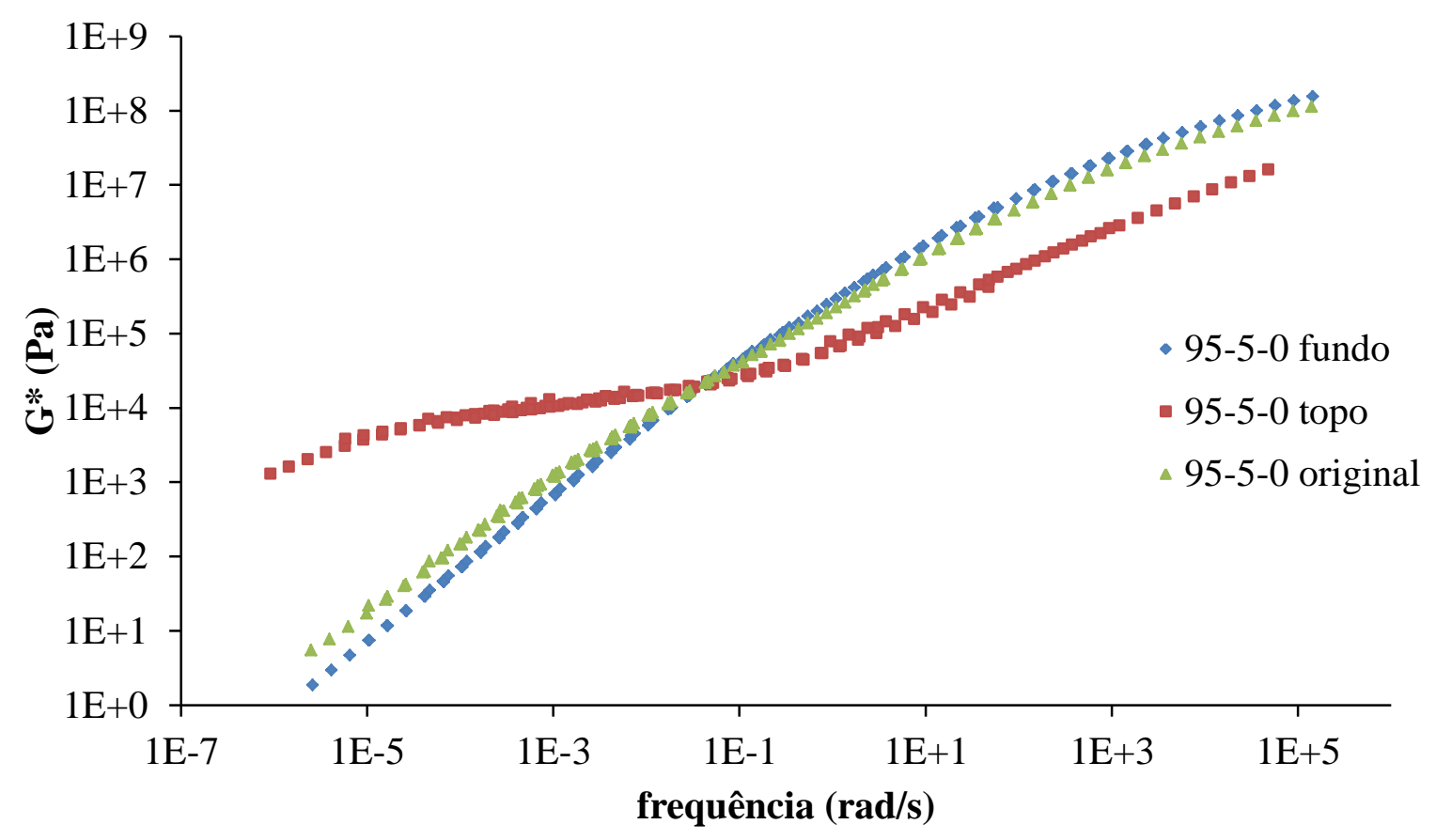

Figura 5.88 - Curvas-mestre de G* da mistura 95-5-0 


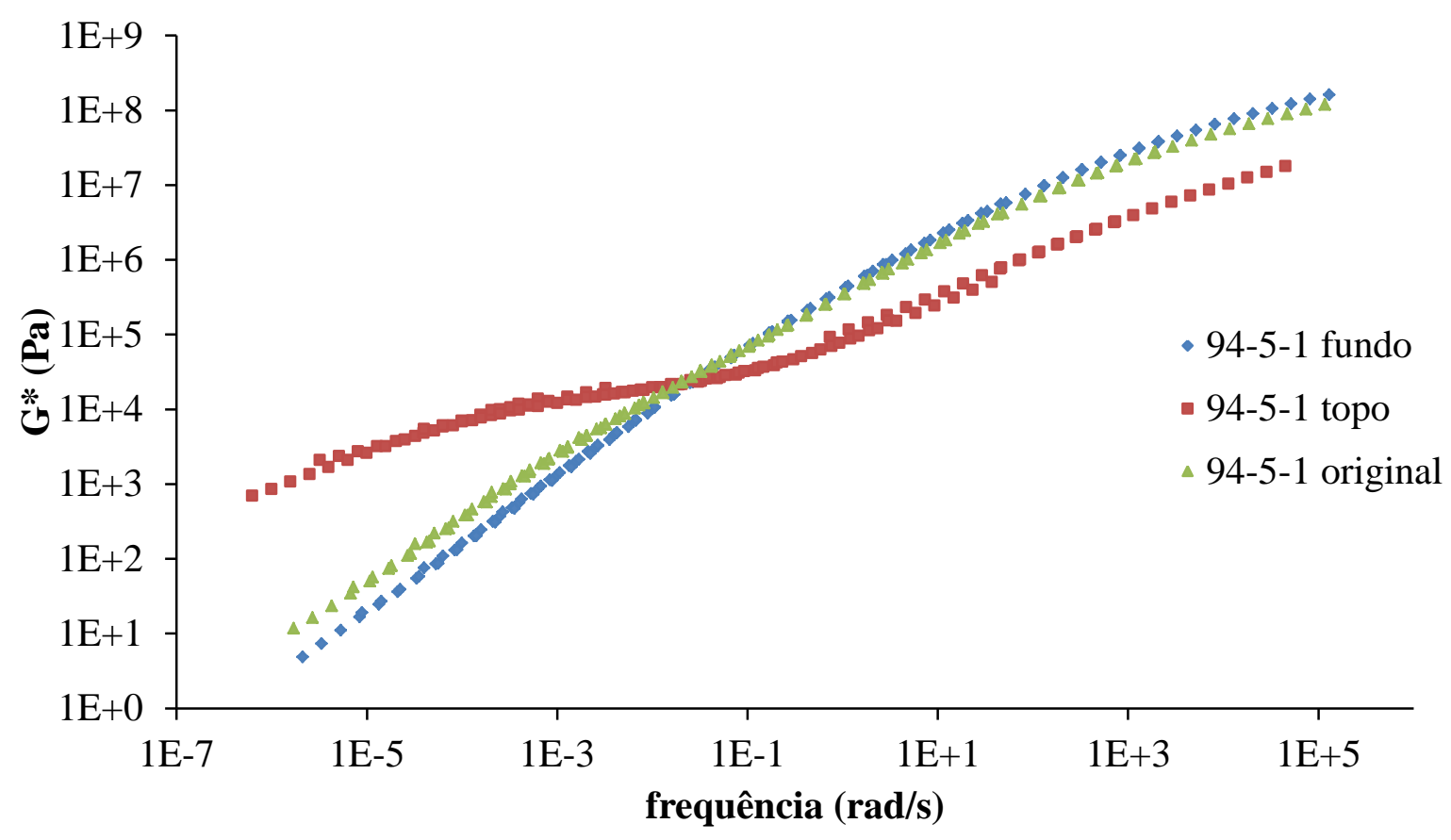

Figura 5.89 - Curvas-mestre de $G^{*}$ da mistura 94-5-1

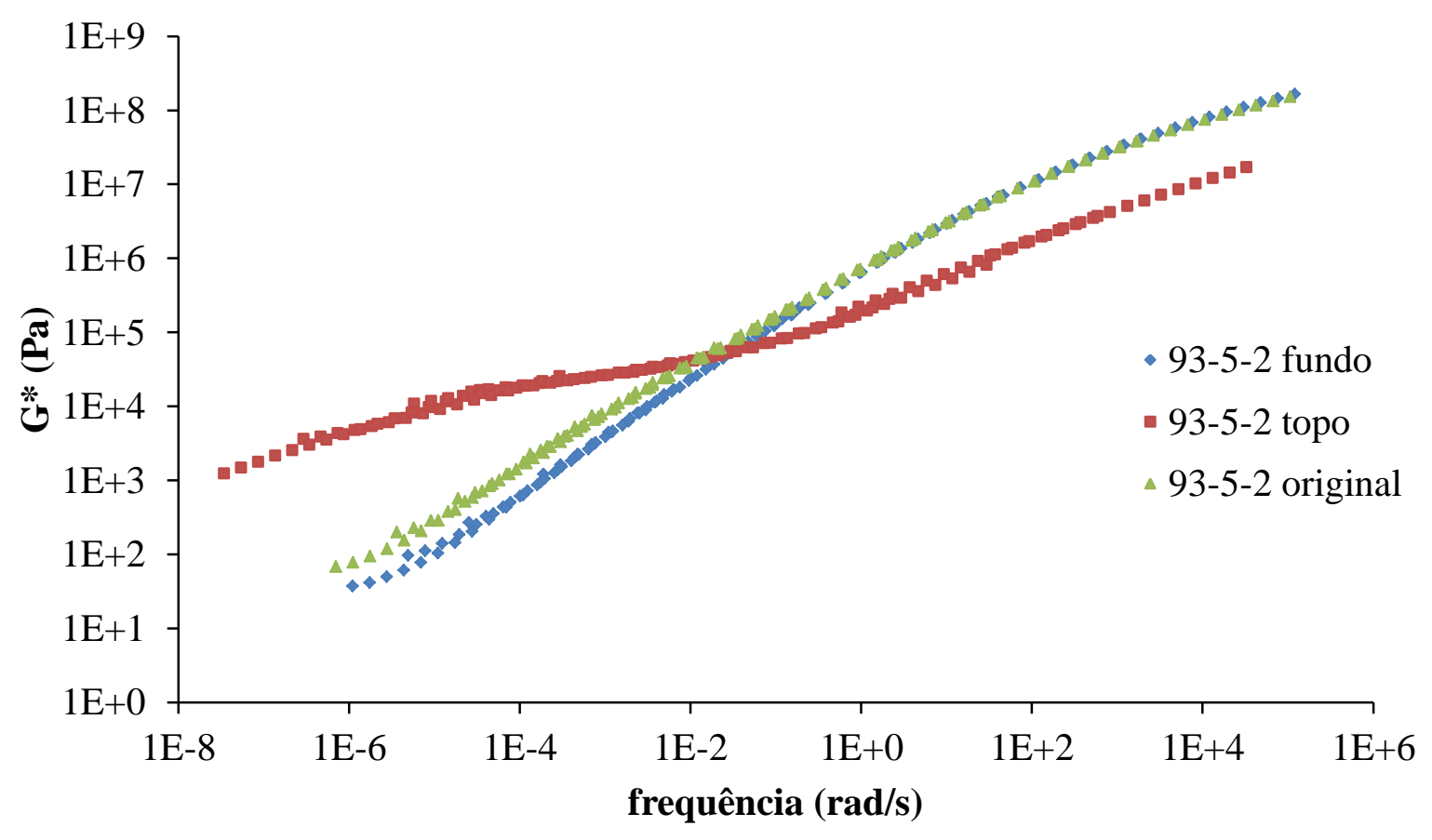

Figura 5.90 - Curvas-mestre de G* da mistura 93-5-2

Para o grupo de misturas com 0\% de SBS (100-0-0, 99-0-1 e 98-0-2), não se verificam variações substanciais entre os valores de $G^{*}$ entre o topo e o fundo (a maior média é da 
mistura 100-0-0: 1,21). Tais resultados permitem afirmar que as misturas asfalto-TITAN são estáveis à estocagem sob temperaturas altas na ausência de agitação.

Para o grupo de misturas com 2,5\% de SBS (97,5-2,5-0, 96,5-2,5-1 e 95,5-2,5-2), observou-se uma relação topo/fundo média de 3,25 vezes para a mistura 97,5-2,5-0, o que seria esperado, tendo em vista que o SBS por ser menos denso que o ligante asfáltico de base tende a subir e se concentrar na superfície. Com a adição de 1\% de TITAN, ocorre uma redução da relação topo/fundo média para 1,44 e, com a adição de $2 \%$ de TITAN, a relação topo/fundo média baixa de 3,25 para 1,78. Percebe-se que a relação topo/fundo média é reduzida para mais que a metade quando se adiciona $1 \%$ de TITAN e é reduzida a quase metade com a adição de $2 \%$ de TITAN. Tais resultados permitem concluir claramente que a adição de TITAN melhora a estabilidade à estocagem dos ligantes asfálticos modificados com teores intermediários de SBS.

Para o grupo de misturas com 5\% de SBS (95-5-0, 94-5-1 e 93-5-2), observou-se uma relação topo/fundo média de 71,10 para a mistura 95-5-0, o que também seria esperado. Com a adição de $1 \%$ de TITAN, ocorre uma redução da relação topo/fundo média para 18,39 e com a adição de $2 \%$ de TITAN, a relação topo/fundo média baixa de 71,10 para 14,32. Neste caso, obteve-se uma diminuição de quase 5 vezes na diferença entre valores de $\mathrm{G}^{*}$ entre o topo e o fundo. Se o valor obtido fosse igual ou próximo a 1,00, poder-se-ia dizer que o TITAN conseguiu homogeneizar perfeitamente a mistura, o que não foi verificado. Todavia, o TITAN se mostrou ser muito efetivo em um certo nível de homogeneização, visto que foram obtidas reduções (em torno de $80 \%$ para altos teores de SBS) na relação entre valores de $\mathrm{G}^{*}$ entre o topo e o fundo. Tais resultados evidenciam claramente que o TITAN melhora a estabilidade à estocagem para os ligantes asfálticos modificados com teores altos de SBS.

O principal objetivo desta dissertação é observar se o TITAN melhora a estabilidade de ligantes asfálticos modificados com SBS. As Tabelas de 5.48 a 5.58 e as Figuras de 5.82 a 5.90 mostram que a adição de TITAN de fato melhora a estabilidade à estocagem dos ligantes asfálticos modificados com SBS. Para teores altos de SBS (da ordem de 5\%), a estabilidade à estocagem melhorou com o acréscimo do percentual de TITAN. 
5.6.7 Estabilidade à estocagem com base nos valores do ângulo de fase ( $\delta$ )

As Figuras de 5.91 a 5.99 apresentam as curvas-mestre para as condições original, topo e fundo.

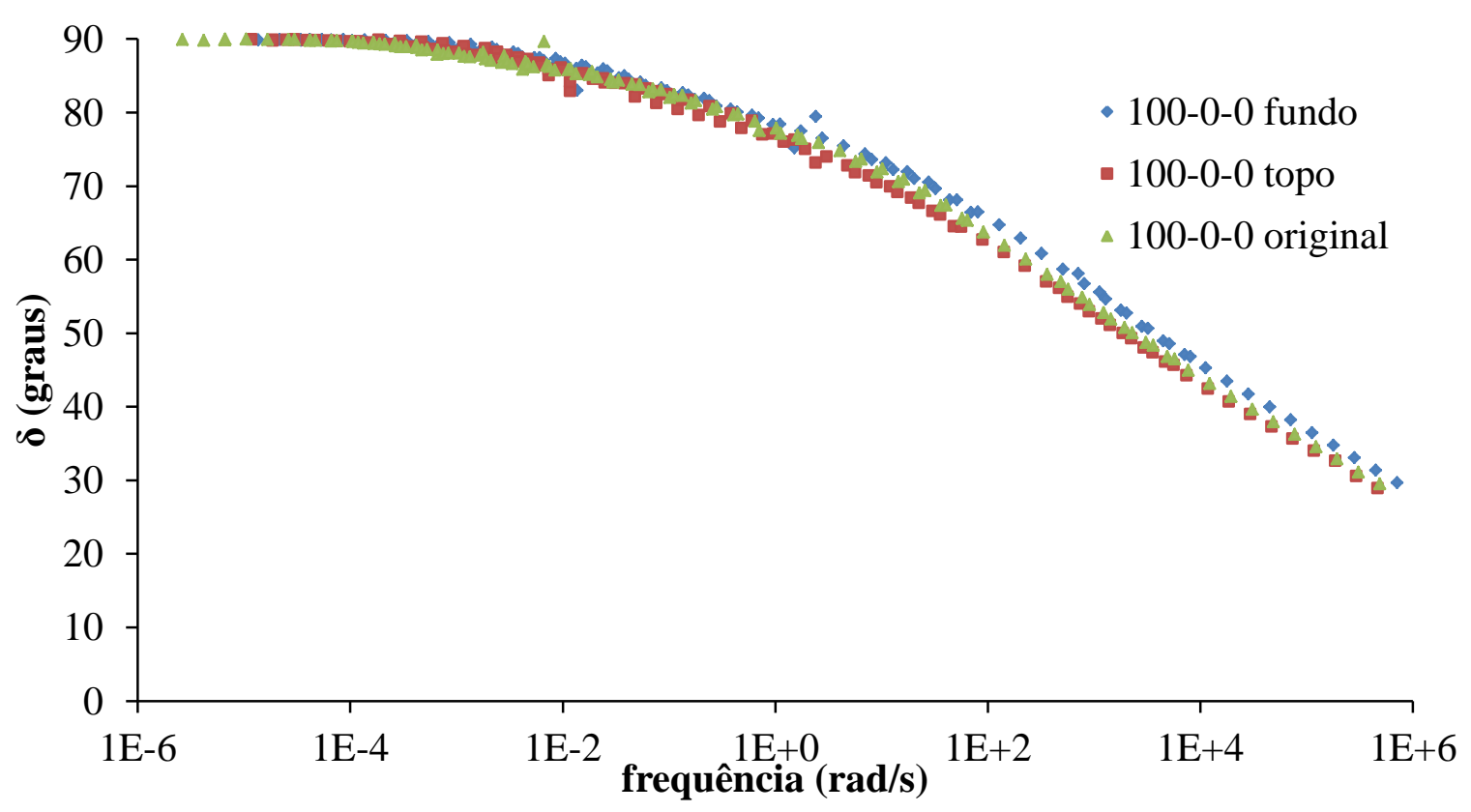

Figura 5.91 - Curvas-mestre de $\delta$ da mistura 100-0-0

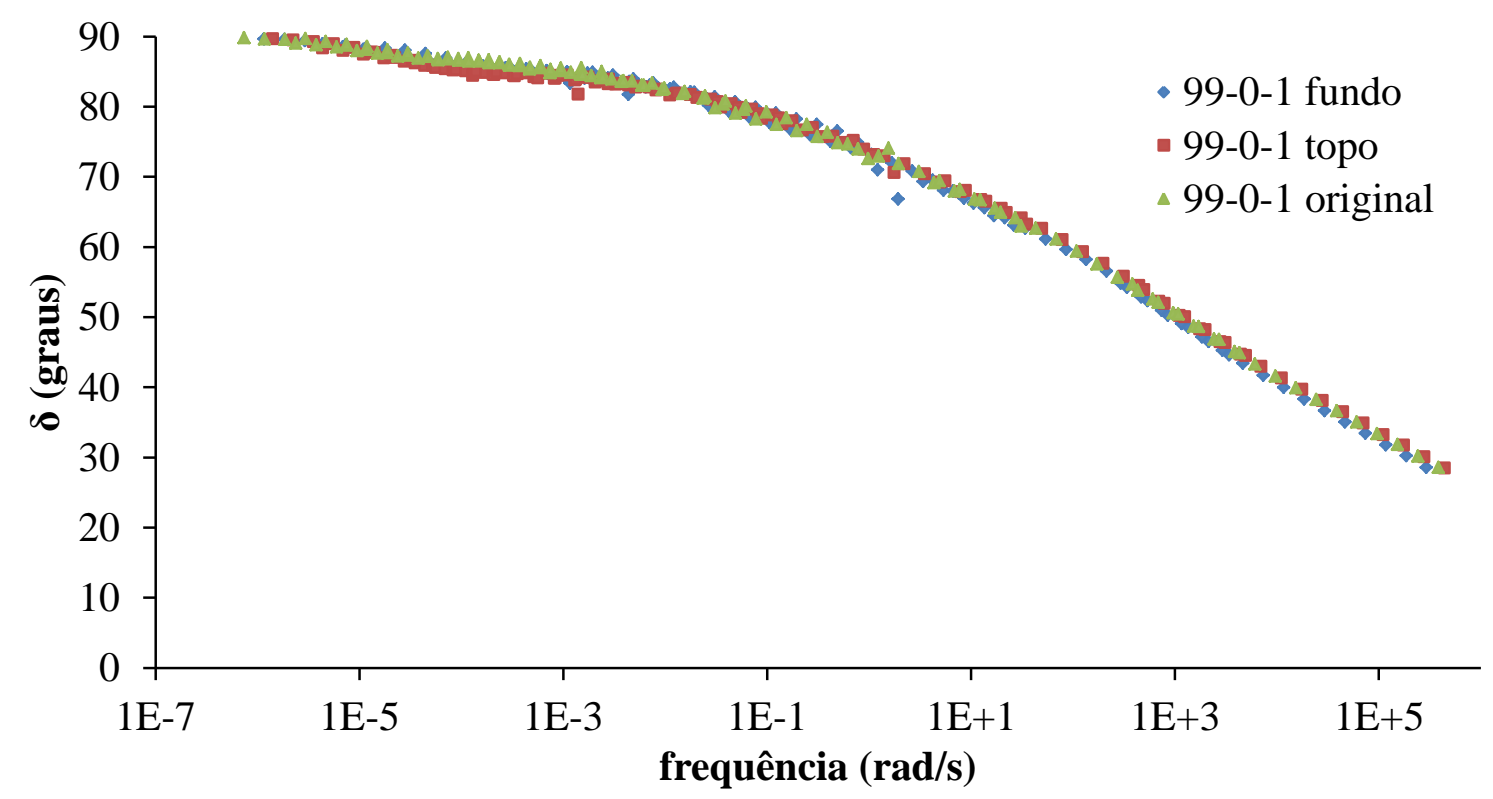

Figura 5.92 - Curvas-mestre de $\delta$ da mistura 99-0-1 


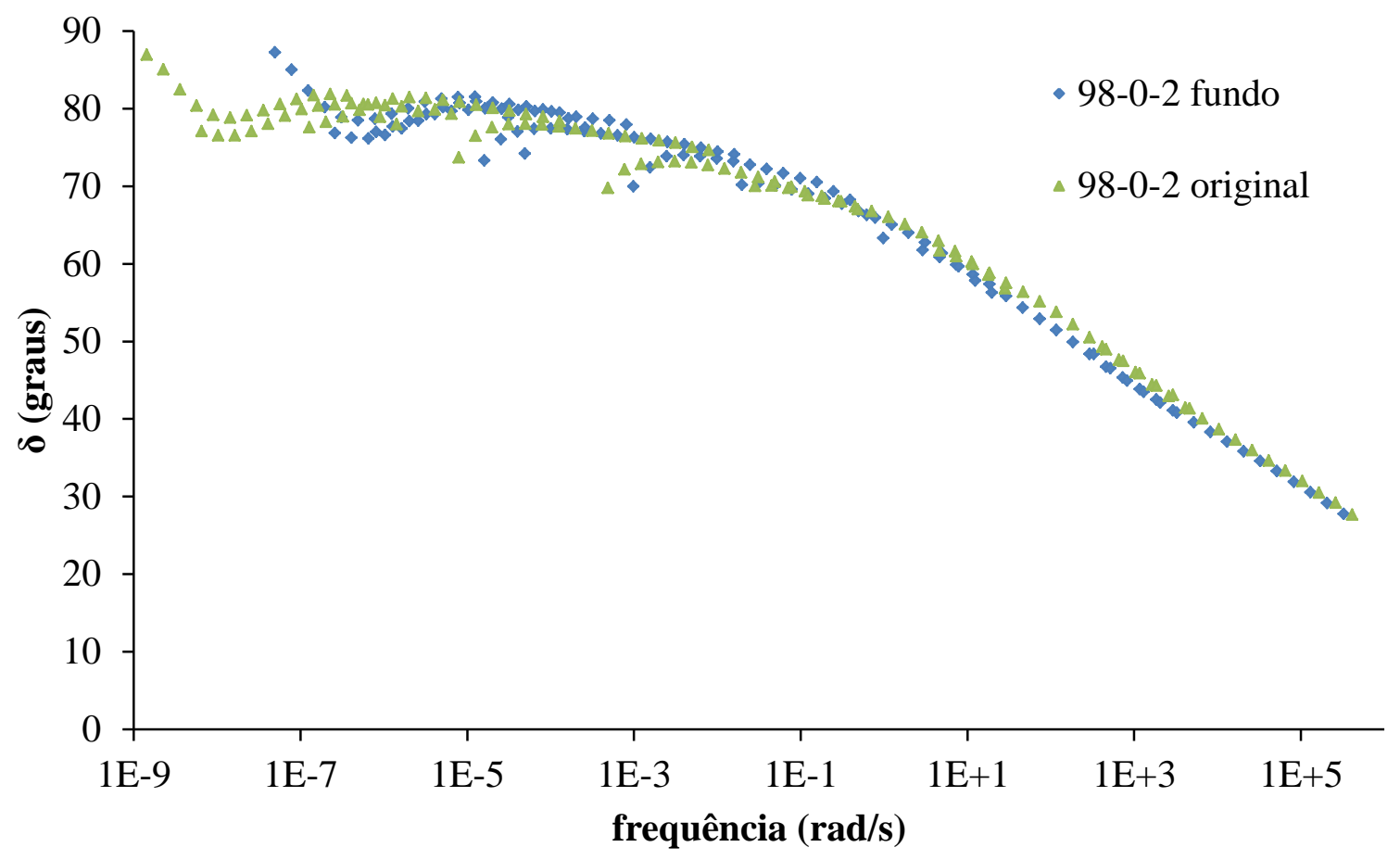

Figura 5.93 - Curvas-mestre de $\delta$ da mistura 98-0-2

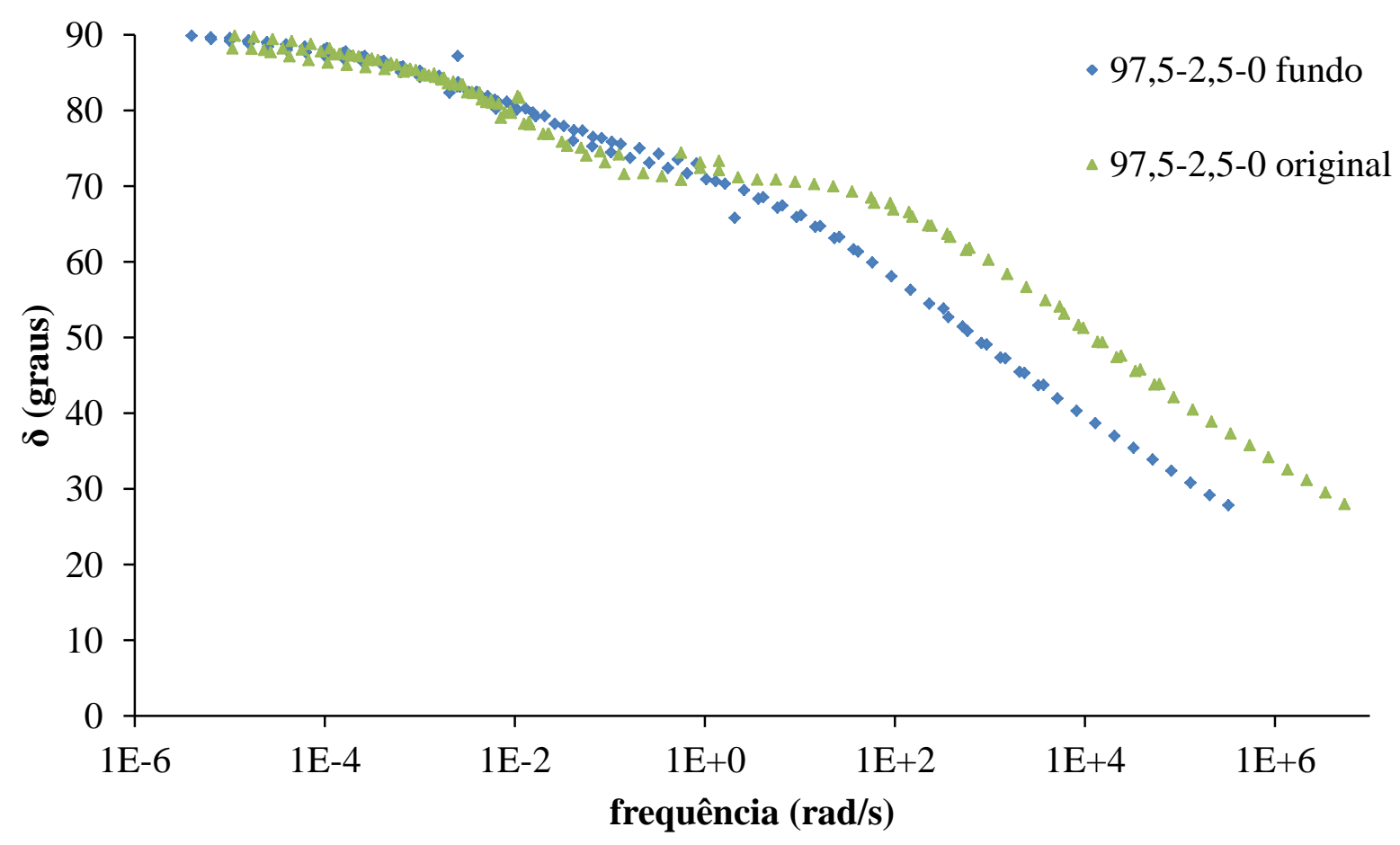

Figura 5.94 - Curvas-mestre de $\delta$ da mistura 97,5-2,5-0 


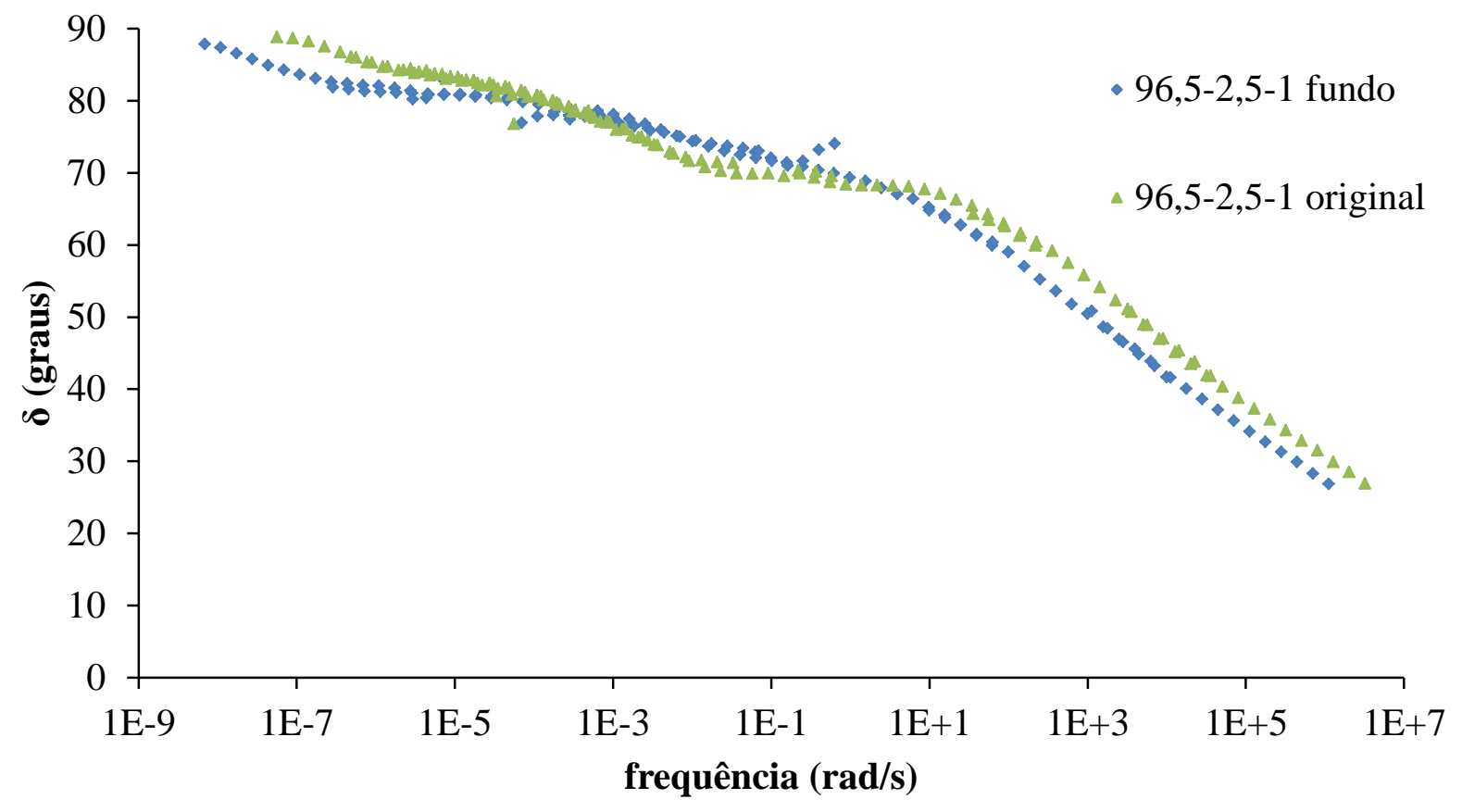

Figura 5.95 - Curvas-mestre de $\delta$ da mistura 96,5-2,5-1

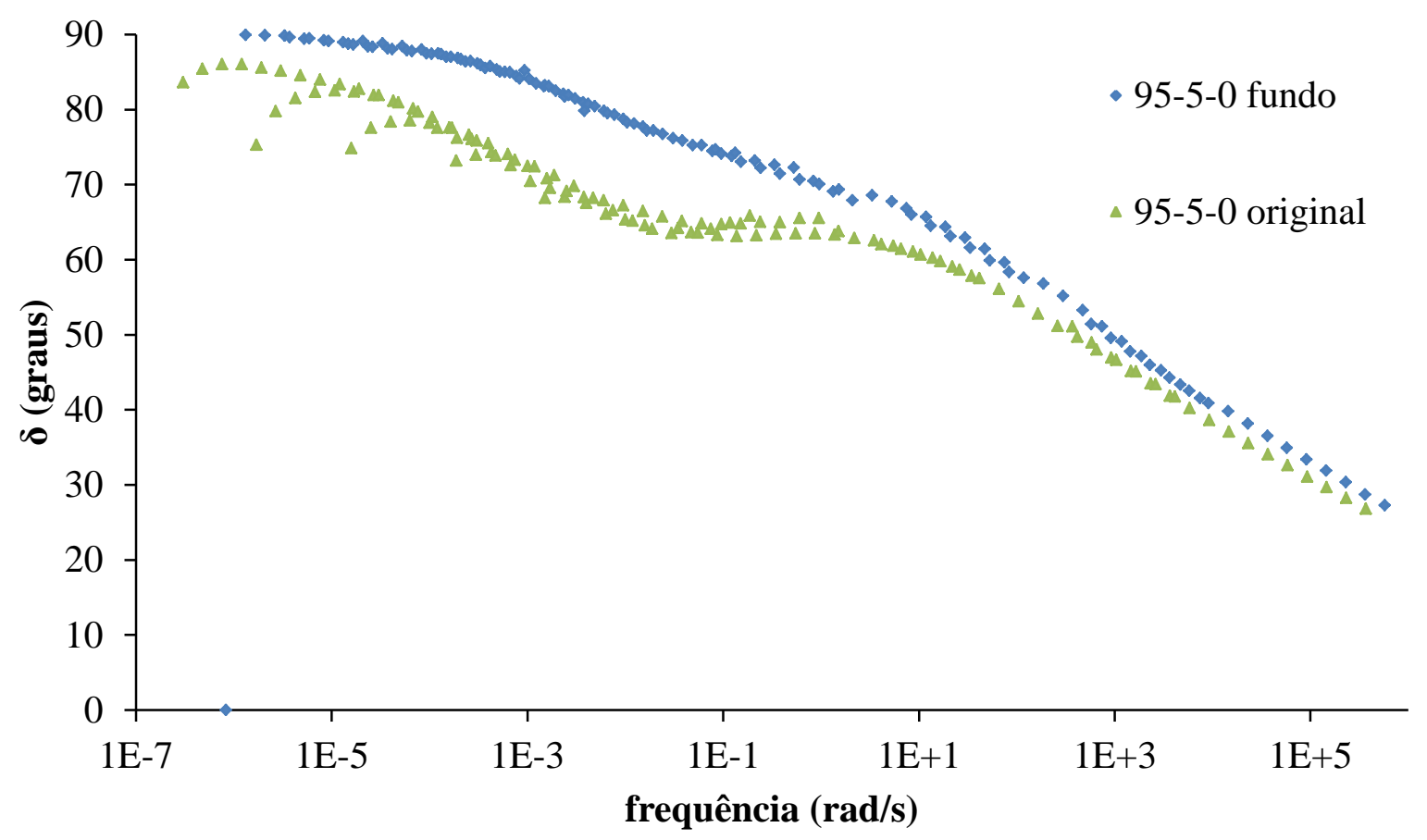

Figura 5.96 - Curvas-mestre de $\delta$ da mistura 95-5-0 


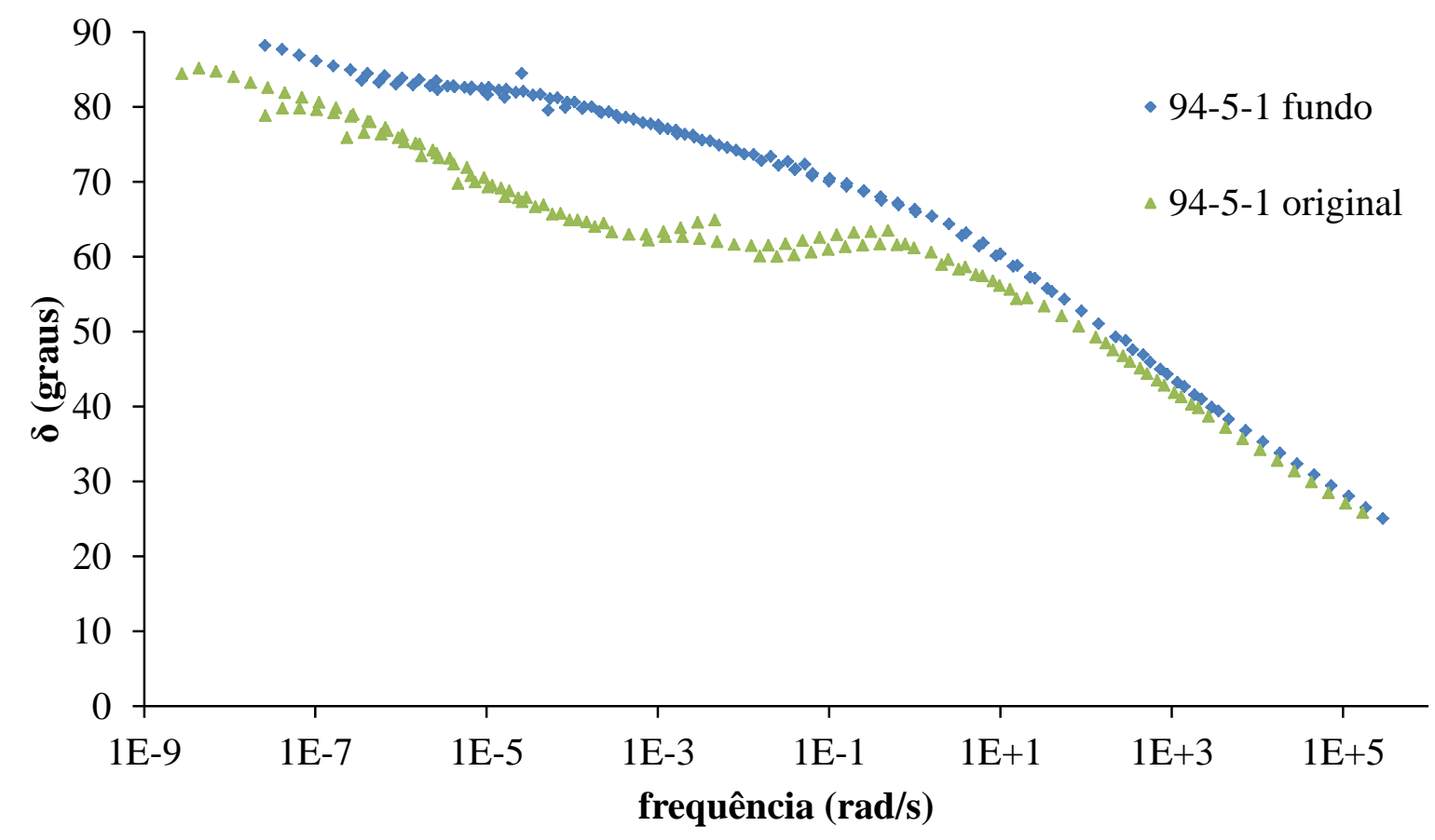

Figura 5.97 - Curvas-mestre de $\delta$ da mistura 94-5-1

Diferentemente da estrutura de análise da estabilidade à estocagem à luz das curvasmestre de $G^{*}$, não foi possível quantificar as diferenças entre valores de delta entre topo e fundo, topo e original e fundo e original, dado o ajuste ruim da maioria das curvas-mestre. Apenas as misturas 100-0-0, 99-0-1 e 98-0-2 apresentaram bons ajustes e o que se observa nestes casos é que não houve variações significativas dos valores de delta - isto indica que estas misturas se mostraram estáveis à estocagem sem agitação e sob altas temperaturas. Para as misturas com 2,5 e 5,0\% de SBS, os ajustes das curvas-mestre de topo são muito ruins, inviabilizando qualquer análise precisa. O que se sabe é que a tendência natural do SBS é a de se acumular no topo, tornando as amostras de topo extremamente modificadas, o que se reflete em valores expressivamente baixos de delta quando comparados aos valores originais. A migração de SBS para o topo se reflete em valores de delta ligeiramente superiores para a amostra de fundo quando comparada à amostra original - tal fenômeno é mais visível para as misturas com 5\% de SBS, as quais apresentam curvas-mestre de fundo e original mais separadas.

Os ajustes ruins da maioria das curvas-mestre das amostras modificadas com SBS se devem, provavelmente, à não validade do princípio de superposição tempo-temperatura para 
tais amostras. Apesar de o programa SHRP (Strategic Highway Research Program) ter admitido que os asfaltos, de maneira geral, atendem ao princípio de superposição tempotemperatura (ANDERSON et al., 1994), há indícios na literatura de que alguns asfaltos (LESUEUR, 2009) e, em particular, asfaltos altamente modificados (FAXINA et al., 2010) de fato não atendem tal princípio. Este fato se torna mais convincente quando se veem curvasmestre de delta como as mostradas aqui para amostras com 2,5 e 5,0\% de SBS. De maneira geral, as curvas-mestre de $\mathrm{G}^{*}$ apresentam bons ajustes, dando a entender que o princípio de superposição tempo-temperatura é válido, no entanto, curvas de delta com ajustes ruins como as mostradas aqui colocam dúvidas sobre a validade do princípio para alguns materiais (FAXINA et al., 2010).

\subsection{Valores de $G^{*}, \delta, G * / \operatorname{sen}(\delta)$ e $G * \operatorname{sen}(\delta)$ obtidos das varredura de frequências}

Os valores de $G^{*}$ e $\delta$ foram obtidos nos ensaios de varredura de frequência e foram usados no cálculo dos parâmetros $G^{*} / \operatorname{sen}(\delta)$ e $G^{*} \cdot \operatorname{sen}(\delta)$ da especificação Superpave. Este item será dividido em três tópicos: (i) comparação entre a mistura 100-0-0 e o ligante asfáltico de base (Replan 50/70), (ii) efeito do envelhecimento e (iii) comparação das misturas com a mistura 100-0-0. Em todo este sub capítulo, G* possui como medida $\mathrm{Pa}, \delta$ possui como medida graus, $\mathrm{G}^{*} / \operatorname{sen}(\delta)$ e $\mathrm{G}^{*} \operatorname{sen}(\delta)$ são expressos em $\mathrm{kPa}$.

5.7.1 Comparação entre a mistura 100-0-0 e o ligante asfáltico de base (Replan 50/70)

As Tabelas 5.59 e 5.60 apresentam os valores de $\mathrm{G}^{*}, \delta, \mathrm{G}^{*} / \operatorname{sen}(\delta)$ e $\mathrm{G}^{*} \cdot \operatorname{sen}(\delta)$ para as temperaturas em que se realizaram as varreduras de frequência $(4,16,28,40,52,64,76$ e $88^{\circ} \mathrm{C}$ ) nas condições virgem, envelhecida a curto prazo e envelhecida a longo prazo. A Tabela 5.59 apresenta estes valores para o ligante asfáltico de base (Replan 50/70) e a Tabela 5.60 se refere aos valores para a mistura 100-0-0. Vale ressaltar que no caso do parâmetro $\mathrm{G}^{*} / \operatorname{sen}(\delta)$, as temperaturas de análise são $52,64,76$ e $88^{\circ} \mathrm{C}$, ao passo que no caso do parâmetro 
$\mathrm{G}^{*} \operatorname{sen}(\delta)$, as temperaturas de análise são $4,16,28$ e $40^{\circ} \mathrm{C}$. A Tabela 5.61 apresenta as relações entre as propriedades e parâmetros obtidos para a mistura 100-0-0 e o ligante asfáltico de base (Replan 50/70).

Tabela 5.59 - Valores de $G^{*}(P a), \delta\left({ }^{\circ}\right), G^{*} / \operatorname{sen}(\delta)(k P a)$ e $G^{*} \operatorname{sen}(\delta)(k P a)$ nas condições virgem, envelhecida a curto prazo e envelhecida a longo prazo, para o CAP Replan 50/70

\begin{tabular}{|c|c|c|c|c|c|c|c|c|}
\hline \multirow{2}{*}{ Parâmetro } & \multicolumn{8}{|c|}{ Temperatura } \\
\hline & 4 & 16 & 28 & 40 & 52 & 64 & 76 & 88 \\
\hline $\mathrm{G}^{*}$ virgem & $77.942,16$ & $11.114,60$ & 876,16 & 91,79 & 7,87 & 1,43 & 0,33 & 0,09 \\
\hline$\delta$ virgem & 34,27 & 51,67 & 69,71 & 78,49 & 84,47 & 87,17 & 88,70 & 89,26 \\
\hline $\mathrm{G}^{*} /$ seno $(\delta)$ virgem & - & - & - & - & 7,90 & 1,44 & 0,33 & 0,09 \\
\hline $\mathrm{G}^{*}$ seno $(\delta)$ virgem & $43.887,58$ & $8.718,69$ & 821,78 & 89,95 & - & - & - & - \\
\hline $\mathrm{G}^{*} \mathrm{RTFOT}$ & $104.164,39$ & $17.423,27$ & $1.733,76$ & 180,13 & 17,68 & 3,16 & 0,68 & 0,17 \\
\hline$\delta$ RTFOT & 31,40 & 46,66 & 63,39 & 73,38 & 79,95 & 84,23 & 87,15 & 88,88 \\
\hline $\mathrm{G}^{*} / \mathrm{seno}(\delta) \mathrm{RTFOT}$ & - & - & - & - & 17,96 & 3,18 & 0,68 & 0,17 \\
\hline $\mathrm{G}^{*} \operatorname{seno}(\delta) \mathrm{RTFOT}$ & $54.269,22$ & $12.671,55$ & $1.550,09$ & 172,60 & - & - & - & - \\
\hline G* PAV & $114.755,31$ & $24.346,35$ & $3.410,62$ & 397,78 & 47,30 & 8,29 & 1,63 & 0,36 \\
\hline$\delta \mathrm{PAV}$ & 27,82 & 39,99 & 54,22 & 65,79 & 73,25 & 79,47 & 84,16 & 87,64 \\
\hline $\mathrm{G}^{*} / \operatorname{seno}(\delta) \mathrm{PAV}$ & - & - & - & - & 49,39 & 8,43 & 1,64 & 0,37 \\
\hline $\mathrm{G}^{*} \operatorname{seno}(\delta) \mathrm{PAV}$ & $53.554,32$ & $15.645,90$ & $2.766,87$ & 362,79 & - & - & - & - \\
\hline
\end{tabular}

Tabela 5.60 - Valores de $G^{*}(P a), \delta\left({ }^{\circ}\right), G^{*} / \operatorname{sen}(\delta)(k P a)$ e $G^{*} \operatorname{sen}(\delta)(k P a)$ nas condições virgem, envelhecida a curto prazo e envelhecida a longo prazo para a mistura 100-0-0

\begin{tabular}{|c|c|c|c|c|c|c|c|c|}
\hline \multirow{2}{*}{ Parâmetro } & \multicolumn{8}{|c|}{ Temperatura } \\
\hline & 4 & 16 & 28 & 40 & 52 & 64 & 76 & 88 \\
\hline $\mathrm{G}^{*}$ virgem & $53.557,60$ & $6.728,90$ & 432,09 & 34,85 & 4,85 & 0,96 & 0,23 & 0,06 \\
\hline$\delta$ virgem & 37,95 & 55,98 & 73,65 & 81,61 & 85,31 & 86,98 & 88,54 & 89,73 \\
\hline $\mathrm{G}^{*} /$ seno $(\delta)$ virgem & - & - & - & - & 4,86 & 0,96 & 0,23 & 0,06 \\
\hline $\mathrm{G}^{*} \operatorname{seno}(\delta)$ virgem & $32.935,68$ & $5.577,09$ & 414,61 & 34,48 & - & - & - & - \\
\hline G* RTFOT & $62.802,91$ & $9.540,94$ & 850,13 & 74,14 & 10,60 & 1,97 & 0,43 & 0,11 \\
\hline$\delta$ RTFOT & 34,61 & 49,88 & 66,52 & 76,30 & 81,51 & 84,97 & 87,40 & 89,11 \\
\hline $\mathrm{G}^{*} / \operatorname{seno}(\delta) \mathrm{RTFOT}$ & - & - & - & - & 10,71 & 1,98 & 0,43 & 0,11 \\
\hline $\mathrm{G}^{*} \operatorname{seno}(\delta) \mathrm{RTFOT}$ & $35.670,34$ & $7.295,77$ & 779,73 & 72,03 & - & - & - & - \\
\hline G* PAV & $81.574,15$ & $15.807,81$ & $1.962,72$ & 203,00 & 27,20 & 4,88 & 0,99 & 0,24 \\
\hline$\delta$ PAV & 29,88 & 42,26 & 57,09 & 68,36 & 75,95 & 81,69 & 85,82 & 88,38 \\
\hline $\mathrm{G}^{*} / \operatorname{seno}(\delta) \mathrm{PAV}$ & - & - & - & - & 28,04 & 4,93 & 0,99 & 0,24 \\
\hline $\mathrm{G}^{*} \operatorname{seno}(\delta) \mathrm{PAV}$ & $40.637,94$ & $10.630,44$ & $1.647,72$ & 188,69 & - & - & - & - \\
\hline
\end{tabular}


Tabela 5.61 - Relações entre propriedades e parâmetros das misturas 100-0-0 e CAP Replan 50/70 nas condições virgem, envelhecida a curto prazo e envelhecida a longo prazo

\begin{tabular}{|c|c|c|c|c|c|c|c|c|c|}
\hline \multirow{2}{*}{ Parâmetro } & \multicolumn{8}{|c|}{ Temperatura } & \multirow{2}{*}{ Média } \\
\hline & 4 & 16 & 28 & 40 & 52 & 64 & 76 & 88 & \\
\hline $\mathrm{G}^{*}$ virgem & 0,69 & 0,61 & 0,49 & 0,38 & 0,62 & 0,67 & 0,69 & 0,65 & 0,60 \\
\hline$\delta$ virgem & 3,68 & 4,31 & 3,94 & 3,12 & 0,84 & $-0,19$ & $-0,16$ & 0,47 & 2,00 \\
\hline $\mathrm{G}^{*} /$ seno $(\delta)$ virgem & - & - & - & - & 0,62 & 0,67 & 0,69 & 0,65 & 0,66 \\
\hline $\mathrm{G}^{*}$ seno $(\delta)$ virgem & 0,75 & 0,64 & 0,50 & 0,38 & - & - & - & - & 0,57 \\
\hline $\mathrm{G}^{*} \mathrm{RTFOT}$ & 0,60 & 0,55 & 0,49 & 0,41 & 0,60 & 0,62 & 0,63 & 0,63 & 0,57 \\
\hline$\delta$ RTFOT & 3,21 & 3,22 & 3,13 & 2,92 & 1,56 & 0,74 & 0,25 & 0,23 & 1,91 \\
\hline G*/seno( $(\delta)$ RTFOT & - & - & - & - & 0,60 & 0,62 & 0,63 & 0,63 & 0,62 \\
\hline $\mathrm{G}^{*} \operatorname{seno}(\delta) \mathrm{RTFOT}$ & 0,66 & 0,58 & 0,50 & 0,42 & - & - & - & - & 0,54 \\
\hline $\mathrm{G}^{*}$ PAV & 0,71 & 0,65 & 0,58 & 0,51 & 0,58 & 0,59 & 0,61 & 0,65 & 0,61 \\
\hline$\delta \mathrm{PAV}$ & 2,06 & 2,27 & 2,87 & 2,57 & 2,70 & 2,22 & 1,66 & 0,74 & 2,14 \\
\hline $\mathrm{G}^{*} / \operatorname{seno}(\delta) \mathrm{PAV}$ & - & - & - & - & 0,57 & 0,58 & 0,61 & 0,64 & 0,60 \\
\hline $\mathrm{G}^{*} \operatorname{seno}(\delta) \mathrm{PAV}$ & 0,76 & 0,68 & 0,60 & 0,52 & - & - & - & - & 0,64 \\
\hline
\end{tabular}

As Tabelas 5.59 a 5.61 mostram que a adição de $4 \%$ de óleo ao CAP puro reduz a rigidez da mistura 100-0-0 a aproximadamente 60\% da rigidez do CAP puro, independente do nível de envelhecimento. Com a adição de óleo, o ângulo de fase aumenta ligeiramente, indicando o aumento da componente viscosa do material. Tais efeitos se refletem em redução do parâmetro $G^{*} / \operatorname{sen}(\delta)$ da amostra 100-0-0 para todas as condições de envelhecimento e em todas as temperaturas, indicando um resultado superior por parte do ligante asfáltico de base. $\mathrm{O}$ aumento deste parâmetro está associado ao aumento da resistência à deformação permanente. Tais efeitos se refletem também na redução do parâmetro $\mathrm{G}^{*} \operatorname{sen}(\delta)$ da amostra 100-0-0 em todas as faixas de temperaturas e em todas as condições de envelhecimento. Neste caso, a adição de óleo aromático reduziu os valores do parâmetro $G^{*} \operatorname{sen}(\delta)$ em comparação ao ligante asfáltico de base, indicando aumento da resistência ao trincamento por fadiga.

\subsubsection{Efeito do envelhecimento}

As Tabelas de 5.62 a 5.71 apresentam as relações RTFOT/virgem e PAV/virgem para $\mathrm{G}^{*}, \delta, \mathrm{G}^{*} / \operatorname{sen}(\delta)$ e $\mathrm{G}^{*} \cdot \operatorname{sen}(\delta)$, das misturas e do ligante asfáltico de base, nas temperaturas de 
ensaio $\left(4,16,28,40,52,64,76\right.$ e $\left.88^{\circ} \mathrm{C}\right)$. A Tabela 5.62 apresenta tais relações para o ligante asfáltico de base (Replan 50/70). A Tabela 5.63 apresenta tais relações para a mistura 100-00. A Tabela 5.64 apresenta tais relações para a mistura 99-0-1. A Tabela 5.65 apresenta tais relações para a mistura 98-0-2. A Tabela 5.66 apresenta tais relações para a mistura 97,5-2,50. A Tabela 5.67 apresenta tais relações para a mistura 96,5-2,5-1. A Tabela 5.68 apresenta tais relações para a mistura 95,5-2,5-2. A Tabela 5.69 apresenta tais relações para a mistura 95-5-0. A Tabela 5.70 apresenta tais relações para a mistura 94-5-1. A Tabela 5.72 apresenta tais relações para a mistura 93-5-2. A Tabela 5.72 apresenta o resumo das relações médias obtidas para $G^{*}, \delta, G^{*} / \operatorname{sen}(\delta)$ e $G^{*} \cdot \operatorname{sen}(\delta)$ para as misturas e ligante asfáltico de base.

Tabela 5.62 - Relações RTFOT/virgem e PAV/virgem para $G^{*}, \delta$, G*/sen $(\delta)$ e $G^{*} \operatorname{sen}(\delta)$ do ligante asfáltico de base (Replan 50/70)

\begin{tabular}{|c|c|c|c|c|c|c|c|c|}
\hline \multirow{2}{*}{$\begin{array}{c}\text { Temperatura } \\
\left({ }^{\circ} \mathrm{C}\right)\end{array}$} & \multicolumn{4}{|c|}{ RTFOT/virgem } & \multicolumn{4}{|c|}{ PAV/virgem } \\
\hline & $\mathbf{G}^{*}$ & $\delta$ & G*/seno $(\delta)$ & $G^{*} \operatorname{seno}(\delta)$ & G* & $\delta$ & G*/seno $(\delta)$ & $G * \operatorname{seno}(\delta)$ \\
\hline 4 & 1,34 & $-2,87$ & - & 1,24 & 1,47 & $-6,45$ & - & 1,22 \\
\hline 16 & 1,57 & $-5,01$ & - & 1,45 & 2,19 & $-11,68$ & - & 1,79 \\
\hline 28 & 1,98 & $-6,32$ & - & 1,89 & 3,89 & $-15,49$ & - & 3,37 \\
\hline 40 & 1,96 & $-5,11$ & - & 1,92 & 4,33 & $-12,70$ & - & 4,03 \\
\hline 52 & 2,25 & $-4,52$ & 2,27 & - & 6,01 & $-11,22$ & 6,25 & - \\
\hline 64 & 2,21 & $-2,94$ & 2,21 & - & 5,78 & $-7,70$ & 5,87 & - \\
\hline 76 & 2,08 & $-1,55$ & 2,08 & - & 5,01 & $-4,54$ & 5,03 & - \\
\hline 88 & 1,84 & $-0,38$ & 1,84 & - & 3,86 & $-1,62$ & 3,86 & - \\
\hline média & 1,90 & $-3,59$ & 2,10 & 1,62 & 4,07 & $-8,93$ & 5,25 & 2,60 \\
\hline
\end{tabular}

Tabela 5.63 - Relações RTFOT/virgem e PAV/virgem para G*, $\delta$, G*/sen $(\delta)$ e $G^{*} \operatorname{sen}(\delta)$ da mistura 100-0-0

\begin{tabular}{|c|c|c|c|c|c|c|c|c|}
\hline \multirow{2}{*}{$\begin{array}{c}\text { Temperatura } \\
\left({ }^{\circ} \mathrm{C}\right)\end{array}$} & \multicolumn{4}{|c|}{ RTFOT/virgem } & \multicolumn{4}{|c|}{ PAV/virgem } \\
\hline & G* & $\delta$ & G*/seno( $(\delta)$ & G*seno $(\delta)$ & $\mathrm{G}^{*}$ & $\delta$ & $\mathrm{G}^{*} / \operatorname{seno}(\delta)$ & $G^{*} \operatorname{seno}(\delta)$ \\
\hline 4 & 1,17 & $-3,34$ & - & 1,08 & 1,52 & $-8,07$ & - & 1,23 \\
\hline 16 & 1,42 & $-6,10$ & - & 1,31 & 2,35 & $-13,72$ & - & 1,91 \\
\hline 28 & 1,97 & $-7,13$ & - & 1,88 & 4,54 & $-16,56$ & - & 3,97 \\
\hline 40 & 2,13 & $-5,31$ & - & 2,09 & 5,82 & $-13,25$ & - & 5,47 \\
\hline 52 & 2,19 & $-3,80$ & 2,20 & - & 5,61 & $-9,36$ & 5,77 & - \\
\hline 64 & 2,05 & $-2,01$ & 2,06 & - & 5,09 & $-5,29$ & 5,14 & - \\
\hline 76 & 1,89 & $-1,14$ & 1,90 & - & 4,40 & $-2,72$ & 4,41 & - \\
\hline 88 & 1,76 & $-0,62$ & 1,76 & - & 3,81 & $-1,35$ & 3,81 & - \\
\hline média & 1,82 & $-3,68$ & 1,98 & 1,59 & 4,14 & $-8,79$ & 4,78 & 3,15 \\
\hline
\end{tabular}


Tabela 5.64 - Relações RTFOT/virgem e PAV/virgem para G*, $\delta, G * / \operatorname{sen}(\delta)$ e G*sen $(\delta)$ da mistura 99-0-1

\begin{tabular}{|c|c|c|c|c|c|c|c|c|}
\hline \multirow{2}{*}{$\begin{array}{c}\text { Temperatura } \\
\left({ }^{\circ} \mathrm{C}\right) \\
\end{array}$} & \multicolumn{4}{|c|}{ RTFOT/virgem } & \multicolumn{4}{|c|}{ PAV/virgem } \\
\hline & $\mathbf{G}^{*}$ & $\delta$ & G*/seno $(\delta)$ & $G * \operatorname{seno}(\delta)$ & $\mathbf{G}^{*}$ & $\delta$ & G*/seno $(\delta)$ & $G * \operatorname{seno}(\delta)$ \\
\hline 4 & 1,17 & $-3,43$ & - & 1,08 & 1,47 & $-7,40$ & - & 1,21 \\
\hline 16 & 1,45 & $-6,12$ & - & 1,33 & 2,27 & $-12,56$ & - & 1,86 \\
\hline 28 & 1,81 & $-6,47$ & - & 1,73 & 3,88 & $-15,08$ & - & 3,40 \\
\hline 40 & 2,02 & $-5,55$ & - & 1,97 & 4,79 & $-12,76$ & - & 4,45 \\
\hline 52 & 2,03 & $-4,15$ & 2,05 & - & 4,70 & $-9,24$ & 4,86 & - \\
\hline 64 & 1,91 & $-2,56$ & 1,92 & - & 4,10 & $-5,68$ & 4,15 & - \\
\hline 76 & 1,78 & $-1,22$ & 1,78 & - & 3,63 & $-2,68$ & 3,65 & - \\
\hline 88 & 1,66 & $-0,76$ & 1,66 & - & 3,28 & $-0,74$ & 3,28 & - \\
\hline Média & 1,73 & $-3,78$ & 1,85 & 1,53 & 3,52 & $-8,27$ & 3,98 & 2,73 \\
\hline
\end{tabular}

Tabela 5.65 - Relações RTFOT/virgem e PAV/virgem para $G^{*}, \delta$, G*/sen $(\delta)$ e $G^{*} \operatorname{sen}(\delta)$ da mistura 98-0-2

\begin{tabular}{|c|c|c|c|c|c|c|c|c|}
\hline \multirow{2}{*}{$\begin{array}{c}\text { Temperatura } \\
\left({ }^{\circ} \mathrm{C}\right)\end{array}$} & \multicolumn{4}{|c|}{ RTFOT/virgem } & \multicolumn{4}{|c|}{ PAV/virgem } \\
\hline & $\mathbf{G}^{*}$ & $\delta$ & G*/seno $(\delta)$ & $G^{*} \operatorname{seno}(\delta)$ & $\mathbf{G}^{*}$ & $\delta$ & $G^{*} / \operatorname{seno}(\delta)$ & $G * \operatorname{seno}(\delta)$ \\
\hline 4 & 1,16 & $-2,36$ & - & 1,09 & 1,42 & $-5,61$ & - & 1,21 \\
\hline 16 & 1,29 & $-3,81$ & - & 1,21 & 1,89 & $-8,50$ & - & 1,63 \\
\hline 28 & 1,49 & $-4,43$ & - & 1,43 & 2,73 & $-10,67$ & - & 2,43 \\
\hline 40 & 1,54 & $-3,43$ & - & 1,51 & 3,13 & $-9,06$ & - & 2,92 \\
\hline 52 & 1,62 & $-1,80$ & 1,63 & - & 3,20 & $-6,32$ & 3,31 & - \\
\hline 64 & 1,48 & $-0,65$ & 1,49 & - & 2,91 & $-4,64$ & 2,96 & - \\
\hline 76 & 1,35 & 1,27 & 1,34 & - & 2,26 & $-0,47$ & 2,26 & - \\
\hline 88 & 1,28 & 1,92 & 1,28 & - & 2,09 & 1,18 & 2,09 & - \\
\hline média & 1,40 & $-1,66$ & 1,43 & 1,31 & 2,45 & $-5,51$ & 2,66 & 2,05 \\
\hline
\end{tabular}

Tabela 5.66 - Relações RTFOT/virgem e PAV/virgem para G*, $\delta, G^{*} / \operatorname{sen}(\delta)$ e $G * \operatorname{sen}(\delta)$ da mistura 97,5-2,5-0

\begin{tabular}{|c|c|c|c|c|c|c|c|c|}
\hline \multirow{2}{*}{$\begin{array}{c}\text { Temperatura } \\
\left({ }^{\circ} \mathrm{C}\right)\end{array}$} & \multicolumn{4}{|c|}{ RTFOT/virgem } & \multicolumn{4}{|c|}{ PAV/virgem } \\
\hline & G* & $\delta$ & G*/seno( $(\delta)$ & G*seno( $\delta)$ & $\mathrm{G}^{*}$ & $\delta$ & G*/seno( $(\delta)$ & G*seno( $(\delta)$ \\
\hline 4 & 1,23 & $-3,14$ & - & 1,14 & 1,56 & $-7,55$ & - & 1,27 \\
\hline 16 & 1,53 & $-5,96$ & - & 1,40 & 2,46 & $-13,59$ & - & 1,96 \\
\hline 28 & 1,92 & $-6,12$ & - & 1,83 & 4,45 & $-15,21$ & - & 3,83 \\
\hline 40 & 1,97 & $-2,14$ & - & 1,94 & 5,27 & $-8,47$ & - & 4,96 \\
\hline 52 & 2,13 & $-5,21$ & 2,18 & - & 5,27 & $-10,48$ & 5,57 & - \\
\hline 64 & 2,11 & $-3,93$ & 2,13 & - & 5,36 & $-10,33$ & 5,56 & - \\
\hline 76 & 1,94 & $-0,42$ & 1,94 & - & 4,79 & $-4,89$ & 4,85 & - \\
\hline 88 & 1,66 & 2,52 & 1,65 & - & 3,87 & $-0,10$ & 3,87 & - \\
\hline média & 1,81 & $-3,05$ & 1,98 & 1,58 & 4,13 & $-8,83$ & 4,96 & 3,00 \\
\hline
\end{tabular}


Tabela 5.67 - Relações RTFOT/virgem e PAV/virgem para $G *, \delta, G * / \operatorname{sen}(\delta)$ e $G * \operatorname{sen}(\delta)$ da mistura 96,5-2,5-1

\begin{tabular}{ccccccccc}
\hline $\begin{array}{c}\text { Temperatura } \\
\left({ }^{\mathbf{}} \mathbf{C}\right)\end{array}$ & \multicolumn{4}{c}{ RTFOT/virgem } & \multicolumn{5}{c}{ PAV/virgem } \\
\cline { 2 - 9 } & $\mathbf{G}^{*}$ & $\boldsymbol{\delta}$ & $\mathbf{G} / \mathbf{s e n o}(\boldsymbol{\delta})$ & $\mathbf{G}^{*} \mathbf{s e n o}(\boldsymbol{\delta})$ & $\mathbf{G}^{*}$ & $\boldsymbol{\delta}$ & $\mathbf{G} / \mathbf{s e n o}(\boldsymbol{\delta})$ & $\mathbf{G}^{*} \mathbf{s e n o}(\boldsymbol{\delta})$ \\
\hline 4 & 1,25 & $-2,59$ & - & 1,16 & 1,50 & $-6,19$ & - & 1,26 \\
16 & 1,47 & $-4,60$ & - & 1,37 & 2,28 & $-11,39$ & - & 1,87 \\
28 & 1,82 & $-5,88$ & - & 1,73 & 4,11 & $-14,38$ & - & 3,53 \\
40 & 1,89 & $-3,11$ & - & 1,85 & 5,15 & $-9,40$ & - & 4,77 \\
52 & 1,39 & $-2,73$ & 1,41 & - & 3,69 & $-8,57$ & 3,90 & - \\
64 & 1,42 & $-2,51$ & 1,44 & - & 3,89 & $-9,56$ & 4,08 & - \\
76 & 1,42 & $-0,81$ & 1,42 & - & 3,58 & $-5,96$ & 3,65 & - \\
88 & 1,40 & 0,86 & 1,39 & - & 3,15 & $-2,46$ & 3,17 & - \\
\hline média & 1,51 & $-2,67$ & 1,42 & 1,53 & 3,42 & $-8,49$ & 3,70 & 2,86 \\
\hline
\end{tabular}

Tabela 5.68 - Relações RTFOT/virgem e PAV/virgem para G*, $\delta, G^{*} / \operatorname{sen}(\delta)$ e $G^{*} \operatorname{sen}(\delta)$ da mistura 95,5-2,5-2

\begin{tabular}{|c|c|c|c|c|c|c|c|c|}
\hline \multirow{2}{*}{$\begin{array}{c}\text { Temperatura } \\
\left({ }^{\circ} \mathrm{C}\right)\end{array}$} & \multicolumn{4}{|c|}{ RTFOT/virgem } & \multicolumn{4}{|c|}{ PAV/virgem } \\
\hline & $\mathbf{G}^{*}$ & $\delta$ & $G * / \operatorname{seno}(\delta)$ & $G * \operatorname{seno}(\delta)$ & $\mathbf{G}^{*}$ & $\delta$ & $G^{*} / \operatorname{seno}(\delta)$ & $G * \operatorname{seno}(\delta)$ \\
\hline 4 & 1,26 & $-1,83$ & - & 1,20 & 1,43 & $-4,98$ & - & 1,23 \\
\hline 16 & 1,38 & $-2,73$ & - & 1,31 & 1,84 & $-7,25$ & - & 1,60 \\
\hline 28 & 1,55 & $-3,72$ & - & 1,48 & 2,54 & $-9,49$ & - & 2,25 \\
\hline 40 & 1,57 & $-2,77$ & - & 1,53 & 2,85 & $-7,00$ & - & 2,65 \\
\hline 52 & 1,31 & $-1,42$ & 1,33 & - & 3,16 & $-6,17$ & 3,32 & - \\
\hline 64 & 1,35 & $-2,42$ & 1,36 & - & 3,39 & $-8,91$ & 3,58 & - \\
\hline 76 & 1,19 & $-0,14$ & 1,19 & - & 2,89 & $-5,08$ & 2,96 & - \\
\hline 88 & 1,15 & 0,80 & 1,14 & - & 2,40 & $-2,14$ & 2,42 & - \\
\hline média & 1,34 & $-1,78$ & 1,26 & 1,38 & 2,56 & $-6,38$ & 3,07 & 1,94 \\
\hline
\end{tabular}

Tabela 5.69 - Relações RTFOT/virgem e PAV/virgem para G*, $\delta, G^{*} / \operatorname{sen}(\delta)$ e $G^{*} \operatorname{sen}(\delta)$ da mistura 95-5-0

\begin{tabular}{|c|c|c|c|c|c|c|c|c|}
\hline \multirow{2}{*}{$\begin{array}{c}\text { Temperatura } \\
\left({ }^{\circ} \mathrm{C}\right)\end{array}$} & \multicolumn{4}{|c|}{ RTFOT/virgem } & \multicolumn{4}{|c|}{ PAV/virgem } \\
\hline & $\mathbf{G}^{*}$ & $\delta$ & $\mathrm{G}^{*} / \operatorname{seno}(\delta)$ & G*seno( $(\delta)$ & $\mathrm{G}^{*}$ & $\delta$ & $G^{*} / \operatorname{seno}(\delta)$ & $\mathrm{G}^{*} \operatorname{seno}(\delta)$ \\
\hline 4 & 1,17 & $-2,55$ & - & 1,09 & 1,45 & $-7,28$ & - & 1,16 \\
\hline 16 & 1,42 & $-4,15$ & - & 1,33 & 2,24 & $-12,13$ & - & 1,79 \\
\hline 28 & 1,67 & $-4,01$ & - & 1,60 & 3,74 & $-13,06$ & - & 3,20 \\
\hline 40 & 1,72 & $-1,41$ & - & 1,70 & 4,33 & $-6,26$ & - & 4,08 \\
\hline 52 & 1,69 & $-1,26$ & 1,71 & - & 3,96 & $-3,52$ & 4,09 & - \\
\hline 64 & 1,67 & $-1,92$ & 1,69 & - & 3,71 & $-7,90$ & 3,93 & - \\
\hline 76 & 1,58 & $-1,00$ & 1,59 & - & 3,66 & $-7,63$ & 3,80 & - \\
\hline 88 & 1,49 & $-0,40$ & 1,50 & - & 3,37 & $-4,20$ & 3,41 & - \\
\hline média & 1,55 & $-2,09$ & 1,62 & 1,43 & 3,31 & $-7,75$ & 3,81 & 2,56 \\
\hline
\end{tabular}


Tabela 5.70 - Relações RTFOT/virgem e PAV/virgem para G*, $\delta, G^{*} / \operatorname{sen}(\delta)$ e $G * \operatorname{sen}(\delta)$ da mistura 94-5-1

\begin{tabular}{|c|c|c|c|c|c|c|c|c|}
\hline \multirow{2}{*}{$\begin{array}{l}\text { Temperatura } \\
\left({ }^{\circ} \mathrm{C}\right)\end{array}$} & \multicolumn{4}{|c|}{ RTFOT/virgem } & \multicolumn{4}{|c|}{ PAV/virgem } \\
\hline & $\mathbf{G}^{*}$ & $\delta$ & G*/seno( $(\delta)$ & $G * \operatorname{seno}(\delta)$ & $\mathrm{G}^{*}$ & $\delta$ & G*/seno( $(\delta)$ & $G * \operatorname{seno}(\delta)$ \\
\hline 4 & 1,24 & $-2,59$ & - & 1,16 & 1,43 & $-6,68$ & - & 1,16 \\
\hline 16 & 1,41 & $-3,93$ & - & 1,32 & 2,03 & $-10,91$ & - & 1,65 \\
\hline 28 & 1,65 & $-3,69$ & - & 1,59 & 3,25 & $-11,96$ & - & 2,80 \\
\hline 40 & 1,63 & $-0,77$ & - & 1,62 & 3,49 & $-5,96$ & - & 3,28 \\
\hline 52 & 1,77 & $-2,58$ & 1,81 & - & 3,76 & $-3,38$ & 3,88 & - \\
\hline 64 & 1,81 & $-3,12$ & 1,86 & - & 3,49 & $-6,64$ & 3,69 & - \\
\hline 76 & 1,63 & $-1,54$ & 1,65 & - & 3,23 & $-6,32$ & 3,36 & - \\
\hline 88 & 1,43 & $-0,41$ & 1,43 & - & 2,78 & $-3,16$ & 2,81 & - \\
\hline média & 1,57 & $-2,33$ & 1,69 & 1,42 & 2,93 & $-6,88$ & 3,44 & 2,22 \\
\hline
\end{tabular}

Tabela 5.71 - Relações RTFOT/virgem e PAV/virgem para G*, $\delta, G^{*} / \operatorname{sen}(\delta)$ e $G^{*} \operatorname{sen}(\delta)$ da mistura 93-5-2

\begin{tabular}{|c|c|c|c|c|c|c|c|c|}
\hline \multirow{2}{*}{$\begin{array}{c}\text { Temperatura } \\
\left({ }^{\circ} \mathrm{C}\right)\end{array}$} & \multicolumn{4}{|c|}{ RTFOT/virgem } & \multicolumn{4}{|c|}{ PAV/virgem } \\
\hline & G* & $\delta$ & G*/seno( $(\delta)$ & $G * \operatorname{seno}(\delta)$ & G* & $\delta$ & G*/seno( $(\delta)$ & $G * \operatorname{seno}(\delta)$ \\
\hline 4 & 0,96 & $-1,89$ & - & 0,90 & 1,15 & $-4,78$ & - & 0,98 \\
\hline 16 & 1,04 & $-2,57$ & - & 0,99 & 1,48 & $-7,25$ & - & 1,26 \\
\hline 28 & 1,16 & $-3,42$ & - & 1,11 & 2,08 & $-9,66$ & - & 1,81 \\
\hline 40 & 1,22 & $-2,18$ & - & 1,19 & 2,45 & $-6,65$ & - & 2,26 \\
\hline 52 & 1,42 & $-1,88$ & 1,44 & - & 2,64 & $-2,60$ & 2,72 & - \\
\hline 64 & 1,50 & $-3,43$ & 1,55 & - & 2,48 & $-4,70$ & 2,61 & - \\
\hline 76 & 1,40 & $-1,22$ & 1,41 & - & 2,28 & $-3,35$ & 2,35 & - \\
\hline 88 & 1,25 & 1,15 & 1,24 & - & 2,06 & $-1,36$ & 2,08 & - \\
\hline média & 1,24 & $-1,93$ & 1,41 & 1,05 & 2,08 & $-5,04$ & 2,44 & 1,58 \\
\hline
\end{tabular}

As Tabelas de 5.62 a 5.71 mostram que os maiores incrementos de $\mathrm{G}^{*}$ provocados pelo envelhecimento acontecem nas temperaturas de $28,40,52$ e $64^{\circ} \mathrm{C}$. A tendência de um incremento de $\mathrm{G}^{*}$ maior nas temperaturas intermediárias e menor nas temperaturas extremas se repete para todas as misturas e para o ligante asfáltico de base. Esta observação é válida para as duas comparações (RTFOT/virgem e PAV/virgem). No caso do ângulo de fase, de uma maneira geral, as misturas apresentam diminuição do ângulo de fase com o envelhecimento. As maiores diferenças encontram-se nas temperaturas baixas (4, 16, 28 e $\left.40^{\circ} \mathrm{C}\right)$. Nas temperaturas mais elevadas, algumas misturas como 98-0-2, 97,5-2,5-0, 96,5-2,51 e 95,5-2,5-2 apresentaram um ganho de $\delta$. 
Tabela 5.72 - Resumo das relações médias para $G *, \delta, G * / \operatorname{sen}(\delta)$ e $G * \operatorname{sen}(\delta)$ das misturas e do ligante asfáltico de base

\begin{tabular}{|c|c|c|c|c|c|c|c|c|}
\hline \multirow{2}{*}{ Mistura } & \multicolumn{4}{|c|}{ RTFOT/virgem } & \multicolumn{4}{|c|}{ PAV/virgem } \\
\hline & $\mathbf{G}^{*}$ & $\delta$ & $G^{*} / \operatorname{seno}(\delta)$ & $G^{*} \operatorname{seno}(\delta)$ & $\mathbf{G}^{*}$ & $\delta$ & G*/seno $(\delta)$ & $G^{*} \operatorname{seno}(\delta)$ \\
\hline Replan 50/70 & 1,90 & $-3,59$ & 2,10 & 1,62 & 4,07 & $-8,93$ & 5,25 & 2,60 \\
\hline $100-0-0$ & 1,82 & $-3,68$ & 1,98 & 1,59 & 4,14 & $-8,79$ & 4,78 & 3,15 \\
\hline $99-0-1$ & 1,73 & $-3,78$ & 1,85 & 1,53 & 3,52 & $-8,27$ & 3,98 & 2,73 \\
\hline $98-0-2$ & 1,40 & $-1,66$ & 1,43 & 1,31 & 2,45 & $-5,51$ & 2,66 & 2,05 \\
\hline $97,5-2,5-0$ & 1,81 & $-3,05$ & 1,98 & 1,58 & 4,13 & $-8,83$ & 4,96 & 3,00 \\
\hline $96,5-2,5-1$ & 1,51 & $-2,67$ & 1,42 & 1,53 & 3,42 & $-8,49$ & 3,70 & 2,86 \\
\hline $95,5-2,5-2$ & 1,34 & $-1,78$ & 1,26 & 1,38 & 2,56 & $-6,38$ & 3,07 & 1,94 \\
\hline $95-5-0$ & 1,55 & $-2,09$ & 1,62 & 1,43 & 3,31 & $-7,75$ & 3,81 & 2,56 \\
\hline $94-5-1$ & 1,57 & $-2,33$ & 1,69 & 1,42 & 2,93 & $-6,88$ & 3,44 & 2,22 \\
\hline $93-5-2$ & 1,24 & $-1,93$ & 1,41 & 1,05 & 2,08 & $-5,04$ & 2,44 & 1,58 \\
\hline
\end{tabular}

Para o parâmetro $\mathrm{G}^{*} / \operatorname{sen}(\delta)$, observa-se que os maiores incrementos se dão nas temperaturas de 52 e $64^{\circ} \mathrm{C}$. De uma maneira geral, todas as misturas e o ligante asfáltico de base apresentam incremento deste parâmetro com o envelhecimento, o que já era esperado, visto que com o processo de envelhecimento o ligante asfáltico se torna mais rígido. Para o parâmetro $\mathrm{G}^{*} \cdot \operatorname{sen}(\delta)$, observa-se que os maiores incrementos se deram nas temperaturas de 28 e $40^{\circ} \mathrm{C}$. $\mathrm{O}$ aumento de $\mathrm{G}^{*} / \operatorname{sen}(\delta)$ com o envelhecimento é benéfico para a resistência á deformação permanente da mistura asfáltica porém o aumento do parâmetro $\mathrm{G}^{*}$. $\operatorname{sen}(\delta)$ tende a prejudicar o comportamento á fadiga em condições de deformação controlada.

A Tabela 5.72 mostra a média das relações de cada propriedade e parâmetro nas duas condições de envelhecimento comparadas com a condição original. $\mathrm{Na}$ relação RTFOT/virgem, para o módulo complexo, observa-se que o maior ganho foi o do ligante asfáltico de base (1,90 vezes), seguido da mistura 100-0-0 (1,82 vezes). O menor ganho foi o da mistura 93-5-2 (1,24 vezes), seguido da mistura 95,5-2,5-2 (1,34 vezes). Pode-se perceber que quanto maior a quantidade de TITAN, menor será o ganho do módulo complexo. Para o ângulo de fase, tem-se que a maior diferença foi a da mistura 99-0-1 (-3,78 graus), seguida pela mistura 100-0-0 (-3,68 graus). A menor diferença foi a da mistura 98-0-2 (-1,66 graus), seguida pela mistura 95,5-2,5-2 (-1,78 graus). Pode-se perceber que quanto maior a quantidade de TITAN, menor será a diferença do ângulo de fase. Embora a redução nos valores de delta provocada pelo envelhecimento seja irrisória, a redução no nível de 
enrijecimento por conta da adição de TITAN é indício de que o material contribui com a redução da sensibilidade das amostras ao envelhecimento a curto prazo.

$\mathrm{Na}$ relação RTFOT/virgem, para o parâmetro $\mathrm{G}^{*} / \operatorname{sen}(\delta)$, observa-se que o maior incremento foi o do ligante asfáltico de base (2,10 vezes), seguido das misturas 100-0-0 e 97,5-2,5-0 (ambas com 1,98 vezes). O menor incremento foi o da mistura 95,5-2,5-2 (1,26 vezes), seguido da mistura 93-5-2 (1,41 vezes). Pode-se perceber que quanto maior a quantidade de TITAN, menor será o incremento deste parâmetro. Para o parâmetro G*.sen $(\delta)$, observa-se que o maior incremento foi o do ligante asfáltico de base (1,62 vezes), seguido da mistura 100-0-0 (1,59 vezes). O menor ganho foi o da mistura 93-5-2 (1,05 vezes), seguido da mistura 98-0-2 (1,31 vezes). Neste caso também pode-se perceber que quanto maior a quantidade de TITAN, menor será o incremento deste parâmetro. Em ambos os casos, o TITAN contribui com a redução do efeito do envelhecimento a curto prazo.

Na relação PAV/virgem, para o módulo complexo, observa-se que o maior incremento foi o da mistura 100-0-0 (4,14 vezes), seguido pelo ligante asfáltico de base (4,07 vezes). $\mathrm{O}$ menor incremento foi o da mistura 93-5-2 (2,08 vezes), seguido da mistura 98-0-2 (2,45 vezes). Pode-se perceber que quanto maior a quantidade de TITAN, menor será o incremento do módulo complexo. Para o ângulo de fase, tem-se que a maior diferença foi a do ligante asfáltico de base (-8,93 graus), seguida pela mistura 97,5-2,5-0 (-8,83 graus). A menor diferença foi a da mistura 93-5-2 (-5,04 graus), seguida pela mistura 98-0-2 (-5,51 graus). Pode-se perceber que quanto maior a quantidade de TITAN, menor será a diferença do ângulo de fase. Embora, neste caso, a redução dos valores de delta seja mais expressiva, merece destaque também o efeito positivo do TITAN em amenizar o efeito do envelhecimento a longo prazo sobre a rigidez das amostras.

No que se refere à relação PAV/virgem, para o parâmetro $\mathrm{G}^{*} / \mathrm{sen}(\delta)$, observa-se que o maior incremento foi o do ligante asfáltico de base (5,25 vezes), seguido da mistura 97,5-2,50 (4,96 vezes). O menor incremento foi o da mistura 93-5-2 (2,44 vezes), seguido da mistura 98-0-2 (2,66 vezes). Pode-se perceber que quanto maior a quantidade de TITAN, menor será o incremento desta propriedade. Para o parâmetro $G^{*} . \operatorname{sen}(\delta)$, observa-se que o maior incremento foi o da mistura 100-0-0 (3,15 vezes), seguido da mistura 97,5-2,5-0 (3,00 vezes). O menor incremento foi o da mistura 93-5-2 (1,58 vezes), seguido da mistura 95,5-2,5-2 (1,94 vezes). Neste caso também, pode-se perceber que quanto maior a quantidade de TITAN, 
menor será o incremento desta propriedade. Em ambos os casos, o TITAN contribui com a redução do efeito do envelhecimento a curto prazo.

Percebe-se que concentrações elevadas de TITAN fazem com que a mistura se torne menos suscetível às variações de módulo complexo e às de ângulo de fase por conta da ação dos envelhecimentos a curto e a longo prazos. As misturas com concentrações baixas ou nulas de TITAN e SBS são mais suscetíveis ao envelhecimento, confirmando o efeito positivo dos modificadores em amenizar os efeitos do envelhecimento. O SBS também faz com que a mistura se torne menos suscetível ao envelhecimento, porém, em menor escala se comparado ao efeito do TITAN.

5.7.3 Comparação das formulações com SBS e TITAN com a mistura 100-0-0 nas diferentes condições de envelhecimento

As Tabelas de 5.73 a 5.75 apresentam as relações de $\mathrm{G}^{*}$ da mistura 100-0-0 com as demais, nas condições virgem (Tabela 5.73), envelhecida a curto prazo (tabela 5.74) e envelhecida a longo prazo (Tabela 5.75). As Tabelas de 5.76 a 5.78 apresentam as diferenças entre valores de delta da mistura 100-0-0 com as demais, nas condições virgem (Tabela 5.76), envelhecida a curto prazo (tabela 5.77) e envelhecida a longo prazo (Tabela 5.78). As Tabelas de 5.79 a 5.81 apresentam as relações do parâmetro $\mathrm{G}^{*} / \operatorname{sen}(\delta)$ da mistura $100-0-0$ com as demais, nas condições virgem (Tabela 5.79), envelhecida a curto prazo (Tabela 5.80) e envelhecida a longo prazo (Tabela 5.81). As Tabelas de 5.82 a 5.84 apresentam as relações do parâmetro $\mathrm{G}^{*} \cdot \operatorname{sen}(\delta)$ da mistura 100-0-0 com as demais, nas condições virgem (Tabela 5.82), envelhecida a curto prazo (tabela 5.83) e envelhecida a longo prazo (Tabela 5.84).

Para a condição virgem (Tabela 5.73), o maior aumento médio do módulo complexo se dá nas misturas com maiores índices de modificação. O maior aumento médio foi o da mistura 93-5-2 (9,42 vezes), seguido da mistura 94-5-1 (4,62 vezes). O menor ganho médio foi o da mistura 99-0-1 (1,55 vezes), seguido da mistura 97,5-2,5-0 (1,56 vezes). Para a condição envelhecida a curto prazo (Tabela 5.74), o maior aumento médio do módulo complexo também se dá nas misturas com maiores índices de modificação. O maior aumento médio foi o da mistura 93-5-2 (6,54 vezes), seguido da mistura 94-5-1 (3,90 vezes). O menor 
aumento médio foi o da mistura 99-0-1 (1,47 vezes), seguido da mistura 97,5-2,5-0 (1,55 vezes). Para a condição envelhecida a longo prazo (Tabela 5.75), o maior incremento médio do módulo complexo, assim como já observado nas demais condições de envelhecimento, se dá nas misturas com maiores índices de modificação. O maior incremento médio foi o da mistura 93-5-2 (4,78 vezes), seguido da mistura 94-5-1 (3,29 vezes). O menor incremento médio foi o da mistura 99-0-1 (1,33 vezes), seguido da mistura 97,5-2,5-0 (1,57 vezes).

Tabela 5.73 - Relações de G* das misturas com SBS e TITAN com a mistura 100-0-0 na condição virgem

\begin{tabular}{cccccccccc}
\hline $\begin{array}{c}\text { Temperatura } \\
\left({ }^{\mathbf{}} \mathbf{C}\right)\end{array}$ & \multicolumn{10}{c}{$\mathbf{G}^{*}{ }_{\text {misturas }} / \mathbf{G}^{*} \mathbf{1 0 0 - 0 - 0}$} \\
\cline { 2 - 10 } & $\mathbf{1 0 0 - 0 - 0}$ & $\mathbf{9 9 - 0 - 1}$ & $\mathbf{9 8 - 0 - 2}$ & $\mathbf{9 7 , 5 - 2 , 5 - 0}$ & $\mathbf{9 6 , 5 - 2 , 5 - 1}$ & $\mathbf{9 5 , 5 - 2 , 5 - 2}$ & $\mathbf{9 5 - 5 - 0}$ & $\mathbf{9 4 - 5 - 1}$ & $\mathbf{9 3 - 5 - 2}$ \\
\hline 4 & 1,00 & 1,17 & 1,25 & 0,99 & 1,09 & 1,14 & 0,98 & 1,04 & 1,40 \\
16 & 1,00 & 1,20 & 1,52 & 1,06 & 1,24 & 1,52 & 1,13 & 1,35 & 2,08 \\
28 & 1,00 & 1,34 & 2,19 & 1,26 & 1,61 & 2,57 & 1,65 & 2,08 & 4,00 \\
40 & 1,00 & 1,65 & 3,65 & 1,53 & 2,43 & 4,72 & 2,35 & 3,72 & 7,92 \\
52 & 1,00 & 1,65 & 3,04 & 1,69 & 3,22 & 4,69 & 3,26 & 4,71 & 9,14 \\
64 & 1,00 & 1,71 & 3,16 & 1,82 & 3,44 & 5,22 & 4,47 & 6,50 & 13,14 \\
76 & 1,00 & 1,80 & 3,79 & 1,93 & 3,73 & 6,38 & 5,25 & 8,23 & 17,90 \\
88 & 1,00 & 1,87 & 4,13 & 2,15 & 3,98 & 7,01 & 5,67 & 9,33 & 19,74 \\
\hline média & 1,00 & 1,55 & 2,84 & 1,56 & 2,59 & 4,16 & 3,09 & 4,62 & 9,42 \\
\hline
\end{tabular}

Tabela 5.74 - Relações de G* das misturas com SBS e TITAN com a mistura 100-0-0 na condição envelhecida a curto prazo

\begin{tabular}{cccccccccc}
\hline $\begin{array}{c}\text { Temperatura } \\
\left({ }^{\mathbf{o}} \mathbf{C}\right)\end{array}$ & $\mathbf{1 0 0 - 0 - 0}$ & $\mathbf{9 9 - 0 - 1}$ & $\mathbf{9 8 - 0 - 2}$ & $\mathbf{9 7 , 5 - 2 , 5 - 0}$ & $\mathbf{9 6 , 5 - 2 , 5 - 1}$ & $\mathbf{9 5 , 5 - 2 , 5 - 2}$ & $\mathbf{9 5 - 5 - 0}$ & $\mathbf{9 4 - 5 - 1}$ & $\mathbf{9 3 - 5 - 2}$ \\
\hline 4 & 1,00 & 1,17 & 1,23 & 1,05 & 1,16 & 1,23 & 0,97 & 1,11 & 1,15 \\
16 & 1,00 & 1,22 & 1,39 & 1,14 & 1,29 & 1,48 & 1,13 & 1,34 & 1,52 \\
28 & 1,00 & 1,23 & 1,65 & 1,23 & 1,49 & 2,02 & 1,40 & 1,74 & 2,37 \\
40 & 1,00 & 1,57 & 2,65 & 1,42 & 2,16 & 3,49 & 1,90 & 2,84 & 4,55 \\
52 & 1,00 & 1,53 & 2,25 & 1,65 & 2,05 & 2,82 & 2,52 & 3,81 & 5,91 \\
64 & 1,00 & 1,59 & 2,28 & 1,87 & 2,39 & 3,42 & 3,63 & 5,74 & 9,59 \\
76 & 1,00 & 1,69 & 2,69 & 1,98 & 2,80 & 4,02 & 4,38 & 7,09 & 13,20 \\
88 & 1,00 & 1,76 & 3,01 & 2,03 & 3,15 & 4,56 & 4,81 & 7,55 & 14,04 \\
\hline média & 1,00 & 1,47 & 2,14 & 1,55 & 2,06 & 2,88 & 2,59 & 3,90 & 6,54 \\
\hline
\end{tabular}

Observa-se ainda pelas Tabelas de 5.73 a 5.75 que, para algumas misturas, na temperatura de $4^{\circ} \mathrm{C}$, a relação $\mathrm{G}^{*}$ misturas $/ \mathrm{G}^{*}{ }_{100-0-0}$ é inferior a 1,0 . Na condição virgem, observa-se esse fato com as misturas 97,5-2,5-0 e 95-5-0. Na condição envelhecida a curto 
prazo, observa-se esse fato com a mistura 95-5-0. Na condição envelhecida a longo prazo, observa-se esse fato com as misturas 95-5-0 e 94-5-1. Isto se dá pelo fato de os modificadores amenizarem o endurecimento provocado pelas temperaturas baixas.

Tabela 5.75 - Relações de G* das misturas com SBS e TITAN com a mistura 100-0-0 na condição envelhecida a longo prazo

\begin{tabular}{cccccccccc}
\hline $\begin{array}{c}\text { Temperatura } \\
\left({ }^{\mathbf{}} \mathbf{C}\right)\end{array}$ & $\mathbf{1 0 0 - 0 - 0}$ & $\mathbf{9 9 - 0 - 1}$ & $\mathbf{9 8 - 0 - 2}$ & $\mathbf{9 7 , 5 - 2 , 5 - 0}$ & $\mathbf{9 6 , 5 - 2 , 5 - 1}$ & $\mathbf{9 5 , 5 - 2 , 5 - 2}$ & $\mathbf{9 5 - 5 - 0}$ & $\mathbf{9 4 - 5 - 1}$ & $\mathbf{9 3 - 5 - 2}$ \\
\hline 4 & 1,00 & 1,13 & 1,16 & 1,02 & 1,07 & 1,07 & 0,93 & 0,98 & 1,06 \\
16 & 1,00 & 1,16 & 1,23 & 1,11 & 1,21 & 1,20 & 1,08 & 1,17 & 1,31 \\
28 & 1,00 & 1,14 & 1,31 & 1,24 & 1,46 & 1,44 & 1,36 & 1,49 & 1,83 \\
40 & 1,00 & 1,36 & 1,96 & 1,39 & 2,15 & 2,30 & 1,74 & 2,23 & 3,34 \\
52 & 1,00 & 1,38 & 1,74 & 1,59 & 2,12 & 2,64 & 2,30 & 3,15 & 4,30 \\
64 & 1,00 & 1,38 & 1,81 & 1,91 & 2,63 & 3,47 & 3,26 & 4,46 & 6,42 \\
76 & 1,00 & 1,49 & 1,95 & 2,10 & 3,03 & 4,19 & 4,36 & 6,05 & 9,30 \\
88 & 1,00 & 1,61 & 2,27 & 2,18 & 3,28 & 4,41 & 5,00 & 6,80 & 10,66 \\
\hline média & 1,00 & 1,33 & 1,68 & 1,57 & 2,12 & 2,59 & 2,50 & 3,29 & 4,78 \\
\hline
\end{tabular}

Observa-se pela Tabela 5.76 que a maior diferença média do ângulo de fase para a condição virgem se dá nas misturas com maiores teores de modificação. A maior diferença média foi a da mistura 93-5-2 (-19,48 graus), seguida da mistura 94-5-1 (-14,57 graus). A menor diferença média foi a da mistura 99-0-1 (-2,30 graus), seguida da mistura 97,5-2,5-0 (4,92 graus). Observa-se pela Tabela 5.77 que a maior diferença média do ângulo de fase para a condição envelhecida a curto prazo também se dá nas misturas com maiores teores de modificação. A maior diferença média foi a da mistura 93-5-2 (-17,73 graus), seguida da mistura 94-5-1 (-12,71 graus). A menor diferença média foi a da mistura 99-0-1 (-2,40 graus), seguida da mistura 97,5-2,5-0 (-4,29 graus). Observa-se pela Tabela 5.78 que a maior diferença média do ângulo de fase para a condição envelhecida a longo prazo, assim como já observado nos outros níveis de envelhecimento, se dá nas misturas com maiores teores de modificação. A maior diferença média foi a da mistura 93-5-2 (-15,73 graus), seguida da mistura 94-5-1 (-12,15 graus). A menor diferença média foi a da mistura 99-0-1 (-1,77 graus), seguida da mistura 98-0-2 (-4,52 graus).

Para todas as misturas a relação entre os valores de ângulo de fase foi negativa, indicando que, para todas as temperaturas, a adição de qualquer quantidade dos modificadores é capaz de reduzir o ângulo de fase. 
Tabela 5.76 - Diferenças entre valores de delta das misturas com SBS e TITAN com a mistura 100-0-0 na condição virgem

\begin{tabular}{|c|c|c|c|c|c|c|c|c|c|}
\hline \multirow{2}{*}{$\begin{array}{c}\text { Temperatura } \\
\left({ }^{\circ} \mathrm{C}\right)\end{array}$} & \multicolumn{9}{|c|}{$\delta_{\text {mistura }}-\delta_{100-0-0}$} \\
\hline & 100-0-0 & 99-0-1 & 98-0-2 & $97,5-2,5-0$ & $96,5-2,5-1$ & $95,5-2,5-2$ & 95-5-0 & 94-5-1 & 93-5-2 \\
\hline 4 & 0,00 & $-1,31$ & $-3,31$ & $-2,17$ & $-3,70$ & $-5,37$ & $-3,89$ & $-5,16$ & $-7,43$ \\
\hline 16 & 0,00 & $-2,15$ & $-7,01$ & $-2,82$ & $-5,31$ & $-10,35$ & $-6,27$ & $-8,44$ & $-13,22$ \\
\hline 28 & 0,00 & $-2,91$ & $-9,59$ & $-5,14$ & $-7,39$ & $-14,30$ & $-11,11$ & $-13,02$ & $-18,42$ \\
\hline 40 & 0,00 & $-3,20$ & $-11,05$ & $-9,98$ & $-11,77$ & $-17,66$ & $-16,82$ & $-19,04$ & $-23,04$ \\
\hline 52 & 0,00 & $-2,26$ & $-8,85$ & $-7,03$ & $-11,45$ & $-16,47$ & $-21,21$ & $-22,29$ & $-26,77$ \\
\hline 64 & 0,00 & $-1,69$ & $-6,52$ & $-3,52$ & $-7,79$ & $-12,05$ & $-16,19$ & $-19,11$ & $-25,16$ \\
\hline 76 & 0,00 & $-2,17$ & $-8,02$ & $-3,86$ & $-6,79$ & $-12,06$ & $-10,98$ & $-14,74$ & $-23,42$ \\
\hline 88 & 0,00 & $-2,68$ & $-8,02$ & $-4,86$ & $-6,02$ & $-10,14$ & $-7,83$ & $-10,72$ & $-18,36$ \\
\hline média & 0,00 & $-2,30$ & $-7,80$ & $-4,92$ & $-7,53$ & $-12,30$ & $-11,79$ & $-14,07$ & $-19,48$ \\
\hline
\end{tabular}

Tabela 5.77 - Diferenças entre valores de delta das misturas com SBS e TITAN com a mistura 100-0-0 na condição envelhecida a curto prazo

\begin{tabular}{cccccccccc}
\hline $\begin{array}{c}\text { Temperatura } \\
\left({ }^{\circ} \mathbf{C}\right)\end{array}$ & \multicolumn{10}{c}{$\boldsymbol{\delta}_{\text {mistura }} \boldsymbol{\delta}_{\mathbf{1 0 0 - 0 - 0}}$} \\
\cline { 2 - 10 } & $\mathbf{1 0 0 - 0 - 0}$ & $\mathbf{9 9 - 0 - 1}$ & $\mathbf{9 8 - 0 - 2}$ & $\mathbf{9 7 , 5 - 2 , 5 - 0}$ & $\mathbf{9 6 , 5 - 2 , 5 - 1}$ & $\mathbf{9 5 , 5 - 2 , 5 - 2}$ & $\mathbf{9 5 - 5 - 0}$ & $\mathbf{9 4 - 5 - 1}$ & $\mathbf{9 3 - 5 - 2}$ \\
\hline 4 & 0,00 & $-1,40$ & $-2,33$ & $-1,97$ & $-2,95$ & $-3,86$ & $-3,10$ & $-4,41$ & $-5,98$ \\
16 & 0,00 & $-2,17$ & $-4,72$ & $-2,68$ & $-3,81$ & $-6,98$ & $-4,32$ & $-6,27$ & $-9,69$ \\
28 & 0,00 & $-2,25$ & $-6,89$ & $-4,13$ & $-6,14$ & $-10,89$ & $-7,99$ & $-9,58$ & $-14,71$ \\
40 & 0,00 & $-3,44$ & $-9,17$ & $-6,81$ & $-9,57$ & $-15,12$ & $-12,92$ & $-14,50$ & $-19,91$ \\
52 & 0,00 & $-2,61$ & $-6,85$ & $-8,44$ & $-10,38$ & $-14,09$ & $-18,67$ & $-21,07$ & $-24,85$ \\
64 & 0,00 & $-2,24$ & $-5,16$ & $-5,44$ & $-8,29$ & $-12,46$ & $-16,10$ & $-20,22$ & $-26,58$ \\
76 & 0,00 & $-2,25$ & $-5,61$ & $-3,14$ & $-6,46$ & $-11,06$ & $-10,84$ & $-15,14$ & $-23,50$ \\
88 & 0,00 & $-2,82$ & $-5,48$ & $-1,72$ & $-4,54$ & $-8,72$ & $-7,61$ & $-10,51$ & $-16,59$ \\
\hline média & 0,00 & $-2,40$ & $-5,78$ & $-4,29$ & $-6,52$ & $-10,40$ & $-10,19$ & $-12,71$ & $-17,73$ \\
\hline
\end{tabular}

Tabela 5.78 - Diferenças entre valores de delta das misturas com SBS e TITAN com a mistura 100-0-0 na condição envelhecida a longo prazo

\begin{tabular}{cccccccccc}
\hline $\begin{array}{c}\text { Temperatura } \\
\left({ }^{\mathbf{}} \mathbf{C}\right)\end{array}$ & \multicolumn{10}{c}{$\boldsymbol{\delta}_{\text {mistura- }} \boldsymbol{\delta}_{\mathbf{1 0 0 - 0 - 0}}$} \\
\cline { 2 - 10 } & $\mathbf{1 0 0 - 0 - 0}$ & $\mathbf{9 9 - 0 - 1}$ & $\mathbf{9 8 - 0 - 2}$ & $\mathbf{9 7 , 5 - 2 , 5 - 0}$ & $\mathbf{9 6 , 5 - 2 , 5 - 1}$ & $\mathbf{9 5 , 5 - 2 , 5 - 2}$ & $\mathbf{9 5 - 5 - 0}$ & $\mathbf{9 4 - 5 - 1}$ & $\mathbf{9 3 - 5 - 2}$ \\
\hline 4 & 0,00 & $-0,64$ & $-0,85$ & $-1,65$ & $-1,82$ & $-2,28$ & $-3,10$ & $-3,77$ & $-4,14$ \\
16 & 0,00 & $-0,99$ & $-1,79$ & $-2,69$ & $-2,98$ & $-3,88$ & $-4,68$ & $-5,63$ & $-6,75$ \\
28 & 0,00 & $-1,43$ & $-3,70$ & $-3,79$ & $-5,21$ & $-7,23$ & $-7,61$ & $-8,42$ & $-11,52$ \\
40 & 0,00 & $-2,71$ & $-6,86$ & $-5,20$ & $-7,92$ & $-11,41$ & $-9,83$ & $-11,75$ & $-16,44$ \\
52 & 0,00 & $-2,14$ & $-5,81$ & $-8,15$ & $-10,66$ & $-13,28$ & $-15,37$ & $-16,31$ & $-20,01$ \\
64 & 0,00 & $-2,08$ & $-5,87$ & $-8,56$ & $-12,06$ & $-15,67$ & $-18,80$ & $-20,46$ & $-24,57$ \\
76 & 0,00 & $-2,13$ & $-5,77$ & $-6,03$ & $-10,03$ & $-14,42$ & $-15,89$ & $-18,34$ & $-24,05$ \\
88 & 0,00 & $-2,07$ & $-5,49$ & $-3,61$ & $-7,13$ & $-10,93$ & $-10,68$ & $-12,53$ & $-18,37$ \\
\hline Média & 0,00 & $-1,77$ & $-4,52$ & $-4,96$ & $-7,23$ & $-9,89$ & $-10,75$ & $-12,15$ & $-15,73$ \\
\hline
\end{tabular}


Observa-se, pela Tabela 5.79, que o maior incremento médio do parâmetro $\mathrm{G}^{*} / \operatorname{sen}(\delta)$ para a condição virgem se dá nas misturas com maiores teores de modificação. O maior incremento médio foi o da mistura 93-5-2 (16,53 vezes), seguido da mistura 94-5-1 (7,59 vezes). O menor incremento médio foi o da mistura 99-0-1 (1,76 vezes), seguido da mistura 97,5-2,5-0 (1,91 vezes). Observa-se, pela Tabela 5.80, que o maior incremento médio do parâmetro $\mathrm{G}^{*} / \operatorname{sen}(\delta)$ para a condição envelhecida a curto prazo também se dá nas misturas com maiores teores de modificação. O maior incremento médio foi o da mistura 93-5-2 (11,90 vezes), seguido da mistura 94-5-1 (6,45 vezes). O menor incremento médio foi o da mistura 99-0-1 (1,65 vezes), seguido da mistura 97,5-2,5-0 (1,90 vezes). Observa-se, pela Tabela 5.81, que o maior incremento médio do parâmetro $G^{*} / \operatorname{sen}(\delta)$ para a condição envelhecida a longo prazo, como já observado nas demais condições de envelhecimento, se dá nas misturas com maiores teores de modificação. O maior incremento médio foi o da mistura 93-5-2 (8,61 vezes), seguido da mistura 94-5-1 (5,53 vezes). O menor incremento médio foi o da mistura 99-0-1 (1,47 vezes), seguido da mistura 98-0-2 (1,97 vezes).

Tabela 5.79 - Relações de G*/sen( $\delta$ ) das misturas com SBS e TITAN com a mistura 1000-0 para na condição virgem

\begin{tabular}{cccccccccc}
\hline \multirow{2}{*}{$\begin{array}{c}\text { Temperatura } \\
\left({ }^{\mathbf{}} \mathbf{C}\right)\end{array}$} & $\mathbf{1 0 0 - 0 - 0}$ & $\mathbf{9 9 - 0 - 1}$ & $\mathbf{9 8 - 0 - 2}$ & $\mathbf{9 7 , 5 - 2 , 5 - 0}$ & $\mathbf{9 6 , 5 - 2 , 5 - 1}$ & $\mathbf{9 5 , 5 - 2 , 5 - 2}$ & $\mathbf{9 5 - 5 - 0}$ & $\mathbf{9 4 - 5 - 1}$ & $\mathbf{9 3 - 5 - 2}$ \\
\cline { 2 - 10 } & 1,00 & 1,65 & 3,12 & 1,72 & 3,34 & 5,01 & 3,61 & 5,27 & 10,68 \\
52 & 1,00 & 1,72 & 3,20 & 1,82 & 3,50 & 5,40 & 4,72 & 7,01 & 14,89 \\
64 & 1,00 & 1,80 & 3,84 & 1,94 & 3,77 & 6,56 & 5,37 & 8,57 & 19,73 \\
76 & 1,00 & 1,88 & 4,17 & 2,16 & 4,00 & 7,13 & 5,73 & 9,50 & 20,83 \\
88 & 1,00 & 1,76 & 3,58 & 1,91 & 3,65 & 6,02 & 4,86 & 7,59 & 16,53 \\
\hline média & & & & & & & &
\end{tabular}

Tabela 5.80 - Relações de G*/sen(ס) das misturas com SBS e TITAN com a mistura 100-0O para na condição envelhecida a curto prazo

\begin{tabular}{cccccccccc}
\hline $\begin{array}{c}\text { Temperatura } \\
\left({ }^{\mathbf{O}} \mathbf{C}\right)\end{array}$ & $\mathbf{1 0 0 - 0 - 0}$ & $\mathbf{9 9 - 0 - 1}$ & $\mathbf{9 8 - 0 - 2}$ & $\mathbf{9 7 , 5 - 2 , 5 - 0}$ & $\mathbf{9 6 , 5 - 2 , 5 - 1}$ & $\mathbf{9 5 , 5 - 2 , 5 - 2}$ & $\mathbf{9 5 - 5 - 0}$ & $\mathbf{9 4 - 5 - 1}$ & $\mathbf{9 3 - 5 - 2}$ \\
\hline 52 & 1,00 & 1,54 & 2,31 & 1,70 & 2,14 & 3,02 & 2,80 & 4,33 & 7,00 \\
64 & 1,00 & 1,60 & 2,31 & 1,89 & 2,44 & 3,58 & 3,88 & 6,33 & 11,22 \\
76 & 1,00 & 1,69 & 2,72 & 1,99 & 2,83 & 4,13 & 4,50 & 7,44 & 14,68 \\
88 & 1,00 & 1,77 & 3,03 & 2,03 & 3,17 & 4,63 & 4,86 & 7,71 & 14,72 \\
\hline média & 1,00 & 1,65 & 2,59 & 1,90 & 2,65 & 3,84 & 4,01 & 6,45 & 11,90 \\
\hline
\end{tabular}


Tabela 5.81 - Relações de G*/sen(ס) das misturas com SBS e TITAN com a mistura 100-00 para na condição envelhecida a longo prazo

\begin{tabular}{cccccccccc}
\hline $\begin{array}{c}\text { Temperatura } \\
\left({ }^{\mathbf{O}} \mathbf{C}\right)\end{array}$ & $\mathbf{1 0 0 - 0 - 0}$ & $\mathbf{9 9 - 0 - 1}$ & $\mathbf{9 8 - 0 - 2}$ & $\mathbf{9 7 , 5 - 2 , 5 - 0}$ & $\mathbf{9 6 , 5 - 2 , 5 - 1}$ & $\mathbf{9 5 , 5 - 2 , 5 - 2}$ & $\mathbf{9 5 - 5 - 0}$ & $\mathbf{9 4 - 5 - 1}$ & $\mathbf{9 3 - 5 - 2}$ \\
\hline 52 & 1,00 & 1,39 & 1,79 & 1,66 & 2,26 & 2,88 & 2,56 & 3,55 & 5,03 \\
64 & 1,00 & 1,39 & 1,85 & 1,98 & 2,78 & 3,76 & 3,62 & 5,04 & 7,56 \\
76 & 1,00 & 1,49 & 1,97 & 2,13 & 3,12 & 4,41 & 4,63 & 6,53 & 10,52 \\
88 & 1,00 & 1,61 & 2,28 & 2,19 & 3,32 & 4,52 & 5,12 & 7,00 & 11,34 \\
\hline média & 1,00 & 1,47 & 1,97 & 1,99 & 2,87 & 3,89 & 3,98 & 5,53 & 8,61 \\
\hline
\end{tabular}

Observa-se, pela Tabela 5.82, que o maior incremento médio do parâmetro $G^{*} \cdot \operatorname{sen}(\delta)$ para a condição virgem se dá nas misturas com maiores teores de modificação. O maior incremento médio foi o da mistura 93-5-2 (3,28 vezes), seguido da mistura 95,5-2,5-2 (2,22 vezes). O menor incremento médio foi o da mistura 97,5-2,5-0 (1,17 vezes), seguido da mistura 99-0-1 (1,31 vezes). Observa-se, pela Tabela 5.83, que o maior incremento médio do parâmetro $\mathrm{G}^{*} \cdot \operatorname{sen}(\delta)$ para a condição envelhecida a curto prazo também se dá nas misturas com maiores teores de modificação. O maior incremento médio foi o da mistura 93-5-2 (2,05 vezes), seguido da mistura 95,5-2,5-2 (1,85 vezes). O menor incremento médio foi o da mistura 97,5-2,5-0 (1,16 vezes), seguido da mistura 95-5-0 (1,25 vezes). Observa-se, pela Tabela 5.84, que o maior incremento médio do parâmetro $G^{*} \cdot \operatorname{sen}(\delta)$ para a condição envelhecida a longo prazo, tal como nas demais condições de envelhecimento, se dá nas misturas com maiores teores de modificação. O maior incremento médio foi o da mistura 935-2 (1,61 vezes), seguido da mistura 96,5-2,5-1 (1,38 vezes). O menor incremento médio foi o da mistura 97,5-2,5-0 (1,13 vezes), seguido da mistura 95-5-0 (1,16 vezes).

Tabela 5.82 - Relações de G*.sen(ס) das misturas com SBS e TITAN com a mistura 100-00 na condição virgem

\begin{tabular}{cccccccccc}
\hline $\begin{array}{c}\text { Temperatura } \\
\left({ }^{\mathbf{o}} \mathbf{C}\right)\end{array}$ & $\mathbf{1 0 0 - 0 - 0}$ & $\mathbf{9 9 - 0 - 1}$ & $\mathbf{9 8 - 0 - 2}$ & $\mathbf{9 7 , 5 - 2 , 5 - 0}$ & $\mathbf{9 6 , 5 - 2 , 5 - 1}$ & $\mathbf{9 5 , 5 - 2 , 5 - 2}$ & $\mathbf{9 5 - 5 - 0}$ & $\mathbf{9 4 - 5 - 1}$ & $\mathbf{9 3 - 5 - 2}$ \\
\hline 4 & 1,00 & 1,14 & 1,15 & 0,95 & 0,99 & 1,00 & 0,89 & 0,92 & 1,16 \\
16 & 1,00 & 1,17 & 1,39 & 1,02 & 1,16 & 1,31 & 1,04 & 1,20 & 1,70 \\
28 & 1,00 & 1,32 & 2,05 & 1,23 & 1,54 & 2,30 & 1,53 & 1,89 & 3,43 \\
40 & 1,00 & 1,64 & 3,47 & 1,47 & 2,31 & 4,28 & 2,15 & 3,34 & 6,84 \\
\hline média & 1,00 & 1,31 & 2,02 & 1,17 & 1,50 & 2,22 & 1,40 & 1,84 & 3,28 \\
\hline
\end{tabular}


Tabela 5.83 - Relações de $G^{*} \cdot \operatorname{sen}(\delta)$ das misturas com SBS e TITAN com a mistura 100-00 na condição envelhecida a curto prazo

\begin{tabular}{cccccccccc}
\hline $\begin{array}{c}\text { Temperatura } \\
\left({ }^{\mathbf{}} \mathbf{C}\right)\end{array}$ & $\mathbf{1 0 0 - 0 - 0}$ & $\mathbf{9 9 - 0 - 1}$ & $\mathbf{9 8 - 0 - 2}$ & $\mathbf{9 7 , 5 - 2 , 5 - 0}$ & $\mathbf{9 6 , 5 - 2 , 5 - 1}$ & $\mathbf{9 5 , 5 - 2 , 5 - 2}$ & $\mathbf{9 5 - 5 - 0}$ & $\mathbf{9 4 - 5 - 1}$ & $\mathbf{9 3 - 5 - 2}$ \\
\hline 4 & 1,00 & 1,13 & 1,15 & 0,99 & 1,07 & 1,11 & 0,89 & 0,98 & 0,97 \\
16 & 1,00 & 1,18 & 1,29 & 1,10 & 1,21 & 1,32 & 1,06 & 1,21 & 1,28 \\
28 & 1,00 & 1,21 & 1,56 & 1,19 & 1,41 & 1,82 & 1,30 & 1,59 & 2,03 \\
40 & 1,00 & 1,55 & 2,51 & 1,37 & 2,04 & 3,14 & 1,74 & 2,58 & 3,90 \\
\hline média & 1,00 & 1,27 & 1,63 & 1,16 & 1,43 & 1,85 & 1,25 & 1,59 & 2,05 \\
\hline
\end{tabular}

Tabela 5.84 - Relações de $G^{*} \cdot \operatorname{sen}(\delta)$ das misturas com SBS e TITAN com a mistura 100-00 na condição envelhecida a longo prazo

\begin{tabular}{cccccccccc}
\hline $\begin{array}{c}\text { Temperatura } \\
\left({ }^{\mathbf{0}} \mathbf{C}\right)\end{array}$ & $\mathbf{1 0 0 - 0 - 0}$ & $\mathbf{9 9 - 0 - 1}$ & $\mathbf{9 8 - 0 - 2}$ & $\mathbf{9 7 , 5 - 2 , 5 - 0}$ & $\mathbf{9 6 , 5 - 2 , 5 - 1}$ & $\mathbf{9 5 , 5 - 2 , 5 - 2}$ & $\mathbf{9 5 - 5 - 0}$ & $\mathbf{9 4 - 5 - 1}$ & $\mathbf{9 3 - 5 - 2}$ \\
\hline 4 & 1,00 & 1,11 & 1,13 & 0,97 & 1,01 & 1,00 & 0,84 & 0,86 & 0,92 \\
16 & 1,00 & 1,14 & 1,19 & 1,05 & 1,14 & 1,10 & 0,98 & 1,04 & 1,13 \\
28 & 1,00 & 1,13 & 1,26 & 1,18 & 1,37 & 1,31 & 1,23 & 1,33 & 1,56 \\
40 & 1,00 & 1,33 & 1,85 & 1,33 & 2,01 & 2,08 & 1,60 & 2,00 & 2,83 \\
\hline média & 1,00 & 1,18 & 1,36 & 1,13 & 1,38 & 1,37 & 1,16 & 1,31 & 1,61 \\
\hline
\end{tabular}

Em termos de módulo complexo, percebe-se que ocorre diminuição dos incrementos de rigidez em função do nível de envelhecimento. O maior incremento médio (mistura 93-5-2) é de 9,42 vezes na condição virgem, de 6,54 vezes na condição envelhecida a curto prazo e 4,78 vezes para a condição envelhecida a longo prazo. Verifica-se uma diminuição de $50 \%$ entre o enrijecimento provocado pelo envelhecimento da condição virgem para a condição envelhecida a longo prazo. Isto mostra que, após o processo de envelhecimento, as misturas com altos teores de TITAN e SBS são menos suscetíveis aos processos de envelhecimento.

No que se refere ao ângulo de fase, percebe-se que ocorre diminuição entre as diferenças de delta em função do nível envelhecimento. A maior diferença média é de -19,48 graus na condição virgem. Para a condição envelhecida a curto prazo, a maior diferença média é de $-17,73$ graus e, para a condição envelhecida a longo prazo, é de -15,73 graus. Nota-se uma diminuição de 3,75 graus entre o material envelhecido no PAV e o material na condição virgem. Isso mostra que, após o processo de envelhecimento, as misturas com altos teores de TITAN e SBS sofrem uma perda maior do ângulo de fase, o que se reflete em misturas com maiores componentes elásticos do que viscosos, se comparado com a condição virgem. 
Em relação ao parâmetro $G^{*} / \operatorname{sen}(\delta)$, percebe-se que ocorre diminuição dos incrementos deste parâmetro com o envelhecimento. O maior incremento médio é de 16,53 vezes na condição virgem. Para a condição envelhecida a curto prazo, o maior incremento médio é de 11,90 vezes e, para a condição envelhecida a longo prazo, é de 8,61 vezes. Observa-se uma diminuição de $52 \%$ entre o enrijecimento provocado pelo envelhecimento a longo prazo e a condição virgem. Isso mostra que, após o processo de envelhecimento, as misturas com altos teores de TITAN e SBS são menos suscetíveis aos processos de envelhecimento.

Quanto ao parâmetro $\mathrm{G}^{*} \cdot \operatorname{sen}(\delta)$, percebe-se que ocorre diminuição dos incrementos deste parâmetro com o envelhecimento. O maior incremento médio é de 3,28 vezes na condição virgem. Para a condição envelhecida a curto prazo, o maior incremento médio é de 2,05 vezes e, para a condição envelhecida a longo prazo, é de 1,61 vezes. Verifica-se uma diminuição de $49 \%$ entre o enrijecimento provocado pelo envelhecimento a longo prazo e a condição virgem. Isso mostra que, após o processo de envelhecimento, as misturas com altos teores de TITAN e SBS são menos suscetíveis aos processos de envelhecimento.

\subsection{Análises simultâneas dos resultados}

A análise simultânea dos resultados das misturas foi realizada em termos da ordenação destes materiais para cada propriedade e parâmetro, assim como realizado por Domingos (2011). Esta ordenação consiste na atribuição de um valor numérico entre 1 e 9 , referente à classificação do ligante asfáltico em um "ranking" dos resultados de todos os materiais. A numeração foi efetuada dos resultados melhores para os piores, de modo que os resultados melhores receberam valores mais baixos e os resultados piores, valores mais elevados. É importante observar que a classificação dos resultados dos ligantes asfálticos como "melhores" e "piores" foi feita com base em determinadas características e que, caso outros pontos de vista (e, por consequência, outras características) sejam adotados na classificação, as ordenações serão consequentemente diferentes. Os melhores resultados correspondem às seguintes características:

a) maior temperatura do grau contínuo $\left(\mathrm{G}^{*} / \mathrm{sen}(\delta)=1 \mathrm{kPa}\right)$ - Tabela 5.1; 
b)menores viscosidades rotacionais na condição virgem nas temperaturas de 135 , $143,150,163$ e $177^{\circ} \mathrm{C}$ - Tabela 5.2;

c) menor incremento de viscosidade rotacional nas temperaturas de 135, 143, 150, 163 e $177^{\circ} \mathrm{C}$ - Tabela 5.4;

d)menores temperaturas de usinagem e compactação - Tabela 5.5;

e) menor perda de massa - Tabela 5.6;

f) maiores percentuais de recuperação $(\mathrm{R})$, para as misturas envelhecidas a curto prazo para a tensão de $3.200 \mathrm{~Pa}$, nas temperaturas de 64 e $70^{\circ} \mathrm{C}$ - Tabela 5.7;

g)menores valores de compliâncias não-recuperáveis $\left(\mathrm{J}_{\mathrm{nr}}\right)$, para as misturas envelhecidas a curto prazo para a tensão de $3.200 \mathrm{~Pa}$, nas temperaturas de $64 \mathrm{e}$ $70^{\circ} \mathrm{C}$ - Tabela 5.8;

h)menores diferenças de compliâncias $\left(\mathrm{J}_{\text {nr,diff }}\right)$ não-recuperáveis, para as misturas envelhecidas a curto prazo nas temperaturas de 64 e $70^{\circ} \mathrm{C}-$ Tabela 5.9;

i) maior comprimento da trinca na ruptura por fadiga (parâmetro $a_{f}$ ), para as misturas na condição envelhecida a longo prazo, na temperatura de $25^{\circ} \mathrm{C}$ - Tabela 5.11 ;

j) maiores vida de fadiga $\left(\mathrm{N}_{\mathrm{f}}\right)$ a 3 e $30 \%$ de deformação, para as misturas na condição envelhecida a longo prazo, na temperatura de $25^{\circ} \mathrm{C}$ - Tabela 5.12;

k) menores valores do parâmetro de fadiga $G^{*} \cdot \operatorname{sen}(\delta)$, para as misturas na condição envelhecida a longo prazo, nas temperaturas de $5,10,15,20,25,30$ e $35^{\circ} \mathrm{C}-$ Tabela 5.13;

1) relações topo/fundo de $G^{*}$ no ensaio de estabilidade à estocagem, obtidas das curvas-mestre, próximas a 1,00, para as frequências de $1 \mathrm{E}-5$ a $1 \mathrm{E}+5$ - Tabela 5.57

m)maiores reduções do ângulo de fase $(\delta)\left(\delta_{\text {mistura }}-\delta_{100-0-0}\right)$ nas três condições de envelhecimento (virgem, RTFOT, PAV), nas temperaturas de 4, 16, 28, 40, 52, 64,76 e $88^{\circ} \mathrm{C}$ - Tabelas de 5.76 a 5.78 ;

n) maiores incrementos de $\mathrm{G}^{*} / \operatorname{sen}(\delta)\left(\mathrm{G}^{*} / \operatorname{sen}(\delta)_{\text {mistura }} / \mathrm{G}^{*} / \operatorname{sen}(\delta)_{100-0-0}\right)$ na condição virgem e envelhecida a curto prazo, para as temperaturas de $52,64,76$ e $88^{\circ} \mathrm{C}-$ Tabelas de 5.79 a 5.81; 
o) menores incrementos de $G^{*} \cdot \operatorname{sen}(\delta)\left(G^{*} \cdot \operatorname{sen}(\delta)_{\text {mistura }} / G^{*} \cdot \operatorname{sen}(\delta)_{100-0-0}\right)$ na condição envelhecida a curto prazo e envelhecida a longo prazo, para as temperaturas de 4 , 16,28 e $40^{\circ} \mathrm{C}$ - Tabelas de 5.82 a 5.84 ;

p) menor sensibilidade ao envelhecimento a curto prazo $\left(\mathrm{G}^{*}{ }_{\mathrm{RTFOT}} / \mathrm{G}^{*}{ }_{\text {virgem }}\right)$ e a longo prazo $\left(\mathrm{G}^{*}{ }_{\mathrm{PAV}} / \mathrm{G}^{*}{ }_{\text {virgem }}\right)$, com base nos resultados de $\mathrm{G}^{*}$ nas temperaturas de 4,16 , $28,40,52,64,76$ e $88^{\circ} \mathrm{C}$ - Tabelas de 5.63 a 5.71 ;

q) maiores reduções do ângulo de fase $(\delta)$, na condição envelhecida a curto prazo $\left(\delta_{\mathrm{RTFOT}}-\delta_{\text {virgem }}\right)$ e na condição envelhecida a longo prazo $\left(\delta_{\mathrm{PAV}}-\delta_{\mathrm{virgem}}\right)$, nas temperaturas de $4,16,28,40,52,64,76$ e $88^{\circ} \mathrm{C}$ - Tabelas de 5.63 a 5.71;

r) maior sensibilidade ao envelhecimento a curto prazo com base nos resultados de $\mathrm{G}^{*} / \operatorname{sen}(\delta)\left(\mathrm{G}^{*} / \operatorname{sen}(\delta)_{\mathrm{RTFOT}} / \mathrm{G}^{*} / \operatorname{sen}(\delta)_{\text {virgem }}\right)$, para as temperaturas de $52,64,76 \mathrm{e}$ $88^{\circ} \mathrm{C}$ - Tabelas de 5.63 a 5.71 ;

s) menor sensibilidade ao envelhecimento a longo prazo com base nos resultados de $\mathrm{G}^{*} \cdot \operatorname{sen}(\delta)\left(\mathrm{G}^{*} \cdot \operatorname{sen}(\delta)_{\mathrm{PAV}} / \mathrm{G}^{*} \cdot \operatorname{sen}(\delta)_{\text {virgem }}\right)$, para as temperaturas de $4,16,28$ e $40^{\circ} \mathrm{C}$ - Tabelas de 5.63 a 5.71 ;

t) menor sensibilidade ao envelhecimento a curto prazo $\left(\mathrm{G}^{*}{ }_{\mathrm{RTFOT}} / \mathrm{G}^{*}{ }_{\text {virgem }}\right)$ e a longo prazo $\left(\mathrm{G}^{*}{ }_{\mathrm{PAV}} / \mathrm{G}^{*}{ }_{\text {virgem }}\right)$, com base nos resultados de $\mathrm{G}^{*}$, para as frequências de $1 \mathrm{E}$ 5 a $1 \mathrm{E}+5$ - Tabelas de 5.19 a 5.27 ;

u) maiores reduções do ângulo de fase $(\delta)$, na condição envelhecida a curto prazo $\left(\delta_{\mathrm{RTFOT}}-\delta_{\text {virgem }}\right)$ e na condição envelhecida a longo prazo $\left(\delta_{\mathrm{PAV}}-\delta_{\text {virgem }}\right)$, para as frequências de $1 \mathrm{E}-5$ a $1 \mathrm{E}+5$ - Tabelas de 5.30 a 5.38 .

A Tabela 5.85 apresenta as ordenações dos ligantes asfálticos para cada propriedade e parâmetro. Os resultados nulos ou inexistentes estão indicados com um traço horizontal (-), não sendo considerados nas ordenações dos ligantes asfálticos e nos cálculos das médias parciais e finais. A Tabela 5.86 apresenta a posição média das misturas para cada propriedade de interesse e a média final foi calculada atribuindo peso 1 para cada componente da média, ou seja, admitiu-se que todas as propriedades e índices constantes da tabela têm a mesma importância ou o mesmo peso sobre a média. Esta suposição pode não ser a mais adequada em todos os casos, já que podem existir condicionantes que podem ter pesos diferentes de outras. 
Tabela 5.85 - Ordenamento das misturas (continua)

\begin{tabular}{|c|c|c|c|c|c|c|c|c|c|c|}
\hline \multirow{2}{*}{$\begin{array}{c}\text { Propriedade } \\
\text { ou parâmetro }\end{array}$} & \multirow{2}{*}{$\begin{array}{c}\text { Temperatura } \\
\left({ }^{\circ} \mathrm{C}\right) \text { ou } \\
\text { relação }\end{array}$} & \multicolumn{9}{|c|}{ Misturas } \\
\hline & & $100-0-0$ & 99-0-1 & 98-0-2 & $97,5-2,5-0$ & $96,5-2,5-1$ & $95,5-2,5-2$ & 95-5-0 & $94-5-1$ & $93-5-2$ \\
\hline grau contínuo & - & 9 & 8 & 5 & 7 & 6 & 3 & 4 & 2 & 1 \\
\hline \multirow{5}{*}{$\begin{array}{l}\text { Viscosidade } \\
\text { Brookfield } \\
\text { virgem }\end{array}$} & 135 & 1 & 2 & 2 & 4 & 5 & 5 & 7 & 8 & 9 \\
\hline & 143 & 1 & 2 & 3 & 4 & 6 & 4 & 9 & 8 & 7 \\
\hline & 150 & 1 & 2 & 2 & 5 & 6 & 4 & 9 & 8 & 7 \\
\hline & 163 & 1 & 2 & 3 & 4 & 5 & 5 & 7 & 9 & 8 \\
\hline & 177 & 1 & 1 & 3 & 4 & 5 & 5 & 7 & 7 & 9 \\
\hline \multirow{5}{*}{$\begin{array}{l}\text { Incremento de } \\
\text { viscosidade }\end{array}$} & 135 & 5 & 3 & 6 & 3 & 7 & 8 & 9 & 2 & 1 \\
\hline & 143 & 8 & 6 & 7 & 1 & 5 & 3 & 8 & 2 & 4 \\
\hline & 150 & 7 & 3 & 8 & 1 & 3 & 5 & 5 & 2 & 9 \\
\hline & 163 & 8 & 9 & 3 & 1 & 6 & 6 & 4 & 1 & 5 \\
\hline & 177 & 8 & 8 & 7 & 1 & 4 & 4 & 2 & 2 & 6 \\
\hline $\begin{array}{l}\text { Temperatura de } \\
\text { usinagem }\end{array}$ & - & 1 & 2 & 2 & 4 & 5 & 5 & 7 & 8 & 8 \\
\hline $\begin{array}{l}\text { Temperatura de } \\
\text { compactação }\end{array}$ & - & 1 & 2 & 2 & 4 & 6 & 4 & 7 & 9 & 7 \\
\hline Perda de massa & - & 2 & 9 & 8 & 3 & 6 & 7 & 1 & 3 & 5 \\
\hline $\begin{array}{l}\text { Percentual de } \\
\text { recuperação }\end{array}$ & 64 & - & - & 6 & 7 & 5 & 4 & 3 & 2 & 1 \\
\hline $\begin{array}{l}\text { RTFOT a } \\
3.200 \mathrm{~Pa}\end{array}$ & 70 & - & - & - & - & 5 & 4 & 1 & 3 & 2 \\
\hline
\end{tabular}


Tabela 5.85 - Ordenamento das misturas (continuação)

\begin{tabular}{|c|c|c|c|c|c|c|c|c|c|c|}
\hline \multirow{2}{*}{$\begin{array}{c}\text { Propriedade } \\
\text { ou parâmetro }\end{array}$} & \multirow{2}{*}{$\begin{array}{c}\text { Temperatura } \\
\left({ }^{\circ} \mathrm{C}\right) \text { ou } \\
\text { relação }\end{array}$} & \multicolumn{9}{|c|}{ Misturas } \\
\hline & & 100-0-0 & 99-0-1 & $98-0-2$ & $97,5-2,5-0$ & $96,5-2,5-1$ & $95,5-2,5-2$ & 95-5-0 & 94-5-1 & $93-5-2$ \\
\hline $\begin{array}{l}\text { Compliância } \\
\text { não- } \\
\text { recuperável }\end{array}$ & 64 & 9 & 8 & 7 & 6 & 5 & 4 & 3 & 2 & 1 \\
\hline $\begin{array}{c}\text { RTFOT a } \\
3.200 \mathrm{~Pa} \\
\end{array}$ & 70 & - & 8 & 7 & 6 & 5 & 4 & 3 & 2 & 1 \\
\hline \multirow{2}{*}{ Jnr,diff } & 64 & 1 & 3 & 7 & 2 & 5 & 9 & 4 & 6 & 8 \\
\hline & 70 & - & 2 & 6 & 1 & 4 & 8 & 3 & 5 & 7 \\
\hline af & 25 & 9 & 8 & 6 & 7 & 5 & 4 & 3 & 2 & 1 \\
\hline \multirow{2}{*}{$\mathrm{Nf}$} & $3 \%$ & 9 & 7 & 8 & 5 & 6 & 3 & 2 & 4 & 1 \\
\hline & $30 \%$ & 1 & 2 & 7 & 3 & 5 & 8 & 4 & 9 & 6 \\
\hline \multirow{7}{*}{$\begin{array}{l}\mathrm{G}^{*} \cdot \operatorname{sen}(\delta) \text { na } \\
\text { condição } \\
\text { envelhecida a } \\
\text { longo prazo }\end{array}$} & 5 & 7 & 9 & 8 & 5 & 6 & 4 & 1 & 2 & 3 \\
\hline & 10 & 3 & 8 & 9 & 4 & 7 & 6 & 1 & 2 & 5 \\
\hline & 15 & 2 & 5 & 9 & 4 & 7 & 6 & 1 & 3 & 8 \\
\hline & 20 & 1 & 4 & 8 & 3 & 7 & 6 & 2 & 5 & 9 \\
\hline & 25 & 1 & 4 & 6 & 2 & 8 & 7 & 3 & 5 & 9 \\
\hline & 30 & 1 & 3 & 5 & 2 & 8 & 7 & 4 & 6 & 9 \\
\hline & 35 & 1 & 2 & 5 & 2 & 8 & 7 & 4 & 6 & 9 \\
\hline
\end{tabular}


Tabela 5.85 - Ordenamento das misturas (continuação)

\begin{tabular}{|c|c|c|c|c|c|c|c|c|c|c|}
\hline \multirow{2}{*}{$\begin{array}{l}\text { Propriedade ou } \\
\text { parâmetro }\end{array}$} & \multirow{2}{*}{$\begin{array}{c}\text { Temperatura } \\
\left({ }^{\circ} \mathrm{C}\right) \text { ou } \\
\text { relação }\end{array}$} & \multicolumn{9}{|c|}{ Misturas } \\
\hline & & $100-0-0$ & 99-0-1 & $98-0-2$ & $97,5-2,5-0$ & $96,5-2,5-1$ & $95,5-2,5-2$ & 95-5-0 & $94-5-1$ & $93-5-2$ \\
\hline \multirow{11}{*}{$\begin{array}{l}\text { Estabilidade à } \\
\text { estocagem } \\
\text { (topo/fundo) }\end{array}$} & $1,00 \mathrm{E}-05$ & 3 & 1 & 2 & 6 & 4 & 5 & 9 & 8 & 7 \\
\hline & $1,00 \mathrm{E}-04$ & 3 & 1 & 2 & 6 & 4 & 5 & 9 & 8 & 7 \\
\hline & $1,00 \mathrm{E}-03$ & 2 & 1 & 3 & 6 & 4 & 5 & 9 & 8 & 7 \\
\hline & $1,00 \mathrm{E}-02$ & 3 & 1 & 2 & 6 & 4 & 5 & 9 & 8 & 7 \\
\hline & $1,00 \mathrm{E}-01$ & 5 & 1 & 3 & 4 & 2 & 5 & 7 & 9 & 8 \\
\hline & $1,00 \mathrm{E}+00$ & 4 & 1 & 3 & 6 & 5 & 2 & 8 & 9 & 7 \\
\hline & $1,00 \mathrm{E}+01$ & 4 & 1 & 3 & 6 & 5 & 2 & 8 & 8 & 7 \\
\hline & $1,00 \mathrm{E}+02$ & 4 & 1 & 2 & 6 & 5 & 2 & 9 & 8 & 7 \\
\hline & $1,00 \mathrm{E}+03$ & 2 & 1 & 2 & 6 & 5 & 4 & 9 & 7 & 7 \\
\hline & $1,00 \mathrm{E}+04$ & 2 & 1 & 3 & 6 & 5 & 4 & 9 & 7 & 7 \\
\hline & $1,00 \mathrm{E}+05$ & 1 & 1 & 3 & 6 & 5 & 4 & 7 & 7 & 7 \\
\hline \multirow{8}{*}{$\begin{array}{c}\text { Delta virgem } \\
\text { (envelhecimento) }\end{array}$} & 4 & 9 & 8 & 6 & 7 & 5 & 2 & 4 & 3 & 1 \\
\hline & 16 & 9 & 8 & 4 & 7 & 6 & 2 & 5 & 3 & 1 \\
\hline & 28 & 9 & 8 & 5 & 7 & 6 & 2 & 4 & 3 & 1 \\
\hline & 40 & 9 & 8 & 6 & 7 & 5 & 3 & 4 & 2 & 1 \\
\hline & 52 & 9 & 8 & 6 & 7 & 5 & 4 & 3 & 2 & 1 \\
\hline & 64 & 9 & 8 & 6 & 7 & 5 & 4 & 3 & 2 & 1 \\
\hline & 76 & 9 & 8 & 5 & 7 & 6 & 3 & 4 & 2 & 1 \\
\hline & 88 & 9 & 8 & 4 & 7 & 6 & 3 & 5 & 2 & 1 \\
\hline
\end{tabular}


Tabela 5.85 - Ordenamento das misturas (continuação)

\begin{tabular}{|c|c|c|c|c|c|c|c|c|c|c|}
\hline \multirow{2}{*}{$\begin{array}{l}\text { Propriedade ou } \\
\text { parâmetro }\end{array}$} & \multirow{2}{*}{$\begin{array}{c}\text { Temperatura } \\
\left({ }^{\circ} \mathrm{C}\right) \text { ou } \\
\text { relação }\end{array}$} & \multicolumn{9}{|c|}{ Misturas } \\
\hline & & 100-0-0 & 99-0-1 & 98-0-2 & $97,5-2,5-0$ & $96,5-2,5-1$ & $95,5-2,5-2$ & 95-5-0 & 94-5-1 & 93-5-2 \\
\hline \multirow{8}{*}{$\begin{array}{c}\text { Delta RTFOT } \\
\text { (envelhecimento) }\end{array}$} & 4 & 9 & 8 & 6 & 7 & 5 & 3 & 4 & 2 & 1 \\
\hline & 16 & 9 & 8 & 4 & 7 & 6 & 2 & 5 & 3 & 1 \\
\hline & 28 & 9 & 8 & 5 & 7 & 6 & 2 & 4 & 3 & 1 \\
\hline & 40 & 9 & 8 & 6 & 7 & 5 & 2 & 4 & 3 & 1 \\
\hline & 52 & 9 & 8 & 7 & 6 & 5 & 4 & 3 & 2 & 1 \\
\hline & 64 & 9 & 8 & 7 & 6 & 5 & 4 & 3 & 2 & 1 \\
\hline & 76 & 9 & 8 & 6 & 7 & 5 & 3 & 4 & 2 & 1 \\
\hline & 88 & 9 & 7 & 5 & 8 & 6 & 3 & 4 & 2 & 1 \\
\hline \multirow{8}{*}{$\begin{array}{c}\text { Delta PAV } \\
\text { (envelhecimento) }\end{array}$} & 4 & 9 & 8 & 7 & 6 & 5 & 4 & 3 & 2 & 1 \\
\hline & 16 & 9 & 8 & 7 & 6 & 5 & 4 & 3 & 2 & 1 \\
\hline & 28 & 9 & 8 & 7 & 6 & 5 & 4 & 3 & 2 & 1 \\
\hline & 40 & 9 & 8 & 6 & 7 & 5 & 3 & 4 & 2 & 1 \\
\hline & 52 & 9 & 8 & 7 & 6 & 5 & 4 & 3 & 2 & 1 \\
\hline & 64 & 9 & 8 & 7 & 6 & 5 & 4 & 3 & 2 & 1 \\
\hline & 76 & 9 & 8 & 7 & 6 & 5 & 4 & 3 & 2 & 1 \\
\hline & 88 & 9 & 8 & 6 & 7 & 5 & 3 & 4 & 2 & 1 \\
\hline \multirow{4}{*}{$\begin{array}{c}\mathrm{G}^{*} / \operatorname{sen}(\delta) \text { na } \\
\text { condição virgem }\end{array}$} & 52 & 9 & 8 & 6 & 7 & 5 & 3 & 4 & 2 & 1 \\
\hline & 64 & 9 & 8 & 6 & 7 & 5 & 3 & 4 & 2 & 1 \\
\hline & 76 & 9 & 8 & 5 & 7 & 6 & 3 & 4 & 2 & 1 \\
\hline & 88 & 9 & 8 & 5 & 7 & 6 & 3 & 4 & 2 & 1 \\
\hline
\end{tabular}


Tabela 5.85 - Ordenamento das misturas (continuação)

\begin{tabular}{|c|c|c|c|c|c|c|c|c|c|c|}
\hline \multirow{2}{*}{$\begin{array}{c}\text { Propriedade } \\
\text { ou parâmetro }\end{array}$} & \multirow{2}{*}{$\begin{array}{c}\text { Temperatura } \\
\left({ }^{\circ} \mathrm{C}\right) \text { ou } \\
\text { relação }\end{array}$} & \multicolumn{9}{|c|}{ Misturas } \\
\hline & & 100-0-0 & 99-0-1 & 98-0-2 & $97,5-2,5-0$ & $96,5-2,5-1$ & $95,5-2,5-2$ & 95-5-0 & 94-5-1 & $93-5-2$ \\
\hline \multirow{4}{*}{$\begin{array}{l}\mathrm{G}^{*} / \mathrm{sen}(\delta) \text { na } \\
\text { condição } \\
\text { envelhecido a } \\
\text { curto prazo }\end{array}$} & 52 & 9 & 8 & 5 & 7 & 6 & 3 & 4 & 2 & 1 \\
\hline & 64 & 9 & 8 & 6 & 7 & 5 & 4 & 3 & 2 & 1 \\
\hline & 76 & 9 & 8 & 6 & 7 & 5 & 4 & 3 & 2 & 1 \\
\hline & 88 & 9 & 8 & 6 & 7 & 5 & 4 & 3 & 2 & 1 \\
\hline \multirow{4}{*}{$\begin{array}{c}\mathrm{G}^{*} \cdot \operatorname{sen}(\delta) \text { na } \\
\text { condição } \\
\text { envelhecido a } \\
\text { curto prazo }\end{array}$} & 4 & 5 & 8 & 9 & 4 & 6 & 7 & 1 & 3 & 2 \\
\hline & 16 & 1 & 4 & 8 & 3 & 6 & 9 & 2 & 5 & 7 \\
\hline & 28 & 1 & 3 & 6 & 2 & 5 & 8 & 4 & 7 & 9 \\
\hline & 40 & 1 & 3 & 6 & 2 & 5 & 8 & 4 & 7 & 9 \\
\hline \multirow{4}{*}{$\begin{array}{l}\mathrm{G}^{*} \cdot \operatorname{sen}(\delta) \text { na } \\
\text { condição } \\
\text { envelhecido a } \\
\text { longo prazo }\end{array}$} & 4 & 6 & 8 & 9 & 4 & 7 & 5 & 1 & 2 & 3 \\
\hline & 16 & 2 & 7 & 9 & 4 & 8 & 5 & 1 & 3 & 6 \\
\hline & 28 & 1 & 2 & 5 & 3 & 8 & 6 & 4 & 7 & 9 \\
\hline & 40 & 1 & 2 & 5 & 3 & 7 & 8 & 4 & 6 & 9 \\
\hline \multirow{8}{*}{$\begin{array}{c}\text { Sensibilidade } \\
\text { ao } \\
\text { envelhecimento } \\
\text { RTFOT/virgem } \\
\text { para G* }\end{array}$} & 4 & 5 & 4 & 2 & 6 & 8 & 9 & 3 & 7 & 1 \\
\hline & 16 & 5 & 7 & 2 & 9 & 8 & 3 & 6 & 4 & 1 \\
\hline & 28 & 9 & 6 & 2 & 8 & 7 & 3 & 5 & 4 & 1 \\
\hline & 40 & 9 & 8 & 2 & 7 & 6 & 3 & 5 & 4 & 1 \\
\hline & 52 & 9 & 7 & 4 & 8 & 2 & 1 & 5 & 6 & 3 \\
\hline & 64 & 8 & 7 & 3 & 9 & 2 & 1 & 5 & 6 & 4 \\
\hline & 76 & 8 & 7 & 2 & 9 & 4 & 1 & 5 & 6 & 3 \\
\hline & 88 & 9 & 7 & 3 & 8 & 4 & 1 & 6 & 5 & 2 \\
\hline
\end{tabular}


Tabela 5.85 - Ordenamento das misturas (continuação)

\begin{tabular}{|c|c|c|c|c|c|c|c|c|c|c|}
\hline \multirow{2}{*}{$\begin{array}{l}\text { Propriedade } \\
\text { ou parâmetro }\end{array}$} & \multirow{2}{*}{$\begin{array}{c}\text { Temperatura } \\
\left({ }^{\circ} \mathrm{C}\right) \text { ou } \\
\text { relação }\end{array}$} & \multicolumn{9}{|c|}{ Misturas } \\
\hline & & $100-0-0$ & 99-0-1 & 98-0-2 & $97,5-2,5-0$ & $96,5-2,5-1$ & $95,5-2,5-2$ & 95-5-0 & 94-5-1 & 93-5-2 \\
\hline \multirow{8}{*}{$\begin{array}{c}\text { Sensibilidade } \\
\text { ao } \\
\text { envelhecimento } \\
\text { RTFOT/virgem } \\
\text { para } \delta\end{array}$} & 4 & 2 & 1 & 7 & 3 & 4 & 9 & 6 & 5 & 8 \\
\hline & 16 & 2 & 1 & 7 & 3 & 4 & 8 & 5 & 6 & 9 \\
\hline & 28 & 1 & 2 & 5 & 3 & 4 & 7 & 6 & 8 & 9 \\
\hline & 40 & 2 & 1 & 3 & 7 & 4 & 5 & 8 & 9 & 6 \\
\hline & 52 & 3 & 2 & 7 & 1 & 4 & 8 & 9 & 5 & 6 \\
\hline & 64 & 7 & 4 & 9 & 1 & 5 & 6 & 8 & 3 & 2 \\
\hline & 76 & 4 & 3 & 9 & 7 & 6 & 8 & 5 & 1 & 2 \\
\hline & 88 & 2 & 1 & 8 & 9 & 6 & 5 & 4 & 3 & 7 \\
\hline \multirow{4}{*}{$\begin{array}{c}\text { Sensibilidade } \\
\text { ao } \\
\text { envelhecimento } \\
\text { RTFOT/virgem } \\
\text { para } G^{*} / \operatorname{sen}(\delta) \\
\end{array}$} & 52 & 1 & 3 & 6 & 2 & 8 & 9 & 5 & 4 & 7 \\
\hline & 64 & 2 & 3 & 7 & 1 & 8 & 9 & 5 & 4 & 6 \\
\hline & 76 & 2 & 3 & 8 & 1 & 6 & 9 & 5 & 4 & 7 \\
\hline & 88 & 1 & 2 & 7 & 3 & 6 & 9 & 4 & 5 & 8 \\
\hline \multirow{8}{*}{$\begin{array}{c}\text { Sensibilidade } \\
\text { ao } \\
\text { envelhecimento } \\
\text { PAV/virgem } \\
\text { para G* }\end{array}$} & 4 & 8 & 6 & 2 & 9 & 7 & 4 & 5 & 3 & 1 \\
\hline & 16 & 8 & 6 & 3 & 9 & 7 & 2 & 5 & 4 & 1 \\
\hline & 28 & 9 & 6 & 3 & 8 & 7 & 2 & 5 & 4 & 1 \\
\hline & 40 & 9 & 6 & 3 & 8 & 7 & 2 & 5 & 4 & 1 \\
\hline & 52 & 9 & 7 & 3 & 8 & 4 & 2 & 6 & 5 & 1 \\
\hline & 64 & 8 & 7 & 2 & 9 & 6 & 3 & 5 & 4 & 1 \\
\hline & 76 & 8 & 6 & 1 & 9 & 5 & 3 & 7 & 4 & 2 \\
\hline & 88 & 8 & 6 & 2 & 9 & 5 & 3 & 7 & 4 & 1 \\
\hline
\end{tabular}


Tabela 5.85 - Ordenamento das misturas (continuação)

\begin{tabular}{|c|c|c|c|c|c|c|c|c|c|c|}
\hline \multirow{2}{*}{$\begin{array}{l}\text { Propriedade } \\
\text { ou parâmetro }\end{array}$} & \multirow{2}{*}{$\begin{array}{c}\text { Temperatura } \\
\left({ }^{\circ} \mathrm{C}\right) \text { ou } \\
\text { relação }\end{array}$} & \multicolumn{9}{|c|}{ Misturas } \\
\hline & & $100-0-0$ & 99-0-1 & 98-0-2 & $97,5-2,5-0$ & $96,5-2,5-1$ & $95,5-2,5-2$ & 95-5-0 & 94-5-1 & $93-5-2$ \\
\hline \multirow{8}{*}{$\begin{array}{c}\text { Sensibilidade } \\
\text { ao } \\
\text { envelhecimento } \\
\text { PAV/virgem } \\
\text { para } \delta\end{array}$} & 4 & 1 & 3 & 7 & 2 & 6 & 8 & 4 & 5 & 9 \\
\hline & 16 & 1 & 3 & 7 & 2 & 5 & 8 & 4 & 6 & 9 \\
\hline & 28 & 1 & 3 & 7 & 2 & 4 & 9 & 5 & 6 & 8 \\
\hline & 40 & 1 & 2 & 4 & 5 & 3 & 6 & 8 & 9 & 7 \\
\hline & 52 & 2 & 3 & 5 & 1 & 4 & 6 & 7 & 8 & 9 \\
\hline & 64 & 7 & 6 & 9 & 1 & 2 & 3 & 4 & 5 & 8 \\
\hline & 76 & 7 & 8 & 9 & 5 & 3 & 4 & 1 & 2 & 6 \\
\hline & 88 & 6 & 7 & 9 & 8 & 3 & 4 & 1 & 2 & 5 \\
\hline \multirow{4}{*}{$\begin{array}{c}\text { Sensibilidade } \\
\text { ao } \\
\text { envelhecimento } \\
\text { PAV/virgem } \\
\text { para G*.sen }(\delta)\end{array}$} & 4 & 7 & 4 & 5 & 9 & 8 & 6 & 3 & 2 & 1 \\
\hline & 16 & 8 & 6 & 3 & 9 & 7 & 2 & 5 & 4 & 1 \\
\hline & 28 & 9 & 6 & 3 & 8 & 7 & 2 & 5 & 4 & 1 \\
\hline & 40 & 9 & 6 & 3 & 8 & 7 & 2 & 5 & 4 & 1 \\
\hline \multirow{11}{*}{$\begin{array}{c}\text { Sensibilidade } \\
\text { ao } \\
\text { envelhecimento } \\
\text { RTFOT/virgem } \\
\text { para G* }\end{array}$} & $1,00 \mathrm{E}-05$ & 7 & 9 & 1 & 8 & 6 & 3 & 5 & 4 & 2 \\
\hline & $1,00 \mathrm{E}-04$ & 6 & 8 & 2 & 9 & 7 & 4 & 5 & 3 & 1 \\
\hline & $1,00 \mathrm{E}-03$ & 6 & 8 & 3 & 9 & 7 & 4 & 5 & 2 & 1 \\
\hline & $1,00 \mathrm{E}-02$ & 7 & 9 & 4 & 8 & 6 & 2 & 5 & 3 & 1 \\
\hline & $1,00 \mathrm{E}-01$ & 9 & 8 & 3 & 6 & 7 & 4 & 5 & 2 & 1 \\
\hline & $1,00 \mathrm{E}+00$ & 9 & 8 & 2 & 6 & 7 & 3 & 5 & 4 & 1 \\
\hline & $1,00 \mathrm{E}+01$ & 8 & 7 & 2 & 9 & 6 & 3 & 5 & 4 & 1 \\
\hline & $1,00 \mathrm{E}+02$ & 9 & 7 & 2 & 8 & 6 & 4 & 5 & 3 & 1 \\
\hline & $1,00 \mathrm{E}+03$ & 7 & 5 & 2 & 9 & 8 & 4 & 6 & 3 & 1 \\
\hline & $1,00 \mathrm{E}+04$ & 5 & 3 & 2 & 9 & 7 & 8 & 6 & 4 & 1 \\
\hline & $1,00 \mathrm{E}+05$ & 4 & 3 & 2 & 8 & 7 & 9 & 6 & 5 & 1 \\
\hline
\end{tabular}


Tabela 5.85 - Ordenamento das misturas (continuação)

\begin{tabular}{|c|c|c|c|c|c|c|c|c|c|c|}
\hline \multirow{2}{*}{$\begin{array}{l}\text { Propriedade } \\
\text { ou parâmetro }\end{array}$} & \multirow{2}{*}{$\begin{array}{c}\text { Temperatura } \\
\left({ }^{\circ} \mathrm{C}\right) \text { ou } \\
\text { relação }\end{array}$} & \multicolumn{9}{|c|}{ Misturas } \\
\hline & & 100-0-0 & 99-0-1 & 98-0-2 & $97,5-2,5-0$ & $96,5-2,5-1$ & $95,5-2,5-2$ & 95-5-0 & 94-5-1 & $93-5-2$ \\
\hline \multirow{11}{*}{$\begin{array}{l}\text { Sensibilidade } \\
\text { ao } \\
\text { envelhecimento } \\
\text { RTFOT/virgem } \\
\text { para } \delta\end{array}$} & $1,00 \mathrm{E}-05$ & 5 & 4 & 2 & - & 1 & 3 & 7 & 6 & - \\
\hline & $1,00 \mathrm{E}-04$ & 6 & 5 & 3 & 4 & 1 & 2 & 8 & 7 & - \\
\hline & $1,00 \mathrm{E}-03$ & 1 & 4 & 5 & 2 & 3 & 8 & 6 & 7 & - \\
\hline & $1,00 \mathrm{E}-02$ & 4 & 2 & 3 & 1 & 5 & 6 & 7 & 8 & - \\
\hline & $1,00 \mathrm{E}-01$ & 3 & 2 & 4 & 5 & 6 & 7 & 8 & 9 & 1 \\
\hline & $1,00 \mathrm{E}+00$ & 1 & 7 & 2 & 4 & 3 & 5 & 8 & 9 & 6 \\
\hline & $1,00 \mathrm{E}+01$ & 3 & 7 & 5 & 4 & 1 & 6 & 8 & 9 & 2 \\
\hline & $1,00 \mathrm{E}+02$ & 5 & 7 & 4 & 3 & 1 & 6 & 8 & 9 & 2 \\
\hline & $1,00 \mathrm{E}+03$ & 4 & 7 & 5 & 3 & 1 & 6 & 8 & 9 & 2 \\
\hline & $1,00 \mathrm{E}+04$ & 6 & 8 & 4 & 3 & 1 & 5 & 7 & 9 & 2 \\
\hline & $1,00 \mathrm{E}+05$ & 6 & 8 & 4 & 3 & 2 & 5 & 7 & 9 & 1 \\
\hline \multirow{11}{*}{$\begin{array}{c}\text { Sensibilidade } \\
\text { ao } \\
\text { envelhecimento } \\
\text { PAV/virgem } \\
\text { para G* }\end{array}$} & $1,00 \mathrm{E}-05$ & 8 & 6 & 1 & 9 & 7 & 3 & 5 & 4 & 2 \\
\hline & $1,00 \mathrm{E}-04$ & 7 & 6 & 4 & 9 & 8 & 3 & 5 & 2 & 1 \\
\hline & $1,00 \mathrm{E}-03$ & 8 & 6 & 4 & 9 & 7 & 2 & 5 & 3 & 1 \\
\hline & $1,00 \mathrm{E}-02$ & 9 & 8 & 4 & 7 & 6 & 2 & 5 & 3 & 1 \\
\hline & $1,00 \mathrm{E}-01$ & 9 & 7 & 4 & 8 & 6 & 2 & 5 & 3 & 1 \\
\hline & $1,00 \mathrm{E}+00$ & 8 & 6 & 3 & 9 & 7 & 2 & 5 & 4 & 1 \\
\hline & $1,00 \mathrm{E}+01$ & 8 & 5 & 3 & 9 & 6 & 2 & 7 & 4 & 1 \\
\hline & $1,00 \mathrm{E}+02$ & 8 & 5 & 3 & 9 & 7 & 2 & 6 & 4 & 1 \\
\hline & $1,00 \mathrm{E}+03$ & 8 & 5 & 3 & 9 & 7 & 2 & 6 & 4 & 1 \\
\hline & $1,00 \mathrm{E}+04$ & 8 & 5 & 3 & 9 & 7 & 2 & 6 & 4 & 1 \\
\hline & $1,00 \mathrm{E}+05$ & 7 & 5 & 4 & 9 & 8 & 3 & 6 & 2 & 1 \\
\hline
\end{tabular}


Tabela 5.85 - Ordenamento das misturas (continuação)

\begin{tabular}{ccccccccccc}
\hline \multirow{2}{*}{$\begin{array}{c}\text { Propriedade } \\
\text { ou parâmetro }\end{array}$} & $\begin{array}{c}\text { Temperatura } \\
\left({ }^{\mathbf{0}} \mathbf{C}\right) \text { ou } \\
\text { relação }\end{array}$ & $\mathbf{1 0 0 - 0 - 0}$ & $\mathbf{9 9 - 0 - 1}$ & $\mathbf{9 8 - 0 - 2}$ & $\mathbf{9 7 , 5 - 2 , 5 - 0}$ & $\mathbf{9 6 , 5 - 2 , 5 - 1}$ & $\mathbf{9 5 , 5 - 2 , 5 - 2}$ & $\mathbf{9 5 - 5 - 0}$ & $\mathbf{9 4 - 5 - 1}$ & $\mathbf{9 3 - 5 - 2}$ \\
\cline { 3 - 10 } & $1,00 \mathrm{E}-05$ & 7 & 5 & 4 & - & 2 & 3 & 1 & 6 & - \\
& $1,00 \mathrm{E}-04$ & 7 & 6 & 4 & 3 & 2 & 5 & 1 & 8 & - \\
& $1,00 \mathrm{E}-03$ & 2 & 5 & 6 & 1 & 4 & 7 & 3 & 8 & - \\
& $1,00 \mathrm{E}-02$ & 3 & 2 & 4 & 1 & 5 & 6 & 7 & 8 & - \\
Sensibilidade & $1,00 \mathrm{E}-01$ & 2 & 1 & 6 & 4 & 5 & 7 & 8 & 9 & 3 \\
ao & $1,00 \mathrm{E}+00$ & 1 & 3 & 6 & 2 & 4 & 7 & 5 & 9 & 8 \\
envelhecimento & $1,00 \mathrm{E}+01$ & 3 & 4 & 8 & 2 & 1 & 6 & 7 & 9 & 5 \\
PAV/virgem & $1,00 \mathrm{E}+02$ & 3 & 5 & 8 & 1 & 2 & 6 & 7 & 9 & 4 \\
para $\delta$ & $1,00 \mathrm{E}+03$ & 4 & 6 & 8 & 1 & 2 & 5 & 7 & 9 & 3 \\
& $1,00 \mathrm{E}+04$ & 4 & 7 & 8 & 1 & 2 & 5 & 6 & 9 & 3 \\
& $1,00 \mathrm{E}+05$ & 5 & 8 & 6 & 1 & 2 & 4 & 7 & 9 \\
\hline
\end{tabular}


Tabela 5.86 - Posições medias das misturas por requisites de interesse (continua)

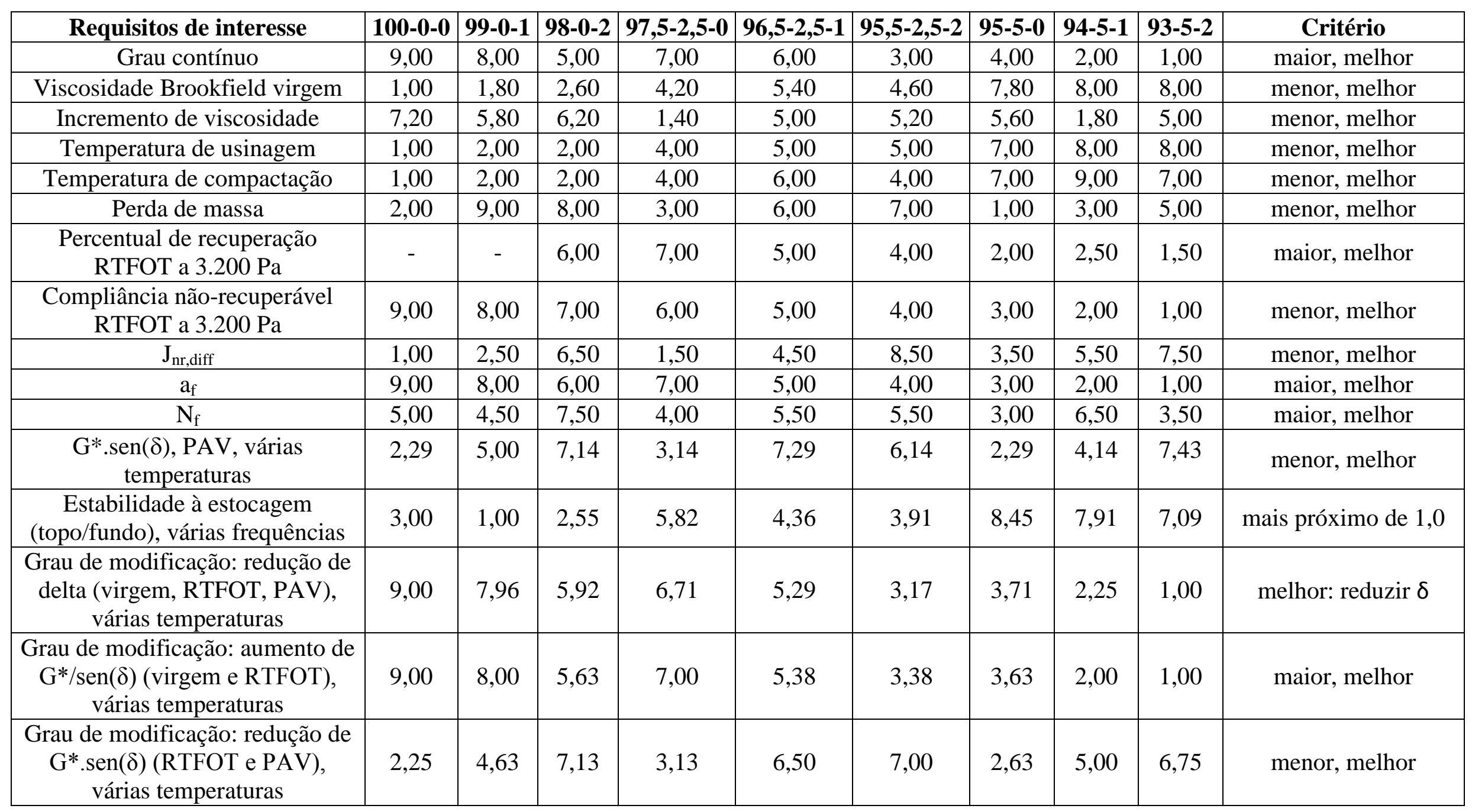


Tabela 5.86 - Posições medias das misturas por requisites de interesse (continuação)

\begin{tabular}{|c|c|c|c|c|c|c|c|c|c|c|}
\hline Requisitos de interesse & 100-0-0 & 99-0-1 & 98-0-2 & $97,5-2,5-0$ & $96,5-2,5-1$ & 95,5-2,5-2 & 95-5-0 & 94-5-1 & 93-5-2 & Critério \\
\hline $\begin{array}{l}\text { Sensibilidade ao envelhecimento } \\
\text { a curto prazo }\left(\mathrm{G}^{*}, \delta \text { e } \mathrm{G}^{*} / \mathrm{sen}(\delta)\right) \text {, } \\
\text { várias temperaturas }\end{array}$ & 4,55 & 3,95 & 5,15 & 5,25 & 5,30 & 5,70 & 5,50 & 4,95 & 4,65 & $\begin{array}{l}\text { pior: aumentar } \mathrm{G}^{*} ; \\
\text { melhor: reduzir } \delta \text { e } \\
\text { aumentar } \mathrm{G}^{*} / \operatorname{sen}(\delta)\end{array}$ \\
\hline $\begin{array}{c}\text { Sensibilidade ao envelhecimento } \\
\text { a curto prazo a } 25^{\circ} \mathrm{C}\left(\mathrm{G}^{*} \mathrm{e} \delta\right), \\
\text { várias frequências }\end{array}$ & 5,50 & 6,18 & 3,00 & 5,76 & 4,50 & 4,86 & 6,36 & 5,82 & 1,56 & $\begin{array}{l}\text { pior: aumentar } \mathrm{G}^{*} ; \\
\text { melhor: reduzir } \delta\end{array}$ \\
\hline $\begin{array}{c}\text { Sensibilidade ao envelhecimento } \\
\text { a longo prazo a } 25^{\circ} \mathrm{C}\left(\mathrm{G}^{*} \mathrm{e} \delta\right), \\
\text { várias frequências }\end{array}$ & 5,86 & 5,27 & 4,73 & 5,38 & 4,86 & 3,91 & 5,45 & 5,91 & 2,28 & $\begin{array}{l}\text { pior: aumentar } \mathrm{G}^{*} \\
\text { melhor: reduzir } \delta\end{array}$ \\
\hline Média final & 4,89 & 5,21 & 5,23 & 4,89 & 5,36 & 4,85 & 4,49 & 4,64 & 4,20 & somatório das colunas \\
\hline
\end{tabular}


As médias finais foram calculadas pela média aritmética simples de todas as ordenações recebidas pelos ligantes asfálticos. A mistura 93-5-2 (4,20) e a mistura 95-5-0 (4,49) possuem as menores médias finais e, portanto, os melhores resultados em um contexto geral. A mistura 96,5-2,5-1 (5,36) e a mistura 98-0-2 (5,23) possuem as maiores médias finais e, portanto, os piores resultados em um contexto geral. Chama a atenção que a diferença entre as posições médias da primeira e da última misturas é pequena, indicando que a única mistura que se destaca ligeiramente das demais é a 93-5-2, na quarta posição, ao passo que todas as demais ocupam a quinta posição.

Embora a adoção de pesos iguais não seja completamente adequada, é preciso reconhecer também que a adoção de pesos distintos pode envolver outras complexidades que podem tornar a análise inviável do ponto de vista prático, parecendo razoável assumi-los como iguais em primeira instância. Para uma análise mais refinada, pesos distintos poderiam ser atribuídos a determinadas propriedades ou grupos de propriedades, como, por exemplo, o grau contínuo ou propriedades combinadas para produzir índices de envelhecimento. Dependendo da propriedade de interesse, os resultados pontuais daquela propriedade devem ser avaliados para escolher a melhor mistura a ser utilizada. Com base neste raciocínio, uma maneira prática seria agrupar os requisitos de interesse nas seguintes 8 categorias:

- sensibilidade ao envelhecimento a curto prazo (incremento de viscosidade, perda de massa e sensibilidade ao envelhecimento a curto prazo nas várias temperaturas e frequências);

- sensibilidade ao envelhecimento a longo prazo (sensibilidade ao envelhecimento a longo prazo nas várias temperaturas e frequências);

- grau de modificação (grau de modificação com base nos valores de $\delta, \mathrm{G}^{*} / \operatorname{sen}(\delta)$ e $\left.\mathrm{G}^{*} \cdot \operatorname{sen}(\delta)\right)$

- maior trabalhabilidade (viscosidade na condição virgem e temperaturas de usinagem e compactação);

- grau contínuo (grau contínuo);

- estabilidade à estocagem (estabilidade à estocagem nas várias frequências);

- contribuição à resistência a deformação permanente (percentual de recuperação a 3.200 Pa, compliância não-recuperável a 3.200 Pa e $\mathrm{J}_{\mathrm{nr} \text {,diff }}$ - a 64 e a $70^{\circ} \mathrm{C}$ ); 
- contribuição à resistência a fadiga (vida de fadiga e parâmetro $\mathrm{a}_{\mathrm{f}}$, ambos a $25^{\circ} \mathrm{C}, \mathrm{e}$ $\mathrm{G}^{*} \cdot \operatorname{sen}(\delta)$ nas várias temperaturas).

As Figuras 5.98 a 5.105 apresentam os valores médios das posições conforme os ordenamentos nestas oito categorias. A Figura 5.98 apresenta a posição média dos ordenamentos da sensibilidade ao envelhecimento a curto prazo. A Figura 5.99 apresenta a posição média dos ordenamentos da sensibilidade ao envelhecimento a longo prazo. A Figura 5.100 apresenta a posição média dos ordenamentos do grau de modificação. A Figura 5.101 apresenta a posição média dos ordenamentos das misturas com maior trabalhabilidade. A Figura 5.102 apresenta a posição média dos ordenamentos do grau contínuo. A Figura 5.103 apresenta a posição média dos ordenamentos da estabilidade à estocagem. A Figura 5.104 apresenta a posição média dos ordenamentos quanto à contribuição à resistência à deformação permanente. A Figura 5.105 apresenta a posição média dos ordenamentos quanto à contribuição à resistência à fadiga.

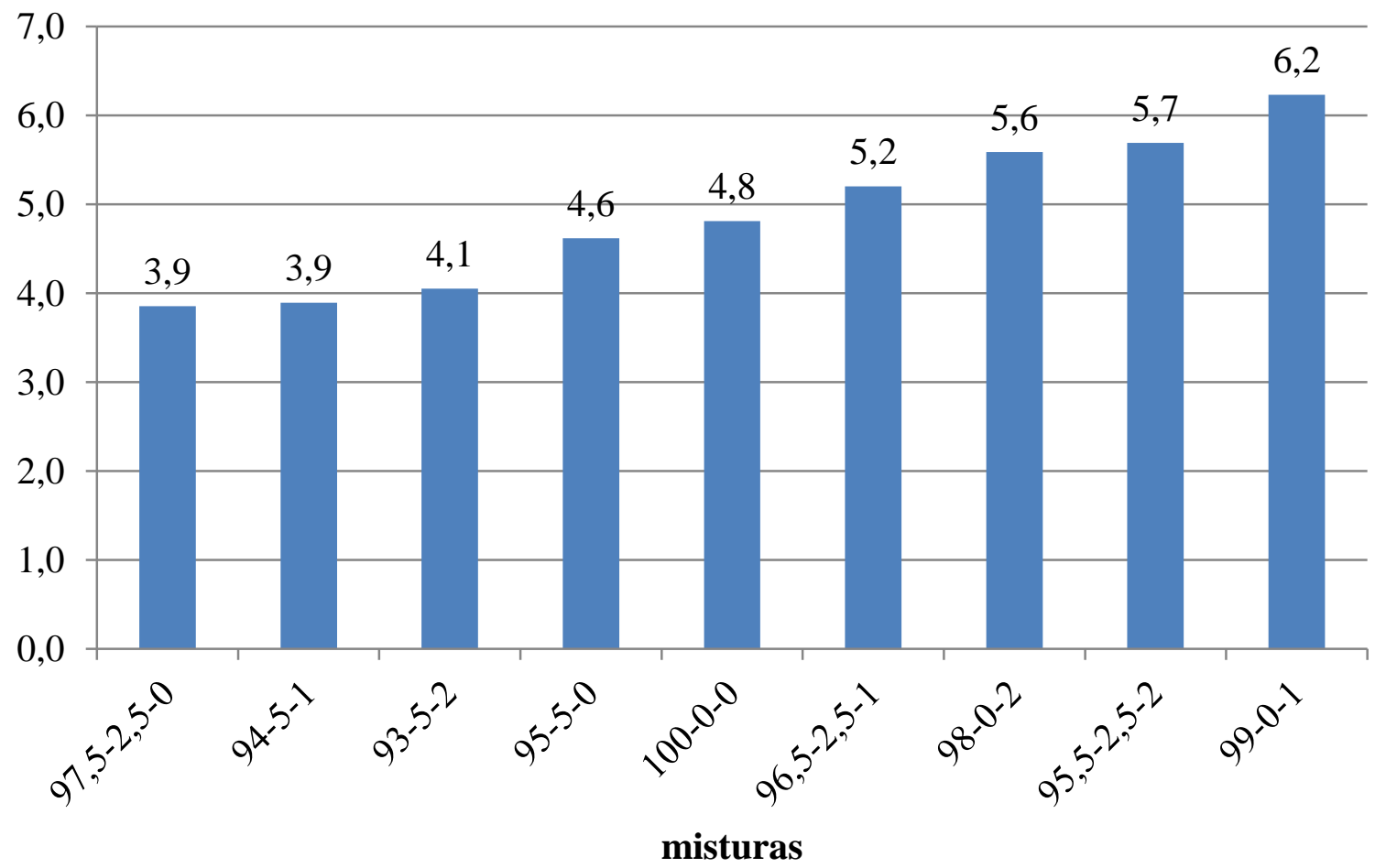

Figura 5.98 - Posição média dos ordenamentos da sensibilidade ao envelhecimento a curto prazo 


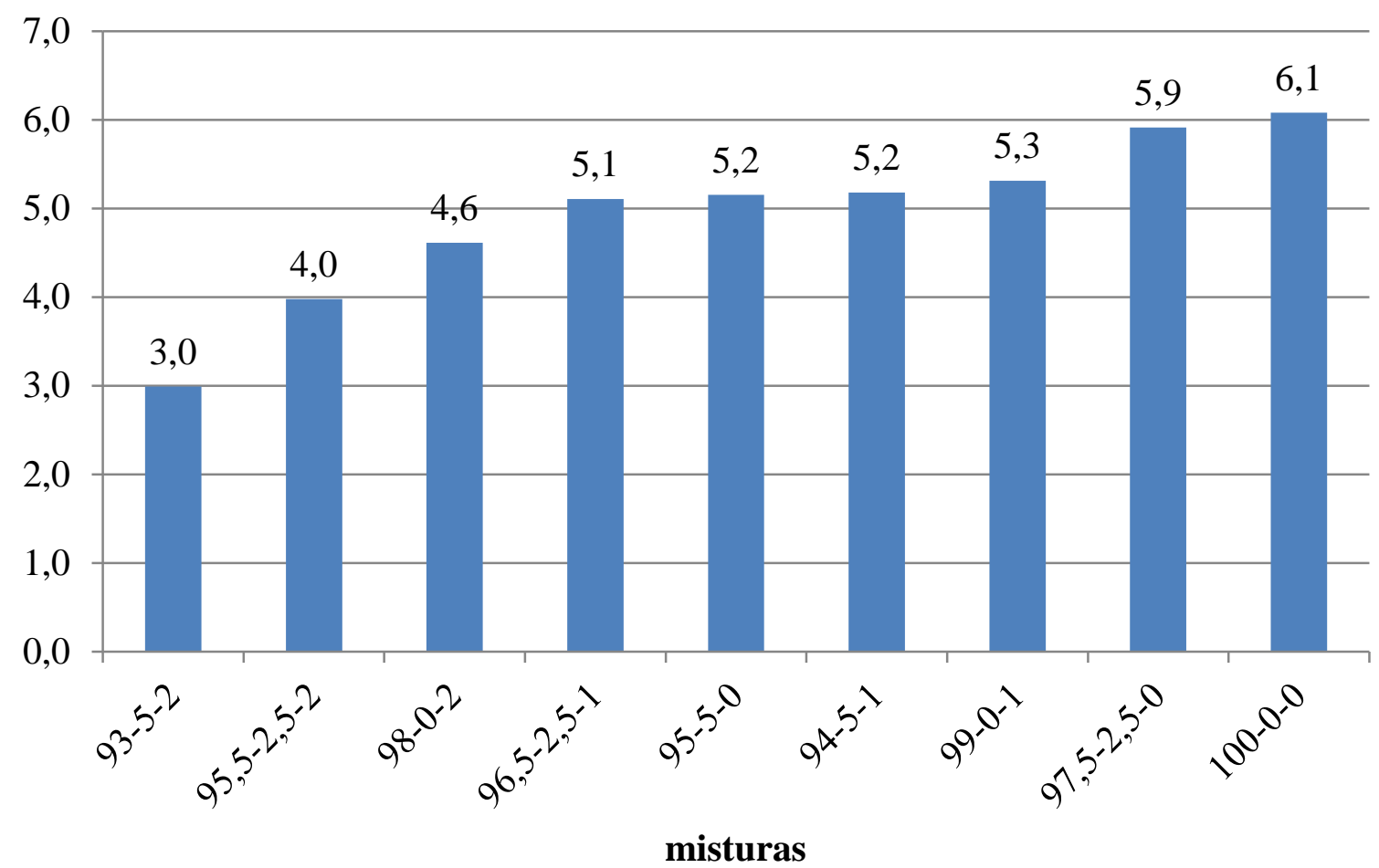

Figura 5.99 - Posição média dos ordenamentos da sensibilidade ao envelhecimento a longo prazo

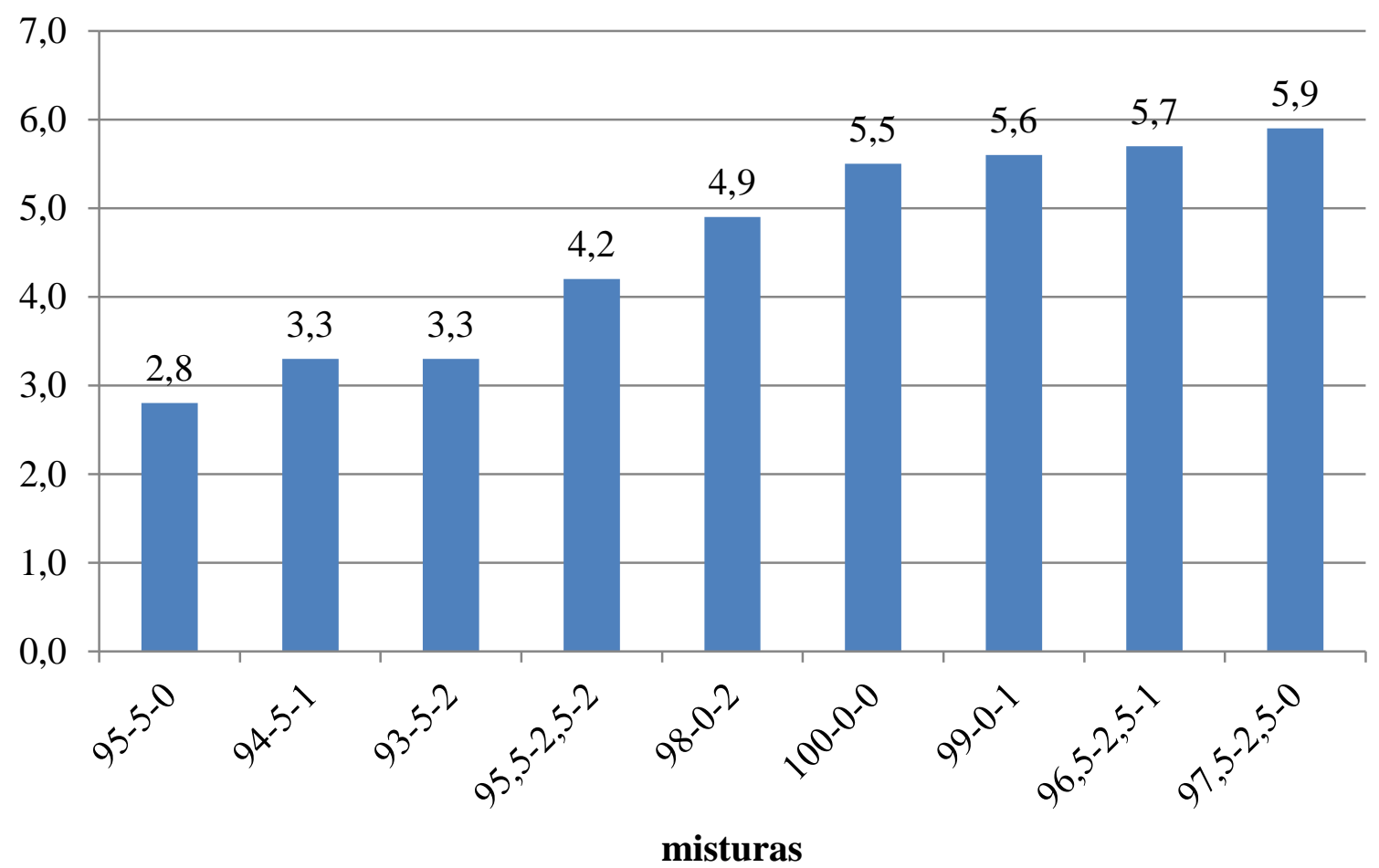

Figura 5.100 - Posição média dos ordenamentos do grau de modificação 


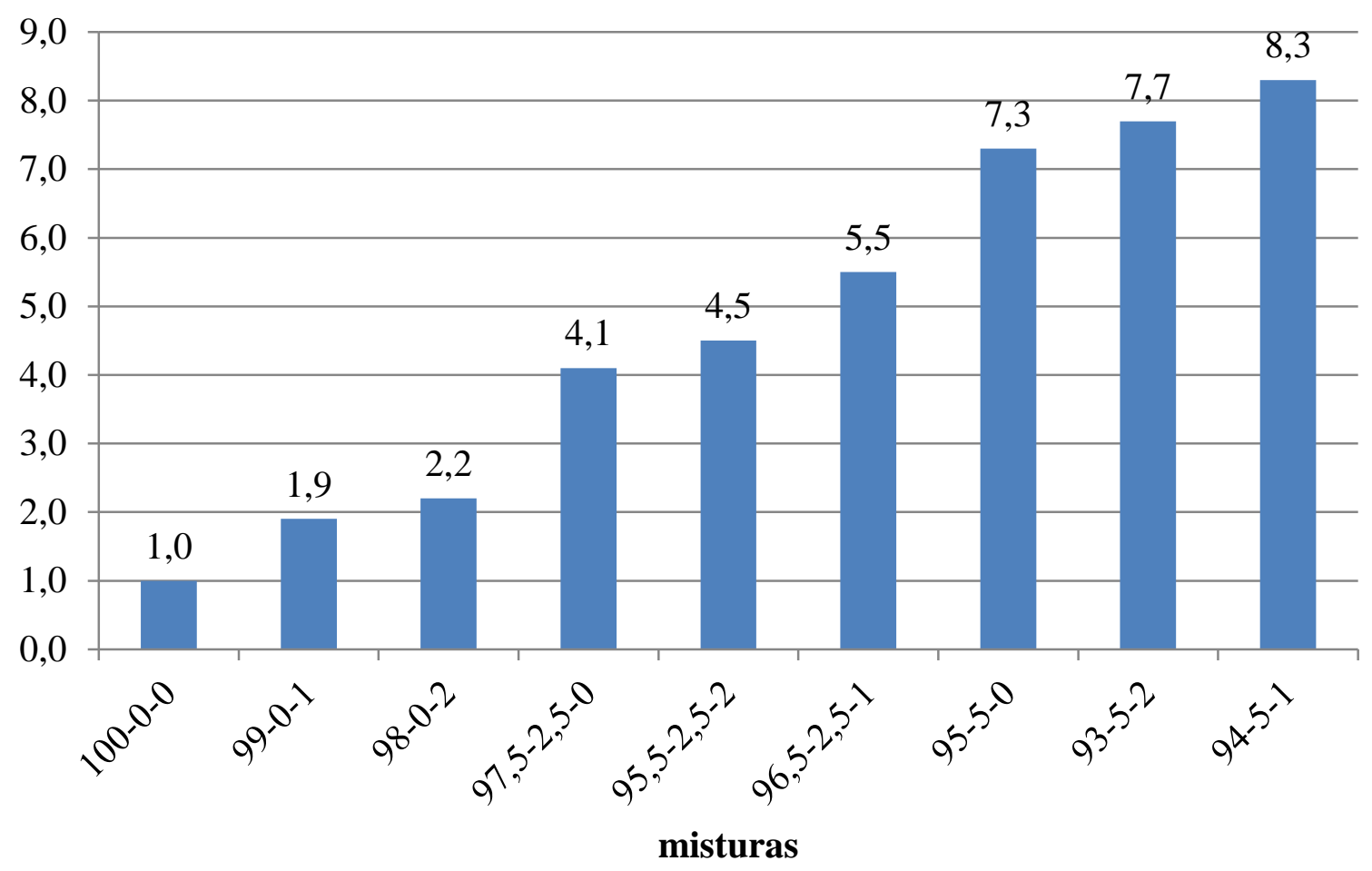

Figura 5.101 - Posição média dos ordenamentos das misturas com maior trabalhabilidade

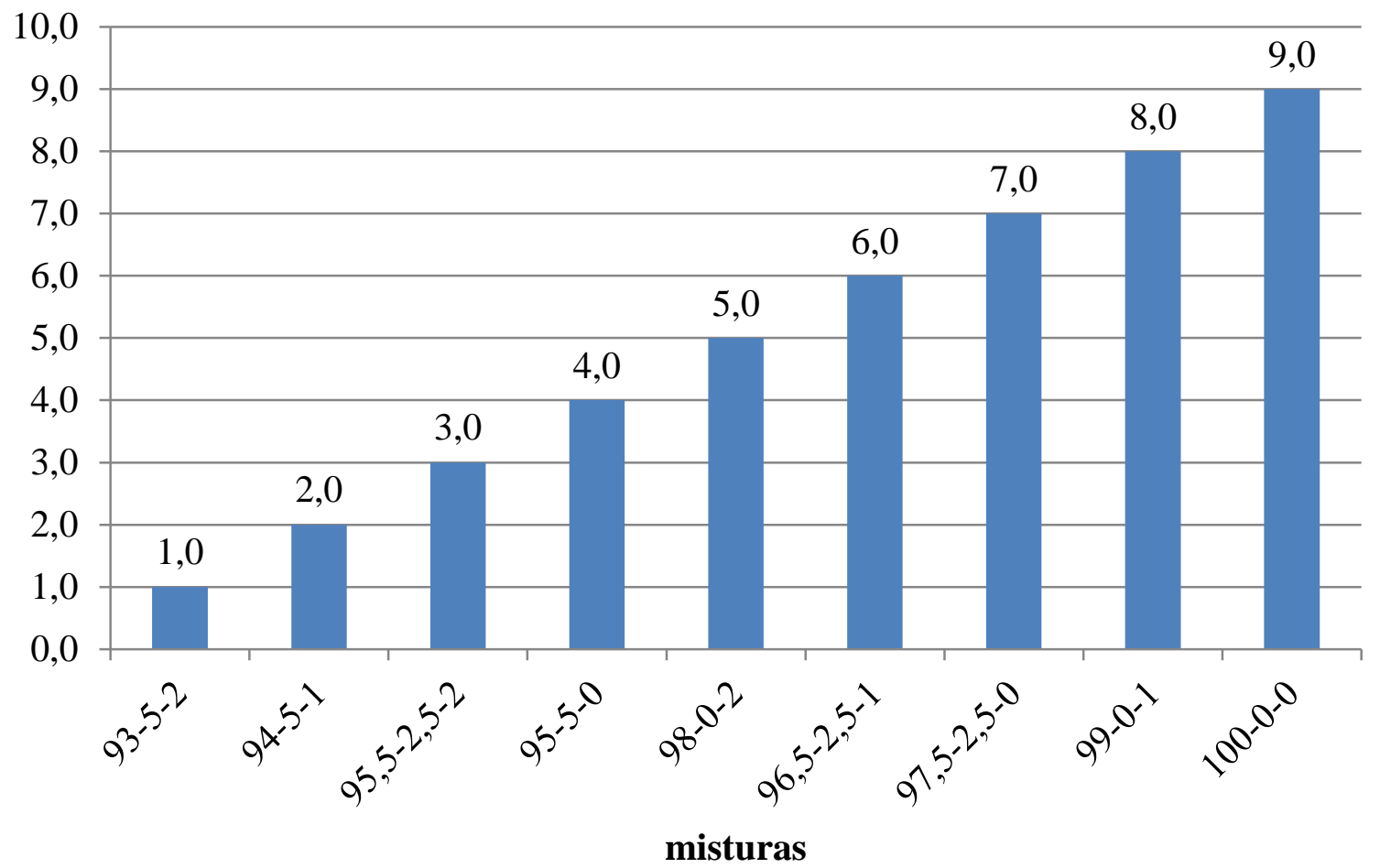

Figura 5.102 - Posição média dos ordenamentos do grau contínuo 


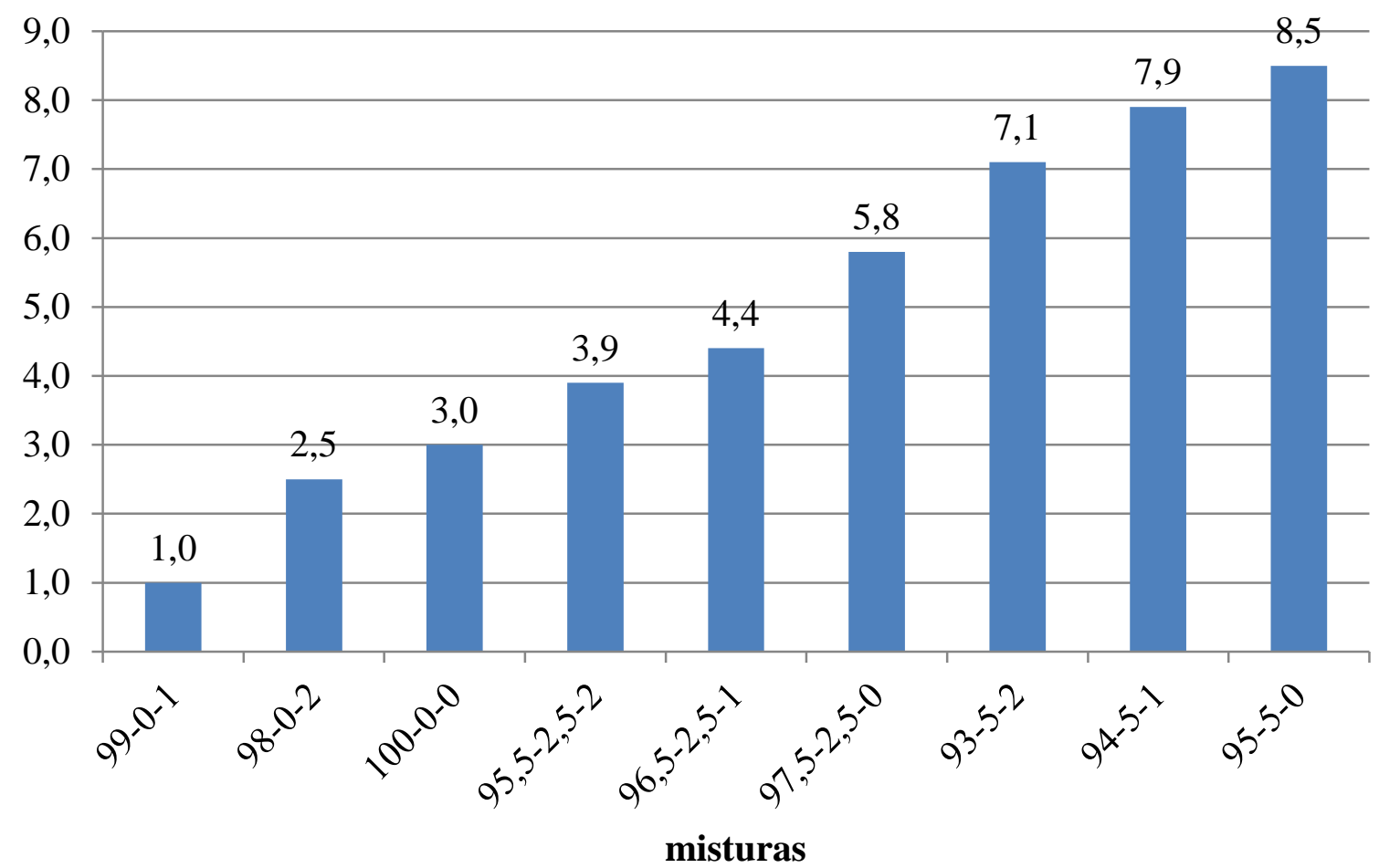

Figura 5.103 - Posição média dos ordenamentos da estabilidade à estocagem

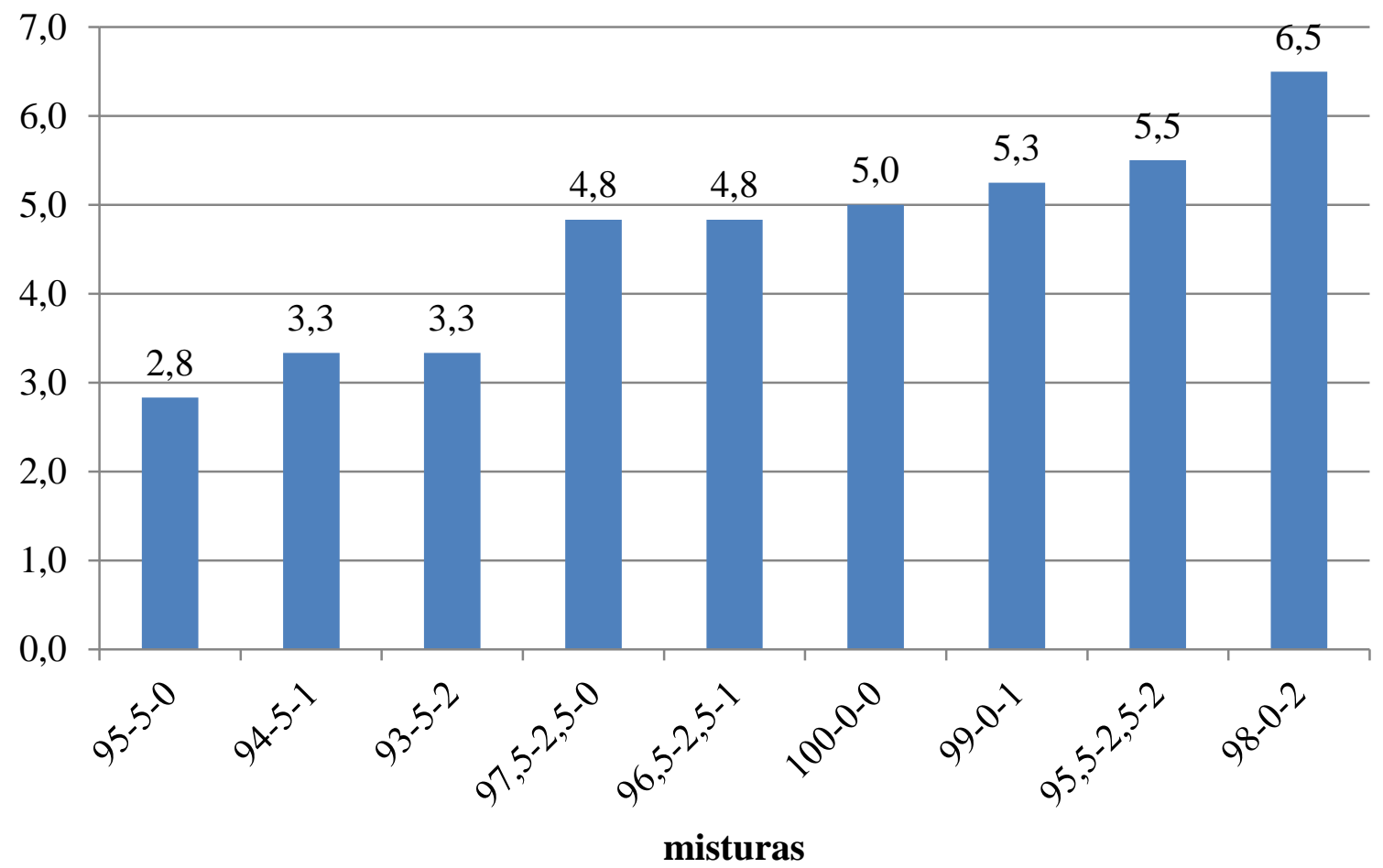

Figura 5.104 - Posição média dos ordenamentos da contribuição à resistência a deformação permanente 


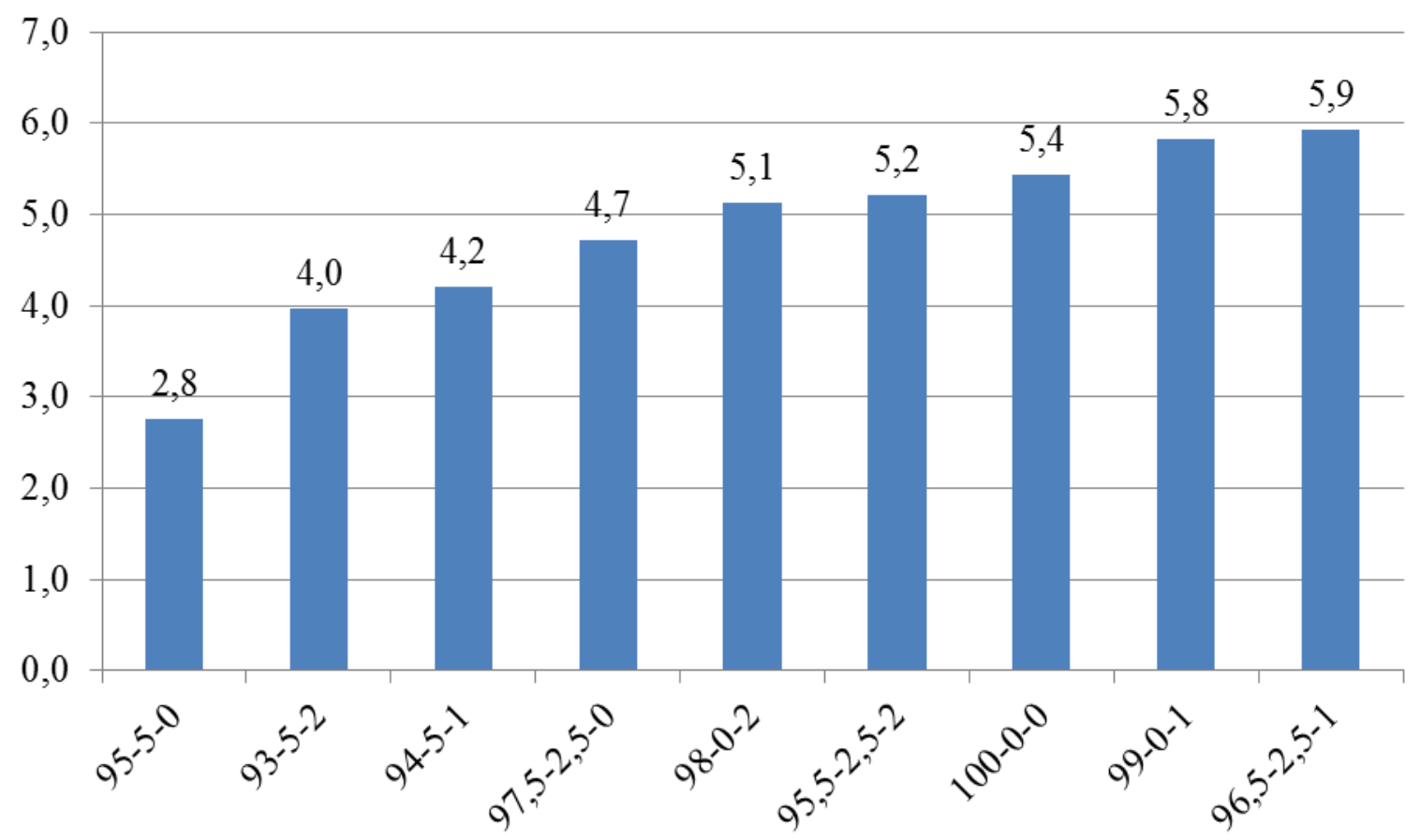

misturas

Figura 5.105 - Posição média dos ordenamentos da contribuição à resistência a fadiga

As posições médias obtidas pelo ordenamento da sensibilidade ao envelhecimento a curto prazo (Figura 5.98) mostram que as misturas com menores médias foram a 97,5-2,5-0 $(3,9)$, a 94-5-1 (3,9) e a 93-5-2 (4,1), representando os melhores resultados para esta categoria. As misturas 99-0-1 (6,2), 95,5-2,5-2 (5,7) e 99-0-1 (5,6) possuem as maiores médias finais e, portanto, os piores resultados para esta categoria. Notam-se algumas colocações muito próximas, indicando que tais misturas são equivalentes em termos do requisito em questão: misturas 97,5-2,5-0, 94-5-1 e 93-5-2 (na posição 4), misturas 95-5-0, 100-0-0 e 96,5-2,5-1 (na posição 5) e misturas 98-0-2, 95,5-2,5-2 e 99-0-1 (na posição 6).

Ao dividir o conjunto de amostras em seis grupos (0\% de SBS, 2,5\% de SBS, $5 \%$ de SBS, $0 \%$ de TITAN, $1 \%$ de TITAN e $2 \%$ de TITAN), é possível avaliar os efeitos das adições sobre o ordenamento do requisito em questão. Para o grupo de misturas com 0\% de SBS (100-0-0, 99-0-1 e 98-0-2), a adição de TITAN em qualquer proporção provoca perda da posição média. Para o grupo de misturas com 2,5\% de SBS (97,5-2,5-0, 96,5-2,5-1 e 95,5-2,52), a adição de TITAN em qualquer proporção provoca perda de posição. Para o grupo de misturas com 5\% de SBS (95-5-0, 94-5-1 e 93-5-2), a adição de TITAN em qualquer proporção provoca ganho de posição. Para o grupo de misturas com 0\% de TITAN (100-0-0, 
97,5-2,5-0 e 95-5-0), a adição de SBS em qualquer proporção provoca ganho de posição. Para o grupo de misturas com $1 \%$ de TITAN (99-0-1, 96,5-2,5-1 e 94-5-1), a adição de SBS em qualquer proporção provoca ganho de posição. Para o grupo de misturas com $2 \%$ de TITAN (98-0-2, 95,5-2,5-2 e 93-5-2), a adição de 2,5\% de SBS provoca perda de posição (de 5,6 para $5,7)$ e, ao se adicionar 5\% de SBS, ocorre ganho de posição (de 5,6 para 4,1). Esta mesma análise foi replicada para as demais categorias de interesse e os resultados estão sintetizados na Tabela 5.88.

No caso do ordenamento da sensibilidade ao envelhecimento a longo prazo (Figura 5.99), as posições médias mostram que a mistura com menor média foi a 93-5-2 (3,0). As misturas 100-0-0 (6,1) e 97,5-2,5-0 (5,9) possuem as maiores médias finais e, portanto, os piores resultados para esta categoria. Notam-se algumas colocações muito próximas, indicando que tais misturas são equivalentes em termos do requisito em questão: mistura 935-2 (na posição 3), mistura 95,5-2,5-2 (na posição 4), misturas 98-0-2, 96,5-2,5-1, 95-5-0, 945-1, 99-0-1 (na posição 5) e misturas 97,5-2,5-0 e 100-0-0 (na posição 6).

As posições médias obtidas pelo ordenamento do grau de modificação (Figura 5.100) mostram que as misturas com menores médias foram a 95-5-0 (2,8), a 94-5-1 (3,3) e a 93-5-2 $(3,3)$. As misturas 97,5-2,5-0 (5,9), 96,5-2,5-1 (5,7) e 99-0-1 (5,6) possuem as maiores médias finais e, portanto, os piores resultados para esta categoria. Notam-se algumas colocações muito próximas, indicando que tais misturas são equivalentes em termos do requisito em questão: misturas 95-5-0, 94-5-1 e 93-5-2 (na posição 3), mistura 95,5-2,5-2 (na posição 4), mistura 98-0-2 (na posição 5) e misturas 100-0-0, 99-0-1, 96,5-2,5-1 e 97,5-2,5-0 (na posição $6)$.

As posições médias obtidas pelo ordenamento das misturas com maior trabalhabilidade (Figura 5.101) mostram que a mistura com menor média foi a 100-0-0 (1,0). As misturas 94,5-1 (8,3) e 93-5-2 (7,7) possuem as maiores médias finais e, portanto, os piores resultados para esta categoria. Notam-se algumas colocações muito próximas, indicando que tais misturas são equivalentes em termos do requisito em questão: mistura 100-0-0 (na posição 1), misturas 99-0-1 e 98-0-2 (na posição 2), mistura 97,5-2,5-0 (na posição 4), mistura 95,5-2,5-2 (na posição 5), mistura 96,5-2,5-1 (na posição 6), mistura 95-5-0 (na posição 7) e misturas 935-2 e 94-5-1 (na posição 8).

As posições médias obtidas pelo ordenamento do grau contínuo (Figura 5.102) mostram que a mistura com menor média foi a 93-5-2 (1,0). A mistura 100-0-0 $(9,0)$ possui a maior 
média final e, portanto, o pior resultado para esta categoria. Por se tratar de um conjunto de colocações baseado apenas nos valores de grau contínuo, não foram verificados conjuntos de misturas com colocações semelhantes.

As posições médias obtidas pelo ordenamento da estabilidade à estocagem (Figura 5.103) mostram que a mistura com menor média foi a 99-0-1 (1,0). A mistura 95-5-0 $(8,5)$ possui a maior média final e, portanto, o pior resultado para esta categoria. Notam-se algumas colocações muito próximas, indicando que tais misturas são equivalentes em termos do requisito em questão: mistura 99-0-1 (na posição 1), misturas 98-0-2 e 100-0-0 (na posição 3), mistura 96,5-2,5-1 (na posição 4), mistura 97,5-2,5-0 (na posição 6), mistura 93-5-2 (na posição 7), mistura 94-5-1 (na posição 8) e mistura 95-5-0 (na posição 9).

As posições médias obtidas pelo ordenamento da contribuição à resistência à deformação permanente (Figura 5.104) mostram que as misturas com menores médias foram a 95-5-0 (2,8), a 94-5-1 (3,3) e a 93-5-2 (3,3). A mistura 98-0-2 (6,5) possui a maior média final e, portanto, o pior resultado para esta categoria. Notam-se algumas colocações muito próximas, indicando que tais misturas são equivalentes em termos do requisito em questão: misturas 95-5-0, 94-5-1 e 93-5-2 (na posição 3), misturas 97,5-2,5-0, 96,5-2,5-1, 100-0-0 e 99-0-1 (na posição 5), 95,5-2,5-2 (na posição 6) e mistura 98-0-2 (na posição 7).

As posições médias obtidas pelo ordenamento da contribuição à resistência à fadiga (Figura 5.105) mostram que a mistura com menor média foi a 95-5-0 (2,8). As misturas 99-0$1(5,8)$ e 96,5-2,5-1 (5,9) possuem as maiores médias finais e, portanto, os piores resultados para esta categoria. Notam-se algumas colocações muito próximas, indicando que tais misturas são equivalentes em termos do requisito em questão: mistura 95-5-0 (na posição 3), misturas 93-5-2 e 94-5-1 (na posição 4), misturas 97,5-2,5-0, 98-0-2, 95,5-2,5-2 e 100-0-0 (na posição 5) e misturas 99-0-1 e 96,5-2,5-1 (na posição 6).

Um resumo das misturas mais e menos adequadas para cada uma das categorias de interesse discutidas anteriormente é apresentado na Tabela 5.87. 
Tabela 5.87 - Resumo das misturas mais e menos adequadas segundo as categorias de interesse

\begin{tabular}{|c|c|c|}
\hline categorias & melhores & piores \\
\hline $\begin{array}{l}\text { sensibilidade ao } \\
\text { envelhecimento a } \\
\text { curto prazo }\end{array}$ & $\begin{array}{c}97,5-2,5-0(3,9), 94-5-1(3,9) \\
\text { e } 93-5-2(4,1)\end{array}$ & $\begin{array}{c}99-0-1(6,2), 95,5-2,5-2(5,7) \\
\text { e } 98-0-2(5,6)\end{array}$ \\
\hline $\begin{array}{l}\text { sensibilidade ao } \\
\text { envelhecimento a } \\
\text { longo prazo }\end{array}$ & $93-5-2(3,0)$ & $\begin{array}{c}100-0-0(6,1) \text { e } 97,5-2,5-0 \\
(5,9)\end{array}$ \\
\hline $\begin{array}{c}\text { grau de } \\
\text { modificação }\end{array}$ & $\begin{array}{c}95-5-0(2,8), 94-5-1(3,3) \mathrm{e} \\
93-5-2(3,3)\end{array}$ & $\begin{array}{c}97,5-2,5-0(5,9), 96,5-2,5-1 \\
(5,7), 99-0-1(5,6) \text { e } 100-0-0 \\
(5,5)\end{array}$ \\
\hline $\begin{array}{c}\text { maior } \\
\text { trabalhabilidade }\end{array}$ & $100-0-0(1,0)$ & $94,5-1(8,3)$ e $93-5-2(7,7)$ \\
\hline grau contínuo & $93-5-2(1,0)$ & $100-0-0(9,0)$ \\
\hline $\begin{array}{l}\text { estabilidade à } \\
\text { estocagem }\end{array}$ & $99-0-1(1,0)$ & $95-5-0(8,5)$ \\
\hline $\begin{array}{l}\text { contribuição à } \\
\text { resistência a } \\
\text { deformação } \\
\text { permanente }\end{array}$ & $\begin{array}{c}95-5-0(2,8), 94-5-1(3,3) \mathrm{e} \\
93-5-2(3,3)\end{array}$ & $98-0-2(6,5)$ \\
\hline $\begin{array}{l}\text { contribuição à } \\
\text { resistência a } \\
\text { fadiga }\end{array}$ & $95-5-0(2,8)$ & $\begin{array}{c}96,5-2,5-1(5,9) \text { e } 99-0-1 \\
(5,8)\end{array}$ \\
\hline classificação geral & 93-5-2 (na posição 4) & demais (na posição 5) \\
\hline
\end{tabular}


Tabela 5.88 - Alteração da posição média em função da presença de modificadores

\begin{tabular}{|c|c|c|c|c|c|c|}
\hline \multirow{2}{*}{ categoria } & \multicolumn{3}{|c|}{ aumento da proporção de TITAN para } & \multicolumn{3}{|c|}{ aumento da proporção de SBS para } \\
\hline & $0 \%$ de SBS & $2,5 \%$ de $\mathrm{SBS}$ & $5 \%$ de SBS & $0 \%$ de TITAN & $1 \%$ de TITAN & $2 \%$ de TITAN \\
\hline $\begin{array}{c}\text { sensibilidade ao } \\
\text { envelhecimento a } \\
\text { curto prazo }\end{array}$ & perda & perda & ganho & ganho & ganho & $\begin{array}{c}2,5 \% \mathrm{SBS} \text { - perda, } \\
5 \% \mathrm{SBS} \text { - ganho }\end{array}$ \\
\hline $\begin{array}{c}\text { sensibilidade ao } \\
\text { envelhecimento a } \\
\text { longo prazo }\end{array}$ & ganho & ganho & $\begin{array}{c}1 \% \text { TITAN - } \\
\text { indiferente, } 2 \% \\
\text { TITAN - ganho }\end{array}$ & ganho & ganho & perda \\
\hline grau de modificação & $\begin{array}{c}1 \% \text { TITAN - } \\
\text { perda, } 2 \% \text { TITAN } \\
\text { - ganho }\end{array}$ & ganho & perda & $\begin{array}{c}2,5 \% \mathrm{SBS} \text { - perda, } \\
5 \% \mathrm{SBS} \text { - ganho }\end{array}$ & ganho & ganho \\
\hline $\begin{array}{c}\text { maior } \\
\text { trabalhabilidade }\end{array}$ & perda & perda & perda & perda & perda & perda \\
\hline grau contínuo & ganho & ganho & ganho & ganho & ganho & ganho \\
\hline $\begin{array}{c}\text { estabilidade à } \\
\text { estocagem }\end{array}$ & ganho & ganho & ganho & perda & perda & perda \\
\hline $\begin{array}{l}\text { contribuição à } \\
\text { resistência a } \\
\text { deformação } \\
\text { permanente }\end{array}$ & perda & perda & perda & ganho & ganho & ganho \\
\hline $\begin{array}{l}\text { contribuição à } \\
\text { resistência a fadiga }\end{array}$ & $\begin{array}{c}1 \% \text { TITAN - } \\
\text { perda, } 2 \% \text { TITAN } \\
\text { - ganho }\end{array}$ & perda & perda & ganho & $\begin{array}{c}2,5 \% \mathrm{SBS} \text { - perda, } \\
5 \% \mathrm{SBS} \text { - ganho }\end{array}$ & $\begin{array}{c}2,5 \% \mathrm{SBS} \text { - perda, } \\
5 \% \mathrm{SBS} \text { - ganho }\end{array}$ \\
\hline
\end{tabular}




\section{CONCLUSÕES}

\subsection{Introdução}

O presente trabalho teve por objetivo principal testar a hipótese de que a adição de TITAN pode melhorar as características reológicas de ligantes asfálticos modificados com SBS. Para isto, foi concebido um experimento baseado no monitoramento de propriedades reológicas dos ligantes asfálticos na condições virgem e envelhecida a curto e a longo prazos. As propriedades reológicas foram selecionadas com base na capacidade de tais propriedades apresentarem indícios da melhoria ou da piora da estabilidade do ligante asfáltico modificado. Dentre as características indicadoras da melhora ou piora da estabilidade destacam-se: (i) a estabilidade à estocagem; (ii) a sensibilidade ao envelhecimento; (iii) a contribuição à resistência à deformação permanente e (iv) a contribuição à resistência à fadiga.

A análise dos resultados foi dividida em duas partes: (1) modelagem de parte das propriedades reológica com base na teoria de experimentos com misturas, que resultou no ajuste de modelos polinomiais e na confecção de gráficos de efeitos dos componentes e superfícies de resposta e (2) análise comparativa dos resultados dos ensaios, que resultou no ordenamento das misturas em relação a requisitos de interesse e em um ordenamento global.

No que tange à análise estatística, foram modeladas propriedades fundamentais em diversas temperaturas, além de parâmetros de especificação e índices de envelhecimento. Com base nos modelos ajustados, foram gerados gráficos de efeitos dos componentes e superfícies de resposta, a fim de avaliar os efeitos isolados e de interação dos componentes, bem como definir regiões dentro do simplex em que figurem misturas cujas propriedades atendam requisitos de especificações vigentes. No que se refere à análise comparativa dos dados, o ordenamento das misturas teve o intuito de indicar, em um contexto geral e também em relações a requisitos específicos, quais misturas se apresentam nas melhores e nas piores colocações em relação às propriedades aqui analisadas.

Na sequência, são apresentadas as principais conclusões obtidas no experimento e as considerações finais da pesquisa. No final, são indicadas algumas sugestões para pesquisas futuras. 


\subsection{Conclusões principais}

A análise estatística e o ordenamento das misturas foram capazes de fornecer evidências concretas acerca do efeito do TITAN e do SBS sobre a estabilidade do ligante asfáltico modificado e também forneceram evidências acerca dos efeitos de cada componente sobre as propriedades analisadas. A seguir, são listadas as principais conclusões do experimento, separadas em termos de efeitos dos componentes, superfícies de resposta e ordenamentos parciais e global.

\subsubsection{Efeitos dos componentes}

A Tabela 6.1 apresenta as conclusões referentes aos efeitos dos componentes obtidas da análise estatística. A adição tanto de copolímero SBS quanto de TITAN provocou efeitos positivos e negativos sobre as propriedades avaliadas, segundo indicado a seguir.

O efeito da adição do copolímero SBS é positivo por aumentar: (i) o grau contínuo, (ii) o percentual de recuperação das misturas envelhecidas a curto prazo, nos níveis de tensão de 100 e 3.200, para as temperaturas de $52,58,64$ e $70^{\circ} \mathrm{C}$; (iii) a tolerância ao dano por fadiga (aumento do parâmetro $\mathrm{a}_{\mathrm{f}}$ ) a $25^{\circ} \mathrm{C}$ das misturas envelhecidas a longo prazo; e (iv) a vida de fadiga das misturas envelhecidas a longo prazo sob baixos níveis de deformação $(2 \%)$ a $25^{\circ} \mathrm{C}$; e reduzir: (i) a sensibilidade ao envelhecimento a curto prazo à luz do incremento de viscosidade nas temperaturas de $135,143,150,163$ e $177^{\circ} \mathrm{C}$; (ii) a compliância nãorecuperável das misturas envelhecidas a curto prazo, nos níveis de tensão de 100 e 3.200 Pa, nas temperaturas de $52,58,64$ e $70^{\circ} \mathrm{C}$; e (iii) o $\mathrm{J}_{\mathrm{nr} \text {,diff }}$ nas temperaturas de 52 e $58^{\circ} \mathrm{C}$.

O efeito da adição do copolímero SBS é negativo ao aumentar: (i) a viscosidade na condição virgem nas temperaturas de 135, 143, 150, 163 e $177^{\circ} \mathrm{C}$; (ii) a viscosidade na condição envelhecida a curto prazo de $135,143,150,163$ e $177^{\circ} \mathrm{C}$; (iii) as temperaturas de usinagem e compactação; (iv) o $\mathrm{J}_{\mathrm{nr} \text {,diff }}$ nas temperaturas de 64 e $70^{\circ} \mathrm{C}$; e (v) a temperatura crítica de fadiga (em que $\mathrm{G}^{*} \cdot \operatorname{sen}(\delta)$ é igual a $5 \mathrm{MPa}$ para tráfego $\mathrm{S}$ e igual a $6 \mathrm{MPa}$ para tráfegos $\mathrm{H} \mathrm{e} \mathrm{V}$ ); e reduzir: (i) a vida de fadiga das misturas envelhecidas a longo prazo sob altos níveis de deformação $(30 \%)$ a $25^{\circ} \mathrm{C}$. 
Tabela 6.1 - Resumo dos efeitos dos componentes (continua)

\begin{tabular}{|c|c|c|c|}
\hline Propriedade & Asfalto+óleo & SBS & TITAN \\
\hline Grau contínuo & $\begin{array}{l}\text { reduz, efeito aproximadamente linear, } \\
\text { pouco efetiva nos teores altos }\end{array}$ & $\begin{array}{c}\text { aumenta, efeito aproximadamente linear } \\
\text { entre teores de } 0,0 \text { a } 2,5 \% \text { e aumento } \\
\text { linear entre teores de } 2,5 \text { a } 5,0 \%\end{array}$ & $\begin{array}{c}\text { aumenta, efeito linear entre teores de } 0 \\
\text { a } 1 \% \text { e aumento aproximadamente } \\
\text { linear entre teores de } 1 \text { a } 2 \%\end{array}$ \\
\hline $\begin{array}{c}\text { Viscosidade virgem } \\
\text { a } 135^{\circ} \mathrm{C}\end{array}$ & reduz, efeito aproximadamente linear & $\begin{array}{c}\text { aumenta, efeito aproximadamente linear } \\
\text { entre teores de } 0,0 \text { a } 2,5 \% \text { e aumento } \\
\text { linear entre teores de } 2,5 \text { a } 5,0 \%\end{array}$ & efeito praticamente nulo \\
\hline $\begin{array}{l}\text { Viscosidade virgem } \\
\text { a } 143^{\circ} \mathrm{C}\end{array}$ & reduz, efeito aproximadamente linear & $\begin{array}{c}\text { aumenta, efeito aproximadamente linear } \\
\text { entre teores de } 0,0 \text { a } 2,5 \% \text { e aumento } \\
\text { linear entre teores de } 2,5 \text { a } 5,0 \%\end{array}$ & efeito praticamente nulo \\
\hline $\begin{array}{l}\text { Viscosidade virgem } \\
\text { a } 150^{\circ} \mathrm{C}\end{array}$ & reduz, efeito aproximadamente linear & aumenta, efeito linear & $\begin{array}{l}\text { efeito praticamente nulo, ponto de } \\
\text { máximo em torno de } 0,5 \%\end{array}$ \\
\hline $\begin{array}{l}\text { Viscosidade virgem } \\
\text { a } 163^{\circ} \mathrm{C}\end{array}$ & reduz, efeito aproximadamente linear & $\begin{array}{c}\text { aumenta, efeito aproximadamente linear } \\
\text { entre teores de } 0,0 \text { a } 2,5 \% \text { e aumento } \\
\text { linear entre teores de } 2,5 \text { a } 5,0 \%\end{array}$ & $\begin{array}{c}\text { efeito praticamente nulo, ponto de } \\
\text { máximo em torno de } 1 \%\end{array}$ \\
\hline $\begin{array}{c}\text { Viscosidade virgem } \\
\text { a } 177^{\circ} \mathrm{C}\end{array}$ & reduz, efeito aproximadamente linear & $\begin{array}{c}\text { aumenta, efeito aproximadamente linear } \\
\text { entre teores de } 0,0 \text { a } 2,5 \% \text { e aumento } \\
\text { linear entre teores de } 2,5 \text { a } 5,0 \%\end{array}$ & $\begin{array}{l}\text { efeito praticamente nulo, ponto de } \\
\text { máximo em torno de } 1 \%\end{array}$ \\
\hline $\begin{array}{c}\text { Viscosidade } \\
\text { RTFOT a } 135^{\circ} \mathrm{C}\end{array}$ & reduz, efeito aproximadamente linear & $\begin{array}{c}\text { aumenta, efeito aproximadamente linear } \\
\text { entre teores de } 0,0 \text { a } 2,5 \% \text { e aumento } \\
\text { linear entre teores de } 2,5 \text { a } 5,0 \%\end{array}$ & efeito praticamente nulo \\
\hline $\begin{array}{l}\text { Viscosidade } \\
\text { RTFOT a } 143^{\circ} \mathrm{C}\end{array}$ & reduz, efeito aproximadamente linear & $\begin{array}{c}\text { aumenta, efeito aproximadamente linear } \\
\text { entre teores de } 0,0 \text { a } 2,5 \% \text { e aumento } \\
\text { linear entre teores de } 2,5 \text { a } 5,0 \%\end{array}$ & efeito praticamente nulo \\
\hline
\end{tabular}


Tabela 6.1 - Resumo dos efeitos dos componentes (continuação)

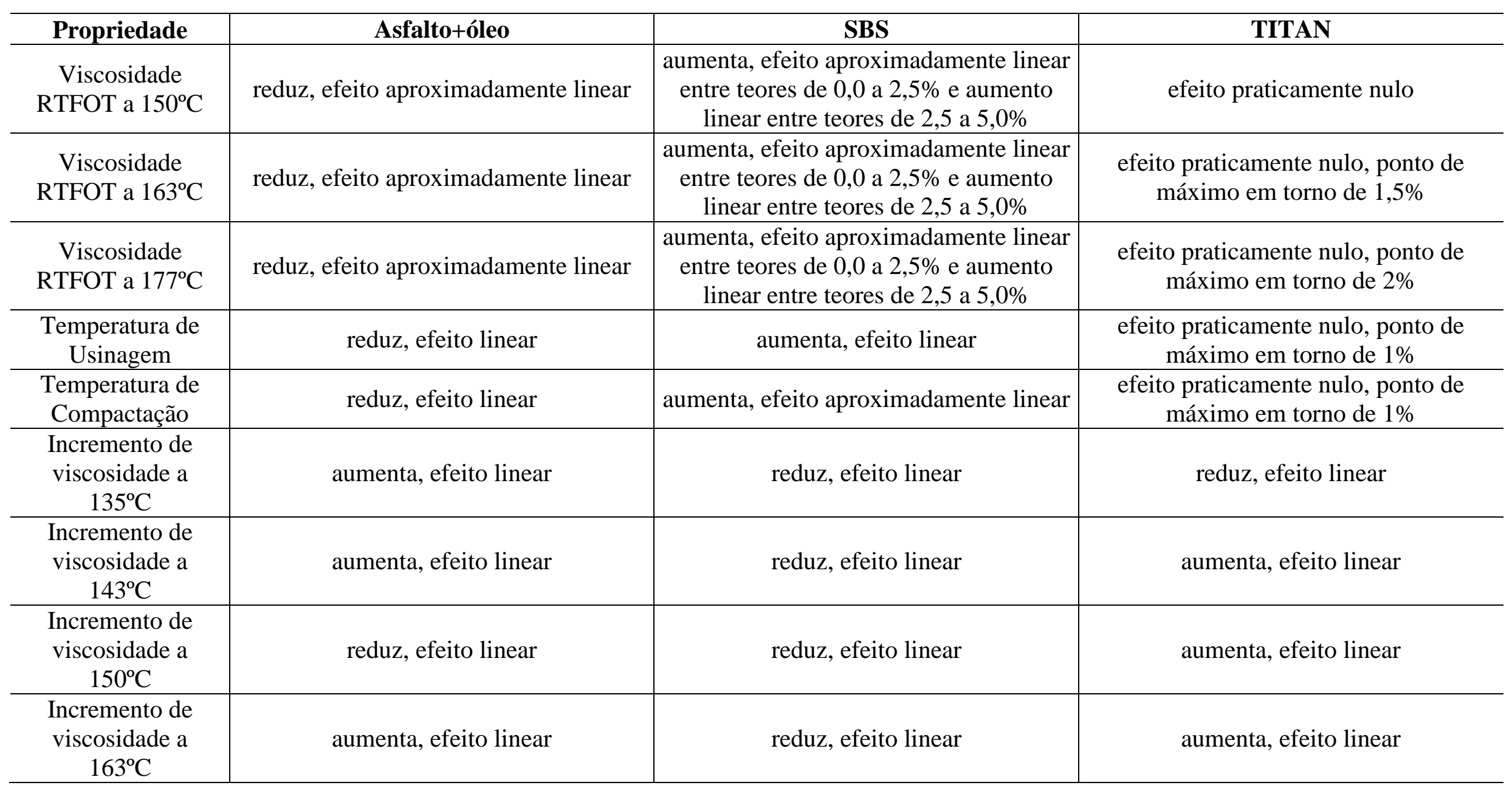


Tabela 6.1 - Resumo dos efeitos dos componentes (continuação)

\begin{tabular}{|c|c|c|c|}
\hline Propriedade & Asfalto+óleo & SBS & TITAN \\
\hline $\begin{array}{l}\text { Incremento de } \\
\text { viscosidade a } \\
177^{\circ} \mathrm{C}\end{array}$ & ponto de mínimo em torno de $96 \%$ & $\begin{array}{l}\text { reduz, efeito linear entre teores de } 0,0 \text { a } \\
2,5 \% \text { e reduz aproximadamente linear } \\
\text { entre teores de } 2,5 \text { a } 5,0 \%\end{array}$ & $\begin{array}{l}\text { reduz, efeito linear entre teores de } 0 \text { a } \\
1 \% \text { e reduz aproximadamente linear } \\
\text { entre teores de } 1 \text { a } 2 \%\end{array}$ \\
\hline $\begin{array}{l}\mathrm{J}_{\mathrm{nr}} 3.200 \mathrm{~Pa} \\
\text { RTFOT a } 58^{\circ} \mathrm{C}\end{array}$ & $\begin{array}{l}\text { aumenta, efeito aproximadamente } \\
\text { linear, pouco efetiva nos teores baixos }\end{array}$ & $\begin{array}{l}\text { reduz, efeito aproximadamente linear } \\
\text { entre teores de } 0,0 \text { a } 2,5 \% \text { e reduz linear } \\
\text { entre teores de } 2,5 \text { a } 5,0 \%\end{array}$ & $\begin{array}{l}\text { reduz, efeito aproximadamente linear } \\
\text { entre teores de } 0 \text { a } 1 \% \text { e redução linear } \\
\text { entre teores de } 1 \text { a } 2 \%\end{array}$ \\
\hline $\begin{array}{c}\mathrm{J}_{\mathrm{nr}} 3.200 \mathrm{~Pa} \\
\text { RTFOT a } 64^{\circ} \mathrm{C}\end{array}$ & $\begin{array}{l}\text { aumenta, efeito aproximadamente } \\
\text { linear, pouco efetiva nos teores baixos }\end{array}$ & $\begin{array}{l}\text { reduz, efeito aproximadamente linear } \\
\text { entre teores de } 0,0 \text { a } 2,5 \% \text { e reduz linear } \\
\text { entre teores de } 2,5 \text { a } 5,0 \%\end{array}$ & $\begin{array}{l}\text { reduz, efeito aproximadamente linear } \\
\text { entre teores de } 0 \text { a } 1 \% \text { e redução linear } \\
\text { entre teores de } 1 \text { a } 2 \%\end{array}$ \\
\hline $\begin{array}{c}\mathrm{J}_{\mathrm{nr}} 3.200 \mathrm{~Pa} \\
\text { RTFOT a } 70^{\circ} \mathrm{C}\end{array}$ & $\begin{array}{l}\text { aumenta, efeito aproximadamente } \\
\text { linear, pouco efetiva nos teores baixos }\end{array}$ & $\begin{array}{l}\text { reduz, efeito aproximadamente linear } \\
\text { entre teores de } 0,0 \text { a } 2,5 \% \text { e reduz linear } \\
\text { entre teores de } 2,5 \text { a } 5,0 \%\end{array}$ & $\begin{array}{l}\text { reduz, efeito aproximadamente linear } \\
\text { entre teores de } 0 \text { a } 1 \% \text { e redução linear } \\
\text { entre teores de } 1 \text { a } 2 \%\end{array}$ \\
\hline $\begin{array}{l}\text { Percentual de } \\
\text { recuperação } 3.200 \\
\text { Pa RTFOT a } 64^{\circ} \mathrm{C} \\
\end{array}$ & reduz, efeito aproximadamente linear & $\begin{array}{l}\text { aumenta, efeito aproximadamente linear } \\
\text { entre teores de } 0,0 \text { a } 2,5 \% \text { e aumento } \\
\text { linear entre teores de } 2,5 \text { a } 5,0 \%\end{array}$ & aumenta, efeito linear \\
\hline $\begin{array}{l}\text { Percentual de } \\
\text { recuperação } 3.200 \\
\text { Pa RTFOT a } 70^{\circ} \mathrm{C}\end{array}$ & $\begin{array}{l}\text { reduz, efeito aproximadamente linear } \\
\text { com ponto de mínimo em torno de } 99 \%\end{array}$ & $\begin{array}{l}\text { aumenta, efeito aproximadamente linear } \\
\text { entre teores de } 0,0 \text { a } 2,5 \% \text { e aumento } \\
\text { linear entre teores de } 2,5 \text { a } 5,0 \% \text {, com } \\
\text { ponto de mínimo em } 1,0 \%\end{array}$ & efeito praticamente nulo \\
\hline
\end{tabular}


Tabela 6.1 - Resumo dos efeitos dos componentes (continuação)

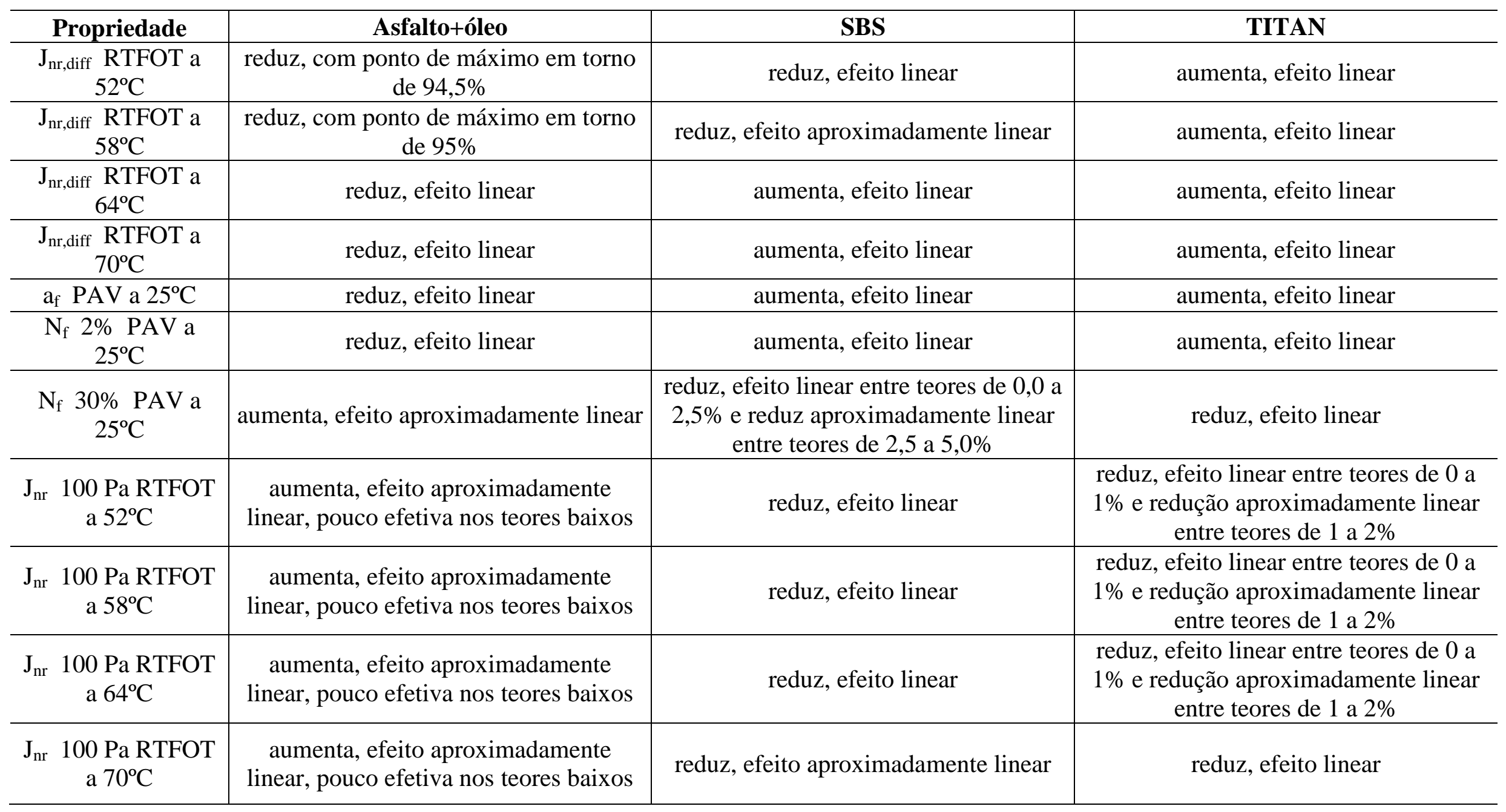


Tabela 6.1 - Resumo dos efeitos dos componentes (continuação)

\begin{tabular}{|c|c|c|c|}
\hline Propriedade & Asfalto+óleo & SBS & TITAN \\
\hline $\begin{array}{c}\text { Percentual de } \\
\text { recuperação } 100 \mathrm{~Pa} \\
\text { RTFOT a } 52^{\circ} \mathrm{C}\end{array}$ & $\begin{array}{l}\text { reduz, efeito aproximadamente linear, } \\
\text { pouco efetiva nos teores baixos }\end{array}$ & aumenta, efeito aproximadamente linear & aumenta, efeito linear \\
\hline $\begin{array}{c}\text { Percentual de } \\
\text { recuperação } 100 \mathrm{~Pa} \\
\text { RTFOT a } 58^{\circ} \mathrm{C}\end{array}$ & $\begin{array}{l}\text { reduz, efeito aproximadamente linear, } \\
\text { pouco efetiva nos teores baixos }\end{array}$ & aumenta, efeito aproximadamente linear & aumenta, efeito linear \\
\hline $\begin{array}{c}\text { Percentual de } \\
\text { recuperação } 100 \mathrm{~Pa} \\
\text { RTFOT a } 64^{\circ} \mathrm{C}\end{array}$ & $\begin{array}{l}\text { reduz, efeito aproximadamente linear, } \\
\text { pouco efetiva nos teores baixos }\end{array}$ & aumenta, efeito aproximadamente linear & aumenta, efeito linear \\
\hline $\begin{array}{c}\text { Percentual de } \\
\text { recuperação } 100 \mathrm{~Pa} \\
\text { RTFOT a } 70^{\circ} \mathrm{C}\end{array}$ & reduz, efeito linear & aumenta, efeito linear & aumenta, efeito linear \\
\hline $\begin{array}{l}\text { Temperatura crítica } \\
\text { de fadiga - tráfego } \\
\text { S) }\left(\mathrm{G}^{*} . \operatorname{sen}(\delta)=5 \mathrm{MPa}\right)\end{array}$ & reduz, efeito linear & aumenta, efeito linear & aumenta, efeito linear \\
\hline $\begin{array}{l}\text { Temperatura crítica } \\
\text { de fadiga - tráfego H } \\
\text { e V }\left(\mathrm{G}^{*} \cdot \operatorname{sen}(\delta)=6 \mathrm{MPa}\right)\end{array}$ & reduz, efeito linear & aumenta, efeito linear & aumenta, efeito linear \\
\hline
\end{tabular}


O efeito da adição de TITAN é positivo ao aumentar: (i) o grau contínuo, (ii) o percentual de recuperação das misturas envelhecidas a curto prazo, nos níveis de tensão de 100 e $3.200 \mathrm{~Pa}$, a 52,58 e $64^{\circ} \mathrm{C}$ - a $70^{\circ} \mathrm{C}$, apenas o percentual de recuperação a $100 \mathrm{~Pa}$ aumenta; (iii) a tolerância ao dano por fadiga (aumento do parâmetro $\mathrm{a}_{\mathrm{f}}$ ) a $25^{\circ} \mathrm{C}$ das misturas envelhecidas a longo prazo; e (iv) a vida de fadiga das misturas envelhecidas a longo prazo sob baixos níveis de deformação $(2 \%)$ a $25^{\circ} \mathrm{C}$; e reduzir: (i) a sensibilidade ao envelhecimento a curto prazo à luz do incremento de viscosidade nas temperaturas de 135 e $177^{\circ} \mathrm{C}$; e (ii) a compliância não-recuperável das misturas envelhecidas a curto prazo, nos níveis de tensão de 100 e $3.200 \mathrm{~Pa}$, nas temperaturas de $52,58,64$ e $70^{\circ} \mathrm{C}$.

O efeito da adição de TITAN é negativo ao aumentar: (i) a sensibilidade ao envelhecimento a curto prazo à luz do incremento de viscosidade nas temperaturas de 143 , 150 e $163^{\circ} \mathrm{C}$; (ii) o $\mathrm{J}_{\mathrm{nr} \text {,diff }}$ nas temperaturas de $52,58,64$ e $70^{\circ} \mathrm{C}$ e (iii) a temperatura crítica de fadiga (em que $\mathrm{G}^{*} \cdot \operatorname{sen}(\delta)$ é igual a $5 \mathrm{MPa}$ para tráfego $\mathrm{S}$ e igual a $6 \mathrm{MPa}$ para tráfegos $\mathrm{H}$ e V); e reduzir a vida de fadiga das misturas envelhecidas a longo prazo sob altos níveis de deformação $(30 \%)$ a $25^{\circ} \mathrm{C}$. O TITAN possui efeito praticamente nulo para: (i) a viscosidade na condição virgem nas temperaturas de $135,143,150,163$ e $177^{\circ} \mathrm{C}$; (ii) a viscosidade na condição envelhecida a curto prazo a 135, 143, 150, 163 e $177^{\circ} \mathrm{C}$; (iii) as temperaturas de usinagem e compactação; e (iv) o percentual de recuperação das misturas envelhecidas a curto prazo a $3.200 \mathrm{~Pa}$, na temperatura de $70^{\circ} \mathrm{C}$.

\subsubsection{Superfícies de resposta}

As Figuras 6.1 e 6.2 apresentam regiões dentro do simplex delimitadas pelas propriedades e parâmetros relativos à deformação permanente, nas temperaturas de 64 e $70^{\circ} \mathrm{C}$ e relativos à fadiga (parâmetro $\mathrm{G}^{*} \cdot \operatorname{sen}(\delta)$ igual a $5 \mathrm{MPa}$ para tráfego $\mathrm{S}$ e igual a $6 \mathrm{MPa}$ para tráfego $\mathrm{H} \mathrm{e} \mathrm{V).}$ 


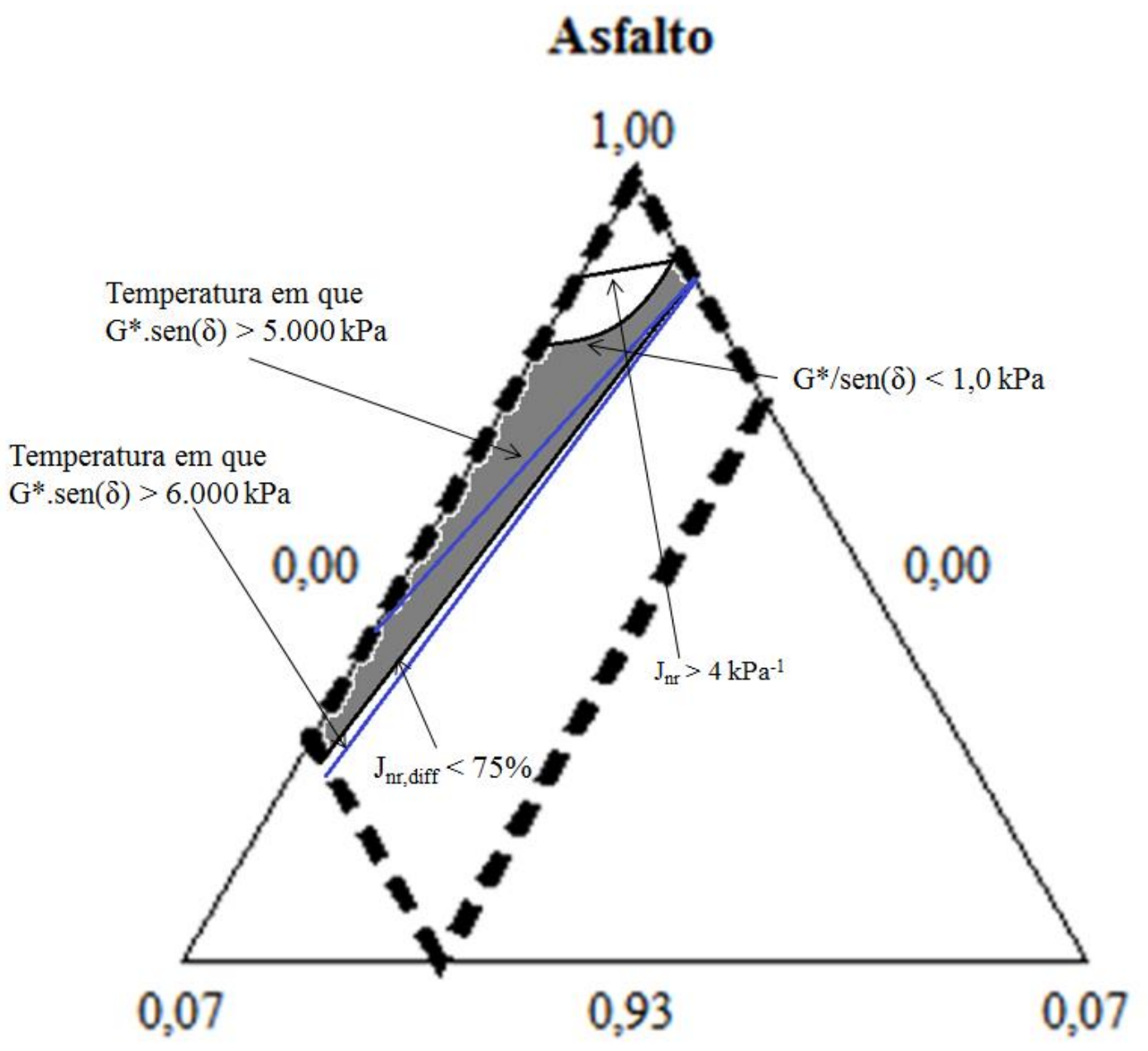

SBS

Titan

Figura 6.1 - Região delimitada no simplex pela aplicação dos critérios de especificação referentes à deformação permanente $\left(a^{\circ} 64^{\circ} \mathrm{C}\right)$ e à fadiga (temperatura crítica de fadiga)

A Figura 6.1 apresenta uma região delimitada no simplex que contém todas as misturas cujas formulações atendem os requisitos de especificações indicados. Observa-se que qualquer teor de SBS, entre 2 e 5\% pode ser empregado nas formulações, mesmo na ausência de TITAN. Caso se queira empregar teores inferiores a 2\% de SBS, é necessário adicionar um teor de TITAN entre 0,6 e 0,8\%. Misturas contendo teores de SBS, entre 2 e 5\%, e TITAN também podem ser compostas, desde que ao se aumentar o teor de SBS se diminua o teor de TITAN - exemplos: para misturas com $2 \%$ de SBS usar de 0,0 a 0,8\% de TITAN e para misturas com 5\% de SBS usar de 0 a 0,2\% de TITAN. O fator com maior poder restritivo

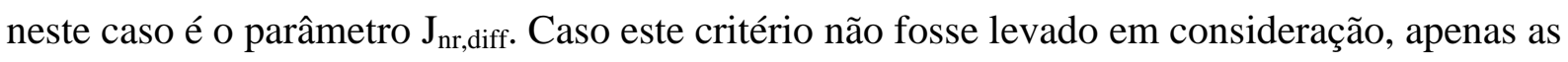
formulações com teores inferiores a $2 \%$ de SBS e $0,6 \%$ de TITAN não seriam recomendadas. 
Em relação à temperatura crítica de fadiga, todas as misturas dentro do espaço amostral apresentam valores de $\mathrm{G}^{*} \cdot \operatorname{sen}(\delta)=5$ ou $6 \mathrm{MPa}$ em temperaturas inferiores a $25^{\circ} \mathrm{C}$. As curvas de nível para $20^{\circ} \mathrm{C}(5 \mathrm{MPa})$ e para $19^{\circ} \mathrm{C}(6 \mathrm{MPa})$ estão indicadas na região apenas em caráter ilustrativo e somente poderiam ser tomadas em conta como critério de escolha caso o critério de $J_{\text {nr,diff }}$ não fosse considerado. Neste caso, poderiam ser selecionadas misturas para atender temperaturas críticas de fadiga superiores a $20^{\circ} \mathrm{C}$.

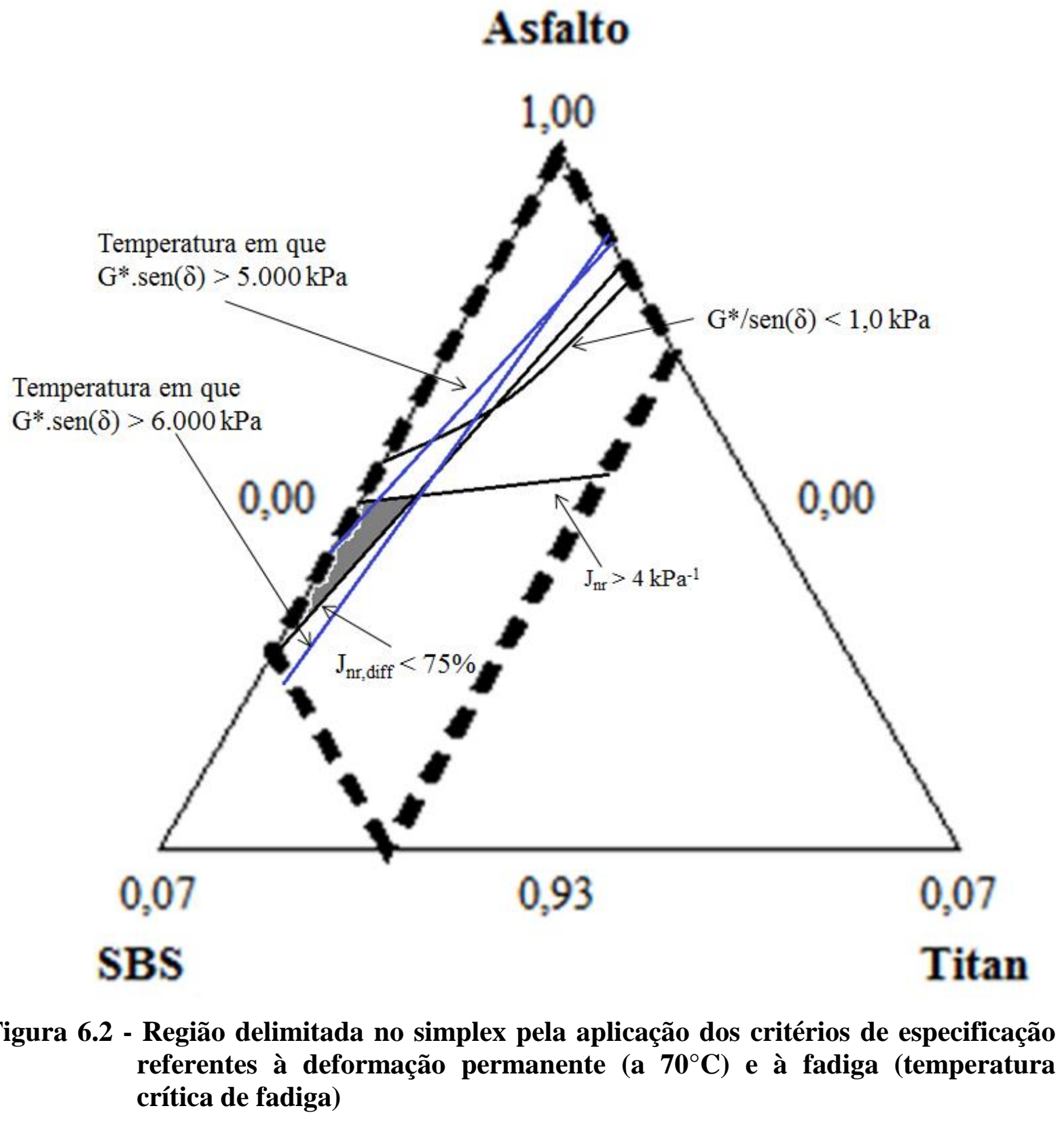


A Figura 6.2 apresenta uma região delimitada no simplex que contém todas as misturas cujas formulações atendem os requisitos de especificações indicados. Observa-se que qualquer teor de SBS, entre 3 e 5\% pode ser empregado nas formulações, mesmo na ausência de TITAN. Misturas contendo teores de SBS, entre 3 e 5\%, e TITAN também podem ser compostas, desde que ao se aumentar o teor de SBS se diminua o teor de TITAN - exemplos: para misturas com $3 \%$ de SBS usar de 0,0 a $0,5 \%$ de TITAN e para misturas com $5 \%$ de SBS usar 0\% de TITAN. Os fatores com maior poder restritivo neste caso são o $\mathrm{J}_{\mathrm{nr}}$ e o parâmetro $\mathrm{J}_{\mathrm{nr} \text {,diff. }}$ Caso o parâmetro $\mathrm{J}_{\mathrm{nr} \text {,diff }}$ não fosse levado em consideração, as formulações com teores inferiores a $3 \%$ de SBS e entre 0 e $1 \%$ de TITAN e as formulações com teores inferiores a $2 \%$ de SBS e entre 1 e $2 \%$ de TITAN não seriam recomendadas. Em relação à temperatura crítica de fadiga, todas as misturas dentro do espaço amostral apresentam valores de $G^{*} \cdot \operatorname{sen}(\delta)=5$ ou $6 \mathrm{MPa}$ em temperaturas inferiores a $25^{\circ} \mathrm{C}$. As curvas de nível para $20^{\circ} \mathrm{C}(5 \mathrm{MPa})$ e para $19^{\circ} \mathrm{C}(6 \mathrm{MPa})$ estão indicadas na região apenas em caráter ilustrativo e somente poderiam ser tomadas em conta como critério de escolha caso o critério de $\mathrm{J}_{\mathrm{nr} \text {,diff }}$ não fosse considerado. Neste caso, poderiam ser selecionadas misturas para atender temperaturas críticas de fadiga superiores a $20^{\circ} \mathrm{C}$.

Neste experimento, optou-se por não variar a proporção de óleo aromático. Observa-se que a fixação da proporção de óleo aromático em $4 \%$ prejudica diversas propriedades do ligante asfáltico de base: (i) o grau contínuo, (ii) a compliância não-recuperável, (iii) a recuperação elástica, (iv) o $J_{n r, d i f f}$, (v) a tolerância ao dano por fadiga (parâmetro $a_{f}$ ) e (vi) a vida de fadiga (parâmetro $\mathrm{N}_{\mathrm{f}}$ ), e (vii) o ângulo de fase. A experiência de trabalhar com estes materiais no laboratório indica que a adição de $4 \%$ de óleo, como praticado aqui, provavelmente nem seja necessária, desde que sejam empregadas concentrações de intermediárias a altas SBS na presença de pelo menos $1 \%$ de TITAN.

\subsubsection{Ordenamento das misturas}

A Figura 6.3 apresenta o ordenamento final baseado na Tabela 5.86, atribuindo-se peso 1 a todas as propriedades analisadas. 


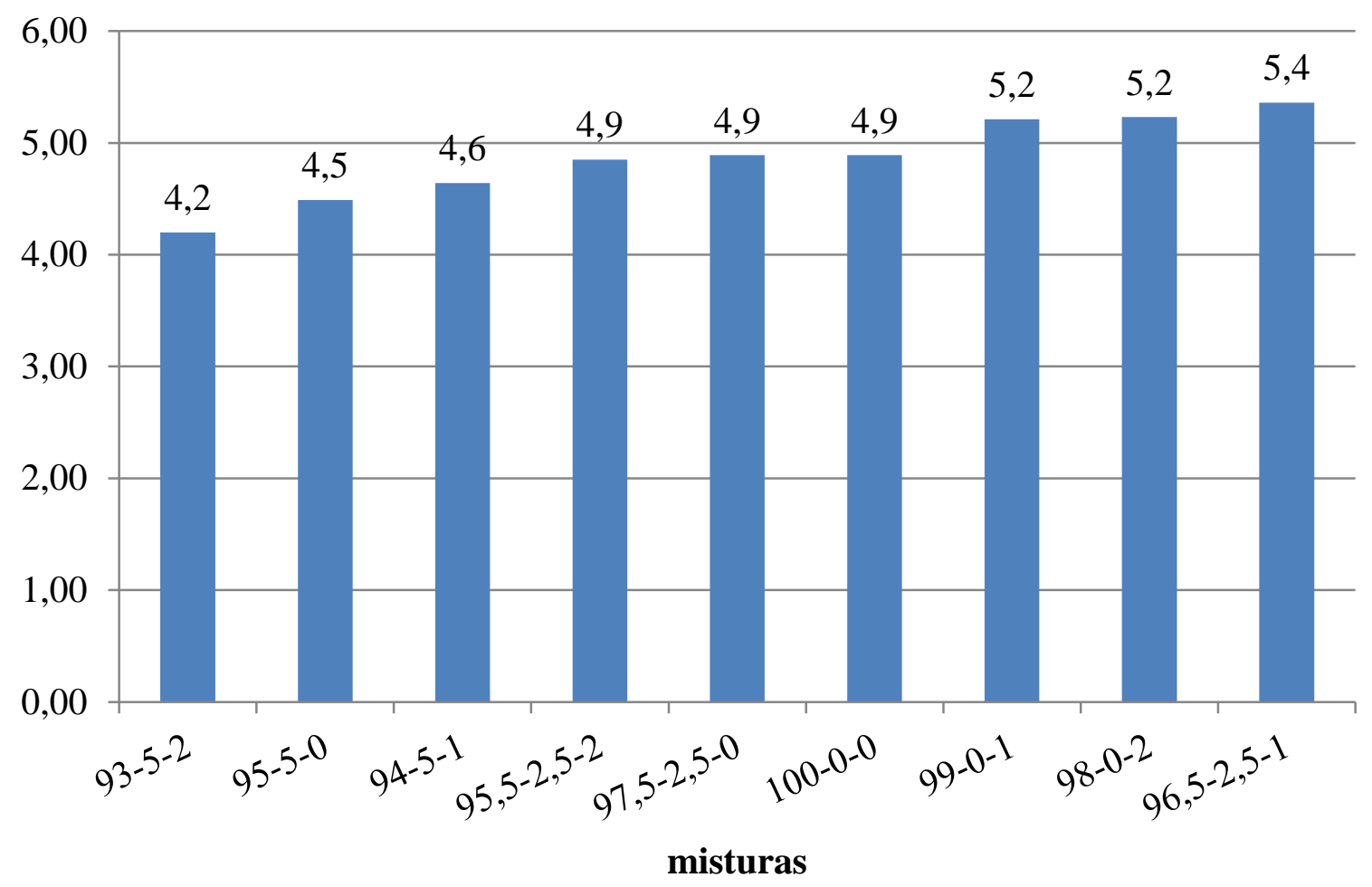

Figura 6.3 - Ordenamento das colocações médias das misturas por requisitos de interesse

O ordenamento mostra que a mistura 93-5-2 apresenta a melhor colocação (menor média final) e, consequentemente, os melhores resultados em um contexto geral. A mistura 96,5-2,5-1 apresenta a pior colocação (maior média final) e, consequentemente, os piores resultados em um contexto geral. A mistura 93-5-2 é a única a ocupar a quarta posição da ordenação, ao passo que todas as demais ocupam a quinta posição.

A Figura 6.4 e 6.5 apresentam um reagrupamento dos resultados do mesmo ordenamento, de forma a tornar mais clara a visualização dos efeitos do aumento da proporção de SBS, para os três níveis de teor de TITAN, e do aumento da proporção de TITAN, para os três níveis de teor de SBS. 


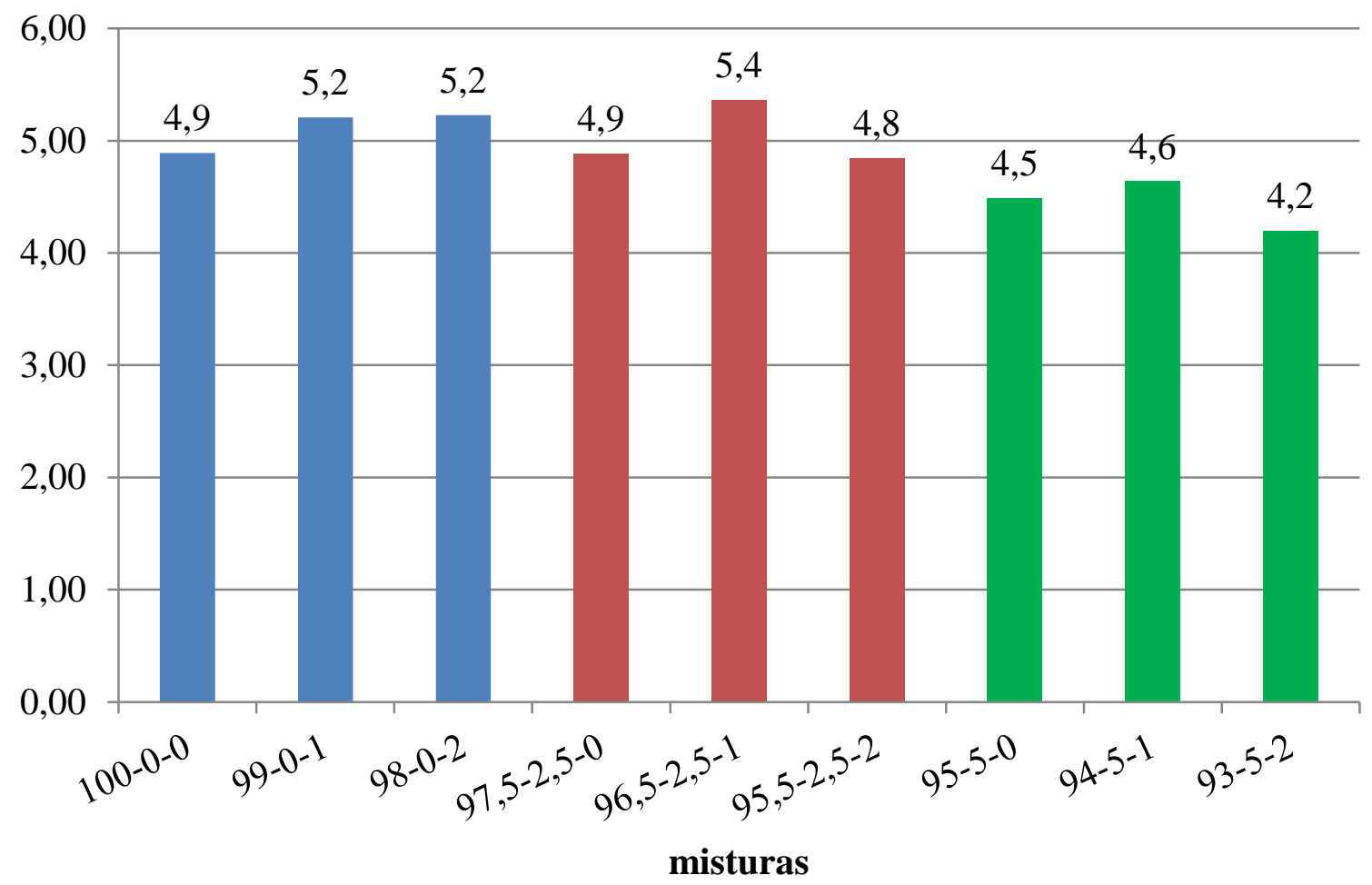

Figura 6.4 - Posições médias das misturas por grupos com teores iguais de SBS

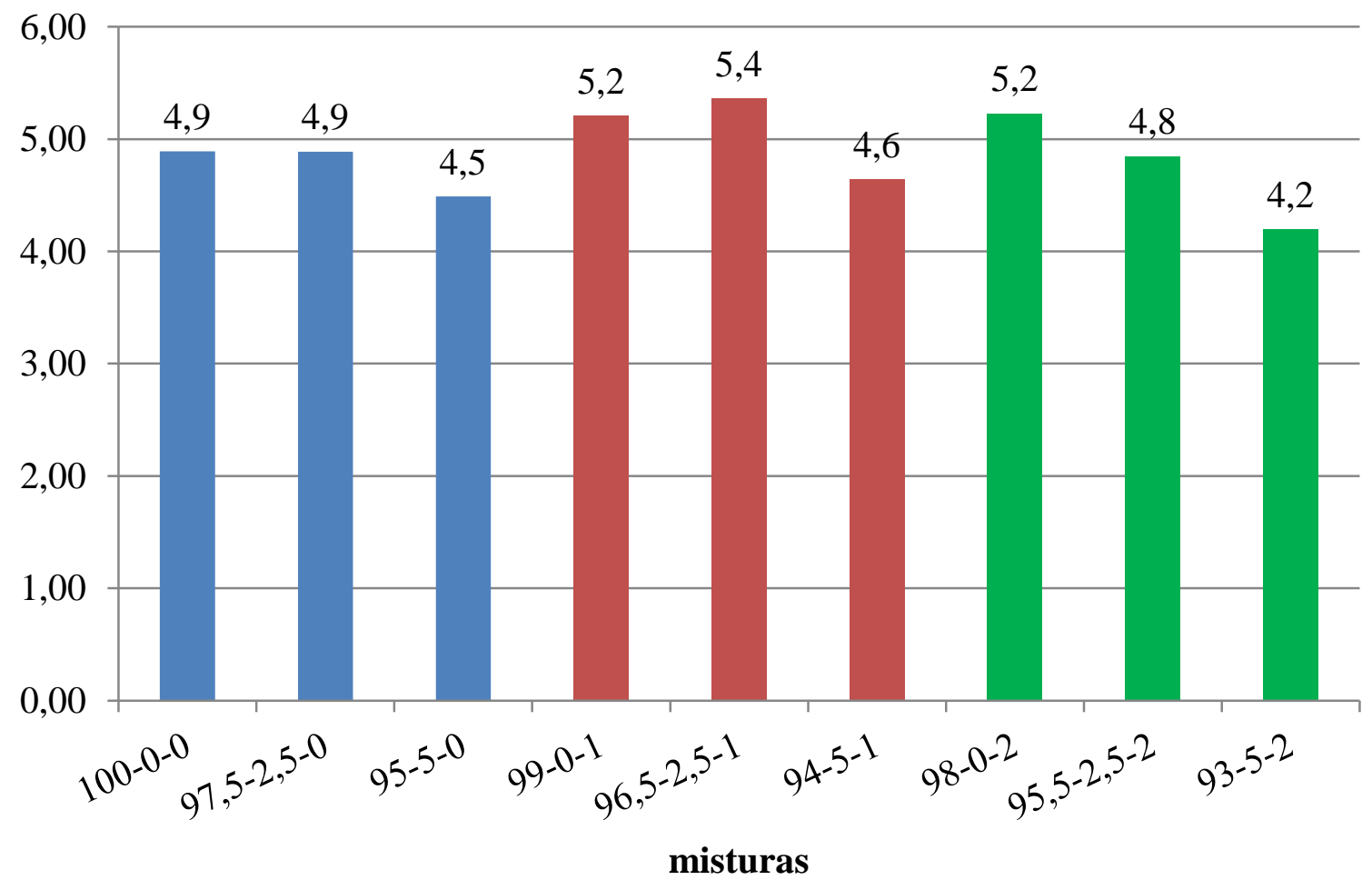

Figura 6.5 - Posições médias das misturas por grupos com teores iguais de TITAN 
Pela Figura 6.4, percebe-se, para o grupo de misturas com 0\% de SBS (100-0-0, 99-0-1 e 98-0-2), que ao se adicionar o TITAN em qualquer proporção, ocorre perda de colocação. Percebe-se, para o grupo de misturas com 2,5\% de SBS (97,5-2,5-0, 96,5-2,5-1 e 95,5-2,5-2), que ao se adicionar $1 \%$ de TITAN, ocorre uma ligeira perda de colocação (de 4,9 para 5,4) e, ao se adicionar $2 \%$ de TITAN, ocorre um ligeiro ganho de colocação (de 4,9 para 4,8). Percebe-se, para o grupo de misturas com 5\% de SBS (95-5-0, 94-5-1 e 93-5-2), que ao se adicionar $1 \%$ de TITAN, ocorre uma ligeira perda de colocação (de 4,5 para 4,6) e, ao se adicionar $2 \%$ de TITAN, ocorre ganho de colocação (de 4,5 para 4,2). Em linhas gerais, se vê uma ligeira perda de colocação, nos três teores de SBS, em torno do teor de $1 \%$ de TITAN, o que leva a crer que este teor impõe um pequeno prejuízo às propriedades e índices monitorados e que teores mais altos de TITAN (ao redor de 2\%) seriam mais indicados. Fica evidente também que a adição de teores mais altos de SBS melhoram ligeiramente a colocação média e também que a adição de teores mais altos de TITAN melhoram ainda mais a colocação média.

Pela Figura 6.5, percebe-se, para o grupo de misturas com 0\% de TITAN (100-0-0, 97,5-2,5-0 e 95-5-0), que a adição de 2,5\% de SBS não altera a colocação média (se mantém em torno da posição 5) e que a adição de 5\% de SBS melhora ligeiramente a colocação média (de 4,9 para 4,5). Percebe-se, para o grupo de misturas com 1\% de TITAN (99-0-1, 96,5-2,5-1 e 94-5-1), que ao se adicionar 2,5\% de SBS ocorre uma ligeira perda de colocação média (de 5,2 para 5,4) e, ao se adicionar 5\% de SBS, ocorre ganho de colocação média (de 5,2 para 4,6). Percebe-se, para o grupo de misturas com $2 \%$ de TITAN (98-0-2, 95,5-2,5-2 e 93-5-2), que ao se adicionar 2,5\% de SBS ocorre ganho de colocação média (de 5,2 para 4,8) e, ao se adicionar 5\% de SBS, ocorre um ganho ainda maior de colocação (de 5,2 para 4,2). Em linhas gerais, o aumento da proporção de copolímero tende a promover ganho de colocação, o que se verifica nos três níveis de teor de TITAN, mas mais notadamente no teor de $2 \%$ de TITAN. Tal constatação vai ao encontro do observado anteriormente, reforçando a evidência de que o teor de $2 \%$ de TITAN se mostra mais efetivo que teores menores. 


\subsubsection{Considerações finais}

Cabe ressaltar algumas considerações quanto às propriedades avaliadas (observar que a mistura 100-0-0 é diferente do CAP de base, visto que a mistura 100-0-0 apresenta 4\% de óleo aromático em peso):

- $\quad$ para aumentar o grau de desempenho (PG) de 64 (PG do CAP 50/70 puro) para 70, formulações como a 96,8-3,2-0, a 98,5-0-1,5, a 97,8-1-1,2, a 97,5-1,5-1, a 97,2-2-0,8 e a $97-$ 2,5-0,5 poderiam ser empregadas; para alcançar o PG 76, formulações como a 94,2-3,8-2, a 95,7-4,3-0, a 96-3,5-0,5, a 96,3-2,5-1,2 e a 96,2-3-0,8 poderiam ser empregadas;

- $\quad$ o TITAN praticamente não afeta a viscosidade seja na condição virgem ou envelhecida a curto prazo, ou seja, nem a aumenta nem a diminui, enquanto o SBS tende a aumentá-la;

- $\quad$ o incremento de viscosidade diminui com a adição de SBS, ao passo que o TITAN, dependendo da temperatura, pode aumentar ou diminuir este índice de envelhecimento; isto quer dizer que o copolímero contribui com o aumento da resistência ao envelhecimento a curto prazo e que o TITAN pode contribuir ou prejudicar, a depender da temperatura;

- nenhuma das misturas apresentou perda de massa, ao passar pelo processo de envelhecimento a curto prazo, maior que $0,5 \%$;

- quando se comparam os índices de sensibilidade ao envelhecimento a curto prazo, observa-se que o incremento de viscosidade das misturas fica em torno de 1,35 vezes (considerando as medidas de viscosidade realizadas nas temperaturas entre 135 e $177^{\circ} \mathrm{C}$ ), enquanto o aumento do módulo complexo $\left(\mathrm{G}^{*}\right)$ fica em torno de 1,55 vezes (considerando as medidas realizadas nas temperaturas entre 4 e $88^{\circ} \mathrm{C}$, com incrementos de $12^{\circ} \mathrm{C}$ ) e o aumento de $\mathrm{G}^{*} / \operatorname{sen}(\delta)$ fica em torno de 1,63 vezes (nas temperaturas entre 52 e $88^{\circ} \mathrm{C}$, com incrementos de $\left.12^{\circ} \mathrm{C}\right)$;

- $\quad$ o TITAN, entre as temperaturas de 4 a $88^{\circ} \mathrm{C}$, é mais efetivo que o SBS em tornar as misturas menos sensíveis ao envelhecimento, tanto a curto quanto a longo prazo, e, sob altas temperaturas $\left(135\right.$ a $\left.177^{\circ} \mathrm{C}\right)$ o TITAN passa a tornar as misturas mais sensíveis ao envelhecimento;

- $\quad$ a adição de TITAN melhora a estabilidade à estocagem do ligante asfáltico modificado com copolímero SBS - exemplos: a relação topo/fundo para o módulo complexo das misturas com $2,5 \%$ de SBS cai de 3,25 para 1,44 com a adição de $1 \%$ de TITAN e cai para 1,78 com a 
adição de 2\% de TITAN; para as misturas com 5,0\% de SBS, a relação topo/fundo para o módulo complexo cai de 71,10 para 18,39 com a adição de $1 \%$ de TITAN e cai para 14,32 com a adição de $2 \%$ de TITAN;

- $\quad$ tanto o TITAN quanto o SBS diminuem os valores de $\mathrm{J}_{\mathrm{nr}}$ a 100 e $3.200 \mathrm{~Pa}$, a 52, 58, 64 e $70^{\circ} \mathrm{C}$, e aumentam o percentual de recuperação a 100 e $3.200 \mathrm{~Pa}$, nestas quatro temperaturas, o que contribui com o aumento da resistência à deformação da mistura asfáltica;

- $\quad$ o TITAN aumenta o parâmetro $\mathrm{J}_{\text {nr,diff }}$ nas temperaturas de $52,58,64$ e $70^{\circ} \mathrm{C}$, ao passo que o SBS aumenta o parâmetro $\mathrm{J}_{\text {nr,diff }}$ apenas a 64 e $70^{\circ} \mathrm{C}$ e o reduz a 52 e $58^{\circ} \mathrm{C}$ - o TITAN não se mostrou um aditivo apropriado para ligantes asfálticos modificados com copolímero SBS à luz deste parâmetro por aumentar expressivamente os valores de $\mathrm{J}_{\mathrm{nr} \text {,diff, }}$, tornando seu emprego inviável em teores acima de $0,5 \%$ para teores de SBS acima de $3 \%$;

- misturas com altos teores de modificadores apresentaram valores de $G^{*} / \operatorname{sen}(\delta)$ muito superiores aos da mistura 100-0-0 (em torno de pelo menos 3 vezes); os valores de $\mathbf{J}_{\mathrm{nr}}$ apresentados pelas misturas com altos teores de modificadores também são pelo menos 3 vezes maiores que os da mistura 100-0-0;

- $\quad$ tanto o TITAN quanto o SBS aumentam a tolerância ao dano por fadiga (aumentam o parâmetro $\mathrm{a}_{\mathrm{f}}$ ) a $25^{\circ} \mathrm{C}$ das misturas envelhecidas a longo prazo e aumentam a vida de fadiga sob baixas amplitudes de deformação a $25^{\circ} \mathrm{C}$; tanto o TITAN quanto o SBS diminuem a vida de fadiga sob altas amplitudes de deformação a $25^{\circ} \mathrm{C}$ e ambos aumentam a temperatura em que o parâmetro $\mathrm{G}^{*} . \operatorname{sen}(\delta)$ atingem os valores de 5 e $6 \mathrm{MPa}$ (tráfegos $\mathrm{S}$ e H/V);

- $\quad$ as formulações com SBS e TITAN apresentaram valores de $G^{*} \cdot \operatorname{sen}(\delta)$ em média 30\% acima dos valores apresentados pelas formulações apenas com SBS; para o parâmetro $\mathrm{a}_{\mathrm{f}}$, este aumento foi em torno de 20\%; para a vida de fadiga a 3\% de amplitude de deformação, este aumento foi de $60 \%$ e, para a vida de fadiga a $30 \%$ de amplitude de deformação, ocorreu uma diminuição de $60 \%$ na vida de fadiga.

Acerca das características escolhidas para mensurar a melhora ou piora da estabilidade das misturas asfalto+SBS com a adição de TITAN, podem ser feitas as seguintes observações: (i) a estabilidade à estocagem é melhorada com a adição de TITAN, em particular no teores entre 1 e 2\%; (ii) a sensibilidade ao envelhecimento tanto a curto quanto a longo prazos diminui com a adição de TITAN; (iii) a adição de TITAN aumenta a resistência à deformação permanente, à luz dos parâmetros $\mathrm{J}_{\mathrm{nr}} \mathrm{e} \mathrm{R}$ e aumenta a sensibilidade dos ligantes asfálticos 
modificados com SBS a mudanças bruscas nos níveis de tensão aplicados; e (iv) a adição de TITAN contribui com o aumento da resistência à fadiga, à luz dos parâmetros $\mathrm{N}_{\mathrm{f}}$, a baixos níveis de deformação, e $\mathrm{a}_{\mathrm{f}}$, e a prejudica reduzindo o parâmetro $\mathrm{N}_{\mathrm{f}}$ a altos níveis de deformação e aumentando a temperatura crítica de fadiga ou o parâmetro $\mathrm{G}^{*} \cdot \operatorname{sen}(\delta)$. Tendo por base estas evidências, é possível concluir que a adição de TITAN, em linhas gerais, melhorou a estabilidade dos ligantes asfálticos modificados com até 5,0\% de SBS. Com base nas análises realizadas, é possível afirmar que teores da ordem de 1 a $2 \%$ de TITAN, para teores de SBS entre 3,0 e 5,0\%, são recomendáveis, à luz das propriedades, índices e parâmetros analisados neste trabalho.

A faixa de valores de TITAN aqui recomenda foi arbitrada considerando os resultados dos ordenamentos e as indicações provenientes da análise de superfície de resposta. O ordenamento final representa uma combinação de diversos ordenamentos individuais, derivados de diversas propriedades, medidas em diversas condições de ensaio, e de diversos índices e parâmetros. No caso das análises das superfícies de resposta, apenas os parâmetros de deformação permanente e fadiga foram considerados. Os ordenamentos forneceram evidências de que teores de TITAN entre 1 e 2\% seriam recomendáveis. Já as análises das

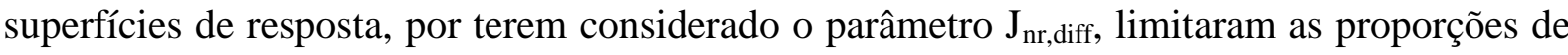
TITAN entre 0 e $0,8 \%$. No entanto, quando se desconsidera o parâmetro $\mathrm{J}_{\mathrm{nr} \text {,diff, }}$ a análise das superfícies de resposta indica que qualquer proporção de TITAN entre 0 e $2 \%$ pode ser utilizada. $\mathrm{O}$ descarte do parâmetro $\mathrm{J}_{\mathrm{nr} \text {,diff }}$ pode ser feito se se considerar que este parâmetro não é um indicador direto de resistência à deformação permanente e indica apenas quão sensível é o ligante asfáltico a mudanças bruscas nos níveis de tensão aplicados.

É importante salientar que os resultados aqui obtidos e as conclusões aqui destacadas somente se aplicam aos materiais empregados no preparo das formulações aqui estudadas, aos limites das proporções de materiais aqui empregadas, às condições de preparação das formulações e de envelhecimento das amostras e às condições de ensaio, não podendo ser extrapolados para outros materiais, para proporções de copolímero SBS e TITAN fora dos intervalos aqui empregados, para condições de preparo das amostras e de envelhecimento distintas das aqui empregadas e para condições de ensaio distintas das aqui empregadas.

Os resultados deste estudo representam uma pequena contribuição à área de ligantes asfálticos nos seguintes aspectos: 
- $\quad$ emprego da cera de polietileno (TITAN) como agente de compatibilização para asfaltos modificados com copolímero SBS;

- $\quad$ esclarecimentos sobre os efeitos da proporção de copolímero SBS e de polietileno de alta densidade e baixo peso molecular oxidado (TITAN) sobre propriedades reológicas de ligantes asfálticos modificados compostos com estes materiais;

- $\quad$ esclarecimento sobre os efeitos do envelhecimentos a curto e a longo prazos (RTFOT e PAV) sobre propriedades reológicas de ligantes asfálticos modificados com os polímeros aqui utilizados; e,

- indicação das formulações mais indicadas de ligantes asfálticos modificados com copolímero SBS e cera de polietileno (TITAN).

\subsection{Sugestões para pesquisas futuras}

Algumas sugestões de pesquisas futuras são listadas:

- $\quad$ aplicar o procedimento empregado aqui para outros tipos de ligante asfáltico;

- expandir o experimento, utilizando diferentes variáveis de processo na fabricação das misturas (tempo, temperatura e velocidade de agitação);

- $\quad$ variar o teor de óleo aromático empregado entre 0 a $4 \%$ em peso para tentar encontrar teores ideais a serem empregados nas misturas compostas com copolímero SBS e TITAN;

- empregar o TITAN associado com outros modificadores que gerem problemas de estabilidade à estocagem, como por exemplo, a borracha moída de pneus insersíveis, o EVA, o polietileno e o SBR, entre outros;

- empregar o TITAN associado a outros modificadores para avaliar possíveis melhoras nas características reológicas do produto final;

- $\quad$ realizar o ensaio LAS com os materiais aqui estudados em outras temperaturas;

- testar os ligantes asfálticos modificados deste trabalho em misturas asfálticas com a realização de ensaios mecânicos;

- testar o ligante asfáltico modificado resultante deste trabalho em outros testes reológicos não realizados nesta pesquisa, como exemplo, o BBR. 


\section{REFERÊNCIAS BIBLIOGRÁFICAS}

AASHTO (2009). AASHTO M320 - Standard specification for performance graded asphalt binder. American Association of State Highway and Transportation Officials, Washington, D.C.

AFLAKI, S; HAJIKARIMI, P. (2012). Implementing viscoelastic rheological methods to evaluate low temperature performance of modified asphalt binders. Construction and Building Materials, v. 36, p. 110-118.

AIREY, G. D. (2002). Rheological evaluation of ethylene vinyl acetate polymer modified bitumens. Construction and Building Materials, v. 16, n. 8, p. 473-487.

AIREY, G. D. (2003). Rheological properties of styrene butadiene styrene polymer modified road bitumens. Fuel, v. 82, n. 14, p. 1709-1719.

AMARAL, S. C. (2000). Estudos de misturas asfálticas densas com agregados do estado do Pará, utilizando asfalto convencional (CAP-40) e asfalto modificado com polímero SBS (Betuflex B 65/60). Dissertação (Mestrado) - Escola de Engenharia de São Carlos, Universidade de São Paulo, São Carlos.

ANDERSON, D. A. et al. (1994). Binder characterization and evaluation, volume 3: Physical characterization. Strategic Highway Research Program, National Research Council, Report No. SHRP-A-369.

ANDERSON, M. et al. (2010). MSCR: A better tool for characterizing high temperature performance properties. Asphalt, v. 25, n. 2.

ASPHALT INSTITUTE. (2010a). Implemetion of the multiple stress creep recovery test and specification. Asphalt Institute Technical Advisory Committee, Federal Highway Administration.

ASPHALT INSTITUTE. (2010b). Guidance on the use of the MSCR test with the AASHTO M320 specification. Asphalt Institute Technical Advisory Committee, Executive Offices and Research Center. Lexington, KY.

BAHIA, H. U. et al. (1999). Non-linear viscoelastic and fatigue properties of asphalt binders. Journal of the Association of Asphalt Paving Technologists, v. 68, p. 1-34. 
BAHIA, H. U. et al. (2001). Development of binder specification parameters based on characterization of damage behavior (With Discussion). Journal of the Association of Asphalt Paving Technologists, v. 70.

BAUMGARDNER, G. L. et al. (2005). Polyphosphoric acid modified asphalt: proposed mechanisms. Journal of the Association of Asphalt Paving Technologists, v. 74, p. 283305.

BECKER M, Y. et al. (2003). Use of rheological compatibility criteria to study SBS modified asphalts. Journal of applied polymer science, v. 90, n. 7, p. 1772-1782.

BELLOMY, R. C.; MCGINNIS, E. L. (1994). Bitumen compositions containing bitumen, polymer and sulfur. U.S. Patent n. 5,371,121.

BRINGEL, R. M. et al. (2006). Comportamento reológico do ligante asfáltico modificado por SBS e diluente aromático como compatibilizante. Instituto Brasileiro de Petróleo e GásIBP, v. 18, p. 27.

BUNCHER, M. (2005). Polyphosphoric acid modification of asphalt. Asphalt Magazine. Fall, p.38-40.

CERATTI, J. A. et al. (1996). Estudo do comportamento mecânico de concreto asfáltico com ligante modificado com polímeros. $\mathbf{1 3}^{\mathbf{0}}$ Encontro de Asfalto, p. 90-103.

CORNELL, J. (2002). Experiments with mixtures: design, models and the analysis of mixture data. New York: John Wiley.

COSTA, C. A. (2002). O desenvolvimento do emprego de asfaltos modificados por polímeros na região Nordeste do Brasil. $\mathbf{1 6}^{\mathbf{0}}$ Encontro de Asfalto, IBP, Rio de Janeiro.

DANTAS, M. S. G. (2000). Obtenção de antioxidante a partir de derivados do LCC. Dissertação (Mestrado) - Universidade Federal do Rio Grande do Norte, Natal.

DANTAS, T. N. C. et al. (2003). Novel antioxidants from cashew nut shell liquid applied to gasoline stabilization. Fuel, v. 82, n. 12, p. 1465-1469.

DE CARCER, Í. et al. (2014). Storage stability of SBS/sulfur modified bitumens at high temperature: Influence of bitumen composition and structure. Construction and Building Materials, v. 52, p. 245-252. 
DNER. (1998). Departamento Nacional de Estradas e Rodagem. Pesquisa de asfaltos modificados por polímeros. Relatório Final. Ministério dos Transportes: Diretoria de Desenvolvimento Tecnológico. Tomo I e II.

DOMINGOS, M. D. I. (2011). Caracterização do comportamento fluência-recuperação de ligantes asfálticos modificados virgens e envelhecidos. Dissertação (Mestrado) - Escola de Engenharia de São Carlos, Universidade de São Paulo, São Carlos.

DOMINGOS, M. D. I. et al. (2012) Viscosidade rotacional de ligantes asfálticos modificados de mesmo grau de desempenho. Revista Transporte. v.20, p. 15-22.

DOMINGOS, M. D. I.; FAXINA, A. L. (2013). Avaliação do comportamento fluênciarecuperação de ligantes asfálticos modificados com SBS e PPA. Revista Transporte. v. 21, p. 51-58.

EL-SHAFIE, M. et al. (2012). The addition effects of macro and nano clay on the performance of asphalt binder. Egyptian Journal of Petroleum, v. 21, p. 149-154.

FAKHRI, M.; et al. (2013) Impact of loading frequency on the fatigue behavior of SBS modified asphalt mixtures. Procedia-Social and Behavioral Sciences, v. 104, p. 69-78.

FAXINA, A. L. (2002). Estudo em laboratório do desempenho de concreto asfáltico usinado a quente empregando ligante tipo asfalto-borracha. Dissertação (Mestrado) Escola de Engenharia de São Carlos, Universidade de São Paulo, São Carlos.

FAXINA, A. L. (2006). Estudo da viabilidade técnica do uso de resíduo de óleo de xisto como óleo extensor em ligantes asfalto-borracha. Tese (Doutorado) - Escola de Engenharia de São Carlos, Universidade de São Paulo, São Carlos.

FAXINA, A.L. et al. (2010). Envelhecimento a curto e longo prazos de asfaltos-borracha compostos com resíduo de óleo de xisto e ácido polifosfórico. In: $25^{\circ}$ Congresso de Pesquisa e Ensino em Transportes, Associação Nacional de Pesquisa e Ensino em Transportes ANPET, Belo Horizonte.

FEE, D.; et al. (2010). Polyphosphoric acid modification of asphalt. Transportation Research Record: Journal of the Transportation Research Board, n. 2179, p. 49-57.

FERNANDES, M. R. S.; LOURENÇO, G. L. (2006). Efeito da adição de polímero e reticulante em propriedades do ligante asfáltico. Instituto Brasileiro de Petróleo, Gás e Biocombustíveis - IBP. 
FERNANDES, R.; et al. (2008). Reologia de asfaltos modificados com SBS. Instituto Brasileiro de Petróleo, Gás e Biocombustíveis - IBP.

GALOOYAK, S. S.; et al. (2010). Rheological properties and storage stability of bitumen/SBS/montmorillonite composites. Construction and Building Materials, v. 24, n. 3, p. 300-307.

HINTZ, C. (2012). Understanding mechanisms leading to asphalt binder fatigue. Ph.D Thesis. University of Wisconsin - Madison, Madison.

IBP (1996). Instituto Brasileiro de Petróleo. Informativo, O Asfalto. Rio de Janeiro, pp. 1-5.

ICL PERFORMANCE PRODUCTS LP. (2008). Best practices for PPA modification of asphalt. Final 053108.

JAHROMI, S. G.; KHODAII, A. (2009). Effects of nanoclay on rheologial properties of bitumen binder. Construction and Building Materials, v. 23, p. 2894-2904.

JASSO, M. et al. (2013). Preparation and properties of conventional asphalt modified by physical mixtures of linear SBS and montmorillonite clay. Construction and Building Materials, v. 38, p. 759-765.

JOHNSON, C. M. (2010). Estimating asphalt binder fatigue resistance using an accelerated test method. Ph.D Thesis. University of Wisconsin - Madison, Madison.

KANG, Y et al. (2015). Rheological behaviors of epoxy asphalt binder in comparison of base asphalt binder and SBS modified asphalt binder. Construction and Building Materials, v. 76, p. 343-350.

KHODAII, A.; MEHRARA, A. (2009). Evaluation of permanent deformation of unmodified and SBS modified asphalt mixtures using dynamic creep test. Construction and Building Materials, v. 23, n. 7, p. 2586-2592.

KING, G. et al. (1999). Additives in asphalt. Journal of the Association of Asphalt Paving Technologists. White Bear Lake, v. 68, p. 32-69.

LEITE, L. F. M. (1999). Estudos de preparo e caracterização de asfaltos modificados por polímero. Tese (Doutorado) - Universidade Federal do Rio de Janeiro, Rio de Janeiro. 
LESUEUR, D. (2009). The colloidal structure of bitumen: Consequences on the rheology and on the mechanisms of bitumen modification. Advances in colloid and interface science, $\mathrm{v}$. 145 , n. 1 , p. 42-82.

LIANG, M. et al. (2015). Investigation of the rheological properties and storage stability of CR/SBS modified asphalt. Construction and Building Materials, v. 74, p. 235-240.

LU, X.; ISACSSON, U. (1997a). Influence of styrene-butadiene-styrene polymer modification on bitumen viscosity. Elsevier, p. 1353-1359.

LU, X.; ISACSSON, U. (1997b). Influence of styrene-butadiene-styrene polymer modification on bitumen viscosity. Fuel, p. 1353-1359.

LU, X. et al. (1998). Low-temperature properties of styrene-butadiene-styrene polymer modified bitumens. Construction and Building Materials, v. 12, n. 8, p. 405-414.

LUCENA, M. C. C. (2005). Caracterização química e reológica de asfaltos modificados por polímeros. Tese (Doutorado) - Universidade Federal do Ceará, Fortaleza.

LUCENA, M. C. C. et al. (2002). Estudo reológico de asfaltos modificados por SBS. Anais do $1^{\circ}$ Encontro de Asfalto do Instituto Brasileiro de Petróleo e Gás - IBP, Rio de Janeiro.

LUCENA, M. C. C. et al. (2003). Efeito da adição de SBS nas propriedades químicas e reológicas de asfalto oriundo de petróleo brasileiro. Anais do $2^{\circ}$ Congresso Brasileiro de P\&D em Petróleo \& Gás, Rio de Janeiro, p. 160-160.

LUCENA, M. C. C. et al. (2004). Reologia e asfaltos brasileiros puros e modificados com SBS. Anais do $28^{\circ}$ Congresso de Pesquisa e Ensino em Transportes, ANPET, Florianópolis, Brasil, p. 15-27.

MALDONADO, P. et al. (1979). Process for preparing polymer-bitumen compositions. US Patent 4145322.

MARTONO, W. et al. (2007). Effect of testing geometry on measuring fatigue of asphalt binders and mastics. Journal of Materials in Civil Engineering, v. 19, n. 9, p. 746-752.

MASSON, J. F. (2008) Brief review of the chemistry of polyphosphoric acid (PPA) and bitumen. Energy \& Fuels, v. 22, n. 4, p. 2637-2640. 
MERUSI, F. et al. (2012). Linear viscoelastic behaviour of asphalt binders modified with polymer/clay nanocomposites. Elsevier, v. 53, p. 335-345.

MONTGOMERY, D. C.; PECK, E. A. (1992). Introduction to linear regression analysis. $2^{\text {nd }}$.ed. New York: John Wiley.

MORAES, R. (2007). Estudo químico e reológico de ligantes asfálticos modificados por polímeros e aditivos. Dissertação (Mestrado) - Universidade Federal do Ceará, Fortaleza.

MORILHA, A. J. (2004). Estudo sobre a ação de modificadores no envelhecimento dos ligantes asfálticos e nas propriedades mecânicas e de fadiga das misturas asfálticas. Dissertação (Mestrado) - Universidade Federal de Santa Catarina, Florianópolis.

MYERS, R. H.; MONTGOMERY, D. C. (1995). Response surface methodology: process and product optimization using designed experiments. New York: John Wiley.

NUÑEZ, J. Y. M. (2013). Caracterização à fadiga de ligantes asfálticos modificados envelhecidos a curto e longo prazo. Dissertação (Mestrado) - Escola de Engenharia de São Carlos, Universidade de São Paulo, São Carlos.

OUYANG, C. et al. (2005). Preparation and properties of styrene-butadiene-styrene copolymer/kaolinite clay compound and asphalt modified with the compound. Polymer degradation and stability, v. 87, n. 2, p. 309-317.

PAMPLONA, T. F. (2013). Efeito da adição de ácido polisfosfórico em ligantes asfálticos de diferentes fontes. Dissertação (Mestrado) - Escola de Engenharia de São Carlos, Universidade de São Paulo, São Carlos.

PAMPLONA, T. F. et al. (2014). Desenvolvimento recentes em ensaios de fadiga em ligantes asfálticos. Revista Transportes. v. 22, n. 3, p. 12-25.

PETZHOLD, C. L. (1989). Influência de ligações de hidrogênio sobre as propriedades de elastômeros e ligas elastoméricas. Dissertação (Mestrado) - Universidade Federal do Rio Grande do Sul, Rio Grande do Sul.

PLANCH, J. P. (1990). Method for the preparation of bitumen polymer compositions. WO Patent, v. 9002776.

POLACCO, G. et al. (2006). Effect of composition on the properties of SEBS modified asphalts. European polymer journal, v. 42, n. 5, p. 1113-1121. 
POLACCO, G. et al. (2006). Relation between polymer architecture and nonlinear viscoelastic behavior of modified asphalts. Current opinion in colloid \& interface science, v. 11, n. 4 , p. $230-245$.

RABÊLO, A. N. (2006). Contribuição ao estudo da imprimação betuminosa das bases rodoviárias do estado do Ceará. Dissertação (Mestrado) - Universidade Federal do Ceará, Fortaleza.

RODRIGUES, F. O. (2010). Efeito do líquido da castanha do caju (LCC) nas propriedades reológicas do ligante asfáltico modificado por SBS. Dissertação (Mestrado) Universidade Federal do Ceará, Fortaleza.

SENGOZ, B.; ISIKYAKAR, G. (2008). Evaluation of the properties and microstructure of SBS and EVA polymer modified bitumen. Construction and Building Materials, v. 22, n. 9, p. 1897-1905.

SHENOY, A. (2002). Fatigue testing and evaluation of asphalt binders using the dynamic shear rheometer. Journal of testing and evaluation, v. 30, n. 4, p. 303-312.

SILVA, L. S. et al. (2004). Study of rheological properties of pure and polymer-modified Brazilian asphalt binders. Journal of Materials Science, v. 39, n. 2, p. 539-546.

SOBREIRO, F. P. (2014). Efeito da adição de ácidos fosfóricos no comportamento reológico de ligantes asfálticos puros e modificados com copolímero SBS. Tese (Doutorado) - Escola de Engenharia de São Carlos, Universidade de São Paulo, São Carlos.

VERONESE, V. B. (2003). Desenvolvimento e avaliação de propriedades de misturas de poliestireno (OS) e copolímeros em bloco estireno-butadieno-estireno (SBS). Dissertação (Mestrado) - Departamento de Engenharia de Minas, Metalúrgica e de Materiais. Universidade Federal do Rio Grande do Sul, Porto Alegre.

WELBORN, J. T.; BABASHAK, J. F. (1958). A New Rubberized Asphalt for Roads.Journal of Highway Division, Proceedings of American Society of Civil Engineering, v. 1651.

WEN, G. et al. (2002) Rheological characterization of storage-stable SBS-modified asphalts. Polymer Testing, v. 21, n. 3, p. 295-302.

WU, S. et al. (2009). Influence of aging on the evolution of structure, morphology and rheology of base and SBS modified bitumen. Construction and Building Materials, v. 23, n. 2, p. 1005-1010. 
XIAO, F. et al. (2014). Rheological property investigations for polymer and polyphosphoric acid modified asphalt binders at high temperatures. Construction and Building Materials, v. 64, p. 316-323.

YILDIRIM, Y. (2007). Polymer modified asphalt binders. Construction and Building Materials, v. 21, n. 1, p. 66-72.

ZHANG, F. et al. (2010). Effect of ageing on rheological properties of storage-stable SBS/sulfurmodified asphalts. Journal of hazardous materials, v. 182, n. 1, p. 507-517.

ZHANG, F.; HU, C. (2013). The research for SBS and SBR compound modified asphalts with polyphosphoric acid and sulfur. Construction and Building Materials, v. 43, p. 461-468. 
ANEXO A

\section{Modelos de regressão, gráficos de efeitos dos componentes, superfícies de resposta e gráficos da análise de resíduos}

Este Anexo é destinado à apresentação dos modelos de regressão, dos gráficos de efeitos dos componentes, das superfícies de resposta e dos gráficos da análise de resíduos das propriedades modeladas descritas no Capítulo 4. A Tabela A.1 apresenta o pontos (ou medições) referentes para cada mistura.

Tabela A.1 - Pontos referentes a cada mistura

\begin{tabular}{cccc}
\hline $\begin{array}{c}\text { Ponto ou } \\
\text { medição }\end{array}$ & Asfalto & SBS & Titan \\
\hline 1, 10, 19 e 28 & 1,000 & 0,000 & 0,00 \\
$2,11,20$ e 29 & 0,980 & 0,000 & 0,02 \\
$3,12,21$ e 30 & 0,950 & 0,050 & 0,00 \\
$4,13,22$ e 31 & 0,930 & 0,050 & 0,02 \\
$5,14,23$ e 32 & 0,990 & 0,000 & 0,01 \\
$6,15,24$ e 33 & 0,975 & 0,025 & 0,00 \\
$7,16,25$ e 34 & 0,940 & 0,050 & 0,01 \\
$8,17,26$ e 35 & 0,955 & 0,025 & 0,02 \\
$9,18,27$ e 36 & 0,965 & 0,025 & 0,01 \\
\hline
\end{tabular}




\section{Modelo A.1 Grau de desempenho contínuo (continuous grade)}

O ponto 8 foi retirado para obtenção deste modelo. A exclusão deste ponto é justificada pela seguinte constatação: este valor destoa dos demais, estando a observação muito acima de 2 desvios padrãos nos gráficos de resíduos, sendo este ponto considerado "outlier". O modelo melhorou sem este ponto, sendo verificado um aumento do $\mathrm{R}^{2}$. Mesmo com a retirada, o valor apresentado pelo VIF ainda foi alto, portanto o modelo apenas pode ser empregado para estimativa de novas ocorrências na região experimental.

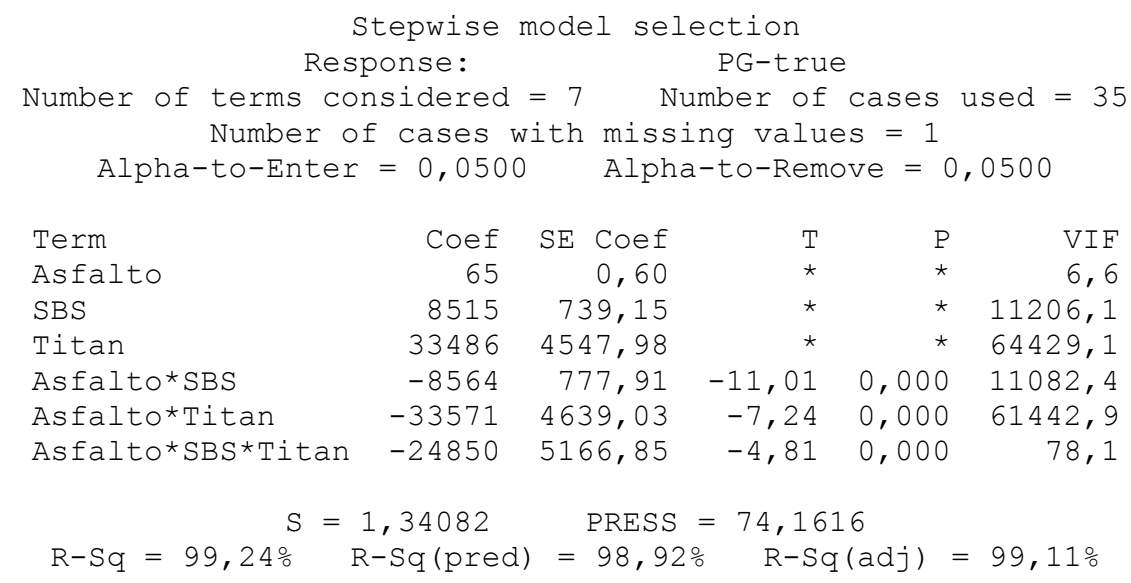

Residual Plots for PG-continuous

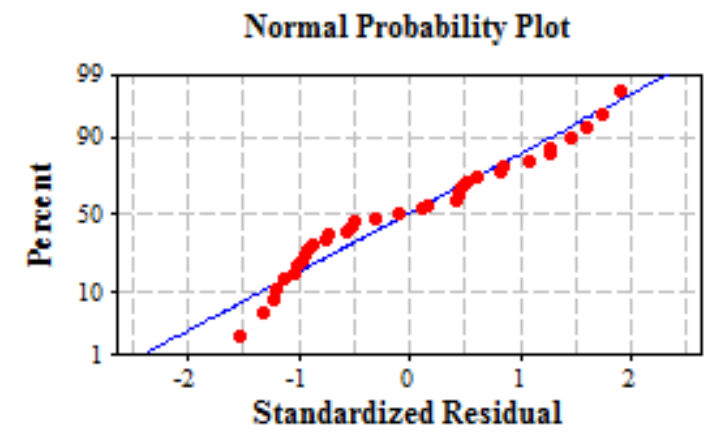

Histogram

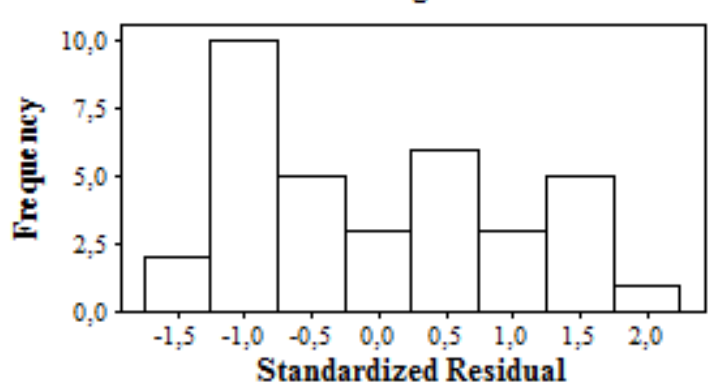

Versus Fits

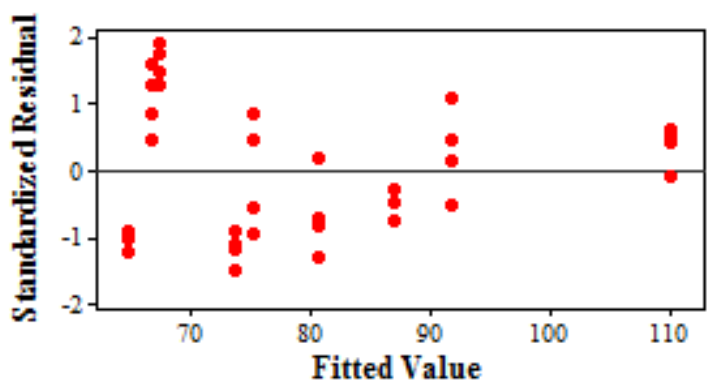

Versus Order

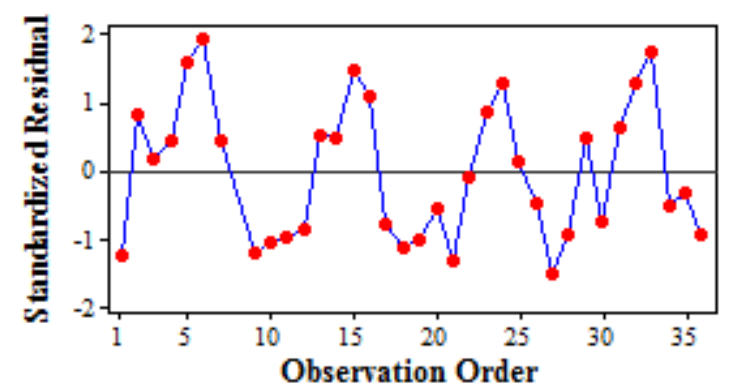

Figura A.1.1 - Análise de resíduos para o grau contínuo das misturas 


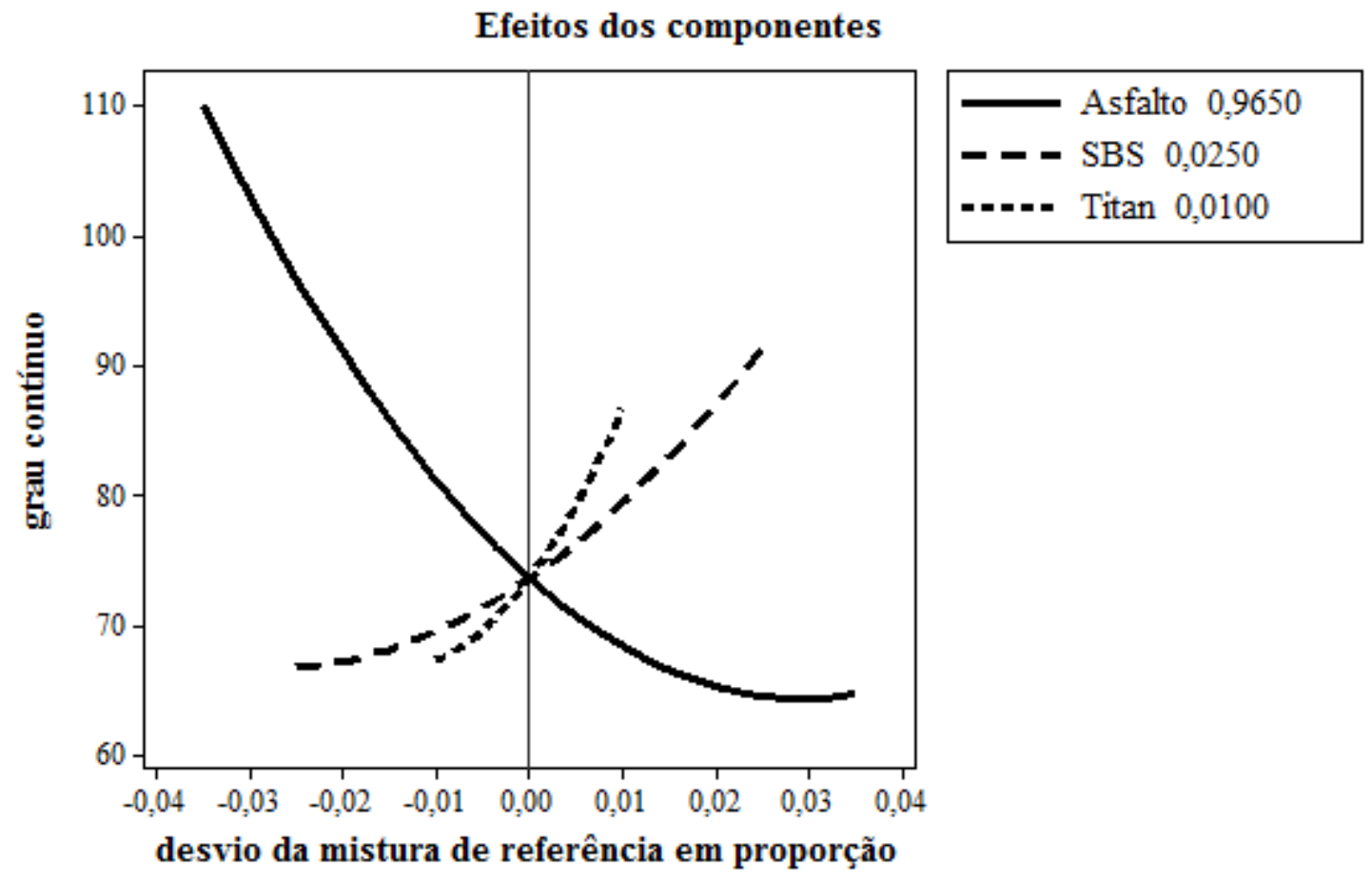

Figura A.1.2 - Efeitos dos componentes para o grau contínuo das misturas

Superfície de resposta para True-grade

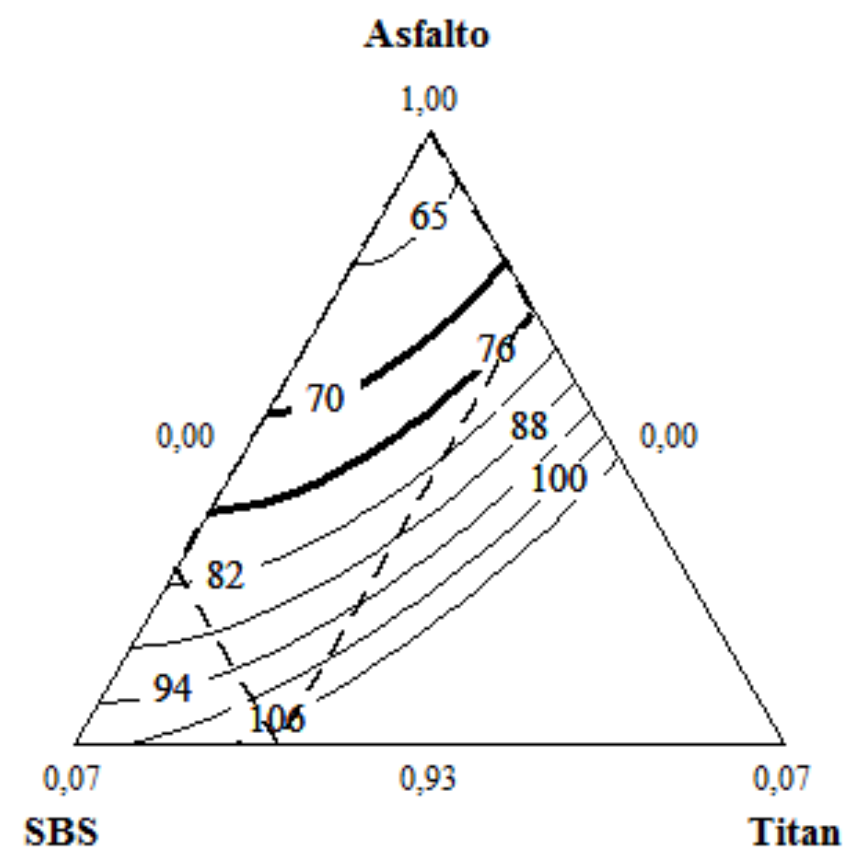

Figura A.1.3 - Superfície de resposta para o grau contínuo das misturas 


\section{Modelo A.2 Viscosidade na condição virgem a $135^{\circ} \mathrm{C}$}

Os pontos $1,3,4,8,13,16,22$ e 30 foram retirados para obtenção deste modelo. A exclusão destes pontos se justifica pela seguinte constatação: estes valores destoam dos demais, sendo observações muito acima de 2 desvios padrão nos gráficos de resíduos, sendo estes pontos considerados "outliers". O modelo melhorou sem estes pontos, sendo verificado um aumento do $\mathrm{R}^{2}$. Mesmo com as retiradas, o valor apresentado pelo VIF ainda foi alto, portanto o modelo apenas pode ser empregado para estimativa de novas ocorrências na região experimental.

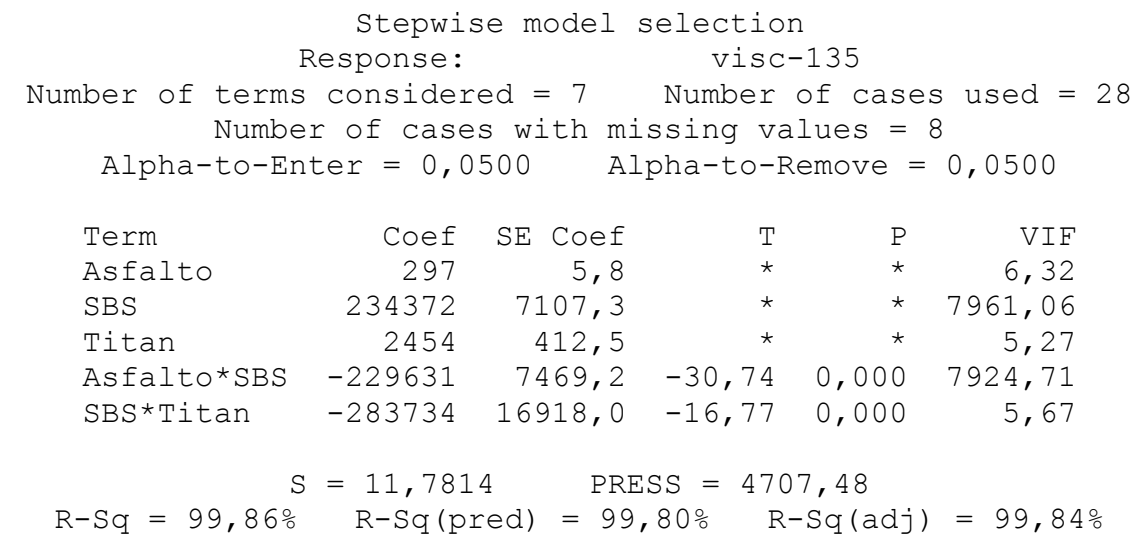

\section{Residual Plots for visc- 135}
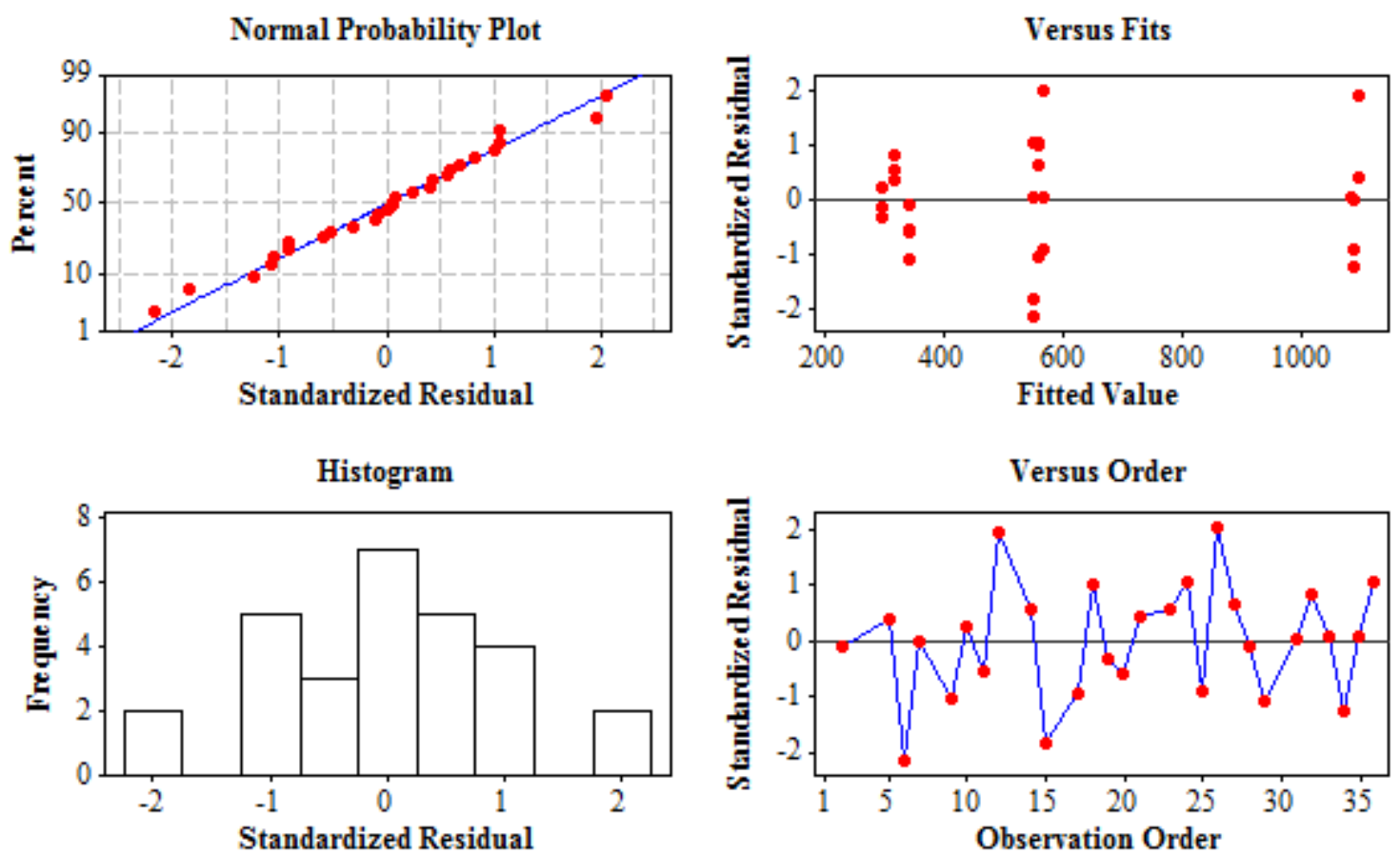

Figura A.2.1 - Análise de resíduos para viscosidade na condição virgem a $135^{\circ} \mathrm{C}$ 
Efeitos dos componentes

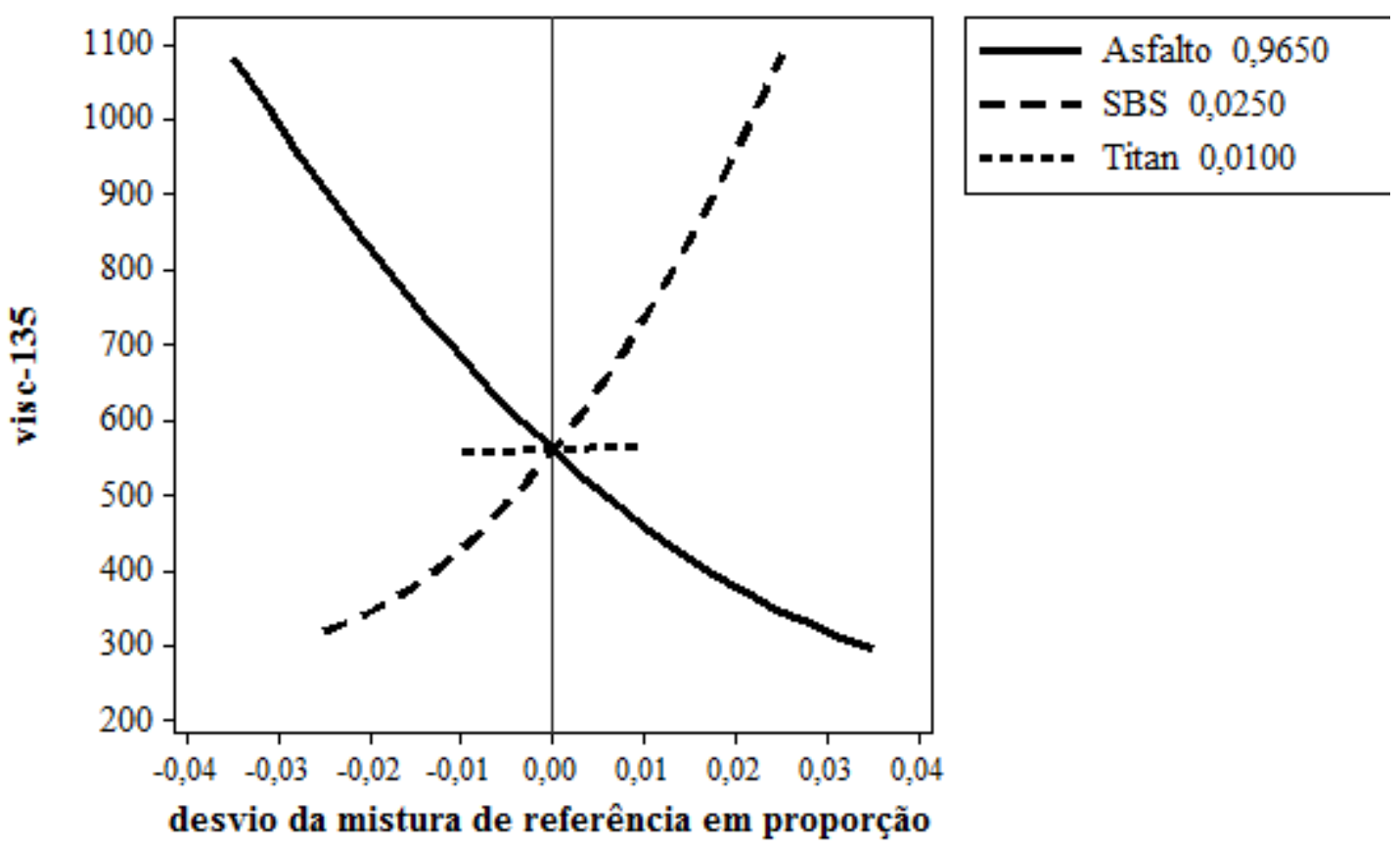

Figura A.2.2 - Efeitos dos componentes para viscosidade na condição virgem a $135^{\circ} \mathrm{C}$

Superfície de resposta para viscosidade virgem a $135^{\circ} \mathrm{C}$

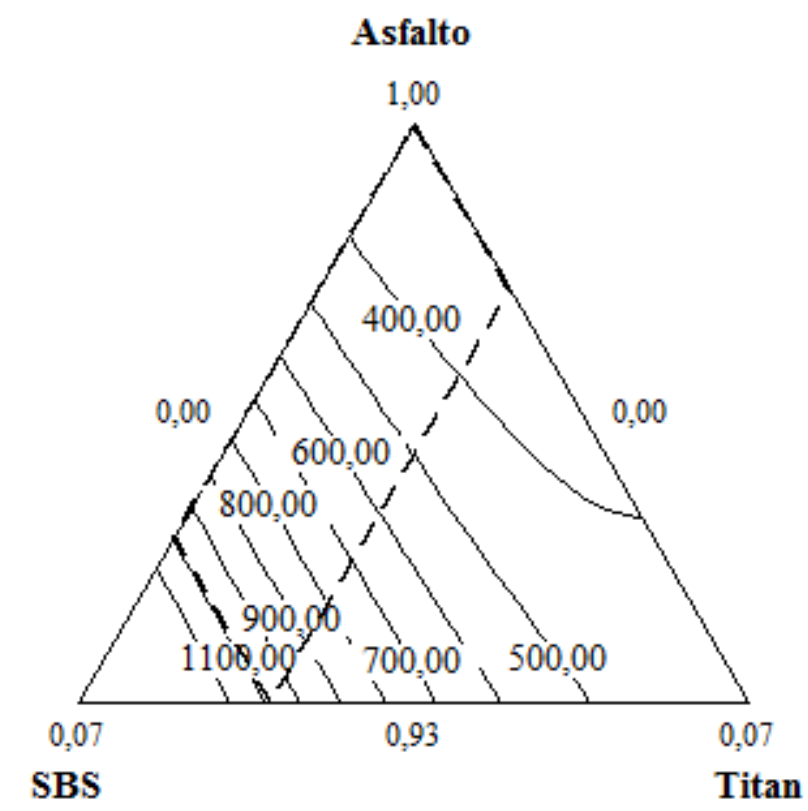

Figura A.2.3 - Superfície de resposta para viscosidade na condição virgem a $135^{\circ} \mathrm{C}$ 


\section{Modelo A.3 Viscosidade na condição virgem a $143^{\circ} \mathrm{C}$}

Os pontos $8,12,13,21,30,31$ e 34 foram retirados para obtenção deste modelo. A exclusão destes pontos se justifica pela seguinte constatação: estes valores destoam dos demais, sendo observações muito acima de 2 desvios padrão nos gráficos de resíduos, sendo estes pontos considerados "outliers". O modelo melhorou sem estes pontos, sendo verificado um aumento do $\mathrm{R}^{2}$. Mesmo com as retiradas, o valor apresentado pelo VIF ainda foi alto, portanto o modelo apenas pode ser empregado para estimativa de novas ocorrências na região experimental.

\begin{tabular}{|c|c|c|c|c|c|}
\hline \multicolumn{6}{|c|}{$\begin{array}{c}\text { Stepwise model } \\
\text { Response: } \\
\text { Number of terms considered }=7 \\
\text { Number of cases with } \mathrm{m} \\
\text { Alpha-to-Enter }=0,0500 \mathrm{~A}\end{array}$} \\
\hline Term & Coef & SE Coef & $\mathrm{T}$ & $\mathrm{P}$ & VIF \\
\hline Asfalto & 206 & 3,6 & * & * & 5,31 \\
\hline SBS & 119895 & 4902,3 & * & * & 7846,11 \\
\hline Titan & 1553 & 270,3 & * & * & 5,12 \\
\hline $\begin{array}{l}\text { Asfalto*SBS } \\
\text { Asfalto*SBS*Titan }\end{array}$ & -115110 & 5127,3 & $-22,45$ & 0,000 & 7698,84 \\
\hline Asfalto*SBS*Titan & -166661 & 13156,2 & $-12,67$ & 0,000 & 8,55 \\
\hline $\mathrm{R}-\mathrm{Sq}=99,84 \%$ & $\begin{array}{l}\text {. } 18557 \\
\text {-Sq (pred }\end{array}$ & $\begin{aligned} & \text { PRESS } \\
= & 99,73\end{aligned}$ & $\begin{array}{rr}= & 2689,6 \\
& R-S q\end{array}$ & $(\operatorname{adj})$ & $99,81 \%$ \\
\hline
\end{tabular}

\section{Residual Plots for visc-143}
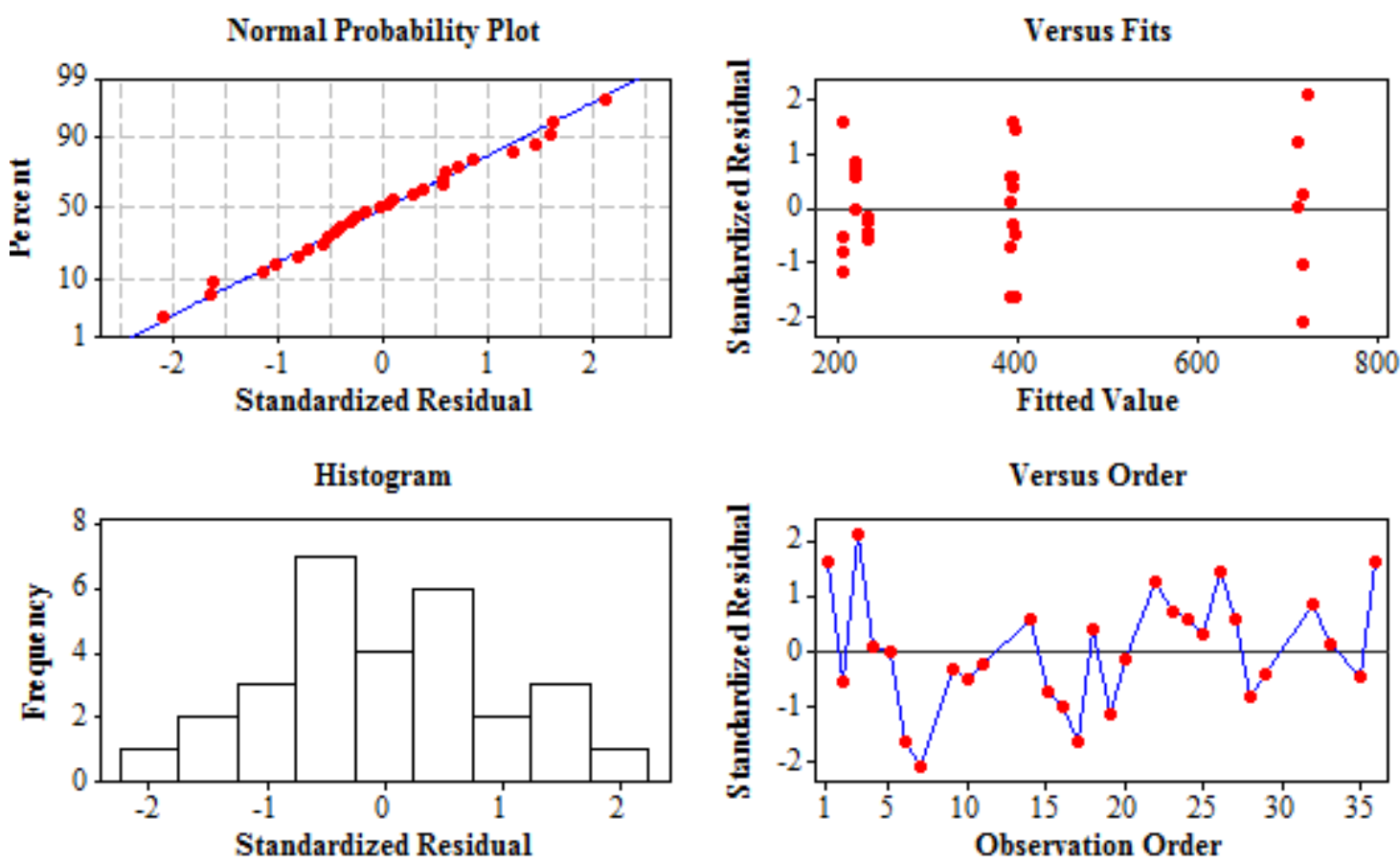

Figura A.3.1 - Análise de resíduos para viscosidade na condição virgem a $143^{\circ} \mathrm{C}$ 


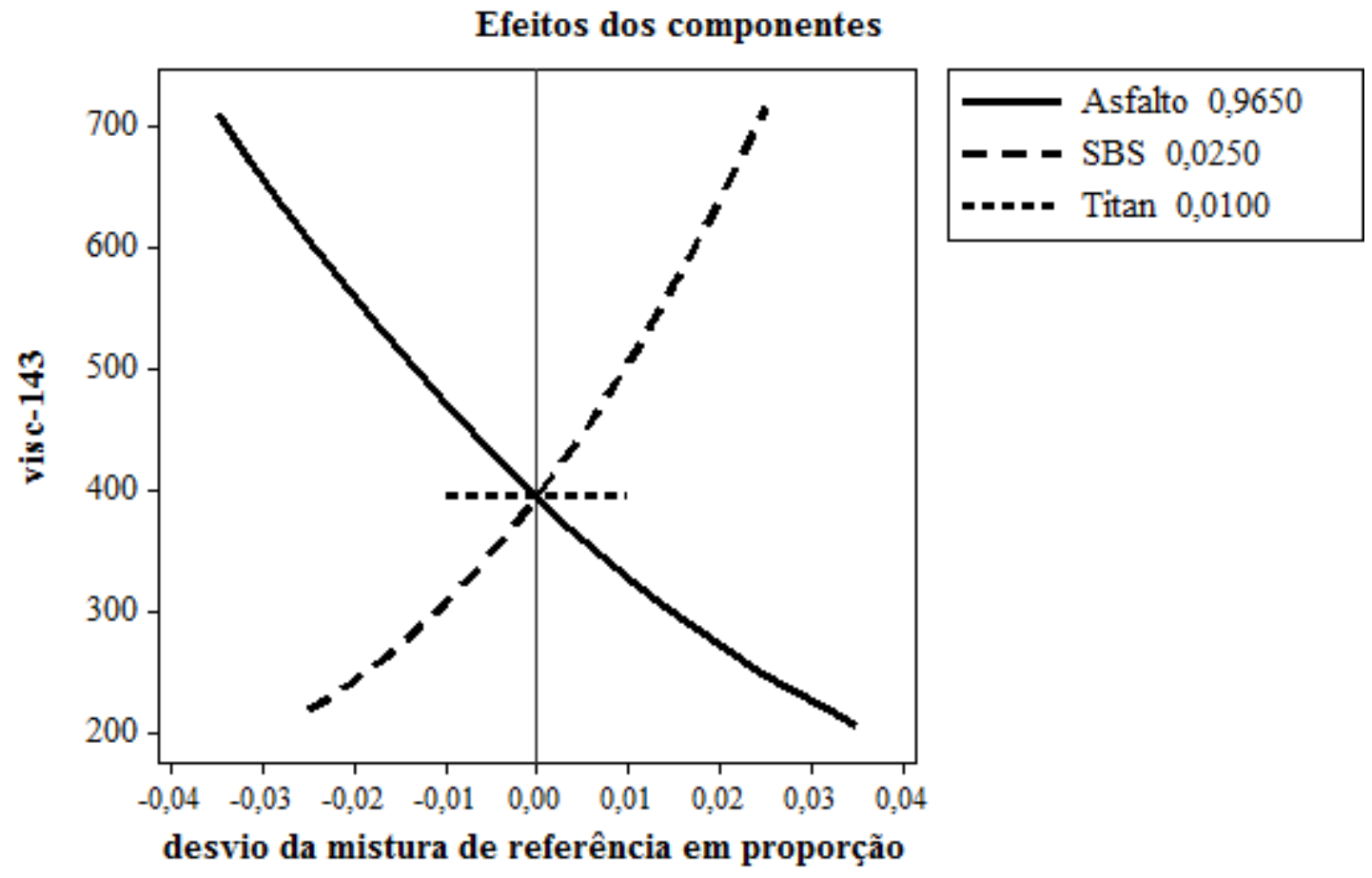

Figura A.3.2 - Efeitos dos componentes para viscosidade na condição virgem a $143^{\circ} \mathrm{C}$

Superfície de resposta para viscosidade virgem a $143^{\circ} \mathrm{C}$

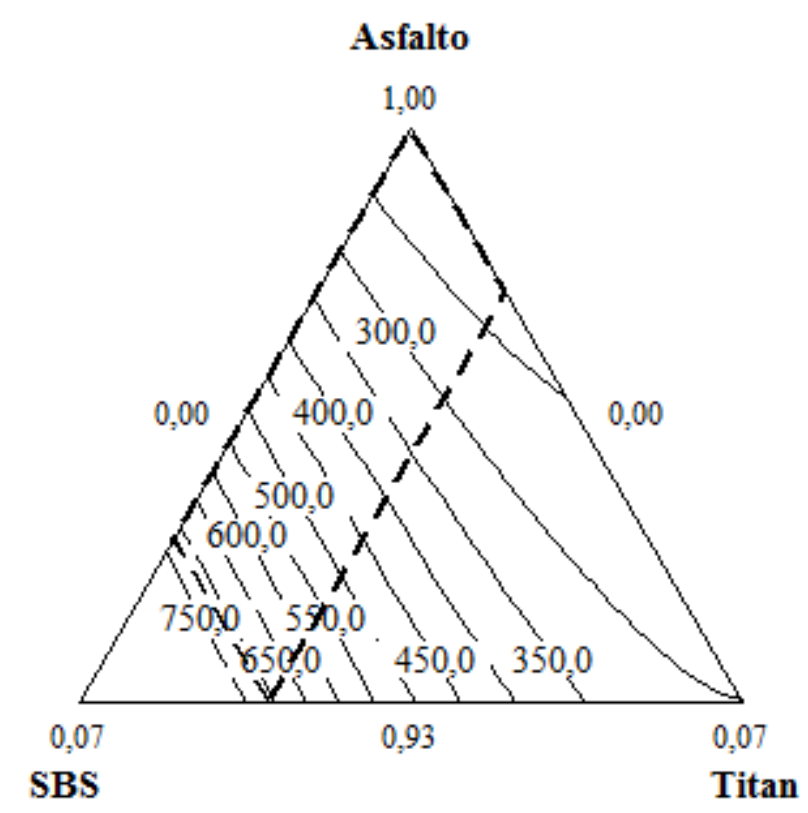

Figura A.3.3 - Superfície de resposta para viscosidade na condição virgem a $143^{\circ} \mathrm{C}$ 


\section{Modelo A.4 Viscosidade na condição virgem a $150^{\circ} \mathrm{C}$}

Não houve retiradas de pontos para obtenção deste modelo. $\mathrm{O}$ valor de $\mathrm{R}^{2}$ obtido pode ser considerado bom, porém o valor apresentado pelo VIF é muito alto, portanto o modelo apenas pode ser empregado para estimativa de novas ocorrências na região experimental.

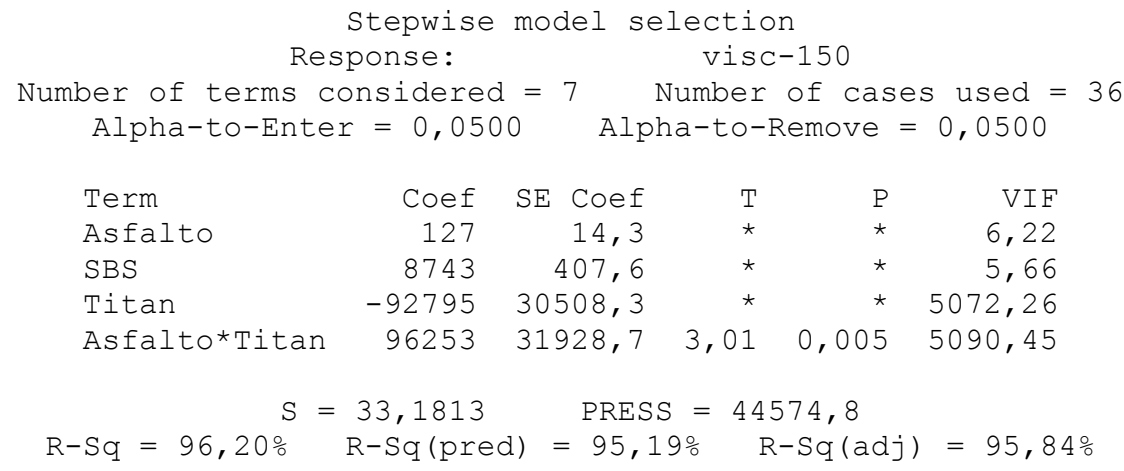

\section{Residual Plots for visc-150}
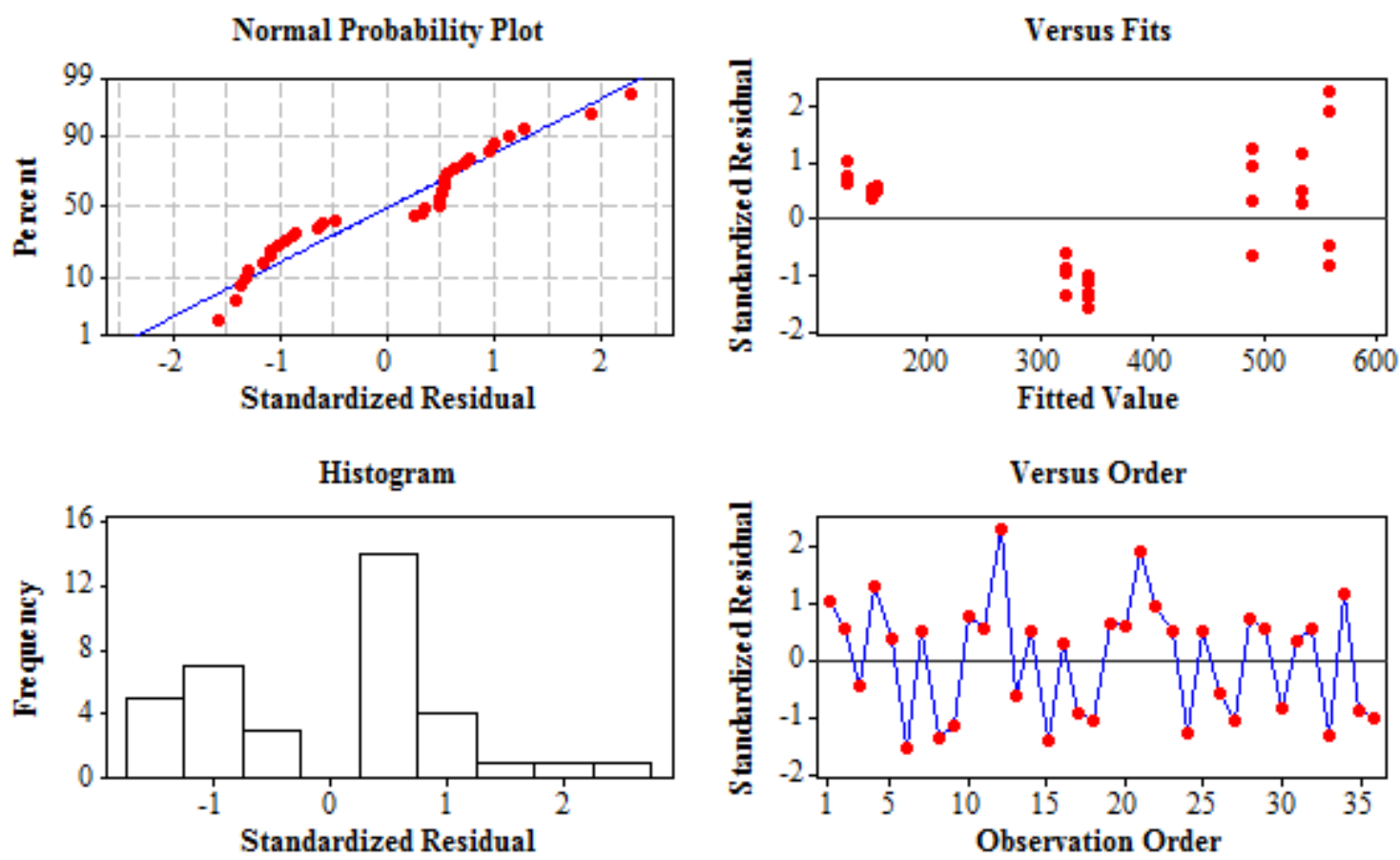

Figura A.4.1 - Análise de resíduos para viscosidade na condição virgem a $150^{\circ} \mathrm{C}$ 


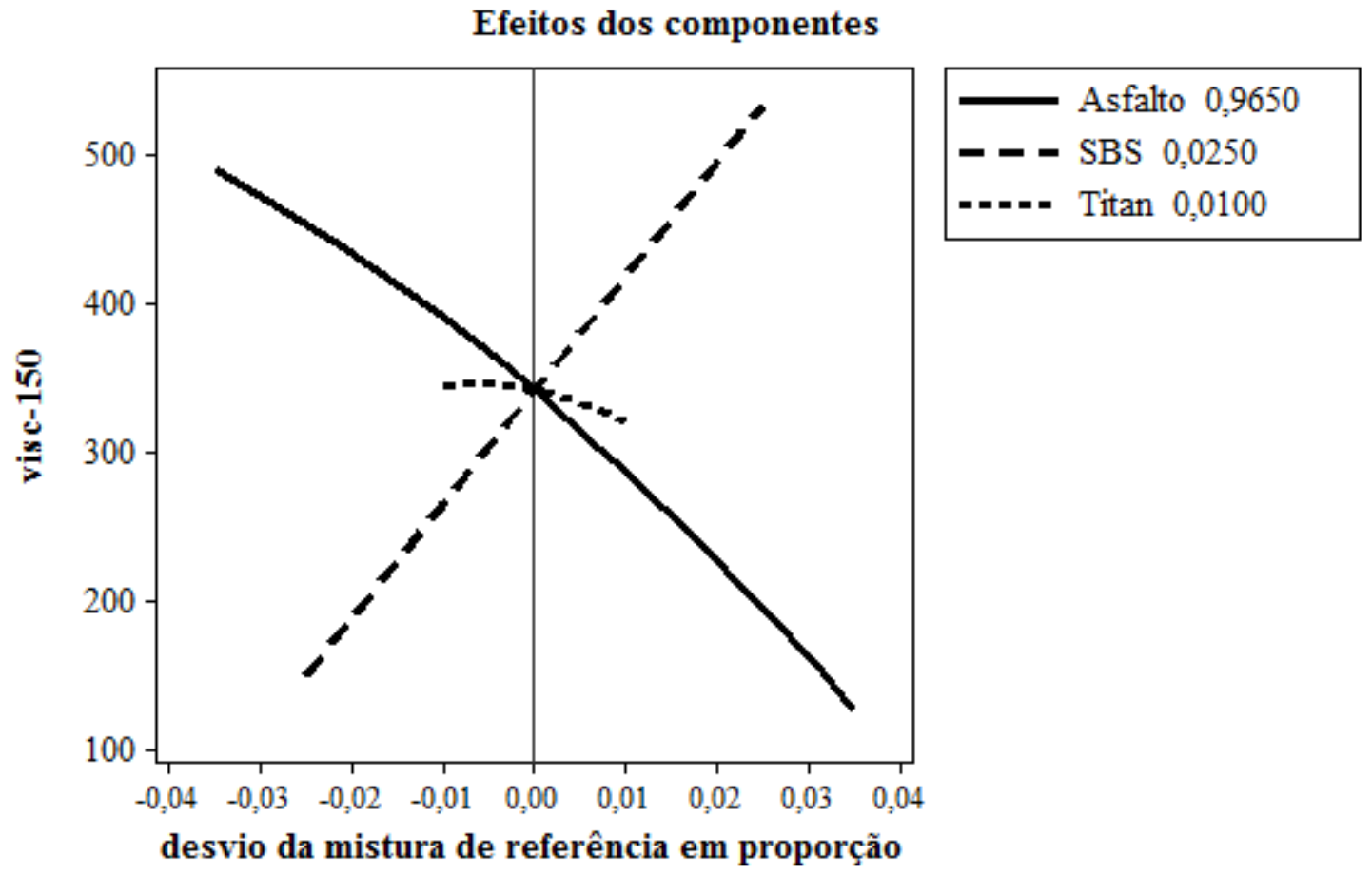

Figura A.4.2 - Efeitos dos componentes para viscosidade na condição virgem a $150^{\circ} \mathrm{C}$

Superficie de resposta para viscosidade a $150^{\circ} \mathrm{C}$

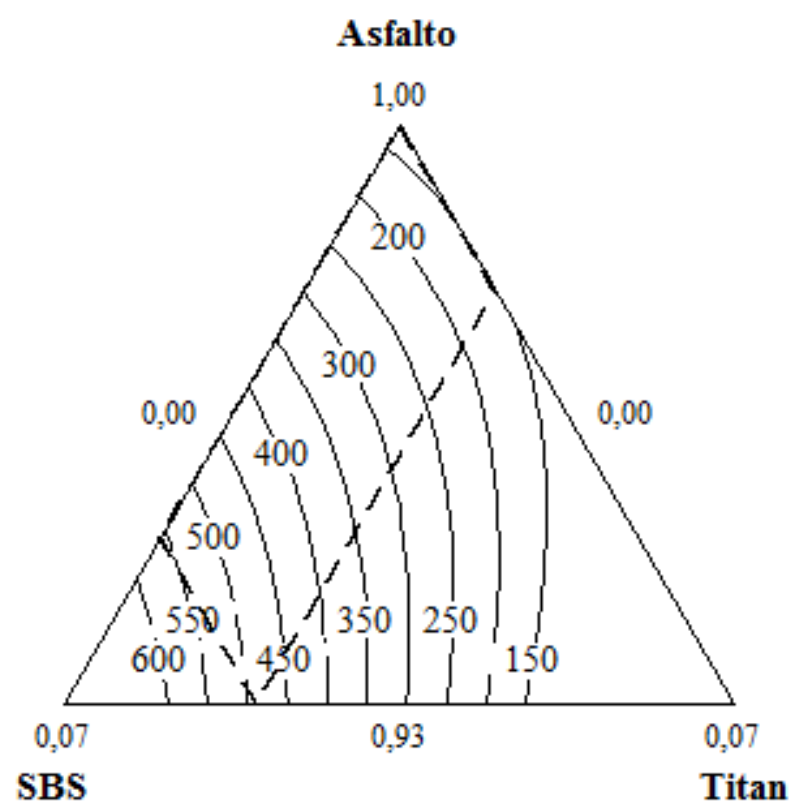

Figura A.4.3 - Superfície de resposta para viscosidade na condição virgem a $150^{\circ} \mathrm{C}$ 


\section{Modelo A.5 Viscosidade na condição virgem a $163^{\circ} \mathrm{C}$}

Os pontos 3,13,16, 30, 31 e 34 foram retirados para obtenção deste modelo. A exclusão destes pontos se justifica pela seguinte constatação: estes valores destoam dos demais, sendo observações muito acima de 2 desvios padrão nos gráficos de resíduos, sendo estes pontos considerados "outliers". O modelo melhorou sem estes pontos, sendo verificado um aumento do $\mathrm{R}^{2}$. Mesmo com as retiradas, o valor apresentado pelo VIF ainda foi alto, portanto o modelo apenas pode ser empregado para estimativa de novas ocorrências na região experimental.

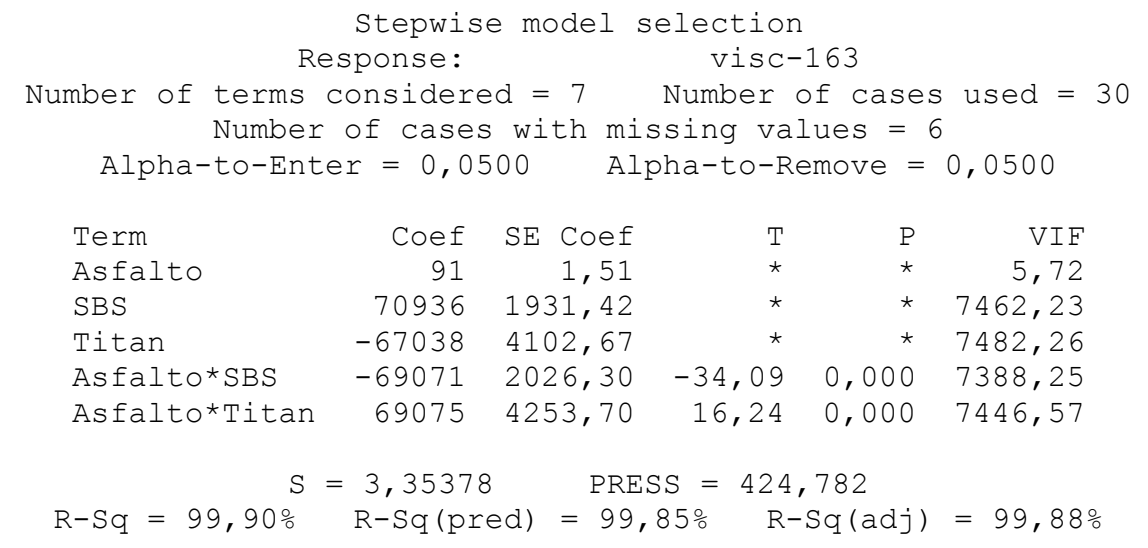

Residual Plots for visc-163
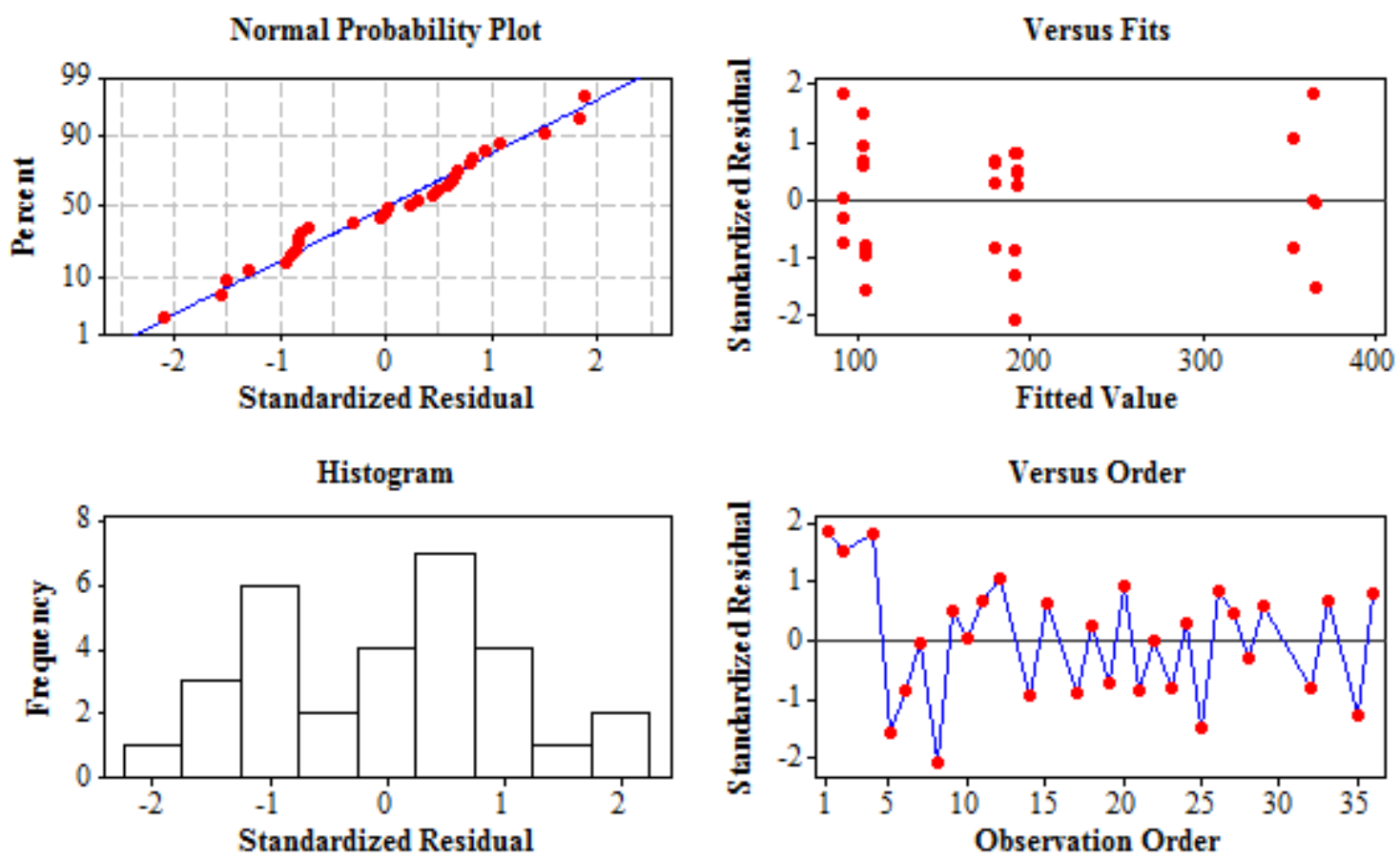

Figura A.5.1 - Análise de resíduos para viscosidade na condição virgem a $163^{\circ} \mathrm{C}$ 
Efeitos dos componentes

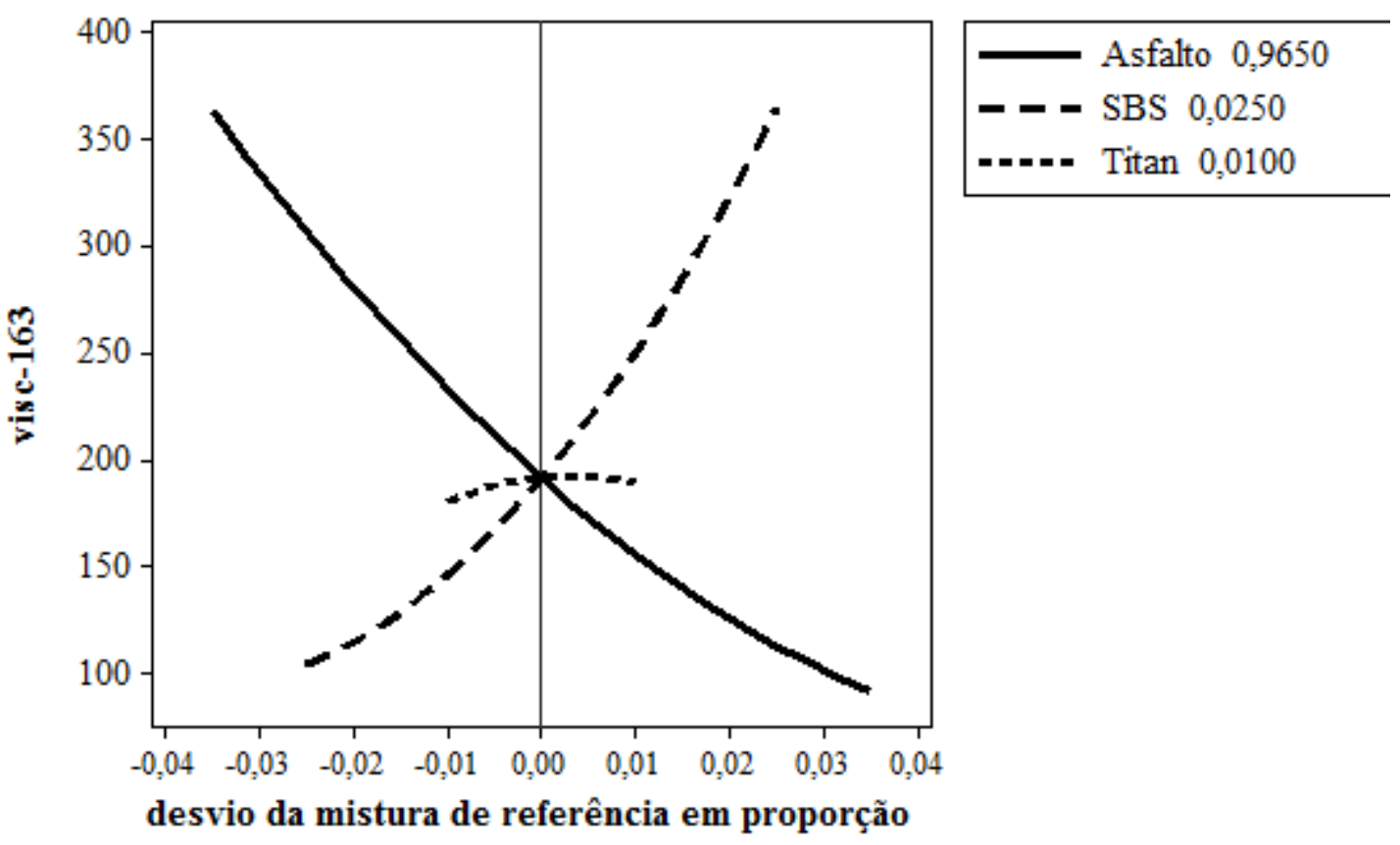

Figura A.5.2 - Efeitos dos componentes para viscosidade na condição virgem a $163^{\circ} \mathrm{C}$

Superfície de resposta para viscosidade virgem a $163^{\circ} \mathrm{C}$

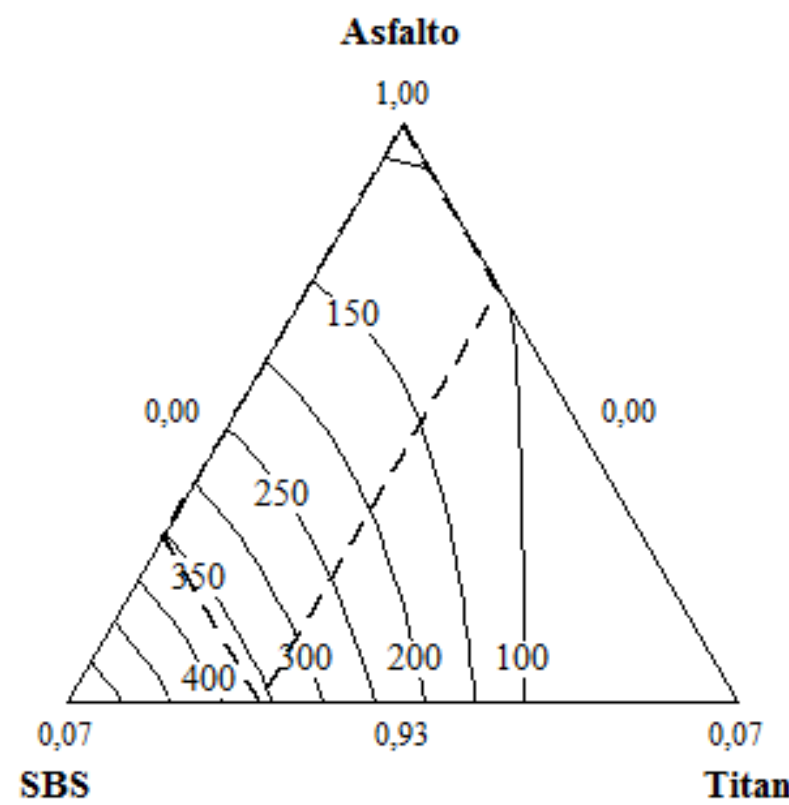

Figura A.5.3 - Superfície de resposta para viscosidade na condição virgem a $163^{\circ} \mathrm{C}$ 


\section{Modelo A.6 Viscosidade na condição virgem a $177^{\circ} \mathrm{C}$}

Os pontos $1,2,4,12,13,16,25,26,30$ e 34 foram retirados para obtenção deste modelo. A exclusão destes pontos se justifica pela seguinte constatação: estes valores destoam dos demais, sendo observações muito acima de 2 desvio padrões nos gráficos de resíduos, sendo estes pontos considerados "outliers". O modelo melhorou sem estes pontos, sendo verificado um aumento do $\mathrm{R}^{2}$. Mesmo com as retiradas, o valor apresentado pelo VIF ainda foi alto, portanto o modelo apenas pode ser empregado para estimativa de novas ocorrências na região experimental.

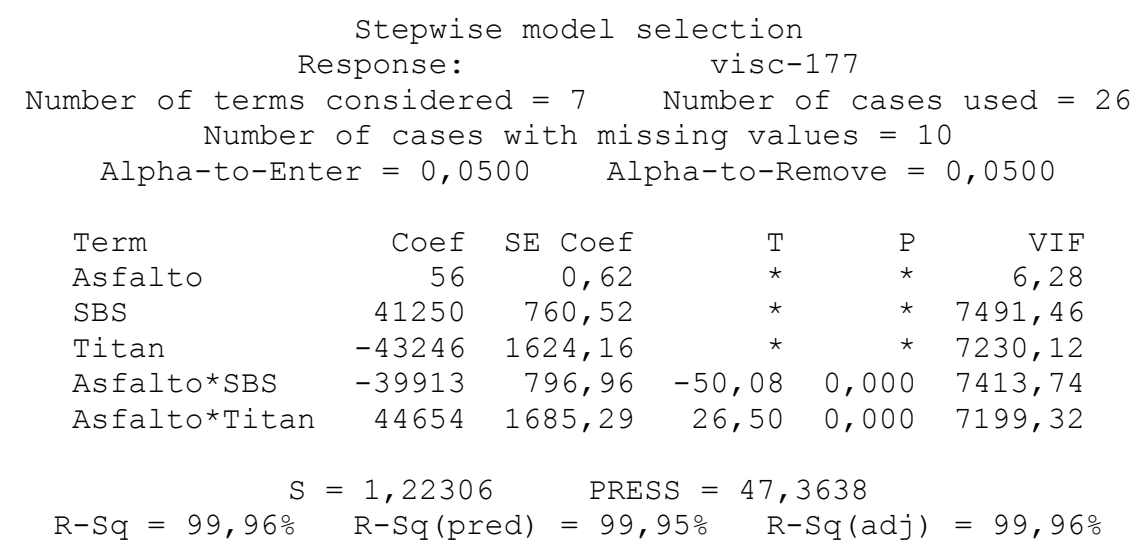

Residual Plots for visc-177

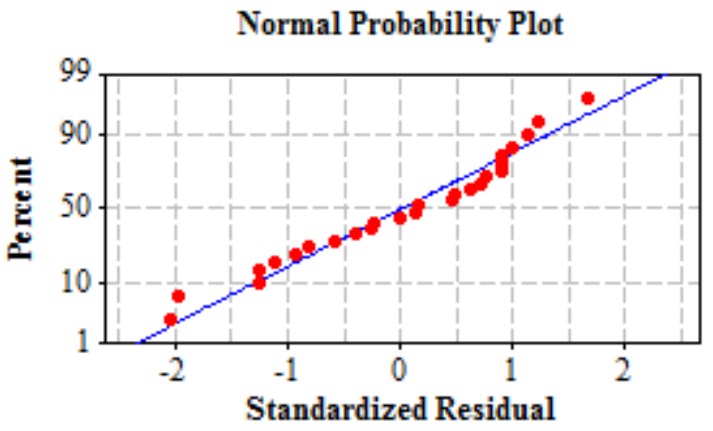

Histogram

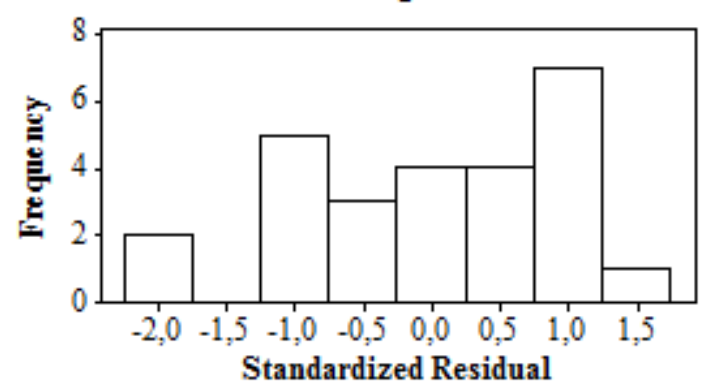

Versus Fits

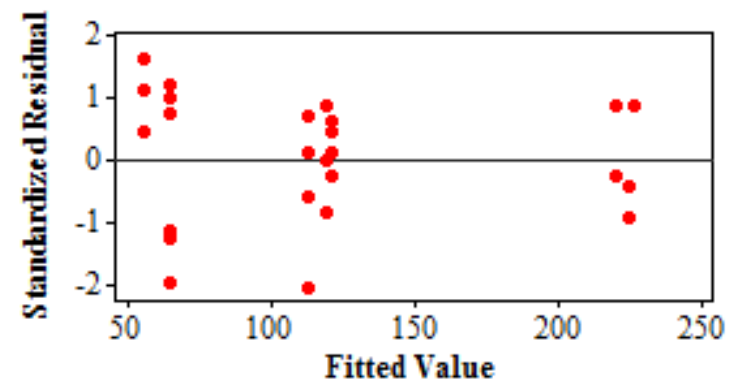

Versus Order

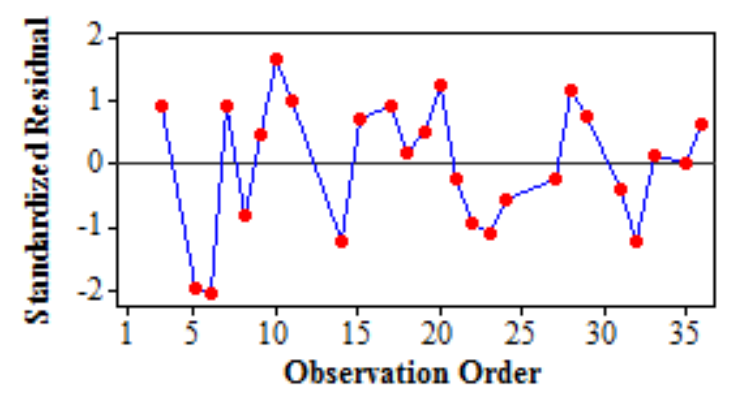

Figura A.6.1 - Análise de resíduos para viscosidade na condição virgem a $177^{\circ} \mathrm{C}$ 


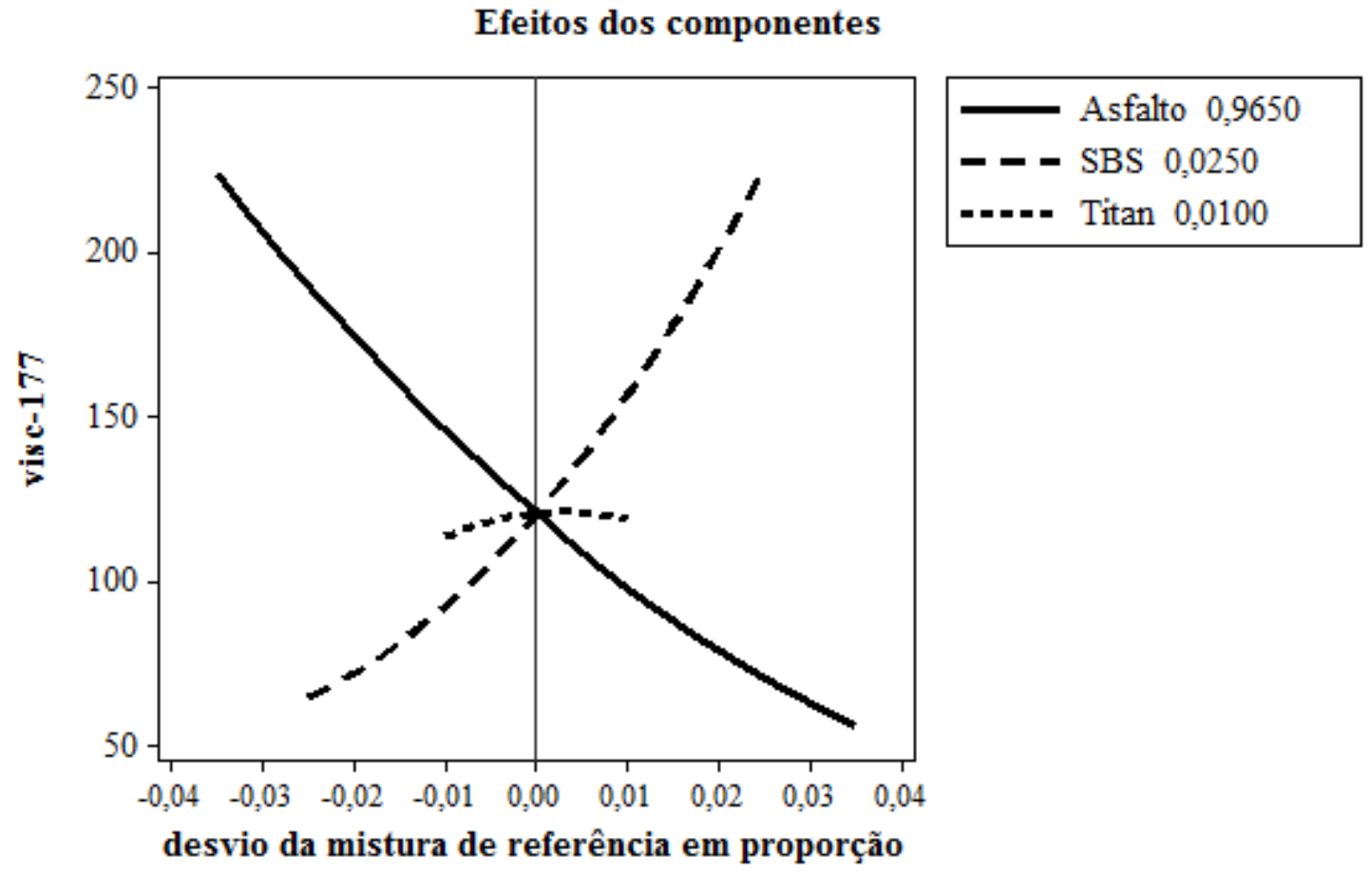

Figura A.6.2 - Efeitos dos componentes para viscosidade na condição virgem a $177^{\circ} \mathrm{C}$

Superfície de resposta para viscosidade virgem a $177^{\circ} \mathrm{C}$

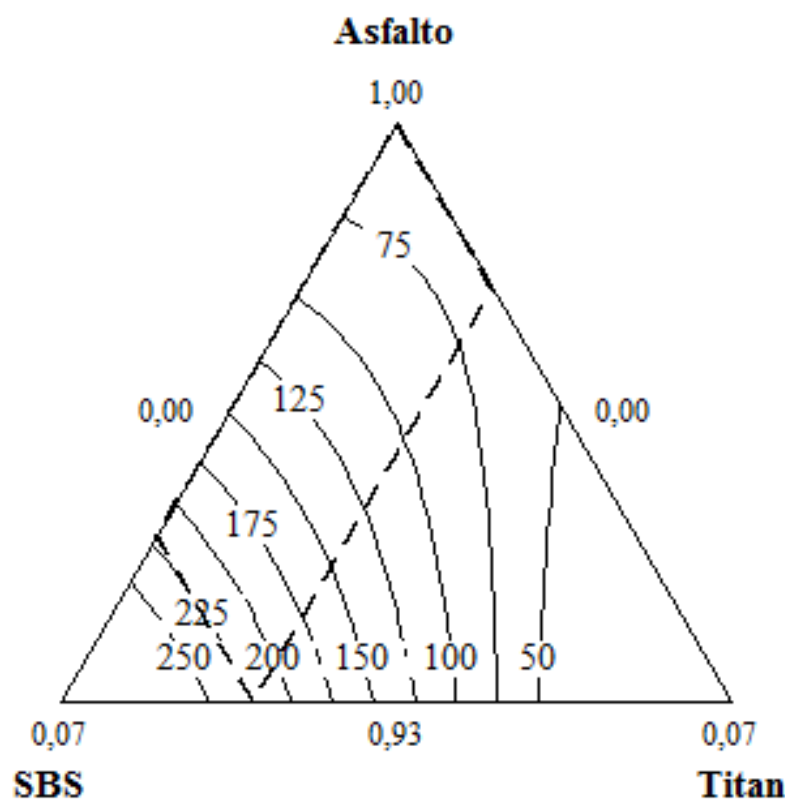

Figura A.6.3 - Superfície de resposta para viscosidade na condição virgem a $177^{\circ} \mathrm{C}$ 


\section{Modelo A.7 Viscosidade na condição envelhecida a curto prazo a $135^{\circ} \mathrm{C}$}

Os pontos 16, 26 e 34 foram retirados para obtenção deste modelo. A exclusão destes pontos se justifica pela seguinte constatação: estes valores destoam dos demais, sendo observações muito acima de 2 desvio padrões nos gráficos de resíduos, sendo estes pontos considerados "outliers". O modelo melhorou sem estes pontos, sendo verificado um aumento do $\mathrm{R}^{2}$. Mesmo com as retiradas o valor apresentado pelo VIF ainda foi alto, portanto o modelo apenas pode ser empregado para estimativa de novas ocorrências na região experimental.

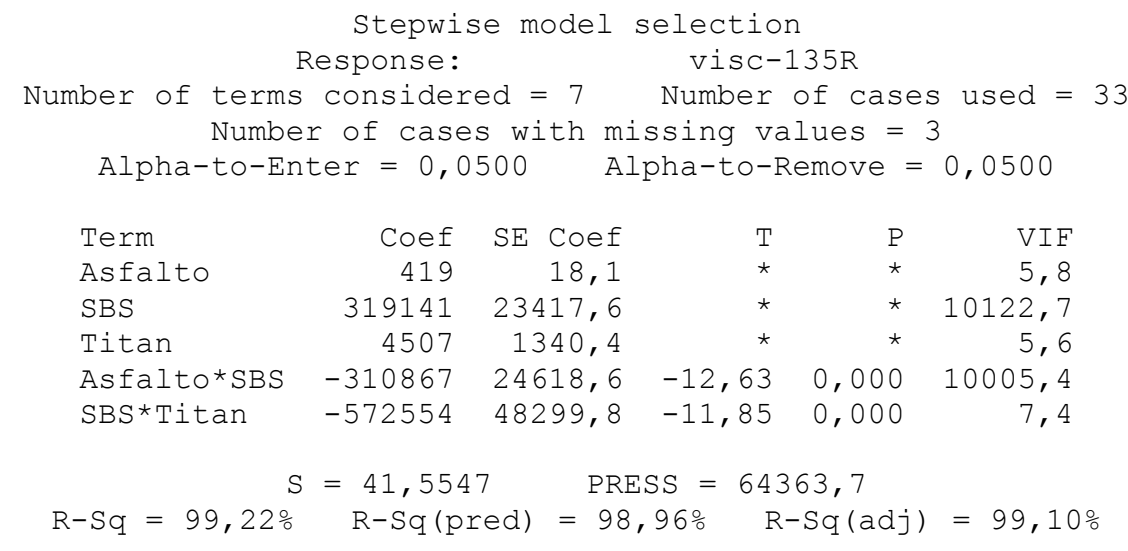

Residual Plots for visc-135R
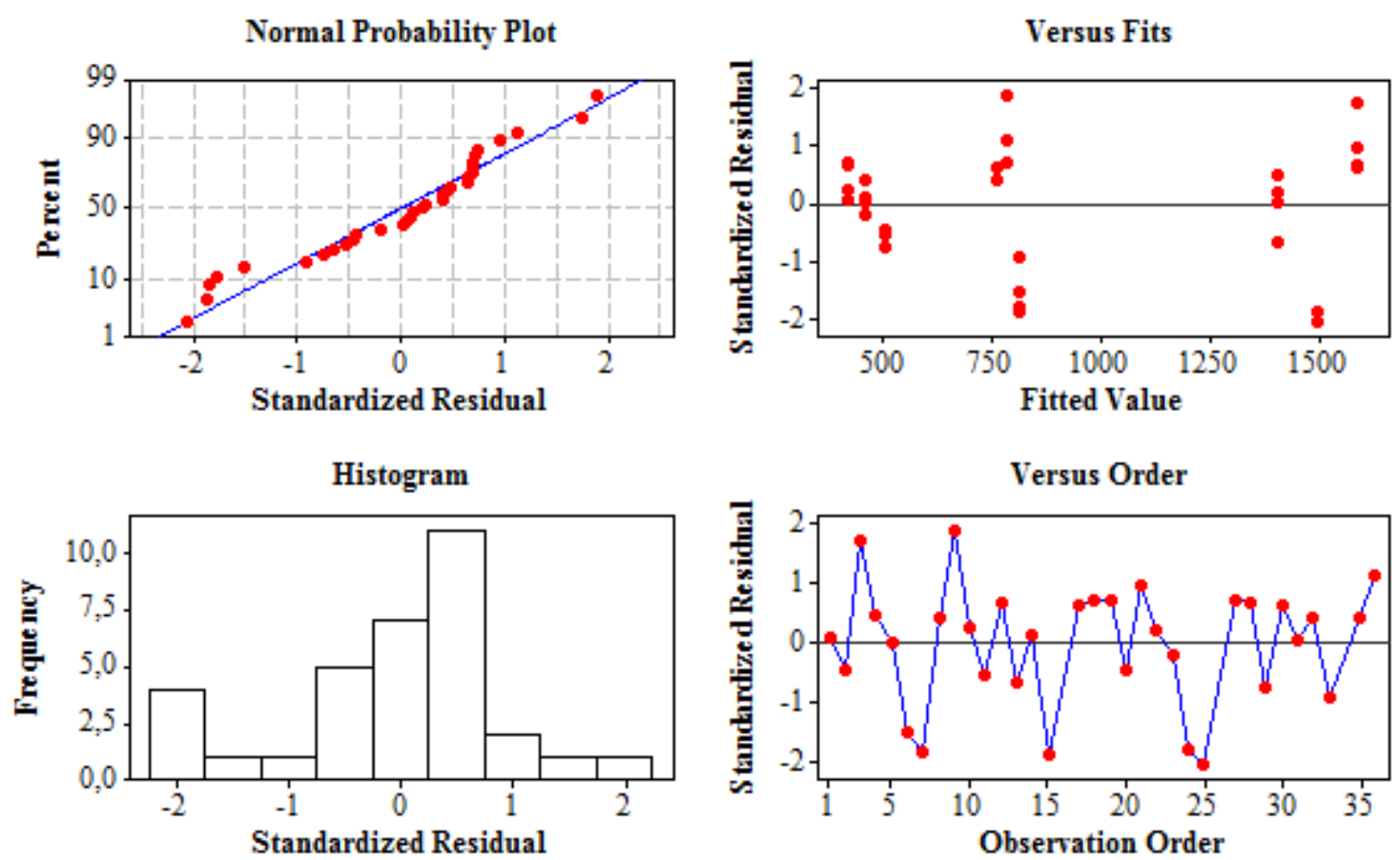

Figura A.7.1 - Análise de resíduos para viscosidade na condição RTFOT a $135^{\circ} \mathrm{C}$ 


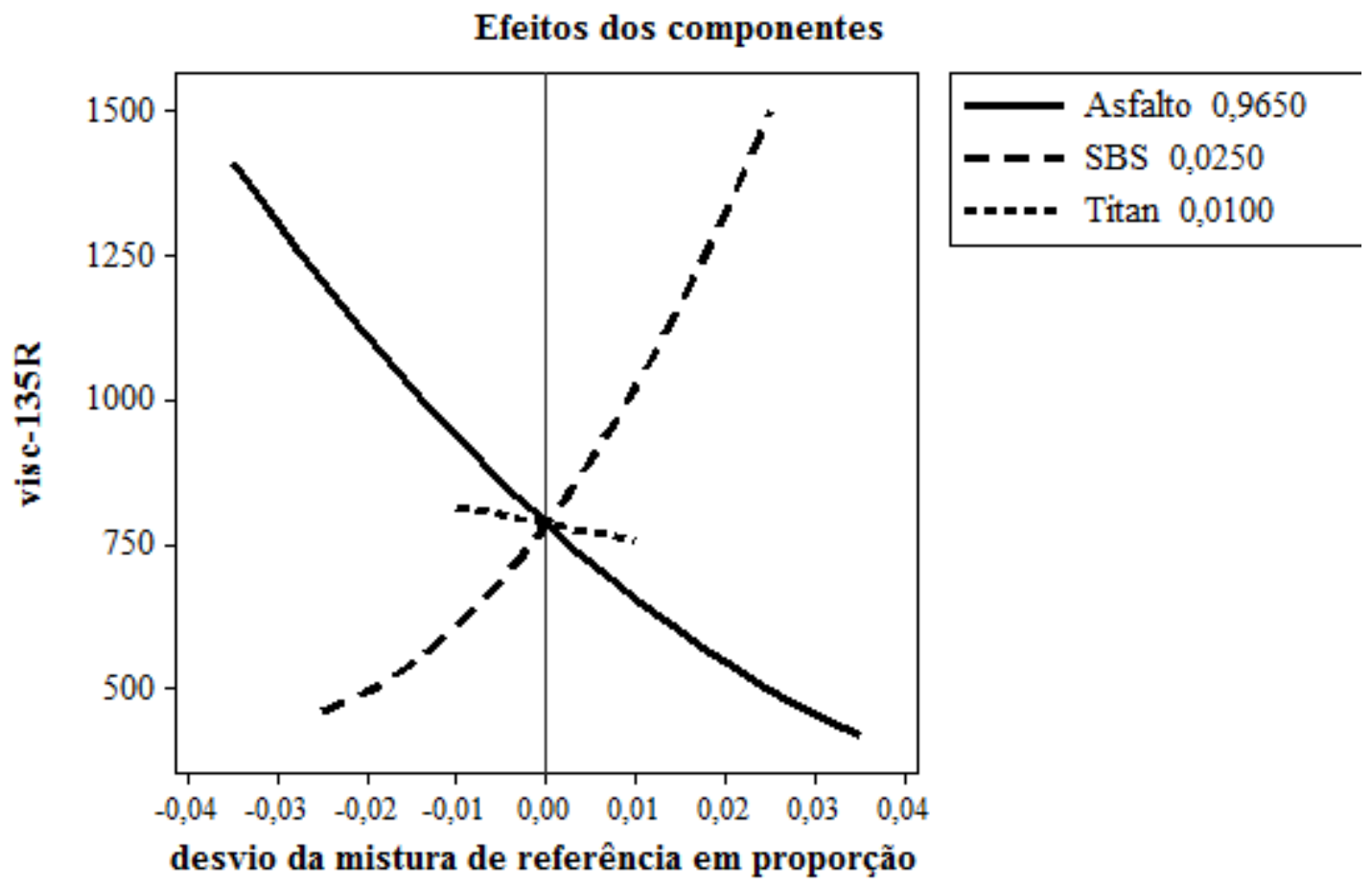

Figura A.7.2 - Efeitos dos componentes para viscosidade na condição RTFOT a $135^{\circ} \mathrm{C}$

Superfície de resposta para viscosidade RTFOT a $135^{\circ} \mathrm{C}$

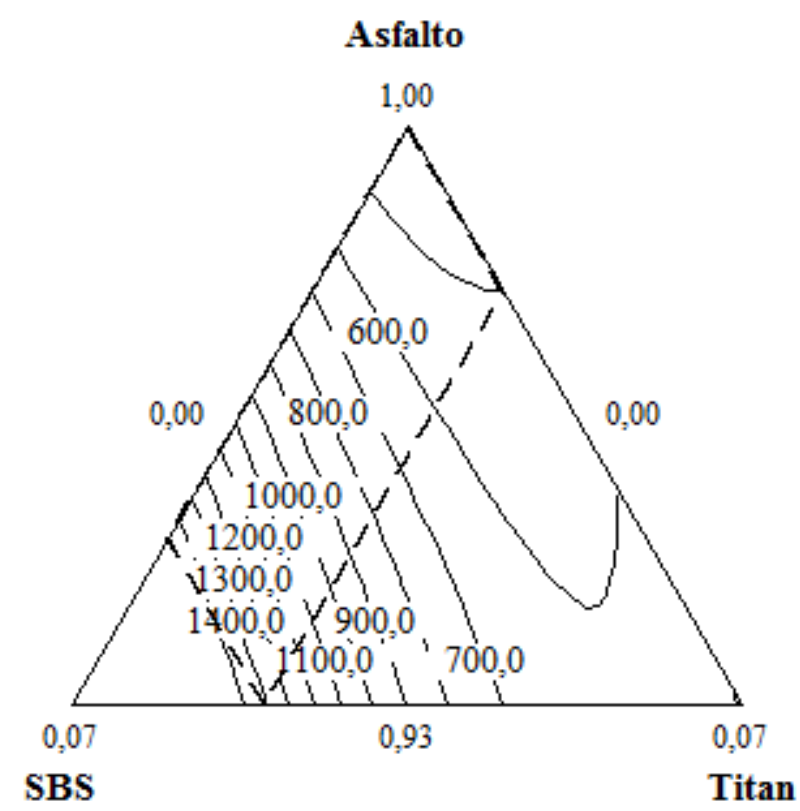

Figura A.7.3 - Superfície de resposta para viscosidade na condição RTFOT a $135^{\circ} \mathrm{C}$ 


\section{Modelo A.8 Viscosidade na condição envelhecida a curto prazo a $143^{\circ} \mathrm{C}$}

Os pontos 3 e 16 foram retirados para obtenção deste modelo. A exclusão destes pontos se justifica pela seguinte constatação: estes valores destoam dos demais, sendo observações muito acima de 2 desvio padrões nos gráficos de resíduos, sendo estes pontos considerados "outliers". O modelo melhorou sem estes pontos, sendo verificado um aumento do $\mathrm{R}^{2}$. Mesmo com as retiradas, o valor apresentado pelo VIF ainda foi alto, portanto o modelo apenas pode ser empregado para estimativa de novas ocorrências na região experimental.

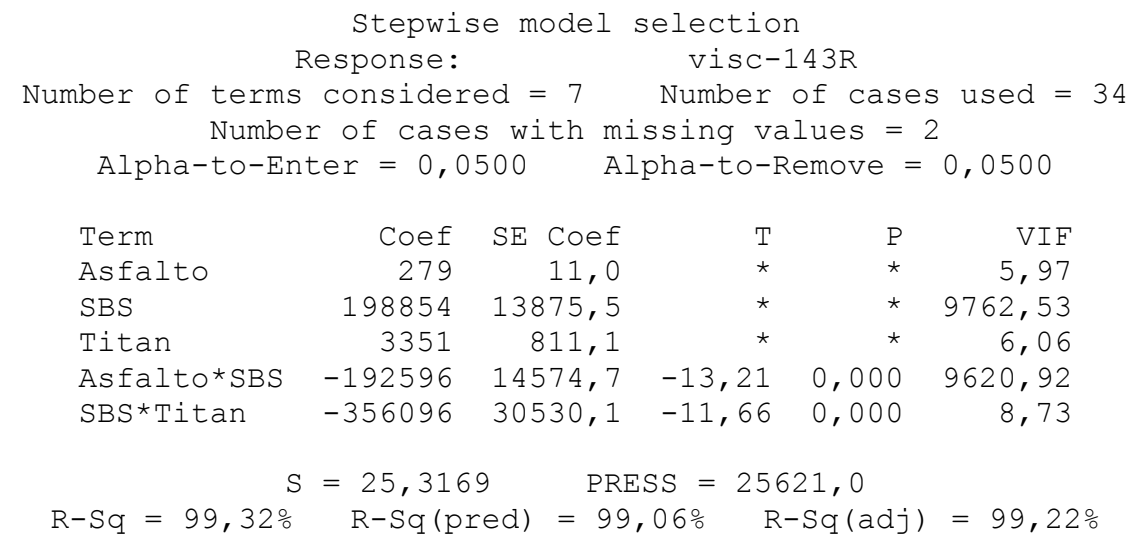

Residual Plots for visc-143R
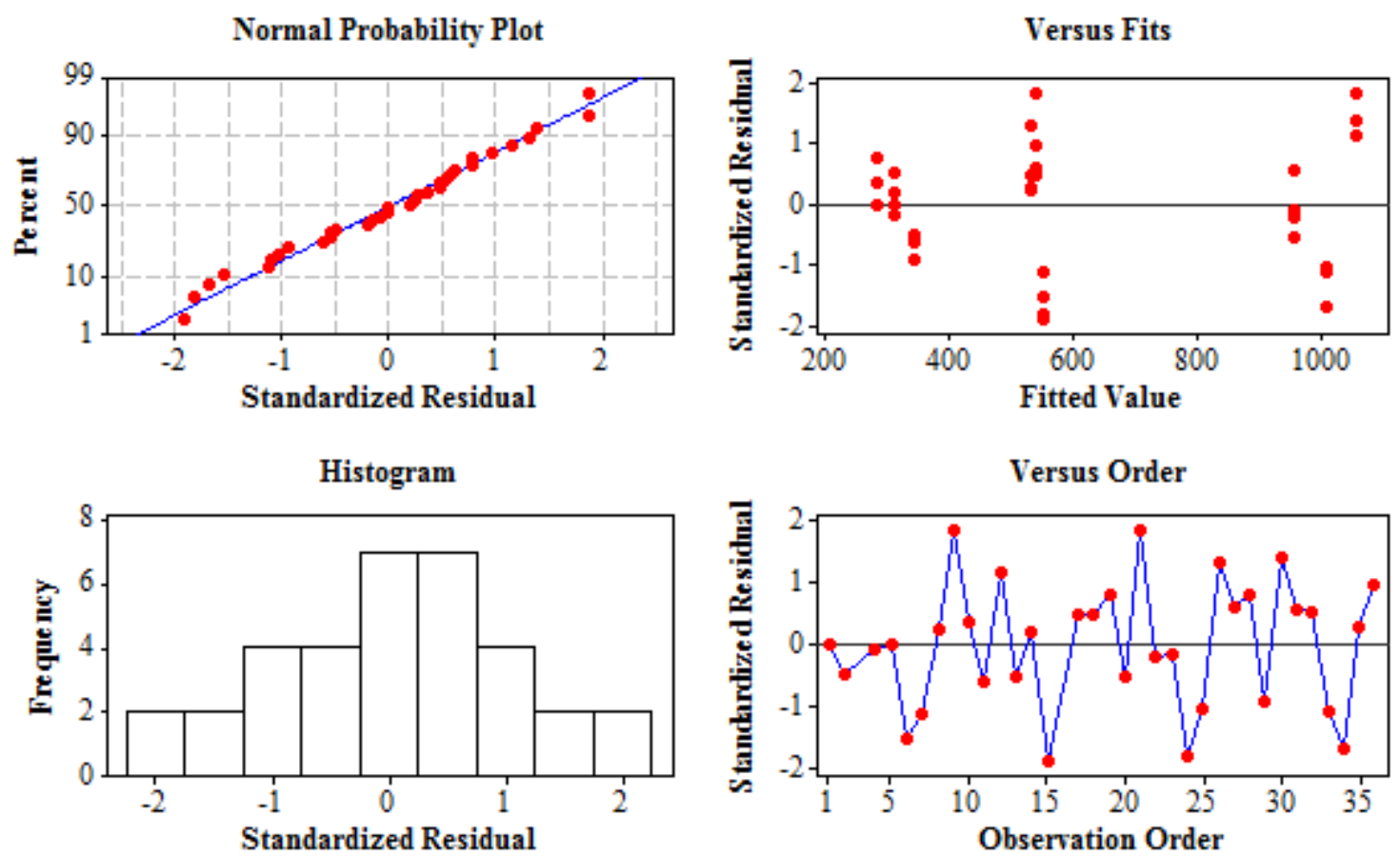

Figura A.8.1 - Análise de resíduos para viscosidade na condição RTFOT a $143^{\circ} \mathrm{C}$ 
Efeitos dos componentes

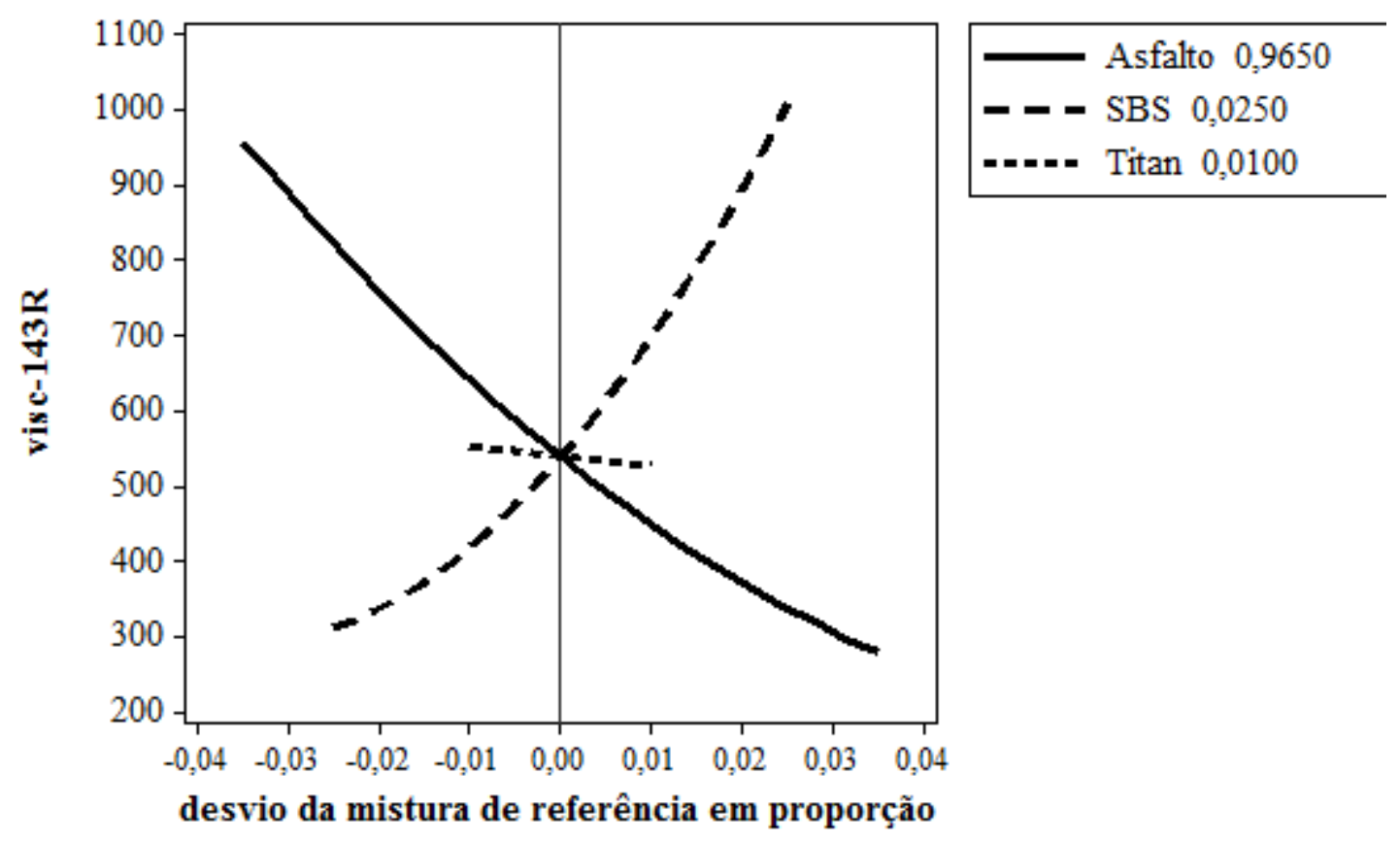

Figura A.8.2 - Efeitos dos componentes para viscosidade na condição RTFOT a $143^{\circ} \mathrm{C}$

Superfície de resposta para viscosidade RTFOT a $143^{\circ} \mathrm{C}$

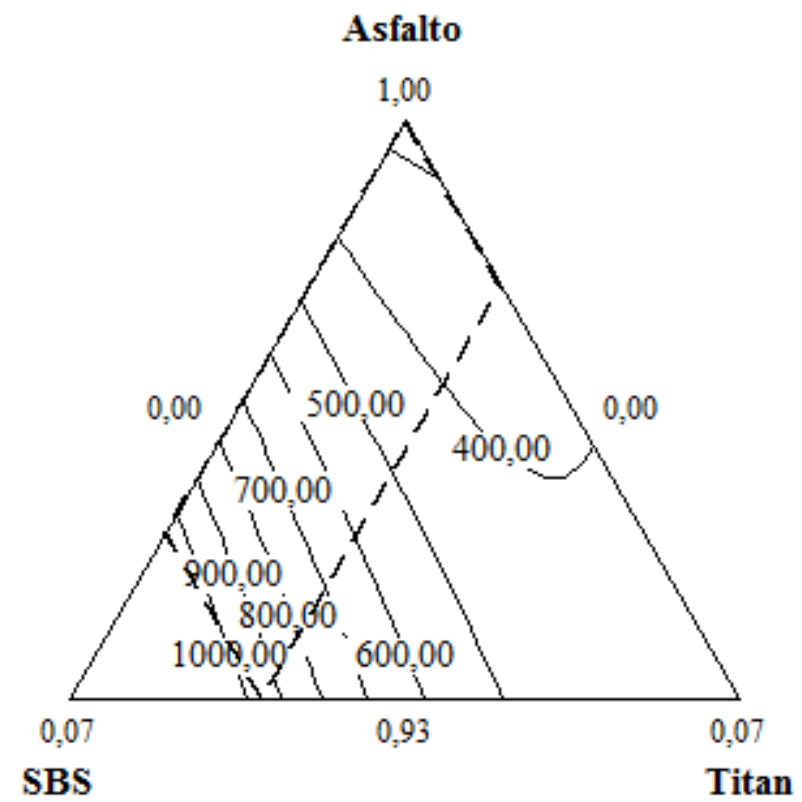

Figura A.8.3 - Superfície de resposta para viscosidade na condição RTFOT a $143^{\circ} \mathrm{C}$ 


\section{Modelo A.9 Viscosidade na condição envelhecida a curto prazo a $150^{\circ} \mathrm{C}$}

Os pontos 3 e 16 foram retirados para obtenção deste modelo. A exclusão destes pontos se justifica pela seguinte constatação: estes valores destoam dos demais, sendo observações muito acima de 2 desvio padrões nos gráficos de resíduos, sendo estes pontos considerados "outliers". O modelo melhorou sem estes pontos, sendo verificado um aumento do $\mathrm{R}^{2}$. Mesmo com as retiradas, o valor apresentado pelo VIF ainda foi alto, portanto o modelo apenas pode ser empregado para estimativa de novas ocorrências na região experimental.

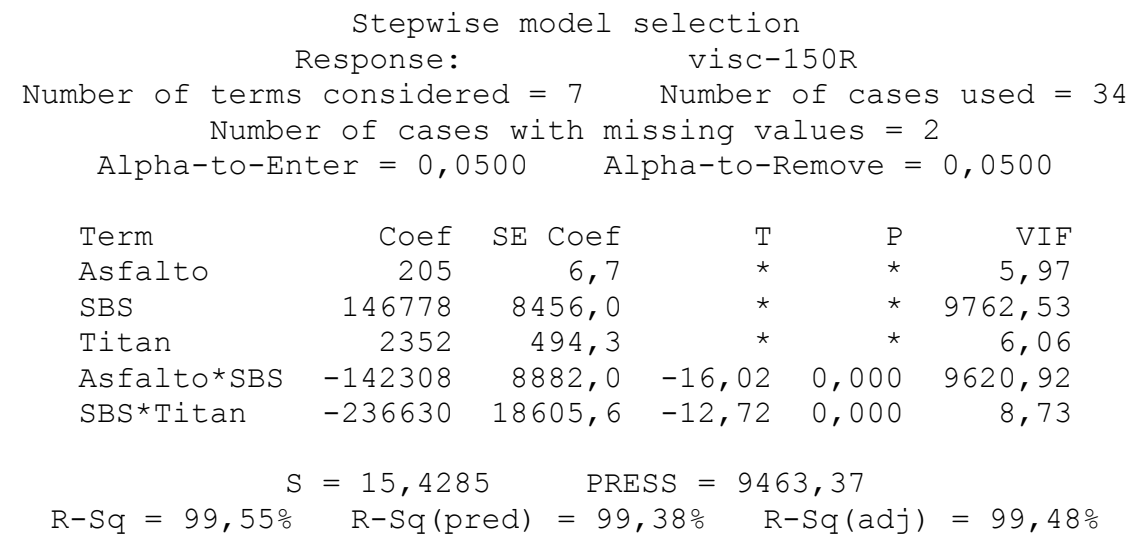

Residual Plots for visc-150R
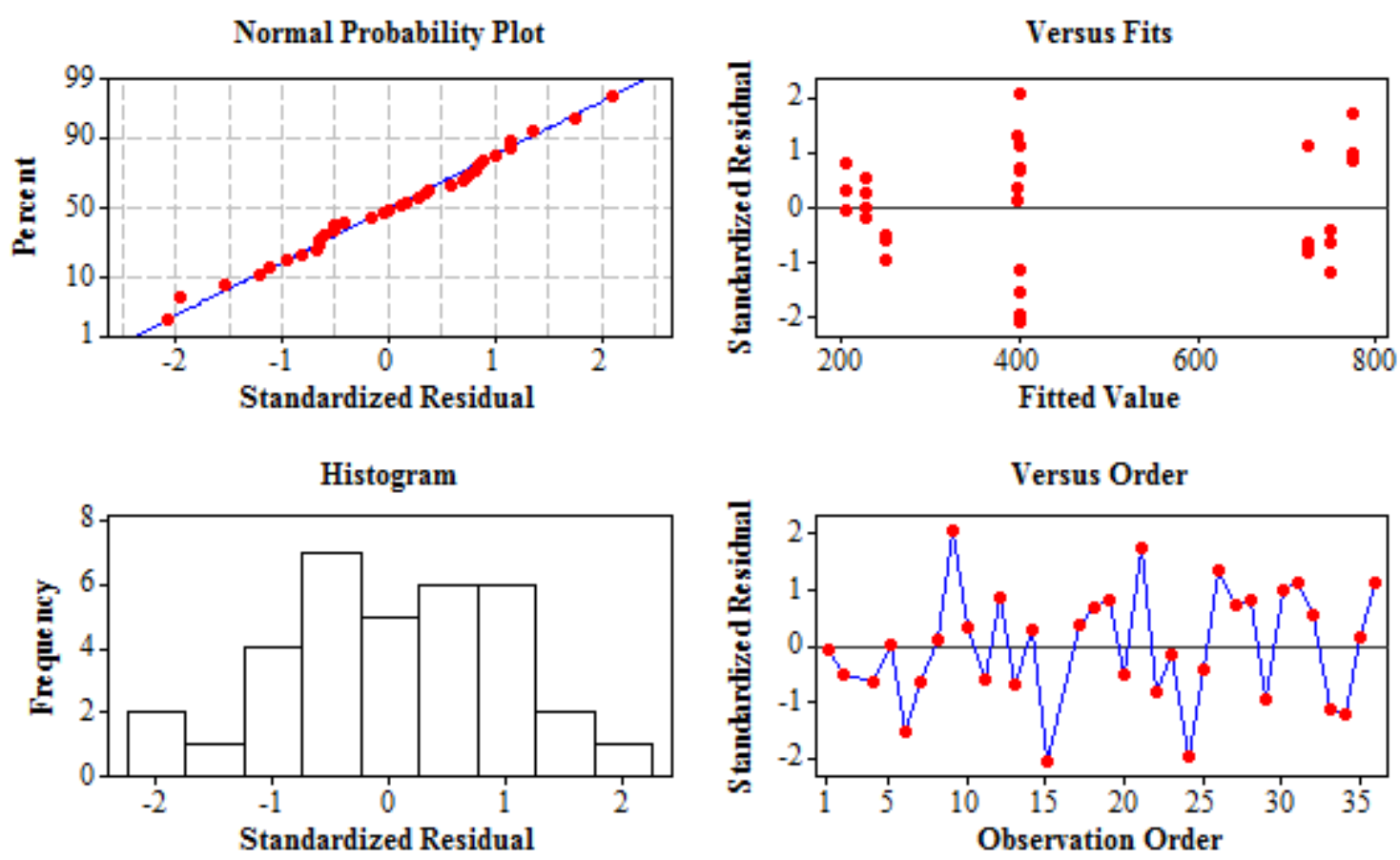

Figura A.9.1 - Análise de resíduos para viscosidade na condição RTFOT a $150^{\circ} \mathrm{C}$ 


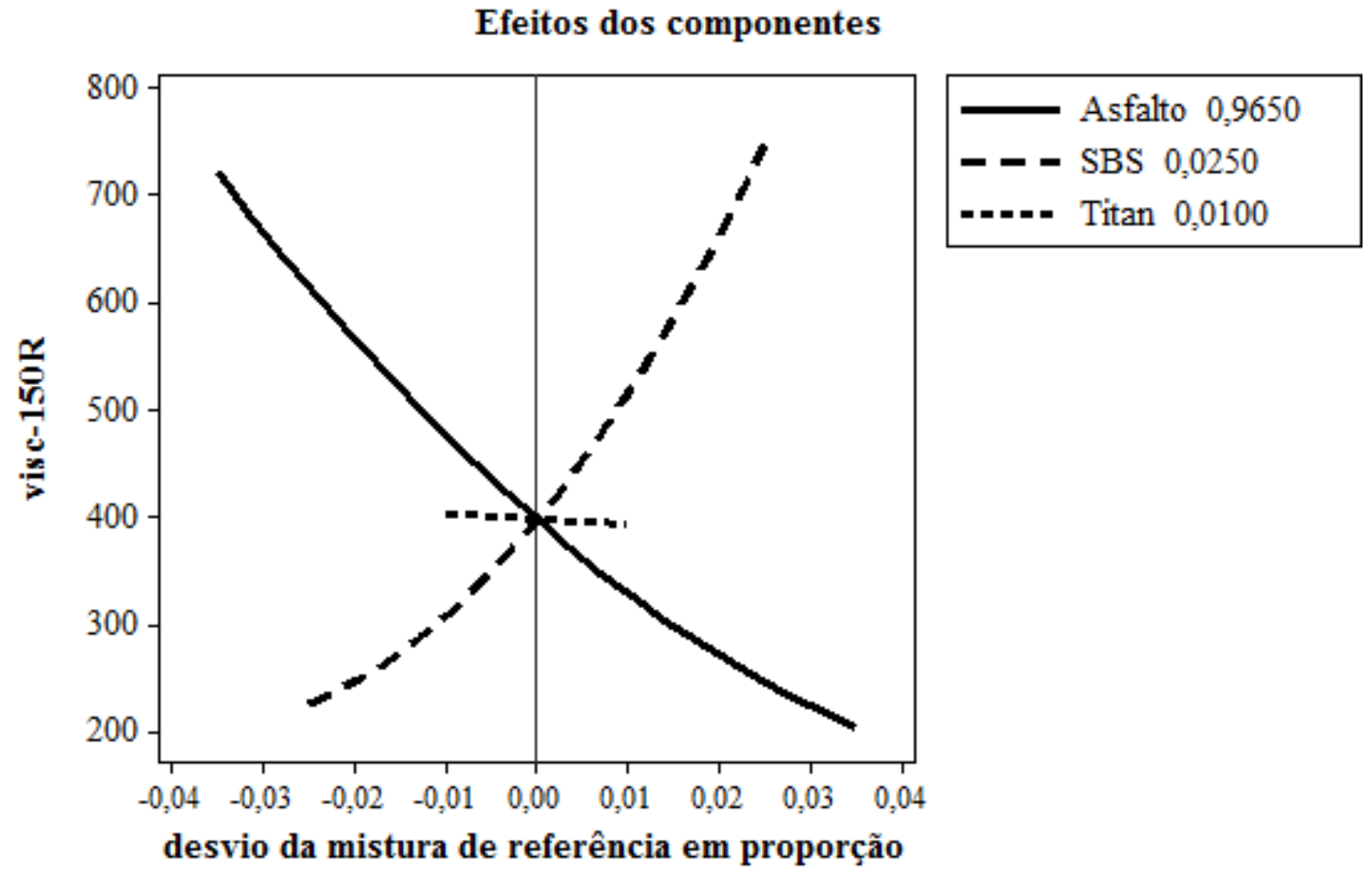

Figura A.9.2 - Efeitos dos componentes para viscosidade na condição RTFOT a $150^{\circ} \mathrm{C}$

Superfície de resposta para viscosidade RTFOT a $150^{\circ} \mathrm{C}$

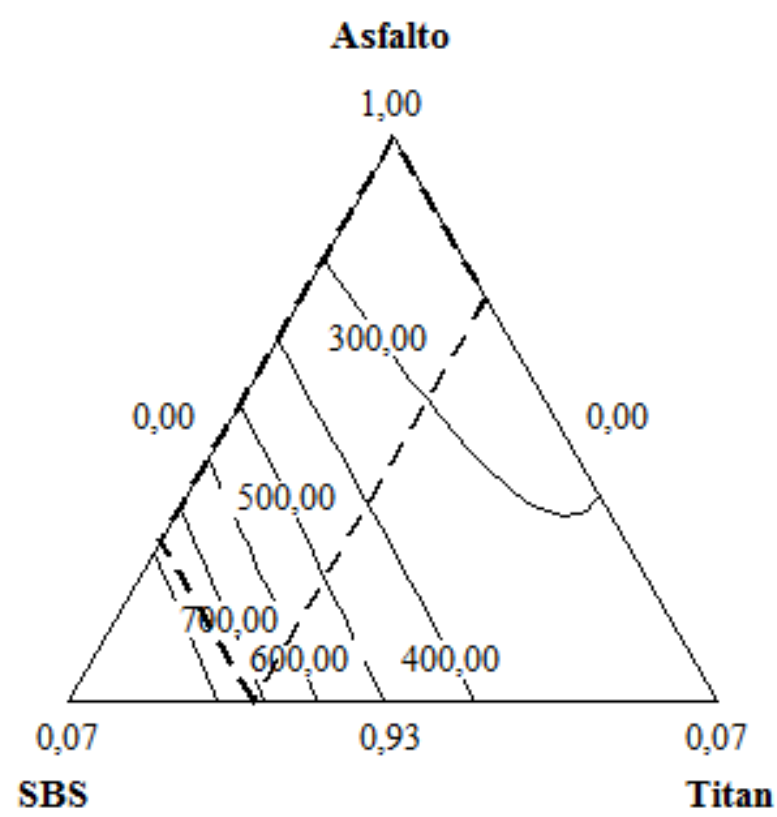

Figura A.9.3 - Superfície de resposta para viscosidade na condição RTFOT a $150^{\circ} \mathrm{C}$ 


\section{Modelo A.10 Viscosidade na condição envelhecida a curto prazo a $163^{\circ} \mathrm{C}$}

Os pontos 3, 9, 15, 16, 24, e 30 foram retirados para obtenção deste modelo. A exclusão destes pontos se justifica pela seguinte constatação: estes valores destoam dos demais, sendo observações muito acima de 2 desvio padrões nos gráficos de resíduos, sendo estes pontos considerados "outliers". O modelo melhorou sem estes pontos, sendo verificado um aumento do $\mathrm{R}^{2}$. Mesmo com as retiradas, o valor apresentado pelo VIF ainda foi alto, portanto o modelo apenas pode ser empregado para estimativa de novas ocorrências na região experimental.

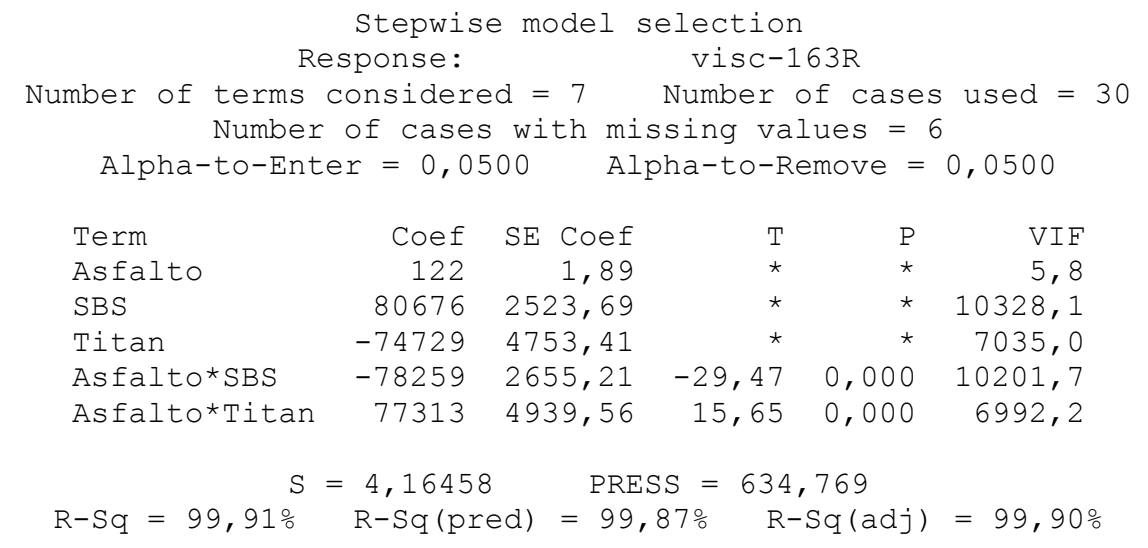

Residual Plots for visc-163R
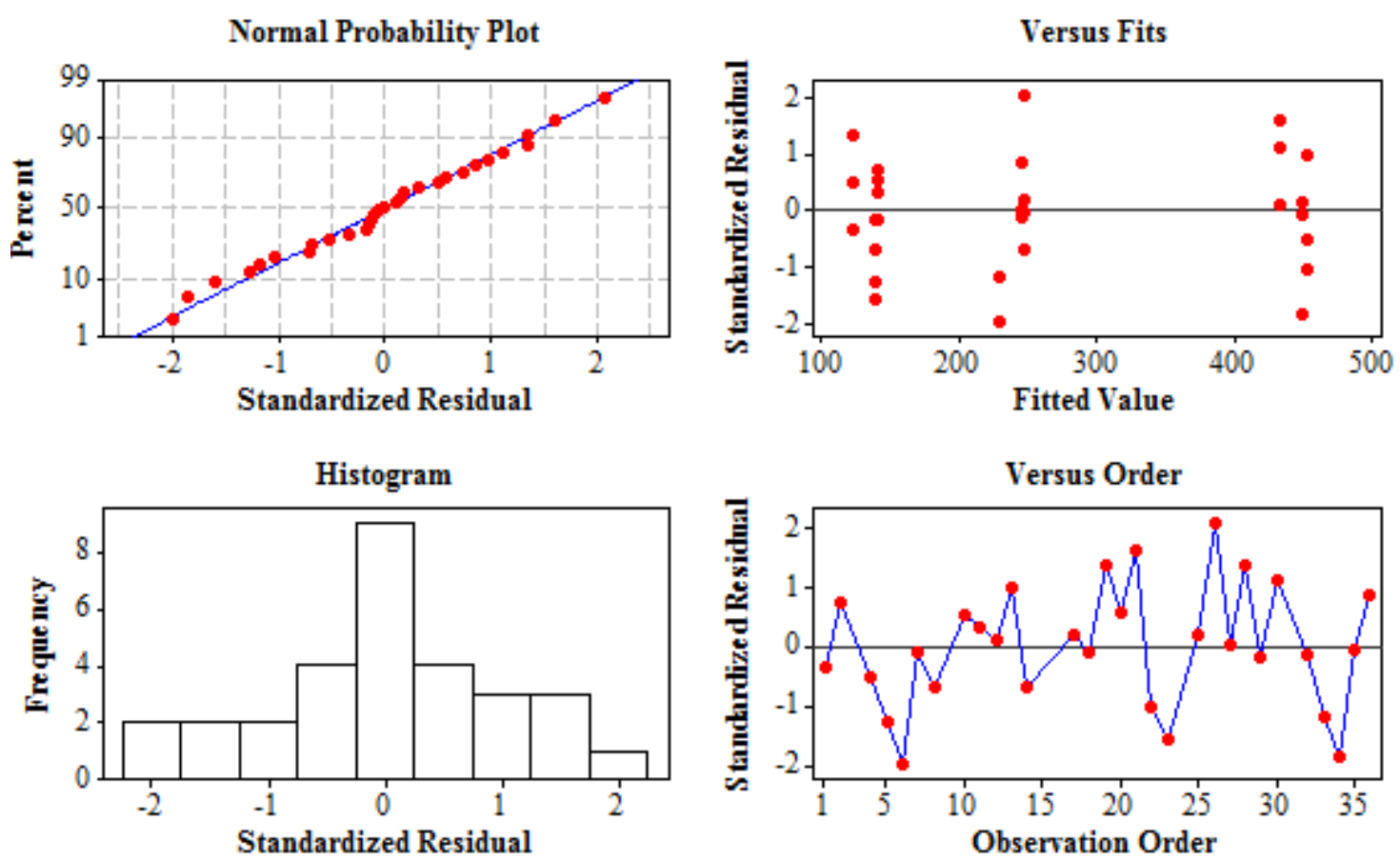

Figura A.10.1 - Análise de resíduos para viscosidade na condição RTFOT a $163^{\circ} \mathrm{C}$ 
Efeitos dos componentes

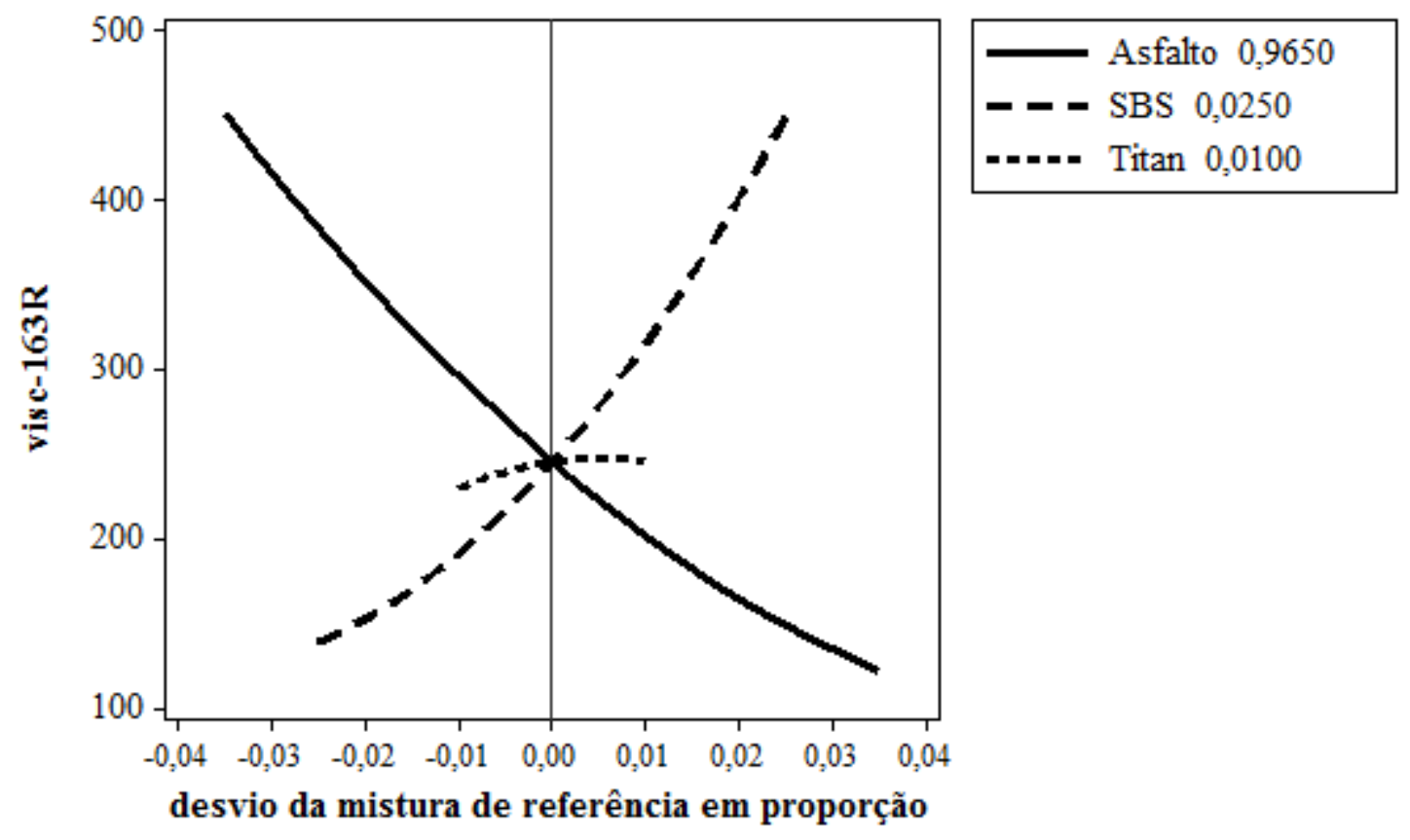

Figura A.10.2 - Efeitos dos componentes para viscosidade na condição RTFOT a $163^{\circ} \mathrm{C}$

Superficie de resposta para viscosidade RTFOT a $163^{\circ} \mathrm{C}$

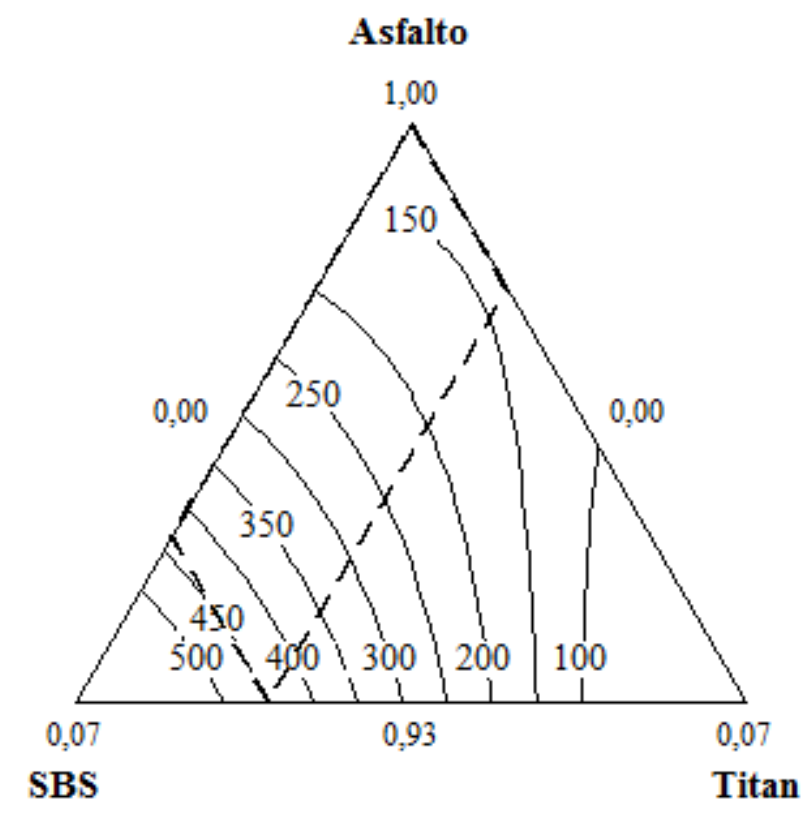

Figura A.10.3 - Superfície de resposta para viscosidade na condição RTFOT a $163^{\circ} \mathrm{C}$ 


\section{Modelo A.11 Viscosidade na condição envelhecida a curto prazo a $177^{\circ} \mathrm{C}$}

Os pontos 3, 9, 16, 31 e 34 foram retirados para obtenção deste modelo. A exclusão destes pontos se justifica pela seguinte constatação: estes valores destoam dos demais, sendo observações muito acima de 2 desvio padrões nos gráficos de resíduos, sendo estes pontos considerados "outliers". O modelo melhorou sem estes pontos, sendo verificado um aumento do $\mathrm{R}^{2}$. Mesmo com as retiradas, o valor apresentado pelo VIF ainda foi alto, portanto o modelo apenas pode ser empregado para estimativa de novas ocorrências na região experimental.

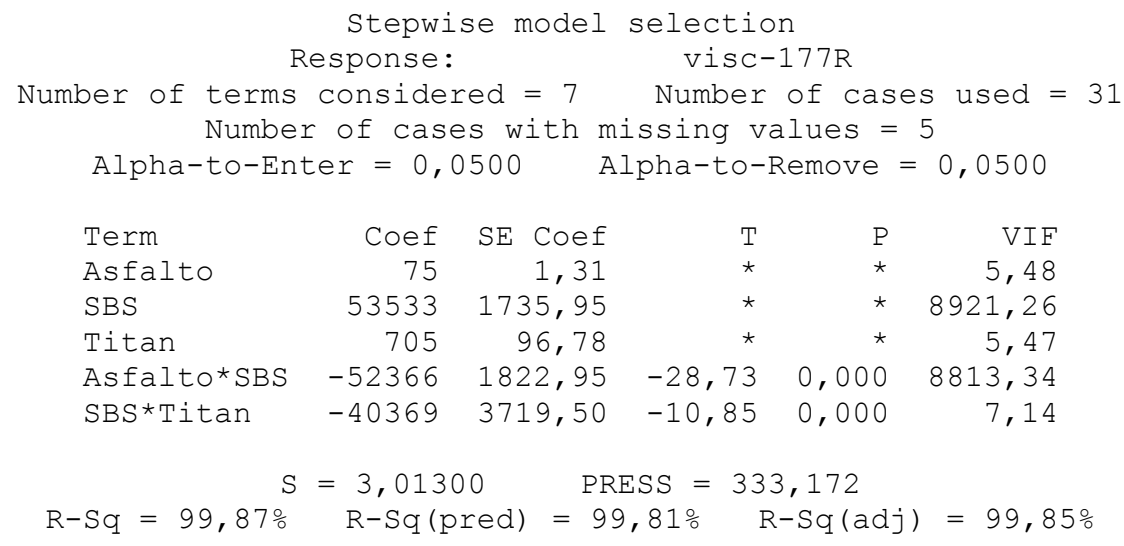

Residual Plots for visc-177R
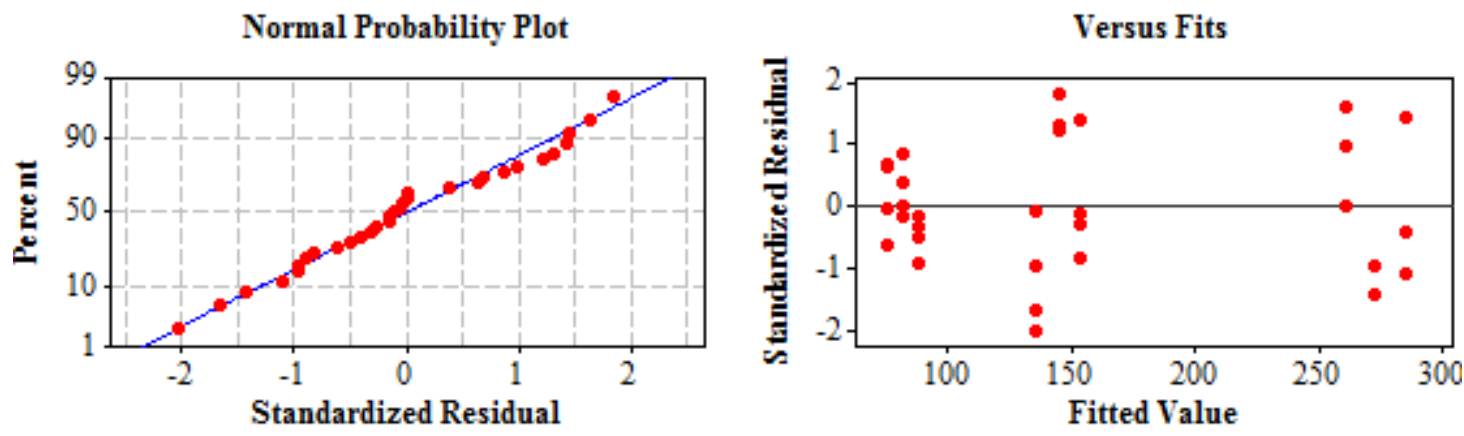

Histogram

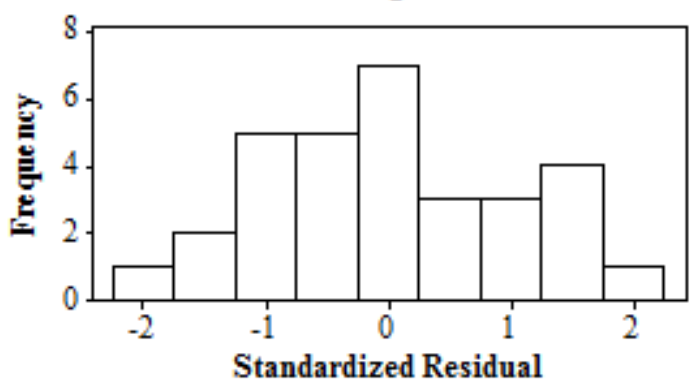

Versus Order

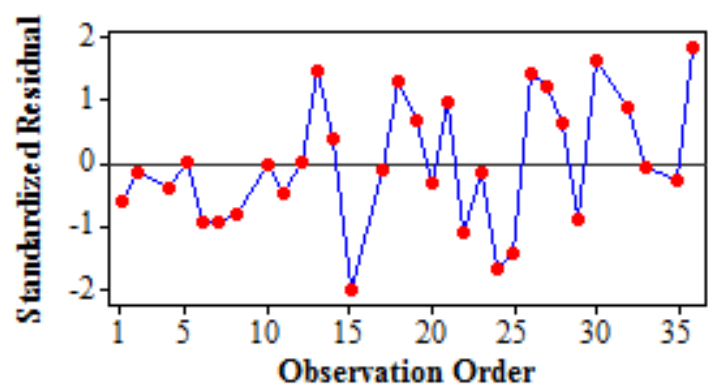

Figura A.11.1 - Análise de resíduos para viscosidade na condição RTFOT a $177^{\circ} \mathrm{C}$ 
Efeitos dos componentes

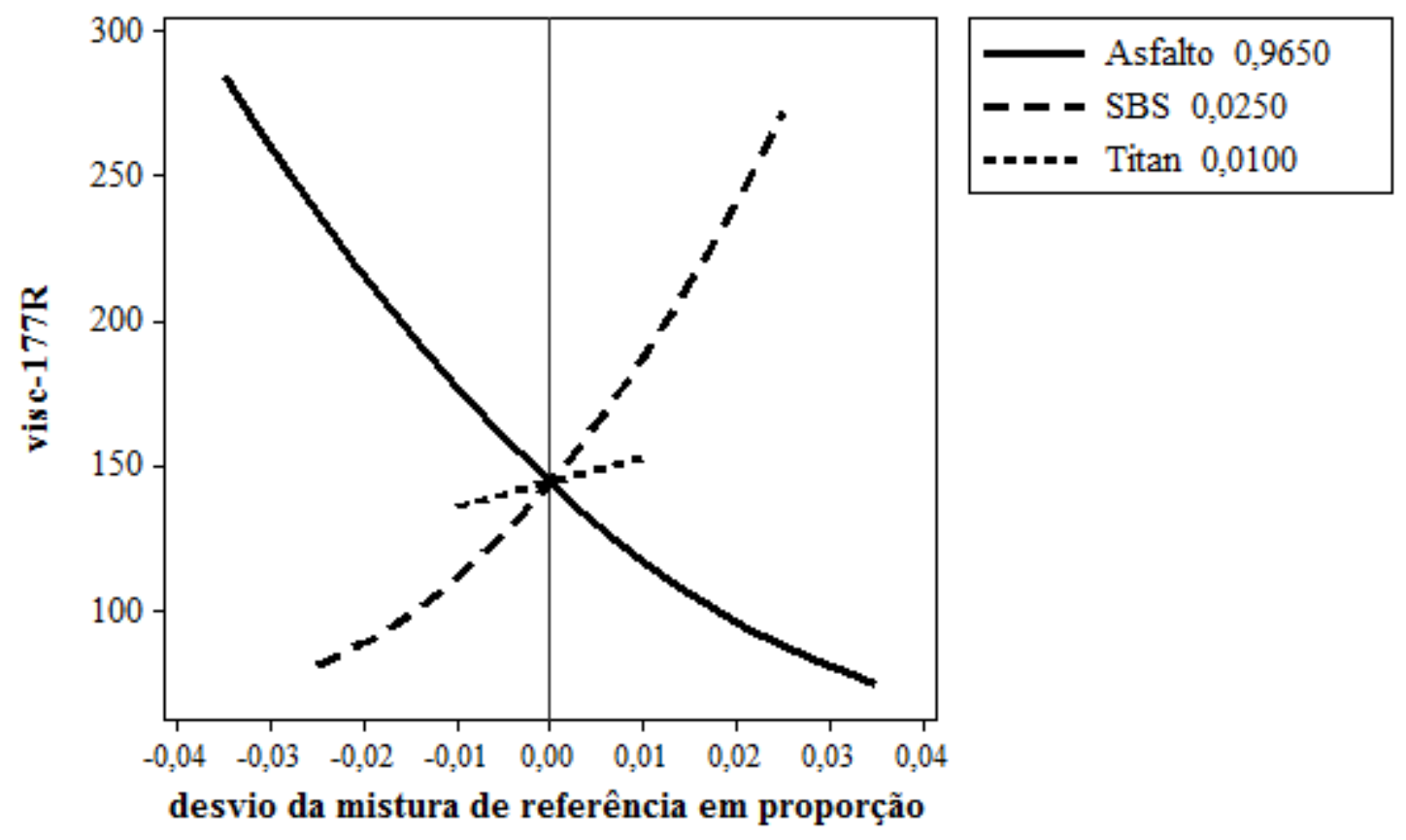

Figura A.11.2 - Efeitos dos componentes para viscosidade na condição RTFOT a $177^{\circ} \mathrm{C}$

Superficie de resposta para viscosidade RTFOT a $177^{\circ} \mathrm{C}$

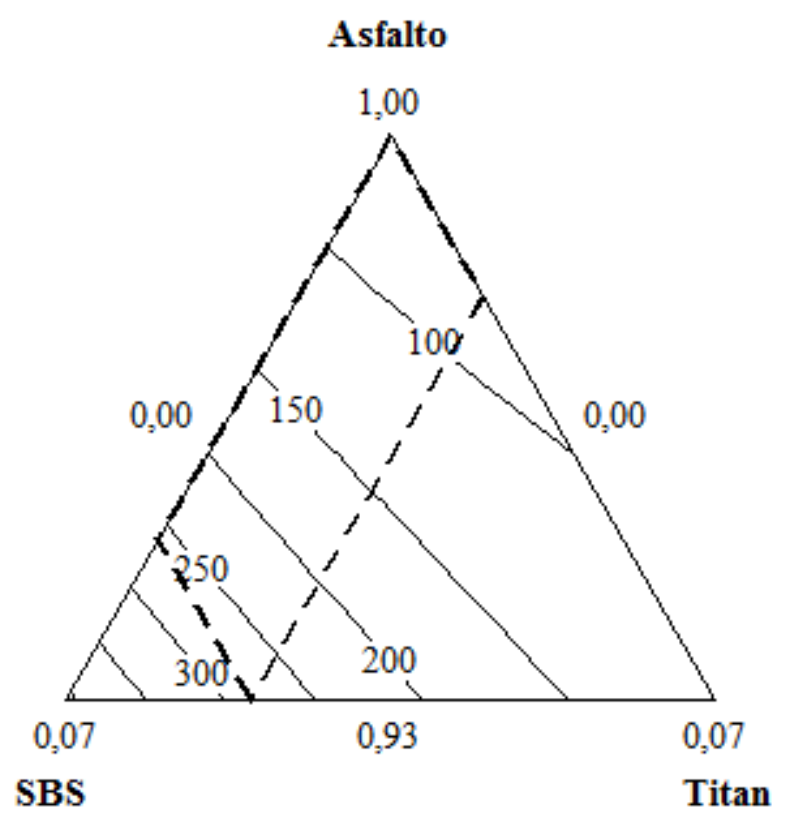

Figura A.11.3 - Superfície de resposta para viscosidade na condição RTFOT a $177^{\circ} \mathrm{C}$ 


\section{Modelo A.12 Temperatura de Compactação das misturas}

Os pontos $1,3,4,8,22,30$ e 34 foram retirados para obtenção deste modelo. A exclusão destes pontos se justifica pela seguinte constatação: estes valores destoam dos demais, sendo observações muito acima de 2 desvio padrões nos gráficos de resíduos, sendo estes pontos considerados "outliers". O modelo melhorou sem estes pontos, sendo verificado um aumento do $\mathrm{R}^{2}$. Mesmo com as retiradas, o valor apresentado pelo VIF ainda foi alto, portanto o modelo apenas pode ser empregado para estimativa de novas ocorrências na região experimental.

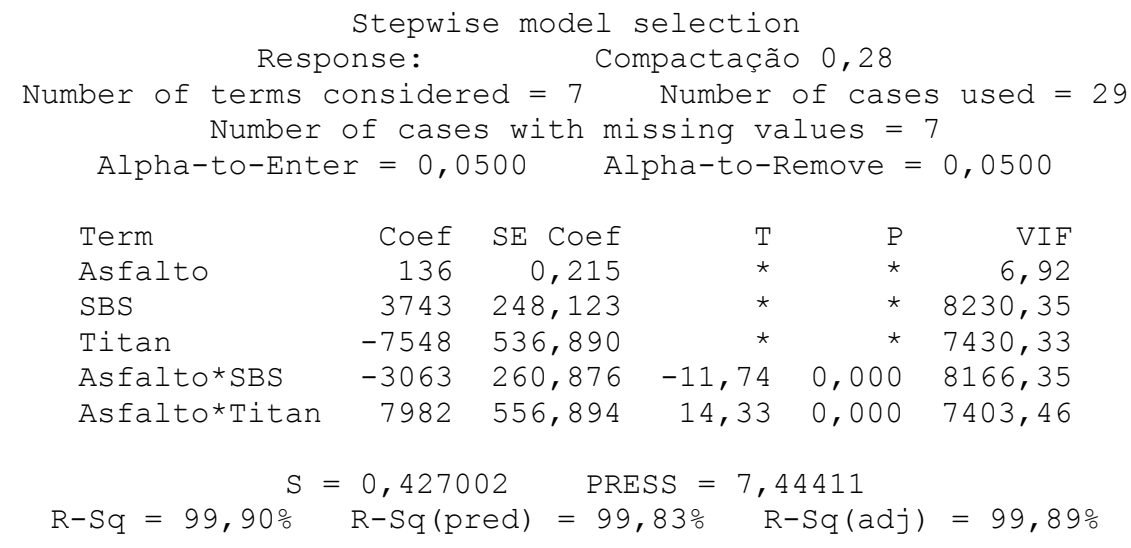

\section{Residual Plots for Compactação 0,28}

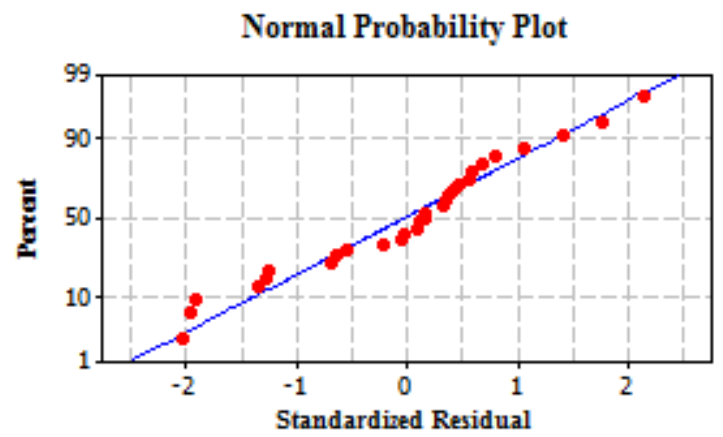

Histogram

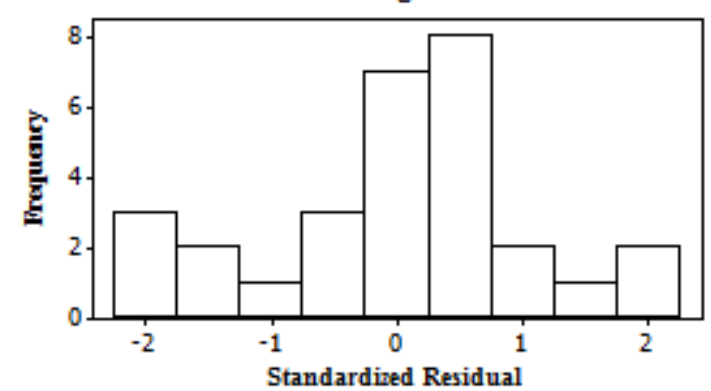

Versus Fits

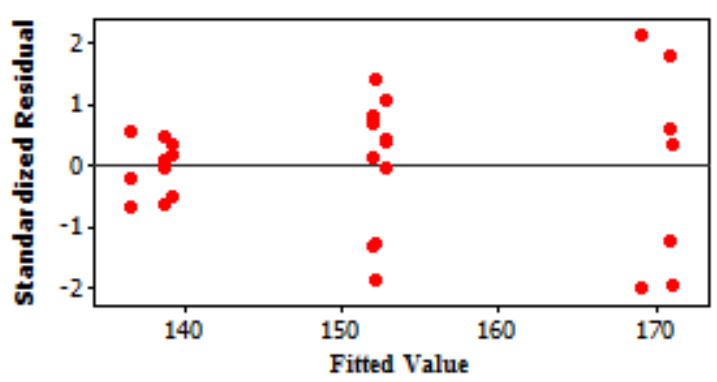

Versus Order

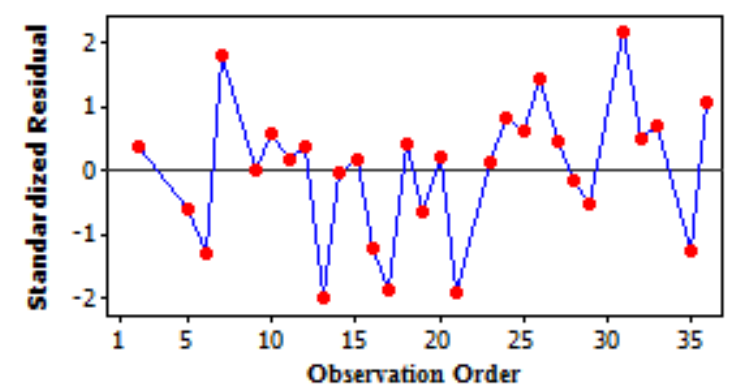

Figura A.12.1 - Análise de resíduos para temperatura de compactação das misturas 
Efeitos dos componentes

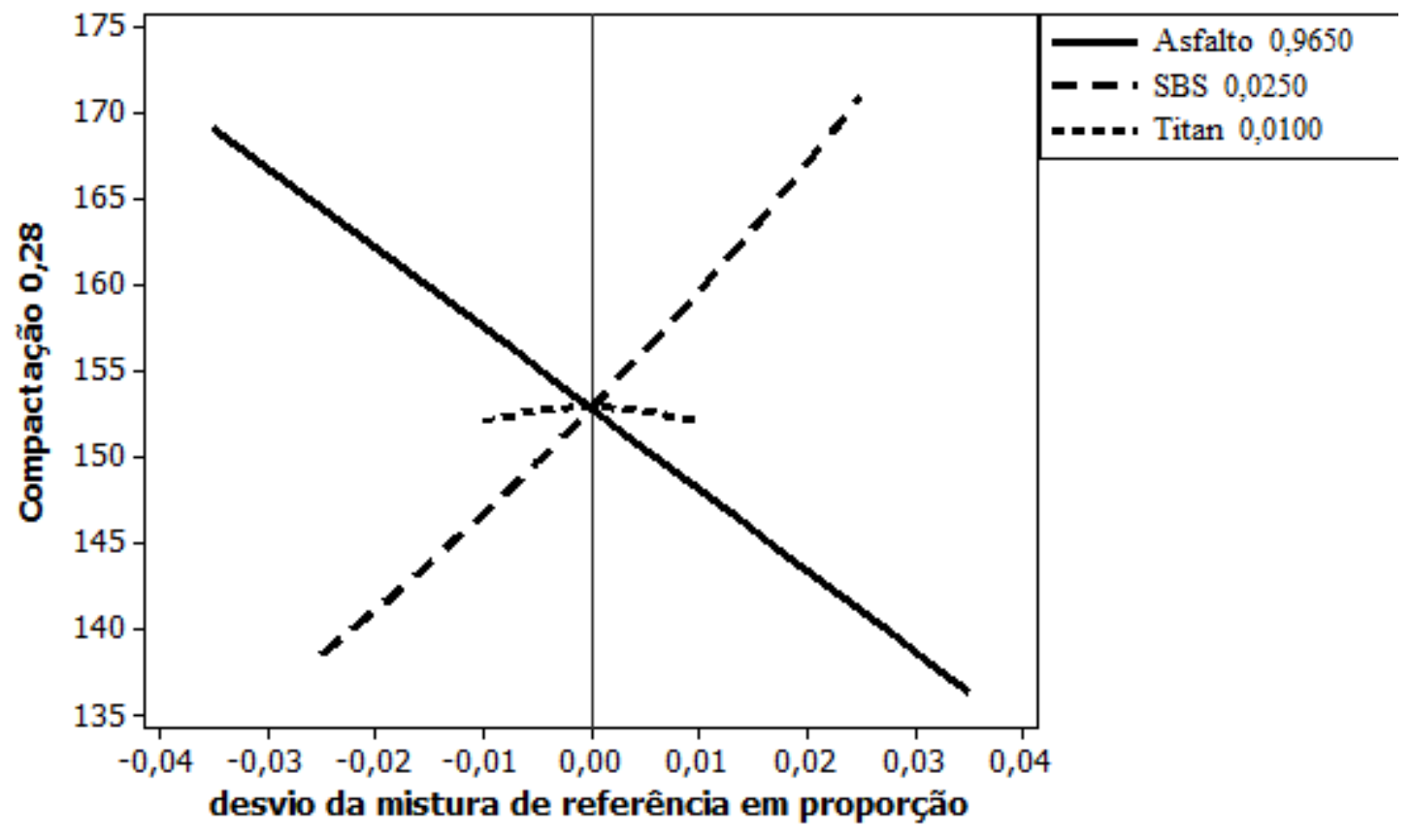

Figura A.12.2 - Efeitos dos componentes para temperatura de compactação das misturas

Superfície de resposta para temperatura de compactação

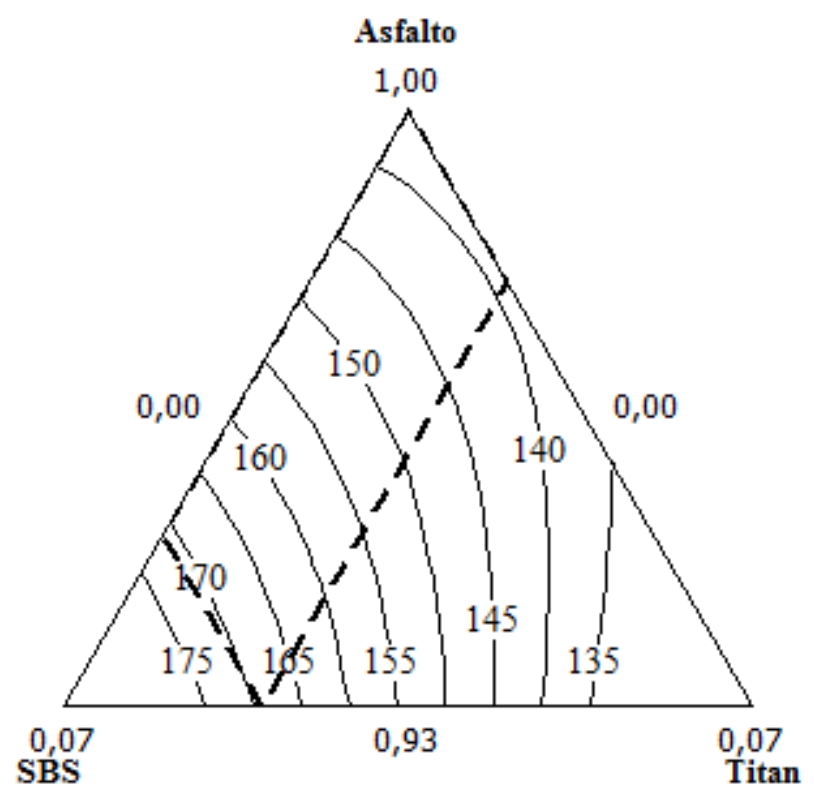

Figura A.12.3 - Superfície de resposta para temperatura de compactação das misturas 


\section{Modelo A.13 Temperatura de usinagem das misturas}

Os pontos 1, 3, 4, 12 e 30 foram retirados para obtenção deste modelo. A exclusão destes pontos se justifica pela seguinte constatação: estes valores destoam dos demais, sendo observações muito acima de 2 desvio padrões nos gráficos de resíduos, sendo estes pontos considerados "outliers". O modelo melhorou sem estes pontos, sendo verificado um aumento do $\mathrm{R}^{2}$. Mesmo com as retiradas, o valor apresentado pelo VIF ainda foi alto, portanto o modelo apenas pode ser empregado para estimativa de novas ocorrências na região experimental.

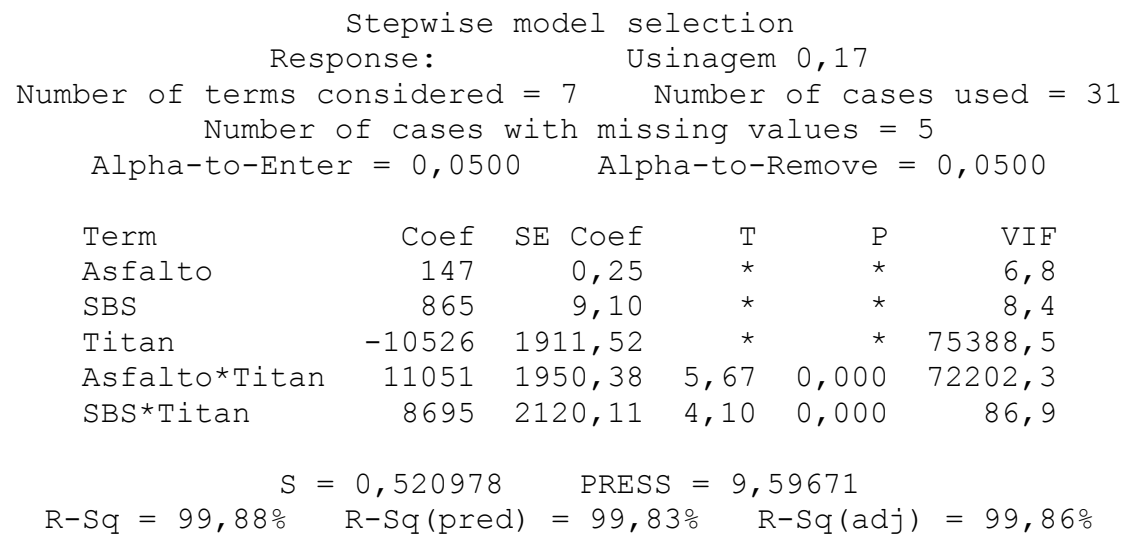

Residual Plots for Usinagem 0,17
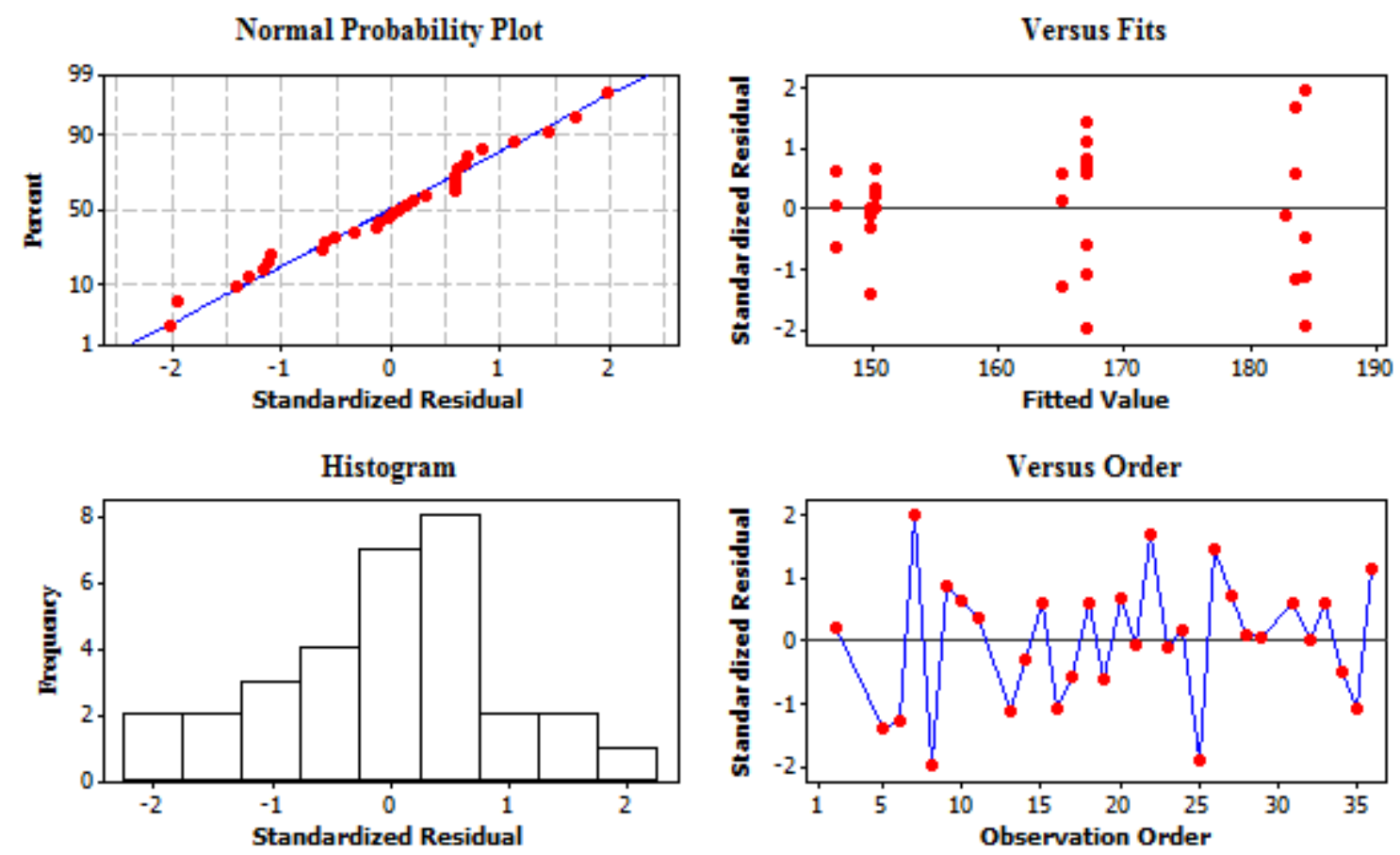

Figura A.13.1 - Análise de resíduos para temperatura de usinagem das misturas 
Efeitos dos componentes

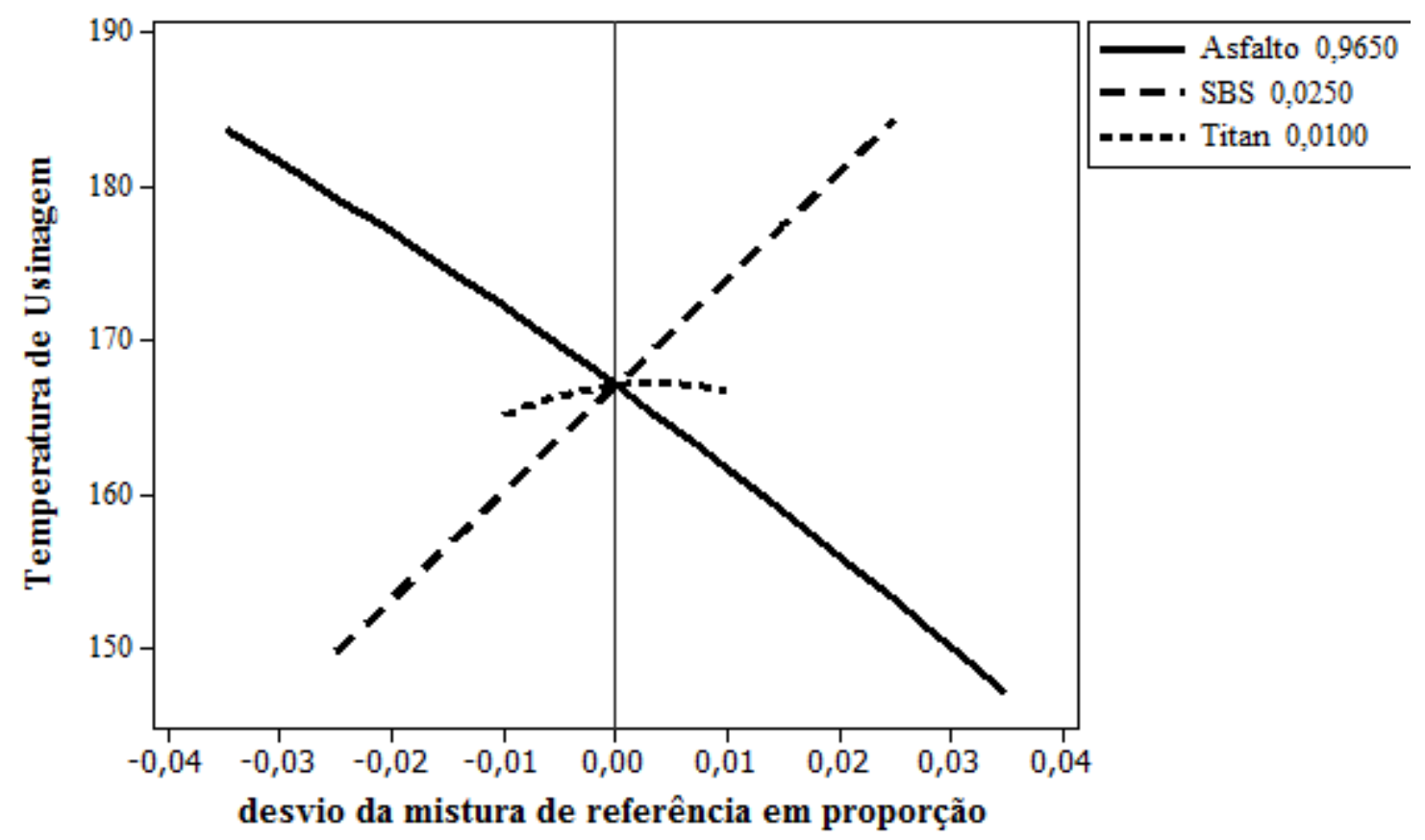

Figura A.13.2 - Efeitos dos componentes para temperatura de usinagem das misturas

Superficie de resposta para temperatura de usinagem

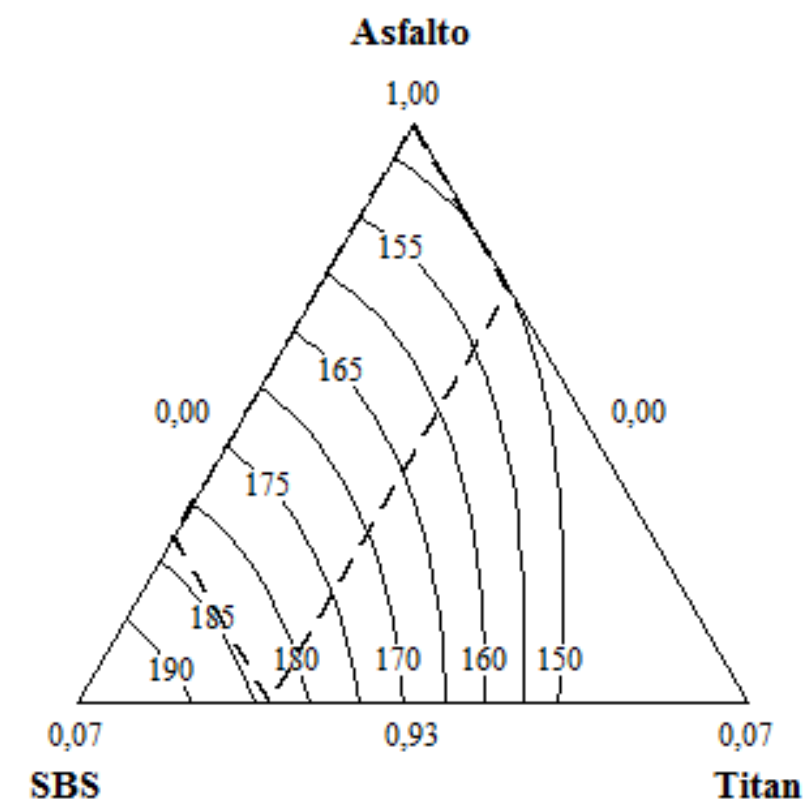

Figura A.13.3 - Superfície de resposta para temperatura de usinagem das misturas 


\section{Modelo A.14 Incremento de viscosidade a $135^{\circ} \mathrm{C}$}

Os pontos 1, 3, 8, 9, 12, 21, 22, 24, 26 e 30 foram retirados para obtenção deste modelo. A exclusão destes pontos são justificados pela seguinte constatação: estes valores destoam dos demais, sendo observações muito acima de 2 desvio padrões nos gráficos de resíduos, sendo estes pontos considerados "outliers". O modelo melhorou sem estes pontos, sendo verificado um aumento do $\mathrm{R}^{2}$. Mesmo com as retiradas o valor apresentado pelo VIF foram satisfatórios, onde os coeficientes dos termos podem ser empregados para explicar a variação entre as misturas.

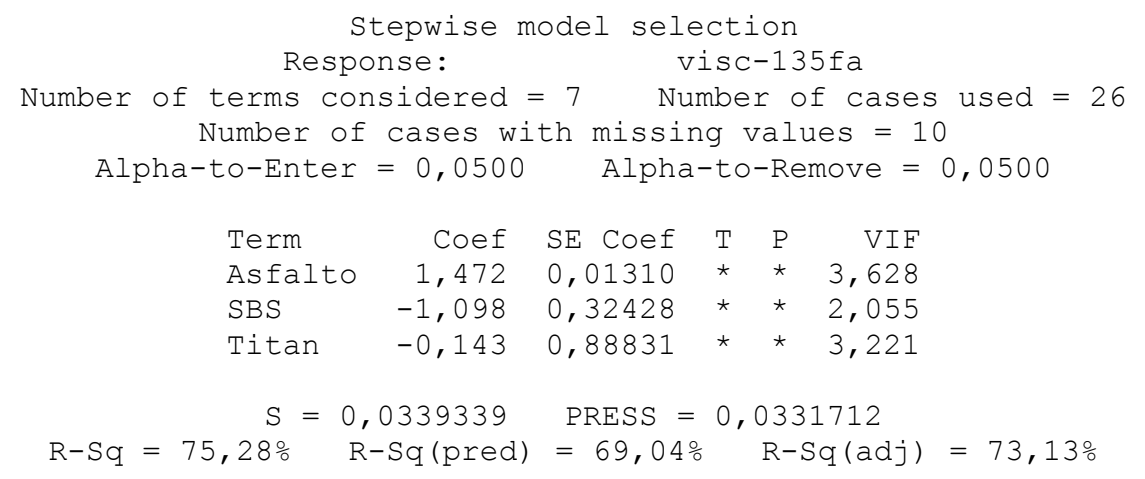

\section{Residual Plots for visc-135fa}
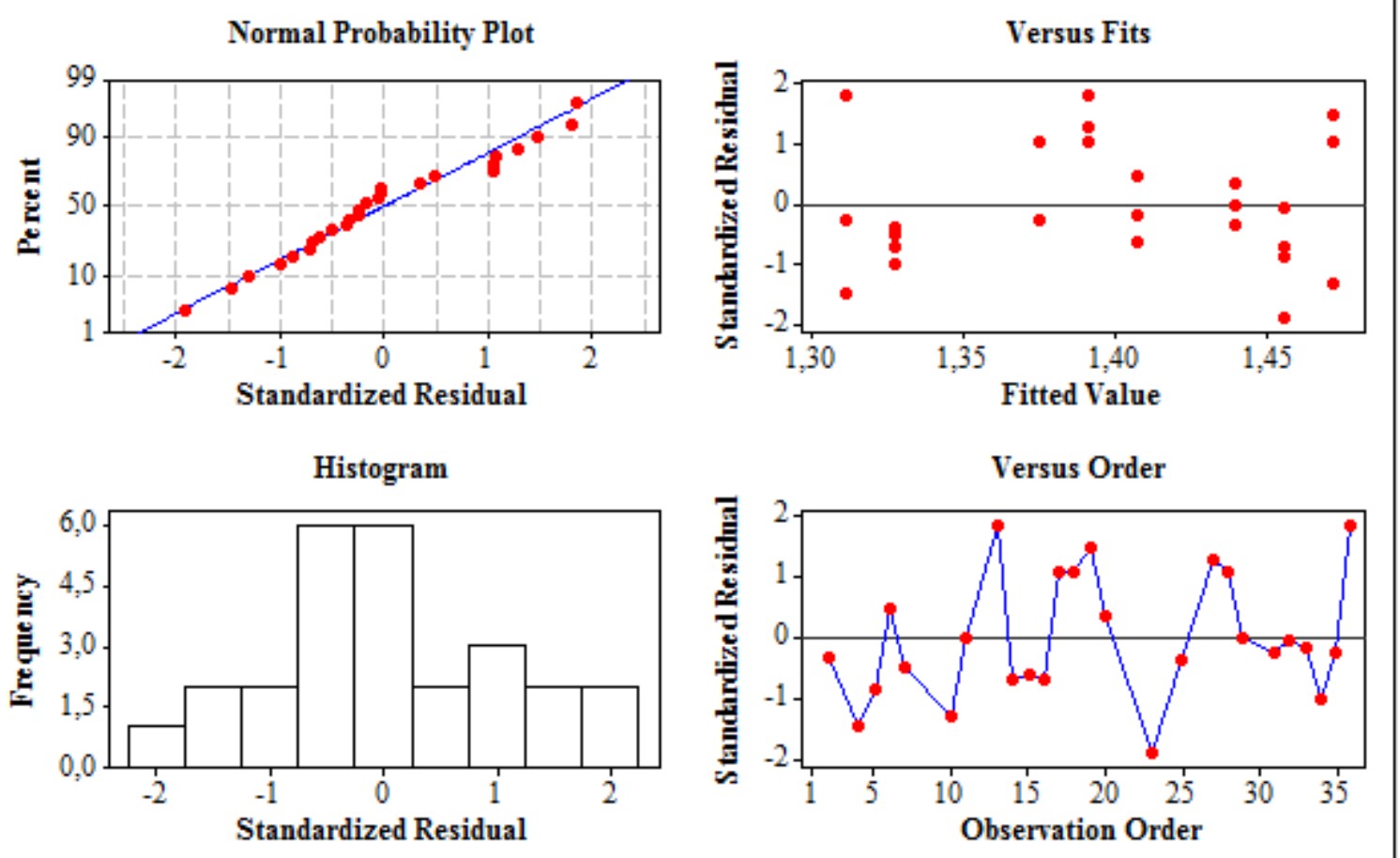

Figura A.14.1 - Análise de resíduos para incremento de viscosidade a $135^{\circ} \mathrm{C}$ 
Efeitos dos componentes

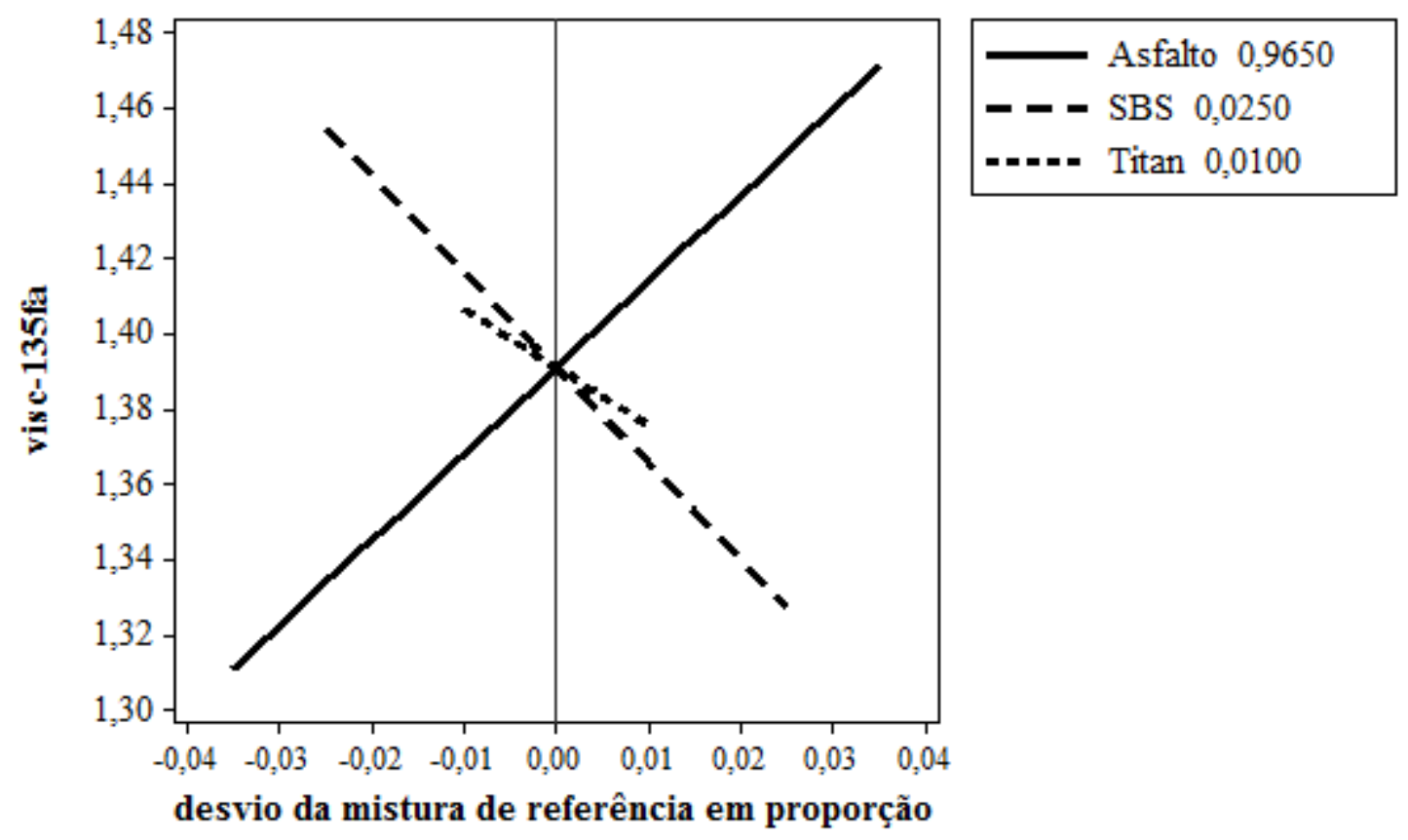

Figura A.14.2 - Efeitos dos componentes para incremento de viscosidade a $135^{\circ} \mathrm{C}$

Superficie de resposta para incremento de viscosidade a $135^{\circ} \mathrm{C}$

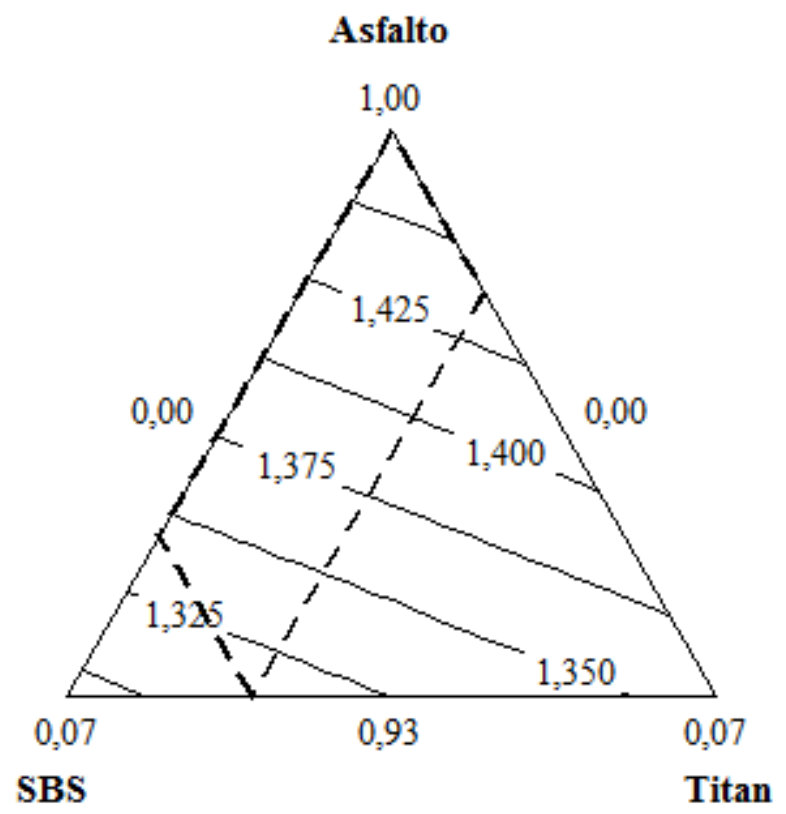

Figura A.14.3 - Superfície de resposta para incremento de viscosidade a $135^{\circ} \mathrm{C}$ 


\section{Modelo A.15 Incremento de viscosidade a $143^{\circ} \mathrm{C}$}

Os pontos 1, 3, 8, 9, 13, 19, 24, 28 e 30 foram retirados para obtenção deste modelo. A exclusão destes pontos são justificados pela seguinte constatação: estes valores destoam dos demais, sendo observações muito acima de 2 desvio padrões nos gráficos de resíduos, sendo estes pontos considerados "outliers". O modelo melhorou sem estes pontos, sendo verificado um aumento do $\mathrm{R}^{2}$. Mesmo com as retiradas o valor apresentado pelo VIF foram satisfatórios, onde os coeficientes dos termos podem ser empregados para explicar a variação entre as misturas.

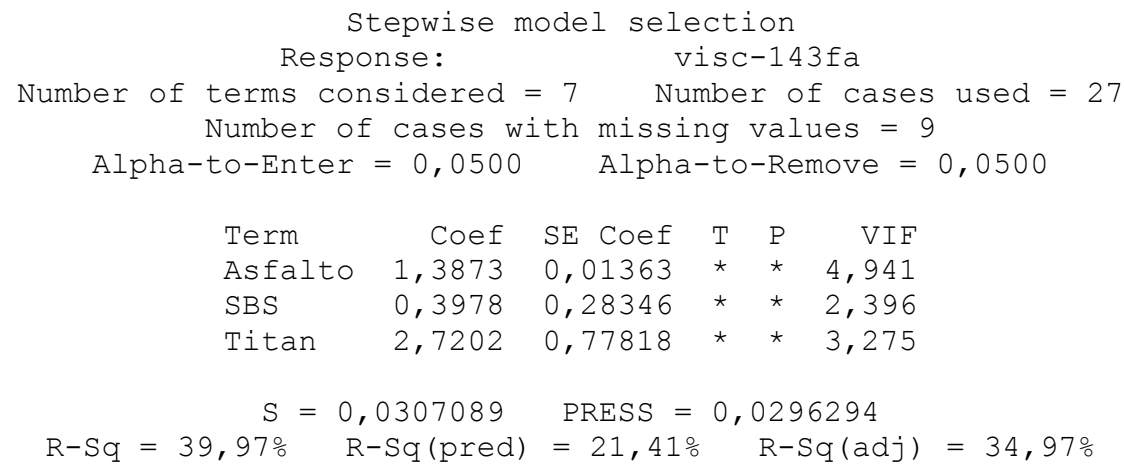

\section{Residual Plots for visc-143fa}
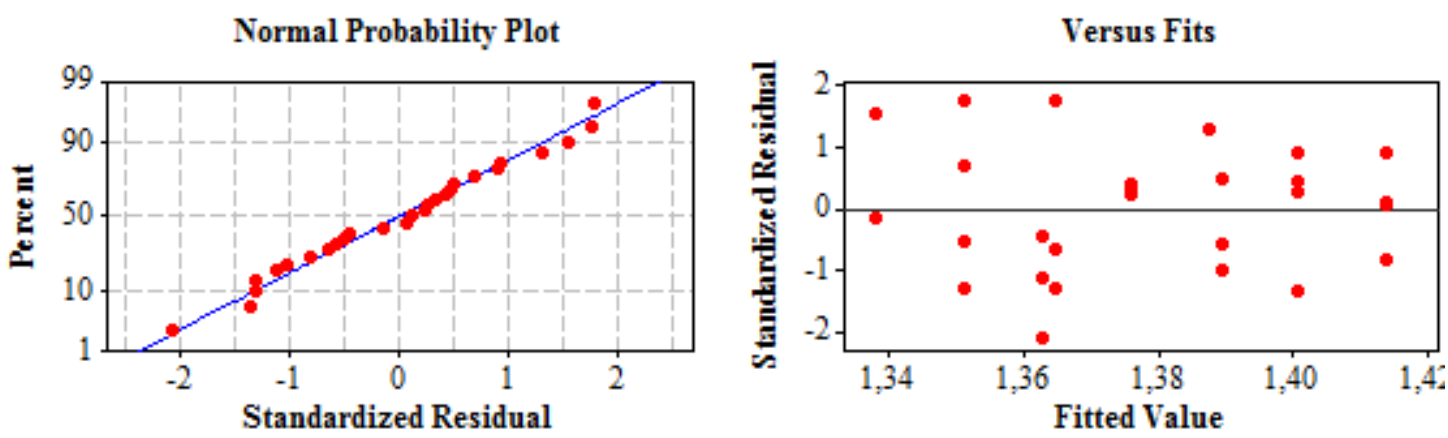

Histogram
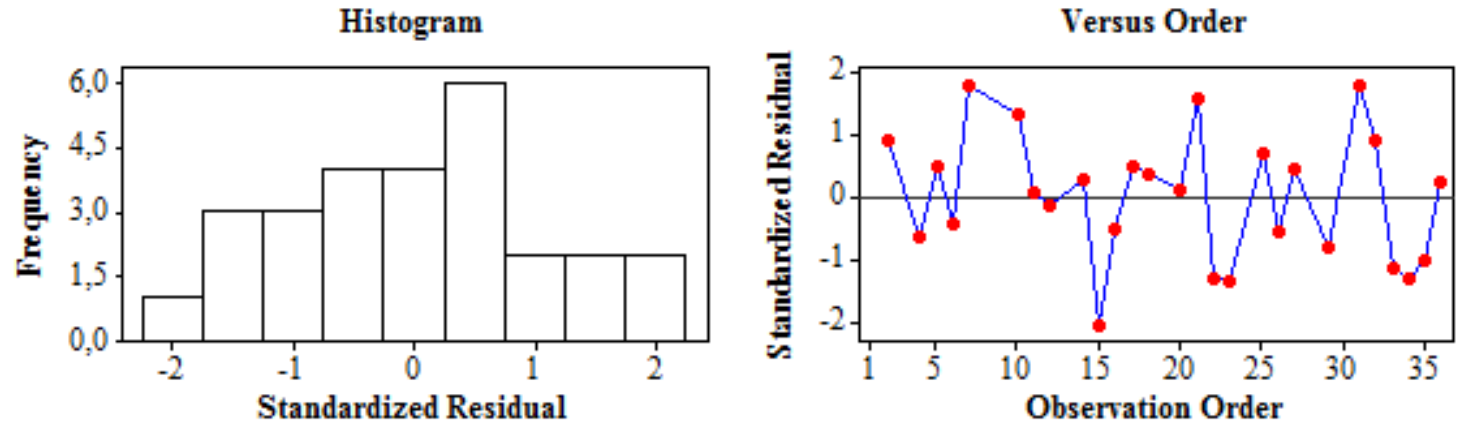

Figura A.15.1 - Análise de resíduos para incremento de viscosidade a $143^{\circ} \mathrm{C}$ 


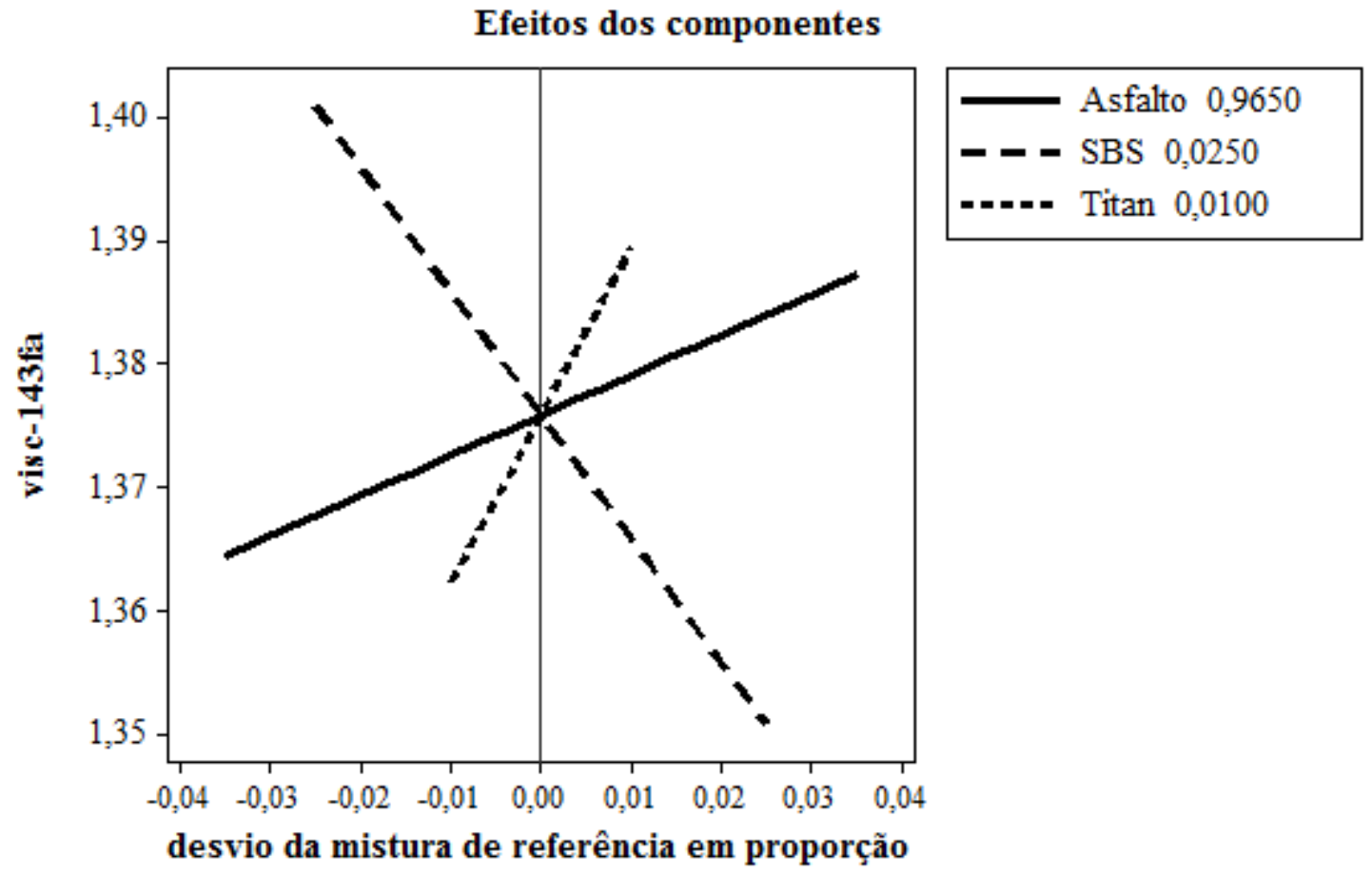

Figura A.15.2 - Efeitos dos componentes para incremento de viscosidade a $143^{\circ} \mathrm{C}$

Superfície de resposta para incremento de viscosidade a $143^{\circ} \mathrm{C}$

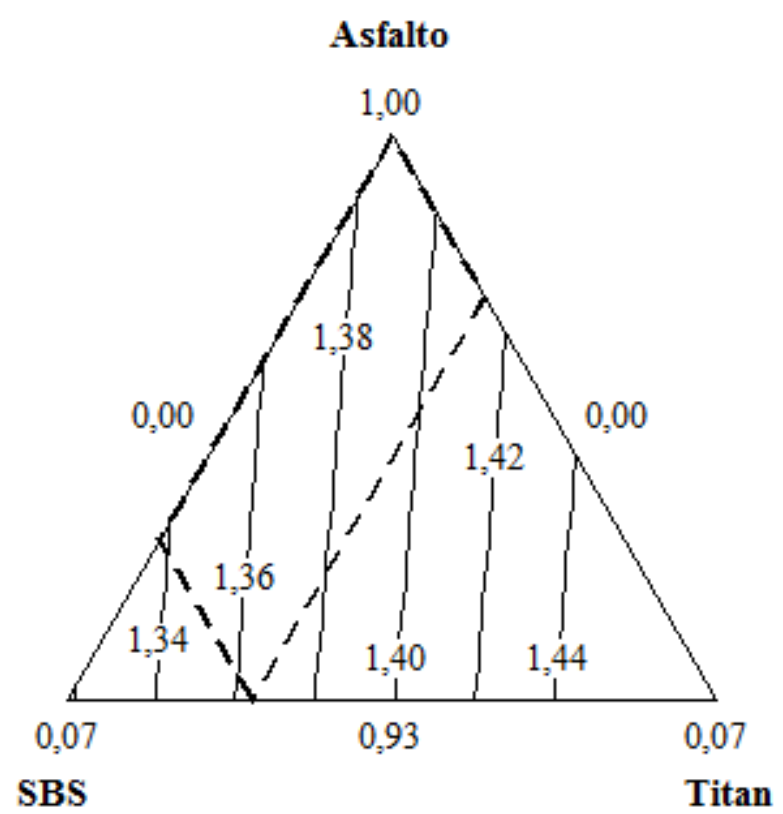

Figura A.15.3 - Superfície de resposta para incremento de viscosidade a $143^{\circ} \mathrm{C}$ 


\section{Modelo A.16 Incremento de viscosidade a $150^{\circ} \mathrm{C}$}

Os pontos $3,9,10,13,19,28,30$ e 31 foram retirados para obtenção deste modelo. A exclusão destes pontos são justificados pela seguinte constatação: estes valores destoam dos demais, sendo observações muito acima de 2 desvio padrões nos gráficos de resíduos, sendo estes pontos considerados "outliers". O modelo melhorou sem estes pontos, sendo verificado um aumento do $\mathrm{R}^{2}$. Mesmo com as retiradas o valor apresentado pelo VIF foram satisfatórios, onde os coeficientes dos termos podem ser empregados para explicar a variação entre as misturas.

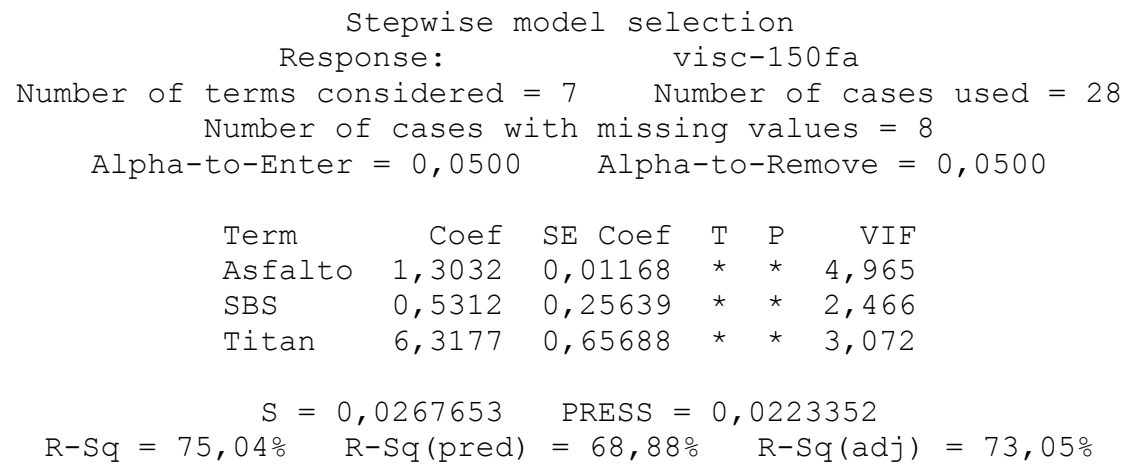

Residual Plots for visc-150fa
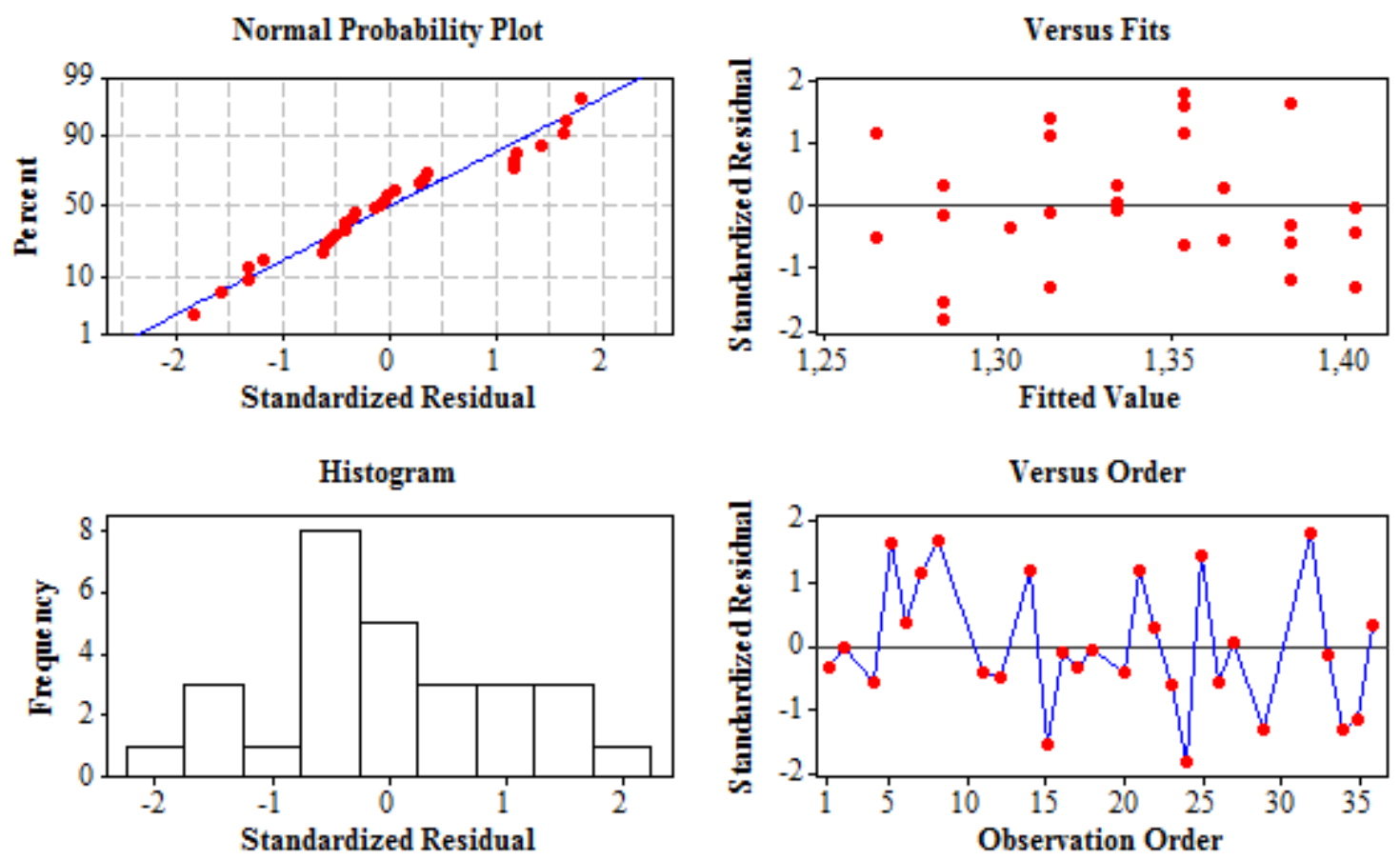

Figura A.16.1 - Análise de resíduos para incremento de viscosidade a $1^{\circ} 0^{\circ} \mathrm{C}$ 


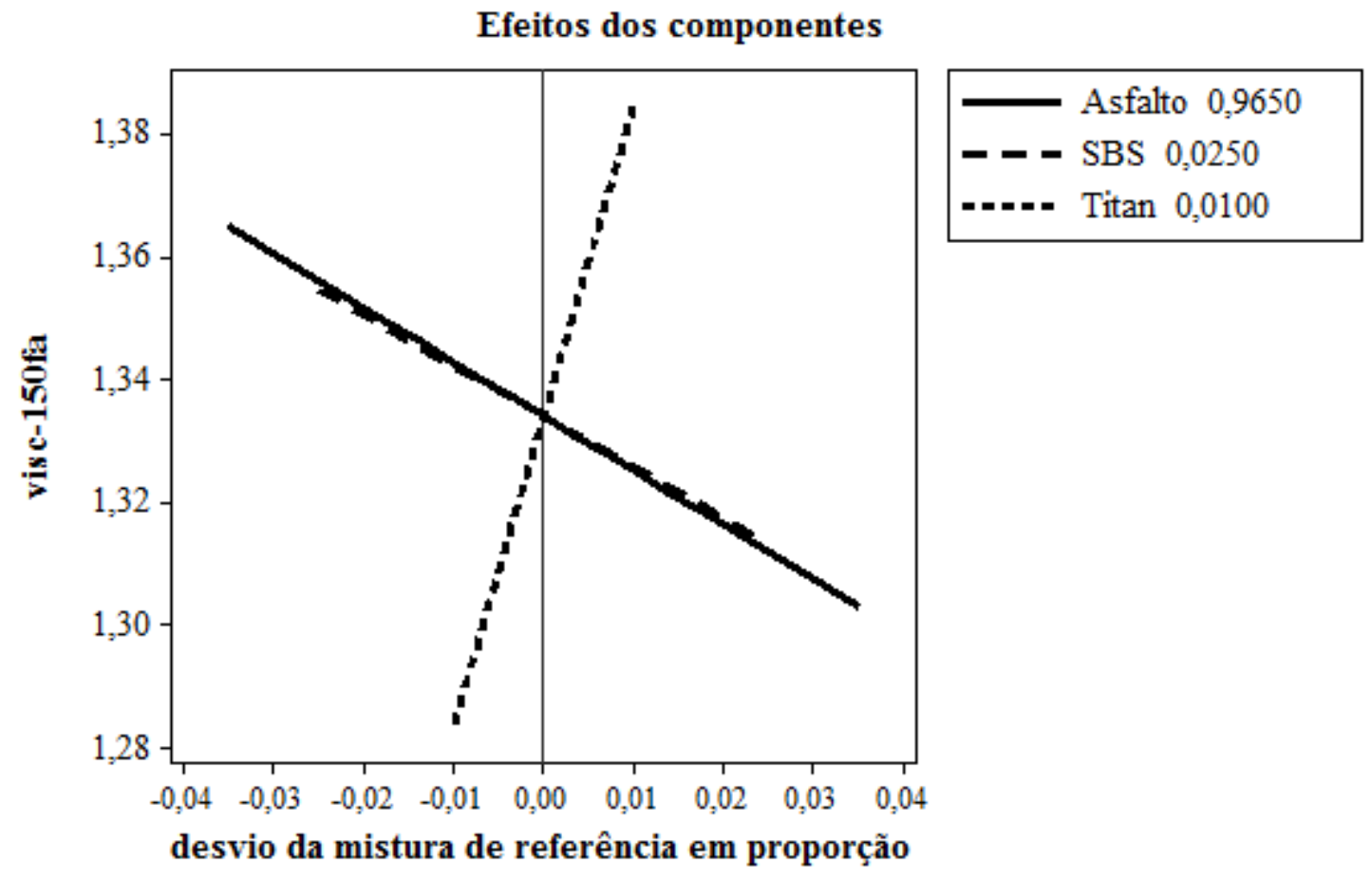

Figura A.16.2 - Efeitos dos componentes para incremento de viscosidade a $150^{\circ} \mathrm{C}$

Superfície de resposta para incremento de viscosidade a $150^{\circ} \mathrm{C}$

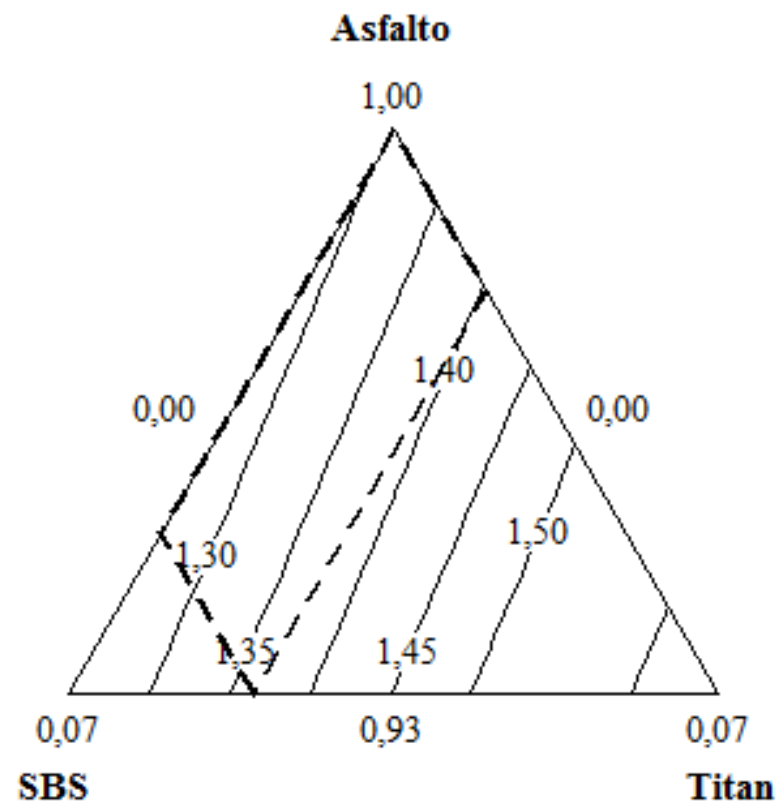

Figura A.16.3 - Superfície de resposta para incremento de viscosidade a $150^{\circ} \mathrm{C}$ 


\section{Modelo A.17 Incremento de viscosidade a $163^{\circ} \mathrm{C}$}

Os pontos 1,3, 9, 13, 15, 19, 24, 28, 30, 31 e 34 foram retirados para obtenção deste modelo. A exclusão destes pontos são justificados pela seguinte constatação: estes valores destoam dos demais, sendo observações muito acima de 2 desvio padrões nos gráficos de resíduos, sendo estes pontos considerados "outliers". O modelo melhorou sem estes pontos, sendo verificado um aumento do $\mathrm{R}^{2}$. Mesmo com as retiradas o valor apresentado pelo VIF foram satisfatórios, onde os coeficientes dos termos podem ser empregados para explicar a variação entre as misturas.

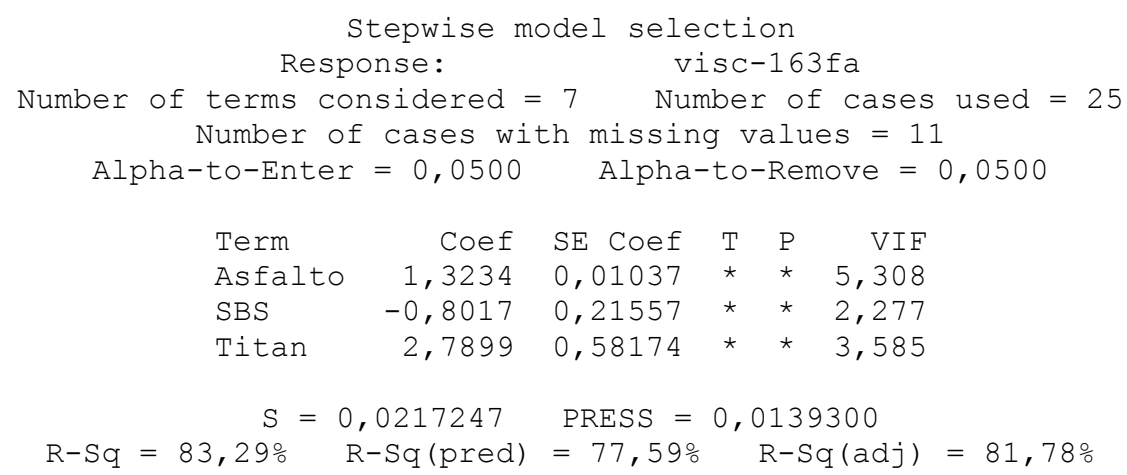

Residual Plots for visc-163fa

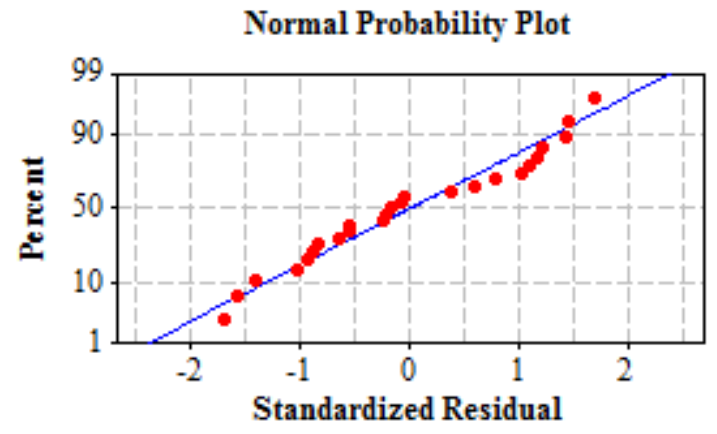

Histogram

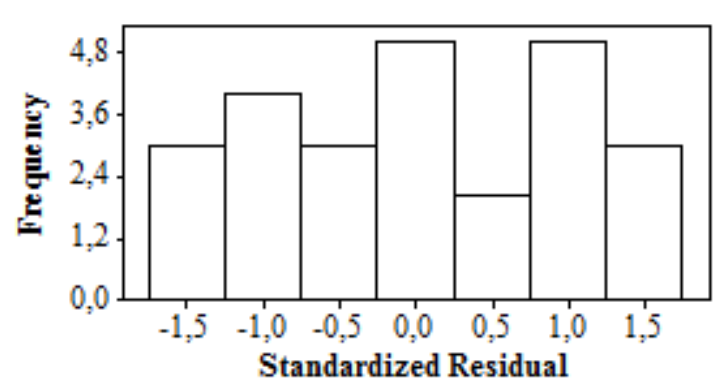

Versus Fits

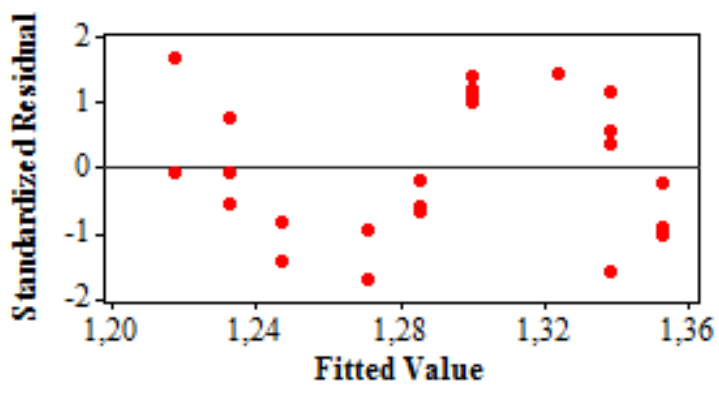

Versus Order

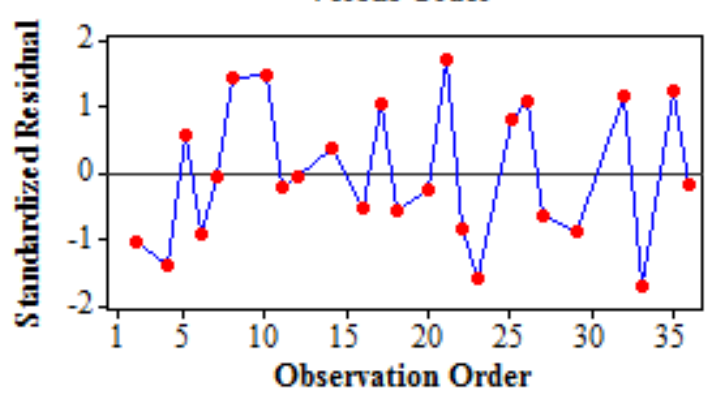

Figura A.17.1 - Análise de resíduos para incremento de viscosidade a $163^{\circ} \mathrm{C}$ 


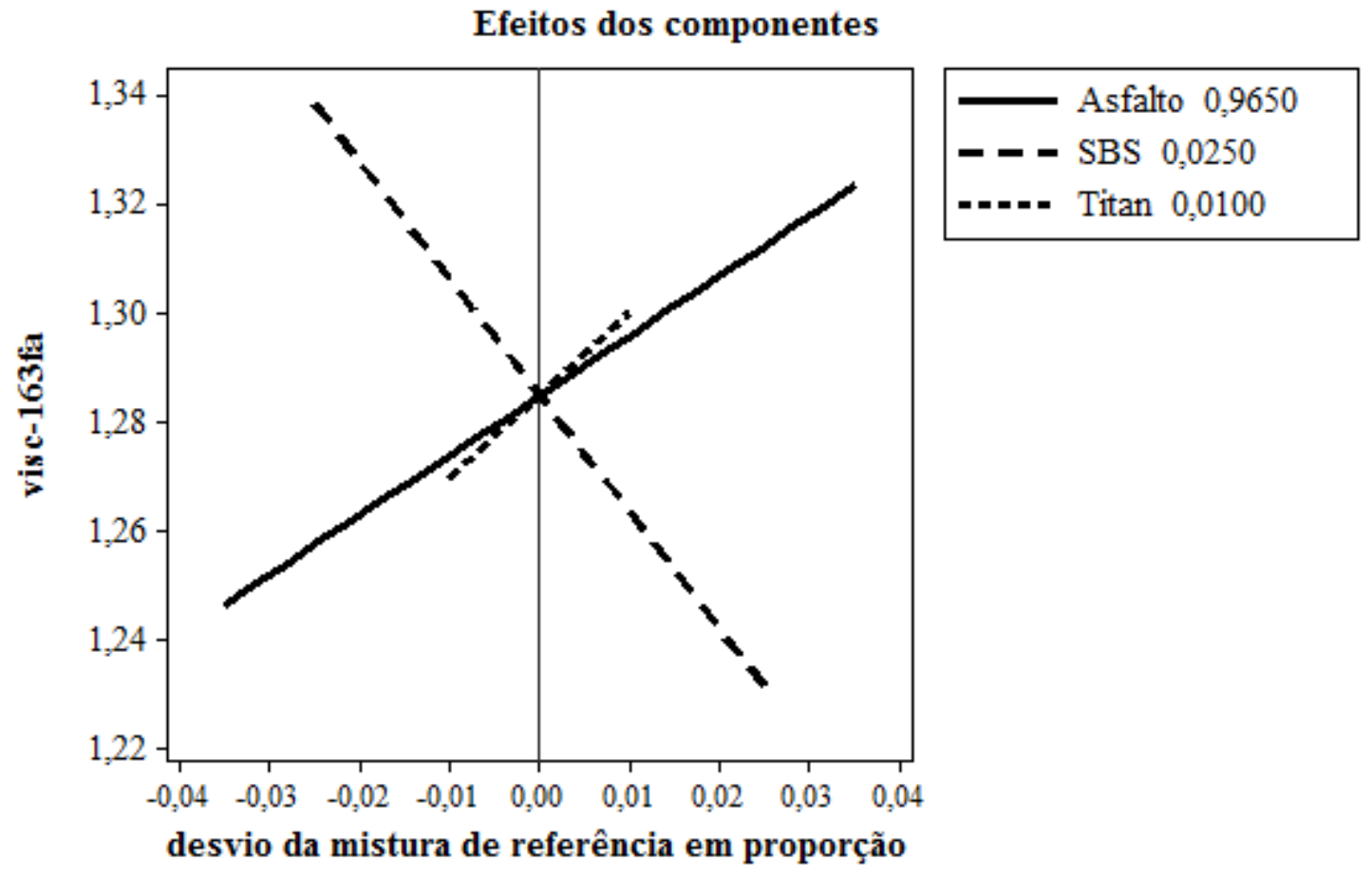

Figura A.17.2 - Efeitos dos componentes para incremento de viscosidade a $163^{\circ} \mathrm{C}$

Superfície de resposta para incremento de viscosidade a $163^{\circ} \mathrm{C}$

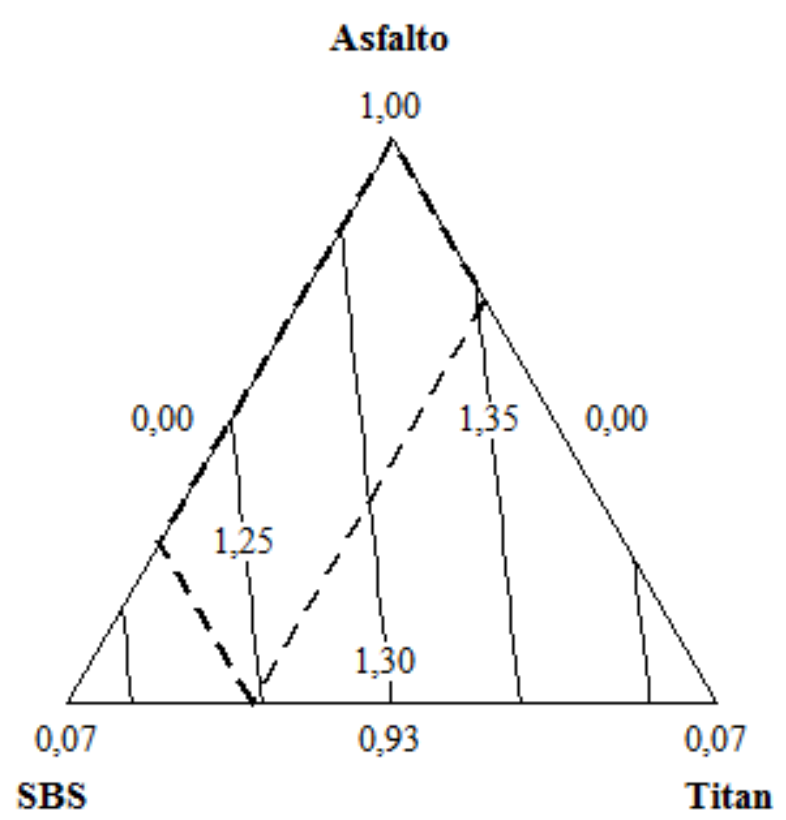

Figura A.17.3 - Superfície de resposta para incremento de viscosidade a $163^{\circ} \mathrm{C}$ 


\section{Modelo A.18 Incremento de viscosidade a $177^{\circ} \mathrm{C}$}

Os pontos 1, 3, 4, 9, 13, 21 e 30 foram retirados para obtenção deste modelo. A exclusão destes pontos são justificados pela seguinte constatação: estes valores destoam dos demais, sendo observações muito acima de 2 desvio padrões nos gráficos de resíduos, sendo estes pontos considerados "outliers". O modelo melhorou sem estes pontos, sendo verificado um aumento do $\mathrm{R}^{2}$. Mesmo com as retiradas o valor apresentado pelo VIF ainda foi alto, portanto o modelo apenas pode ser empregado para estimativa de novas ocorrências na região experimental.

Stepwise model selection
Response:
visc-177fa
Number of terms considered $=7$ $\begin{gathered}\text { Number of cases used = } 29 \\ \text { Number of cases with missing values = }\end{gathered}$

Residual Plots for visc-177fa
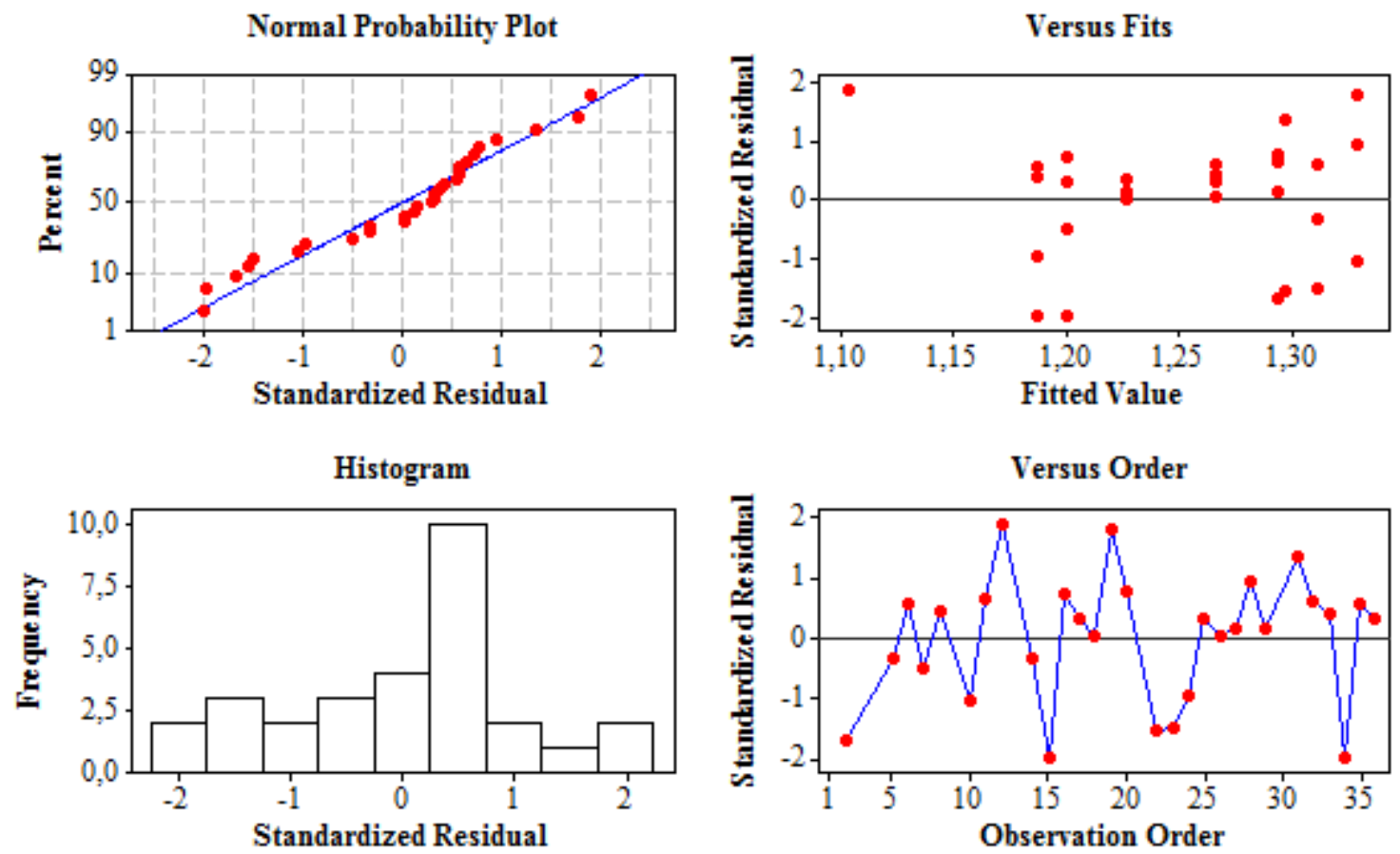

Figura A.18.1 - Análise de resíduos para incremento de viscosidade a $177^{\circ} \mathrm{C}$ 


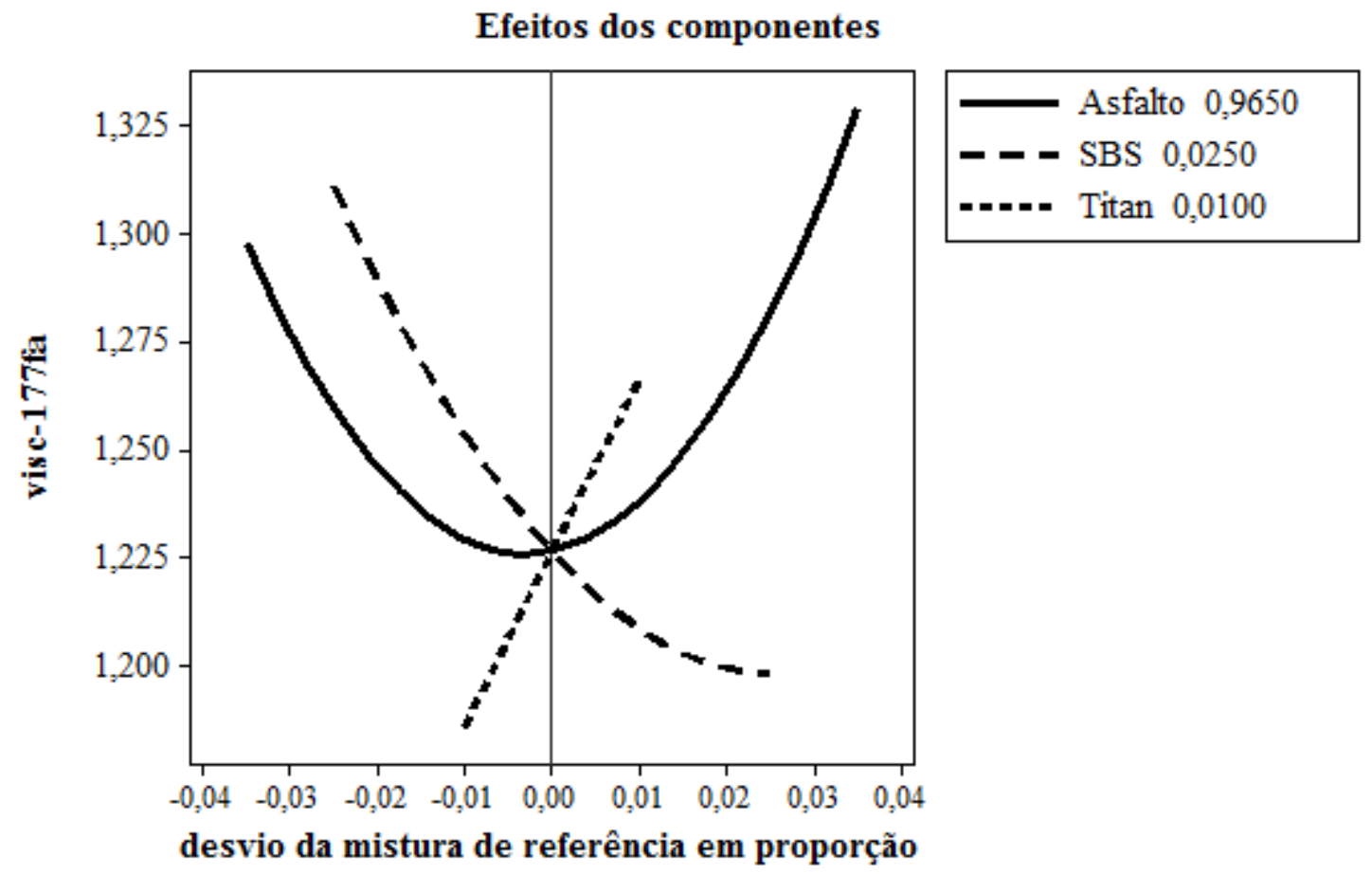

Figura A.18.2 - Efeitos dos componentes para incremento de viscosidade a $177^{\circ} \mathrm{C}$

Superficie de resposta para incremento de viscosidade a $177^{\circ} \mathrm{C}$

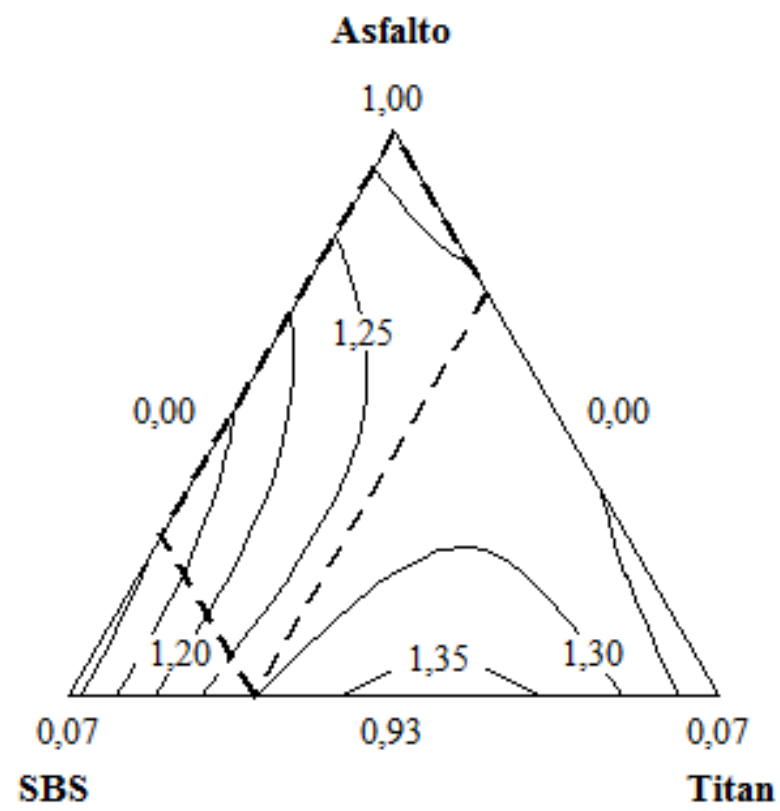

Figura A.18.3 - Superfície de resposta para incremento de viscosidade a $177^{\circ} \mathrm{C}$ 


\section{Modelo A.19 Compliância não-recuperável $\left(\mathrm{J}_{\mathrm{nr}}\right)$ a 3.200 Pa a $52^{\circ} \mathrm{C}$ após RTFOT}

Não houve retirada de pontos para obtenção deste modelo. A retirada de pontos piorou o $\mathrm{R}^{2}$ e ocorreu um aumento do valor apresentado pelo VIF, portanto o modelo apenas pode ser empregado para estimativa de novas ocorrências na região experimental.

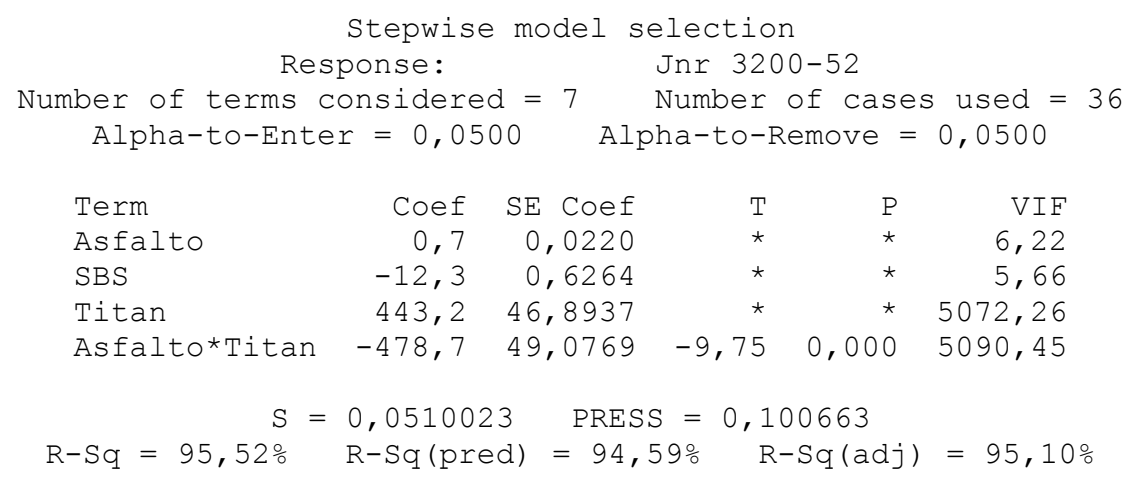

Residual Plots for Jnr 3200-52
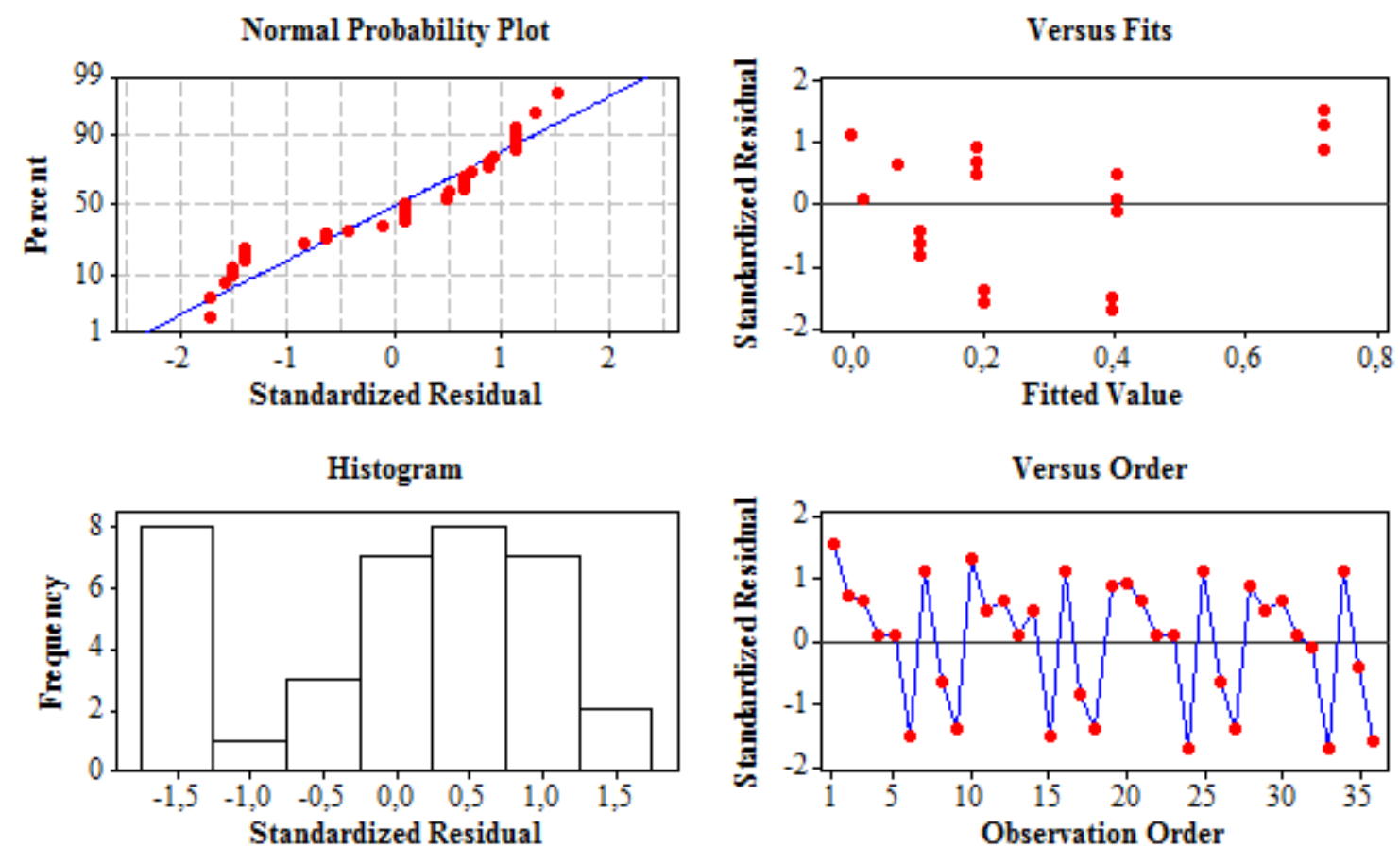

Figura A.19.1 - Análise de resíduos para $\mathrm{J}_{\mathrm{nr}}$ a 3.200 Pa a $5^{\circ} \mathrm{C}$ após RTFOT 


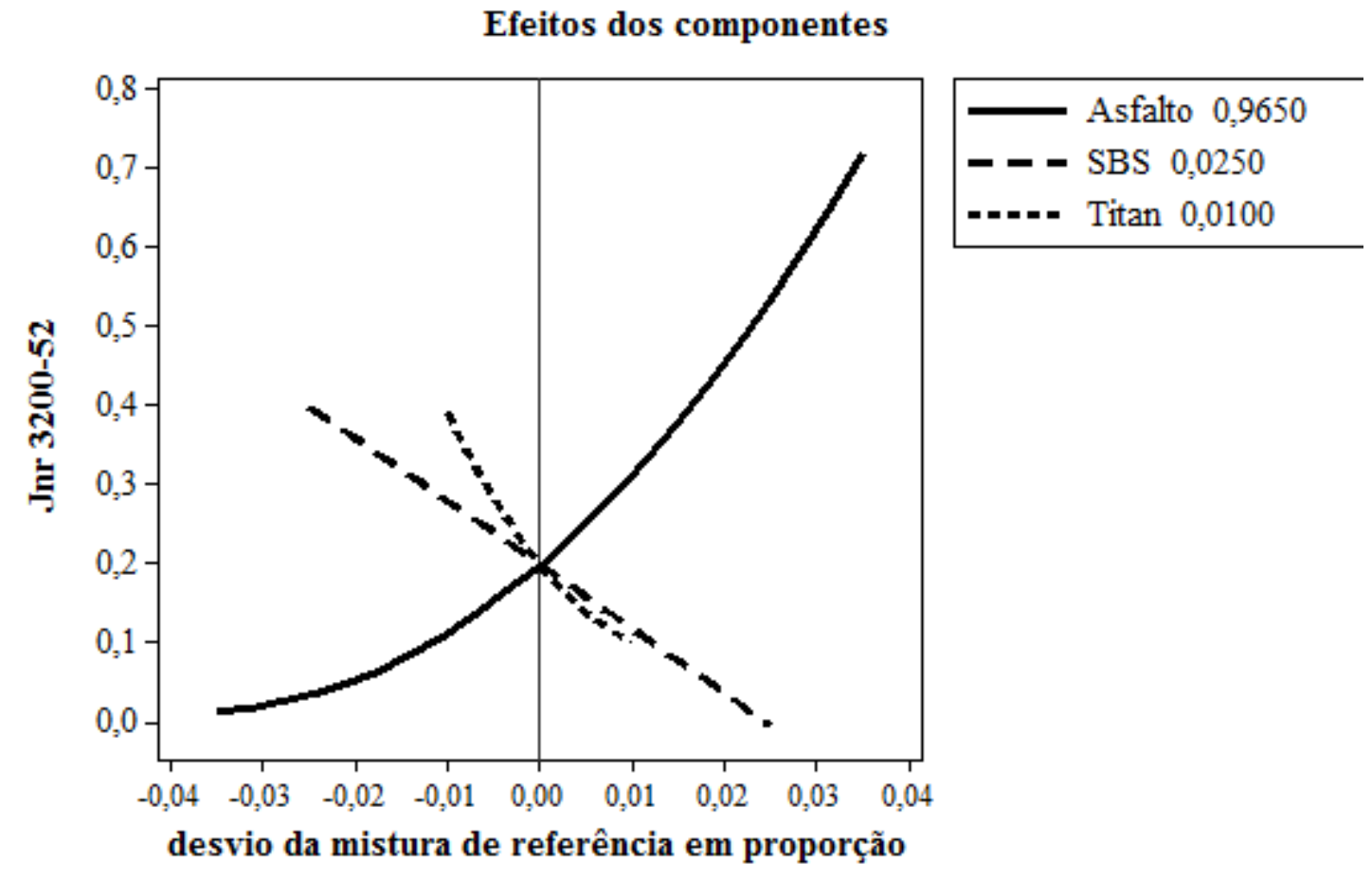

Figura A.19.2 - Efeitos dos componentes para $\mathrm{J}_{\mathrm{nr}}$ a 3.200 Pa a $52^{\circ} \mathrm{C}$ após RTFOT Superfície de resposta para $\mathrm{Jnr} 3200$ a $52^{\circ} \mathrm{C}$

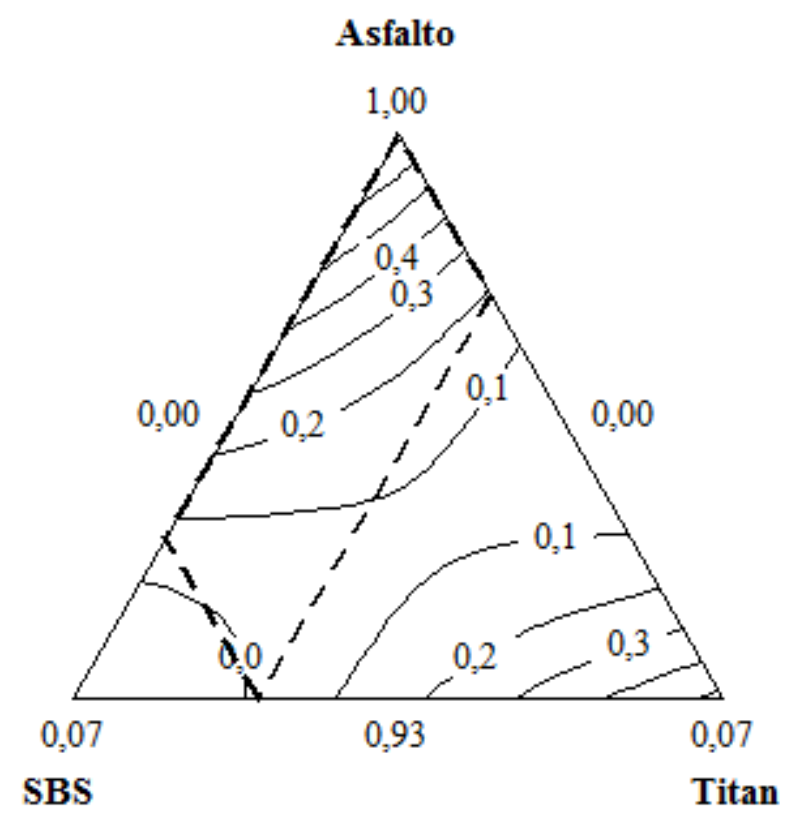

Figura A.19.3 - Superfície de resposta para $\mathrm{J}_{\mathrm{nr}}$ a 3.200 Pa a $5^{\circ} \mathrm{C}$ após $\mathrm{RTFOT}$ 


\section{Modelo A.20 Compliância não-recuperável $\left(J_{n r}\right)$ a 3.200 Pa a $58^{\circ} \mathrm{C}$ após RTFOT}

Não houve retirada de pontos para obtenção deste modelo. Em uma tentativa de retirada de pontos, ocorreu a piora do $\mathrm{R}^{2}$ e ocorreu um aumento do valor apresentado pelo VIF, portanto o modelo apenas pode ser empregado para estimativa de novas ocorrências na região experimental.

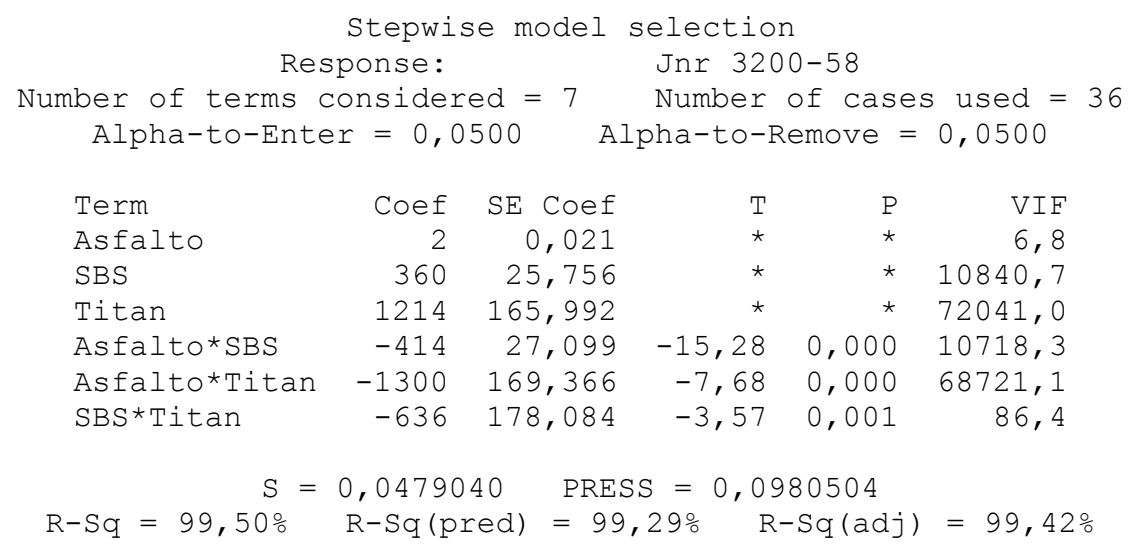

Residual Plots for Jnr 3200-58

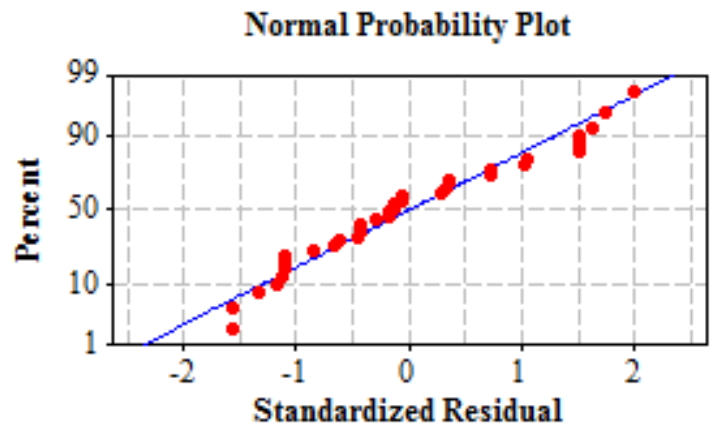

Histogram

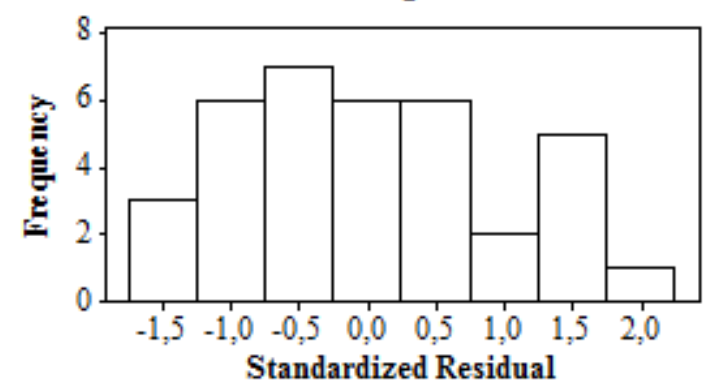

Versus Fits

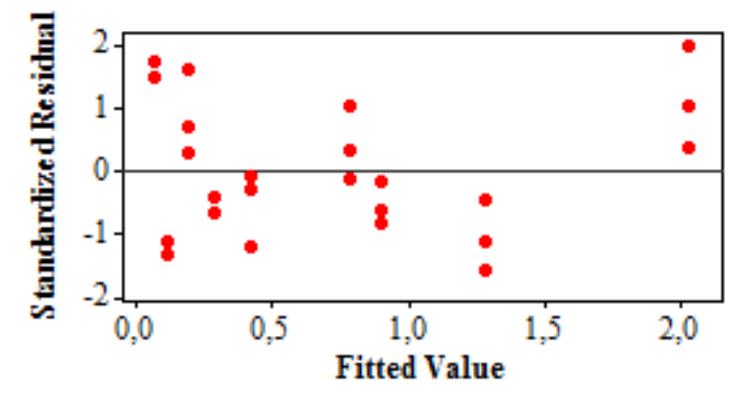

Versus Order

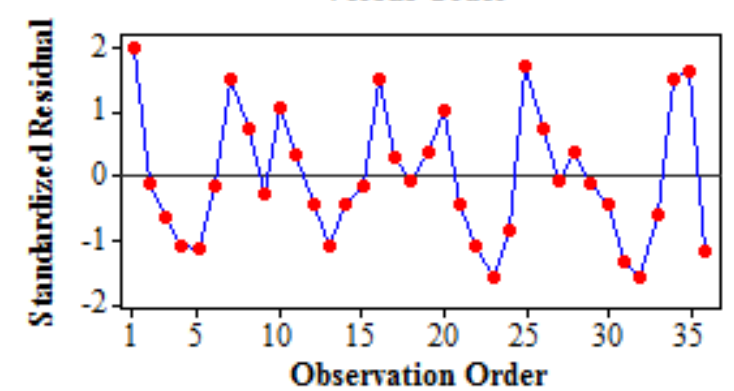

Figura A.20.1 - Análise de resíduos para $\mathrm{J}_{\mathrm{nr}}$ a 3.200 Pa a $5^{\circ} \mathrm{C}$ após RTFOT 


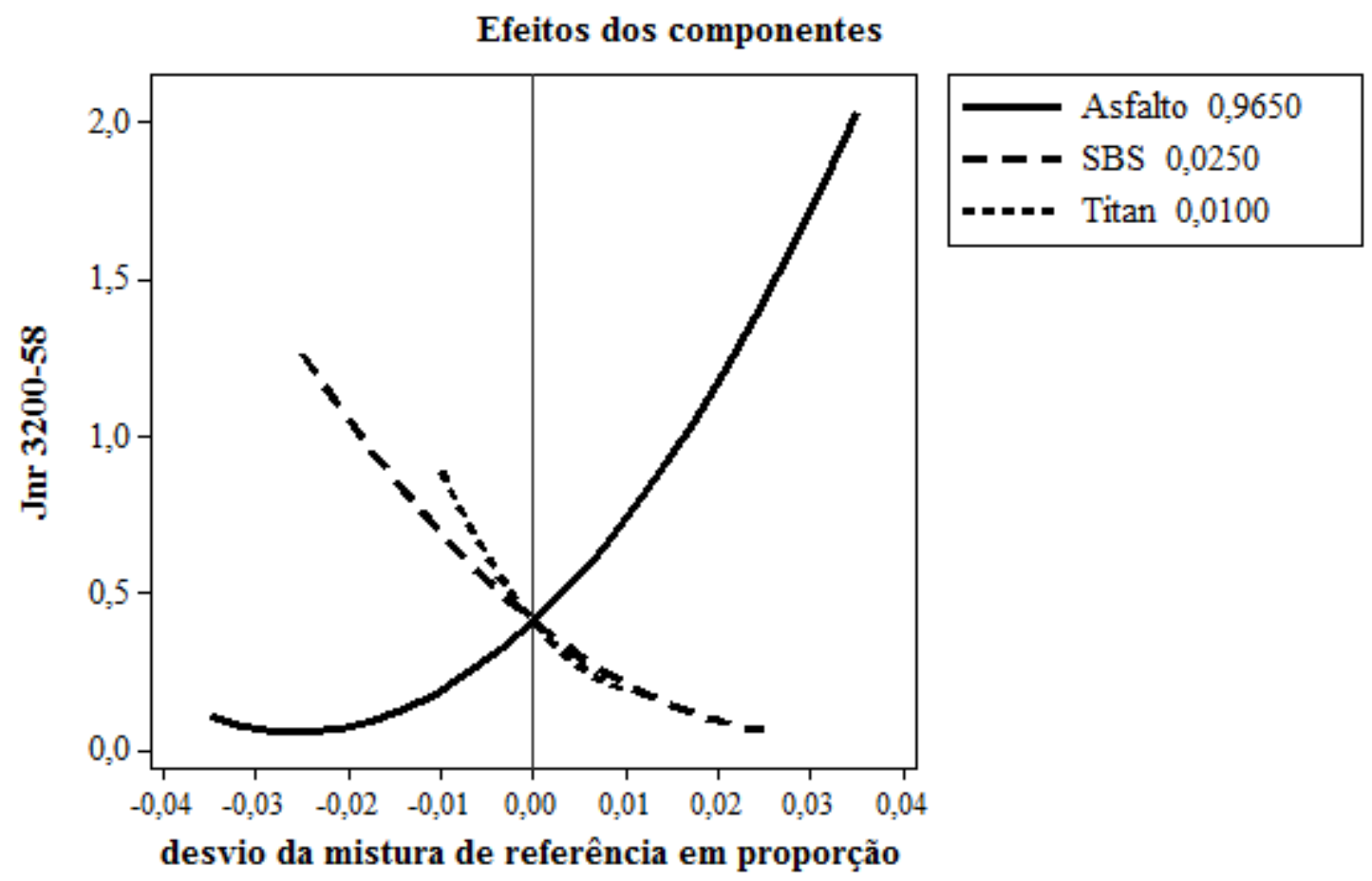

Figura A.20.2 - Efeitos dos componentes para $\mathrm{J}_{\mathrm{nr}}$ a 3.200 Pa a $5^{\circ} \mathrm{C}$ após RTFOT Superfície de resposta para $\mathrm{Jnr} 3200$ a $58^{\circ} \mathrm{C}$

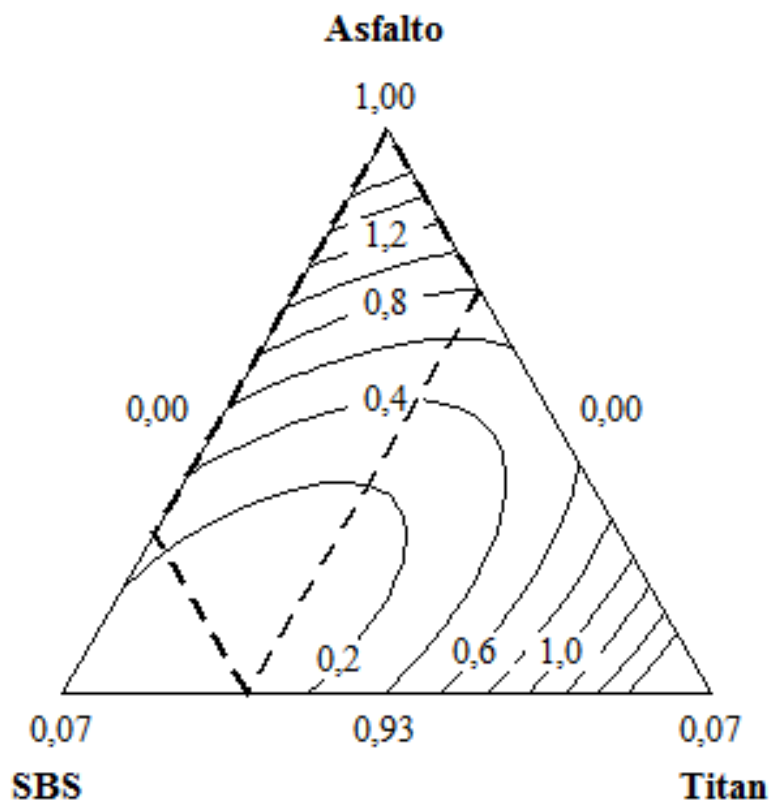

Figura A.20.3 - Superfície de resposta para $\mathrm{J}_{\mathrm{nr}}$ a 3.200 Pa a $58^{\circ} \mathrm{C}$ após $\mathrm{RTFOT}$ 


\section{Modelo A.21 Compliância não-recuperável $\left(\mathrm{J}_{\mathrm{nr}}\right)$ a 3.200 Pa a $64^{\circ} \mathrm{C}$ após RTFOT}

Não houve retirada de pontos para obtenção deste modelo. Em uma tentativa de retirada de pontos, ocorreu a piora do $\mathrm{R}^{2}$ e ocorreu um aumento do valor apresentado pelo VIF, portanto o modelo apenas pode ser empregado para estimativa de novas ocorrências na região experimental.

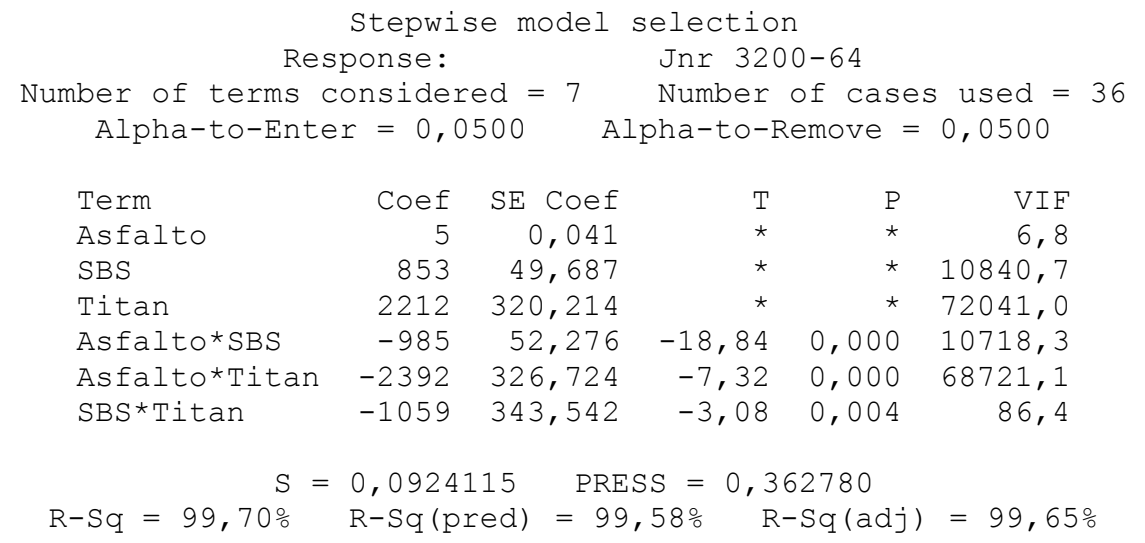

Residual Plots for Jnr 3200-64
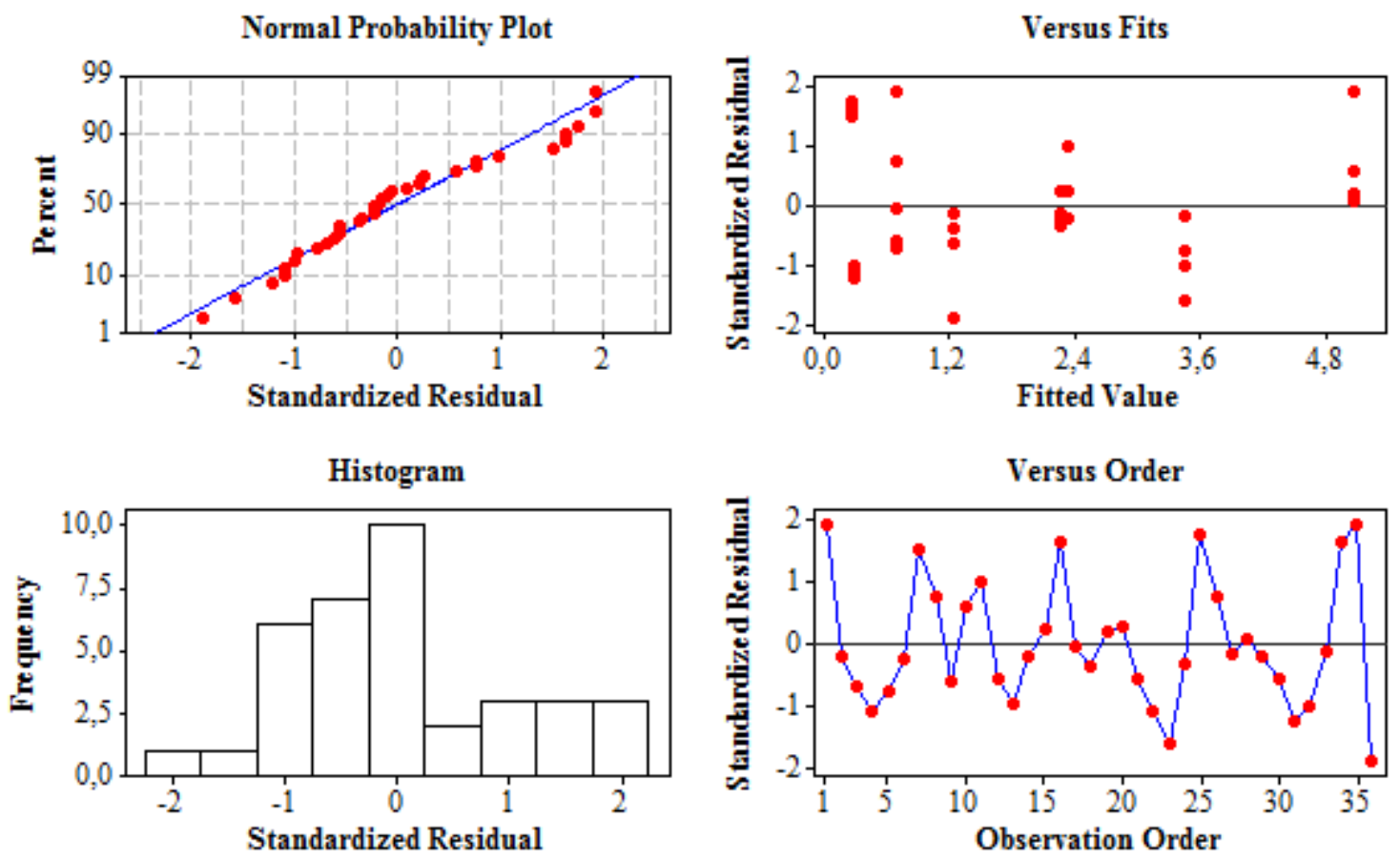

Figura A.21.1 - Análise de resíduos para $\mathrm{J}_{\mathrm{nr}}$ a 3.200 Pa a $64^{\circ} \mathrm{C}$ após RTFOT 
Efeitos dos componentes

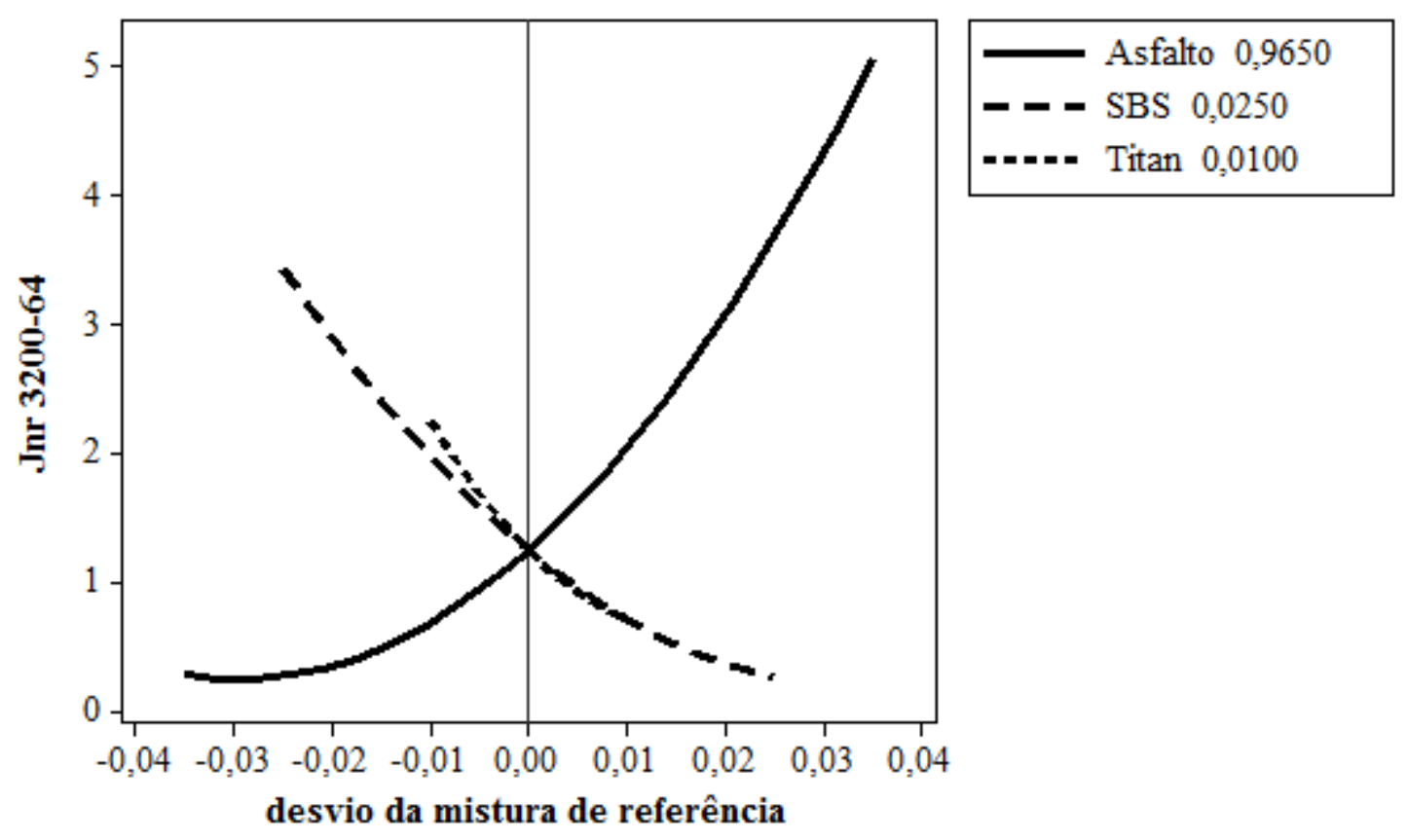

Figura A.21.2 - Efeitos dos componentes para $\mathrm{J}_{\mathrm{nr}}$ a 3.200 Pa a $64^{\circ} \mathrm{C}$ após RTFOT

Superficie de resposta para $\mathrm{Jnr} 3200$ a $64^{\circ} \mathrm{C}$

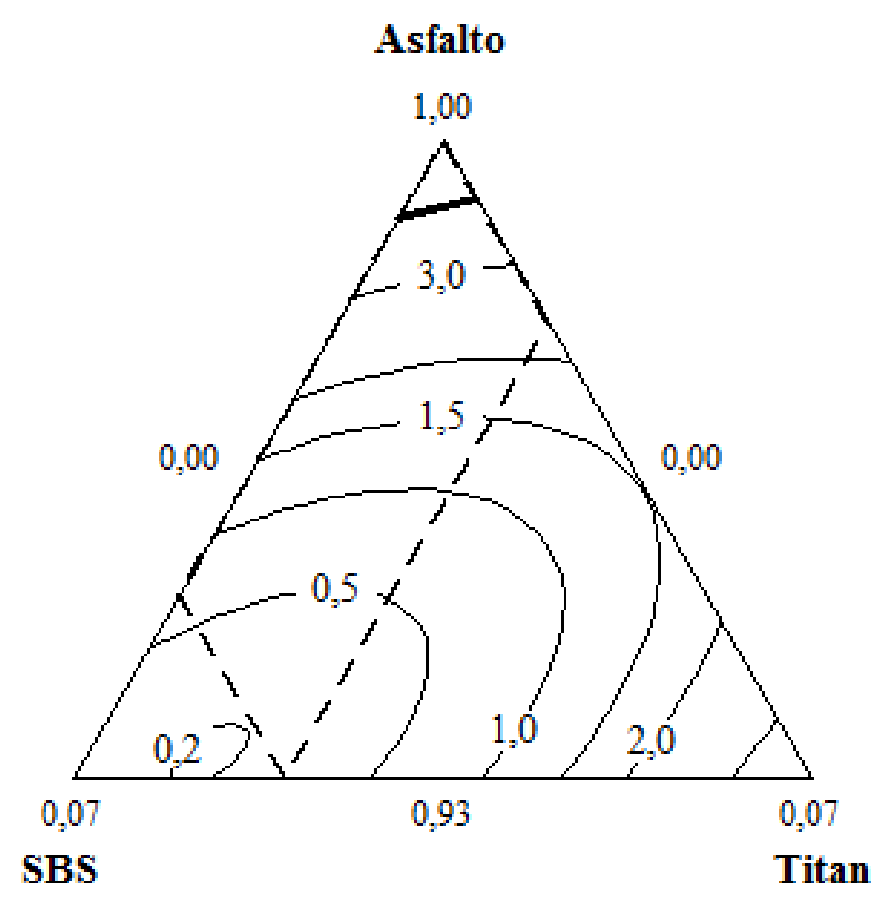

Figura A.21.3 - Superfície de resposta para $\mathrm{J}_{\mathrm{nr}}$ a 3.200 Pa a $64^{\circ} \mathrm{C}$ após $\mathrm{RTFOT}$ 


\section{Modelo A.22 Compliância não-recuperável $\left(\mathrm{J}_{\mathrm{nr}}\right)$ a 3.200 Pa a $7^{\circ} \mathrm{C}$ após RTFOT}

Os pontos 1, 10, 19 e 28 não foram determinados, pois o ensaio não pôde ser realizado a $70^{\circ} \mathrm{C}$ para a mistura $100-0-0$ em virtude dos altos valores de $\mathrm{J}_{\mathrm{nr}}$ obtidos já na temperatura de $64^{\circ} \mathrm{C}$. O valor do VIF ficou acima dos limites indicados, portanto o modelo apenas pode ser empregado para estimativa de novas ocorrências na região experimental.

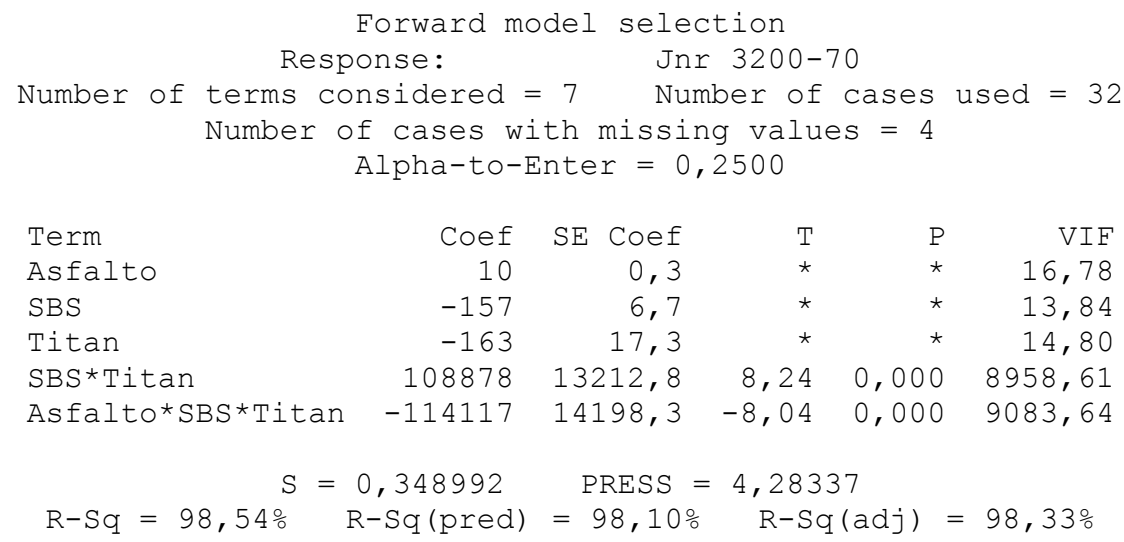

Residual Plots for Jnr 3200-70
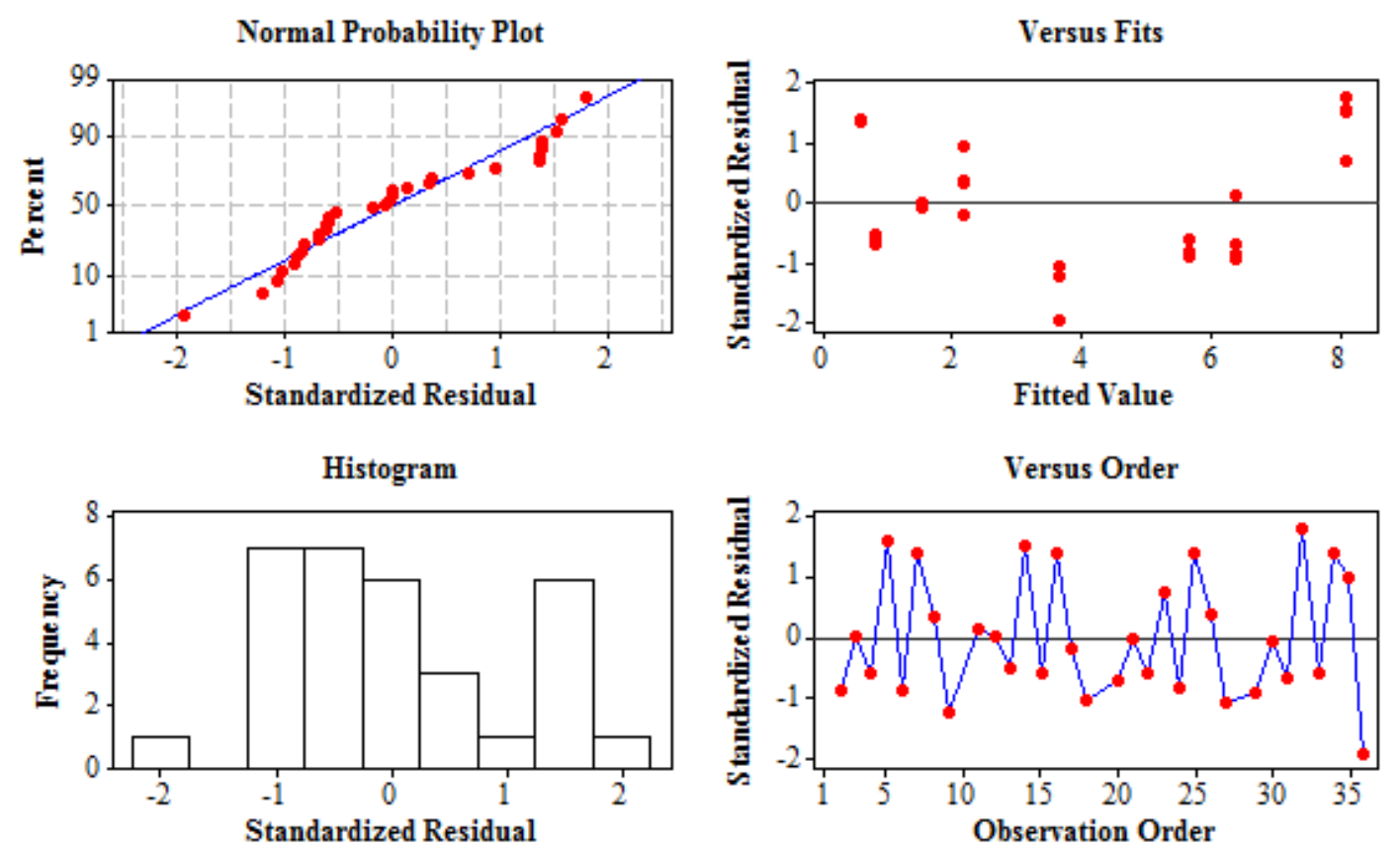

Figura A.22.1 - Análise de resíduos para $\mathrm{J}_{\mathrm{nr}}$ a 3.200 Pa a $70^{\circ} \mathrm{C}$ após RTFOT 


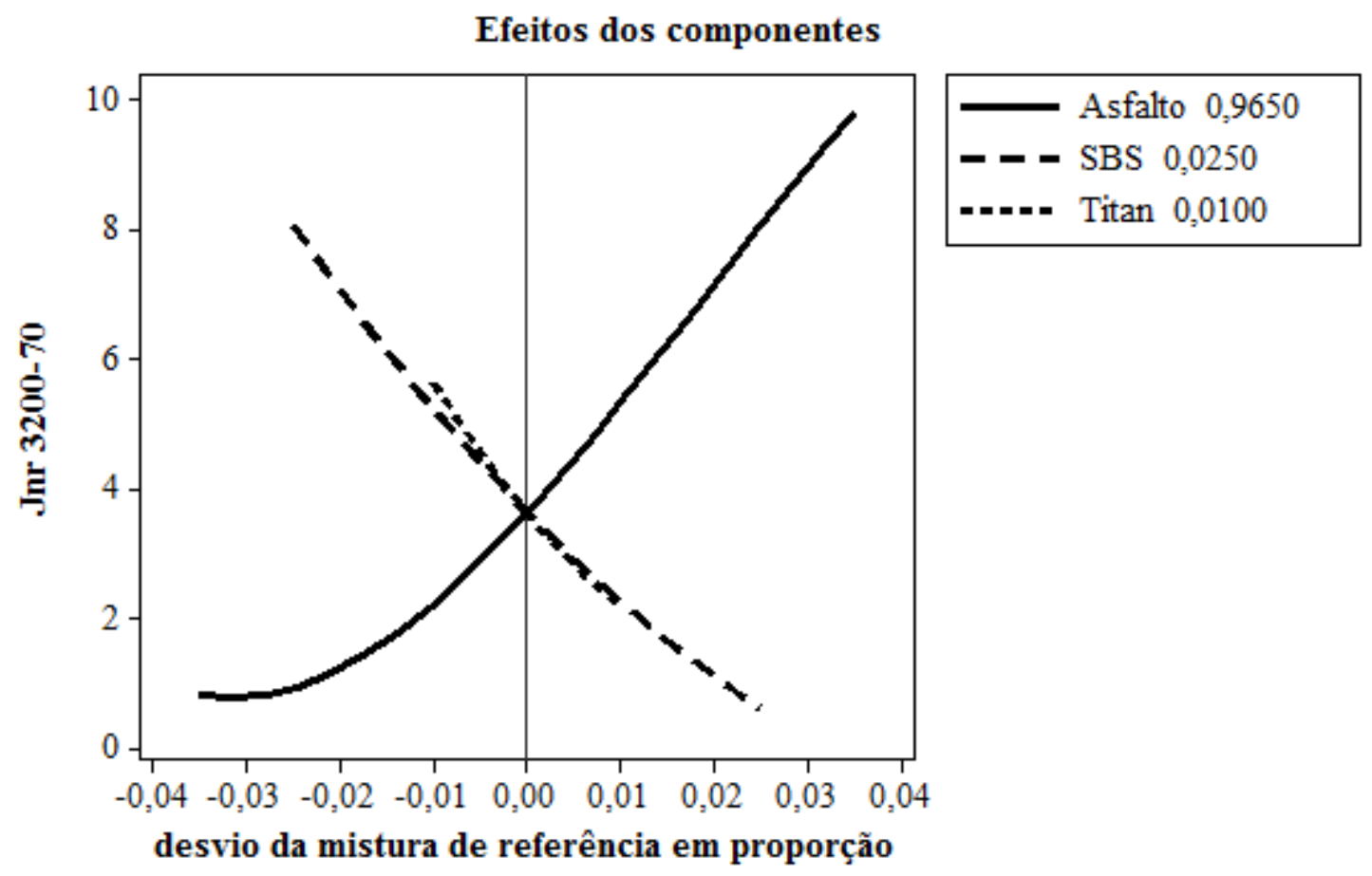

Figura A.22.2 - Efeitos dos componentes para $\mathrm{J}_{\mathrm{nr}}$ a 3.200 Pa a $7^{\circ} \mathrm{C}$ após RTFOT

Superfície de resposta para $\mathrm{Jnr} 3200$ a $70^{\circ} \mathrm{C}$

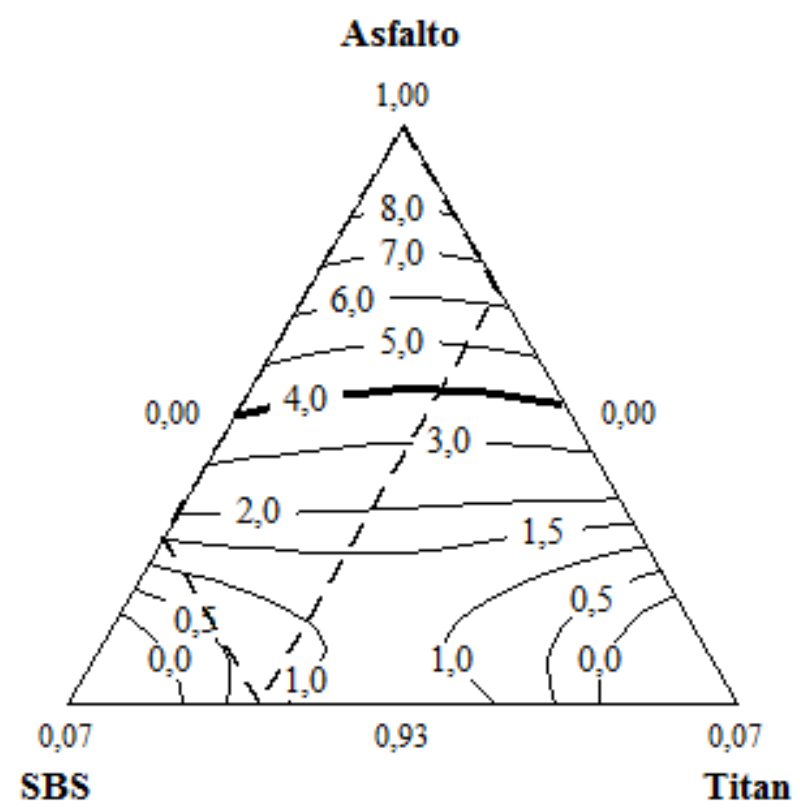

Figura A.22.3 - Superfície de resposta para $\mathrm{J}_{\mathrm{nr}}$ a 3.200 Pa a $7^{\circ} \mathrm{C}$ após RTFOT 


\section{Modelo A.23 Percentual de recuperação (R) a 3.200 Pa a $52^{\circ} \mathrm{C}$ após RTFOT}

Não houve retiradas de pontos para obtenção deste modelo. $\mathrm{O}$ valor de $\mathrm{R}^{2}$ foi bom e o valor pelo VIF é muito bom, portanto os coeficientes dos termos podem ser empregados para explicar o efeito das proporções dos materiais sobre os resultados de percentual de recuperação.

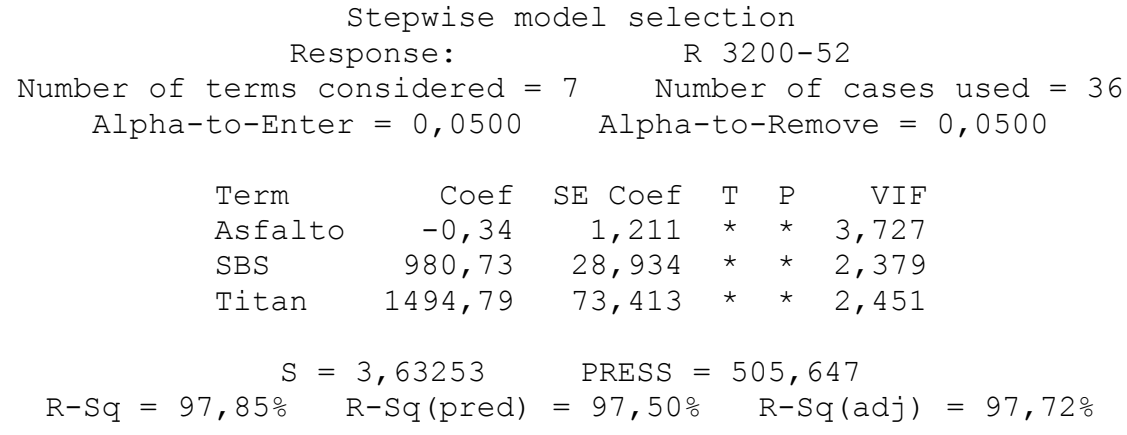

Residual Plots for R 3200-52

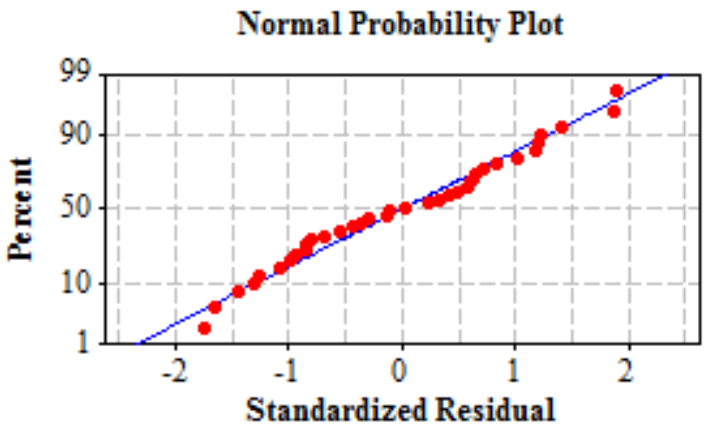

Histogram

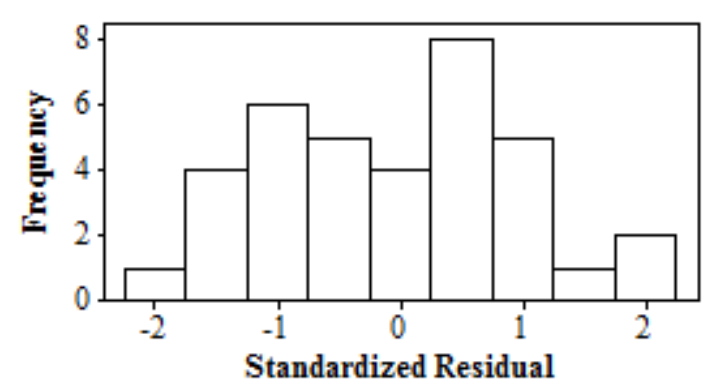

Versus Fits

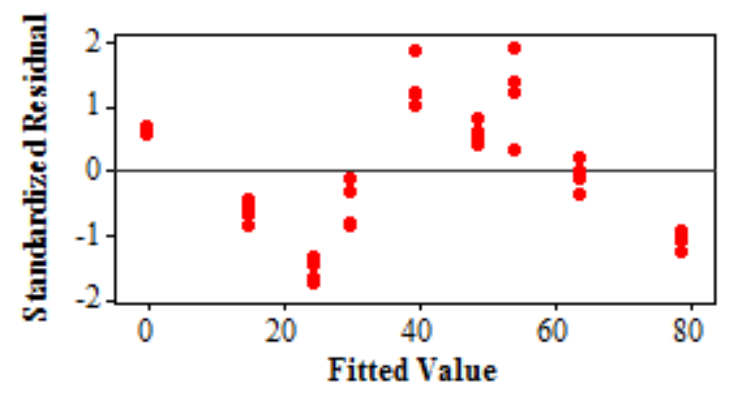

Versus Order

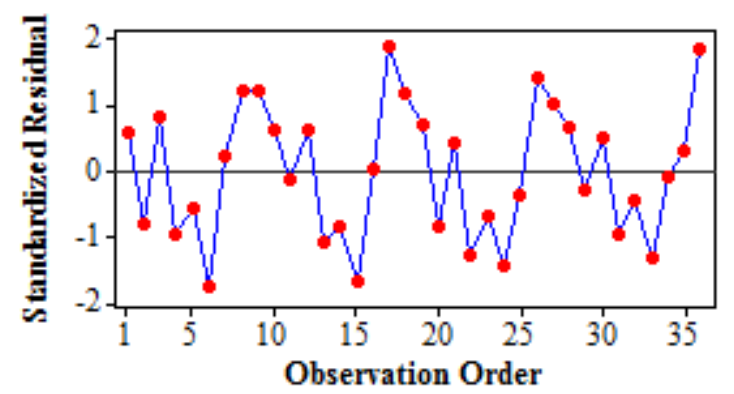

Figura A.23.1 - Análise de resíduos para $\mathrm{R}$ a 3.200 Pa a $^{\circ}{ }^{\circ} \mathrm{C}$ após RTFOT 
Efeitos dos componentes

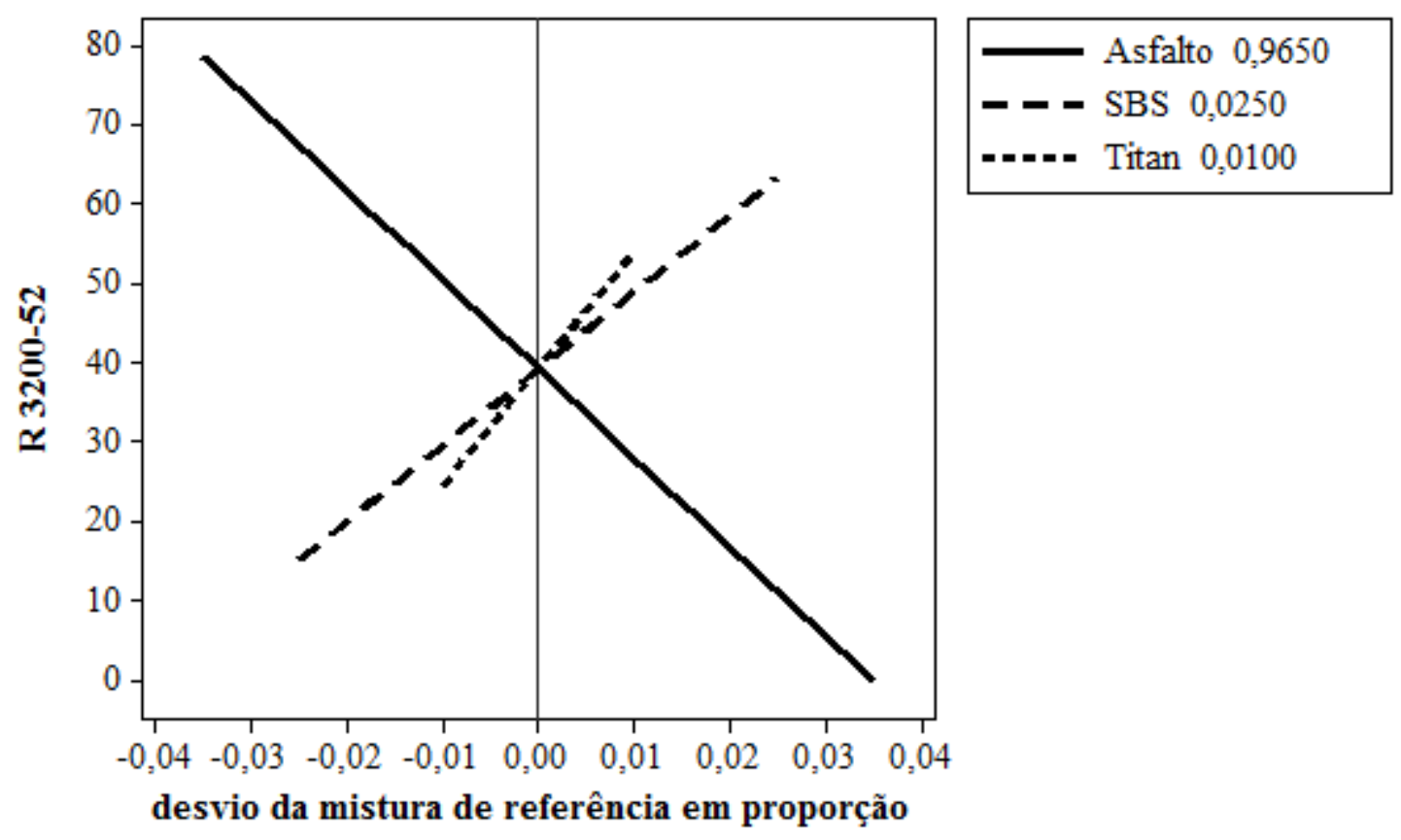

Figura A.23.2 - Efeitos dos componentes para $\mathrm{R}$ a 3.200 Pa a $52^{\circ} \mathrm{C}$ após RTFOT

Superficie de resposta para $\mathrm{R} 3200$ a $52^{\circ} \mathrm{C}$

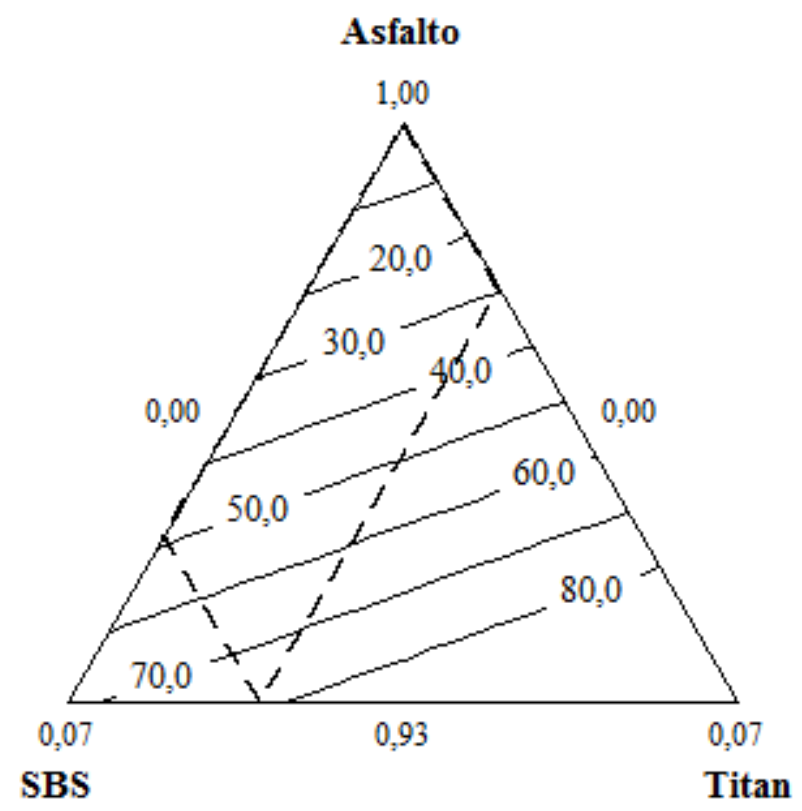

Figura A.23.3 - Superfície de resposta para $R$ a 3.200 Pa a $52^{\circ} \mathrm{C}$ após RTFOT 


\section{Modelo A.24 Percentual de recuperação (R) a 3.200 Pa a $58^{\circ} \mathrm{C}$ após RTFOT}

Os pontos $6,7,8,15,17,22,24,26,33$ e 36 foram retirados para obtenção deste modelo. As exclusões destes pontos se justifica pela seguinte constatação: estes valores destoam dos demais, sendo observações muito acima de 2 desvios padrão nos gráficos de resíduos, sendo estes pontos considerado "outliers". O modelo melhorou sem estes pontos, sendo verificado um aumento do $\mathrm{R}^{2}$. Mesmo com a retirada, o valor apresentado pelo VIF ainda foi alto, portanto o modelo apenas pode ser empregado para estimativa de novas ocorrências na região experimental.

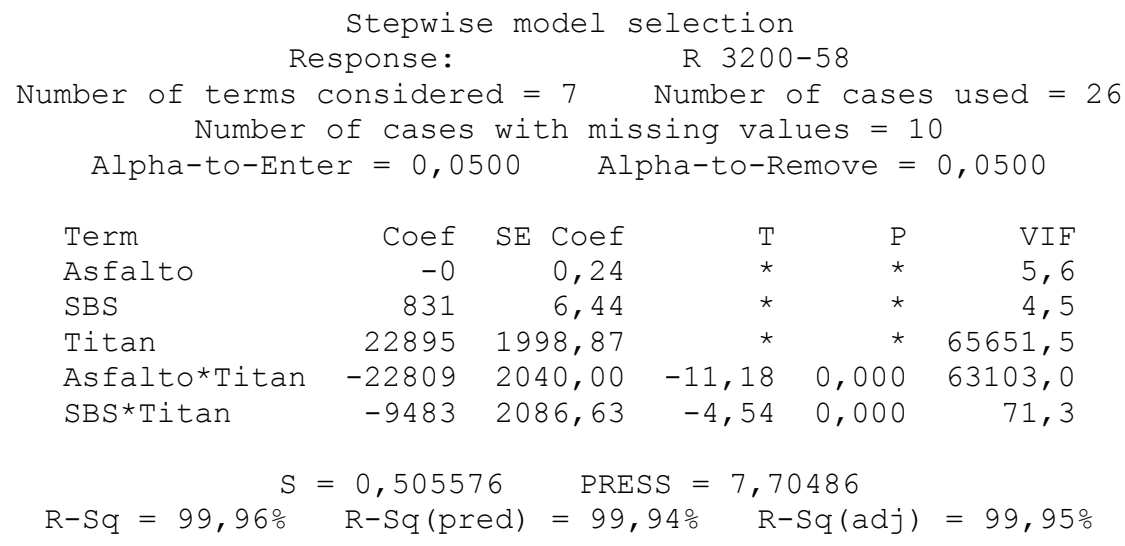

Residual Plots for R 3200-58
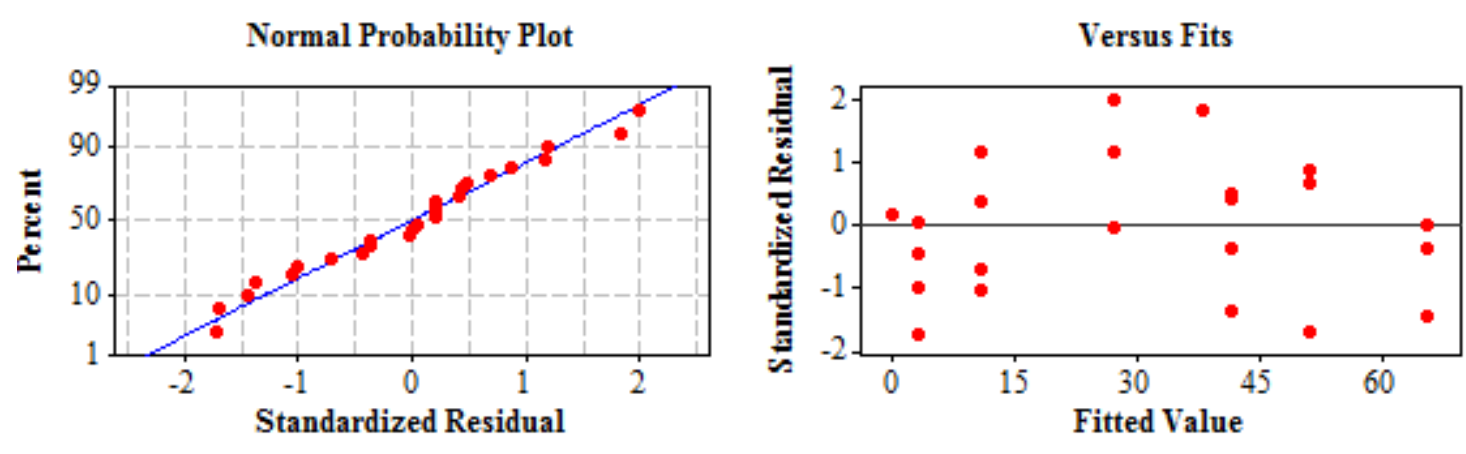

Histogram
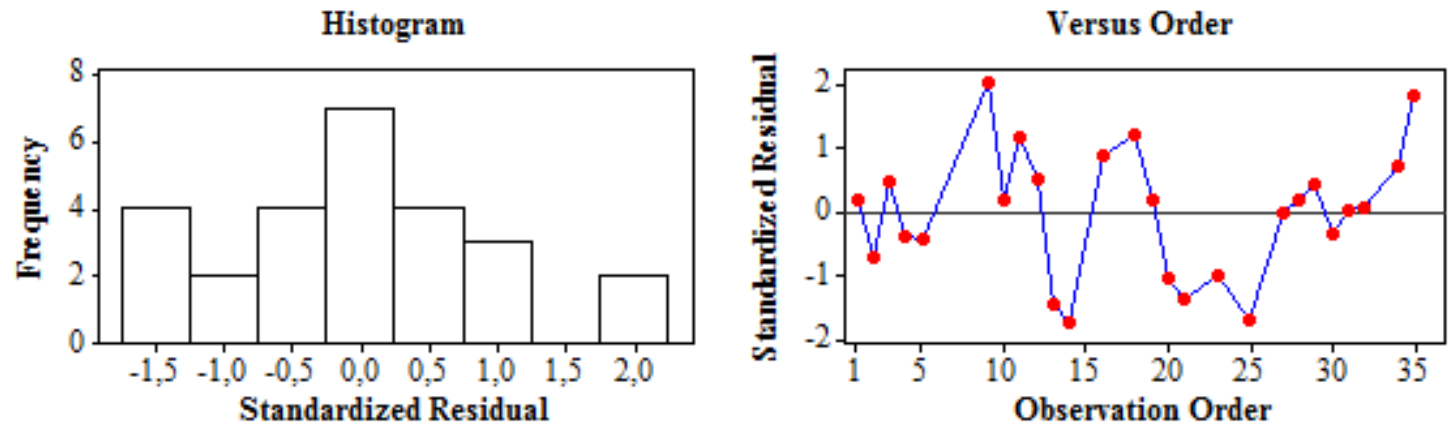

Figura

A.24.1 - Análise de resíduos para $\mathrm{R}$ a $3.200 \mathrm{~Pa}$ a $58^{\circ} \mathrm{C}$ após RTFOT 
Efeitos dos componentes

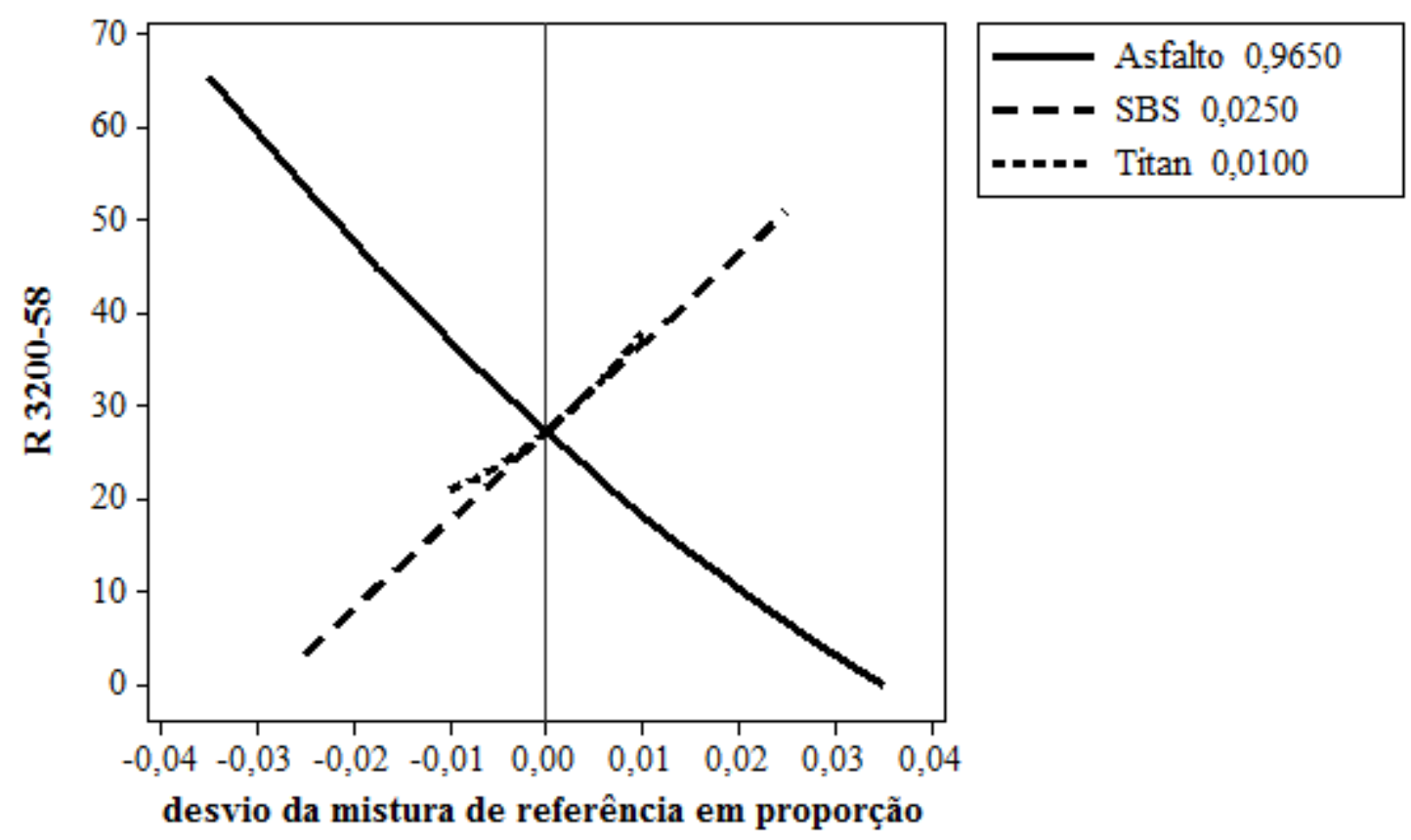

Figura A.24.2 - Efeitos dos componentes para $\mathrm{R}$ a 3.200 Pa a $5^{\circ} \mathrm{C}$ após RTFOT

Superfície de resposta para $\mathrm{R} 3200$ a $58^{\circ} \mathrm{C}$

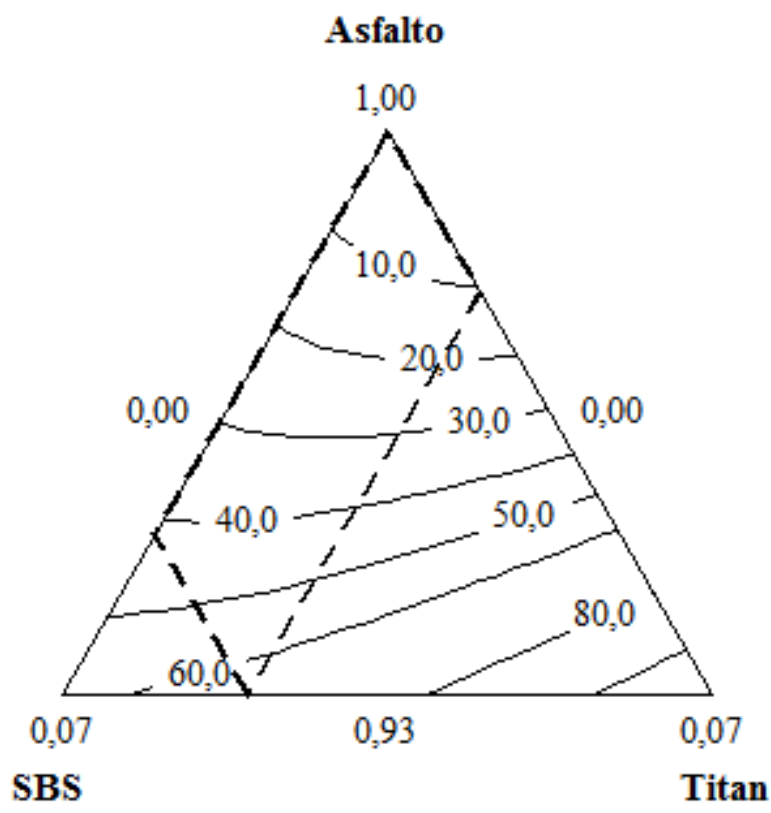

Figura A.24.3 - Superfície de resposta para $\mathrm{R}$ a 3.200 Pa a $58^{\circ} \mathrm{C}$ após RTFOT 


\section{Modelo A.25 Percentual de recuperação (R) a 3.200 Pa a $64^{\circ} \mathrm{C}$ após RTFOT}

O ponto 17 foi retirado para obtenção deste modelo. As exclusão deste ponto é justificada pela seguinte constatação: este valor destoa dos demais, sendo observação muito acima de 2 desvio padrões nos gráficos de resíduos, sendo este ponto considerado "outlier". O modelo melhorou sem este ponto, sendo verificado um aumento do $\mathrm{R}^{2}$. Mesmo com a retirada, o valor apresentado pelo VIF ainda foi alto, portanto o modelo apenas pode se empregado para estimativas de novas ocorrências na região experimental.

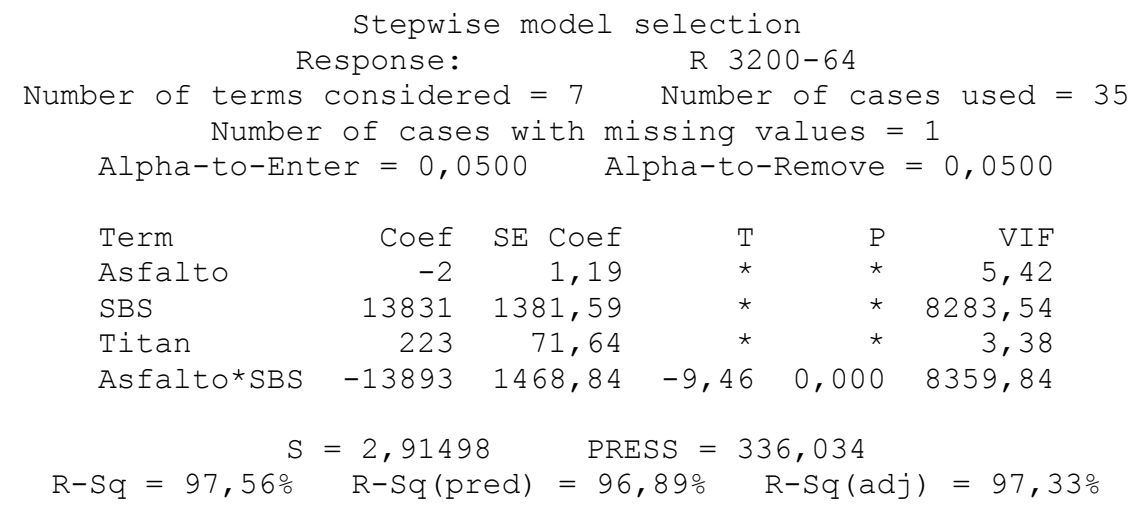

Residual Plots for R 3200-64
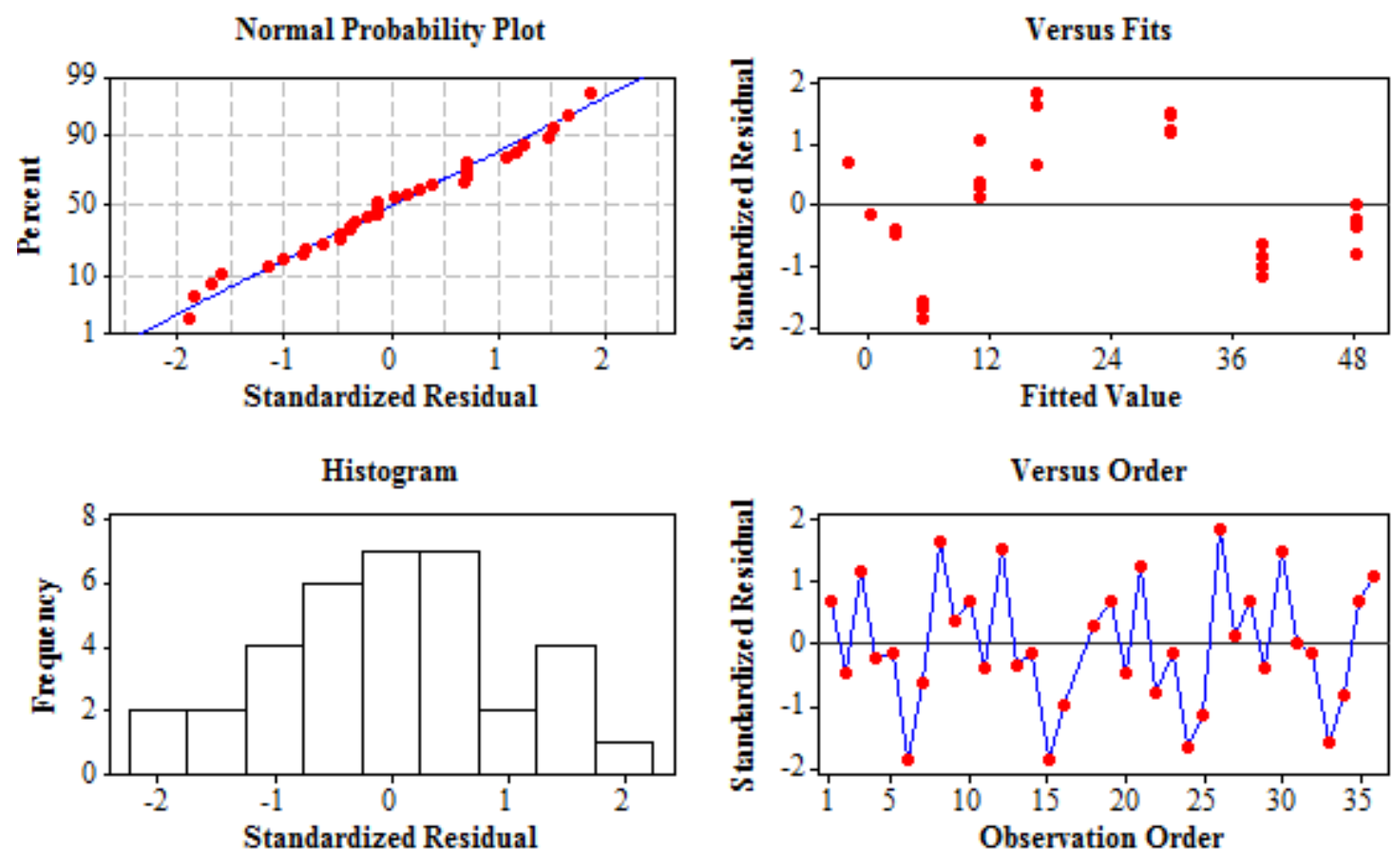

Figura

A.25.1 - Análise de resíduos para $\mathrm{R}$ a 3.200 Pa a $64^{\circ} \mathrm{C}$ após RTFOT 


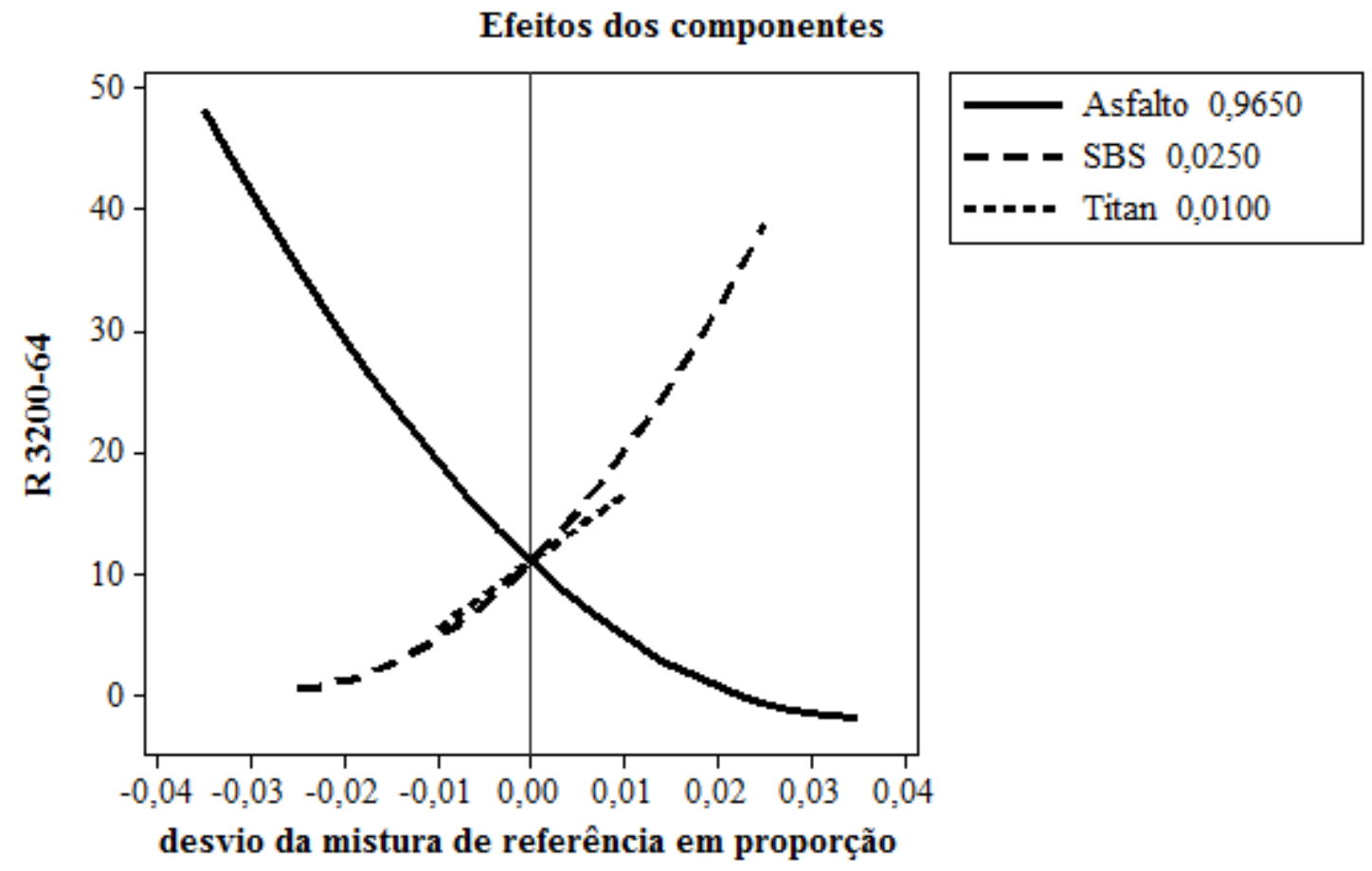

Figura A.25.2 - Efeitos dos componentes para $\mathrm{R}$ a 3.200 Pa a $64^{\circ} \mathrm{C}$ após RTFOT

Superfície de resposta para $R 3200$ a $64^{\circ} \mathrm{C}$

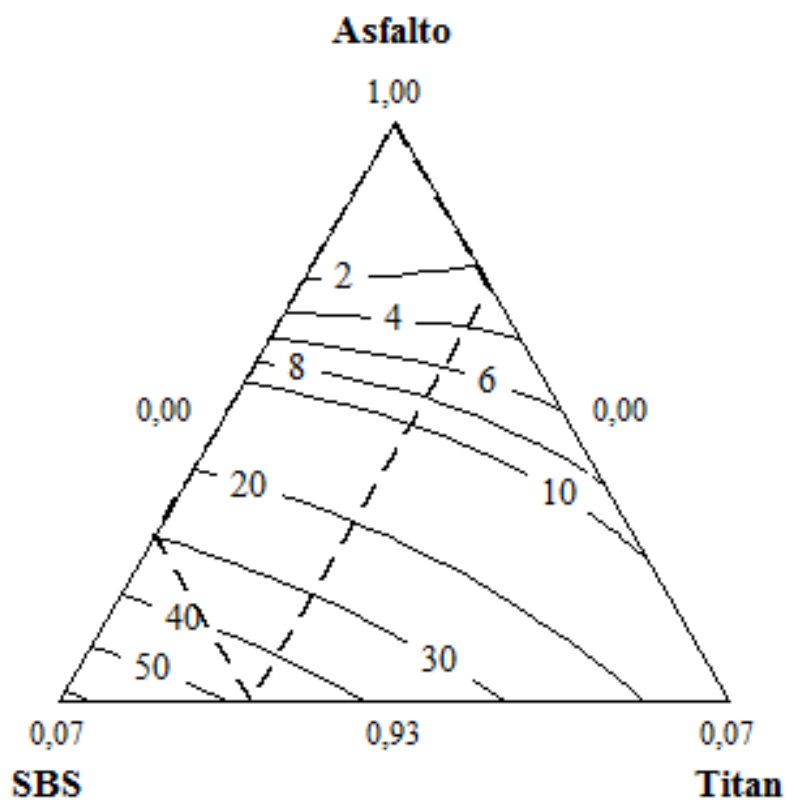

Figura A.25.3 - Superfície de resposta para $\mathrm{R}$ a 3.200 Pa a $64^{\circ} \mathrm{C}$ após RTFOT 


\section{Modelo A.26 Percentual de recuperação $(R)$ a 3.200 Pa a $70^{\circ} \mathrm{C}$ após RTFOT}

Não houve retiradas de pontos para obtenção deste modelo. O valor do $\mathrm{R}^{2}$ foi bom, porém o valor apresentado pelo VIF foi acima dos limites, portanto o modelo apenas pode ser empregado para estimativa de novas ocorrências na região experimental.

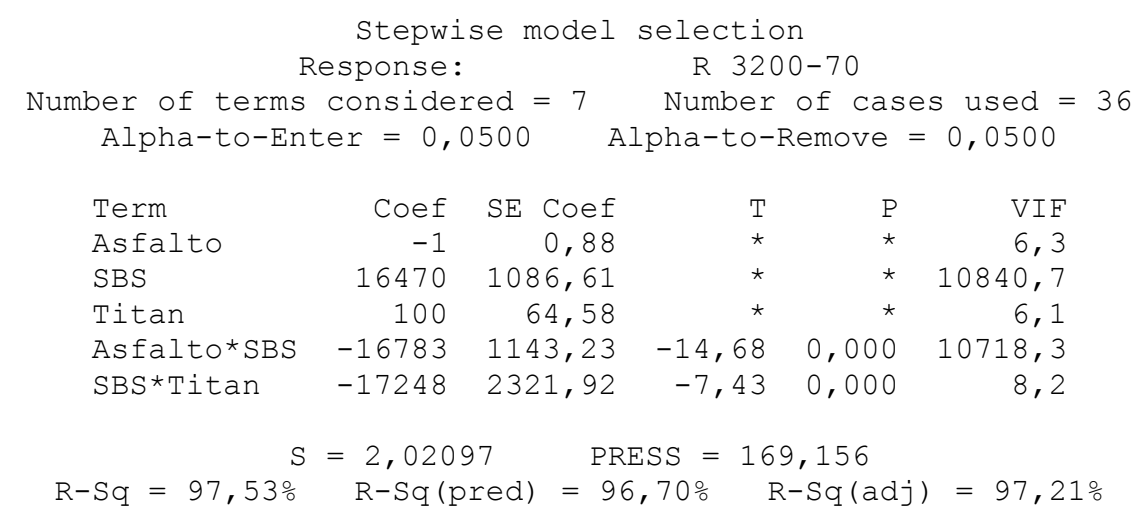

Residual Plots for R 3200-70

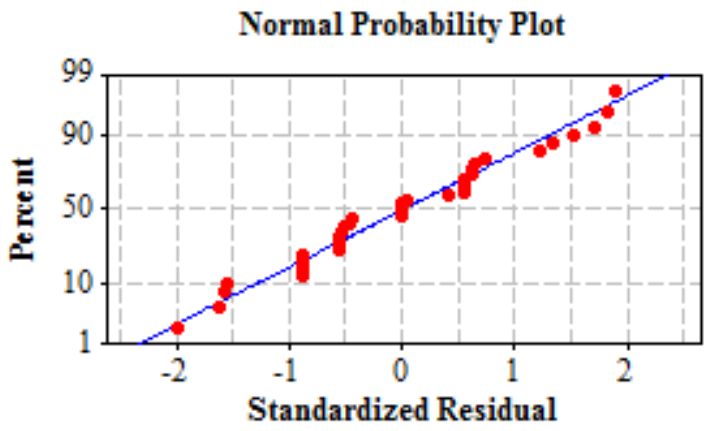

Histogram

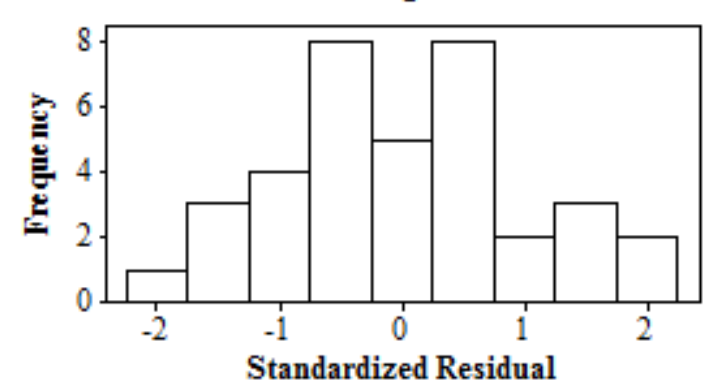

Versus Fits

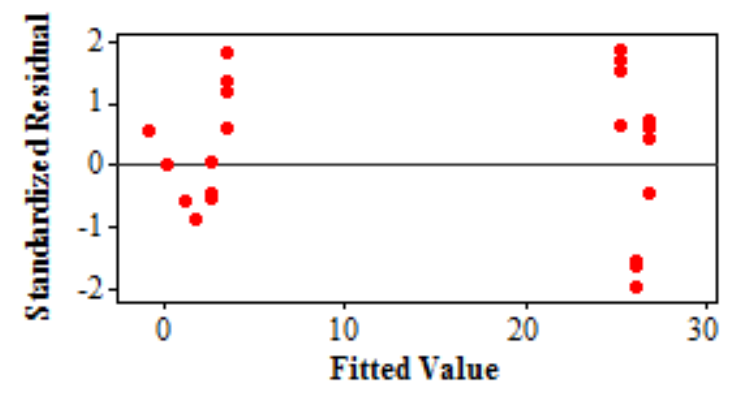

Versus Order

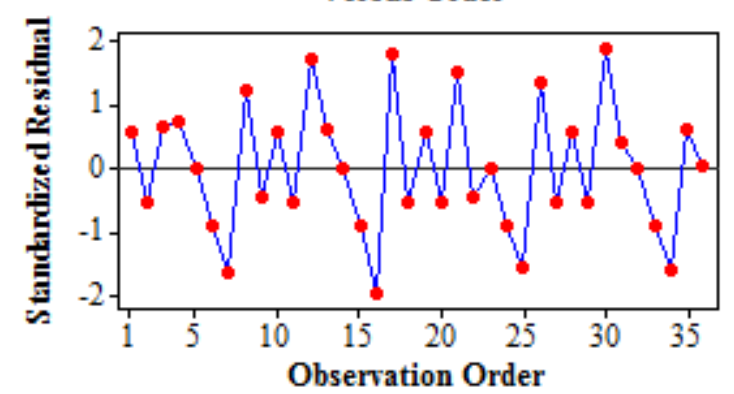

Figura A.26.1 - Análise de resíduos para $\mathrm{R}$ a 3.200 Pa a $70^{\circ} \mathrm{C}$ após RTFOT 
Efeitos dos componentes

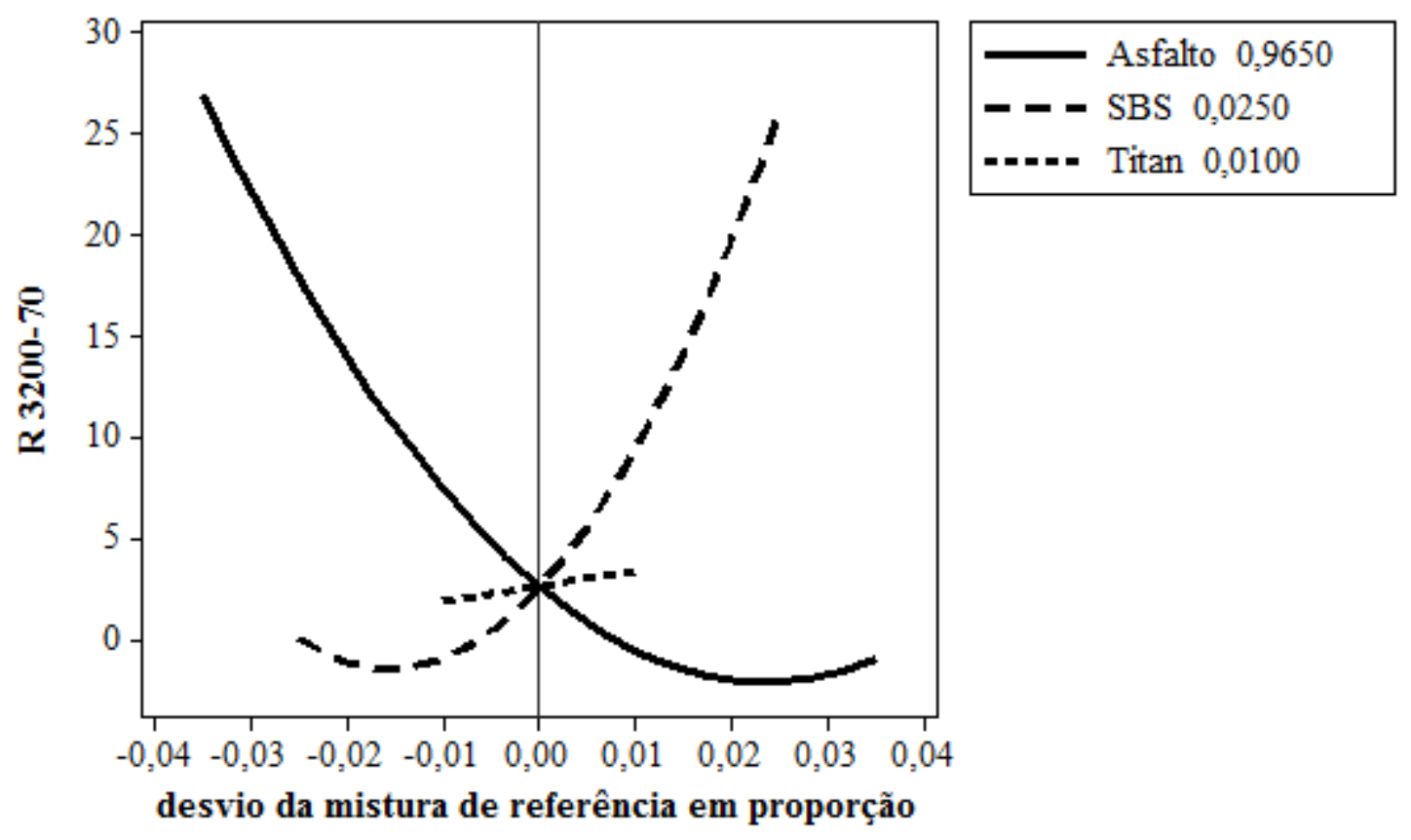

Figura A.26.2 - Efeitos dos componentes para $\mathrm{R}$ a 3.200 Pa a $70^{\circ} \mathrm{C}$ após RTFOT Superfície de resposta para $\mathrm{R3200}$ a $70^{\circ} \mathrm{C}$

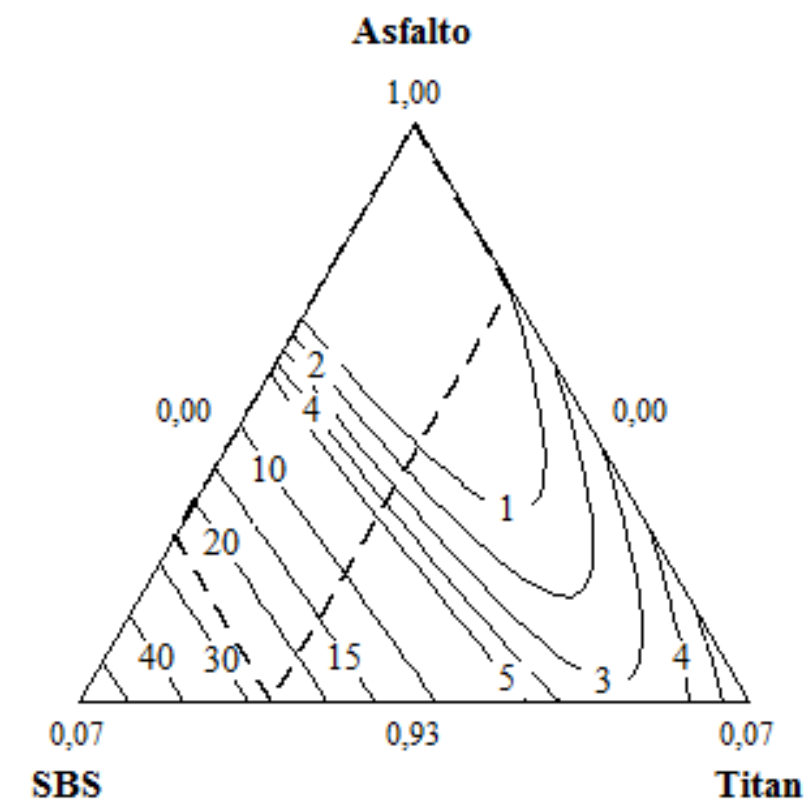

Figura A.26.3 - Superfície de resposta para $\mathrm{R}$ a $3.200 \mathrm{~Pa}$ a $7^{\circ} \mathrm{C}$ após RTFOT 


\section{Modelo A.27 Parâmetro $\mathrm{J}_{\mathrm{nr}, \text { diff }}$ a $52^{\circ} \mathrm{C}$ após RTFOT}

Os pontos 11 e 29 foram retirados para obtenção deste modelo. As exclusões destes pontos se justificam pela seguinte constatação: estes valores destoam dos demais, sendo observações muito acima de 2 desvio padrões nos gráficos de resíduos, sendo estes pontos considerado "outliers". O modelo melhorou sem estes pontos, sendo verificado um aumento do $\mathrm{R}^{2}$. Com a redução dos valores dos VIFs, os coeficientes dos termos do modelo podem ser empregados para explicar o efeito das proporções dos materiais sobre os resultados de $\mathrm{J}_{\mathrm{nr} \text {,diff }}$.

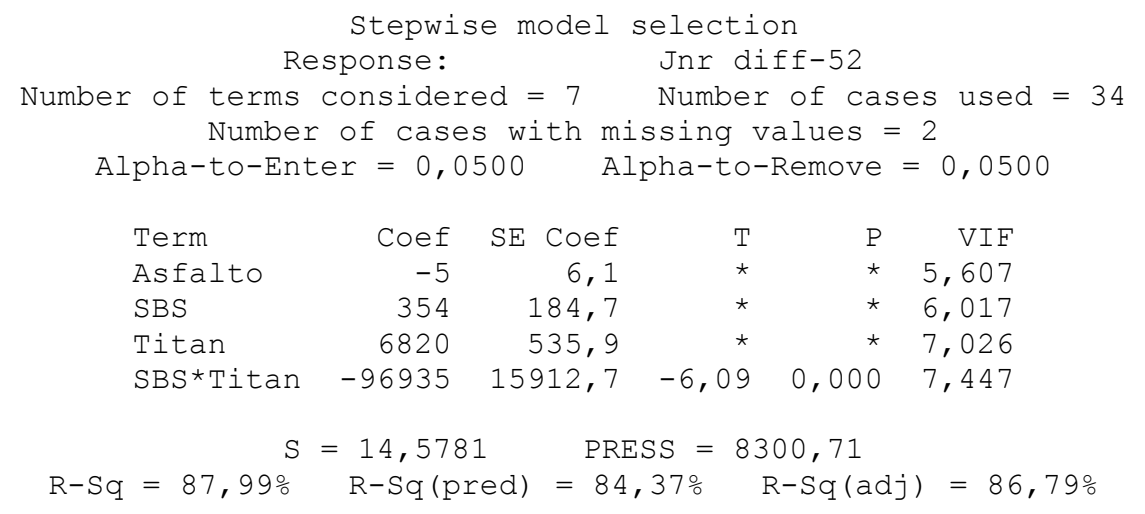

Residual Plots for Jnr diff-52
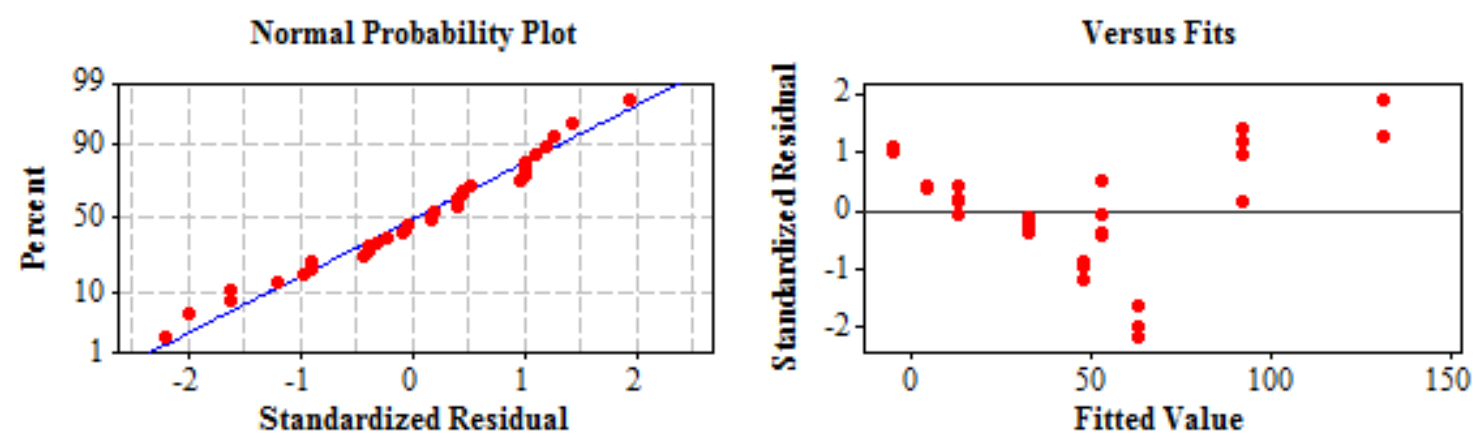

Histogram
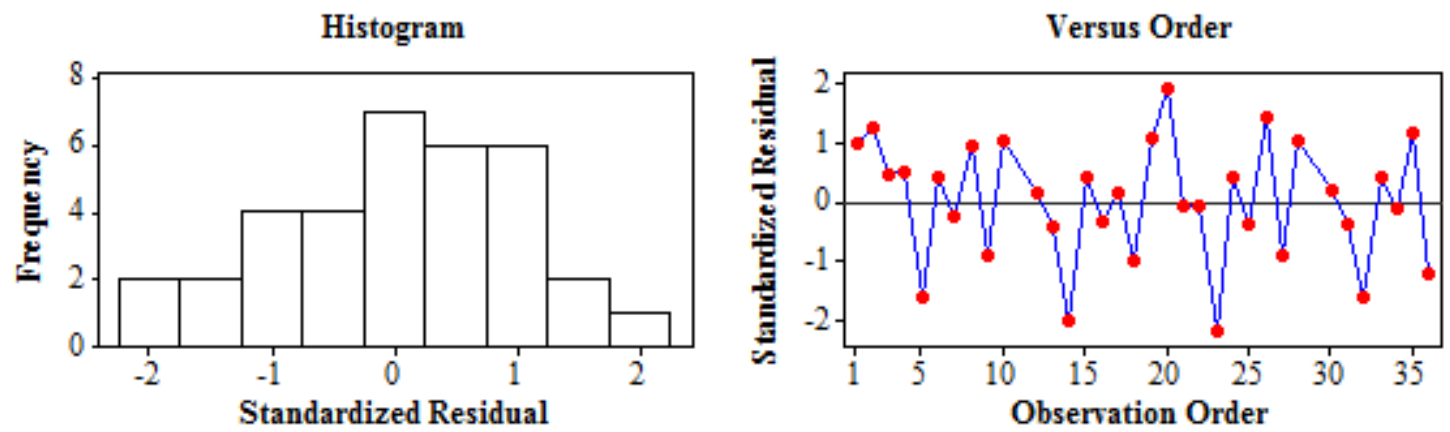

Figura A.27.1 - Análise de resíduos para $\mathrm{J}_{\mathrm{nr}, \text { diff }}$ a 52 $^{\circ} \mathrm{C}$ após RTFOT 
Efeitos dos componentes

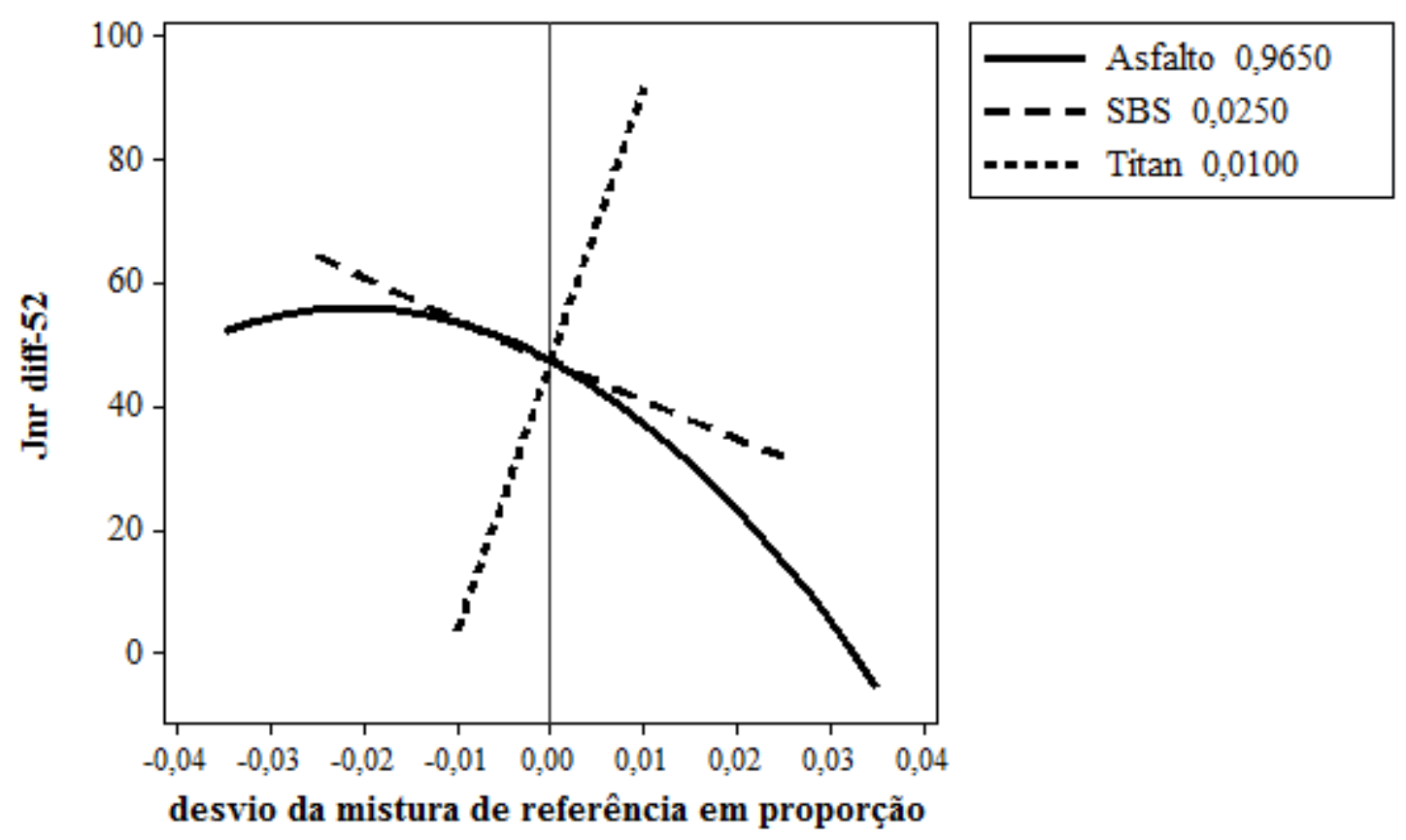

Figura A.27.2 - Efeitos dos componentes para $\mathrm{J}_{\mathrm{nr} \text {,diff }}$ 52 $^{\circ} \mathrm{C}$ após RTFOT Superficie de resposta para $\mathrm{Jnr}$, diff $52^{\circ} \mathrm{C}$

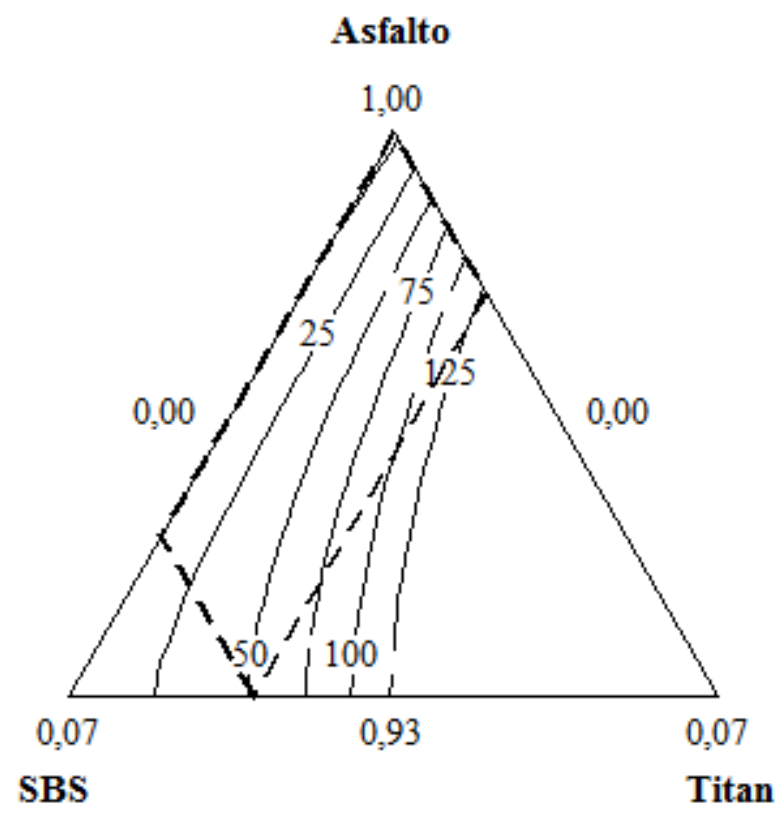

Figura A.27.3 - Superfície de resposta para $\mathrm{J}_{\mathrm{nr}, \text { diff }} \mathbf{5 2}^{\circ} \mathrm{C}$ após RTFOT 


\section{Modelo A.28 Parâmetro $\mathrm{J}_{\mathrm{nr} \text {,diff }} \mathbf{5 8}^{\circ} \mathrm{C}$ após RTFOT}

Os pontos 5, 11, 14, 23 e 32 foram retirados para obtenção deste modelo. As exclusões destes pontos se justificam pela seguinte constatação: estes valores destoam dos demais, sendo observações muito acima de 2 desvio padrões nos gráficos de resíduos, sendo estes pontos considerado "outliers". O modelo melhorou sem estes pontos, sendo verificado um aumento do $\mathrm{R}^{2}$. Com a redução dos valores dos VIFs, os coeficientes dos termos do modelo podem ser empregados para explicar o efeito das proporções dos materiais sobre os resultados de $J_{\text {nr,diff. }}$

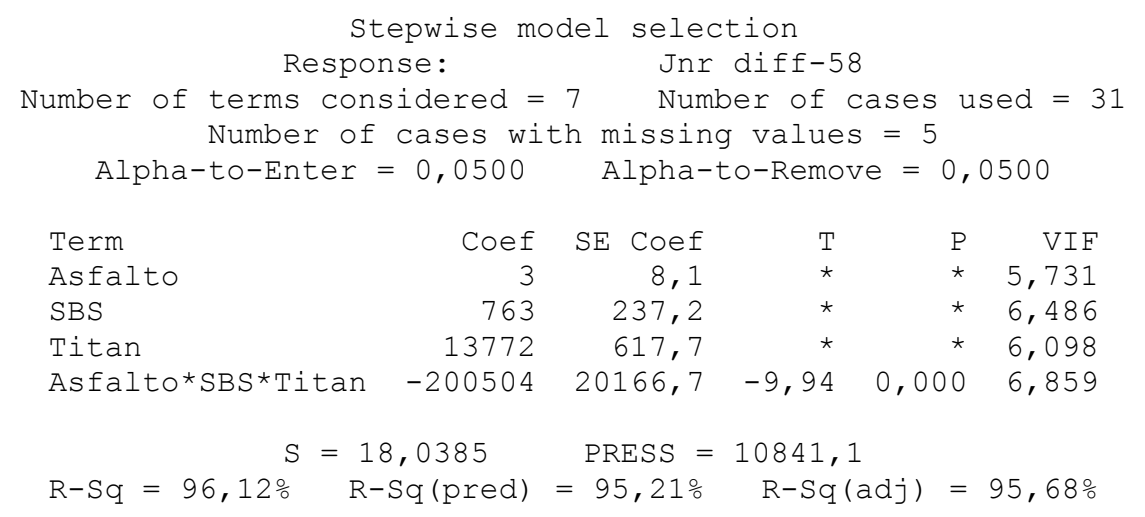

\section{Residual Plots for Jnr diff-58}
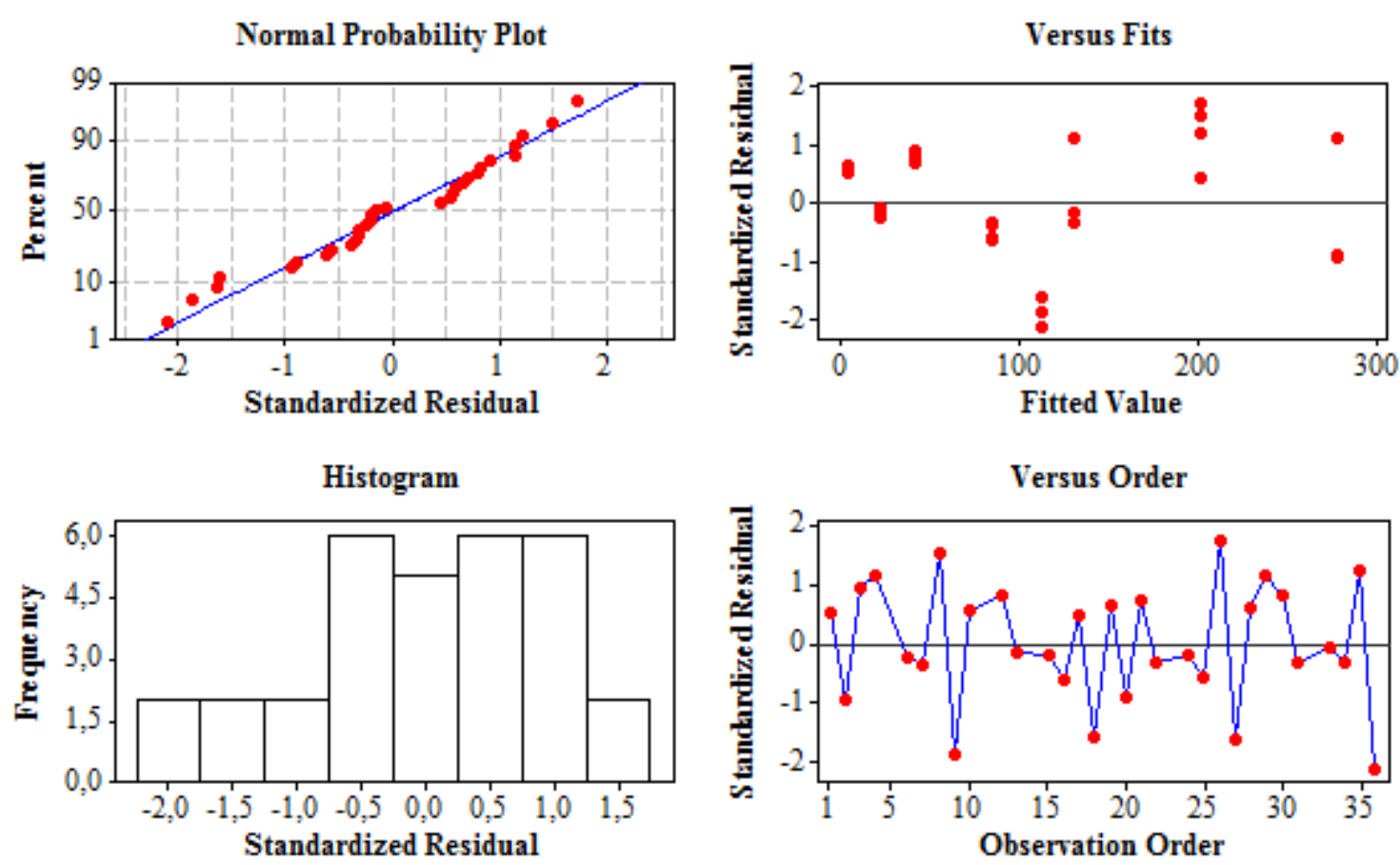

Figura A.28.1 - Análise de resíduos para $\mathrm{J}_{\mathrm{nr}, \text { diff }}$ a $58^{\circ} \mathrm{C}$ após $\mathrm{RTFOT}$ 


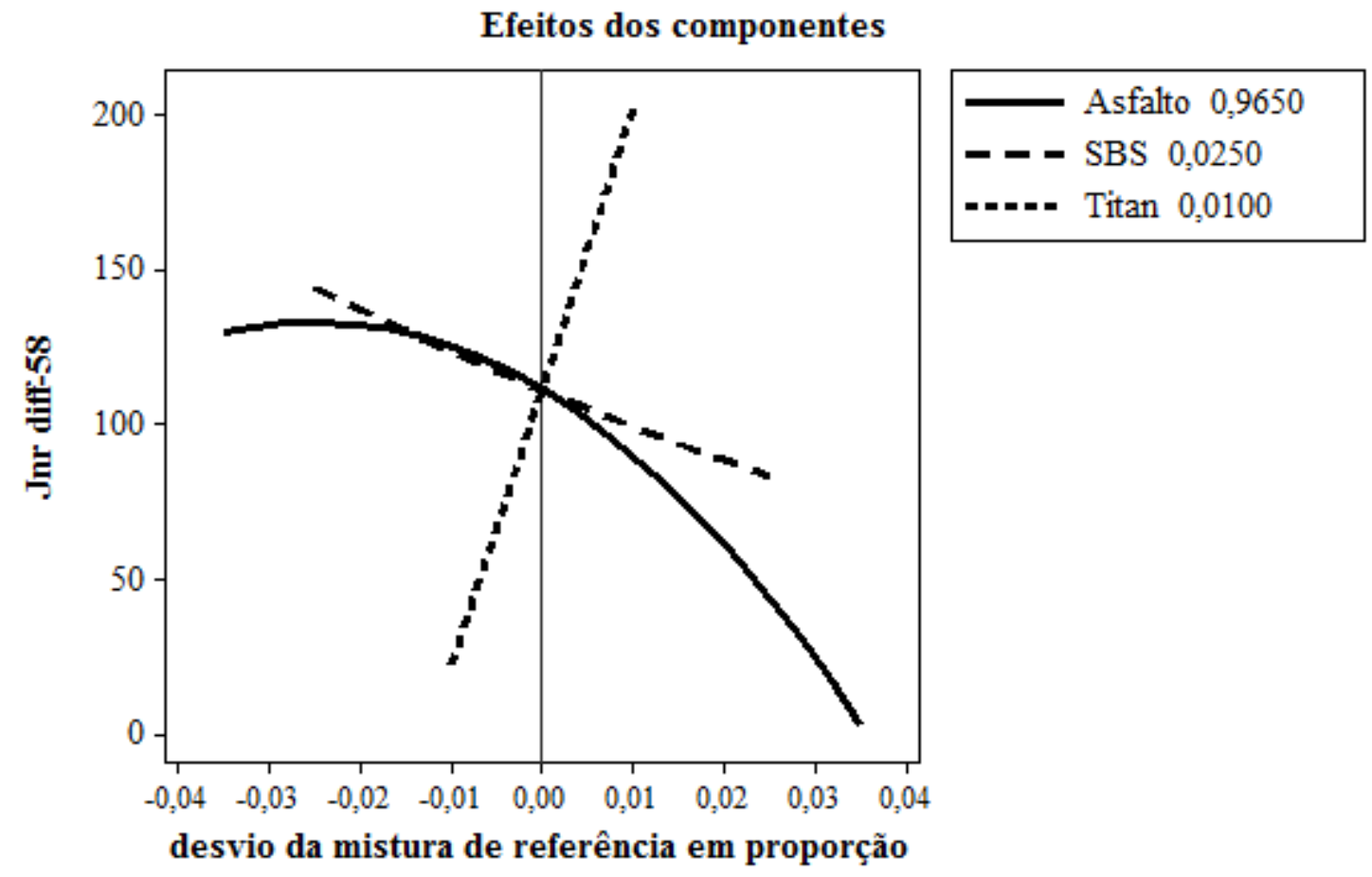

Figura A.28.2 - Efeitos dos componentes para $\mathrm{J}_{\mathrm{nr} \text {,diff }} \mathbf{5 8}^{\circ} \mathrm{C}$ após RTFOT

Superfície de resposta para $\mathrm{Jnr}$,diff a $58^{\circ} \mathrm{C}$

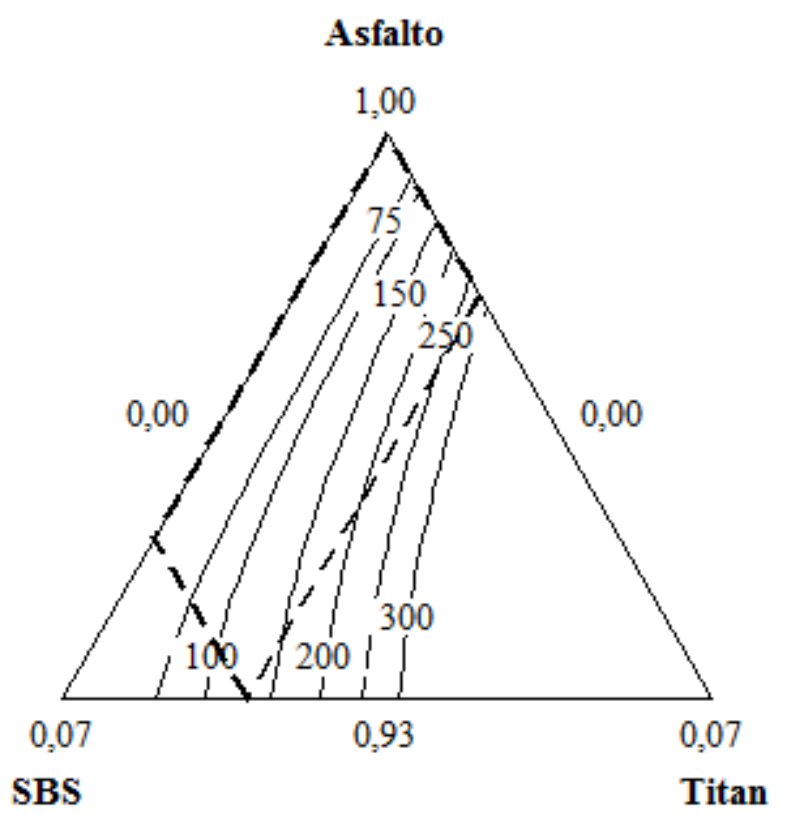

Figura A.28.3 - Superfície de resposta para $\mathrm{J}_{\mathrm{nr}, \text { diff }} \mathbf{5 8}^{\circ} \mathrm{C}$ após RTFOT 


\section{Modelo A.29 Parâmetro $\mathrm{J}_{\mathrm{nr}, \text { diff }}$ a $64^{\circ} \mathrm{C}$ após RTFOT}

Os pontos 5, 11, 17, 26 e 35 foram retirados para obtenção deste modelo. As exclusões destes pontos são justificados pela seguinte constatação: estes valores destoam dos demais, sendo observações muito acima de 2 desvio padrões nos gráficos de resíduos, sendo estes pontos considerado "outliers". O modelo melhorou sem estes pontos, sendo verificado um aumento do $\mathrm{R}^{2}$. Com a redução dos valores dos VIFs, os coeficientes dos termos do modelo podem ser empregador para explicar o efeito das proporções dos materiais sobre os resultados de $J_{\text {nr,diff. }}$

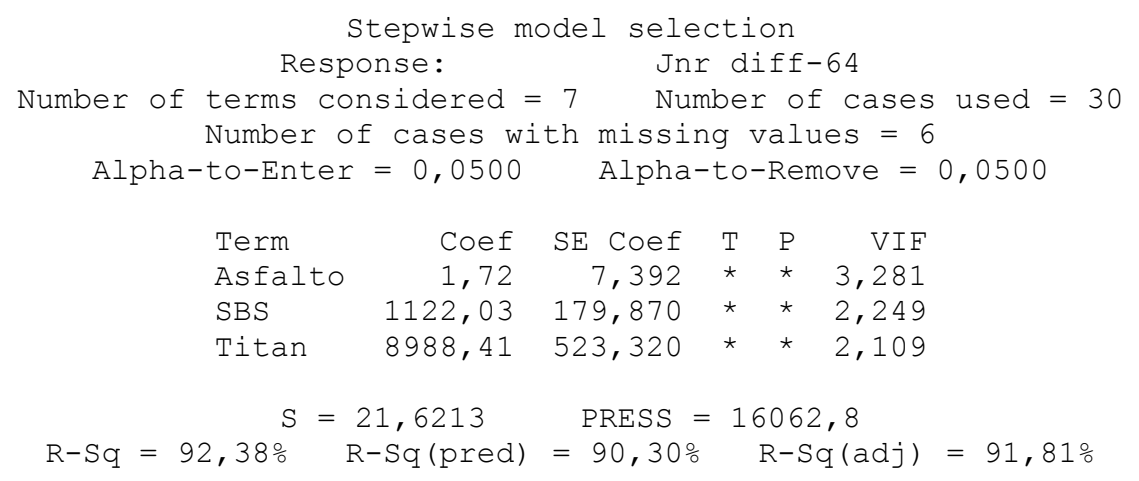

Residual Plots for Jnr diff-64
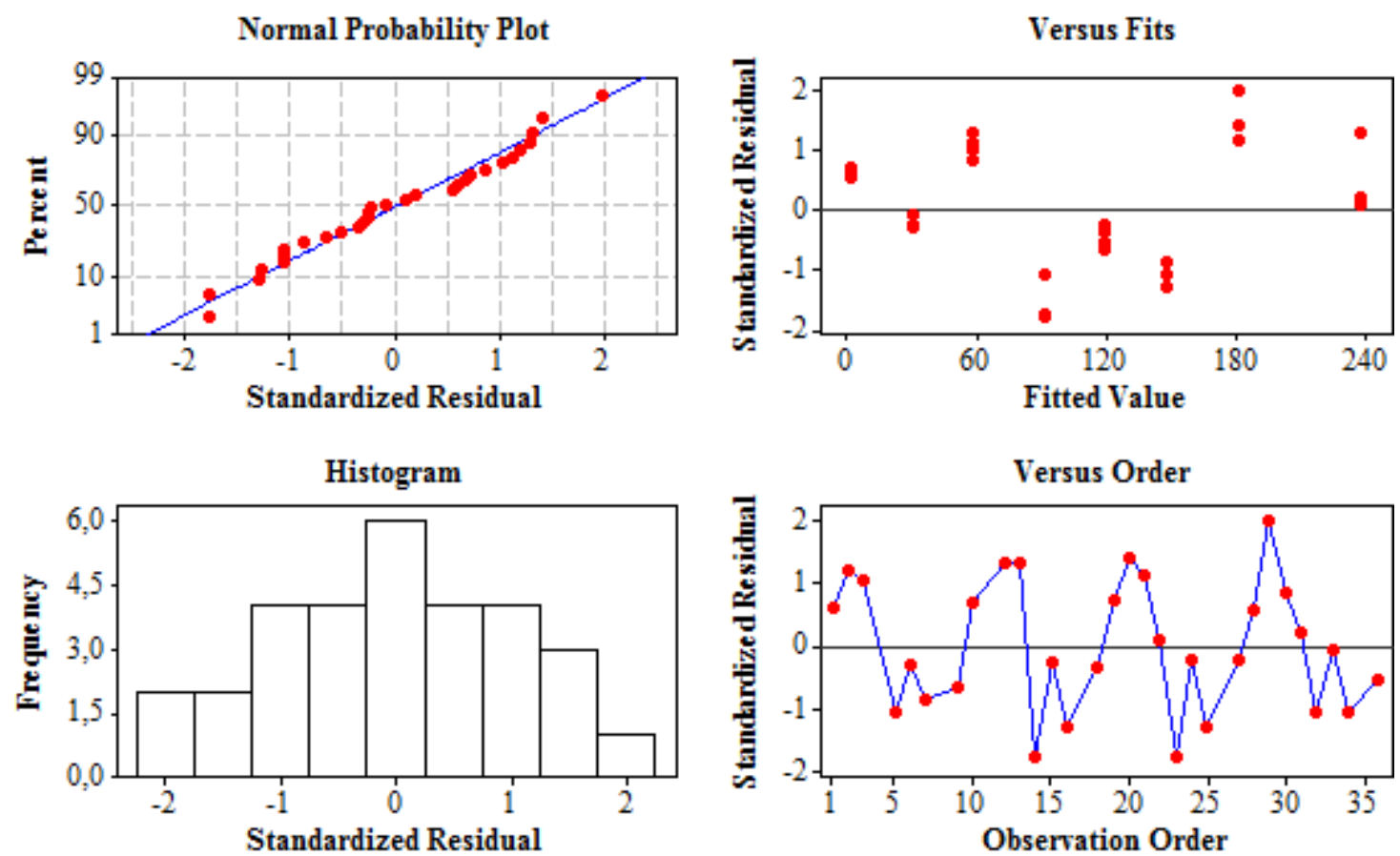

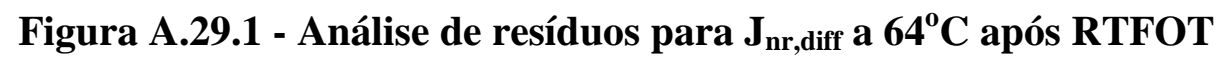




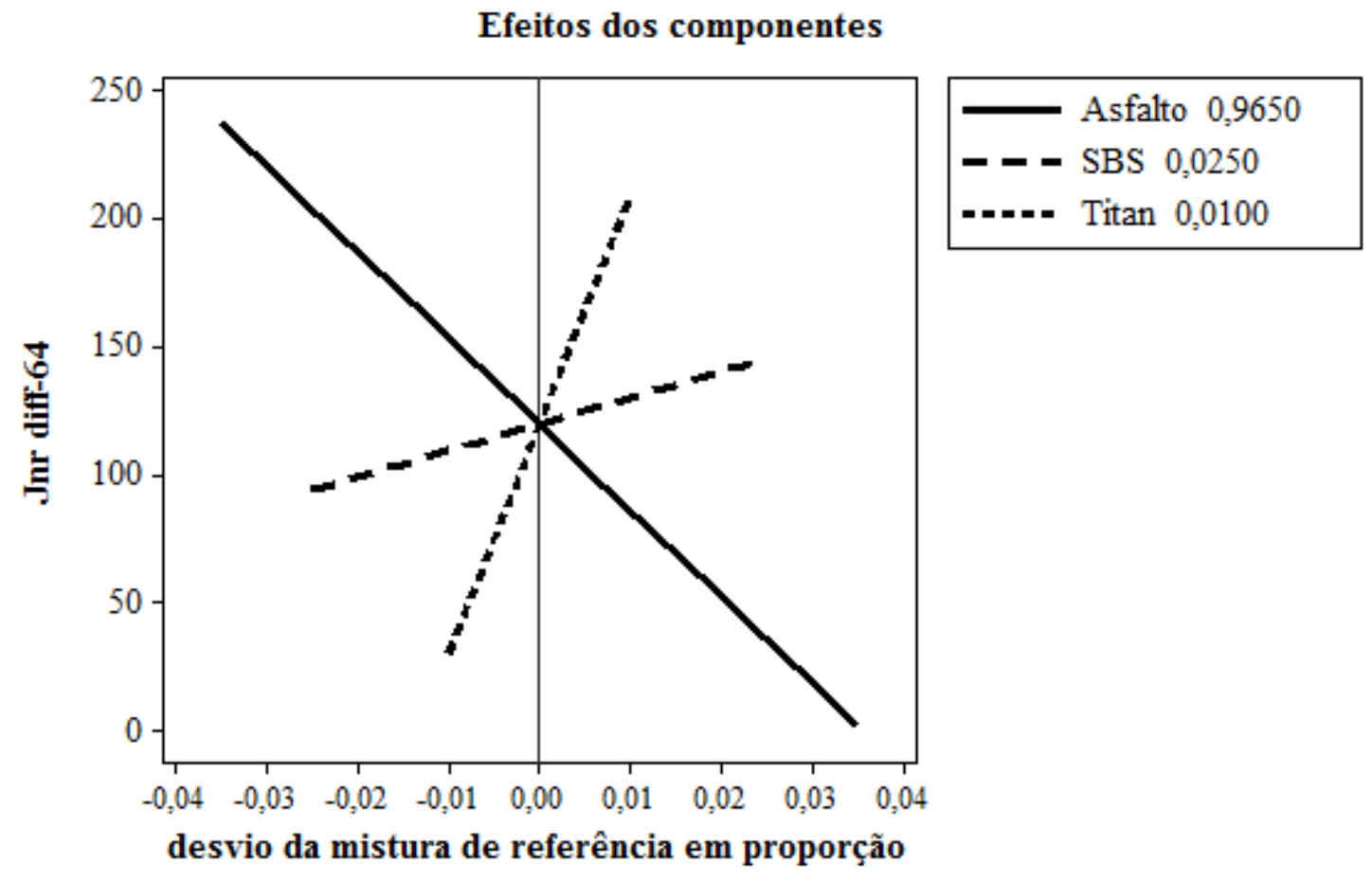

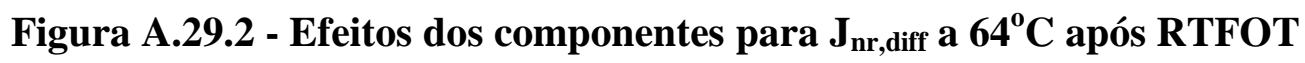

Superficie de resposta para $\mathrm{Jnr}$, diff a $64^{\circ} \mathrm{C}$

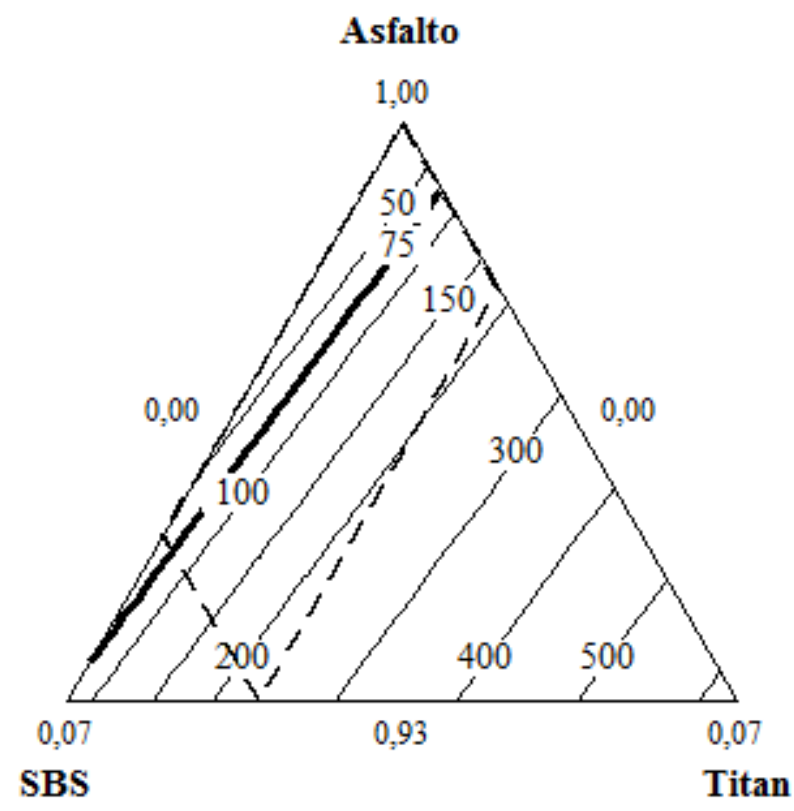

Figura A.29.3 - Superfície de resposta para $\mathrm{J}_{\mathrm{nr}, \text { diff a }} 64^{\circ} \mathrm{C}$ após RTFOT 


\section{Modelo A.30 Parâmetro $\mathrm{J}_{\mathrm{nr}, \text { diff }} \mathbf{7 0}^{\circ} \mathrm{C}$ após RTFOT}

Os pontos 1, 10, 19 e 28 não tinham resultados, pois a $70^{\circ} \mathrm{C}$ para a mistura $100-0-0$ não foi realizado o ensaio de MSCR, pois estes pontos a $64^{\circ} \mathrm{C}$ já apresentavam valores muito acima dos prescritos em norma. $\mathrm{O}$ valor do VIF foi considerado satisfatório, de forma que os coeficientes dos termos do modelo podem ser empregados para explicar o efeito das proporções dos materiais sobre os resultados de $\mathrm{J}_{\mathrm{nr}, \text { diff. }}$.

Stepwise model selection

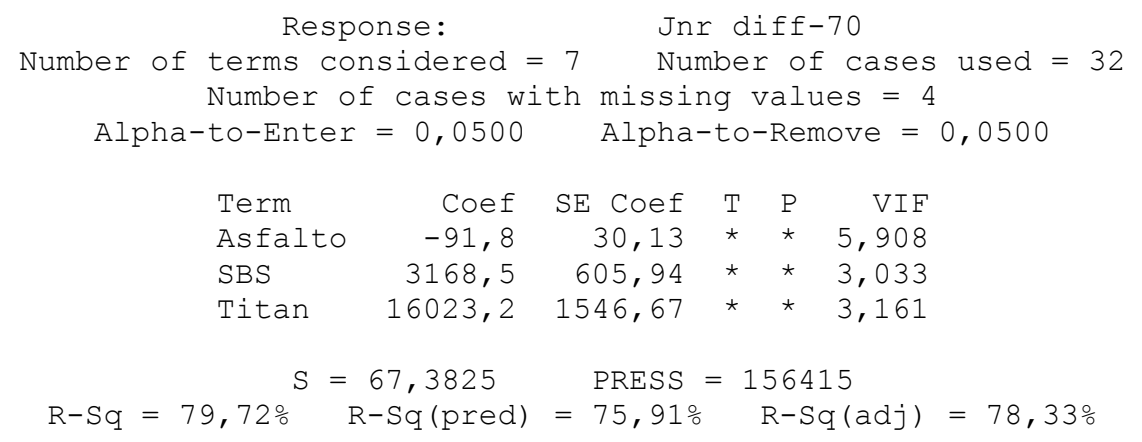

\section{Residual Plots for Jnr diff-70}
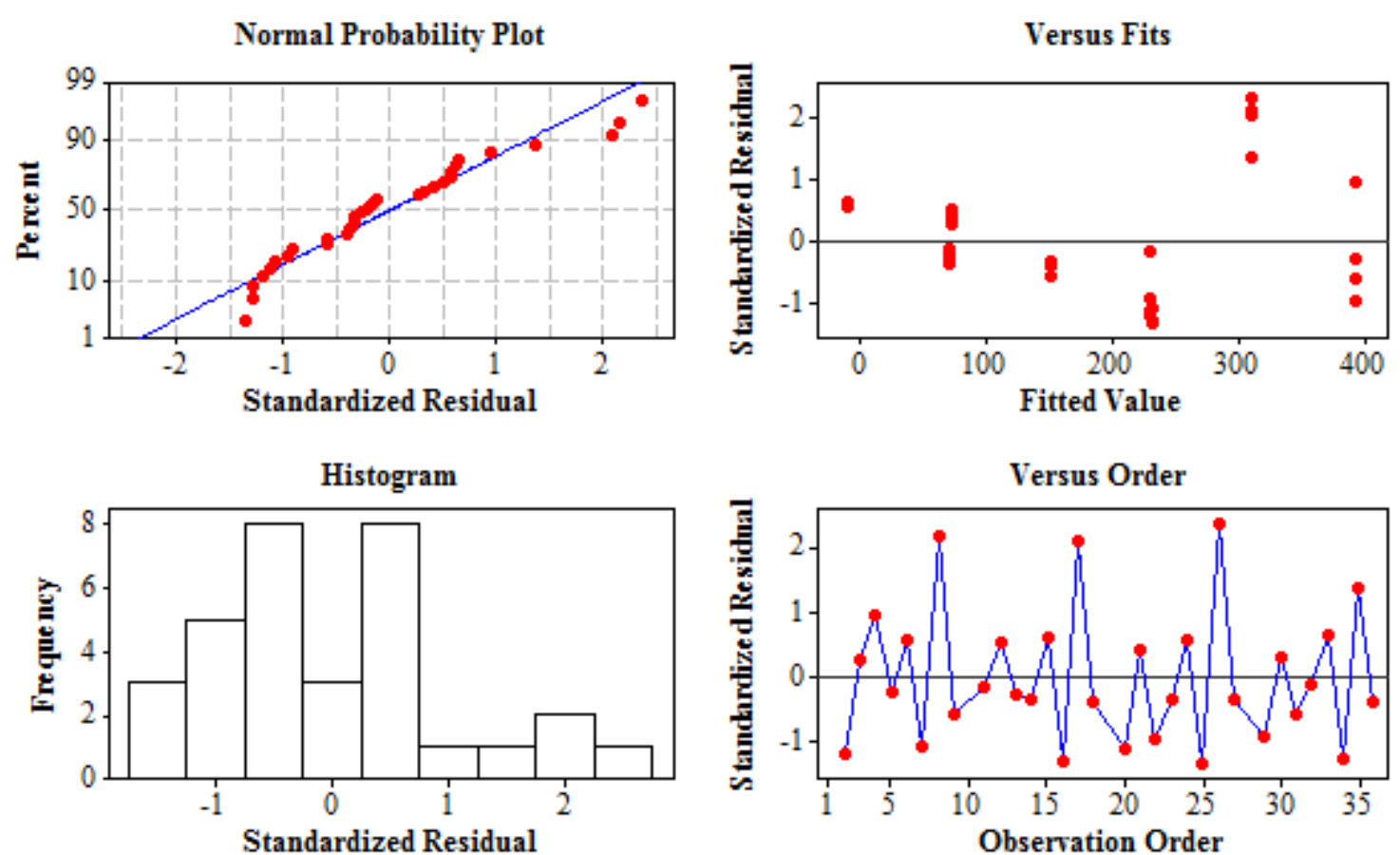

Figura A.30.1 - Análise de resíduos para $\mathrm{J}_{\mathrm{nr}, \text { diff }} \mathbf{7 0}^{\circ} \mathrm{C}$ após RTFOT 


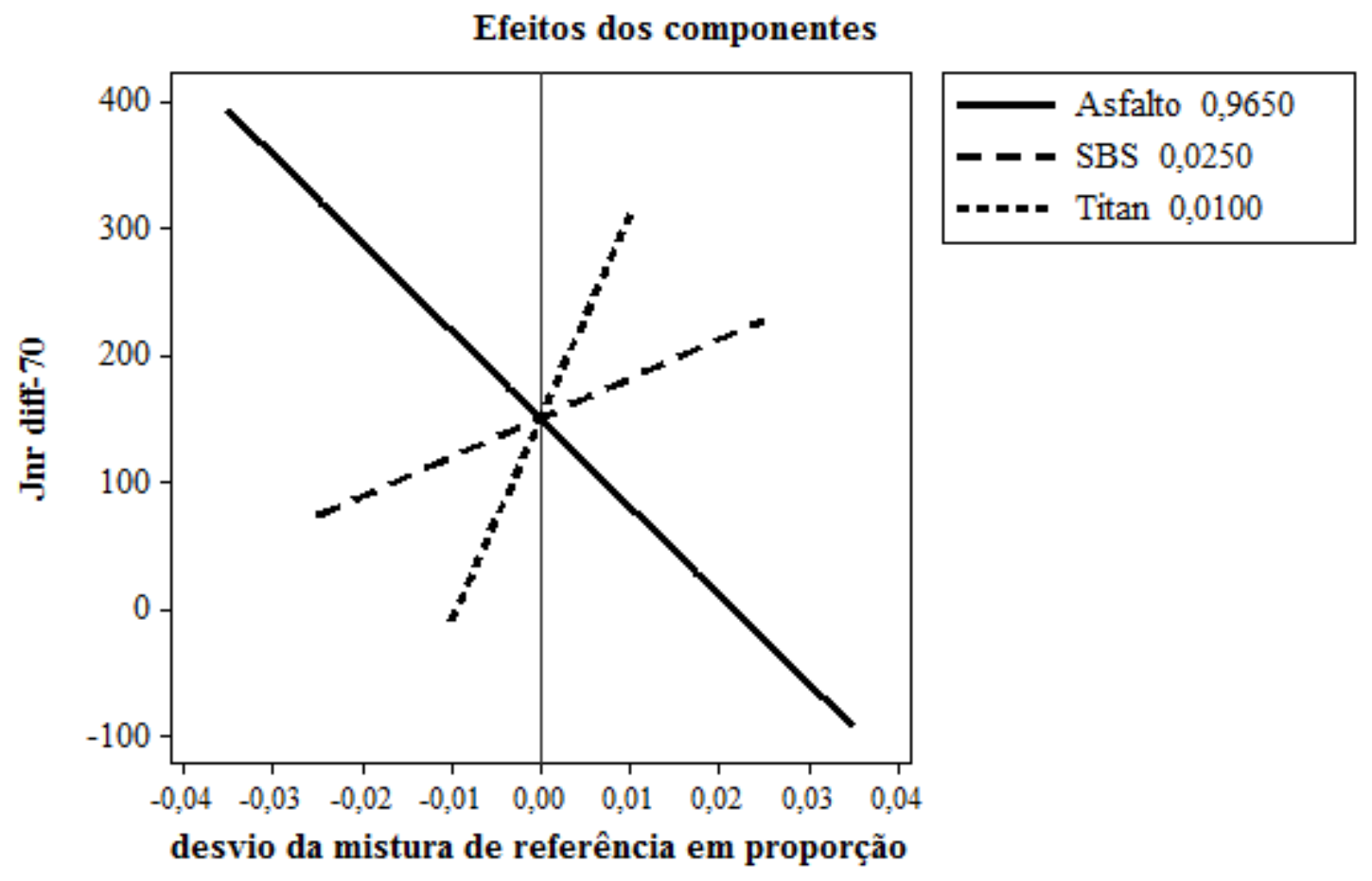

Figura A.30.2 - Efeitos dos componentes para $\mathrm{J}_{\mathrm{nr} \text {,diff }}$ a $70^{\circ} \mathrm{C}$ após RTFOT

Superfície de resposta para $\mathrm{Jnr}$, diff a $70^{\circ} \mathrm{C}$

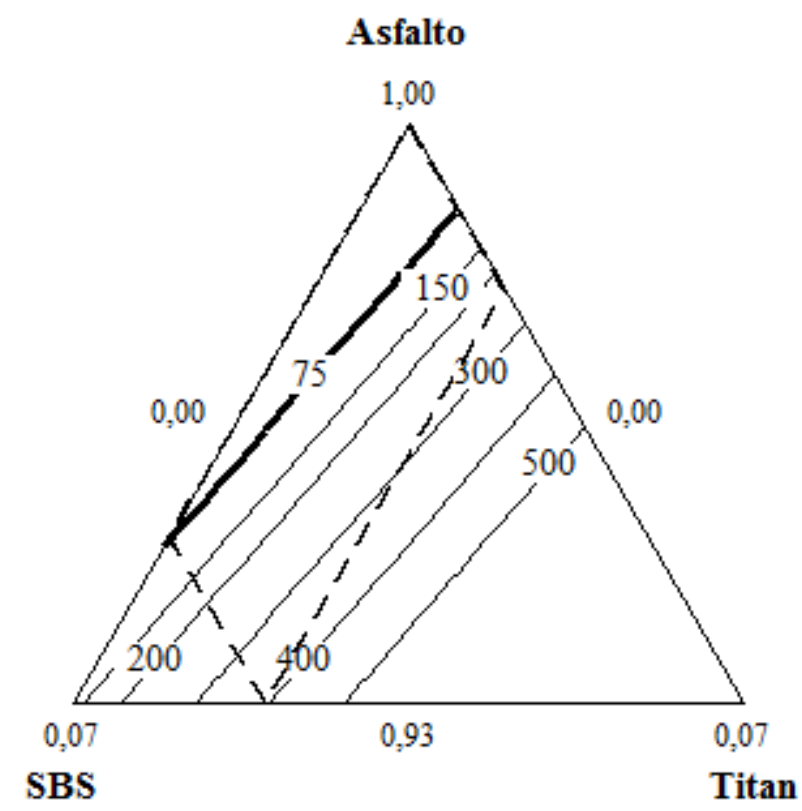

Figura A.30.3 - Superfície de resposta para $\mathrm{J}_{\mathrm{nr}, \text { diff }} \mathbf{7 0}^{\circ} \mathrm{C}$ após RTFOT 


\section{Modelo A.31 Comprimento da trinca na ruptura por fadiga $\left(a_{f}\right) a^{\circ} \mathrm{C}$ após PAV}

Os pontos 1, 16, 17 e 27 foram retirados para obtenção deste modelo. As exclusões destes pontos se justificam pela seguinte constatação: estes valores destoam dos demais, sendo observações muito acima de 2 desvio padrões nos gráficos de resíduos, sendo estes pontos considerado "outliers". O modelo melhorou sem estes pontos, sendo verificado um aumento do $\mathrm{R}^{2}$. Mesmo com as retiradas o valor apresentado pelo VIF foram satisfatórios, onde os coeficientes dos termos podem ser empregados para explicar a variação entre as misturas.

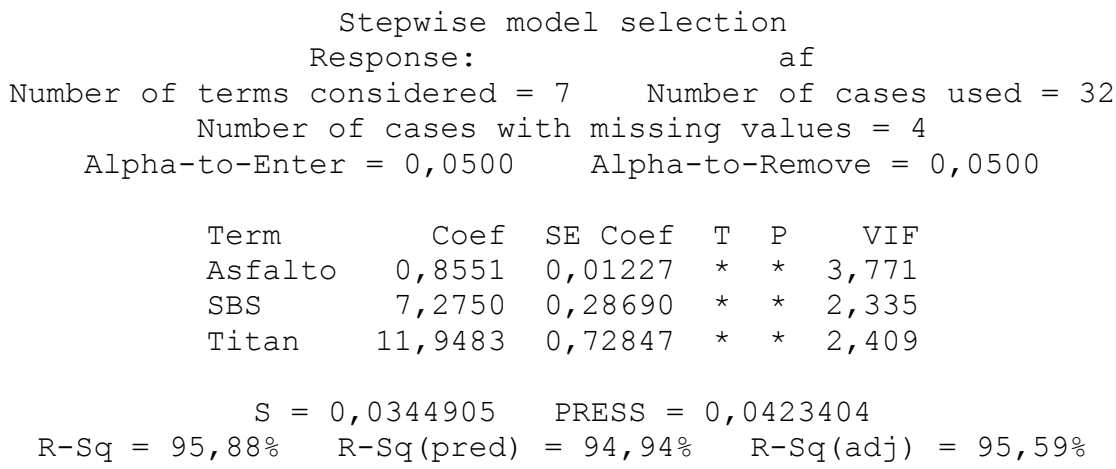

\section{Residual Plots for af}
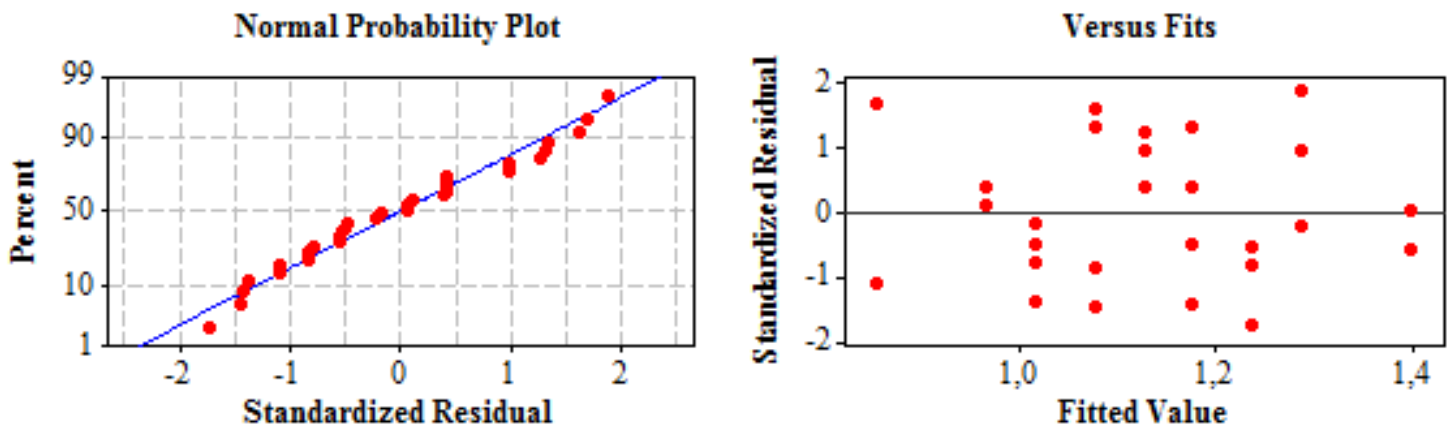

Histogram

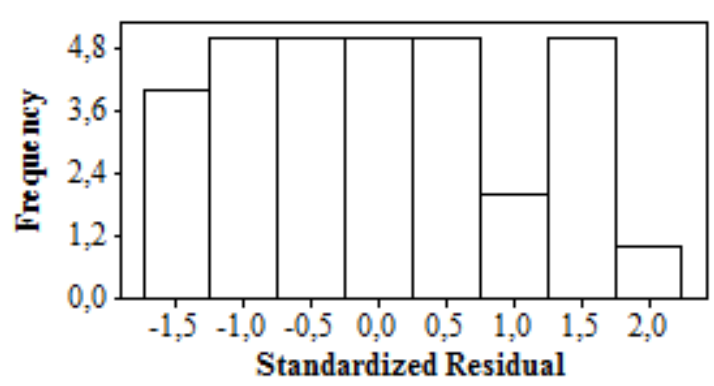

Versus Order

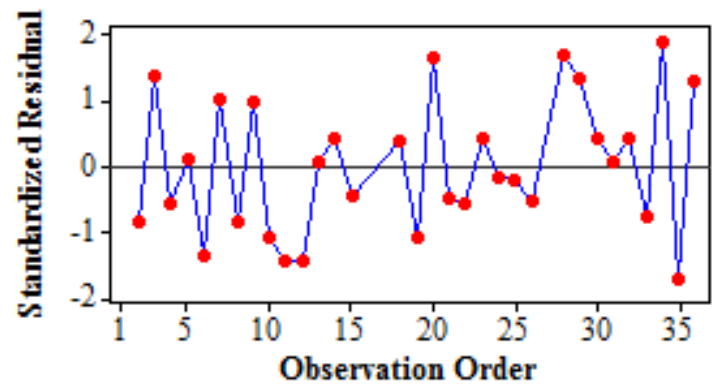

Figura A.31.1 - Análise de resíduos para $\mathrm{a}_{\mathrm{f}}$ a $25^{\circ} \mathrm{C}$ após PAV 


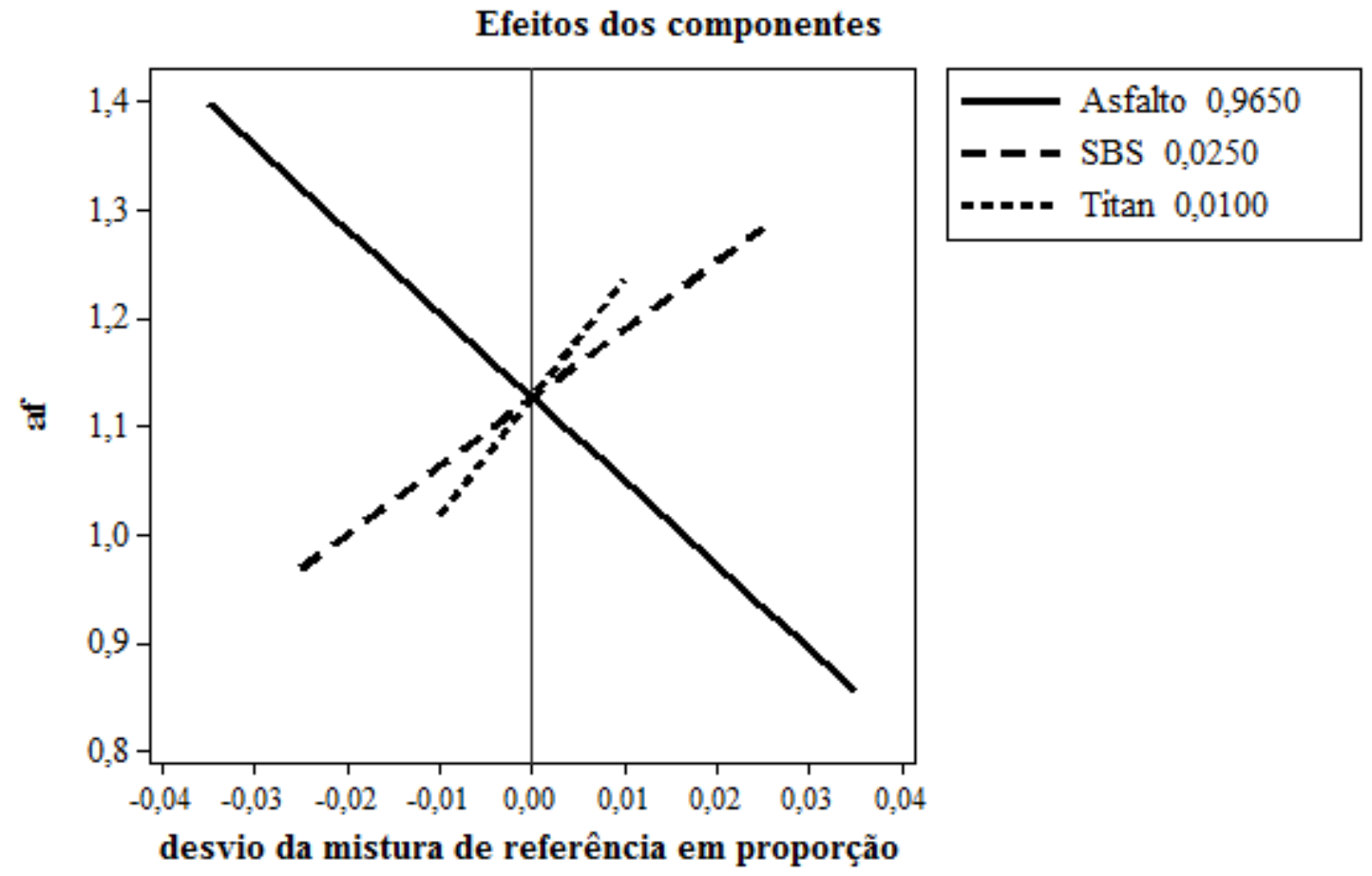

Figura A.31.2 - Efeitos dos componentes para $a_{\mathrm{f}}$ a $25^{\circ} \mathrm{C}$ após PAV

Superficie de resposta para af

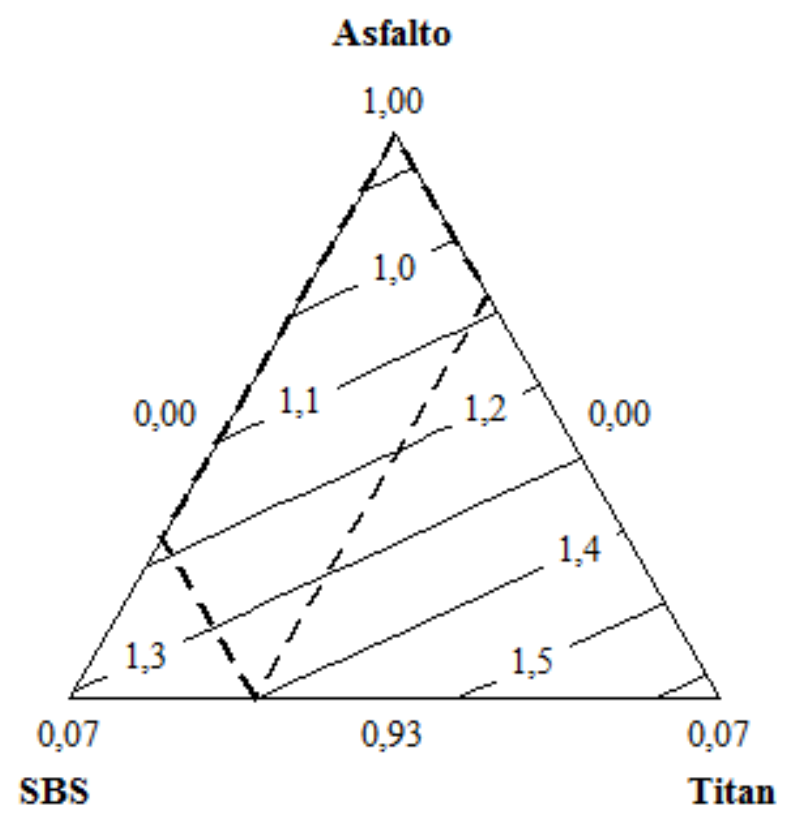

Figura A.31.3 - Superfície de resposta para $a_{f}$ a $25^{\circ} \mathrm{C}$ após PAV 


\section{Modelo A.32 Vida de fadiga $\left(\mathrm{N}_{\mathrm{f}}\right)$ a $25^{\circ} \mathrm{C}$ após PAV a uma deformação de $2 \%$}

Os pontos 4, 7, 12, 16, 27 e 36 foram retirados para obtenção deste modelo. As exclusões destes pontos se justificam pela seguinte constatação: estes valores destoam dos demais, sendo observações muito acima de 2 desvio padrões nos gráficos de resíduos, sendo estes pontos considerado "outliers". O modelo melhorou sem estes pontos, sendo verificado um aumento do $\mathrm{R}^{2}$. Mesmo com as retiradas o valor apresentado pelo VIF foram satisfatórios, onde os coeficientes dos termos podem ser empregados para explicar a variação entre as misturas.

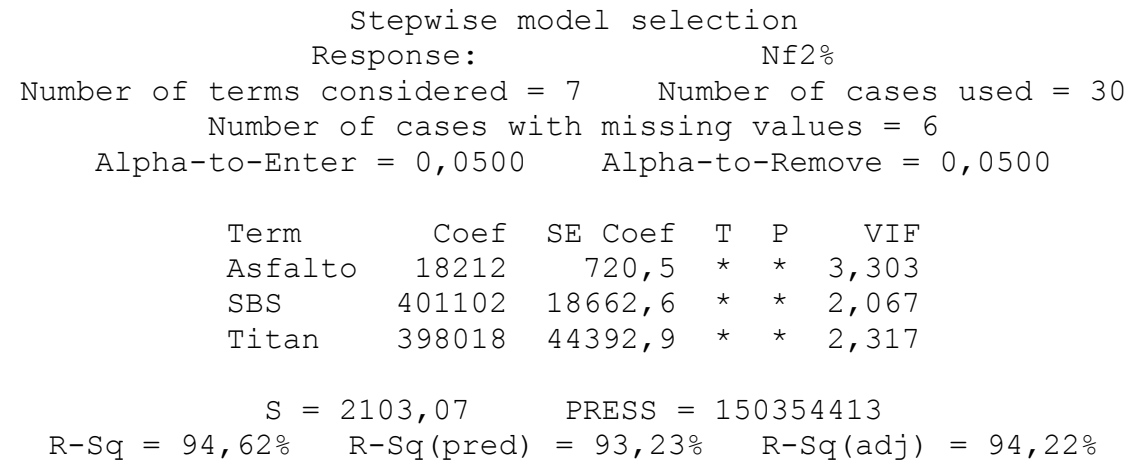

\section{Residual Plots for Nf2\%}
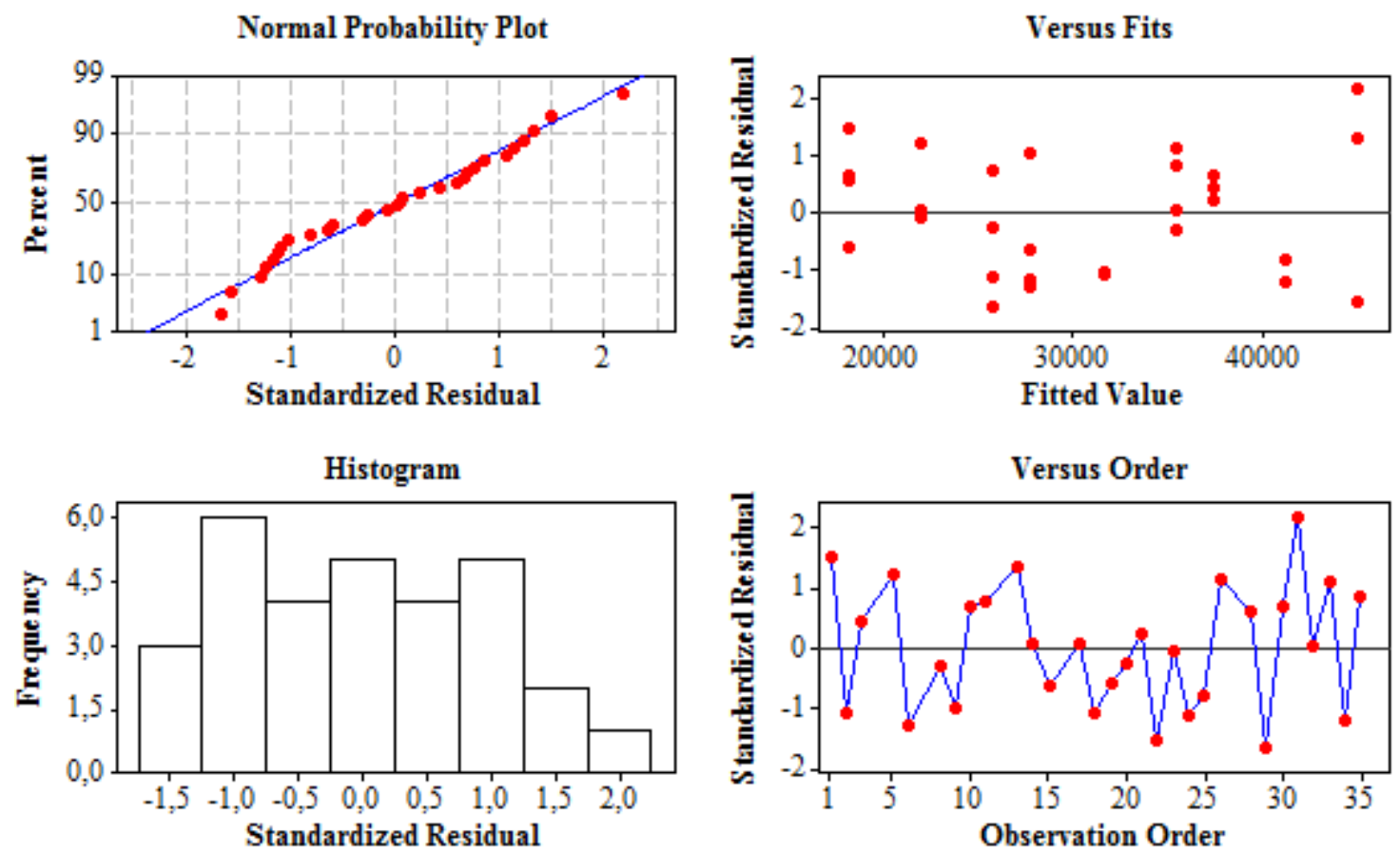

Figura A.32.1 - Análise de resíduos para $\mathrm{N}_{\mathrm{f}}$ a $2 \%$ a $25^{\circ} \mathrm{C}$ após PAV 


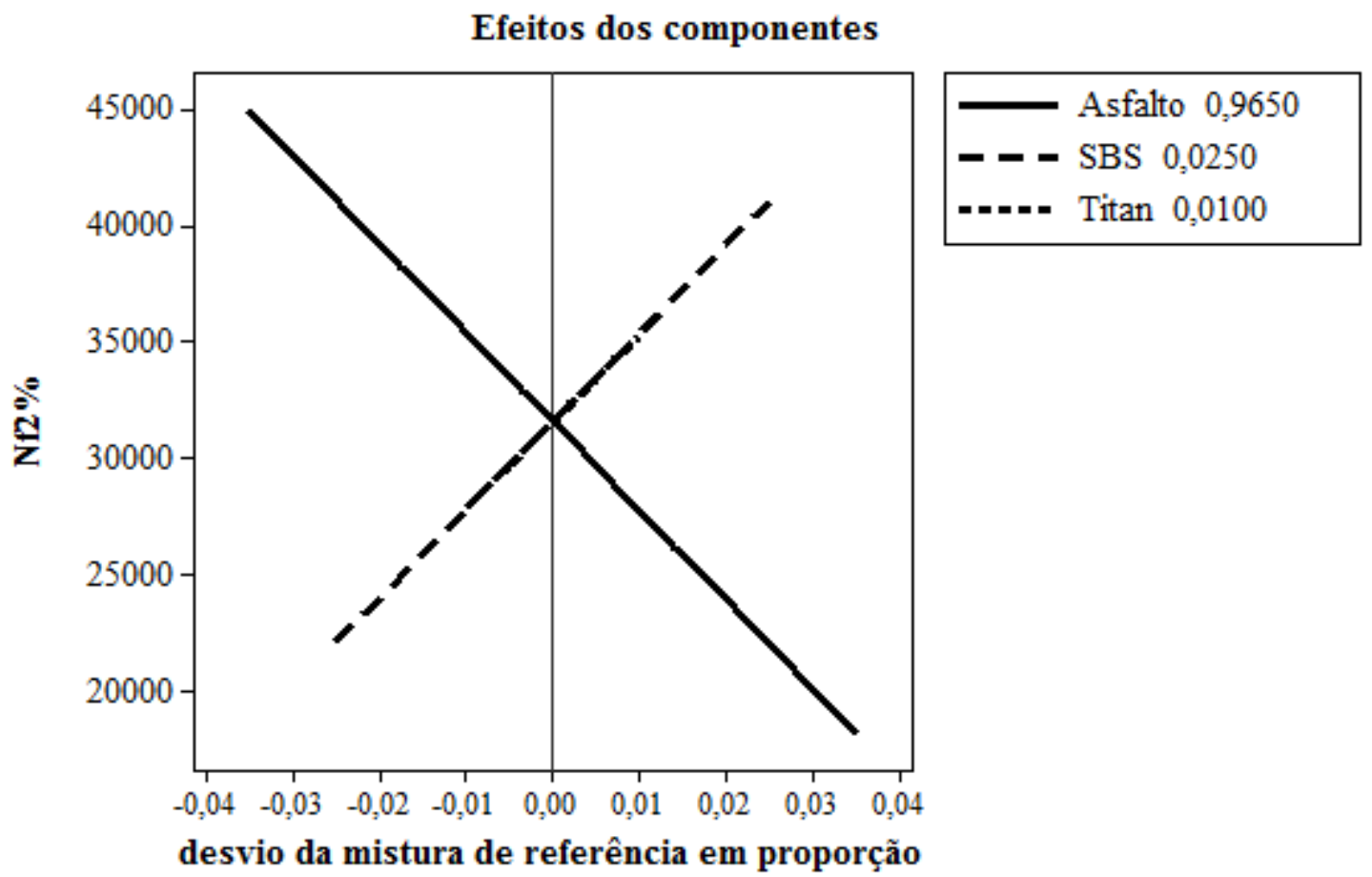

Figura A.32.2 - Efeitos dos componentes para $\mathrm{N}_{\mathrm{f}}$ a $2 \%$ a $25^{\circ} \mathrm{C}$ após PAV

Superficie de resposta para Nf $\mathbf{2} \%$

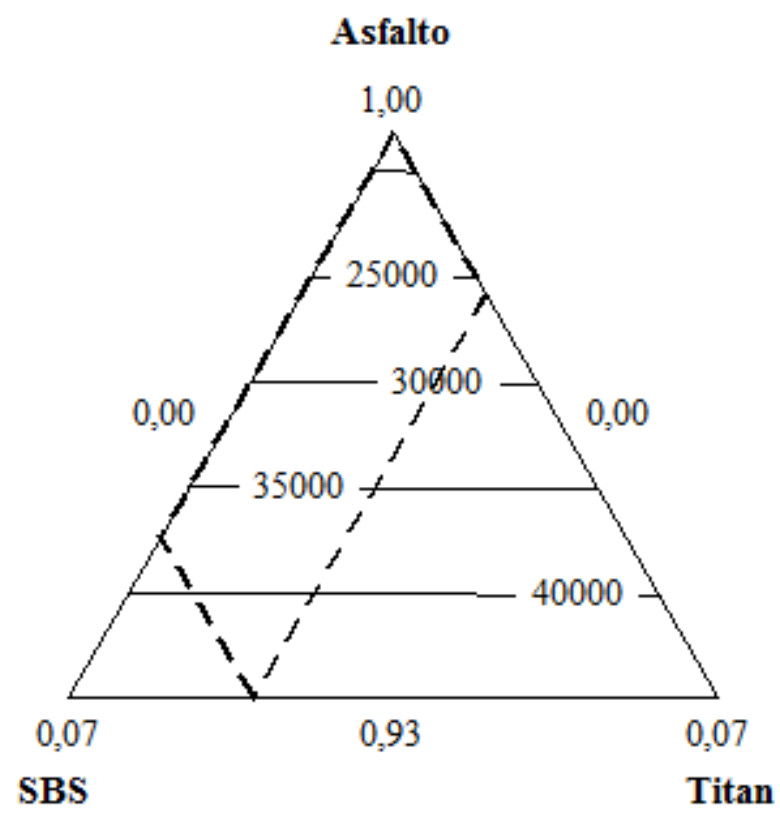

Figura A.32.3 - Superfície de resposta para $\mathrm{N}_{\mathrm{f}}$ a $2 \%$ a $25^{\circ} \mathrm{C}$ após PAV 


\section{Modelo A.33 Vida de fadiga $\left(\mathrm{N}_{\mathrm{f}}\right)$ a $25^{\circ} \mathrm{C}$ após PAV a uma deformação de $30 \%$}

Os pontos 5 e 19 foram retirados para obtenção deste modelo. As exclusões destes pontos são justificados pela seguinte constatação: estes valores destoam dos demais, sendo observações muito acima de 2 desvio padrões nos gráficos de resíduos, sendo estes pontos considerado "outliers". O modelo melhorou sem este ponto, sendo verificado um aumento do $\mathrm{R}^{2}$. Mesmo com a retirada o valor apresentado pelo VIF ainda foi alto, portanto o modelo apenas pode ser empregado para estimativa de novas ocorrências na região experimental.

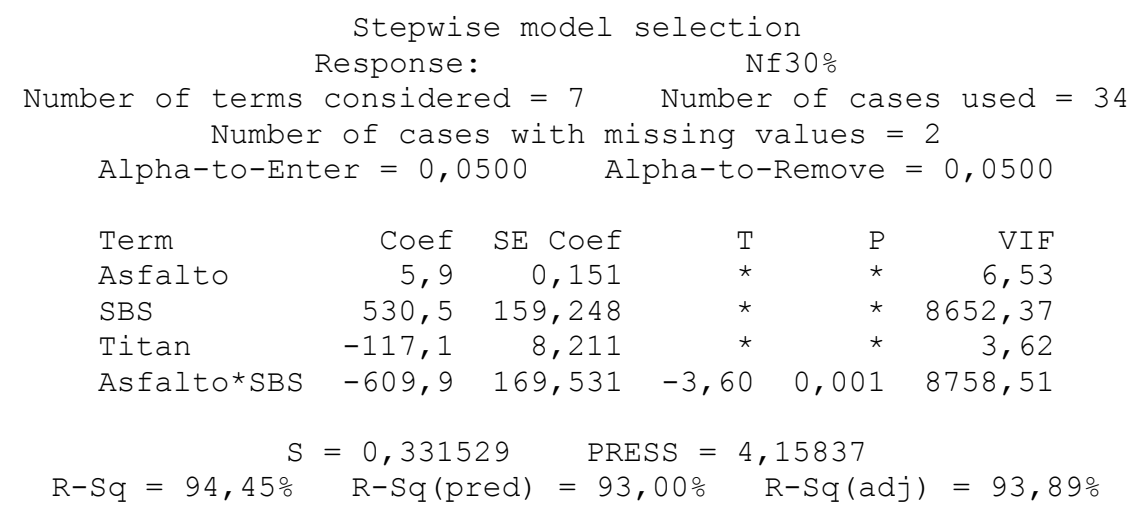

\section{Residual Plots for Nf30\%}
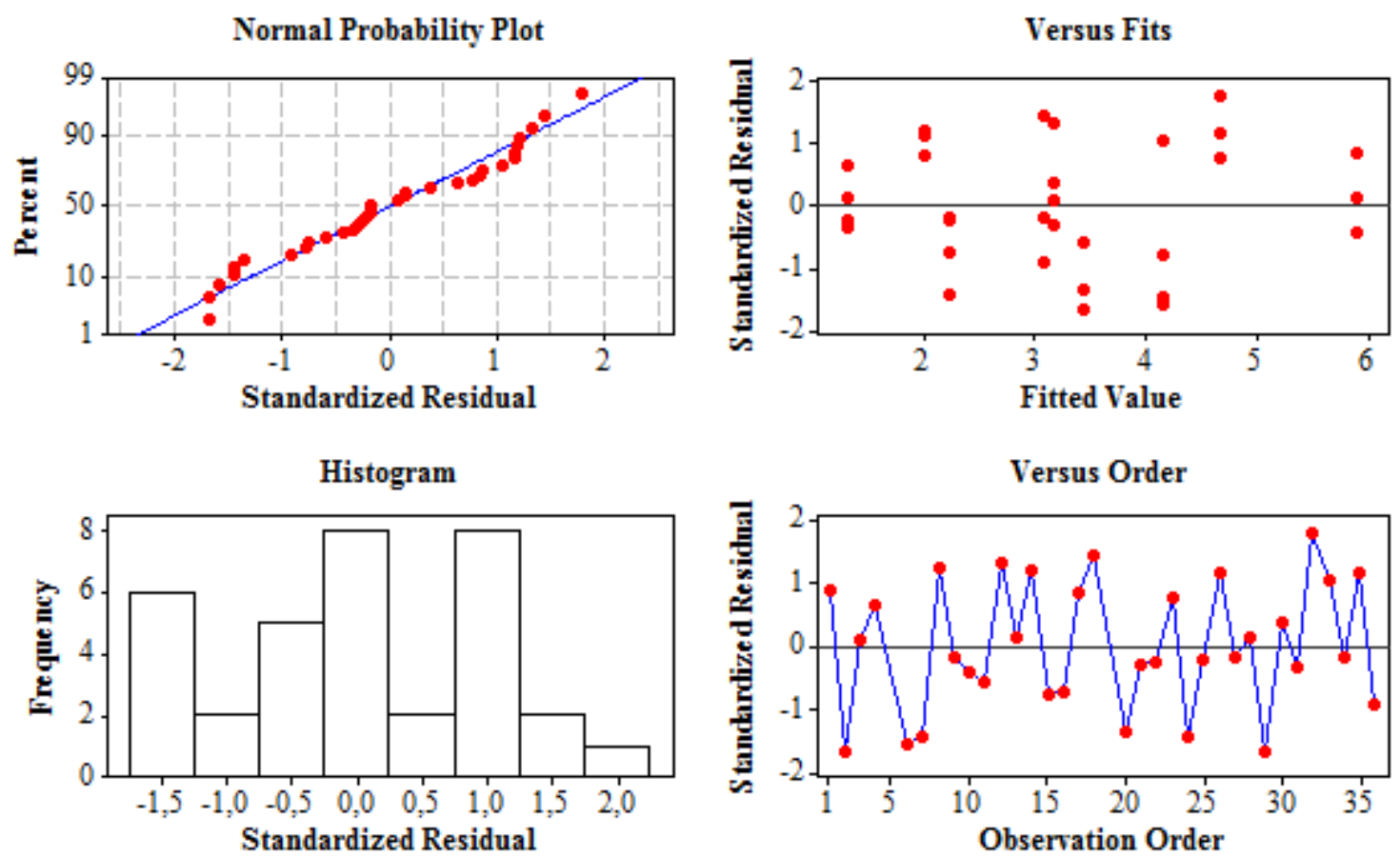

Figura A.33.1 - Análise de resíduos para $\mathrm{N}_{\mathrm{f}}$ a $30 \%$ a $25^{\circ} \mathrm{C}$ após PAV 
Efeitos dos componentes

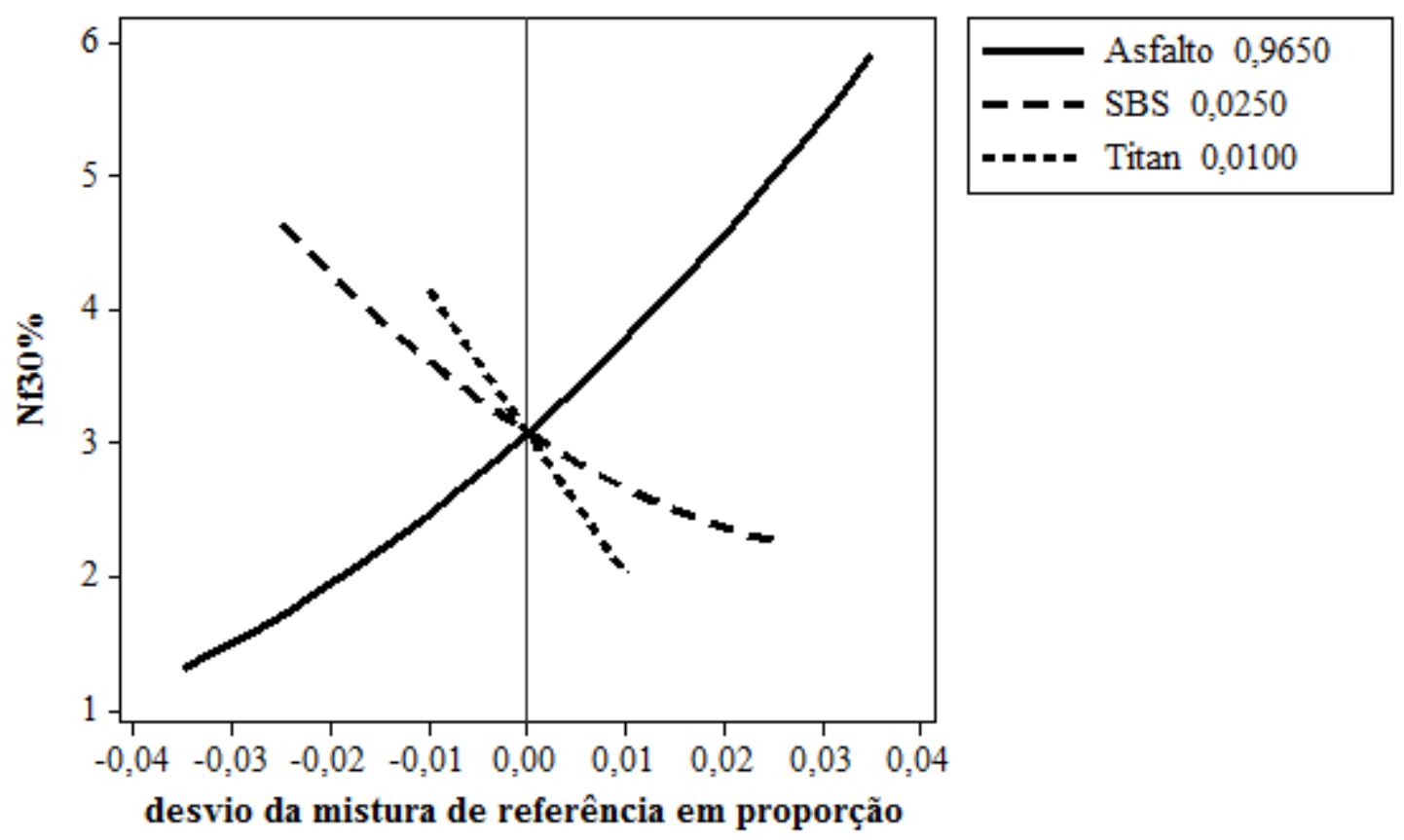

Figura A.33.2 - Efeitos dos componentes para $\mathrm{N}_{\mathrm{f}}$ a $30 \%$ a $25^{\circ} \mathrm{C}$ após PAV

Superfície de resposta para Nf $\mathbf{3 0} \%$

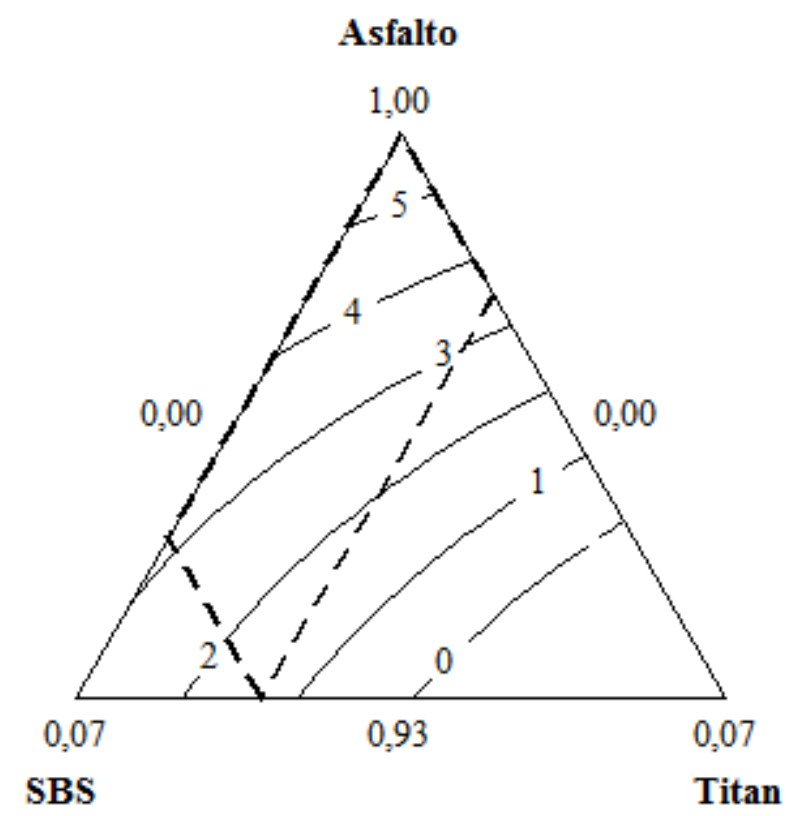

Figura A.33.3 - Superfície de resposta para $\mathrm{N}_{\mathrm{f}}$ a $30 \%$ a $25^{\circ} \mathrm{C}$ após PAV 


\section{Modelo A.34 Compliância não-recuperável $\left(\mathrm{J}_{\mathrm{nr}}\right)$ a 100 Pa a $52^{\circ} \mathrm{C}$ após RTFOT}

Não houve retiradas de pontos para obtenção deste modelo. $\mathrm{O} \mathrm{R}^{2}$ encontrado foi bom, mas o valor apresentado pelo VIF foi alto, portanto o modelo apenas pode ser empregado para estimativa de novas ocorrências na região experimental.

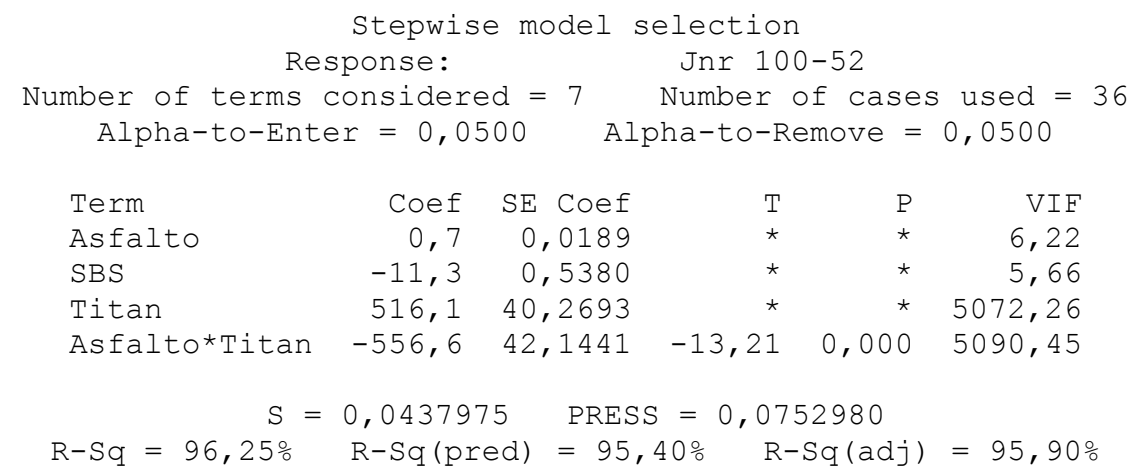

\section{Residual Plots for Jnr 100-52}
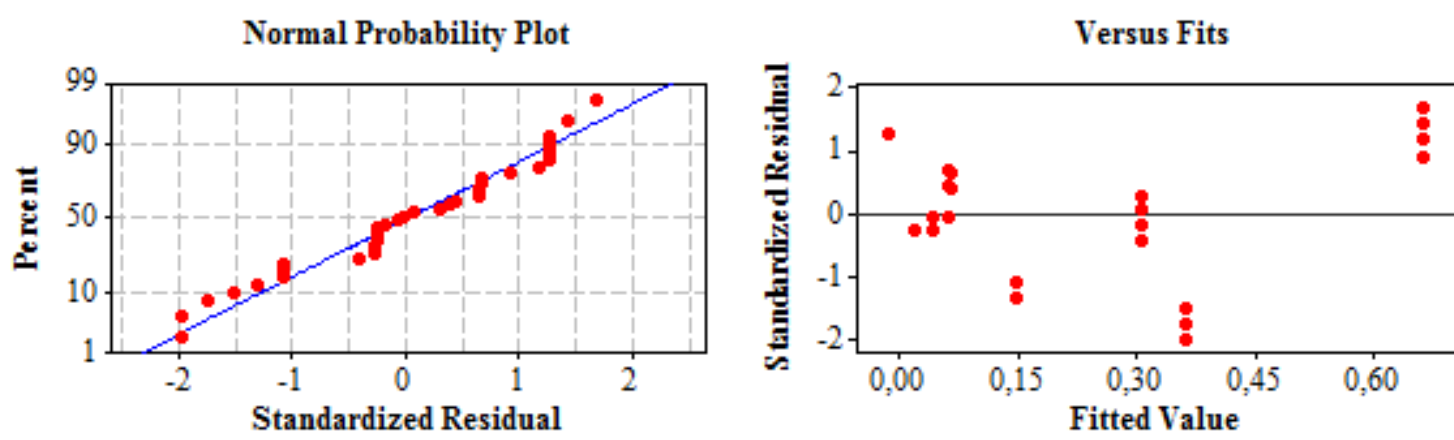

Histogram
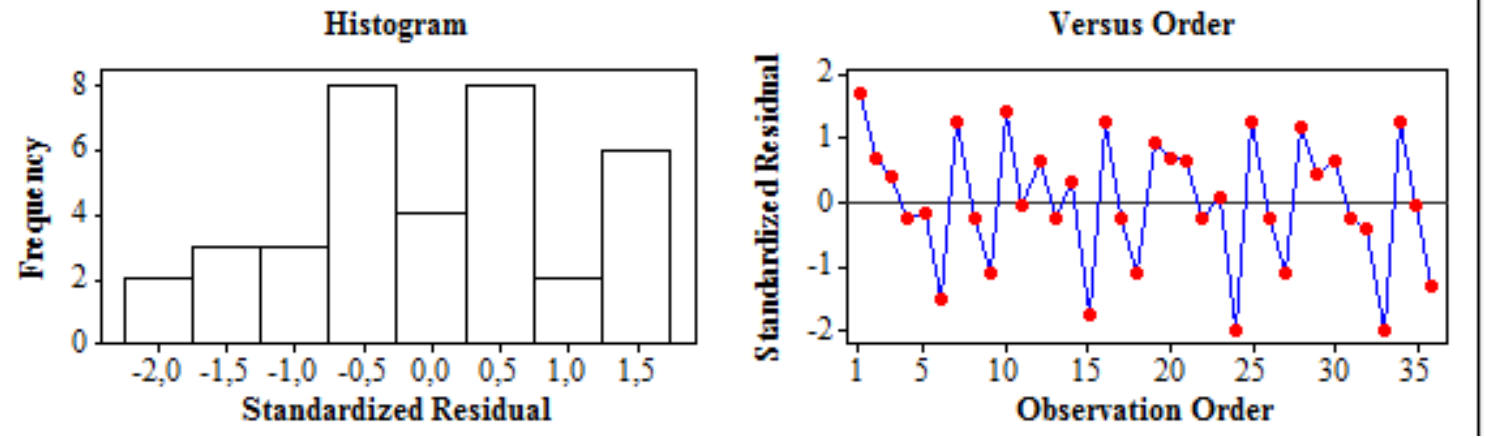

Figura A.34.1 - Análise de resíduos para $\mathrm{J}_{\mathrm{nr}}$ a $100 \mathrm{~Pa}$ a $52^{\circ} \mathrm{C}$ após RTFOT 
Efeitos dos componentes

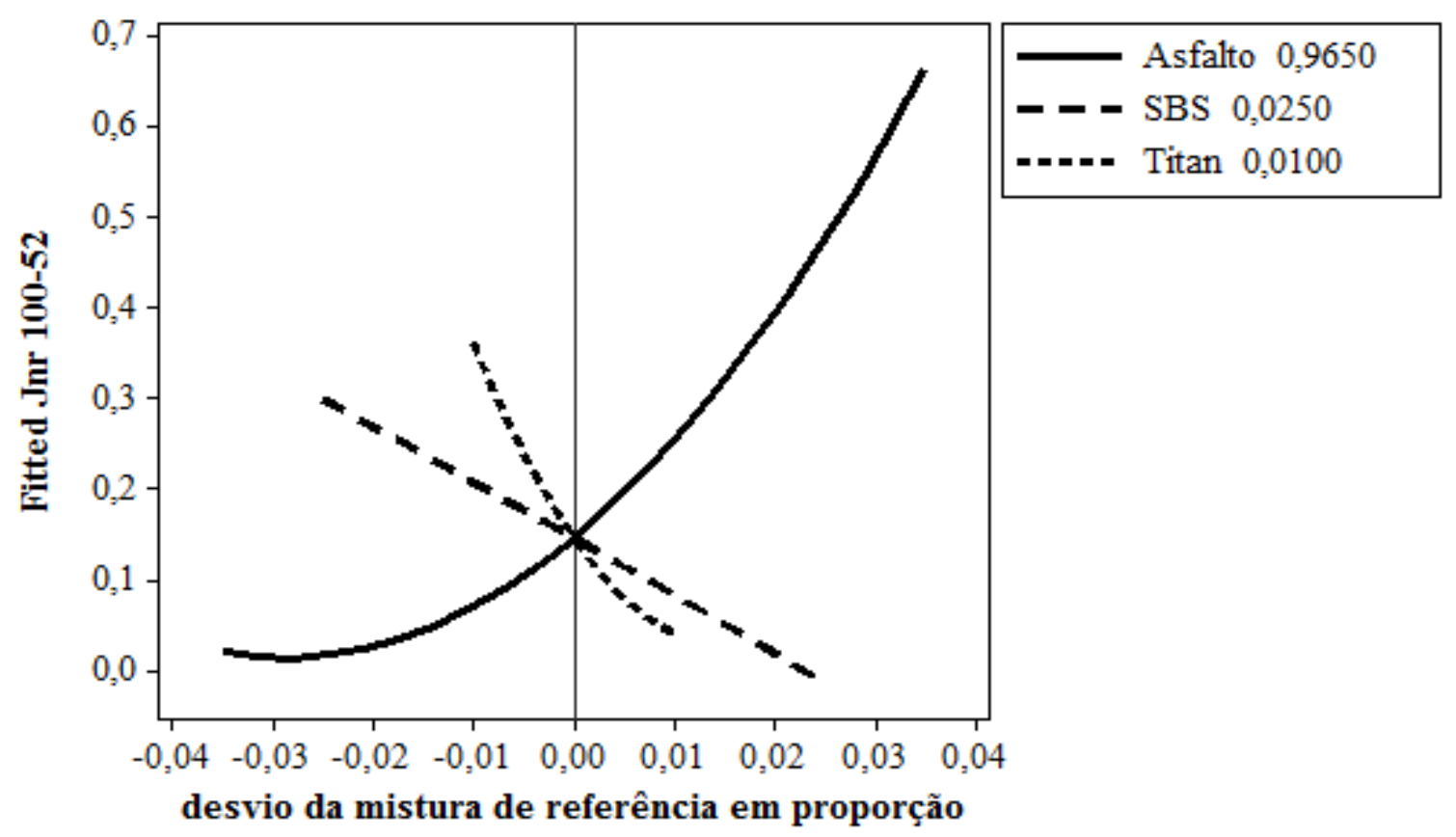

Figura A.34.2 - Efeitos dos componentes para $\mathrm{J}_{\mathrm{nr}}$ a 100 Pa a $52^{\circ} \mathrm{C}$ após RTFOT

Superficie de resposta para $\mathrm{Jnr} 100$ a $52^{\circ} \mathrm{C}$

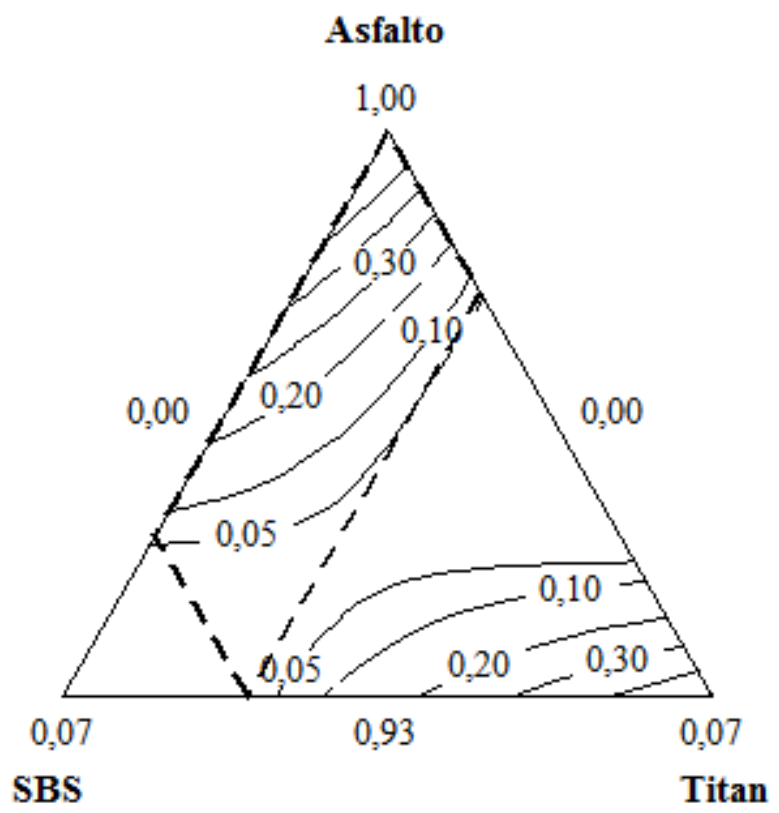

Figura A.34.3 - Superfície de resposta para $\mathrm{J}_{\mathrm{nr}}$ a $100 \mathrm{~Pa}$ a $52^{\circ} \mathrm{C}$ após RTFOT 


\section{Modelo A.35 Compliância não-recuperável $\left(\mathrm{J}_{\mathrm{nr}}\right)$ a 100 Pa após RTFOT a $5^{\circ} \mathrm{C}$}

Não houve retiradas de pontos para obtenção deste modelo. $\mathrm{O} \mathrm{R}^{2}$ encontrado foi bom, mas o valor apresentado pelo VIF foi alto, portanto o modelo apenas pode ser empregado para estimativa de novas ocorrências na região experimental.

\begin{tabular}{|c|c|c|c|c|c|}
\hline $\begin{array}{l}\text { Res } \\
\text { Number of terms } \\
\text { Alpha-to-Ente }\end{array}$ & $\begin{array}{l}\text { Stepwi } \\
\text { ponse: } \\
\text { onsider } \\
r=0\end{array}$ & $\begin{array}{l}\text { e model } \\
\text { ed }=7 \\
500\end{array}$ & $\begin{array}{l}\text { electio } \\
\text { Jnr } 10 \\
\text { Number } \\
\text { oha-to-1 }\end{array}$ & $\begin{array}{l}0-58 \\
\text { of case } \\
\text { emove }=\end{array}$ & $\begin{array}{l}\text { s used }= \\
0,0500\end{array}$ \\
\hline Term & Coef & SE Coef & $\mathrm{T}$ & $\mathrm{P}$ & VIF \\
\hline Asfalto & 2 & 0,048 & * & * & 6,22 \\
\hline SBS & -31 & 1,368 & * & $\star$ & 5,66 \\
\hline Titan & 1394 & 102,420 & * & $\star$ & 5072,26 \\
\hline Asfalto*Titan & -1501 & 107,188 & $-14,01$ & 0,000 & 5090,45 \\
\hline $\begin{array}{r}\mathrm{S}= \\
\mathrm{R}-\mathrm{Sq}=96,50 \%\end{array}$ & $\begin{array}{l}0,1113 \\
\mathrm{R}-\mathrm{Sq}(\mathrm{p}\end{array}$ & ed) $=9$ & $\begin{array}{l}S=0, \\
78 \%\end{array}$ & $\begin{array}{l}9305 \\
\text { Sq (adj) }\end{array}$ & $=96,17 \%$ \\
\hline
\end{tabular}

Residual Plots for Jnr 100-58
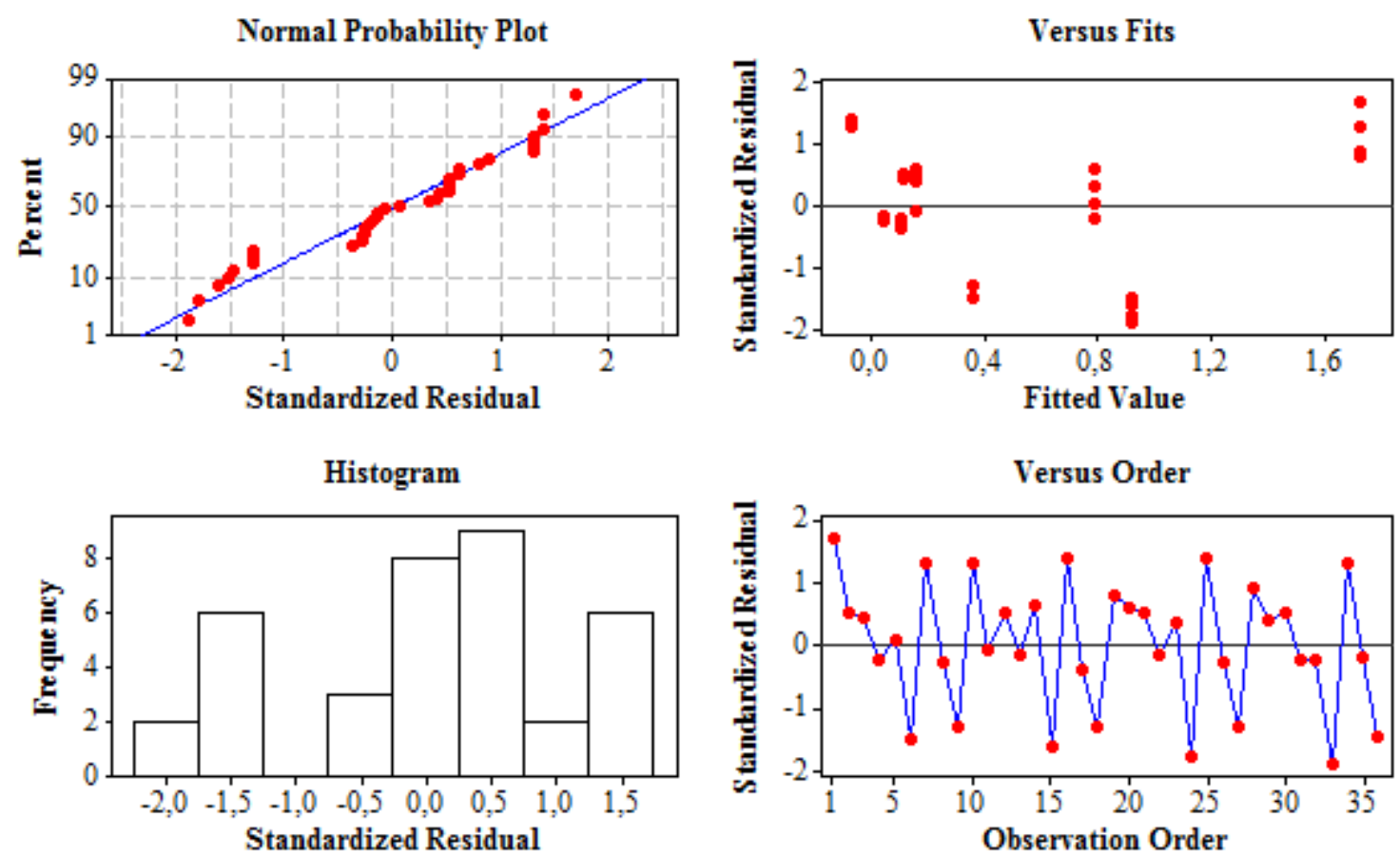

Figura A.35.1 - Análise de resíduos para $\mathrm{J}_{\mathrm{nr}}$ a 100 Pa a $58^{\circ} \mathrm{C}$ após RTFOT 


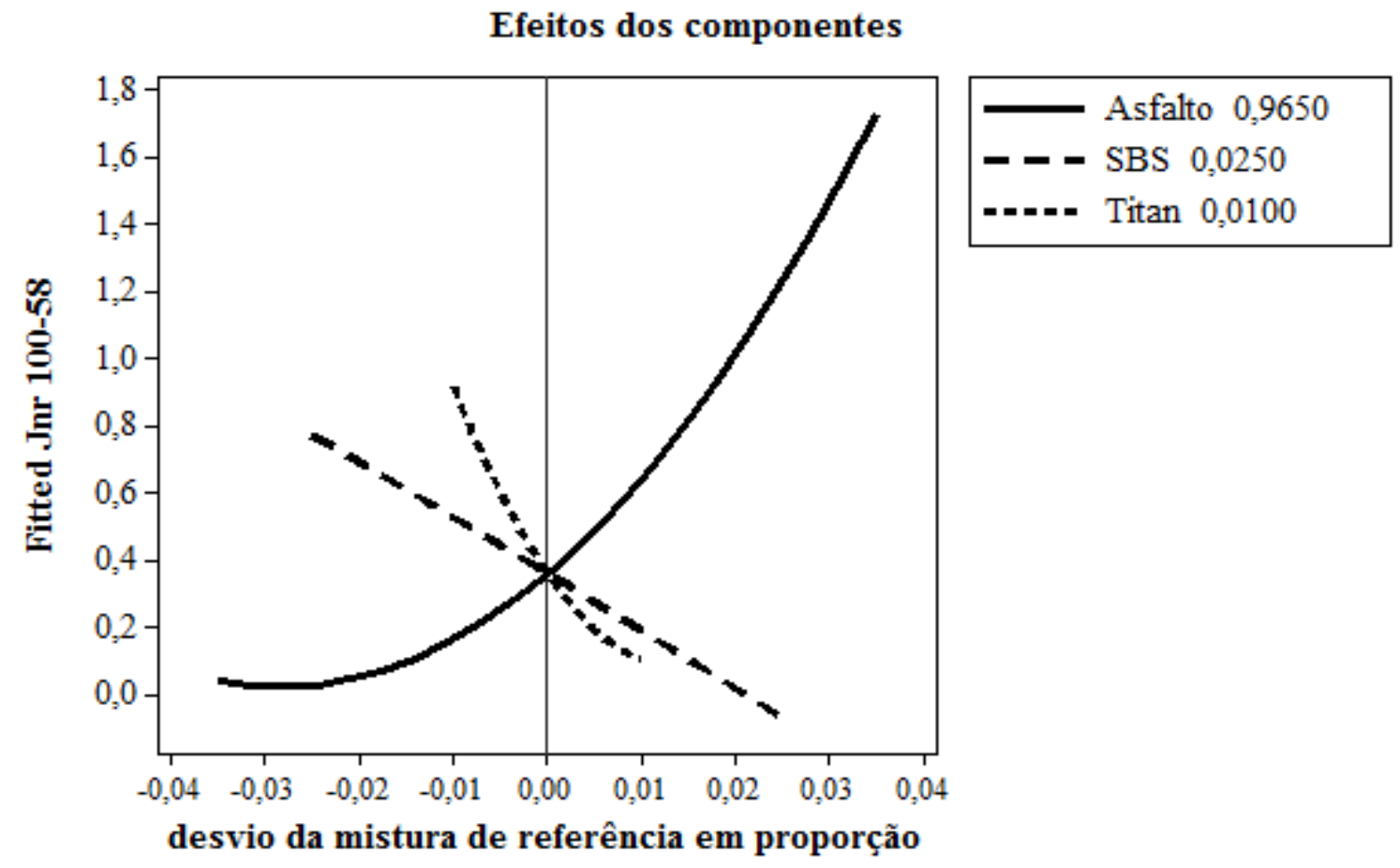

Figura A.35.2 - Efeitos dos componentes $\mathrm{J}_{\mathrm{nr}}$ a 100 Pa a $58^{\circ} \mathrm{C}$ após RTFOT

Superfície de resposta para $\mathrm{Jnr} 100$ a $58^{\circ} \mathrm{C}$

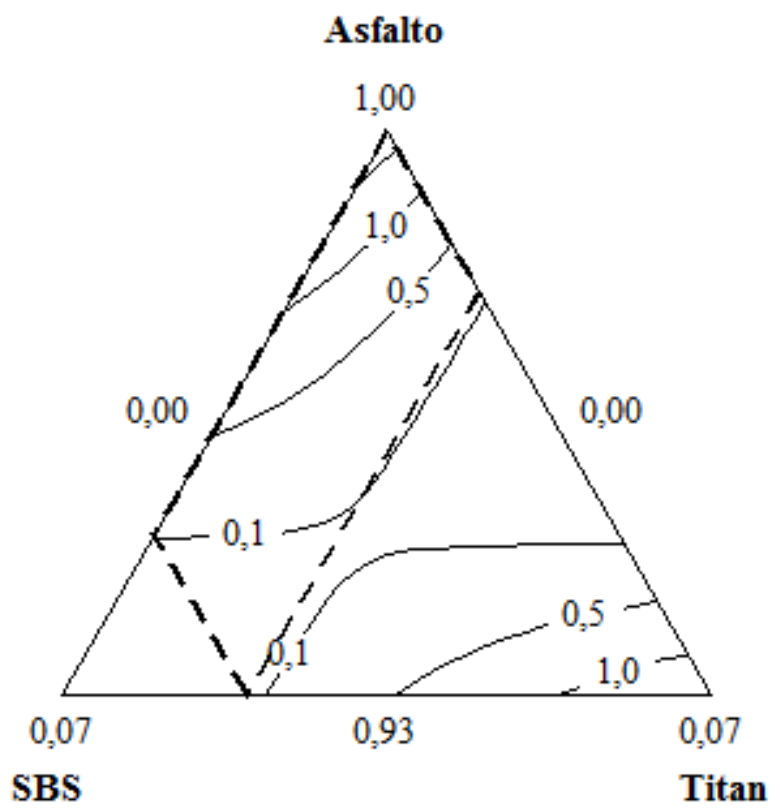

Figura A.35.3 - Superfície de resposta para $\mathrm{J}_{\mathrm{nr}}$ a 100 Pa a $58^{\circ} \mathrm{C}$ após RTFOT 


\section{Modelo A.36 Compliância não-recuperável $\left(J_{n r}\right)$ a 100 Pa após RTFOT a $64^{\circ} \mathrm{C}$}

Não houve retiradas de pontos para obtenção deste modelo. $\mathrm{O} \mathrm{R}^{2}$ encontrado foi bom, mas o valor apresentado pelo VIF foi alto, portanto o modelo apenas pode ser empregado para estimativa de novas ocorrências na região experimental.

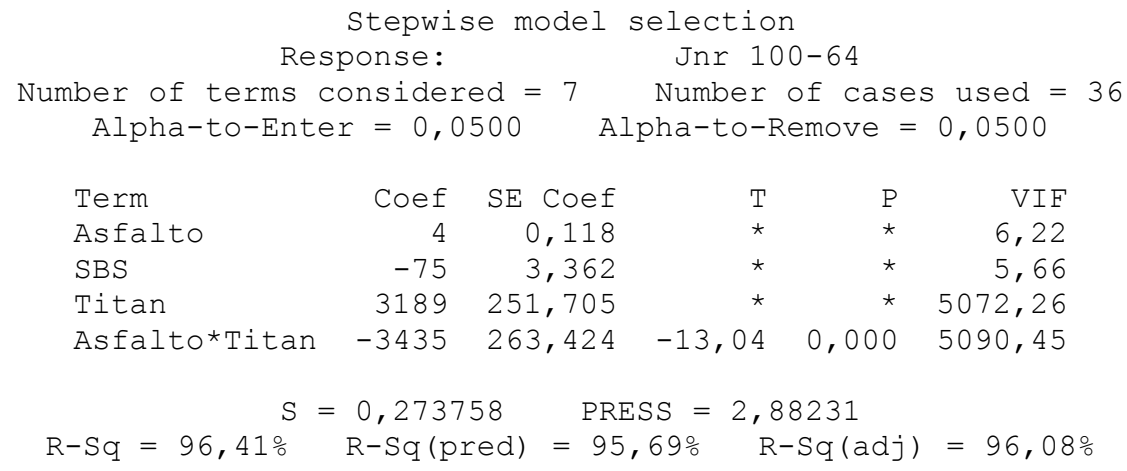

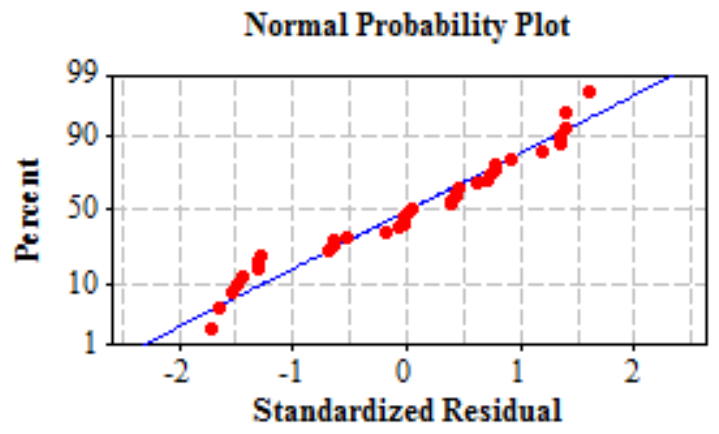

Histogram

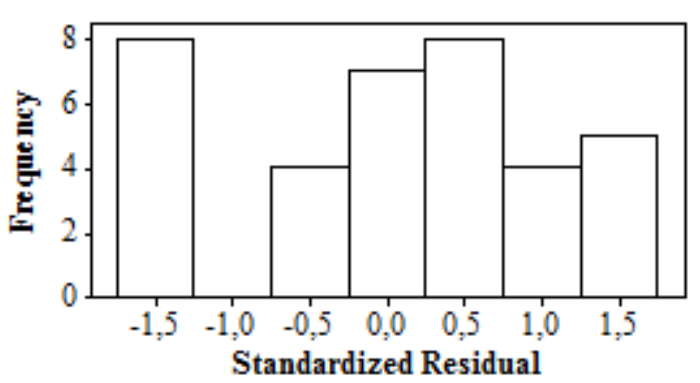

Versus Fits

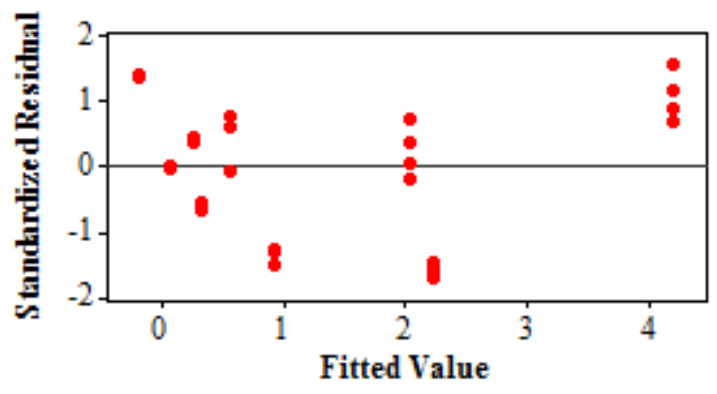

Versus Order

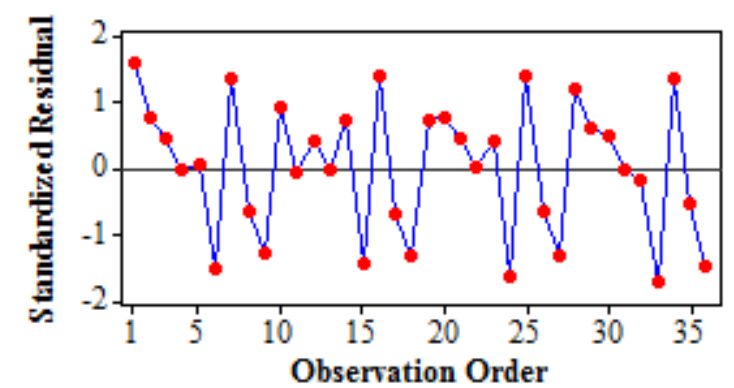

Figura A.36.1 - Análise de resíduos para $\mathrm{J}_{\mathrm{nr}}$ a 100 Pa a $64^{\circ} \mathrm{C}$ após RTFOT 


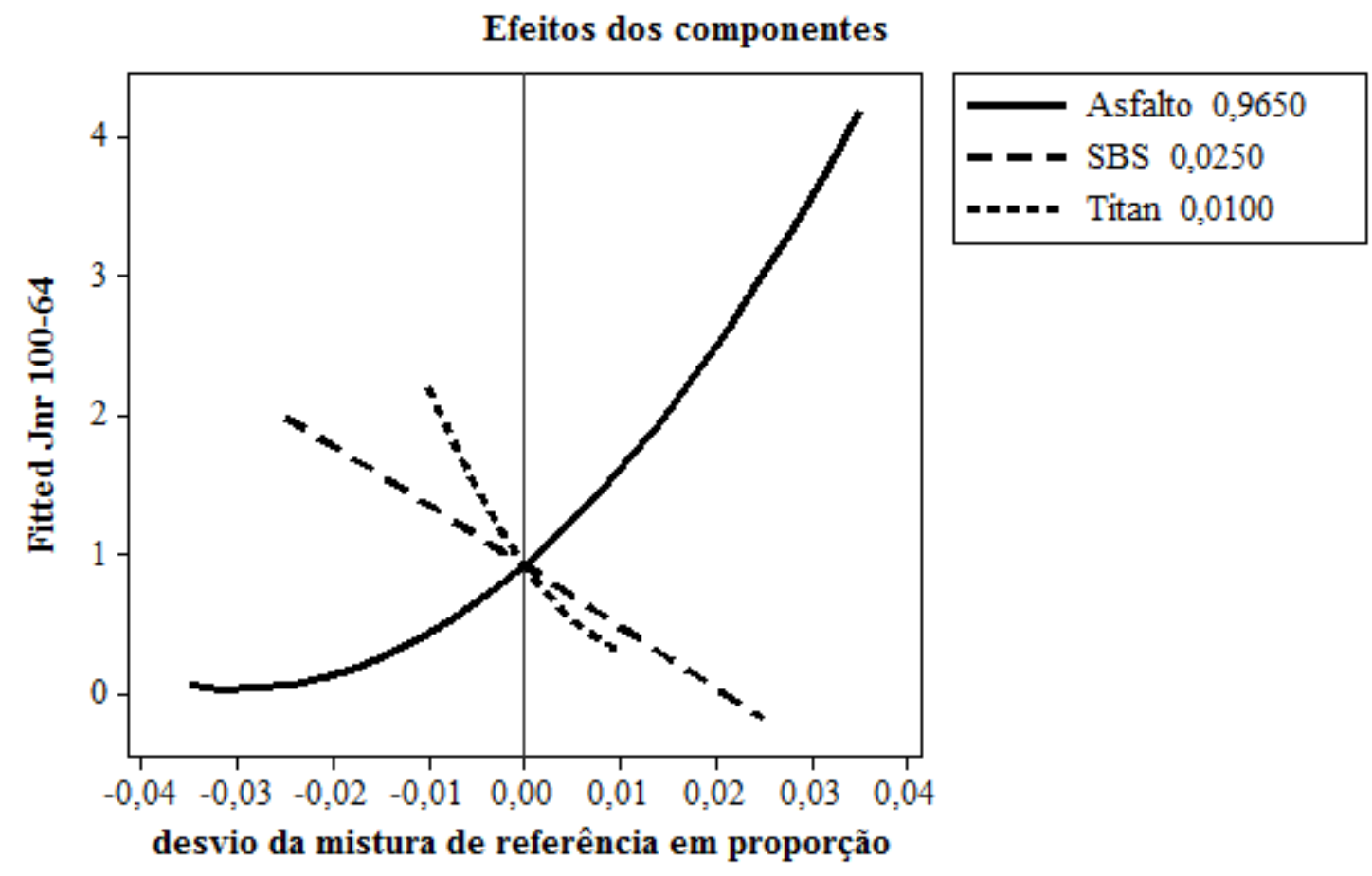

Figura A.36.2 - Efeitos dos componentes para $\mathrm{J}_{\mathrm{nr}}$ a 100 Pa a $64^{\circ} \mathrm{C}$ após RTFOT Superficie de resposta para $\mathrm{Jnr} 100$ a $64^{\circ} \mathrm{C}$

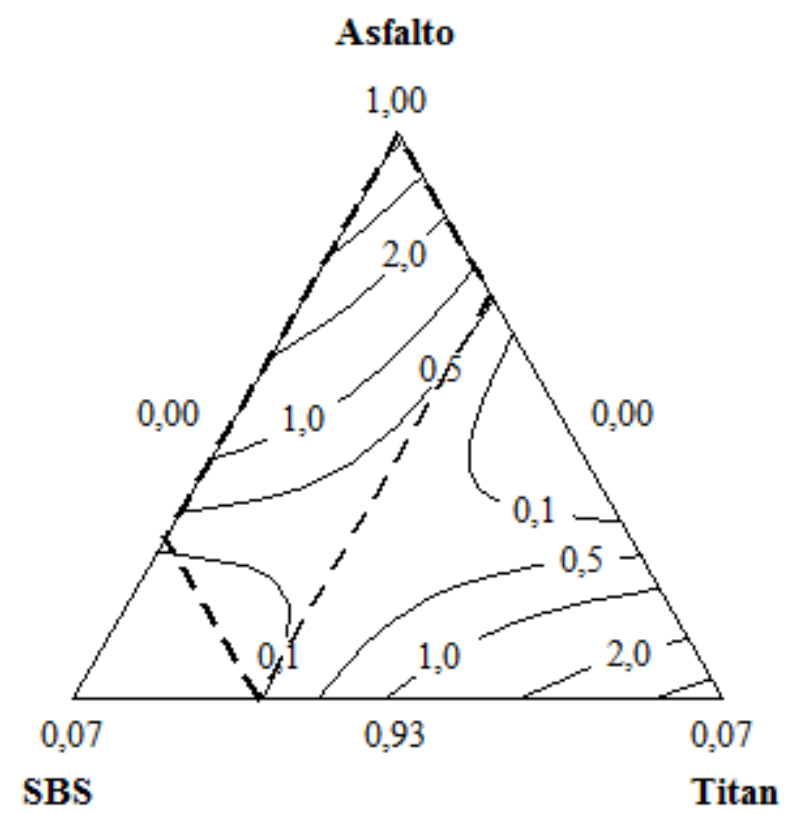

Figura A.36.3 - Superfície de resposta para $\mathrm{J}_{\mathrm{nr}}$ a 100 Pa a $64^{\circ} \mathrm{C}$ após RTFOT 


\section{Modelo A.37 Compliância não-recuperável $\left(J_{n r}\right)$ a 100 Pa após RTFOT a $7^{\circ} \mathrm{C}$}

Os pontos 1, 10, 19 e 28 não foram considerados, pois o ensaio MSCR da mistura 1000-0 não foi realizado a $70^{\circ} \mathrm{C}$ dado que os resultados para $64^{\circ} \mathrm{C}$ já se mostraram bastante superiores aos valores de referência da norma ASTM. O valor do VIF ficou acima dos limites indicados, portanto o modelo apenas pode ser empregado para estimativa de novas ocorrências na região experimental.

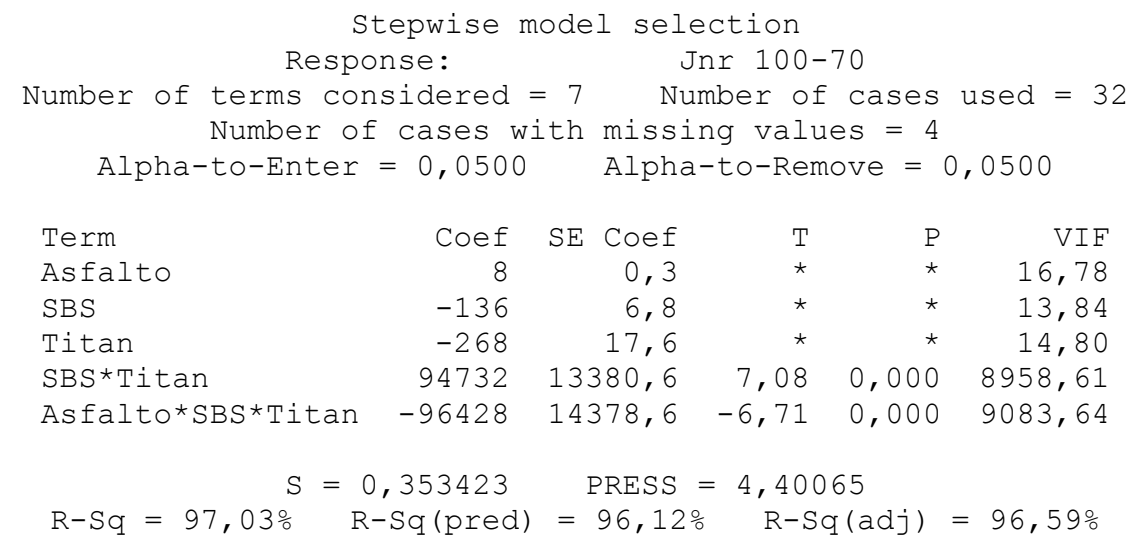

Residual Plots for Jnr 100-70
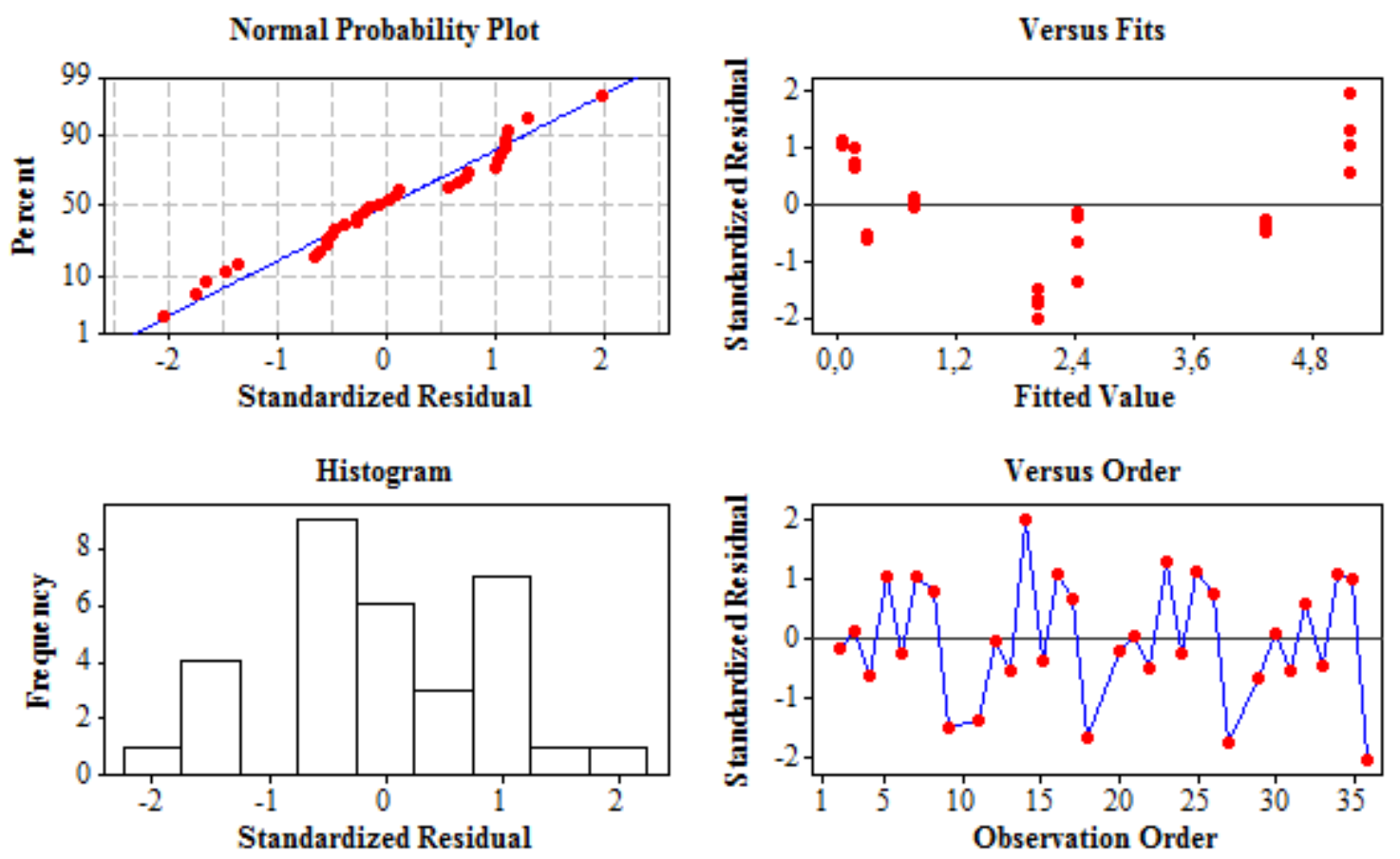

Figura A.37.1 - Análise de resíduos para $\mathrm{J}_{\mathrm{nr}}$ a $100 \mathrm{~Pa}$ a $7^{\circ} \mathrm{C}$ após RTFOT 


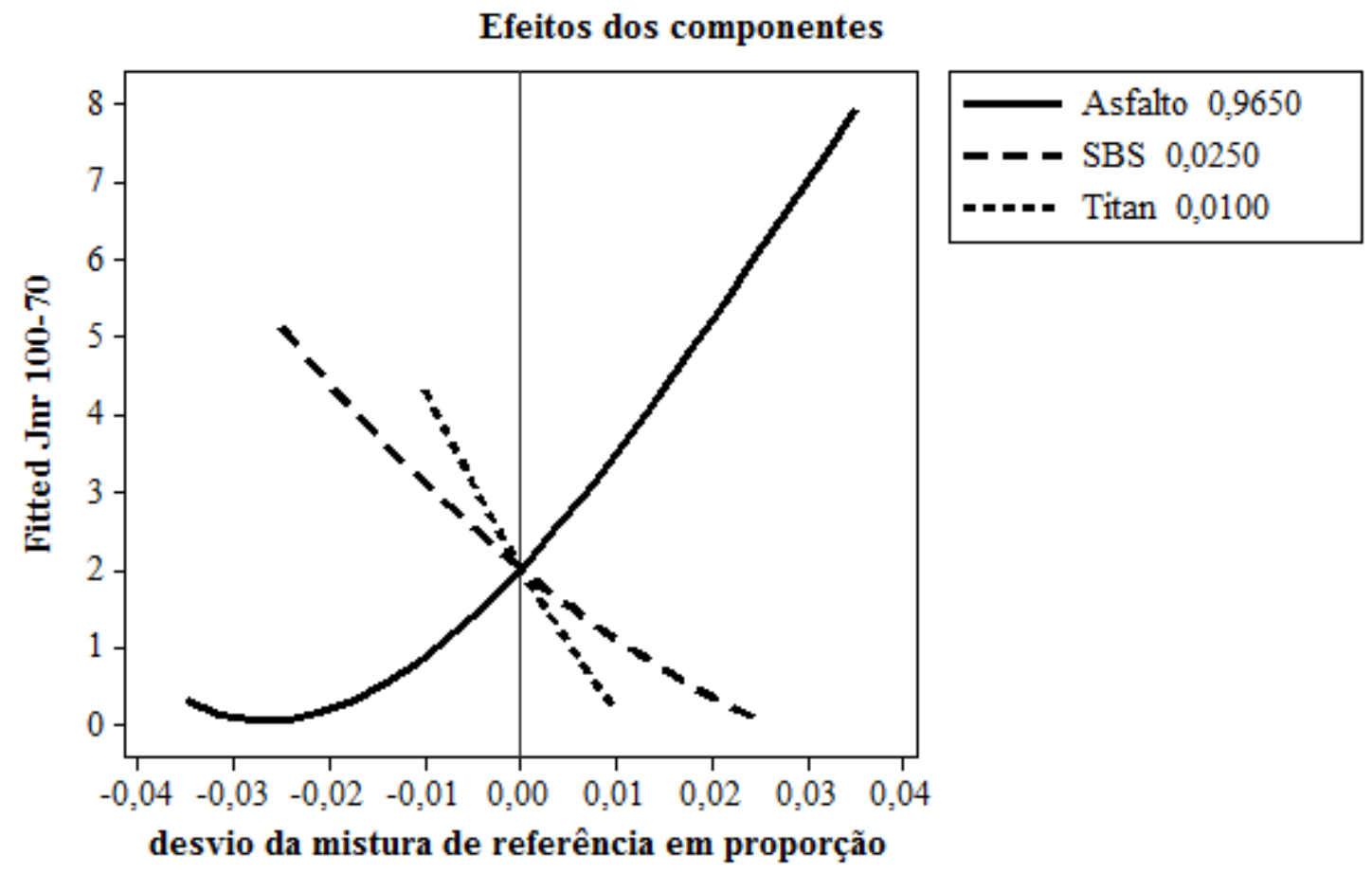

Figura A.37.2 - Efeitos dos componentes para $\mathrm{J}_{\mathrm{nr}}$ a 100 Pa a $70^{\circ} \mathrm{C}$ após RTFOT Superfície de resposta para $\mathrm{Jnr} 100$ a $70^{\circ} \mathrm{C}$

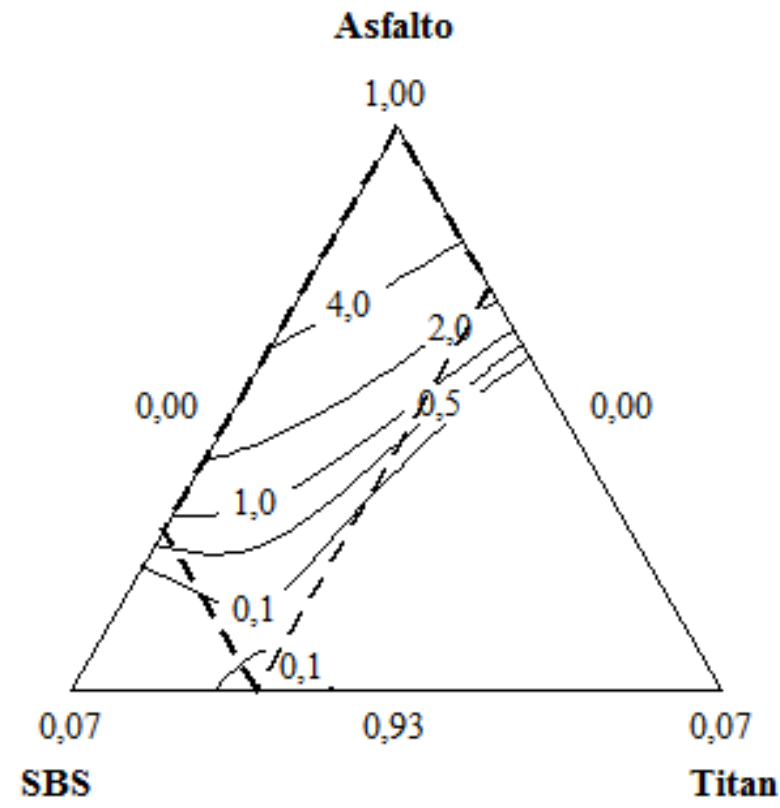

Figura A.37.3 - Superfície de resposta para $\mathrm{J}_{\mathrm{nr}}$ a 100 Pa a $7^{\circ} \mathrm{C}$ após RTFOT 


\section{Modelo A.38 Percentual de recuperação $(R)$ a $100 P a$ a $52^{\circ} \mathrm{C}$ após RTFOT}

O ponto 11 foi retirado para obtenção deste modelo. As exclusão deste ponto é justificada pela seguinte constatação: este valor destoa dos demais, sendo observação muito acima de 2 desvio padrões nos gráficos de resíduos, sendo este ponto considerado "outlier". O modelo melhorou sem este ponto, sendo verificado um aumento do $\mathrm{R}^{2}$. Mesmo com a retirada, o valor apresentado pelo VIF ainda foi alto, portanto o modelo apenas pode ser empregado para estimativa de novas ocorrências na região experimental.

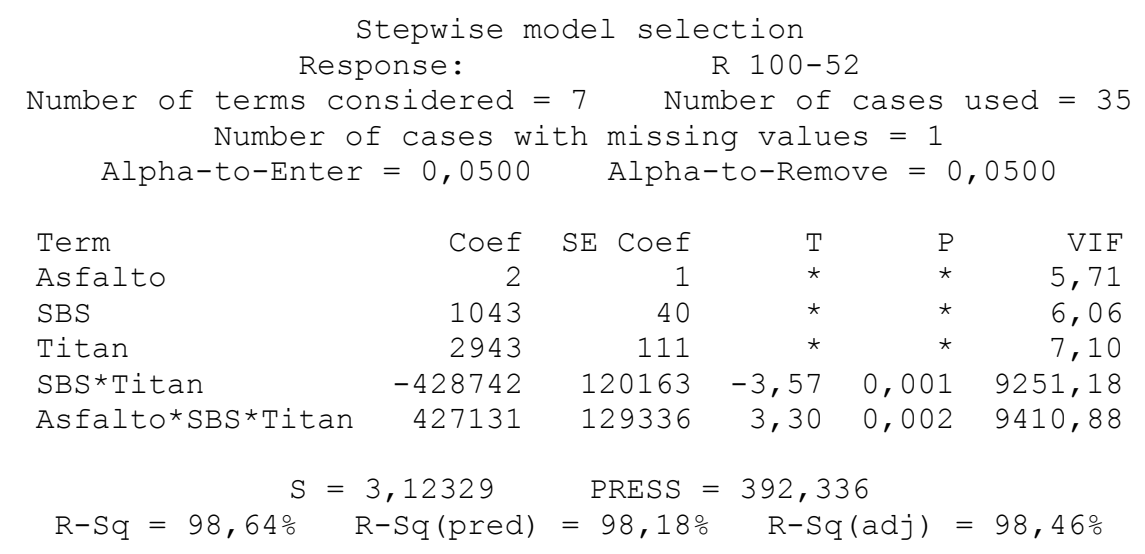

\section{Residual Plots for R 100-52}
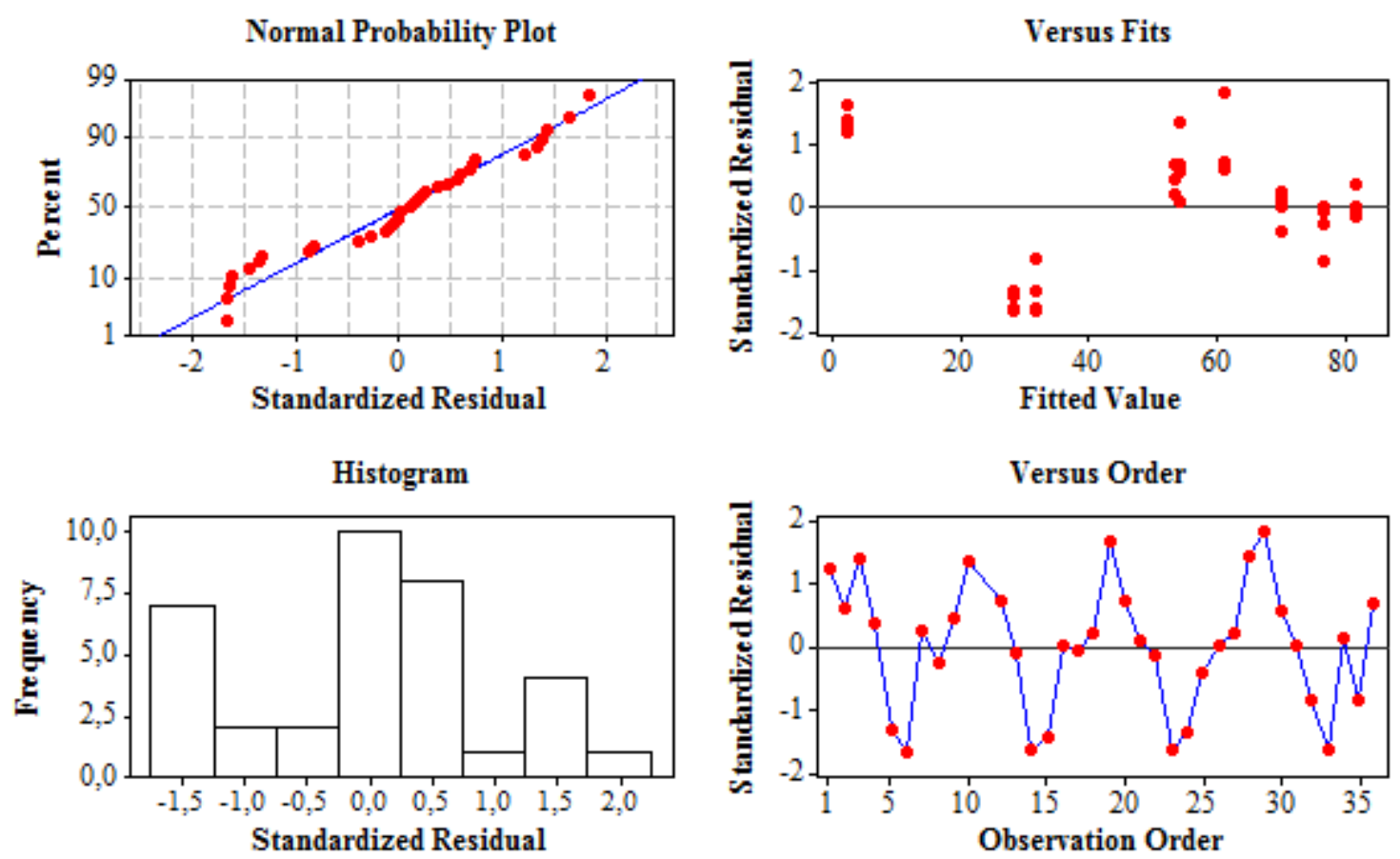

Figura A.38.1 - Análise de resíduos para $\mathrm{R}$ a 100 Pa após RTFOT a $52^{\circ} \mathrm{C}$ 
Efeitos dos componentes

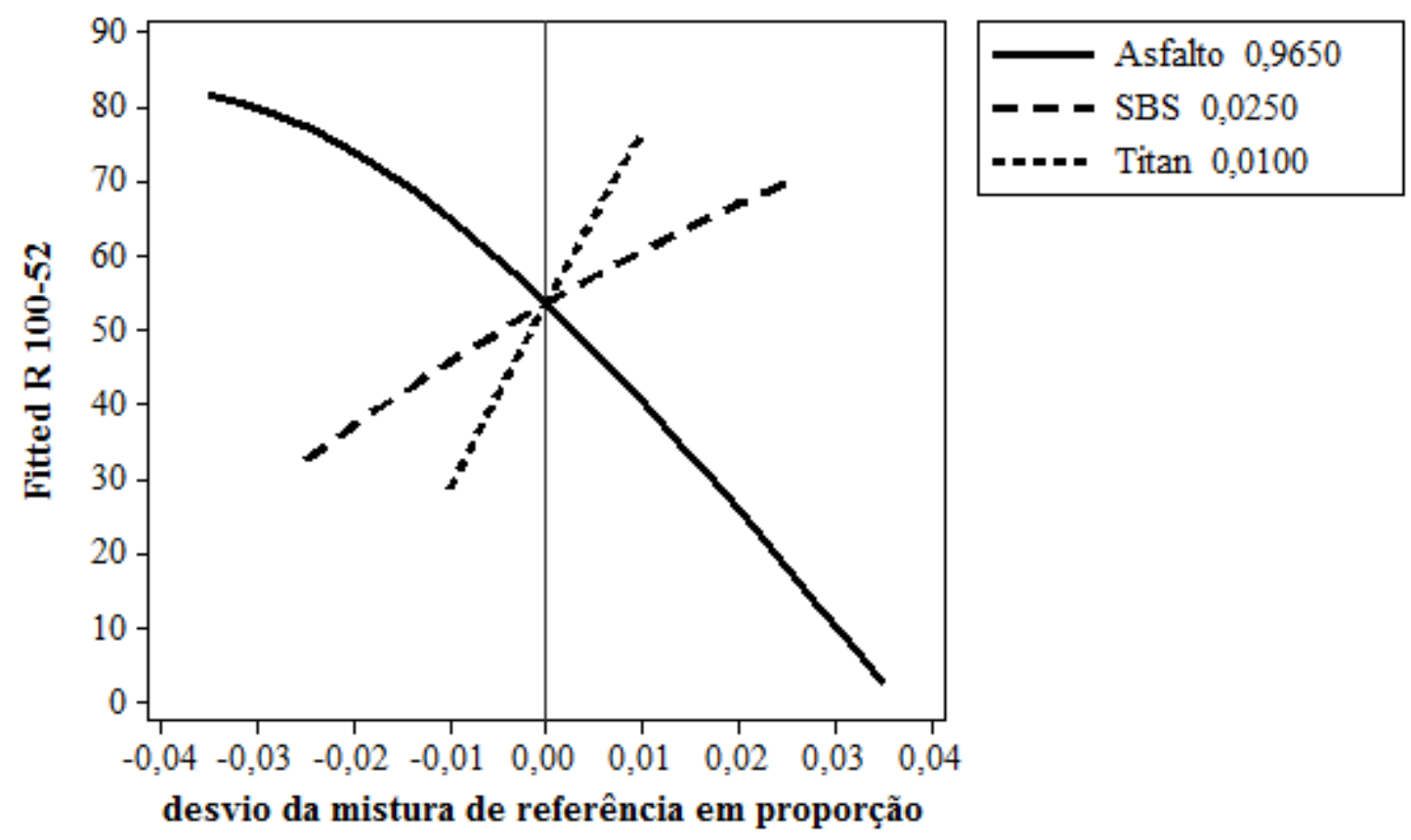

Figura A.38.2 - Efeitos dos componentes para $R$ a 100 Pa após RTFOT a $52^{\circ} \mathrm{C}$

Superfície de resposta para $\mathrm{R} 100$ a $52^{\circ} \mathrm{C}$

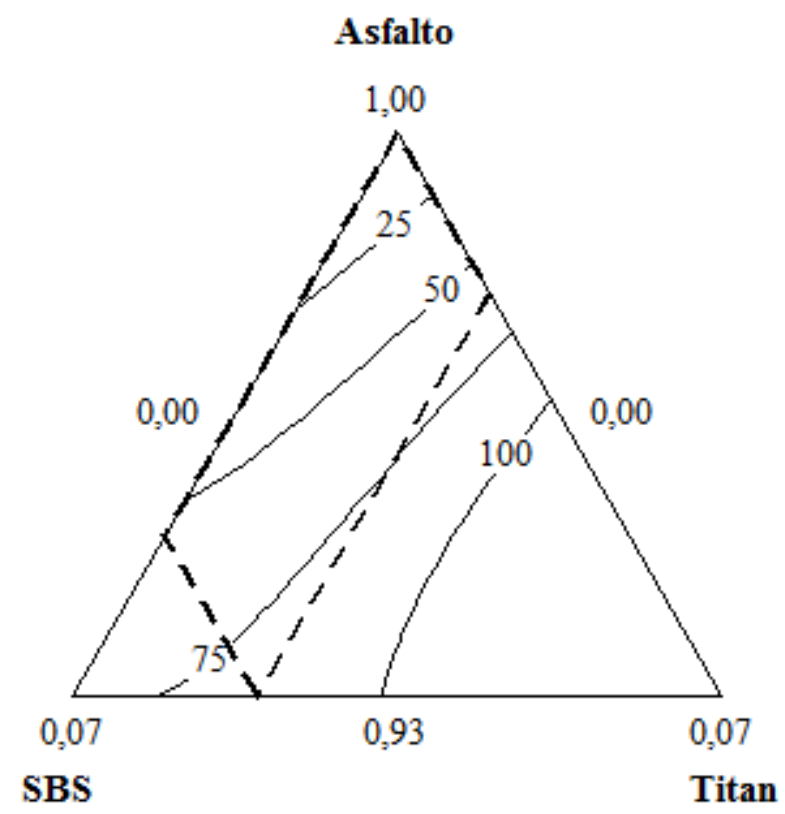

Figura A.38.3 - Superfície de resposta para $\mathrm{R}$ a 100 Pa após $\mathrm{RTFOT}$ a $52^{\circ} \mathrm{C}$ 


\section{Modelo A.39 Percentual de recuperação $(R)$ a $100 P a$ a $58^{\circ} \mathrm{C}$ após RTFOT}

Não houve retiradas de pontos para obtenção deste modelo. O R ${ }^{2}$ encontrado foi bom, mas o valor apresentado pelo VIF foi alto, portanto o modelo apenas pode ser empregado para estimativa de novas ocorrências na região experimental.

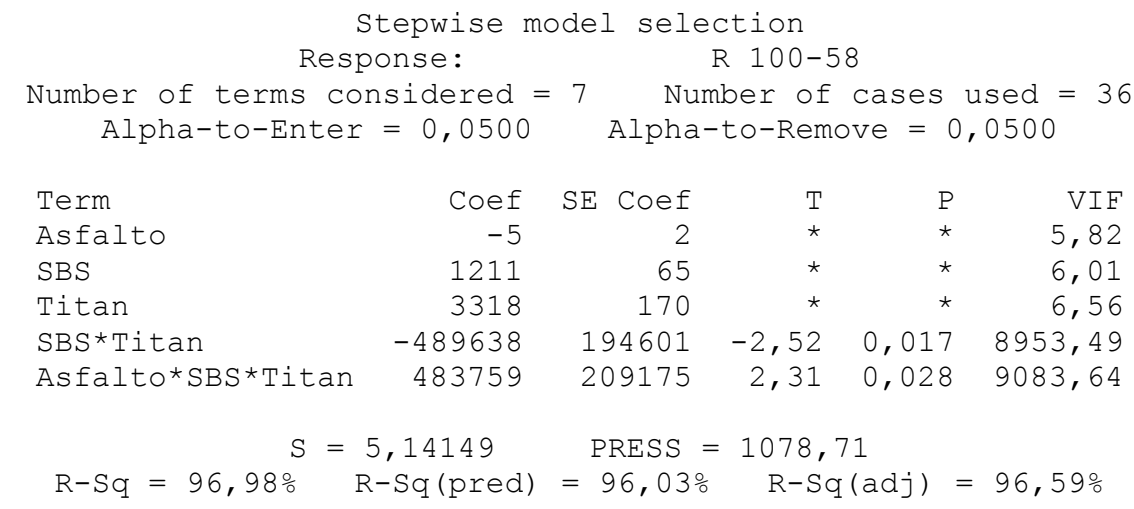

Residual Plots for R 100-58
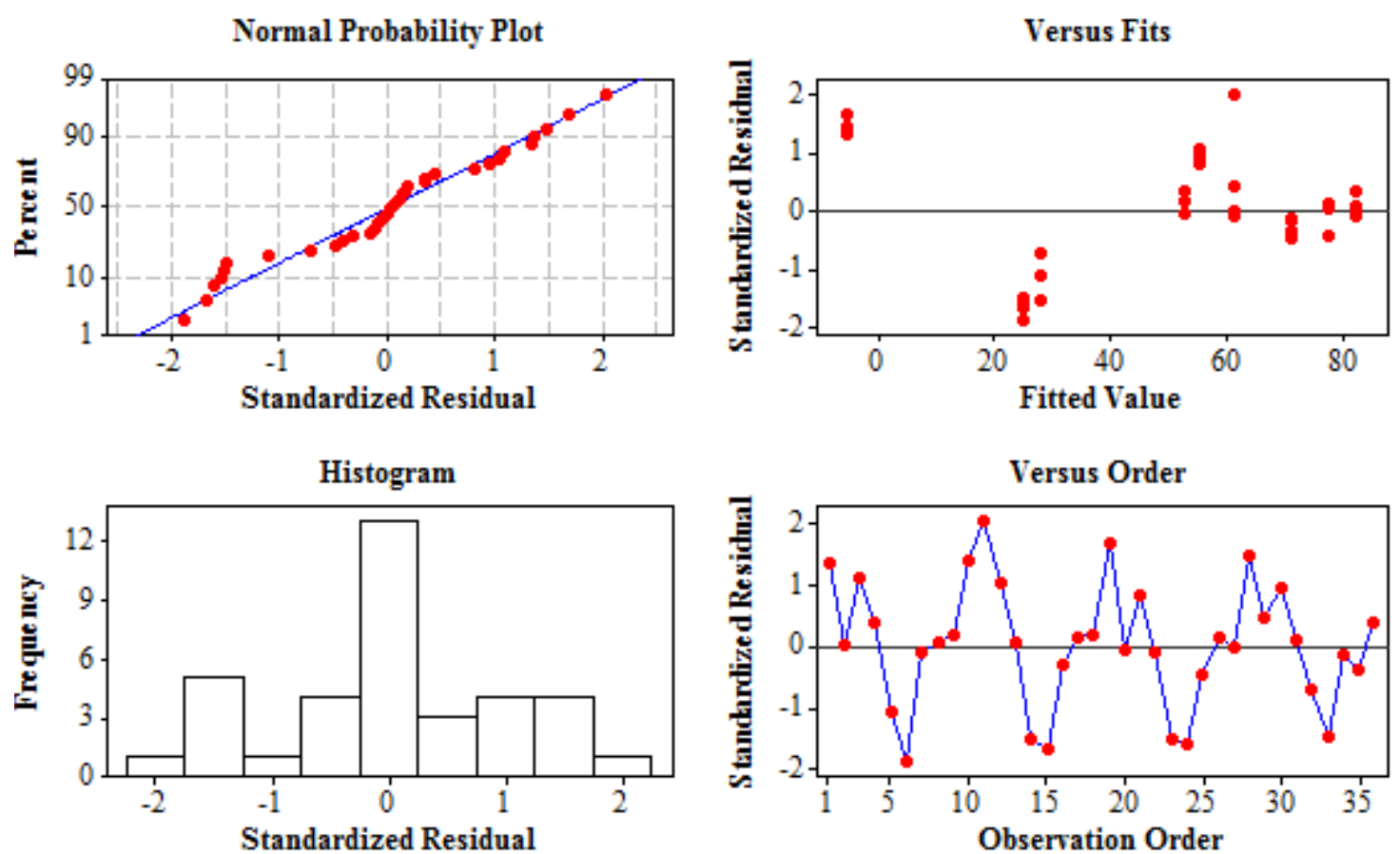

Figura A.39.1 - Análise de resíduos para $\mathrm{R}$ a 100 Pa a $58^{\circ} \mathrm{C}$ após RTFOT 


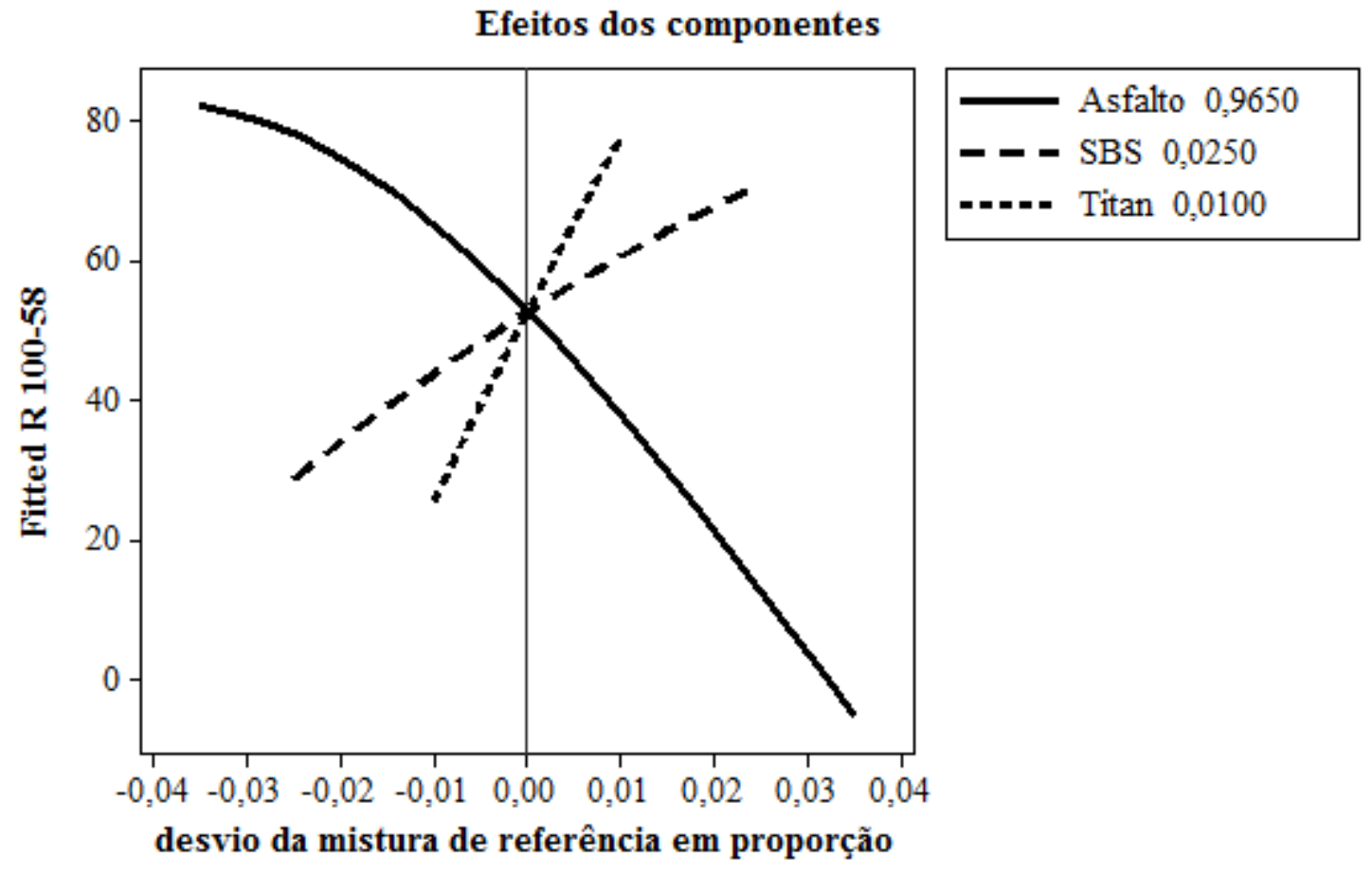

Figura A.39.2 - Efeitos dos componentes para $\mathrm{R}$ a 100 Pa a $58^{\circ} \mathrm{C}$ após RTFOT

Superficie de resposta $\mathrm{R} 100$ a $58^{\circ} \mathrm{C}$

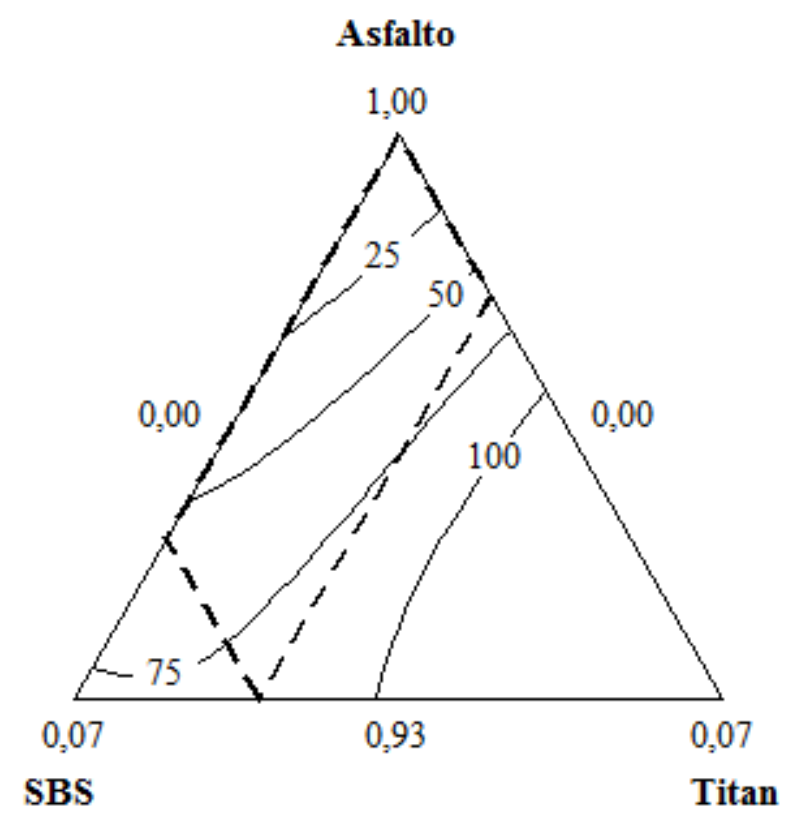

Figura A.39.3 - Superfície de resposta para $\mathrm{R}$ a $100 \mathrm{~Pa}$ a $58^{\circ} \mathrm{C}$ após RTFOT 


\section{Modelo A.40 Percentual de recuperação $(R)$ a $100 P a$ a $64^{\circ} \mathrm{C}$ após RTFOT}

Não houve retiradas de pontos para obtenção deste modelo. $\mathrm{O} \mathrm{R}^{2}$ encontrado foi bom, mas o valor apresentado pelo VIF foi alto, portanto o modelo apenas pode ser empregado para estimativa de novas ocorrências na região experimental.

\begin{tabular}{|c|c|c|c|c|c|}
\hline $\begin{array}{l}\text { Resp } \\
\text { umber of terms co } \\
\text { Alpha-to-Enter }\end{array}$ & $\begin{array}{l}\text { tepwise } \mathrm{m} \\
\text { onse: } \\
\text { sidered } \\
=0,0500\end{array}$ & $\begin{array}{lr}7 & \mathrm{Nu} \\
& \text { Alpha }\end{array}$ & $\begin{array}{l}\text { Ction } \\
\text { R } 100- \\
\text { Lber of } \\
\text { to-Rem }\end{array}$ & $\begin{array}{l}\text { cases } \\
\text { ve }=0\end{array}$ & $\begin{array}{l}\text { used }= \\
0500\end{array}$ \\
\hline Term & Coef & SE Coef & $\mathrm{T}$ & $P$ & VIF \\
\hline Asf & -9 & 3 & * & 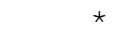 & 5,82 \\
\hline SBS & 1191 & 83 & * & * & \\
\hline it & 29 & 217 & * & * & \\
\hline $\mathrm{SB}$ & -6450 & 247890 & $-2,60$ & 14 & 95 \\
\hline Asfalto*SBS*Titan & 662179 & 266456 & 2,49 & 0,019 & 9083 \\
\hline $\begin{array}{r}\mathrm{S}= \\
\mathrm{R}-\mathrm{Sq}=95,31 \%\end{array}$ & $q($ pred) & $\begin{aligned} & \text { PRESS } \\
= & 93,79\end{aligned}$ & $2-S$ & $(\operatorname{adj})$ & $94,71 \%$ \\
\hline
\end{tabular}

Residual Plots for R 100-64
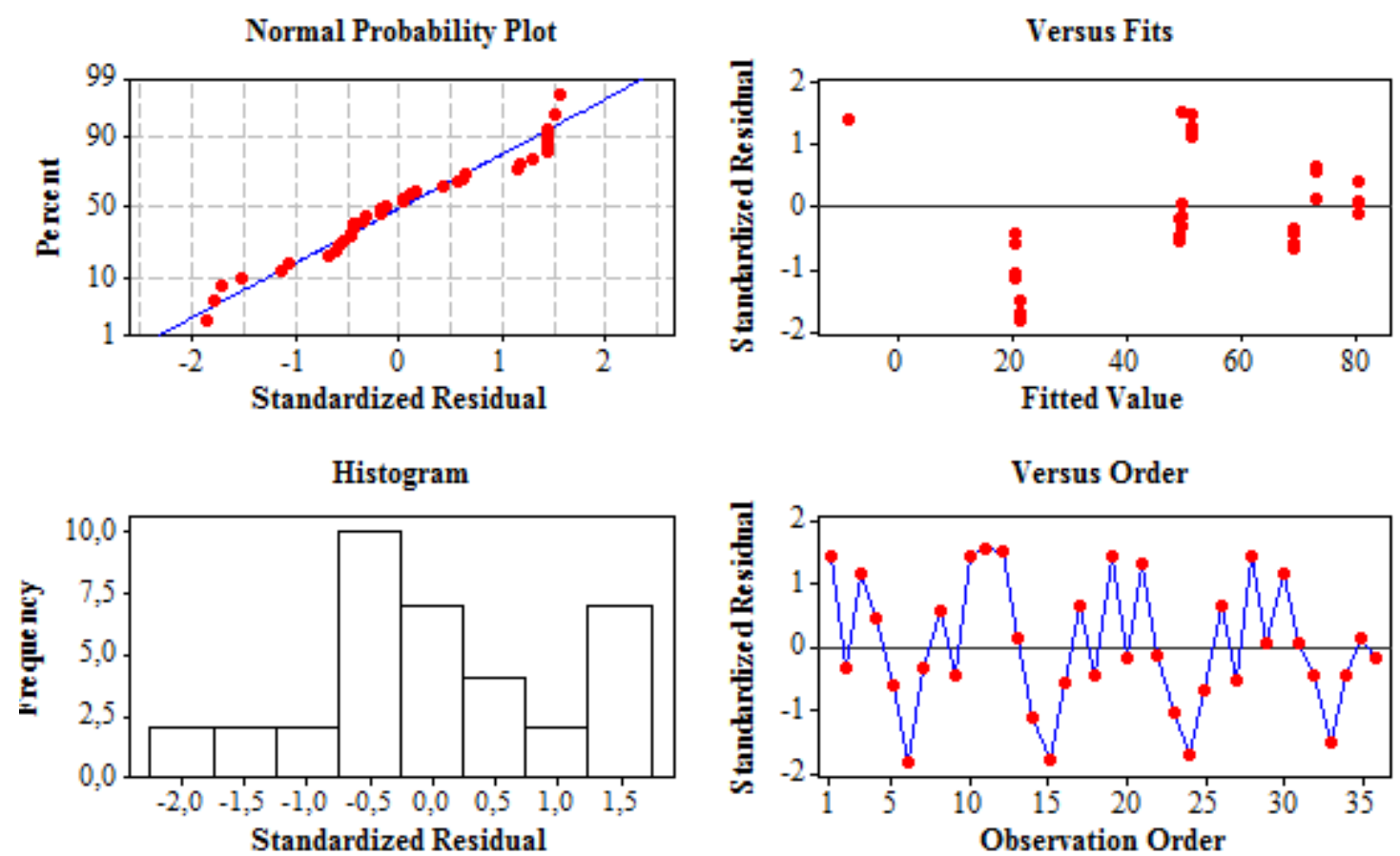

Figura A.40.1 - Análise de resíduos para $\mathrm{R}$ a 100 Pa a $64^{\circ} \mathrm{C}$ após RTFOT 


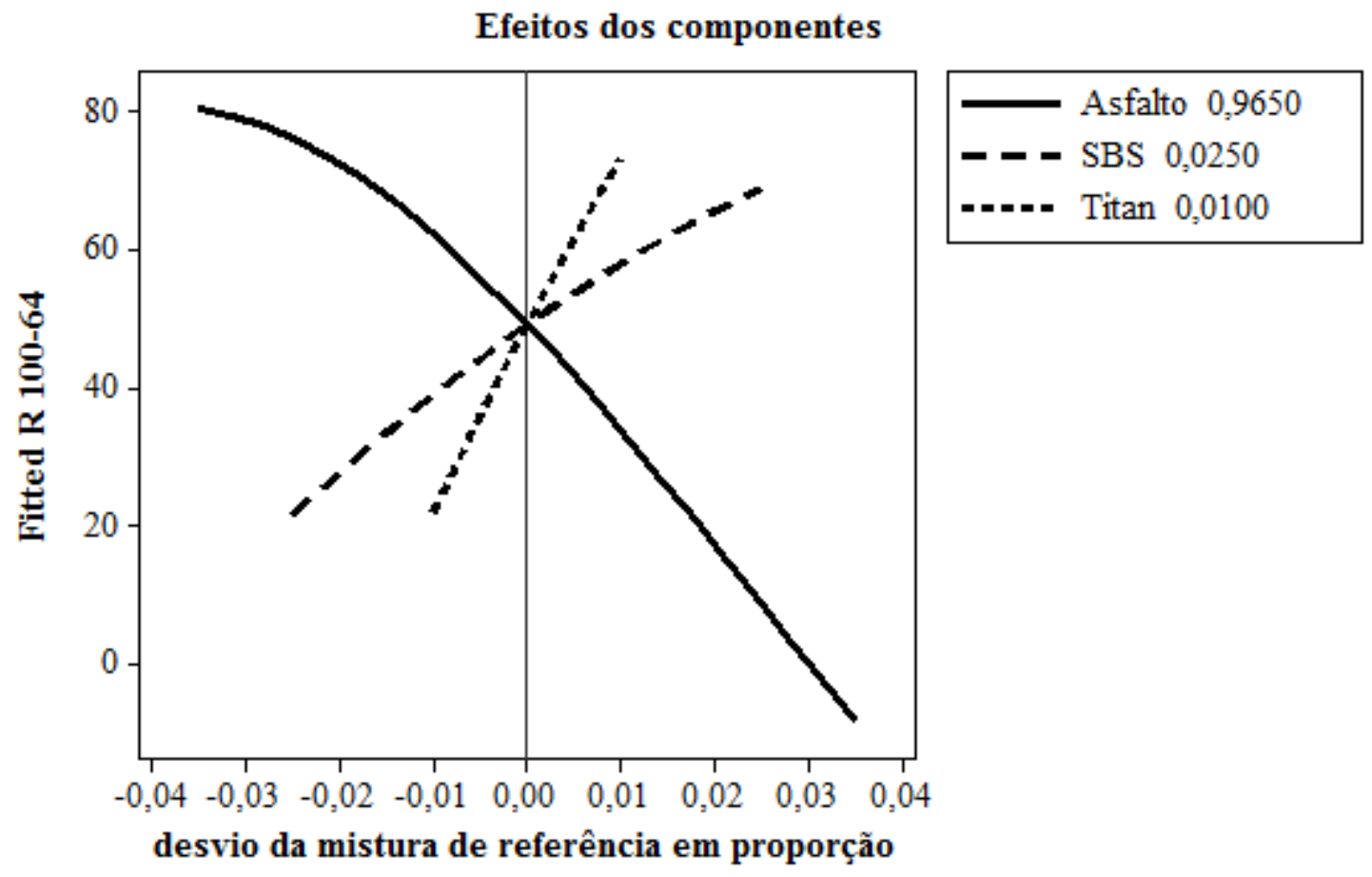

Figura A.40.2 - Efeitos dos componentes para $R$ a 100 Pa a $64^{\circ} \mathrm{C}$ após RTFOT

Superfície de resposta para $\mathrm{R} 100$ a $64^{\circ} \mathrm{C}$

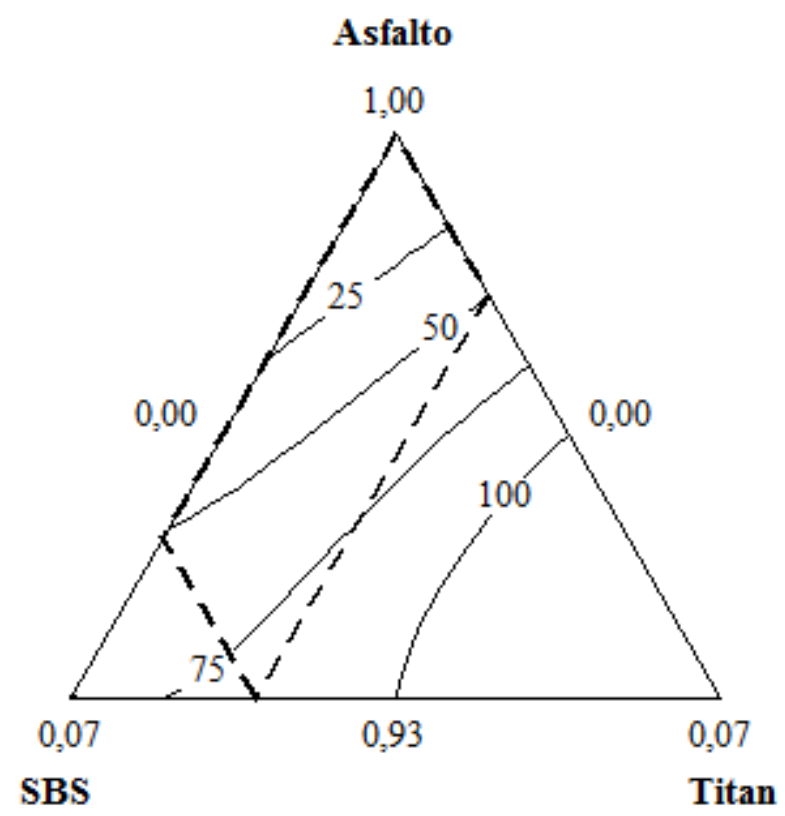

Figura A.40.3 - Superfície de resposta para $\mathrm{R}$ a 100 Pa a $64^{\circ} \mathrm{C}$ após RTFOT 


\section{Modelo A.41 Percentual de recuperação $(\mathrm{R})$ a $100 \mathrm{~Pa}$ a $70^{\circ} \mathrm{C}$ após RTFOT}

O ponto 11 foi retirado para obtenção deste modelo. As exclusão deste ponto é justificada pela seguinte constatação: este valor destoa dos demais, sendo observação muito acima de 2 desvio padrões nos gráficos de resíduos, sendo este ponto considerado "outlier". O modelo melhorou sem este ponto, sendo verificado um aumento do $\mathrm{R}^{2}$. Mesmo com a retirada, o valor apresentado pelo VIF ainda foi alto, portanto o modelo apenas pode ser empregado para estimativa de novas ocorrências na região experimental.

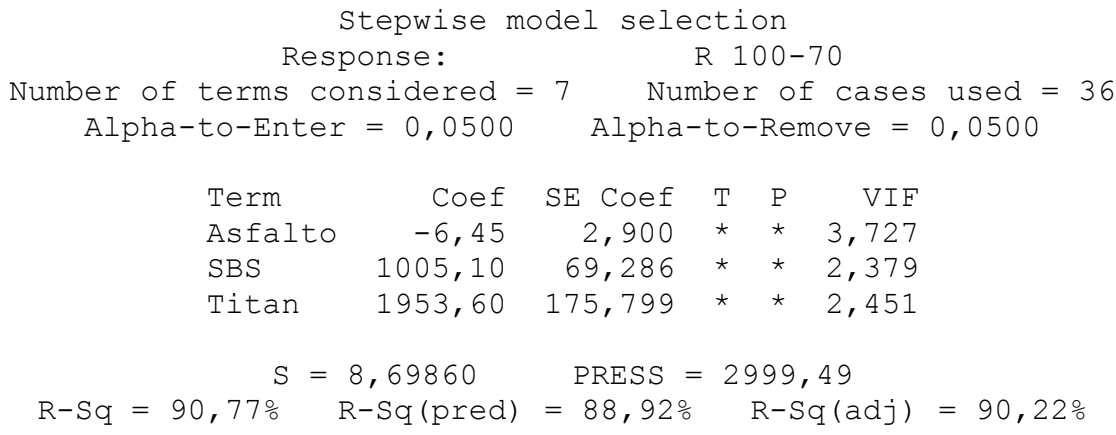

Residual Plots for R 100-70

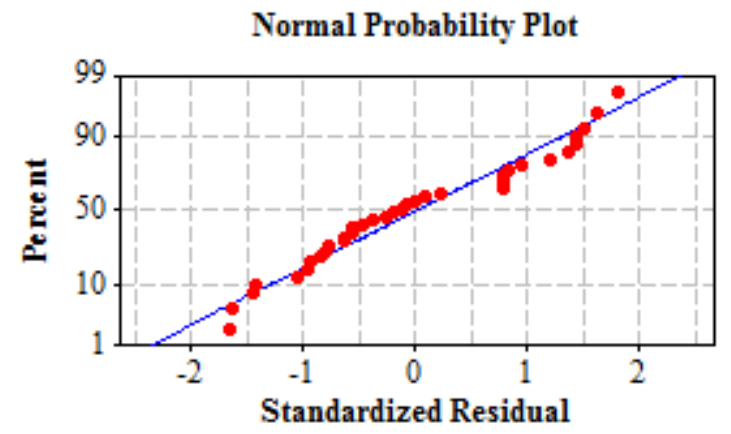

Histogram

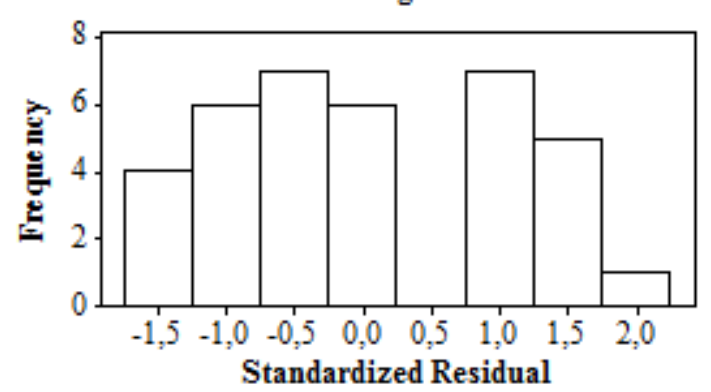

Versus Fits

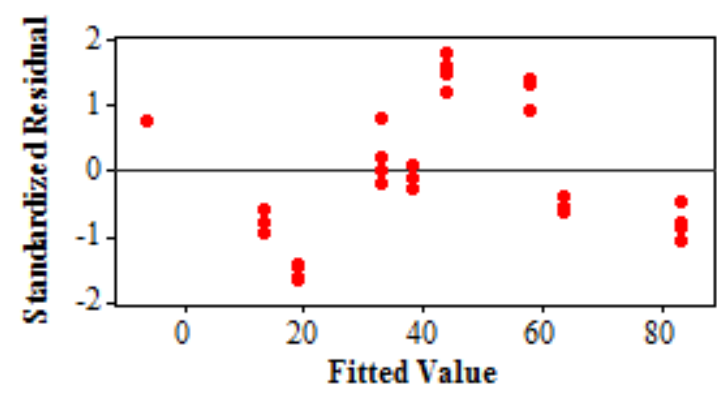

Versus Order

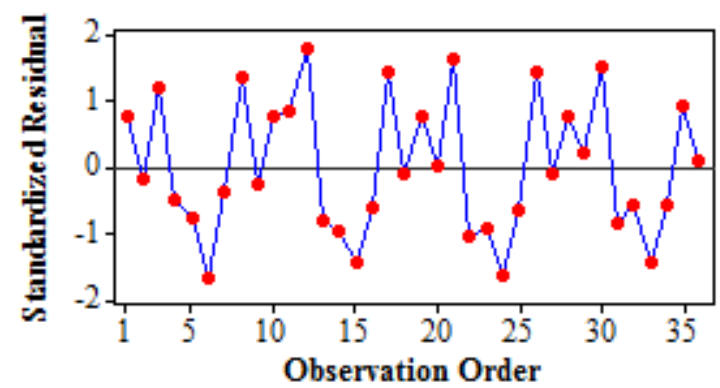

Figura A.41.1 - Análise de resíduos para $\mathrm{R}$ a $100 \mathrm{~Pa}$ a $7^{\circ} \mathrm{C}$ após RTFOT 


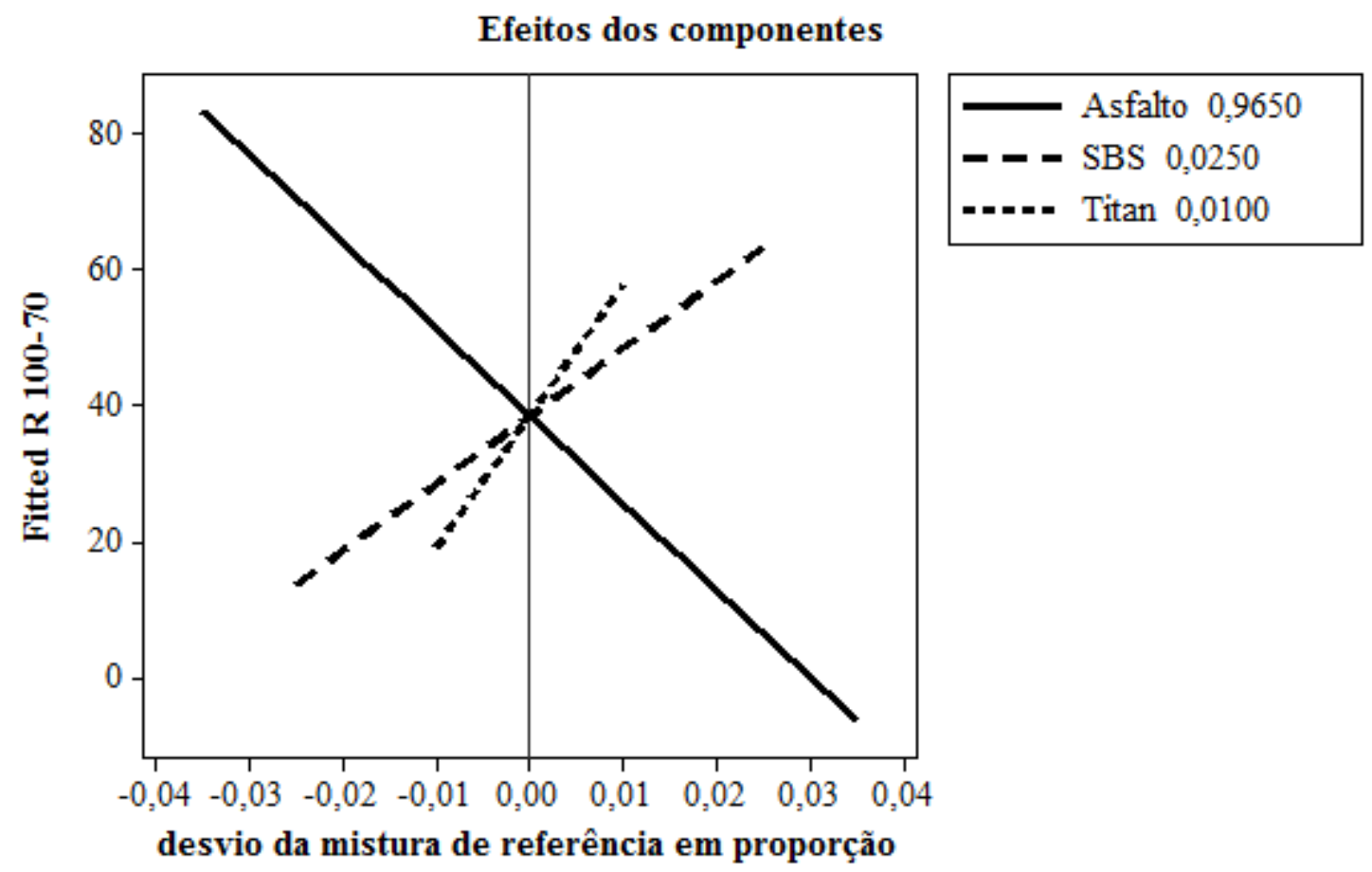

Figura A.41.2 - Efeitos dos componentes para $\mathrm{R}$ a $100 \mathrm{~Pa}$ a $70^{\circ} \mathrm{C}$ após RTFOT

Superficie de resposta para $\mathrm{R} 100$ a $70^{\circ} \mathrm{C}$

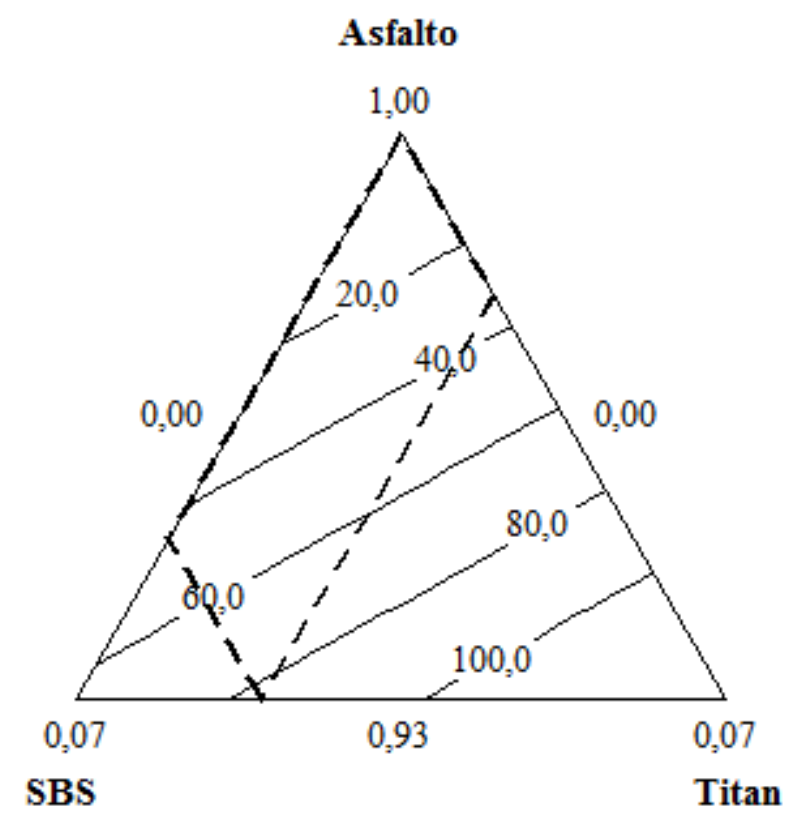

Figura A.41.3 - Superfície de resposta para $\mathrm{R}$ a $100 \mathrm{~Pa}$ a $7^{\circ} \mathrm{C}$ após RTFOT 
Modelo A.42 Temperatura crítica de fadiga após PAV para tráfego $S(G * \cdot \operatorname{sen}(\delta)=$ $5 \mathrm{MPa})$

Não houve retirada de pontos para obtenção deste modelo. $\mathrm{O} \mathrm{R}^{2}$ obtido é relativamente alto e os valores dos VIFs são baixos, permitindo o uso dos coeficientes dos termos do modelo para analisar o peso da contribuição de cada componente sobre a resposta.

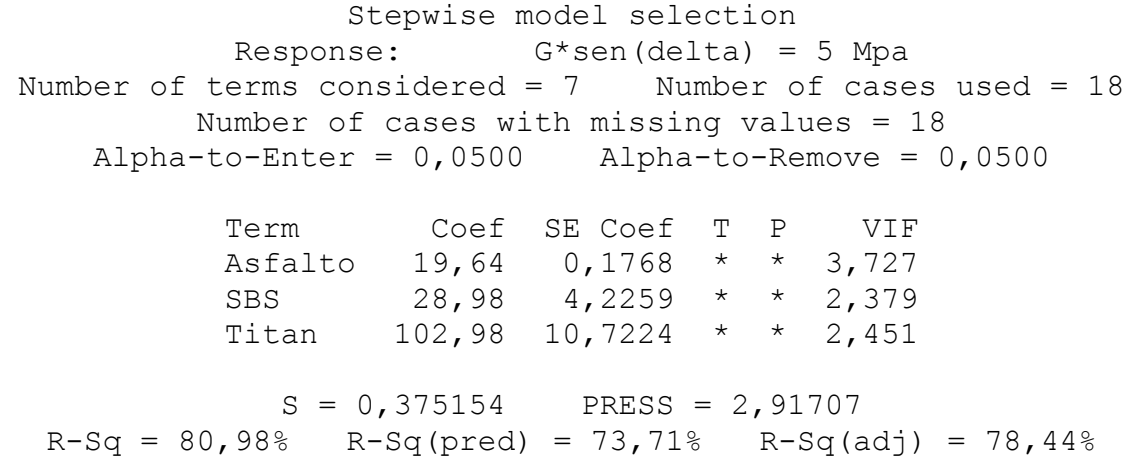

Residual Plots for $\mathrm{G}^{*}$ sen(delta) = 5 Mpa

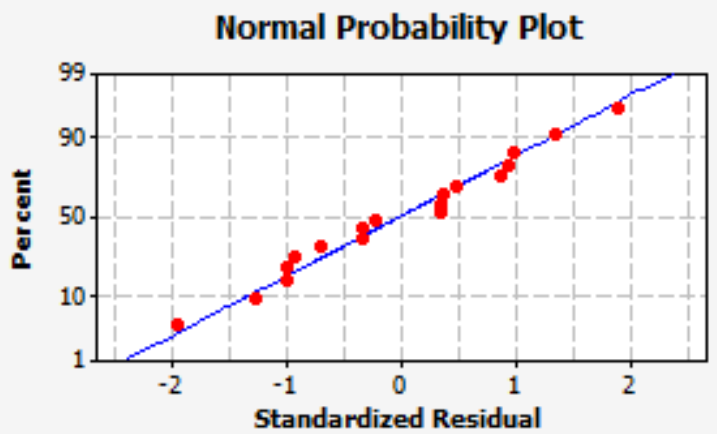

Histogram

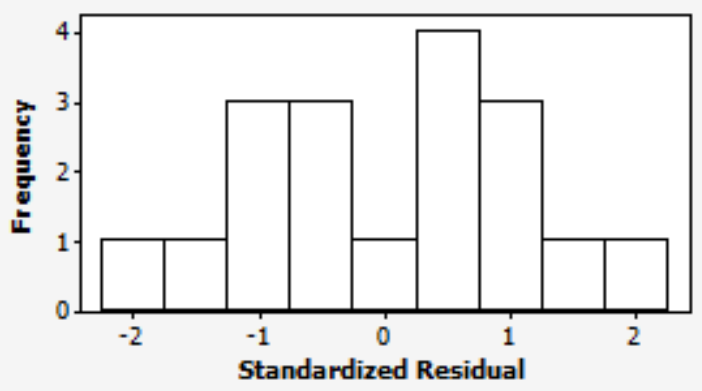

Versus Fits

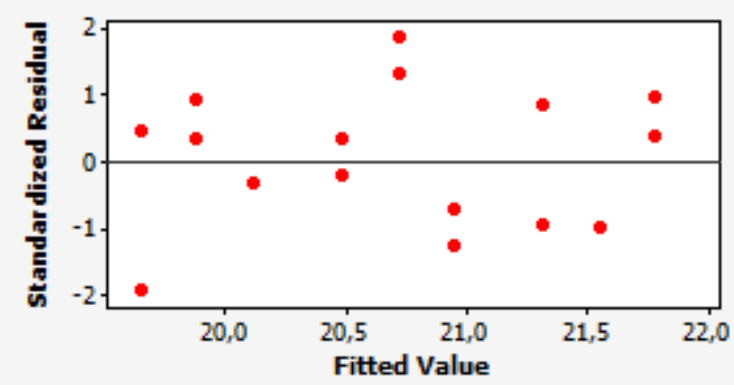

Versus Order

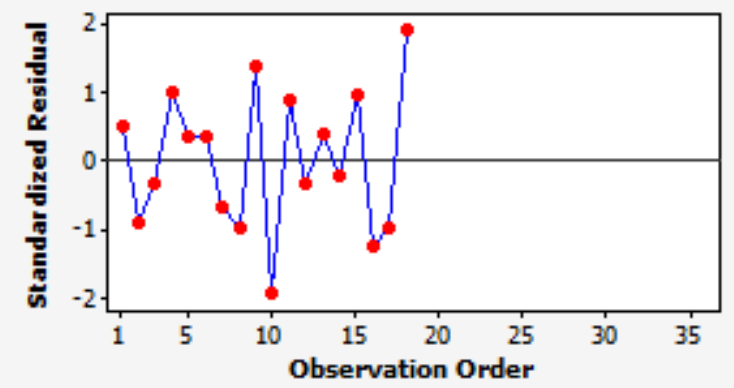

Figura A.42.1 - Análise de resíduos para $G^{*} \cdot \operatorname{sen}(\delta)=5$ MPa após PAV 


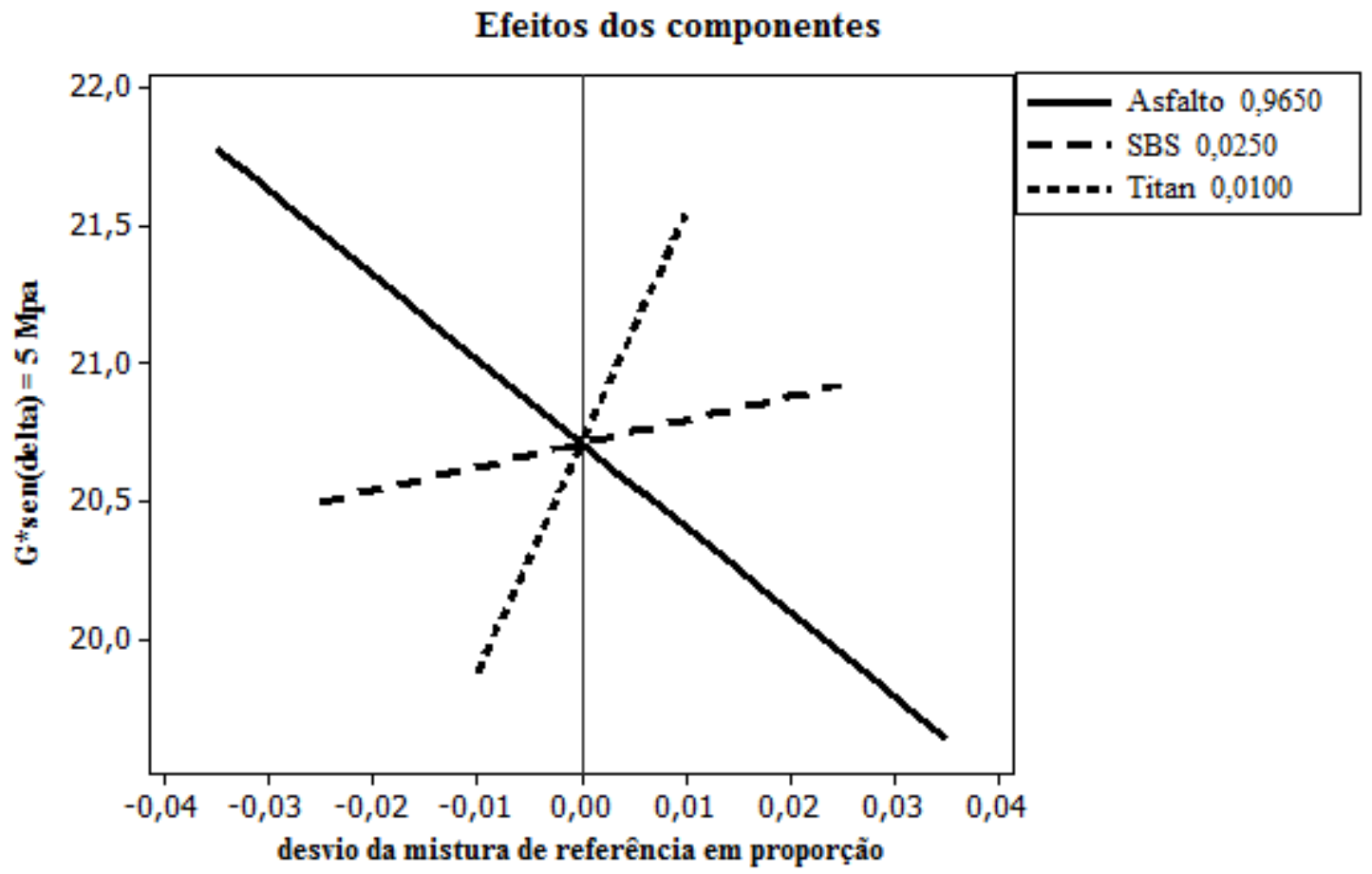

Figura A.42.2 - Efeitos dos componentes para $G^{*} \cdot \operatorname{sen}(\delta)=5$ MPa após PAV

Superficie de resposta para $G^{*} \operatorname{sen}($ delta $)=5 \mathrm{Mpa}$

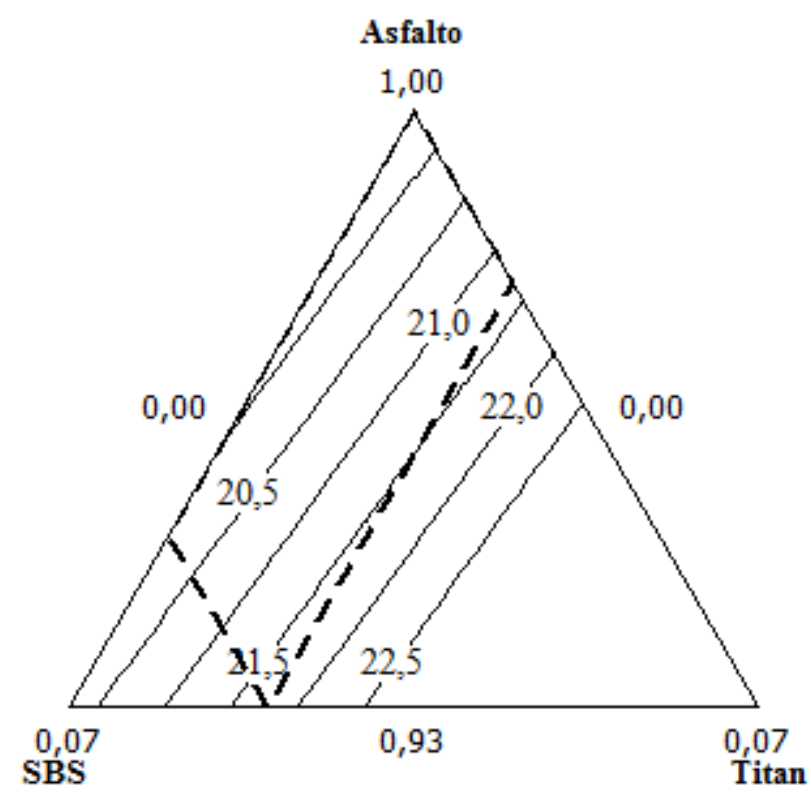

Figura A.42.3 - Superfície de resposta para $G^{*} \cdot \operatorname{sen}(\delta)=5$ MPa após PAV 
Modelo A.43 Temperatura crítica de fadiga após PAV para tráfego $\mathrm{H}$ e $\mathrm{V}$ $\left(G^{*} \cdot \operatorname{sen}(\delta)=6 \mathrm{MPa}\right)$

Não houve retirada de pontos para obtenção deste modelo. $\mathrm{O} \mathrm{R}^{\mathbf{2}}$ obtido é relativamente alto e os valores dos VIFs são baixos, permitindo o uso dos coeficientes dos termos do modelo para analisar o peso da contribuição de cada componente sobre a resposta.

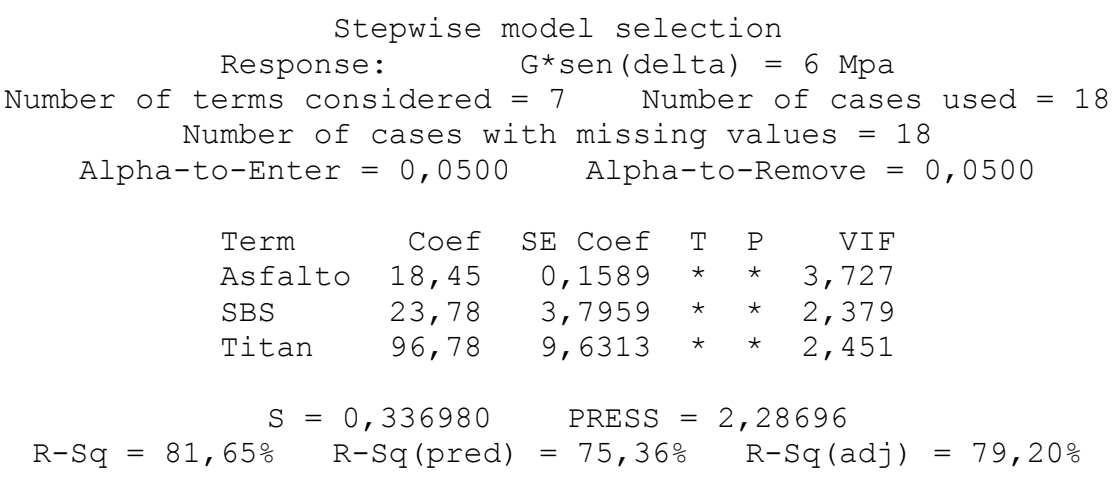

Residual Plots for $\mathrm{G}^{*} \operatorname{sen}($ delta $)=6 \mathrm{Mpa}$
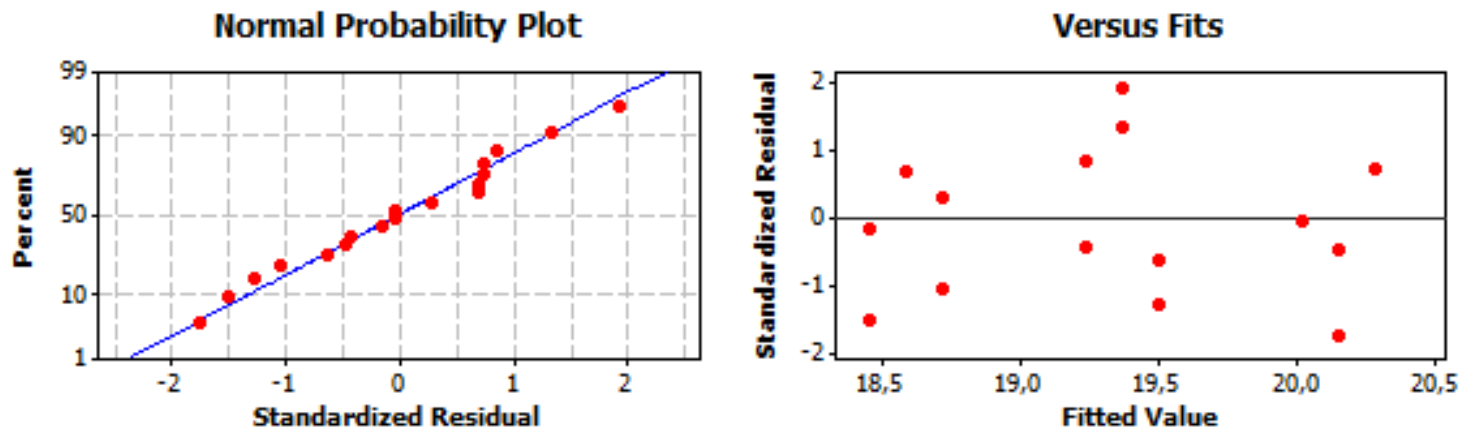

Histogram
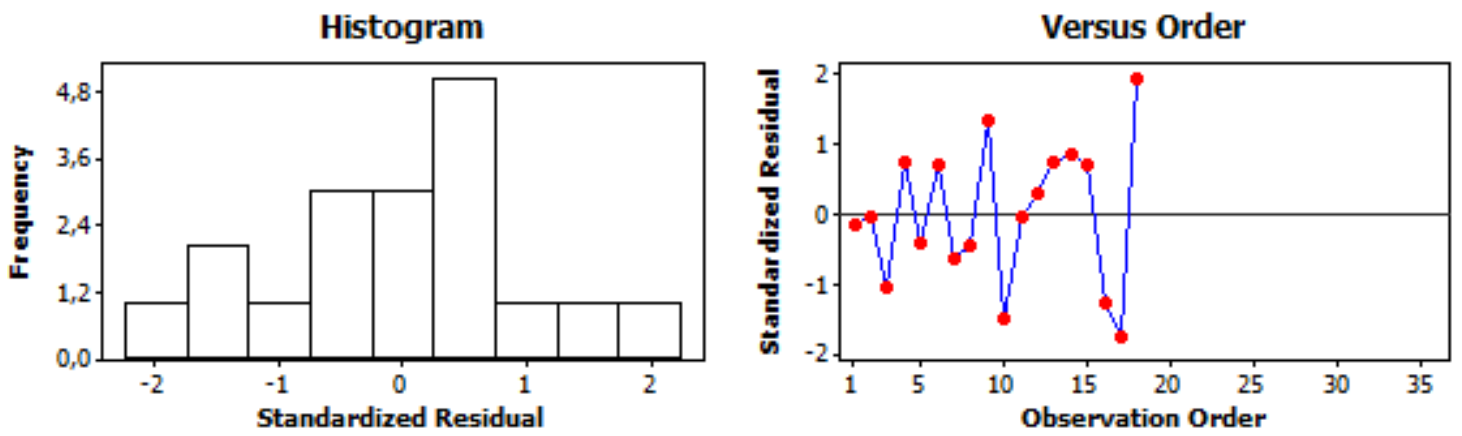

Figura A.43.1 - Análise de resíduos para $G^{*} \cdot \operatorname{sen}(\delta)=6$ MPa após PAV 
Efeitos dos componentes

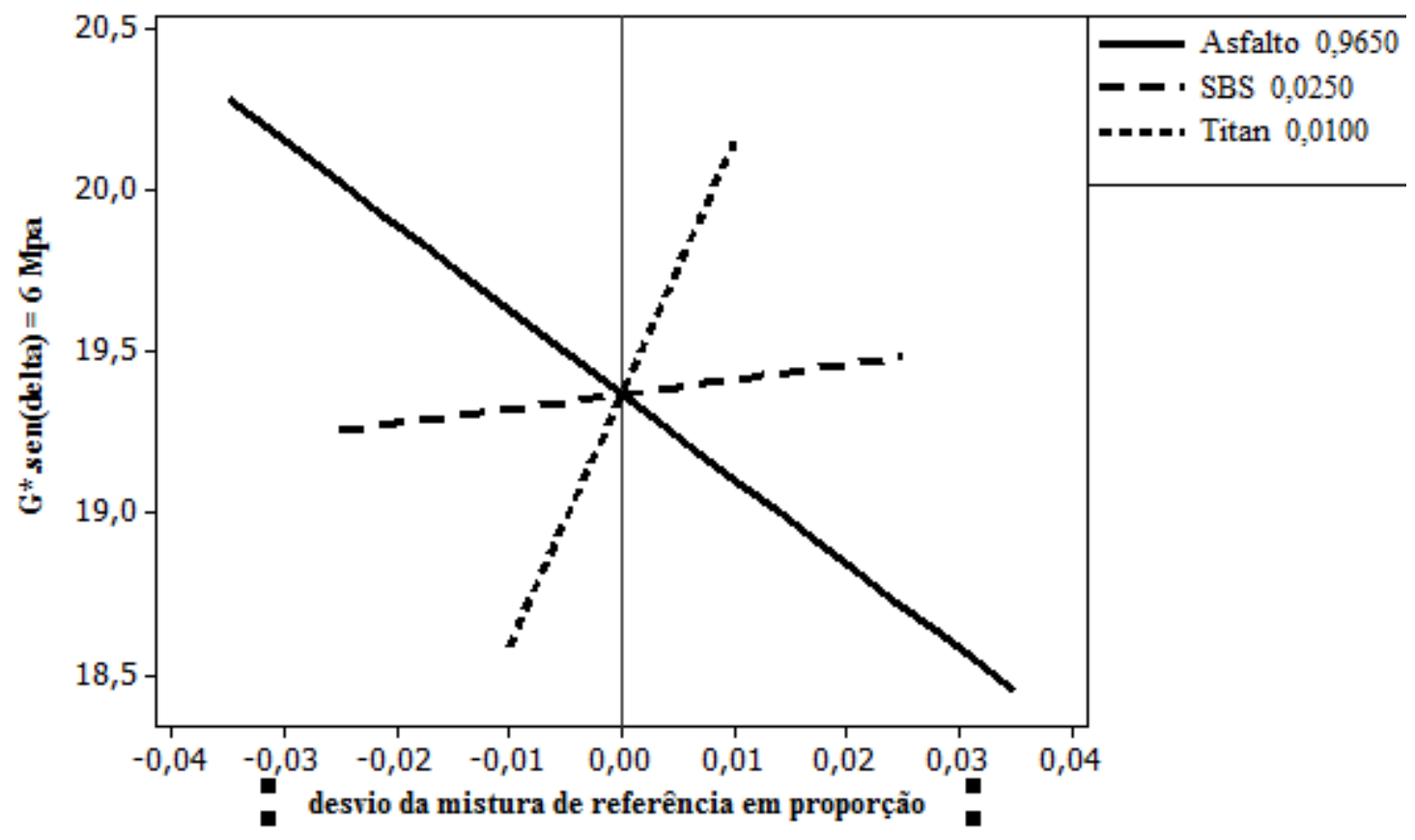

Figura A.43.2 - Efeitos dos componentes para $G^{*} \cdot \operatorname{sen}(\delta)=6$ MPa após PAV

\section{Superfície de resposta para $\mathrm{G}^{*} \operatorname{sen}($ delta $)=6 \mathrm{Mpa}$}

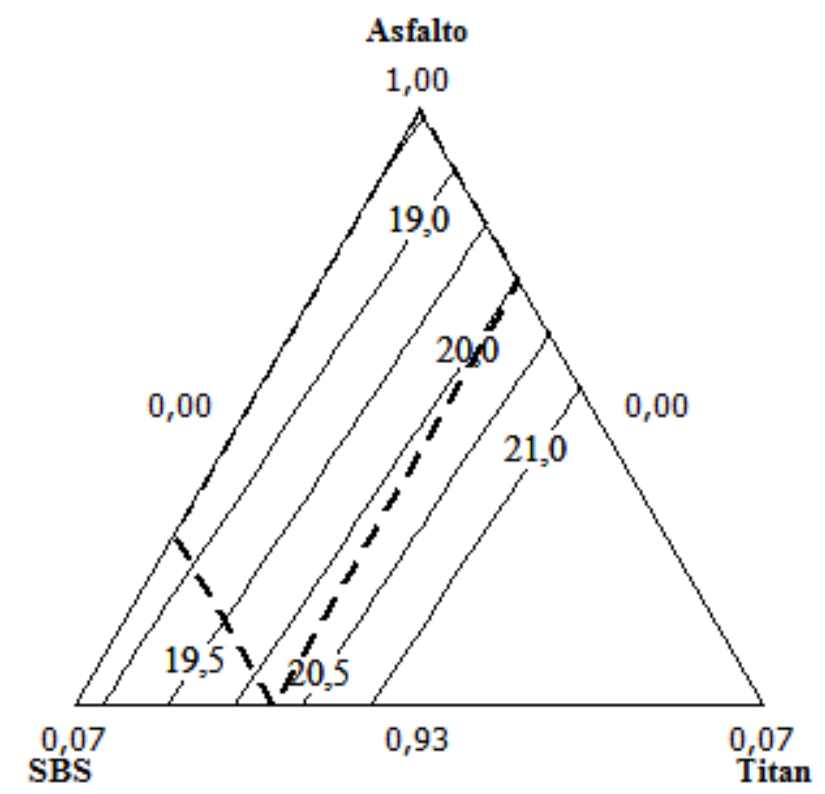

Figura A.43.3 - Superfície de resposta para $G^{*} \cdot \operatorname{sen}(\delta)=6$ MPa após PAV 